CARLA MARÇAL SILVA

\title{
DESENVOLVIMENTO DE PROCEDIMENTO EXPERIMENTAL PARA OXIDAÇÃO QUÍMICA POR OZÔNIO, EM ESCALA DE LABORATÓRIO, PARA DEGRADAÇÃO DE TETRACLOROETILENO EM FASE DISSOLVIDA
}

São Paulo 
CARLA MARÇAL SILVA

\title{
DESENVOLVIMENTO DE PROCEDIMENTO EXPERIMENTAL PARA OXIDAÇÃO QUÍMICA POR OZÔNIO, EM ESCALA DE LABORATÓRIO, PARA DEGRADAÇÃO DE TETRACLOROETILENO EM FASE DISSOLVIDA
}

\author{
Dissertação apresentada à Escola \\ Politécnica da Universidade de São \\ Paulo para obtenção do título de Mestre \\ em Engenharia \\ Área de concentração: Engenharia \\ Hidráulica e Ambiental. \\ Orientadora: Professora Titular Maria \\ Eugenia Gimenez Boscov
}

São Paulo

2015 
Este exemplar foi revisado e corrigido em relação à versão original, sob responsabilidade única do autor e com a anuência de seu orientador.

São Paulo, 31 de março de 2015.

Assinatura do autor

Assinatura do orientador

FICHA CATALOGRÁFICA

Silva, Carla Marçal

Desenvolvimento de procedimento experimental para oxidação química por ozônio, em escala de laboratório, para degradação de tetracloroetileno em fase dissolvida / C. M. Silva. -- versão corr. -- São Paulo, 2015.

$154 \mathrm{p}$.

Dissertação (Mestrado) - Escola Politécnica da Universidade de São Paulo. Departamento de Engenharia Hidráulica e Ambiental.

1.Oxidação 2.Ozônio 3.Remediação 4.Tetracloroetileno I.Universidade de São Paulo. Escola Politécnica. Departamento de Engenharia Hidráulica e Ambiental II.t. 


\section{DEDICATÓRIA}

Dedico a minha família, em especial, aos meus pais Silvia e Robert, a minha irmã Roberta, a minha avó Mathilde e ao meu namorado Pedro. 


\section{AGRADECIMENTOS}

Gostaria de agradecer as pessoas que tornaram essa pesquisa viável, sem a ajuda das quais este trabalho não teria se concretizado.

A minha orientadora Maria Eugênia pela oportunidade, compreensão, aprendizado, e por viabilizar a execução deste trabalho obtendo recursos e estabelecendo parcerias com a Brasil Ozônio;

Ao amigo Paulo Firmino pelo incentivo e apoio nos momentos difíceis, por todo o aprendizado e ajuda na concepção do aparato experimental, e pela participação ativa na parte experimental;

A amiga Adriana Velosa pelo aprendizado, ajuda e paciência no desenvolvimento da metodologia experimental dos ensaios e de análise química, pela participação ativa nos ensaios, e pela amizade;

A Brasil Ozônio, em especial ao Sammy Menasce que apoiou financeiramente esta pesquisa, viabilizando a compra de todos os itens necessários e disponibilizando o sistema de geração de ozônio. A Tais Cecchi e ao Rafael dos Santos por toda ajuda para viabilizar as compras, e os testes preliminares, pelo aprendizado e pela amizade;

À Bioagri Ambiental, em especial a Giovana Toledo, a Sabrina Regattieri, a Luci Andrietta e a Débora Silva. A Giovana e a Sabrina que viabilizaram a minha visita a Bioagri; e a Luci e a Débora que foram super receptivas e atenciosas durante e após a visita, tirando as muitas dúvidas naturais a quem nunca teve contato com um cromatógrafo;

Ao Claudio Augusto Oller do Nascimento que disponibilizou toda a estrutura de equipamentos do Laboratório de Engenharia Química da Escola Politécnica da USP;

Ao Ms. João Del Giudice Neto, do Núcleo de Pesquisa Reserva Biológica Mogi Guaçu, que me autorizou a coletar o solo e as águas subterrâneas utilizados neste trabalho; 
Ao Antônio Heitzmann, e ao João Carlos pela ajuda na coleta das amostras e orientação nos ensaios de caracterização geotécnica;

Ao Fred Lage, pelas diversas dicas, orientações e indicação de referências;

Ao Osmar Gomes e a Rafaela Araujo pelo tempo dedicado, ajuda e orientação na especificação dos materiais necessários para esta pesquisa e por todos os ensinamentos sobre análise química;

Ao Antônio Marcelo, a Kátia Mellito, ao Mark Klemmer, e ao Milton Scoparo que estiveram sempre a disposição para esclarecer dúvidas, disponibilizar materiais relacionados ao tema e me explicar com atenção e conhecimento;

A lara Camargo e ao Paulo Hemsi pelas importantes considerações feitas durante o Exame de Qualificação.

Ao Giovanni Penner pela sugestão inicial de investigação desta pesquisa, bem como por apoiar este mestrado e permitir minha dedicação aos estudos e ao trabalho.

A Rosa Chamma, ao Sérgio Kataoka e ao Claudio Lemos pelo apoio a este mestrado, o que permitiu minha dedicação aos estudos conjuntamente às atividades profissionais.

Ao Martin Bittens pelo treinamento, aprendizado e tempo dedicado;

A Kátia Ribeiro e ao Rodrigo Ramos pelos ensinamentos e ajuda;

A Miriam Antônio de Abreu, a Celyna Karitás, a Mariana Ciriaco, sempre prestativas, me disponibilizaram diversas bibliografias e me ajudaram a sanar dúvidas relacionadas a parte analítica;

A Maria Cristina Oliveira, a Neusa Niwa, a Viviane, ao Nelson, e ao Reinaldo, da Companhia Ambiental do Estado de São Paulo, CETESB, que me receberam nos seus respectivos laboratórios, e tiraram uma série de dúvidas sobre o método analítico para determinação dos subprodutos do composto de interesse na fase gasosa;

Ao Professor Roque Pivelli, Fábio e Laerte, por disponibilizar os galões para coleta das amostras de água subterrânea;

A Viviane Tavares e a Daniela por emprestar o eletrodo de ORP; 
Ao Bruno Oishi por me acompanhar até o carro as muitas noites e madrugadas que foram necessárias para finalizar os meus experimentos;

Aos meus familiares e amigos, pelo grande incentivo nesta importante etapa de minha vida;

Aos meus pais Silvia e Robert por seu fundamental apoio e incentivo aos estudos.

Aos queridos Regina, Luiz e D. Nícia pelo apoio, e por me acolher e me receber tão bem durante a minha estadia no período final desta pesquisa;

Ao Pedro Barbiere pela compreensão e por abdicar de muitos momentos de convívio para me ajudar e/ou me apoiar neste mestrado. 


\section{RESUMO}

O objetivo principal desta pesquisa foi desenvolver um aparato e procedimento experimental para estudar a oxidação química de organoclorados por injeção de ozônio em escala de laboratório. A concepção do ensaio desenvolvido permite realizar ensaios de coluna em meio aquoso ou em meio poroso, saturado ou não saturado, com monitoramento da concentração e da pressão absoluta de ozônio na entrada e na saída da coluna, do $\mathrm{pH}$, da temperatura do meio, da temperatura ambiente e controle da vazão.

Nesta pesquisa foram realizados ensaios para verificar a degradação de PCE em fase dissolvida em concentração de saturação em diversos meios: água ultrapura, águas subterrâneas coletadas em um poço cacimba e em um poço tubular profundo, e soluções de bicarbonato de sódio.

A investigação experimental compreendeu ensaios de saturação e decaimento de ozônio, ensaios batch e ensaios de coluna em meios com valores de $\mathrm{pH}$ variados. Os resultados indicaram que o ozônio em fase dissolvida atinge a saturação após aproximadamente 15 minutos de injeção, com concentrações saturadas variando entre 90 e $170 \mu \mathrm{mol} / \mathrm{L}$, dependendo do meio aquoso de estudo. O decaimento biexponencial do ozônio dissolvido mostrou tempos de meia vida t 1 e t2, que variaram conforme o meio de estudo, entre 4 e 26 minutos, e 14 e 193 minutos, respectivamente. O decaimento monoexponencial resultou em tempos de meia vida entre 12 e 76 minutos.

Os ensaios batch em meio aquoso mostraram degradação significativa do PCE por ozônio dissolvido comparativamente à degradação em água ultrapura não ozonizada. $\mathrm{A}$ adição de bicarbonato de sódio diminuiu os tempos de meia vida do ozônio em água, mas não intensificou a degradação do PCE em sistema fechado (ensaios batch).

Os ensaios de coluna em meio aquoso indicaram que a volatilização e o arraste são os principais mecanismos de remoção de PCE por injeção de ozônio. As concentrações de PCE em fase dissolvida observadas no início do ensaio de coluna foram quase completamente volatilizadas e recuperadas no trap, tanto nos ensaios com a injeção de oxigênio quanto nos ensaios com injeção de ozônio. As concentrações de PCE na 
coluna no final dos ensaios foram inferiores ou ligeiramente superiores ao valor de intervenção estabelecido pela CETESB em 2014.

Os ensaios de coluna em meio sólido (microesferas de vidro e areia) indicaram que ocorre degradação do PCE, com remoção quase total na coluna, porém com menor recuperação no trap. Possivelmente, o maior tempo de residência na coluna favorece as reações do ozônio com o PCE.

Palavras-chave: Oxidação. Ozônio. Remediação. Tetracloroetileno. 


\begin{abstract}
The aim of this research was to develop experimental apparatus and procedure to investigate chemical oxidation of chlorinated organic compounds by ozone injection at laboratory scale, in aqueous media and in saturated or unsaturated porous media. The test allows control of ozone inlet and outlet pressures and concentrations, $\mathrm{pH}$, room and column temperature, and ozone flow.
\end{abstract}

In this research, tests were performed to investigate degradation of PCE dissolved at maximum solubility concentration in several media: ultrapure water, groundwater collected in a shallow well and in a deep well, and sodium bicarbonate solutions.

The experimental investigation comprised ozone saturation and decay tests, batch tests, and column tests in aqueous media with several $\mathrm{pH}$ values. Results indicated that dissolved ozone reaches saturation after approximately 15 minutes of injection, at saturated concentrations between 90 and $170 \mu \mathrm{mol} / \mathrm{L}$, depending on the aqueous medium. Second order ozone decay half lives $t_{1}$ and $t_{2}$ vary, respectively, between 4-26 minutes and 14-193 minutes depending on the aqueous medium. First order decay half lives varied between 12-76 minutes.

Batch tests in aqueous media showed significant PCE degradation by dissolved ozone as compared to degradation in non ozonized ultrapure water. Addiction of sodium bicarbonate decreased ozone half-lives in water but did not intensify PCE degradation as observed in the results of batch tests.

Column tests in aqueous media evinced that stripping and volatilization are the mains mechanisms of PCE removal by ozone injection. Initial concentrations of dissolved PCE in the column were almost completely volatilized and recovered in the trap, for ozone injection as well as for oxygen injection. Final concentrations of dissolved PCE in the column were in the order of ppb and very near the limit allowable value according to the environmental agency of the state of São Paulo. 
Column tests in solid media indicate that PCE degrades and is removed from the column, but not totally recovered in the trap; probably, the more extended residence time in the column enhances reactions of ozone and PCE.

Keywords: Oxidation. Ozone. Remediation. Perchloroethylene. 


\section{LISTA DE FIGURAS}

Figura 1.1 Técnicas de remediação utilizadas no estado de São Paulo. Fonte: CETESB, 2014

Figura 3.1 Esquema sobre o comportamento de compostos DNAPL em subsuperfície (sem escala) 14

Figura 3.2 Processos de particionamento do contaminante no solo, ar e água em subsuperfície. Fonte: Modificado de USEPA (Agência de Proteção Ambiental dos

Estados Unidos), 2004a . 18

Figura 3.3. Cadeia de decloração redutiva abiótica de organoclorados. .23

Figura 3.4 Processo de formação do ozônio. Fonte: Brasil Ozônio, 2012. 26

Figura 3.5 Mecanismo de funcionamento de um gerador de ozônio por descarga elétrica. 26

Figura 3.6 Modelo conceitual geral de ozonização in situ na zona saturada, com extração a vácuo para captura de emissões de voláteis e $\mathrm{O}_{3}$. Fonte: HULING; PIVETZ, 2006 .30

Figura 3.7 A. Molécula do ozônio. B. Sequência de reações de ozônio com um eteno. C. Quebra das reações intermediárias para formar água e duas moléculas de aldeído. Fonte: Suthersan e Payne, 2005. 38

Figura 3.8 Ilustração conceitual das demandas "finita" e "cinética" de ozônio. Fonte: Clayton et al., 2011 .42

Figura 3.9 Diferenças entre o fluxo de bolhas e os canais de ar em condições ideais (meio homogêneo). Fonte: Clayton et al, 2011

Figura 3.10 Canais de ar e regimes de fluxo contínuo em condições ideais (meio homogêneo). Fonte: Clayton et al., 2011 .49

Figura 4.1 Horizontes do solo. 64

Figura 4.2 Geração de bolhas pelos difusores: (a) Na esquerda, difusor n 2 (40-100 $\mu \mathrm{m})$, e na direita $n^{\circ} 4(10-16 \mu \mathrm{m})(\mathrm{b}) \mathrm{Na}$ esquerda, difusor $n^{\circ} 3(16-40 \mu \mathrm{m})$, e na direita $\mathrm{n}^{\circ} 4(10-16 \mu \mathrm{m})$ .71

Figura 4.3 Projeto esquemático do aparato experimental .75 
Figura 4.4 Detalhe do funcionamento do sistema by-pass.......................................

Figura 4.5 Gerador de ozônio $\mathrm{BRO}_{3}$ da empresa Brasil Ozônio ...................................77

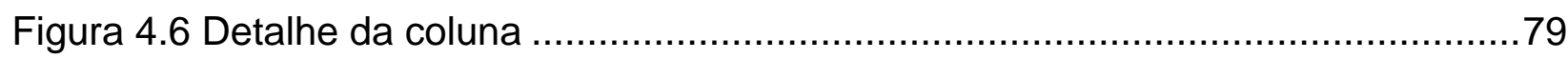

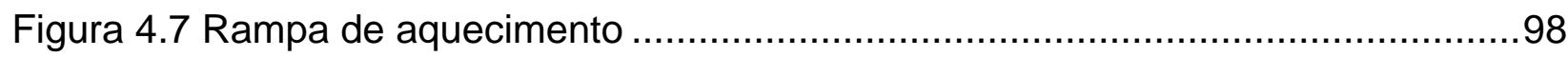

Figura 5.1 Distribuição granulométrica do solo, areia e microesferas de vidro. Fonte: Laboratório de Mecânica dos Solos - EPUSP, 2013 ..............................................102

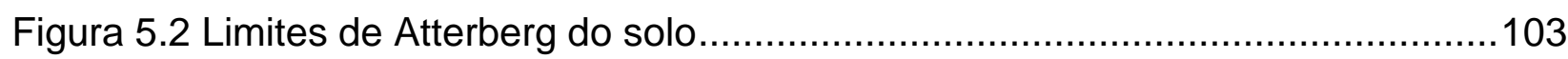

Figura 5.3 Ensaio de injeção de oxigênio em água ultrapura: espectros de quatro amostras coletadas na coluna (10 e 25 minutos após o início da injeção, e 5 e 10 minutos após o desligamento da injeção) ….........................................................110

Figura 5.4 Ensaio de saturação e decaimento de ozônio em água ultrapura: espectros de amostras coletadas na coluna durante e após o desligamento da injeção - cubeta aberta

Figura 5.5 Ensaio de saturação e decaimento de ozônio em água ultrapura: espectros de amostras coletadas na coluna durante e após o desligamento da injeção - cubeta fechada

Figura 5.6 Ensaio de degradação de PCE por injeção de ozônio: espectros de amostras coletadas na coluna - cubeta fechada 113

Figura 5.7 Ensaio de degradação de PCE de controle de água ultrapura (injeção de oxigênio): espectros de amostras coletadas na coluna - cubeta fechada 114 Figura 5.8 Ensaios de saturação de ozônio em fase dissolvida 115 Figura 5.9 Monitoramento do pH durante os ensaios de saturação de ozônio em fase dissolvida..... 117

Figura 5.10 Ensaios de cinética de decaimento de ozônio em fase dissolvida 118

Figura 5.11 Meia vida biexponencial e monoexponencial do ozônio dissolvido em função da concentração de bicarbonato de sódio . 120

Figura 5.12 Ensaios de saturação de ozônio em fase gasosa 121

Figura 5.13 Ensaio de coluna com oxigênio em solução saturada de PCE para determinar a duração dos ensaios batch e de coluna..... 122 Figura 5.14 Ensaios batch de degradação de PCE em meio aquoso: médias e desviospadrão das quintuplicatas. 
Figura 5.15 Monitoramento do $\mathrm{pH}$ durante os ensaios batch em meio aquoso 126 Figura 5.16 Ensaios batch de degradação de PCE em meio poroso: médias e desviospadrão das triplicatas. 128

Figura 5.17 Resultados dos ensaios de coluna de degradação de PCE em meio aquoso 130

Figura 5.18 Monitoramento do $\mathrm{pH}$ durante os ensaios de coluna em meio aquoso.....132 Figura 5.19 Monitoramento da pressão durante os ensaios de coluna em meio aquoso 133

Figura 5.20 Resultados dos ensaios de coluna de degradação de PCE em meio poroso 134

Figura 5.21 Resultados dos ensaios de coluna de degradação de PCE em meio poroso

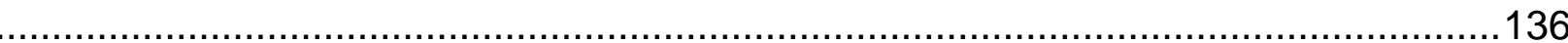

Figura 5.22 Curva de calibração de PCE em ppb. 137

Figura 5.23 Cromatograma completo 138

Figura 5.24 Espectro de massa do PCE 138

Figura 5.25 Espectro de massa do clorobenzeno 138 


\section{LISTA DE TABELAS}

Tabela 1.1 Técnicas de remediação em relação à localização dos contaminantes .........2 Tabela 1.2 Técnicas de remediação em função do tipo e concentração do contaminante

Tabela 1.3 Aptidão dos processos de descontaminação dependendo do tipo de solo. ...3

Tabela 1.4 Subprodutos decorrentes dos usos de oxidantes.........................................5

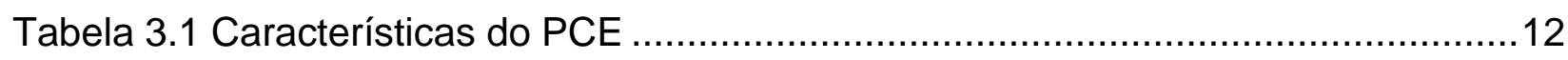

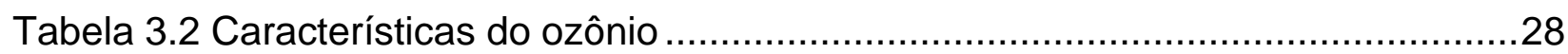

Tabela 4.1 Coordenadas e cota altimétrica dos pontos de coleta de solo e poços ........62

Tabela 4.2 Porosidades dos difusores de ozônio ..........................................................70

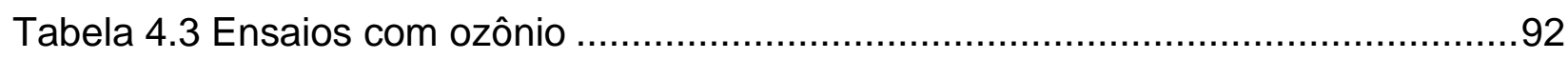

Tabela 4.3 Ensaios com ozônio (continuação) ………...........................................93

Tabela 4.4 Condições da rampa de aquecimento do CG..........................................98

Tabela 5.1 Resultados dos ensaios de caracterização geotécnica .............................104

Tabela 5.2 Resultados de caracterização físico-química do solo................................105

Tabela 5.3 Resultados de difração de raios x (DRX) e fluorescência de raios x (FRX)106

Tabela 5.4 Caracterização físico-química e química das águas. .................................108

Tabela 5.5 Valores de pH e meia-vida mono e biexponencial dos meios de estudo....117 Tabela 5.6 Ensaios batch de degradação de PCE e meio aquoso (concentrações em

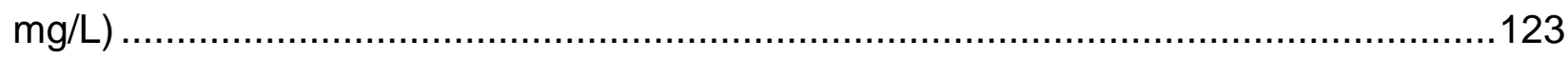

Tabela 5.7 Ensaios batch de degradação de PCE em meio aquoso (massa em $\mu \mathrm{g}$ ) ..124 Tabela 5.8 Ensaios batch de degradação de PCE em meio poroso (massa em $\mu \mathrm{g}$ ) ...127 Tabela 5.9 Ensaios de coluna para degradação de PCE em meio aquoso

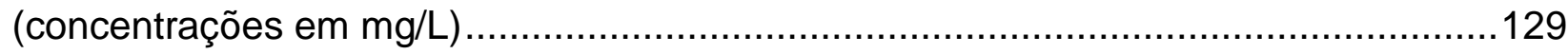

Tabela 5.10 Ensaios de coluna para degradação de PCE em meio poroso (concentrações em mg/L). 134 


\section{SUMÁRIO}

1 INTRODUÇÃO

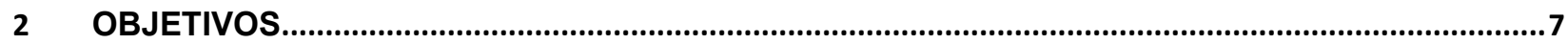

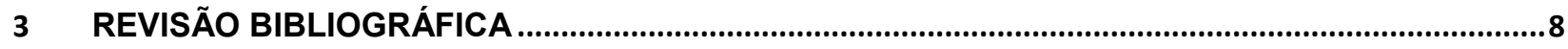

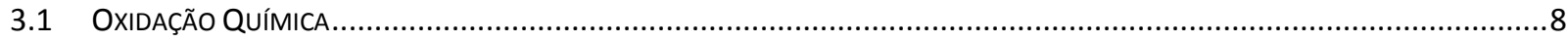

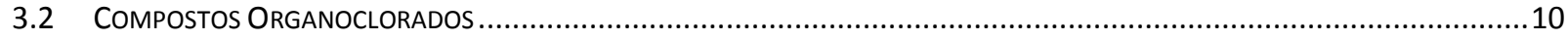

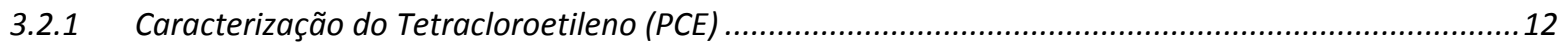

3.2.2 Partição dos Organoclorados em Subsuperfície ...........................................................................17

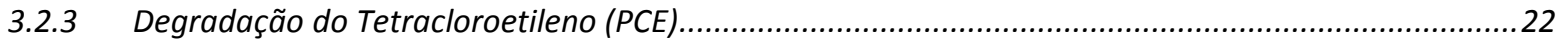

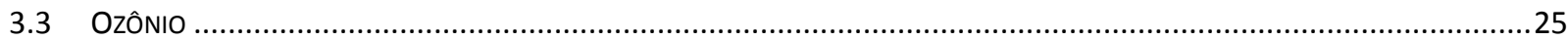

3.3.1 A Remediação de Áreas Contaminadas com Ozônio ...........................................................................29

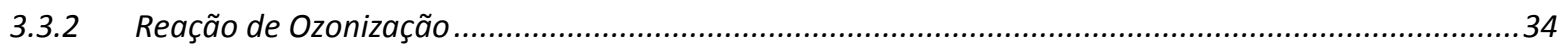

3.3.3 Degradação do Tetracloroetileno (PCE) por reações de ozonização ....................................................36

3.3.4 Fatores que Influem na Oxidação de Ozônio .......................................................................................

3.3.5 Transferência de Massa e Particionamento de Ozônio em Subsuperfície ...........................................44

3.3.6 Ensaios Laboratoriais com Ozônio ..........................................................................................

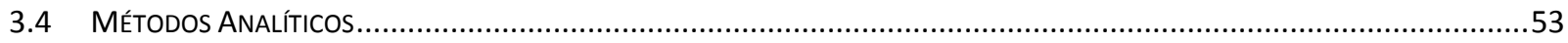

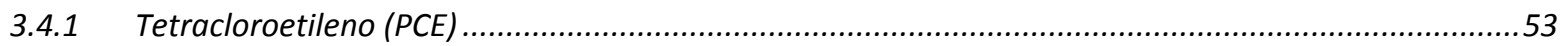

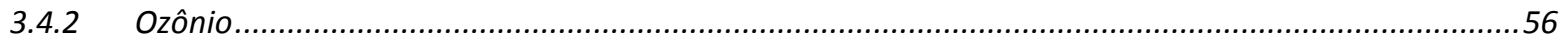

4 MATERIAIS E MÉTODOS

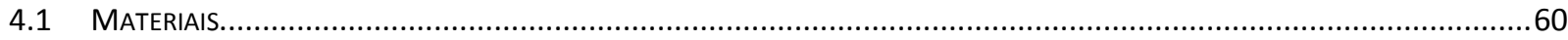

4.1.1 Caracterização da Área de Coleta de Amostras de Solo e Água Subterrânea ......................................62

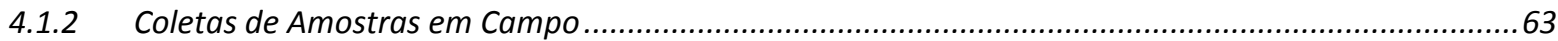

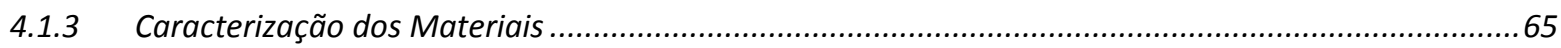

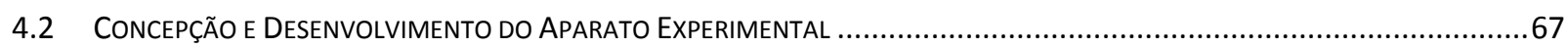

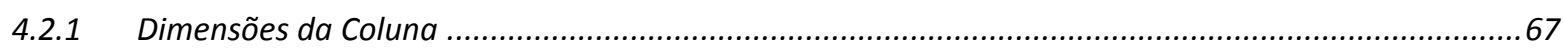

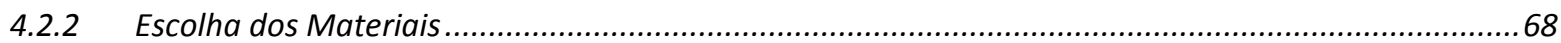

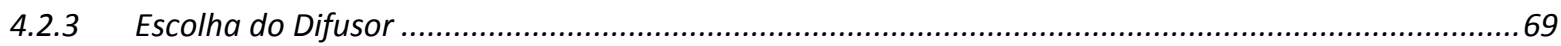

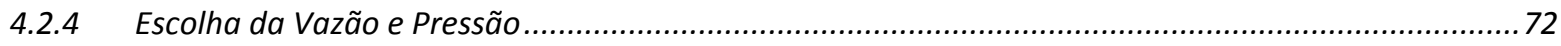

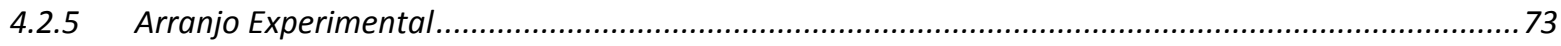




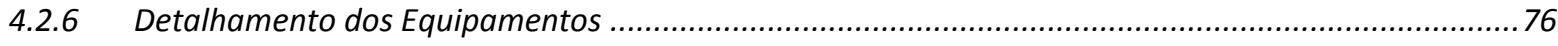

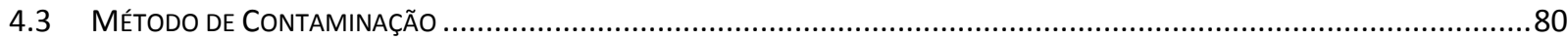

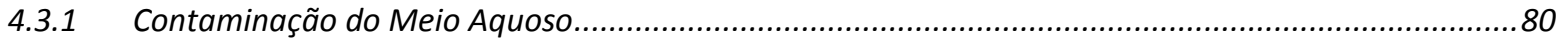

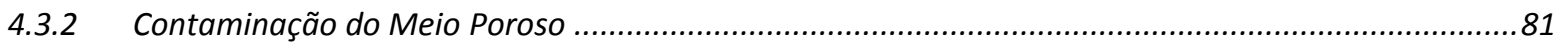

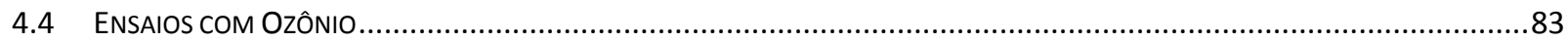

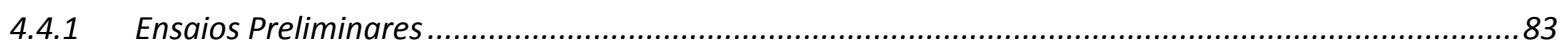

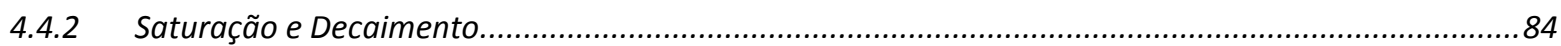

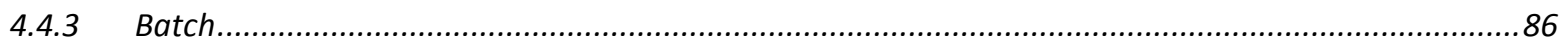

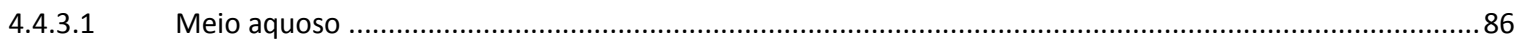

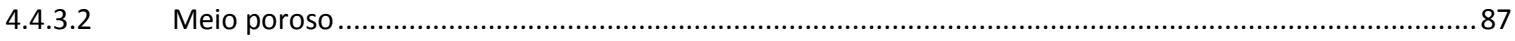

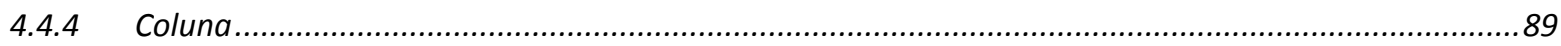

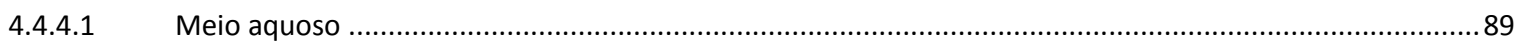

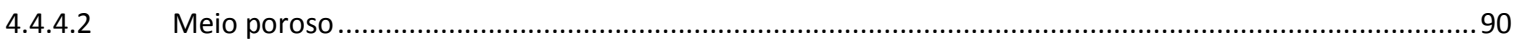

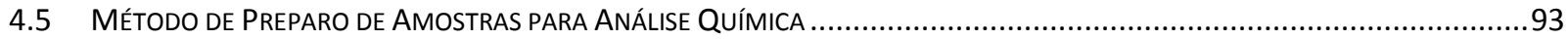

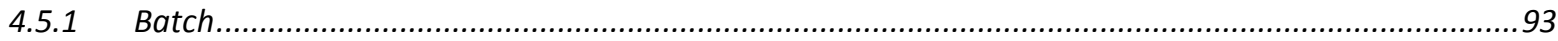

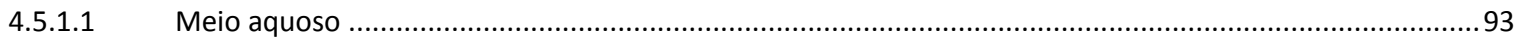

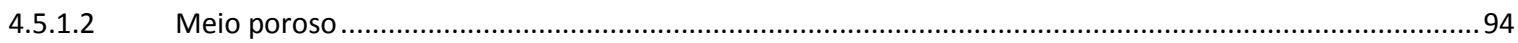

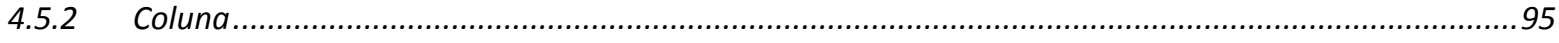

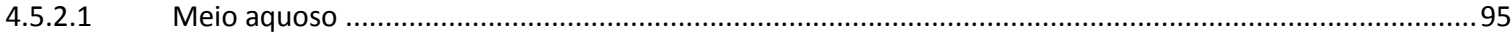

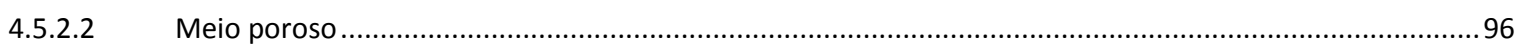

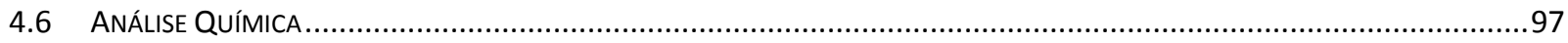

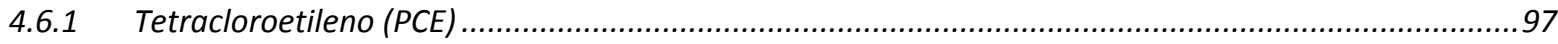

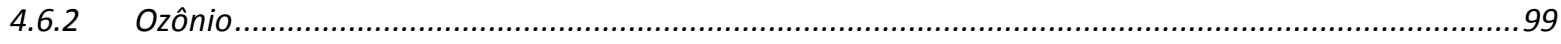

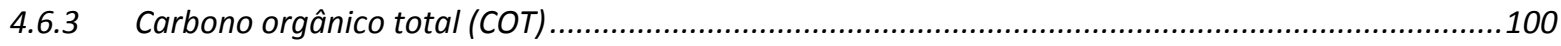

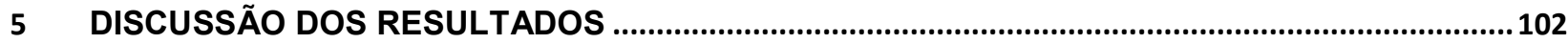

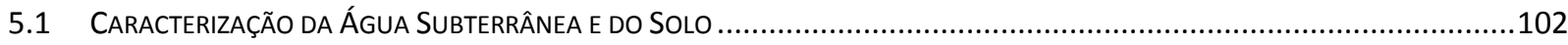

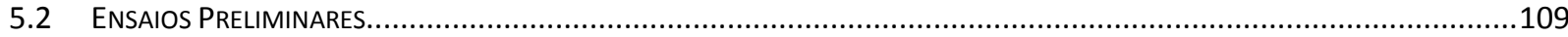

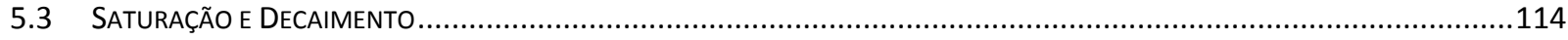

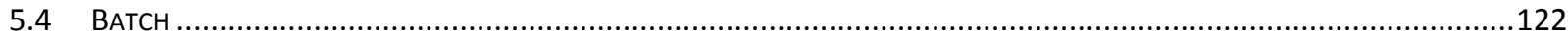

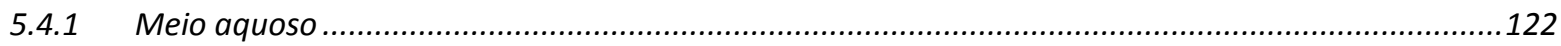

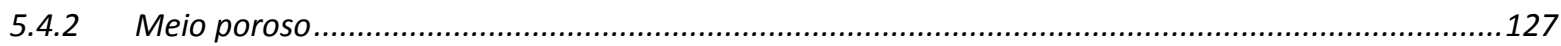

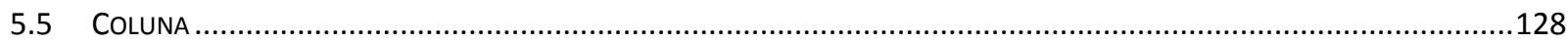

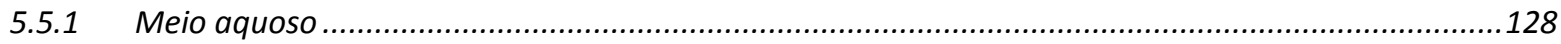

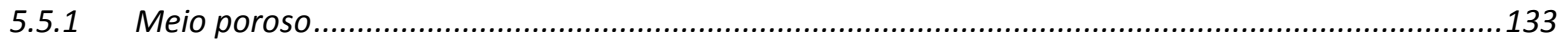

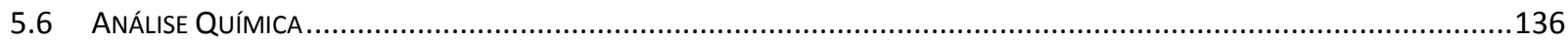




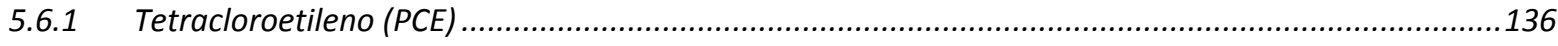

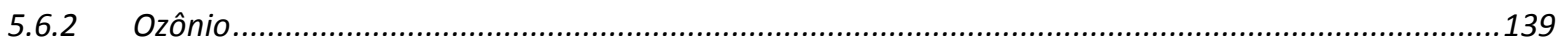

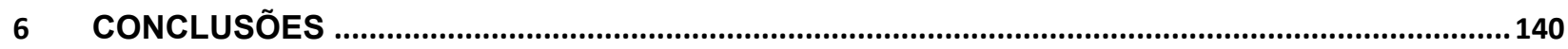

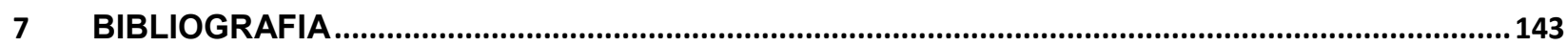

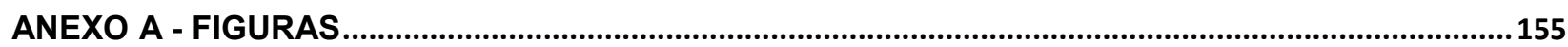

ANEXO B - RELATÓRIO FOTOGRÁFICO ..................................................................................156

ANEXO C - VALORES DE SOLUBILIDADE EM ÁGUA PARA PCE ................................................. 157

ANEXO D - CERTIFICADO DE CALIBRAÇÃO, CADEIAS DE CUSTÓDIA E LAUDOS .........................159

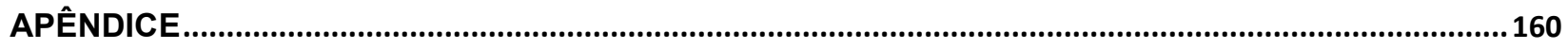




\section{INTRODUÇÃO}

A constatação, pelo órgão ambiental competente, de que uma área contaminada representa um risco para a saúde humana e o meio ambiente, por meio dos resultados de um estudo de investigação detalhada e avaliação de risco, constitui o ponto de partida para a definição da concepção da remediação, com vistas ao uso pretendido para a área (CETESB, 1999).

As áreas contaminadas apresentam um quadro muito variado relativo aos tipos de contaminantes, suas concentrações e sua distribuição no solo. Pode-se considerar a possibilidade de ocorrência de contaminantes nas seguintes fases:

- livre, como produto puro no subsolo de forma contínua,

- residual, como produto puro no subsolo retido nos poros por capilaridade;

- gasosa ou vapor, quando o contaminante se apresenta como um gás, nas condições normais do meio ambiente, ou se encontra volatilizado;

- adsorvida, quando os contaminantes estão retidos nas partículas do solo por processos de adsorção, sobretudo em solos com alto teor de argila ou de matéria orgânica;

- dissolvida, quando o contaminante está dissolvido em meio aquoso.

A escolha da técnica mais apropriada para remediar uma área contaminada deve levar em consideração a geologia local, as características e fases do contaminante, a eficiência esperada e o tempo de remediação. Recentemente, o conceito de sustentabilidade também passou a ser aplicado à remediação, compreendendo práticas sustentáveis durante a investigação, construção, desenvolvimento e monitoramento de locais de remediação (EPA, 2010; ITRC, 2011; SURF, 2014).

O Decreto 59.263 publicado pelo estado de São Paulo em 2013 impôs maior rigor na escolha das técnicas de investigação, fundamentais para uma boa caracterização e posterior escolha da técnica de remediação mais adequada (SÃO PAULO, 2013). 
Nas Tabelas 1.1, 1.2 e 1.3 são apresentadas, respectivamente, as técnicas de remediação indicadas em função da localização do contaminante no solo, do tipo e da concentração do contaminante, e da granulometria do solo. Com base nessas informações, pode-se identificar a necessidade de aplicar mais de um tipo de remediação em uma área contaminada (CETESB, 1999).

Tabela 1.1 Técnicas de remediação em relação à localização dos contaminantes

\begin{tabular}{|c|c|c|c|c|c|c|}
\hline \multirow[b]{2}{*}{ Técnica } & \multicolumn{4}{|c|}{ Localização } & \multicolumn{2}{|c|}{ Atributos } \\
\hline & $\begin{array}{l}\text { Solo Não } \\
\text { Saturado }\end{array}$ & $\begin{array}{c}\text { Solo } \\
\text { Saturado }\end{array}$ & $\begin{array}{l}\text { Leito de } \\
\text { Rocha }\end{array}$ & $\begin{array}{c}\text { Água } \\
\text { Subterrânea }\end{array}$ & $\begin{array}{l}\text { Permeável } \\
\text { Homogêneo }\end{array}$ & $\begin{array}{c}\text { Baixa Permea- } \\
\text { bilidade } \\
\text { Heterogêneo }\end{array}$ \\
\hline \multicolumn{7}{|l|}{ ISCO } \\
\hline Persulfato Ativado & $\mathbf{x}$ & $\mathbf{x}$ & $\mathbf{x}$ & $\mathbf{x}$ & $\mathbf{x}$ & $\mathbf{x}$ \\
\hline Fenton & & $\bar{x}$ & $\mathbf{x}$ & $\mathbf{x}$ & $\mathbf{x}$ & \\
\hline Permanganato & $\mathbf{x}$ & $\mathbf{x}$ & $\bar{x}$ & $\mathbf{x}$ & $\bar{x}$ & $\mathbf{x}$ \\
\hline Ozônio & $\mathbf{x}$ & $\mathbf{x}$ & & $\mathbf{x}$ & $\mathbf{x}$ & \\
\hline Biorremediação & $\mathbf{x}$ & $\bar{x}$ & $\bar{x}$ & $\bar{x}$ & $\bar{x}$ & $\bar{x}$ \\
\hline ISCR & & $\bar{x}$ & $\bar{x}$ & $\bar{x}$ & $\mathbf{x}$ & \\
\hline MNA & & & & $\mathbf{x}$ & $\mathbf{x}$ & $\mathbf{x}$ \\
\hline PRB-ZVI & & & & $\bar{x}$ & $\mathbf{x}$ & $\bar{x}$ \\
\hline Escavação & $\mathbf{x}$ & & & & $\bar{x}$ & $\bar{x}$ \\
\hline SVE & $\mathbf{x}$ & & & & $\mathbf{x}$ & \\
\hline DPE & $\mathbf{x}$ & $\mathbf{x}$ & & $\mathbf{x}$ & $\mathbf{x}$ & \\
\hline Air Sparging & $\mathbf{x}$ & $\mathbf{x}$ & $\mathbf{x}$ & $\mathbf{x}$ & $\mathbf{x}$ & \\
\hline Pump and Treat & & $\mathbf{x}$ & $\mathbf{x}$ & $\mathbf{x}$ & $\mathbf{x}$ & \\
\hline Estabilização & $\mathbf{x}$ & $\mathbf{x}$ & & & $\mathbf{x}$ & $\mathbf{x}$ \\
\hline Contenção & $\mathbf{x}$ & $\mathbf{x}$ & $\mathbf{x}$ & $\mathbf{x}$ & $\mathbf{x}$ & $\mathbf{x}$ \\
\hline \multicolumn{7}{|c|}{$\begin{array}{l}\text { Legenda das Tabelas } 1 \text { e 2: x - Tecnicamente viável. ISCO: In Situ Chemical Oxidation (oxidação } \\
\text { química in situ); ISCR: In Situ Chemical Reduction (redução química in situ); MNA: Monitored Natural } \\
\text { Atenuation (atenuação natural monitorada); PBR-ZVI: Permeable Reactive Barriers-Zero Valent Iron } \\
\text { (barreiras permeáveis reativas com ferro de valência zero); SVE: Soil Vapor Extraction (extração de } \\
\text { vapores do solo); DPE: Dual Phase Extraction (extração em duas fases); Air Sparging: injeção de ar; } \\
\text { Pump and Treat: bombeamento e tratamento; VOC: Volatile Organic Compounds (compostos orgânicos } \\
\text { voláteis); NAPL: Non Aqueous Phase Liquid (líquido não miscível na água). (1) Recalcitrante = } \\
\text { persistente. }\end{array}$} \\
\hline
\end{tabular}

Fonte: Block; Cutler, 2005 
Tabela 1.2 Técnicas de remediação em função do tipo e concentração do contaminante

\begin{tabular}{|c|c|c|c|c|c|c|c|c|}
\hline \multirow[b]{2}{*}{ Técnica } & \multicolumn{4}{|c|}{ Tipo de Contaminante } & \multicolumn{4}{|c|}{ Concentração de Contaminante } \\
\hline & VOC & $\begin{array}{l}\text { Não- } \\
\text { VOC }\end{array}$ & $\begin{array}{c}\text { Altamente } \\
\text { Recalcitrante }^{(1)} \\
\end{array}$ & Metais & Baixa & Alta & $\begin{array}{c}\text { NAPL } \\
\text { Residual }\end{array}$ & $\begin{array}{l}\text { NAPL } \\
\text { Livre } \\
\end{array}$ \\
\hline \multicolumn{9}{|l|}{ ISCO } \\
\hline Persulfato Ativado & $\mathbf{x}$ & $\mathbf{x}$ & $\mathbf{x}$ & & $\mathbf{x}$ & $\mathbf{x}$ & $\mathbf{x}$ & $\mathbf{x}$ \\
\hline Fenton & $\mathbf{x}$ & $\mathbf{x}$ & & & $\mathbf{x}$ & $\mathbf{x}$ & $\mathbf{x}$ & \\
\hline Permanganato & $\mathbf{x}$ & PAHs & & & $\mathbf{x}$ & $\mathbf{x}$ & $\mathbf{x}$ & $\mathbf{x}$ \\
\hline Ozônio & $\mathbf{x}$ & $\mathbf{x}$ & $\mathbf{x}$ & & $\mathbf{x}$ & $\mathbf{x}$ & $\mathbf{x}$ & \\
\hline Biorremediação & $\mathbf{x}$ & $\mathbf{x}$ & & & $\mathbf{x}$ & & & \\
\hline MNA & $\mathbf{x}$ & $\mathbf{x}$ & & $\mathbf{X}$ & $\mathbf{x}$ & & & \\
\hline ISCR & $\mathbf{x}$ & $\mathbf{x}$ & $\mathbf{x}$ & Alguns & $\mathbf{x}$ & $\mathbf{x}$ & $\mathbf{x}$ & \\
\hline PRB-ZVI & $\mathbf{x}$ & $\mathbf{x}$ & $\mathbf{x}$ & Alguns & $\mathbf{x}$ & $\mathbf{x}$ & & \\
\hline Escavação & $\mathbf{x}$ & $\mathbf{x}$ & $\mathbf{x}$ & $\mathbf{x}$ & $\mathbf{x}$ & $\mathbf{x}$ & $\mathbf{x}$ & \\
\hline SVE & $x$ & & $\mathbf{x}$ & & $\mathbf{x}$ & & Se VOC & \\
\hline DPE & $\mathbf{x}$ & $\mathbf{x}$ & $\mathbf{x}$ & & $\mathbf{x}$ & & Se VOC & \\
\hline Air Sparging & $\mathbf{x}$ & $\mathbf{x}$ & $\mathbf{x}$ & & $\mathbf{x}$ & & Se VOC & \\
\hline Pump and Treat & $\mathbf{x}$ & $\mathbf{x}$ & & & $\mathbf{x}$ & $\mathbf{x}$ & & $\mathbf{x}$ \\
\hline Estabilização & & $\mathbf{x}$ & $\mathbf{X}$ & $\mathbf{x}$ & $\mathbf{x}$ & $\mathbf{x}$ & $\mathbf{x}$ & \\
\hline Contenção & $\mathbf{x}$ & $\mathbf{x}$ & $\mathbf{x}$ & $\mathbf{x}$ & $\mathbf{x}$ & $\mathbf{x}$ & $\mathbf{x}$ & $\mathbf{x}$ \\
\hline
\end{tabular}

Fonte: Block; Cutler, 2005

Tabela 1.3 Aptidão dos processos de descontaminação dependendo do tipo de solo.

\begin{tabular}{|l|c|c|c|c|c|}
\hline \multirow{2}{*}{ Tipo de Solo } & \multicolumn{5}{|c|}{ Processos de Descontaminação } \\
\cline { 2 - 7 } & $\begin{array}{c}\text { Processos } \\
\text { Térmicos }\end{array}$ & $\begin{array}{c}\text { Processos } \\
\text { Químicos }\end{array}$ & $\begin{array}{c}\text { Processos } \\
\text { Biológicos }\end{array}$ & $\begin{array}{c}\text { Lavagem } \\
\text { de Solo }\end{array}$ & $\begin{array}{c}\text { Processos } \\
\text { Pneumáticos }\end{array}$ \\
\hline Saibro/Areias & A & A & A & A & A \\
\hline $\begin{array}{l}\text { Saibro/Areias } \\
\text { siltosas/Siltes }\end{array}$ & A & A & A & A & A \\
\hline $\begin{array}{l}\text { Saibro/Areias muito } \\
\text { siltosas/ } \\
\text { Siltes argilosos }\end{array}$ & A & A & A & A & A \\
\hline $\begin{array}{l}\text { Silte de baixa ou } \\
\text { média plasticidade }\end{array}$ & A & A & CC & CC & NA \\
\hline $\begin{array}{l}\text { Argila de alta } \\
\text { plasticidade }\end{array}$ & A & CC & NA & NA & NA \\
\hline $\begin{array}{l}\text { Solos de granulação } \\
\text { mesclada com } \\
\text { misturas orgânicas }\end{array}$ & A & CC & A & A & A \\
\hline $\begin{array}{l}\text { Silte com misturas } \\
\text { orgânicas }\end{array}$ & A & CC & CC & NA & NA \\
\hline $\begin{array}{l}\text { Argila com misturas } \\
\text { orgânicas }\end{array}$ & A & NA & NA & NA & NA \\
\hline Solos orgânicos & A & NA & NA & NA & NA \\
Legenda: NA - Geralmente Não Apropriado; A - Geralmente Apropriado e CC - Decisão Caso a Caso. \\
\hline
\end{tabular}

Fonte: CETESB, 1999 
As técnicas mais utilizadas na remediação de áreas contaminadas no estado de São Paulo são apresentadas na Figura 1.1.

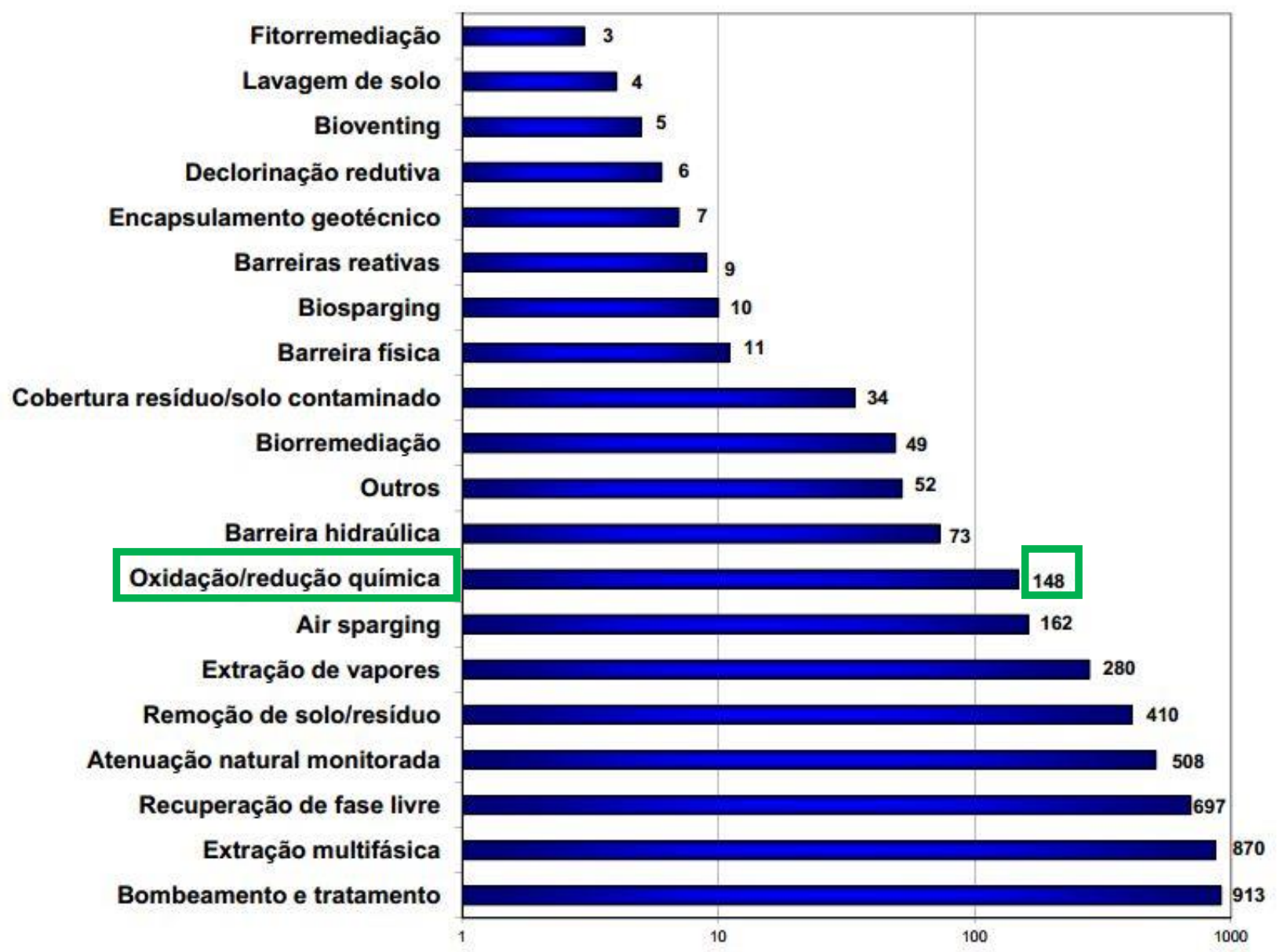

Figura 1.1 Técnicas de remediação utilizadas no estado de São Paulo. Fonte: CETESB, 2014

De acordo com a Figura 1.1, a técnica de bombeamento e tratamento é a mais empregada, ainda que apresente um longo tempo de tratamento. Observa-se também que em apenas 3,5\% das 4.251 áreas contaminadas em processo de remediação cadastradas no estado de São Paulo foram aplicadas técnicas de oxidação ou redução química até dezembro de 2013 (CETESB, 2014).

$\mathrm{Na}$ oxidação química utilizam-se compostos químicos oxidantes para transformar contaminantes perigosos presentes no solo e nas águas subterrâneas em compostos não nocivos, como água e dióxido de carbono. Tem sido utilizada por mais de 100 anos para abastecimento de água e tratamento de esgotos, mas é uma técnica relativamente 
nova no mercado para remediação em subsuperfície, sendo necessárias ainda pesquisas para melhorar sua aplicação. O diferencial é o curto tempo necessário para a remediação, porém os custos são elevados comparados aos de outras técnicas.

Entre os possíveis agentes oxidantes estão o ozônio, o peróxido de hidrogênio, o permanganato de potássio, persulfatos, hipoclorito, cloro, dióxido de cloro e o reagente Fenton, composto por peróxido de hidrogênio e ferro (CETESB, 1999; USEPA, 2011).

Dentre os tipos de oxidantes citados nas Tabelas 1.1 e 1.2, o ozônio se diferencia dos demais por ser o único existente na forma de gás, podendo ser produzido a partir do ar ambiente.

O produto preferencial de degradação do ozônio, o oxigênio, não polui e é indispensável às atividades biológicas aeróbias dos ecossistemas aquáticos; seu outro subproduto, a água, tampouco é poluente. Entretanto, a interação do ozônio com os contaminantes pode gerar substâncias tóxicas.

As reações dos oxidantes podem formar subprodutos até mais tóxicos que os compostos poluentes originais (JARDIM; CANELA, 2004; MAHMOUD; FREIRE, 2006). $\mathrm{Na}$ Tabela 1.4 é possível observar alguns subprodutos comumente encontrados dos oxidantes mais conhecidos.

Tabela 1.4 Subprodutos decorrentes dos usos de oxidantes

\begin{tabular}{|c|c|}
\hline Oxidante & Subprodutos \\
\hline $\mathrm{H}_{2} \mathrm{O}_{2}$ & Ácidos Orgânicos (Oxálico, Fórmico, Acético) e Quinonas \\
\hline $\mathrm{O}_{3}$ & Orgânicos Bromados, Ácidos Orgânicos \\
\hline $\mathrm{Cl}_{2}$ & Orgânicos Clorados \\
\hline $\mathrm{KMnO}_{4}$ & $\mathrm{MnO}_{2}(\mathrm{~s})$ \\
\hline
\end{tabular}

Fonte: Jardim e Canela, 2004

A oxidação química de diversos poluentes por ozônio é viável tecnicamente (Tabela 1.2), incluindo os combustíveis, pesticidas e organoclorados (BLOCK; CUTLER, 2005). Os organoclorados alifáticos ou solventes clorados encontram-se em 7,36\% das áreas contaminadas cadastradas no estado de São Paulo até dezembro de 2013 (CETESB, 
2014). São compostos orgânicos halogenados, onde o cloro substitui o hidrogênio em hidrocarbonetos de cadeia aberta. Dentre eles, destacam-se alguns etanos e etenos clorados, como o tricloroetano e o dicloroetano, o tricloroeteno, o dicloroeteno e o tetracloroetileno (ou percloroetileno - PCE), que são intensivamente empregados no processo produtivo de diversos tipos de indústrias e em estabelecimentos comerciais, como lavanderias que realizam lavagem a seco. Os compostos oriundos da degradação de etenos clorados podem apresentar riscos à saúde dos trabalhadores dos estabelecimentos que os produzem ou os utilizam, assim como de moradores do entorno, por ingestão, contato dérmico e inalação dos vapores provenientes da volatilização dos compostos a partir da água subterrânea. Além disso, esses compostos apresentam persistência e são mais densos que a água, ou seja, apresentam tendência à percolação até atingir grandes profundidades, características que podem dificultar a remediação.

A remediação de áreas contaminadas por solventes clorados tem sido efetuada geralmente com técnicas que se baseiam na decloração redutiva, ou seja, na cadeia de degradação por troca de cloro por hidrogênio, gerando no final o eteno. Porém, os compostos intermediários, como o cloreto de vinila, podem ser mais tóxicos do que o produto original, ou seja, uma redução incompleta pode trazer riscos à saúde humana.

A possibilidade de tratar por meio de injeção de ozônio terrenos contaminados por solventes clorados é promissora, pois se espera alta eficiência do processo, devido à reatividade do ozônio. Observa-se, porém, que a eficiência em campo pode ser diminuída drasticamente pela dificuldade de espalhamento do ozônio em caso de baixa permeabilidade do solo e/ou existência de caminhos preferenciais de percolação.

É importante a realização de ensaios preliminares em laboratório para verificação da viabilidade técnica de degradação do contaminante com o ozônio, para identificação das variáveis que podem influenciar na remediação e para determinação de parâmetros de operação em campo. A bibliografia especializada, contudo, não oferece muitas informações sobre arranjos e procedimentos experimentais, assim como sobre técnicas analíticas apropriadas, para estudos em escala de laboratório de degradação de organoclorados em solos por injeção de ozônio. 


\section{OBJETIVOS}

Este trabalho tem o objetivo principal de desenvolver o equipamento e o procedimento experimental para o ensaio de oxidação de PCE por ozônio em amostras de solo e água subterrânea, como etapa preliminar de estudos de remediação de áreas contaminadas por PCE.

O objetivo complementar é estudar a viabilidade técnica da oxidação por ozônio para degradação da fase dissolvida de PCE em amostras de água subterrânea do estado de São Paulo, por meio de ensaios batch e de coluna em escala de laboratório.

Os objetivos específicos são: a definição do tipo de solo para estudo nesta pesquisa, do local de coleta, método de coleta de amostras de água subterrânea e solo; a caracterização de amostras de águas subterrâneas por ensaios físico-químicos e químicos, a caracterização de amostras de solo por ensaios geotécnicos, físicoquímicos, químicos e mineralógicos; o desenvolvimento do arranjo experimental; o desenvolvimento de um método de contaminação em laboratório das amostras de água subterrânea e solo; a definição dos meios de interesse para estudo; a realização de ensaios de saturação e decaimento de ozônio em diversos meios aquosos; o desenvolvimento de procedimento experimental para ensaios batch e de coluna; a seleção de técnicas analíticas, desenvolvimento de método para o preparo de amostras para análise química de PCE e desenvolvimento do método para análise química de PCE; e a realização dos ensaios batch e de coluna propriamente ditos com quantificação de ozônio e PCE.

Foram definidos como meios de estudo para meio aquoso: água ultrapura, água ultrapura com diferentes concentrações de $\mathrm{NaHCO}_{3}$, água subterrâneas provenientes de poço cacimba e poço tubular profundo, enquanto para o meio poroso foram estudados: microesferas de vidro, areia e solo. 


\section{REVISÃO BIBLIOGRÁFICA}

\subsection{Oxidação Química}

A Companhia Ambiental do Estado de São Paulo - CETESB (1999) define oxidação química como uma técnica que utiliza compostos químicos oxidantes para transformar contaminantes perigosos presentes no solo e nas águas subterrâneas em compostos não nocivos, como água e dióxido de carbono. No caso de compostos clorados, pode também ser gerado cloro (USEPA, 2011).

Esta técnica pode ser aplicada a muitos tipos de compostos químicos, como combustíveis, solventes e pesticidas. Baseia-se na aplicação de oxidantes para quebrar as ligações de carbono do contaminante orgânico, reduzindo a massa, mobilidade e toxicidade por meio da conversão dos contaminantes em compostos minerais (CARUS REMEDIATION TECHNOLOGIES, 2010).

A oxidação química apresenta maior eficiência, definida como massa de contaminante transformada por massa de oxidante, na remoção das fases dissolvida e adsorvida na área fonte. Portanto, a técnica é indicada para remediação de áreas pequenas, onde a massa de contaminante é mais concentrada, para tratar contaminantes da área fonte na zona saturada e franja capilar (HULING; PIVETZ, 2006; USEPA, 2008).

Em locais onde é necessário o tratamento da área fonte na zona não saturada, o mais indicado é que outra técnica de remediação seja empregada, como por exemplo, a extração de vapores do solo (USEPA, 2008). Na existência de produto em fase livre, outras técnicas de remediação têm sido conduzidas anteriormente à oxidação química para que o custo da remediação seja viável, evitando-se o uso de grande quantidade de oxidante para consumir o produto bruto.

A oxidação química não envolve necessariamente a escavação de solo ou bombeamento de água subterrânea. Os oxidantes podem ser injetados por meio de perfurações no solo, em diferentes profundidades, incluindo os poços de monitoramento 
instalados durante a investigação da área. Para tornar a descontaminação mais rápida, os oxidantes podem ser injetados num poço e bombeados em outro a jusante, forçando um fluxo que auxilia na mistura dos oxidantes com os contaminantes na água subterrânea e solo. A mistura de oxidantes e contaminantes é bombeada e reinjetada no primeiro poço, ou seja, é recirculada. O controle do processo, sobretudo referente às taxas, frequência de aplicação, difusão da mistura de reagentes e maximização da dispersão, é importante para evitar que o tratamento ocorra apenas por caminhos preferenciais, sem atingir toda a massa de solos contaminados (CETESB, 1999).

Novas técnicas para a aplicação dos oxidantes no solo envolvem a mistura do oxidante no solo, como o método geotécnico de Cutter Soil Mixing: inicialmente desestrutura-se o solo com uma ferramenta cortante rotativa, com o auxílio de água, até a profundidade desejada; após a retirada do material excedente, injeta-se o oxidante em movimento ascendente, misturando-o com o solo in situ. $\mathrm{O}$ equipamento tem capacidade de penetração até $25 \mathrm{~m}$ de profundidade e o raio de abrangência pode variar entre $0,15 \mathrm{a}$ 0,6 m (RANDO; ANDROMALOS; BOSCOV, 2013).

As principais restrições à aplicação da oxidação química são: elevado teor de matéria orgânica no solo; pH do solo acima de 8; elevados teores de dureza ou carbonatos nas águas subterrâneas; distribuição de contaminantes até camadas muito profundas do subsolo; elevados teores de finos no solo; e heterogeneidade das formações constituintes do subsolo (CETESB, 1999).

Para verificação da viabilidade da técnica em uma área contaminada, cabe lembrar que o processo de oxidação química é afetado por fatores como temperatura, $\mathrm{pH}$, teor de umidade, concentração de oxigênio na fase líquida, impurezas, presença de catalisadores, concentração e propriedades químicas dos contaminantes (CETESB, 1999). O grupo de trabalho norte-americano Interstate Technology and Regulatory Cooperation Work Group - ITRC (2001) recomenda, previamente à aplicação da técnica, estimar a massa de contaminante na zona não saturada e saturada; a alcalinidade, o teor de matéria orgânica e as concentrações de ferro e manganês no solo e na água subterrânea; a demanda química de oxigênio; a heterogeneidade, a porosidade, o gradiente hidráulico, a permeabilidade e o teor de umidade da zona 
saturada; o potencial de óxi-redução e oxigênio dissolvido da água subterrânea; a condutividade hidráulica do solo à água subterrânea; e a impureza do oxidante. Segundo o ITRC (2001), essas informações são necessárias para verificar a viabilidade da técnica e estimar a dosagem, a distribuição e a distância dos pontos de injeção de oxidante, a frequência de aplicação e a concentração de oxidante.

\subsection{Compostos Organoclorados}

Os hidrocarbonetos halogenados, grupo que inclui os solventes clorados, são compostos orgânicos que apresentam a substituição de pelo menos um átomo de hidrogênio por átomo de halogênio (flúor, cloro, bromo, iodo e ástato). Especificamente, compostos organoclorados ou solventes clorados são hidrocarbonetos nos quais ocorre a substituição de átomos de hidrogênio por átomos de cloro.

Os hidrocarbonetos halogenados são subdivididos em alifáticos (cadeias abertas) e aromáticos (apresentam como cadeia principal um ou vários anéis benzênicos).

Organoclorados alifáticos são tipicamente constituídos por um ou dois átomos de carbono e entre um e seis átomos de cloro (SALE et al., 2008), com ao menos um átomo de cloro ligado covalentemente. Podem ser compostos por cadeias abertas e/ou conter anéis aromáticos; os átomos de cloro podem estar localizados nas cadeias abertas ou nos anéis aromáticos. Resultam da reação do gás cloro com produtos petroquímicos.

Dentre os organoclorados estão: cloreto de metileno ou diclorometano (DCM); clorofórmio ou triclorometano (TCM); tetracloreto de carbono ou tetraclorometano (PCM); 1,1-dicloroetano (1,1-DCA); 1,2-dicloroetano (1,2-DCA); 1,1,1-tricloroetano (1,1,1-TCA $) ; \quad$ 1,1,2-tricloroetano $\quad(1,1,2-\mathrm{TCA}) ; \quad$ 1,1,2,2-tetracloroetano; $1,1,1,2-$ tetracloroetano; 1,2-dicloropropano; 1,1-dicloroeteno (1,1-DCE); 1,2-dicloroeteno (cis,trans 1,2-DCE); tricloroeteno (TCE); tetracloroetileno (PCE); cloreto de vinila (VC) (SALGADO; MARONA, 2004). 
São compostos moleculares de baixo ponto de fusão e ebulição quando comparados aos compostos iônicos, e maus condutores de corrente elétrica quando puros.

Os organoclorados foram produzidos pela primeira vez na Alemanha no século XIX e por volta de 1906 nos Estados Unidos. A produção de PCE e TCE iniciou-se em 1923; e em 1930, o PCM passou a ser comumente utilizado para lavagem a seco, em substituição à gasolina.

Os organoclorados mais comumente utilizados pela indústria são 1,1,1-TCA, DCM, PCE, e TCE. Estes compostos químicos são empregados na fabricação de adesivos, aerossóis, borracha laminada, espuma de uretano (polímero), na lavagem a seco, nas indústrias têxtil, de produtos de limpeza, de eletrônicos, e de aeronaves, como desengraxante de peças metálicas, na remoção de tinta, e no processamento de fotografias e em gráficas (PANKOW; CHERRY, 1996).

O PCE, objeto de estudo deste trabalho, é utilizado em processos de lavagem a seco, no desengraxe de peças metálicas, como intermediário químico (ACGIH, 1996; ECSA, 2001 in SALGADO; MARONA, 2004) e na produção de removedores de tintas, tintas de impressão, fluidos especiais de limpeza e lubrificantes de silicone (ECSA, 2003 in SALGADO; MARONA, 2004).

Os solventes são substâncias orgânicas líquidas de várias faixas de lipossolubilidade (acúmulo nas gorduras dos organismos) e de volatilidade, que associadas ao pequeno tamanho molecular, fazem com que a inalação seja a principal via de exposição e proporcionam fácil absorção através de pulmões, trato gastrointestinal e pele (BRUCKNER; WARREN, 2001 in SALGADO; MARONA, 2004).

As preocupações com a saúde humana e o meio ambiente surgiram em 1970, fato que provocou uma diminuição na produção desses compostos. Baseando-se em estudos em humanos e animais, os organoclorados como o DCM, o TCM, o PCM, o PCE e o TCE são considerados prováveis carcinógenos para os humanos, com confirmada atividade carcinogênica em animais. Os efeitos deletérios ao organismo humano e ao ambiente vêm justificando o uso controlado e seguro, e restringindo a produção de 
organoclorados, conforme definido pelo Protocolo de Montreal para o 1,1,1-TCA e o PCM (SALGADO; MARONA, 2004).

O PCE, um líquido incolor e volátil à temperatura ambiente, com odor de éter, pode afetar o sistema nervoso por meio da inalação de altas concentrações em espaços fechados e pouco ventilados, causando tontura, dor de cabeça, sonolência, náusea, dificuldade de fala, inconsciência e morte; o contato dérmico por longo período pode irritar a pele; e a ingestão de água e alimentos contaminados pode ocasionar taquicardia, palpitações, desmaio e vômito (CETESB, 2012).

\subsubsection{Caracterização do Tetracloroetileno (PCE)}

Na Tabela 3.1 são apresentadas as principais características físicas e químicas do PCE.

Tabela 3.1 Características do PCE

\begin{tabular}{|c|c|}
\hline Características/ Compostos & PCE \\
\hline CAS registry number ${ }^{(1)}$ & $127-18-4$ \\
\hline Fórmula molecular & $\mathrm{C}_{2} \mathrm{Cl}_{4}{ }^{(4)}$ \\
\hline Massa molecular $(\mathrm{g} / \mathrm{mol})$ & $165,8^{(3)}$ \\
\hline Densidade $\left(\mathrm{g} / \mathrm{cm}^{3}\right)$ & 1,63 a $25^{\circ} \mathrm{C}^{(3)}$ \\
\hline Ponto de fusão $\left({ }^{\circ} \mathrm{C}\right)$ & $-19^{(4 b)}$ \\
\hline Ponto de ebulição $\left({ }^{\circ} \mathrm{C}\right)$ & $121,4^{(3)}$ \\
\hline Pressão de vapor $\left(\mathrm{mmHg}\right.$ a $\left.25^{\circ} \mathrm{C}\right)$ & $18,9^{(3)}$ \\
\hline Constante da Lei de Henry $(\mathrm{H})\left(\mathrm{atm} \cdot \mathrm{m}^{3} / \mathrm{mol}\right.$ a $\left.25^{\circ} \mathrm{C}\right)$ & $1,74 \times 10^{-2(3)}$ \\
\hline Solubilidade em água $\left(\mathrm{mg} / \mathrm{L}\right.$ a $\left.25^{\circ} \mathrm{C}\right)$ & $200^{(3)}$ \\
\hline Log Kow & $2,53(4 d)$ \\
\hline Coeficiente de partição octanol-água (Kow) $(\mathrm{mL} / \mathrm{g})$ & 338,84 \\
\hline Coeficiente de partição carbono orgânico-água $\left(\mathrm{K}_{\mathrm{oc}}\right)(\mathrm{mL} / \mathrm{g})$ & $364^{(3)}$ \\
\hline Coeficiente de adsorção em solo $\left(\mathrm{K}_{\mathrm{d}}\right)(\mathrm{mL} / \mathrm{g})$ & $3,64(5)$ \\
\hline Mobilidade & moderada \\
\hline Viscosidade absoluta (cP a $\left.25^{\circ} \mathrm{C}\right)$ & $0,9(3)$ \\
\hline Polaridade & apolar \\
\hline Meia vida na atmosfera (dias) & $96-251^{(2)}$ \\
\hline
\end{tabular}


Legenda: PCE - Tetracloroeteno, Percloroetileno; CAS - Chemical Abstracts Service (Serviço de Resumo Químico) - Identificação única cadastrada pela Sociedade Química Americana.

Fontes:

(1) Decisão de Diretoria n¹95 (CETESB, 2005);

(2) FIT - Ficha de Informação Toxicológica (CETESB, 2012);

(3) PANKOW; CHERRY, 1996;

(4) MONTGOMERY, 2007;

(4a) WINDHOLZ et al., 1983 in MONTGOMERY, 2007;

(4b) WEAST, 1986 in MONTGOMERY, 2007;

(4c) flow-type generation system, spectrometry, KANDA et al., 2005 in MONTGOMERY, 2007;

(4d) a $23^{\circ} \mathrm{C}$ Shake flask-LSC, BANERJEE et al., 1980; VEITH et al., 1980 in MONTGOMERY, 2007;

(4e) a $25^{\circ} \mathrm{C}$ Shake flask-chemical reaction, JOHNSON; PIRET, 1948 in MONTGOMERY, 2007;

(4f) calculado a partir de MERCER et al., 1990 in MONTGOMERY, 2007;

(4g) LIDE, 1990 in MONTGOMERY, 2007;

(5) $K_{d}=K_{o c}{ }^{*} f_{o c}$. Considerando $f_{o c}$ (fração de carbono orgânico)=0,01 ou 1\%.

A densidade de substâncias hidrofóbicas ou de baixa solubilidade em água (produto puro, fase livre, NAPL - Non-Aqueous Phase Liquid) indica a tendência de o composto flutuar ou afundar na água. Por outro lado, substâncias hidrofílicas ou miscíveis se misturam ou dissolvem em contato com a água. O PCE se caracteriza por ser mais denso que a água, o que permite que percole em fluxo vertical descendente pela zona saturada em direção a níveis mais profundos do aquífero (Figura 3.1). Quando encontra uma camada de permeabilidade mais baixa, tende a se concentrar formando bolsões (pools) de produto em fase livre ou fase densa não aquosa (Dense Non-Aqueous Phase Liquid - DNAPL), os quais contribuem para o aumento da contaminação em fase dissolvida (PANKOW; CHERRY, 1996). 


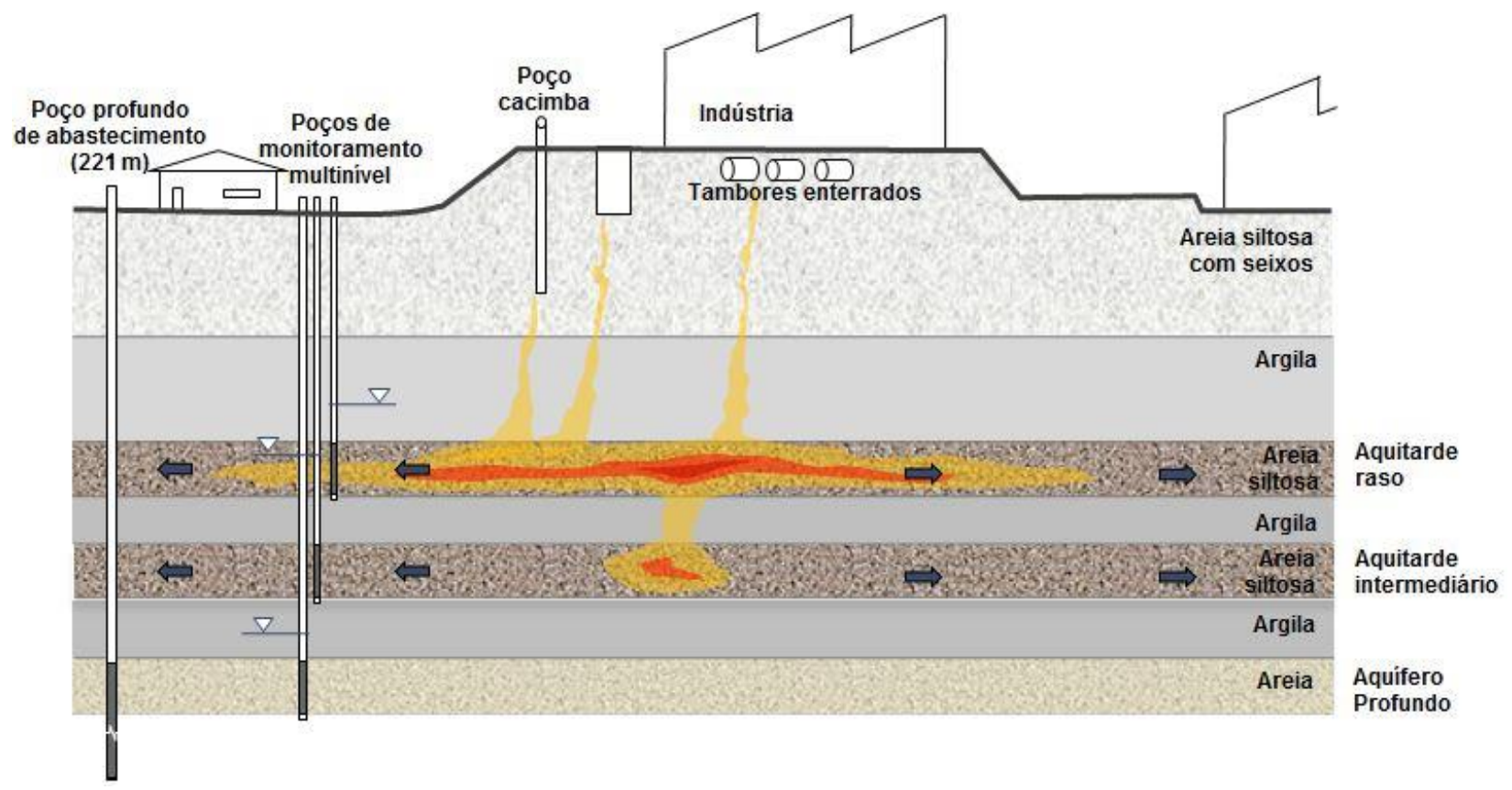

Figura 3.1 Esquema sobre o comportamento de compostos DNAPL em subsuperfície (sem escala)

Os pontos de fusão e ebulição apontam, respectivamente, a temperatura na qual o composto sólido passa para a fase líquida e a temperatura na qual o composto líquido passa para a fase gasosa quando a pressão de vapor do líquido é igual à pressão atmosférica. O PCE tem baixo ponto de fusão e ponto de ebulição mais elevado do que o da água, o que indica que se encontra na forma líquida à temperatura ambiente.

A pressão de vapor de uma substância é a pressão exercida pelo vapor em condições de equilíbrio termodinâmico com o líquido que lhe deu origem. Quanto maior a pressão de vapor, mais volátil é o líquido, e menor sua temperatura de ebulição em relação a outros líquidos com menor pressão de vapor à mesma temperatura de referência. À pressão de vapor está relacionada a volatilização de compostos a partir da água subterrânea para a zona não saturada e da água superficial para a atmosfera (MONTGOMERY, 1997). Os compostos orgânicos voláteis (VOC - Volatile Organic Compounds), grupo no qual os etenos clorados estão enquadrados, caracterizam-se pela alta pressão de vapor, ou seja, tendem a passar da fase livre para gás 
(volatilização direta), podendo persistir no ar em concentrações elevadas muito tempo após o encerramento de uma atividade (SMA; SSE, 2009). A pressão de vapor dos organoclorados a $25^{\circ} \mathrm{C}$ varia entre 18,9 e $1.600 \mathrm{~mm} \mathrm{Hg}$, sendo o PCE o menos volátil.

Assim como a pressão de vapor, a constante da Lei de Henry e o ponto de ebulição influenciam na taxa de volatilização do composto. Segunda a lei de Henry, a pressão parcial de uma substância na fase gasosa é diretamente proporcional à fração molar dissolvida. A constante da Lei de Henry mede a tendência de partição do contaminante entre fase aquosa e gasosa, sendo que valores altos indicam menor solubilidade do gás sob determinada pressão parcial, ou seja, maior tendência do composto volatilizar a partir da fase dissolvida (USEPA, 1998). Na Tabela 3.1 pode-se observar que a constante de Henry do PCE é 0,0174 atm. $\mathrm{m}^{3} / \mathrm{mol}$ a $25^{\circ} \mathrm{C}$ e o ponto de ebulição, $121,4^{\circ} \mathrm{C}$. Comparativamente, esses valores para o oxigênio são, respectivamente, $0,635 \mathrm{~atm} \cdot \mathrm{m}^{3} / \mathrm{mol}^{\text {e }} 100^{\circ} \mathrm{C}$, e para o benzeno, $0,00555 \mathrm{~atm} \cdot \mathrm{m}^{3} / \mathrm{mol}$ e $80,1^{\circ} \mathrm{C}$.

A solubilidade em água de um composto é a medida da massa máxima do composto que pode ser dissolvida em água, definida como a concentração saturada de um composto na água em uma dada temperatura e pressão. Valores altos de solubilidade indicam que os compostos podem ocorrer em altas concentrações na água subterrânea em fase dissolvida, gerando risco potencial à saúde humana, enquanto baixa solubilidade mostra a dificuldade de removê-los da zona saturada, pois podem se acumular na forma de pools na superfície de camadas menos permeáveis por décadas ou séculos (PANKOW; CHERRY, 1996; USEPA, 2013). Compostos com elevada solubilidade tendem a dessorver do solo (têm baixos valores de $K_{o c}$ ), ou seja, são mais móveis e suscetíveis à biodegradação, ao passo que compostos com baixa solubilidade tendem a ficar adsorvidos no solo, apresentam elevado Koc, e tendem a bioacumular em organismos aquáticos (MONTGOMERY, 1997).

O coeficiente de partição octanol-água ( $\mathrm{K}_{\text {ow }}$ ) indica a preferência de um composto permanecer dissolvido na água subterrânea do que adsorvido no solo, o que aumenta a mobilidade no meio saturado e diminui o retardamento (CUNHA, 2010; USEPA, 2013). A sorção aumenta conforme a hidrofobicidade de uma espécie aumenta, ou seja, quanto maior o Kow, maior a tendência de ficar adsorvido no solo e ter uma mobilidade 
menor. O coeficiente Kow é também utilizado para estimar o potencial de bioacumulação de um composto. $\mathrm{O}$ valor do $\mathrm{K}_{\mathrm{ow}}$ do PCE indica um moderado potencial de bioacumulação sob condições constantes de exposição (MONTGOMERY, 2007).

O coeficiente de distribuição ou de adsorção do solo ( $\left.\mathrm{K}_{\mathrm{d}}\right)$, assim como o coeficiente de partição carbono orgânico-água (Koc), estão relacionados à capacidade de o composto ficar adsorvido na matéria orgânica existente em volta dos grãos devido à presença de carbono orgânico. Dessa forma, quanto menores os valores de $\mathrm{K}_{o c}$ e $\mathrm{K}_{d}$, menor será a massa de contaminante adsorvido no solo e maior será a concentração dissolvida na água subterrânea (CUNHA, 2010). Compostos que formam ligação forte com o carbono orgânico apresentam baixa solubilidade, enquanto compostos com pouca tendência de adsorção em partículas orgânicas têm elevada solubilidade (MONTGOMERY, 1996).

Os baixos coeficientes de partição octanol-água e carbono orgânico-água significam que a ligação dos organoclorados com solo ou rocha é fraca tanto na zona não saturada quanto na zona saturada; então a sorção não retardará o movimento dos contaminantes, os quais podem se deslocar à mesma velocidade da água subterrânea (PANKOW; CHERRY, 1996).

Quanto maior a viscosidade dos fluidos, menor sua mobilidade. Por apresentarem baixos valores de viscosidade (menores que a da água), o caminhamento dos compostos etenos clorados em subsuperfície pode se dar juntamente com o da água subterrânea. A mobilidade aumenta com o aumento da razão densidade/viscosidade. Valores baixos de viscosidade absoluta, como o do PCE apresentado na Tabela 3.1, permitem um caminhamento descendente em subsuperfície relativamente rápido.

A polaridade é determinada pelo equilíbrio das cargas na molécula. Compostos apolares apresentam cargas equilibradas em diferentes pontos da molécula; em geral, possuem baixo ponto de fusão e ebulição, e são insolúveis ou pouco solúveis em água. Moléculas polares apresentam pontos de fusão e ebulição mais elevados; são solúveis em água e em outras substâncias polares (LIMA, 2011). O PCE e o eteno são moléculas apolares, praticamente insolúveis em água, e solubilizam preferencialmente em substâncias apolares ou fracamente polares. 
A baixa tensão interfacial dos compostos etenos clorados em contato com a água indica a facilidade de caminhamento em pequenas fraturas e espaços porosos em direção a maiores profundidades em subsuperfície (PANKOW; CHERRY, 1996).

A meia vida de um composto é o tempo necessário para que metade da massa inicial seja degradada. Os compostos eteno clorados possuem uma meia vida curta na água, indicando ausência de tendência de bioacumulação (USEPA, 2013).

Conclui-se que a volatilidade e a mobilidade dos compostos em subsuperfície estão relacionadas às suas propriedades físicas e químicas, e à interação com o meio. A densidade, a viscosidade, a solubilidade, os pontos de fusão e ebulição, a pressão de vapor, a constante da Lei de Henry, a tensão interfacial e a meia-vida, assim como os coeficientes de partição octanol-água, carbono orgânico-água e de adsorção no solo, influenciarão conjuntamente sua mobilidade e seu particionamento em subsuperfície.

\subsubsection{Partição dos Organoclorados em Subsuperfície}

O PCE caracteriza-se por ser um composto volátil, que pode migrar por longas distâncias na forma de vapores na zona não saturada, assim como dissolver parcialmente na água, contaminando as águas subterrâneas.

Considerando um derrame próximo à superfície do terreno, o PCE migraria através da zona não saturada. Uma parte do líquido poderia ser imobilizada devido à força capilar, tornando-se fase residual, ou formaria bolsões no topo de lentes de baixa permeabilidade. A fase vapor migraria para a atmosfera; por outro lado, a presença de uma camada impermeável na superfície do solo reteria os vapores e aumentaria a migração lateral.

Na Figura 3.2 são apresentados os processos de partição dos organoclorados. 


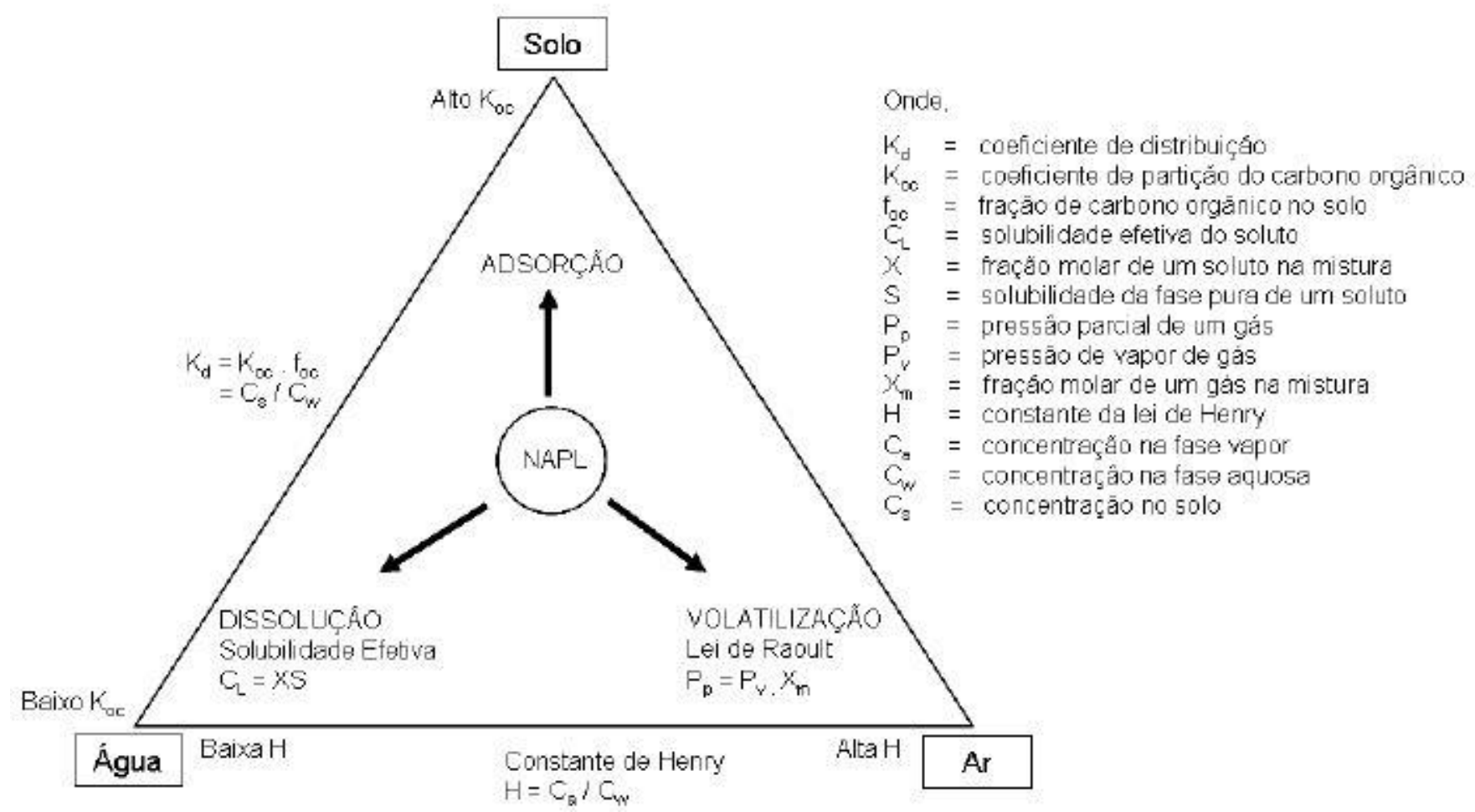

Figura 3.2 Processos de particionamento do contaminante no solo, ar e água em subsuperfície. Fonte: Modificado de USEPA (Agência de Proteção Ambiental dos Estados Unidos), 2004a

A volatilização direta é determinada pela pressão de vapor e composição do líquido que dá origem ao vapor. Para um líquido com apenas um constituinte, a concentração de equilíbrio do vapor é dada pela pressão de vapor do composto puro; em um líquido composto por uma mistura de constituintes, a concentração de equilíbrio do vapor de cada constituinte é aproximada pela Lei de Raoult, expressa pela eq.3.1. Em uma situação dinâmica, a concentração de vapor alterará conforme o composto é esgotado ou enriquecido em relação aos outros compostos.

$$
c=X_{t} \cdot P^{0} / R T
$$

Onde $P^{0}$ é a pressão de vapor do composto puro de um constituinte particular na temperatura $T(\mathrm{~K}), X_{t}$ é a fração molar do composto na fase líquida, e $R$ é a constante 
universal dos gases perfeitos $\left(0,082\right.$ atm $\cdot$ L. $\left.\mathrm{K}^{-1} \cdot \mathrm{mol}^{-1}\right)$. A concentração do vapor $c$ é expressa em mols por volume.

Parte do vapor volatilizado a partir do NAPL é dissolvida na água do solo. O particionamento entre as fases aquosa e gasosa no equilíbrio é representado pela Lei de Henry (eq.3.2).

$$
C_{a}=H C_{w}
$$

Onde $C_{a}$ é a concentração $\left(\mathrm{mol} / \mathrm{m}^{3}\right)$ ou pressão parcial do vapor no ar (atm), $C_{w}$ é a concentração na água $\left(\mathrm{mol} / \mathrm{m}^{3}\right)$, e $\mathrm{H}$ é a constante da Lei de Henry (adimensional ou atm. $\mathrm{m}^{3} / \mathrm{mol}$, dependendo de $C_{a}$ ).

Uma parte do NAPL em fase líquida pode também ser dissolvida na água. Um NAPL pode ser um composto simples ou uma mistura de compostos. Na forma pura, organoclorados são líquidos e mostram uma ampla variação de solubilidade em água. Para uma mistura de NAPLs orgânicos, a concentração na fase aquosa de cada componente que está em equilíbrio com a mistura pode ser aproximada por expressão semelhante à Lei de Raoult para pressão de vapor (eq.3.3).

$$
C_{\text {sat }, m}=X_{m} C_{\text {sat }}^{0}
$$

Onde $C_{s a t, m}$ é a solubilidade aquosa de componente $m$ da mistura, $X_{m}$ é a fração molar do componente $m$ na mistura do NAPL, e $C_{\text {sat }}^{0}$ é a solubilidade do composto $m$ puro.

A presença de NAPL nos poros do solo reduz a permeabilidade relativa do meio à água. Dentro das camadas de solo com NAPL em fase livre ou em pools de NAPL, o NAPL pode chegar a ocupar entre 50 e $70 \%$ do volume de vazios e reduzir substancialmente o fluxo de água subterrânea. A dissolução ocorre predominantemente junto ao topo e margens laterais das camadas e pools, a uma velocidade tão baixa, que 
demoraria mais de séculos para causar uma contaminação significativa da água subterrânea (PANKOW; CHERRY, 1996).

A taxa de transferência de massa ou dissolução de um NAPL para a água subterrânea pode ser expressa pela eq.3.4.

$$
\mathrm{dC} / \mathrm{dt}=\mathrm{ka}\left(\mathrm{C}_{\mathrm{sat}}-\mathrm{C}\right)
$$

Onde $C$ é a concentração dissolvida no tempo $t, C_{\text {sat }}$ é a solubilidade em água, $k$ é o coeficiente de transferência de massa e a é a área específica da interface água-NAPL. A taxa de dissolução da massa de NAPL em subsuperfície depende, portanto, da solubilidade efetiva e difusividade do composto, da distribuição física do composto no meio (área de contato entre o NAPL e a água subterrânea) e da velocidade da água subterrânea.

Finalmente, haverá uma distribuição de massa entre a fase líquida e a fase sólida do solo (grãos do solo). A adsorção caracteriza-se pela concentração de espécies químicas (adsorvatos) da fase vaporizada ou da solução intersticial na superfície dos sólidos do solo (adsorvente). Este acúmulo na superfície ocorre, em geral, quando a energia de atração à superfície do sólido é maior que a energia coesiva da espécie química. Do ponto de vista termodinâmico, a concentração de uma substância da fase vaporizada ou líquida em uma superfície sólida corresponde a uma redução da liberdade de movimento das moléculas/íons e, portanto, perda na entropia do sistema. O processo de adsorção deve, consequentemente, ser exotérmico.

O particionamento entre as fases líquida e sólida no equilíbrio é expresso por uma equação que relaciona a concentração sorvida pela fase sólida em função da concentração dissolvida na fase líquida em uma dada temperatura em situação de equilíbrio, denominada isoterma. O particionamento de equilíbrio linear, instantâneo e reversível entre as fases líquida e sólida é descrito pela isoterma linear (eq. 3.5).

$$
K_{d}=C_{g} / C_{w}
$$


Onde $\mathrm{K}_{\mathrm{d}}$ é o coeficiente de distribuição ou coeficiente de partição, e $\mathrm{C}_{\mathrm{s}}$ e $\mathrm{C}_{\mathrm{w}}$ são as concentrações do composto nas fases sólida (massa de sorvato/massa de sólidos) e líquida (massa de soluto/volume de água), respectivamente.

$\mathrm{O}$ coeficiente de distribuição ou partição $\mathrm{K}_{\mathrm{d}}$ pode ser estimado pela eq.3.6.

$$
K_{d}=K_{o c} f_{o c}
$$

Onde $\mathrm{K}_{\mathrm{oc}}$ é o coeficiente de particionamento carbono orgânico-água e $\mathrm{f}_{\mathrm{oc}}$ é a fração de carbono orgânico no solo.

Os poluentes orgânicos dissolvidos em subsuperfície sofrem retardamento da velocidade do fluxo e diminuição da mobilidade, o que torna seu movimento mais lento que o da água subterrânea, conforme a eq.3.7.

$$
R=v / v_{0}
$$

Onde $R$ é o fator de retardamento, e $\mathrm{v}$ e $\mathrm{v}_{\mathrm{c}}$ são a velocidade linear média da água subterrânea e do contaminante, respectivamente.

O fator de retardamento pode ser associado ao coeficiente de distribuição ou partição (eq.3.8).

$$
R=1+\left(\rho_{b} K_{d} / n\right)
$$

Onde $\rho_{b}$ é a massa específica seca do solo e $n$ indica a porosidade do solo.

O fator de retardamento do PCE em aquíferos com muito pouco carbono orgânico $(0,007$ a $0,025 \%)$ determinado a partir da sorção varia de 1,10 a 1,46 (LARSEN et al. 1992). 


\subsubsection{Degradação do Tetracloroetileno (PCE)}

Praticamente todo o PCE liberado no ambiente volatiliza para a atmosfera em poucos dias, onde pode ser degradado por foto-oxidação e radicais hidroxilas em um tempo relativamente curto. A meia vida varia da ordem de horas até pouco mais de dois meses segundo USEPA (2013), de 70 a 251 dias segundo Salgado e Marona (2004), e de 96 a 251 dias segundo CETESB (2012). A reação do PCE com o ozônio na atmosfera é extremamente lenta (SALGADO; MARONA, 2004); em um dia não se consegue oxidar PCE em reação direta com ozônio (HULING; PIVETZ, 2006).

A degradação do PCE em água não é significativa, pois tanto as velocidades de fotólise como de hidrólise são muito lentas quando comparadas à rápida volatilização (SALGADO; MARONA, 2004; INCHEM, 2014). A fotólise indireta de PCE pode ocorrer em águas naturais na presença de foto sensibilizadores, como substâncias húmicas. Meias vidas de 3 a 30 dias foram observadas em águas de rio, e de 30 a 300 dias em lagos e águas subterrâneas (INCHEM, 2014); valores de 180 e 89 dias foram reportados para águas aeróbias e anaeróbias, respectivamente (PUBCHEM, 2014).

No solo, os organoclorados podem ser transformados microbiologicamente ou abioticamente em outros compostos orgânicos. Porém, devido à degradabilidade baixa tanto em meios biológicos, como em meios de reação química abiótica, a meia vida dos organoclorados em subsuperfície pode ser muito longa (PANKOW; CHERRY, 1996).

A degradação aeróbia é limitada porque as bactérias aeróbias não utilizam compostos clorados alifáticos como substrato primário, e mesmo quando podem consumir esses compostos como substrato secundário, necessitam da adição de nitrogênio, fósforo e aceptores de elétrons (LI, 2002). Por outro lado, todos os etenos clorados do tipo DNAPL são biodegradáveis anaerobicamente na presença de um consórcio adequado de micróbios, que pode ou não estar presente no local (USEPA, 2013).

Os organoclorados são biodegradados por processos de acepção de elétrons, doação de elétrons e cometabolismo, ou pela combinação de dois ou mais desses processos. 
Após o consumo de oxigênio do meio, os micro-organismos anaeróbios utilizam, em ordem preferencial, o $\mathrm{NO}_{3}{ }^{-}$, o $\mathrm{FeOOH}, \mathrm{o} \mathrm{SO}_{4}{ }^{2-}$ e o $\mathrm{CO}_{2}$ (SMA; SSE, 2009).

O principal processo abiótico de degradação do PCE é a decloração redutiva, segundo a qual íons de cloro são substituídos por átomos de hidrogênio, realizada por meio de um agente redutor, como o ferro de valência nula. A decloração redutiva pode também ser biótica (bactérias utilizam o poluente em seu metabolismo). A Figura 3.3 mostra a sequência de decloração redutiva abiótica, na qual a velocidade das reações decresce com o decréscimo de número de átomos de cloro ligados ao composto (LI, 2002).

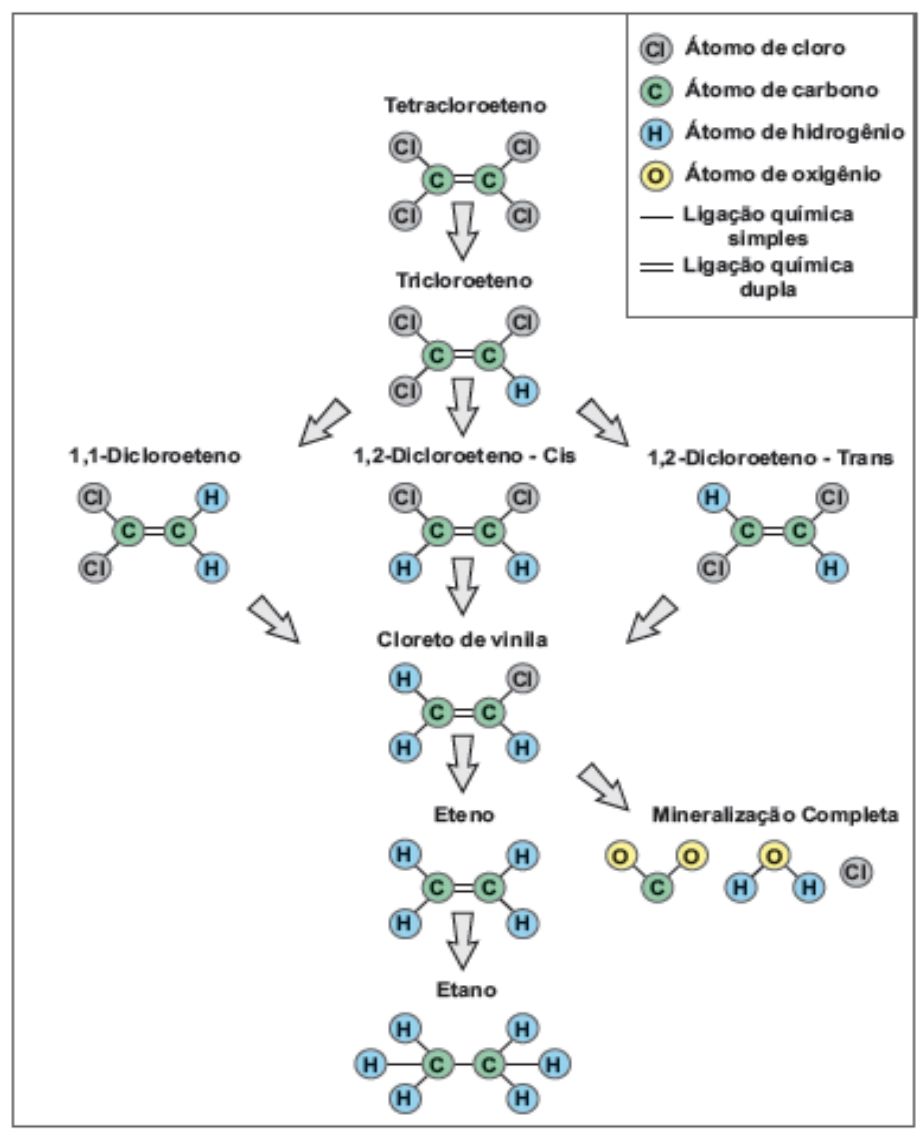

Figura 3.3. Cadeia de decloração redutiva abiótica de organoclorados.

Fonte: Modificado da USEPA (Agência de Proteção Ambiental dos Estados Unidos), 1998b

Outro processo abiótico de degradação de PCE é a decloração oxidativa, alcançada através de processos oxidativos avançados (POA). A oxidação é uma reação onde o composto perde elétrons e o agente oxidante ganha elétrons; pode ser associada à 
introdução de oxigênio em uma molécula ou à conversão de uma molécula para um estado de oxidação mais elevado. O potencial de oxidação diminui com o aumento da halogenação.

Segundo Fetter (1994), as reações de oxidação que podem ocorrer são: adição de um radical hidroxila em um alcano (C-C) no lugar de um átomo de hidrogênio, que não é o caso do PCE (alceno); em um carbono ligado a um íon cloro, seguido da oxidação do íon cloro; formação de um epóxi (resina) a partir de uma dupla ligação entre átomos de carbono (alceno); e adição de um íon cloro e um íon hidroxila a uma dupla ligação entre átomos de carbono (alceno). Dentre as reações de oxidação possíveis, a epoxidação pode ser a mais significativa, pois envolve a adição de oxigênio através da dupla ligação entre átomos de carbono de um alceno (PANKOW; CHERRY, 1996).

Os POAs baseiam-se nos radicais livres reativos liberados de oxidantes e capazes de oxidar compostos orgânicos complexos. Os oxidantes mais frequentemente utilizados são: peróxido de hidrogênio, permanganato, persulfato, Fenton (peróxido de hidrogênio com ferro) e ozônio. O ozônio e o peróxido de hidrogênio podem também ser utilizados sob radiação ultravioleta ou na presença de outros compostos.

O peróxido de hidrogênio e o Fenton atuam por oxidação direta (pouco importante no caso de compostos orgânicos, como o PCE) e pela liberação de radicais e outros intermediários reativos: hidroxilas, ânion superóxido, radical perhidroxila, entre outros.

O persulfato pode reagir por transferência direta de elétrons ou formação de radicais livres, o sulfato e o hidroxila. As reações com transferência de elétrons são lentas e seletivas, enquanto os radicais livres têm reatividade não específica. Há evidências de que o ânion superóxido e o radical perhidroxila podem também ser importantes.

O mecanismo de oxidação do permanganato é diferente dos outros POAs: reage primariamente através de reações de transferência direta de elétrons, mais do que através de radicais gerados (SIEGRIST; CRIMPI, SIMPKIN, 2011).

As reações de decloração oxidativa por ozônio, foco desta pesquisa, serão apresentadas no item 3.3.3. 


\subsection{Ozônio}

O ozônio é um gás de cor azul clara, altamente reativo, formado pela ligação de três átomos de oxigênio. Encontra-se em pequenas concentrações em toda a atmosfera, mas em maior concentração na camada de ozônio, situada na estratosfera média e inferior, entre 30 e $50 \mathrm{~km}$ de altitude (RCC, 2000; BAIRD, 2002; BRAGA et al., 2002; BONCZ, 2002).

É formado na atmosfera pelos raios ultravioletas do sol ou pela descarga elétrica de raios. A incidência dos raios ultravioletas com comprimento de onda inferior a $200 \mathrm{~nm}$ (h) causa a separação de dois átomos de oxigênio, produzindo o oxigênio atômico $(O)$, como mostra a eq.3.9 (BRAGA et al., 2002).

$$
O_{2}+h \leftrightarrow 2 O
$$

O oxigênio atômico reage com $\mathrm{O}_{2}$, sempre com a presença de um parceiro que absorve o excesso de energia, geralmente o nitrogênio $(M)$, resultando na formação do ozônio $\left(\mathrm{O}_{3}\right)$, conforme a eq.3.10.

$$
O+O_{2}+M \leftrightarrow O_{3}+M(3.10)
$$

O ozônio pode também ser gerado artificialmente, geralmente pela aplicação de uma descarga elétrica (efeito corona) durante a passagem de uma corrente de oxigênio por uma câmara de reação. A geração de ozônio por descarga elétrica, conhecida como processo de Siemens, é muito semelhante à síntese natural do ozônio atmosférico por descargas elétricas de raios: uma alta voltagem de alta frequência é aplicada ao fluxo de ar seco ou oxigênio passando através de um tubo de descarga corona (RCC, 2000, BONCZ, 2002; BRASIL OZÔNIO, 2012). A geração de ozônio por radiação ultravioleta ou descarga elétrica está apresentada esquematicamente na Figura 3.4. 


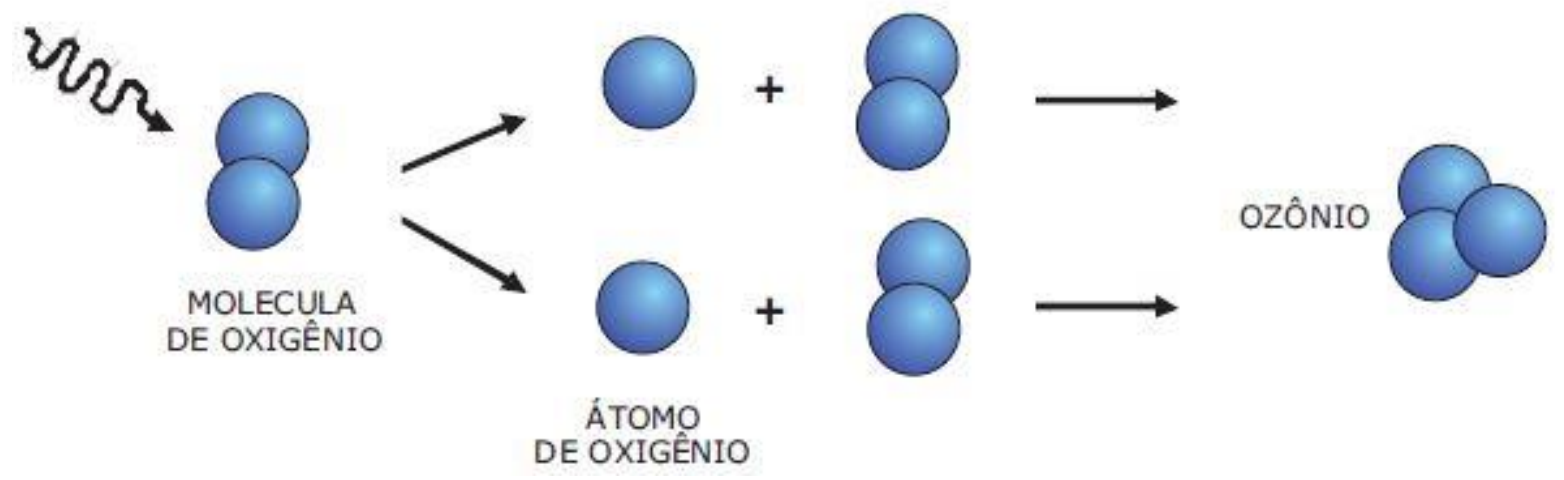

Figura 3.4 Processo de formação do ozônio. Fonte: Brasil Ozônio, 2012.

Um típico gerador de ozônio é alimentado por oxigênio, que flui para um conjunto de tubos de descarga corona. A descarga elétrica nos tubos resulta na dissociação de moléculas de oxigênio e recombinação de átomos de oxigênio formados com moléculas de oxigênio produzindo ozônio, de acordo com as eq. 3.9 e 3.10. Ar ou oxigênio puro entra entre duas placas ionizadas, gerando ozônio (Figura 3.5).

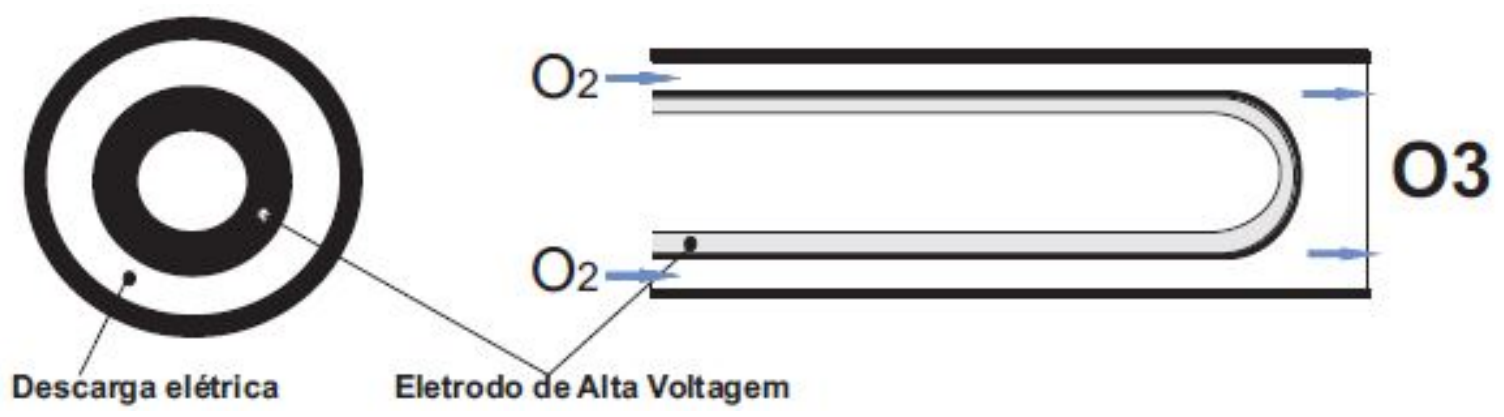

Figura 3.5 Mecanismo de funcionamento de um gerador de ozônio por descarga elétrica. Fonte: Brasil Ozônio, 2012

Geradores abastecidos por ar geralmente produzem concentrações de ozônio de até 1 $2 \%$ por volume e, abastecidos por oxigênio, de até 8-10\% (CLAYTON et al., 2011). Atualmente, geradores de ozônio alcançam uma eficiência de aproximadamente 0,05 a $0,125 \mathrm{~kg} \mathrm{O} / \mathrm{KWh}$, dependendo da utilização de ar ou oxigênio puro. Os mais importantes fatores que influenciam na eficiência do processo de geração são: pressão e temperatura de operação, velocidade do fluxo, umidade de alimentação do gás, 
energia elétrica e frequência da alta voltagem aplicada. $O$ aumento da frequência diminui a produção de ozônio, mas aumenta sua concentração (BONCZ, 2002).

Devido à sua elevada instabilidade, o ozônio precisa ser gerado no local de uso. $\mathrm{O}$ ozônio é amplamente empregado no tratamento de água potável, água de piscina, água proveniente de poços artesianos, minas, caixas d'água residenciais e comerciais, água de chuva reusada, aquários de água doce e salgada, na higienização de recipientes de envase de água, na desodorização de ambientes, em lavadores de gases, torres de resfriamento, piscicultura, agricultura e hidroponia, assim como no tratamento de efluentes domésticos e industriais, com ênfase em efluentes oriundos de tinturarias e lavanderias, que apresentam maior quantidade de carga orgânica (BONCZ, 2002; BRASIL OZÔNIO, 2012).

O ozônio é um desinfetante eficaz, que atua no controle microbiológico, floculando e oxidando materiais particulados, matéria orgânica e poluentes gasosos, além de remover cor, odor e toxicidade. No tratamento de efluentes, reduz as demandas química e bioquímica de oxigênio ( $\mathrm{BBO}$ e $\mathrm{DQO}$ ), degrada compostos nãobiodegradáveis e oxida metais pesados, aumentando a disponibilidade de oxigênio na água (BRASIL OZÔNIO, 2012).

As propriedades físicas e químicas do gás ozônio estão apresentadas na Tabela 3.2. 
Tabela 3.2 Características do ozônio

\begin{tabular}{|c|c|}
\hline Características & Ozônio \\
\hline CAS registry number & $10028-15-6^{(2)}$ \\
\hline Fórmula molecular & $\mathrm{O}_{3}{ }^{(1 \mathrm{a})}$ \\
\hline Peso molecular ( $\mathrm{g} / \mathrm{mol})$ & $48^{(1 a)}$ \\
\hline Ponto de fusão $\left({ }^{\circ} \mathrm{C}\right)$ a $1 \mathrm{~atm}$ & $-251,0^{(4)}$ \\
\hline Ponto de ebulição $\left({ }^{\circ} \mathrm{C}\right)$ a 1 atm & $-111,9^{(2)}$ \\
\hline Temperatura crítica $\left({ }^{\circ} \mathrm{C}\right)$ & $-12,0^{(2),(4)}$ \\
\hline Potencial de redução padrão (V) sob condições ácidas & $2,076^{(1 \mathrm{a})(2)}$ \\
\hline Potencial de redução padrão (V) sob condições basicas & $1,24^{(2)}$ \\
\hline Formação de energia livre de Gibbs $\left(\Delta \mathrm{G}_{\mathrm{f}} \mathrm{f}\right)(\mathrm{KJ} / \mathrm{mol})$ & $163,14^{(2)}$ \\
\hline Densidade $\left(\mathrm{g} / \mathrm{cm}^{3}\right)$ & $0,002106^{(1 \mathrm{a})}$ \\
\hline 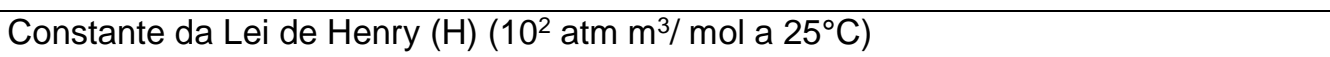 & $1,18^{(1 b)}$ \\
\hline Solubilidade em água e concentração de $5 \%$ de massa $\mathrm{O}_{3}$ em $\mathrm{O}_{2}$ puro $\left(\mathrm{mg} / \mathrm{L}\right.$ a $\left.25^{\circ} \mathrm{C}\right)$ & $13,7^{(1 b)}$ \\
\hline Meia vida na atmosfera (minutos) & $\begin{array}{c}2 \text { (gás); } \\
20 \text { (líquido) }^{(3)}\end{array}$ \\
\hline
\end{tabular}

\section{Fontes:}

(1) Clayton, Petri e Huling, 2011.

(1a) Lide, 2006 in Clayton, Petri e Huling, 2011;

(1b) Langlais et al., 1991 in Clayton, Petri e Huling, 2011.

(2) Boncz, 2002.

(3) RCC, 2000.

(4) Beltrán, 2004.

A temperatura crítica é a temperatura acima da qual uma substância não pode existir no estado líquido, independente da pressão (CRC, 1988). O ponto de ebulição e a temperatura crítica apontam que, sob as condições normais de 1 atm, o ozônio é um composto gasoso, enquanto a formação de energia livre de Gibbs positiva e elevada indica a instabilidade do ozônio. Devido à sua instabilidade, o ozônio é quase sempre encontrado como parte de uma mistura de oxigênio e ozônio. A molécula é altamente reativa e apresenta um elevado potencial de redução de $2,07 \mathrm{~V}$, sob condições ácidas, e 1,24 V, sob condições básicas, como mostram as eq. 3.11 e 3.12 (BONCZ, 2002).

$$
\begin{array}{ll}
\mathrm{O}_{3}+\mathrm{H}_{2} \mathrm{O}+2 e^{-} \rightarrow \mathrm{O}_{2}+2^{\circ} \mathrm{OH} & p H=14 ; E_{0}=1,24 \mathrm{~V}(3.11) \\
\mathrm{O}_{3}+2 \mathrm{H}_{3} \mathrm{O}^{+}+2 e^{-} \rightarrow \mathrm{O}_{2}+3 \mathrm{H}_{2} \mathrm{O} & p H=0 ; E_{0}=2,07 \mathrm{~V}(3.12)
\end{array}
$$


A concentração de ozônio dissolvido em equilíbrio com um gás contendo ozônio sob uma determinada pressão parcial é afetada pelos parâmetros que determinam a autodecomposição do ozônio e por alguns sais, sendo mais perceptível quando catalisada por $\mathrm{OH}^{-}(\mathrm{BONCZ}, 2002)$.

O ozônio é altamente instável e reativo, decompondo-se com uma meia vida de cerca de 2 minutos no ar; e de aproximadamente 20 minutos na água, transformando-se em oxigênio ou em radicais hidroxilas. A curta meia vida e alta reatividade tornam-no um produto interessante para remediação, pois reage rapidamente com os contaminantes e logo se transforma em oxigênio (RCC, 2000).

A solubilidade em água aumenta com o aumento das concentrações de ozônio na fase gasosa (lei de Henry) e diminui com o aumento da temperatura. As concentrações de ozônio nunca alcançam o limite de solubilidade na fase aquosa devido às reações de decomposição em água, especialmente sob condições alcalinas (LANGLAIS et al., 1991).

\subsubsection{A Remediação de Áreas Contaminadas com Ozônio}

O ozônio tem sido utilizado na remediação de áreas contaminadas por benzeno, tolueno, etilbenzeno e xileno (BTEX), hidrocarbonetos derivados de petróleo totais (TPH), metil terc-butil éter (MTBE), 1,4-Dioxano, hidrocarbonetos policíclicos aromáticos (PAHs), solventes clorados alifáticos (etenos e etanos), benzenos clorados (CB), fenóis, compostos inorgânicos (ferro, manganês, nitrito, enxofre) e compostos altamente explosivos (nitroamina, e explosivos nitroaromáticos, como RDX, TNT, nitrotolueno, nitrobenzeno) (RCC, 2000; ITRC, 2005; CLAYTON et al., 2007; USEPA, 2004b).

Pode ser utilizado para remediar contaminação em água subterrânea e solo, tanto na zona não saturada como saturada. Pode ser aplicado em subsuperfície na forma gasosa (ozone sparging) ou líquida (injeção de ozônio dissolvido). Como gás, geralmente é aplicado em poços típicos de air sparging, com ou sem ar. Como líquido, o ozônio dissolvido é aplicado em poços de injeção, em trincheiras ou em galerias de infiltração (RCC, 2000). 
A injeção de ozônio na forma gasosa na zona saturada promove a volatilização, fornece oxigênio para degradação aeróbica e induz transformações oxidativas (HULING; PIVETZ, 2006). Sob condições de pH elevado, aumenta a taxa de degradação de alguns contaminantes (como os fenólicos), a formação de radicais livres hidroxilas e o potencial de dissociação das formas iônicas (CETESB, 1999). A oxidação por ozônio pode requerer um tempo de injeção mais longo que outros oxidantes; devido à sua alta reatividade, o ozônio pode não ser adequado para difusão lenta em solos de baixa permeabilidade (USEPA, 2013).

A aplicação de ozônio para oxidação de poluentes em subsuperfície está apresentada esquematicamente na Figura 3.6.

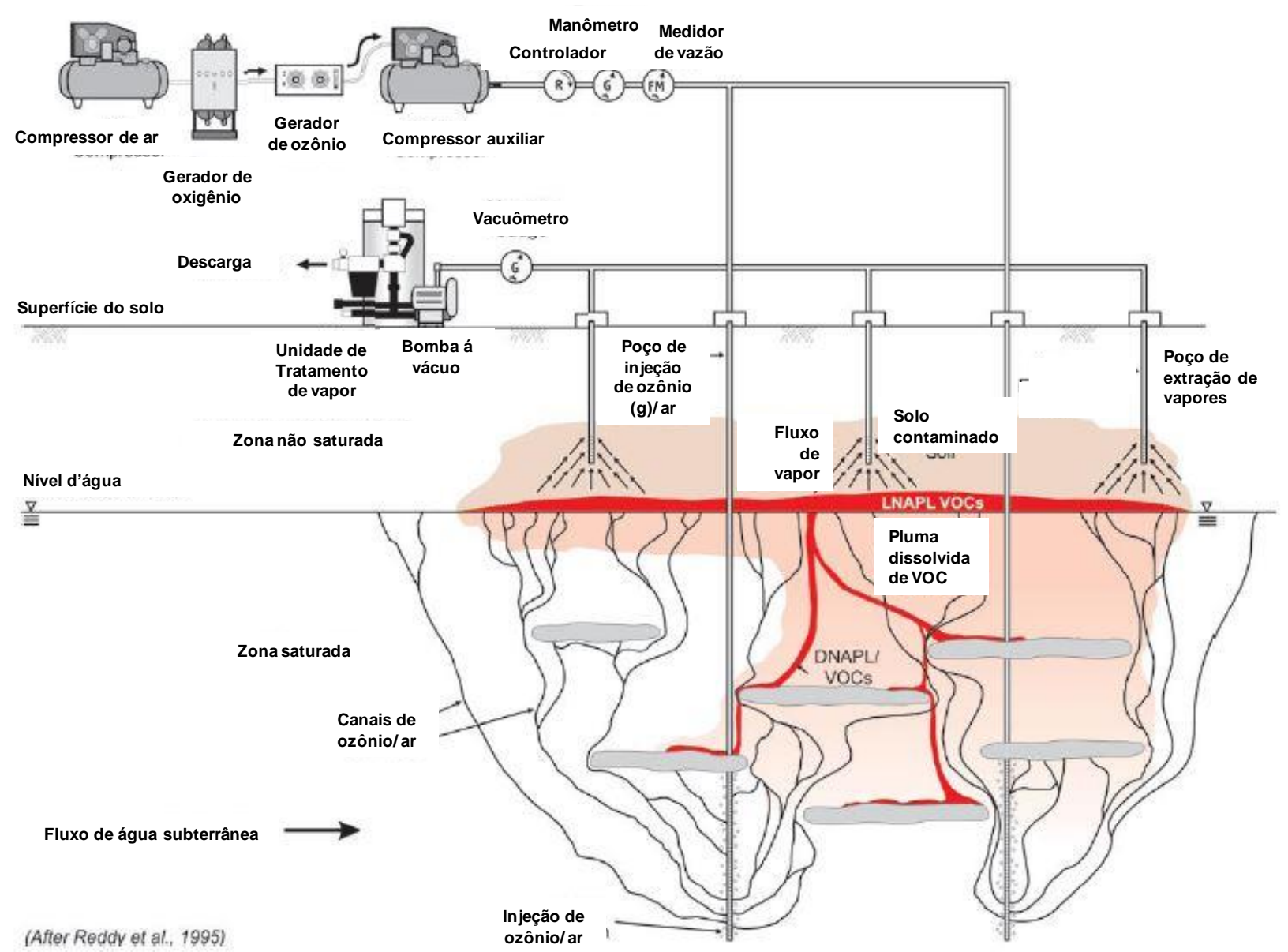

Figura 3.6 Modelo conceitual geral de ozonização in situ na zona saturada, com extração a vácuo para captura de emissões de voláteis e $\mathrm{O}_{3}$. Fonte: HULING; PIVETZ, 2006 
Contaminantes orgânicos podem estar presentes na fase aquosa, dissolvidos em água; na fase sólida, adsorvidos no solo; ou como fase livre contínua ou residual (NAPL), podendo ser oxidados em qualquer uma das três fases. A quantidade de oxidante e o número de aplicações necessárias dependem da fase em que se encontra o contaminante (NAPLs > sólido > aquosa). Quando contaminantes são oxidados na fase aquosa, o gradiente de concentração em relação às outras fases aumenta, a transferência de massa para a fase aquosa consequentemente aumenta, e ocorre a transferência dos contaminantes da fase sólida (dessorção) e da fase NAPL (dissolução).

As características físicas e químicas em subsuperfície (hidrogeologia, geologia, geoquímica) variam de local para local e impactam o destino e transporte do oxidante injetado. Heterogeneidades naturais em subsuperfície, tais como zonas de alta permeabilidade (paleocanais preenchidos de areia, fraturas), e alterações antrópicas podem criar caminhos preferenciais. Os caminhos preferenciais encontrados em sistemas fraturados e meios porosos inconsolidados resultam em caminhos de fluxo imprevisíveis em termos de velocidades e direção, tanto para a água subterrânea como para o oxidante injetado, podendo constituir um impedimento significativo para a distribuição uniforme e efetiva do oxidante em subsuperfície.

Estudos de Masten e Davies (1997) indicam que o ozônio injetado pode ser transportado por canais preferenciais formados na região próxima ao ponto de injeção. Adicionalmente, sob elevadas pressões de injeção, podem ocorrer fraturas induzidas hidraulicamente no meio e/ou perda do oxidante injetado. Esses problemas podem ser detectados e evitados através de uma boa caracterização do local, monitoramento da água subterrânea e diminuição da distância entre os poços de injeção (CLAYTON et al., 2011).

São apresentados a seguir três estudos de caso que utilizaram ozônio para remediar compostos organoclorados em água subterrânea. Não foram encontrados na literatura casos de remediação de zona não saturada. A detecção de compostos organoclorados adsorvidos em solo é difícil e menos frequente do que em água, e nos casos em que ocorreu a identificação desses contaminantes adsorvidos na fase sólida, o solo 
contaminado foi removido e destinado à incineração. Por fim, ressalta-se que nesses casos a injeção de ozônio foi associada a outras técnicas.

Em 1997, Kerfoot et al. (1998) realizaram um estudo de oxidação de ozônio em escala piloto de uma pluma de fase dissolvida de organoclorados em Utrecht, Holanda. O subsolo era composto por uma camada de argila de cerca de $2 \mathrm{~m}$ de espessura, sobreposta a uma espessa camada de areia fina até $38 \mathrm{~m}$ de profundidade, sobreposta por sua vez a uma camada de argila; o nível d'água estava situado a aproximadamente $3 \mathrm{~m}$ de profundidade. A pluma de TCE, originada de uma obra de construção civil e com extensão de $244 \mathrm{~m}$, estava situada na camada de areia fina. Metade da área sobrejacente à pluma de TCE foi contaminada com benzeno, tolueno, etilbenzeno e xileno - BTEX devido a um vazamento de combustíveis. Foi utilizado um sistema combinando injeção de microbolhas (de aproximadamente 20 a $50 \mu \mathrm{m}$ de diâmetro e meia vida entre 20 e 40 horas) de ozônio micro encapsulado diretamente na água subterrânea para promover a oxidação e extração de vapores in situ para remover os compostos orgânicos voláteis dissolvidos na água. O teste experimental teve duração de 10 dias e resultou na diminuição das concentrações de compostos orgânicos voláteis halogenados - HVOC de $14.500 \mu \mathrm{g} / \mathrm{L}$ para menos que $1.000 \mu \mathrm{g} / \mathrm{L}$ (93\%) e BTEX de $54 \mu \mathrm{g} / \mathrm{L}$ para $17 \mu \mathrm{g} / \mathrm{L}(68,5 \%)$.

Dreiling (1998) utilizou ozônio e injeção de ar em escala piloto para a remediação de PCE em água subterrânea contaminada em três lavanderias de lavagem a seco em Kansas, EUA. O solo era composto por sedimento aluvial inconsolidado e aterro (areia, silte e argila). O nível d'água encontrava-se entre 4,2 e 4,8 $\mathrm{m}$ de profundidade. A pluma de PCE estava limitada no topo em 4,5 m de profundidade com concentrações máximas variando entre 30 e $600 \mu \mathrm{g} / \mathrm{L}$. Utilizaram-se três técnicas: injeção de ar (air sparging) com extração de vapores do solo (soil vapor extraction); remoção por arraste com ar em poço (in-well stripping); e combinação de injeção de ar e ozônio com circulação vertical de água subterrânea (C-Sparge ${ }^{\mathrm{TM}}$ ). As atividades de teste piloto nos três locais foram conduzidas por 5 meses. Os resultados obtidos nos poços de monitoramento localizados a $3 \mathrm{~m}$ do poço de injeção de ozônio indicaram uma redução na concentração de PCE de 34 para $3 \mu \mathrm{g} / \mathrm{L}$. A injeção de ar com extração de vapores 
resultou em uma redução de $66 \%$ da concentração de PCE; a remoção por arraste com ar em poço, de 87\%; a injeção com ar, $71 \%$, e a injeção de ozônio, $91 \%$.

Kerfoot et al. (2007) relatam a remediação por injeção de ozônio de organoclorados (PCE, TCE, cis 1,2-DCE, e VC) liberados no solo e na água subterrânea por um vazamento em uma indústria próxima ao principal poço de abastecimento de água pública local. O subsolo era composto por um depósito fluvial de areia e cascalho com lentes descontínuas de silte, e o nível d'água encontrava-se a 1,5 m de profundidade. $\mathrm{O}$ depósito de areia e cascalho mais profundo apresentava alta transmissividade e condutividade hidráulica maior que $60 \mathrm{~m} / \mathrm{dia}$. As lentes de silte próximas da superfície causaram a elevação da água durante condições de fortes tempestades. Um poço de monitoramento mostrou concentrações de VOC total de $959 \mu \mathrm{g} / \mathrm{L}$.

Optou-se pela injeção de Fenton durante 8 meses, mas esta técnica foi interrompido devido ao potencial de inundação ocasionado pelos movimentos ascendentes do reagente, à migração de vapores através das juntas do piso de concreto, aos potenciais danos no piso de concreto e fundação, e às múltiplas injeções que seriam necessárias para remover o significativo rebound. Para substituição da técnica, a atenuação natural monitorada e a fitorremediação foram recusadas pela agência reguladora devido ao extenso tempo de tratamento frente à necessidade de redução imediata das concentrações. A biorremediação anaeróbia também foi descartada, já que após a degradação do PCE e do TCE em VC, seria necessária ainda a injeção de metano e tolueno para formação de subprodutos não nocivos. O sistema C-Sparge ${ }^{\mathrm{TM}}$ foi instalado 2,5 m abaixo do nível d'água e os dois poços de recirculação próximos à área fonte, a cerca de $9 \mathrm{~m}$ abaixo do nível d'água. A remediação com injeção de ozônio, iniciada em fevereiro de 2000, diminuiu as concentrações de VOC nos poços a jusante em mais de 95\% até o final de 2001 e em mais de 99\% em 2007, resultando em concentrações inferiores ao padrão de potabilidade. 


\subsubsection{Reação de Ozonização}

O ozônio é um forte oxidante que degrada contaminantes através de reações na fase gasosa e aquosa; para degradar a fase livre são indicadas outras técnicas, dada a grande quantidade de oxidante necessária. Atua de três maneiras: diretamente na oxidação das ligações insaturadas carbono-carbono da molécula do contaminante; degradando-se em oxigênio, o qual intensifica a biodegradação natural ou oxidação biológica; ou indiretamente, degradando-se em radicais livres hidroxilas altamente reativos, que por sua vez oxidam as moléculas orgânicas (USEPA, 2013; RCC, 2000; CETESB, 1999; BONCZ, 2002).

As principais reações envolvidas no processo de ozonização são:

Oxidação

$$
\begin{aligned}
& \mathrm{O}_{3}+2 \mathrm{H}^{+}+2 e^{-} \rightarrow \mathrm{O}_{2}+\mathrm{H}_{2} \mathrm{O} E^{0}=2,07 v(3.13) \\
& 2^{*} \mathrm{OH}+2 \mathrm{H}^{+}+2 e^{-} \rightarrow 2 \mathrm{H}_{2} \mathrm{O} E^{0}=2,76 v(3.14)
\end{aligned}
$$

Decomposição

$$
2 \mathrm{O}_{3} \rightarrow 3 \mathrm{O}_{2} \quad 4^{*} \mathrm{OH} \rightarrow 2 \mathrm{H}_{2} \mathrm{O}+\mathrm{O}_{2}
$$

Formação de radical hidroxila

$$
\begin{array}{r}
\mathrm{O}_{3}+\mathrm{H}_{2} \mathrm{O} \rightarrow \mathrm{O}_{2}+2^{*} \mathrm{OH} \text { (lenta) (3.16) } \\
2 \mathrm{O}_{3}+3 \mathrm{H}_{2} \mathrm{O} \rightarrow 4 \mathrm{O}_{2}+2^{*} \mathrm{OH}+2 \mathrm{H}_{2} \mathrm{O} \text { (rápida) }
\end{array}
$$

O ozônio reage por oxidação direta dos compostos orgânicos, reação favorecida em pH baixo (eq.3.13). Dois mecanismos comuns de oxidação direta com ozônio incluem a adição cíclica de ozônio a uma ligação de alcenos (uma dupla ligação de carbonos) e o ataque eletrofílico de hidrocarbonetos aromáticos (LANGLAIS et al., 1991). 
A molécula de ozônio é eletricamente neutra, mas é polar, o que contribui para a reatividade do ozônio. Como resultado desta estrutura dipolar, a molécula de ozônio pode conduzir entre 1 e 3 ciclo adições dipolares nas ligações insaturadas, com a formação de ozonídeo primário. Em um solvente protônico como a água, este ozonídeo primário decompõe-se em um composto carbonila (aldeído ou cetona) e um íon dipolar que conduz rapidamente para um hidroxi-hidroperóxido, que por sua vez, decompõe-se em um composto carbonila e peróxido de hidrogênio (LANGLAIS, 1991).

O ozônio pode decompor-se em radicais livres, predominantemente em soluções aquosas neutras e alcalinas. A formação de radicais hidroxilas pode ser lenta (eq.3.16) ou rápida (eq.3.17). A oxidação indireta pelos radicais hidroxilas está expressa na eq.3.14, sendo a taxa de decomposição do ozônio diretamente proporcional ao pH, ou seja, com o aumento do $\mathrm{pH}$, a taxa de decomposição também aumenta. Os radicais livres conduzem a reações de propagação que geram uma ampla variedade de espécies de oxigênio reativo, formadas sob diferentes condições (eq.3.18).

$$
\mathrm{O}_{3}+\mathrm{OH}^{-} \rightarrow \text { Espécies de oxigênio altamente reativas (3.18) }
$$

O forte potencial de oxidação de ozônio e das espécies reativas de oxigênio que podem ser derivadas desta decomposição depende das taxas de reação cinética. As reações de oxidação direta entre ozônio e um substrato orgânico gasoso ou aquoso são expressos pela reação cinética de segunda ordem (eq.3.19).

$$
\frac{\partial c_{o x}}{\partial t}=-k_{2} C_{o x} C_{o r g}
$$

Onde $C_{o x}$ é a concentração de oxidante $(\mathrm{M}), C_{o r g}$ é a concentração de substrato $(\mathrm{M}), k_{2}$ é a taxa constante de segunda ordem $\left(\mathrm{M}^{-1} \mathrm{~s}^{-1}\right), t$ é o tempo (s), sendo $\mathrm{M}=\mathrm{mol} / \mathrm{L}$.

Segundo Clayton et al. (2011), os radicais livres derivados da decomposição do ozônio, especialmente radicais hidroxilas, também seguem as reações cinéticas de segunda ordem. Taxas constantes de radicais hidroxilas para diversos reagentes orgânicos e 
inorgânicos têm sido reportadas nos intervalos de $10^{9}$ a $10^{10} \mathrm{M}^{-1} \mathrm{~s}^{-1}$, o que corresponde a uma meia vida na ordem de $10^{-9} \mathrm{~s}$. A transformação de contaminantes por reações cinéticas de radicais livres pode ser complexa devido a reações de propagação de radicais livres, assim como a formação de diferentes espécies de radicais e intermediários de reação. Esses radicais e intermediários podem ter meia vida de curta duração, frequentemente não sendo identificados e quantificados, embora tenham impacto significativo na reação. Os autores concluem, portanto, que a modelagem das transformações de contaminantes sob essas condições oxidativas pode ser difícil.

Geralmente, quanto mais rápida a taxa cinética de uma reação, mais disponível o composto está para a oxidação. Contudo, considerando a mistura de contaminantes, a matéria orgânica natural do meio, os minerais inorgânicos que competem pelo ozônio e os seus radicais livres em taxas cinéticas variadas, verifica-se que não é possível estimar a remoção de contaminantes baseado somente na cinética, devendo-se adequar modelos empíricos a dados experimentais.

Em geral, as reações cinéticas são aceleradas com a temperatura, o que pode aumentar a taxa de oxidação do contaminante, aumentando também as reações de autodecomposição. Em experimentos observando a progressão da temperatura, Dunn e Lunn (2002) observaram que um solo seco com matéria orgânica apresenta um aumento de temperatura muito maior do que solos úmidos e que o aumento da temperatura está associado a uma maior eficácia na remoção de contaminantes.

Outro fator relacionado à temperatura é a constante da Lei de Henry, que aumenta com a temperatura, indicando que concentrações menores de ozônio dissolvido estarão presentes em elevadas temperaturas (LANGLAIS et al., 1991).

\subsubsection{Degradação do Tetracloroetileno (PCE) por reações de ozonização}

Os etenos clorados contém uma dupla ligação entre átomos de carbono, e devido à alta reatividade do ozônio com ligações de alcenos, possuem altas taxas de reação com o ozônio, sendo comprovada sua eficiência em diversos estudos de laboratório e campo, compilados em Clayton et al. (2011). Segundo Kerfoot (2000), o tratamento de etenos 
clorados com ozônio é mais eficiente que de outros alifáticos clorados como os etanos clorados e metanos clorados.

A degradação de alcenos por ozônio ocorre através da oxidação direta, onde o ozônio é adicionado à ligação de alceno para formar intermediários oxigenados como o fosgênio $\left(\mathrm{COCl}_{2}\right)$ ou gás cloreto de carbonila, conhecido por se decompor rapidamente em água devido às reações de hidrólise. Dessa forma, os produtos primários da ozonização de etenos clorados são os cloretos e os dióxidos de carbono, conforme observado por Sunder e Hempel (1997) em um experimento para tratamento de TCE e PCE.

A Figura 3.7 mostra uma reação de ozonização direta com um eteno, por ciclo adição. A molécula de ozônio tem uma estrutura dipolar (Figura 3.7.A). As reações de etenos com ozônio requerem ligações de 2 cargas simultaneamente, formando a primeira reação intermediária, a molozonide (produto da cicloadição de um alceno por ozônio) (Figura 3.7.B). 


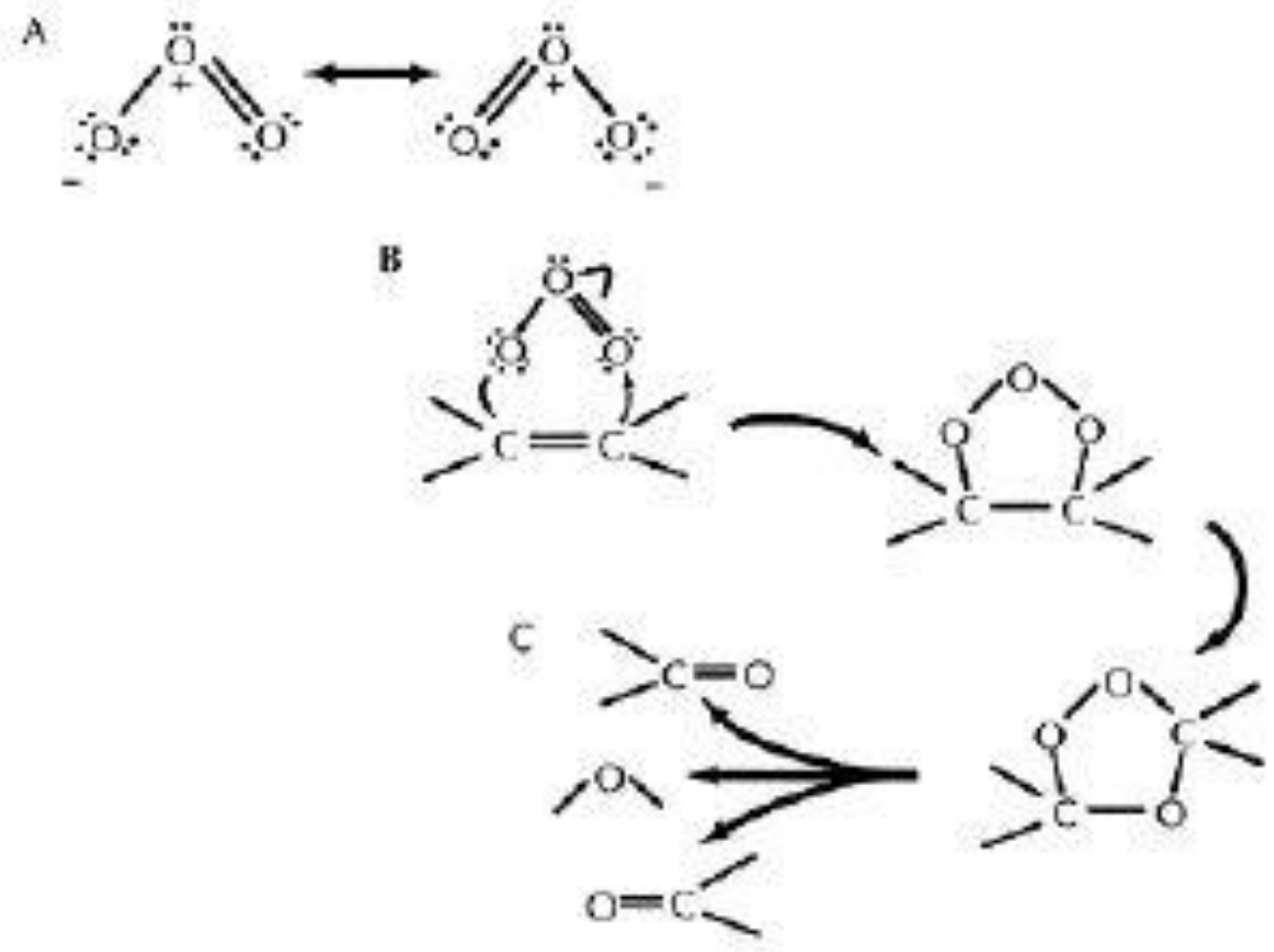

Figura 3.7 A. Molécula do ozônio. B. Sequência de reações de ozônio com um eteno. C. Quebra das reações intermediárias para formar água e duas moléculas de aldeído. Fonte: Suthersan e Payne, 2005

A formação de uma ligação inicial é um evento relativamente improvável para uma reação eteno-ozônio, e a probabilidade de ocorrência diminui conforme o nível de cloração aumenta. Esta reação lenta provavelmente é refletida por uma taxa cinética de segunda ordem constante para reação de ozônio com etenos, e de longe a menor taxa com PCE, o mais altamente clorado dos etenos. A taxa de segunda ordem por degradação direta com o ozônio do TCE é $17 \mathrm{M}^{-1} \mathrm{~s}^{-1}$, enquanto a do PCE é menor que $1 \times 10^{-1} \mathrm{M}^{-1} \mathrm{~s}^{-1}$; por degradação indireta pelo radical hidroxila, esses valores são, respectivamente, $4 \times 10^{9}$ e $3 \times 10^{9} \mathrm{M}^{-1} \mathrm{~s}^{-1}$ (SUTHERSAN; PAYNE, 2005).

No caso do PCE, portanto, a oxidação direta deve-se ao mecanismo de cicloadição, pelo qual o ozônio se liga a um alceno e forma um intermediário complexo heterocíclico (ozonização primária), que é instável e se decompõe rapidamente para quebrar a ligação carbono-carbono e liberar um grupo carbonila. Os compostos carbonilos liberados pela oxidação direta são instáveis e sujeitos a outras reações de hidrólise que 
podem degradar o composto. Além disso, o peróxido de hidrogênio $\left(\mathrm{H}_{2} \mathrm{O}_{2}\right)$ pode se formar como um subproduto dessas reações e contribuir com outros mecanismos de oxidação (LANGLAIS et al., 1991; BELTRÁN, 2004).

Os radicais hidroxilas gerados pelo decaimento do ozônio também podem atacar as ligações de alcenos. O uso combinado de ozônio e peróxido de hidrogênio, chamado de peroxônio, para gerar radicais hidroxilas, tem sido aplicado para degradar alcenos (SUTHERSAN; PAYNE, 2005). Em um sistema de peroxônio investigado por Sunder e Hempel (1997), doses elevadas de peróxido de hidrogênio resultaram em um aumento da degradação de TCE e PCE, indicando a ação dos radicais hidroxilas.

De acordo com dados obtidos em Siegrist, Crimi e Simpkin (2011), a degradação do PCE por ozônio apresenta resultados excelentes (numa escala que varia entre excelente, bom, razoável, ruim, N/R). A aplicação de ozônio para promover a oxidação do composto apresenta melhores resultados em condições geoquímicas com pH de até 7, alcalinidade de até $1.000 \mathrm{mg} / \mathrm{L} \mathrm{CaCO}_{3}$, concentração de cloretos de até $1.000 \mathrm{mg} / \mathrm{L}$, fração de carbono orgânico de até $0,3 \%$, e de concentrações muito baixa a moderadas de contaminantes (MORAES et al., 2013).

O 1,4-Dioxano é um contaminante secundário frequentemente encontrado em locais contaminados por organoclorados, uma vez que é adicionado aos organoclorados como estabilizante. Diversos autores demonstraram que o 1,4-Dioxano em água subterrânea pode ser completamente degradado por ozônio, ainda que a ozonização seja demorada (BROWN et al., 2004). Suh e Mohseni (2004) verificaram que a degradação do 1,4Dioxano resultou em mineralização relativamente baixa do dióxido de carbono $\left(\mathrm{CO}_{2}\right)$, indicando que intermediários orgânicos estavam sendo formados, dentre eles, ácidos orgânicos e álcoois com baixo peso molecular. Os autores observaram ainda que estes subprodutos eram mais biodegradáveis que o composto de origem e que os subprodutos produzidos em $\mathrm{pH}$ alcalino ou com doses moderadas de peróxido de hidrogênio (peroxônio) eram mais prontamente biodegradáveis que aqueles produzidos em pH ácido e sem peróxido de hidrogênio. Os sistemas de peroxônio, assim como os sistemas de ozônio em pH elevado, são mais propensos a envolver oxidação por radicais livres, enquanto os sistemas de ozônio em pH baixo são mais propensos a 
envolver oxidação direta por ozônio. Os resultados indicam que os produtos formados nas reações com radicais hidroxilas com o dioxano podem ser mais biodegradáveis do que aqueles produzidos por reação direta com ozônio (CLAYTON et al., 2011).

A ozonização gera numerosas classes de produtos de decomposição parcial e de reações finais que podem ser de interesse para a proteção da água potável. Reações intermediárias incluem cetonas, aldeídos e ácidos carboxílicos. Muitos destes produtos intermediários são menos reativos com ozônio ou com os radicais hidroxilas do que os compostos orgânicos originais e podem ser acumulados quando ocorre competição cinética de mais substratos reativos. O formaldeído é um exemplo de um potencial produto das reações de ozonização; sua taxa cinética de segunda ordem para a decomposição com ozônio é $0,1 \mathrm{M}^{-1} \mathrm{~s}^{-1}$, menor do que valores de interesse para utilizar ozonização (ACERO et al., 2001 in SUTHERSAN; PAYNE, 2005). Em muitos casos, os produtos intermediários e subprodutos são altamente solúveis e biodegradáveis em condições aeróbicas.

Um estudo estequiométrico da degradação do PCE por ozônio ${ }^{1}$ indica que a mineralização completa seria expressa pela eq. 3.20:

$$
1 \mathrm{C}_{2} \mathrm{Cl}_{4}+{ }^{2} / 3 \mathrm{O}_{3}+5 / 2 \mathrm{H}_{2} \mathrm{O} \rightarrow 4 \mathrm{HCl}+2 \mathrm{CO}_{2}+1 / 2 \mathrm{H}_{2} \mathrm{O}(3.20)
$$

Porém, conforme discutido, pode ocorre a formação de outros produtos, sendo que o principal intermediário esperado é o fosgênio expresso pelo resultado da soma das eq.3.21 e 3.22, que é demonstrado na eq. 3.23:

$$
\begin{aligned}
& 1 \mathrm{C}_{2} \mathrm{Cl}_{4}+1 \mathrm{O}_{3} \rightarrow 2 \mathrm{COCl}_{2}+1 / 2 \mathrm{O}_{2} \\
& \underline{2 \mathrm{COCl}_{2}+2 \mathrm{H}_{2} \mathrm{O} \rightarrow 4 \mathrm{HCl}+2 \mathrm{CO}_{2}}
\end{aligned}
$$

$$
1 \mathrm{C}_{2} \mathrm{Cl}_{4}+1 \mathrm{O}_{3}+2 \mathrm{H}_{2} \mathrm{O} \rightarrow 4 \mathrm{HCl}+2 \mathrm{CO}_{2}+1 / 2 \mathrm{O}_{2}
$$

\footnotetext{
${ }^{1}$ MOREIRA JÚNIOR, P.F. (2014). Comunicação pessoal.
} 


\subsubsection{Fatores que Influem na Oxidação de Ozônio}

As taxas de reação de ozônio são, principalmente, influenciadas pelos seguintes parâmetros: teor de água, $\mathrm{pH}$, matéria orgânica natural (MON), concentrações e características do contaminante, e concentrações de metais reativos e das espécies inorgânicas. Conforme a quantidade desses parâmetros aumenta, as reações de ozônio aumentam e a distância de transporte diminui.

A oxidação da MON pelo gás ozônio na zona não saturada restringe as distâncias do transporte de ozônio em subsuperfície (HSU; MASTEN, 2001; CHOI et al., 2002; JUNG et al., 2004). Shin et al. (2004) apud Clayton et al. (2011) relataram uma redução de $30 \%$ da MON como resultado da injeção de ozônio por uma coluna de solo, indicando que a demanda total de ozônio inclui oxidação parcial do teor de MON no solo.

Hsu e Masten (2001) desenvolveram um modelo de transporte para o gás ozônio em solos não saturados, com dados experimentais obtidos em ensaios de coluna com presença de fenantreno. Os resultados indicaram que a MON retardou o transporte de ozônio, sendo consumidos cerca de 5,4 mg de ozônio por mg de MON, prejudicando a eficiência da reação de ozônio e a eficácia do tratamento do contaminante.

Kainulainen et al. (1994) observaram que o ozônio degradou substâncias húmicas, reduzindo seu tamanho molecular médio por uma ordem de magnitude. Embora o aumento da demanda por ozônio possa impactar a eficiência da reação, a quebra da matéria orgânica pode ser vantajosa para o tratamento do contaminante, facilitando a sorção de contaminantes hidrofóbicos mais disponíveis para a oxidação e aumentando a eficácia do tratamento. Olenbusch et al. (1998) notaram que a decomposição de produtos de substâncias húmicas oxidadas por ozônio contribuíram para a formação de um substrato capaz de promover a biodegradação (CLAYTON et al., 2011).

A injeção de ozônio em solos altamente orgânicos é um desafio técnico e econômico, entretanto, a viabilidade deve ser avaliada caso a caso. Intervalos de injeção limitados e prazos de injeção mais longos podem ser necessários para obter sucesso em locais com alto teor de MON. 
Além disso, características hidrogeológicas e litológicas do meio poroso contribuem significativamente no processo de transporte de gás. É importante entender a direção potencial do ozônio e os mecanismos de transporte para projetar os sistemas de distribuição de ozônio.

Geralmente, há duas características de reações em relação ao tempo que afetam o transporte de ozônio pelo solo. O mecanismo de "demanda finita", no qual o consumo de ozônio diminui com o tempo, é observado para matéria orgânica natural, contaminantes orgânicos e espécies minerais reduzidas, como os compostos sulfídicos. No mecanismo de "demanda cinética", por outro lado, o ozônio é consumido via reações catalíticas, sendo a água e os óxidos metálicos os reagentes que controlam a "demanda cinética" de longo prazo (CLAYTON et al, 2011). Na "demanda finita", o ozônio é exaurido a certa distância do ponto de injeção e gradualmente vai sendo transportado pelo meio poroso a maiores distâncias, aumentando o raio de influência ao longo do tempo, até o limite controlado pelo "demanda cinética" (Figura 3.8).

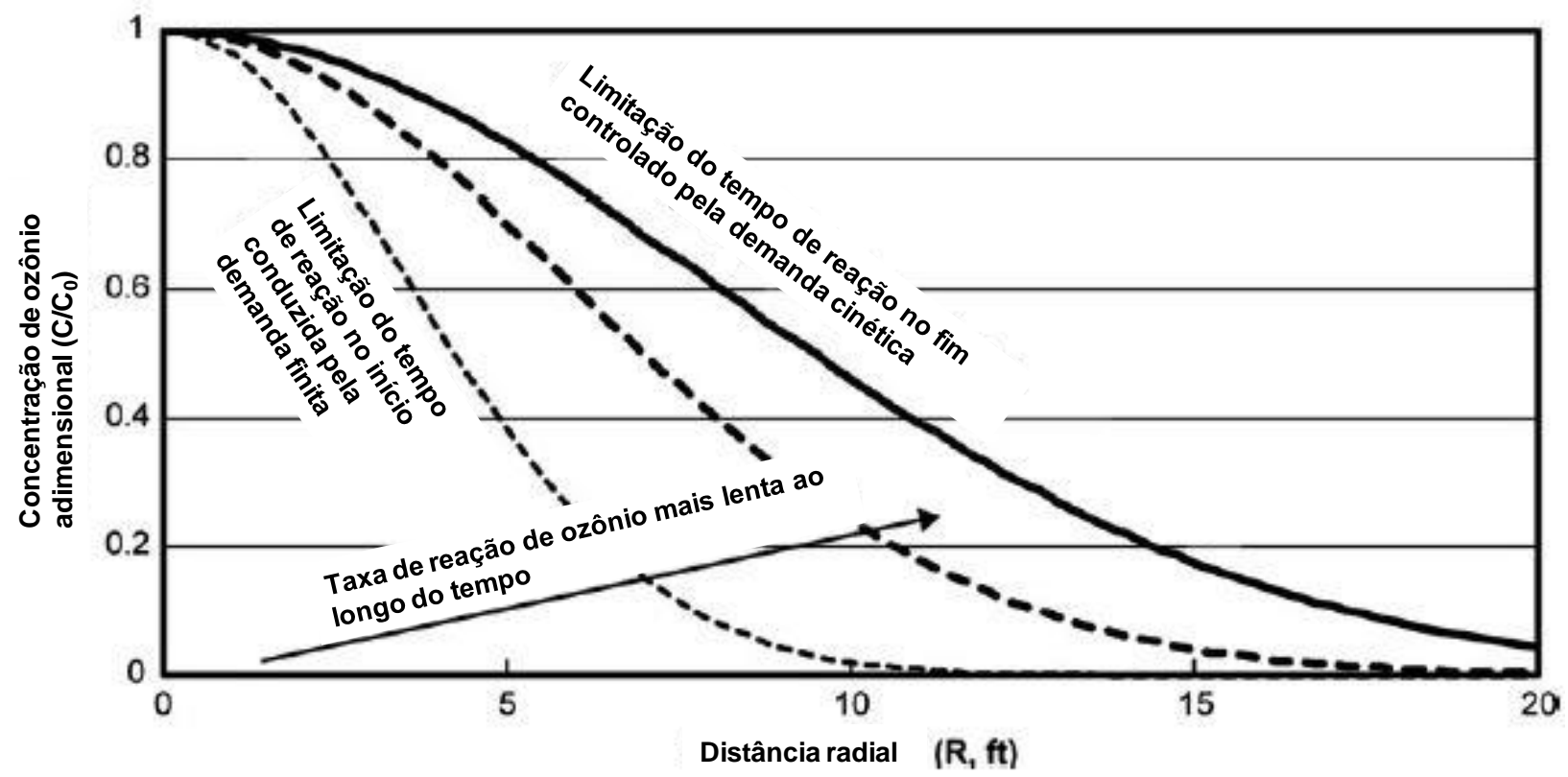

Figura 3.8 llustração conceitual das demandas "finita" e "cinética" de ozônio. Fonte: Clayton et al., 2011 
Óxidos de ferro e manganês são catalisadores naturais, reagem com ozônio em subsuperfície e podem exercer uma "demanda cinética" por ozônio, resultando no aumento da formação de radicais livres, e consequentemente, da degradação de contaminantes (NAYDENOV; MEHANDJIEV, 1993; ANDREOZZI et al., 1996; CHOI et al., 2002; JUNG et al., 2004). Entretanto, pode haver maior dificuldade dos minerais obterem contato suficiente com o oxidante devido à diminuição no potencial de oxidação.

Choi et al. (2002) e Jung et al. (2004) reportaram um amento na degradação de hidrocarbonetos de petróleo como o fenantreno em solos de campo em relação a sistemas envolvendo esferas de vidro e areia de sílica pura. Alguns desses experimentos envolveram pré-tratamento do solo a elevadas temperaturas para eliminar a MON, fornecendo evidências que a presença de minerais naturais do solo intensifica a degradação do contaminante. Naydenov e Mehandjiev (1993) e Andreozzi et al. (1996) reportaram a degradação de contaminantes orgânicos por ozônio catalisadas por dióxido de manganês $\left(\mathrm{MnO}_{2}\right)$, já que os óxidos de manganês estavam presentes como minerais do solo e encontravam-se disponíveis para catalisar as reações de oxidação química com ozônio gasoso, e provavelmente, com ozônio líquido.

Os solutos dissolvidos, tais como carbonato, bicarbonato, sulfato e cloreto, têm um potencial significativo para interagir com radicais hidroxila e gerar reações intermediárias; entretanto, os radicais formados durante a oxidação dos contaminantes orgânicos não degradam tão efetivamente quanto os radicais hidroxilas e podem ser prejudiciais à eficácia do tratamento, especialmente onde os processos de oxidação com radicais livres predominam (ADAMS; RANDTKE, 1992; SUNDER; HEMPEL, 1997).

As concentrações elevadas de contaminantes, seja na forma de elevadas concentrações sorvidas ou NAPLs, podem limitar o transporte de ozônio devido à demanda de ozônio exercida por essas reações ( $\mathrm{CHOl}$ et al., 2002). Neste caso, é importante planejar e estimar distâncias de transporte mais curtas, espaçamento mais próximo dos poços de injeção e monitoramento, prazos mais longos de injeção de ozônio e cargas de ozônio maiores. Foram verificadas diminuições no transporte de ozônio durante a ozonização de diesel em solo (1.500 mg/kg) (CHOl et al., 2002) e 
concentrações relativamente baixas de PAHs (50 mg/kg) (ZHANG et al., 2005), resultados que demonstram que meios porosos altamente contaminados provavelmente exigem um prazo mais longo de ozonização para alcançar o objetivo do tratamento do que solos pouco contaminados.

A decomposição de ozônio é muito mais rápida na fase aquosa que na fase gasosa devido à forte reação de catálise pelo íon hidróxido. A meia vida (em pH 7) a $20^{\circ} \mathrm{C}$ do ozônio líquido é 20 minutos, enquanto a do gás ozônio é 3 dias. Esses valores são baseados na decomposição termal e não consideram efeitos catalisadores como umidade, carga orgânica, e outros. O processo de decomposição catalítica, no qual o ozônio se dissolve em fase aquosa, diminui efetivamente o transporte de ozônio (JUNG et al., 2004).

Por outro lado, a presença de água nos espaços do meio poroso reduz a saturação por ar e o contato das fases sólido-gás entre contaminantes não voláteis e ozônio. Um teor de umidade elevado limita o transporte de massa de ozônio, podendo tornar espécies reativas de ozônio associadas às superfícies sólidas (MON, óxidos de metais, contaminantes) menos disponíveis para reação (CHOI et al., 2002; JUNG et al., 2004). Em solos não saturados com alto teor de umidade e presença de contaminantes relativamente não voláteis, tais como óleo cru ou PAHs, a injeção de ozônio apresentou eficácia reduzida (ZHANG et al., 2005; O'MAHONY et al., 2006). Observou-se remoção de pireno mais lenta em solos úmidos do que em solos secos, com redução na eficiência conforme o teor de umidade aumenta (LUSTER-TEASLEY et. al, 2009).

Vale enfatizar que o teor de umidade ideal depende das condições específicas do local, do tipo de contaminante e de seu particionamento em subsuperfície.

3.3.5 Transferência de Massa e Particionamento de Ozônio em Subsuperfície

Durante a injeção de ozônio em subsuperfície, o transporte de massa e os mecanismos de transferência de massa determinam o sucesso ou o fracasso do processo de tratamento. 
A oxidação química in situ é menos frequentemente usada na zona não saturada que na zona saturada. A introdução de ozônio na zona saturada é realizada através de poços de injeção, onde o ar ou o oxigênio puro contendo ozônio é injetado sob pressão.

$\mathrm{Na}$ zona vadosa, há poros preenchidos com ar interconectados, por onde o ar percola livremente, isto é, flui devido a um gradiente de pressão. A água se encontra ao redor das partículas sólidas ou ocupando parte dos vazios, formando meniscos nos contatos com o ar. Reações podem ocorrer na fase gasosa com contaminantes volatizados, bem como contaminantes em fase sorvida ou em fase líquida não-aquosa (NAPL), nas interfaces sólida ou líquida.

O transporte de ozônio injetado como gás na zona vadosa é fortemente limitado pela perda de ozônio gasoso ao longo do tempo por autodecomposição, pela distância do transporte e pela transferência de massa entre as fases gasosa, aquosa, NAPL e sorvida do contaminante; as reações com os sólidos podem ser também importantes, especialmente para baixos teores de umidade (CLAYTON et al., 2011).

Mesmo assim, a oxidação in situ por ozônio na zona não saturada tem vantagens em relação à zona saturada: (1) as concentrações de ozônio que podem ser alcançadas na fase gasosa são de maior ordem de magnitude que as obtidas em solução aquosa, (2) o ozônio é mais estável na fase gasosa do que na aquosa, (3) o transporte difusivo de ozônio no ar é muito maior que na água, (4) maiores velocidades de fluxo podem ser alcançadas na zona não saturada do que na água subterrânea (MASTEN; DAVIES, 1997); e (5) a distribuição da massa de gás ozônio na zona não saturada, geralmente, é mais efetiva que na zona saturada. Contudo, a distribuição e transporte do gás ozônio na zona não saturada são muito mais vulneráveis a caminhos preferenciais atribuídos às heterogeneidades na permeabilidade (HULING; PIVETZ, 2006).

Um gás pode se mover em um meio poroso percolando por canais com vazios cheios de ar conectados ou por difusão na água do solo.

A percolação de gases pode ser expressa pela lei de Darcy, sendo o gradiente hidráulico expresso como gradiente de pressões. Assim, a vazão com que um gás percola no solo por fluxo em vazios não saturados por água é diretamente proporcional 
ao gradiente de pressões e à área da seção transversal disponível ao fluxo. A permeabilidade ao gás é geralmente representada pelo coeficiente de permeabilidade intrínseco, com dimensão de comprimento ao quadrado.

Difusão é o processo pelo qual espécies iônicas e moleculares dissolvidas em água são transportadas de áreas com altas concentrações para áreas com baixas concentrações. A difusão de um soluto através da água é descrito pela Lei de Fick, a qual descreve o fluxo unidimensional de um soluto em estado estacionário, conforme mostra a eq.3.24.

$$
F=-D d C / d x(3.24)
$$

Onde F é o fluxo de massa do soluto por unidade de área por unidade de tempo; D é o coeficiente de difusão (área por tempo); C é a concentração do soluto (massa por volume); $d C / d x$ é o gradiente de concentração (massa por volume por distância).

O sinal negativo indica que o movimento ocorre da maior para a menor concentração. Valores de $\mathrm{D}$ são bem conhecidos para eletrólitos em água a $25^{\circ} \mathrm{C}$, variando entre $1 \times 10^{-}$ ${ }^{9}$ e $2 \times 10^{-9} \mathrm{~m}^{2} / \mathrm{s}$ para os íons principais nas águas subterrâneas $-\mathrm{Na}^{+}, \mathrm{K}^{+}, \mathrm{Mg}^{2+}, \mathrm{Ca}^{2+}, \mathrm{Cl}^{-}$ , $\mathrm{HCO}_{3}{ }^{-}$e $\mathrm{SO}_{4}{ }^{2-}$ (FREEZE; CHERRY, 1979) - e entre $6 \times 10^{-10}$ e $2 \times 10^{-9} \mathrm{~m}^{2} / \mathrm{s}$ para diversos íons presentes nas águas (ROWE, QUIGLEY, BOOKER, 1995).

Para sistemas unidimensionais onde as concentrações podem ser alteradas com 0 tempo, ou seja, em regime transiente, pode-se aplicar a segunda Lei de Fick (eq.3.25).

$$
\partial C / \partial t=D \partial^{2} C / \partial x^{2}(3.25)
$$

Em um meio poroso, os íons ou moléculas seguem caminhos mais longos devido à presença de grãos minerais. Neste caso, utiliza-se o coeficiente de difusão efetivo, representado por $D^{*}$ (eq.3.26)

$$
D^{*}=w D(3.26)
$$


Onde w é um coeficiente empírico, tortuosidade, determinado por experimentos de laboratório.

A concentração de gás dissolvida na água do solo depende da pressão a que o gás está submetido. O particionamento de um contaminante entre a fase líquida e a fase gasosa é governado pela Lei de Henry. O transporte de massa de ozônio da fase gasosa para aquosa aumenta quanto maior for a concentração de ozônio no ar e mais baixa a concentração de ozônio na água. Um experimento realizado por Johnson (1998) mostra que a remoção de voláteis em áreas tratadas com injeção de ar próximas a canais com presença de ar foi mais rápida do que em regiões saturadas de água. É possível supor que a oxidação do contaminante ocorre por mecanismos de transporte similares: (1) a difusão e a volatilização de contaminantes em canais com ozônio e ar, onde ocorrem as reações de oxidação na fase gasosa, e (2) a difusão do ozônio na água do solo, onde ocorrem as reações de oxidação do contaminante em fase aquosa.

Dado o número limitado de estudos sobre o destino e o transporte do gás ozônio em subsuperfície, uma análise crítica da técnica de remediação denominada Air Sparging (AS), que foi mais amplamente investigada e apresenta similaridades com a injeção de ozônio, pode ajudar a inferir o destino e transporte de ozônio na zona saturada. No AS, o transporte de gás pode ocorrer através dos seguintes processos: fluxo de gás contínuo em meio poroso parcialmente saturado e bolhas de gás.

Em meio poroso granular, as bolhas de ar podem se mover para cima por flutuação, porque a força de empuxo de diferentes bolhas pode exceder a pressão de entrada de ar capilar. O fluxo de bolhas somente ocorre em formações de areia muito grossa ou cascalho com pressão de entrada de ar muito baixa.

Clayton et al. (2011) citam um estudo de laboratório em que, quando o tamanho do grão excedia $4 \mathrm{~mm}$ (cascalho), o AS resultou no transporte de bolhas; contudo, quando o tamanho do grão foi reduzido para $0,75 \mathrm{~mm}$, os canais de gás predominaram e bolhas não foram observadas. Bolhas dominaram em um meio com um diâmetro médio dos grãos de $1,7 \mathrm{~mm}$, e canais de gás predominaram em um meio com partículas de diâmetro de 0,4 mm (CHAO et al., 2008). Os autores comentam que, em um meio de 
vazios muito grandes, as bolhas migram para cima e para fora em um padrão de cone, resultando em um maior contato com o solo do aquífero; contudo, onde o fluxo de bolhas ocorre unindo pequenas bolhas para formar bolhas grandes (coalescência), e eventualmente ocorrem canais de ar contínuos, verifica-se que o transporte de bolhas torna-se limitado lateralmente e verticalmente.

Quando o solo se caracteriza pela presença de grãos médios a finos, espera-se que o fluxo de ar ocorra em canais de ar. As diferenças entre o fluxo de bolhas e o fluxo de canais de ar podem ser observadas na Figura 3.9.

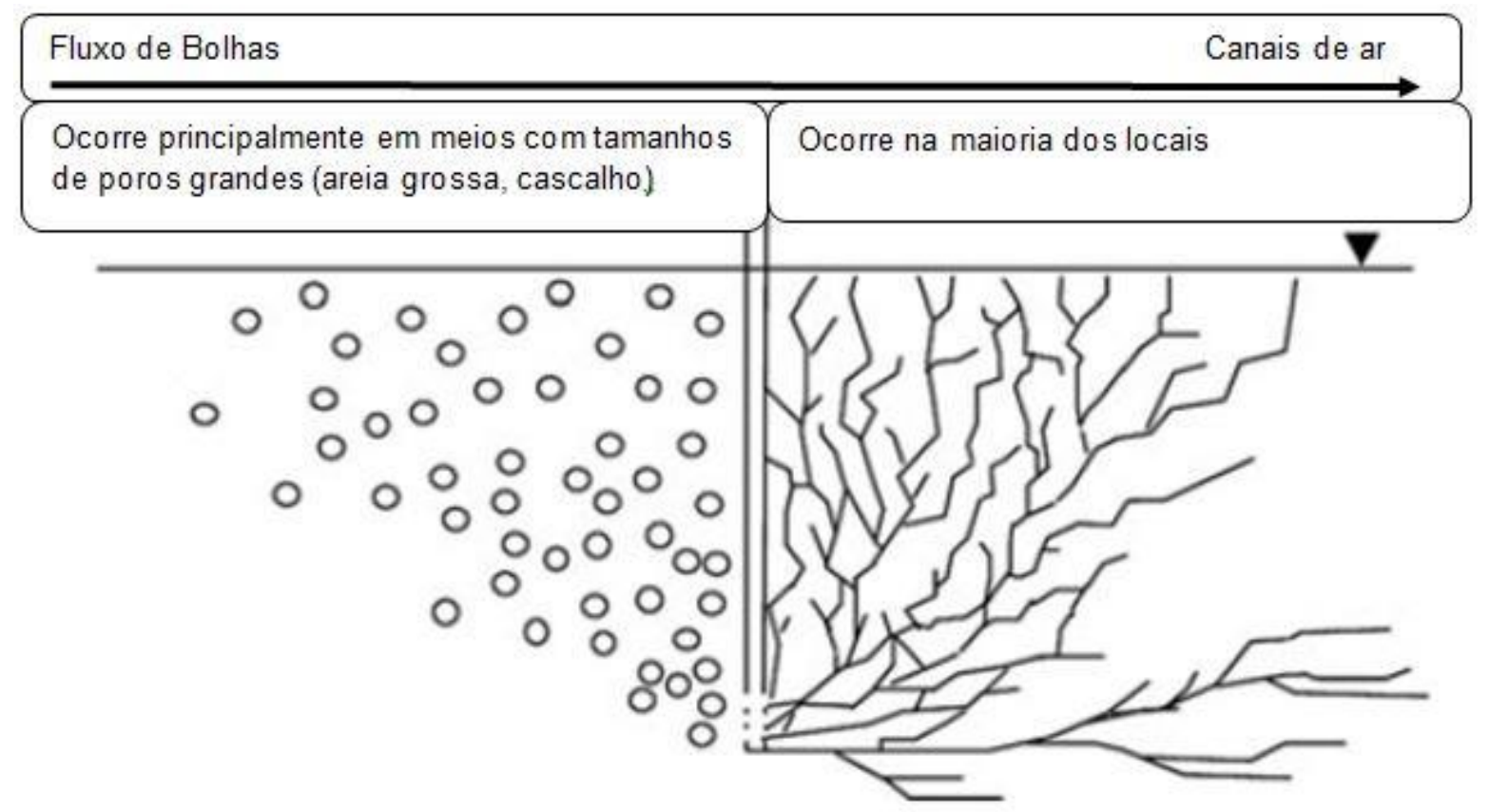

Figura 3.9 Diferenças entre o fluxo de bolhas e os canais de ar em condições ideais (meio homogêneo). Fonte: Clayton et al, 2011

O fluxo em canais de ar em subsuperfície ocorre sob pressões capilares que são próximas da pressão de entrada de ar no meio. Em um sistema ideal, conforme mostra a Figura 3.10, os canais de ar formam uma rede de canais de ar interconectados em forma de V (ELDER; BENSON, 1999). 


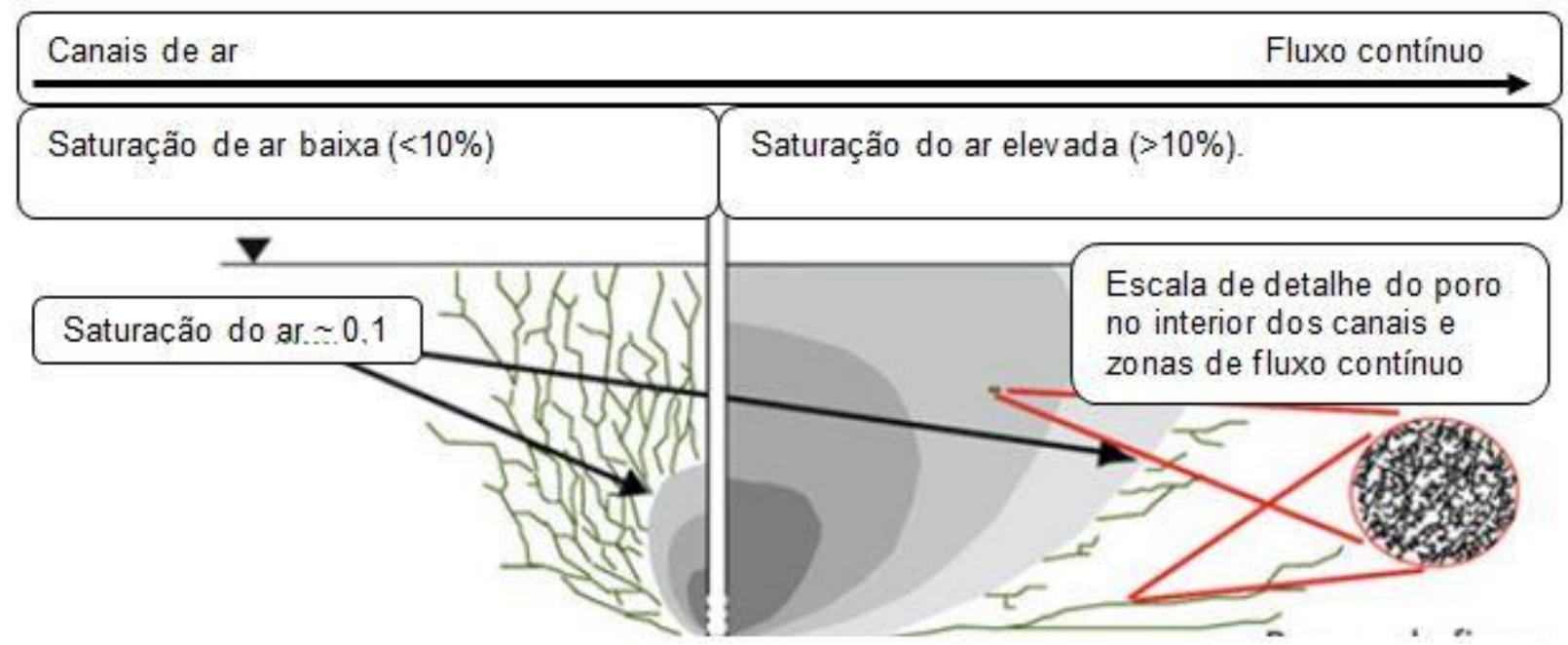

Figura 3.10 Canais de ar e regimes de fluxo contínuo em condições ideais (meio homogêneo). Fonte: Clayton et al., 2011

Contudo, o transporte de gás (ar ou ozônio injetado) na zona saturada na maioria dos locais é caracterizado por condições de transporte não ideais, onde os canais de ar são heterogeneamente distribuídos. Clayton (1998) mostrou que a saturação do ar em solos finos é baixa $(<10 \%)$, favorecendo a formação de canais. Clayton e Nelson (1995) in CLAYTON et al. (2011) observaram em campo medidas de saturação do gás e concentrações de ozônio dissolvido maiores nos 20 minutos iniciais de injeção, devido à maior penetração de ar que ocorre antes de entrar em contato com o nível d'água, motivo que torna a injeção pulsada vantajosa.

Clayton (1998) notou que as saturações do ar medidas em campo e laboratório para condições de fluxo contínuo foram compatíveis com a formação de uma região de saturação do ar relativamente mais uniforme $(<10 \%-30 \%)$, ao contrário dos supostos canais separados por regiões saturadas de água. No campo, as saturações de ar de $30 \%$ foram observadas em areia fina a distâncias de até $7 \mathrm{~m}$ do ponto de injeção, o que indica espalhamento do ozônio mais eficiente em locais de granulometria mais fina, já que a saturação do ar mais elevada resultará em um transporte de massa de ozônio maior e contato com os contaminantes mais uniforme. Contudo, em sites argilosos, a baixa permeabilidade pode limitar a injeção de ozônio. 
A complexidade do transporte de massa para injeção de gás e os processos de transporte em subsuperfície dificultam estimativas da eficácia da injeção do ozônio na zona saturada. Em um estudo de AS, a volatilização do contaminante durante a aplicação da técnica foi limitada a uma zona localizada nas proximidades de um canal de gás, e a concentração de VOC manteve-se relativamente constante fora da zona de transporte de massa (BRAIDA; ONG, 2001 in CLAYTON et al., 2011). Este resultado foi atribuído às limitações da difusão, tais como a difusividade do contaminante, o tamanho da partícula e a uniformidade do meio.

\subsubsection{Ensaios Laboratoriais com Ozônio}

Foram consultados diversos artigos de ensaios laboratório com ozônio que estudavam diversos contaminantes em diferentes meios de estudo. Estes artigos embasaram algumas escolhas de materiais compatíveis com o oxidante e contribuíram, de alguma forma, para a definição do método de contaminação, para a montagem do arranjo experimental desenvolvido neste trabalho e para adoção dos métodos analíticos para quantificação do ozônio e do PCE, dentre eles, estão:

Car e Baird (2000) estudaram a mineralização abiótica em amostras tratadas com ozônio e peroxônio (ozônio com peróxido de hidrogênio), com o objetivo de otimizar o tempo de contato para determinar a eficiência do ozônio e do peroxônio remover por oxidação química compostos orgânicos dissolvidos. Para isso, foram realizados ensaios batch em temperatura ambiente. $\mathrm{O}$ aparato experimental desenvolvido para realizar os ensaios em escala de bancada consideraram uma coluna de vidro Pyrex de $54 \mathrm{~cm}$ de diâmetro interno por $107 \mathrm{~cm}$ de altura, com um difusor de vidro sinterizado na entrada, e acessórios e tubulações em aço inoxidável ou teflon. Além disso, foi utilizado um regulador de pressão em linha com válvulas agulhas em série, um medidor de vazão digital.

Para este estudo, o ozônio foi gerado a partir do ar ambiente ou de oxigênio puro, sendo ligado no mínimo 15 minutos antes do início do ensaio para estabilização. A concentração de ozônio na entrada gerado a partir de oxigênio era de 49 mg/L e do ar 
ambiente de $30 \mathrm{mg} / \mathrm{L}$, enquanto na saída foi utilizado um monitor de ozônio PCl. O fluxo do gerador de ozônio foi alimentado contínuamente usando uma vazão de $433 \mathrm{~mL} / \mathrm{min}$ no fundo do reator para formação de micro bolhas durante o tempo do ensaio. Estudos anteriores com corante determinaram que a turbulência e agitação resultante da aeração do reator em coluna forneceu uma mistura adequada. Uma amostra de controle de água foi analisada pelo método índigo blue para obter a concentração de ozônio dissolvido, cujo resultado indicou concentrações entre 5 e $8 \mathrm{mg} / \mathrm{L}$, enquanto a concentração de ozônio dissolvido de uma amostra de efluente foi de $5 \mathrm{mg} / \mathrm{L}$ após um tempo de contato de 5 minutos.

Poznyak, Manzo, e Mayorga (2003) realizaram ensaios batch com ozônio em um reator de $250 \mathrm{~mL}$ para decompor PCE e TCE dissolvidos em água destilada. Para o ensaio, foram estabelecidas as seguintes condições: concentração inicial de ozônio de $1 \times 10^{-3}$ $\mathrm{mol} / \mathrm{L}$, concentração inicial de PCE de $9 \times 10^{-7} \mathrm{~mol} / \mathrm{L}$ e de TCE de $3,5 \times 10^{-6} \mathrm{~mol} / \mathrm{L}$, e vazão do fluxo de ozônio gerado a partir de oxigênio de $5 \mathrm{~L} / \mathrm{min}$, e temperatura de $20^{\circ} \mathrm{C}$. Para obter uma melhor distribuição de ozônio foi utilizado um agitador magnético na água operando a $120 \mathrm{rpm}$. A concentração de ozônio foi determinada na fase gás, na saída do reator pelo analisador de ozônio BMT 963, enquanto a concentração de PCE e TCE foram determinadas por um cromatógrafo gasoso acoplado a um detector de ionização por chama (FID) usando extração líquido-líquido com clorofórmio. Adicionalmente foram realizadas simulação numéricas, cujos resultados indicaram, que em condições ideais, a máxima de composição do PCE e TCE por ozonização seria de $95 \%$, enquanto os resultados do ensaios batch mostraram que, em condições ideais, foi possível eliminar mais que $95 \%$ dos poluentes em aproximadamente $135 \mathrm{~s}$ de ozonização.

Choi et al (2002) realizaram ensaios em coluna para delinear as características do transporte de ozônio gasoso na zona não saturada.

Neste estudo, três tipos de meio poroso foram testados: microesferas de vidro, areia e solo. A areia e o solo superficial foram coletados em campo com profundidade de até $1,0 \mathrm{~m}$. As contas de vidro foram lavadas com água, assadas a $500^{\circ} \mathrm{C}$ por $24 \mathrm{~h} \mathrm{e}$ armazenadas em temperatura ambiente. A areia foi peneirada em peneira 400 a 600 
$\mu \mathrm{m}$ e lavada com água. As amostras de solo foram secas ao ar em temperatura ambiente por pelo menos uma semana, peneiradas em peneiras no50 a $16(0,3$ a 1,2 $\mathrm{mm}$ ) e lavadas com água. A areia e o solo foram aquecidos a $500^{\circ} \mathrm{C}$ por $24 \mathrm{~h}$ para eliminar a matéria orgânica do solo adsorvida na superfície.

Para estudar a remoção de hidrocarbonetos por ozônio, amostras foram preparadas contaminando o meio poroso com fenantreno (dissolvido em cloreto de metila) ou diesel. O cloreto de metila que transportou o fenantreno, volatilizou durante o tempo de ação (1 semana). As concentrações iniciais de fenantreno e diesel foram 100 a 1.400 $\mathrm{mg} / \mathrm{kg}$, respectivamente.

O ozônio foi gerado a partir do oxigênio seco $99,99 \%$ e foi hidratado para evitar que as colunas de meio poroso ressecassem com a passagem de gás através do frasco lavador de gás contendo água deionizada acidificada em $\mathrm{pH} 2$ com ácido fosfórico. $\mathrm{O}$ ozônio gasoso, a temperatura e a pressão foram monitorados pelo monitor de ozônio antes da entrada da coluna, enquanto a saída de gás ozônio foi trapeada com solução de iodeto de potássio para calcular a quantidade de ozônio consumido no reator.

Nos experimentos foram utilizadas colunas de vidro Pyrex de $2,5 \mathrm{~cm}$ de diâmetro interno por 20 ou $30 \mathrm{~cm}$ de altura, com difusor de vidro poroso colocado em cada tampa para promover a distribuição de ozônio gasoso na coluna. A tampa, o corpo da coluna, e os acessórios da coluna foram fabricados em teflon, vidro Pyrex e aço inoxidável, respectivamente para evitar a deterioração provocada pelo ozônio. As colunas foram inicialmente preenchidas com água e pequenas quantidades de areia foram adicionadas sucessivamente, tomando-se cuidado para não ocorrer a formação de camadas durante o empacotamento. Uma membrana de nylon foi utilizada no fundo de cada coluna e duas camadas de filtro de fibra de vidro foram colocadas no topo do solo empacotado para distribuir água uniformemente na entrada. Um pequeno orifício na tampa superior manteve a pressão atmosférica na região superior de cada coluna durante o aumento do teor de umidade. $O$ grau de saturação requerido na coluna de solo foi atingido pela manutenção da condição de fluxo estacionário. Uma distribuição homogênea do teor de umidade pela coluna foi obtido pela instalação de uma tubulação de teflon na saída para manter a pressão negativa constante no fundo da coluna. 
O ozônio gasoso foi passado através do controlador de vazão para regular para o valor de vazão desejado. O ozônio gasoso que passou através da coluna de solo passou por um espectrofotômetro UV equipado com uma célula de fluxo para monitoramento contínuo da concentração de ozônio gasoso. Durante todo o ensaio, o ozônio gasoso foi medido no comprimento de onda de $254 \mathrm{~nm}$, e os resultados foram registrados no sistema de aquisição de dados do computador. Este sistema permitiu que a curva breakthrough de ozônio fosse plotada continuamente. Somente a concentração de ozônio em equilíbrio foi alcançada, uma válvula de três vias conectou o fluxo direto de ozônio à coluna. A saída de ozônio foi trapeada em solução de $\mathrm{KI}$ para quantificar o ozônio.

A remoção máxima de fenantreno após $1 \mathrm{~h}$ de injeção de ozônio foi alcançada nas colunas empacotadas com areia assada, seguida em ordem decrescente, pelas microesferas de vidro, e pela areia, indicando que a decomposição do ozônio catalítica com matéria orgânica em colunas empacotadas com areia assada melhorou a formação de radicais hidroxila e resultou no aumento da remoção de contaminantes. Em geral a eficiência de remoção dos multicomponentes $\mathrm{C}_{10}-\mathrm{C}_{24}$ DROs após $14 \mathrm{~h}$ de ozonização foi de $78,7 \%$.

\subsection{Métodos Analíticos}

\subsubsection{Tetracloroetileno (PCE)}

Para análise de compostos halogenados voláteis na água podem ser utilizados os métodos de cromatografia gasosa com detector por ionização em chama (FID), detector por captura de elétrons (ECD) e cromatógrafo gasoso acoplado ao espectrômetro de massa.

A cromatografia é um método de análise química baseado na distribuição diferencial dos componentes da amostra entre uma fase móvel e uma fase estacionária. Pode ser de três tipos: cromatografia líquido-sólido, líquido-líquido, ou gás-líquido. Esta última é 
frequentemente chamada de cromatografia gasosa. $\mathrm{Na}$ cromatografia gasosa (CG), a fase móvel é representada pelo gás transportador inerte; e a fase estacionária, por um líquido mantido em um sólido adsorvente. A separação ocorre com base na pressão de vapor dos compostos volatilizados e na afinidade deles pela fase estacionária que passa pela coluna (Hewitt, 1991).

O gás escolhido para fase móvel deve ser inerte, puro e compatível com o sistema detector usado. Em geral, os gases transportadores mais comumente utilizados para uma elevada eficiência da coluna são nitrogênio e argônio; contudo, se a velocidade de separação é mais importante, gases de baixo peso molecular como o hélio ou hidrogênio podem ser usados.

Previamente a análise, as amostras são dissolvidas em um solvente volátil, como acetona ou metanol e acondicionadas em vials. A seguir, estas são retiradas através de um septo de vedação com auxílio de uma seringa, e injetadas em uma coluna separadora de espiral de vidro ou aço inoxidável revestida por um filme de fase estacionária. As amostras podem ser diretamente injetadas na coluna (splitless) ou ser divididas (split) e ter somente uma quantidade determinada aplicada na coluna, prevenindo que a coluna seja sobrecarregada. A coluna é mantida em um forno com temperatura controlada que volatiliza o composto a ser analisado. No final da coluna, o soluto passa por um detector seletivo, que diferencia os compostos de interesse e os materiais extraídos.

Qualquer coluna de CG de fase estacionária deve ser termicamente estável na temperatura usada para análise, e pode ser de dois tipos: comprimida (packed) ou capilar (capillary). A coluna capilar é utilizada para analisar traços de amostras ambientais devido a sua elevada sensibilidade e reprodutibilidade; enquanto as colunas comprimidas são utilizadas apenas para análise de compostos apolares e pouco polares.

As amostras ambientais podem ser encontradas em três matrizes principais: sólida, líquida, ou gasosa. As técnicas de extração para análise cromatográfica podem variar 
de acordo com cada meio, mas em geral os métodos usados são: lixiviação; partição líquido-líquido, partição gás-líquido, equilíbrio gás-sólido, e partição líquido-sólido.

Na lixiviação, os compostos de interesse são extraídos de um sólido por um solvente, técnica usada para análise de contaminantes orgânicos por soxhlet, onde a amostra é mantida em um dedal de papel, e enxaguada repetidamente com água morna até que o material extraível seja removido.

Na partição líquido-líquido, os compostos de interesse são extraídos da solução da amostra usando outro líquido imiscível.

A partição gás-líquido, utilizada para análise de contaminantes voláteis, consiste na retirada de uma amostra de gás de um espaço vazio (headspace) após entrar em equilíbrio estático com um líquido.

No equilíbrio gás-sólido, amostras de materiais voláteis são extraídas usando um gás inerte como o hélio ou o nitrogênio.

$\mathrm{Na}$ partição líquido-sólido, os compostos de interesse em água podem ser concentrados em resinas, e subsequentemente diluídos (Hewitt, 1991).

O detector por captura de elétrons (ECD) é seletivo para compostos eletronegativos, especialmente para moléculas cloradas, fluoradas, e bromadas, sendo sensível para alguns destes compostos em partes por trilhão (ppt). No interior do detector tem níquel 63 radioativo selado, que emite elétrons (partículas beta) que colidem e ionizam as moléculas de gás formadas (nitrogênio ou P5). Esta reação forma uma nuvem estável de elétrons livres na célula do detector. Quando compostos eletronegativos entram na célula ECD de uma coluna, eles imediatamente combinam com alguns dos elétrons livres, reduzindo temporariamente o número remanescente na nuvem de elétrons. Quando a quantidade de elétrons diminui, a taxa de pulso aumenta para manter a corrente constante igual a corrente parada. Ao contrário de outros detectores que medem um aumento no sinal de resposta, o detector eletrônico ECD mede a taxa de pulso necessária para manter a corrente parada (SRI, 2014). 


\subsubsection{Ozônio}

Existem alguns métodos químicos para a determinação de ozônio em ar e em água (SACHDEV et al, 1972; RIDLEY et al, 1992; PLAISANCE et al 2007; PARRISH e FEHSENFELD 2000; SCHURATH et al, 1991), porém poucos são seletivos e sensíveis para a determinação deste analito em tempo real. A principal dificuldade está na etapa de amostragem, pois o ozônio possui um elevado potencial de oxidação e reage com diferentes moléculas, o que pode interferir na sua quantificação.

A seguir serão detalhados os principais métodos para determinação de ozônio reconhecidos pela Associação Internacional de Ozônio (IOA). Vale ressaltar que métodos como a análise direta amperométrica, calorimetria, e mudanças de pressão isotérmicas também são aplicáveis a determinação de ozônio gasoso, entretanto o método de análise direta amperométrica apresenta os mesmos interferentes do método iodométrico.

O método iodométrico é o método químico mais utilizado, e foi considerado por muito tempo um padrão para determinação da concentração de ozônio em ar (BIKDSALL, 1952). Este método baseia-se na reação de redução de iodeto a iodo (eq. 3.27), e sofre interferência das moléculas que interagem com o iodeto (PASSARETTI FILHO, 2010).

$$
\mathrm{O}_{3}+2 \mathrm{I}^{-}+\mathrm{H}_{2} \mathrm{O} \rightarrow \mathrm{O}_{2}+\mathrm{I}_{2}+2 \mathrm{OH}^{-} \text {(3.27) }
$$

As medições podem ser feitas diretamente no gerador ou na fase líquida, sendo o gás borbulhado por um frasco contendo iodeto de potássio $(\mathrm{KI})$, onde o iodeto $\left(\mathrm{I}^{-}\right)$é oxidado pelo ozônio (eq.3.28) (LANGLAIS et al, 1991; GOTTSCHALK et al, 2000). O iodo (I2), produto da reação, é titulado com tiossulfato de sódio $\left(\mathrm{Na}_{2} \mathrm{~S}_{2} \mathrm{O}_{3}\right)$. A concentração de ozônio pode ser calculada pelo consumo de $\mathrm{Na}_{2} \mathrm{~S}_{2} \mathrm{O}_{3}$ (eq.3.29) (GOTTSCHALK et al., 2000; IOA, 1996).

$$
\mathrm{KI}+\mathrm{O}_{3}+\mathrm{H}_{2} \mathrm{O} \rightarrow \mathrm{I}_{2}+\mathrm{O}_{2}+\mathrm{KOH}(3.28)
$$




$$
3 \mathrm{I}_{2}+6 \mathrm{~S}_{2} \mathrm{O}_{3}^{2-} \rightarrow 6 \mathrm{I}^{-}+3 \mathrm{~S}_{4} \mathrm{O}_{6}^{2-}(3.29)
$$

Dentre os interferentes do método de iodometria estão oxidantes como os óxidos de nitrogênio, que podem se formar durante a geração de ozônio no ar. A sua determinação pode ser feita por absorção em solução de hidróxido de sódio com subsequente determinação do íon nitrito. Os efeitos do óxido de nitrito podem ser eliminados passando o gás contendo ozônio por permanganato de potássio.

A determinação do ozônio gasoso ou dissolvido pelo espectrofotômeto baseia-se na absorção de luz na região de curto comprimento de onda UV com uma absorção máxima de 253,7 nm para ozônio gasoso e 260 nm para ozônio dissolvido. Em 253,7 $\mathrm{nm}$, os valores geralmente aceitos para o coeficiente de absorção de ozônio na fase gasosa é $3.000 \pm 30 \mathrm{M}^{-1} \mathrm{~cm}^{-1}$ a 273K e $1 \mathrm{~atm}$ (LANGLAIS et al., 1991; GOTTSCHALK et al., 2000; MCELROY et al. (USEPA), 1997); enquanto para $260 \mathrm{~nm}$, este coefciente deve estar entre 2.900 e $3600 \mathrm{M}^{-1} \mathrm{~cm}^{-1}$ (LANGLAIS et al., 1991). A diminuição da intensidade UV para $\lambda=254 \mathrm{~nm}$ é proporcional a concentração de ozônio baseada na lei de absorção de Lambert-Beer (eq. 3.30).

$$
I_{l}=I_{0} 10^{\varepsilon \cdot(M) l}(3.30)
$$

Onde: $I_{l}$ Intensidade passando através da célula de absorção contendo a amostra; $I_{0}$ Intensidade passando através da célula de absorção contendo a referência; $c(M)$ concentração em molar; $l$ largura interna da célula de absorção em $\mathrm{cm} ; \varepsilon$ coeficiente de extinção molar em $(\mathrm{Mcm})^{-1}$.

$\varepsilon_{254 \mathrm{~nm}}$ cerca de $3.000(\mathrm{Mcm})^{-1}$, dependendo da fonte na literatura.

A Lei de Lambert-Beer é válida entre $0,1<\frac{\lg I_{I}}{I_{0}}<1$ e a variação da concentração depende da largura de absorção da célula. Os sistemas existentes podem medir 
concentrações maiores que $600 \mathrm{mg} / \mathrm{L}$ na fase gasosa (GOTTSCHALK et al., 2000; MCELROY et al. (USEPA), 1997).

O método de combustão catalítica utiliza pelistores para medir os gases ou vapores combustíveis no ar, acima do limite inferior de explosividade (LIE) do gás. O LIE de um gás é a concentração mínima de um gás no ar que uma fonte de ignição causará uma explosão.

O sensor padrão consiste em um par de elementos combinados, tipicamente referido como um detector ou compensador (elemento referência). O detector compreende uma bobina de fio de platina embutida dentro de uma esfera de material catalítico, enquanto o compensador é similar, exceto pelas esferas que não contém material catalítico e são inertes.

Ambos elementos tem como seu princípio de funcionamento a ponte de Wheatstone, que produz energia somente se a resistência do detector diferir daquela do compensador.

A ponte é alimentada por uma tensão de corrente direta constante capaz de aquecer o par de elementos entre $500^{\circ} \mathrm{C}$ e $550^{\circ} \mathrm{C}$. O gás inflamável em contato com o detector oxida apenas o elemento catalítico que por sua vez aumenta a resistência gerando uma variação de corrente elétrica na ponte diretamente proporcional a queima deste filamento. Esta variação de corrente é convertida pelo instrumento em LIE, ou seja, o intervalo no qual a concentração é explosiva. O compensador ajuda a compensar as mudanças de temperatura ambiente, pressão e umidade, que afeta ambos elementos igualmente (CITYTECH, 2013; CHROMPACK, 2013).

A calorimetria se baseia na entalpia da decomposição catalisada de ozônio ( $H=142,3$ $\mathrm{kJ} / \mathrm{mol}$ ), cuja diferença de temperatura observada entre o gás que entra e o gás que reage no catalisador é medido por meios de termopares situados em uma célula bem isolada. Esta diferença de temperatura é proporcional a concentração de ozônio no gás (ar ou oxigênio) (LANGLAIS et al, 1991). 
O método de mudança de pressão isotérmica é baseado na geração de um número aumentado de moléculas de gás durante a destruição de ozônio a temperatura constante, cuja reação é apresentada na eq. 3.31.

$$
2 \mathrm{O}_{3} \rightarrow 3 \mathrm{O}_{2}
$$

Quando esta reação ocorre isotermicamente em um frasco fechado, o aumento da pressão do gás contido é proporcional a concentração de ozônio (LANGLAIS et al, 1991). 


\section{MATERIAIS E MÉTODOS}

A investigação experimental compreendeu a coleta e caracterização de amostras de água subterrânea e solo da Reserva Biológica de Mogi Guaçu; a concepção e o desenvolvimento de um equipamento para ensaios de injeção de ozônio em coluna; a seleção do método de contaminação artificial de água por PCE; realização de ensaios de saturação e decaimento de ozônio; o desenvolvimento do procedimento experimental para ensaios batch e de coluna para degradação de PCE por injeção de ozônio; a seleção de técnicas analíticas; e a realização de ensaios químicos analíticos para quantificação de PCE e ozônio.

Os efluentes líquidos gerados nos experimentos laboratoriais foram acondicionados em tambores para solventes orgânicos, que serão posteriormente destinados adequadamente.

\subsection{Materiais}

A água deionizada isenta de contaminantes orgânicos e iônicos foi purificada pelo sistema Milli- $\mathrm{Q}^{\circledR}$ Gradient com fonte de alimentação Elix 10, sendo referida como água ultrapura ao longo do texto. Foi utilizada nos ensaios com o objetivo de verificar os resultados em uma matriz inerte e sem impurezas.

As microesferas de vidro polidas (glass beads), com $2 \mathrm{~mm}$ de diâmetro, fabricadas pela alemã Sigmund Lindner, foram adquiridas comercialmente da marca Schott para a utilização nos ensaios com passagem de ozônio a fim de representar um material inerte de distribuição porosimétrica bem estabelecida. Na sua composição são encontrados silicato de sódio e cálcio, considerado o tipo de vidro mais comum. Dentre suas especificações estão: peso específico de $2,5 \mathrm{~kg} / \mathrm{L}$, diâmetro de 2,0 $\pm 0,2 \mathrm{~mm}$, densidade aparente de $1,5 \mathrm{~kg} / \mathrm{L}$, e esfericidade $\geq 0,98$. Segundo informações fornecidas pelo fabricante, as contas de vidro são compostas por $69,10 \%$ de dióxido de sílica $\left(\mathrm{SiO}_{2}\right)$, $14,55 \%$ de óxido de sódio $\left(\mathrm{Na}_{2} \mathrm{O}\right.$ ), 8,20\% de óxido de cálcio $(\mathrm{CaO}), 3,15 \%$ de óxido de alumínio $\left(\mathrm{Al}_{2} \mathrm{O}_{3}\right), 1,45 \%$ de óxido de magnésio ( $\left.\mathrm{MgO}\right), 1,20 \%$ de óxido bórico $\left(\mathrm{B}_{2} \mathrm{O}_{3}\right), \mathrm{e}$ 
$1,15 \%$ de óxido de zinco $(\mathrm{ZnO})$. O teor de metais pesados das contas de vidro está dentro dos limites permitidos pela Diretiva no 65 publicada pelo Conselho e Parlamento Europeu em 08 de Junho de 2011, com concentrações de cádmio (Cd) inferiores a 100 ppm e de chumbo $(\mathrm{Pb})$, cromo hexavalente $(\mathrm{Cr} \mathrm{VI})$ e mercúrio $(\mathrm{Hg})$ inferiores a 1.000 ppm. Vale ressaltar que os valores orientadores para esses metais publicados pela CETESB para o estado de São Paulo em 2014 são mais restritivos que os limites europeus, exceto para cádmio, que apresenta valor de intervenção de 140 ppm para cenário industrial, e chumbo, que apresenta valor de intervenção de 4.400 ppm para cenário industrial. Considerando ainda o cenário residencial, os valores de intervenção do cromo hexavalente e mercúrio são de, respectivamente, 10 e 7 ppm.

A areia média lavada foi adquirida comercialmente da marca $A B$ Areias, cuja extração é feita pela empresa Roseira Extração e Comércio de Areia e Pedra Ltda. e tem o propósito de representar um material de distribuição granulométrica uniforme e o mais semelhante possível das microesferas de vidro.

O solo laterítico predominantemente arenoso selecionado para o presente estudo foi coletado na Trilha do Goiabal, a cerca de 40 metros do início do acesso ao Setor de Pesquisa Perturbatória SPP-01, Gleba A, da Reserva Biológica Mogi Guaçu, localizada no bairro Martinho Prado Júnior, município de Mogi Guaçu, SP. As coordenadas UTM do ponto de coleta do solo segundo DATUM Sistema de Referência Geocêntrico para as Américas (SIRGAS, 2000) estão apresentadas na Tabela 4.1 e na Figura A.1 (Anexo A).

A água subterrânea foi coletada em dois poços existentes na Fazenda Campininha: um poço cacimba localizado atrás da sede do Instituto de Botânica (Norte) e um poço tubular profundo situado na lateral Este da sede do Instituto Florestal, ambos situados no bairro Martinho Prado Júnior, município de Mogi Guaçu, SP. As coordenadas UTM dos pontos de coleta de água subterrânea segundo DATUM Sistema de Referência Geocêntrico para as Américas (SIRGAS 2000), Fuso $23 S$ estão apresentadas na Tabela 4.1 e no Anexo A. 
Tabela 4.1 Coordenadas e cota altimétrica dos pontos de coleta de solo e poços

\begin{tabular}{|l|c|c|c|}
\hline \multicolumn{1}{|c|}{ Pontos de coleta de solo e poços } & \multicolumn{2}{c|}{ Coordenadas UTM } & \multirow{2}{*}{ Cota (m) } \\
\cline { 2 - 4 } & Norte (m) & Este (m) & \\
\hline Solo (amostras indeformadas e deformadas) & 7.537 .282 & 276.832 & 648 \\
\hline Água Subterrânea (Poço cacimba) - P-01 & 7.537 .843 & 277.703 & 645 \\
\hline Água Subterrânea (Poço Tubular Profundo) - P-02 & 7.535 .137 & 278.061 & 632 \\
\hline
\end{tabular}

Fonte: Informações coletadas com GPS Garmin, modelo GPSmap 62sc, DATUM SIRGAS 2000, Fuso 235

4.1.1 Caracterização da Área de Coleta de Amostras de Solo e Água Subterrânea

A área de estudo, Fazenda Campininha, está situada na porção sudoeste do município de Mogi Guaçu, o qual faz limite com os municípios de Aguaí e Pirassununga ao Norte; Conchal e Moji Mirim ao Sul; Leme e Araras a Oeste; e Estiva Gerbi a Leste.

A Fazenda Campininha, que engloba a Reserva Biológica Mogi Guaçu (Instituto de Botânica - Glebas A e B), a Estação Experimental Mogi Guaçu (Instituto Florestal) e a Reserva Ecológica Mogi Guaçu, perfaz uma área total de 4.500,76 ha. Suas divisas são contornadas pelo Rio Mogi Guaçu ao Sul e pelo Rio Capetinga ao Norte.

O solo regional é classificado pedologicamente como um Latossolo Vermelho Amarelo (Figura A.2 - Anexo A). No âmbito geológico, a área está predominantemente englobada pela Formação Aquidauana, por depósitos aluvionares ao Sul e depósitos colúvio-eluvionares ao Norte nas proximidades dos rios (Figura A.3 - Anexo A).

As amostras de solo e água subterrânea foram coletadas na área correspondente à Formação Aquidauana, depositada sob influência do ambiente glacial, em subambientes fluvial e lacustre, cuja base encontra-se sobre o Embasamento PréCambriano. Esta formação é dividida em três intervalos: um inferior, composto por arenitos vermelhos a róseos, granulação média a grossa, estratificação cruzada 
acanalada, e diamictitos, arenitos esbranquiçados e conglomerado basal intercalados; um médio, composto por siltitos, folhelhos e arenitos finos, vermelhos a róseos, laminados, com intercalações de diamictito e folhelho de cor cinza-esverdeado; e uma superior, constituída predominantemente por arenitos vermelhos com estratificação cruzada (CPRM, 2006).

No que se refere ao contexto hidrogeológico regional (Figura A.4 - Anexo A), verifica-se que a área de estudo encontra-se situada na Depressão Periférica Paulista, onde está inserida a faixa aflorante do Aquífero Tubarão, zona do Mogi Guaçu, de colinas amplas de topos tabulares e altitudes entre 500 e 650 m; verifica-se ainda a compartimentação da produtividade em escala local, cujas águas são fracamente salinas, bicarbonatadas cálcicas, e apresentam pH variando entre 4,8 e 8,9.

\subsubsection{Coletas de Amostras em Campo}

As amostras deformadas de solo foram coletadas no horizonte $\mathrm{B}$, conforme ilustrado esquematicamente na Figura 4.1, em uma profundidade entre 0,4 e 0,8 m. Com o auxílio de uma pá e uma enxada previamente lavadas, foi aberto um buraco em formato quadrado na superfície do solo com dimensões de $0,8 \mathrm{~m}$ por $0,8 \mathrm{~m}$, cerca de $7,5 \mathrm{~m}$ a Este do acesso pela Trilha do Goiabal. O critério para escolha da profundidade de coleta do solo foi a obtenção de um solo sem a presença de raízes e sem uma porcentagem elevada de matéria orgânica. As amostras deformadas foram coletadas com um trado caneco de 2" e seguiram os procedimentos da norma técnica ABNT NBR 15.492/2007 - Sondagem de reconhecimento para fins de qualidade ambiental.

Também foram coletados 8 anéis volumétricos de aço inox com amostras indeformadas para caracterização do solo, com auxílio de um coletor da Eijekelkamp, sendo quatro a $0,4 \mathrm{~m}$ e quatro a 0,6 m de profundidade. As posições de coleta são indicadas em uma figura esquemática apresentada na Figura A.1 (Anexo A).

As amostras deformadas foram acondicionadas parte em sacos com capacidade para $30 \mathrm{~kg}$ e parte em sacos zips, enquanto os cilindros de aço inox com as amostras indeformadas foram embalados com papel filme, papel alumínio e por fim em sacos zips 
selados após a retirada de ar do interior, devidamente identificados com a data de coleta, horário, numeração do anel e profundidade de coleta.

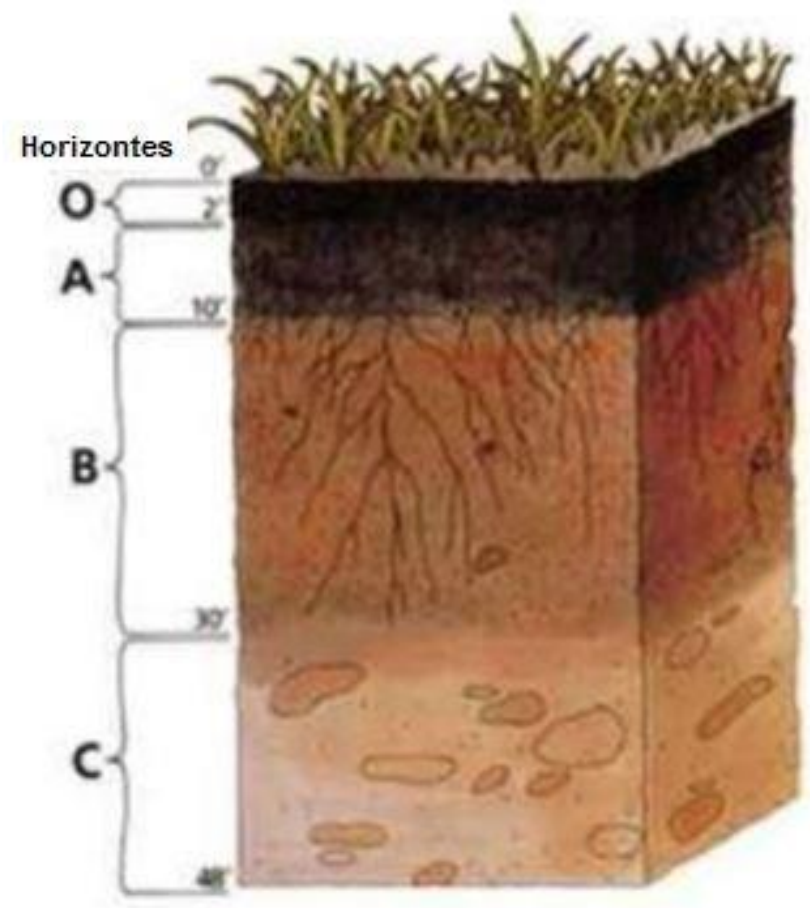

Figura 4.1 Horizontes do solo

A água subterrânea foi coletada em um poço cacimba com profundidade de $8,3 \mathrm{~m}$ e nível d'água de $3,0 \mathrm{~m}$; e em um poço tubular profundo, com profundidade de $120 \mathrm{~m}$, com bombas de captação fixas existentes em ambos os poços. O objetivo foi comparar águas subterrâneas com diferentes composições químicas.

Para amostragem de águas subterrâneas, deixou-se a água correr por alguns minutos, a fim de evitar coletar amostras de água parada na tubulação e garantir que a água fosse representativa do aquífero.

As amostras de água subterrânea coletadas foram armazenadas em galões de $20 \mathrm{~L}$, devidamente identificados. 


\subsubsection{Caracterização dos Materiais}

O solo, a areia, e as microesferas de vidro foram caracterizados geotecnicamente no Laboratório de Mecânica dos Solos da Escola Politécnica da Universidade de São Paulo (LMS-EPUSP). A caracterização física e química do solo foi realizada pela Escola Superior de Agricultura Luiz de Queiroz da Universidade de São Paulo (ESALQ) e a caracterização mineralógica do solo, pelo Laboratório de Caracterização Tecnológica da Escola Politécnica da Universidade de São Paulo (LCT-EPUSP).

Para caracterização geotécnica do solo foram realizados os seguintes ensaios: distribuição granulométrica por peneiramento e sedimentação conforme a norma ABNT NBR 7181/1984; limites de Atterberg (ABNT NBR 7180/1984 e 6459/1984); a massa específica dos grãos (ABNT NBR 6508/1984); o teor de umidade por estufa (ABNT NBR 6457/1986); o teor de matéria orgânica por mufla (ABNT NBR 13600/1996); e porosidade (por picnômetro a ar, seguindo manual da Eijekelkamp).

Para caracterização geotécnica da areia e das microesferas de vidro foram realizados ensaios para determinar a distribuição granulométrica por peneiramento; e o índice de vazios máximo e mínimo (ABNT NBR 12004/1990 e ABNT NBR 12051/1991, respectivamente). Para a areia, também foi determinada a massa específica dos grãos (ABNT NBR 6508/1984).

A análise granulométrica por densímetro, conforme método Bouyoucos descrito no Boletim técnico 106, IAC, 2009, a densidade real, a densidade de partículas, a porosidade total, a porosidade efetiva, a macroporosidade e a microporosidade foram determinados para caracterização física do solo, considerando a capacidade de campo igual a 0,1 bar, conforme estabelecido no manual da Empresa Brasileira de Pesquisa Agropecuária (EMBRAPA, 1997), considerando macroporosidade, o volume de água drenado até 0,1 bar, e microporosidade, a retenção de água entre 0,1 bar e a secagem na estufa a $105^{\circ} \mathrm{C}$.

Para caracterização química, foram determinados: a capacidade de troca catiônica (CTC) por métodos de espectrofotometria e titulação descritos no manual da EMBRAPA 
(1997), o potencial hidrogeniônico $(\mathrm{pH})$, a condutividade elétrica (CE), o teor de matéria orgânica e a fração de carbono orgânico total (foc ou COT) por titulação com solução de dicromato de potássio (Boletim técnico 106, IAC, 2009). Este último parâmetro também foi determinado por combustão via seca, indicando adicionalmente os valores em porcentagem de nitrogênio e sua relação com o carbono.

Por fim, a caracterização mineralógica do solo e da areia foi realizada por meio da quantificação de fases por difratometria de raios $X$, para determinação dos minerais presentes no solo; e fluorescência de raios $X$, para determinação da porcentagem de elementos existentes nas amostras de solo (análise química semiquantitativa). A difratometria utilizou o método do pó, enquanto a fluorescência realizou análise sem padrões dos elementos químicos detectados de flúor a urânio.

As técnicas dos ensaios supracitados encontram-se descritos mais detalhadamente no Apêndice.

A caracterização das amostras de água subterrânea foi realizada no Laboratório de Engenharia Química da Escola Politécnica da Universidade de São Paulo. Foram monitorados os seguintes parâmetros físico-químicos: temperatura, potencial hidrogeniônico $(\mathrm{pH})$, condutividade elétrica, potencial de óxido-redução (ORP). Além disso, foram realizadas as determinações da alcalinidade, o teor de carbono orgânico total e carbono inorgânico, e metais dissolvidos (lista CETESB).

A determinação do $\mathrm{pH}$ e da temperatura foi realizada com auxílio do pHmetro da Tecnal, modelo Tec-3MP; a CE pelo condutívimetro da Tecnal, modelo Tec-4MP, e o ORP pelo medidor da Logem, modelo SCAN 922, com eletrodo de potencial de ORP da sensorglass, modelo SRR03 selado com anel de prata (reduz contaminação cruzada com a amostra), todos previamente calibrados com as respectivas soluções padrões.

A determinação da alcalinidade foi realizada por titulação acidificando o meio com volume conhecido de ácido sulfúrico. A base de hidróxido de sódio $0,05 \mathrm{M}$ foi padronizada usando biftalato de potássio. A diferença da titulação entre a água subterrânea e a água ultrapura representa a quantidade de base presente na água que se pretende determinar a alcalinidade em bicarbonato de sódio. 
A determinação do teor de matéria orgânica foi realizada em duplicata, com o equipamento COT da Shimadzu, modelo TOC-L, que está acoplado ao amostrador automático da Shimadzu, modelo ASI-L.

Para a determinação dos metais dissolvidos, as amostras de água subterrânea do poço cacimba e poço tubular profundo, identificadas respectivamente como P-01 e P-02 foram filtradas em membranas de 0,45 $\mu \mathrm{m}$ com auxílio de bomba a vácuo, armazenadas em frascos com capacidade para $250 \mathrm{~mL}$ com ácido nítrico $\left(\mathrm{HNO}_{3}\right)$ para preservação, e acondicionadas em caixa térmica de isopor para garantir temperaturas de $4 \pm 2^{\circ} \mathrm{C}$ durante o transporte até o destino final no laboratório Bioagri Ambiental, em Piracicaba - SP, conforme recomendações do Guia de Coleta e Preservação de Amostras de Água da CETESB (CETESB, 2011).

Foram analisados os metais da Lista CETESB: alumínio, antimônio, arsênio, bário, boro, cádmio chumbo, cobalto, cobre, cromo, ferro, manganês, mercúrio, molibdênio, níquel, prata, selênio, vanádio e zinco, de acordo com o método SMEWW 3125B (2012). O certificado de acreditação do laboratório para análise desses parâmetros, a cadeia de custódia e os laudos com os resultados analíticos encontram-se no Anexo D.

\subsection{Concepção e Desenvolvimento do Aparato Experimental}

\subsubsection{Dimensões da Coluna}

Após levantamento bibliográfico dos ensaios com injeção de ozônio em escala de laboratório para estudo de água e solo contaminados com hidrocarbonetos e clorados, observaram-se dimensões de colunas ou reatores em coluna variando entre $1,5 \mathrm{~cm}$ de diâmetro interno e $6 \mathrm{~cm}$ de altura, e $54 \mathrm{~cm}$ de diâmetro interno e $107 \mathrm{~cm}$ de altura. A relação de proporcionalidade entre o diâmetro interno e a altura da coluna, entretanto, variou de 1 para 2 a 1 para 12. (CARR; BAIRD, 2000; POZNYAK; MANZO; MAYORGA, 2003; SUNDER; HEMPEL, 1997; PENNELL et al., 1994; ALVAREZ et al., 2012; CHOI et al., 2002; JUNG; KIM; CHOI, 2004). 
Após consulta a especialista ${ }^{2}$ foi definida a relação entre o diâmetro interno e a altura da coluna de 1 para 10 para evitar a formação de vórtices. Ademais, a relação entre diâmetro da coluna e diâmetro da partícula deve ser maior do que 20 para que os efeitos de parede no transporte de massa sejam desprezíveis (ARBUCKLE; HO, 1990; HRISTOVSKI, BAUMGARDNER, WESTERHOFF, 2007).

Como o diâmetro máximo das microesferas de vidro, da areia e do solo estudado é 2,0 $\mathrm{mm}$, o diâmetro mínimo recomendado para a coluna é de $40 \mathrm{~mm}$. A coluna foi, portanto, construída com $5 \mathrm{~cm}$ de diâmetro interno e $50 \mathrm{~cm}$ de altura.

\subsubsection{Escolha dos Materiais}

Para a coluna e conexões do aparato experimental foram utilizados materiais inertes compatíveis com o ozônio e PCE, dentre os quais estão o teflon, aço inoxidável, vidro borossilicato e nylon (CARR; BAIRD, 2000; PENNELL et al., 1994; CHOI et al., 2002; JUNG; KIM; CHOI, 2004). Para o ozônio, especialistas consultados indicaram adicionalmente aos materiais já citados, o uso de alumínio, silicone, viton e kynar (PVDF).

A partir da durabilidade e resistência dos materiais ao ozônio e PCE, optou-se por fabricar o corpo da coluna em vidro borossilicato. Para vedação da coluna, as extremidades (topo e base) são flangeadas e apresentam um sulco para encaixe do 0 ring de silicone.

Na tampa da entrada da coluna (base), também de vidro borossilicato, foi fundida uma placa porosa no4 (10-16 $\mu \mathrm{m})$ de vidro sinterizado da marca Schott. Em sua parte interna, pode-se colocar uma tela de nylon de 120 ou 150 mesh para evitar que grãos finos da areia e do solo obstruam os poros da placa porosa.

A tampa de saída da coluna (topo), de teflon, possui um orifício central com engate em aço inoxidável para conectar a mangueira de silicone ou teflon e três orifícios laterais: um com septo de borracha Thermogreen® para coleta de amostras líquidas e gasosas,

\footnotetext{
${ }^{2}$ LAGE FILHO, F. A. (2013). Comunicação pessoal.
} 
um com dois o-rings de silicone vedando o eletrodo para medição do $\mathrm{pH}$, e um para eletrodo de temperatura (neste caso, o orifício foi perfurado de forma a que o eletrodo fique encaixado sem folga e sem a necessidade de material vedante).

\subsubsection{Escolha do Difusor}

Carr e Baird (2000) e Pennell et al. (1994) utilizaram nos seus aparatos experimentais um difusor na entrada da coluna para promover a distribuição radial e uniforme do fluxo de gás, enquanto Choi et al. (2002) usaram um papel filtro de fibra de vidro para essa finalidade. Considerando essas referências e após consultas a especialistas ${ }^{3}$, optou-se por um difusor de vidro sinterizado para distribuição uniforme do fluxo e formação de bolhas pequenas, já que quanto menor a bolha, maior a superfície de contato, menor o grau de coalescência, melhor a transferência de ozônio da fase gasosa para a fase líquida e, consequentemente, maior a eficiência.

Ao consultar os fabricantes de difusores de vidro sinterizado, foi constatada a existência de diferentes espessuras, diâmetros e porosidades. As porosidades estão descritas na Tabela 4.2.

Inicialmente, houve uma tentativa de definir uma porosidade intermediária, que cumprisse a função de formação de bolhas de ozônio do menor tamanho possível, mas que também não restringisse o fluxo de gás. A partir desse levantamento de informações, optou-se por iniciar os testes com a placa porosa № 1 imersa em um aquário totalmente preenchido com água, que mostraram que o tamanho da bolha formada era muito grande, tornando desnecessário testar a placa com porosidade $n^{\circ} 0$.

${ }^{3}$ LAGE FILHO; F. A. e CECCHI, T. (2013). Comunicação pessoal. 
Tabela 4.2 Porosidades dos difusores de ozônio

\begin{tabular}{|c|c|c|c|}
\hline Porosidade & Norma ISSO 4793 & $\begin{array}{c}\text { Valor nominal do } \\
\text { diâmetro máximo dos } \\
\text { poros }(\mu \mathrm{m})\end{array}$ & Campos de aplicação \\
\hline 0 & P250 & $160-250$ & $\begin{array}{l}\text { Distribuição de gases. Distribuição em líquidos } \\
\text { de gás sob baixa pressão. Filtração de } \\
\text { precipitados extremamente grosseiros }\end{array}$ \\
\hline 1 & P160 & $100-160$ & $\begin{array}{l}\text { Filtração grosseira, Filtração de precipitados } \\
\text { grosseiros, distribuição de gases líquidos. } \\
\text { Distribuição de líquidos, filtros de poros para } \\
\text { gases, aparelhos de extração para material de } \\
\text { grão grosseiro. Bases para camadas soltas de } \\
\text { filtração para precipitados gelatinosos. }\end{array}$ \\
\hline 2 & P100 & $40-100$ & $\begin{array}{l}\text { Filtração preparatória fina. Trabalhos } \\
\text { preparatórios com precipitados finos. Filtração } \\
\text { de mercúrio }\end{array}$ \\
\hline 3 & P40 & $16-40$ & $\begin{array}{l}\text { Filtração analítica. Trabalhos analíticos com } \\
\text { precipitados semi-finos. Trabalhos preparatórios } \\
\text { com precipitados finos. Filtração na química de } \\
\text { celulose, filtros finos para gás. Aparelhos de } \\
\text { extração para materiais de grão fino. }\end{array}$ \\
\hline 4 & P16 & $10-16$ & $\begin{array}{l}\text { Filtração analítica fina. Trabalhos analíticos com } \\
\text { precipitados muito finos (como p.ex. BaSO2 O4, } \\
\text { Cu2O). Trabalhos preparatórios com } \\
\text { precipitados correspondentemente finos. } \\
\text { Válvulas de mercúrio (retenção e bloqueio). }\end{array}$ \\
\hline 5 & $\mathrm{P} 1,6$ & $1-1,6$ & Filtração de bactérias. \\
\hline
\end{tabular}

A seguir, um funil de büchner com porosidade $\mathrm{n}^{\circ} 3$ foi testado e as bolhas ainda eram grandes, tornando também desnecessário testar a placa de porosidade $n=2$. Especialistas em ozônio consideraram que os testes realizados com a placa de porosidade $n^{\circ} 4$ foram satisfatórios, mas ainda assim foi solicitada ao fabricante uma placa de porosidade ํㅡ 5 para comparação. A placa de porosidade $n^{0}$ 5, contudo, restringia o fluxo devido à pequena porosidade, necessitando de pressão superior à fornecida pelo concentrador de oxigênio utilizado nesses testes preliminares; optou-se, portanto, pela placa porosa n- 4 . A Figura 4.2 ilustra a diferença no tamanho de bolhas das placas de porosidade 1,3 e 4 . 


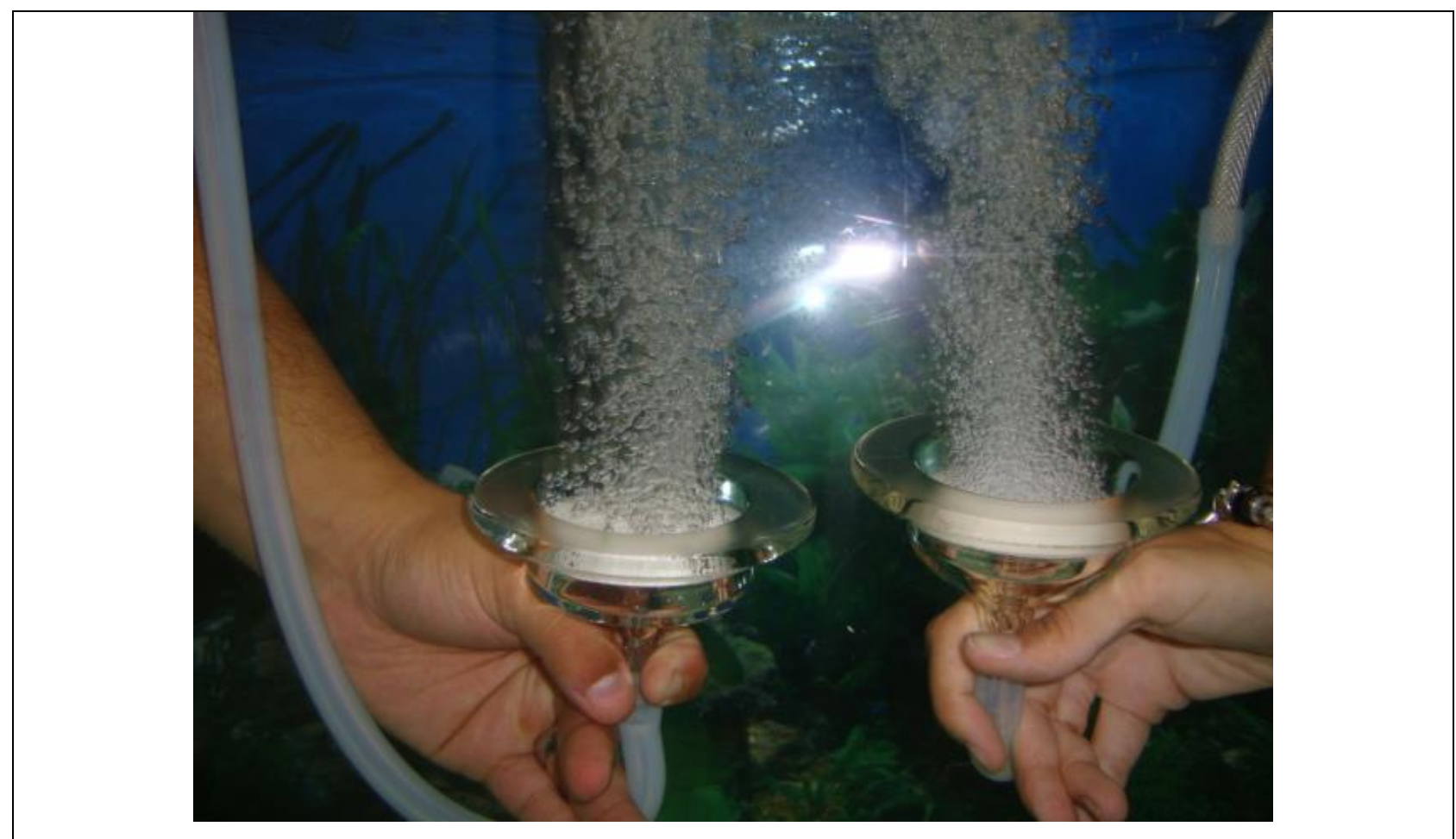

(a)

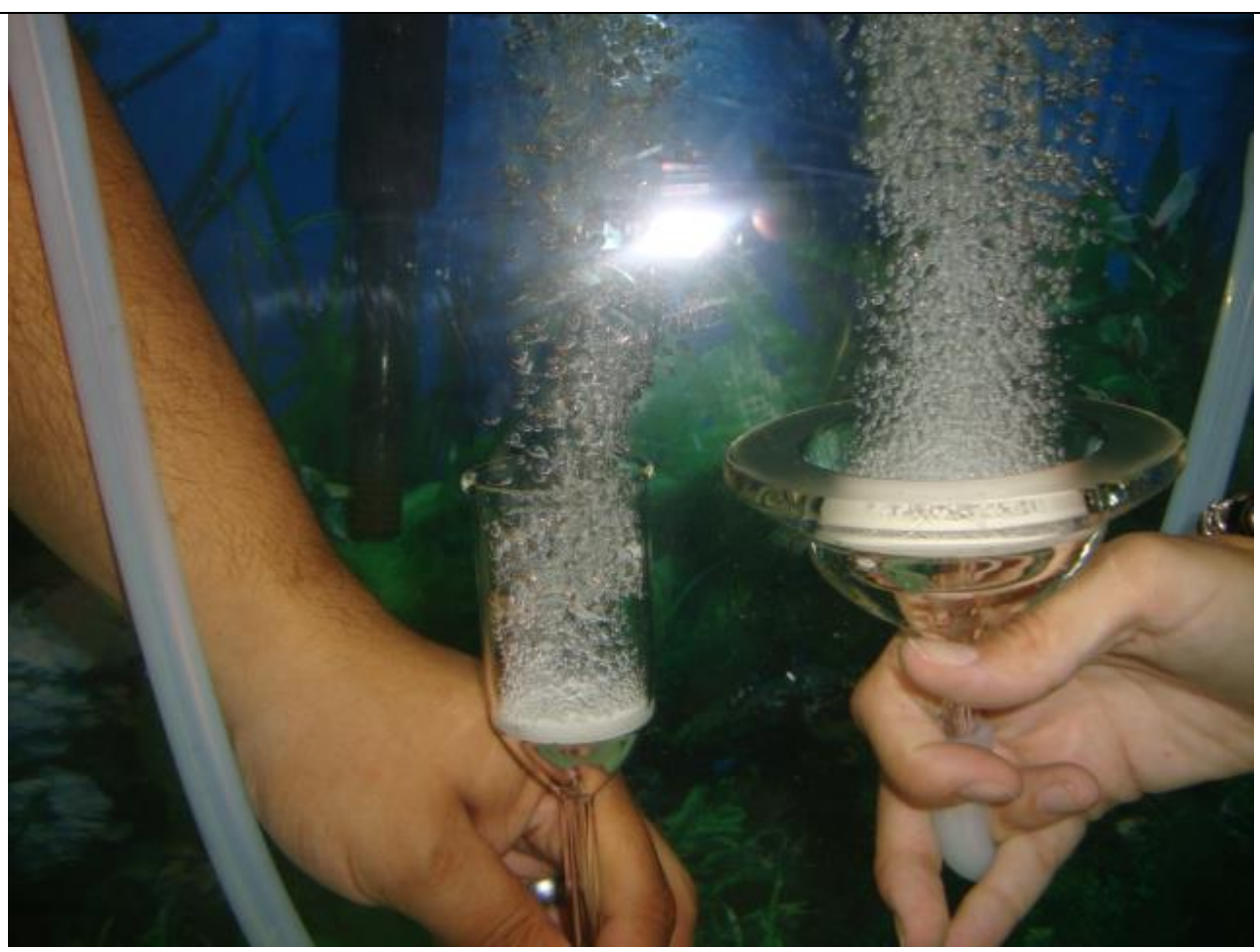

(b)

Figura 4.2 Geração de bolhas pelos difusores: (a) Na esquerda, difusor $n^{\circ} 2$ (40-100 $\left.\mu \mathrm{m}\right)$, e na direita $n^{\circ} 4(10-16 \mu \mathrm{m})(\mathrm{b}) \mathrm{Na}$ esquerda, difusor $n^{\circ} 3(16-40 \mu \mathrm{m})$, e na direita $\mathrm{n}^{\circ} 4(10-16 \mu \mathrm{m})$ 


\subsubsection{Escolha da Vazão e Pressão}

Foram realizados testes nos quais foi observado que a vazão de gás tinha igual ou maior relevância que a porosidade no tamanho e distribuição das bolhas geradas.

O gerador de ozônio utilizado nesta pesquisa, modelo Plus 2.1 da Brasil Ozônio, aplica vazão mínima de 2,5 L/min. Estudos da Brasil Ozônio4 (2014) ao longo dos últimos 9 anos, variando a vazão de ozônio entre 2,5 e $10 \mathrm{~L} / \mathrm{min}$ e as concentrações entre 1 e 20 $\mathrm{g} / \mathrm{m}^{3}$ (nas CNTP), e analisando a transferência de ozônio em água por um venturi, determinaram que a vazão ótima de gás é de $5 \mathrm{~L} / \mathrm{min}$. Atualmente, o gerador de ozônio possui tecnologia mais avançada obtida através de pesquisa e desenvolvimento de processos e produtos, peças e componentes. Com esse avanço a concentração máxima passou a ser de $55 \mathrm{~g} / \mathrm{m}^{3}$, entretanto a vazão de operação do gerador de ozônio se manteve.

Contudo, a vazão mínima de 2,5 L/min ainda gera bolhas grandes, mesmo com o difusor $n^{\circ} 4$. Para determinar a vazão e a pressão ideais, foram realizados testes de injeção de ar comprimido na coluna preenchida com água, com controle de vazão por válvula do tipo agulha e pressão absoluta variando entre 300 e $110.000 \mathrm{~Pa}$. Por observação visual, definiu-se a vazão ideal em função do tamanho de formação da bolha com aparência de chuvisco, ou seja, com maior superfície de contato e maior tempo de permanência na coluna. Esta vazão, medida por bolhômetro, foi $0,122 \mathrm{~L} / \mathrm{min}$ e a pressão correspondente foi de $109.000 \mathrm{~Pa}$.

Foram realizados então testes com o gerador de ozônio utilizado nesta pesquisa para tentar obter a vazão e pressão ideais. Esses testes necessitaram de calibração prévia do controlador de vazão MKS. Como a vazão mínima gerada pelo equipamento é de 2,5 L/min, reduziu-se a vazão por meio de conexões $\mathrm{T}$ : uma parte da vazão foi direcionada para a entrada da coluna, sendo medida pelo bolhômetro, e a parte restante foi desviada para descarte no destruidor de ozônio (cerca de 95\% do ozônio foi descartado). Com este procedimento, obtiveram-se bolhas de ozônio do tipo chuvisco.

\footnotetext{
${ }^{4}$ Brasil Ozônio (2014). Comunicação pessoal.
} 
Os valores de vazão e pressão considerados ideais para formação uniforme de bolhas pequenas no aparato experimental desenvolvido resultaram em, respectivamente, 0,0975 L/min e $110.000 \mathrm{~Pa}$.

\subsubsection{Arranjo Experimental}

O aparato e o método experimental desenvolvidos nesta pesquisa estão apresentados esquematicamente nas Figura 4.3 e Figura 4.4.

Inicialmente a coluna é preenchida com o meio de estudo, colocada no suporte e presa com braçadeiras metálicas. Amostras em triplicata são retiradas pelo septo na tampa de saída (topo) da coluna para determinação da concentração inicial de PCE antes do início do ensaio.

O sistema de alimentação de ozônio é composto por um cilindro de oxigênio $\left(\mathrm{O}_{2}\right)$, um controlador de vazão e um gerador de ozônio $\left(\mathrm{O}_{3}\right)$. O ozônio gerado é separado em dois fluxos, um para a coluna $(0,0975 \mathrm{~L} / \mathrm{min})$ e outro para descarte $(2,4025 \mathrm{~L} / \mathrm{min})$, sendo controlado de forma que a vazão definida para os ensaios seja mantida ao longo do ensaio.

Portanto, a saída do gerador de ozônio está conectada a uma mangueira de silicone em $T$, onde parte do fluxo é conduzida para um controlador de vazão e outra parte passa por uma válvula agulha de precisão de aço inoxidável. A válvula agulha controla o fluxo de descarte do processo, que é direcionado para o destruidor de ozônio acoplado a dois filtros de carvão ativado para absorção do PCE volatilizado e posterior descarte de oxigênio na atmosfera.

A parte do fluxo de ozônio que passa pelo controlador de vazão segue para um sensor de pressão (que também mede a temperatura ambiente) e para um sistema de by-pass manual, o qual direciona o fluxo de forma a obter na entrada ou na saída da coluna, por inversão manual do sentido das válvulas de três vias, a absorbância ou a transmitância de ozônio no espectrofotômetro UV-Visível da Micronal. O sistema de by-pass é 
posicionado para ler os valores de absorbância na saída da coluna somente após estabilizar a absorbância na entrada.

Após a leitura da absorbância, o ozônio gasoso passa pelo difusor na base da coluna em fluxo ascendente. $\mathrm{Na}$ saída da coluna, eletrodos fixados na tampa de teflon monitoram o pH e a temperatura no interior da coluna. $\mathrm{O}$ gás sai da coluna através do orifício central pela mangueira de teflon e o PCE é condensado no trap com metanol.

O trap é composto por um balão volumétrico com capacidade de $1 \mathrm{~L}$ e tampa com sistema de frasco lavador de gás. Este sistema fica imerso em um béquer em banho de álcool e gelo seco, que resfria e condensa todo o PCE que volatilizou para a atmosfera. A amostra condensada é resuspendida após o término do ensaio com água ultrapura, sem deixar espaço vazio no gargalo do balão. Coletam-se amostras do trap em triplicata para determinação da concentração de PCE por cromatografia gasosa acoplada ao espectrômetro de massa (GC/MS).

O fluxo de ozônio passa pelo trap, segue para o sensor de pressão e retorna para o sistema by-pass, onde será conduzido para medição da absorbância e descarte posterior, ou conduzido diretamente para o descarte. A perda de ozônio no trap é considerada desprezível.

Amostras em triplicata são retiradas pelo septo na tampa de saída (topo) para determinação da concentração final de PCE na coluna após o término do ensaio.

Em resumo, são monitoradas a vazão, a pressão e a absorbância do ozônio antes da entrada na coluna, assim como a temperatura, o pH, a pressão e a absorbância na saída da coluna. A absorbância não é lida simultaneamente na entrada e na saída, pois se utiliza o mesmo equipamento de medição, cuja leitura pode ser alternada manualmente por meio de um sistema de by-pass. São determinadas as concentrações de PCE na coluna no início e no final do ensaio (dissolvido) e no trap (volatilizado). 


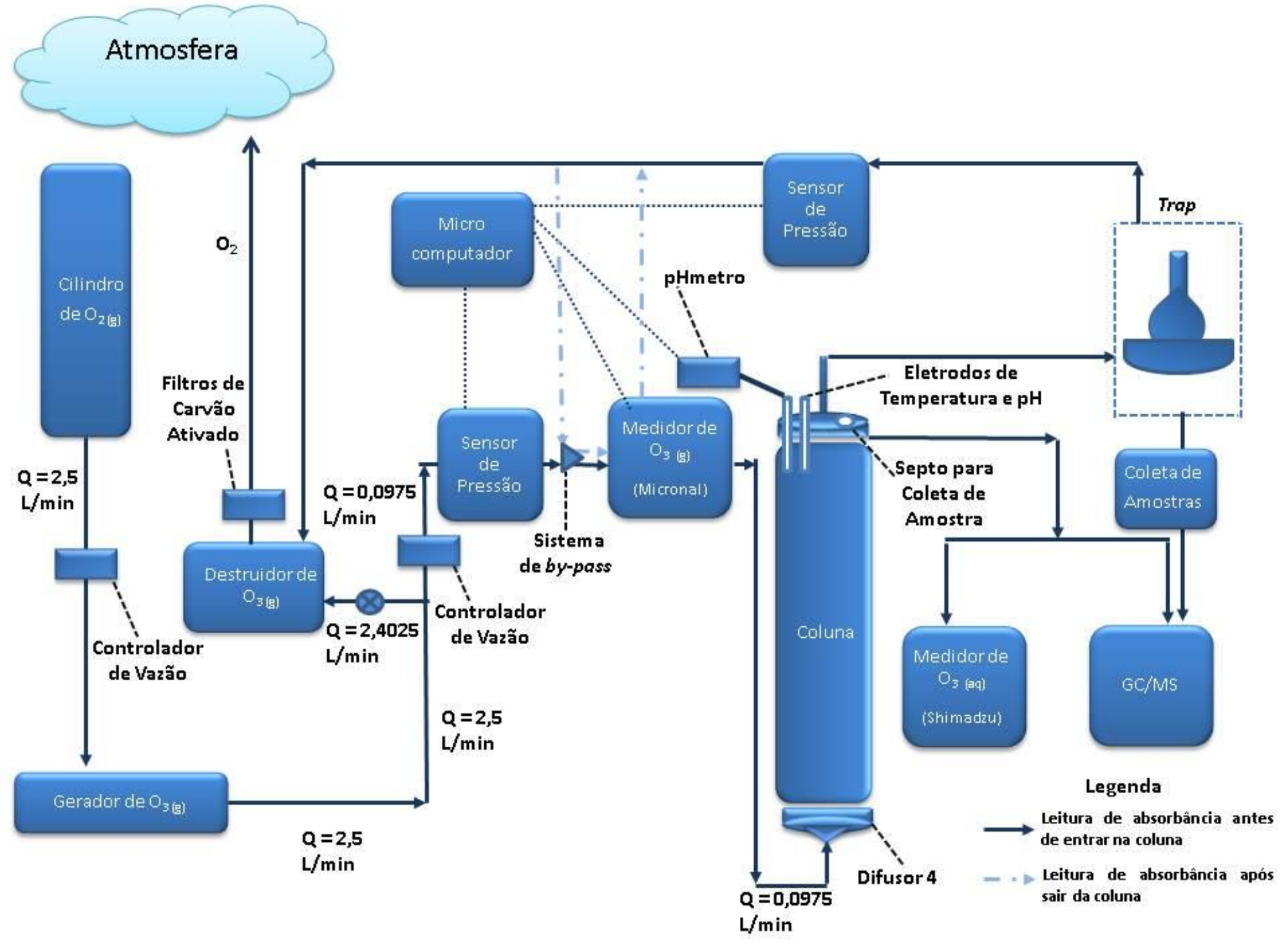

Figura 4.3 Projeto esquemático do aparato experimental 


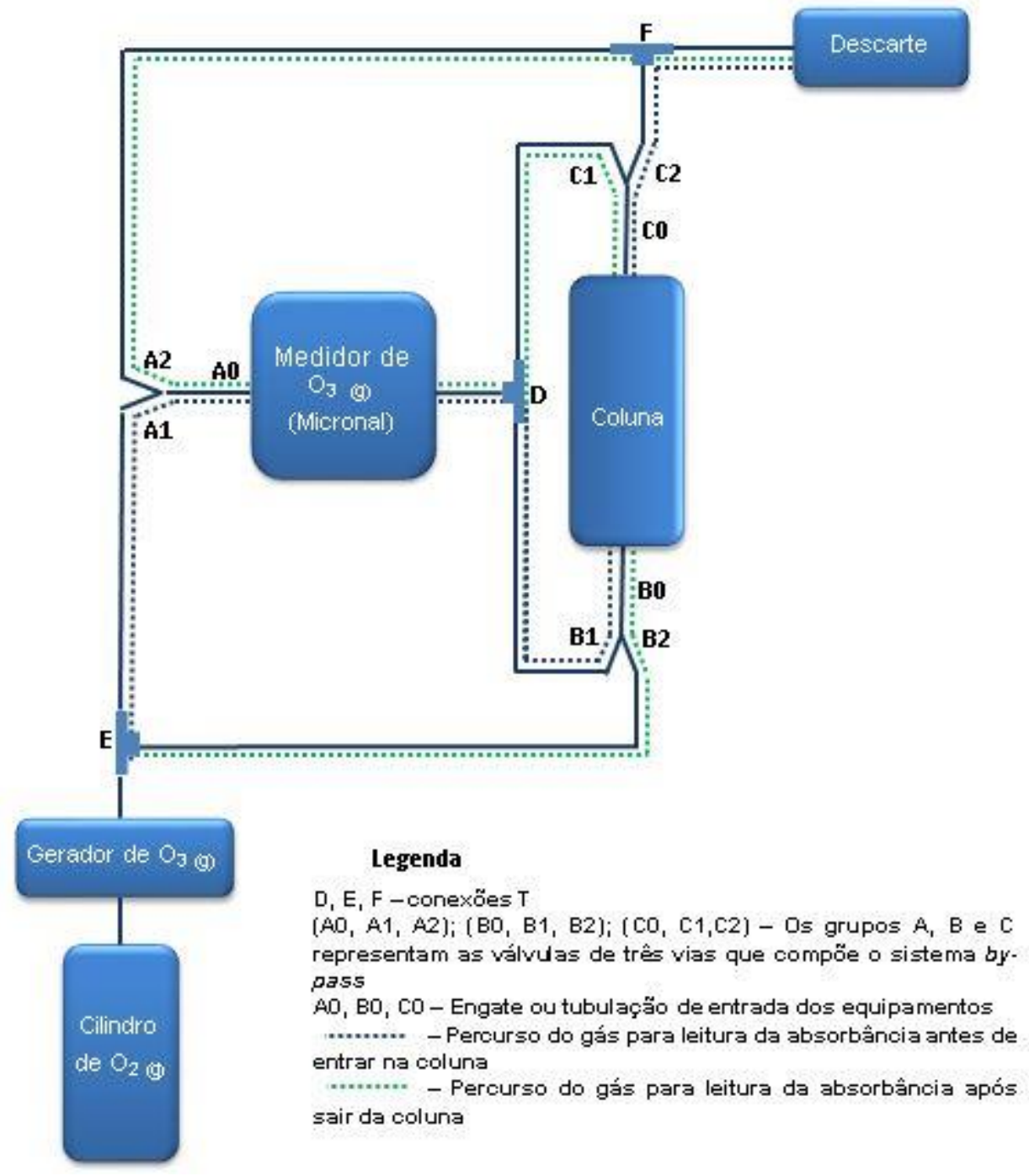

Figura 4.4 Detalhe do funcionamento do sistema by-pass

\subsubsection{Detalhamento dos Equipamentos}

O cilindro de oxigênio medicinal X50S com 99,998\% de pureza e 0,002\% de gás carbônico $\left(\mathrm{CO}_{2}\right)$ foi utilizado para abastecer o gerador de ozônio com oxigênio, sendo que a pressão de trabalho adotada foi de $1,5 \mathrm{kgf} / \mathrm{cm}^{2}$, que corresponde a 147.099,75 Pa.

O gerador de ozônio modelo BRO3-PLUS 2.1 (Figura 4.5), utilizado nesta pesquisa, trabalha com vazão mínima de 2,5 L/min e máxima de 5 L/min, produção de ozônio de até $12 \mathrm{~g} / \mathrm{h}$ e concentração de ozônio de até $55 \mathrm{~g} / \mathrm{m}^{3}$. 


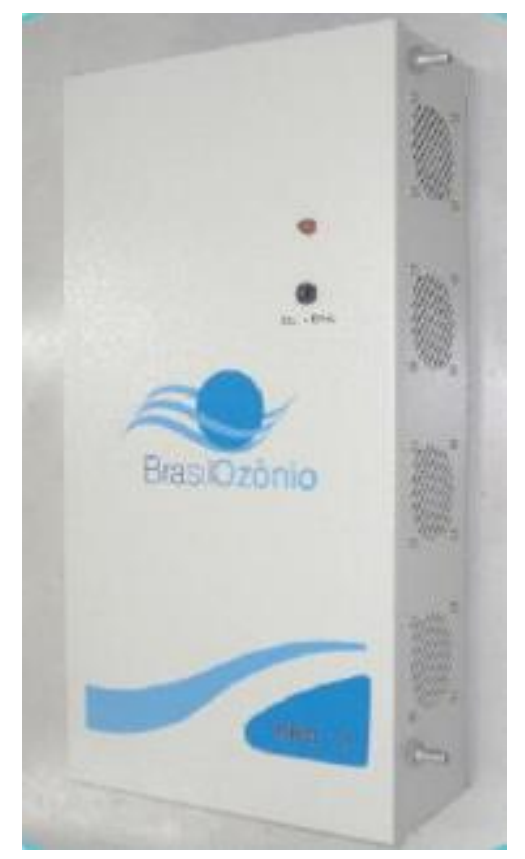

Figura 4.5 Gerador de ozônio $\mathrm{BRO}_{3}$ da empresa Brasil Ozônio

O controlador de vazão da MKS Instruments, modelo Multi Gas Controller 647B, permite controlar o fluxo de até 4 gases diferentes. Nesta pesquisa foram utilizados dois canais, o canal $2(\mathrm{CH} 2)$ para controlar a vazão de 2,5 L/min de oxigênio que sai do cilindro e entra no gerador de ozônio, e o canal $4(\mathrm{CH} 4)$ para controlar a vazão de 0,097 L/min de entrada de ozônio na coluna.

No experimento são utilizados dois sensores BMP 085 para leitura da pressão do ozônio e temperatura ambiente antes de entrar na coluna e após a saída da coluna. O sensor BMP 085 faz a estatística do sinal e a leitura da pressão absoluta e da temperatura de forma constante pela sua saída digital, entre 30.000 e $140.000 \mathrm{~Pa}$, e 0 e $65^{\circ} \mathrm{C}$, respectivamente.

Os sensores BMP 085 estão conectados a placas arduínos uno independentes. A placa arduíno uno é um microprocessador AT Mega 328 com 6 entradas analógicas de 0 a 5 volts e 13 saídas digitais de 0 ou 5 volts, que recebe os sinais de um sensor e transmite os dados via serial para um computador com um software que faz a leitura pela porta serial. Neste caso, foi utilizado o Labview da National Instruments, por intermédio do qual os sinais são coletados, armazenados em uma planilha, 
integrados e representados em um gráfico ao longo do experimento, permitindo a visualização do comportamento da variável em tempo real.

O Labview também é utilizado para as leituras de $\mathrm{pH}$ e temperatura realizadas pelo pHmetro da Tecnal (eletrodos inseridos na tampa de saída da coluna) e de absorbância pelo espectrofotômetro UV-Visível da Micronal.

O espectrofotômetro UV-Visível da Micronal, modelo B582, utiliza a espectroscopia de absorção ultravioleta (faixa entre 200 e 400 nm), uma lâmpada de descarga de deutério como fonte de radiação, e uma cubeta de fluxo de quartzo com caminho óptico de $1 \mathrm{~mm}$ para leitura. Com este equipamento é possível fazer leituras de absorbância e de transmitância no comprimento de onda correspondente ao ozônio gasoso (254 nm); neste trabalho, foram feitas leituras de absorbância.

A coluna foi fabricada com vidro borossilicato com $50 \mathrm{~mm}$ de diâmetro interno por $500 \mathrm{~mm}$ de altura. Suas extremidades são flangeadas e apresentam um sulco entre o diâmetro interno e externo para acomodamento de um anel o-ring de silicone, material comprovadamente inerte e resistente à oxidação pelo ozônio. Um esquema ilustrativo da coluna está apresentado na Figura 4.6.

Como o gás é conduzido em fluxo ascendente, somente a tampa de vidro posicionada na entrada (base da coluna) apresenta um difusor de vidro sinterizado no 4, correspondente a uma porosidade de 10 a $16 \mu \mathrm{m}$. Para ensaios com material sólido, sejam eles areia ou solo, coloca-se uma tela de nylon junto ao difusor para evitar que os grãos finos do solo obstruam os poros do difusor.

Os engates das tampas foram dimensionados para encaixe de mangueira de silicone de $1 / 4$ de polegada (diâmetro interno de $6,35 \mathrm{~mm}$, e externo de $12 \mathrm{~mm}$ ), compatível com a mangueira de saída do gerador de ozônio. A tampa da saída da coluna (topo da coluna) foi fabricada em teflon, com um encaixe para um eletrodo de $\mathrm{pH}$, outro encaixe para um eletrodo de temperatura, um septo para retirada de amostras e um engate central para conectar a mangueira de teflon até o trap. 


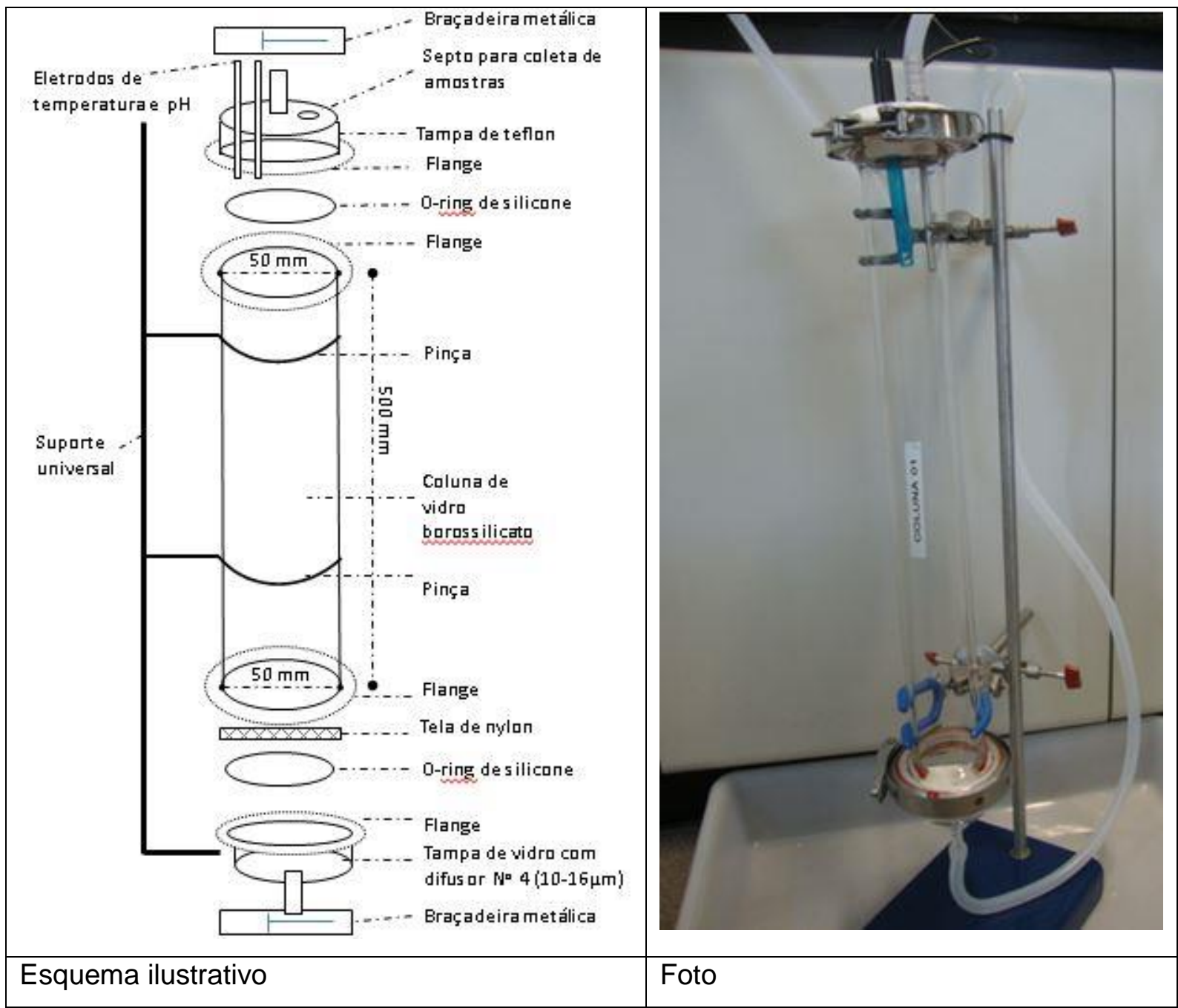

Figura 4.6 Detalhe da coluna

O trap é composto por um balão volumétrico com capacidade de $1 \mathrm{~L}$ e tampa com sistema de frasco lavador de gás imersos em um béquer em banho de álcool e gelo seco.

O destruidor de ozônio, equipamento fabricado pela Brasil Ozônio, possui uma resistência elétrica com filtro de alumina que aquece o gás a uma temperatura de até 150ㄷ․ A alta temperatura acelera a reação de quebra da molécula de ozônio, alterando-o novamente para a forma de oxigênio.

Os filtros químicos classe I contra vapores orgânicos da Lumac são filtros de carvão ativado que foram acoplados ao destruidor de ozônio para reter o PCE que volatilizou para a atmosfera. 
O bolhômetro, utilizado para determinação da vazão ideal, é composto de um tubo de vidro borossilicato graduado, com diâmetro interno de $26 \mathrm{~mm}$, com capacidade para medir um volume entre 0 e $200 \mathrm{~mL}$. Para realizar a medição é necessário promover a formação de bolhas, inserindo detergente no bolhômetro vazio, permitindo a passagem do gás por uma conexão lateral atrelada ao sistema cuja vazão se deseja medir, e bombeando ar com uma seringa de plástico acoplada na base do bolhômetro. Para a determinação da vazão, é necessário cronometrar o tempo que a bolha formada leva para percorrer o volume graduado.

A válvula agulha de precisão para controlar a vazão de descarte possui as seguintes especificações: aço inoxidável de 316 de pureza, conexão das roscas 1/8" e pressão máxima de 6.000 psi.

O espectrofotômetro UV-Visível da Shimadzu modelo UV2600, utiliza a espectroscopia de absorção ultravioleta (faixa entre 200 e 400 nm), uma lâmpada de descarga de deutério como fonte de radiação, e uma cubeta de quartzo fechada hermeticamente com rolha de teflon e caminho óptico de $10 \mathrm{~mm}$ para leitura. Com este equipamento é possível fazer leituras de absorbância e de transmitância no comprimento de onda correspondente ao ozônio dissolvido (260 nm); neste trabalho, foram feitas leituras de absorbância. Este aparelho foi utilizado para os ensaios de saturação e decaimento do ozônio, e para leituras de ozônio e PCE nos ensaios batch e de coluna.

cromatógrafo gasoso GC-17A acoplado ao espectrômetro de massa GCMSQP5050A da Shimadzu foi utilizado para determinação da concentração de PCE.

\subsection{Método de Contaminação}

Para contaminação dos materiais foi utilizado PCE puro $(99,5 \%)$ da Synth, adquirido comercialmente.

\subsubsection{Contaminação do Meio Aquoso}

A escolha da concentração inicial de PCE para simular contaminação em fase dissolvida baseou-se na saturação do PCE em água. A bibliografia indica valores 
muito variáveis de solubilidade em água do PCE a $25^{\circ} \mathrm{C}$ (Anexo $\mathrm{C}$ ), sendo que a maior parte dos valores encontrados estão entre 150 e 200 mg/L.

Com base nesses valores, colocou-se água ultrapura ou subterrânea em um balão volumétrico com capacidade para $2 \mathrm{~L}$, adicionaram-se $10 \mathrm{~mL}$ de PCE e preencheuse com água o balão até a tampa para não deixar espaços vazios ("pescoço") no gargalo e assim evitar que o composto volatilizasse. Esta mistura foi agitada intensamente por 2 minutos com o objetivo de obter a saturação e o equilíbrio do composto com a água. Depois de observar a separação total das fases, ou seja, as gotículas de PCE em suspensão decantam novamente e só permanece na água o PCE realmente dissolvido, considera-se que o composto alcançou a máxima solubilidade em água. As soluções saturadas assim preparadas foram mantidas em salas climatizadas até o início dos ensaios.

Determinou-se a concentração de cada solução por GC/MS, obtendo-se o valor de solubilidade do PCE em água (em torno de $150 \mathrm{mg} / \mathrm{L}$ ).

Foram também preparadas soluções saturadas de PCE em frascos com capacidade de $125 \mathrm{~mL}$ e $1 \mathrm{~L}$, obtendo-se resultados de solubilidade semelhantes aos obtidos nos balões de $2 \mathrm{~L}$. Adotaram-se os frascos de $125 \mathrm{~mL}$ para os ensaios batch e os de $2 \mathrm{~L}$ para os ensaios de coluna (a qual tem volume de $1,1 \mathrm{~L}$ ).

As soluções saturadas de PCE foram refrigeradas em geladeira por 30 minutos antes de sua utilização nos ensaios de coluna.

\subsubsection{Contaminação do Meio Poroso}

Previamente à contaminação, as microesferas de vidro foram lavadas, secas na estufa a $60^{\circ} \mathrm{C}$ por $24 \mathrm{~h}$ e armazenadas em temperatura ambiente. Parte das microesferas foi lavada com ácido para remoção dos metais aderidos à superfície, e posteriormente com solução de hidróxido de sódio e água ultrapura, e parte diretamente com água ultrapura.

A areia foi lavada cinco vezes em água ultrapura, seca na estufa a $60^{\circ} \mathrm{C}$ por $24 \mathrm{~h}$ e armazenada em temperatura ambiente. 
O solo foi passado na peneira de malha 10 ( $2 \mathrm{~mm}$ de abertura), seco na estufa a $60^{\circ} \mathrm{C}$ e homogeneizado.

Para os ensaios batch, $10 \mathrm{~g}$ de material sólido (microesferas de vidro, areia e solo) foram acrescidos aos frascos preparados segundo método apresentado no item 4.4.3.

Para contaminação do material sólido (microesferas de vidro e areia) em coluna, preencheu-se a coluna seguindo os critérios do ensaio de índice de vazios máximo (item 4.1.3), segundo a eq.4.1, e a seguir adicionou-se a solução contaminada. Antes da colocação na coluna, o material sólido foi refrigerado por 30 minutos em geladeira.

$$
\mathrm{m}_{\mathrm{s}}=\rho_{\mathrm{s}} \frac{\mathrm{V}}{1+\mathrm{e}_{\text {max }}}=\rho_{\mathrm{s}} \frac{\pi \mathrm{D}^{2} \mathrm{~L}}{4\left(1+\mathrm{e}_{\text {max }}\right)}
$$

Onde: $\mathrm{m}_{\mathrm{s}}$ : massa do material seco (microesferas de vidro e areia); $\rho_{s}$ : massa específica dos grãos; V: volume da coluna; emax: índice de vazios máximo; D: diâmetro da coluna; e L: altura da coluna.

Para o solo, procurou-se atingir o índice de vazios de campo, com base na densidade natural e teor de umidade natural das amostras indeformadas (eq. 4.2), o qual também foi refrigerado por 30 minutos em geladeira e após o empacotamente, foi adicionada a solução contaminada.

$$
\mathrm{m}_{\mathrm{s}}=\rho_{\text {campo }} \frac{\mathrm{V}}{1+\mathrm{W}_{\text {campo }}}=\rho_{\text {campo }} \frac{\pi \mathrm{D}^{2} \mathrm{~L}}{4\left(1+\mathrm{w}_{\text {campo }}\right)}
$$

Onde: $\mathrm{m}_{\mathrm{s}}$ : massa do material seco (solo); Pcampo: massa específica natural do solo; V:

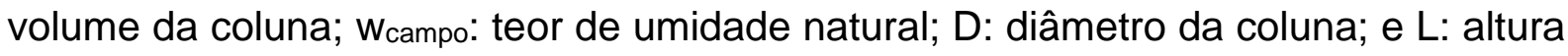
da coluna. 


\subsection{Ensaios com Ozônio}

Preliminarmente, foram realizados ensaios de saturação de ozônio em fase dissolvida e gasosa, e de decaimento apenas em fase dissolvida.

A seguir foram realizados ensaios batch e de coluna para verificar a degradação de PCE em fase dissolvida pela injeção de ozônio gasoso em meio aquoso.

O sistema de alimentação de ozônio descrito no item 4.2.5 era ligado antes do início dos ensaios por no mínimo 30 minutos, tempo de estabilização e aquecimento do equipamento.

\subsubsection{Ensaios Preliminares}

Inicialmente o aparato e o procedimento experimental foram testados por meio de um ensaio de injeção de oxigênio em água ultrapura. A coluna foi preenchida com água ultrapura e injetou-se oxigênio por 25 minutos com a pressão e vazão selecionadas para os ensaios de injeção de ozônio (item 4.2.4). Quatro amostras de água foram coletadas, duas durante a injeção de oxigênio (após 10 e 25 minutos do início) e duas após o desligamento da injeção (5 e 10 minutos).

Foram também feitos ensaios de saturação e decaimento de ozônio em água ultrapura. Para isso, foram realizados alguns testes para retiradas de amostras da coluna a cada 1 minuto, até verificar que uma frequência de leitura a cada 5 minutos era suficiente para obter os dados dos ensaios de saturação de ozônio dissolvido e também para os estudos preliminares de decaimento, que consideraram num primeiro momento, a observação após o desligamento da injeção para determinar o tempo de duração dos ensaios a serem realizados na investigação experimental.

Durante os ensaios preliminares, substituiu-se o concentrador de oxigênio inicialmente utilizado, Respironics Millennium M5, pelo cilindro de oxigênio medicinal X50S, que permite maior controle da pressão e vazão.

As amostras coletadas nesses ensaios foram analisadas no espectrofotômetro UVVisível da Shimadzu, modelo UV-2600, com cubeta de quartzo de caminho óptico de $1 \mathrm{~cm}$, inicialmente aberta e depois hermeticamente fechada com rolha de teflon. 
Testaram-se complementarmente formas de preenchimento da cubeta fechada para verificar sua interferência nos valores medidos de absorbância: totalmente e parcialmente preenchida, preenchida em uma única vez ou em duas etapas.

Ensaios de cinética de ozônio foram conduzidos em algumas condições: após 30 minutos de injeção, após tempo suficiente para atingir a constância do pH (70 minutos) e com adição de bicarbonato de sódio para alterar o pH.

Para os ensaios de degradação de PCE por ozônio e de controle de água ultrapura com oxigênio, a coluna foi preenchida com solução saturada de PCE em água ultrapura e foi injetado gás. Foram coletadas amostras da coluna a cada 5 minutos por aproximadamente 2 horas.

\subsubsection{Saturação e Decaimento}

Os ensaios de saturação e de decaimento de ozônio em meio aquoso foram realizados com água ultrapura, águas subterrâneas provenientes de poço cacimba e de poço tubular profundo (item 4.1.1), e soluções tampão de bicarbonato de sódio $\left(\mathrm{NaHCO}_{3}\right)$ preparadas com água ultrapura em concentrações de 0,45 mg/L, $1 \mathrm{mg} / \mathrm{L}$, $25 \mathrm{mg} / \mathrm{L}, 50 \mathrm{mg} / \mathrm{L}, 75 \mathrm{mg} / \mathrm{L}, 100 \mathrm{mg} / \mathrm{L}$ e $200 \mathrm{mg} / \mathrm{L}$. É importante ressaltar que o bicarbonato de sódio é um sal encontrado naturalmente em águas subterrâneas, com concentração tanto maior, quanto maior o tempo de residência no aquífero. As duas primeiras concentrações foram definidas a partir da alcalinidade das águas subterrâneas utilizadas nos ensaios e os demais valores foram baseados em bibliografia especializada sobre as concentrações de sais dissolvidos nas águas subterrâneas.

Para a quantificação do ozônio em fase dissolvida por meio da absorbância, utilizouse o espectrofotômetro UV-Visível da Shimadzu, modelo UV-2600, com cubeta de quartzo hermeticamente fechada com rolha de teflon e caminho óptico de $1 \mathrm{~cm}$. Nos ensaios de saturação, selecionou-se uma faixa de varredura de comprimento de onda entre 200 e $400 \mathrm{~nm}$ (faixa não visível), para a leitura no comprimento de onda máximo de ozônio em fase dissolvida, equivalente a $260 \mathrm{~nm}$. Nos ensaios de decaimento, fixou-se o comprimento de onda único de $260 \mathrm{~nm}$. Para o cálculo de concentração a partir da absorbância, adotou-se o valor de absortividade molar de 
3.314 para o comprimento de onda de $260 \mathrm{~nm}$ em meio aquoso (FORNI et al., 1982 in OPPENLÄNDER, 2003).

Nos ensaios de saturação, após a estabilização do sistema de alimentação de ozônio, a coluna era preenchida com água (ultrapura, subterrânea, ou água ultrapura com bicarbonato de sódio dissolvido) e por 60 minutos coletavam-se amostras líquidas da coluna a cada 5 minutos para leitura da absorbância. As amostras foram retiradas por seringa gastight de $5 \mathrm{~mL}$ pelo septo da tampa de saída da coluna (topo).

Os ensaios foram repetidos para determinar a saturação de ozônio em fase gasosa. A concentração de ozônio em fase gasosa foi monitorada em tempo real por meio da leitura da absorbância em linha na entrada e saída da coluna pelo espectrofotômetro UV-Visível da Micronal, modelo B582, com uma célula de fluxo de quartzo, com caminho óptico de $1 \mathrm{~mm}$, no comprimento de onda máximo de $254 \mathrm{~nm}$. Esta cubeta permite a leitura de concentrações de ozônio concentrado (superiores comparativamente às lidas na cubeta de caminho óptico de $10 \mathrm{~mm}$ ).

Em ensaios preliminares observou-se que o fluxo de ozônio na entrada da coluna estabiliza-se rapidamente e se mantém constante durante o ensaio (para isso o sistema de alimentação de ozônio foi ligado meia hora antes do início do ensaio). Nos ensaios de saturação de ozônio em fases gasosa realizou-se, portanto, a leitura da absorbância na entrada da coluna por aproximadamente um minuto, até atingir a constância, e a seguir o sistema by-pass foi invertido para leitura da absorbância na saída da coluna. Para o cálculo da concentração de ozônio gasoso no comprimento de onda de $254 \mathrm{~nm}$ foi utilizado o valor de absortividade molar de 3.024 (CASTRO, 2010).

Após a saturação, foi coletada uma amostra de água saturada de ozônio da coluna para determinação da cinética de decaimento do ozônio em fase dissolvida no espectrofotômetro da Shimadzu, com leituras a cada 1 ou 5 minutos, durante algumas horas, tempos definidos de acordo com cada ensaio após testes preliminares. 


\subsubsection{Batch}

Os ensaios batch para o meio aquoso e meio poroso foram realizados para investigar a degradação do PCE pelo ozônio dissolvido em sistema fechado, considerando o estudo de meios com valores de $\mathrm{pH}$ variados.

\subsubsection{Meio aquoso}

Foram realizados ensaios com água ultrapura, águas subterrâneas provenientes de poço cacimba e de poço tubular profundo, e solução tampão de bicarbonato de sódio de $25 \mathrm{mg} / \mathrm{L}$, além de ensaio de controle.

Inicialmente saturou-se a água (água ultrapura, subterrânea ou solução de bicarbonato de sódio) com ozônio na coluna. Coletaram-se amostras da água da coluna e realizaram-se leituras da absorbância no espectrofotômetro UV-Visível da Shimadzu a cada 5 minutos, até a estabilização dos valores de absorbância indicar saturação. A água foi refrigerada antes de ser colocada na coluna por no mínimo 1 hora para aumentar o tempo de permanência do ozônio dissolvido, já que temperaturas menores aumentam a solubilidade do ozônio em meio aquoso.

Após a saturação com ozônio, 5 amostras do meio aquoso de $42 \mathrm{~mL}$ (quintuplicata) foram retiradas da coluna pelo septo da tampa de saída (topo), com o auxílio de uma seringa gastight de $50 \mathrm{~mL}$ com válvula de amostragem (para evitar perda de gás). Essas amostras foram colocadas em vials de vidro com capacidade de aproximadamente $42 \mathrm{~mL}$ com tampa de rosca e septo de teflon, juntamente com 0,4 $\mathrm{mL}$ de solução de água ultrapura saturada de PCE de modo a preencher completamente o volume do vial sem formar bolha ou espaço vazio. O sistema de alimentação de ozônio permaneceu ligado durante a retirada de todas as amostras.

No ensaio de controle utilizou-se $42 \mathrm{~mL}$ de água ultrapura não saturada com ozônio, juntamente com 0,4 mL de solução de água ultrapura saturada de PCE, os quais foram acondicionados em vials de $42 \mathrm{~mL}$ iguais aos utilizados nos outros ensaios. Os ensaios de controle também foram realizados em quintuplicata. 
A seguir os vials foram colocados na incubadora refrigerada da Tecnal, modelo TE421 , sem agitação, para manter a temperatura controlada a $20^{\circ} \mathrm{C}$ durante 0 tempo de duração do experimento. A duração do experimento, de $1 \mathrm{~h} 50$, foi definida com base no tempo de arraste de PCE em coluna com passagem de oxigênio (controle do ensaio de coluna).

Foram coletadas amostras no início e no final do ensaio de cada vial (coleta e preparo no item 4.5.1) para quantificação de PCE no GC/MS.

Foram ainda realizadas leituras de varredura entre 200 e $400 \mathrm{~nm}$ em cubeta de quartzo de caminho óptico de $1 \mathrm{~cm}$ para determinação quantitativa de ozônio e qualitativa de PCE em fase dissolvida no espectrofotômetro UV-Visível da Shimadzu, com coleta de amostra de um único vial no início e dos cinco vials no fim do ensaio.

\subsubsection{Meio poroso}

Para o meio poroso foram realizados ensaios com microesferas de vidro, areia, e solo, além de ensaio de controle de adsorção do solo.

Inicialmente colocou-se o volume de aproximadamente $1,1 \mathrm{~L}$ de água ultrapura, previamente refrigerada por no mínimo 1 hora, na coluna para saturação com ozônio. A água foi refrigerada previamente para aumentar o tempo de permanência do ozônio dissolvido, já que temperaturas menores aumentam a solubilidade do ozônio em meio aquoso. Foram coletadas amostras da água ultrapura da coluna para leituras da absorbância a cada 5 minutos no comprimento de onda de $260 \mathrm{~nm}$, correspondente ao ozônio, no espectrofotômetro UV-Visível da Shimadzu, até a estabilização dos valores de absorbância indicar saturação.

Após a saturação com ozônio, 3 amostras do meio aquoso (triplicata) foram retiradas da coluna pelo septo da tampa de saída (topo), com o auxílio de uma seringa gastight de $50 \mathrm{~mL}$ com válvula de amostragem para evitar perda de gás. O sistema de alimentação de ozônio permaneceu ligado durante a retirada de todas as amostras. 
As amostras foram colocadas em vials com capacidade de aproximadamente $42 \mathrm{~mL}$, após pesar o frasco com a tampa e $10 \mathrm{~g}$ de material sólido, seja microesferas de vidro, areia ou solo, juntamente com $0,4 \mathrm{~mL}$ de solução de água ultrapura saturada de PCE. A água ultrapura saturada com ozônio foi adicionada até transbordar, o frasco foi agitado 3 vezes, completou-se o espaço vazio com água ultrapura saturada com ozônio até formar um excesso no bocal do frasco e agitou-se novamente 3 vezes, de modo a evitar a formação de espaços vazios e bolhas no vial No ensaio de controle de adsorção de solo adotou-se o procedimento descrito anteriormente, entretanto adicionou-se água ultrapura não ozonizada.

A seguir os vials foram colocados na incubadora refrigerada da Tecnal, modelo TE421 , sem agitação, para manter a temperatura controlada a $20^{\circ} \mathrm{C}$ durante 0 tempo de duração do experimento. A duração do experimento, de 1h50, foi definida com base no tempo de arraste de PCE em coluna com passagem de oxigênio (controle do ensaio de coluna).

Foram coletadas amostras do meio aquoso no início e no final do ensaio de cada vial (coleta e preparo no item 4.5.1) para quantificação de PCE no GC/MS.

Devido a um problema no equipamento do laboratório, as análises químicas dos ensaios batch em meio poroso foram realizadas em laboratório comercial. Foi analisada a Lista de VOC varredura, de acordo com os métodos USEPA 8260C (2006) e 5021A (2003). O certificado de acreditação do laboratório para análise desses parâmetros, as cadeias de custódia e os laudos com os resultados analíticos encontram-se no Anexo D. 


\subsubsection{Coluna}

Os ensaios de coluna foram realizados para investigar a degradação do PCE por injeção de ozônio, considerando o estudo de meios com valores de $\mathrm{pH}$ variados.

\subsubsection{Meio aquoso}

Foram realizados ensaios com água ultrapura, águas subterrâneas provenientes de poço cacimba e de poço tubular profundo, e solução tampão de bicarbonato de sódio de $25 \mathrm{mg} / \mathrm{L}, 75 \mathrm{mg} / \mathrm{L}$ e $200 \mathrm{mg} / \mathrm{L}$, saturadas de PCE, além de ensaio de controle de água ultrapura com passagem de oxigênio em água ultrapura saturada de PCE.

Nesses ensaios, após o preenchimento da coluna com um volume de $1,1 \mathrm{~L}$ de solução saturada de PCE, injetou-se ozônio por 1h50, segundo os mesmos critérios para definição de tempo utilizado nos ensaios batch.

Durante o ensaio foram monitorados $\mathrm{opH}$ e a temperatura no interior da coluna, a pressão na entrada e na saída da coluna, e a absorbância de ozônio em fase gasosa na entrada da coluna e na saída da coluna após sua estabilização na entrada.

Foram coletadas amostras no início e no final de cada ensaio com a finalidade de verificar as concentrações residuais de PCE em fase dissolvida e a transferência de massa do composto altamente volátil para a atmosfera.

As amostras foram retiradas da coluna em triplicata com auxílio de uma seringa gastight de $50 \mathrm{~mL}$ com válvula de amostragem (para evitar perda de gás) inserida no septo da tampa de saída (topo), e do trap lavado com metanol e ressuspendido em água ultrapura.

Foram coletadas adicionalmente amostras do trap e do final da coluna para tentar determinar os intermediários formados durante o ensaio.

Foram ainda realizadas leituras de varredura entre 200 e 400 nm em cubeta de quartzo de caminho óptico de $1 \mathrm{~cm}$ para determinação quantitativa de ozônio e 
qualitativa de PCE em fase dissolvida no espectrofotômetro UV-Visível da Shimadzu, em amostras coletadas no início, meio e fim do ensaio.

\subsubsection{Meio poroso}

Foram realizados ensaios com microesferas de vidro, areia e solo. Os ensaios com solo, entretanto, não foram bem sucedidos mesmo após diversas tentativas, devido à pressão de ozônio associada ao atrito insuficiente entre solo e vidro, o que provocava o faturamento do solo e o destacamento de camadas, além de criar caminhos preferenciais. Observou-se que era necessário aumentar a rugosidade das paredes da coluna por jateamento, porém não houve tempo para realizar esta alteração no equipamento.

A massa de microesferas de vidro, areia e solo (cerca de $1,5 \mathrm{~kg}$ ) e o volume de solução saturada de PCE (cerca de $400 \mathrm{~mL}$ ) foram definidos em função do índice de vazios máximo (microesferas de vidro e areia) ou da densidade natural (solo). material foi colocado na coluna de maneira gradual, ou seja, a cada $1 / 4$ de material sólido acomodado, $1 / 4$ de volume da solução saturada de PCE era adicionado. O material sólido e a solução saturada de PCE foram refrigerados previamente à colocação na coluna de forma a minimizar perdas de PCE por volatilização.

O sistema de alimentação de ozônio foi ligado cerca de 20 minutos antes do início do ensaio para que a geração de ozônio estivesse estabilizada, entretanto, uma válvula no aparato experimental evitava que o ozônio gerado fluísse para a coluna, sendo direcionado para o descarte.

Antes de iniciar a injeção de ozônio eram coletadas amostras em triplicata dos sólidos e do líquido intersticial. Após a coleta de amostras de sólidos, a coluna era fechada para coleta de amostras líquidas com auxílio de uma seringa gastight de 50 $\mathrm{mL}$ com válvula de amostragem (para evitar perda de gás) inserida no septo da tampa de saída (topo).

Após fechada a coluna, a válvula que permitia o acesso do ozônio à entrada da coluna era aberta e ocorria a injeção de ozônio por 1h50, segundo os mesmos critérios para definição de tempo utilizado nos ensaios batch. 
Durante o ensaio foram monitorados $\mathrm{opH}$ e a temperatura no interior da coluna, $\mathrm{a}$ pressão na entrada e na saída da coluna, e a absorbância de ozônio em fase gasosa na entrada da coluna e na saída da coluna após sua estabilização na entrada para elaborar a breakthrough curve.

No final de cada ensaio foram coletadas amostras em triplicata dos sólidos, do líquido intersticial e do trap com a finalidade de verificar, respectivamente, as concentrações residuais de PCE nas fases residual no meio poroso, dissolvida e a transferência de massa do composto altamente volátil para a atmosfera.

As amostras líquidas foram retiradas da coluna em triplicata com auxílio de uma seringa gastight de $50 \mathrm{~mL}$ com válvula de amostragem (para evitar perda de gás) inserida no septo da tampa de saída (topo), e do trap lavado com metanol e ressuspendido em água ultrapura.

Foram coletadas adicionalmente amostras líquidas da coluna no final do ensaio e do trap para tentar determinar os intermediários formados durante o ensaio.

Devido a um problema no equipamento do laboratório, as análises químicas dos ensaios batch em meio poroso foram realizadas em laboratório comercial. Foi analisada a Lista de VOC varredura, de acordo com os métodos USEPA 8260C (2006) e 5021A (2003). O certificado de acreditação do laboratório para análise desses parâmetros, as cadeias de custódia e os laudos com os resultados analíticos encontram-se no Anexo D.

Os ensaios de saturação e decaimento de ozônio, batch, e de coluna realizados nos diversos meios de estudo foram compilados e apresentados na Tabela 4.3. 
Tabela 4.3 Ensaios com ozônio

\begin{tabular}{|c|c|c|c|c|}
\hline Ensaios & Material & Gás & $\begin{array}{l}\text { Contaminação } \\
\text { por PCE }\end{array}$ & $\begin{array}{c}\text { Tempo de } \\
\text { contato } \\
\text { (h) }\end{array}$ \\
\hline \multirow{10}{*}{ Saturação } & Água ultrapura & Ozônio & \multirow{10}{*}{$\begin{array}{c}\text { Não } \\
\text { contaminado }\end{array}$} & 0,55 \\
\hline & Água subterrânea - poço cacimba & Ozônio & & \multirow{9}{*}{1} \\
\hline & $\begin{array}{l}\text { Água subterrânea - poço tubular } \\
\text { profundo }\end{array}$ & Ozônio & & \\
\hline & $\mathrm{NaHCO}_{3} 0,45 \mathrm{mg} / \mathrm{L}$ & Ozônio & & \\
\hline & $\mathrm{NaHCO}_{3} 1 \mathrm{mg} / \mathrm{L}$ & Ozônio & & \\
\hline & $\mathrm{NaHCO}_{3} 25 \mathrm{mg} / \mathrm{L}$ & Ozônio & & \\
\hline & $\mathrm{NaHCO}_{3} 50 \mathrm{mg} / \mathrm{L}$ & Ozônio & & \\
\hline & $\mathrm{NaHCO}_{3} 75 \mathrm{mg} / \mathrm{L}$ & Ozônio & & \\
\hline & $\mathrm{NaHCO}_{3} 100 \mathrm{mg} / \mathrm{L}$ & Ozônio & & \\
\hline & $\mathrm{NaHCO}_{3} 200 \mathrm{mg} / \mathrm{L}$ & Ozônio & & \\
\hline \multirow{10}{*}{ Decaimento } & Água ultrapura & Ozônio & \multirow{10}{*}{$\begin{array}{c}\text { Não } \\
\text { contaminado }\end{array}$} & 10 \\
\hline & Água subterrânea - poço cacimba & Ozônio & & 2 \\
\hline & $\begin{array}{llll}\text { Água subterrânea } & \text { - poço } & \text { tubular } \\
\text { profundo }\end{array}$ & Ozônio & & 2 \\
\hline & $\mathrm{NaHCO}_{3} 0,45 \mathrm{mg} / \mathrm{L}$ & Ozônio & & 5 \\
\hline & $\mathrm{NaHCO}_{3} 1 \mathrm{mg} / \mathrm{L}$ & Ozônio & & $1 \mathrm{~h} 30$ \\
\hline & $\mathrm{NaHCO}_{3} 25 \mathrm{mg} / \mathrm{L}$ & Ozônio & & 2 \\
\hline & $\mathrm{NaHCO}_{3} 50 \mathrm{mg} / \mathrm{L}$ & Ozônio & & 2 \\
\hline & $\mathrm{NaHCO}_{3} 75 \mathrm{mg} / \mathrm{L}$ & Ozônio & & 2 \\
\hline & $\mathrm{NaHCO}_{3} 100 \mathrm{mg} / \mathrm{L}$ & Ozônio & & 3 \\
\hline & $\mathrm{NaHCO}_{3} 200 \mathrm{mg} / \mathrm{L}$ & Ozônio & & 2 \\
\hline \multirow{9}{*}{ Batch } & Controle de água ultrapura & - & \multirow{9}{*}{ Contaminado } & \multirow{9}{*}{$1 \mathrm{~h} 50$} \\
\hline & Água ultrapura & Ozônio & & \\
\hline & Água subterrânea - poço cacimba & Ozônio & & \\
\hline & $\begin{array}{l}\text { Água subterrânea } \\
\text { profundo }\end{array}$ & Ozônio & & \\
\hline & $\mathrm{NaHCO}_{3} 25 \mathrm{mg} / \mathrm{L}$ & Ozônio & & \\
\hline & Microesferas de vidro & Ozônio & & \\
\hline & Areia & Ozônio & & \\
\hline & Controle de adsorção no solo & - & & \\
\hline & Solo & Ozônio & & \\
\hline
\end{tabular}


Tabela 4.4 Ensaios com ozônio (continuação).

\begin{tabular}{|c|c|c|c|c|}
\hline Ensaios & Material & Gás & $\begin{array}{l}\text { Contaminação } \\
\text { por PCE }\end{array}$ & $\begin{array}{l}\text { Tempo de } \\
\text { contato } \\
\text { (h) }\end{array}$ \\
\hline \multirow{9}{*}{ Coluna } & Controle de água ultrapura & Oxigênio & \multirow{9}{*}{ Contaminado } & \multirow{9}{*}{$1 \mathrm{~h} 50$} \\
\hline & Água ultrapura & Ozônio & & \\
\hline & Água subterrânea - poço cacimba & Ozônio & & \\
\hline & $\begin{array}{l}\text { Água subterrânea - poço tubular } \\
\text { profundo }\end{array}$ & Ozônio & & \\
\hline & $\mathrm{NaHCO}_{3} 25 \mathrm{mg} / \mathrm{L}$ & Ozônio & & \\
\hline & $\mathrm{NaHCO}_{3} 75 \mathrm{mg} / \mathrm{L}$ & Ozônio & & \\
\hline & $\mathrm{NaHCO}_{3} 200 \mathrm{mg} / \mathrm{L}$ & Ozônio & & \\
\hline & Microesferas de vidro & Ozônio & & \\
\hline & Areia & Ozônio & & \\
\hline
\end{tabular}

\subsection{Método de Preparo de Amostras para Análise Química}

\subsubsection{Batch}

\subsubsection{Meio aquoso}

As amostras para quantificação de PCE no início e no final dos ensaios batch foram preparadas com adição, nessa ordem, de $100 \mu \mathrm{L}$ de 2-propanol, $1 \mathrm{~mL}$ de amostra coletada em cada vial da quintuplicata do batch, $20 \mu \mathrm{L}$ de padrão interno $(1,4-$ diclorobenzeno-d-4, clorobenzeno-d-5, e fluorbenzeno, em concentração de 50 ppm em metanol), $10 \mu \mathrm{L}$ de hidróxido de sódio ( $\mathrm{NaOH}$ ) 0,5\%, $9 \mathrm{~mL}$ de água ultrapura e uma espátula de sulfato de sódio anidro $\left(\mathrm{Na}_{2} \mathrm{SO}_{4}\right)$.

Foram utilizados vials com capacidade de aproximadamente $20 \mathrm{~mL}$, lacrados com lacre de alumínio e septo de teflon. Durante o preparo das amostras, esses vials ficaram acondicionados em caixa térmica com gelo triturado, de forma a minimizar perdas por volatilização.

Após o preparo das amostras, os vials foram retirados da caixa térmica e esperou-se que chegassem à temperatura ambiente. Foram então levadas para estufa a $60^{\circ} \mathrm{C}$ 
por no mínimo 30 minutos antes da análise química, tempo mínimo necessário para que as fases líquida e gasosa entrassem em equilíbrio.

Também foram coletadas amostras no final dos ensaios batch para determinar qualitativamente os intermediários da reação de degradação de PCE por ozônio. As amostras foram armazenadas e refrigeradas temporariamente em tubos cônicos do tipo falcon para posterior preparo com sulfato de sódio anidro e análise em GC/MS e HPLC/MS.

\subsubsection{Meio poroso}

As amostras para quantificação de PCE no início e no final dos ensaios batch foram preparadas com adição, nessa ordem, de $200 \mu \mathrm{L}$ de 2-propanol, 2,1 mL de amostra coletada em cada vial da quintuplicata do batch, $20 \mu \mathrm{L}$ de hidróxido de sódio $(\mathrm{NaOH})$ $0,5 \%, 18,9 \mathrm{~mL}$ de água ultrapura.

No preparo de amostras também foi adotada a determinação do volume por peso, já que estas amostras foram enviadas para laboratório comercial em vials de $20 \mathrm{~mL}$ preenchidos conforme descrito anteriormente e para assegurar que não haveria a formação de espaços vazios ou bolhas, antes de lacrar os vials foi adicionada água ultrapura até formar excesso na "boca" do vial, e após secar o frasco, tinha seu peso determinado.

Para a determinação do volume por pesagem foram pesados em balança devidamente calibrada: o vial com capacidade para aproximadamente $20 \mathrm{~mL}(\mathrm{P} 1)$, 0 lacre com o septo (P2), o vial com a amostra preparada não preenchida completamente e sem o lacre e septo (P3), e a amostra preenchida completamente e com o lacre e septo (P4).

Foram utilizados vials com capacidade de aproximadamente $20 \mathrm{~mL}$, lacrados com lacre de alumínio e septo de teflon. Durante o preparo das amostras, esses vials ficaram acondicionados em caixa térmica com gelo triturado, de forma a minimizar perdas por volatilização.

Após o preparo das amostras, os vials foram mantidos em temperatura de $4 \pm 2^{\circ} \mathrm{C}$ desde a retirada das amostras, durante o transporte até a chegada no laboratório, 
conforme procedimentos descritos no Guia de Coleta e Preservação de Amostras de Água (CETESB, 2011).

Estas amostras foram enviadas para análise química em laboratório comercial devido a quebra do cromatógrafo gasoso acoplado ao espectrômetro de massa que foi utilizado para as outras análises realizadas neste trabalho.

\subsubsection{Coluna}

\subsubsection{Meio aquoso}

As amostras do meio aquoso para quantificação de PCE no início de cada ensaio de coluna e no trap lavado com metanol e ressuspendido em água ultrapura foram preparadas com adição, nessa ordem, de uma espátula de sulfato de sódio anidro, $10 \mathrm{~mL}$ de água ultrapura, $20 \mu \mathrm{L}$ da mesma solução estoque de padrão interno utilizada no preparo de amostras dos ensaios batch e $10 \mu \mathrm{L}$ de amostra do meio de estudo.

No caso das amostras para quantificação de PCE no final de cada ensaio de coluna, foram adicionados uma espátula de sulfato de sódio anidro, $20 \mu \mathrm{L}$ da solução estoque de padrão interno e $10 \mathrm{~mL}$ de amostra do meio de estudo. Observou-se após ensaios preliminares que as concentrações finais na coluna são cerca de 1.000 vezes menores do que as iniciais e as do trap, não sendo necessária a diluição da amostra em água ultrapura.

Foram utilizados vials com capacidade de aproximadamente $20 \mathrm{~mL}$, lacrados com lacre de alumínio e septo de teflon. Durante o preparo das amostras, esses vials ficaram acondicionados em caixa térmica com gelo triturado, de forma a minimizar perdas por volatilização.

Após o preparo das amostras, os vials foram retirados da caixa térmica e esperou-se que chegassem à temperatura ambiente. Foram então levadas para estufa a $60^{\circ} \mathrm{C}$ por no mínimo 30 minutos antes da análise química, tempo mínimo necessário para que as fases líquida e gasosa entrassem em equilíbrio. 
Também foram coletadas amostras da coluna no final do ensaio e do trap para determinar qualitativamente os intermediários da reação de degradação de PCE por ozônio. As amostras foram armazenadas e refrigeradas temporariamente em tubos cônicos do tipo falcon para posterior preparo com sulfato de sódio anidro e análise em GC/MS e HPLC/MS.

\subsubsection{Meio poroso}

As amostras do meio poroso para quantificação de PCE no início de cada ensaio de coluna e no trap lavado com metanol e ressuspendido em água ultrapura foram preparadas com adição, nessa ordem, $20 \mu \mathrm{L}$ de amostra do meio de estudo e $20 \mathrm{~mL}$ de água ultrapura.

No caso das amostras para quantificação de PCE no final de cada ensaio de coluna, foram completamente preenchidos com amostra do meio de estudo. Após ensaios preliminares, observou-se que as concentrações finais na coluna são cerca de 1.000 vezes menores do que as iniciais e as do trap, não sendo necessária a diluição da amostra em água ultrapura.

Por outro lado, as amostras do meio poroso coletadas no início e no fim da coluna foram retiradas da coluna com um amostrador EnCore adaptado que permite que uma pequena massa de amostra seja colocada dentro de um vial, o qual foi compactado de forma a minimizar os espaços vazios e a migração do PCE para a fase gasosa.

Foram utilizados vials com capacidade de aproximadamente $20 \mathrm{~mL}$, lacrados com lacre de alumínio e septo de teflon. Durante o preparo das amostras, esses vials ficaram acondicionados em caixa térmica com gelo triturado, de forma a minimizar perdas por volatilização.

Após o preparo das amostras, os vials foram mantidos em temperatura de $4 \pm 2^{\circ} \mathrm{C}$ desde a retirada das amostras, durante o transporte até a chegada no laboratório, conforme procedimentos descritos no Guia de Coleta e Preservação de Amostras de Água (CETESB, 2011). 
Estas amostras foram enviadas para análise química em laboratório comercial devido a quebra do cromatógrafo gasoso acoplado ao espectrômetro de massa que foi utilizado para as outras análises realizadas neste trabalho.

Também foram coletadas amostras do meio aquoso da coluna no final do ensaio e do trap para determinar qualitativamente os intermediários da reação de degradação de PCE por ozônio. As amostras foram armazenadas e refrigeradas temporariamente em tubos cônicos do tipo falcon para posterior preparo com sulfato de sódio anidro e análise em HPLC/MS.

\subsection{Análise Química}

\subsubsection{Tetracloroetileno (PCE)}

O equipamento utilizado para determinação do PCE foi um cromatógrafo gasoso GC-17A acoplado a um espectrômetro de massa GCMS-QP5050A, ambos da Shimadzu, e instalados no laboratório de Engenharia Química da EPUSP.

Os métodos analíticos adotados para análise química de PCE em água subterrânea foi o EPA SW 846 8260C para determinação e o 5021 para extração.

Os vials com as amostras preparadas para análise foram retirados da estufa a $60^{\circ} \mathrm{C}$ após o mínimo de 30 minutos. A amostra do headspace (gás em equilíbrio com a fase líquida dentro do vial) foi retirada através da perfuração do septo de teflon e injetada manualmente no injetor do GC com uma seringa gastight com válvula de amostragem, sendo o volume de injeção igual a $1 \mathrm{~mL}$.

O cromatógrafo gasoso utilizou hélio premier X50S como gás de arraste, coluna capilar teste DB5-MS $30 \mathrm{~m}$ x 0,25 mm x 0,25 $\mu \mathrm{m}$ para separação das amostras, temperatura de injeção de $280^{\circ} \mathrm{C}$, Splitless, fluxo de gás da coluna de $0,9 \mathrm{~mL} / \mathrm{min}$, e as condições da rampa de aquecimento (temperatura do forno da coluna), conforme apresentado na Tabela 4.4 e Figura 4.7. 
Tabela 4.5 Condições da rampa de aquecimento do CG

\begin{tabular}{|l|l|l|}
\hline $\mathrm{T}\left({ }^{\circ} \mathrm{C}\right)$ & Rampa $\left({ }^{\circ} \mathbf{C} / \mathbf{m i n}\right)$ & Espera $(\mathbf{m i n})$ \\
\hline 50 & 0 & 2 \\
\hline 80 & 30 & 0 \\
\hline 160 & 12 & 0,5 \\
\hline
\end{tabular}

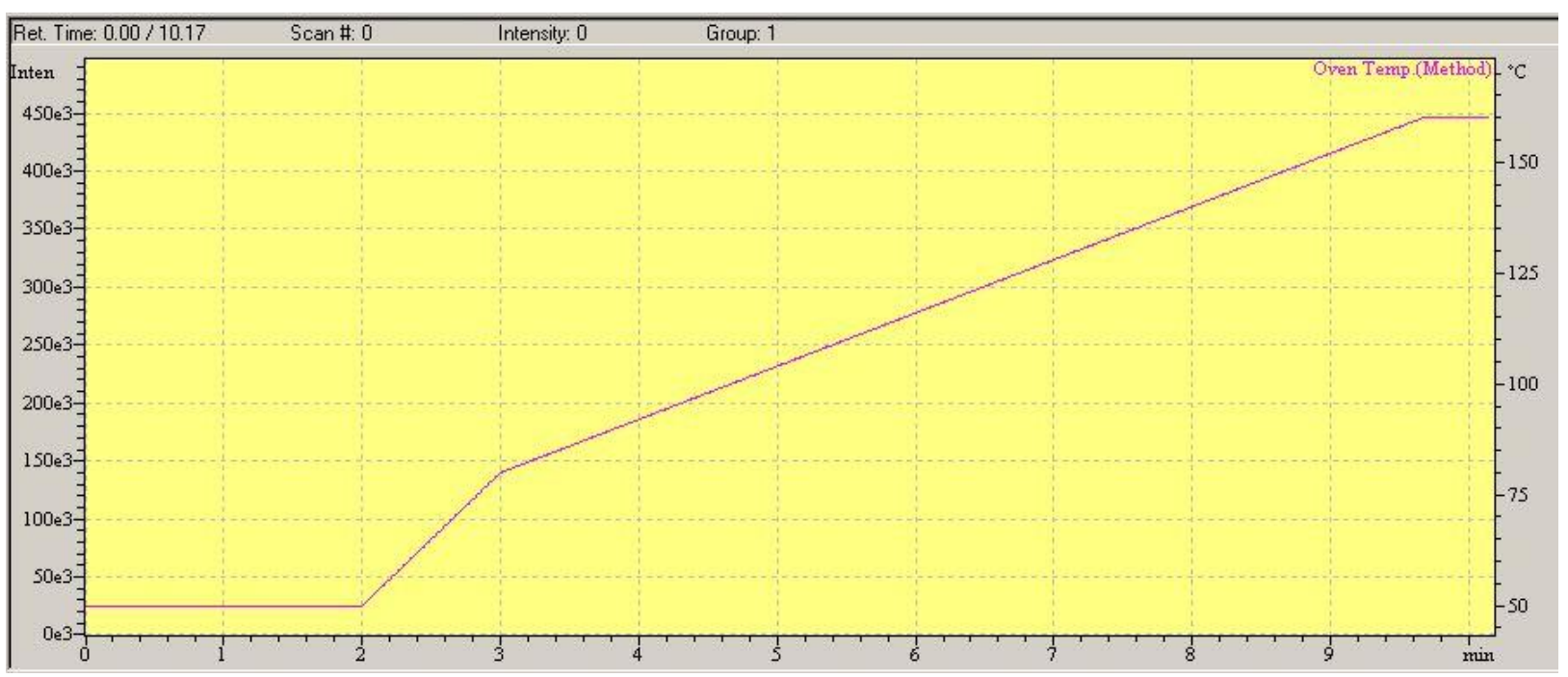

Figura 4.7 Rampa de aquecimento

As seguintes condições foram selecionadas para a análise das amostras: método MS, ionização do tipo El, variação de massa a ser monitorada entre 45 e $350 \mathrm{~m} / \mathrm{z}$.

A curva de calibração considerou 5 pontos entre 10 e 100 ppb, a utilização de sulfato de sódio anidro para auxiliar na extração de vapores, e o uso de $20 \mu \mathrm{L}$ de solução de padrão interno de 1,4-diclorobenzeno-d-4, clorobenzeno-d-5 e fluorbenzeno em metanol.

Os intermediários formados a partir da reação de degradação do PCE por injeção de ozônio foram analisados para identificação qualitativa. As amostras coletadas no final dos ensaios batch e de coluna foram analisadas no GC/MS citado anteriormente e no HPLC/MS. A bibliografia sugere a formação de aldeídos, cetonas e ácidos carboxílicos. 


\subsubsection{Ozônio}

Inicialmente, foi considerada a utilização de sensores portáteis para medição de ozônio gasoso na saída da coluna. Para verificar a sensibilidade e confiabilidade dos equipamentos portáteis, foram realizados testes em uma caixa organizadora de plástico, com orifícios para encaixe das mangueiras de entrada e saída de gás, na qual foi injetado ozônio e colocados diferentes sensores: Tongdy sensor de ambiente com detecção máxima de 5000 pb, Ecosensor 15,89 ppm e BMT.

Os dois primeiros equipamentos testados chegaram à capacidade de detecção máxima em cerca de 1 minuto, portanto o uso de medidores portáteis de ozônio foi descartado. O BMT não apresentou vazão suficiente durante o teste, tendo sido também descartado.

Posteriormente, foi realizado um teste com o espectrofotômetro UV-Visível, da Micronal, Modelo B582, que utiliza uma cubeta de fluxo de quartzo de caminho óptico de $1 \mathrm{~mm}$ para leitura da absorbância ou da transmitância. O ozônio gasoso pode ser medido no comprimento de onda máximo de $254 \mathrm{~nm}$.

Para calibração das leituras realizadas no espectrofotômetro foi realizada a determinação da concentração de ozônio pelo método iodométrico, seguindo protocolo analítico da Associação Internacional de Ozônio (IOA, 1996).

Para medição de ozônio em fase aquosa foi realizado um teste do método colorimétrico (Chemets Ozone R-7404), kit para ozônio dissolvido, com escala de cores de 0 a 3 ppm, que utiliza ampolas com reagentes selecionados préquantificados e selados a vácuo. Entretanto, este método foi considerado impreciso para um trabalho científico.

Foi realizado um teste com o espectrofotômetro UV-Visível, da Shimadzu, modelo UV-2600, que utiliza uma cubeta de quartzo hermeticamente fechada com rolha de teflon, e caminho óptico de $1 \mathrm{~cm}$ para leitura da absorbância ou da transmitância. As leituras foram realizadas no comprimento de onda máximo de $260 \mathrm{~nm}$ para ozônio em fase dissolvida. Este método foi calibrado através de determinação da concentração de ozônio pelo método iodométrico. 
O método de medição de ozônio em fase gasosa foi utilizado para monitoramento na entrada da coluna, e após sua estabilização, para monitoramento na saída da coluna; enquanto o método de medição de ozônio em fase dissolvida foi utilizado nos ensaios de saturação e decaimento de ozônio e para monitoramento das concentrações de ozônio e degradação do PCE nos ensaios batch e de coluna.

\subsubsection{Carbono orgânico total (COT)}

Foram realizados alguns testes para determinar o carbono orgânico total (COT) de soluções saturadas com PCE, com a finalidade de conseguir fazer um balanço de massa de carbono e verificar se houve mineralização completa nos ensaios batch e coluna.

As análises foram realizadas no analisador de COT da Shimadzu, modelo TOC-L, que está acoplado ao amostrador automático da Shimadzu, modelo ASI-L. O equipamento faz as leituras de carbono total (TC) e de carbono inorgânico (IC), e por diferença determina o COT.

O preparo das amostras preparadas consideraram uma concentração de PCE dissolvida de $150 \mathrm{mg} / \mathrm{L}$, correspondente à leitura de COT de $21,7 \mathrm{mg} / \mathrm{L}$.

Análises preliminares de COT de amostras de soluções de PCE com concentrações entre 100 e $200 \mathrm{mg} / \mathrm{L}$, realizadas através de curvas de calibração disponíveis no equipamento, indicaram porcentagem desprezível de IC. Os pontos dessas curvas disponíveis não estavam coerentes e resolveu-se, portanto, fazer nova calibração, apenas para TC.

A curva de calibração de TC de 0,5 a 20 ppm foi preparada com amostras diluídas manualmente a partir de uma solução mãe de biftalato de potássio em água ultrapura. As amostras de concentrações para a curva de calibração foram mantidas refrigeradas até a injeção.

Entretanto, por se tratar de um composto muito volátil, havia perdas significativas entre as 3 leituras realizadas, a partir da qual o analisador calculava a concentração de carbono média. Por isso, decidiu-se por considerar apenas a primeira leitura. 
Entretanto, as amostras do trap dos ensaios em coluna ressuspendidas apenas em água ultrapura perdiam quantidade considerável de PCE, resultando em concentrações muito abaixo do esperado. Optou-se por fazer o trap em metanol, o que acabou por inviabilizar a leitura de COT para balanço de massa de carbono, por causa da existência de carbono no metanol. 


\section{DISCUSSÃO DOS RESULTADOS}

\subsection{Caracterização da Água Subterrânea e do Solo}

Os resultados dos ensaios geotécnicos realizados no LMS-EPUSP com as microesferas de vidro, a areia e as amostras de solo coletadas a 0,4 e $0,6 \mathrm{~m}$ de profundidade estão nas Figuras 5.1, 5.2, e na Tabela 5.1. A Tabela 5.2 apresenta a caracterização físico-química do solo efetuada pela ESALQ, enquanto os resultados da caracterização mineralógica e química do solo e da areia executados no LCTEPUSP encontram-se na Tabela 5.3.

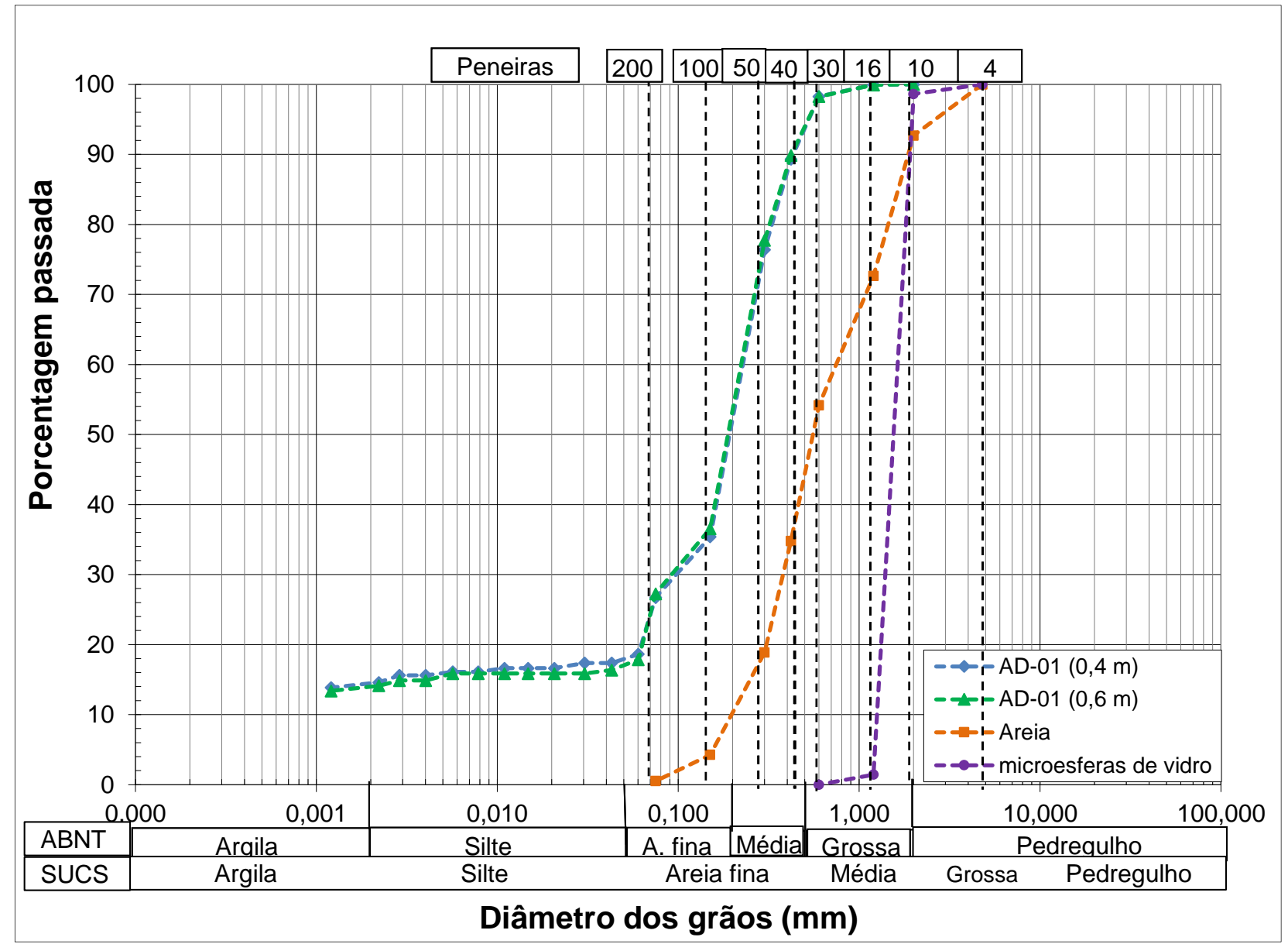

Figura 5.1 Distribuição granulométrica do solo, areia e microesferas de vidro. Fonte: Laboratório de Mecânica dos Solos - EPUSP, 2013 


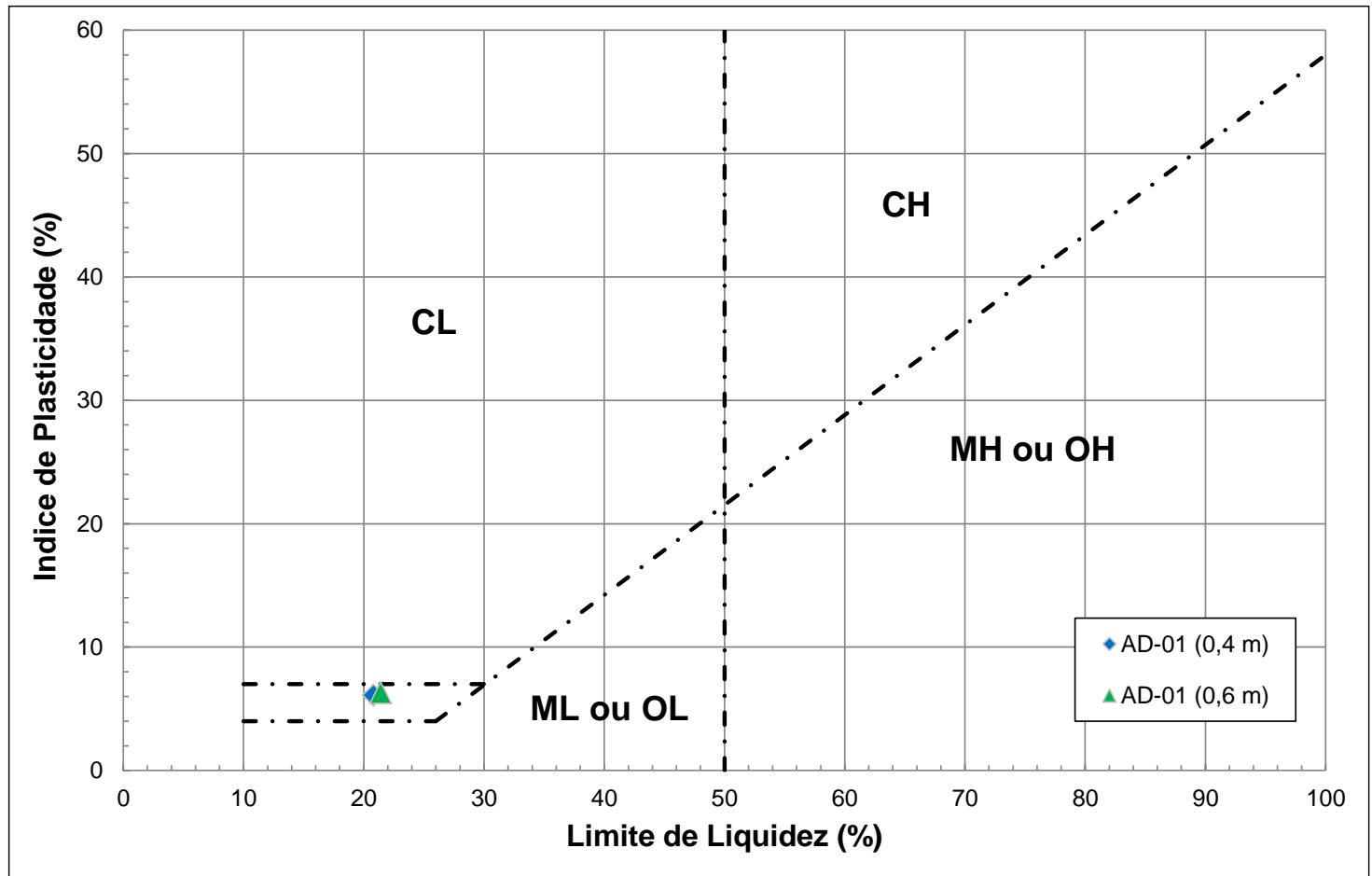

Figura 5.2 Limites de Atterberg do solo 
Tabela 5.1 Resultados dos ensaios de caracterização geotécnica

\begin{tabular}{|c|c|c|c|c|}
\hline Identificação da amostra & $\begin{array}{l}\text { AD-01 } \\
(0,4 \mathrm{~m})\end{array}$ & $\begin{array}{l}\text { AD-01 } \\
(0,6 \mathrm{~m})\end{array}$ & Areia & $\begin{array}{l}\text { Microesferas } \\
\text { de vidro }\end{array}$ \\
\hline Argila* (\%) & 14,5 & 14,0 & - & - \\
\hline Silte* (\%) & 4,5 & 3,0 & - & - \\
\hline Areia total $^{*}(\%)$ & 81,0 & 83,0 & 100,0 & 100,0 \\
\hline Areia fina* $(\%)$ & 34,0 & 37,0 & 35,0 & - \\
\hline Areia media* $(\%)$ & 41,0 & 40,5 & 58,0 & 98,6 \\
\hline Areia grossa* $(\%)$ & 6,0 & 5,5 & 7,0 & 1,4 \\
\hline Limite de liquidez (\%) & 21 & 21 & - & - \\
\hline Limite de plasticidade (\%) & 15 & 15 & - & - \\
\hline Índice de plasticidade (\%) & 6 & 6 & - & - \\
\hline Massa específica dos grãos $\left(\mathrm{g} / \mathrm{cm}^{3}\right)$ & 2,68 & 2,70 & 2,63 & 2,50 \\
\hline Massa específica natural do solo $\left(\mathrm{g} / \mathrm{cm}^{3}\right)$ & 2,109 & 2,176 & - & - \\
\hline Teor de umidade gravimétrico natural (\%) & 9,19 & 10,81 & - & - \\
\hline Porosidade total (\%) & 42 & 43 & 46 & 38 \\
\hline Matéria orgânica (\%) (mufla) & 1,00 & 0,81 & - & - \\
\hline Índice de vazios máximo & - & - & $0,86 \pm 0,03$ & $0,58 \pm 0,01$ \\
\hline Índice de vazios mínimo & - & - & 0,68 & 0,61 \\
\hline $\mathrm{pH} \mathrm{H} \mathrm{H}_{2} \mathrm{O}^{* * * *}$ & 4,05 & 4,20 & 8,06 & $\begin{array}{l}9,65^{\star \star} \\
9,07^{\star \star \star}\end{array}$ \\
\hline Condutividade elétrica $(\mu \mathrm{S} / \mathrm{cm})$ & 71,76 & 36,27 & 205,4 & $\begin{array}{l}71,38^{* *} \\
35,5^{\star * *}\end{array}$ \\
\hline Potencial de óxi-redução (mV) & 456,4 & 345,7 & 220,1 & $\begin{array}{c}160,3^{\star *} \\
235,3^{\star * *}\end{array}$ \\
\hline Classificação do solo (Sistema Americano) & $\begin{array}{c}\text { Areia } \\
\text { franca }\end{array}$ & $\begin{array}{c}\text { Areia } \\
\text { franca }\end{array}$ & - & - \\
\hline $\begin{array}{l}\text { Classificação do solo (Sistema Unificado de } \\
\text { Classificação de Solos) }\end{array}$ & SC-SM & SC-SM & SP & SP \\
\hline
\end{tabular}

Legenda: *Sistema Unificado de Classificação de Solos; ${ }^{* *}$ microesfera de vidro lavada sem ácido; ${ }^{* * *}$ microesfera de vidro lavada com ácido, ${ }^{* * * *}$ Método USEPA 9045D/2004. Fonte: Laboratório de Mecânica dos Solos - EPUSP, 2013; Laboratório de Engenharia QuímicaEPUSP, 2014 
Tabela 5.2 Resultados de caracterização físico-química do solo

\begin{tabular}{|c|c|c|}
\hline Identificação da amostra & AD-01 $(0,4 \mathrm{~m})$ & AD-01 $(0,6 \mathrm{~m})$ \\
\hline Argila (\%) & 22,6 & 22,5 \\
\hline Silte (\%) & 1,8 & 1,7 \\
\hline Areia total (\%) & 75,7 & 75,8 \\
\hline Areia fina $(\%)$ & 37,8 & 39,9 \\
\hline Areia média-fina (\%) & 5,0 & 5,4 \\
\hline Areia média (\%) & 29,5 & 27,3 \\
\hline Areia média-grossa (\%) & 0,2 & 0,3 \\
\hline Areia grossa $(\%)$ & 3,2 & 2,9 \\
\hline Massa específica dos grãos $\left(\mathrm{g} / \mathrm{cm}^{3}\right)$ & 2,66 & 2,67 \\
\hline Massa específica relativa $\left(\mathrm{g} / \mathrm{cm}^{3}\right)$ & 1,33 & 1,47 \\
\hline Porosidade total (\%) & 50 & 45 \\
\hline Porosidade efetiva (\%) & 31 & 24 \\
\hline Macroporosidade (\%) & 34 & 27 \\
\hline Microporosidade (\%) & 16 & 17 \\
\hline Classe de textura (USDA) & Média arenosa & Média arenosa \\
\hline Nitrogênio (\%) & 0,12 & 0,10 \\
\hline Carbono (\%) & 1,23 & 0,90 \\
\hline Matéria orgânica (\%) & 0,7 & $<0,4$ \\
\hline Carbono orgânico (\%) & 0,4 & 0,2 \\
\hline Condutividade elétrica $(\mu \mathrm{S} / \mathrm{cm})$ & 43,52 & 23,14 \\
\hline $\mathrm{pH} \mathrm{H} \mathrm{H}_{2} \mathrm{O}$ & 4,4 & 4,6 \\
\hline $\mathrm{pH} \mathrm{KCl}$ & 3,9 & 3,9 \\
\hline $\mathrm{P}(\mathrm{mg} / \mathrm{kg})$ & 1 & $<1$ \\
\hline $\mathrm{K}(\mathrm{mmolc} / \mathrm{Kg})$ & $<0,3$ & $<0,3$ \\
\hline $\mathrm{Ca}(\mathrm{mmolc} / \mathrm{Kg})$ & $<2$ & $<2$ \\
\hline $\mathrm{Mg}(\mathrm{mmolc} / \mathrm{Kg})$ & $<1$ & $<1$ \\
\hline $\mathrm{Al}(\mathrm{mmolc} / \mathrm{Kg})$ & 6 & 7 \\
\hline $\mathrm{H}+\mathrm{Al}(\mathrm{mmolc} / \mathrm{Kg})$ & 59 & 35 \\
\hline Soma de bases trocáveis (mmolc/Kg) & 1,3 & 1,3 \\
\hline CTC $(\mathrm{mmolc} / \mathrm{Kg})$ & 60,6 & 36,7 \\
\hline Saturação da CTC por bases (\%) & 2 & 4 \\
\hline Saturação por alumínio (\%) & 81 & 83 \\
\hline
\end{tabular}

Fonte: Departamento de Ciência do Solo - ESALQ, 2014. 
Tabela 5.3 Resultados de difração de raios $\times(D R X)$ e fluorescência de raios $\times(F R X)$

\begin{tabular}{|c|c|c|c|c|c|c|c|}
\hline \multirow{3}{*}{ Fórmula } & \multicolumn{4}{|c|}{ AD-01 $(0,6 \mathrm{~m})$} & \multicolumn{3}{|c|}{ A-01 Areia } \\
\hline & \multicolumn{2}{|c|}{ FRX } & \multicolumn{2}{|c|}{ DRX } & \multirow{2}{*}{\begin{tabular}{|c|} 
FRX \\
$\begin{array}{l}\text { Quantitativo } \\
\text { (com } \\
\text { padrão) (\%) }\end{array}$
\end{tabular}} & \multicolumn{2}{|c|}{ DRX } \\
\hline & $\begin{array}{l}\text { Quantitativo } \\
\text { (sem } \\
\text { padrão) (\%) }\end{array}$ & $\begin{array}{l}\text { Quantitativo } \\
\text { (com } \\
\text { padrão) (\%) }\end{array}$ & $\begin{array}{l}\text { Nome do } \\
\text { Composto }\end{array}$ & $\begin{array}{c}\% \\
\text { Estimada }\end{array}$ & & $\begin{array}{l}\text { Nome do } \\
\text { Composto }\end{array}$ & $\begin{array}{c}\% \\
\text { Estimada }\end{array}$ \\
\hline $\mathrm{Al}_{2} \mathrm{O}_{3}$ & 7,73 & 7,71 & - & - & 3,51 & - & - \\
\hline$\overline{\mathrm{SiO}_{2}}$ & 83,8 & 83,7 & Quartzo & 77 & 91,7 & Quartzo & 84 \\
\hline $\mathrm{P}_{2} \mathrm{O}_{5}$ & 0,045 & $<0,10$ & - & - & $<0,10$ & - & - \\
\hline $\mathrm{TiO}_{2}$ & 0,853 & 0,74 & $\begin{array}{c}\text { Anatásio } \\
\text { Rutilo }\end{array}$ & $\begin{array}{l}1 \\
1 \\
\end{array}$ & 0,26 & - & - \\
\hline $\mathrm{Cr}_{2} \mathrm{O}_{3}$ & 0,044 & - & - & - & - & - & - \\
\hline $\mathrm{Fe}_{2} \mathrm{O}_{3}$ & 3,29 & 2,92 & Hematita & 2 & 0,42 & - & - \\
\hline $\mathrm{CuO}$ & 0,03 & - & - & - & - & - & - \\
\hline $\mathrm{ZrO}_{2}$ & 0,053 & - & - & - & - & - & - \\
\hline $\mathrm{PbO}$ & 0,056 & - & - & - & - & - & - \\
\hline$\overline{P F}$ & 4,12 & 4,12 & - & - & 0,62 & - & - \\
\hline $\mathrm{MnO}$ & - & $<0,10$ & - & - & $<0,10$ & - & - \\
\hline $\mathrm{MgO}$ & - & $<0,10$ & - & - & $<0,10$ & - & - \\
\hline $\mathrm{CaO}$ & - & $<0,10$ & - & - & 0,27 & - & - \\
\hline $\mathrm{Na}_{2} \mathrm{O}$ & - & $<0,10$ & - & - & 0,34 & - & - \\
\hline $\mathrm{K}_{2} \mathrm{O}$ & - & $<0,10$ & - & - & 1,83 & - & - \\
\hline $\mathrm{Al}_{2}\left(\mathrm{Si}_{2} \mathrm{O}_{5}\right)(\mathrm{OH})_{4}$ & - & - & Caulinita & 16 & - & - & - \\
\hline $\mathrm{Al}(\mathrm{OH})_{3}$ & - & - & Gibbsita & 3 & - & - & - \\
\hline $\mathrm{KAISi}_{3} \mathrm{O}_{8}$ & - & - & - & - & - & Microclínio & 8 \\
\hline $\begin{array}{l}\mathrm{KAl}_{3} \mathrm{Si}_{3} \\
\mathrm{O}_{10}(\mathrm{OH})_{2}\end{array}$ & - & - & - & - & - & Muscovita & 5 \\
\hline $\begin{array}{l}(\mathrm{Na}, \mathrm{Ca}) \\
\mathrm{Al}(\mathrm{Si}, \mathrm{Al})_{3} \mathrm{O}_{8}\end{array}$ & - & - & - & - & - & Albita & 3 \\
\hline
\end{tabular}

Fonte: Laboratório de Caracterização Tecnológica - EPUSP, 2014

A baixa porcentagem de finos do solo e os limites de consistência indicam que o solo é uma areia com finos pouco plásticos (Figura 5.2). Segundo o Sistema Unificado de Classificação de Solos, trata-se de SC-SM, areia com finos silto-argilosos. Segundo o Sistema Americano, as amostras de solo são classificadas de acordo com o triângulo textural como areia franca.

Os resultados da distribuição granulométrica obtidos pela ESALQ concordam com os valores obtidos no Laboratório de Mecânica dos Solos da EPUSP, mostrando que o solo é predominantemente arenoso e classificado por textura média arenosa segundo o Departamento de Agricultura dos Estados Unidos (USDA). 
Os valores de condutividade elétrica no solo são baixos nas profundidades investigadas, e potencial de óxi-redução com caráter oxidante, que indicam, respectivamente, pequena quantidade de íons dissolvidos e presença de metais.

Os minerais predominantes no solo são o quartzo e a caulinita, com presença de gibbsita, hematita, rutilo e anatásio. A análise quantitativa por fluorescência de raios X está coerente com a análise mineralógica.

O solo apresenta baixo teor de matéria orgânica (igual ou inferior a 1\%), porosidade elevada (maior que 40\%), baixa CTC e é ácido, o que está de acordo com o esperado para solos arenosos laterizados (NOGAMI; VILLIBOR, 1995).

O solo, portanto, é representativo da região, tanto no contexto pedológico, uma vez que apresenta características físicas, químicas e mineralógicas típicas dos latossolos, quanto geológico, por ser predominantemente formado de areia de quartzo.

A areia média lavada é classificada como SP, areia uniforme ou mal distribuída granulometricamente. Esta areia apresenta $\mathrm{pH}$ moderadamente elevado, valor de condutividade elétrica intermediário que indica a presença de íons dissolvidos, e potencial de óxi-redução com caráter oxidante, que aponta a presença de metais.

O mineral predominante na areia é o quartzo, com presença de microclínio e albita, que são tipos de feldspato; e de muscovita, um tipo de mica. Esses minerais são bem característicos na composição da areia. A análise quantitativa por fluorescência de raios $\mathrm{X}$ está coerente com a análise mineralógica.

As microesferas de vidro lavadas sem e com ácido que, assim como a areia, também podem ser classificados por serem uniformes, apresentam pH elevado, condutividade elétrica baixa e potencial de óxi-redução de caráter oxidante, que indicam, respectivamente a presença de poucos íons dissolvidos e a existência de metais.

Os resultados da caracterização físico-química e química das águas ultrapura e subterrâneas são apresentados na Tabela 5.4. Nesta tabela são também apresentados os resultados da medição dos parâmetros físico-químicos para a 
solução de bicarbonato de sódio na concentração de $200 \mathrm{mg} / \mathrm{L}$ para efeitos de comparação.

Tabela 5.4 Caracterização físico-química e química das águas.

\begin{tabular}{|c|c|c|c|c|c|}
\hline \multirow{2}{*}{ Caracterização } & \multirow{2}{*}{$\begin{array}{c}\text { Água } \\
\text { ultrapura }\end{array}$} & \multirow{2}{*}{$\begin{array}{c}\mathrm{NaHCO}_{3} \\
200 \mathrm{mg} / \mathrm{L}\end{array}$} & \multicolumn{2}{|c|}{ Água subterrânea } & \multirow{2}{*}{$\begin{array}{c}\text { VI } \\
\text { (CETESB } \\
2014) \\
(\mu \mathrm{g} / \mathrm{L})\end{array}$} \\
\hline & & & P-01 & P-02 & \\
\hline Alcalinidade de $\mathrm{NaHCO}_{3}(\mathrm{mg} / \mathrm{L})$ & 0,0 & 200,0 & 0,5 & 1,0 & - \\
\hline $\mathrm{pH}$ & 5,9 & 8,54 & 6,58 & 8,16 & - \\
\hline Temperatura $\left({ }^{\circ} \mathrm{C}\right)$ & 20,3 & 21,3 & 20,1 & 19,9 & - \\
\hline Condutividade elétrica $(\mu \mathrm{S} / \mathrm{cm})$ & 5,27 & 201,00 & 9,03 & 120,00 & - \\
\hline Potencial de óxi-redução (mV) & 343,7 & 218,9 & 282,7 & 236,7 & - \\
\hline Carbono total (mg/L) & 0,43 & NA & 3,22 & 26,81 & - \\
\hline Alumínio dissolvido ( $\mu \mathrm{g} / \mathrm{L})$ & NA & NA & $<1$ & $<1$ & - \\
\hline Antimônio dissolvido $(\mu \mathrm{g} / \mathrm{L})$ & NA & NA & $<1$ & $<1$ & 5 \\
\hline Arsênio dissolvido $(\mu \mathrm{g} / \mathrm{L})$ & NA & NA & $<1$ & $<1$ & 10 \\
\hline Bário dissolvido ( $\mu \mathrm{g} / \mathrm{L})$ & NA & NA & 8,71 & 382 & 700 \\
\hline Boro dissolvido $(\mu \mathrm{g} / \mathrm{L})$ & NA & NA & $<1$ & $<1$ & 2.400 \\
\hline Cádmio dissolvido $(\mu \mathrm{g} / \mathrm{L})$ & NA & NA & $<1$ & $<1$ & 5 \\
\hline Chumbo dissolvido ( $\mu \mathrm{g} / \mathrm{L})$ & NA & NA & $<1$ & $<1$ & 10 \\
\hline Cobalto dissolvido $(\mu \mathrm{g} / \mathrm{L})$ & NA & NA & $<1$ & $<1$ & 70 \\
\hline Cobre dissolvido $(\mu \mathrm{g} / \mathrm{L})$ & NA & NA & $<1$ & $<1$ & 2.000 \\
\hline Cromo dissolvido $(\mu \mathrm{g} / \mathrm{L})$ & NA & NA & $<1$ & $<1$ & 50 \\
\hline Ferro dissolvido $(\mu \mathrm{g} / \mathrm{L})$ & NA & NA & 21,4 & 1.010 & - \\
\hline Manganês dissolvido ( $\mu \mathrm{g} / \mathrm{L})$ & NA & NA & 2,5 & $<1$ & - \\
\hline Mercúrio dissolvido ( $\mu \mathrm{g} / \mathrm{L})$ & NA & NA & $<0,1$ & $<0,1$ & 1 \\
\hline Molibdênio dissolvido $(\mu \mathrm{g} / \mathrm{L})$ & NA & NA & $<1$ & $<1$ & 30 \\
\hline Níquel dissolvido $(\mu \mathrm{g} / \mathrm{L})$ & NA & NA & $<1$ & $<1$ & 70 \\
\hline Prata dissolvido $(\mu \mathrm{g} / \mathrm{L})$ & NA & NA & $<1$ & $<1$ & 50 \\
\hline Selênio dissolvido $(\mu \mathrm{g} / \mathrm{L})$ & NA & NA & $<1$ & $<1$ & 10 \\
\hline Vanádio dissolvido $(\mu \mathrm{g} / \mathrm{L})$ & NA & NA & $<1$ & $<1$ & - \\
\hline Zinco dissolvido $(\mu \mathrm{g} / \mathrm{L})$ & NA & NA & 19,6 & 274 & 1.800 \\
\hline
\end{tabular}

Fonte: Parâmetros F-Q: Laboratório da Engenharia Química - EPUSP, 2014; Metais: Bioagri Ambiental, 2014

As águas subterrâneas são fracamente bicarbonatadas, moderadamente básicas no poço cacimba (P-01) e básicas no poço tubular profundo (P-02), características concordantes com o contexto hidrogeológico regional. Foram ainda detectados bário, ferro, manganês e zinco dissolvidos nas águas subterrâneas em 
concentrações inferiores aos valores de intervenção estabelecidos pela CETESB (2014).

Os parâmetros ferro e manganês não apresentam valores de intervenção estabelecidos pela CETESB, já que são metais comumente encontrados naturalmente no solo. $O$ ferro pode estar associado à presença de hematita, constatada na análise de difratometria de raios X. Adicionalmente, nota-se que as concentrações de metais, principalmente de ferro detectada no poço tubular profundo é maior que a do poço cacimba, indício que corrobora com a hipótese de ocorrência natural, uma vez que um tempo de residência maior no aquífero propicia a dissolução de metais e a presença de uma quantidade maior de íons dissolvidos (conforme comprovado pela medição da condutividade elétrica). Os valores de potencial de óxi-redução indicam que as águas subterrâneas amostradas apresentam caráter oxidante e os baixos valores de carbono total coincidem com os resultados obtidos para as amostras de solo coletadas na mesma região, indicando praticamente ausência de matéria orgânica.

\subsection{Ensaios Preliminares}

Os resultados do ensaio de injeção de oxigênio em água ultrapura estão apresentados na Figura 5.3, que mostra o espectro para as quatro amostras coletadas na coluna. Observa-se que as quatro curvas são coincidentes, comprovando que o oxigênio não é absorvido na faixa UV-não visível estudada. 


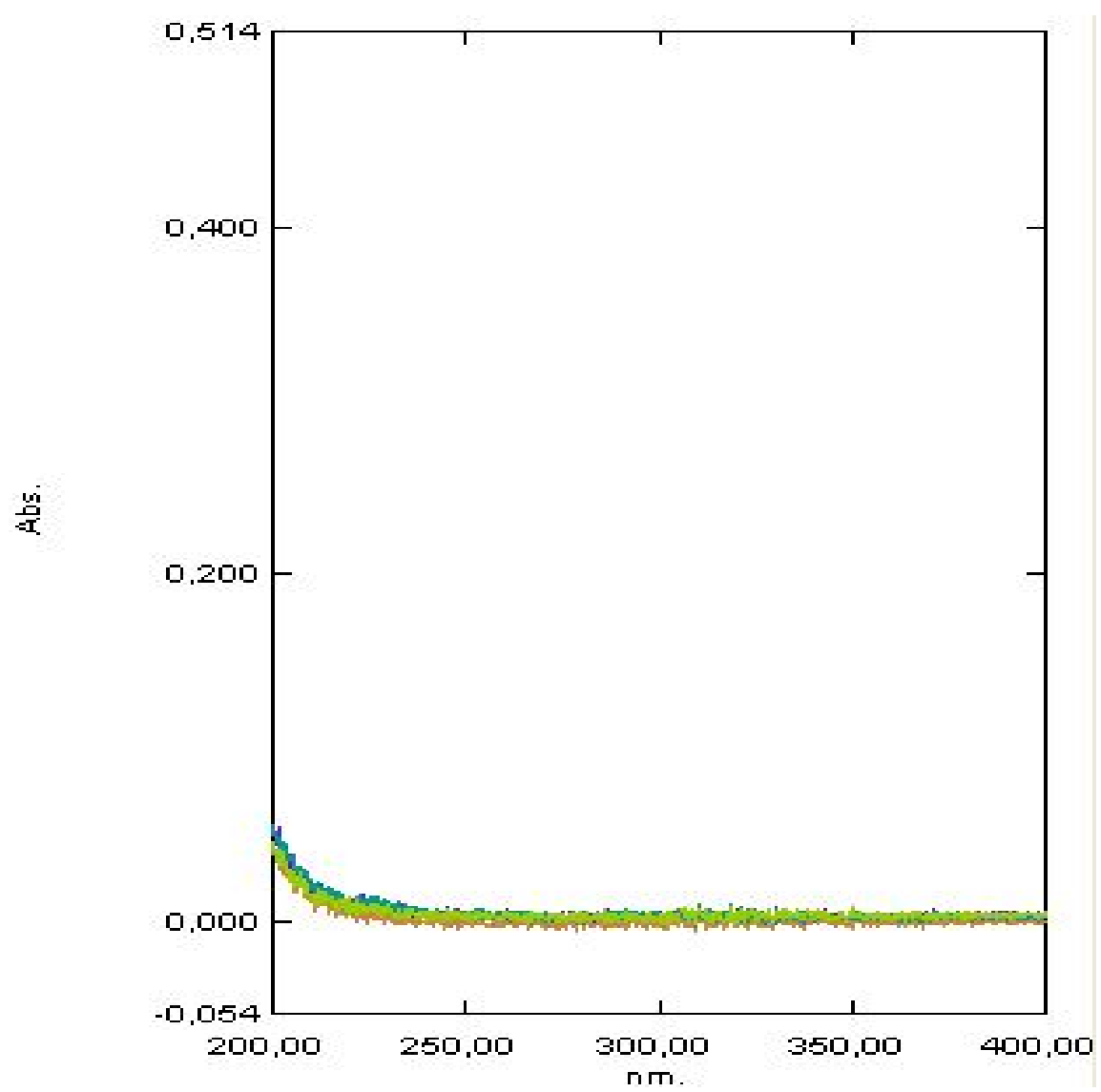

Figura 5.3 Ensaio de injeção de oxigênio em água ultrapura: espectros de quatro amostras coletadas na coluna (10 e 25 minutos após o início da injeção, e 5 e 10 minutos após o desligamento da injeção)

Os resultados dos ensaios preliminares de saturação e decaimento de ozônio em água ultrapura são mostrados na Figura 5.4. Esta figura mostra os espectros de duas amostras retiradas 15 e 20 minutos após o início da injeção de ozônio e de 8 amostras retiradas de 5 em 5 minutos após o desligamento da injeção, até completar 40 minutos. As amostras coletadas após 15 e 20 minutos de injeção de ozônio mostraram espectros praticamente coincidentes, com o pico de absorbância de 0,463 no comprimento de $260 \mathrm{~nm}$. Após o desligamento da injeção, o ozônio decaiu até a absorbância de 0,102 após 40 minutos. Observa-se que em 15 minutos o ozônio já havia atingido a saturação em água ultrapura e decaiu a $18 \%$ do valor de saturação inicial em 40 minutos, mostrando sua instabilidade em água. 


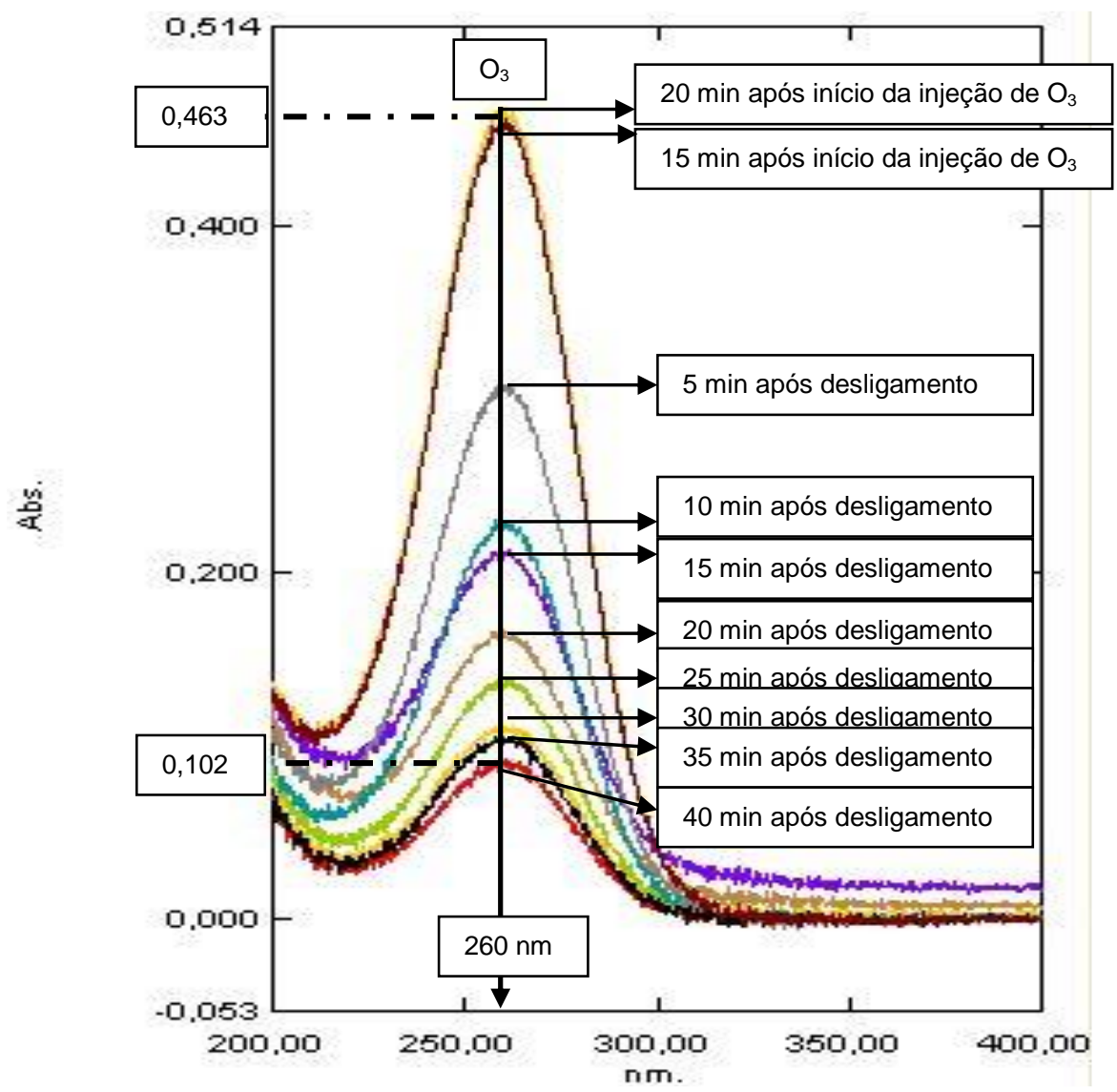

Figura 5.4 Ensaio de saturação e decaimento de ozônio em água ultrapura: espectros de amostras coletadas na coluna durante e após o desligamento da injeção - cubeta aberta

Para afastar a hipótese de que a perda de ozônio fosse devida ao método de leitura (volatilização na cubeta aberta), refez-se o ensaio analisando as amostras no espectrofotômetro UV-visível com cubeta hermeticamente fechada. A saturação durou 50 minutos, com amostras coletadas a 35, 40, 45 e 50 minutos, Amostras foram então retiradas a partir de 10 minutos do desligamento do gerador de ozônio, e de 5 em 5 minutos até completar 180 minutos. Os espectros estão apresentados na Figura 5.5. 


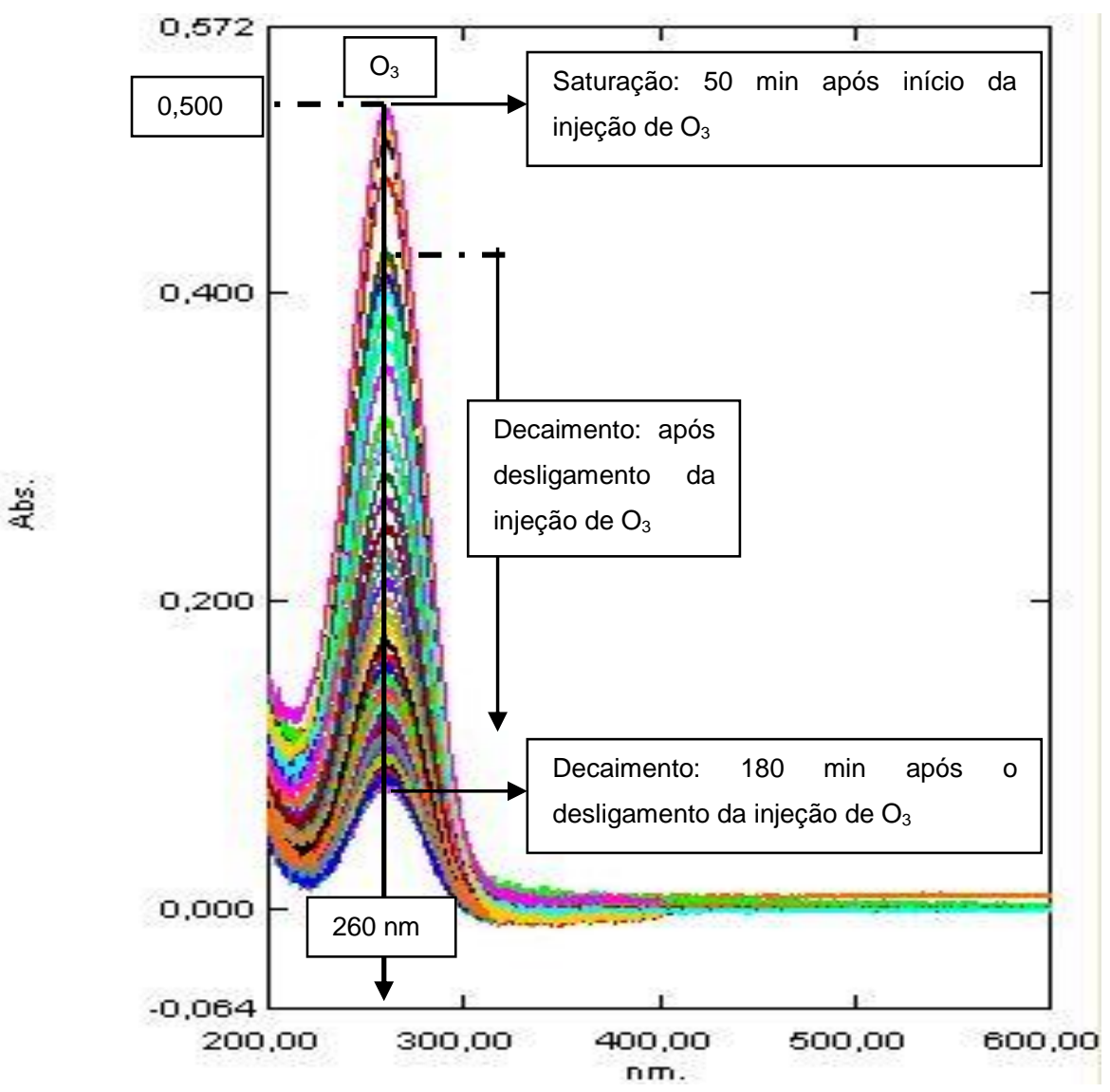

Figura 5.5 Ensaio de saturação e decaimento de ozônio em água ultrapura: espectros de amostras coletadas na coluna durante e após o desligamento da injeção - cubeta fechada

Observa-se que os picos das amostras saturadas analisadas na cubeta fechada apresentaram valores de absorbância (aproximadamente 0,500) superiores aos observados em cubeta aberta. Mesmo assim, fica comprovada a instabilidade do ozônio, pois em 40 e em 180 minutos, a absorbância caiu para, respectivamente, $53 \%$ e $16 \%$ da concentração de saturação.

Com esses resultados, adotou-se para o prosseguimento da pesquisa o uso de cubeta hermeticamente fechada totalmente preenchida de uma única vez.

Nos ensaios de cinética de decaimento de ozônio, observou-se que a água ultrapura, cujo pH inicial é 6,0, após 70 minutos apresentou $\mathrm{pH}$ constante igual a 3,70. Por outro lado, em ensaio com 30 minutos de injeção de ozônio, o pH final foi de 4,46. No ensaio com adição de bicarbonato de sódio, houve formação de bolhas na cubeta devido ao tempo excessivo de duração deste ensaio preliminar. 
Esses ensaios permitiram definir os parâmetros de entrada do método de cinética de decaimento para estimativa de meia-vida, quais sejam, frequência de leituras e duração total do ensaio.

Os resultados dos ensaios de degradação de PCE mostraram, ao longo do tempo, a formação do espectro de ozônio e a redução do espectro de PCE, cujo comprimento de onda foi considerado $220 \mathrm{~nm}$. Esses resultados podem ser observados na Figura 5.6.

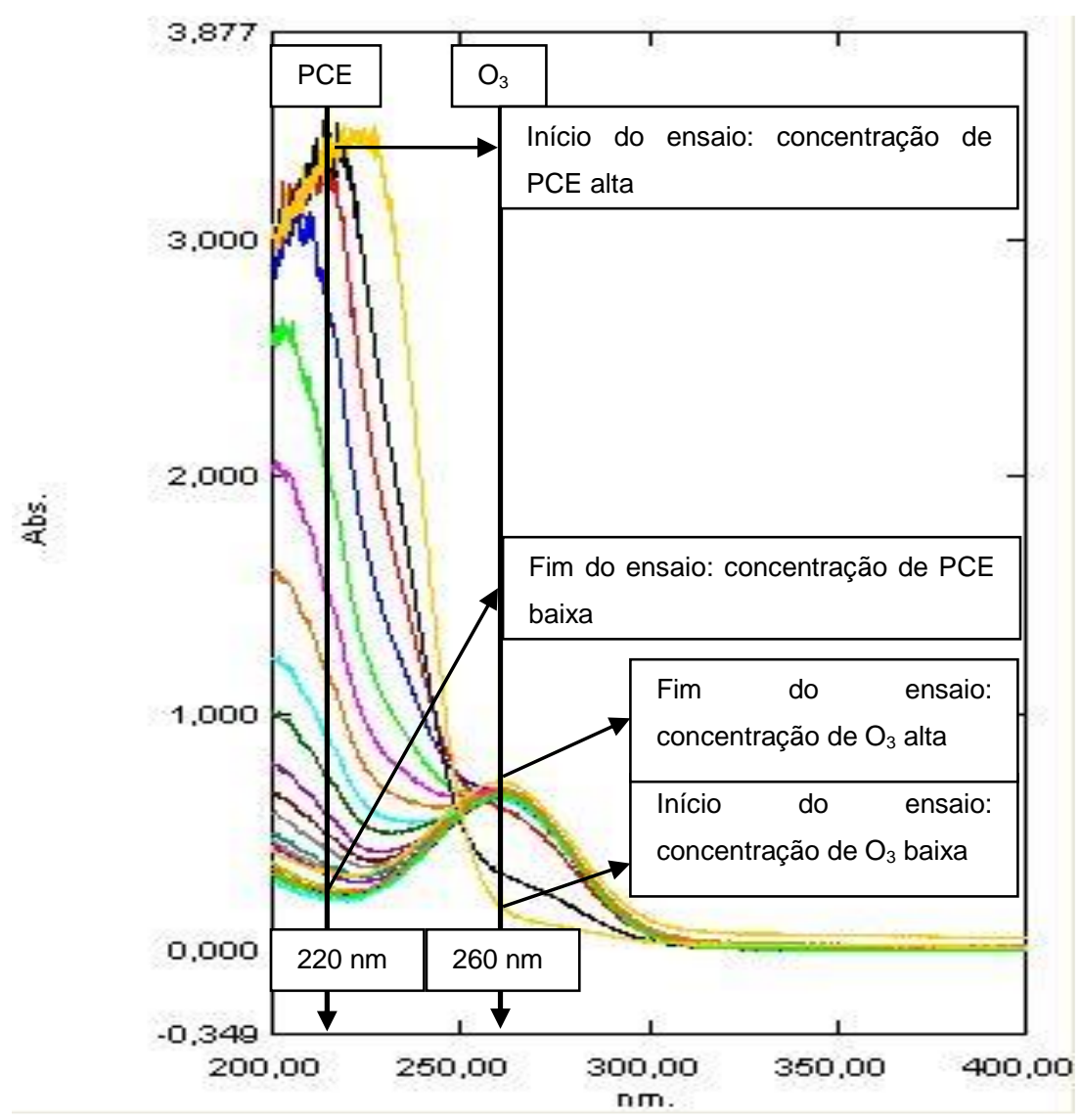

Figura 5.6 Ensaio de degradação de PCE por injeção de ozônio: espectros de amostras coletadas na coluna - cubeta fechada

Os resultados do ensaio de controle de água ultrapura mostraram redução do espectro de PCE (Figura 5.7) semelhante aos obtidos com ozônio, sugerindo o arraste do PCE pelo gás injetado. Ainda restou a dúvida se, no caso do ozônio, ocorre degradação além do arraste. 


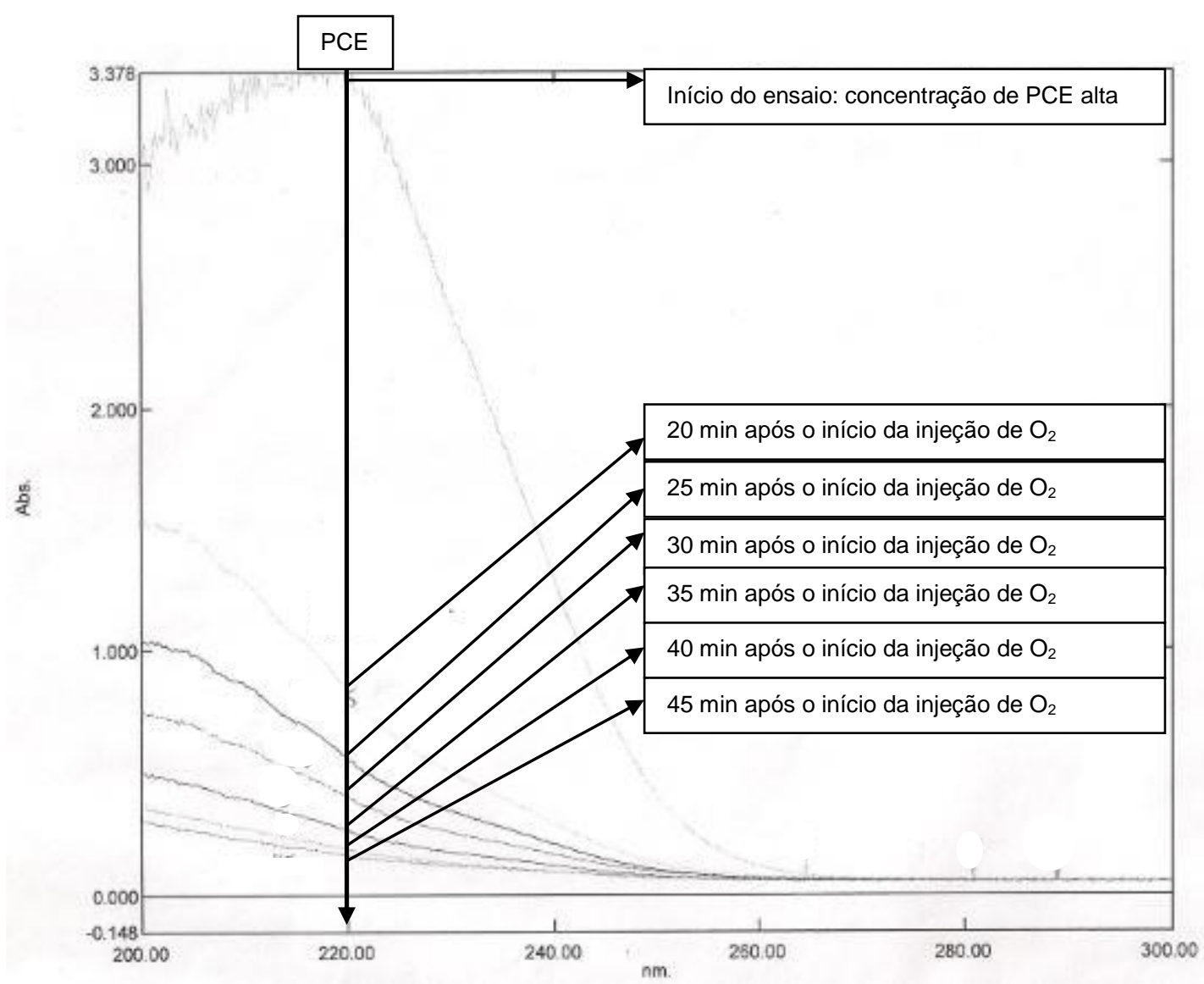

Figura 5.7 Ensaio de degradação de PCE de controle de água ultrapura (injeção de oxigênio): espectros de amostras coletadas na coluna - cubeta fechada

Para investigar a degradação do PCE por ozônio, tendo em vista a ocorrência de arraste, constatou-se a importância de quantificar a concentração de PCE na fase gasosa na saída da coluna, assim como de verificar a degradação de PCE por ozônio sem borbulhamento do gás, em sistema fechado.

Nos ensaios posteriores, adotou-se o comprimento de onda de $260 \mathrm{~nm}$ para o ozônio dissolvido e de 254 nm para o ozônio gasoso.

\subsection{Saturação e Decaimento}

Os resultados dos ensaios de saturação de ozônio em fase dissolvida estão apresentados na Figura 5.8, na forma de concentrações medidas no comprimento de onda de $260 \mathrm{~nm}$ em função do tempo de injeção de ozônio na coluna. Estes valores correspondem aos picos dos espectros de cada amostra coletada na coluna. 


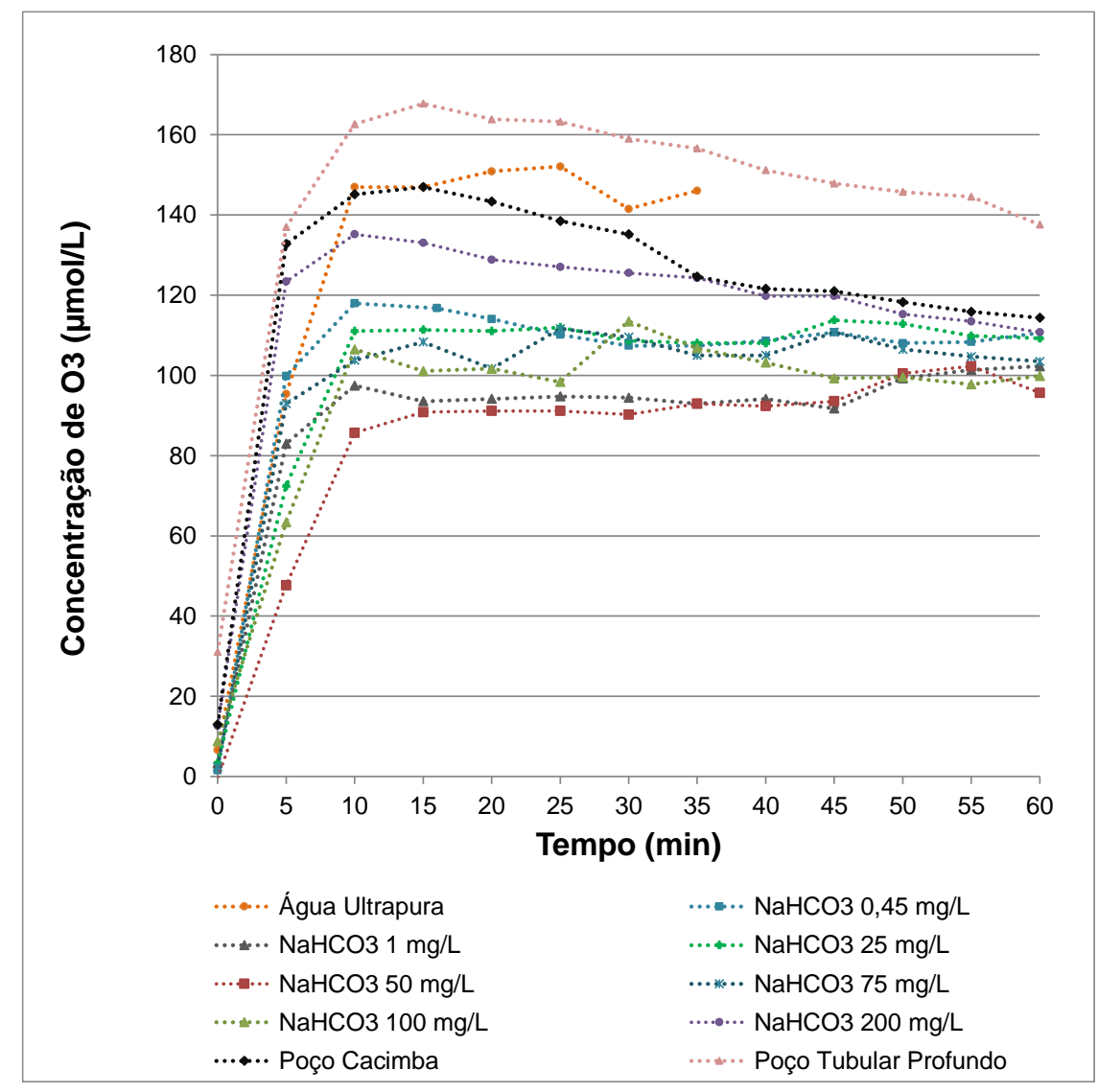

Figura 5.8 Ensaios de saturação de ozônio em fase dissolvida

Observa-se que a concentração de ozônio dissolvido aumenta rapidamente até o tempo de 10 a 15 minutos, tendendo à constância para tempos maiores no caso da água ultrapura e das soluções de bicarbonato de sódio com concentração menor ou igual a $100 \mathrm{mg} / \mathrm{L}$, e decrescendo suavemente no caso das águas subterrâneas e da solução de bicarbonato de sódio a $200 \mathrm{mg} / \mathrm{L}$. A oscilação observada nos patamares de concentração em função do tempo pode ser explicada pela instabilidade do gás.

Os valores finais de concentração de ozônio dissolvido tendem a um valor final entre 100 e $120 \mu \mathrm{mol} / \mathrm{L}$ para as soluções com bicarbonato de sódio e para a água do poço cacimba. Não se pode afirmar, contudo, que seria esta a faixa de valores finais para a água ultrapura e para a água do poço tubular profundo.

As curvas de saturação de ozônio em fase dissolvida das soluções de bicarbonato de sódio de 0,45 mg/L e $1 \mathrm{mg} / \mathrm{L}$, concentrações correspondentes, respectivamente, às obtidas nas águas do poço cacimba e do poço tubular profundo, diferem 
significativamente das curvas das águas subterrâneas, indicando que a alcalinidade não é o único fator que controla a concentração de saturação de ozônio na água. Complementarmente, verificou-se que as concentrações de saturação de ozônio nas águas subterrâneas (147-167 $\mu \mathrm{mol} / \mathrm{L})$ foram mais elevadas que as concentrações nas soluções de bicarbonato de sódio correspondentes (98-118 $\mu \mathrm{mol} / \mathrm{L})$.

Com base nesses resultados, considerou-se para o planejamento dos ensaios posteriores que 15 minutos de injeção seriam suficientes para a saturação de ozônio na água. Mesmo assim, as concentrações de ozônio dissolvido foram monitoradas em todos os ensaios por meio da leitura dos espectros.

Durante os ensaios de saturação de ozônio, monitorou-se também o pH do meio de estudo, por meio do eletrodo inserido na tampa de saída da coluna (Figura 5.9). Os valores iniciais de $\mathrm{pH}$ encontram-se na Tabela 5.5.

$\mathrm{O} \mathrm{pH}$ da água ultrapura diminuiu durante o ensaio (35 minutos) de 5,8 para 5,3. $\mathrm{O}$ $\mathrm{pH}$ da água subterrânea do poço tubular profundo apresentou um aumento durante o ensaio de 60 minutos, de 7,9 a 8,3, enquanto o pH da água subterrânea do poço cacimba aumentou de 6,2 para 7,0. As soluções de bicarbonato com concentrações de $25 \mathrm{mg} / \mathrm{L}$ cumpriram a função de tamponamento, permanecendo o pH entre 8,0 e 8,5. A adição de bicarbonato de sódio em baixas concentrações $(0,45 \mathrm{mg} / \mathrm{L}$ e 1 $\mathrm{mg} / \mathrm{L}$ ) não tornou as soluções básicas, nem possibilitou a capacidade de tamponamento, uma vez que o pH diminuiu ao longo do tempo.

Observa-se também que não há uma correlação direta entre a concentração de ozônio dissolvido e o pH do meio de estudo. 


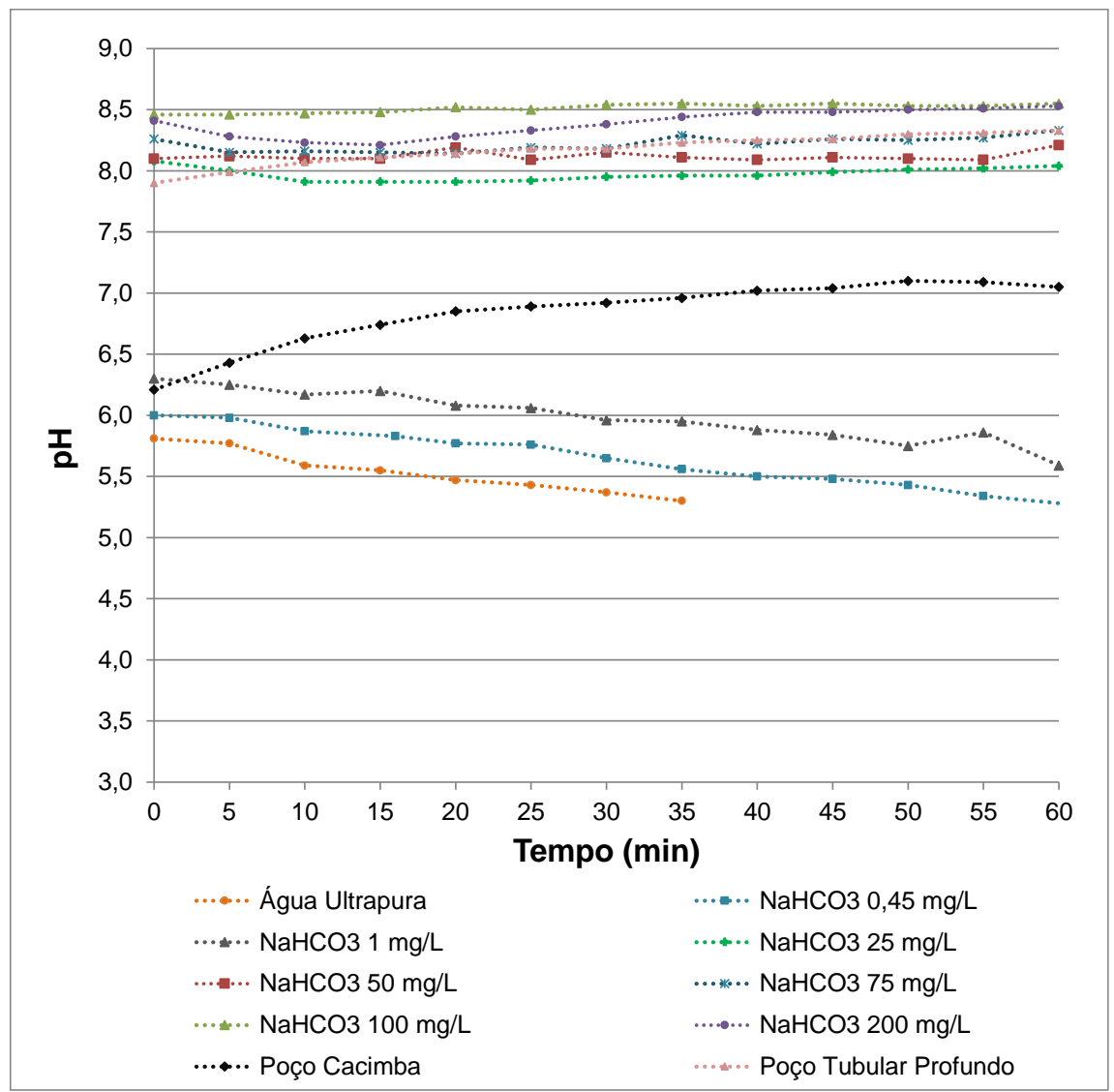

Figura 5.9 Monitoramento do pH durante os ensaios de saturação de ozônio em fase dissolvida

Tabela 5.5 Valores de pH e meia-vida mono e biexponencial dos meios de estudo.

\begin{tabular}{|c|c|c|c|c|c|c|c|}
\hline \multirow[b]{2}{*}{ Meio de estudo } & \multirow[b]{2}{*}{$\begin{array}{l}\text { Valor } \\
\text { inicial } \\
\text { de pH }\end{array}$} & \multirow[b]{2}{*}{$\begin{array}{l}\text { Valor } \\
\text { final } \\
\text { de pH }\end{array}$} & \multicolumn{2}{|c|}{ Monoexponencial } & \multicolumn{3}{|c|}{ Biexponencial } \\
\hline & & & $\begin{array}{c}\text { Tempo de } \\
\text { meia-vida } \\
t_{1}(\min )\end{array}$ & $\mathbf{R}^{2}$ & $\begin{array}{c}\text { Tempo de } \\
\text { meia-vida } \\
t_{1}(\min )\end{array}$ & $\begin{array}{c}\text { Tempo de } \\
\text { meia-vida } \\
t_{2}(\min )\end{array}$ & $\mathbf{R}^{2}$ \\
\hline \multirow{2}{*}{ Água ultrapura } & 5,8 & 5,3 & 76 & 0,97 & 26 & 166 & 0,99 \\
\hline & 5,5 & 5,2 & & & 21 & 193 & 0,99 \\
\hline Poço cacimba & 6,2 & 7,0 & 18 & 0,98 & 6 & 32 & 0,99 \\
\hline $\begin{array}{ll}\text { Poço } & \text { tubular } \\
\text { profundo } & \\
\end{array}$ & 7,9 & 8,3 & 17 & 0,99 & 8 & 27 & 0,99 \\
\hline $\mathrm{NaHCO}_{3} 0,45 \mathrm{mg} / \mathrm{L}$ & 6,0 & 5,3 & 41 & 0,98 & 20 & 130 & 0,99 \\
\hline $\mathrm{NaHCO}_{3} 1,0 \mathrm{mg} / \mathrm{L}$ & 6,3 & 5,6 & 31 & 0,98 & 7 & 68 & 0,99 \\
\hline $\mathrm{NaHCO}_{3} 25 \mathrm{mg} / \mathrm{L}$ & 8,1 & 8,0 & 20 & 0,98 & 7 & 40 & 0,99 \\
\hline $\mathrm{NaHCO}_{3} 50 \mathrm{mg} / \mathrm{L}$ & 8,1 & 8,2 & 18 & 0,98 & 6 & 33 & 0,99 \\
\hline $\mathrm{NaHCO}_{3} 75 \mathrm{mg} / \mathrm{L}$ & 8,3 & 8,3 & 14 & 0,98 & 6 & 25 & 0,99 \\
\hline $\mathrm{NaHCO}_{3} 100 \mathrm{mg} / \mathrm{L}$ & 8,4 & 8,5 & 15 & 0,99 & 6 & 25 & 0,99 \\
\hline $\mathrm{NaHCO}_{3} 200 \mathrm{mg} / \mathrm{L}$ & 8,4 & 8,5 & 12 & 0,99 & 4 & 14 & 0,99 \\
\hline
\end{tabular}


Os resultados dos ensaios de cinética de decaimento de ozônio em fase dissolvida, realizados com as amostras coletadas no final dos ensaios de saturação de ozônio, encontram-se na Figura 5.10.

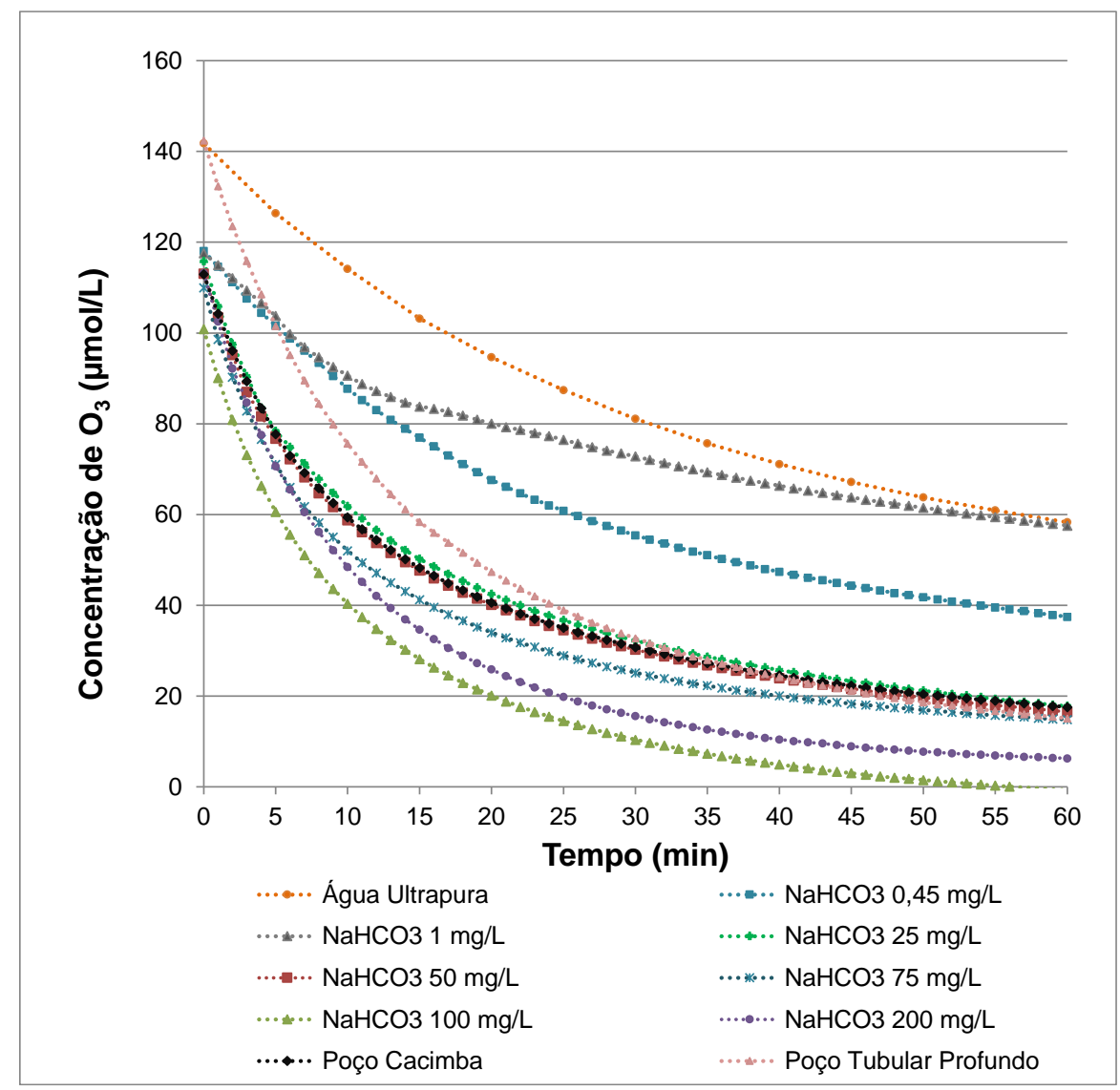

Figura 5.10 Ensaios de cinética de decaimento de ozônio em fase dissolvida

Por meio das curvas de decaimento foi calculada a meia-vida do ozônio em cada um dos meios de estudo, conforme apresentado na Tabela 5.5. As curvas apresentam comportamento biexponencial, ou seja, uma função de decaimento exponencial de segunda ordem, segundo a eq. 5.1.

$$
y(x)=y_{0}+A_{1} e^{-(x / t 1)}+A_{2} e^{-(x / t 2)}
$$

Esse comportamento biexponencial foi observado em todos os meios de estudo e pode estar associado à complexidade da decomposição do ozônio. No início do ensaio o tempo de decaimento é rápido, e após um tempo do início do ensaio (que varia com o meio de estudo), o tempo de decaimento aumenta. Esse comportamento 
cinético indica que o ozônio provavelmente está reagindo, no início do ensaio, com uma substância disponível no meio, que forma intermediários durante o ensaio. Esses intermediários gerados podem reagir com o ozônio de forma mais lenta, alterando o tempo de decaimento da reação.

As meias vidas t 1 e t2 do ozônio nas águas subterrâneas são inferiores do que em água ultrapura. As meias vidas $\mathrm{t}_{1}$ das águas subterrâneas (6 minutos para o poço cacimba e 8 minutos para o poço tubular profundo) e das soluções de bicarbonato de sódio com concentração entre 1 e $100 \mathrm{mg} / \mathrm{L}$ (6-7 minutos) são semelhantes. Para as soluções com concentração de 0,45 mg/L e $200 \mathrm{mg} / \mathrm{L}$, $\mathrm{t}_{1}$ é igual 20 e 4 minutos, respectivamente. Para a ultrapura, $\mathrm{t}_{1}$ foi estimado entre 21 e 26 minutos.

As meias vidas t2 das águas subterrâneas (32 minutos para o poço cacimba e 27 minutos para o poço tubular profundo) são também semelhantes às das soluções de bicarbonato de sódio com concentração entre 25 e $100 \mathrm{mg} / \mathrm{L}$ (25-40 minutos). Para as soluções com concentração de 0,45 mg/L, $1 \mathrm{mg} / \mathrm{L}$ e $200 \mathrm{mg} / \mathrm{L}$, t2 é igual 130, 68 e 14 e 4 minutos, respectivamente. Para a ultrapura, t2 foi estimado entre 166 e 193 minutos.

Adicionalmente foi calculado o tempo de meia vida monoexponencial, através da equação eq. 5.2 apresentada a seguir.

$$
y(x)=y_{0}+A_{1} e^{-(x / t 1)}(5.2)
$$

As meias vidas $t_{1}$ variaram entre 12 e 76 min, sendo o menor valor observado na solução com maior concentração de bicarbonato e o maior valor observado na água ultrapura. As águas subterrâneas dos poços cacimba e tubular profundo apresentaram, respectivamente, 18 e $17 \mathrm{~min}$. As soluções de bicarbonato apresentaram uma correlação inversamente proporcional ao tempo de meia vida, ou seja, as soluções com menor concentração de bicarbonato apresentaram maior tempo de meia vida (41 min) e as soluções bicarbonatadas mais concentradas mostraram tempos de meia vida menores (12 min). 
Observa-se ainda que as meias vidas com comportamento biexponencial também tendem a diminuir com o aumento da concentração de bicarbonato de sódio (Figura 5.11). Com isso, espera-se maior formação de radicais hidroxilas, que são mais reativos, portanto, que a degradação de PCE venha a ser maior com adição de bicarbonato de sódio.

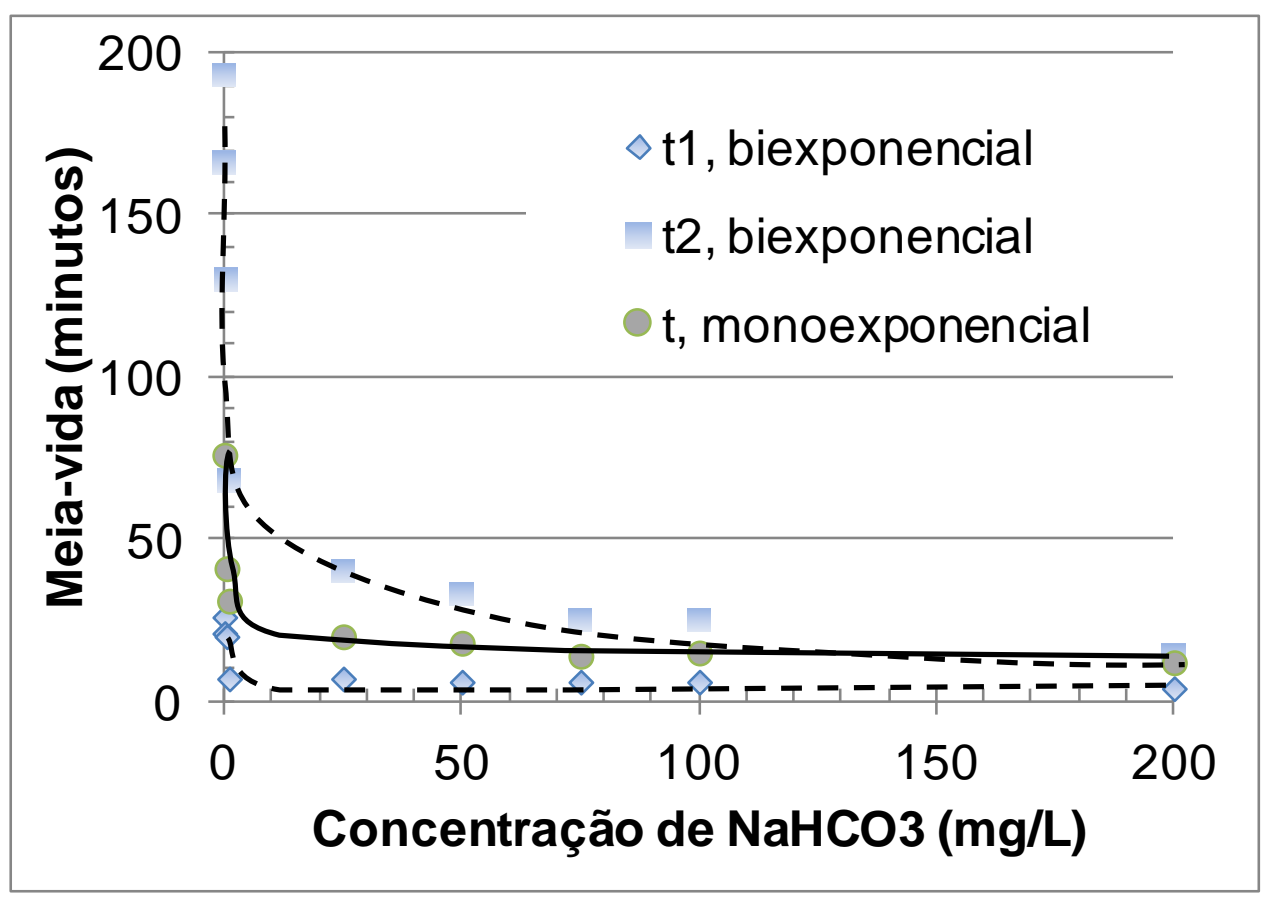

Figura 5.11 Meia vida biexponencial e monoexponencial do ozônio dissolvido em função da concentração de bicarbonato de sódio

Na Figura 5.12 são apresentados os resultados dos ensaios de saturação de ozônio em fase gasosa. Estão indicadas as concentrações observadas até cinco minutos de ensaio na entrada da coluna e na saída da coluna até 20 minutos de injeção de ozônio. 


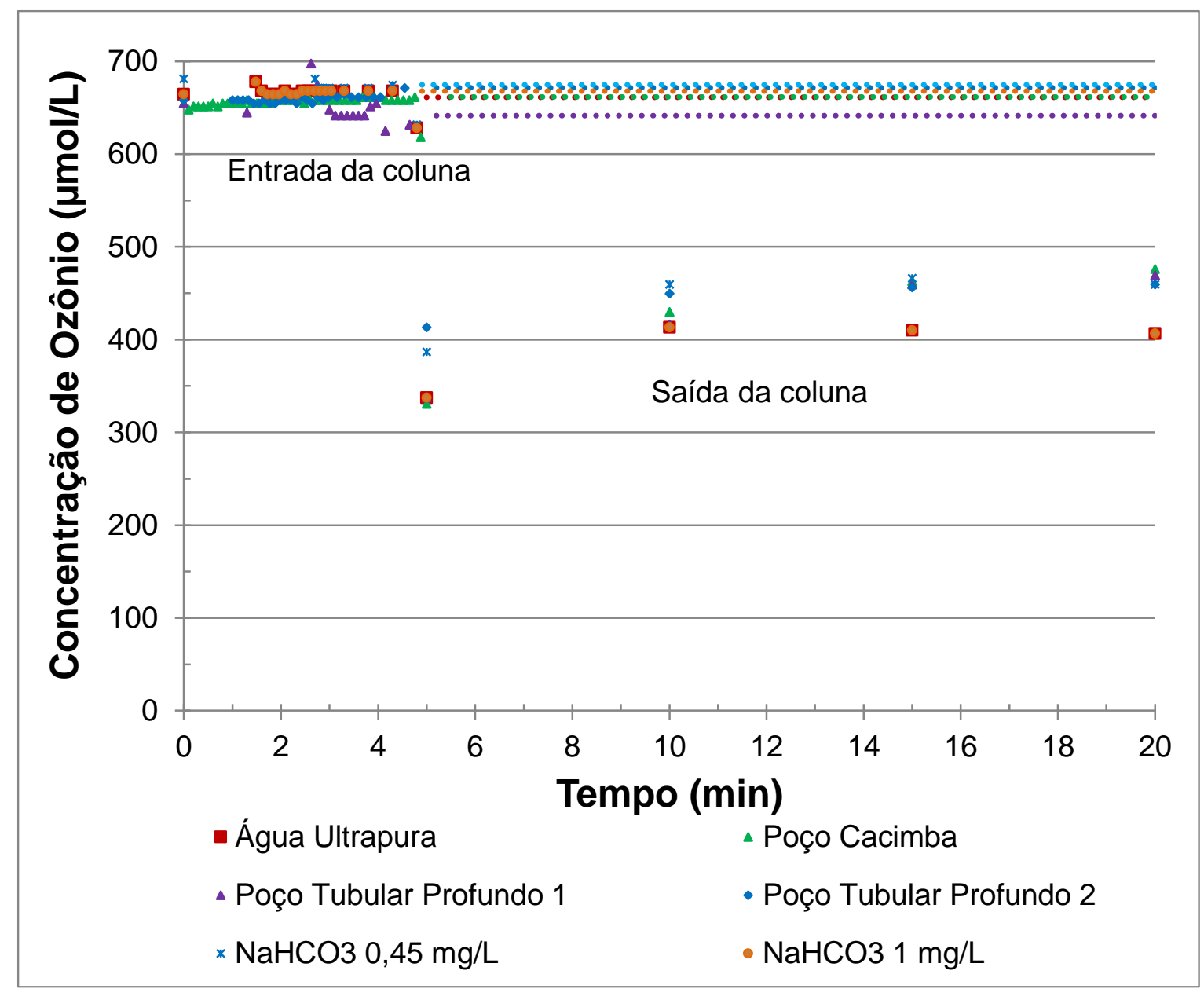

Figura 5.12 Ensaios de saturação de ozônio em fase gasosa

As concentrações de ozônio antes de entrar na coluna, entre 650-680 $\mu \mathrm{mol} / \mathrm{L}$, são maiores do que na saída, entre 450-500 $\mu \mathrm{mol} / \mathrm{L}$ para todos os meios de estudo, com exceção da solução de bicarbonato de sódio na concentração de 1 mg/L.

Esta diferença pode ocorrer devido ao decaimento do ozônio durante o tempo de percurso na coluna (segundo Tabela 5.5, meia vida em fase gasosa de 2 minutos), à dissolução no meio de estudo e a reações com alguma substância durante o percurso.

Foi também realizado um ensaio com solução saturada de PCE e injeção de oxigênio (Figura 5.13), para determinar o tempo de duração dos ensaios batch e de coluna. Com base nos espectros ao longo do ensaio, o tempo adotado foi de 1 h50min. 


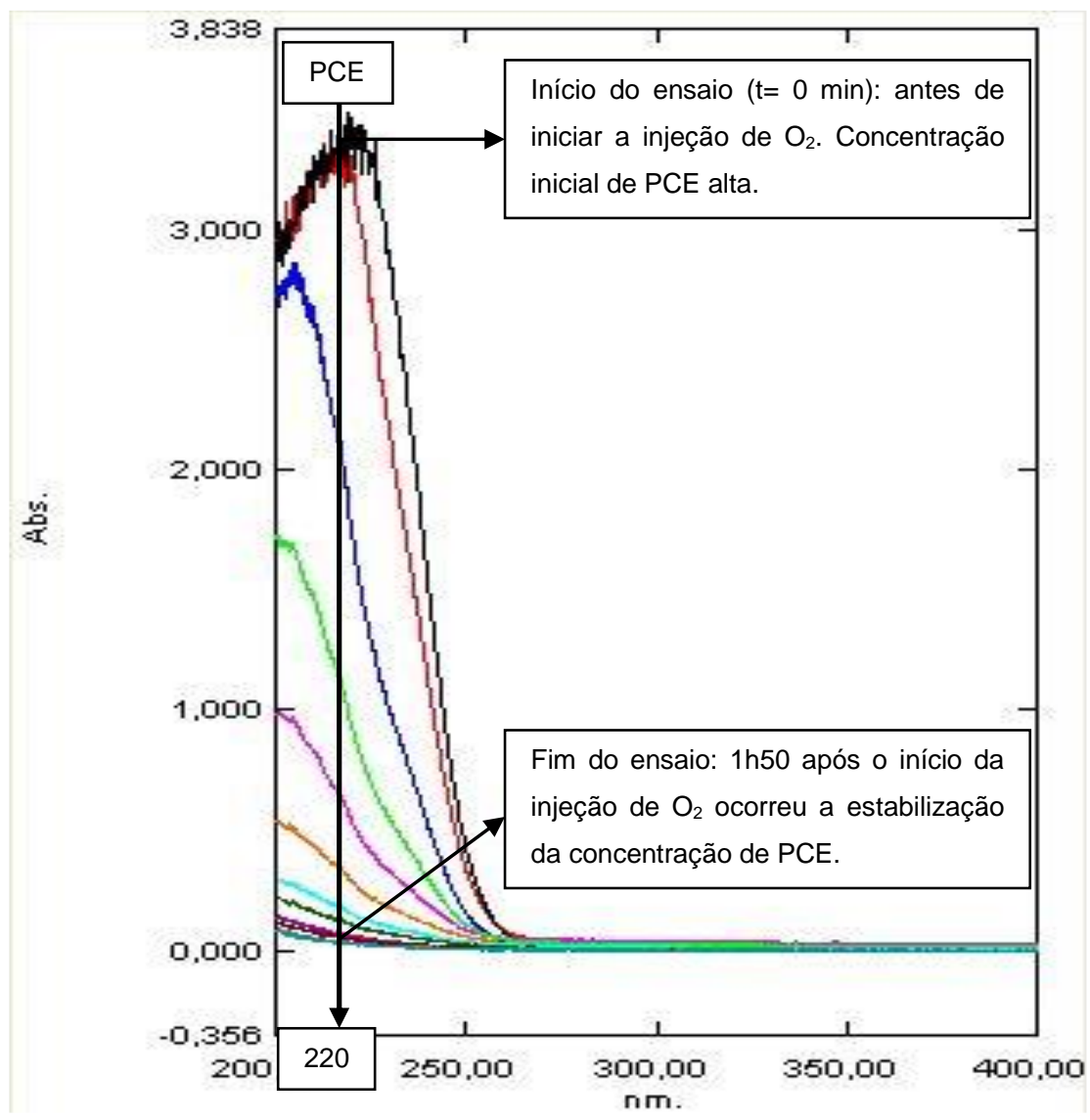

Figura 5.13 Ensaio de coluna com oxigênio em solução saturada de PCE para determinar a duração dos ensaios batch e de coluna

\subsection{Batch}

\subsubsection{Meio aquoso}

Os resultados de meio aquoso dos ensaios batch de degradação de PCE realizados para diversos meios de estudo durante 1 hora e 50 minutos estão apresentados nas Tabelas 5.6 (concentração em mg/L) e 5.7 (massa em $\mu \mathrm{g}$ ), e na Figura 5.14 (representados em massa - $\mu \mathrm{g}$ ).

Durante o tempo de saturação do meio de estudo por ozônio, foi controlada a vazão e monitoraram-se a temperatura, pressão e pH. Os valores de pressão absoluta se mantiveram constantes em todos os ensaios realizados, de $114.000 \mathrm{~Pa}$ na entrada da coluna e 93.000 Pa (pressão atmosférica) na saída. Ao inverter o sistema by-pass para monitorar a absorbância na saída da coluna, os valores de pressão na entrada 
da coluna eram alterados para 117.000 Pa, provavelmente devido à menor perda de carga do gás, que flui direto para a coluna sem passar pelo espectrofotômetro.

Tabela 5.6 Ensaios batch de degradação de PCE e meio aquoso (concentrações em mg/L)

\begin{tabular}{|c|c|c|c|c|c|c|c|}
\hline Amostra & $\begin{array}{l}\text { Controle } \\
\text { de Água } \\
\text { ultrapura }\end{array}$ & $\begin{array}{c}\text { Água } \\
\text { ultrapura } \\
1\end{array}$ & $\begin{array}{c}\text { Água } \\
\text { ultrapura } \\
2\end{array}$ & $\begin{array}{c}\text { Poço } \\
\text { Cacimba }\end{array}$ & $\begin{array}{c}\text { Poço } \\
\text { Tubular } \\
\text { Profundo } \\
1\end{array}$ & $\begin{array}{c}\text { Poço } \\
\text { Tubular } \\
\text { Profundo } \\
2\end{array}$ & $\begin{array}{l}\mathrm{NaHCO}_{3} \\
25 \mathrm{mg} / \mathrm{L}\end{array}$ \\
\hline \multicolumn{8}{|c|}{ Início } \\
\hline Amostra 1 & 182,81 & 187,92 & 137,71 & & 143,40 & & 152,35 \\
\hline Amostra 2 & 174,96 & & 158,01 & 135,91 & 165,35 & 150,53 & 167,78 \\
\hline Amostra 3 & 169,71 & & 142,35 & 142,92 & 165,74 & 141,90 & 167,71 \\
\hline Amostra 4 & 155,25 & 144,47 & & & & 132,91 & \\
\hline Amostra 5 & 147,65 & & 161,39 & 140,65 & & & \\
\hline Média & 166,07 & 166,20 & 149,87 & 139,83 & 158,16 & 141,78 & 162,61 \\
\hline $\begin{array}{l}\text { Desvio } \\
\text { padrão }\end{array}$ & 14,39 & 30,72 & 11,60 & 3,58 & 12,78 & 8,81 & 8,89 \\
\hline $\begin{array}{l}\text { Coeficiente } \\
\text { de variação } \\
(\%)\end{array}$ & 8,7 & 18,5 & 7,7 & 2,6 & 8,1 & 6,2 & 5,5 \\
\hline \multicolumn{8}{|c|}{ Fim } \\
\hline Amostra 1 & 152,38 & 67,29 & 74,91 & 55,64 & 31,88 & & 80,37 \\
\hline Amostra 2 & 168,34 & 75,80 & 70,13 & 34,60 & 46,48 & 21,49 & 42,70 \\
\hline Amostra 3 & 141,11 & 68,51 & 68,70 & 45,45 & & 24,57 & 62,85 \\
\hline Amostra 4 & 149,94 & 62,43 & 67,17 & 33,81 & 30,19 & 29,07 & 62,43 \\
\hline Amostra 5 & 157,65 & & 61,60 & 35,44 & & & \\
\hline Média & 153,89 & 68,51 & 68,50 & 40,99 & 36,18 & 25,04 & 62,09 \\
\hline $\begin{array}{l}\text { Desvio } \\
\text { padrão }\end{array}$ & 10,05 & 5,53 & 4,83 & 9,46 & 8,96 & 3,81 & 15,39 \\
\hline $\begin{array}{l}\text { Coeficiente } \\
\text { de } \quad \text { variação } \\
(\%)\end{array}$ & 6,5 & 8,1 & 7,1 & 23,1 & 24,8 & 15,2 & 24,8 \\
\hline
\end{tabular}


Tabela 5.7 Ensaios batch de degradação de PCE em meio aquoso (massa em $\mu \mathrm{g}$ )

\begin{tabular}{|c|c|c|c|c|c|c|c|}
\hline Amostra & $\begin{array}{c}\text { Controle de } \\
\text { Água } \\
\text { ultrapura }\end{array}$ & $\begin{array}{c}\text { Água } \\
\text { ultrapura } 1\end{array}$ & $\begin{array}{c}\text { Água } \\
\text { ultrapura } 2\end{array}$ & $\begin{array}{c}\text { Poço } \\
\text { Cacimba }\end{array}$ & \begin{tabular}{|c|} 
Poço \\
Tubular \\
Profundo \\
1
\end{tabular} & \begin{tabular}{|c|} 
Poço \\
Tubular \\
Profundo \\
2 \\
\end{tabular} & $\begin{array}{l}\mathrm{NaHCO}_{3} \\
25 \mathrm{mg} / \mathrm{L}\end{array}$ \\
\hline \multicolumn{8}{|c|}{ Início } \\
\hline Amostra 1 & 75,68 & 77,80 & 57,01 & & 59,37 & & 63,07 \\
\hline Amostra 2 & 72,43 & & 65,42 & 56,27 & 68,45 & 62,32 & 69,46 \\
\hline Amostra 3 & 70,26 & & 58,93 & 59,17 & 68,62 & 58,75 & 69,43 \\
\hline Amostra 4 & 64,27 & 59,81 & & & & 55,02 & \\
\hline Amostra 5 & 61,13 & 0,00 & 66,82 & 58,23 & & & \\
\hline Média & 68,75 & 68,81 & 62,04 & 57,89 & 65,48 & 58,70 & 67,32 \\
\hline $\begin{array}{l}\text { Desvio } \\
\text { padrão }\end{array}$ & 5,96 & 12,72 & 4,80 & 1,48 & 5,29 & 3,65 & 3,68 \\
\hline $\begin{array}{l}\text { Coeficiente } \\
\text { de variação } \\
(\%)\end{array}$ & 8,7 & 18,5 & 7,7 & 2,6 & 8,1 & 6,2 & 5,5 \\
\hline \multicolumn{8}{|c|}{ Fim } \\
\hline Amostra 1 & 64,61 & 28,53 & 31,76 & 23,59 & 13,52 & & 34,08 \\
\hline Amostra 2 & 71,37 & 32,14 & 29,74 & 14,67 & 19,71 & 9,11 & 18,10 \\
\hline Amostra 3 & 59,83 & 29,05 & 29,13 & 19,27 & & 10,42 & 26,65 \\
\hline Amostra 4 & 63,58 & 26,47 & 28,48 & 14,33 & 12,80 & 12,32 & 26,47 \\
\hline Amostra 5 & 66,84 & & 26,12 & 15,03 & & & \\
\hline Média & 65,25 & 29,05 & 29,04 & 17,38 & 15,34 & 10,62 & 26,32 \\
\hline $\begin{array}{l}\text { Desvio } \\
\text { padrão }\end{array}$ & 4,26 & 2,34 & 2,05 & 4,01 & 3,80 & 1,61 & 6,53 \\
\hline $\begin{array}{l}\text { Coeficiente } \\
\text { de variação } \\
(\%)\end{array}$ & 6,5 & 8,1 & 7,1 & 23,1 & 24,8 & 15,2 & 24,8 \\
\hline
\end{tabular}




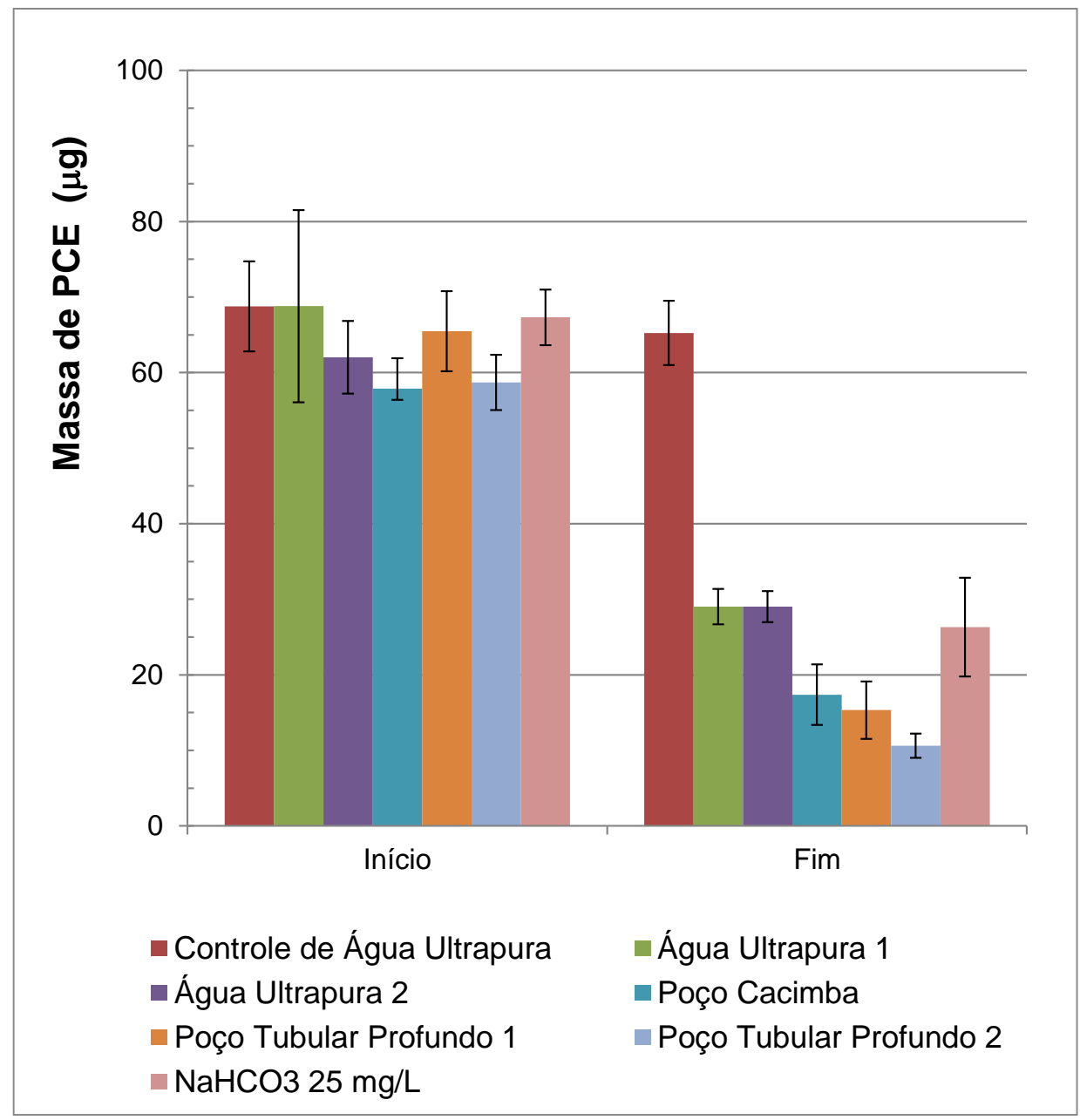

Figura 5.14 Ensaios batch de degradação de PCE em meio aquoso: médias e desviospadrão das quintuplicatas

A análise dos resultados mostra que o PCE não se degradou em água ultrapura durante o ensaio de controle. Com a saturação de ozônio na água ultrapura, o PCE degradou-se em sistema fechado: os dois ensaios nesta condição (água ultrapura 1 e água ultrapura 2) mostraram redução significativa da concentração de PCE, entre 54 e $59 \%$ considerando-se as médias dos ensaios. A degradação de PCE nos poços de água subterrânea também foi significativa e maior do que na água ultrapura.

Comparando-se os resultados com água ultrapura e solução de bicarbonato de sódio a $25 \mathrm{mg} / \mathrm{L}$, não se pode afirmar que a correção de $\mathrm{pH}$ e tamponamento auxiliem a degradação de PCE em sistema fechado. Embora os ensaios de decaimento de ozônio tivessem indicado menores meias vidas com a adição de bicarbonato de sódio, possibilitando a geração de radicais hidroxilas, mais reativos do que o ozônio, não se observou eficiência nesse tipo de tratamento. 
A variação de $\mathrm{pH}$ durante o tempo de estabilização do ozônio, previamente ao preparo dos vials dos ensaios batch está apresentada na Figura 5.15.

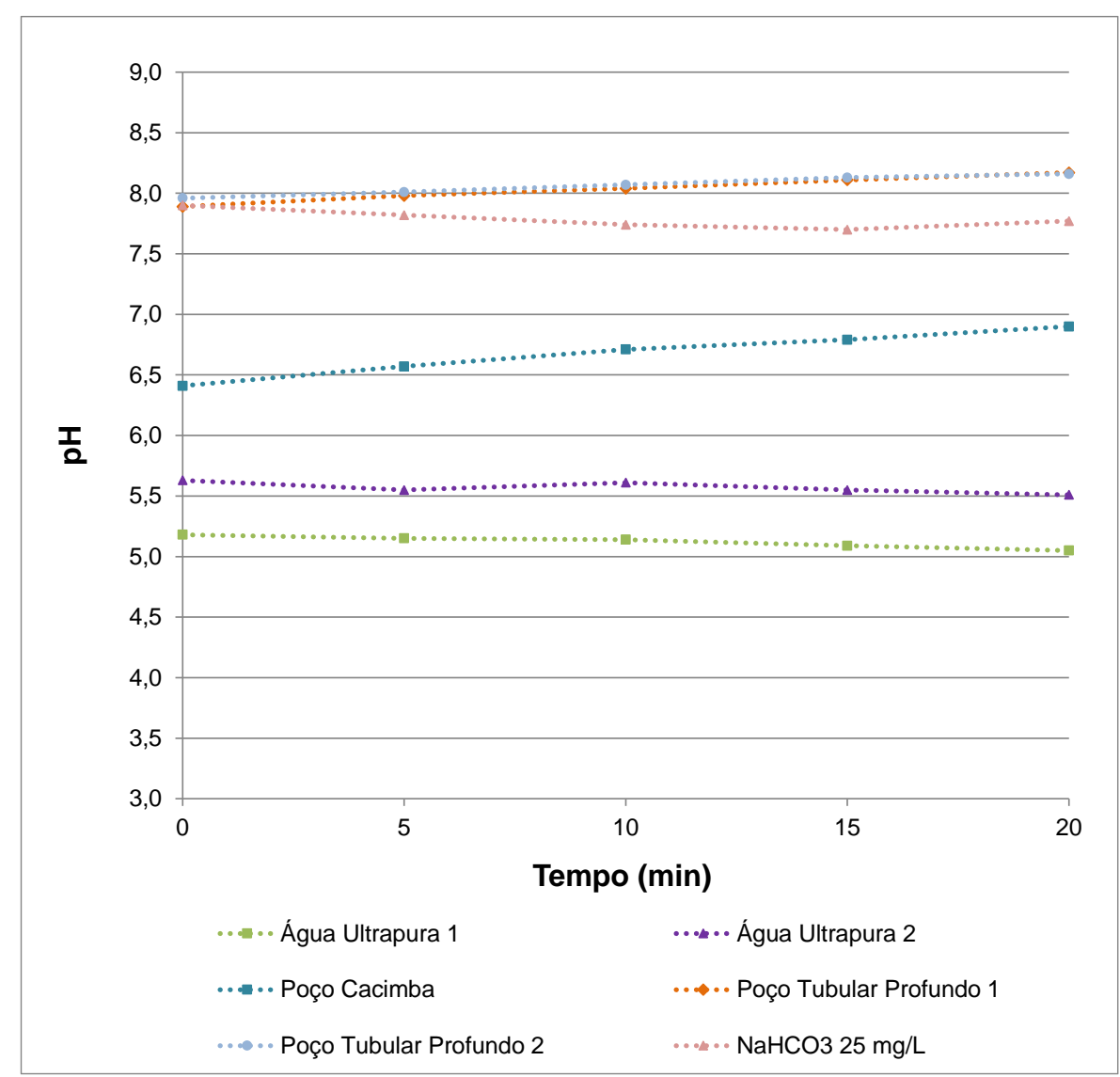

Figura 5.15 Monitoramento do $\mathrm{pH}$ durante os ensaios batch em meio aquoso

$\mathrm{O} \mathrm{pH}$ da água ultrapura diminuiu durante o ensaio de 5,2 a 5,1 em um ensaio e de 5,6 para 5,5 na duplicata. $\mathrm{O} \mathrm{pH}$ da água subterrânea do poço tubular profundo aumentou de 7,9 a 8,2 em um ensaio e de 8,0 a 8,2 na duplicata, enquanto o pH da água subterrânea do poço cacimba aumentou de 6,4 para 6,9. A solução de bicarbonato com concentração de $25 \mathrm{mg} / \mathrm{L}$ diminuiu de 7,9 para 7,8 . Pode-se concluir, portanto, que $\mathrm{o} \mathrm{pH}$ dos meios aquosos estudados permaneceu praticamente inalterado durante os 20 minutos iniciais da estabilização do ozônio.

$\mathrm{O} \mathrm{pH}$ monitorado nos ensaios batch apresentou comportamento similar ao observado nos ensaios de saturação de ozônio em fase dissolvida, a menos a duração do ensaio. 


\subsubsection{Meio poroso}

Os resultados dos ensaios batch de degradação de PCE nas microesferas de vidro, areia e solo durante 1 hora e 50 minutos estão apresentados na Figura 5.16 e na Tabela 5.8, assim como os resultados do ensaio de controle do solo.

Monitoraram-se a vazão, temperatura, pressão e pH durante o tempo de saturação da água ultrapura por ozônio (cerca de 20 minutos).

As análises químicas foram realizadas em laboratório comercial devido à quebra de uma peça do cromatógrafo gasoso. Foi analisada a Lista de VOC varredura, mas só foi detectado e quantificado o PCE.

Observa-se uma grande variação dos resultados, o que impede concluir a respeito da degradação de PCE nos meios sólidos estudados. Não houve, porém, a possibilidade de repetir os ensaios devido aos limites de custo e prazo.

Tabela 5.8 Ensaios batch de degradação de PCE em meio poroso (massa em $\mu \mathrm{g}$ )

\begin{tabular}{|c|c|c|c|c|}
\hline Amostra & $\begin{array}{l}\text { Microesferas de } \\
\text { vidro }\end{array}$ & Areia & $\begin{array}{c}\text { Controle de } \\
\text { Adsorção de Solo }\end{array}$ & Solo \\
\hline \multicolumn{5}{|c|}{ Início } \\
\hline Amostra 1 & 3,64 & 15,33 & 44,05 & 40,52 \\
\hline Amostra 2 & 29,48 & 10,26 & 40,27 & 41,82 \\
\hline Amostra 3 & 1,85 & 15,14 & 40,17 & 26,20 \\
\hline Média & 11,66 & 13,58 & 41,49 & 36,18 \\
\hline Desvio padrão & 15,46 & 2,87 & 2,21 & 8,67 \\
\hline $\begin{array}{l}\text { Coeficiente de } \\
\text { variação (\%) }\end{array}$ & 132,61 & 21,16 & 5,33 & 23,96 \\
\hline \multicolumn{5}{|c|}{ Fim } \\
\hline Amostra 1 & 0,38 & 8,28 & 34,17 & 35,33 \\
\hline Amostra 2 & 1,11 & 12,01 & 37,54 & 31,75 \\
\hline Amostra 3 & 0,38 & 30,99 & & 13,22 \\
\hline Média & 0,62 & 17,09 & 35,85 & 26,77 \\
\hline Desvio padrão & 0,42 & 12,18 & 2,38 & 11,87 \\
\hline $\begin{array}{l}\text { Coeficiente de } \\
\text { variação }(\%)\end{array}$ & 67,60 & 71,27 & 6,63 & 44,35 \\
\hline
\end{tabular}




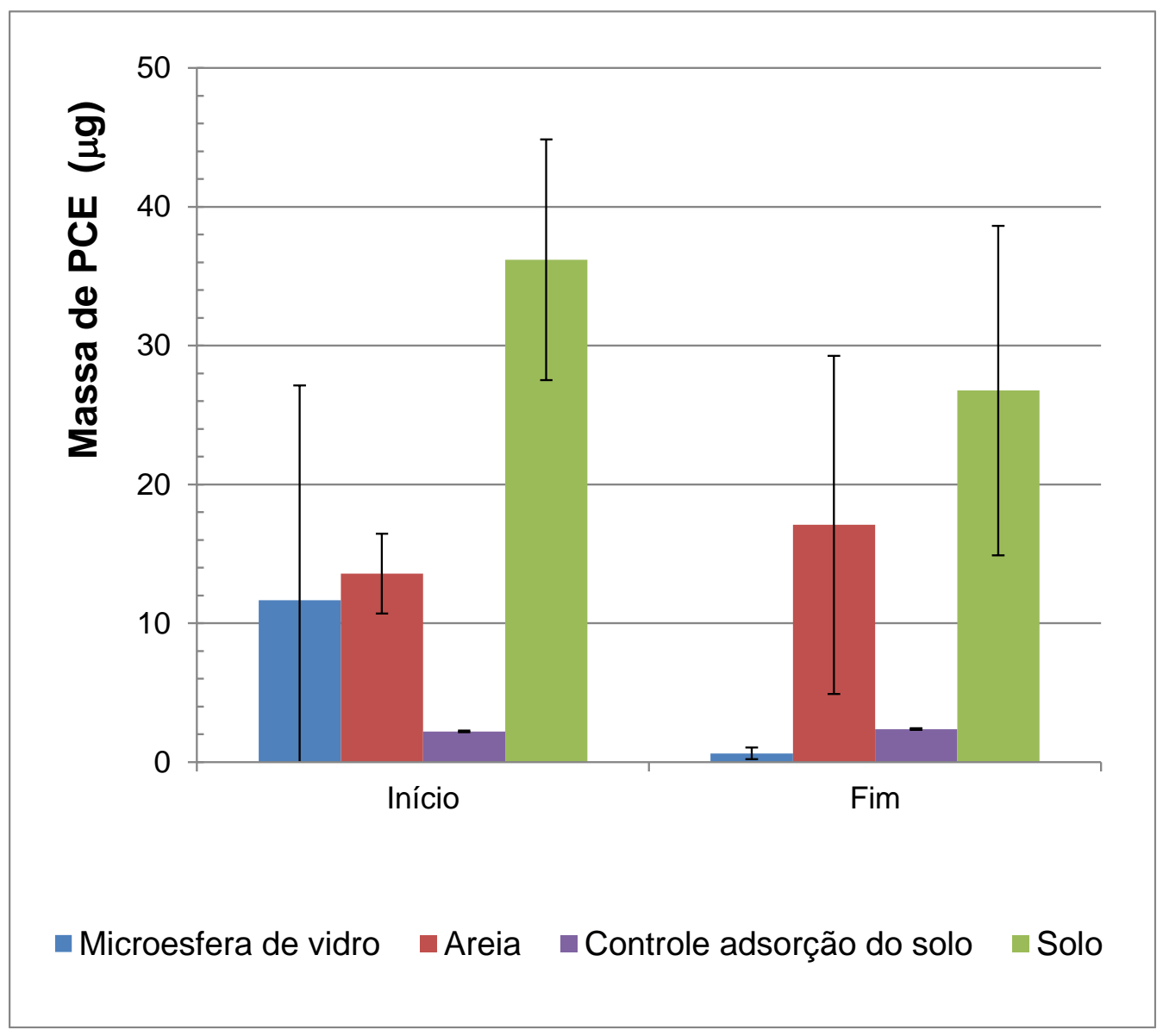

Figura 5.16 Ensaios batch de degradação de PCE em meio poroso: médias e desviospadrão das triplicatas.

\subsection{Coluna}

\subsubsection{Meio aquoso}

Os resultados para o meio aquoso dos ensaios de coluna de degradação de PCE em diversos meios de estudo por injeção de ozônio durante 1 hora e 50 minutos estão apresentados na Tabela 5.9 e na Figura 5.17.

Durante a injeção de ozônio, foi controlada a vazão e monitoraram-se a temperatura, pressão e $\mathrm{pH}$. Os valores de pressão absoluta se mantiveram constantes em todos os ensaios realizados, apresentando os mesmos valores descritos nos ensaios batch. Na Figura 5.19 é possível observar o monitoramento da pressão ao longo dos ensaios de coluna realizados. 
Tabela 5.9 Ensaios de coluna para degradação de PCE em meio aquoso (concentrações em $\mathrm{mg} / \mathrm{L})$

\begin{tabular}{|c|c|c|c|c|c|c|}
\hline Amostra & $\begin{array}{c}\text { Controle de } \\
\text { Água } \\
\text { ultrapura } 1\end{array}$ & $\begin{array}{c}\text { Controle de } \\
\text { Água } \\
\text { ultrapura } 2\end{array}$ & $\begin{array}{c}\text { Água } \\
\text { ultrapura } 1\end{array}$ & $\begin{array}{c}\text { Água } \\
\text { ultrapura } 2\end{array}$ & $\begin{array}{l}\text { Poço } \\
\text { Cacimba }\end{array}$ & $\begin{array}{c}\text { Poço } \\
\text { Tubular } \\
\text { Profundo }\end{array}$ \\
\hline \multicolumn{7}{|c|}{ Coluna - Início do Ensaio } \\
\hline Amostra 1 & 81,13 & 121,44 & 90,72 & & 42,80 & 45,89 \\
\hline Amostra 2 & 72,56 & 113,56 & 86,92 & 103,07 & 63,94 & 42,29 \\
\hline Amostra 3 & 65,98 & 108,12 & 66,50 & 80,64 & 64,16 & 47,60 \\
\hline Média & 73,22 & 114,37 & 81,38 & 91,85 & 56,97 & 45,26 \\
\hline Desvio padrão & 7,60 & 6,70 & 13,03 & 15,86 & 12,27 & 2,71 \\
\hline $\begin{array}{ll}\begin{array}{l}\text { Coeficiente } \\
\text { variação (\%) }\end{array} & \text { de } \\
\end{array}$ & 10,4 & 5,9 & 16,0 & 17,3 & 21,5 & 6,0 \\
\hline \multicolumn{7}{|c|}{ Coluna - Final do Ensaio } \\
\hline Amostra 1 & 0,047 & 0,140 & 0,062 & 0,049 & 0,007 & 0,008 \\
\hline Amostra 2 & 0,047 & 0,109 & 0,047 & 0,032 & 0,012 & \\
\hline Amostra 3 & 0,045 & 0,060 & 0,060 & 0,032 & 0,008 & 0,010 \\
\hline Média & 0,046 & 0,103 & 0,057 & 0,038 & 0,009 & 0,009 \\
\hline Desvio padrão & 0,001 & 0,040 & 0,008 & 0,009 & 0,003 & 0,002 \\
\hline $\begin{array}{ll}\begin{array}{ll}\text { Coeficiente } \\
\text { variação (\%) }\end{array} & \text { de } \\
\end{array}$ & 2,5 & 39,0 & 14,0 & 25,2 & 29,0 & 16,6 \\
\hline \multicolumn{7}{|c|}{ Trap } \\
\hline Amostra 1 & 62,42 & 103,94 & 91,33 & 113,60 & 51,77 & 41,58 \\
\hline Amostra 2 & 69,86 & 106,73 & 77,70 & 91,07 & 52,99 & 40,17 \\
\hline Amostra 3 & 70,95 & 102,56 & 88,71 & 98,53 & 59,40 & 46,67 \\
\hline Média & 67,74 & 104,41 & 85,92 & 101,07 & 54,72 & 42,81 \\
\hline Desvio padrão & 4,64 & 2,12 & 7,23 & 11,48 & 4,10 & 3,42 \\
\hline $\begin{array}{ll}\begin{array}{ll}\text { Coeficiente } \\
\text { variação (\%) }\end{array} & \text { de } \\
\end{array}$ & 6,9 & 2,0 & 8,4 & 11,4 & 7,5 & 8,0 \\
\hline
\end{tabular}



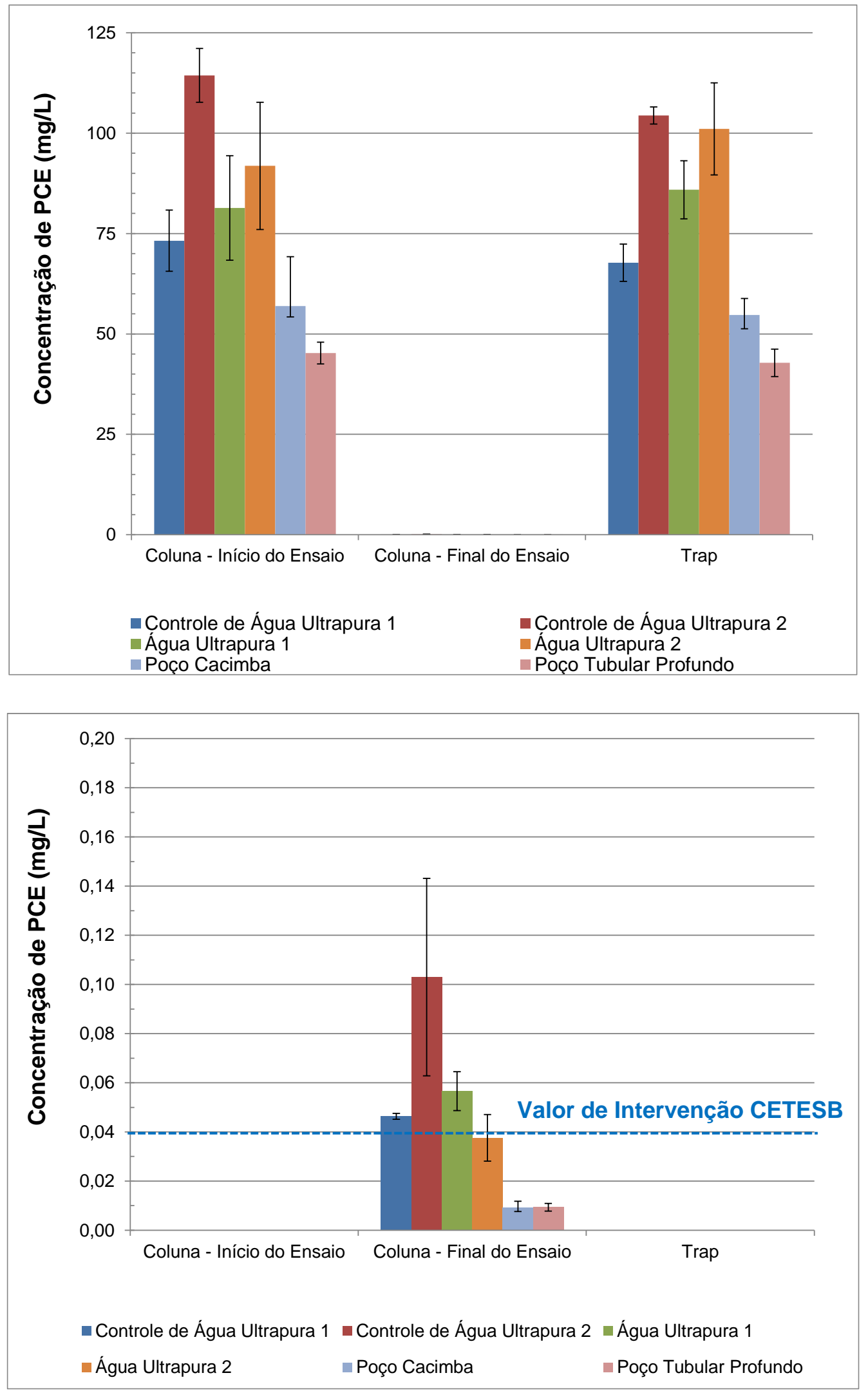

Figura 5.17 Resultados dos ensaios de coluna de degradação de PCE em meio aquoso 
Nos dois ensaios de controle de água ultrapura, observou-se que o PCE foi arrastado pelo oxigênio, uma vez que as concentrações na coluna no início do ensaio foram estatisticamente iguais às concentrações obtidas no trap, e que as concentrações na coluna no final do ensaio encontravam-se na ordem de ppb e menores do que $0,1 \%$ das iniciais.

Porém, as concentrações finais na coluna obtidas nos ensaios com injeção de oxigênio em água ultrapura ficaram um pouco acima do valor de intervenção estabelecido pela CETESB em 2014 (0,04 mg/L).

Para os ensaios de injeção de ozônio em água ultrapura, as concentrações na coluna no início do ensaio foram estatisticamente iguais às concentrações obtidas no trap, As concentrações na coluna no final do ensaio encontravam-se na ordem de ppb e também menores do que $0,1 \%$ das iniciais, próximas ao valor de intervenção, comprovando que o mecanismo de remoção dominante é o arraste de PCE, ou seja, funcionou como ozone sparging.

Para as águas subterrâneas, as concentrações no início do ensaio e no trap também foram semelhantes, entretanto as concentrações na coluna no final do ensaio deram inferiores ao valor de intervenção CETESB para as águas subterrâneas tanto do poço cacimba quanto do poço tubular profundo.

Cabe observar que as concentrações iniciais foram diferentes nos diversos ensaios, devido ao composto ser muito volátil e sua solubilidade em água ser muito baixa. Isto explica também a variação de valores entre as triplicatas. Os resultados apresentados foram os selecionados entre diversos ensaios realizados; por exemplo, os ensaios de coluna com soluções de bicarbonato de sódio foram descartados por apresentar resultados inconsistentes.

As concentrações das triplicatas no trap apresentaram menor coeficiente de variação do que as amostras da coluna, porque o gás foi condensado e ressuspendido em água ultrapura gelada, que diminui a volatilização, e em metanol, que tem afinidade pelo composto.

Houve diversas tentativas de minimizar as diferenças entre as concentrações iniciais dos ensaios e as variações entre as triplicatas. Essas tentativas foram aperfeiçoando 
o procedimento experimental durante o desenvolvimento desta pesquisa. Por exemplo, a utilização de seringas com válvula de amostragem, a utilização já mencionada de água gelada e metanol no trap, a troca de septo do injetor do cromatógrafo gasoso a cada 30 injeções, a coleta de uma única amostra da coluna e distribuição em três alíquotas para o preparo das triplicatas a serem analisadas em vez de coletar 3 amostras sucessivas, a refrigeração da solução de PCE por meia hora antes de vertê-la na coluna, entre outras. Esses cuidados diminuíram o coeficiente de variação das triplicatas, mas mesmo assim, houve dificuldade na reprodutibilidade das concentrações iniciais de PCE na coluna entre os diferentes ensaios.

A Figura 5.18 mostra que $0 \mathrm{pH}$ monitorado durante o tempo de execução dos ensaios de coluna variou no início do ensaio até apresentar uma tendência mais estável. Os ensaios de controle de água ultrapura apresentaram aumento dos valores de $\mathrm{pH}$ ao longo do ensaio. A água subterrânea do poço tubular profundo apresentou um decréscimo inicial e depois mostrou aumento. A água subterrânea do poço cacimba e do ensaio com água ultrapura apresentaram uma diminuição significativa.

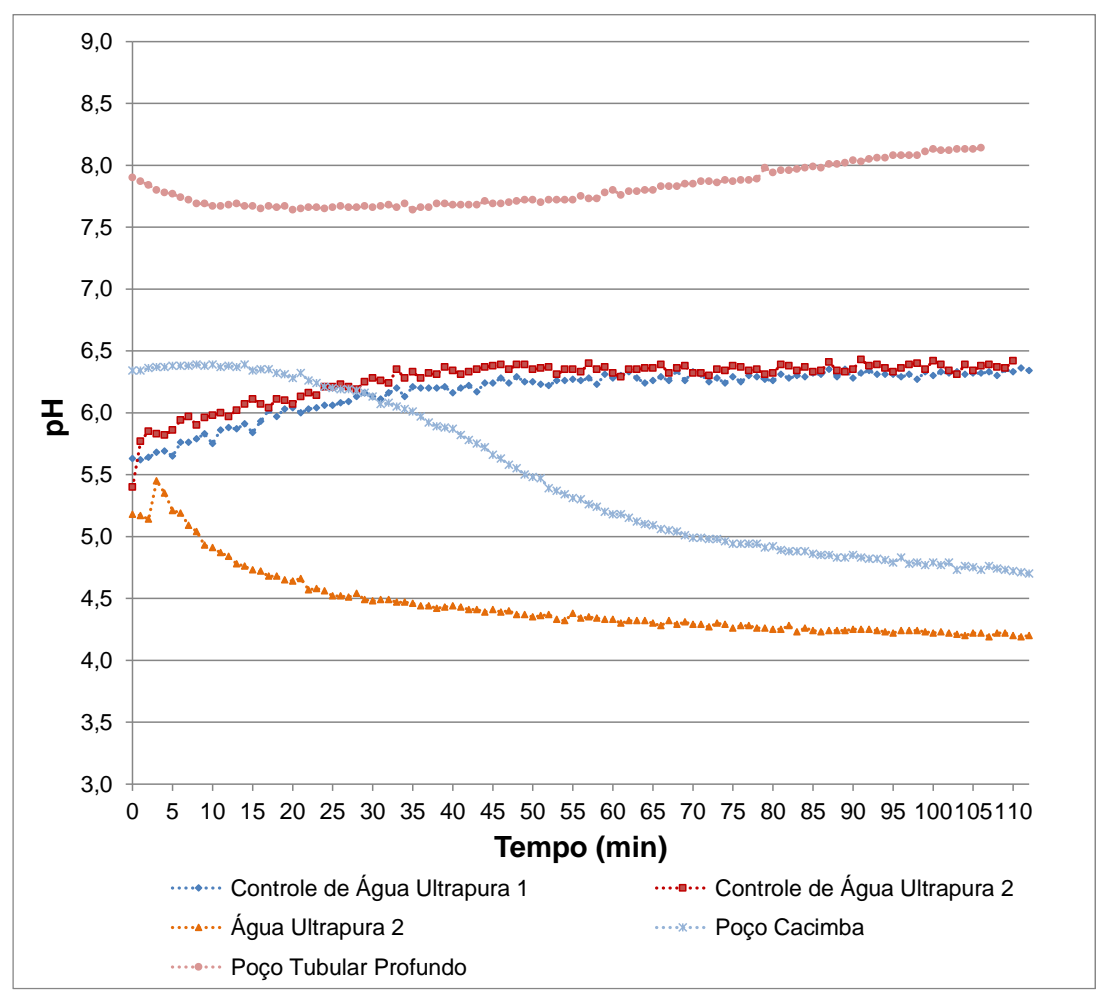

Figura 5.18 Monitoramento do $\mathrm{pH}$ durante os ensaios de coluna em meio aquoso 


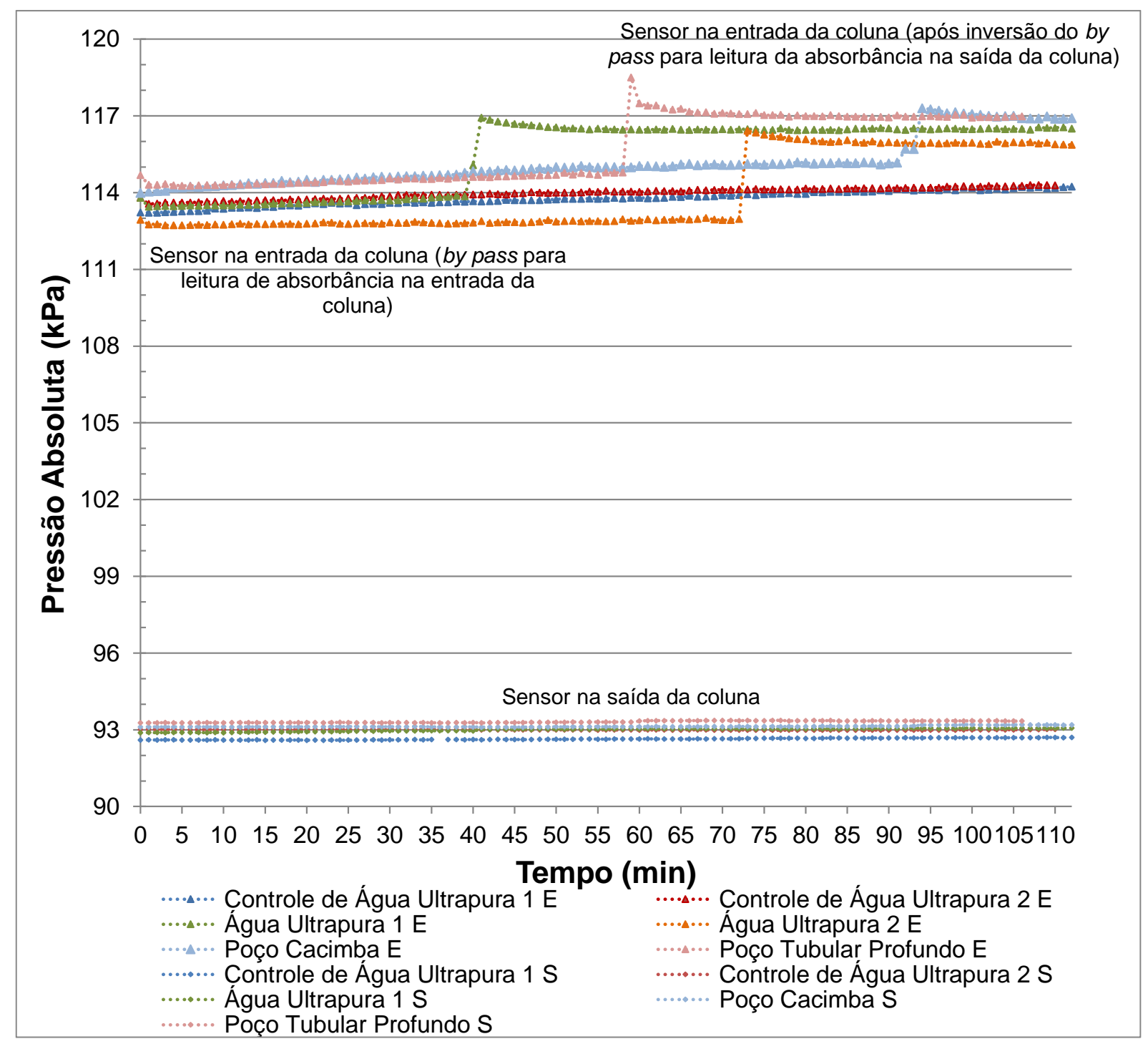

Figura 5.19 Monitoramento da pressão durante os ensaios de coluna em meio aquoso

\subsubsection{Meio poroso}

Os resultados para o meio poroso dos ensaios de coluna de degradação de PCE em diversos meios de estudo por injeção de ozônio durante 1 hora e 50 minutos estão apresentados na Tabela 5.10 e na Figura 5.20.

Durante a injeção de ozônio foram controlados e monitorados os mesmos parâmetros monitorados para os ensaios em coluna para meio aquoso. 
Tabela 5.10 Ensaios de coluna para degradação de PCE em meio poroso (concentrações $\mathrm{em} \mathrm{mg} / \mathrm{L})$

\begin{tabular}{|c|c|c|c|c|c|c|c|}
\hline \multirow[b]{2}{*}{$\begin{array}{l}\text { Microesferas } \\
\text { de vidro }\end{array}$} & \multicolumn{2}{|c|}{ Coluna (mg/kg) } & \multirow{2}{*}{$\begin{array}{c}\text { VI (CETESB, } \\
2014) \\
\text { cenário } \\
\text { agrícola } \\
(\mathrm{mg} / \mathrm{kg}) \\
\end{array}$} & \multicolumn{2}{|c|}{ Coluna (mg/L) } & \multirow[b]{2}{*}{$\begin{array}{c}\text { Trap } \\
\text { (mg/L) }\end{array}$} & \multirow{2}{*}{$\begin{array}{c}\text { VI } \\
\text { (CETESB } \\
2014) \\
(\mathrm{mg} / \mathrm{L})\end{array}$} \\
\hline & $\begin{array}{l}\text { Início do } \\
\text { Ensaio }\end{array}$ & $\begin{array}{c}\text { Final do } \\
\text { Ensaio }\end{array}$ & & $\begin{array}{l}\text { Início do } \\
\text { Ensaio }\end{array}$ & $\begin{array}{c}\text { Final do } \\
\text { Ensaio }\end{array}$ & & \\
\hline Amostra 1 & 3,70 & $<0,1$ & \multirow{4}{*}{0,6} & 55,80 & $<1$ & 16,20 & \multirow{4}{*}{0,04} \\
\hline Amostra 2 & 0,23 & $<0,1$ & & 61,80 & $<1$ & 16,50 & \\
\hline Amostra 3 & 2,00 & $<0,1$ & & 57,20 & $<1$ & 14,20 & \\
\hline Média & 1,98 & 0,10 & & 58,27 & 1,00 & 15,63 & \\
\hline Desvio padrão & 1,74 & 0,00 & - & 3,14 & 0,00 & 1,25 & - \\
\hline $\begin{array}{l}\text { Coeficiente de } \\
\text { variação (\%) }\end{array}$ & 87,78 & 0,00 & - & 5,39 & 0,00 & 8,00 & - \\
\hline \multirow[b]{2}{*}{ Areia } & \multicolumn{2}{|c|}{ Coluna (mg/kg) } & \multirow{2}{*}{$\begin{array}{c}\text { VI (CETESB, } \\
2014) \\
\text { cenário } \\
\text { agrícola } \\
(\mathrm{mg} / \mathrm{kg})\end{array}$} & \multicolumn{2}{|c|}{ Coluna (mg/L) } & & \multirow{2}{*}{$\begin{array}{c}\text { VI } \\
\text { (CETESB, } \\
2014) \\
(\mathbf{m g} / \mathrm{L})\end{array}$} \\
\hline & $\begin{array}{l}\text { Início do } \\
\text { Ensaio }\end{array}$ & $\begin{array}{c}\text { Final do } \\
\text { Ensaio }\end{array}$ & & $\begin{array}{l}\text { Início do } \\
\text { Ensaio }\end{array}$ & $\begin{array}{c}\text { Final do } \\
\text { Ensaio }\end{array}$ & $\begin{array}{l}\text { Trap } \\
(\mathrm{mg} / \mathrm{L})\end{array}$ & \\
\hline Amostra 1 & 11,80 & 0,05 & \multirow{4}{*}{0,6} & 59,40 & 0,042 & 16,30 & \multirow{4}{*}{0,04} \\
\hline Amostra 2 & 11,40 & 0,02 & & 61,20 & 0,041 & 13,80 & \\
\hline Amostra 3 & 10,40 & 0,01 & & 59,90 & 0,044 & 15,70 & \\
\hline Média & 11,20 & 0,03 & & 60,17 & 0,042 & 15,27 & \\
\hline Desvio padrão & 0,72 & 0,02 & - & 0,93 & 0,00 & 1,31 & - \\
\hline $\begin{array}{l}\text { Coeficiente de } \\
\text { variação (\%) }\end{array}$ & 6,44 & 73,68 & - & 1,54 & 4,40 & 8,55 & - \\
\hline
\end{tabular}

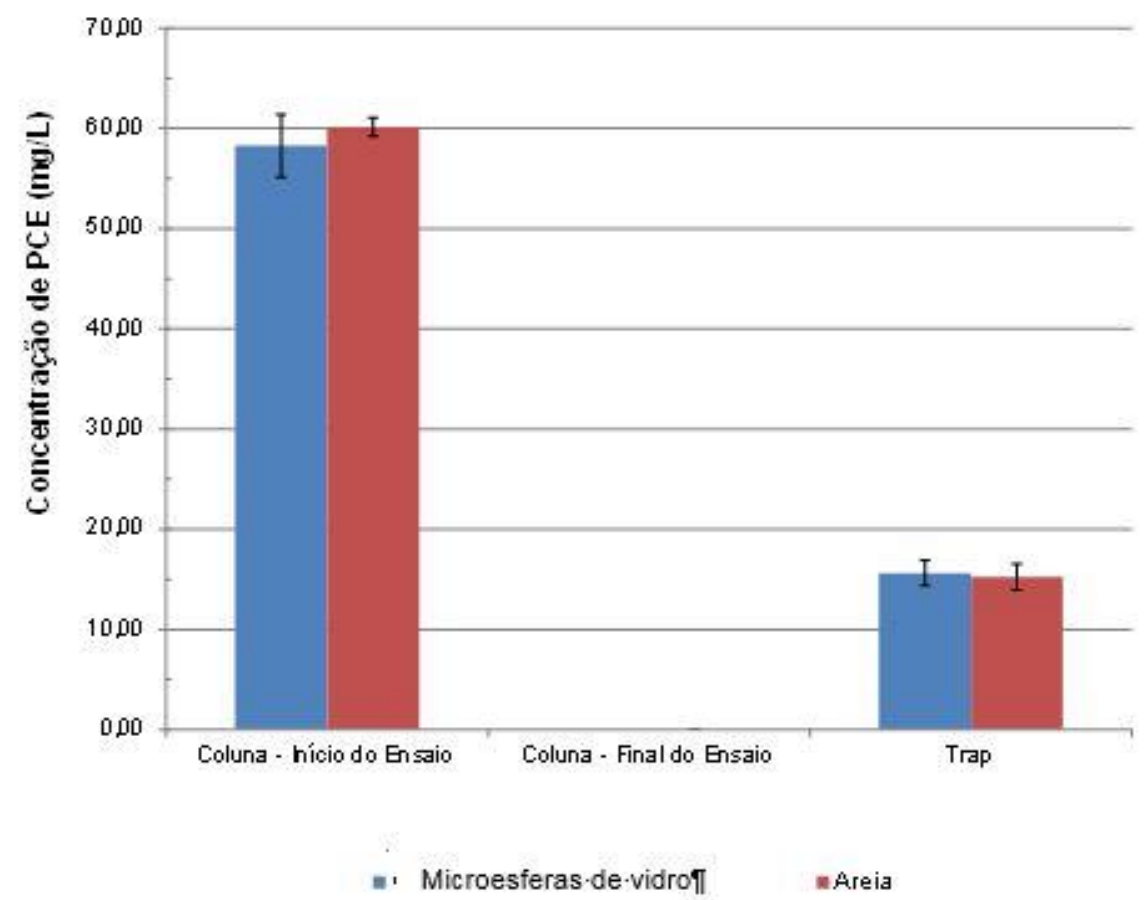

Figura 5.20 Resultados dos ensaios de coluna de degradação de PCE em meio poroso 
Assim como nos ensaios de coluna para meio aquoso, a concentração inicial foi praticamente eliminada da coluna, entretanto a recuperação dessa concentração no trap foi de cerca de 1/4. Esse cenário observado para o meio poroso mostra um comportamento diferente do observado para o meio aquoso, no qual houve recuperação no trap de uma concentração muito próxima à inicial da coluna. Essas observações indicam que, para o meio poroso, ocorre a diminuição da velocidade de arraste e, portanto, há tempo para o ozônio injetado reagir com o meio de estudo. Além da volatilização e arraste do PCE observados nos ensaios de meio aquoso, verifica-se também a ocorrência de degradação.

Adicionalmente, os resultados obtidos para as amostras sólidas foram comparados com o valor de intervenção (VI) estabelecido pela CETESB em 2014 (0,6 mg/kg) para o cenário agrícola, que é o mais restritivo. As concentrações das amostras líquidas coletadas nos ensaios com meio poroso foram comparadas com o $\mathrm{VI}$ da CETESB de 2014 (0,04 mg/L).

Os resultados das amostras líquidas e sólidas do final do ensaio de coluna apresentaram concentrações inferiores ao VI CETESB, exceto para as amostras líquidas do ensaio com areia, que apresentaram concentrações iguais ou ligeiramente superiores ao padrão ambiental adotado.

Os dados de monitoramento das concentrações de ozônio gasoso na saída da coluna permitem analisar o transporte de ozônio pelo meio poroso. Na Figura 5.21 estão apresentadas as breakthrough curves para as microesferas de vidro e para a areia. 


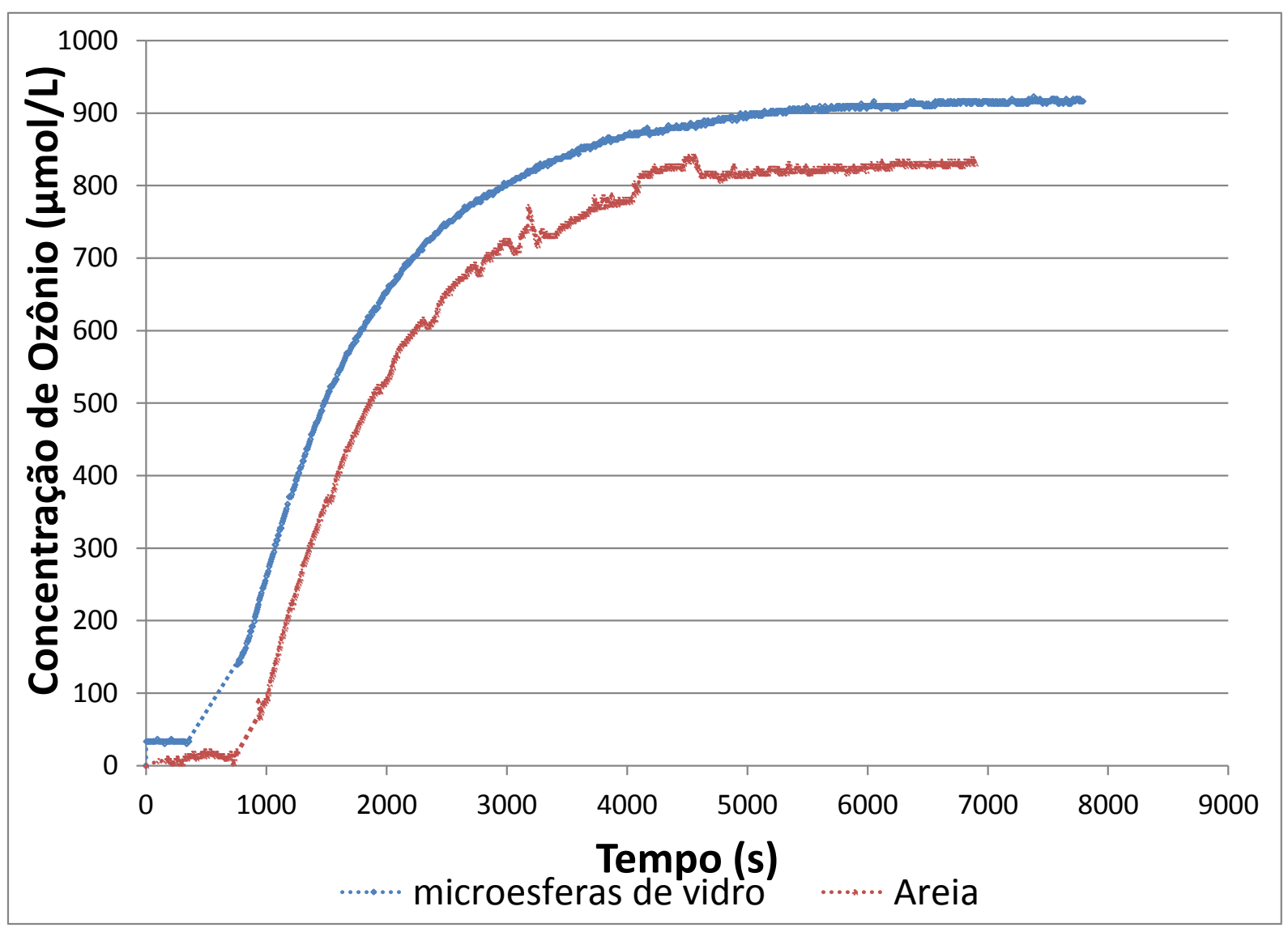

Figura 5.21 Resultados dos ensaios de coluna de degradação de PCE em meio poroso

\subsection{Análise Química}

\subsubsection{Tetracloroetileno (PCE)}

A análise quantitativa do PCE apresentou uma série de dificuldades para reprodutibilidade dos pontos da curva de calibração, provavelmente devidas ao efeito da volatilidade do PCE no preparo e na injeção das amostras, uma vez que o equipamento utilizado não possui injetor automático.

Para minimizar o erro do operador, foi utilizado padrão interno certificado com fluorbenzeno, 1,4-diclorobenzeno e clorobenzeno-d5, importante para a validação do método.

Dentre os compostos presentes no padrão interno, adotou-se o clorobenzeno para relativização da área com o $\mathrm{PCE}$, já que esse composto apresentou pico com maior 
intensidade e valores de triplicata mais reprodutíveis comparativamente aos outros compostos.

A curva de calibração obtida está apresentada na Figura 5.22. Em todos os ensaios realizados, a concentração de PCE foi calculada através da razão das áreas do PCE e do clorobenzeno.

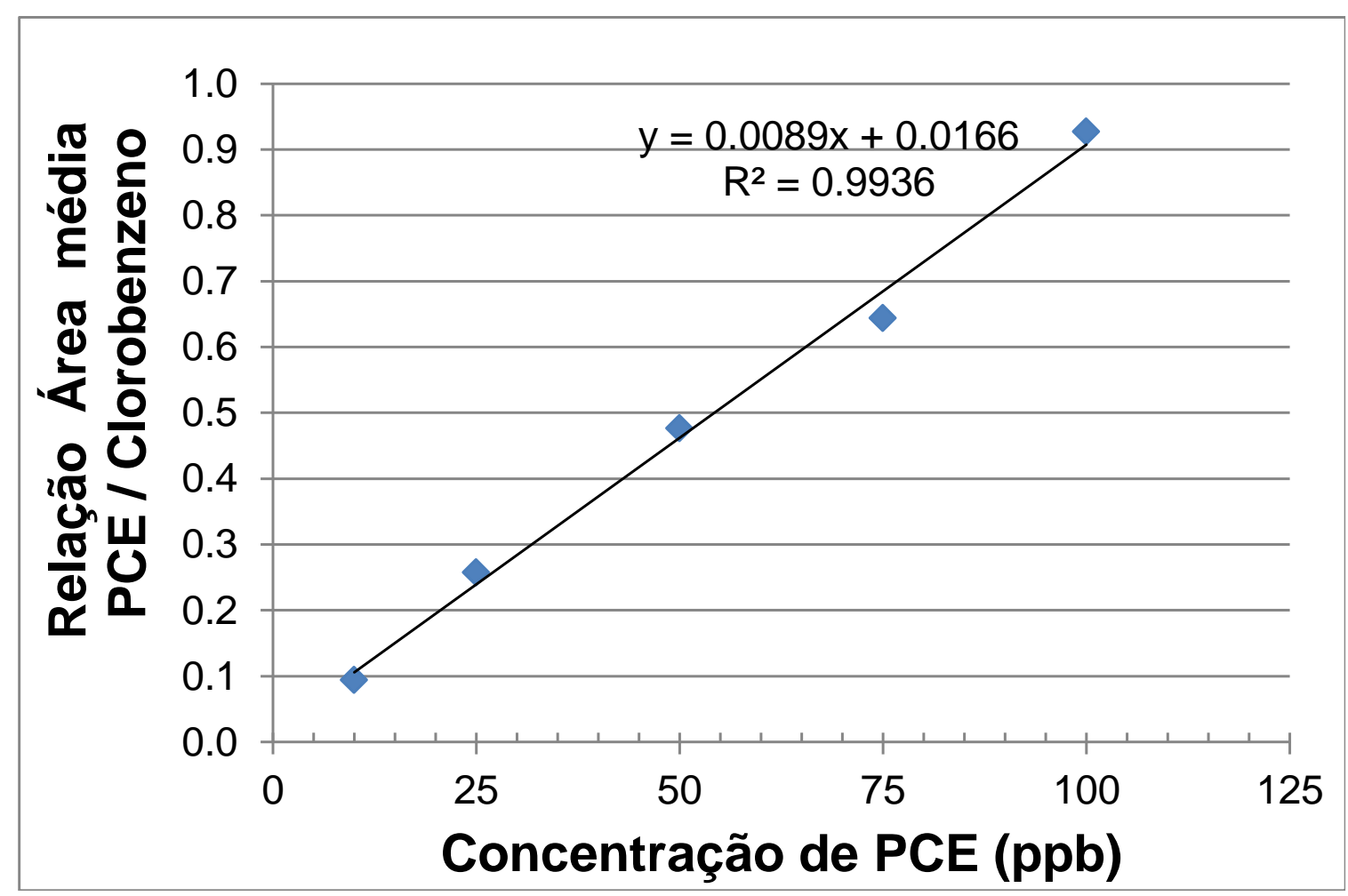

Figura 5.22 Curva de calibração de PCE em ppb.

Nas Figura 5.23, Figura 5.24 e Figura 5.25 são apresentados como exemplo um cromatograma completo (10,17 minutos) e os espectros de massa do PCE e do clorobenzeno, respectivamente. O tempo de retenção do PCE foi de 4,17 minutos, e o do clorobenzeno, de 4,67 minutos. 


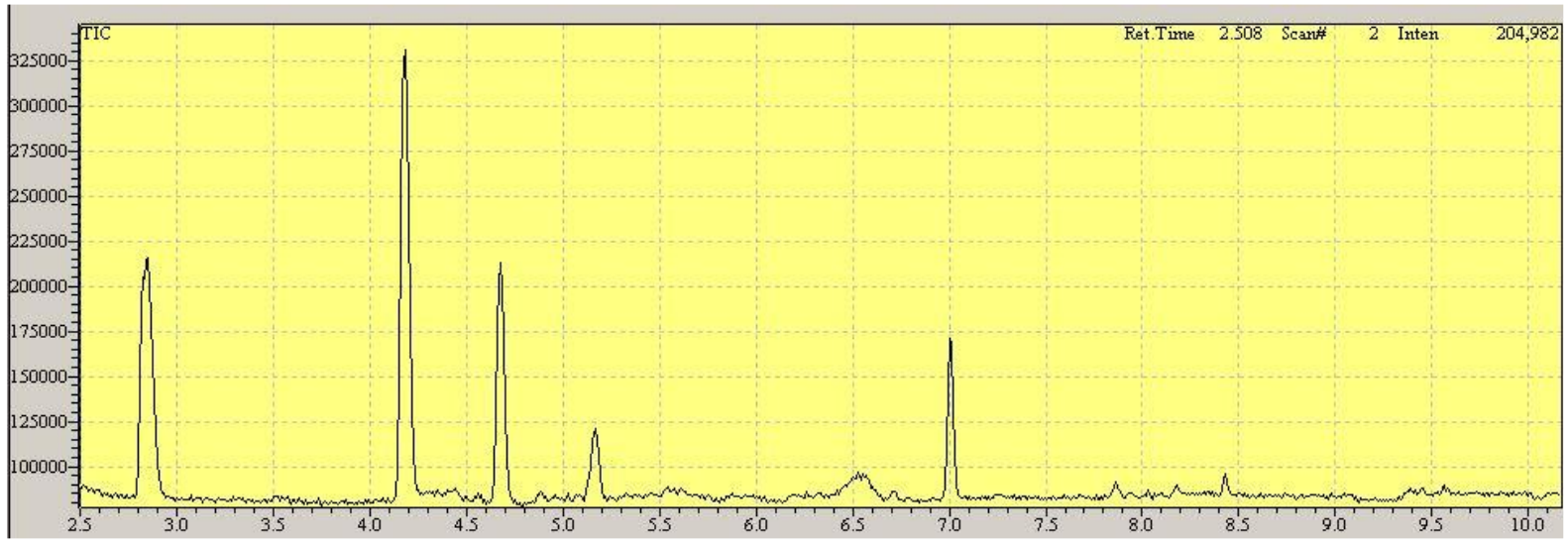

Figura 5.23 Cromatograma completo

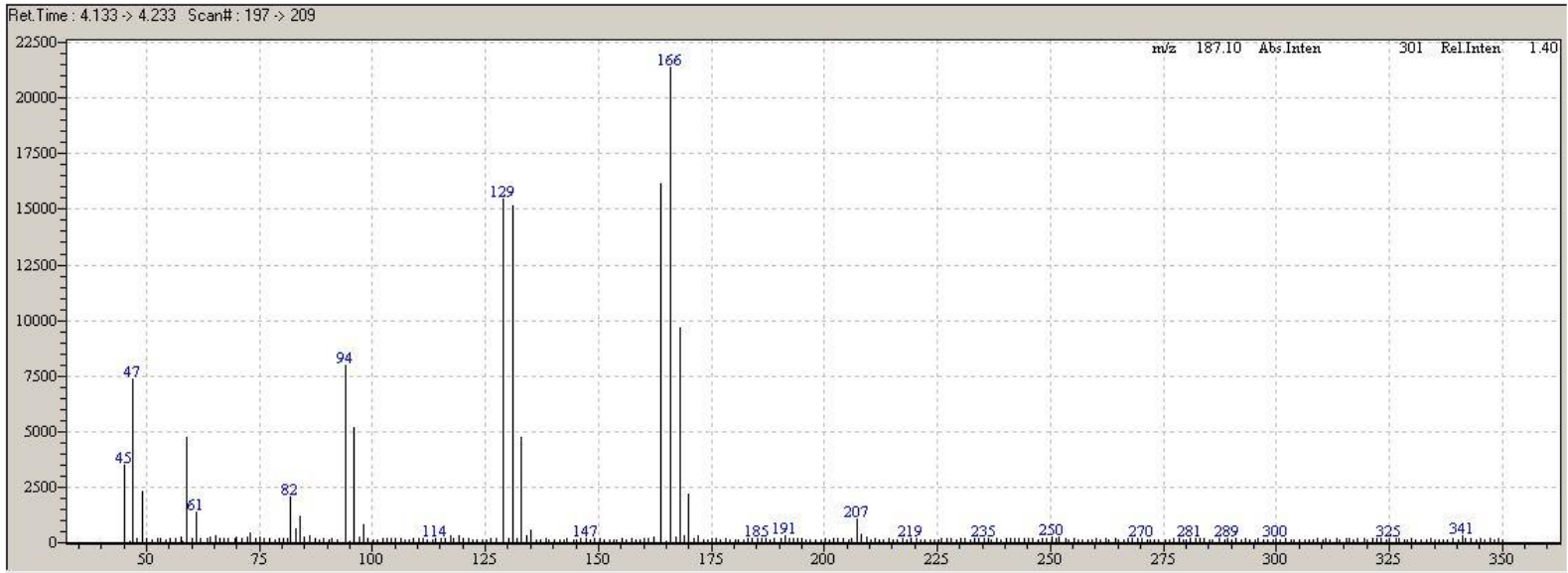

Figura 5.24 Espectro de massa do PCE

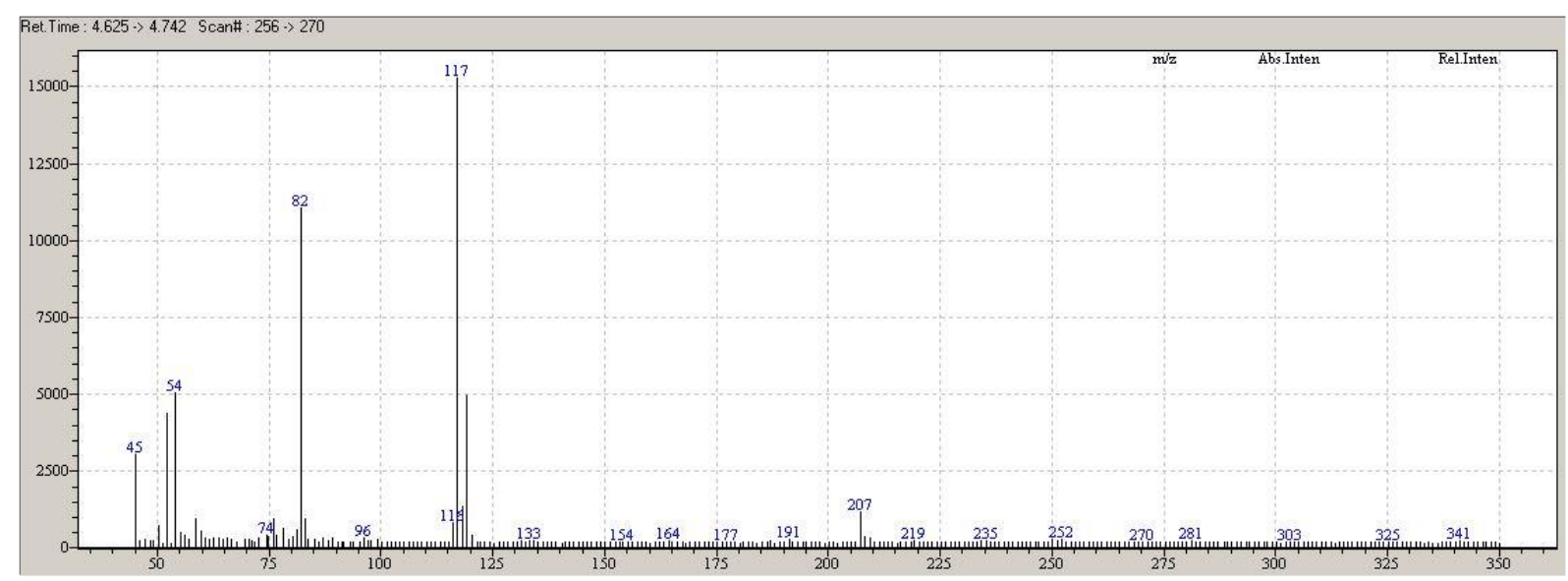

Figura 5.25 Espectro de massa do clorobenzeno

As análises das amostras coletadas nos ensaios batch e de coluna não conseguiu identificar qualitativamente os intermediários da reação entre o PCE e o ozônio. 


\subsubsection{Ozônio}

As leituras de absorbância dos espectrofotômetros UV-Visível Micronal e Shimadzu foram calibradas segundo o método iodométrico da Associação Internacional de Ozônio (IOA, 1996), respectivamente para ozônio gasoso e dissolvido. Este método utiliza titulação com tiossulfato para determinação das concentrações molares de ozônio.

Para o ozônio gasoso, a concentração obtida pelo método iodométrico foi de 426 $\mu \mathrm{mol} / \mathrm{L}$, enquanto a leitura no espectrofotômetro indicou um valor correspondente de $611,77 \mu \mathrm{mol} / \mathrm{L}$. Cabe lembrar que este resultado considerou cálculos para correção de temperatura e pressão para as condições normais de temperatura e pressão.

Para o ozônio dissolvido, a concentração obtida pelo método iodométrico foi de 103 $\mu \mathrm{mol} / \mathrm{L}$, enquanto a leitura no espectrofotômetro indicou um valor correspondente de $150 \mu \mathrm{mol} / \mathrm{L}$.

Tanto para o ozônio gasoso quanto para o ozônio dissolvido os valores obtidos pelo método iodométrico foram inferiores às leituras realizadas pelos espectrofotômetros. Essa perda observada na determinação das concentrações de ozônio pelo método iodométrico pode ser justificada devido aos frascos lavadores de ozônio terem sido posicionados no final do aparato experimental o que sugere aumento do tempo de residência do gás e perdas ao longo do percurso pelas tubulações do aparato experimental. 


\section{CONCLUSÕES}

Neste trabalho foram desenvolvidos aparato e procedimento experimental para o estudo de oxidação química de compostos organoclorados por injeção de ozônio gasoso em escala de laboratório, por meio de ensaio de coluna.

A concepção possibilita ensaios de degradação de diversos compostos em meios aquosos e em meios porosos saturados e não saturados, com monitoramento das fases dissolvida, volatilizada e adsorvida.

Nesta pesquisa, o aparato e o procedimento foram testados para a investigação de degradação de PCE dissolvido em meio aquoso, com monitoramento das fases dissolvida e volatilizada. As demais possibilidades deverão ser testadas e validadas em pesquisas posteriores.

A degradação por ozônio do PCE dissolvido na fase aquosa foi investigada por meio de ensaios de coluna e de ensaios batch. Foram também realizados ensaios de saturação e decaimento de ozônio.

Os resultados indicaram que o ozônio em fase dissolvida atinge a saturação em aproximadamente 15 minutos de injeção, com concentrações saturadas variando entre 100 e $170 \mu \mathrm{mol} / \mathrm{L}$, dependendo do meio aquoso de estudo (água ultrapura, águas subterrâneas, soluções de bicarbonato de sódio).

O decaimento do ozônio, biexponencial, variou conforme o meio de estudo. Foram estudados meios com diferentes concentrações de bicarbonato de sódio, que indicaram que o tempo de meia vida tende a diminuir com o aumento da concentração de bicarbonato de sódio. Os tempos de meia vida para o ozônio em fase dissolvida $t_{1}$ variaram entre 4 e 26 minutos, enquanto os tempos $t_{2}$ variaram entre 14 e 193 minutos. Esses resultados indicam que o ozônio reage, no início do ensaio, com uma substância disponível no meio, gerando intermediários, os quais reagem mais lentamente com o ozônio. Esse comportamento cinético pode estar associado à complexidade da decomposição do ozônio. Para um ajuste monoexponencial da curva de decaimento, o tempo de meia vida variou entre $12 \mathrm{e}$ 76 minutos dependendo do meio. 
Os ensaios batch para meio aquoso forneceram resultados satisfatórios para degradação de PCE por ozônio em meio aquoso. Dentre os meios estudados, a água subterrânea do poço tubular profundo mostrou redução de PCE variando entre 70 e $75 \%$, seguida da água subterrânea do poço cacimba com $64 \%$, da solução de bicarbonato de sódio $25 \mathrm{mg} / \mathrm{L}$ de 55\%, e da agua ultrapura, de 47 a 52\%. Mesmo com as elevadas taxas de degradação de PCE em sistema fechado, no caso da água ultrapura as concentrações no final do ensaio encontravam-se ligeiramente acima dos valores de intervenção estabelecidos pela CETESB em 2014.

A adição de bicarbonato de sódio diminuiu as meias vidas do ozônio em água. Com isso, esperava-se maior formação de radicais hidroxilas, mais reativos, e, portanto, maior degradação de PCE. Os ensaios batch, contudo, não mostraram diferença significativa na degradação do PCE com a adição de bicarbonato de sódio.

Os ensaios batch em meio poroso não foram conclusivos devido à grande variação entre replicatas. As análises químicas foram realizadas em laboratório comercial e os ensaios não puderam ser refeitos devido a limitações de tempo e recursos.

Nos ensaios de coluna para meio aquoso foram determinadas as concentrações de PCE dissolvidas na coluna no início e no fim do ensaio, bem como a concentração de PCE volatilizada e arrastada pelo gás durante o ensaio, por meio de um trap na saída da coluna. A montagem experimental possibilita também que sejam monitorados ao longo do tempo as concentrações e pressões de ozônio na entrada e saída da coluna.

Os ensaios de coluna de controle de água ultrapura, realizados com água ultrapura saturada de PCE e oxigênio, mostraram que, em média, entre 91 e $93 \%$ da massa de PCE retirada da coluna sofreu arraste e foi recuperada no trap. Isso indica que a injeção de oxigênio promoveu a volatilização e arraste do PCE. Nos ensaios com injeção de ozônio, tanto para a água ultrapura saturada de ozônio como para as águas subterrâneas do poço cacimba e do poço tubular profundo saturadas de ozônio, também não se observou diferença estatística entre os valores de massa de PCE inicial na coluna e recuperada no trap, indicando novamente volatilização e arraste praticamente integral do PCE. 
As concentrações de PCE na coluna no final de todos os ensaios encontravam-se na ordem de ppb, próximas ao valor de intervenção para águas subterrâneas estipulado pela CETESB em 2014: inferiores no caso das águas subterrâneas e água ultrapura tratadas por ozônio, e superiores para os ensaios de controle de água ultrapura (com oxigênio).

Estes resultados comprovam que o mecanismo de remoção dominante é o arraste do PCE, ao contrário da degradação de PCE obtida nos ensaios batch em sistema fechado. Com isso, para a continuação da pesquisa, sugere-se realizar ensaios de coluna para o meio aquoso com injeção de ozônio gasoso pulsada e testar também a injeção de água saturada de ozônio (ozônio dissolvido).

Os ensaios de coluna em meio poroso com microesferas de vidro e areia indicaram que a massa inicial de PCE é removida da coluna, não apenas por volatilização e arraste, mas também por degradação do PCE, pois apenas aproximadamente $25 \%$ da massa é recuperada no trap. Provavelmente, o tempo mais longo de residência na coluna devido ao meio poroso promove as reações do ozônio com o PCE. Os ensaios com solo não puderam ser concluídos por necessidade de aumentar a rugosidade interna das paredes da coluna para evitar a formação de caminhos preferenciais, o que não foi possível devido a limitações de tempo e recursos.

Para prosseguimento desta pesquisa sugere-se realizar ensaios em escala de laboratório variando a concentração e a pressão de injeção de ozônio. É necessário repetir os ensaios batch para os meios porosos e para outros tempos. Os ensaios de coluna de solo devem ser realizados com coluna fosca internamente para aumentar o atrito do vidro com o solo. Propõe-se ainda o estudo de meios porosos nas colunas com variação da porosidade, ou mesmo a utilização de amostras indeformadas de solo para simular condições mais próximas das reais. Sugere-se monitorar o íon cloreto durante os ensaios, uma vez que a reação do PCE com o ozônio gera $\mathrm{HCl}$. Outros desdobramentos da pesquisa são o estudo da injeção em solo não saturado, assim como dos fatores que influenciam na oxidação: teor de matéria orgânica, diferentes granulometrias, $\mathrm{pH}$, teor de umidade e a presença de metais reativos. Por último, esses estudos deverão então ser realizados em escala piloto e escala real. 


\section{BIBLIOGRAFIA}

ABNT - ASSOCIAÇÃO BRASILEIRA DE NORMAS TÉCNICAS. NBR 13600: Solo - Determinação do teor de matéria orgânica por queima a $440^{\circ} \mathrm{C}$. Rio de Janeiro, 1996.

ABNT - ASSOCIAÇÃO BRASILEIRA DE NORMAS TÉCNICAS. NBR 7180: Solo - Determinação do limite de plasticidade. Rio de Janeiro, 1984a.

ABNT - ASSOCIAÇÃO BRASILEIRA DE NORMAS TÉCNICAS. NBR 6459: Solo - Determinação do limite de liquidez. Rio de Janeiro, 1984b.

ABNT - ASSOCIAÇÃO BRASILEIRA DE NORMAS TÉCNICAS. NBR 6457: Amostras de Solo - Preparação para ensaios de compactação e ensaios de caracterização, Anexo - Determinação do teor de umidade de solos. Rio de Janeiro, 1986.

ABNT - ASSOCIAÇÃO BRASILEIRA DE NORMAS TÉCNICAS. NBR 7181: Solo - Análise granulométrica. Rio de Janeiro, 1988a.

ABNT - ASSOCIAÇÃO BRASILEIRA DE NORMAS TÉCNICAS. NBR 7182: Solo - Ensaio de compactação. Rio de Janeiro, 1988b.

ABNT - ASSOCIAÇÃO BRASILEIRA DE NORMAS TÉCNICAS. NBR 6508: Grãos de solo que passam na peneira de $4,8 \mathrm{~mm}$. Determinação da massa específica, 1984.

ABNT - ASSOCIAÇÃO BRASILEIRA DE NORMAS TÉCNICAS, MB-3324: Solo Determinação do índice de vazios máximo de solos não coesivos. Rio de Janeiro, 1990.

ABNT - ASSOCIAÇÃO BRASILEIRA DE NORMAS TÉCNICAS. MB-3388: Solo Determinação do índice de vazios mínimo de solos não coesivos, Rio de Janeiro, 1991,

ABNT - ASSOCIAÇÃO BRASILEIRA DE NORMAS TÉCNICAS. NBR 15492: Sondagens de reconhecimento para fins de qualidade ambiental - Procedimento, 2007.

ADAMS, C.D.; RANDTKE, S. J. Ozonation byproducts of atrazine in synthetic and natural waters. Environmental Science \& Technology 26:2218-2227, 1992. 
ALBERS, A. P. F.; MELCHIADES, F. G.; MACHADO, R.; BALDO, J.B.; BOSCHI, A. O. Um método simples de caracterização de argilominerais por difração de raios X. Cerâmica 48 (305) Jan/Fev/Mar 2002.

ALVAREZ, M. G.; POZNYAK, T. ; LEAL, E. R.; SÁNCHEZ, C. S. Anthracene decomposition in soils by conventional ozonation. Journal of Environmental Management 113(2012) 545-551, 2012.

ANDREOZZI, R.; INSOLA, A.; CAPRIO, V.; MAROTTA, R.; TUFANO, V. The use of manganese dioxide as a heterogeneous catalyst for oxalic acid ozonation in aqueous solution. Applied Catalysis A: General 138:75-81, 1996.

ARBUCKLE, W. B.; HO, Y-F. Adsorber column diameter:particle diameter ratio requirements. Research Journal Water Pollution Control Federation, 62(1):88-90, 1990.

ATSDR - Agency for Toxic Substances and Disease Registry, Department of Health and Human Services. Public Health Service, Toxicological profile for trichloroethylene, $1997 . \quad$ Disponível em: http://www.atsdr.cdc.gov/toxprofiles/tp.asp?id=173\&tid=30, Data de Acesso: 10 de Fevereiro de 2013.

BAIRD, C, Química Ambiental. São Paulo: Bookman, 2002.

BARBOZA, A. C. L.; SILVA JúNIOR, G. C. da; MELLO, C. L. Caracterização de parâmetros hidráulicos em depósitos fluviais paleogênicos na Bacia de Volta Redonda, RJ. Anuário do Instituto de Geociências, volume 30, ํㅡ 2, Rio de Janeiro, 2007.

BELTRÁN, F. J. Ozone reaction kinetics for water and wastewater systems. CRC Press/ Lewis Publishers, Boca Raton, Florida, United States of America, 2004.

BLOCK, P.; CUTLER, W. "Klozur® Activated Persulfate for Site Remediation: Comparative Evaluation of Treatment Efficacy and Implementation Costs" (Persulfato Ativado Klozur ${ }^{\mathrm{TM}}$ para Remediação de Sítios: Avaliação Comparativa da Eficácia do Tratamento e Custos de Implementação), $4^{\text {th }}$ International Conference on Oxidation and Reduction Technologies for In Situ Treatment of Soil and Groundwater, October, 2005.

BOOK Brasil Ozônio, 2012. 
BONCZ, M. Á. Oxidação seletiva de compostos orgânicos em água residuária por ozônio baseado em processos de oxidação. PhD Tese, Universidade de Wageningen, Wageningen, Holanda, 2002. 168 p.

BOULDING, J. R.; GINN, J. S. Pratical Handbook of soil, vadose zone, and ground-water contamination, Assessment, Prevention, and Remediation. Lewis Publishers, CRC Press: Boca Raton, Florida, United States of America, 2004. Second Edition.

BRAGA, B.; HESPANHOL, I.; CONEJO, J. G .L.; BARROS, M. T. L. de; SPENCER, M.; PORTO, M.; NUCCI, N.; JULIANO, N.; EIGER, S. Introdução à Engenharia Ambiental. São Paulo: Prentice Hall, 2002.

BROOKS, M. C.; WISE, W. R.; ANNABLE, M.D. Fundamental changes in situ air sparging flow patterns. Ground Water Monitoring and Remediation 19:105-113, 1999.

BUNCE, N. J.; SCHNEIDER, U. A. Chemical lifetimes of chlorinated aliphatic priority pollutants in the Canadian troposphere. Journal Photochem, Photobiol, 1994, (Chem,, 81 (1994) 93-101).

CAMARGO, O. A. de; MONIZ, A. C.; JORGE, J. A.; VALADARES, J. M. A. S. Boletim Técnico oㅜ 106. Métodos de Análise Química, Mineralógica e Física de Solos do Instituto Agronômico de Campinas, Campinas, 2009.

CASTRO, F. D. de. Degradação do ácido 2,4 - diclorofenoxiacético (2,4-D) com ozônio eletrogerado. Dissertação de mestrado. Universidade Federal de Uberlândia. 2010. 80 p.

CARR, S. A.; BAIRD, R. B. Mineralization as a mechanic for TOC removal: study of ozone/ozone-peroxide oxidation using FT-IR. Water Res Vol,34, n,16, pp 40364048, 2000.

CARUS REMEDIATION TECHNOLOGIES. Produtos, Revista Pollution Engineering. Edição de Março de 2010. Número 4. São Paulo, 2010.

CETESB - COMPANHIA AMBIENTAL DO ESTADO DE SÃO PAULO. Ficha de Informação Toxicológica (FIT). São Paulo: 2012.

CETESB - COMPANHIA AMBIENTAL DO ESTADO DE SÃO PAULO. Manual de Gerenciamento de Áreas Contaminadas/ CETESB GTZ. 2, ed. São Paulo: CETESB, 1999. 389p. 
CETESB - COMPANHIA AMBIENTAL DO ESTADO DE SÃO PAULO. Texto explicativo. Relação de áreas contaminadas e reabilitadas no Estado de São Paulo. São Paulo, 2013. Publicado em 2014.

CETESB - COMPANHIA AMBIENTAL DO ESTADO DE SÃO PAULO. Valores Orientadores para Solos e Águas Subterrâneas no Estado de São Paulo - 2014 em substituição aos valores orientadores 2005. São Paulo, 2014. 4 p. In: Decisão de Diretoria № 045/2014/E/C/l, de 20 de Fevereiro de 2014.

CETESB - COMPANHIA AMBIENTAL DO ESTADO DE SÃO PAULO. Relatório de Estabelecimento de Valores Orientadores para Solos e Águas Subterrâneas no Estado de São Paulo, São Paulo. 2001. 73 p.

CETESB - COMPANHIA AMBIENTAL DO ESTADO DE SÃO PAULO. Guia de Coleta e Preservação de Amostras de Água. São Paulo, 2011.

CHAO, K,-P.; ONG, S. K.; HUANG, M. C. Mass transfer of VOCs in laboratoryscale air sparging tank. Journal of Hazardous Materials 152:1098-1107, 2008.

CHOI, H.; LIM, H. N.; KIM, J; HWANG, T. M.; KANG, J. W. Transport characteristics of gas phase ozone in unsaturated porous media for in situ chemical oxidation. Journal of Contaminant Hydrology 57(2002)81-98, 2002.

CHIOU, C. T. Partition and adsorption of organic contaminants in environmental systems. Wiley-Interscience: Hoboken, New Jersey, United States of America, 2002.

CLAYTON, W. S.; PETRI, B. G.; HULING, S. G. In Situ Chemical Oxidation for Groundwater Remediation. SERDP, ESTCP, Springer Science, New York, New York, United States of America, 2011.

CLAYTON, W. S. A field and laboratory investigation of air fingering during air sparging. Ground Water Monitoring and Remediation 17:134-145, 1998.

CRC, Handbook of Chemistry and Physics. R. C. Weast (editor). CRC Press, Boca Raton, Florida, United States of America, 1988. Primeira edição.

CUNHA, A. S. da. Aplicação de técnicas químicas de remediação em áreas contaminadas por compostos organoclorados. Dissertação de Mestrado. Instituto de Geociências/ USP. São Paulo, 2010. 101 p.

DFFCUL - Departamento de Física da Faculdade de Ciências da Universidade de Lisboa. Trabalho prático: Fluorescência de raios $X$. Disponível em: http://www.lip.pt/ luis/fr/rx.pdf. Data de Acesso: 09 de Fevereiro de 2013. 
DREILING, D. N.; HENNING, L. G.; JURGENS, R. D.; e BALLARD, D. L. Multisite comparison of chlorinated solvent remediation using innovative technology. Battelle, First International Conference on Remediation of Chlorinated and Recalcitrant Compounds. Monterey, California, United States of America, 1998. 20-21 p. In: EPA - Field Applications of In Situ Remediation Technologies: Chemical Oxidation, 1998.

ELDER, C. R.; BENSON, C. H. Air channel formation, size, spacing and tortuosity during air sparging. Ground Water Monitoring and Remediation 19:171-181, 1999.

EMBRAPA - Centro Nacional de Pesquisa do Solo; SBCS - Sociedade Brasileira de Ciência do Solo. Manual de Descrição e Coleta de Solo no Campo. Viçosa, 2005.

ENVIROLOGEK. Chemical Oxidation. Disponível em: http://www.envirologek.com/Chemical Oxidation br.php. Data de acesso: 15 de Maio de 2011.

ENZWEILER, J. Espectrometria de fluorescência de raios X. Universidade de Química Federal do Paraná. Paraná, 2010.

EXOVA. 1,4-Dioxane by GCMS. Disponível em: http://www.wcaslab.com/tech/dioxane.html. Data de acesso: 06 de Fevereiro de 2013.

FEITOSA, F. A. C.; MANOEL FILHO, J. Hidrogeologia conceitos e aplicações. Fortaleza: Serviço Geológico do Brasil - CPRM; Laboratório de Hidrogeologia da Universidade Federal de Pernambuco - LABHID -UFPE, 2000. Segunda edição. FETTER, C. W. Applied Hydrogeology. University of Wisconsin, Oshkosh. Third edition. Prentice Hall, Englewood Cliffs, New Jersey, United States of America, 1994.

FREEZE, R. A.; CHERRY, J. A. Groundwater, Prentice Hall, Englewood Cliffs, New Jersey, 1979.

GONÇALVES, C.; SILVÉRIO, P. F.; YAMAMOTO, C. R.; e ARANTES, G. Análise de metais dissolvidos em águas: uma comparação entre filtração em campo $x$ filtração em laboratório. XV Congresso Brasileiro de Águas Subterrâneas, 2008. 
HAAG, W. R.; YAO, D. Rate constants for reaction of hydroxyl radicals with several drinking water contaminants. Environmental Science \& Technology 26:1005-1013, 1992.

HEIN, G. L.; GIERKE, J. S.; HUTZLER, N. J.; FALTA, R. W. Three-dimensional experimental testing of a two-phase flow-modeling approach for air sparging. Ground Water Monitoring and Remediation 17:222-230, 1997.

HEWITT, C. N. Instrumental Analysis of Pollutants. England: Elsevier Applied Science, 1991.

HRISTOVSKI, K.; BAUMGARDNER, A.; WESTERHOFF, P. Selecting metal oxide nanomaterials for arsenic removal in fixed bed columns: From nanopowders to aggregated nanoparticle media. Journal of Hazardous Materials 147(1-2):265274, 2007.

HSU, I. Y.; MASTEN, S. J. Modeling transport of gaseous ozone in unsaturated soils. Journal of Environmental Engineering 127:546-554, 2001.

HULING, S. G.; PIVETZ, B. E. Engineering Issue: In Situ Chemical Oxidation. USEPA - United States Environmental Protection Agency Cincinnati. Ohio, United States of America, 2006. (EPA/600/R-06/072)

IAC - Instituto Agronômico de Campinas. Métodos de Análise Química, Mineralógica e Física de Solos do Instituto Agronômico de Campinas. Boletim técnico 106. IAC, 2009.

IHSS - International Humic Substances Society. What are humic substances? Disponível em: http://www.humicsubstances.org/whatarehs.html. Data de acesso: 09 de Fevereiro de 2013.

INCHEM - International Chemical. Tetrachloroethylene. In: http://www.inchem.org/ Data de Acesso: 20 de Junho de 2014.

IOA - International Ozone Association. lodometric Method for the determination of Ozone in a Process Gas. Revised Standardized Procedure 001/96. 1996.

IQ - Instituto de Química, Espectrometria de Emissão Atômica (ICP-AES). Central analítica do Instituto de Química da Universidade de São Paulo - USP, São Paulo, Disponível em: http://ca.iq.usp.br/conteudo2.php?itemid=31\&alt=ICPAES\&C=\&paiid=16. Data de Acesso: 10 de Fevereiro de 2013. 
ITRC - INTERSTATE TECHNOLOGY AND REGULATORY COOPERATION WORK GROUP. Technical and regulatory guidance for In Situ Chemical Oxidation of contaminated soil and groundwater. First Edition, 2001. 25 p.

ITRC - INTERSTATE TECHNOLOGY AND REGULATORY COOPERATION WORK GROUP. Technical and regulatory guidance for In Situ Chemical Oxidation of contaminated soil and groundwater. Second edition, 2005.

JARDIM, W. F.; CANELA, M. C. Fundamentos da oxidação química no tratamento de efluentes e remediação de solos. Instituto de Química/ UNICAMP, Campinas, 2004. $10 \mathrm{p}$.

JOHNSON, P. C. Assessment of the contributions of volatilization and biodegradation to in situ air sparging performance. Environmental Science \& Technology 32:276-281, 1998.

JUNG, H.; KIM, J.; CHOI, H. Reaction kinetics of ozone in variably saturated porous media. Journal of Environmental Engineering 130:432-441, 2004.

KERFOOT, W. B.; EHLERINGER, B; MUNCY, J. Ozone sparging closure of an industrial VOC spill site adjacent to a water supply well site. Mashpee, Massachusetts, Cleveland, Ohio Enon, Ohio, 2007.

KERFOOT, W. B.; SCHOUTEN, C. J. J. M.; VAN ENGEN-BEUKEBOOM, V. C. M. Kinetic Analysis of Pilot Test Results of the C-Sparge ${ }^{\mathrm{TM}}$ Process, Battelle, First International Conference on Remediation of Chlorinated and Recalcitrant Compounds, Monterey, California, United States of America, 1998. 23-24p. In: EPA - Field Applications of In Situ Remediation Technologies: Chemical Oxidation, 1998.

KWAN, W. P.; VOELKER, B. M. Rates of hydroxyl radical generation and organic compound oxidation in mineral-catalyzed Fenton-like systems. Environmental Science \& Technology 37:1150-1158, 2003.

LANGLAIS, B.; RECKHOW, D. A.; BRINK, D. R. Ozone in water treatment Application and Engineering. Lewis Publishers, Chelsea, Michigan, United States of America; American Water Works Association Research Foundation, Denver, Colorado, United States of America, 1991.

LIMA, J. B. V. Propriedades dos contaminantes orgânicos (slides de aula da disciplina GSA-5827 - Geoquímica e transporte de contaminantes orgânicos em subsuperfície). São Paulo, 2011. 
LUSTER-TEASLEY, S.; UBAKA-BLACKMOORE, N.; MASTEN, S. J. Evaluation of soil pH and moisture content on in-situ ozonation of pyrene in soils. Journal of Hazardous Materials 167:701-706, 2009.

MAHMOUD, A.; FREIRE, R. S. Métodos emergentes para aumentar a eficiência do ozônio no tratamento de águas contaminadas. Centro de Capacitação e Pesquisa em Meio Ambiente, Cubatão, SP, 2006. (Química Nova, Vol, 30, №, 1 , 198-205, 2007).

MASSAD, F. Notas de apoio às aulas: Ensaios básicos de laboratório. Escola Politécnica da Universidade de São Paulo - EPUSP, Departamento de Engenharia de Estruturas e Geotécnica - PEF, São Paulo: 2007.

MASTEN, S. J.; DAVIES, S. H. R. Efficacy of in situ ozonation for the remediation of PAH contaminated soils. Journal of Contaminant Hydrology 28: 327-335, 1997. MONTGOMERY, J. H. Groundwater Chemicals Desk Reference. Lewis Publishers, CRC Press, Boca Raton, Florida, United States of America, 2007. Fourth edition.

NAYDENOV, A.; MEHANDJIEV, D. Complete oxidation of benzene on manganese dioxide by ozone. Applied Catalysis A: General 97:17-22, 1993.

NOGAMI, J. S.; VILLIBOR, D. F. Pavimentação de baixo custo com solos lateríticos. Ed. Vilibor, 1995. 240p.

O'MAHONY, M. M.; DOBSON, A. D. W.; BARNES, J. D.; SINGLETON, I. The use of ozone in the remediation of polycyclic aromatic hydrocarbon contaminated soil. Chemosphere 63:307-314, 2006.

OPPENLÄNDER, T. A. Photochoemical Purification of Water and Air. Advanced Oxidation Processes (AOPs): Reactor Concepts. WILEY-VCH, 2003.

PANKOW, J. F.; CHERRY, J. A. Dense chlorinated solvents and other DNAPLs in groundwater: History, Behavior, and Remediation. Waterloo Press, Ontario, Canada, United States of America, 1996.

PENNEL, K. D.; MINQUAN, J.; ABRIOLA, L. M.; POPE, G. A. Surfactant enhanced remediation of soil columns contaminated by residual tetrachloroethylene. Journal of Contaminant Hydrology 16 (1994) 35-53, 1994. PINTO, C. de S. Curso básico de mecânica dos solos em 16 aulas. São Paulo: Oficina de Textos, 2006. 
POZNYAK, T. I.; MANZO, A.; MAYORGA, J. L. Elimination of chlorinated unsaturated hydrocarbons from water by ozonation. Simulation and experimental data comparison. Revista de la Sociedad Química de México, Vol. 47, Núm. 1 (2003) 58-65, 2003.

PUBCHEM.

Tetrachloroethylene.

Disponível

em:

http://www.ncbi.nlm.nih.gov/pccompound Data de Acesso: 20 de Junho de 2014. RANDO, I. P.; BOSCOV, M. E. G.; ANDROMALOS, K. B. Evaluation of two soil mixing techniques for the isolation and encapsulation of impacted materials in environmental applications. In: AquaConSoil Barcelona 2013 - 12th International UFZ-Deltares Conference on Groundwater-Soil Systems and Water Resource Management, 2013, Barcelona. AquaConSoil Barcelona 2013 - 12th International UFZ-Deltares Conference on Groundwater-Soil Systems and Water Resource Management, 2013.

RCC - RESOURCE CONTROL CORPORATION. In-Situ oxidation of Petroleum Hydrocarbons utilizing ozone. Cases Histories, Rancocas, New Jersey, United States of America, 2000.

RONQUIM, C. C. Boletim de Pesquisa e Desenvolvimento 8: Conceitos de fertilidade do solo e manejo adequado para as regiões tropicais. Empresa Brasileira de Pesquisa Agropecuária - Embrapa, Campinas, 2010.

ROWE, R. K.; QUIGLEY, R.M.; BOOKER, J.R. Clayey barrier systems for waste disposal facilities. E\&FN Spon (Chapman \& Hall). First Edition. London, 1995. $390 \mathrm{pp}$.

SALE, T.; NEWELL, C.; STROO, H.; HINCHEE, R.; e JOHNSON, P. Frequently asked questions regarding management of chorinated solvents in soils and groundwater. Environmental Security Technology Certification Program - ESTCP, 2008.

SALGADO, P. E. de T.; MARONA, H. R. N. Informações gerais e ecotoxicológicas de solventes clorados. Série cadernos de referência ambiental, v.15. Salvador, 2004.

SÃO PAULO. Decreto Estadual $n^{\circ} 59.263$, de 5 de junho de 2013. Regulamenta a Lei $n^{\circ} 13.577$, de 8 de julho de 2009, que dispõe sobre diretrizes e procedimentos para a proteção da qualidade do solo e gerenciamento de áreas 
contaminadas, e dá providências correlatas. Diário Oficial do Estado, São Paulo, 6 jun.2013.

SCIULLI, B. E. Remediação do composto tetracloroeteno em subsuperfície através do processo de Oxidação Química In Situ (ISCO). Dissertação de mestrado, Instituto de Geociências/ USP. São Paulo, 2008. 129 p.

SRI Instruments. Electron Capture Detector. Disponível em: http://www.srigc.com/ECDman.pdf Data de acesso: 22/04/2014.

SILVÉRIO, P. F.; e GONÇALVES, C. Influência dos métodos de determinação da fração de carbono orgânico em solos nos estudos de qualidade da água subterrânea e de avaliação de risco. XV Congresso Brasileiro de Águas Subterrâneas, 2008.

SMA, SSE - Secretaria do Meio Ambiente; e Secretaria de Saneamento e Energia do Estado de São Paulo. Projeto Jurubatuba: restrição e controle de uso de água subterrânea / Departamento de Águas e Energia Elétrica, Instituto Geológico, Secretaria de Estado do Meio Ambiente, Secretaria de Estado de Saneamento e Energia. São Paulo : DAEE/IG, 2009.

SRC - Syracuse Research Corporation. Disponível em: http://www.srcinc.com/what-we-do/databaseforms. aspx?id=386. Syracuse, New York, United States. Data de acesso: 20 de Janeiro de 2013.

STAEHELIN, J.; HOIGNÉ J. Decomposition of ozone in water: Rate of initiation by hydroxide ions and hydrogen peroxide. Environmental Science \& Technology 16:676-681, 1982.

STAEHELIN, J.; BÜHLER, R.E.; HOIGNÉ, J. Ozone decomposition in water studied by pulse radiolysis, $2, \mathrm{OH}$ and $\mathrm{HO} 4$ as chain intermediates. The Journal of Physical Chemistry 88:5999-6004, 1984.

SUNDER, M.; HEMPEL, D.C. Oxidation of tri- and perchloroethene in aqueous solution with ozone and hydrogen peroxide in a tube reactor. Water Res 31:3340, 1997.

SUNG, M.; HUANG, C. P. In situ removal of 2-chlorophenol from unsaturated soils by ozonation. Environmental Science Technology 36:2911-2918, 2002.

SURF - Sustainable Remediation Forum. Disponível em: http://www.sustainableremediation.org/ Data de acesso: 29/01/2014 
SUTHERSAN, S. S.; PAYNE, F. C. In Situ Remediation Engineering. CRC Press, Washington, District of Columbia, United States of America, 2005.

TEEL, A. L.; WARBERG, C. R.; ATKINSON, D. A.; WATTS, R. J. Comparison of mineral and soluble iron Fenton's catalysts for the treatment of trichloroethylene. Water Res 35:977-984, 2001.

UDESC - Universidade do Estado de Santa Catarina. Roteiro - Granulometria. Centro de Ciências Tecnológicas - CCT, Laboratório de Mecânica dos Solos. Disponível

em:

http://www.joinville.udesc.br/portal/departamentos/dec/labmes/arquivos/Roteiro\% 20-\%20ENSAIO\%20DE\%20GRANULOMETRIA.pdf. Data de acesso: 09 de Fevereiro de 2013.

USEPA - UNITED STATES ENVIRONMENTAL PROTECTION AGENCY, Formulation of preliminary assessment of halogenated organic compounds in man and environmental media. Research triangle park, North Carolina, United States of America, 1979. (EPA/560/13-79-006).

USEPA - UNITED STATES ENVIRONMENTAL PROTECTION AGENCY. Chapter VII - Air Sparging. 1994.

USEPA - UNITED STATES ENVIRONMENTAL PROTECTION AGENCY. Field Applications of In Situ Remediation Technologies: Chemical Oxidation. Washington, District of Columbia, United States of America, 1998a.

USEPA - UNITED STATES ENVIRONMENTAL PROTECTION AGENCY. Technical protocol for evaluating natural attenuation of chlorinated solvents in ground water. Washington, District of Columbia, United States of America, 1998b. (EPA/600/R-98-128).

USEPA - UNITED STATES ENVIRONMENTAL PROTECTION AGENCY. Method 5021A - Volatile Organic Compounds in Various Sample Matrices Using Equilibrium Headspace Analysis. Revision 1. United States of America, 2003.

USEPA - UNITED STATES ENVIRONMENTAL PROTECTION AGENCY. Monitored Natural Attenuation. United States of America, 2004a. (EPA/510/R-04002).

USEPA - UNITED STATES ENVIRONMENTAL PROTECTION AGENCY. How to evaluate alternative cleanup technologies for underground storage tank sites. A 
guide for corrective action plan reviewers, Chapter XIII - Chemical Oxidation, United States of America, 2004b. (EPA/510/R-04-002).

USEPA - UNITED STATES ENVIRONMENTAL PROTECTION AGENCY. Method 9045D - Soil and Waste pH. United States of America, 2004c.

USEPA - UNITED STATES ENVIRONMENTAL PROTECTION AGENCY. Method 8260C - Volatile Organic Compounds by Gas Chromatography/ Mass Spectrometry (GC/MS). Revision3. United States of America, 2006.

USEPA - UNITED STATES ENVIRONMENTAL PROTECTION AGENCY. Chemical Oxidation Guidance. Illinois, United States of America, 2008. 7p.

USEPA - UNITED STATES ENVIRONMENTAL PROTECTION AGENCY. In Situ Chemical Oxidation. Disponível em: http://www.clu-in.org/. Data de acesso: 22 de Maio de 2011.

USEPA - UNITED STATES ENVIRONMENTAL PROTECTION AGENCY. Regional Screening Levels for Chemical Contaminants at Superfund Sites. Disponível em: http://www.epa.gov/region09/waste/sfund/prg/index.html Data de acesso: Maio de 2013.

USEPA - UNITED STATES ENVIRONMENTAL PROTECTION AGENCY. 1,4Dioxane, detection and site characterization. Disponível em: http://www.cluin.org/contaminantfocus/default.focus/sec/1.4dioxane/cat/Detection and Site Ch aracterization/. Data de acesso: 06 de fevereiro de 2013.

ZHANG, H.; JI, L.; WU, F.; TAN, J. In situ ozonation of anthracene in unsaturated porous media. Journal of Hazardous Materials B120:143-148, 2005. 


\section{ANEXO A - FIGURAS}

Figura A.1 Mapa de localização dos pontos de coleta de solo e água subterrânea.

Figura A.2 Mapa pedológico regional.

Figura A.3 Mapa geológico regional.

Figura A.3 Mapa hidrogeológico regional. 


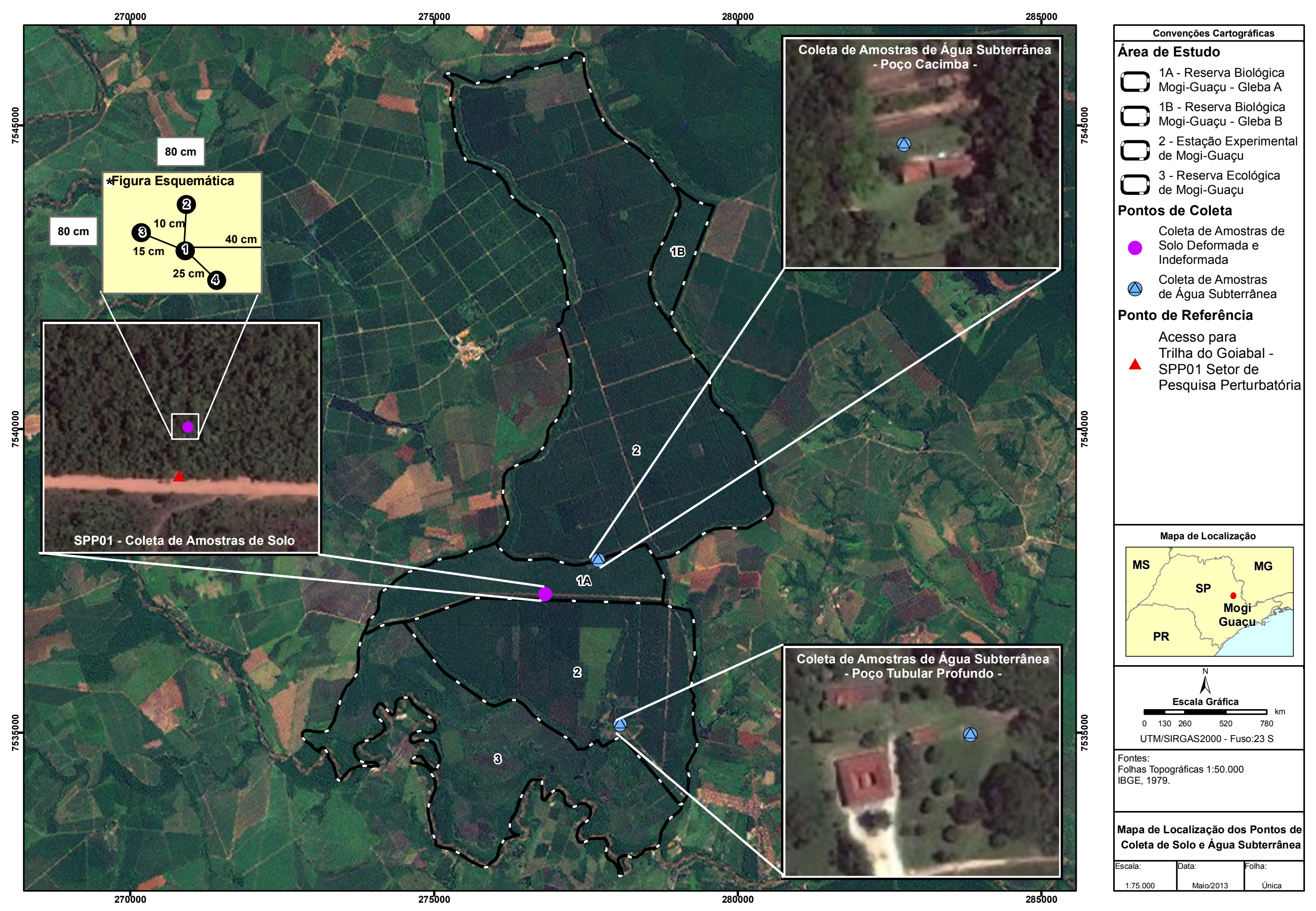




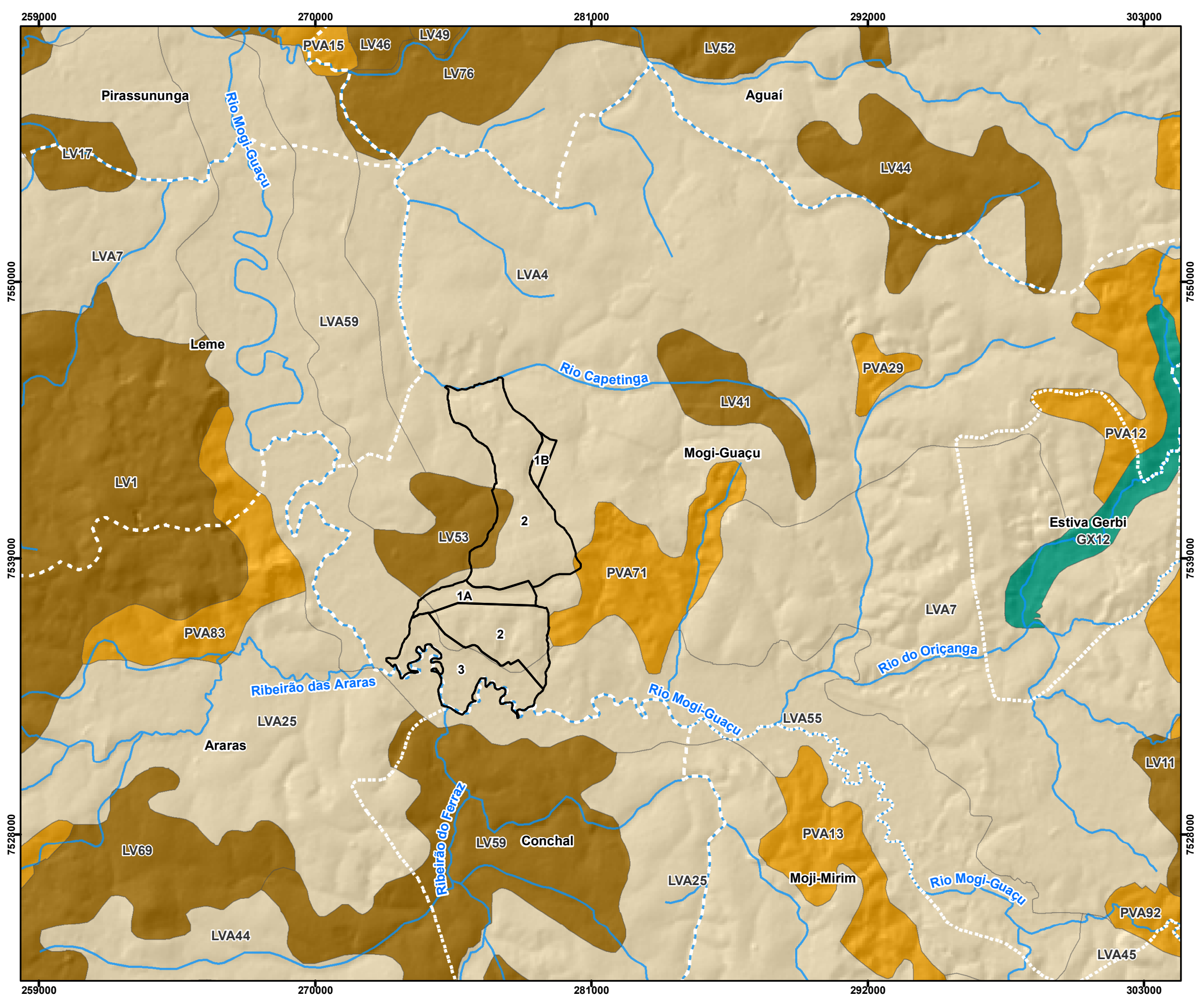

\section{Rede de Drenagem}

n Curso d'Água

Pedologia

Latossolos Vermelhos

Latossolos

Vermelho-Amarelos

Argissolos

Vermelho-Amarelos

Gleissolos Háplicos

Área de Estudo

$1 \mathrm{~A}$ - Reserva Biológica

Mogi-Guaçu - Gleba A

1B - Reserva Biológica

$\square$ Mogi-Guaçu - Gleba B

2 - Estação Experimental

de Mogi-Guaçu

3 - Reserva Ecológica

de Mogi-Guaçu

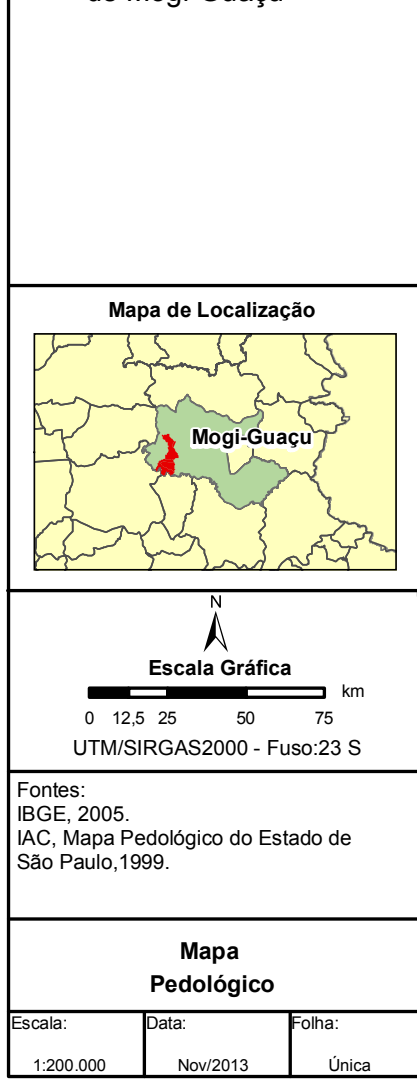




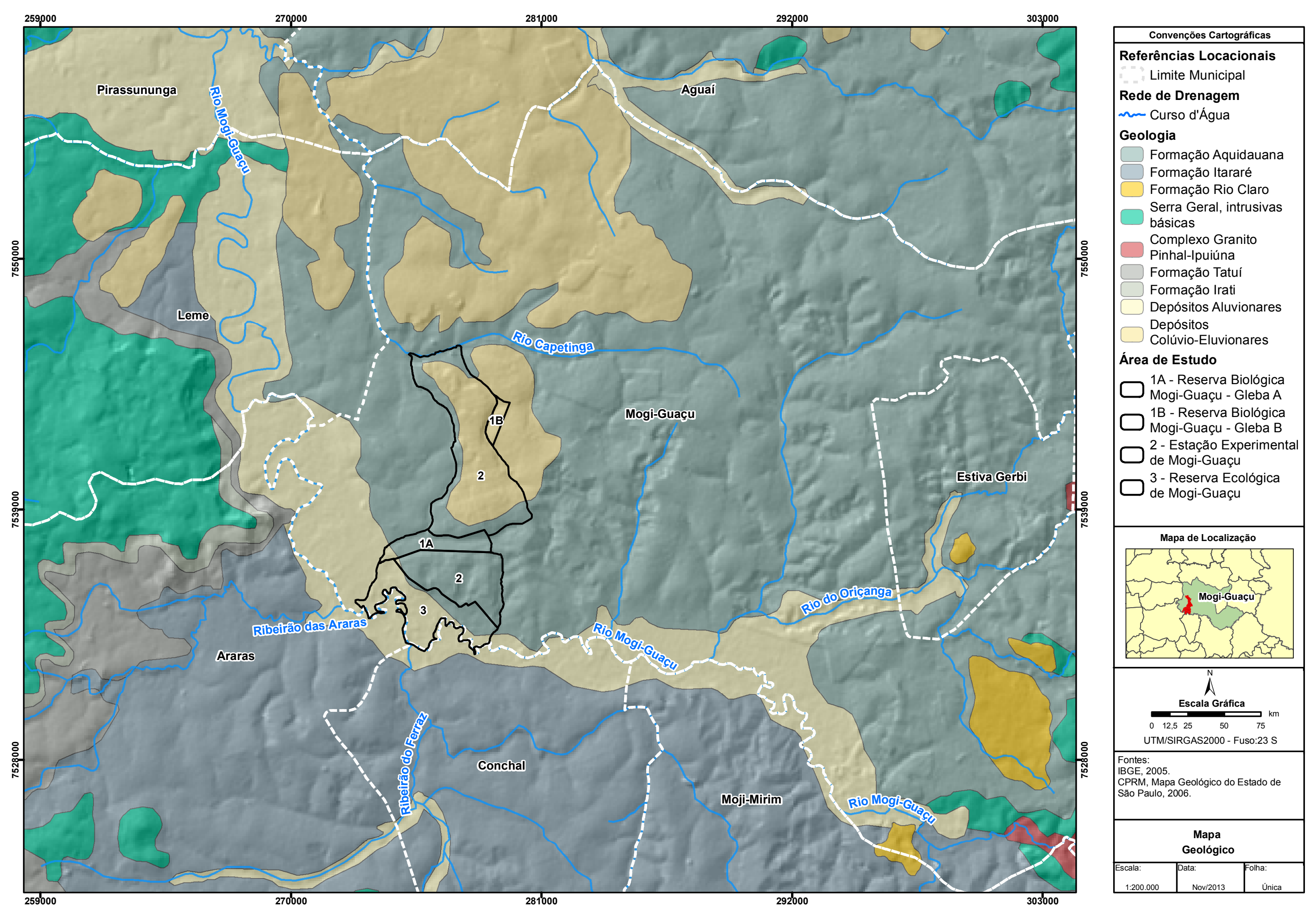



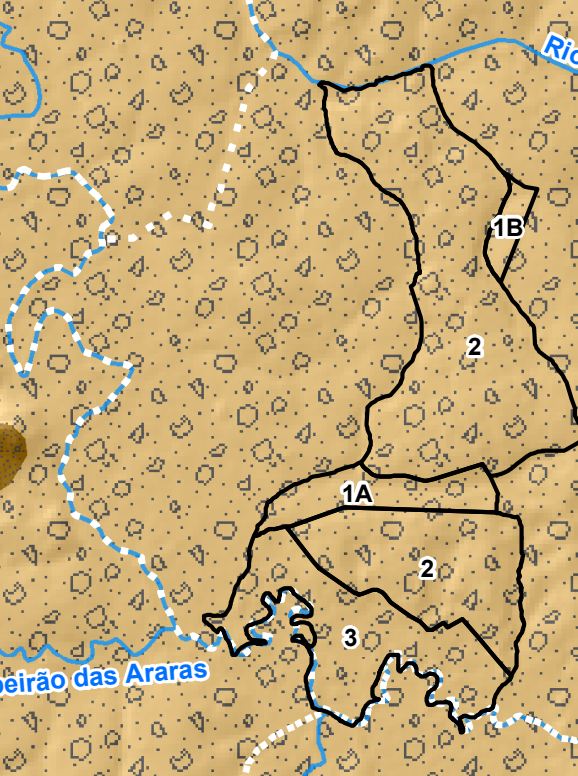

Aquifero Sedimentar

horizontes e corpos loc, extensão regional, em

ถें.

Aquiclude

- Terrenos sedimentares praticamente impermeáveis,

Aquiferos Fraturados

- Pré-cambriano - descontínuo, extensão regional,

com porosidade e permeabilidade associados a
fraturas.

- Serra Geral intrusivas - descontinuo, extensão limitada, com porosidas.
associadas a fraturas.

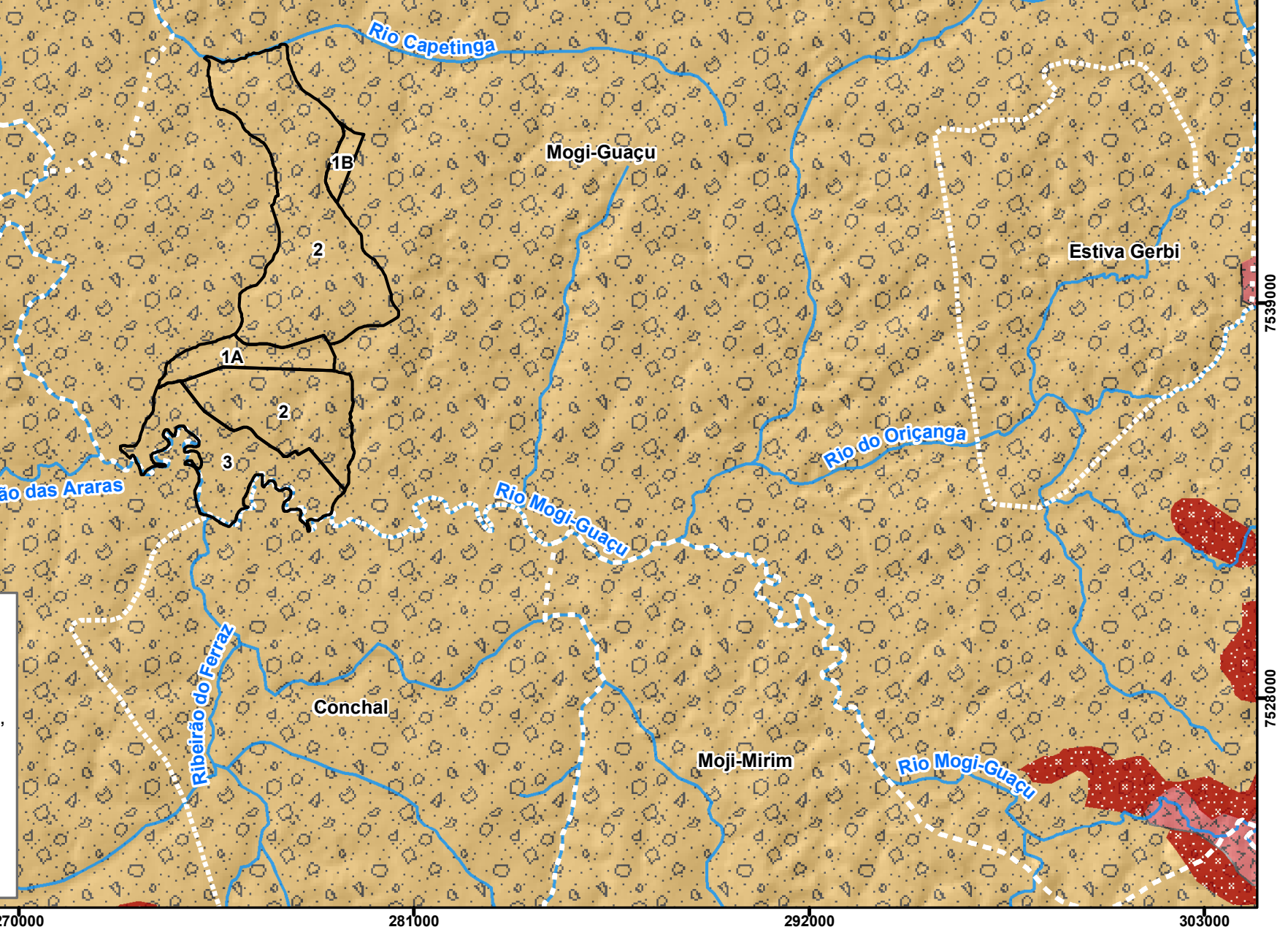

Convenções Cartográficas

Referências Locacionais Limite Municipal

\section{Rede de Drenagem}

n Curso d'Água

\section{Aquíferos}

Aquiclude Passa Dois

$\therefore$ Aquífero Tubarão

¿- Aquífero Pré Cambriano

$\therefore$ Aquífero Serra Geral,

$\therefore$ Intrusivas

\section{Área de Estudo}

$\square$ 1A - Reserva Biológica

1B - Reserva Biológica

Mogi-Guaçu - Gleba B

2 - Estação Experimental

$\square$ de Mogi-Guaçu

3 - Reserva Ecológica

de Mogi-Guaçu

Mapa de Localização

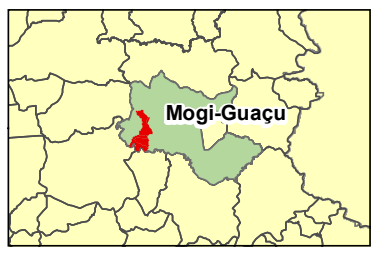

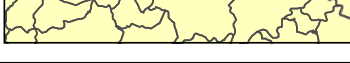
N

$\underset{12,525 \quad 50 \quad 75}{25}$

UTM/SIRGAS2000 - Fuso:23 S

Fontes:

DAEE, IG, IPT e CPRM, Mapa

Hidrogeológico do Estado de

São Paulo, 2005.

Mapa

Hidrogeológico

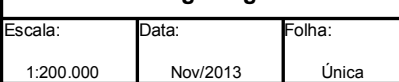


ANEXO B - RELATÓRIO FOTOGRÁFICO 


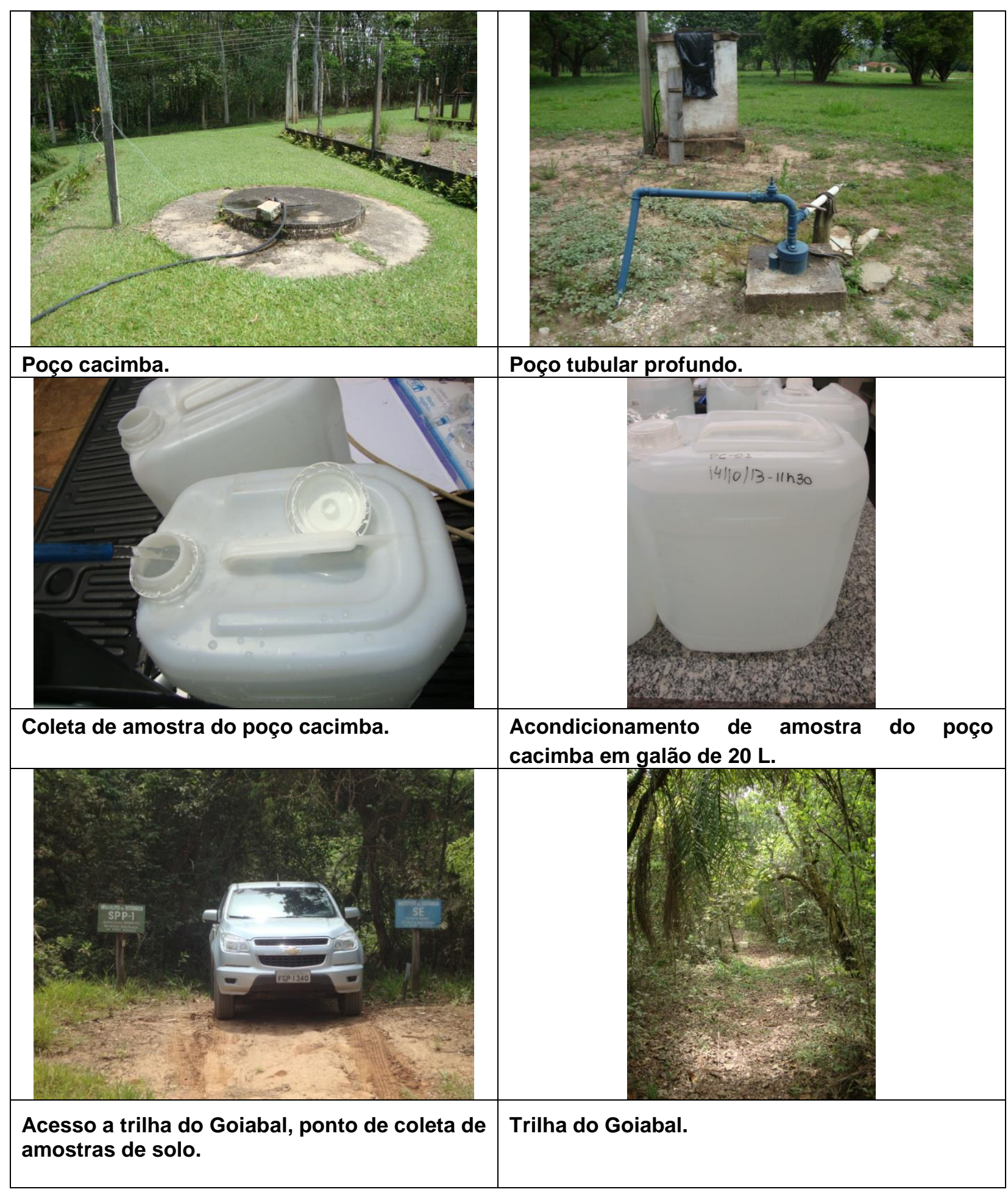




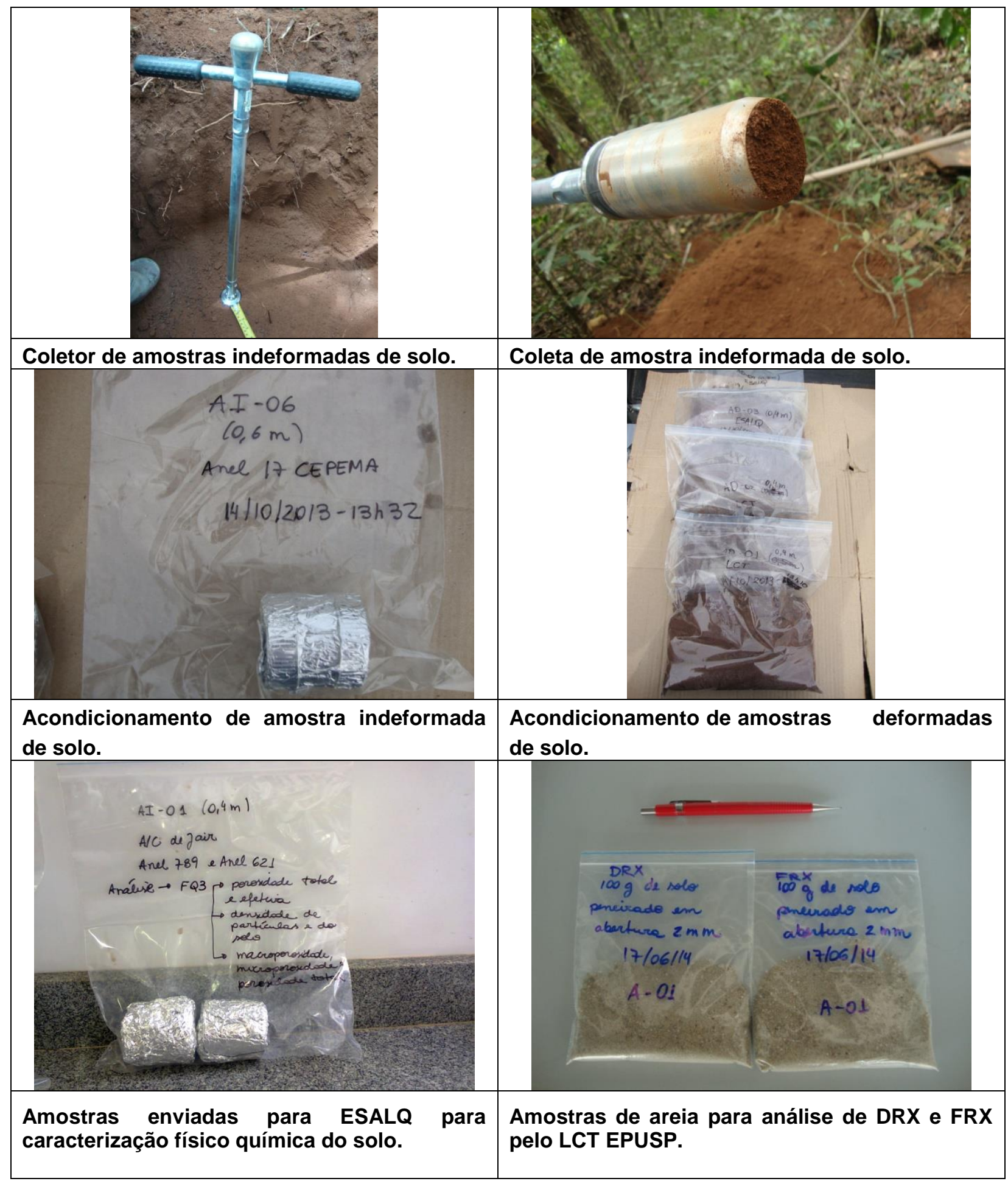




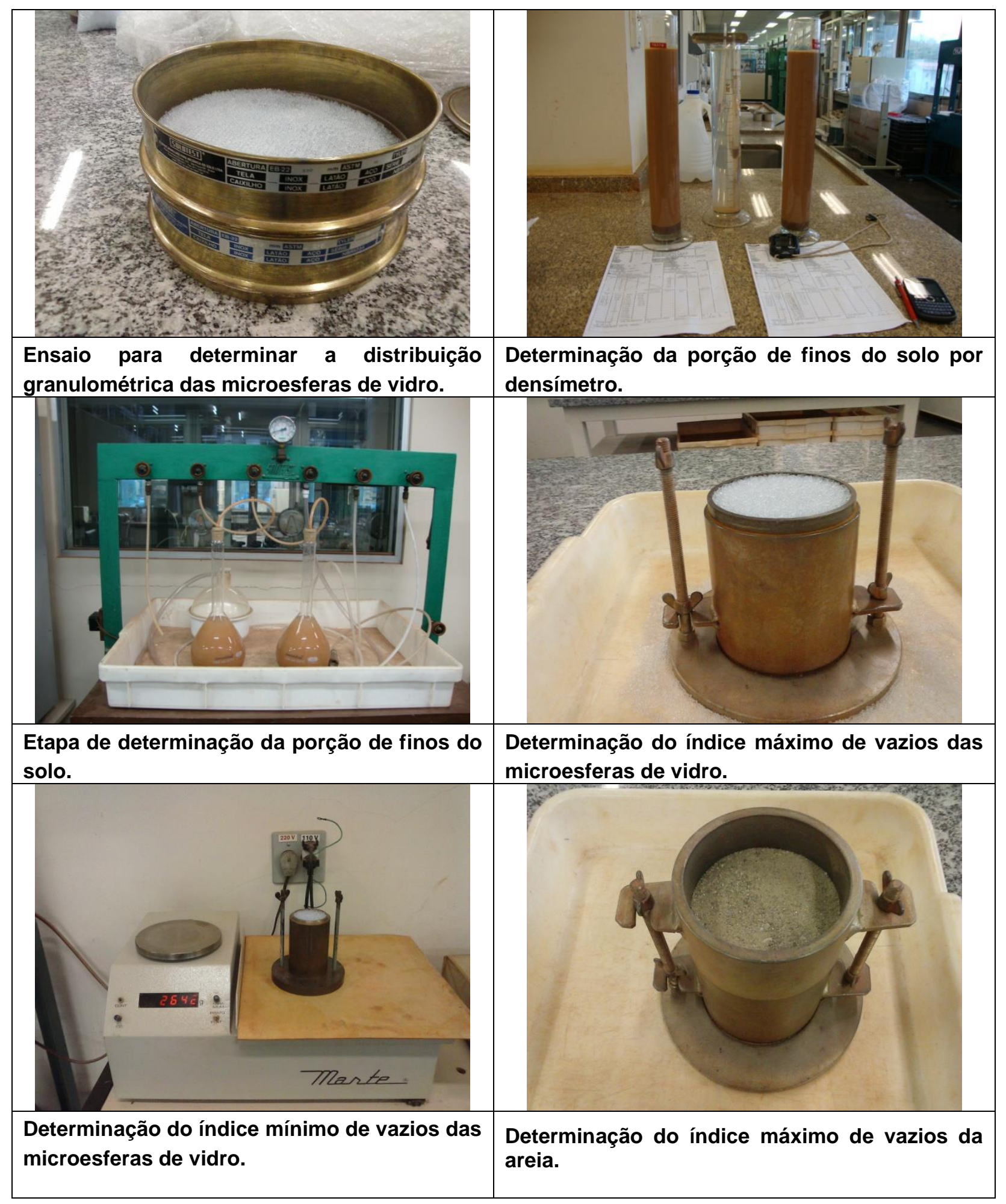




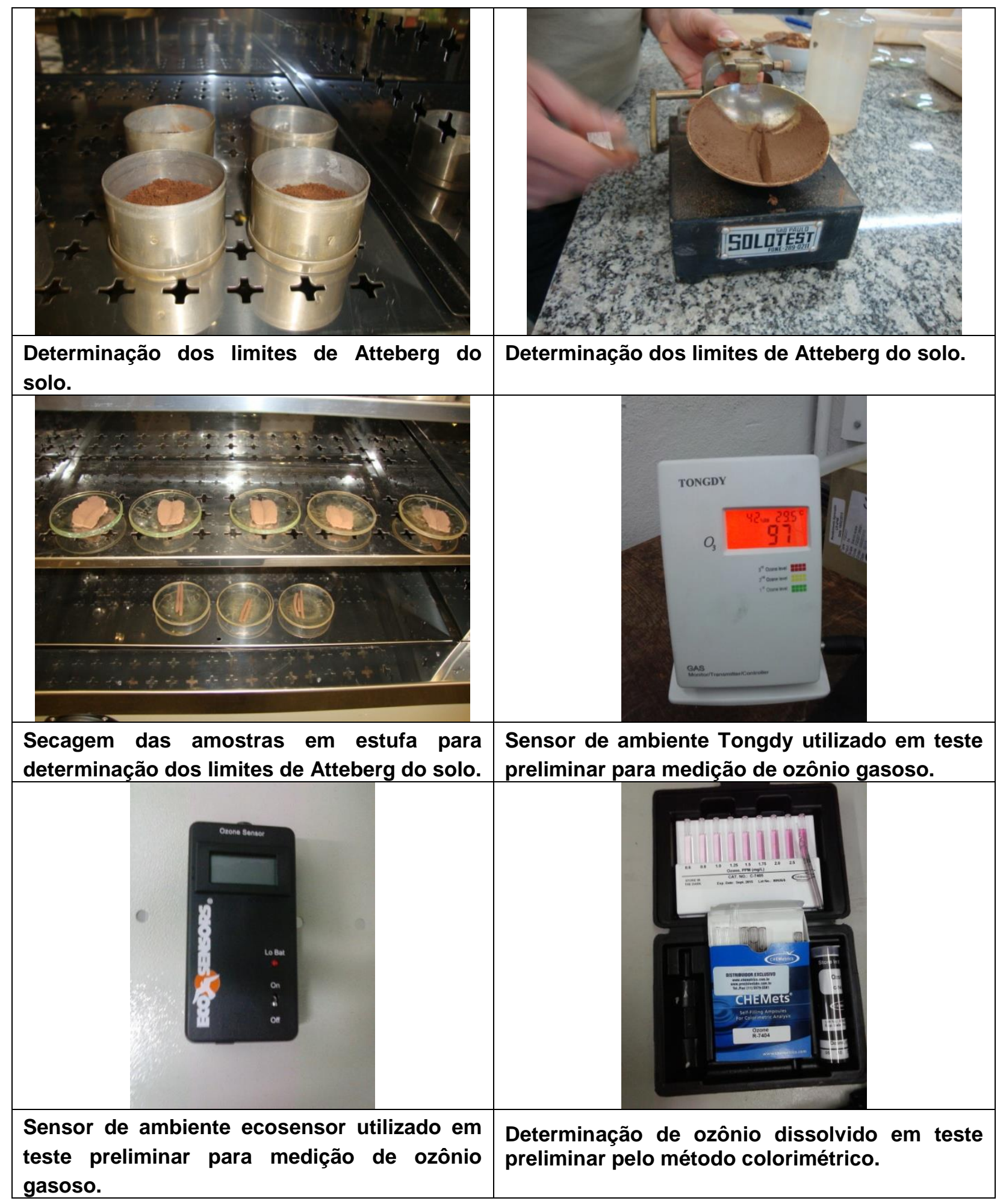




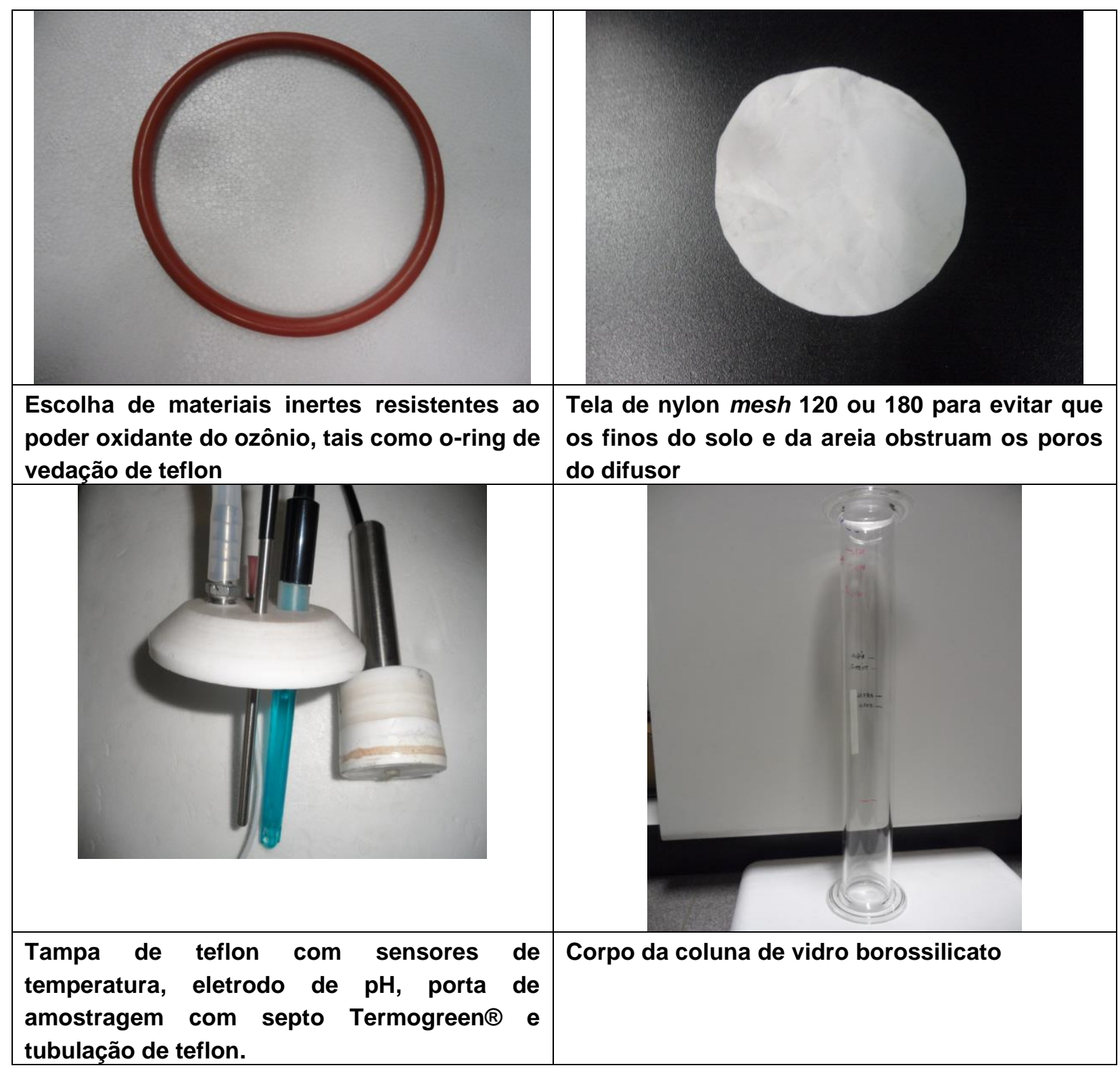




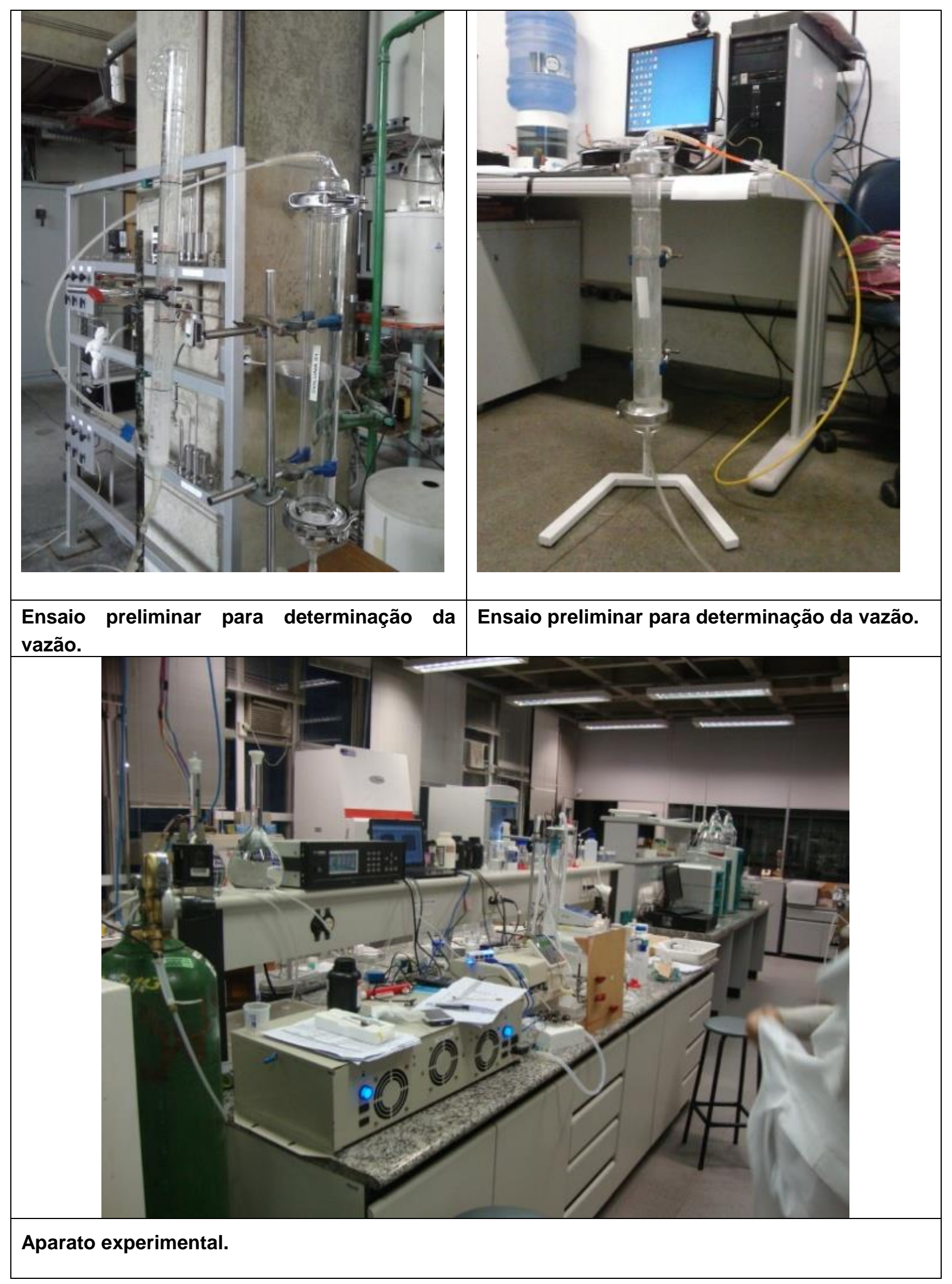




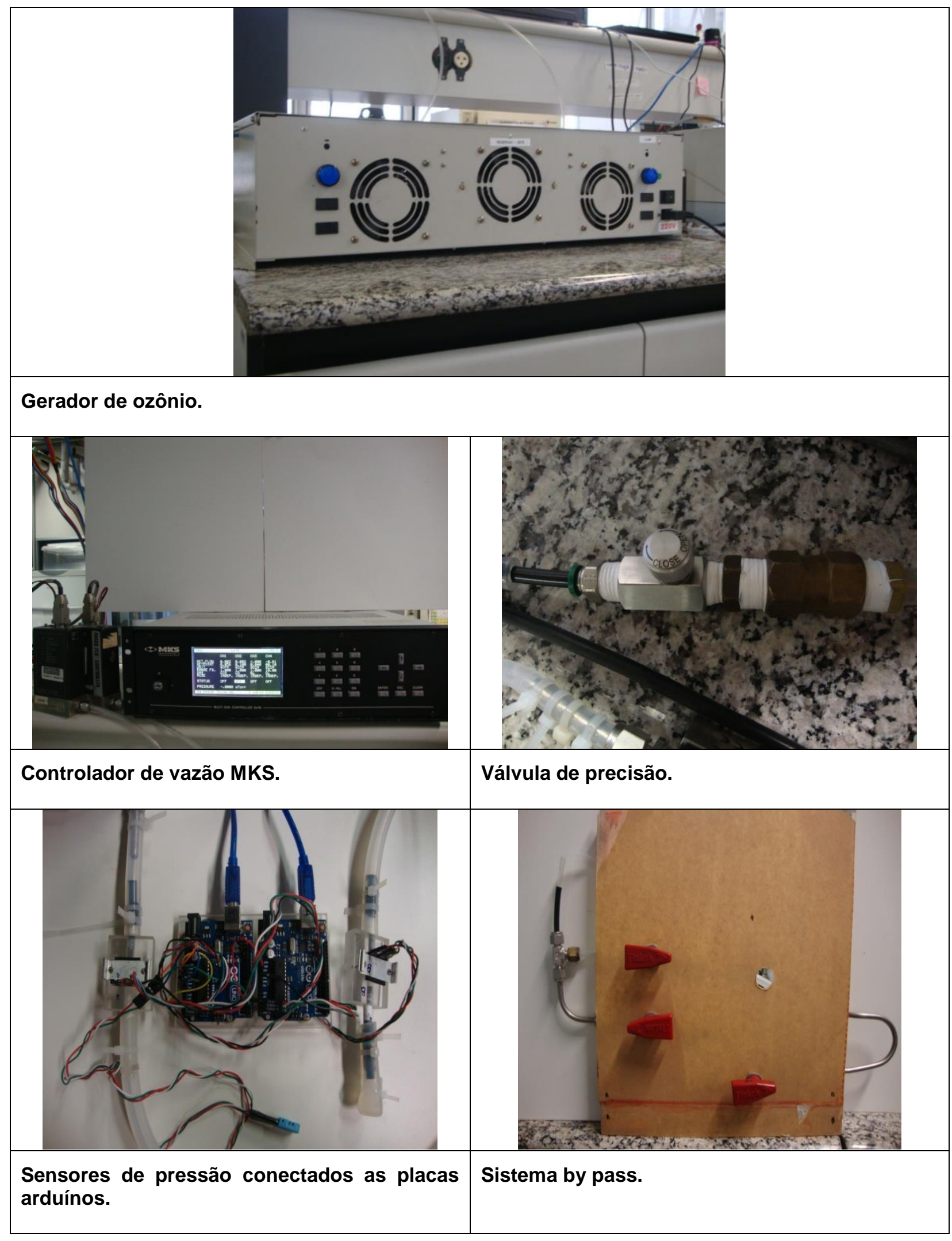




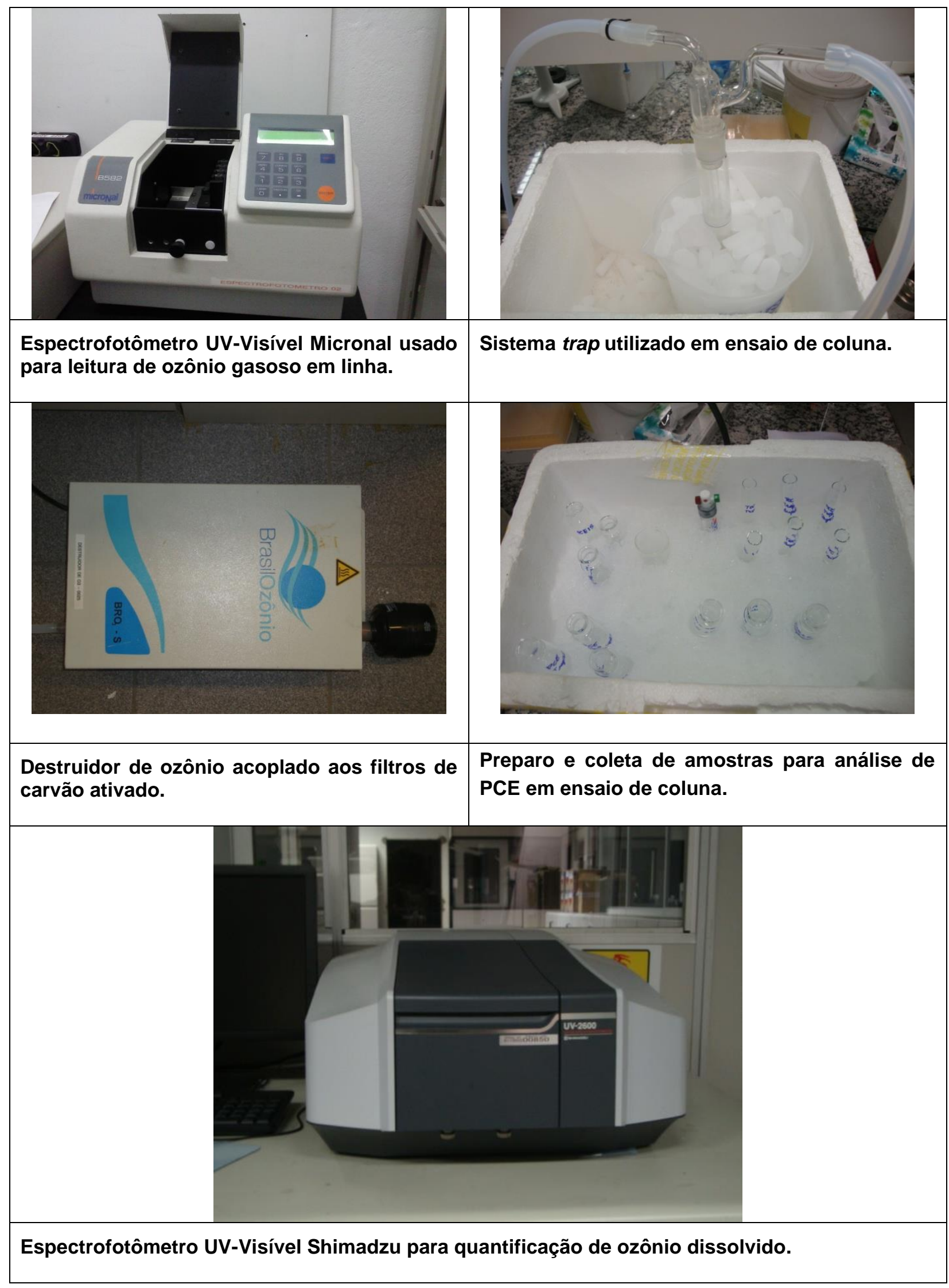




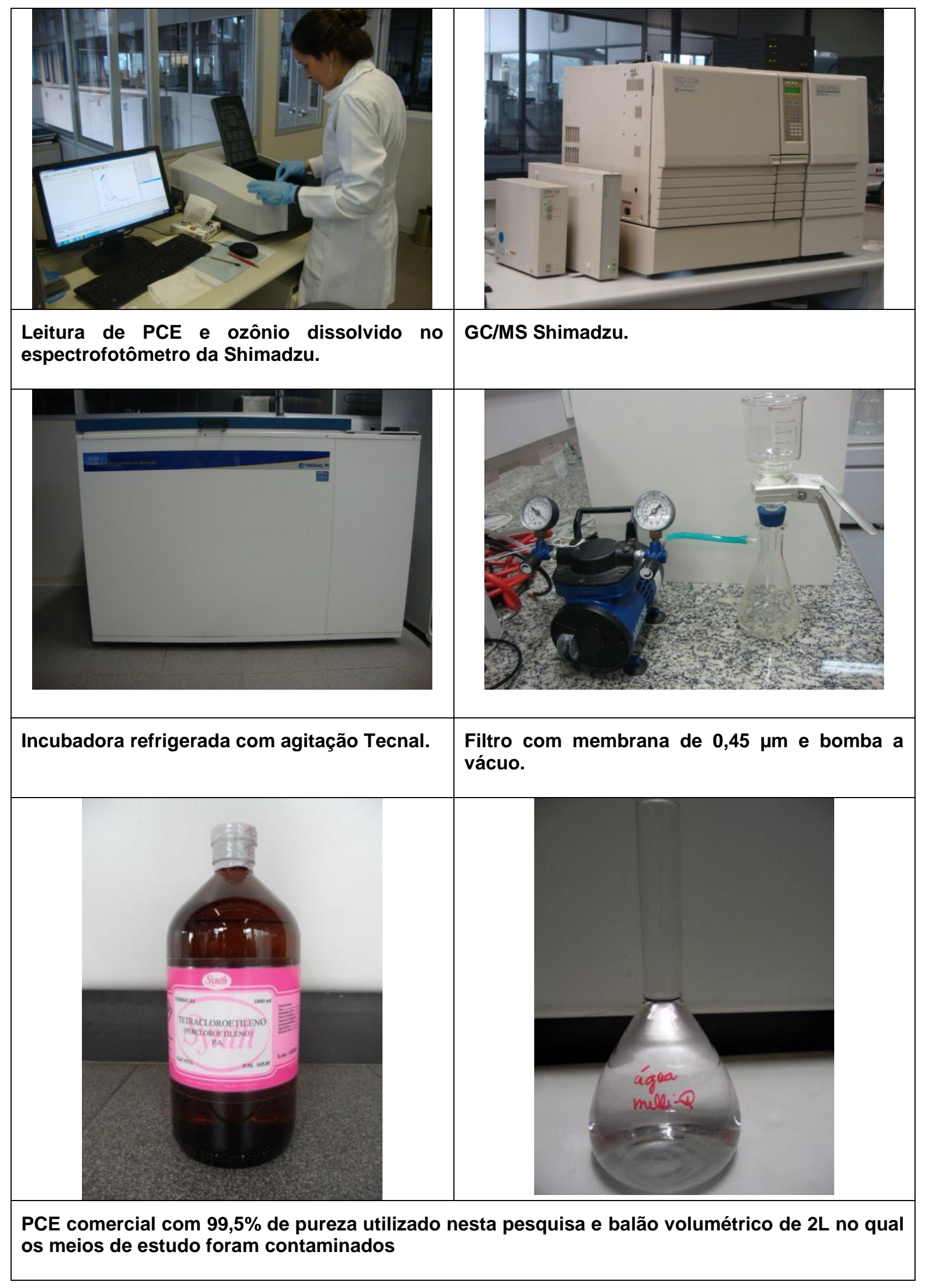




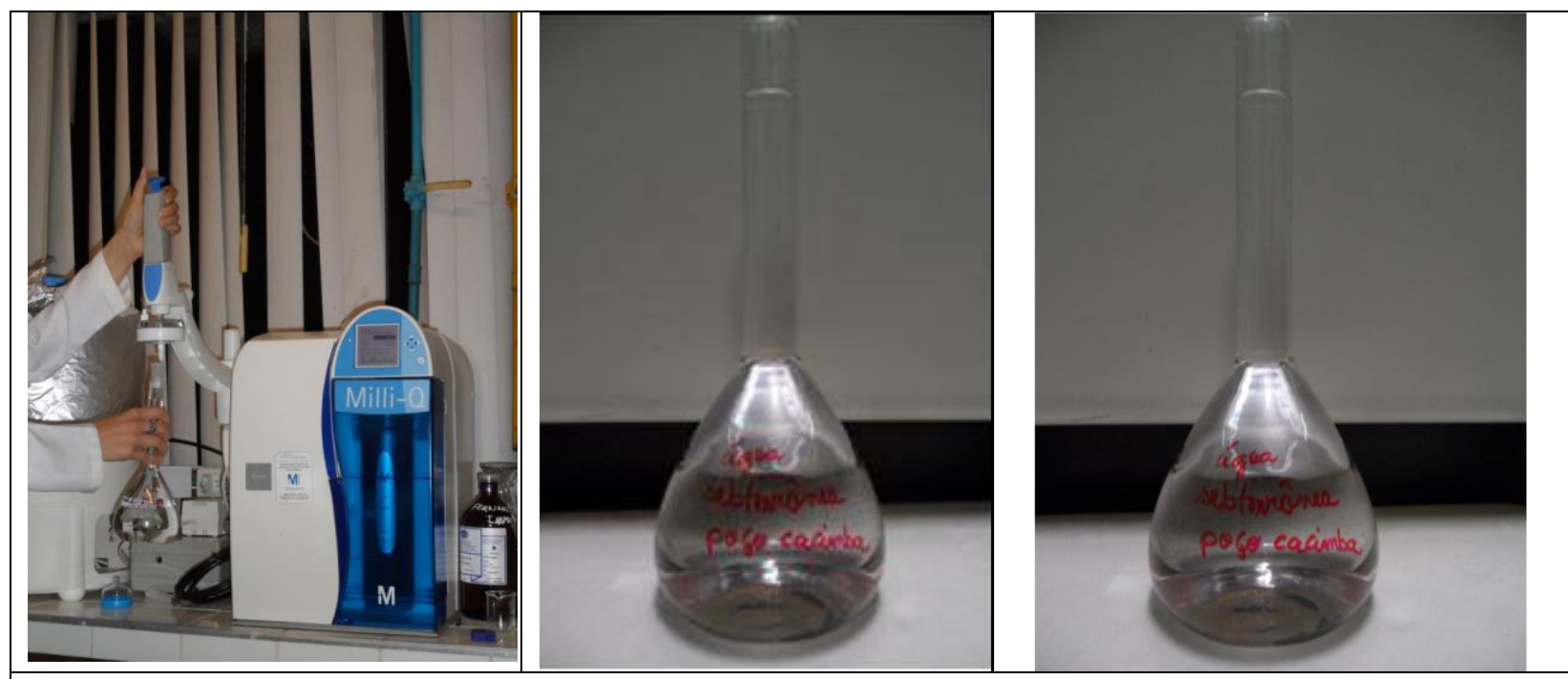

Matrizes do meio aquoso contaminadas artificialmente: água ultrapura, solução de $\mathrm{NaHCO}_{3} \mathrm{em}$ diversas concentrações, águas subterrâneas provenientes do poço cacimba e do poço tubular profundo.
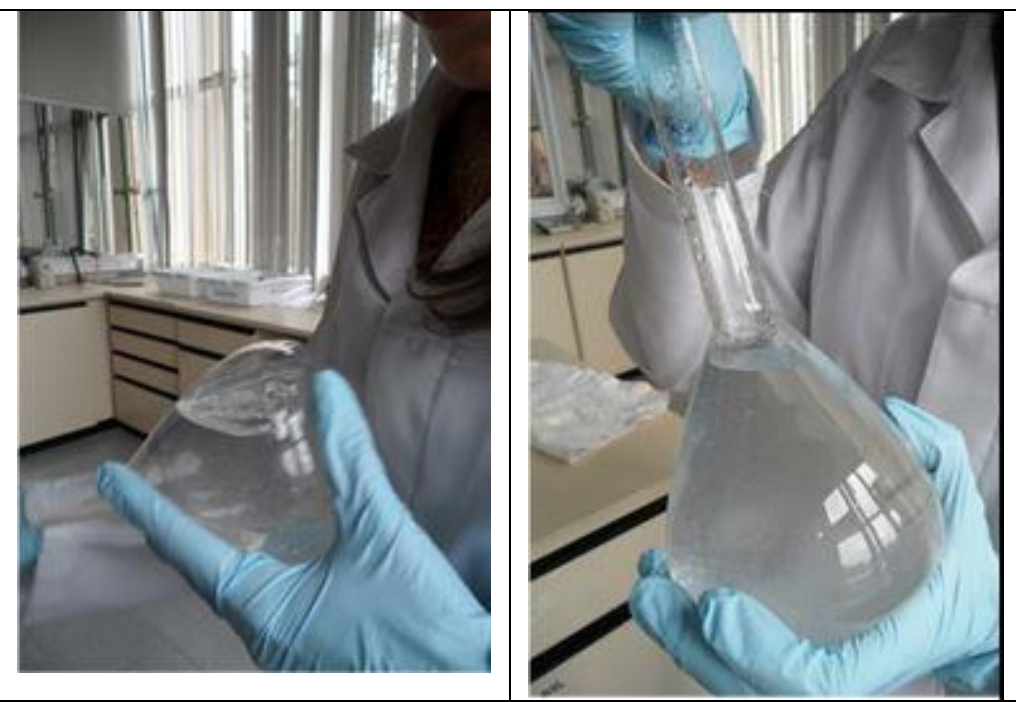

Método de contaminação do meio de estudo: Agitação intensa por 2 min para obter a saturação e equilíbrio do composto com a água. Ocorre a formação de gotículas de PCE em suspensão no meio de estudo. Após a separação total das fases, permanece na água apenas o PCE dissolvido em concentração da solubilidade máxima em água (150 mg/L)

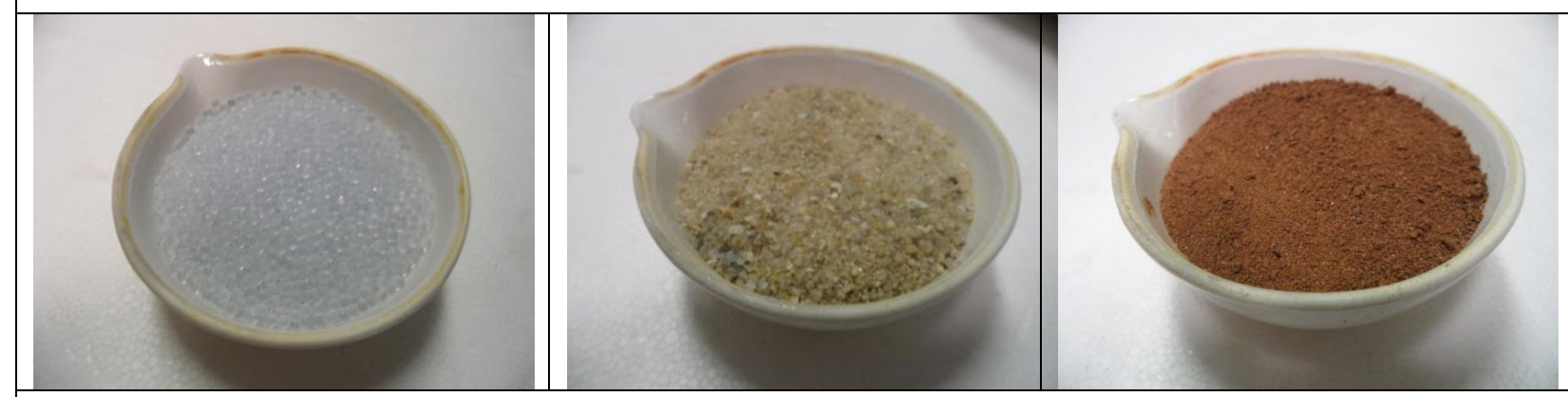

Matrizes do meio poroso contaminadas com PCE em laboratório: microesfera de vidro, areia e solo 


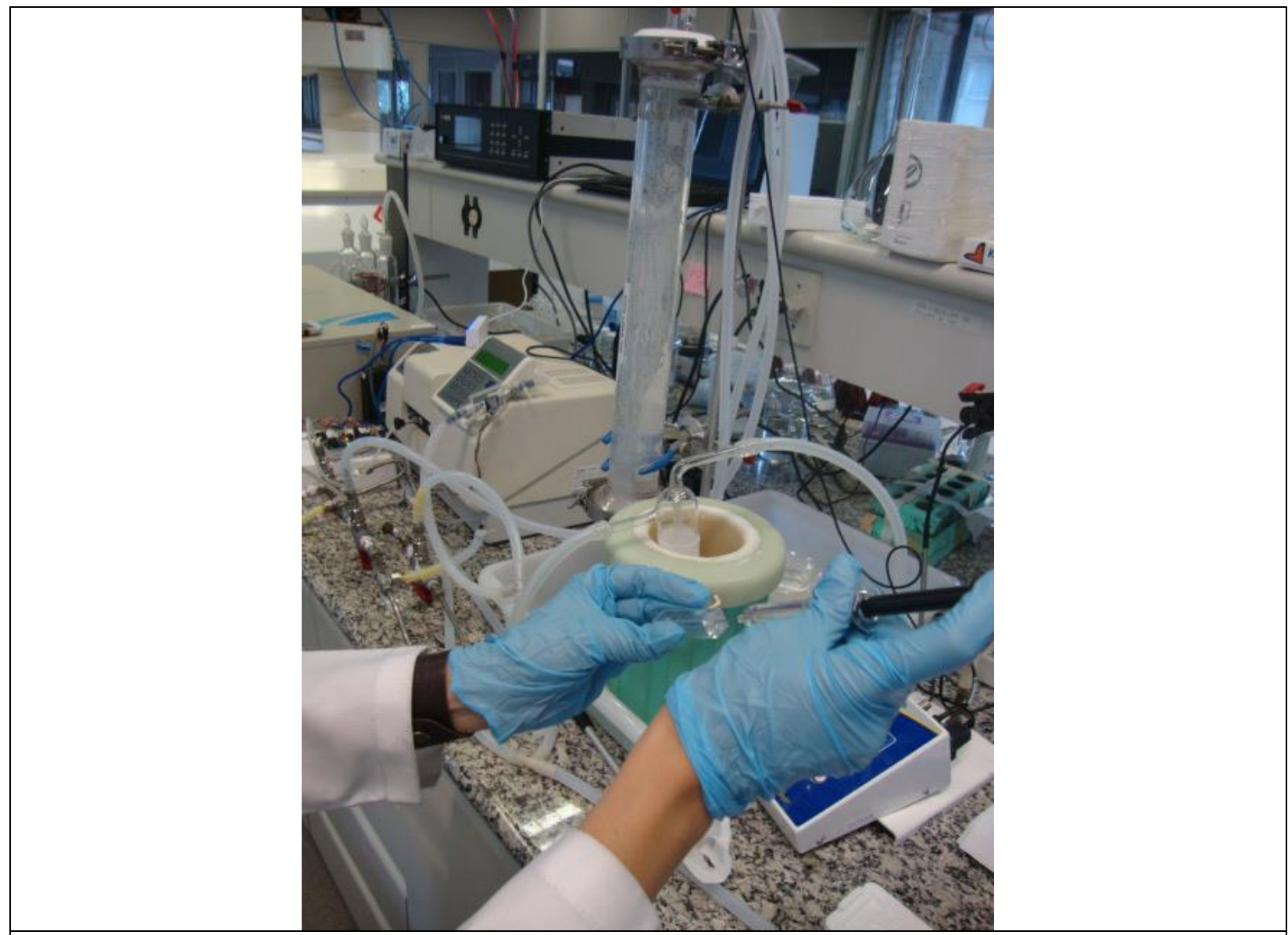

Ensaios de saturação e decaimento: coleta de amostra para leitura de PCE e ozônio dissolvido em cubeta de quartzo no espectrofotômetro da Shimadzu.
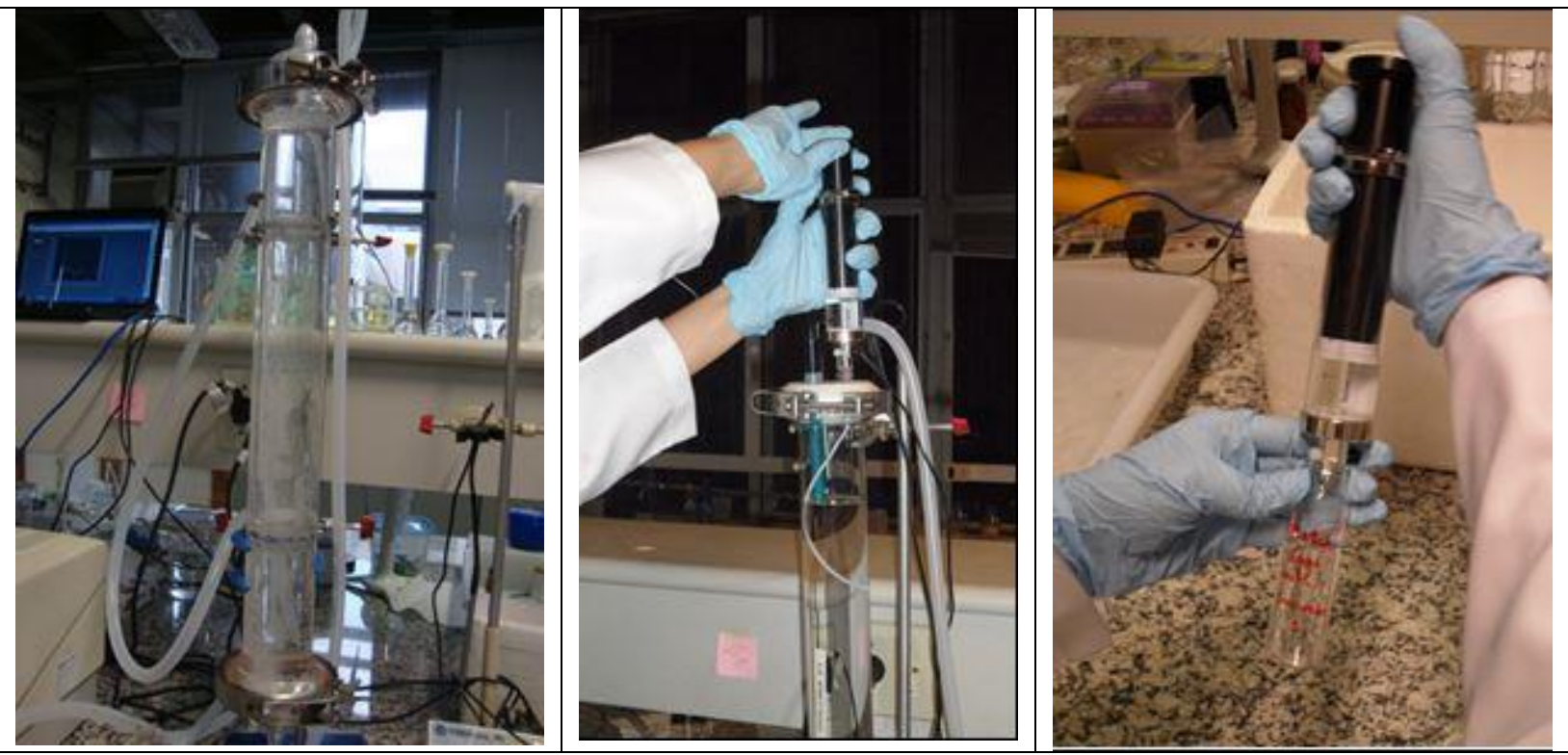

Ensaios batch em meio aquoso: coluna com meio de estudo sendo saturado de ozônio; coleta de amostras da coluna para os ensaios batch; e preparação do vial de $40 \mathrm{~mL}$ para batch. 


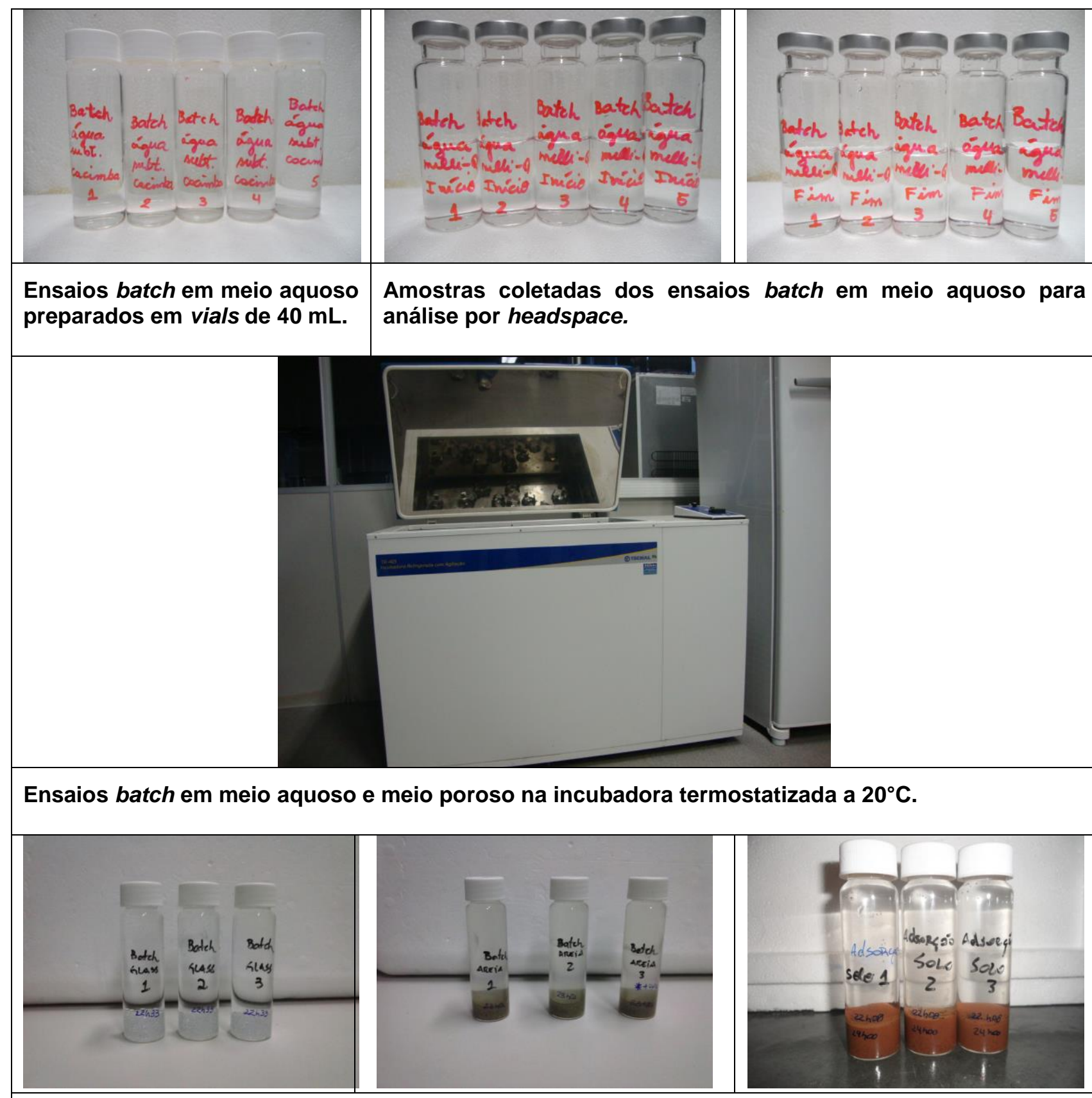

Ensaios batch em meio poroso em vials de $40 \mathrm{~mL}$ : microesferas de vidro, areia, controle de adsorção no solo.

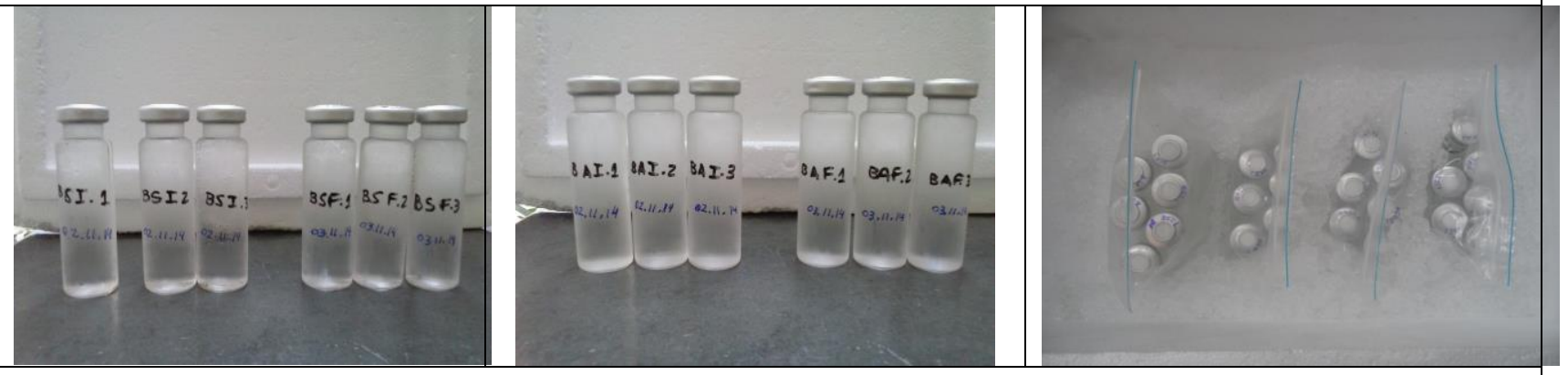

Coleta de amostras dos ensaios batch em meio poroso e acondicionamento e preservação de amostras refrigeradas a $4 . \pm 2^{\circ} \mathrm{C}$ 


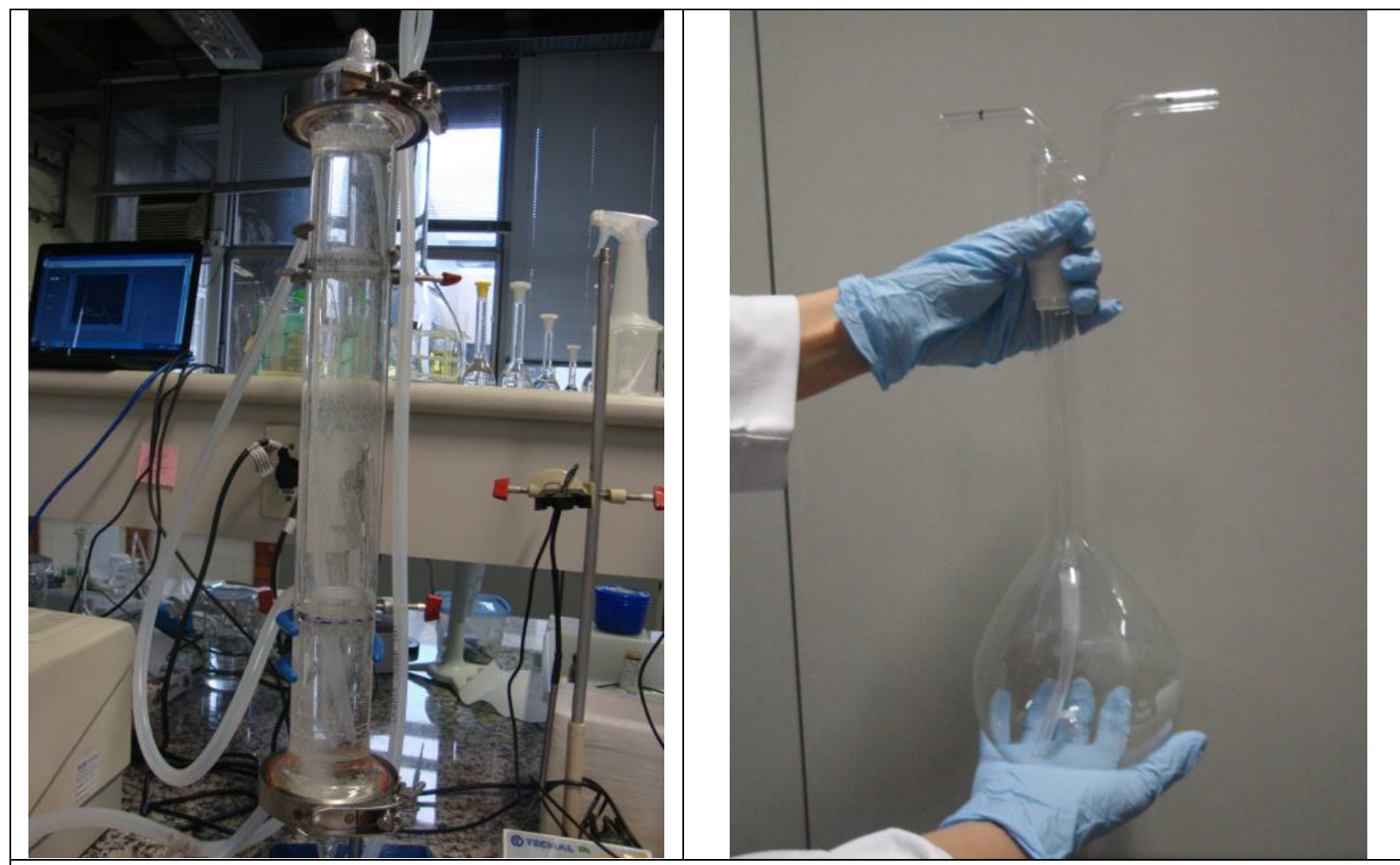

Ensaios coluna em meio aquoso: coluna com sistema de alimentação de ozônio ligado detalhe do frasco lavador de gás utilizado como trap em $\mathrm{MeOH}$.

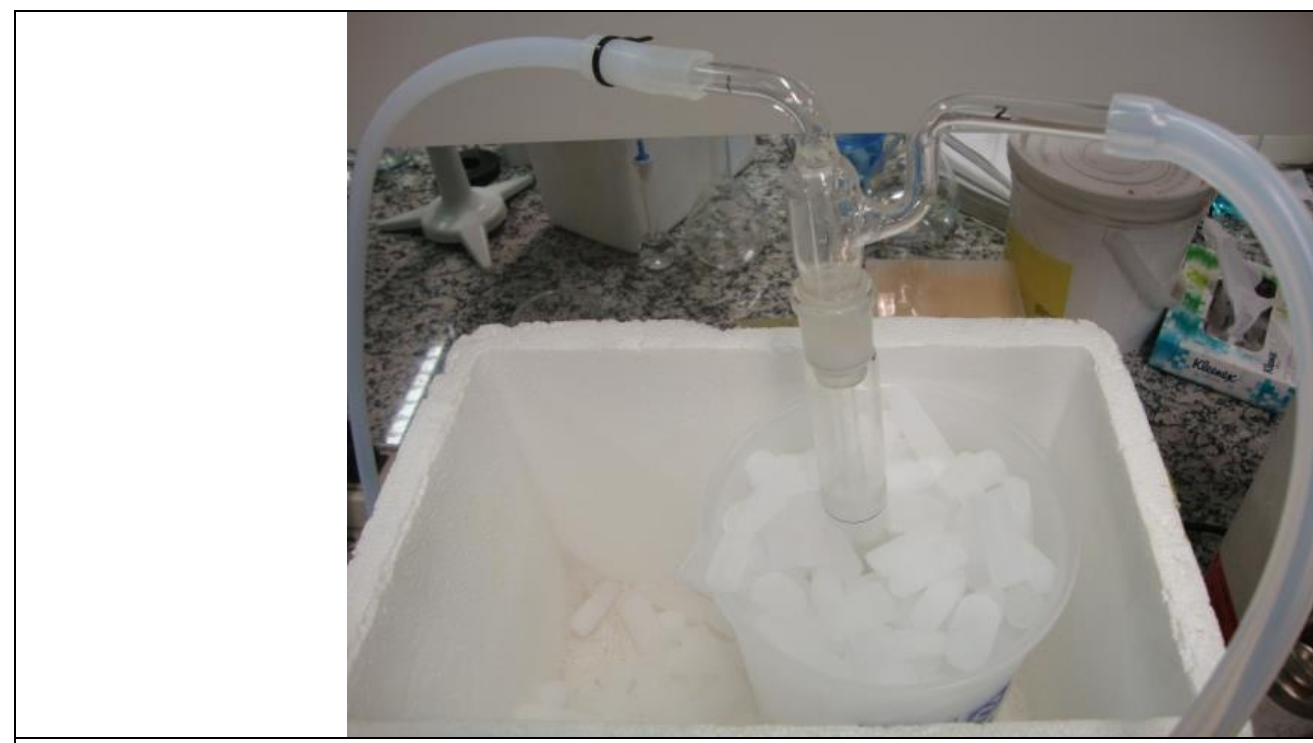

Ensaios coluna em meio aquoso, detalhe do sistema trap com gelo seco para condensar o PCE que volatilizar. 


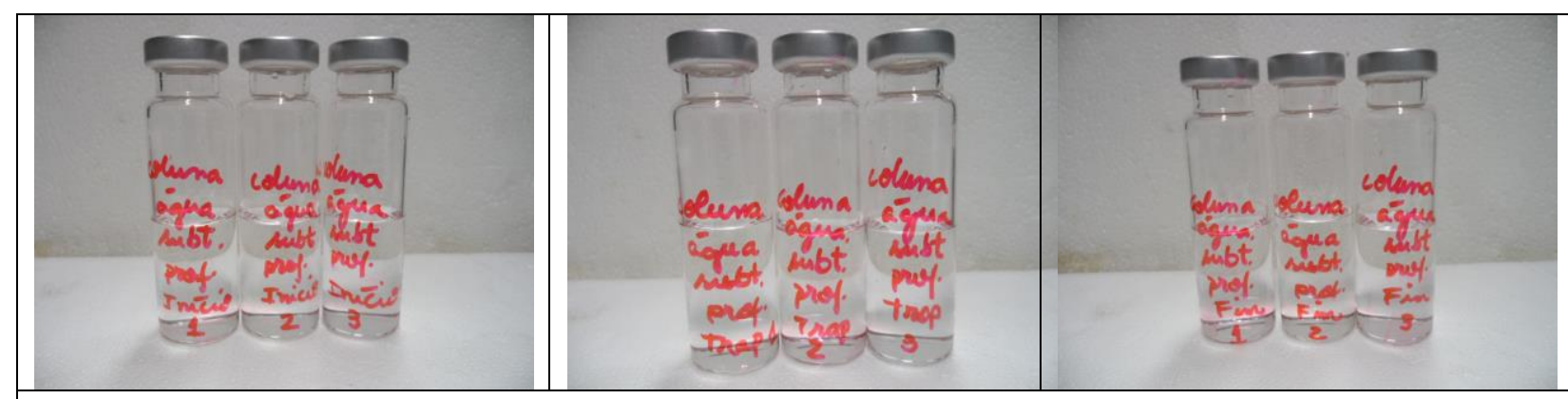

Coleta de amostras dos ensaios coluna em meio aquoso

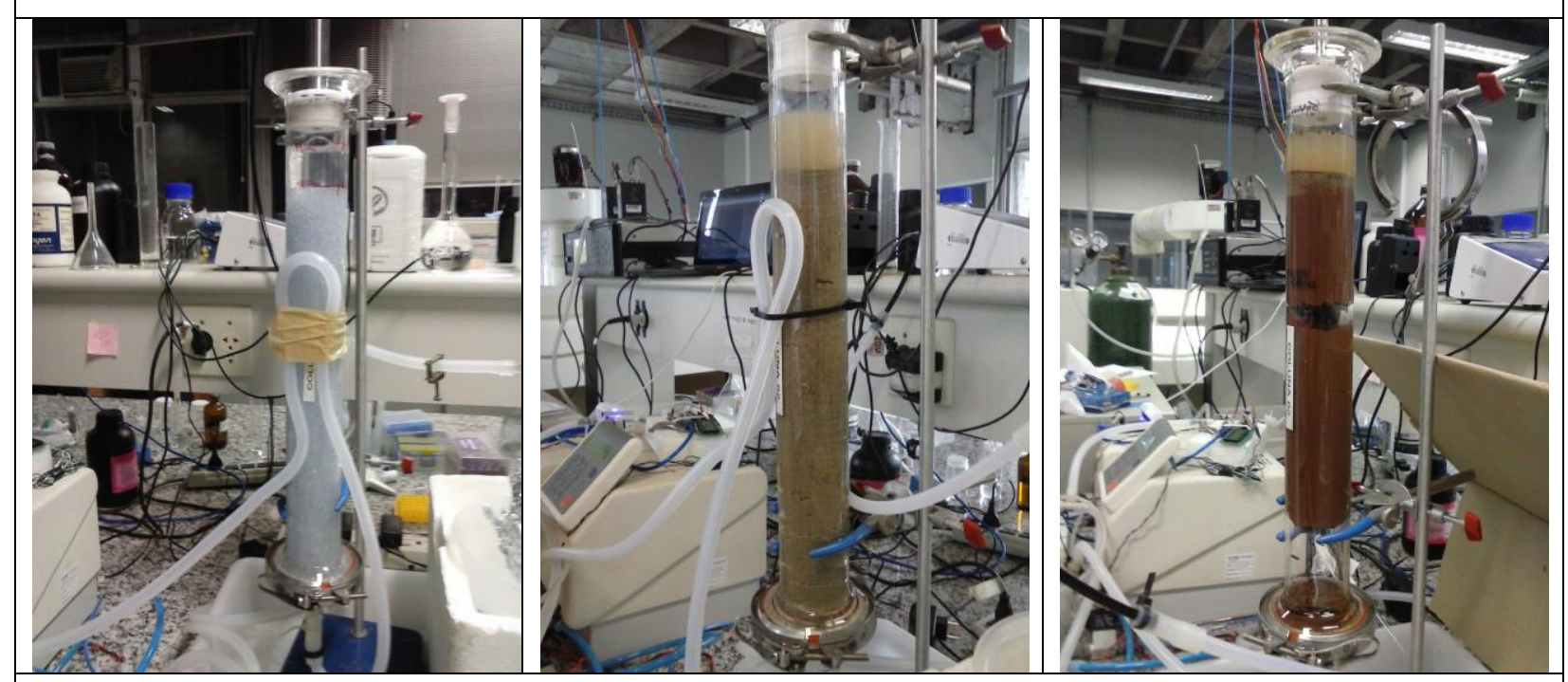

Ensaio de coluna em meio poroso: microesferas de vidro, areia e solo.

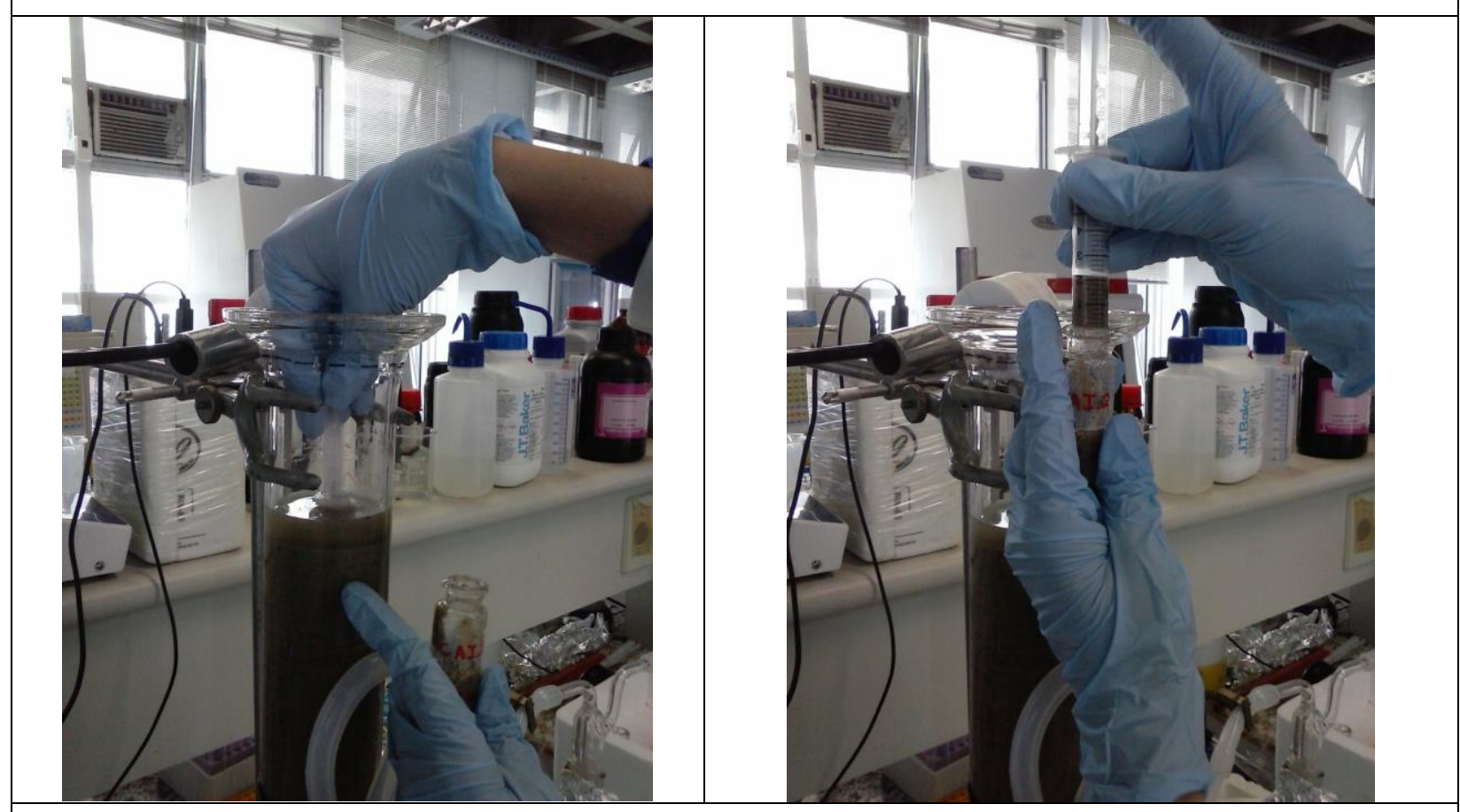

Coleta de amostras do ensaio de coluna em meio poroso com coletor EnCore adaptado. 


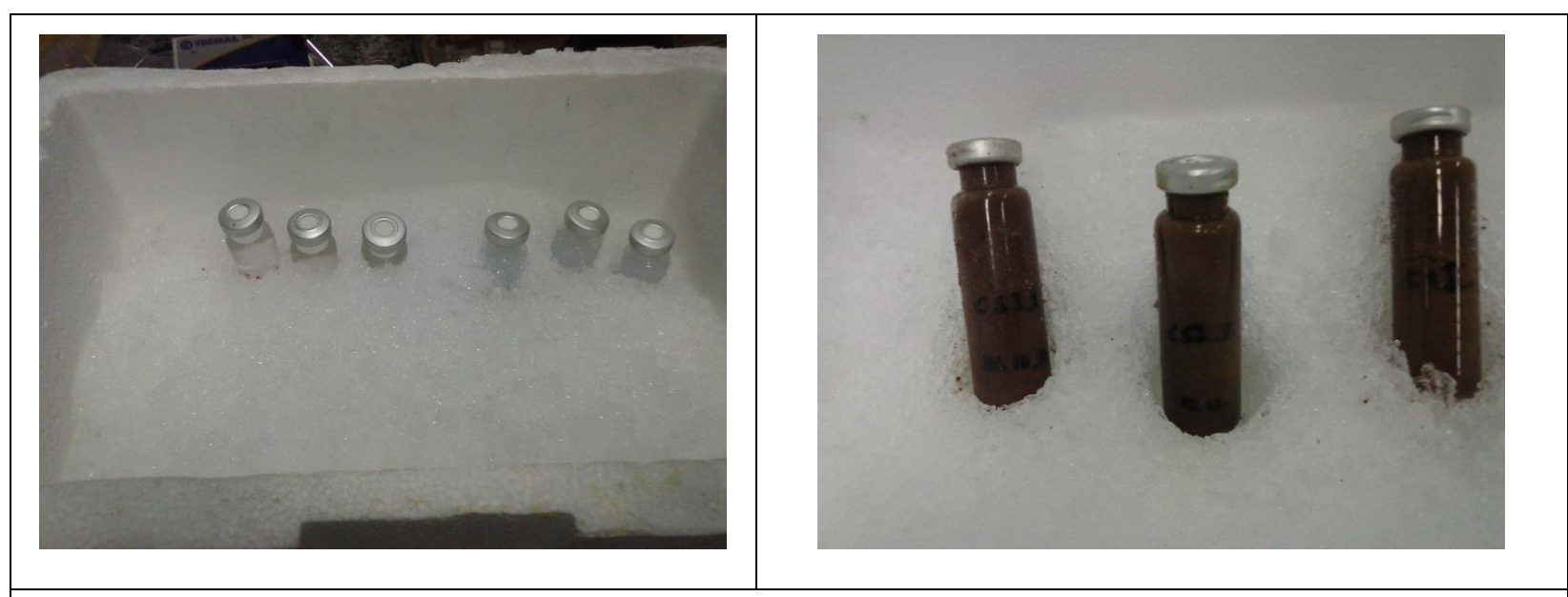

Coleta de amostras ensaios de coluna (meio poroso).

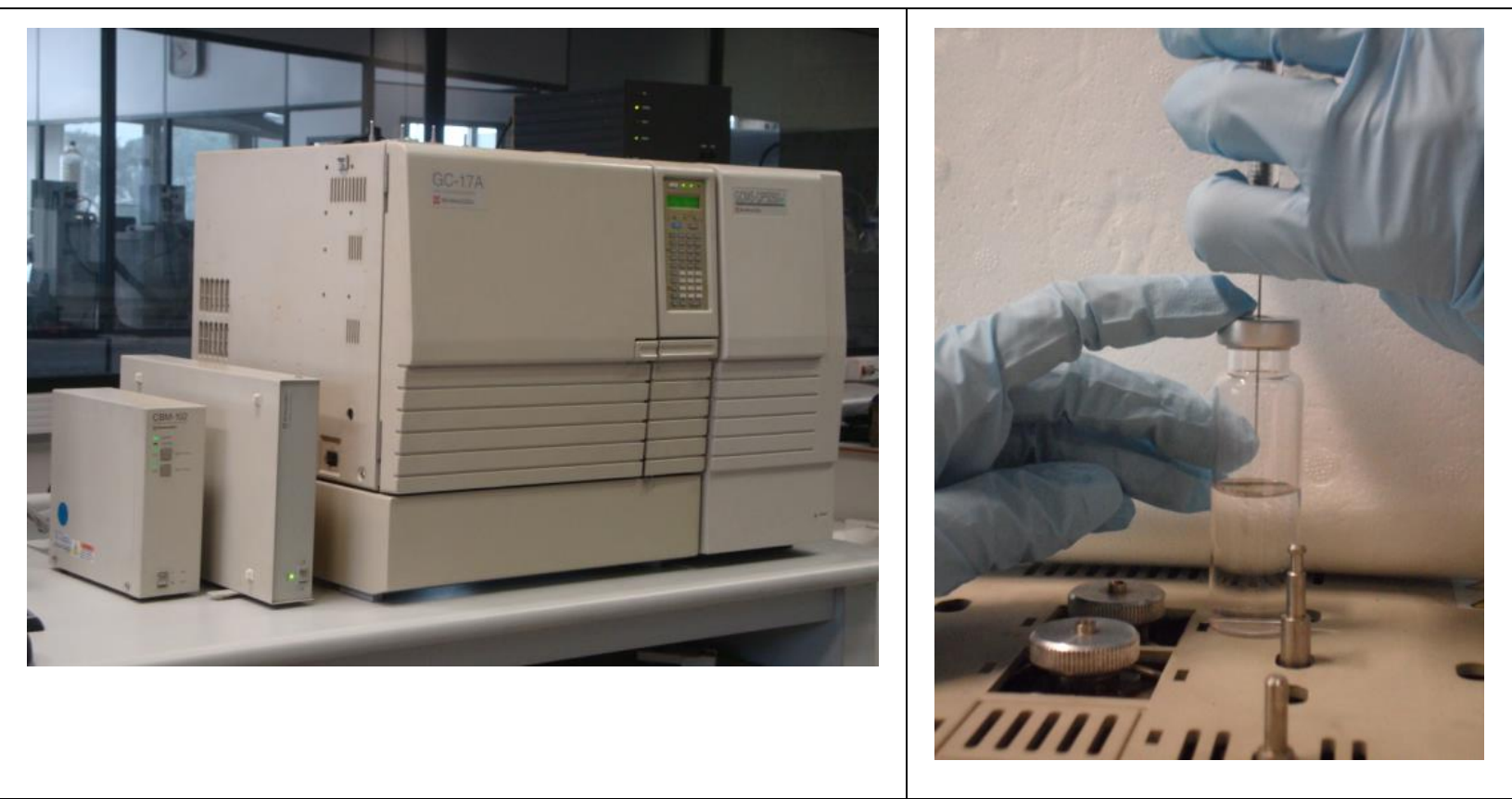

Análises Químicas: GC/MS método EPA SW 846 8260C; extração de VOC: EPA SW 8465021 A preparação de amostras por headspace. 
ANEXO C - VALORES DE SOLUBILIDADE EM ÁGUA PARA PCE 
Na Tabela C.1 podem ser observados os valores de solubilidade de PCE em água.

Tabela C.1 Solubilidade de PCE em água.

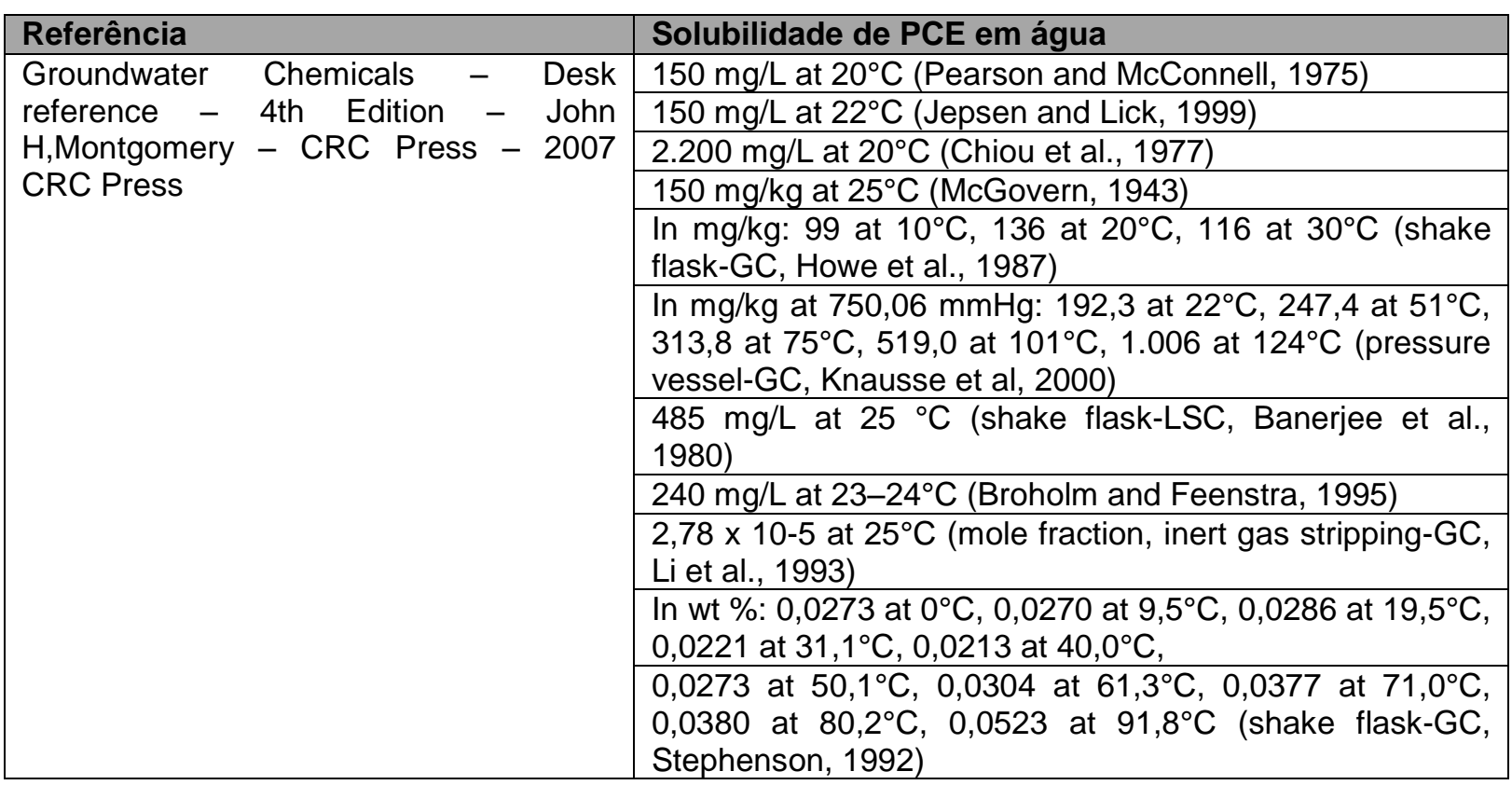


ANEXO D - CERTIFICADO DE CALIBRAÇÃO, CADEIAS DE CUSTÓdIA E LAUDOS 


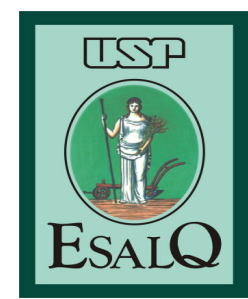

Universidade de São Paulo

\section{Escola Superior de Agricultura "Luiz de Queiroz" \\ Departamento de Ciência do Solo}

\section{Resultado de Análise Granulométrica}

Interessado: 1920 Fund. Patria - Fund. Parque Alta Tec. Reg. Iperó e Adj.

Tipo de Análise: SF3

Endereço: $\quad$ R Jose Antonio Scaciota 165

Portal do Cedro Ipero SP CEP 18560000

Requisição:

$4813 / 2$

Data de Emissão: $23 / 01 / 2014$

Material analisado: Terra

Concluídas em: 15/01/2014

\begin{tabular}{|c|c|c|c|c|c|c|c|c|c|c|c|}
\hline \multirow{2}{*}{$\begin{array}{l}\text { Identif. da } \\
\text { Amostra }\end{array}$} & \multicolumn{6}{|c|}{ Areias $(\mathbf{g} / \mathbf{k g})$} & \multirow{2}{*}{$\begin{array}{l}\text { Silte } \\
(\mathbf{g} / \mathbf{k g})\end{array}$} & \multicolumn{2}{|c|}{ Argilas $(\mathrm{g} / \mathrm{kg})$} & \multirow{2}{*}{$\begin{array}{l}\text { Flocula- } \\
\text { ção (\%) }\end{array}$} & \multirow{2}{*}{$\begin{array}{c}\text { Classe de } \\
\text { Textura }\end{array}$} \\
\hline & AMG & $A G$ & AM & AF & AMF & AT & & c/disp. & água & & \\
\hline AD - 01/0,4m & 2 & 32 & 295 & 378 & 50 & 757 & 18 & 226 & 75 & 67 & md-ar. \\
\hline$A D-02 / 0,6 m$ & 3 & 29 & 273 & 399 & 54 & 758 & 17 & 225 & 75 & 67 & md-ar. \\
\hline
\end{tabular}

Métodos: Bouyoucos (densímetro); S.S.S.A. Book Series: 5 Methods of Siol Analysis Part4;

Classe de diametro $(\mathrm{mm})$ U.S.D.A.

5 frações de areia: muito grossa $(M G)=2$ a 1 ; grossa $(G)=1$ a 0,5 ; média $(M)=0,5$ a 0,25 ; fina $(F)=0,25$ a 0,10 ; muito fina $(M F)=0,10$ a 0,05 ; areia total $(A T)=2$ a 0,05 ; silte $=0,05$ a 0,002 ; argila total $<0,002$; argila água $<0,002$.

2 frações de areia: grossa $(G)=2$ a 0,25 e fina $(F)=0,25$ a 0,05 ; areia total $(A T)=2$ a 0,05 ; silte $=0,05$ a 0,002 ; argila total $<0,002$

Classe de textura: Argila (c/ dispersante) até $149 \mathrm{~g} / \mathrm{kg}=$ arenosa (ar); de 150 a $249 \mathrm{~g} / \mathrm{kg}$

= média arenosa (md-ar); de 250 a $349 \mathrm{~g} / \mathrm{kg}$ = média argilosa (md-arg);

de 350 a $599 \mathrm{~g} / \mathrm{kg}$ = argilosa (arg); de $600 \mathrm{~g} / \mathrm{kg}$ ou superior - muito argilosa (m-arg).

Observações:

Amostra coletada pelo interessado; ( \# ) elemento não determinado.

Este documento pode ser reproduzido somente por completo.

Os resultados deste relatório se referem somente às amostras enviadas ao laboratório.

Signatário Autorizado 


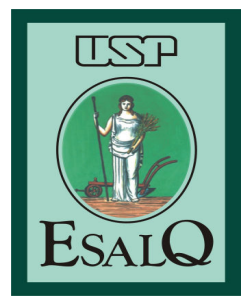

Universidade de São Paulo

Escola Superior de Agricultura "Luiz de Queiroz"

Departamento de Ciência do Solo

RESULTADO DE ANÁLISE

Interessado: 1920 Fund. Patria - Fund. Parque Alta Tec. Reg. Iperó e Adj.

Tipo de Análise:

FQ1

Endereço :

R Jose Antonio Scaciota 165

Portal do Cedro Ipero / SP CEP 18560000

Requisição:

4813/5

Data de Emissão:

$23 / 01 / 2014$

Material analisado: Terra

Análises concluídas em: 10/01/2014

\begin{tabular}{|c|c|c|c|c|c|c|c|}
\hline Amostra & $\mathrm{pH} \mathrm{H} 2 \mathrm{O}$ & $\mathrm{pH} \mathrm{KCl}$ & $\mathrm{pH} \mathrm{CaCl} 2$ & $\begin{array}{c}\text { M. O.(1) } \\
\text { g/dm3 }\end{array}$ & $\begin{array}{c}\text { C. O.(1) } \\
\text { g/dm3 }\end{array}$ & $\begin{array}{c}\text { M. O.(2) } \\
\mathrm{g} / \mathrm{kg}\end{array}$ & $\begin{array}{c}\text { C. O.(2) } \\
\mathrm{g} / \mathrm{kg}\end{array}$ \\
\hline$A D-01 / 0,4 m$ & $\#$ & \# & \# & \# & \# & 7 & 4 \\
\hline$A D-02 / 0,6 m$ & \# & \# & $\#$ & \# & $\#$ & $<4$ & 2 \\
\hline
\end{tabular}

Métodos:

pH em água, $\mathrm{pH}$ em KCl (Manual de métodos de análise de solo. EMBRAPA. $2^{\mathrm{a}}$ edição, 1997).

$\mathrm{pH}$ em $\mathrm{CaCl} 2$, matéria orgânica (MO) por colorimetria (Manual de análise química para avaliação

da fertilidade de solos tropicais. IAC, 2001). Matéria orgânica (MO) por titulação (Métodos de

Análise Química, Mineralógica e Física de Solos do Instituto Agronômico de Campinas.

Boletim técnico 106, IAC, 2009). Cond. elétrica - condutivimetro, nitrogênio total - digestão

sulfúrica/Kjeldahl, N-NO3 e N-NH4 - MgO e Liga de devarda/Kjeldahl.

Observações:

Amostra coletada pelo interessado; ( \# ) elemento não determinado;

Este documento pode ser reproduzido somente por completo.

Os resultados deste relatório se referem somente às amostras enviadas ao laboratório.

(<) menor que o Limite de Quantificação (LQ). 


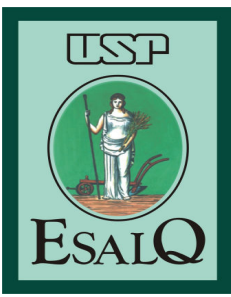

Universidade de São Paulo

\section{Escola Superior de Agricultura "Luiz de Queiroz"}

Departamento de Ciência do Solo

\section{RESULTADO DE ANÁLISE}

Interessado:

1920 Fund. Patria - Fund. Parque Alta Tec. Reg. Iperó e Adj.

Tipo de Análise:

FQ2

Endereço:

\begin{tabular}{lcccc}
\hline Amostra & $\begin{array}{c}\mathrm{N}(\text { total }) \\
\mathrm{mg} / \mathrm{kg}\end{array}$ & $\begin{array}{c}\mathrm{N}(\mathrm{NH} 4+) \\
\mathrm{mg} / \mathrm{kg}\end{array}$ & $\begin{array}{c}\mathrm{N}(\mathrm{NO}-3) \\
\mathrm{mg} / \mathrm{kg}\end{array}$ & $\begin{array}{c}\text { C.E. } \\
\mu \mathrm{S} / \mathrm{cm}\end{array}$ \\
\hline AD - 01/0,4m & $\#$ & $\#$ & $\#$ & 43,52 \\
AD - 02/0,6m & $\#$ & $\#$ & $\#$ & 23,14
\end{tabular}

Métodos :

Cond. Elétrica - condutivímetro $(1: 2,5)$;

$\mathrm{N}$ total - dig. sulfúrica/kjeldahl; N-NO3; N-NH4 - MgO e liga de Raney/Kjeldahl.

Observações:

Amostra coletada pelo interessado; ( \# ) elemento não determinado;

Este documento pode ser reproduzido somente por completo.

Os resultados deste relatório se referem somente às amostras enviadas ao laboratório. 


\section{Universidade de São Paulo \\ Escola Superior de Agricultura "Luiz de Queiroz" \\ Departamento de Ciência do Solo}

\section{Resultado de Análise}

Interessado:

1920 Fund. Patria - Fund. Parque Alta Tec. Reg. Iperó e Adj.

Endereço:
$\mathrm{R}$ Jose Antonio Scaciota $\mathrm{N}^{\circ}: 165$

Portal do Cedro Ipero / SP CEP 18560000

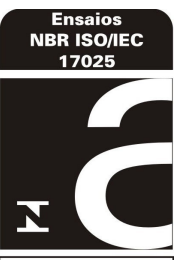

CRL 0543

Tipo de Análise:

SQ7.1

Requisição:

4813/1

Data de Emissão:

$23 / 01 / 2014$

Material analisado:

Terra

Análises concluídas em: 10/01/2014

\begin{tabular}{lcccccccccccc}
\hline Amostra & $\mathrm{pH} \mathrm{H} 2 \mathrm{O}$ & $\mathrm{pH} \mathrm{KCl}$ & $\mathrm{P}$ & $\mathrm{K}$ & $\mathrm{Ca}$ & $\mathrm{Mg}$ & $\mathrm{Al}$ & $\mathrm{H}+\mathrm{Al}$ & $\mathrm{SB}$ & $\mathrm{CTC}$ & $\mathrm{V}$ & $\mathrm{m}$ \\
\hline $\mathrm{AD}-01 / 0,4 \mathrm{~m}$ & 4,4 & 3,9 & 1 & $<0,3$ & $<2$ & $<1$ & 6 & 59 & 1,3 & 60,6 & 2 & 81 \\
$\mathrm{AD}-02 / 0,6 \mathrm{~m}$ & 4,6 & 3,9 & $<1$ & $<0,3$ & $<2$ & $<1$ & 7 & 35 & 1,3 & 36,7 & 4 & 83
\end{tabular}

\footnotetext{
Unidades:

$\mathrm{P}(\mathrm{mg} . \mathrm{Kg}-1)$; K, Ca, Mg, Al, H+Al, SB, CTC (mmolc Kg-1); V e m (\%).

$\mathrm{SB}$ : Soma de bases trocáveis; CTC: Capacidade de troca de cátions;
}

V: Saturação da CTC por bases; m: Saturação por Alumínio.

Métodos:

pH em água, $\mathrm{pH}$ em $\mathrm{KCl}$, cálcio $(\mathrm{Ca})$ e magnésio $(\mathrm{Mg})$ em espectrofotômetro de absorção

atômica extraído com acetato de amônio, potássio $(K)$ em espectrofotômetro de emissão

atômica extraído com acetato de amônio, acidez potencial $(\mathrm{H}+\mathrm{Al})$ por titulometria extraída

com acetato de cálcio, alumínio (Al) por titulometria extraído com cloreto de potássio,

fósforo $(\mathrm{P})$ por colorimetria extraído com mehlich 1.

(Manual de métodos de análise de solo. EMBRAPA. $2^{\mathrm{a}}$ edição, 1997).

Observações:

Amostra coletada pelo interessado; ( \# ) elemento não determinado;

Este documento pode ser reproduzido somente por completo.

Os resultados deste relatório se referem somente às amostras enviadas ao laboratório.

(<) menor que o Limite de Quantificação (LQ). 


\section{RESULTADO DE QUANTIFICAÇÃO DE FASES POR DIFRATOMETRIA DE RAIOS X}

CERTIFICADO: DRX 001-14

DATA: 08/01/14

CLIENTE: FUND. PARQUE DE ALTA TEC. DA REGIÃO DE IPERÓ E ADJACÊNCIAS

AMOSTRA: AD $01(0,6 \mathrm{~m})$

IDENT. LCT: 485-2228.HPF

\section{MÉTODO}

O estudo foi efetuado através do método do pó, mediante o emprego de difratômetro de raios X, marca PANalytical, modelo X'Pert PRO com detector X'Celerator.

A identificação das fases cristalinas, abaixo discriminadas, foi obtida por comparação do difratograma da amostra com os bancos de dados PDF2 do ICDD - International Centre for Diffraction Data (2003) e PAN-ICSD - PANalytical Inorganic Crystal Structure Database (2007).

A estimativa da proporção de fases presentes, indicada na tabela de resultados, foi feita a partir da conjugação do resultado de difração de raios $X$ e de análises químicas.

\section{RESULTADOS}

Os resultados obtidos estão listados na tabela abaixo:

\begin{tabular}{cllc}
\hline ICDD & Nome do composto & Fórmula Química & $\begin{array}{c}\% \\
\text { estimada }\end{array}$ \\
\hline $01-085-0795$ & Quartzo & $\mathrm{SiO}_{2}$ & 77 \\
$01-083-0971$ & Caulinita & $\mathrm{Al}_{2}\left(\mathrm{Si}_{2} \mathrm{O}_{5}\right)(\mathrm{OH})_{4}$ & 16 \\
$01-074-1775$ & Gibbsita & $\mathrm{Al}_{4}(\mathrm{OH})_{3}$ & 3 \\
$01-073-2234$ & Hematita & $\mathrm{Fe}_{2} \mathrm{O}_{3}$ & 2 \\
$01-083-2243$ & Anatásio & $\mathrm{TiO}_{2}$ & 1 \\
$01-089-4920$ & Rutilo & $\mathrm{TiO}_{2}$ & 1 \\
\hline
\end{tabular}

O difratograma obtido (cor vermelha), onde são assinaladas as linhas de difração correspondente(s) à(s) fase(s) identificada(s) (cada fase em uma cor distinta) é apresentado anexo.

Prof. Dr. Henrique Kahn Coordenador do LCT Poli/USP
Dra. Maria Manuela Lé Tassinari Pesquisadora do LCT Poli/USP
M.Sc. Juliana Lívi Antoniassi Pesquisadora do LCT Poli/USP 


\section{DIFRATOGRAMA DE RAIOS X}

Counts

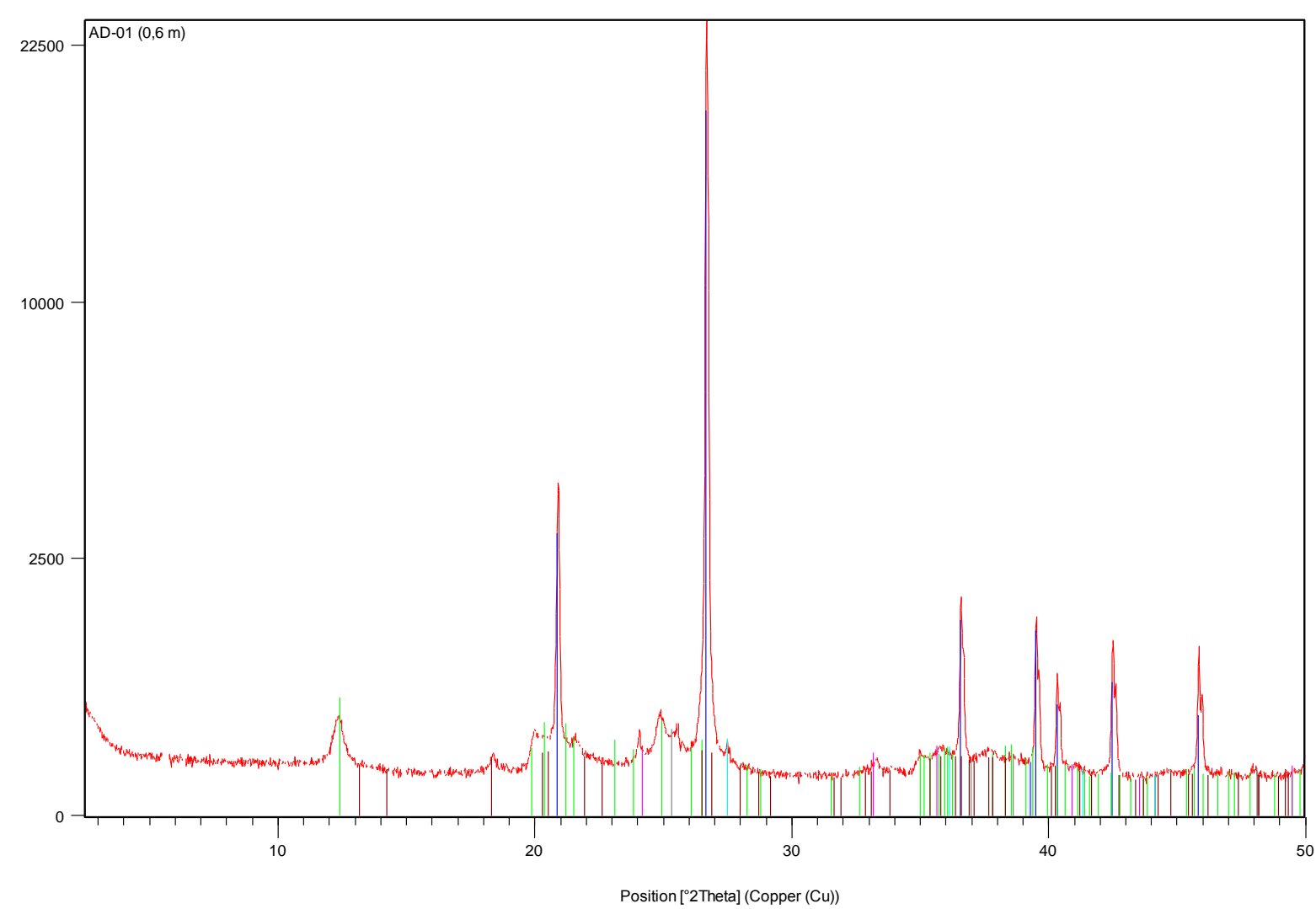

\section{FASES IDENTIFICADAS}

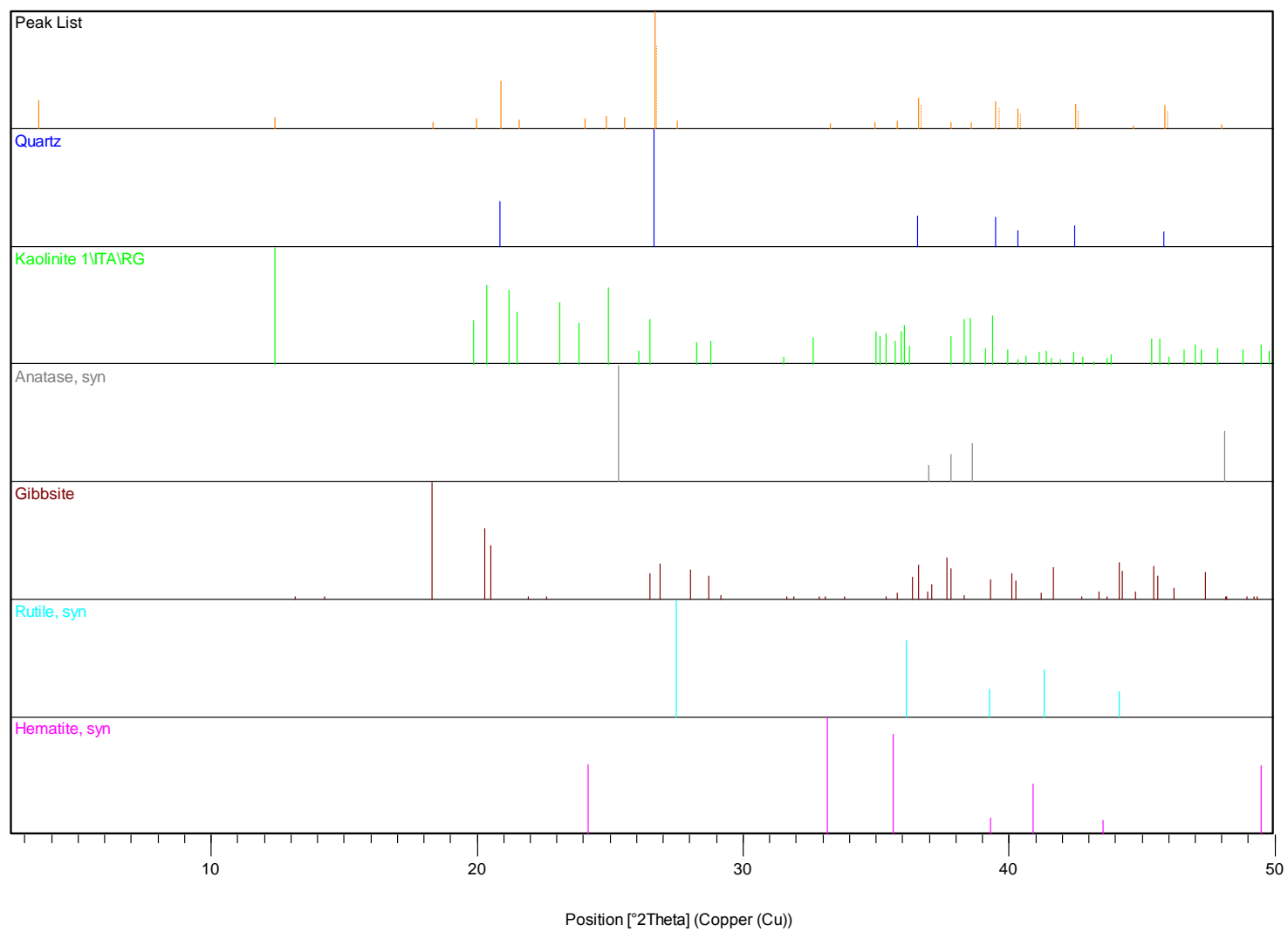




\section{RESULTADOS DE ANÁLISE QUÍMICA}

CERTIFICADO: AQ 1463-13

REQ: $1363-13$

DATA: $20 / 12 / 13$

\section{CLIENTE: FUND. PARQUE DE ALTA TEC. DA REGIÃO DE IPERÓ E ADJACÊNCIAS}

1. MÉTODO: Os teores apresentados foram determinados por análise sem padrões (standardless) dos elementos químicos detectados, de flúor a urânio, em espectrômetro por fluorescência de raios X Axios Advanced, marca PANalytical. Perda ao fogo (PF) efetuada a $1.050^{\circ} \mathrm{C}$ por $1 \mathrm{~h}$.

2. RESULTADOS: Valores expressos em \%, normalizados a $100 \%$.

\begin{tabular}{|l|c|}
\hline № LCT & $10778 / 13$ \\
\hline Amostra & AD-01 (0,6m) \\
\hline \hline $\mathrm{Al}_{2} \mathrm{O}_{3}$ & 7,73 \\
\hline $\mathrm{SiO}_{2}$ & 83,8 \\
\hline $\mathrm{P}_{2} \mathrm{O}_{5}$ & 0,045 \\
\hline $\mathrm{TiO}_{2}$ & 0,853 \\
\hline $\mathrm{Cr}_{2} \mathrm{O}_{3}$ & 0,044 \\
\hline $\mathrm{Fe}_{2} \mathrm{O}_{3}$ & 3,29 \\
\hline $\mathrm{CuO}$ & 0,03 \\
\hline $\mathrm{ZrO}$ & 0,053 \\
\hline $\mathrm{PbO}$ & 0,056 \\
\hline $\mathrm{PF}$ & 4,12 \\
\hline
\end{tabular}

Prof. Dr. Henrique Kahn Coordenador do LCT Poli/USP
Freud S. Campbell

Pesquisador do LCT Poli/USP Químico - CRQ 04200380-4 ${ }^{\mathrm{a} R}$ 


\section{RESULTADO DE QUANTIFICAÇÃO DE FASES POR DIFRATOMETRIA DE RAIOS X}

CERTIFICADO: DRX 190-14

DATA: $26 / 06 / 14$

CLIENTE: FUND. PARQUE DE ALTA TEC. DA REGIÃO DE IPERÓ E ADJACÊNCIAS

AMOSTRA: A - 01 solo pen. $2 \mathrm{~mm}$

IDENT. LCT: 184-0817.HPF

\section{MÉTODO}

O estudo foi efetuado através do método do pó, mediante o emprego de difratômetro de raios X, marca PANalytical, modelo X'Pert PRO com detector X'Celerator.

A identificação das fases cristalinas, abaixo discriminadas, foi obtida por comparação do difratograma da amostra com os bancos de dados PDF2 do ICDD - International Centre for Diffraction Data (2003) e PAN-ICSD - PANalytical Inorganic Crystal Structure Database (2007).

A estimativa da proporção de fases presentes, indicada na tabela de resultados, foi feita a partir da conjugação do resultado de difração de raios $X$ e de análises químicas.

\section{RESULTADOS}

Os resultados obtidos estão listados na tabela abaixo:

\begin{tabular}{cllc}
\hline ICDD & Nome do composto & Fórmula Química & $\begin{array}{c}\% \\
\text { estimada }\end{array}$ \\
\hline $01-085-0794$ & Quartzo & $\mathrm{SiO}_{2}$ & 84 \\
$00-019-0932$ & Microclínio & $\mathrm{KAlSi}_{3} \mathrm{O}_{8}$ & 8 \\
$01-074-2428$ & Muscovita & $\mathrm{KAl}_{3} \mathrm{Si}_{3} \mathrm{O}_{10}(\mathrm{OH})_{2}$ & 5 \\
$00-041-1480$ & Albita & $(\mathrm{Na}, \mathrm{Ca}) \mathrm{Al}(\mathrm{Si}, \mathrm{Al})_{3} \mathrm{O}_{8}$ & 3 \\
\hline
\end{tabular}

O difratograma obtido (cor vermelha), onde são assinaladas as linhas de difração correspondente(s) à(s) fase(s) identificada(s) (cada fase em uma cor distinta) é apresentado anexo.

Prof. Dr. Henrique Kahn Coordenador do LCT Poli/USP
Dra. Maria Manuela Lé Tassinari Pesquisadora do LCT Poli/USP
M.Sc. Juliana Lívi Antoniassi

Pesquisadora do LCT Poli/USP 


\section{DIFRATOGRAMA DE RAIOS $\mathrm{X}$}

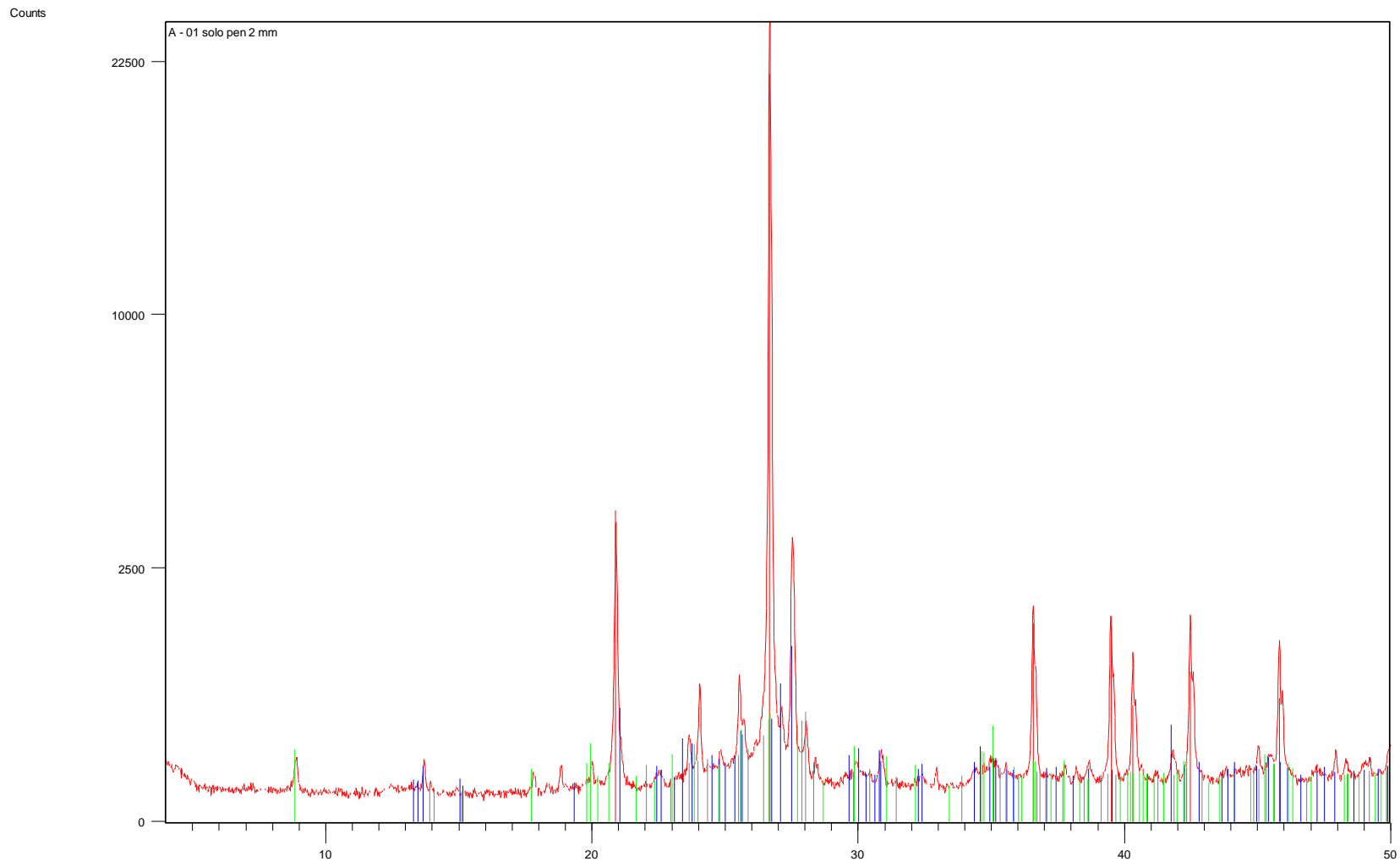

\section{FASES IDENTIFICADAS}

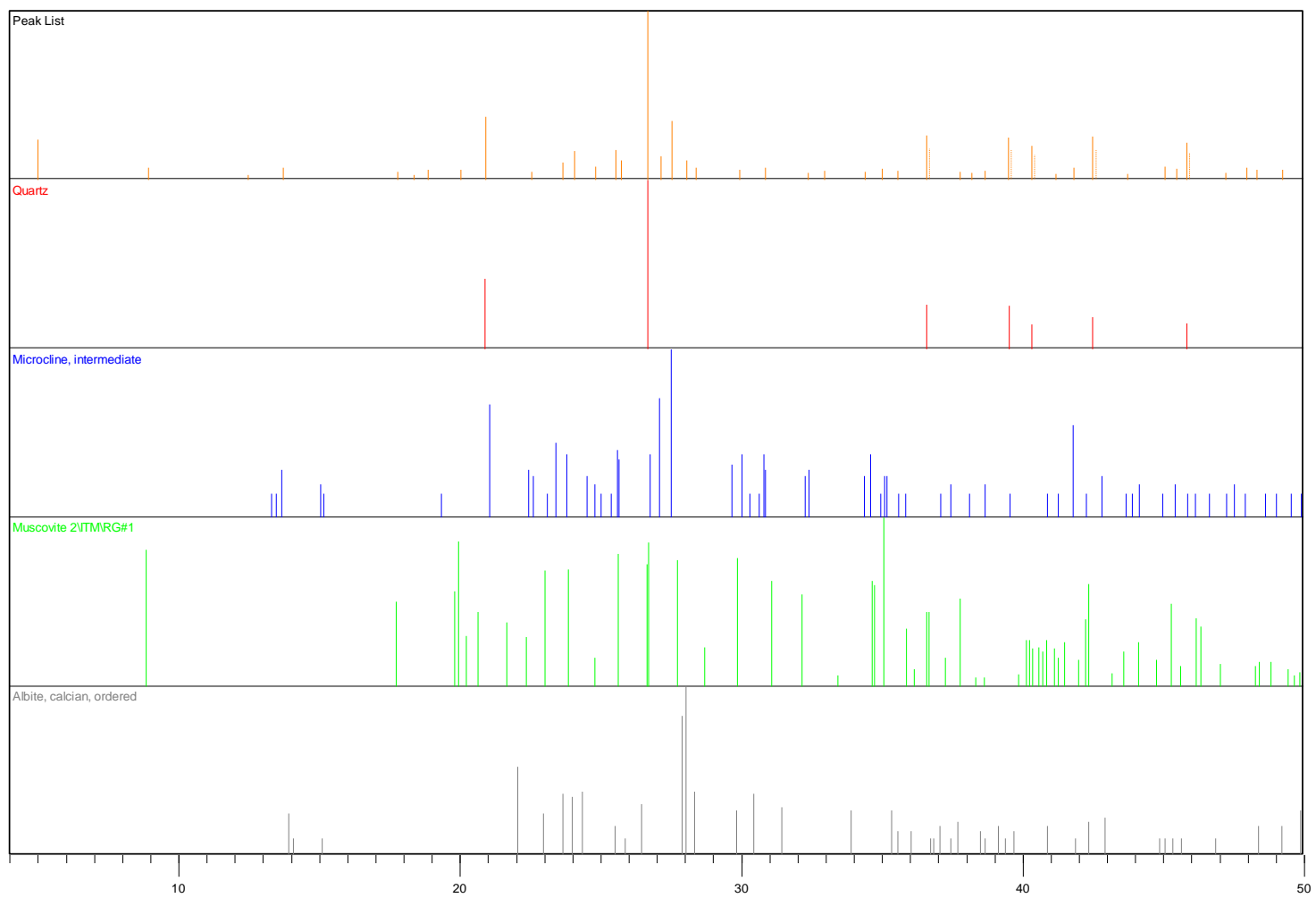


Escola Politécnica da Universidade de São Paulo Departamento de Engenharia de Minas e de Petróleo Laboratório de Caracterização Tecnológica Av. Prof. Mello Moraes, 2373 CEP 05508-030 São Paulo - SP www.lct.poli.usp.br Tel: 11 3091-5151 Fax: 11 3091-6037 o-mail: Ict@let.poli.usp.br

\section{RESULTADOS DE ANÁLISE QUÍMICA}

CERTIFICADO: AQ 615-14 REQ. 552-14 DATA: 25/06/14

CLIENTE: FUND. PARQUE DE ALTA TEC. DA REGIÃO DE IPERÓ E ADJACÊNCIAS

1. MÉTODO: Os teores apresentados foram determinados por análise quantitativa em amostra fundida com tetraborato de lítio anidro, por comparação com materiais certificados de referência na calibração Areias TBL, em espectrômetro de fluorescência de raios X Axios Advanced, marca PANalytical. Perda ao fogo (PF) efetuada a $1.050^{\circ} \mathrm{C}$ por $1 \mathrm{~h}$.

2. RESULTADOS: Análise quantitativa, valores expressos em \%.

\begin{tabular}{|l|c|}
\hline $\mathrm{N}^{\circ} \mathrm{LCT}$ & $4513 / 14$ \\
\hline Amostra & A - 01 solo pen. 2mm \\
\hline \hline $\mathrm{SiO}_{2}$ & 91,7 \\
\hline $\mathrm{Al}_{2} \mathrm{O}_{3}$ & 3,51 \\
\hline $\mathrm{Fe}_{2} \mathrm{O}_{3}$ & 0,42 \\
\hline $\mathrm{MnO}$ & $<0,10$ \\
\hline $\mathrm{MgO}$ & $<0,10$ \\
\hline $\mathrm{CaO}$ & 0,27 \\
\hline $\mathrm{Na}{ }_{2} \mathrm{O}$ & 0,34 \\
\hline $\mathrm{K}_{2} \mathrm{O}$ & 1,83 \\
\hline $\mathrm{TiO}_{2}$ & 0,26 \\
\hline $\mathrm{P}_{2} \mathrm{O}_{5}$ & $<0,10$ \\
\hline $\mathrm{PF}$ & 0,62 \\
\hline
\end{tabular}

Prof. Dr. Henrique Kahn Coordenador do LCT Poli/USP
Dra. Giuliana Ratti Pesquisadora do LCT Poli/USP Química - CRQ 04105009-4 ${ }^{3} \mathrm{R}$
Freud S Campbell Pesquisador do LCT Poli/USP Químico - CRQ 04200380-4 ${ }^{a} R$ 
República Federativa do Brasil

Ministério do Desenvolvimento, Indústria e Comércio Exterior

Instituto Nacional de Metrologia, Qualidade e Tecnologia - Inmetro

\title{
Coordenação Geral de Acreditação
}

Signatário dos Acordos de Reconhecimento Mútuo da International Laboratory Accreditation Cooperation (ILAC), da Interamerican Accreditation Cooperation (IAAC)

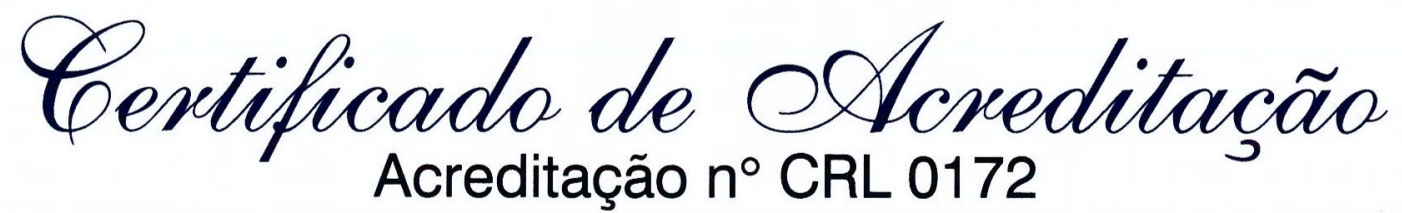

Acreditação inicial: 20-4-2004

\author{
BIOAGRI AMBIENTAL LTDA. \\ RUA AUJOVIL MARTINI, 201 - DOIS CÓRREGOS \\ PIRACICABA-SP
}

A Coordenação Geral de Acreditação do Inmetro concede acreditação ao Laboratório acima identificado, segundo os requisitos estabelecidos na ABNT NB́R ISO/IEC 17025:2005. Esta acreditação constitui a expressão formal do reconhecimento da sua competência para realizar os ensaios constantes no Escopo de Acreditação.

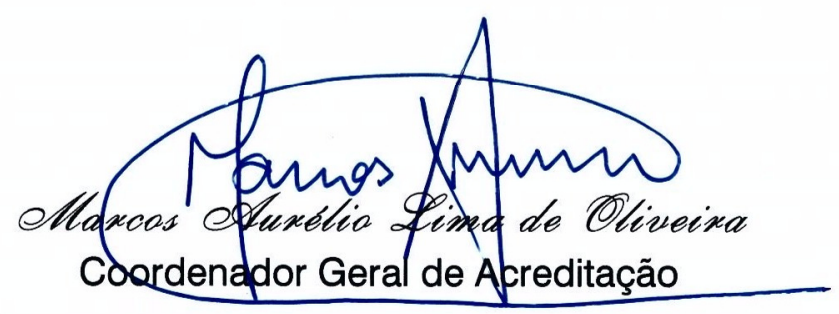




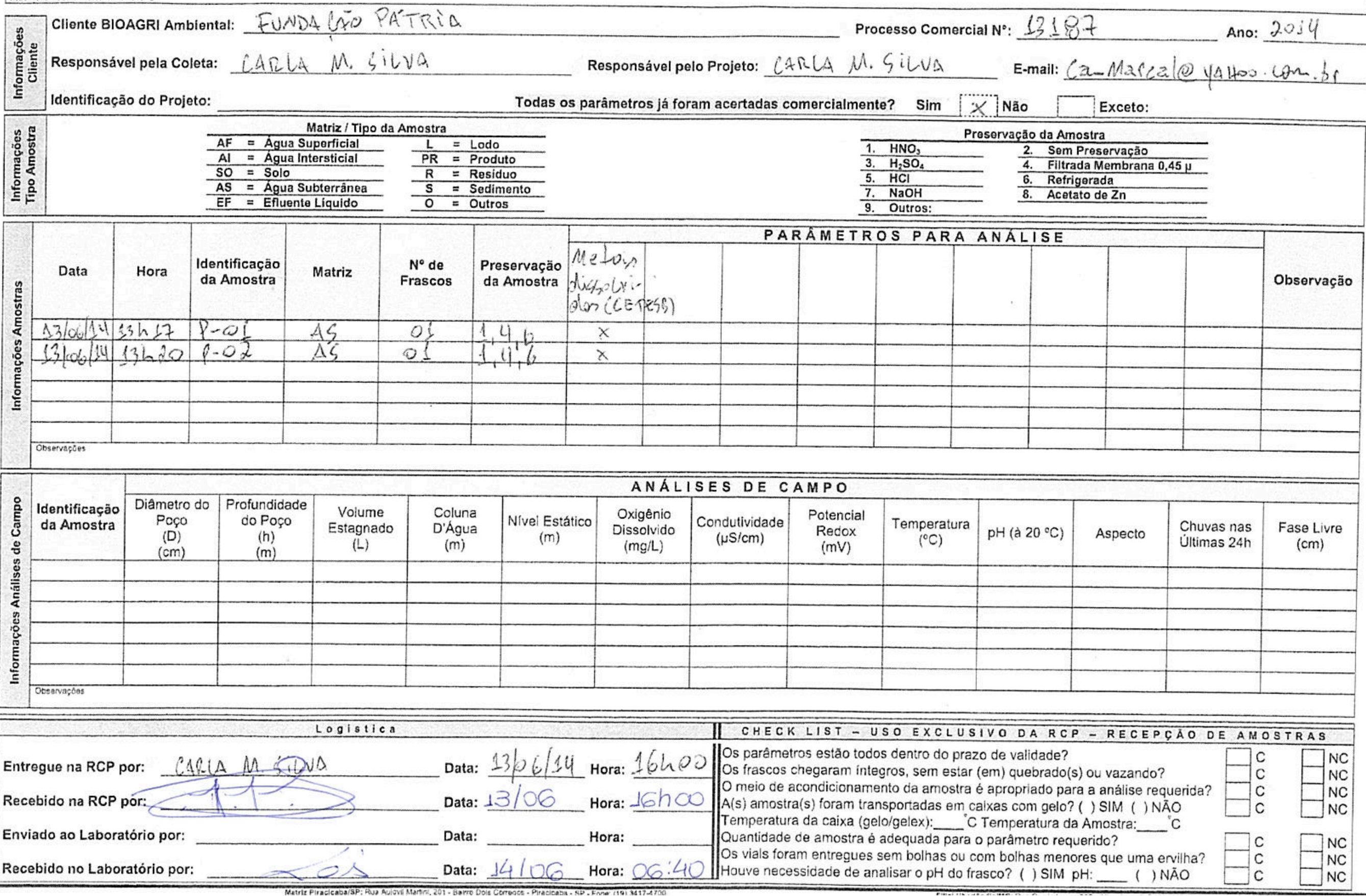




\begin{tabular}{|c|}
\hline RESUMO DOS RESULTADOS DA AMOSTRA \\
$\begin{array}{c}\text { N }^{\circ} \\
\text { Processo Comercial } \mathbf{N}^{\circ} \text { 13187/2014-1 }\end{array}$ \\
\hline
\end{tabular}

\begin{tabular}{|l|l|}
\hline \multicolumn{2}{|c|}{ DADOS REFERENTES AO CLIENTE } \\
\hline Empresa solicitante: & Fundacao Parque de Alta Tecnologia da Regiao de Ipero e Adjacencias \\
\hline Endereço: & Rua Jose Antonio Scaciota, 165 - - Portal do Cedro - Iperó - SP - CEP: 18.560-000 . \\
\hline Nome do Solicitante: & Carla Marçal \\
\hline
\end{tabular}

\begin{tabular}{|l|l|l|l|}
\hline \multicolumn{5}{|c|}{ DADOS REFERENTES A AMOSTRA } \\
\hline Identificação do Cliente: & $\mathrm{P}-01$ & \\
\hline Amostra Rotulada como: & Água Subterrânea & Data da coleta: & 13/06/2014 13:17:00 \\
\hline Coletor: & Interessado & Data de Elaboração do RRA: & $23 / 06 / 2014$ \\
\hline Data da entrada no laboratório: & $14 / 06 / 2014$ 06:38 & \\
\hline
\end{tabular}

\section{RESULTADOS PARA A AMOSTRA}

\begin{tabular}{|c|c|c|c|}
\hline Parâmetros & Unidade & LQ & Resultados analíticos \\
\hline Alumínio & $\mu \mathrm{g} / \mathrm{L}$ & 1 & $<1$ \\
\hline Antimônio & $\mu \mathrm{g} / \mathrm{L}$ & 1 & $<1$ \\
\hline Arsênio & $\mu \mathrm{g} / \mathrm{L}$ & 1 & $<1$ \\
\hline Bário & $\mu \mathrm{g} / \mathrm{L}$ & 1 & 8,71 \\
\hline Boro & $\mu \mathrm{g} / \mathrm{L}$ & 1 & $<1$ \\
\hline Cádmio & $\mu \mathrm{g} / \mathrm{L}$ & 1 & $<1$ \\
\hline Chumbo & $\mu \mathrm{g} / \mathrm{L}$ & 1 & $<1$ \\
\hline Cobalto & $\mu \mathrm{g} / \mathrm{L}$ & 1 & $<1$ \\
\hline Cobre & $\mu \mathrm{g} / \mathrm{L}$ & 1 & $<1$ \\
\hline Cromo & $\mu \mathrm{g} / \mathrm{L}$ & 1 & $<1$ \\
\hline Ferro & $\mu \mathrm{g} / \mathrm{L}$ & 1 & 21,4 \\
\hline Manganês & $\mu \mathrm{g} / \mathrm{L}$ & 1 & 2,50 \\
\hline Mercúrio & $\mu \mathrm{g} / \mathrm{L}$ & 0,1 & $<0,1$ \\
\hline Molibdênio & $\mu \mathrm{g} / \mathrm{L}$ & 1 & $<1$ \\
\hline Níquel & $\mu \mathrm{g} / \mathrm{L}$ & 1 & $<1$ \\
\hline Prata & $\mu \mathrm{g} / \mathrm{L}$ & 1 & $<1$ \\
\hline Selênio & $\mu \mathrm{g} / \mathrm{L}$ & 1 & $<1$ \\
\hline Vanádio & $\mu \mathrm{g} / \mathrm{L}$ & 1 & $<1$ \\
\hline Zinco & $\mu \mathrm{g} / \mathrm{L}$ & 1 & 19,6 \\
\hline
\end{tabular}

Notas

LQ = Limite de Quantificação da Amostra ( $L Q$ = LQM x fator de preparo da amostra x correção base seca, quando aplicável);

LQM = Limite de Quantificação do Método.

Abrangência

$\mathrm{O}(\mathrm{s})$ resultado(s) referem-se somente à(s) amostra(s) analisada(s).

Este Resumo de Resultados só pode ser reproduzido por inteiro e sem nenhuma alteração.

Dados de Origem

Resumo dos resultados da amostra ${ }^{\circ}$ 145434/2014-0 preparado com os dados dos relatórios de ensaio: 145434/2014-0 - Piracicaba anexados a este documento.

Chave de Validação: bb722f2867a4ca4f94853e3fb8669705

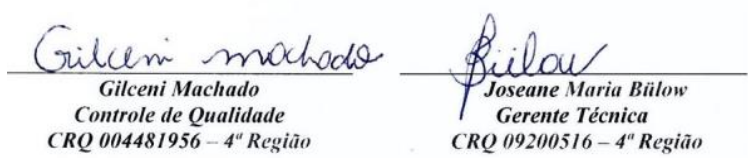




\section{RELATÓRIO DE ENSAIO N ${ }^{\circ}$ 145434/2014-0 - Piracicaba} Processo Comercial $N^{\circ}$ 13187/2014-1

\begin{tabular}{|l|l|}
\hline \multicolumn{2}{|c|}{ DADOS REFERENTES AO CLIENTE } \\
\hline Empresa solicitante: & Fundacao Parque de Alta Tecnologia da Regiao de Ipero e Adjacencias \\
\hline Endereço: & Rua Jose Antonio Scaciota, 165 - - Portal do Cedro - Iperó - SP - CEP: 18.560-000 . \\
\hline Nome do Solicitante: & Carla Marçal \\
\hline
\end{tabular}

\begin{tabular}{|l|l|l|l|l|}
\hline \multicolumn{5}{|c|}{ DADOS REFERENTES A AMOSTRA } \\
\hline Identificação do Cliente: & $\mathrm{P}-01$ \\
\hline Amostra Rotulada como: & Água Subterrânea & Data da coleta: & 13/06/2014 13:17:00 \\
\hline Coletor: & Interessado & Data de Elaboração do RE: & $23 / 06 / 2014$ \\
\hline Data da entrada no laboratório: & $14 / 06 / 2014$ 06:38 &
\end{tabular}

\section{RESULTADOS PARA A AMOSTRA}

\begin{tabular}{|c|c|c|c|c|c|}
\hline Parâmetros & CAS & Unidade & LQ & Resultados analíticos & Data do Ensaio \\
\hline Alumínio & $7429-90-5$ & $\mu \mathrm{g} / \mathrm{L}$ & 1 & $<1$ & 16/06/2014 15:47 \\
\hline Antimônio & $7440-36-0$ & $\mu \mathrm{g} / \mathrm{L}$ & 1 & $<1$ & 16/06/2014 15:47 \\
\hline Arsênio & $7440-38-2$ & $\mu \mathrm{g} / \mathrm{L}$ & 1 & $<1$ & $16 / 06 / 201415: 47$ \\
\hline Bário & 7440-39-3 & $\mu \mathrm{g} / \mathrm{L}$ & 1 & 8,71 & $16 / 06 / 201415: 47$ \\
\hline Boro & $7440-42-8$ & $\mu \mathrm{g} / \mathrm{L}$ & 1 & $<1$ & $16 / 06 / 201415: 47$ \\
\hline Cádmio & $7440-43-9$ & $\mu \mathrm{g} / \mathrm{L}$ & 1 & $<1$ & $16 / 06 / 201415: 47$ \\
\hline Chumbo & $7439-92-1$ & $\mu \mathrm{g} / \mathrm{L}$ & 1 & $<1$ & $16 / 06 / 201415: 47$ \\
\hline Cobalto & $7440-48-4$ & $\mu \mathrm{g} / \mathrm{L}$ & 1 & $<1$ & 16/06/2014 15:47 \\
\hline Cobre & $7440-50-8$ & $\mu \mathrm{g} / \mathrm{L}$ & 1 & $<1$ & $16 / 06 / 201415: 47$ \\
\hline Cromo & $7440-47-3$ & $\mu \mathrm{g} / \mathrm{L}$ & 1 & $<1$ & $16 / 06 / 201415: 47$ \\
\hline Ferro & $7439-89-6$ & $\mu \mathrm{g} / \mathrm{L}$ & 1 & 21,4 & $16 / 06 / 201415: 47$ \\
\hline Manganês & $7439-96-5$ & $\mu \mathrm{g} / \mathrm{L}$ & 1 & 2,50 & $16 / 06 / 201415: 47$ \\
\hline Mercúrio & 7439-97-6 & $\mu \mathrm{g} / \mathrm{L}$ & 0,1 & $<0,1$ & $16 / 06 / 201415: 47$ \\
\hline Molibdênio & 7439-98-7 & $\mu \mathrm{g} / \mathrm{L}$ & 1 & $<1$ & $16 / 06 / 201415: 47$ \\
\hline Níquel & $7440-02-0$ & $\mu \mathrm{g} / \mathrm{L}$ & 1 & $<1$ & $16 / 06 / 201415: 47$ \\
\hline Prata & $7440-22-4$ & $\mu \mathrm{g} / \mathrm{L}$ & 1 & $<1$ & $16 / 06 / 201415: 47$ \\
\hline Selênio & $7782-49-2$ & $\mu \mathrm{g} / \mathrm{L}$ & 1 & $<1$ & $16 / 06 / 201415: 47$ \\
\hline Vanádio & $7440-62-2$ & $\mu \mathrm{g} / \mathrm{L}$ & 1 & $<1$ & $16 / 06 / 201415: 47$ \\
\hline Zinco & $7440-66-6$ & $\mu \mathrm{g} / \mathrm{L}$ & 1 & 19,6 & 16/06/2014 15:47 \\
\hline
\end{tabular}

CONTROLE DE Q UALIDADE DO LAB ORATÓRIO

Controle de Q ualidade - Metais Dissolvidos - Água - ICP-MS 146511/2014-0 - Branco de Análise - Metais Dissolvidos - Águas ICP-MS

\begin{tabular}{|c|c|c|c|}
\hline Parâmetros & Unidade & LQ & Resultados analíticos \\
\hline Boro & $\mu \mathrm{g} / \mathrm{L}$ & 1 & $<1$ \\
\hline Alumínio & $\mu \mathrm{g} / \mathrm{L}$ & 1 & $<1$ \\
\hline Mercúrio & $\mu \mathrm{g} / \mathrm{L}$ & 0,1 & $<0,1$ \\
\hline Vanádio & $\mu \mathrm{g} / \mathrm{L}$ & 1 & $<1$ \\
\hline Cromo & $\mu \mathrm{g} / \mathrm{L}$ & 1 & $<1$ \\
\hline Manganês & $\mu \mathrm{g} / \mathrm{L}$ & 1 & $<1$ \\
\hline Ferro & $\mu \mathrm{g} / \mathrm{L}$ & 1 & $<1$ \\
\hline Cobalto & $\mu \mathrm{g} / \mathrm{L}$ & 1 & $<1$ \\
\hline Níquel & $\mu \mathrm{g} / \mathrm{L}$ & 1 & $<1$ \\
\hline Cobre & $\mu \mathrm{g} / \mathrm{L}$ & 1 & $<1$ \\
\hline Zinco & $\mu \mathrm{g} / \mathrm{L}$ & 1 & $<1$ \\
\hline Arsênio & $\mu \mathrm{g} / \mathrm{L}$ & 1 & $<1$ \\
\hline Selênio & $\mu \mathrm{g} / \mathrm{L}$ & 1 & $<1$ \\
\hline Molibdênio & $\mu \mathrm{g} / \mathrm{L}$ & 1 & $<1$ \\
\hline Prata & $\mu \mathrm{g} / \mathrm{L}$ & 1 & $<1$ \\
\hline Cádmio & $\mu \mathrm{g} / \mathrm{L}$ & 1 & $<1$ \\
\hline Antimônio & $\mu \mathrm{g} / \mathrm{L}$ & 1 & $<1$ \\
\hline Bário & $\mu \mathrm{g} / \mathrm{L}$ & 1 & $<1$ \\
\hline Chumbo & $\mu \mathrm{g} / \mathrm{L}$ & 1 & $<1$ \\
\hline
\end{tabular}




\begin{tabular}{|c|c|c|c|c|}
\hline Parâmetros & $\begin{array}{l}\text { Q uantidade } \\
\text { Adicionada }\end{array}$ & Unidade & $\begin{array}{c}\text { Resultado da } \\
\text { Recuperação (\%) }\end{array}$ & Faixa Aceitável de Recuperação (\%) \\
\hline \multicolumn{5}{|c|}{ 146512/2014-0 - Amostra Controle - Metais Dissolvidos - Água ICP-MS } \\
\hline Lítio & 10 & $\mu \mathrm{g} / \mathrm{L}$ & 102 & $80-120$ \\
\hline Vanádio & 10 & $\mu \mathrm{g} / \mathrm{L}$ & 112 & $80-120$ \\
\hline Cobalto & 10 & $\mu \mathrm{g} / \mathrm{L}$ & 112 & $80-120$ \\
\hline Zinco & 10 & $\mu \mathrm{g} / \mathrm{L}$ & 112 & $80-120$ \\
\hline Molibdênio & 10 & $\mu \mathrm{g} / \mathrm{L}$ & 101 & $80-120$ \\
\hline Antimônio & 10 & $\mu \mathrm{g} / \mathrm{L}$ & 81 & $80-120$ \\
\hline Chumbo & 10 & $\mu \mathrm{g} / \mathrm{L}$ & 107 & $80-120$ \\
\hline \multicolumn{5}{|c|}{$\begin{array}{l}\text { Surrogates } \\
\quad \text { 146511/2014-0 - B ranco de Análise - Metais Dissolvidos - Águas ICP-MS }\end{array}$} \\
\hline Itrio (Metais Dissolvidos) & 50 & $\%$ & 97,0 & $70-130$ \\
\hline \multicolumn{5}{|c|}{ 146512/2014-0 - Amostra Controle - Metais Dissolvidos - Água ICP-MS } \\
\hline Itrio (Metais Dissolvidos) & 50 & $\%$ & 126 & $70-130$ \\
\hline \multicolumn{5}{|l|}{ 145434/2014-0 - P-01 } \\
\hline Itrio (Metais Dissolvidos) & 50 & $\%$ & 122 & $70-130$ \\
\hline
\end{tabular}

Notas

LQ = Limite de Quantificação da Amostra (LQ = LQM x fator de preparo da amostra x correção base seca, quando aplicável);

LQM = Limite de Quantificação do Método.

Abrangência

(s) resultado(s) referem-se somente à(s) amostra(s) analisada(s).

Este Relatório de Ensaio só pode ser reproduzido por inteiro e sem nenhuma alteração.

Plano de Amostragem

Plano de amostragem de responsabilidade do interessado.

Responsabilidade Técnica

Os ensaios foram realizados na unidade da Bioagri Ambiental Ltda. - Matriz, situada na Rua Aljovil Martini, 177/201, Bairro Dois Córregos, Cep. 14420-833, Piracicaba/SP, registrada no CRQ 4 Região sob n $16082-F$ e responsabilidade técnica do profissional José Carlos Moretti, CRQ n $04107238,4^{a}$.Região.

Declaracão da Incerteza de Medição

Nos arquivos da Unidade da Garantia da Qualidade constam a incerteza expandida (U), que é baseada na incerteza padrão combina da, com um nível de confiança de $95 \%$ (k=2), que seră disponibilizada sempre que solicitado pelo cliente.

Referências Metodológicas

Análises foram realizadas conforme a última versão do Standard Methods for the Examination of Water \& Wastewater 22nd 2012(SMWW), EPA e ABNT (quando aplicável).

Metais (ICP-MS): Determinação: SMWW 3125 B / Preparo: EPA 3010A:1992 e EPA 3005:1992

Revisores

Rogério Caldorin

Chave de Validação: bb722f2867a4ca4f94853e3fb8669705

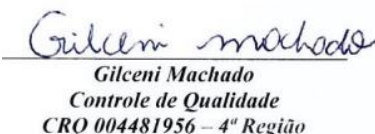

CRO 004481956-4" Regiâo

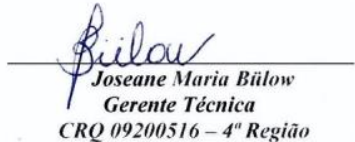




\begin{tabular}{|c|}
\hline RESUMO DOS RESULTADOS DA AMOSTRA \\
$\begin{array}{c}\mathbf{N}^{\circ} \\
\text { Processo Comercial } \mathbf{N}^{\circ} \text { 13187/2014-1 }\end{array}$ \\
\hline
\end{tabular}

\begin{tabular}{|l|l|}
\hline \multicolumn{2}{|c|}{ DADOS REFERENTES AO CLIENTE } \\
\hline Empresa solicitante: & Fundacao Parque de Alta Tecnologia da Regiao de Ipero e Adjacencias \\
\hline Endereço: & Rua Jose Antonio Scaciota, 165 - - Portal do Cedro - Iperó - SP - CEP: 18.560-000 . \\
\hline Nome do Solicitante: & Carla Marçal \\
\hline
\end{tabular}

\begin{tabular}{|c|c|c|c|c|}
\hline \multicolumn{5}{|c|}{ DADOS REFERENTES A AMOSTRA } \\
\hline Identificação do Cliente: & \multicolumn{4}{|c|}{ P-02 } \\
\hline Amostra Rotulada como: & \multicolumn{4}{|c|}{ Água Subterrânea } \\
\hline Coletor: & \multicolumn{2}{|c|}{ Interessado } & Data da coleta: & 13/06/2014 13:20:00 \\
\hline Data da entrada no labora & rio: & 14/06/2014 06:39 & Data de Elabora & \begin{tabular}{|l|l|} 
ão do RRA: & $23 / 06 / 2014$
\end{tabular} \\
\hline
\end{tabular}

\section{RESULTADOS PARA A AMOSTRA}

\begin{tabular}{|c|c|c|c|}
\hline Parâmetros & Unidade & LQ & Resultados analíticos \\
\hline Alumínio & $\mu \mathrm{g} / \mathrm{L}$ & 1 & $<1$ \\
\hline Antimônio & $\mu \mathrm{g} / \mathrm{L}$ & 1 & $<1$ \\
\hline Arsênio & $\mu \mathrm{g} / \mathrm{L}$ & 1 & $<1$ \\
\hline Bário & $\mu \mathrm{g} / \mathrm{L}$ & 5 & 382 \\
\hline Boro & $\mu \mathrm{g} / \mathrm{L}$ & 1 & $<1$ \\
\hline Cádmio & $\mu \mathrm{g} / \mathrm{L}$ & 1 & $<1$ \\
\hline Chumbo & $\mu \mathrm{g} / \mathrm{L}$ & 1 & $<1$ \\
\hline Cobalto & $\mu \mathrm{g} / \mathrm{L}$ & 1 & $<1$ \\
\hline Cobre & $\mu \mathrm{g} / \mathrm{L}$ & 1 & $<1$ \\
\hline Cromo & $\mu \mathrm{g} / \mathrm{L}$ & 1 & $<1$ \\
\hline Ferro & $\mu \mathrm{g} / \mathrm{L}$ & 20 & 1010 \\
\hline Manganês & $\mu \mathrm{g} / \mathrm{L}$ & 1 & $<1$ \\
\hline Mercúrio & $\mu \mathrm{g} / \mathrm{L}$ & 0,1 & $<0,1$ \\
\hline Molibdênio & $\mu \mathrm{g} / \mathrm{L}$ & 1 & $<1$ \\
\hline Níquel & $\mu \mathrm{g} / \mathrm{L}$ & 1 & $<1$ \\
\hline Prata & $\mu \mathrm{g} / \mathrm{L}$ & 1 & $<1$ \\
\hline Selênio & $\mu \mathrm{g} / \mathrm{L}$ & 1 & $<1$ \\
\hline Vanádio & $\mu \mathrm{g} / \mathrm{L}$ & 1 & $<1$ \\
\hline Zinco & $\mu \mathrm{g} / \mathrm{L}$ & 5 & 274 \\
\hline
\end{tabular}

Notas

LQ = Limite de Quantificação da Amostra ( $L Q$ = LQM x fator de preparo da amostra x correção base seca, quando aplicável);

LQM = Limite de Quantificação do Método.

Abrangência

$\mathrm{O}(\mathrm{s})$ resultado(s) referem-se somente à(s) amostra(s) analisada(s).

Este Resumo de Resultados só pode ser reproduzido por inteiro e sem nenhuma alteração.

Dados de Origem

Resumo dos resultados da amostra ${ }^{\circ}$ 145435/2014-0 preparado com os dados dos relatórios de ensaio: 145435/2014-0 - Piracicaba anexados a este documento.

Chave de Validação: 442a977cc26f83a16cf8c916052b165a

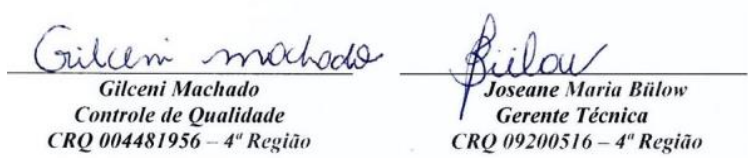




\section{RELATÓRIO DE ENSAIO N ${ }^{\circ}$ 145435/2014-0 - Piracicaba} Processo Comercial $N^{\circ}$ 13187/2014-1

\begin{tabular}{|l|l|}
\hline \multicolumn{2}{|c|}{ DADOS REFERENTES AO CLIENTE } \\
\hline Empresa solicitante: & Fundacao Parque de Alta Tecnologia da Regiao de Ipero e Adjacencias \\
\hline Endereço: & Rua Jose Antonio Scaciota, 165 - - Portal do Cedro - Iperó - SP - CEP: 18.560-000 . \\
\hline Nome do Solicitante: & Carla Marçal \\
\hline
\end{tabular}

\begin{tabular}{|l|l|l|l|l|}
\hline \multicolumn{5}{|c|}{ DADOS REFERENTES A AMOSTRA } \\
\hline Identificação do Cliente: & $\mathrm{P}-02$ \\
\hline Amostra Rotulada como: & Água Subterrânea & Data da coleta: & 13/06/2014 13:20:00 \\
\hline Coletor: & Interessado & Data de Elaboração do RE: & $23 / 06 / 2014$ \\
\hline Data da entrada no laboratório: & $14 / 06 / 2014$ 06:39 &
\end{tabular}

\section{RESULTADOS PARA A AMOSTRA}

\begin{tabular}{|c|c|c|c|c|c|}
\hline Parâmetros & CAS & Unidade & LQ & Resultados analíticos & Data do Ensaio \\
\hline Alumínio & $7429-90-5$ & $\mu \mathrm{g} / \mathrm{L}$ & 1 & $<1$ & 16/06/2014 15:47 \\
\hline Antimônio & $7440-36-0$ & $\mu \mathrm{g} / \mathrm{L}$ & 1 & $<1$ & 16/06/2014 15:47 \\
\hline Arsênio & $7440-38-2$ & $\mu \mathrm{g} / \mathrm{L}$ & 1 & $<1$ & $16 / 06 / 201415: 47$ \\
\hline Bário & 7440-39-3 & $\mu \mathrm{g} / \mathrm{L}$ & 5 & 382 & $16 / 06 / 201415: 47$ \\
\hline Boro & $7440-42-8$ & $\mu \mathrm{g} / \mathrm{L}$ & 1 & $<1$ & $16 / 06 / 201415: 47$ \\
\hline Cádmio & $7440-43-9$ & $\mu \mathrm{g} / \mathrm{L}$ & 1 & $<1$ & $16 / 06 / 201415: 47$ \\
\hline Chumbo & $7439-92-1$ & $\mu \mathrm{g} / \mathrm{L}$ & 1 & $<1$ & $16 / 06 / 201415: 47$ \\
\hline Cobalto & $7440-48-4$ & $\mu \mathrm{g} / \mathrm{L}$ & 1 & $<1$ & 16/06/2014 15:47 \\
\hline Cobre & $7440-50-8$ & $\mu \mathrm{g} / \mathrm{L}$ & 1 & $<1$ & $16 / 06 / 201415: 47$ \\
\hline Cromo & $7440-47-3$ & $\mu \mathrm{g} / \mathrm{L}$ & 1 & $<1$ & $16 / 06 / 201415: 47$ \\
\hline Ferro & $7439-89-6$ & $\mu \mathrm{g} / \mathrm{L}$ & 20 & 1010 & $16 / 06 / 201415: 47$ \\
\hline Manganês & $7439-96-5$ & $\mu \mathrm{g} / \mathrm{L}$ & 1 & $<1$ & $16 / 06 / 201415: 47$ \\
\hline Mercúrio & 7439-97-6 & $\mu \mathrm{g} / \mathrm{L}$ & 0,1 & $<0,1$ & $16 / 06 / 201415: 47$ \\
\hline Molibdênio & 7439-98-7 & $\mu \mathrm{g} / \mathrm{L}$ & 1 & $<1$ & $16 / 06 / 201415: 47$ \\
\hline Níquel & 7440-02-0 & $\mu \mathrm{g} / \mathrm{L}$ & 1 & $<1$ & $16 / 06 / 201415: 47$ \\
\hline Prata & $7440-22-4$ & $\mu \mathrm{g} / \mathrm{L}$ & 1 & $<1$ & $16 / 06 / 201415: 47$ \\
\hline Selênio & $7782-49-2$ & $\mu \mathrm{g} / \mathrm{L}$ & 1 & $<1$ & $16 / 06 / 201415: 47$ \\
\hline Vanádio & $7440-62-2$ & $\mu \mathrm{g} / \mathrm{L}$ & 1 & $<1$ & $16 / 06 / 201415: 47$ \\
\hline Zinco & $7440-66-6$ & $\mu \mathrm{g} / \mathrm{L}$ & 5 & 274 & 16/06/2014 15:47 \\
\hline
\end{tabular}

CONTROLE DE Q UALIDADE DO LAB ORATÓRIO

Controle de Q ualidade - Metais Dissolvidos - Água - ICP-MS 146511/2014-0 - Branco de Análise - Metais Dissolvidos - Águas ICP-MS

\begin{tabular}{|c|c|c|c|}
\hline Parâmetros & Unidade & LQ & Resultados analíticos \\
\hline Boro & $\mu \mathrm{g} / \mathrm{L}$ & 1 & $<1$ \\
\hline Alumínio & $\mu \mathrm{g} / \mathrm{L}$ & 1 & $<1$ \\
\hline Mercúrio & $\mu \mathrm{g} / \mathrm{L}$ & 0,1 & $<0,1$ \\
\hline Vanádio & $\mu \mathrm{g} / \mathrm{L}$ & 1 & $<1$ \\
\hline Cromo & $\mu \mathrm{g} / \mathrm{L}$ & 1 & $<1$ \\
\hline Manganês & $\mu \mathrm{g} / \mathrm{L}$ & 1 & $<1$ \\
\hline Ferro & $\mu \mathrm{g} / \mathrm{L}$ & 1 & $<1$ \\
\hline Cobalto & $\mu \mathrm{g} / \mathrm{L}$ & 1 & $<1$ \\
\hline Níquel & $\mu \mathrm{g} / \mathrm{L}$ & 1 & $<1$ \\
\hline Cobre & $\mu \mathrm{g} / \mathrm{L}$ & 1 & $<1$ \\
\hline Zinco & $\mu \mathrm{g} / \mathrm{L}$ & 1 & $<1$ \\
\hline Arsênio & $\mu \mathrm{g} / \mathrm{L}$ & 1 & $<1$ \\
\hline Selênio & $\mu \mathrm{g} / \mathrm{L}$ & 1 & $<1$ \\
\hline Molibdênio & $\mu \mathrm{g} / \mathrm{L}$ & 1 & $<1$ \\
\hline Prata & $\mu \mathrm{g} / \mathrm{L}$ & 1 & $<1$ \\
\hline Cádmio & $\mu \mathrm{g} / \mathrm{L}$ & 1 & $<1$ \\
\hline Antimônio & $\mu \mathrm{g} / \mathrm{L}$ & 1 & $<1$ \\
\hline Bário & $\mu \mathrm{g} / \mathrm{L}$ & 1 & $<1$ \\
\hline Chumbo & $\mu \mathrm{g} / \mathrm{L}$ & 1 & $<1$ \\
\hline
\end{tabular}




\begin{tabular}{|c|c|c|c|c|}
\hline Parâmetros & $\begin{array}{l}\text { Q uantidade } \\
\text { Adicionada }\end{array}$ & Unidade & $\begin{array}{c}\text { Resultado da } \\
\text { Recuperação (\%) }\end{array}$ & Faixa Aceitável de Recuperação (\%) \\
\hline \multicolumn{5}{|c|}{ 146512/2014-0 - Amostra Controle - Metais Dissolvidos - Água ICP-MS } \\
\hline Lítio & 10 & $\mu \mathrm{g} / \mathrm{L}$ & 102 & $80-120$ \\
\hline Vanádio & 10 & $\mu \mathrm{g} / \mathrm{L}$ & 112 & $80-120$ \\
\hline Cobalto & 10 & $\mu \mathrm{g} / \mathrm{L}$ & 112 & $80-120$ \\
\hline Zinco & 10 & $\mu \mathrm{g} / \mathrm{L}$ & 112 & $80-120$ \\
\hline Molibdênio & 10 & $\mu \mathrm{g} / \mathrm{L}$ & 101 & $80-120$ \\
\hline Antimônio & 10 & $\mu \mathrm{g} / \mathrm{L}$ & 81 & $80-120$ \\
\hline Chumbo & 10 & $\mu \mathrm{g} / \mathrm{L}$ & 107 & $80-120$ \\
\hline \multicolumn{5}{|c|}{$\begin{array}{l}\text { Surrogates } \\
\quad \text { 146511/2014-0 - B ranco de Análise - Metais Dissolvidos - Águas ICP-MS }\end{array}$} \\
\hline Itrio (Metais Dissolvidos) & 50 & $\%$ & 97,0 & $70-130$ \\
\hline \multicolumn{5}{|c|}{ 146512/2014-0 - Amostra Controle - Metais Dissolvidos - Água ICP-MS } \\
\hline Itrio (Metais Dissolvidos) & 50 & $\%$ & 126 & $70-130$ \\
\hline \multicolumn{5}{|l|}{ 145435/2014-0 - P-02 } \\
\hline Itrio (Metais Dissolvidos) & 50 & $\%$ & 124 & $70-130$ \\
\hline
\end{tabular}

Notas

LQ = Limite de Quantificação da Amostra (LQ = LQM x fator de preparo da amostra x correção base seca, quando aplicável);

LQM = Limite de Quantificação do Método.

Abrangência

(s) resultado(s) referem-se somente à(s) amostra(s) analisada(s).

Este Relatório de Ensaio só pode ser reproduzido por inteiro e sem nenhuma alteração.

Plano de Amostragem

Plano de amostragem de responsabilidade do interessado.

Responsabilidade Técnica

Os ensaios foram realizados na unidade da Bioagri Ambiental Ltda. - Matriz, situada na Rua Aljovil Martini, 177/201, Bairro Dois Córregos, Cep. 14420-833, Piracicaba/SP, registrada no CRQ 4 Região sob n $16082-F$ e responsabilidade técnica do profissional José Carlos Moretti, CRQ n ${ }^{\circ} 04107238,4^{a}$. Região.

Declaracão da Incerteza de Medição

Nos arquivos da Unidade da Garantia da Qualidade constam a incerteza expandida (U), que é baseada na incerteza padrão combina da, com um nível de confiança de $95 \%$ (k=2), que seră disponibilizada sempre que solicitado pelo cliente.

Referências Metodológicas

Análises foram realizadas conforme a última versão do Standard Methods for the Examination of Water \& Wastewater 22nd 2012(SMWW), EPA e ABNT (quando aplicável).

Metais (ICP-MS): Determinação: SMWW 3125 B / Preparo: EPA 3010A:1992 e EPA 3005:1992

Revisores

Rogério Caldorin

Chave de Validação: 442a977cc26f83a16cf8c916052b165a

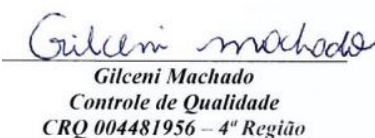

CRO 004481956-4" Regiâo

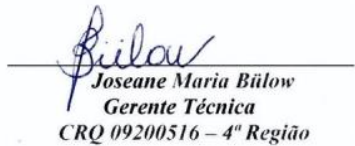


Empresa Solicitante:

Empresa Solicitante: ZVNDACAD UUfDiA Processo Comercial №:

Responsável pela Coleta: $72 t(-h t \sin 2 \theta$ Data da Coleta: $02,031111,4$

Amostra:

Líquida

Água (L) Efluente ( )

Sólida

Outros:

1 - INSPEÇÃO DAS AMOSTRAS EM SÃO PAULO/PAULÍNIA

Critérios da inspeção da temperatura conforme POP GE 017:

I-Amostra recebida com mais de 4 horas da coleta:

-Temperatura $\leq 6^{\circ} \mathrm{C}=$ Conforme

-Temperatura $>6^{\circ} \mathrm{C}+$ Amostra com pouco ou nenhum gelo $=$ Não conforme

II-Amostra recebida com menos de 4 horas da coleta:

-Temperatura $>6^{\circ} \mathrm{C}+$ Caixa com bastante gelo cobrindo as amostras $=$ Conforme

-Temperatura $\leq 6^{\circ} \mathrm{C}=$ Conforme

Temperatura da(s) amostra(s) nas caixas recebidas abaixo:

\begin{tabular}{|c|c|c|c|c|c|c|}
\hline $\mathrm{N}^{\circ} \mathrm{CX} /{ }^{\circ} \mathrm{C}$ & $\mathrm{N}^{\circ} \mathrm{CX} /{ }^{\circ} \mathrm{C}$ & $\mathrm{N}^{\circ} \mathrm{CX} /{ }^{\circ} \mathrm{C}$ & $\mathrm{N}^{\circ} \mathrm{CX} /{ }^{\circ} \mathrm{C}$ & $\mathrm{N}^{\circ} \mathrm{CX} /{ }^{\circ} \mathrm{C}$ & $\mathrm{N}^{\circ} \mathrm{CX} /{ }^{\circ} \mathrm{C}$ & $\mathrm{N}^{\circ} \mathrm{CX} /{ }^{\circ} \mathrm{C}$ \\
\hline $30 / 2$ & 1 & 1 & $/$ & 1 & $/$ & 1 \\
\hline 1 & 1 & 1 & 1 & 1 & 1 & 1 \\
\hline
\end{tabular}

Código do(s) equipamento(s) utilizado(s): 10.2, Responsável pela Inspeção

tonenes

\section{2 - RECEBIMENTO DAS AMOSTRAS EM PIRACICABA}

\section{Requisitos Especificados}

Obs.: Para checar os itens de Inspeção, consultar Guia de Coleta

(s) amostra(s) foram transportadas em caixas com gelo? ( $\alpha) \operatorname{Sim}(\quad)$ Não

Temperatura da(s) amostra(s) nas caixas recebidas abaixo:

01

\begin{tabular}{|c|c|c|c|c|c|c|}
\hline $\mathrm{N}^{\circ} \mathrm{CX} /{ }^{\circ} \mathrm{C}$ & $\mathrm{N}^{\circ} \mathrm{CX} /{ }^{\circ} \mathrm{C}$ & $\mathrm{N}^{\circ} \mathrm{CX} /{ }^{\circ} \mathrm{C}$ & $\mathrm{N}^{\circ} \mathrm{CX} /{ }^{\circ} \mathrm{C}$ & $\mathrm{N}^{\circ} \mathrm{CX} /{ }^{\circ} \mathrm{C}$ & $\mathrm{N}^{\circ} \mathrm{CX} /{ }^{\circ} \mathrm{C}$ & $\mathrm{N}^{\circ} \mathrm{CX} /{ }^{\circ} \mathrm{C}$ \\
\hline 31,3 & 1 & 1 & 1 & 1 & 1 & 1 \\
\hline 1 & 1 & 1 & 1 & 1 & 1 & 1 \\
\hline
\end{tabular}

Código do(s) equipamento(s) utilizado(s):

02 A Ficha de Coleta/Cadeia de Custódia está preenchida corretamente?

03 A identificação das amostras coincide com a da Cadeia de Custódia?

04 Os frascos chegaram integros, sem estar (em) quebrado(s) ou vazando?

05 Os parâmetros estão todos dentro do prazo de validade?

06 meio de acondicionamento da amostra é apropriado para a análise requerida?

07 Quantidade de amostra é adequada para o parâmetro requerido?

08 Os vials foram entregues sem bolhas ou com bolhas menores que uma ervilha?

09 Houve necessidade de checar o pH do frasco?( )Não ( )Sim, adequado? ( )Sim ( )Não

PREENCHIMENTO OBRIGATORIO:

Responsável pelo Recebimento/Triagem:

Data:

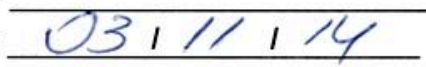

INSPEÇÃO DA AMOSTRA

Responsável pela Inspeção:

Data:

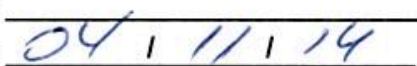

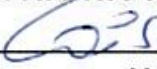

Hora:

h 30 $\min$

Espaco reservado para informacões da amostra e outras observacões pertinentes (ou NC):

Grupo: 36052 


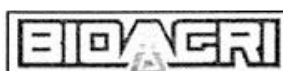

Cadeia de Custódia - CC

A $M$ B B I E N N T A A L

Processo Comercial No: 23961

Ano: 2014

¿. Cliente BIOAGRI Ambiental: Fundaços Pátrua Responsável pelo Projeto: Corla m. Sclaer-mail: ca-marabla yahos

- Identificação do Projeto: mestrodor Todas os parâmetros já foram acertadas comercialmente? $\operatorname{Sim} \quad \times \quad$ Não $\quad \square$ Exceto:

Matriz / Tipo da Amostra

\begin{tabular}{|c|c|c|}
\hline \multicolumn{3}{|c|}{ Preservaçăo da Amostra } \\
\hline $\mathrm{HNO}_{3}$ & 2. & Sem Preservação \\
\hline $\mathrm{H}_{2} \mathrm{SO}_{4}$ & 4. & Filtrada Membrana $0,45 \mu$ \\
\hline $\mathrm{HCl}$ & 6. & Refrigerada \\
\hline $\mathrm{NaOH}$ & 8. & Acetato de $\mathrm{Zn}$ \\
\hline
\end{tabular}

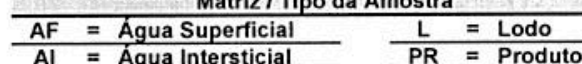
\begin{tabular}{ll}
$A l$ & $=$ Água Intersticial \\
\hline$S O$ & PR $=$ Produto
\end{tabular}

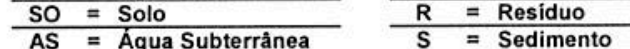
$A S=$ Agua Subterranea
$\mathrm{EF}=$ Efluente Liquido

\begin{tabular}{|c|c|c|c|c|}
\hline \multirow{7}{*}{ 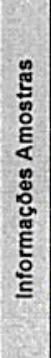 } & Data & Hora & $\begin{array}{l}\text { Identificação } \\
\text { da Amostra }\end{array}$ & Matriz \\
\hline & $02,11,14$ & $22 h 29$ & BGBI 1 & AS \\
\hline & 02.11 .14 & $22 h 30$ & $B G B I 2$ & AS \\
\hline & 02.11 .14 & $22 h 31$ & $B G B I 3$ & AS \\
\hline & $03,11.14$ & $\operatorname{coh} 25$ & $B G B F$ & AS \\
\hline & 03.11 .14 & $00 h 26$ & BGBF2 & AS \\
\hline & 03.11 .14 & $\infty \mathrm{h} 27$ & $B G B F 3$ & AS \\
\hline
\end{tabular}

9. Outros: Mem

ROS PARA ANÁLISE

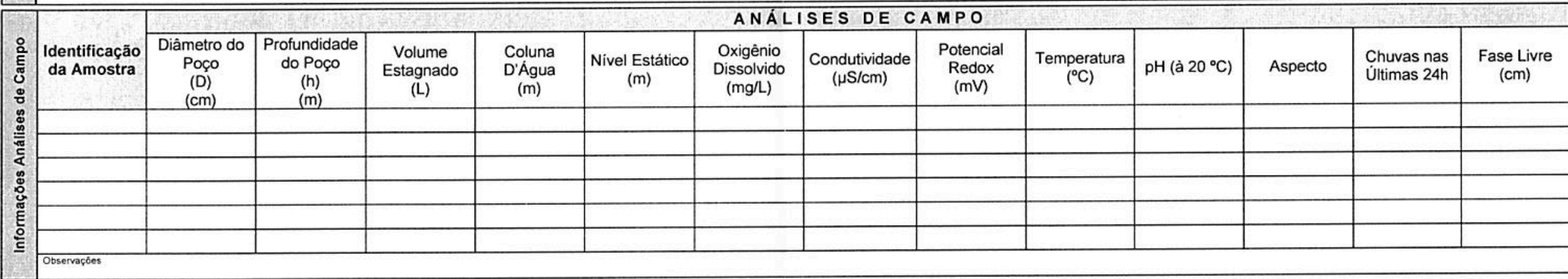

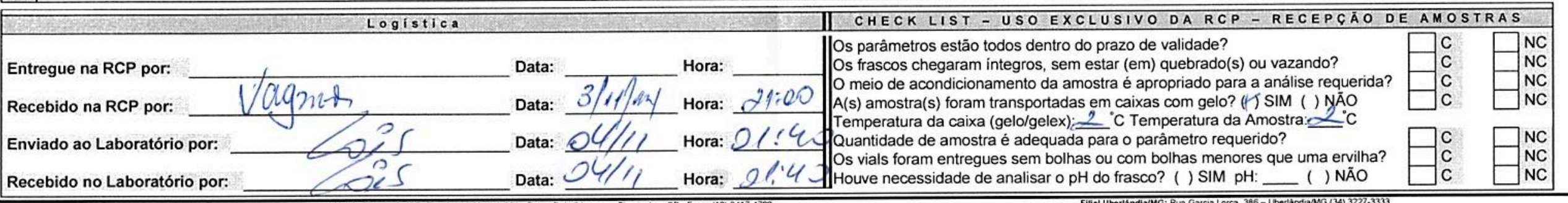
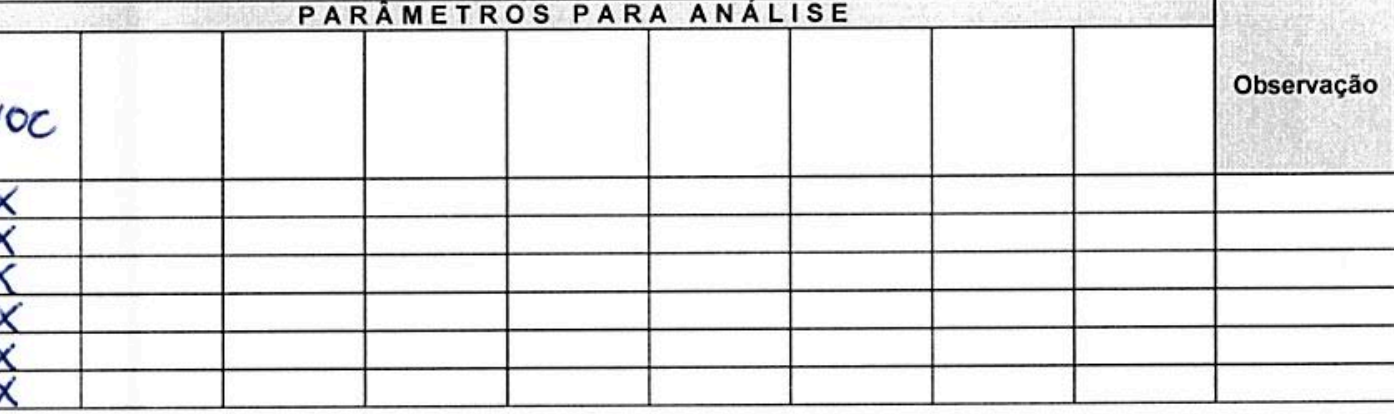
Os parâmetros estão todos dentro do prazo de validade?

s frascos chegaram integros, sem estar (em) quebrado(s) ou vazando?

A(s) amostra(s) foram transportadas em caixas com gelo? (f) SIM ( ) NAOO

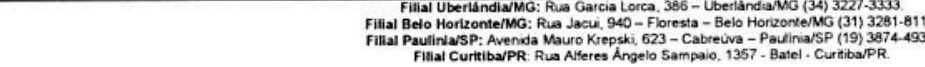


¿ Cliente BIOAGRI Ambiental: Fundoça pótria Responsável pelo Projeto: Carla m. Slve, E-mail: ca-marcal@y yahoo.com.b Responsável pela coleta: Carla in. Sulva Todas os parámetros já foram acertadas comercialmente? Sim $\times$ Năo $\square$ Exceto:

\begin{tabular}{|c|c|c|c|c|c|c|}
\hline \multirow{6}{*}{ 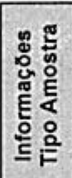 } & \multicolumn{6}{|c|}{ Matriz / Tipo da Amostra } \\
\hline & $\mathrm{AF}$ & $=$ & Água Superficial & $\mathrm{L}$ & $=$ & \\
\hline & Al & $\equiv$ & Agua Intersticial & $\mathrm{PR}$ & $=$ & Produto \\
\hline & so & $=$ & Solo & $R$ & $=$ & Resíduo \\
\hline & AS & $=$ & Água Subterrânea & $\mathrm{s}$ & $=$ & Sedimento \\
\hline & EF & $=$ & Efluente Liquido & 0 & $=$ & Outros \\
\hline
\end{tabular}

\begin{tabular}{|c|c|c|c|}
\hline & \multicolumn{3}{|c|}{ Preservaçāo da Amostra } \\
\hline 1. & $\mathrm{HNO}_{3}$ & 2. & Sem Preservação \\
\hline & $\mathrm{H}_{2} \mathrm{SO}_{4}$ & 4. & Filtrada Membrana $0,45 \mu$ \\
\hline 5. & $\mathrm{HCl}$ & 6. & Refrigerada \\
\hline & $\mathrm{NaOH}$ & & Acetato de $\mathrm{Zn}$ \\
\hline
\end{tabular}
$\mathrm{EF}=$ Efluente Liquido

9. Outros: 6. Refrigerada

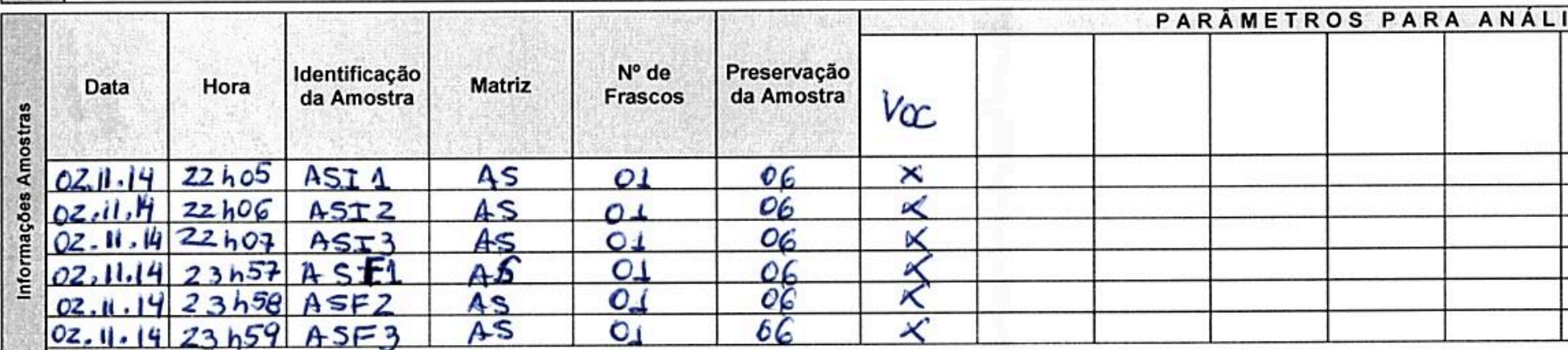

\section{ISE}

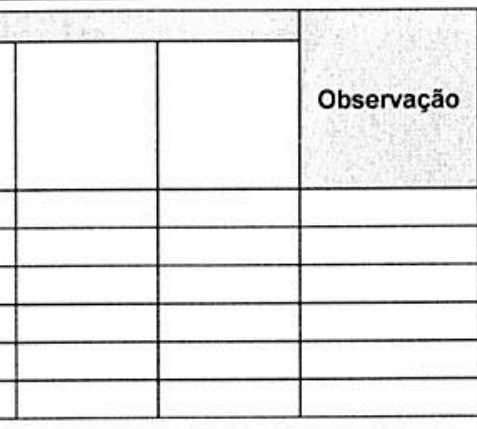
02.11 .1423 . 259 ASF

\begin{tabular}{|c|c|c|c|c|c|c|c|}
\hline \multirow[b]{2}{*}{ 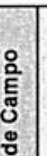 } & \multirow[b]{2}{*}{$\begin{array}{l}\text { Identificação } \\
\text { da Amostra }\end{array}$} & \multicolumn{6}{|r|}{$A N A ́ L I$} \\
\hline & & $\begin{array}{l}\text { Diâmetro do } \\
\text { Poço } \\
\text { (D) } \\
\text { (cm) }\end{array}$ & $\begin{array}{l}\text { Profundidade } \\
\text { do Poço } \\
\text { (h) } \\
\text { (m) }\end{array}$ & $\begin{array}{l}\text { Volume } \\
\text { Estagnado } \\
\text { (L) }\end{array}$ & $\begin{array}{l}\text { Coluna } \\
\text { D'Água } \\
\text { (m) }\end{array}$ & $\begin{array}{l}\text { Nivel Estático } \\
(\mathrm{m})\end{array}$ & $\begin{array}{c}\text { Oxigênio } \\
\text { Dissolvido } \\
\text { (mg/L) }\end{array}$ \\
\hline & & & & & & & \\
\hline & & & & & & & \\
\hline & & & & & & & \\
\hline & & & & & & & \\
\hline & & & & & & & \\
\hline & & & & & & & \\
\hline & Observaches & & & & & & \\
\hline
\end{tabular}

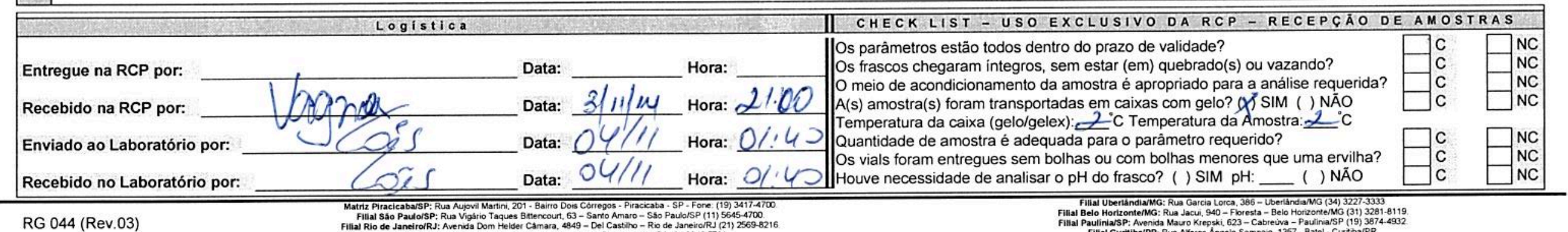




\section{EII믐ㅁㅁ}

A $M$ M 8 i E E N T A A L

Cadeia de Custódia - CC

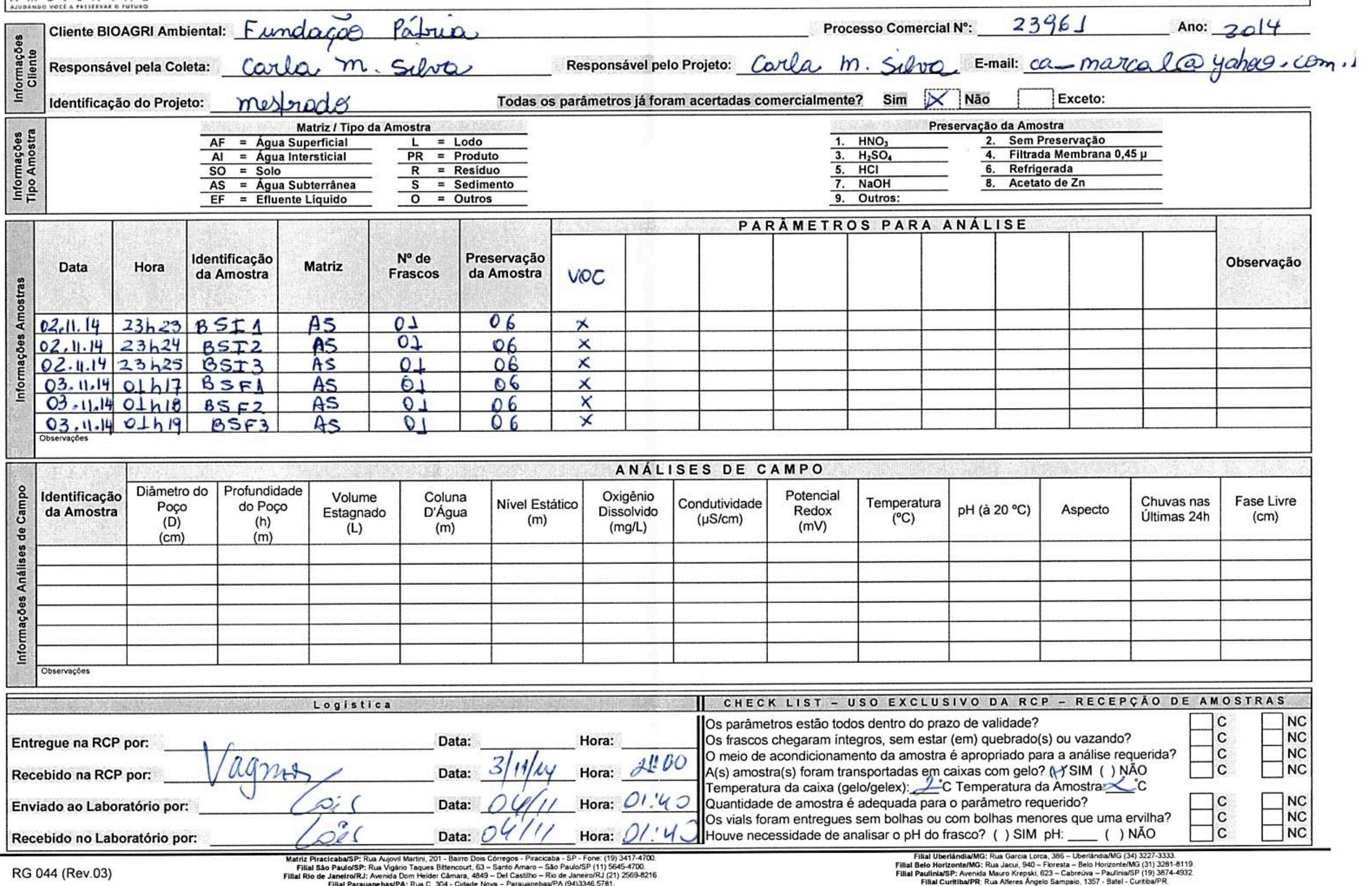




\section{비마데

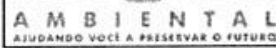

\section{Cadeia de Custódia - CC}

- Cliente BIOAGRI Ambiental: Fundaçao Pátrua

Processo Comercial N: $2396 \mathrm{~J}$ Ano: 2014

Responsável pela Coleta: carla $m$. Suher Identificação do Projeto: mestrodo Responsável pelo Projeto: carla.m. Silva E-mail:cammarcal@yahoo.com.br

\section{If $\quad$ Matriz / Tipo da Amostra}

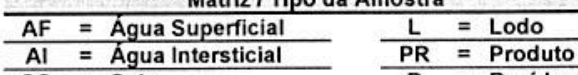
$\mathrm{SO}=$ Solo $\quad R=$ Residuo \begin{tabular}{ll} 
AS $=$ Água Subterrånea & $\mathrm{S}=$ Sedime \\
\hline $\mathrm{EF}$ & $=$ Efluente Liquido \\
\hline
\end{tabular} Todas os parâmetros já foram acertadas comercialmente? Sim $X]$ Năo $\square$ Exceto:

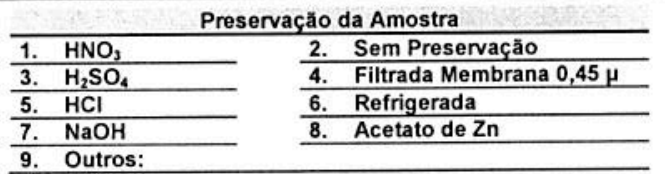

\begin{tabular}{|l|l|l|l|l|l|}
\hline & & & & & PARÁMETROS PARA ANÁLISE
\end{tabular}

\begin{tabular}{|c|c|c|c|}
\hline Data & Hora & $\begin{array}{l}\text { da Amostra } \\
\text { daticacao }\end{array}$ & Matriz \\
\hline 02.11 .14 & 22458 & $B A I 1$ & As \\
\hline $02,11.14$ & 22559 & BAI 2 & AS \\
\hline $02,11,14$ & $27 h 00$ & $B A I 3$ & AS \\
\hline 03.11 .14 & $20 h 52$ & $B A F \mid$ & AS \\
\hline $03,11,14$ & $00 h 53$ & $B A F 2$ & AS \\
\hline $03,11.14$ & $\infty h 54$ & $B A F 3$ & AS \\
\hline
\end{tabular}

Frascos $\quad \begin{gathered}\text { Preservação } \\ \text { da Amostra }\end{gathered}$

\begin{tabular}{l|l|l} 
& & VoC \\
\hline 01 & 06 & $x$ \\
01 & 06 & $x$ \\
01 & 06 & $x$ \\
01 & 06 & $x$ \\
01 & 06 & $x$ \\
01 & 06 & $x$
\end{tabular}

\section{|}

\begin{tabular}{|c|c|c|c|c|c|c|c|c|}
\hline \multirow[b]{2}{*}{$\begin{array}{l}\circ \\
\text { है } \\
\text { हैं } \\
\text { : }\end{array}$} & \multirow[b]{2}{*}{$\begin{array}{l}\text { Identificação } \\
\text { da Amostra }\end{array}$} & \multicolumn{7}{|c|}{ ANÁLISE } \\
\hline & & $\begin{array}{l}\text { Diâmetro do } \\
\text { Poço } \\
\text { (D) } \\
\text { (cm) }\end{array}$ & $\begin{array}{l}\text { Profundidade } \\
\text { do Poço } \\
\text { (h) } \\
\text { (m) }\end{array}$ & $\begin{array}{l}\text { Volume } \\
\text { Estagnado } \\
\text { (L) }\end{array}$ & $\begin{array}{c}\text { Coluna } \\
\text { D'Água } \\
\text { (m) }\end{array}$ & $\begin{array}{l}\text { Nivel Estático } \\
(\mathrm{m})\end{array}$ & $\begin{array}{l}\text { Oxigênio } \\
\text { Dissolvido } \\
\text { (mg/L) }\end{array}$ & Co \\
\hline 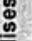 & & & & & & & & \\
\hline 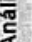 & & & & & & & & \\
\hline 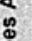 & & & & & & & & \\
\hline (ِّ & & & & & & & & \\
\hline छّ & & & & & & & & \\
\hline 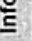 & & & & & & & & \\
\hline & Doservaçdes & & & & & & & \\
\hline
\end{tabular}

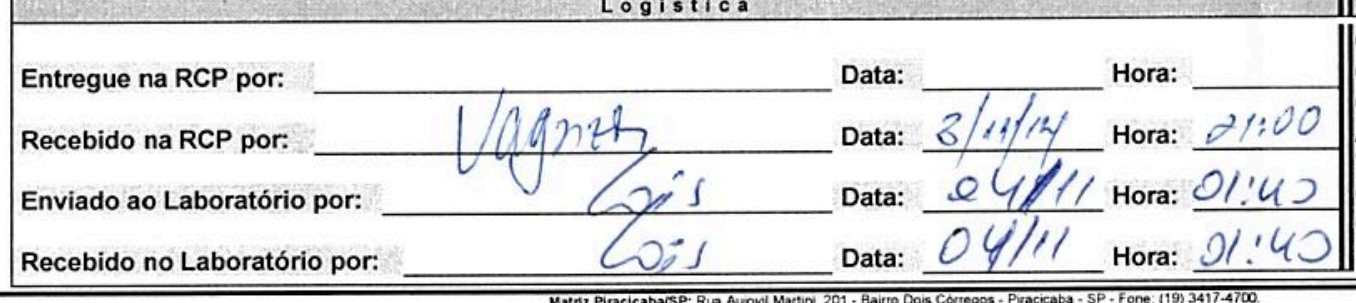

RG 044 (Rev.03)

meio de acondicionamento da amostra e apropriado para a análise requerida?

A(s) amostra(s) foram transportadas em caixas com gelo? () SIM ( ) NAO

Quantidade de amostra é adequada para o parâmetro requerido?

s vials foram entregues sem bolhas ou com bolhas menores que uma ervilha? Houve necessidade de analisar o pH do frasco? () SIM pH: ( ) NÄO

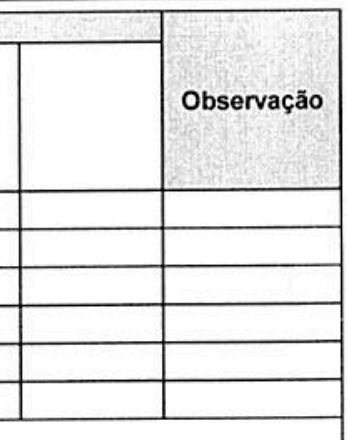

ervação

Potencial

S $/ \mathrm{cm}) \quad$ Redox

\begin{tabular}{|c|c|c|c|c|}
\hline $\begin{array}{c}\text { Temperatura } \\
\left({ }^{\circ} \mathrm{C}\right)\end{array}$ & $\mathrm{pH}\left({\left.\mathrm{à} 20^{\circ} \mathrm{C}\right)}^{\circ}\right.$ & Aspecto & $\begin{array}{c}\text { Chuvas nas } \\
\text { Ültimas 24h }\end{array}$ & $\begin{array}{c}\text { Fase Livre } \\
(\mathrm{cm})\end{array}$ \\
\hline & & & & \\
\hline & & & & \\
\hline & & & & \\
\hline & & & & \\
\hline & & & & \\
\hline
\end{tabular}




\section{RELATÓRIO DE ENSAIO N $^{\circ}$ 292978/2014-0 - Piracicaba} Processo Comercial $N^{\circ}$ 23961/2014-2

\begin{tabular}{|l|l|}
\hline \multicolumn{2}{|c|}{ DADOS REFERENTES AO CLIENTE } \\
\hline Empresa solicitante: & Fundacao Parque de Alta Tecnologia da Regiao de Ipero e Adjacencias \\
\hline Endereço: & Rua Jose Antonio Scaciota, 165 - - Portal do Cedro - Iperó - SP - CEP: 18.560-000 . \\
\hline Nome do Solicitante: & Carla Marçal \\
\hline
\end{tabular}

\section{DADOS REFERENTES A AMOSTRA}

Identificação do Cliente: Amostra Rotulada como:

Coletor:

BGBI 1

Data da entrada no laboratório:

Água Subterrânea Projeto Mestrado Interessado

\begin{tabular}{l|l} 
Data da coleta: & $02 / 11 / 201422: 29: 00$
\end{tabular}

\section{RESULTADOS PARA A AMOSTRA}

\begin{tabular}{|c|c|c|c|c|c|c|}
\hline Parâmetros & CAS & Unidade & LQ & Resultados analíticos & Incerteza & Data do Ensaio \\
\hline 1,1,1-Tricloroetano & $71-55-6$ & $\mu \mathrm{g} / \mathrm{L}$ & 1 & $<1$ & n.a. & 13/11/2014 01:15 \\
\hline 1,1,2-Tricloroetano & $79-00-5$ & $\mu \mathrm{g} / \mathrm{L}$ & 1 & $<1$ & n.a. & 13/11/2014 01:15 \\
\hline 1,1,2,2-Tetracloroetano & $79-34-5$ & $\mu \mathrm{g} / \mathrm{L}$ & 1 & $<1$ & n.a. & 13/11/2014 01:15 \\
\hline 1,1-Dicloroetano & $75-34-3$ & $\mu \mathrm{g} / \mathrm{L}$ & 1 & $<1$ & n.a. & 13/11/2014 01:15 \\
\hline 1,1-Dicloroeteno & $75-35-4$ & $\mu \mathrm{g} / \mathrm{L}$ & 1 & $<1$ & n.a. & 13/11/2014 01:15 \\
\hline 1,1-Dicloropropeno & $563-58-6$ & $\mu \mathrm{g} / \mathrm{L}$ & 1 & $<1$ & n.a. & 13/11/2014 01:15 \\
\hline 1,2,3-Triclorobenzeno & $87-61-6$ & $\mu \mathrm{g} / \mathrm{L}$ & 1 & $<1$ & n.a. & 13/11/2014 01:15 \\
\hline 1,2,4-Triclorobenzeno & $120-82-1$ & $\mu \mathrm{g} / \mathrm{L}$ & 1 & $<1$ & n.a. & 13/11/2014 01:15 \\
\hline 1,2-Dibromo-3-Cloropropano & $96-12-8$ & $\mu \mathrm{g} / \mathrm{L}$ & 5 & $<5$ & n.a. & 13/11/2014 01:15 \\
\hline 1,2-Dicloroetano & $107-06-2$ & $\mu \mathrm{g} / \mathrm{L}$ & 1 & $<1$ & n.a. & 13/11/2014 01:15 \\
\hline 1,2-Dicloropropano & $78-87-5$ & $\mu \mathrm{g} / \mathrm{L}$ & 1 & $<1$ & n.a. & 13/11/2014 01:15 \\
\hline 1,3-Dicloropropano & $142-28-9$ & $\mu \mathrm{g} / \mathrm{L}$ & 5 & $<5$ & n.a. & 13/11/2014 01:15 \\
\hline 1,4-Diclorobenzeno & $106-46-7$ & $\mu \mathrm{g} / \mathrm{L}$ & 1 & $<1$ & n.a. & 13/11/2014 01:15 \\
\hline 2,2-Dicloropropano & $594-20-7$ & $\mu \mathrm{g} / \mathrm{L}$ & 1 & $<1$ & n.a. & $13 / 11 / 201401: 15$ \\
\hline 4-Metil-2-Pentanona & $108-10-1$ & $\mu \mathrm{g} / \mathrm{L}$ & 5 & $<5$ & n.a. & 13/11/2014 01:15 \\
\hline Benzeno & $71-43-2$ & $\mu \mathrm{g} / \mathrm{L}$ & 1 & $<1$ & n.a. & 13/11/2014 01:15 \\
\hline Bromobenzeno & $108-86-1$ & $\mu \mathrm{g} / \mathrm{L}$ & 1 & $<1$ & n.a. & 13/11/2014 01:15 \\
\hline Bromodiclorometano & $75-27-4$ & $\mu \mathrm{g} / \mathrm{L}$ & 1 & $<1$ & n.a. & 13/11/2014 01:15 \\
\hline Bromofórmio & $75-25-2$ & $\mu \mathrm{g} / \mathrm{L}$ & 1 & $<1$ & n.a. & $13 / 11 / 201401: 15$ \\
\hline Bromoclorometano & $74-97-5$ & $\mu \mathrm{g} / \mathrm{L}$ & 5 & $<5$ & n.a. & 13/11/2014 01:15 \\
\hline Cis-1,2-Dicloroeteno & $156-59-2$ & $\mu \mathrm{g} / \mathrm{L}$ & 1 & $<1$ & n.a. & 13/11/2014 01:15 \\
\hline Cis-1,3-Dicloropropeno & $10061-01-5$ & $\mu \mathrm{g} / \mathrm{L}$ & 1 & $<1$ & n.a. & 13/11/2014 01:15 \\
\hline Diclorometano & $75-09-2$ & $\mu \mathrm{g} / \mathrm{L}$ & 1 & $<1$ & n.a. & 13/11/2014 01:15 \\
\hline Cloreto de Vinila & $75-01-4$ & $\mu \mathrm{g} / \mathrm{L}$ & 1 & $<1$ & n.a. & 13/11/2014 01:15 \\
\hline Clorobenzeno & $108-90-7$ & $\mu \mathrm{g} / \mathrm{L}$ & 1 & $<1$ & n.a. & 13/11/2014 01:15 \\
\hline Cloroetano & $75-00-3$ & $\mu \mathrm{g} / \mathrm{L}$ & 1 & $<1$ & n.a. & 13/11/2014 01:15 \\
\hline Clorofórmio & $67-66-3$ & $\mu \mathrm{g} / \mathrm{L}$ & 1 & $<1$ & n.a. & 13/11/2014 01:15 \\
\hline Clorometano & $74-87-3$ & $\mu \mathrm{g} / \mathrm{L}$ & 10 & $<10$ & n.a. & 13/11/2014 01:15 \\
\hline Dibromoclorometano & $124-48-1$ & $\mu \mathrm{g} / \mathrm{L}$ & 1 & $<1$ & n.a. & 13/11/2014 01:15 \\
\hline Dissulfeto de Carbono & $75-15-0$ & $\mu \mathrm{g} / \mathrm{L}$ & 1 & $<1$ & n.a. & 13/11/2014 01:15 \\
\hline Estireno & $100-42-5$ & $\mu \mathrm{g} / \mathrm{L}$ & 1 & $<1$ & n.a. & $13 / 11 / 201401: 15$ \\
\hline Etilbenzeno & $100-41-4$ & $\mu \mathrm{g} / \mathrm{L}$ & 1 & $<1$ & n.a. & 13/11/2014 01:15 \\
\hline Hexaclorobutadieno & $87-68-3$ & $\mu \mathrm{g} / \mathrm{L}$ & 1 & $<1$ & n.a. & 13/11/2014 01:15 \\
\hline m,p-Xilenos & --- & $\mu \mathrm{g} / \mathrm{L}$ & 2 & $<2$ & n.a. & 13/11/2014 01:15 \\
\hline o-Xileno & $95-47-6$ & $\mu \mathrm{g} / \mathrm{L}$ & 1 & $<1$ & n.a. & 13/11/2014 01:15 \\
\hline p-Isopropiltolueno & $99-87-6$ & $\mu \mathrm{g} / \mathrm{L}$ & 1 & $<1$ & n.a. & 13/11/2014 01:15 \\
\hline Tetracloreto de Carbono & $56-23-5$ & $\mu \mathrm{g} / \mathrm{L}$ & 1 & $<1$ & n.a. & 13/11/2014 01:15 \\
\hline Tetracloroeteno & $127-18-4$ & $\mu \mathrm{g} / \mathrm{L}$ & 1 & 9,7 & 1,8 & 13/11/2014 01:15 \\
\hline Tolueno & $108-88-3$ & $\mu \mathrm{g} / \mathrm{L}$ & 1 & $<1$ & n.a. & 13/11/2014 01:15 \\
\hline Trans-1,2-Dicloroeteno & $156-60-5$ & $\mu \mathrm{g} / \mathrm{L}$ & 1 & $<1$ & n.a. & 13/11/2014 01:15 \\
\hline Tricloroeteno & $79-01-6$ & $\mu \mathrm{g} / \mathrm{L}$ & 1 & $<1$ & n.a. & 13/11/2014 01:15 \\
\hline 1,1,1,2-Tetracloroetano & $630-20-6$ & $\mu \mathrm{g} / \mathrm{L}$ & 1 & $<1$ & n.a. & 13/11/2014 01:15 \\
\hline
\end{tabular}




\begin{tabular}{|c|c|c|c|c|c|c|}
\hline Parâmetros & CAS & Unidade & LQ & Resultados analíticos & Incerteza & Data do Ensaio \\
\hline 1,2,3-Tricloropropano & $96-18-4$ & $\mu \mathrm{g} / \mathrm{L}$ & 5 & $<5$ & n.a. & 13/11/2014 01:15 \\
\hline 1,3,5-Trimetilbenzeno & $108-67-8$ & $\mu \mathrm{g} / \mathrm{L}$ & 1 & $<1$ & n.a. & 13/11/2014 01:15 \\
\hline 1,2,4-Trimetilbenzeno & $95-63-6$ & $\mu \mathrm{g} / \mathrm{L}$ & 1 & $<1$ & n.a. & 13/11/2014 01:15 \\
\hline 1,2-Dibromoetano & $106-93-4$ & $\mu \mathrm{g} / \mathrm{L}$ & 1 & $<1$ & n.a. & 13/11/2014 01:15 \\
\hline 1,2-Diclorobenzeno & $95-50-1$ & $\mu \mathrm{g} / \mathrm{L}$ & 1 & $<1$ & n.a. & 13/11/2014 01:15 \\
\hline 1,3-Diclorobenzeno & $541-73-1$ & $\mu \mathrm{g} / \mathrm{L}$ & 1 & $<1$ & n.a. & 13/11/2014 01:15 \\
\hline 2-Clorotolueno & $95-49-8$ & $\mu \mathrm{g} / \mathrm{L}$ & 1 & $<1$ & n.a. & 13/11/2014 01:15 \\
\hline Dibromometano & $74-95-3$ & $\mu \mathrm{g} / \mathrm{L}$ & 1 & $<1$ & n.a. & 13/11/2014 01:15 \\
\hline Metiletilcetona & $78-93-3$ & $\mu \mathrm{g} / \mathrm{L}$ & 2500 & $<2500$ & n.a. & 13/11/2014 01:15 \\
\hline Naftaleno & $91-20-3$ & $\mu \mathrm{g} / \mathrm{L}$ & 1 & $<1$ & n.a. & 13/11/2014 01:15 \\
\hline n-Butilbenzeno & $104-51-8$ & $\mu \mathrm{g} / \mathrm{L}$ & 1 & $<1$ & n.a. & 13/11/2014 01:15 \\
\hline n-Propilbenzeno & $103-65-1$ & $\mu \mathrm{g} / \mathrm{L}$ & 1 & $<1$ & n.a. & 13/11/2014 01:15 \\
\hline 4-Clorotolueno & $106-43-4$ & $\mu \mathrm{g} / \mathrm{L}$ & 1 & $<1$ & n.a. & 13/11/2014 01:15 \\
\hline sec-Butilbenzeno & $135-98-8$ & $\mu \mathrm{g} / \mathrm{L}$ & 1 & $<1$ & n.a. & 13/11/2014 01:15 \\
\hline terc-Butilbenzeno & $98-06-6$ & $\mu \mathrm{g} / \mathrm{L}$ & 1 & $<1$ & n.a. & 13/11/2014 01:15 \\
\hline trans-1,3-Dicloropropeno & $10061-02-6$ & $\mu \mathrm{g} / \mathrm{L}$ & 1 & $<1$ & n.a. & 13/11/2014 01:15 \\
\hline Isopropilbenzeno & $98-82-8$ & $\mu \mathrm{g} / \mathrm{L}$ & 1 & $<1$ & n.a. & 13/11/2014 01:15 \\
\hline 1,3,5-Triclorobenzeno & $108-70-3$ & $\mu \mathrm{g} / \mathrm{L}$ & 1 & $<1$ & n.a. & 13/11/2014 01:15 \\
\hline
\end{tabular}

\section{CONTROLE DE QUALIDADE DO LABORATÓRIO}

302692/2014-0 - Branco de Análise - VOC - Água

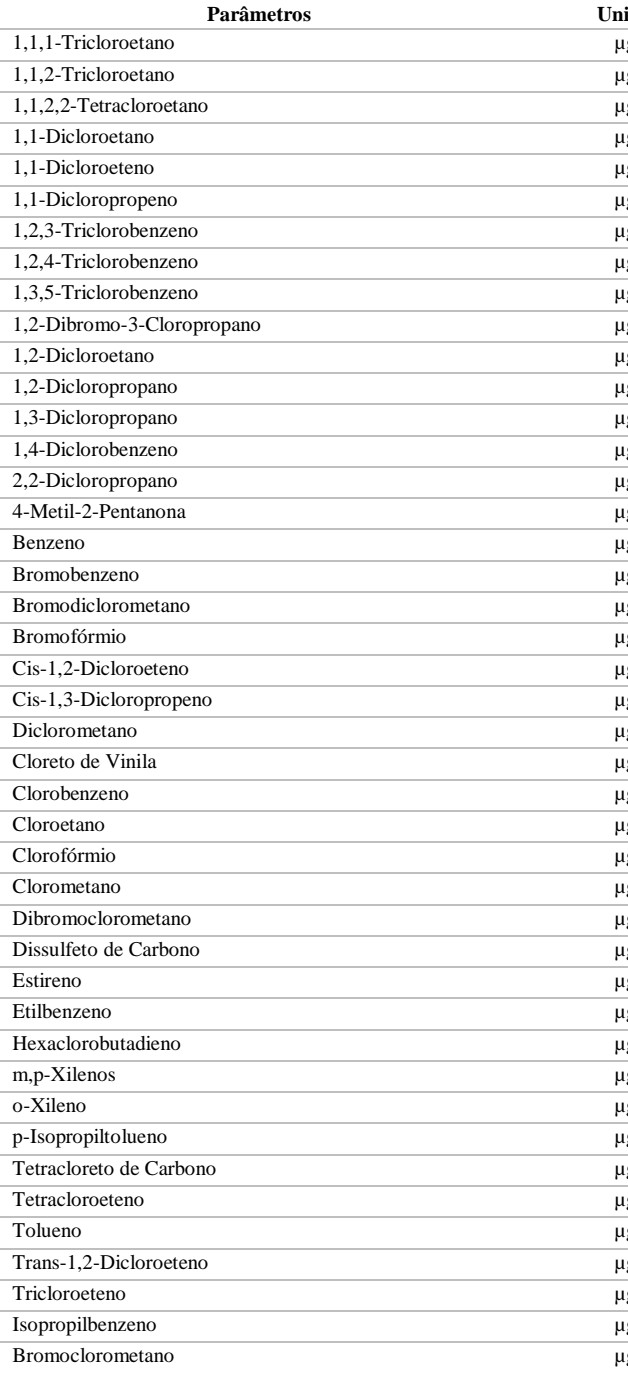

Controle de Qualidade - VOC - Água

\begin{tabular}{|c|c|c|}
\hline Unidade & LQ & Resultados analíticos \\
\hline$\mu \mathrm{g} / \mathrm{L}$ & 1 & $<1$ \\
\hline$\mu \mathrm{g} / \mathrm{L}$ & 1 & $<1$ \\
\hline$\mu \mathrm{g} / \mathrm{L}$ & 1 & $<1$ \\
\hline$\mu \mathrm{g} / \mathrm{L}$ & 1 & $<1$ \\
\hline$\mu \mathrm{g} / \mathrm{L}$ & 1 & $<1$ \\
\hline$\mu \mathrm{g} / \mathrm{L}$ & 1 & $<1$ \\
\hline$\mu \mathrm{g} / \mathrm{L}$ & 1 & $<1$ \\
\hline$\mu \mathrm{g} / \mathrm{L}$ & 1 & $<1$ \\
\hline$\mu \mathrm{g} / \mathrm{L}$ & 1 & $<1$ \\
\hline$\mu \mathrm{g} / \mathrm{L}$ & 5 & $<5$ \\
\hline$\mu \mathrm{g} / \mathrm{L}$ & 1 & $<1$ \\
\hline$\mu \mathrm{g} / \mathrm{L}$ & 1 & $<1$ \\
\hline$\mu \mathrm{g} / \mathrm{L}$ & 5 & $<5$ \\
\hline$\mu \mathrm{g} / \mathrm{L}$ & 1 & $<1$ \\
\hline$\mu \mathrm{g} / \mathrm{L}$ & 1 & $<1$ \\
\hline$\mu \mathrm{g} / \mathrm{L}$ & 5 & $<5$ \\
\hline$\mu \mathrm{g} / \mathrm{L}$ & 1 & $<1$ \\
\hline$\mu \mathrm{g} / \mathrm{L}$ & 1 & $<1$ \\
\hline$\mu \mathrm{g} / \mathrm{L}$ & 1 & $<1$ \\
\hline$\mu \mathrm{g} / \mathrm{L}$ & 1 & $<1$ \\
\hline$\mu \mathrm{g} / \mathrm{L}$ & 1 & $<1$ \\
\hline$\mu \mathrm{g} / \mathrm{L}$ & 1 & $<1$ \\
\hline$\mu \mathrm{g} / \mathrm{L}$ & 1 & $<1$ \\
\hline$\mu \mathrm{g} / \mathrm{L}$ & 1 & $<1$ \\
\hline$\mu \mathrm{g} / \mathrm{L}$ & 1 & $<1$ \\
\hline$\mu \mathrm{g} / \mathrm{L}$ & 1 & $<1$ \\
\hline$\mu \mathrm{g} / \mathrm{L}$ & 1 & $<1$ \\
\hline$\mu \mathrm{g} / \mathrm{L}$ & 10 & $<10$ \\
\hline$\mu \mathrm{g} / \mathrm{L}$ & 1 & $<1$ \\
\hline$\mu \mathrm{g} / \mathrm{L}$ & 1 & $<1$ \\
\hline$\mu \mathrm{g} / \mathrm{L}$ & 1 & $<1$ \\
\hline$\mu \mathrm{g} / \mathrm{L}$ & 1 & $<1$ \\
\hline$\mu \mathrm{g} / \mathrm{L}$ & 1 & $<1$ \\
\hline$\mu \mathrm{g} / \mathrm{L}$ & 2 & $<2$ \\
\hline$\mu \mathrm{g} / \mathrm{L}$ & 1 & $<1$ \\
\hline$\mu \mathrm{g} / \mathrm{L}$ & 1 & $<1$ \\
\hline$\mu \mathrm{g} / \mathrm{L}$ & 1 & $<1$ \\
\hline$\mu \mathrm{g} / \mathrm{L}$ & 1 & $<1$ \\
\hline$\mu \mathrm{g} / \mathrm{L}$ & 1 & $<1$ \\
\hline$\mu \mathrm{g} / \mathrm{L}$ & 1 & $<1$ \\
\hline$\mu \mathrm{g} / \mathrm{L}$ & 1 & $<1$ \\
\hline$\mu \mathrm{g} / \mathrm{L}$ & 1 & $<1$ \\
\hline$\mu \mathrm{g} / \mathrm{L}$ & 5 & $<5$ \\
\hline
\end{tabular}




\begin{tabular}{|c|c|c|c|c|}
\hline Parâmetros & $\begin{array}{l}\text { Quantidade } \\
\text { Adicionada }\end{array}$ & Unidade & $\begin{array}{c}\text { Resultado da } \\
\text { Recuperação (\%) }\end{array}$ & Faixa Aceitável de Recuperação (\%) \\
\hline \multicolumn{5}{|c|}{ 302694/2014-0 - Amostra Controle - VOC - Água } \\
\hline 1,1-Dicloroeteno & 20 & $\mu \mathrm{g} / \mathrm{L}$ & 100 & $70-130$ \\
\hline Benzeno & 20 & $\mu \mathrm{g} / \mathrm{L}$ & 125 & $70-130$ \\
\hline Tricloroeteno & 20 & $\mu \mathrm{g} / \mathrm{L}$ & 110 & $70-130$ \\
\hline Tolueno & 20 & $\mu \mathrm{g} / \mathrm{L}$ & 95 & $70-130$ \\
\hline Clorobenzeno & 20 & $\mu \mathrm{g} / \mathrm{L}$ & 105 & $70-130$ \\
\hline \multicolumn{5}{|c|}{$\begin{array}{l}\text { Surrogates } \\
\text { 302692/2014-0 - Branco de Análise - VOC - Água }\end{array}$} \\
\hline p-Bromofluorbenzeno & 20 & $\%$ & 76,5 & $70-130$ \\
\hline Dibromofluorometano & 20 & $\%$ & 130 & $70-130$ \\
\hline \multicolumn{5}{|c|}{ 302694/2014-0 - Amostra Controle - VOC - Água } \\
\hline p-Bromofluorbenzeno & 20 & $\%$ & 78,6 & $70-130$ \\
\hline Dibromofluorometano & 20 & $\%$ & 130 & $70-130$ \\
\hline \multicolumn{5}{|l|}{ 292978/2014-0 - BGBI 1} \\
\hline Dibromofluorometano & 20 & $\%$ & 70,0 & $70-130$ \\
\hline p-Bromofluorbenzeno & 20 & $\%$ & 72,6 & $70-130$ \\
\hline
\end{tabular}

Notas

LQ = Limite de Quantificação.

n.a. = Não Aplicável.

Abrangência

$\mathrm{O}(\mathrm{s})$ resultado(s) referem-se somente à(s) amostra(s) analisada(s).

Este Relatório de Ensaio só pode ser reproduzido por inteiro e sem nenhuma alteração.

Plano de Amostragem

Plano de amostragem de responsabilidade do interessado.

Responsabilidade Técnica

Os ensaios foram realizados na unidade da Bioagri Ambiental Ltda. - Matriz, situada na Rua Aljovil Martini, 177/201, Bairro Dois Córregos, Cep. 14420-833, Piracicaba/SP, registrada no CRQ 4 Região sob n⿳亠丷厂 $16082-\mathrm{F}$ e responsabilidade técnica do profissional Marcos Donizete Ceccatto, CRQ n ${ }^{\circ} 04364387,4^{\mathrm{a}}$.Região.

Referências Metodológicas

Análises foram realizadas conforme a última versão do Standard Methods for the Examination of Water \& Wastewater 22nd 2012(SMWW), EPA e ABNT (quando aplicável). VOC: EPA 8260 C: 2006, 5021A: 2003

Metiletilcetona: EPA 8260 C: 2006, 5021 A: 2003

Revisores

Débora Fernandes da Silva

Chave de Validação: 0411a85d6eb9b5322b43fd661442b2d6
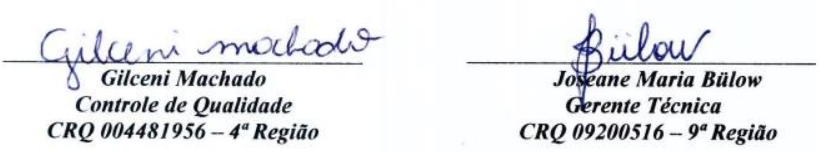


\section{RELATÓRIO DE ENSAIO N ${ }^{\circ}$ 292979/2014-0 - Piracicaba Processo Comercial $N^{\circ}$ 23961/2014-2}

\begin{tabular}{|l|l|}
\hline \multicolumn{2}{|c|}{ DADOS REFERENTES AO CLIENTE } \\
\hline Empresa solicitante: & Fundacao Parque de Alta Tecnologia da Regiao de Ipero e Adjacencias \\
\hline Endereço: & Rua Jose Antonio Scaciota, 165 - - Portal do Cedro - Iperó - SP - CEP: 18.560-000 . \\
\hline Nome do Solicitante: & Carla Marçal \\
\hline
\end{tabular}

\section{DADOS REFERENTES A AMOSTRA}

Identificação do Cliente: Amostra Rotulada como:

Coletor:

BGBI 2

Data da entrada no laboratório:

Água Subterrânea Projeto Mestrado Interessado

\begin{tabular}{l|l} 
Data da coleta: & $02 / 11 / 2014$ 22:30:00
\end{tabular}

\section{RESULTADOS PARA A AMOSTRA}

\begin{tabular}{|c|c|c|c|c|c|c|}
\hline Parâmetros & CAS & Unidade & LQ & Resultados analíticos & Incerteza & Data do Ensaio \\
\hline 1,1,1-Tricloroetano & $71-55-6$ & $\mu \mathrm{g} / \mathrm{L}$ & 1 & $<1$ & n.a. & $13 / 11 / 201405: 43$ \\
\hline 1,1,2-Tricloroetano & $79-00-5$ & $\mu \mathrm{g} / \mathrm{L}$ & 1 & $<1$ & n.a. & 13/11/2014 05:43 \\
\hline 1,1,2,2-Tetracloroetano & $79-34-5$ & $\mu \mathrm{g} / \mathrm{L}$ & 1 & $<1$ & n.a. & $13 / 11 / 201405: 43$ \\
\hline 1,1-Dicloroetano & $75-34-3$ & $\mu \mathrm{g} / \mathrm{L}$ & 1 & $<1$ & n.a. & $13 / 11 / 201405: 43$ \\
\hline 1,1-Dicloroeteno & $75-35-4$ & $\mu \mathrm{g} / \mathrm{L}$ & 1 & $<1$ & n.a. & 13/11/2014 05:43 \\
\hline 1,1-Dicloropropeno & $563-58-6$ & $\mu \mathrm{g} / \mathrm{L}$ & 1 & $<1$ & n.a. & $13 / 11 / 201405: 43$ \\
\hline 1,2,3-Triclorobenzeno & $87-61-6$ & $\mu \mathrm{g} / \mathrm{L}$ & 1 & $<1$ & n.a. & $13 / 11 / 201405: 43$ \\
\hline 1,2,4-Triclorobenzeno & $120-82-1$ & $\mu \mathrm{g} / \mathrm{L}$ & 1 & $<1$ & n.a. & 13/11/2014 05:43 \\
\hline 1,2-Dibromo-3-Cloropropano & $96-12-8$ & $\mu \mathrm{g} / \mathrm{L}$ & 5 & $<5$ & n.a. & $13 / 11 / 201405: 43$ \\
\hline 1,2-Dicloroetano & $107-06-2$ & $\mu \mathrm{g} / \mathrm{L}$ & 1 & $<1$ & n.a. & 13/11/2014 05:43 \\
\hline 1,2-Dicloropropano & $78-87-5$ & $\mu \mathrm{g} / \mathrm{L}$ & 1 & $<1$ & n.a. & 13/11/2014 05:43 \\
\hline 1,3-Dicloropropano & $142-28-9$ & $\mu \mathrm{g} / \mathrm{L}$ & 5 & $<5$ & n.a. & 13/11/2014 05:43 \\
\hline 1,4-Diclorobenzeno & $106-46-7$ & $\mu \mathrm{g} / \mathrm{L}$ & 1 & $<1$ & n.a. & $13 / 11 / 201405: 43$ \\
\hline 2,2-Dicloropropano & $594-20-7$ & $\mu \mathrm{g} / \mathrm{L}$ & 1 & $<1$ & n.a. & $13 / 11 / 201405: 43$ \\
\hline 4-Metil-2-Pentanona & $108-10-1$ & $\mu \mathrm{g} / \mathrm{L}$ & 5 & $<5$ & n.a. & 13/11/2014 05:43 \\
\hline Benzeno & $71-43-2$ & $\mu \mathrm{g} / \mathrm{L}$ & 1 & $<1$ & n.a. & 13/11/2014 05:43 \\
\hline Bromobenzeno & $108-86-1$ & $\mu \mathrm{g} / \mathrm{L}$ & 1 & $<1$ & n.a. & 13/11/2014 05:43 \\
\hline Bromodiclorometano & $75-27-4$ & $\mu \mathrm{g} / \mathrm{L}$ & 1 & $<1$ & n.a. & $13 / 11 / 201405: 43$ \\
\hline Bromofórmio & $75-25-2$ & $\mu \mathrm{g} / \mathrm{L}$ & 1 & $<1$ & n.a. & $13 / 11 / 201405: 43$ \\
\hline Bromoclorometano & $74-97-5$ & $\mu \mathrm{g} / \mathrm{L}$ & 5 & $<5$ & n.a. & $13 / 11 / 201405: 43$ \\
\hline Cis-1,2-Dicloroeteno & $156-59-2$ & $\mu \mathrm{g} / \mathrm{L}$ & 1 & $<1$ & n.a. & 13/11/2014 05:43 \\
\hline Cis-1,3-Dicloropropeno & $10061-01-5$ & $\mu \mathrm{g} / \mathrm{L}$ & 1 & $<1$ & n.a. & 13/11/2014 05:43 \\
\hline Diclorometano & $75-09-2$ & $\mu \mathrm{g} / \mathrm{L}$ & 1 & $<1$ & n.a. & $13 / 11 / 201405: 43$ \\
\hline Cloreto de Vinila & $75-01-4$ & $\mu \mathrm{g} / \mathrm{L}$ & 1 & $<1$ & n.a. & $13 / 11 / 201405: 43$ \\
\hline Clorobenzeno & $108-90-7$ & $\mu \mathrm{g} / \mathrm{L}$ & 1 & $<1$ & n.a. & $13 / 11 / 201405: 43$ \\
\hline Cloroetano & $75-00-3$ & $\mu \mathrm{g} / \mathrm{L}$ & 1 & $<1$ & n.a. & 13/11/2014 05:43 \\
\hline Clorofórmio & $67-66-3$ & $\mu \mathrm{g} / \mathrm{L}$ & 1 & $<1$ & n.a. & 13/11/2014 05:43 \\
\hline Clorometano & $74-87-3$ & $\mu \mathrm{g} / \mathrm{L}$ & 10 & $<10$ & n.a. & $13 / 11 / 2014$ 05:43 \\
\hline Dibromoclorometano & $124-48-1$ & $\mu \mathrm{g} / \mathrm{L}$ & 1 & $<1$ & n.a. & 13/11/2014 05:43 \\
\hline Dissulfeto de Carbono & $75-15-0$ & $\mu \mathrm{g} / \mathrm{L}$ & 1 & $<1$ & n.a. & $13 / 11 / 201405: 43$ \\
\hline Estireno & $100-42-5$ & $\mu \mathrm{g} / \mathrm{L}$ & 1 & $<1$ & n.a. & 13/11/2014 05:43 \\
\hline Etilbenzeno & $100-41-4$ & $\mu \mathrm{g} / \mathrm{L}$ & 1 & $<1$ & n.a. & 13/11/2014 05:43 \\
\hline Hexaclorobutadieno & $87-68-3$ & $\mu \mathrm{g} / \mathrm{L}$ & 1 & $<1$ & n.a. & 13/11/2014 05:43 \\
\hline m,p-Xilenos & --- & $\mu \mathrm{g} / \mathrm{L}$ & 2 & $<2$ & n.a. & 13/11/2014 05:43 \\
\hline o-Xileno & $95-47-6$ & $\mu \mathrm{g} / \mathrm{L}$ & 1 & $<1$ & n.a. & $13 / 11 / 201405: 43$ \\
\hline p-Isopropiltolueno & $99-87-6$ & $\mu \mathrm{g} / \mathrm{L}$ & 1 & $<1$ & n.a. & $13 / 11 / 201405: 43$ \\
\hline Tetracloreto de Carbono & $56-23-5$ & $\mu \mathrm{g} / \mathrm{L}$ & 1 & $<1$ & n.a. & 13/11/2014 05:43 \\
\hline Tetracloroeteno & $127-18-4$ & $\mu \mathrm{g} / \mathrm{L}$ & 1 & 77,4 & 15 & 13/11/2014 05:43 \\
\hline Tolueno & $108-88-3$ & $\mu \mathrm{g} / \mathrm{L}$ & 1 & $<1$ & n.a. & $13 / 11 / 201405: 43$ \\
\hline Trans-1,2-Dicloroeteno & $156-60-5$ & $\mu \mathrm{g} / \mathrm{L}$ & 1 & $<1$ & n.a. & $13 / 11 / 201405: 43$ \\
\hline Tricloroeteno & $79-01-6$ & $\mu \mathrm{g} / \mathrm{L}$ & 1 & $<1$ & n.a. & $13 / 11 / 201405: 43$ \\
\hline 1,1,1,2-Tetracloroetano & $630-20-6$ & $\mu \mathrm{g} / \mathrm{L}$ & 1 & $<1$ & n.a. & $13 / 11 / 201405: 43$ \\
\hline
\end{tabular}




\begin{tabular}{|c|c|c|c|c|c|c|}
\hline Parâmetros & CAS & Unidade & LQ & Resultados analíticos & Incerteza & Data do Ensaio \\
\hline 1,2,3-Tricloropropano & $96-18-4$ & $\mu \mathrm{g} / \mathrm{L}$ & 5 & $<5$ & n.a. & 13/11/2014 05:43 \\
\hline 1,3,5-Trimetilbenzeno & $108-67-8$ & $\mu \mathrm{g} / \mathrm{L}$ & 1 & $<1$ & n.a. & 13/11/2014 05:43 \\
\hline 1,2,4-Trimetilbenzeno & $95-63-6$ & $\mu \mathrm{g} / \mathrm{L}$ & 1 & $<1$ & n.a. & $13 / 11 / 201405: 43$ \\
\hline 1,2-Dibromoetano & $106-93-4$ & $\mu \mathrm{g} / \mathrm{L}$ & 1 & $<1$ & n.a. & $13 / 11 / 201405: 43$ \\
\hline 1,2-Diclorobenzeno & $95-50-1$ & $\mu \mathrm{g} / \mathrm{L}$ & 1 & $<1$ & n.a. & $13 / 11 / 201405: 43$ \\
\hline 1,3-Diclorobenzeno & $541-73-1$ & $\mu \mathrm{g} / \mathrm{L}$ & 1 & $<1$ & n.a. & $13 / 11 / 201405: 43$ \\
\hline 2-Clorotolueno & $95-49-8$ & $\mu \mathrm{g} / \mathrm{L}$ & 1 & $<1$ & n.a. & $13 / 11 / 201405: 43$ \\
\hline Dibromometano & $74-95-3$ & $\mu \mathrm{g} / \mathrm{L}$ & 1 & $<1$ & n.a. & $13 / 11 / 201405: 43$ \\
\hline Metiletilcetona & 78-93-3 & $\mu \mathrm{g} / \mathrm{L}$ & 2500 & $<2500$ & n.a. & $13 / 11 / 201405: 43$ \\
\hline Naftaleno & $91-20-3$ & $\mu \mathrm{g} / \mathrm{L}$ & 1 & $<1$ & n.a. & $13 / 11 / 201405: 43$ \\
\hline n-Butilbenzeno & $104-51-8$ & $\mu \mathrm{g} / \mathrm{L}$ & 1 & $<1$ & n.a. & $13 / 11 / 201405: 43$ \\
\hline n-Propilbenzeno & $103-65-1$ & $\mu \mathrm{g} / \mathrm{L}$ & 1 & $<1$ & n.a. & 13/11/2014 05:43 \\
\hline 4-Clorotolueno & $106-43-4$ & $\mu \mathrm{g} / \mathrm{L}$ & 1 & $<1$ & n.a. & $13 / 11 / 201405: 43$ \\
\hline sec-Butilbenzeno & $135-98-8$ & $\mu \mathrm{g} / \mathrm{L}$ & 1 & $<1$ & n.a. & 13/11/2014 05:43 \\
\hline terc-Butilbenzeno & $98-06-6$ & $\mu \mathrm{g} / \mathrm{L}$ & 1 & $<1$ & n.a. & 13/11/2014 05:43 \\
\hline trans-1,3-Dicloropropeno & $10061-02-6$ & $\mu \mathrm{g} / \mathrm{L}$ & 1 & $<1$ & n.a. & $13 / 11 / 201405: 43$ \\
\hline Isopropilbenzeno & $98-82-8$ & $\mu \mathrm{g} / \mathrm{L}$ & 1 & $<1$ & n.a. & 13/11/2014 05:43 \\
\hline 1,3,5-Triclorobenzeno & $108-70-3$ & $\mu \mathrm{g} / \mathrm{L}$ & 1 & $<1$ & n.a. & 13/11/2014 05:43 \\
\hline
\end{tabular}

\section{CONTROLE DE QUALIDADE DO LABORATÓRIO}

302692/2014-0 - Branco de Análise - VOC - Água

\begin{tabular}{|c|c|}
\hline \multirow{2}{*}{\multicolumn{2}{|c|}{$\begin{array}{ll} & \text { Parâmetros } \\
1,1,1-\text { Tricloroetano } & \end{array}$}} \\
\hline & \\
\hline \multicolumn{2}{|l|}{ 1,1,2-Tricloroetano } \\
\hline \multicolumn{2}{|l|}{ 1,1,2,2-Tetracloroetano } \\
\hline \multicolumn{2}{|l|}{ 1,1-Dicloroetano } \\
\hline \multicolumn{2}{|l|}{ 1,1-Dicloroeteno } \\
\hline \multicolumn{2}{|l|}{ 1,1-Dicloropropeno } \\
\hline \multicolumn{2}{|l|}{ 1,2,3-Triclorobenzeno } \\
\hline \multicolumn{2}{|l|}{ 1,2,4-Triclorobenzeno } \\
\hline \multicolumn{2}{|l|}{ 1,3,5-Triclorobenzeno } \\
\hline \multicolumn{2}{|l|}{ 1,2-Dibromo-3-Cloropropano } \\
\hline \multicolumn{2}{|l|}{ 1,2-Dicloroetano } \\
\hline \multicolumn{2}{|l|}{ 1,2-Dicloropropano } \\
\hline \multicolumn{2}{|l|}{ 1,3-Dicloropropano } \\
\hline \multicolumn{2}{|l|}{ 1,4-Diclorobenzeno } \\
\hline \multicolumn{2}{|l|}{ 2,2-Dicloropropano } \\
\hline \multicolumn{2}{|l|}{ 4-Metil-2-Pentanona } \\
\hline \multicolumn{2}{|l|}{ Benzeno } \\
\hline \multicolumn{2}{|l|}{ Bromobenzeno } \\
\hline \multicolumn{2}{|l|}{ Bromodiclorometano } \\
\hline \multicolumn{2}{|l|}{ Bromofórmio } \\
\hline \multicolumn{2}{|l|}{ Cis-1,2-Dicloroeteno } \\
\hline \multicolumn{2}{|l|}{ Cis-1,3-Dicloropropeno } \\
\hline \multicolumn{2}{|l|}{ Diclorometano } \\
\hline \multicolumn{2}{|l|}{ Cloreto de Vinila } \\
\hline \multicolumn{2}{|l|}{ Clorobenzeno } \\
\hline \multicolumn{2}{|l|}{ Cloroetano } \\
\hline Clorofórmio & \\
\hline Clorometano & \\
\hline Dibromoclorometano & \\
\hline Dissulfeto de Carbono & \\
\hline Estireno & \\
\hline Etilbenzeno & \\
\hline Hexaclorobutadieno & \\
\hline m,p-Xilenos & \\
\hline o-Xileno & \\
\hline p-Isopropiltolueno & \\
\hline Tetracloreto de Carbono & \\
\hline Tetracloroeteno & \\
\hline Tolueno & \\
\hline Trans-1,2-Dicloroeteno & \\
\hline Tricloroeteno & \\
\hline Isopropilbenzeno & \\
\hline Bromoclorometano & \\
\hline
\end{tabular}

Controle de Qualidade - VOC - Água

\begin{tabular}{|c|c|c|}
\hline Unidade & LQ & Resultados analíticos \\
\hline$\mu \mathrm{g} / \mathrm{L}$ & 1 & $<1$ \\
\hline$\mu \mathrm{g} / \mathrm{L}$ & 1 & $<1$ \\
\hline$\mu \mathrm{g} / \mathrm{L}$ & 1 & $<1$ \\
\hline$\mu \mathrm{g} / \mathrm{L}$ & 1 & $<1$ \\
\hline$\mu \mathrm{g} / \mathrm{L}$ & 1 & $<1$ \\
\hline$\mu \mathrm{g} / \mathrm{L}$ & 1 & $<1$ \\
\hline$\mu \mathrm{g} / \mathrm{L}$ & 1 & $<1$ \\
\hline$\mu \mathrm{g} / \mathrm{L}$ & 1 & $<1$ \\
\hline$\mu \mathrm{g} / \mathrm{L}$ & 1 & $<1$ \\
\hline$\mu \mathrm{g} / \mathrm{L}$ & 5 & $<5$ \\
\hline$\mu \mathrm{g} / \mathrm{L}$ & 1 & $<1$ \\
\hline$\mu \mathrm{g} / \mathrm{L}$ & 1 & $<1$ \\
\hline$\mu \mathrm{g} / \mathrm{L}$ & 5 & $<5$ \\
\hline$\mu \mathrm{g} / \mathrm{L}$ & 1 & $<1$ \\
\hline$\mu \mathrm{g} / \mathrm{L}$ & 1 & $<1$ \\
\hline$\mu \mathrm{g} / \mathrm{L}$ & 5 & $<5$ \\
\hline$\mu \mathrm{g} / \mathrm{L}$ & 1 & $<1$ \\
\hline$\mu \mathrm{g} / \mathrm{L}$ & 1 & $<1$ \\
\hline$\mu \mathrm{g} / \mathrm{L}$ & 1 & $<1$ \\
\hline$\mu \mathrm{g} / \mathrm{L}$ & 1 & $<1$ \\
\hline$\mu \mathrm{g} / \mathrm{L}$ & 1 & $<1$ \\
\hline$\mu \mathrm{g} / \mathrm{L}$ & 1 & $<1$ \\
\hline$\mu \mathrm{g} / \mathrm{L}$ & 1 & $<1$ \\
\hline$\mu \mathrm{g} / \mathrm{L}$ & 1 & $<1$ \\
\hline$\mu \mathrm{g} / \mathrm{L}$ & 1 & $<1$ \\
\hline$\mu \mathrm{g} / \mathrm{L}$ & 1 & $<1$ \\
\hline$\mu \mathrm{g} / \mathrm{L}$ & 1 & $<1$ \\
\hline$\mu \mathrm{g} / \mathrm{L}$ & 10 & $<10$ \\
\hline$\mu \mathrm{g} / \mathrm{L}$ & 1 & $<1$ \\
\hline$\mu \mathrm{g} / \mathrm{L}$ & 1 & $<1$ \\
\hline$\mu \mathrm{g} / \mathrm{L}$ & 1 & $<1$ \\
\hline$\mu \mathrm{g} / \mathrm{L}$ & 1 & $<1$ \\
\hline$\mu \mathrm{g} / \mathrm{L}$ & 1 & $<1$ \\
\hline$\mu \mathrm{g} / \mathrm{L}$ & 2 & $<2$ \\
\hline$\mu \mathrm{g} / \mathrm{L}$ & 1 & $<1$ \\
\hline$\mu \mathrm{g} / \mathrm{L}$ & 1 & $<1$ \\
\hline$\mu \mathrm{g} / \mathrm{L}$ & 1 & $<1$ \\
\hline$\mu \mathrm{g} / \mathrm{L}$ & 1 & $<1$ \\
\hline$\mu \mathrm{g} / \mathrm{L}$ & 1 & $<1$ \\
\hline$\mu \mathrm{g} / \mathrm{L}$ & 1 & $<1$ \\
\hline$\mu \mathrm{g} / \mathrm{L}$ & 1 & $<1$ \\
\hline$\mu \mathrm{g} / \mathrm{L}$ & 1 & $<1$ \\
\hline$\mu \mathrm{g} / \mathrm{L}$ & 5 & $<5$ \\
\hline
\end{tabular}




\begin{tabular}{|c|c|c|c|c|}
\hline Parâmetros & $\begin{array}{l}\text { Quantidade } \\
\text { Adicionada }\end{array}$ & Unidade & $\begin{array}{c}\text { Resultado da } \\
\text { Recuperação (\%) }\end{array}$ & Faixa Aceitável de Recuperação (\%) \\
\hline \multicolumn{5}{|c|}{ 302694/2014-0 - Amostra Controle - VOC - Água } \\
\hline 1,1-Dicloroeteno & 20 & $\mu \mathrm{g} / \mathrm{L}$ & 100 & $70-130$ \\
\hline Benzeno & 20 & $\mu \mathrm{g} / \mathrm{L}$ & 125 & $70-130$ \\
\hline Tricloroeteno & 20 & $\mu \mathrm{g} / \mathrm{L}$ & 110 & $70-130$ \\
\hline Tolueno & 20 & $\mu \mathrm{g} / \mathrm{L}$ & 95 & $70-130$ \\
\hline Clorobenzeno & 20 & $\mu \mathrm{g} / \mathrm{L}$ & 105 & $70-130$ \\
\hline \multicolumn{5}{|c|}{$\begin{array}{l}\text { Surrogates } \\
\text { 302692/2014-0 - Branco de Análise - VOC - Água }\end{array}$} \\
\hline p-Bromofluorbenzeno & 20 & $\%$ & 76,5 & $70-130$ \\
\hline Dibromofluorometano & 20 & $\%$ & 130 & $70-130$ \\
\hline \multicolumn{5}{|c|}{ 302694/2014-0 - Amostra Controle - VOC - Água } \\
\hline p-Bromofluorbenzeno & 20 & $\%$ & 78,6 & $70-130$ \\
\hline Dibromofluorometano & 20 & $\%$ & 130 & $70-130$ \\
\hline \multicolumn{5}{|l|}{ 292979/2014-0 - BGBI 2} \\
\hline Dibromofluorometano & 20 & $\%$ & 97,2 & $70-130$ \\
\hline p-Bromofluorbenzeno & 20 & $\%$ & 72,7 & $70-130$ \\
\hline
\end{tabular}

Notas

LQ = Limite de Quantificação.

n.a. $=$ Não Aplicável.

Abrangência

$\mathrm{O}(\mathrm{s})$ resultado(s) referem-se somente à(s) amostra(s) analisada(s).

Este Relatório de Ensaio só pode ser reproduzido por inteiro e sem nenhuma alteração.

Plano de Amostragem

Plano de amostragem de responsabilidade do interessado.

Responsabilidade Técnica

Os ensaios foram realizados na unidade da Bioagri Ambiental Ltda. - Matriz, situada na Rua Aljovil Martini, 177/201, Bairro Dois Córregos, Cep. 14420-833, Piracicaba/SP, registrada no CRQ 4 Região sob n⿳亠丷厂 $16082-\mathrm{F}$ e responsabilidade técnica do profissional Marcos Donizete Ceccatto, CRQ n ${ }^{\circ} 04364387,4^{\mathrm{a}}$.Região.

Referências Metodológicas

Análises foram realizadas conforme a última versão do Standard Methods for the Examination of Water \& Wastewater 22nd 2012(SMWW), EPA e ABNT (quando aplicável). VOC: EPA 8260 C: 2006, 5021A: 2003

Metiletilcetona: EPA 8260 C: 2006, 5021 A: 2003

Revisores

Débora Fernandes da Silva

Chave de Validação: 58f7b28e969d19e4c7c824aa0bb6f966
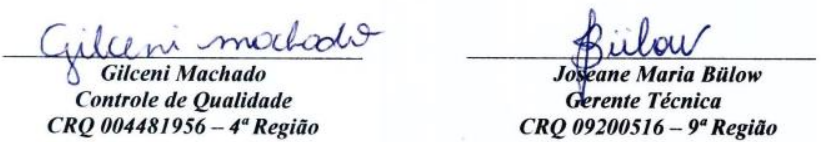


\section{RELATÓRIO DE ENSAIO $\mathrm{N}^{\circ}$ 292980/2014-0 - Piracicaba} Processo Comercial $N^{\circ}$ 23961/2014-2

\begin{tabular}{|l|l|}
\hline \multicolumn{2}{|c|}{ DADOS REFERENTES AO CLIENTE } \\
\hline Empresa solicitante: & Fundacao Parque de Alta Tecnologia da Regiao de Ipero e Adjacencias \\
\hline Endereço: & Rua Jose Antonio Scaciota, 165 - - Portal do Cedro - Iperó - SP - CEP: 18.560-000 . \\
\hline Nome do Solicitante: & Carla Marçal \\
\hline
\end{tabular}

\section{DADOS REFERENTES A AMOSTRA}

Identificação do Cliente: Amostra Rotulada como:

Coletor:

BGBI 3

Data da entrada no laboratório:

Água Subterrânea Projeto Mestrado Interessado

Data da coleta: $\quad$ 02/11/2014 22:31:00

\section{RESULTADOS PARA A AMOSTRA}

\begin{tabular}{|c|c|c|c|c|c|c|}
\hline Parâmetros & CAS & Unidade & LQ & Resultados analíticos & Incerteza & Data do Ensaio \\
\hline 1,1,1-Tricloroetano & $71-55-6$ & $\mu \mathrm{g} / \mathrm{L}$ & 1 & $<1$ & n.a. & 13/11/2014 01:39 \\
\hline 1,1,2-Tricloroetano & $79-00-5$ & $\mu \mathrm{g} / \mathrm{L}$ & 1 & $<1$ & n.a. & 13/11/2014 01:39 \\
\hline 1,1,2,2-Tetracloroetano & $79-34-5$ & $\mu \mathrm{g} / \mathrm{L}$ & 1 & $<1$ & n.a. & 13/11/2014 01:39 \\
\hline 1,1-Dicloroetano & $75-34-3$ & $\mu \mathrm{g} / \mathrm{L}$ & 1 & $<1$ & n.a. & 13/11/2014 01:39 \\
\hline 1,1-Dicloroeteno & $75-35-4$ & $\mu \mathrm{g} / \mathrm{L}$ & 1 & $<1$ & n.a. & 13/11/2014 01:39 \\
\hline 1,1-Dicloropropeno & $563-58-6$ & $\mu \mathrm{g} / \mathrm{L}$ & 1 & $<1$ & n.a. & 13/11/2014 01:39 \\
\hline 1,2,3-Triclorobenzeno & $87-61-6$ & $\mu \mathrm{g} / \mathrm{L}$ & 1 & $<1$ & n.a. & 13/11/2014 01:39 \\
\hline 1,2,4-Triclorobenzeno & $120-82-1$ & $\mu \mathrm{g} / \mathrm{L}$ & 1 & $<1$ & n.a. & 13/11/2014 01:39 \\
\hline 1,2-Dibromo-3-Cloropropano & $96-12-8$ & $\mu \mathrm{g} / \mathrm{L}$ & 5 & $<5$ & n.a. & 13/11/2014 01:39 \\
\hline 1,2-Dicloroetano & $107-06-2$ & $\mu \mathrm{g} / \mathrm{L}$ & 1 & $<1$ & n.a. & 13/11/2014 01:39 \\
\hline 1,2-Dicloropropano & $78-87-5$ & $\mu \mathrm{g} / \mathrm{L}$ & 1 & $<1$ & n.a. & 13/11/2014 01:39 \\
\hline 1,3-Dicloropropano & $142-28-9$ & $\mu \mathrm{g} / \mathrm{L}$ & 5 & $<5$ & n.a. & 13/11/2014 01:39 \\
\hline 1,4-Diclorobenzeno & $106-46-7$ & $\mu \mathrm{g} / \mathrm{L}$ & 1 & $<1$ & n.a. & 13/11/2014 01:39 \\
\hline 2,2-Dicloropropano & $594-20-7$ & $\mu \mathrm{g} / \mathrm{L}$ & 1 & $<1$ & n.a. & 13/11/2014 01:39 \\
\hline 4-Metil-2-Pentanona & $108-10-1$ & $\mu \mathrm{g} / \mathrm{L}$ & 5 & $<5$ & n.a. & 13/11/2014 01:39 \\
\hline Benzeno & $71-43-2$ & $\mu \mathrm{g} / \mathrm{L}$ & 1 & $<1$ & n.a. & 13/11/2014 01:39 \\
\hline Bromobenzeno & $108-86-1$ & $\mu \mathrm{g} / \mathrm{L}$ & 1 & $<1$ & n.a. & 13/11/2014 01:39 \\
\hline Bromodiclorometano & $75-27-4$ & $\mu \mathrm{g} / \mathrm{L}$ & 1 & $<1$ & n.a. & 13/11/2014 01:39 \\
\hline Bromofórmio & $75-25-2$ & $\mu \mathrm{g} / \mathrm{L}$ & 1 & $<1$ & n.a. & 13/11/2014 01:39 \\
\hline Bromoclorometano & $74-97-5$ & $\mu \mathrm{g} / \mathrm{L}$ & 5 & $<5$ & n.a. & 13/11/2014 01:39 \\
\hline Cis-1,2-Dicloroeteno & $156-59-2$ & $\mu \mathrm{g} / \mathrm{L}$ & 1 & $<1$ & n.a. & 13/11/2014 01:39 \\
\hline Cis-1,3-Dicloropropeno & $10061-01-5$ & $\mu \mathrm{g} / \mathrm{L}$ & 1 & $<1$ & n.a. & 13/11/2014 01:39 \\
\hline Diclorometano & $75-09-2$ & $\mu \mathrm{g} / \mathrm{L}$ & 1 & $<1$ & n.a. & 13/11/2014 01:39 \\
\hline Cloreto de Vinila & $75-01-4$ & $\mu \mathrm{g} / \mathrm{L}$ & 1 & $<1$ & n.a. & 13/11/2014 01:39 \\
\hline Clorobenzeno & $108-90-7$ & $\mu \mathrm{g} / \mathrm{L}$ & 1 & $<1$ & n.a. & 13/11/2014 01:39 \\
\hline Cloroetano & $75-00-3$ & $\mu \mathrm{g} / \mathrm{L}$ & 1 & $<1$ & n.a. & 13/11/2014 01:39 \\
\hline Clorofórmio & $67-66-3$ & $\mu \mathrm{g} / \mathrm{L}$ & 1 & $<1$ & n.a. & 13/11/2014 01:39 \\
\hline Clorometano & $74-87-3$ & $\mu \mathrm{g} / \mathrm{L}$ & 10 & $<10$ & n.a. & 13/11/2014 01:39 \\
\hline Dibromoclorometano & $124-48-1$ & $\mu \mathrm{g} / \mathrm{L}$ & 1 & $<1$ & n.a. & 13/11/2014 01:39 \\
\hline Dissulfeto de Carbono & $75-15-0$ & $\mu \mathrm{g} / \mathrm{L}$ & 1 & $<1$ & n.a. & 13/11/2014 01:39 \\
\hline Estireno & $100-42-5$ & $\mu \mathrm{g} / \mathrm{L}$ & 1 & $<1$ & n.a. & 13/11/2014 01:39 \\
\hline Etilbenzeno & $100-41-4$ & $\mu \mathrm{g} / \mathrm{L}$ & 1 & $<1$ & n.a. & 13/11/2014 01:39 \\
\hline Hexaclorobutadieno & $87-68-3$ & $\mu \mathrm{g} / \mathrm{L}$ & 1 & $<1$ & n.a. & 13/11/2014 01:39 \\
\hline m,p-Xilenos & --- & $\mu \mathrm{g} / \mathrm{L}$ & 2 & $<2$ & n.a. & 13/11/2014 01:39 \\
\hline o-Xileno & $95-47-6$ & $\mu \mathrm{g} / \mathrm{L}$ & 1 & $<1$ & n.a. & 13/11/2014 01:39 \\
\hline p-Isopropiltolueno & $99-87-6$ & $\mu \mathrm{g} / \mathrm{L}$ & 1 & $<1$ & n.a. & 13/11/2014 01:39 \\
\hline Tetracloreto de Carbono & $56-23-5$ & $\mu \mathrm{g} / \mathrm{L}$ & 1 & $<1$ & n.a. & 13/11/2014 01:39 \\
\hline Tetracloroeteno & $127-18-4$ & $\mu \mathrm{g} / \mathrm{L}$ & 1 & 4,9 & 0,93 & 13/11/2014 01:39 \\
\hline Tolueno & $108-88-3$ & $\mu \mathrm{g} / \mathrm{L}$ & 1 & $<1$ & n.a. & 13/11/2014 01:39 \\
\hline Trans-1,2-Dicloroeteno & $156-60-5$ & $\mu \mathrm{g} / \mathrm{L}$ & 1 & $<1$ & n.a. & 13/11/2014 01:39 \\
\hline Tricloroeteno & $79-01-6$ & $\mu \mathrm{g} / \mathrm{L}$ & 1 & $<1$ & n.a. & 13/11/2014 01:39 \\
\hline 1,1,1,2-Tetracloroetano & $630-20-6$ & $\mu \mathrm{g} / \mathrm{L}$ & 1 & $<1$ & n.a. & 13/11/2014 01:39 \\
\hline
\end{tabular}




\begin{tabular}{|c|c|c|c|c|c|c|}
\hline Parâmetros & CAS & Unidade & LQ & Resultados analíticos & Incerteza & Data do Ensaio \\
\hline 1,2,3-Tricloropropano & $96-18-4$ & $\mu \mathrm{g} / \mathrm{L}$ & 5 & $<5$ & n.a. & 13/11/2014 01:39 \\
\hline 1,3,5-Trimetilbenzeno & $108-67-8$ & $\mu \mathrm{g} / \mathrm{L}$ & 1 & $<1$ & n.a. & 13/11/2014 01:39 \\
\hline 1,2,4-Trimetilbenzeno & $95-63-6$ & $\mu \mathrm{g} / \mathrm{L}$ & 1 & $<1$ & n.a. & 13/11/2014 01:39 \\
\hline 1,2-Dibromoetano & $106-93-4$ & $\mu \mathrm{g} / \mathrm{L}$ & 1 & $<1$ & n.a. & 13/11/2014 01:39 \\
\hline 1,2-Diclorobenzeno & $95-50-1$ & $\mu \mathrm{g} / \mathrm{L}$ & 1 & $<1$ & n.a. & 13/11/2014 01:39 \\
\hline 1,3-Diclorobenzeno & $541-73-1$ & $\mu \mathrm{g} / \mathrm{L}$ & 1 & $<1$ & n.a. & 13/11/2014 01:39 \\
\hline 2-Clorotolueno & $95-49-8$ & $\mu \mathrm{g} / \mathrm{L}$ & 1 & $<1$ & n.a. & 13/11/2014 01:39 \\
\hline Dibromometano & $74-95-3$ & $\mu \mathrm{g} / \mathrm{L}$ & 1 & $<1$ & n.a. & 13/11/2014 01:39 \\
\hline Metiletilcetona & 78-93-3 & $\mu \mathrm{g} / \mathrm{L}$ & 2500 & $<2500$ & n.a. & 13/11/2014 01:39 \\
\hline Naftaleno & $91-20-3$ & $\mu \mathrm{g} / \mathrm{L}$ & 1 & $<1$ & n.a. & 13/11/2014 01:39 \\
\hline n-Butilbenzeno & $104-51-8$ & $\mu \mathrm{g} / \mathrm{L}$ & 1 & $<1$ & n.a. & $13 / 11 / 201401: 39$ \\
\hline n-Propilbenzeno & $103-65-1$ & $\mu \mathrm{g} / \mathrm{L}$ & 1 & $<1$ & n.a. & 13/11/2014 01:39 \\
\hline 4-Clorotolueno & $106-43-4$ & $\mu \mathrm{g} / \mathrm{L}$ & 1 & $<1$ & n.a. & 13/11/2014 01:39 \\
\hline sec-Butilbenzeno & $135-98-8$ & $\mu \mathrm{g} / \mathrm{L}$ & 1 & $<1$ & n.a. & 13/11/2014 01:39 \\
\hline terc-Butilbenzeno & $98-06-6$ & $\mu \mathrm{g} / \mathrm{L}$ & 1 & $<1$ & n.a. & 13/11/2014 01:39 \\
\hline trans-1,3-Dicloropropeno & $10061-02-6$ & $\mu \mathrm{g} / \mathrm{L}$ & 1 & $<1$ & n.a. & 13/11/2014 01:39 \\
\hline Isopropilbenzeno & $98-82-8$ & $\mu \mathrm{g} / \mathrm{L}$ & 1 & $<1$ & n.a. & 13/11/2014 01:39 \\
\hline 1,3,5-Triclorobenzeno & $108-70-3$ & $\mu \mathrm{g} / \mathrm{L}$ & 1 & $<1$ & n.a. & 13/11/2014 01:39 \\
\hline
\end{tabular}

\section{CONTROLE DE QUALIDADE DO LABORATÓRIO}

302692/2014-0 - Branco de Análise - VOC - Água

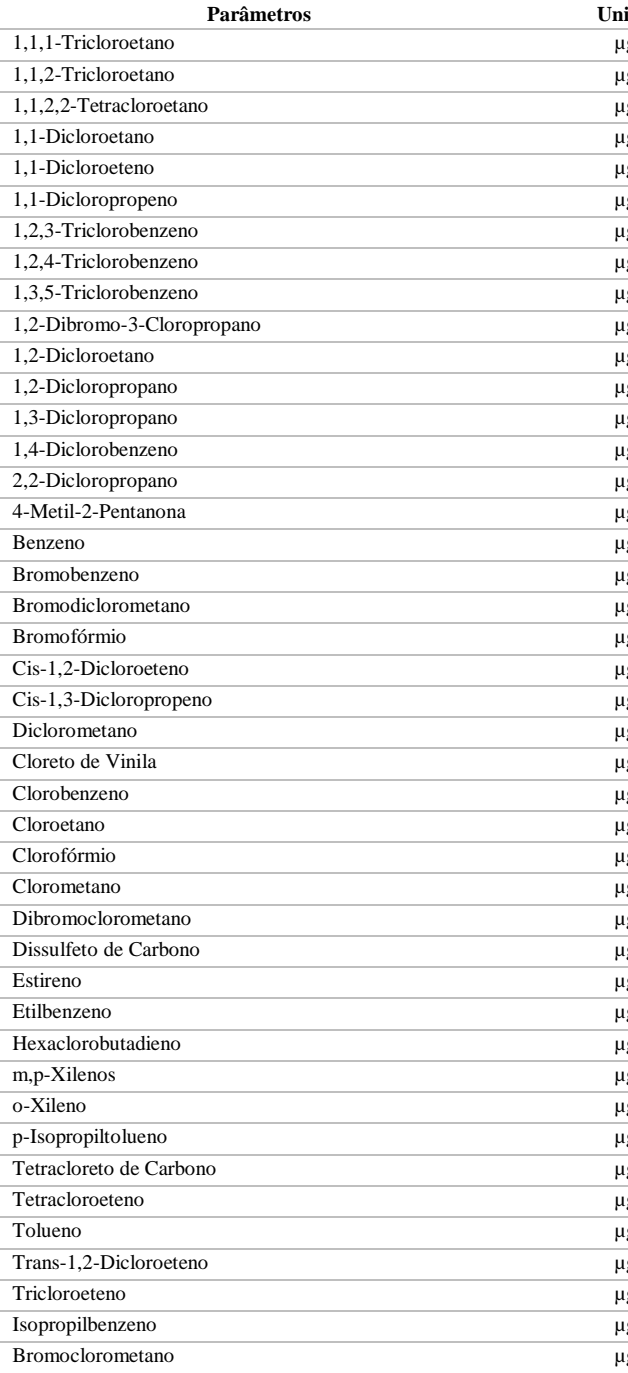

Controle de Qualidade - VOC - Água

\begin{tabular}{|c|c|c|}
\hline Unidade & LQ & Resultados analíticos \\
\hline$\mu \mathrm{g} / \mathrm{L}$ & 1 & $<1$ \\
\hline$\mu \mathrm{g} / \mathrm{L}$ & 1 & $<1$ \\
\hline$\mu \mathrm{g} / \mathrm{L}$ & 1 & $<1$ \\
\hline$\mu \mathrm{g} / \mathrm{L}$ & 1 & $<1$ \\
\hline$\mu \mathrm{g} / \mathrm{L}$ & 1 & $<1$ \\
\hline$\mu \mathrm{g} / \mathrm{L}$ & 1 & $<1$ \\
\hline$\mu \mathrm{g} / \mathrm{L}$ & 1 & $<1$ \\
\hline$\mu \mathrm{g} / \mathrm{L}$ & 1 & $<1$ \\
\hline$\mu \mathrm{g} / \mathrm{L}$ & 1 & $<1$ \\
\hline$\mu \mathrm{g} / \mathrm{L}$ & 5 & $<5$ \\
\hline$\mu \mathrm{g} / \mathrm{L}$ & 1 & $<1$ \\
\hline$\mu \mathrm{g} / \mathrm{L}$ & 1 & $<1$ \\
\hline$\mu \mathrm{g} / \mathrm{L}$ & 5 & $<5$ \\
\hline$\mu \mathrm{g} / \mathrm{L}$ & 1 & $<1$ \\
\hline$\mu \mathrm{g} / \mathrm{L}$ & 1 & $<1$ \\
\hline$\mu \mathrm{g} / \mathrm{L}$ & 5 & $<5$ \\
\hline$\mu \mathrm{g} / \mathrm{L}$ & 1 & $<1$ \\
\hline$\mu \mathrm{g} / \mathrm{L}$ & 1 & $<1$ \\
\hline$\mu \mathrm{g} / \mathrm{L}$ & 1 & $<1$ \\
\hline$\mu \mathrm{g} / \mathrm{L}$ & 1 & $<1$ \\
\hline$\mu \mathrm{g} / \mathrm{L}$ & 1 & $<1$ \\
\hline$\mu \mathrm{g} / \mathrm{L}$ & 1 & $<1$ \\
\hline$\mu \mathrm{g} / \mathrm{L}$ & 1 & $<1$ \\
\hline$\mu \mathrm{g} / \mathrm{L}$ & 1 & $<1$ \\
\hline$\mu \mathrm{g} / \mathrm{L}$ & 1 & $<1$ \\
\hline$\mu \mathrm{g} / \mathrm{L}$ & 1 & $<1$ \\
\hline$\mu \mathrm{g} / \mathrm{L}$ & 1 & $<1$ \\
\hline$\mu \mathrm{g} / \mathrm{L}$ & 10 & $<10$ \\
\hline$\mu \mathrm{g} / \mathrm{L}$ & 1 & $<1$ \\
\hline$\mu \mathrm{g} / \mathrm{L}$ & 1 & $<1$ \\
\hline$\mu \mathrm{g} / \mathrm{L}$ & 1 & $<1$ \\
\hline$\mu \mathrm{g} / \mathrm{L}$ & 1 & $<1$ \\
\hline$\mu \mathrm{g} / \mathrm{L}$ & 1 & $<1$ \\
\hline$\mu \mathrm{g} / \mathrm{L}$ & 2 & $<2$ \\
\hline$\mu \mathrm{g} / \mathrm{L}$ & 1 & $<1$ \\
\hline$\mu \mathrm{g} / \mathrm{L}$ & 1 & $<1$ \\
\hline$\mu \mathrm{g} / \mathrm{L}$ & 1 & $<1$ \\
\hline$\mu \mathrm{g} / \mathrm{L}$ & 1 & $<1$ \\
\hline$\mu \mathrm{g} / \mathrm{L}$ & 1 & $<1$ \\
\hline$\mu \mathrm{g} / \mathrm{L}$ & 1 & $<1$ \\
\hline$\mu \mathrm{g} / \mathrm{L}$ & 1 & $<1$ \\
\hline$\mu \mathrm{g} / \mathrm{L}$ & 1 & $<1$ \\
\hline$\mu \mathrm{g} / \mathrm{L}$ & 5 & $<5$ \\
\hline
\end{tabular}




\begin{tabular}{|c|c|c|c|c|}
\hline Parâmetros & $\begin{array}{l}\text { Quantidade } \\
\text { Adicionada }\end{array}$ & Unidade & $\begin{array}{c}\text { Resultado da } \\
\text { Recuperação (\%) }\end{array}$ & Faixa Aceitável de Recuperação (\%) \\
\hline \multicolumn{5}{|c|}{ 302694/2014-0 - Amostra Controle - VOC - Água } \\
\hline 1,1-Dicloroeteno & 20 & $\mu \mathrm{g} / \mathrm{L}$ & 100 & $70-130$ \\
\hline Benzeno & 20 & $\mu \mathrm{g} / \mathrm{L}$ & 125 & $70-130$ \\
\hline Tricloroeteno & 20 & $\mu \mathrm{g} / \mathrm{L}$ & 110 & $70-130$ \\
\hline Tolueno & 20 & $\mu \mathrm{g} / \mathrm{L}$ & 95 & $70-130$ \\
\hline Clorobenzeno & 20 & $\mu \mathrm{g} / \mathrm{L}$ & 105 & $70-130$ \\
\hline \multicolumn{5}{|c|}{$\begin{array}{l}\text { Surrogates } \\
\text { 302692/2014-0 - Branco de Análise - VOC - Água }\end{array}$} \\
\hline p-Bromofluorbenzeno & 20 & $\%$ & 76,5 & $70-130$ \\
\hline Dibromofluorometano & 20 & $\%$ & 130 & $70-130$ \\
\hline \multicolumn{5}{|c|}{ 302694/2014-0 - Amostra Controle - VOC - Água } \\
\hline p-Bromofluorbenzeno & 20 & $\%$ & 78,6 & $70-130$ \\
\hline Dibromofluorometano & 20 & $\%$ & 130 & $70-130$ \\
\hline \multicolumn{5}{|l|}{ 292980/2014-0 - BGBI 3} \\
\hline Dibromofluorometano & 20 & $\%$ & 98,1 & $70-130$ \\
\hline p-Bromofluorbenzeno & 20 & $\%$ & 76,4 & $70-130$ \\
\hline
\end{tabular}

Notas

LQ = Limite de Quantificação.

n.a. = Não Aplicável.

Abrangência

$\mathrm{O}(\mathrm{s})$ resultado(s) referem-se somente à(s) amostra(s) analisada(s).

Este Relatório de Ensaio só pode ser reproduzido por inteiro e sem nenhuma alteração.

Plano de Amostragem

Plano de amostragem de responsabilidade do interessado.

Responsabilidade Técnica

Os ensaios foram realizados na unidade da Bioagri Ambiental Ltda. - Matriz, situada na Rua Aljovil Martini, 177/201, Bairro Dois Córregos, Cep. 14420-833, Piracicaba/SP, registrada no CRQ 4 Região sob n⿳亠丷厂 $16082-\mathrm{F}$ e responsabilidade técnica do profissional Marcos Donizete Ceccatto, CRQ n ${ }^{\circ} 04364387,4^{\mathrm{a}}$.Região.

Referências Metodológicas

Análises foram realizadas conforme a última versão do Standard Methods for the Examination of Water \& Wastewater 22nd 2012(SMWW), EPA e ABNT (quando aplicável). VOC: EPA 8260 C: 2006, 5021A: 2003

Metiletilcetona: EPA 8260 C: 2006, 5021 A: 2003

Revisores

Débora Fernandes da Silva

Chave de Validação: 25686e820e71d45155bee858076170b0
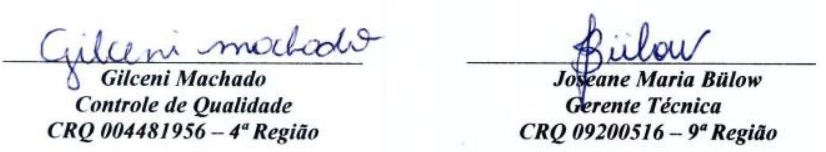


\section{RELATÓRIO DE ENSAIO N ${ }^{\circ}$ 292981/2014-0 - Piracicaba Processo Comercial $N^{\circ}$ 23961/2014-2}

\begin{tabular}{|l|l|}
\hline \multicolumn{2}{|c|}{ DADOS REFERENTES AO CLIENTE } \\
\hline Empresa solicitante: & Fundacao Parque de Alta Tecnologia da Regiao de Ipero e Adjacencias \\
\hline Endereço: & Rua Jose Antonio Scaciota, 165 - - Portal do Cedro - Iperó - SP - CEP: 18.560-000 . \\
\hline Nome do Solicitante: & Carla Marçal \\
\hline
\end{tabular}

\section{DADOS REFERENTES A AMOSTRA}

Identificação do Cliente: Amostra Rotulada como:

Coletor:

BGBF 1

Data da entrada no laboratório:

Água Subterrânea Projeto Mestrado

Interessado

\begin{tabular}{l|ll} 
Data da coleta: & $03 / 11 / 2014$ 00:25:00
\end{tabular}

\section{RESULTADOS PARA A AMOSTRA}

\begin{tabular}{|c|c|c|c|c|c|c|}
\hline Parâmetros & CAS & Unidade & LQ & Resultados analíticos & Incerteza & Data do Ensaio \\
\hline 1,1,1-Tricloroetano & $71-55-6$ & $\mu \mathrm{g} / \mathrm{L}$ & 1 & $<1$ & n.a. & 13/11/2014 02:03 \\
\hline 1,1,2-Tricloroetano & $79-00-5$ & $\mu \mathrm{g} / \mathrm{L}$ & 1 & $<1$ & n.a. & 13/11/2014 02:03 \\
\hline 1,1,2,2-Tetracloroetano & $79-34-5$ & $\mu \mathrm{g} / \mathrm{L}$ & 1 & $<1$ & n.a. & 13/11/2014 02:03 \\
\hline 1,1-Dicloroetano & $75-34-3$ & $\mu \mathrm{g} / \mathrm{L}$ & 1 & $<1$ & n.a. & 13/11/2014 02:03 \\
\hline 1,1-Dicloroeteno & $75-35-4$ & $\mu \mathrm{g} / \mathrm{L}$ & 1 & $<1$ & n.a. & 13/11/2014 02:03 \\
\hline 1,1-Dicloropropeno & $563-58-6$ & $\mu \mathrm{g} / \mathrm{L}$ & 1 & $<1$ & n.a. & 13/11/2014 02:03 \\
\hline 1,2,3-Triclorobenzeno & $87-61-6$ & $\mu \mathrm{g} / \mathrm{L}$ & 1 & $<1$ & n.a. & 13/11/2014 02:03 \\
\hline 1,2,4-Triclorobenzeno & $120-82-1$ & $\mu \mathrm{g} / \mathrm{L}$ & 1 & $<1$ & n.a. & 13/11/2014 02:03 \\
\hline 1,2-Dibromo-3-Cloropropano & $96-12-8$ & $\mu \mathrm{g} / \mathrm{L}$ & 5 & $<5$ & n.a. & 13/11/2014 02:03 \\
\hline 1,2-Dicloroetano & $107-06-2$ & $\mu \mathrm{g} / \mathrm{L}$ & 1 & $<1$ & n.a. & 13/11/2014 02:03 \\
\hline 1,2-Dicloropropano & $78-87-5$ & $\mu \mathrm{g} / \mathrm{L}$ & 1 & $<1$ & n.a. & 13/11/2014 02:03 \\
\hline 1,3-Dicloropropano & $142-28-9$ & $\mu \mathrm{g} / \mathrm{L}$ & 5 & $<5$ & n.a. & 13/11/2014 02:03 \\
\hline 1,4-Diclorobenzeno & $106-46-7$ & $\mu \mathrm{g} / \mathrm{L}$ & 1 & $<1$ & n.a. & 13/11/2014 02:03 \\
\hline 2,2-Dicloropropano & $594-20-7$ & $\mu \mathrm{g} / \mathrm{L}$ & 1 & $<1$ & n.a. & 13/11/2014 02:03 \\
\hline 4-Metil-2-Pentanona & $108-10-1$ & $\mu \mathrm{g} / \mathrm{L}$ & 5 & $<5$ & n.a. & 13/11/2014 02:03 \\
\hline Benzeno & $71-43-2$ & $\mu \mathrm{g} / \mathrm{L}$ & 1 & $<1$ & n.a. & 13/11/2014 02:03 \\
\hline Bromobenzeno & $108-86-1$ & $\mu \mathrm{g} / \mathrm{L}$ & 1 & $<1$ & n.a. & 13/11/2014 02:03 \\
\hline Bromodiclorometano & $75-27-4$ & $\mu \mathrm{g} / \mathrm{L}$ & 1 & $<1$ & n.a. & 13/11/2014 02:03 \\
\hline Bromofórmio & $75-25-2$ & $\mu \mathrm{g} / \mathrm{L}$ & 1 & $<1$ & n.a. & 13/11/2014 02:03 \\
\hline Bromoclorometano & $74-97-5$ & $\mu \mathrm{g} / \mathrm{L}$ & 5 & $<5$ & n.a. & 13/11/2014 02:03 \\
\hline Cis-1,2-Dicloroeteno & $156-59-2$ & $\mu \mathrm{g} / \mathrm{L}$ & 1 & $<1$ & n.a. & 13/11/2014 02:03 \\
\hline Cis-1,3-Dicloropropeno & $10061-01-5$ & $\mu \mathrm{g} / \mathrm{L}$ & 1 & $<1$ & n.a. & 13/11/2014 02:03 \\
\hline Diclorometano & $75-09-2$ & $\mu \mathrm{g} / \mathrm{L}$ & 1 & $<1$ & n.a. & 13/11/2014 02:03 \\
\hline Cloreto de Vinila & $75-01-4$ & $\mu \mathrm{g} / \mathrm{L}$ & 1 & $<1$ & n.a. & 13/11/2014 02:03 \\
\hline Clorobenzeno & $108-90-7$ & $\mu \mathrm{g} / \mathrm{L}$ & 1 & $<1$ & n.a. & 13/11/2014 02:03 \\
\hline Cloroetano & $75-00-3$ & $\mu \mathrm{g} / \mathrm{L}$ & 1 & $<1$ & n.a. & 13/11/2014 02:03 \\
\hline Clorofórmio & $67-66-3$ & $\mu \mathrm{g} / \mathrm{L}$ & 1 & $<1$ & n.a. & 13/11/2014 02:03 \\
\hline Clorometano & $74-87-3$ & $\mu \mathrm{g} / \mathrm{L}$ & 10 & $<10$ & n.a. & 13/11/2014 02:03 \\
\hline Dibromoclorometano & $124-48-1$ & $\mu \mathrm{g} / \mathrm{L}$ & 1 & $<1$ & n.a. & 13/11/2014 02:03 \\
\hline Dissulfeto de Carbono & $75-15-0$ & $\mu \mathrm{g} / \mathrm{L}$ & 1 & $<1$ & n.a. & 13/11/2014 02:03 \\
\hline Estireno & $100-42-5$ & $\mu \mathrm{g} / \mathrm{L}$ & 1 & $<1$ & n.a. & 13/11/2014 02:03 \\
\hline Etilbenzeno & $100-41-4$ & $\mu \mathrm{g} / \mathrm{L}$ & 1 & $<1$ & n.a. & 13/11/2014 02:03 \\
\hline Hexaclorobutadieno & $87-68-3$ & $\mu \mathrm{g} / \mathrm{L}$ & 1 & $<1$ & n.a. & 13/11/2014 02:03 \\
\hline $\mathrm{m}, \mathrm{p}$-Xilenos & --- & $\mu \mathrm{g} / \mathrm{L}$ & 2 & $<2$ & n.a. & 13/11/2014 02:03 \\
\hline o-Xileno & $95-47-6$ & $\mu \mathrm{g} / \mathrm{L}$ & 1 & $<1$ & n.a. & 13/11/2014 02:03 \\
\hline p-Isopropiltolueno & $99-87-6$ & $\mu \mathrm{g} / \mathrm{L}$ & 1 & $<1$ & n.a. & 13/11/2014 02:03 \\
\hline Tetracloreto de Carbono & $56-23-5$ & $\mu \mathrm{g} / \mathrm{L}$ & 1 & $<1$ & n.a. & 13/11/2014 02:03 \\
\hline Tetracloroeteno & $127-18-4$ & $\mu \mathrm{g} / \mathrm{L}$ & 1 & $<1$ & n.a. & 13/11/2014 02:03 \\
\hline Tolueno & $108-88-3$ & $\mu \mathrm{g} / \mathrm{L}$ & 1 & $<1$ & n.a. & 13/11/2014 02:03 \\
\hline Trans-1,2-Dicloroeteno & $156-60-5$ & $\mu \mathrm{g} / \mathrm{L}$ & 1 & $<1$ & n.a. & 13/11/2014 02:03 \\
\hline Tricloroeteno & $79-01-6$ & $\mu \mathrm{g} / \mathrm{L}$ & 1 & $<1$ & n.a. & 13/11/2014 02:03 \\
\hline 1,1,1,2-Tetracloroetano & $630-20-6$ & $\mu \mathrm{g} / \mathrm{L}$ & 1 & $<1$ & n.a. & 13/11/2014 02:03 \\
\hline
\end{tabular}




\begin{tabular}{|c|c|c|c|c|c|c|}
\hline Parâmetros & CAS & Unidade & LQ & Resultados analíticos & Incerteza & Data do Ensaio \\
\hline 1,2,3-Tricloropropano & $96-18-4$ & $\mu \mathrm{g} / \mathrm{L}$ & 5 & $<5$ & n.a. & 13/11/2014 02:03 \\
\hline 1,3,5-Trimetilbenzeno & $108-67-8$ & $\mu \mathrm{g} / \mathrm{L}$ & 1 & $<1$ & n.a. & 13/11/2014 02:03 \\
\hline 1,2,4-Trimetilbenzeno & $95-63-6$ & $\mu \mathrm{g} / \mathrm{L}$ & 1 & $<1$ & n.a. & 13/11/2014 02:03 \\
\hline 1,2-Dibromoetano & $106-93-4$ & $\mu \mathrm{g} / \mathrm{L}$ & 1 & $<1$ & n.a. & 13/11/2014 02:03 \\
\hline 1,2-Diclorobenzeno & $95-50-1$ & $\mu \mathrm{g} / \mathrm{L}$ & 1 & $<1$ & n.a. & 13/11/2014 02:03 \\
\hline 1,3-Diclorobenzeno & $541-73-1$ & $\mu \mathrm{g} / \mathrm{L}$ & 1 & $<1$ & n.a. & 13/11/2014 02:03 \\
\hline 2-Clorotolueno & $95-49-8$ & $\mu \mathrm{g} / \mathrm{L}$ & 1 & $<1$ & n.a. & 13/11/2014 02:03 \\
\hline Dibromometano & $74-95-3$ & $\mu \mathrm{g} / \mathrm{L}$ & 1 & $<1$ & n.a. & 13/11/2014 02:03 \\
\hline Metiletilcetona & 78-93-3 & $\mu \mathrm{g} / \mathrm{L}$ & 2500 & $<2500$ & n.a. & 13/11/2014 02:03 \\
\hline Naftaleno & $91-20-3$ & $\mu \mathrm{g} / \mathrm{L}$ & 1 & $<1$ & n.a. & 13/11/2014 02:03 \\
\hline n-Butilbenzeno & $104-51-8$ & $\mu \mathrm{g} / \mathrm{L}$ & 1 & $<1$ & n.a. & $13 / 11 / 201402: 03$ \\
\hline n-Propilbenzeno & $103-65-1$ & $\mu \mathrm{g} / \mathrm{L}$ & 1 & $<1$ & n.a. & 13/11/2014 02:03 \\
\hline 4-Clorotolueno & $106-43-4$ & $\mu \mathrm{g} / \mathrm{L}$ & 1 & $<1$ & n.a. & 13/11/2014 02:03 \\
\hline sec-Butilbenzeno & $135-98-8$ & $\mu \mathrm{g} / \mathrm{L}$ & 1 & $<1$ & n.a. & 13/11/2014 02:03 \\
\hline terc-Butilbenzeno & $98-06-6$ & $\mu \mathrm{g} / \mathrm{L}$ & 1 & $<1$ & n.a. & 13/11/2014 02:03 \\
\hline trans-1,3-Dicloropropeno & $10061-02-6$ & $\mu \mathrm{g} / \mathrm{L}$ & 1 & $<1$ & n.a. & 13/11/2014 02:03 \\
\hline Isopropilbenzeno & $98-82-8$ & $\mu \mathrm{g} / \mathrm{L}$ & 1 & $<1$ & n.a. & 13/11/2014 02:03 \\
\hline 1,3,5-Triclorobenzeno & $108-70-3$ & $\mu \mathrm{g} / \mathrm{L}$ & 1 & $<1$ & n.a. & 13/11/2014 02:03 \\
\hline
\end{tabular}

\section{CONTROLE DE QUALIDADE DO LABORATÓRIO}

302692/2014-0 - Branco de Análise - VOC - Água

\begin{tabular}{|c|c|}
\hline \multirow{2}{*}{\multicolumn{2}{|c|}{$\begin{array}{ll} & \text { Parâmetros } \\
1,1,1-\text { Tricloroetano } & \end{array}$}} \\
\hline & \\
\hline \multicolumn{2}{|l|}{ 1,1,2-Tricloroetano } \\
\hline \multicolumn{2}{|l|}{ 1,1,2,2-Tetracloroetano } \\
\hline \multicolumn{2}{|l|}{ 1,1-Dicloroetano } \\
\hline \multicolumn{2}{|l|}{ 1,1-Dicloroeteno } \\
\hline \multicolumn{2}{|l|}{ 1,1-Dicloropropeno } \\
\hline \multicolumn{2}{|l|}{ 1,2,3-Triclorobenzeno } \\
\hline \multicolumn{2}{|l|}{ 1,2,4-Triclorobenzeno } \\
\hline \multicolumn{2}{|l|}{ 1,3,5-Triclorobenzeno } \\
\hline \multicolumn{2}{|l|}{ 1,2-Dibromo-3-Cloropropano } \\
\hline \multicolumn{2}{|l|}{ 1,2-Dicloroetano } \\
\hline \multicolumn{2}{|l|}{ 1,2-Dicloropropano } \\
\hline \multicolumn{2}{|l|}{ 1,3-Dicloropropano } \\
\hline \multicolumn{2}{|l|}{ 1,4-Diclorobenzeno } \\
\hline \multicolumn{2}{|l|}{ 2,2-Dicloropropano } \\
\hline \multicolumn{2}{|l|}{ 4-Metil-2-Pentanona } \\
\hline \multicolumn{2}{|l|}{ Benzeno } \\
\hline \multicolumn{2}{|l|}{ Bromobenzeno } \\
\hline \multicolumn{2}{|l|}{ Bromodiclorometano } \\
\hline \multicolumn{2}{|l|}{ Bromofórmio } \\
\hline \multicolumn{2}{|l|}{ Cis-1,2-Dicloroeteno } \\
\hline \multicolumn{2}{|l|}{ Cis-1,3-Dicloropropeno } \\
\hline \multicolumn{2}{|l|}{ Diclorometano } \\
\hline \multicolumn{2}{|l|}{ Cloreto de Vinila } \\
\hline \multicolumn{2}{|l|}{ Clorobenzeno } \\
\hline \multicolumn{2}{|l|}{ Cloroetano } \\
\hline Clorofórmio & \\
\hline Clorometano & \\
\hline Dibromoclorometano & \\
\hline Dissulfeto de Carbono & \\
\hline Estireno & \\
\hline Etilbenzeno & \\
\hline Hexaclorobutadieno & \\
\hline m,p-Xilenos & \\
\hline o-Xileno & \\
\hline p-Isopropiltolueno & \\
\hline Tetracloreto de Carbono & \\
\hline Tetracloroeteno & \\
\hline Tolueno & \\
\hline Trans-1,2-Dicloroeteno & \\
\hline Tricloroeteno & \\
\hline Isopropilbenzeno & \\
\hline Bromoclorometano & \\
\hline
\end{tabular}

Controle de Qualidade - VOC - Água

\begin{tabular}{|c|c|c|}
\hline Unidade & LQ & Resultados analíticos \\
\hline$\mu \mathrm{g} / \mathrm{L}$ & 1 & $<1$ \\
\hline$\mu \mathrm{g} / \mathrm{L}$ & 1 & $<1$ \\
\hline$\mu \mathrm{g} / \mathrm{L}$ & 1 & $<1$ \\
\hline$\mu \mathrm{g} / \mathrm{L}$ & 1 & $<1$ \\
\hline$\mu \mathrm{g} / \mathrm{L}$ & 1 & $<1$ \\
\hline$\mu \mathrm{g} / \mathrm{L}$ & 1 & $<1$ \\
\hline$\mu \mathrm{g} / \mathrm{L}$ & 1 & $<1$ \\
\hline$\mu \mathrm{g} / \mathrm{L}$ & 1 & $<1$ \\
\hline$\mu \mathrm{g} / \mathrm{L}$ & 1 & $<1$ \\
\hline$\mu \mathrm{g} / \mathrm{L}$ & 5 & $<5$ \\
\hline$\mu \mathrm{g} / \mathrm{L}$ & 1 & $<1$ \\
\hline$\mu \mathrm{g} / \mathrm{L}$ & 1 & $<1$ \\
\hline$\mu \mathrm{g} / \mathrm{L}$ & 5 & $<5$ \\
\hline$\mu \mathrm{g} / \mathrm{L}$ & 1 & $<1$ \\
\hline$\mu \mathrm{g} / \mathrm{L}$ & 1 & $<1$ \\
\hline$\mu \mathrm{g} / \mathrm{L}$ & 5 & $<5$ \\
\hline$\mu \mathrm{g} / \mathrm{L}$ & 1 & $<1$ \\
\hline$\mu \mathrm{g} / \mathrm{L}$ & 1 & $<1$ \\
\hline$\mu \mathrm{g} / \mathrm{L}$ & 1 & $<1$ \\
\hline$\mu \mathrm{g} / \mathrm{L}$ & 1 & $<1$ \\
\hline$\mu \mathrm{g} / \mathrm{L}$ & 1 & $<1$ \\
\hline$\mu \mathrm{g} / \mathrm{L}$ & 1 & $<1$ \\
\hline$\mu \mathrm{g} / \mathrm{L}$ & 1 & $<1$ \\
\hline$\mu \mathrm{g} / \mathrm{L}$ & 1 & $<1$ \\
\hline$\mu \mathrm{g} / \mathrm{L}$ & 1 & $<1$ \\
\hline$\mu \mathrm{g} / \mathrm{L}$ & 1 & $<1$ \\
\hline$\mu \mathrm{g} / \mathrm{L}$ & 1 & $<1$ \\
\hline$\mu \mathrm{g} / \mathrm{L}$ & 10 & $<10$ \\
\hline$\mu \mathrm{g} / \mathrm{L}$ & 1 & $<1$ \\
\hline$\mu \mathrm{g} / \mathrm{L}$ & 1 & $<1$ \\
\hline$\mu \mathrm{g} / \mathrm{L}$ & 1 & $<1$ \\
\hline$\mu \mathrm{g} / \mathrm{L}$ & 1 & $<1$ \\
\hline$\mu \mathrm{g} / \mathrm{L}$ & 1 & $<1$ \\
\hline$\mu \mathrm{g} / \mathrm{L}$ & 2 & $<2$ \\
\hline$\mu \mathrm{g} / \mathrm{L}$ & 1 & $<1$ \\
\hline$\mu \mathrm{g} / \mathrm{L}$ & 1 & $<1$ \\
\hline$\mu \mathrm{g} / \mathrm{L}$ & 1 & $<1$ \\
\hline$\mu \mathrm{g} / \mathrm{L}$ & 1 & $<1$ \\
\hline$\mu \mathrm{g} / \mathrm{L}$ & 1 & $<1$ \\
\hline$\mu \mathrm{g} / \mathrm{L}$ & 1 & $<1$ \\
\hline$\mu \mathrm{g} / \mathrm{L}$ & 1 & $<1$ \\
\hline$\mu \mathrm{g} / \mathrm{L}$ & 1 & $<1$ \\
\hline$\mu \mathrm{g} / \mathrm{L}$ & 5 & $<5$ \\
\hline
\end{tabular}




\begin{tabular}{|c|c|c|c|c|}
\hline Parâmetros & $\begin{array}{l}\text { Quantidade } \\
\text { Adicionada }\end{array}$ & Unidade & $\begin{array}{c}\text { Resultado da } \\
\text { Recuperação (\%) }\end{array}$ & Faixa Aceitável de Recuperação (\%) \\
\hline \multicolumn{5}{|c|}{ 302694/2014-0 - Amostra Controle - VOC - Água } \\
\hline 1,1-Dicloroeteno & 20 & $\mu \mathrm{g} / \mathrm{L}$ & 100 & $70-130$ \\
\hline Benzeno & 20 & $\mu \mathrm{g} / \mathrm{L}$ & 125 & $70-130$ \\
\hline Tricloroeteno & 20 & $\mu \mathrm{g} / \mathrm{L}$ & 110 & $70-130$ \\
\hline Tolueno & 20 & $\mu \mathrm{g} / \mathrm{L}$ & 95 & $70-130$ \\
\hline Clorobenzeno & 20 & $\mu \mathrm{g} / \mathrm{L}$ & 105 & $70-130$ \\
\hline \multicolumn{5}{|c|}{$\begin{array}{l}\text { Surrogates } \\
\text { 302692/2014-0 - Branco de Análise - VOC - Água }\end{array}$} \\
\hline p-Bromofluorbenzeno & 20 & $\%$ & 76,5 & $70-130$ \\
\hline Dibromofluorometano & 20 & $\%$ & 130 & $70-130$ \\
\hline \multicolumn{5}{|c|}{ 302694/2014-0 - Amostra Controle - VOC - Água } \\
\hline p-Bromofluorbenzeno & 20 & $\%$ & 78,6 & $70-130$ \\
\hline Dibromofluorometano & 20 & $\%$ & 130 & $70-130$ \\
\hline \multicolumn{5}{|l|}{ 292981/2014-0 - BGBF 1} \\
\hline Dibromofluorometano & 20 & $\%$ & 101 & $70-130$ \\
\hline p-Bromofluorbenzeno & 20 & $\%$ & 75,1 & $70-130$ \\
\hline
\end{tabular}

Notas

LQ = Limite de Quantificação.

n.a. $=$ Não Aplicável.

Abrangência

$\mathrm{O}(\mathrm{s})$ resultado(s) referem-se somente à(s) amostra(s) analisada(s).

Este Relatório de Ensaio só pode ser reproduzido por inteiro e sem nenhuma alteração.

Plano de Amostragem

Plano de amostragem de responsabilidade do interessado.

Responsabilidade Técnica

Os ensaios foram realizados na unidade da Bioagri Ambiental Ltda. - Matriz, situada na Rua Aljovil Martini, 177/201, Bairro Dois Córregos, Cep. 14420-833, Piracicaba/SP, registrada no CRQ 4 Região sob no $16082-\mathrm{F}$ e responsabilidade técnica do profissional Marcos Donizete Ceccatto, CRQ n⿳ ${ }^{\circ} 04364387,4^{\mathrm{a}}$.Região.

Referências Metodológicas

Análises foram realizadas conforme a última versão do Standard Methods for the Examination of Water \& Wastewater 22nd 2012(SMWW), EPA e ABNT (quando aplicável). VOC: EPA 8260 C: 2006, 5021A: 2003

Metiletilcetona: EPA 8260 C: 2006, 5021 A: 2003

Revisores

Débora Fernandes da Silva

Chave de Validação: c7d0ef56fbcb1a2a076dcbd0ddb7c433
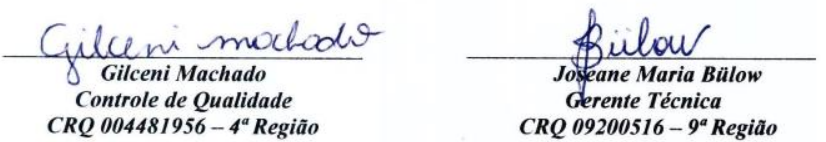


\section{RELATÓRIO DE ENSAIO N ${ }^{\circ}$ 292982/2014-0 - Piracicaba Processo Comercial $N^{\circ}$ 23961/2014-2}

\begin{tabular}{|l|l|}
\hline \multicolumn{2}{|c|}{ DADOS REFERENTES AO CLIENTE } \\
\hline Empresa solicitante: & Fundacao Parque de Alta Tecnologia da Regiao de Ipero e Adjacencias \\
\hline Endereço: & Rua Jose Antonio Scaciota, 165 - - Portal do Cedro - Iperó - SP - CEP: 18.560-000 . \\
\hline Nome do Solicitante: & Carla Marçal \\
\hline
\end{tabular}

DADOS REFERENTES A AMOSTRA

\begin{tabular}{|l|l|l|l|l|}
\hline Identificação do Cliente: & \multicolumn{4}{l|}{ BGBF 2} \\
\hline Amostra Rotulada como: & \multicolumn{2}{|l|}{ Água Subterrânea Projeto Mestrado } \\
\hline Coletor: & Interessado & Data da coleta: & $03 / 11 / 2014$ 00:26:00 \\
\hline Data da entrada no laboratório: & $04 / 11 / 201401: 21$ & Data de Elaboração do RE: & $14 / 11 / 2014$ \\
\hline
\end{tabular}

\section{RESULTADOS PARA A AMOSTRA}

\begin{tabular}{|c|c|c|c|c|c|c|}
\hline Parâmetros & CAS & Unidade & LQ & Resultados analíticos & Incerteza & Data do Ensaio \\
\hline 1,1,1-Tricloroetano & $71-55-6$ & $\mu \mathrm{g} / \mathrm{L}$ & 1 & $<1$ & n.a. & $13 / 11 / 201402: 28$ \\
\hline 1,1,2-Tricloroetano & $79-00-5$ & $\mu \mathrm{g} / \mathrm{L}$ & 1 & $<1$ & n.a. & 13/11/2014 02:28 \\
\hline 1,1,2,2-Tetracloroetano & $79-34-5$ & $\mu \mathrm{g} / \mathrm{L}$ & 1 & $<1$ & n.a. & 13/11/2014 02:28 \\
\hline 1,1-Dicloroetano & 75-34-3 & $\mu \mathrm{g} / \mathrm{L}$ & 1 & $<1$ & n.a. & 13/11/2014 02:28 \\
\hline 1,1-Dicloroeteno & $75-35-4$ & $\mu \mathrm{g} / \mathrm{L}$ & 1 & $<1$ & n.a. & 13/11/2014 02:28 \\
\hline 1,1-Dicloropropeno & $563-58-6$ & $\mu \mathrm{g} / \mathrm{L}$ & 1 & $<1$ & n.a. & $13 / 11 / 201402: 28$ \\
\hline 1,2,3-Triclorobenzeno & $87-61-6$ & $\mu \mathrm{g} / \mathrm{L}$ & 1 & $<1$ & n.a. & 13/11/2014 02:28 \\
\hline 1,2,4-Triclorobenzeno & $120-82-1$ & $\mu \mathrm{g} / \mathrm{L}$ & 1 & $<1$ & n.a. & 13/11/2014 02:28 \\
\hline 1,2-Dibromo-3-Cloropropano & $96-12-8$ & $\mu \mathrm{g} / \mathrm{L}$ & 5 & $<5$ & n.a. & $13 / 11 / 201402: 28$ \\
\hline 1,2-Dicloroetano & $107-06-2$ & $\mu \mathrm{g} / \mathrm{L}$ & 1 & $<1$ & n.a. & $13 / 11 / 201402: 28$ \\
\hline 1,2-Dicloropropano & $78-87-5$ & $\mu \mathrm{g} / \mathrm{L}$ & 1 & $<1$ & n.a. & $13 / 11 / 201402: 28$ \\
\hline 1,3-Dicloropropano & $142-28-9$ & $\mu \mathrm{g} / \mathrm{L}$ & 5 & $<5$ & n.a. & 13/11/2014 02:28 \\
\hline 1,4-Diclorobenzeno & $106-46-7$ & $\mu \mathrm{g} / \mathrm{L}$ & 1 & $<1$ & n.a. & 13/11/2014 02:28 \\
\hline 2,2-Dicloropropano & 594-20-7 & $\mu \mathrm{g} / \mathrm{L}$ & 1 & $<1$ & n.a. & $13 / 11 / 201402: 28$ \\
\hline 4-Metil-2-Pentanona & $108-10-1$ & $\mu \mathrm{g} / \mathrm{L}$ & 5 & $<5$ & n.a. & $13 / 11 / 201402: 28$ \\
\hline Benzeno & $71-43-2$ & $\mu \mathrm{g} / \mathrm{L}$ & 1 & $<1$ & n.a. & $13 / 11 / 201402: 28$ \\
\hline Bromobenzeno & $108-86-1$ & $\mu \mathrm{g} / \mathrm{L}$ & 1 & $<1$ & n.a. & 13/11/2014 02:28 \\
\hline Bromodiclorometano & $75-27-4$ & $\mu \mathrm{g} / \mathrm{L}$ & 1 & $<1$ & n.a. & $13 / 11 / 201402: 28$ \\
\hline Bromofórmio & $75-25-2$ & $\mu \mathrm{g} / \mathrm{L}$ & 1 & $<1$ & n.a. & $13 / 11 / 201402: 28$ \\
\hline Bromoclorometano & $74-97-5$ & $\mu \mathrm{g} / \mathrm{L}$ & 5 & $<5$ & n.a. & $13 / 11 / 201402: 28$ \\
\hline Cis-1,2-Dicloroeteno & $156-59-2$ & $\mu \mathrm{g} / \mathrm{L}$ & 1 & $<1$ & n.a. & 13/11/2014 02:28 \\
\hline Cis-1,3-Dicloropropeno & $10061-01-5$ & $\mu \mathrm{g} / \mathrm{L}$ & 1 & $<1$ & n.a. & 13/11/2014 02:28 \\
\hline Diclorometano & $75-09-2$ & $\mu \mathrm{g} / \mathrm{L}$ & 1 & $<1$ & n.a. & $13 / 11 / 201402: 28$ \\
\hline Cloreto de Vinila & 75-01-4 & $\mu \mathrm{g} / \mathrm{L}$ & 1 & $<1$ & n.a. & $13 / 11 / 201402: 28$ \\
\hline Clorobenzeno & $108-90-7$ & $\mu \mathrm{g} / \mathrm{L}$ & 1 & $<1$ & n.a. & 13/11/2014 02:28 \\
\hline Cloroetano & $75-00-3$ & $\mu \mathrm{g} / \mathrm{L}$ & 1 & $<1$ & n.a. & 13/11/2014 02:28 \\
\hline Clorofórmio & $67-66-3$ & $\mu \mathrm{g} / \mathrm{L}$ & 1 & $<1$ & n.a. & 13/11/2014 02:28 \\
\hline Clorometano & $74-87-3$ & $\mu \mathrm{g} / \mathrm{L}$ & 10 & $<10$ & n.a. & $13 / 11 / 201402: 28$ \\
\hline Dibromoclorometano & $124-48-1$ & $\mu \mathrm{g} / \mathrm{L}$ & 1 & $<1$ & n.a. & 13/11/2014 02:28 \\
\hline Dissulfeto de Carbono & $75-15-0$ & $\mu \mathrm{g} / \mathrm{L}$ & 1 & $<1$ & n.a. & $13 / 11 / 201402: 28$ \\
\hline Estireno & $100-42-5$ & $\mu \mathrm{g} / \mathrm{L}$ & 1 & $<1$ & n.a. & $13 / 11 / 201402: 28$ \\
\hline Etilbenzeno & $100-41-4$ & $\mu \mathrm{g} / \mathrm{L}$ & 1 & $<1$ & n.a. & 13/11/2014 02:28 \\
\hline Hexaclorobutadieno & $87-68-3$ & $\mu \mathrm{g} / \mathrm{L}$ & 1 & $<1$ & n.a. & $13 / 11 / 201402: 28$ \\
\hline m,p-Xilenos & --- & $\mu \mathrm{g} / \mathrm{L}$ & 2 & $<2$ & n.a. & 13/11/2014 02:28 \\
\hline o-Xileno & $95-47-6$ & $\mu \mathrm{g} / \mathrm{L}$ & 1 & $<1$ & n.a. & $13 / 11 / 201402: 28$ \\
\hline p-Isopropiltolueno & $99-87-6$ & $\mu \mathrm{g} / \mathrm{L}$ & 1 & $<1$ & n.a. & 13/11/2014 02:28 \\
\hline Tetracloreto de Carbono & $56-23-5$ & $\mu \mathrm{g} / \mathrm{L}$ & 1 & $<1$ & n.a. & 13/11/2014 02:28 \\
\hline Tetracloroeteno & $127-18-4$ & $\mu \mathrm{g} / \mathrm{L}$ & 1 & 2,9 & 0,55 & 13/11/2014 02:28 \\
\hline Tolueno & $108-88-3$ & $\mu \mathrm{g} / \mathrm{L}$ & 1 & $<1$ & n.a. & $13 / 11 / 201402: 28$ \\
\hline Trans-1,2-Dicloroeteno & $156-60-5$ & $\mu \mathrm{g} / \mathrm{L}$ & 1 & $<1$ & n.a. & 13/11/2014 02:28 \\
\hline Tricloroeteno & $79-01-6$ & $\mu \mathrm{g} / \mathrm{L}$ & 1 & $<1$ & n.a. & 13/11/2014 02:28 \\
\hline 1,1,1,2-Tetracloroetano & $630-20-6$ & $\mu \mathrm{g} / \mathrm{L}$ & 1 & $<1$ & n.a. & $13 / 11 / 201402: 28$ \\
\hline
\end{tabular}




\begin{tabular}{|c|c|c|c|c|c|c|}
\hline Parâmetros & CAS & Unidade & LQ & Resultados analíticos & Incerteza & Data do Ensaio \\
\hline 1,2,3-Tricloropropano & $96-18-4$ & $\mu \mathrm{g} / \mathrm{L}$ & 5 & $<5$ & n.a. & 13/11/2014 02:28 \\
\hline 1,3,5-Trimetilbenzeno & $108-67-8$ & $\mu \mathrm{g} / \mathrm{L}$ & 1 & $<1$ & n.a. & 13/11/2014 02:28 \\
\hline 1,2,4-Trimetilbenzeno & $95-63-6$ & $\mu \mathrm{g} / \mathrm{L}$ & 1 & $<1$ & n.a. & 13/11/2014 02:28 \\
\hline 1,2-Dibromoetano & $106-93-4$ & $\mu \mathrm{g} / \mathrm{L}$ & 1 & $<1$ & n.a. & 13/11/2014 02:28 \\
\hline 1,2-Diclorobenzeno & $95-50-1$ & $\mu \mathrm{g} / \mathrm{L}$ & 1 & $<1$ & n.a. & $13 / 11 / 201402: 28$ \\
\hline 1,3-Diclorobenzeno & $541-73-1$ & $\mu \mathrm{g} / \mathrm{L}$ & 1 & $<1$ & n.a. & $13 / 11 / 201402: 28$ \\
\hline 2-Clorotolueno & $95-49-8$ & $\mu \mathrm{g} / \mathrm{L}$ & 1 & $<1$ & n.a. & $13 / 11 / 201402: 28$ \\
\hline Dibromometano & $74-95-3$ & $\mu \mathrm{g} / \mathrm{L}$ & 1 & $<1$ & n.a. & $13 / 11 / 201402: 28$ \\
\hline Metiletilcetona & $78-93-3$ & $\mu \mathrm{g} / \mathrm{L}$ & 2500 & $<2500$ & n.a. & $13 / 11 / 201402: 28$ \\
\hline Naftaleno & $91-20-3$ & $\mu \mathrm{g} / \mathrm{L}$ & 1 & $<1$ & n.a. & $13 / 11 / 201402: 28$ \\
\hline n-Butilbenzeno & $104-51-8$ & $\mu \mathrm{g} / \mathrm{L}$ & 1 & $<1$ & n.a. & $13 / 11 / 201402: 28$ \\
\hline n-Propilbenzeno & $103-65-1$ & $\mu \mathrm{g} / \mathrm{L}$ & 1 & $<1$ & n.a. & $13 / 11 / 201402: 28$ \\
\hline 4-Clorotolueno & $106-43-4$ & $\mu \mathrm{g} / \mathrm{L}$ & 1 & $<1$ & n.a. & $13 / 11 / 201402: 28$ \\
\hline sec-Butilbenzeno & $135-98-8$ & $\mu \mathrm{g} / \mathrm{L}$ & 1 & $<1$ & n.a. & 13/11/2014 02:28 \\
\hline terc-Butilbenzeno & $98-06-6$ & $\mu \mathrm{g} / \mathrm{L}$ & 1 & $<1$ & n.a. & $13 / 11 / 201402: 28$ \\
\hline trans-1,3-Dicloropropeno & $10061-02-6$ & $\mu \mathrm{g} / \mathrm{L}$ & 1 & $<1$ & n.a. & $13 / 11 / 201402: 28$ \\
\hline Isopropilbenzeno & $98-82-8$ & $\mu \mathrm{g} / \mathrm{L}$ & 1 & $<1$ & n.a. & 13/11/2014 02:28 \\
\hline 1,3,5-Triclorobenzeno & $108-70-3$ & $\mu \mathrm{g} / \mathrm{L}$ & 1 & $<1$ & n.a. & 13/11/2014 02:28 \\
\hline
\end{tabular}

\section{CONTROLE DE QUALIDADE DO LABORATÓRIO}

302692/2014-0 - Branco de Análise - VOC - Água

\begin{tabular}{|c|c|}
\hline \multirow{2}{*}{\multicolumn{2}{|c|}{$\begin{array}{ll} & \text { Parâmetros } \\
1,1,1-\text { Tricloroetano } & \end{array}$}} \\
\hline & \\
\hline \multicolumn{2}{|l|}{ 1,1,2-Tricloroetano } \\
\hline \multicolumn{2}{|l|}{ 1,1,2,2-Tetracloroetano } \\
\hline \multicolumn{2}{|l|}{ 1,1-Dicloroetano } \\
\hline \multicolumn{2}{|l|}{ 1,1-Dicloroeteno } \\
\hline \multicolumn{2}{|l|}{ 1,1-Dicloropropeno } \\
\hline \multicolumn{2}{|l|}{ 1,2,3-Triclorobenzeno } \\
\hline \multicolumn{2}{|l|}{ 1,2,4-Triclorobenzeno } \\
\hline \multicolumn{2}{|l|}{ 1,3,5-Triclorobenzeno } \\
\hline \multicolumn{2}{|l|}{ 1,2-Dibromo-3-Cloropropano } \\
\hline \multicolumn{2}{|l|}{ 1,2-Dicloroetano } \\
\hline \multicolumn{2}{|l|}{ 1,2-Dicloropropano } \\
\hline \multicolumn{2}{|l|}{ 1,3-Dicloropropano } \\
\hline \multicolumn{2}{|l|}{ 1,4-Diclorobenzeno } \\
\hline \multicolumn{2}{|l|}{ 2,2-Dicloropropano } \\
\hline \multicolumn{2}{|l|}{ 4-Metil-2-Pentanona } \\
\hline \multicolumn{2}{|l|}{ Benzeno } \\
\hline \multicolumn{2}{|l|}{ Bromobenzeno } \\
\hline \multicolumn{2}{|l|}{ Bromodiclorometano } \\
\hline \multicolumn{2}{|l|}{ Bromofórmio } \\
\hline \multicolumn{2}{|l|}{ Cis-1,2-Dicloroeteno } \\
\hline \multicolumn{2}{|l|}{ Cis-1,3-Dicloropropeno } \\
\hline \multicolumn{2}{|l|}{ Diclorometano } \\
\hline \multicolumn{2}{|l|}{ Cloreto de Vinila } \\
\hline \multicolumn{2}{|l|}{ Clorobenzeno } \\
\hline \multicolumn{2}{|l|}{ Cloroetano } \\
\hline Clorofórmio & \\
\hline Clorometano & \\
\hline Dibromoclorometano & \\
\hline Dissulfeto de Carbono & \\
\hline Estireno & \\
\hline Etilbenzeno & \\
\hline Hexaclorobutadieno & \\
\hline m,p-Xilenos & \\
\hline o-Xileno & \\
\hline p-Isopropiltolueno & \\
\hline Tetracloreto de Carbono & \\
\hline Tetracloroeteno & \\
\hline Tolueno & \\
\hline Trans-1,2-Dicloroeteno & \\
\hline Tricloroeteno & \\
\hline Isopropilbenzeno & \\
\hline Bromoclorometano & \\
\hline
\end{tabular}

Controle de Qualidade - VOC - Água

\begin{tabular}{|c|c|c|}
\hline Unidade & LQ & Resultados analíticos \\
\hline$\mu \mathrm{g} / \mathrm{L}$ & 1 & $<1$ \\
\hline$\mu \mathrm{g} / \mathrm{L}$ & 1 & $<1$ \\
\hline$\mu \mathrm{g} / \mathrm{L}$ & 1 & $<1$ \\
\hline$\mu \mathrm{g} / \mathrm{L}$ & 1 & $<1$ \\
\hline$\mu \mathrm{g} / \mathrm{L}$ & 1 & $<1$ \\
\hline$\mu \mathrm{g} / \mathrm{L}$ & 1 & $<1$ \\
\hline$\mu \mathrm{g} / \mathrm{L}$ & 1 & $<1$ \\
\hline$\mu \mathrm{g} / \mathrm{L}$ & 1 & $<1$ \\
\hline$\mu \mathrm{g} / \mathrm{L}$ & 1 & $<1$ \\
\hline$\mu \mathrm{g} / \mathrm{L}$ & 5 & $<5$ \\
\hline$\mu \mathrm{g} / \mathrm{L}$ & 1 & $<1$ \\
\hline$\mu \mathrm{g} / \mathrm{L}$ & 1 & $<1$ \\
\hline$\mu \mathrm{g} / \mathrm{L}$ & 5 & $<5$ \\
\hline$\mu \mathrm{g} / \mathrm{L}$ & 1 & $<1$ \\
\hline$\mu \mathrm{g} / \mathrm{L}$ & 1 & $<1$ \\
\hline$\mu \mathrm{g} / \mathrm{L}$ & 5 & $<5$ \\
\hline$\mu \mathrm{g} / \mathrm{L}$ & 1 & $<1$ \\
\hline$\mu \mathrm{g} / \mathrm{L}$ & 1 & $<1$ \\
\hline$\mu \mathrm{g} / \mathrm{L}$ & 1 & $<1$ \\
\hline$\mu \mathrm{g} / \mathrm{L}$ & 1 & $<1$ \\
\hline$\mu \mathrm{g} / \mathrm{L}$ & 1 & $<1$ \\
\hline$\mu \mathrm{g} / \mathrm{L}$ & 1 & $<1$ \\
\hline$\mu \mathrm{g} / \mathrm{L}$ & 1 & $<1$ \\
\hline$\mu \mathrm{g} / \mathrm{L}$ & 1 & $<1$ \\
\hline$\mu \mathrm{g} / \mathrm{L}$ & 1 & $<1$ \\
\hline$\mu \mathrm{g} / \mathrm{L}$ & 1 & $<1$ \\
\hline$\mu \mathrm{g} / \mathrm{L}$ & 1 & $<1$ \\
\hline$\mu \mathrm{g} / \mathrm{L}$ & 10 & $<10$ \\
\hline$\mu \mathrm{g} / \mathrm{L}$ & 1 & $<1$ \\
\hline$\mu \mathrm{g} / \mathrm{L}$ & 1 & $<1$ \\
\hline$\mu \mathrm{g} / \mathrm{L}$ & 1 & $<1$ \\
\hline$\mu \mathrm{g} / \mathrm{L}$ & 1 & $<1$ \\
\hline$\mu \mathrm{g} / \mathrm{L}$ & 1 & $<1$ \\
\hline$\mu \mathrm{g} / \mathrm{L}$ & 2 & $<2$ \\
\hline$\mu \mathrm{g} / \mathrm{L}$ & 1 & $<1$ \\
\hline$\mu \mathrm{g} / \mathrm{L}$ & 1 & $<1$ \\
\hline$\mu \mathrm{g} / \mathrm{L}$ & 1 & $<1$ \\
\hline$\mu \mathrm{g} / \mathrm{L}$ & 1 & $<1$ \\
\hline$\mu \mathrm{g} / \mathrm{L}$ & 1 & $<1$ \\
\hline$\mu \mathrm{g} / \mathrm{L}$ & 1 & $<1$ \\
\hline$\mu \mathrm{g} / \mathrm{L}$ & 1 & $<1$ \\
\hline$\mu \mathrm{g} / \mathrm{L}$ & 1 & $<1$ \\
\hline$\mu \mathrm{g} / \mathrm{L}$ & 5 & $<5$ \\
\hline
\end{tabular}




\begin{tabular}{|c|c|c|c|c|}
\hline Parâmetros & $\begin{array}{l}\text { Quantidade } \\
\text { Adicionada }\end{array}$ & Unidade & $\begin{array}{c}\text { Resultado da } \\
\text { Recuperação (\%) }\end{array}$ & Faixa Aceitável de Recuperação (\%) \\
\hline \multicolumn{5}{|c|}{ 302694/2014-0 - Amostra Controle - VOC - Água } \\
\hline 1,1-Dicloroeteno & 20 & $\mu \mathrm{g} / \mathrm{L}$ & 100 & $70-130$ \\
\hline Benzeno & 20 & $\mu \mathrm{g} / \mathrm{L}$ & 125 & $70-130$ \\
\hline Tricloroeteno & 20 & $\mu \mathrm{g} / \mathrm{L}$ & 110 & $70-130$ \\
\hline Tolueno & 20 & $\mu \mathrm{g} / \mathrm{L}$ & 95 & $70-130$ \\
\hline Clorobenzeno & 20 & $\mu \mathrm{g} / \mathrm{L}$ & 105 & $70-130$ \\
\hline \multicolumn{5}{|c|}{$\begin{array}{l}\text { Surrogates } \\
\text { 302692/2014-0 - Branco de Análise - VOC - Água }\end{array}$} \\
\hline p-Bromofluorbenzeno & 20 & $\%$ & 76,5 & $70-130$ \\
\hline Dibromofluorometano & 20 & $\%$ & 130 & $70-130$ \\
\hline \multicolumn{5}{|c|}{ 302694/2014-0 - Amostra Controle - VOC - Água } \\
\hline p-Bromofluorbenzeno & 20 & $\%$ & 78,6 & $70-130$ \\
\hline Dibromofluorometano & 20 & $\%$ & 130 & $70-130$ \\
\hline \multicolumn{5}{|l|}{ 292982/2014-0 - BGBF 2} \\
\hline Dibromofluorometano & 20 & $\%$ & 102 & $70-130$ \\
\hline p-Bromofluorbenzeno & 20 & $\%$ & 78,4 & $70-130$ \\
\hline
\end{tabular}

Notas

LQ = Limite de Quantificação.

n.a. $=$ Não Aplicável.

Abrangência

$\mathrm{O}(\mathrm{s})$ resultado(s) referem-se somente à(s) amostra(s) analisada(s).

Este Relatório de Ensaio só pode ser reproduzido por inteiro e sem nenhuma alteração.

Plano de Amostragem

Plano de amostragem de responsabilidade do interessado.

Responsabilidade Técnica

Os ensaios foram realizados na unidade da Bioagri Ambiental Ltda. - Matriz, situada na Rua Aljovil Martini, 177/201, Bairro Dois Córregos, Cep. 14420-833, Piracicaba/SP, registrada no CRQ 4 Região sob no $16082-\mathrm{F}$ e responsabilidade técnica do profissional Marcos Donizete Ceccatto, CRQ n ${ }^{\circ} 04364387,4^{\mathrm{a}}$.Região.

Referências Metodológicas

Análises foram realizadas conforme a última versão do Standard Methods for the Examination of Water \& Wastewater 22nd 2012(SMWW), EPA e ABNT (quando aplicável). VOC: EPA 8260 C: 2006, 5021A: 2003

Metiletilcetona: EPA 8260 C: 2006, 5021 A: 2003

Revisores

Débora Fernandes da Silva

Chave de Validação: fae6baff3a07cbf56cb1daa77f4de3c7
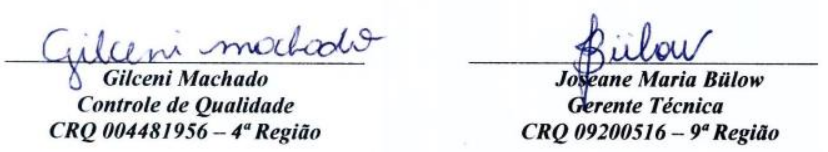


\section{RELATÓRIO DE ENSAIO $\mathrm{N}^{\circ}$ 292983/2014-0 - Piracicaba} Processo Comercial $N^{\circ}$ 23961/2014-2

\begin{tabular}{|l|l|}
\hline \multicolumn{2}{|c|}{ DADOS REFERENTES AO CLIENTE } \\
\hline Empresa solicitante: & Fundacao Parque de Alta Tecnologia da Regiao de Ipero e Adjacencias \\
\hline Endereço: & Rua Jose Antonio Scaciota, 165 - - Portal do Cedro - Iperó - SP - CEP: 18.560-000 . \\
\hline Nome do Solicitante: & Carla Marçal \\
\hline
\end{tabular}

DADOS REFERENTES A AMOSTRA

\begin{tabular}{|c|c|c|c|c|c|}
\hline Identificação do Cliente: & \multicolumn{5}{|c|}{ BGBF 3} \\
\hline Amostra Rotulada como: & \multicolumn{5}{|c|}{ Água Subterrânea Projeto Mestrado } \\
\hline Coletor: & \multicolumn{2}{|c|}{ Interessado } & Data da coleta: & \multicolumn{2}{|c|}{ 03/11/2014 00:27:00 } \\
\hline \multicolumn{2}{|c|}{ Data da entrada no laboratório: } & 04/11/2014 01:21 & \multicolumn{2}{|c|}{ Data de Elaboração do RE: } & $14 / 11 / 2014$ \\
\hline
\end{tabular}

RESULTADOS PARA A AMOSTRA

\begin{tabular}{|c|c|c|c|c|c|c|}
\hline Parâmetros & CAS & Unidade & LQ & Resultados analíticos & Incerteza & Data do Ensaio \\
\hline 1,1,1-Tricloroetano & $71-55-6$ & $\mu \mathrm{g} / \mathrm{L}$ & 1 & $<1$ & n.a. & $13 / 11 / 201402: 52$ \\
\hline 1,1,2-Tricloroetano & $79-00-5$ & $\mu \mathrm{g} / \mathrm{L}$ & 1 & $<1$ & n.a. & 13/11/2014 02:52 \\
\hline 1,1,2,2-Tetracloroetano & $79-34-5$ & $\mu \mathrm{g} / \mathrm{L}$ & 1 & $<1$ & n.a. & 13/11/2014 02:52 \\
\hline 1,1-Dicloroetano & $75-34-3$ & $\mu \mathrm{g} / \mathrm{L}$ & 1 & $<1$ & n.a. & $13 / 11 / 201402: 52$ \\
\hline 1,1-Dicloroeteno & $75-35-4$ & $\mu \mathrm{g} / \mathrm{L}$ & 1 & $<1$ & n.a. & 13/11/2014 02:52 \\
\hline 1,1-Dicloropropeno & $563-58-6$ & $\mu \mathrm{g} / \mathrm{L}$ & 1 & $<1$ & n.a. & $13 / 11 / 201402: 52$ \\
\hline 1,2,3-Triclorobenzeno & $87-61-6$ & $\mu \mathrm{g} / \mathrm{L}$ & 1 & $<1$ & n.a. & 13/11/2014 02:52 \\
\hline 1,2,4-Triclorobenzeno & $120-82-1$ & $\mu \mathrm{g} / \mathrm{L}$ & 1 & $<1$ & n.a. & $13 / 11 / 201402: 52$ \\
\hline 1,2-Dibromo-3-Cloropropano & $96-12-8$ & $\mu \mathrm{g} / \mathrm{L}$ & 5 & $<5$ & n.a. & 13/11/2014 02:52 \\
\hline 1,2-Dicloroetano & $107-06-2$ & $\mu \mathrm{g} / \mathrm{L}$ & 1 & $<1$ & n.a. & $13 / 11 / 201402: 52$ \\
\hline 1,2-Dicloropropano & $78-87-5$ & $\mu \mathrm{g} / \mathrm{L}$ & 1 & $<1$ & n.a. & $13 / 11 / 201402: 52$ \\
\hline 1,3-Dicloropropano & $142-28-9$ & $\mu \mathrm{g} / \mathrm{L}$ & 5 & $<5$ & n.a. & $13 / 11 / 201402: 52$ \\
\hline 1,4-Diclorobenzeno & $106-46-7$ & $\mu \mathrm{g} / \mathrm{L}$ & 1 & $<1$ & n.a. & 13/11/2014 02:52 \\
\hline 2,2-Dicloropropano & $594-20-7$ & $\mu \mathrm{g} / \mathrm{L}$ & 1 & $<1$ & n.a. & $13 / 11 / 201402: 52$ \\
\hline 4-Metil-2-Pentanona & $108-10-1$ & $\mu \mathrm{g} / \mathrm{L}$ & 5 & $<5$ & n.a. & $13 / 11 / 201402: 52$ \\
\hline Benzeno & $71-43-2$ & $\mu \mathrm{g} / \mathrm{L}$ & 1 & $<1$ & n.a. & $13 / 11 / 201402: 52$ \\
\hline Bromobenzeno & $108-86-1$ & $\mu \mathrm{g} / \mathrm{L}$ & 1 & $<1$ & n.a. & 13/11/2014 02:52 \\
\hline Bromodiclorometano & $75-27-4$ & $\mu \mathrm{g} / \mathrm{L}$ & 1 & $<1$ & n.a. & 13/11/2014 02:52 \\
\hline Bromofórmio & $75-25-2$ & $\mu \mathrm{g} / \mathrm{L}$ & 1 & $<1$ & n.a. & $13 / 11 / 201402: 52$ \\
\hline Bromoclorometano & $74-97-5$ & $\mu \mathrm{g} / \mathrm{L}$ & 5 & $<5$ & n.a. & 13/11/2014 02:52 \\
\hline Cis-1,2-Dicloroeteno & $156-59-2$ & $\mu \mathrm{g} / \mathrm{L}$ & 1 & $<1$ & n.a. & $13 / 11 / 201402: 52$ \\
\hline Cis-1,3-Dicloropropeno & $10061-01-5$ & $\mu \mathrm{g} / \mathrm{L}$ & 1 & $<1$ & n.a. & 13/11/2014 02:52 \\
\hline Diclorometano & $75-09-2$ & $\mu \mathrm{g} / \mathrm{L}$ & 1 & $<1$ & n.a. & 13/11/2014 02:52 \\
\hline Cloreto de Vinila & $75-01-4$ & $\mu \mathrm{g} / \mathrm{L}$ & 1 & $<1$ & n.a. & 13/11/2014 02:52 \\
\hline Clorobenzeno & $108-90-7$ & $\mu \mathrm{g} / \mathrm{L}$ & 1 & $<1$ & n.a. & $13 / 11 / 201402: 52$ \\
\hline Cloroetano & $75-00-3$ & $\mu \mathrm{g} / \mathrm{L}$ & 1 & $<1$ & n.a. & $13 / 11 / 201402: 52$ \\
\hline Clorofórmio & $67-66-3$ & $\mu \mathrm{g} / \mathrm{L}$ & 1 & $<1$ & n.a. & 13/11/2014 02:52 \\
\hline Clorometano & $74-87-3$ & $\mu \mathrm{g} / \mathrm{L}$ & 10 & $<10$ & n.a. & 13/11/2014 02:52 \\
\hline Dibromoclorometano & $124-48-1$ & $\mu \mathrm{g} / \mathrm{L}$ & 1 & $<1$ & n.a. & 13/11/2014 02:52 \\
\hline Dissulfeto de Carbono & $75-15-0$ & $\mu \mathrm{g} / \mathrm{L}$ & 1 & $<1$ & n.a. & 13/11/2014 02:52 \\
\hline Estireno & $100-42-5$ & $\mu \mathrm{g} / \mathrm{L}$ & 1 & $<1$ & n.a. & $13 / 11 / 201402: 52$ \\
\hline Etilbenzeno & $100-41-4$ & $\mu \mathrm{g} / \mathrm{L}$ & 1 & $<1$ & n.a. & $13 / 11 / 201402: 52$ \\
\hline Hexaclorobutadieno & $87-68-3$ & $\mu \mathrm{g} / \mathrm{L}$ & 1 & $<1$ & n.a. & 13/11/2014 02:52 \\
\hline m,p-Xilenos & --- & $\mu \mathrm{g} / \mathrm{L}$ & 2 & $<2$ & n.a. & 13/11/2014 02:52 \\
\hline o-Xileno & $95-47-6$ & $\mu \mathrm{g} / \mathrm{L}$ & 1 & $<1$ & n.a. & 13/11/2014 02:52 \\
\hline p-Isopropiltolueno & $99-87-6$ & $\mu \mathrm{g} / \mathrm{L}$ & 1 & $<1$ & n.a. & 13/11/2014 02:52 \\
\hline Tetracloreto de Carbono & $56-23-5$ & $\mu \mathrm{g} / \mathrm{L}$ & 1 & $<1$ & n.a. & 13/11/2014 02:52 \\
\hline Tetracloroeteno & $127-18-4$ & $\mu \mathrm{g} / \mathrm{L}$ & 1 & $<1$ & n.a. & 13/11/2014 02:52 \\
\hline Tolueno & $108-88-3$ & $\mu \mathrm{g} / \mathrm{L}$ & 1 & $<1$ & n.a. & $13 / 11 / 201402: 52$ \\
\hline Trans-1,2-Dicloroeteno & $156-60-5$ & $\mu \mathrm{g} / \mathrm{L}$ & 1 & $<1$ & n.a. & 13/11/2014 02:52 \\
\hline Tricloroeteno & $79-01-6$ & $\mu \mathrm{g} / \mathrm{L}$ & 1 & $<1$ & n.a. & 13/11/2014 02:52 \\
\hline 1,1,1,2-Tetracloroetano & $630-20-6$ & $\mu \mathrm{g} / \mathrm{L}$ & 1 & $<1$ & n.a. & 13/11/2014 02:52 \\
\hline
\end{tabular}




\begin{tabular}{|c|c|c|c|c|c|c|}
\hline Parâmetros & CAS & Unidade & LQ & Resultados analíticos & Incerteza & Data do Ensaio \\
\hline 1,2,3-Tricloropropano & $96-18-4$ & $\mu \mathrm{g} / \mathrm{L}$ & 5 & $<5$ & n.a. & 13/11/2014 02:52 \\
\hline 1,3,5-Trimetilbenzeno & $108-67-8$ & $\mu \mathrm{g} / \mathrm{L}$ & 1 & $<1$ & n.a. & $13 / 11 / 201402: 52$ \\
\hline 1,2,4-Trimetilbenzeno & $95-63-6$ & $\mu \mathrm{g} / \mathrm{L}$ & 1 & $<1$ & n.a. & $13 / 11 / 201402: 52$ \\
\hline 1,2-Dibromoetano & $106-93-4$ & $\mu \mathrm{g} / \mathrm{L}$ & 1 & $<1$ & n.a. & 13/11/2014 02:52 \\
\hline 1,2-Diclorobenzeno & $95-50-1$ & $\mu \mathrm{g} / \mathrm{L}$ & 1 & $<1$ & n.a. & $13 / 11 / 201402: 52$ \\
\hline 1,3-Diclorobenzeno & $541-73-1$ & $\mu \mathrm{g} / \mathrm{L}$ & 1 & $<1$ & n.a. & $13 / 11 / 201402: 52$ \\
\hline 2-Clorotolueno & $95-49-8$ & $\mu \mathrm{g} / \mathrm{L}$ & 1 & $<1$ & n.a. & $13 / 11 / 201402: 52$ \\
\hline Dibromometano & $74-95-3$ & $\mu \mathrm{g} / \mathrm{L}$ & 1 & $<1$ & n.a. & $13 / 11 / 201402: 52$ \\
\hline Metiletilcetona & 78-93-3 & $\mu \mathrm{g} / \mathrm{L}$ & 2500 & $<2500$ & n.a. & $13 / 11 / 201402: 52$ \\
\hline Naftaleno & $91-20-3$ & $\mu \mathrm{g} / \mathrm{L}$ & 1 & $<1$ & n.a. & $13 / 11 / 201402: 52$ \\
\hline n-Butilbenzeno & $104-51-8$ & $\mu \mathrm{g} / \mathrm{L}$ & 1 & $<1$ & n.a. & $13 / 11 / 201402: 52$ \\
\hline n-Propilbenzeno & $103-65-1$ & $\mu \mathrm{g} / \mathrm{L}$ & 1 & $<1$ & n.a. & 13/11/2014 02:52 \\
\hline 4-Clorotolueno & $106-43-4$ & $\mu \mathrm{g} / \mathrm{L}$ & 1 & $<1$ & n.a. & $13 / 11 / 201402: 52$ \\
\hline sec-Butilbenzeno & $135-98-8$ & $\mu \mathrm{g} / \mathrm{L}$ & 1 & $<1$ & n.a. & 13/11/2014 02:52 \\
\hline terc-Butilbenzeno & $98-06-6$ & $\mu \mathrm{g} / \mathrm{L}$ & 1 & $<1$ & n.a. & $13 / 11 / 201402: 52$ \\
\hline trans-1,3-Dicloropropeno & $10061-02-6$ & $\mu \mathrm{g} / \mathrm{L}$ & 1 & $<1$ & n.a. & $13 / 11 / 201402: 52$ \\
\hline Isopropilbenzeno & $98-82-8$ & $\mu \mathrm{g} / \mathrm{L}$ & 1 & $<1$ & n.a. & 13/11/2014 02:52 \\
\hline 1,3,5-Triclorobenzeno & $108-70-3$ & $\mu \mathrm{g} / \mathrm{L}$ & 1 & $<1$ & n.a. & 13/11/2014 02:52 \\
\hline
\end{tabular}

\section{CONTROLE DE QUALIDADE DO LABORATÓRIO}

302692/2014-0 - Branco de Análise - VOC - Água

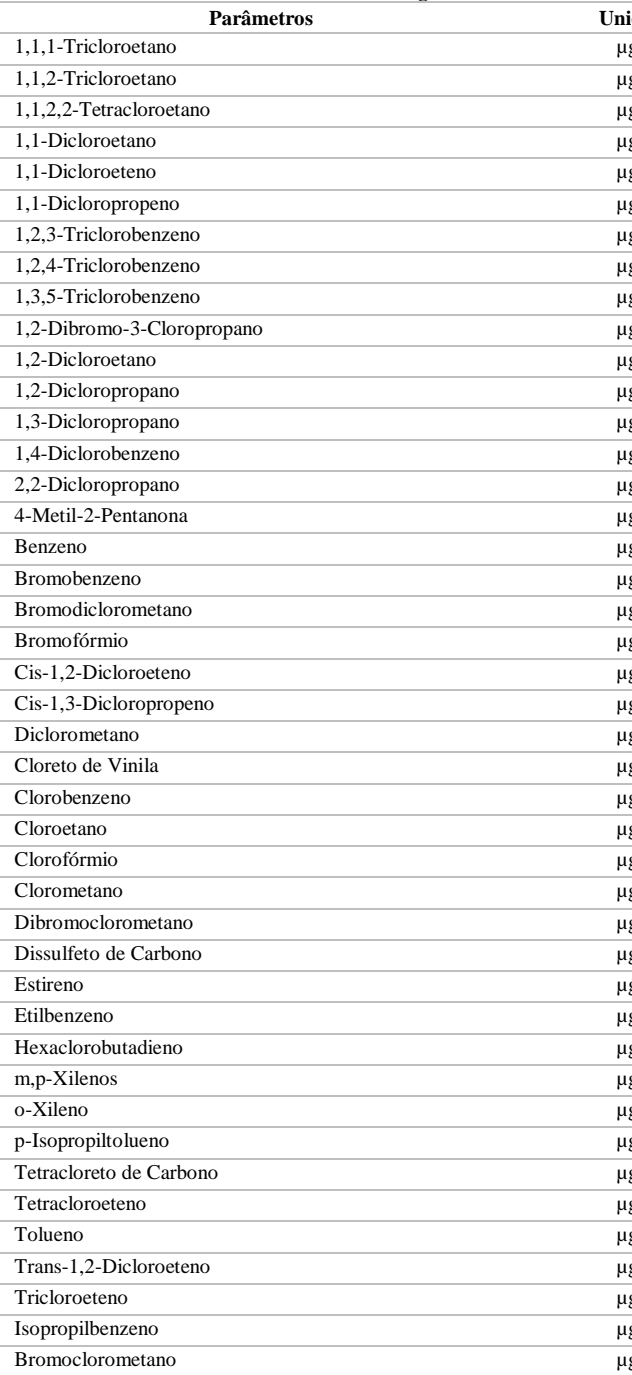

Controle de Qualidade - VOC - Água

\begin{tabular}{|c|c|c|}
\hline Unidade & LQ & Resultados analíticos \\
\hline$\mu \mathrm{g} / \mathrm{L}$ & 1 & $<1$ \\
\hline$\mu \mathrm{g} / \mathrm{L}$ & 1 & $<1$ \\
\hline$\mu \mathrm{g} / \mathrm{L}$ & 1 & $<1$ \\
\hline$\mu \mathrm{g} / \mathrm{L}$ & 1 & $<1$ \\
\hline$\mu \mathrm{g} / \mathrm{L}$ & 1 & $<1$ \\
\hline$\mu \mathrm{g} / \mathrm{L}$ & 1 & $<1$ \\
\hline$\mu \mathrm{g} / \mathrm{L}$ & 1 & $<1$ \\
\hline$\mu \mathrm{g} / \mathrm{L}$ & 1 & $<1$ \\
\hline$\mu \mathrm{g} / \mathrm{L}$ & 1 & $<1$ \\
\hline$\mu \mathrm{g} / \mathrm{L}$ & 5 & $<5$ \\
\hline$\mu \mathrm{g} / \mathrm{L}$ & 1 & $<1$ \\
\hline$\mu \mathrm{g} / \mathrm{L}$ & 1 & $<1$ \\
\hline$\mu \mathrm{g} / \mathrm{L}$ & 5 & $<5$ \\
\hline$\mu \mathrm{g} / \mathrm{L}$ & 1 & $<1$ \\
\hline$\mu \mathrm{g} / \mathrm{L}$ & 1 & $<1$ \\
\hline$\mu \mathrm{g} / \mathrm{L}$ & 5 & $<5$ \\
\hline$\mu \mathrm{g} / \mathrm{L}$ & 1 & $<1$ \\
\hline$\mu \mathrm{g} / \mathrm{L}$ & 1 & $<1$ \\
\hline$\mu \mathrm{g} / \mathrm{L}$ & 1 & $<1$ \\
\hline$\mu \mathrm{g} / \mathrm{L}$ & 1 & $<1$ \\
\hline$\mu \mathrm{g} / \mathrm{L}$ & 1 & $<1$ \\
\hline$\mu \mathrm{g} / \mathrm{L}$ & 1 & $<1$ \\
\hline$\mu \mathrm{g} / \mathrm{L}$ & 1 & $<1$ \\
\hline$\mu \mathrm{g} / \mathrm{L}$ & 1 & $<1$ \\
\hline$\mu \mathrm{g} / \mathrm{L}$ & 1 & $<1$ \\
\hline$\mu \mathrm{g} / \mathrm{L}$ & 1 & $<1$ \\
\hline$\mu \mathrm{g} / \mathrm{L}$ & 1 & $<1$ \\
\hline$\mu \mathrm{g} / \mathrm{L}$ & 10 & $<10$ \\
\hline$\mu \mathrm{g} / \mathrm{L}$ & 1 & $<1$ \\
\hline$\mu \mathrm{g} / \mathrm{L}$ & 1 & $<1$ \\
\hline$\mu \mathrm{g} / \mathrm{L}$ & 1 & $<1$ \\
\hline$\mu \mathrm{g} / \mathrm{L}$ & 1 & $<1$ \\
\hline$\mu \mathrm{g} / \mathrm{L}$ & 1 & $<1$ \\
\hline$\mu \mathrm{g} / \mathrm{L}$ & 2 & $<2$ \\
\hline$\mu \mathrm{g} / \mathrm{L}$ & 1 & $<1$ \\
\hline$\mu \mathrm{g} / \mathrm{L}$ & 1 & $<1$ \\
\hline$\mu \mathrm{g} / \mathrm{L}$ & 1 & $<1$ \\
\hline$\mu \mathrm{g} / \mathrm{L}$ & 1 & $<1$ \\
\hline$\mu \mathrm{g} / \mathrm{L}$ & 1 & $<1$ \\
\hline$\mu \mathrm{g} / \mathrm{L}$ & 1 & $<1$ \\
\hline$\mu \mathrm{g} / \mathrm{L}$ & 1 & $<1$ \\
\hline$\mu \mathrm{g} / \mathrm{L}$ & 1 & $<1$ \\
\hline$\mu \mathrm{g} / \mathrm{L}$ & 5 & $<5$ \\
\hline
\end{tabular}




\begin{tabular}{|c|c|c|c|c|}
\hline Parâmetros & $\begin{array}{l}\text { Quantidade } \\
\text { Adicionada }\end{array}$ & Unidade & $\begin{array}{c}\text { Resultado da } \\
\text { Recuperação (\%) }\end{array}$ & Faixa Aceitável de Recuperação (\%) \\
\hline \multicolumn{5}{|c|}{ 302694/2014-0 - Amostra Controle - VOC - Água } \\
\hline 1,1-Dicloroeteno & 20 & $\mu \mathrm{g} / \mathrm{L}$ & 100 & $70-130$ \\
\hline Benzeno & 20 & $\mu \mathrm{g} / \mathrm{L}$ & 125 & $70-130$ \\
\hline Tricloroeteno & 20 & $\mu \mathrm{g} / \mathrm{L}$ & 110 & $70-130$ \\
\hline Tolueno & 20 & $\mu \mathrm{g} / \mathrm{L}$ & 95 & $70-130$ \\
\hline Clorobenzeno & 20 & $\mu \mathrm{g} / \mathrm{L}$ & 105 & $70-130$ \\
\hline \multicolumn{5}{|c|}{$\begin{array}{l}\text { Surrogates } \\
\text { 302692/2014-0 - Branco de Análise - VOC - Água }\end{array}$} \\
\hline p-Bromofluorbenzeno & 20 & $\%$ & 76,5 & $70-130$ \\
\hline Dibromofluorometano & 20 & $\%$ & 130 & $70-130$ \\
\hline \multicolumn{5}{|c|}{ 302694/2014-0 - Amostra Controle - VOC - Água } \\
\hline p-Bromofluorbenzeno & 20 & $\%$ & 78,6 & $70-130$ \\
\hline Dibromofluorometano & 20 & $\%$ & 130 & $70-130$ \\
\hline \multicolumn{5}{|l|}{ 292983/2014-0 - BGBF 3} \\
\hline Dibromofluorometano & 20 & $\%$ & 96,8 & $70-130$ \\
\hline p-Bromofluorbenzeno & 20 & $\%$ & 73,7 & $70-130$ \\
\hline
\end{tabular}

Notas

LQ = Limite de Quantificação.

n.a. = Não Aplicável.

Abrangência

$\mathrm{O}(\mathrm{s})$ resultado(s) referem-se somente à(s) amostra(s) analisada(s).

Este Relatório de Ensaio só pode ser reproduzido por inteiro e sem nenhuma alteração.

Plano de Amostragem

Plano de amostragem de responsabilidade do interessado.

Responsabilidade Técnica

Os ensaios foram realizados na unidade da Bioagri Ambiental Ltda. - Matriz, situada na Rua Aljovil Martini, 177/201, Bairro Dois Córregos, Cep. 14420-833, Piracicaba/SP, registrada no CRQ 4 Região sob n⿳亠丷厂 $16082-\mathrm{F}$ e responsabilidade técnica do profissional Marcos Donizete Ceccatto, CRQ n ${ }^{\circ} 04364387,4^{\mathrm{a}}$.Região.

Referências Metodológicas

Análises foram realizadas conforme a última versão do Standard Methods for the Examination of Water \& Wastewater 22nd 2012(SMWW), EPA e ABNT (quando aplicável). VOC: EPA 8260 C: 2006, 5021A: 2003

Metiletilcetona: EPA 8260 C: 2006, 5021 A: 2003

Revisores

Débora Fernandes da Silva

Chave de Validação: f9d8ebbf3122549fe55961b8e072d714
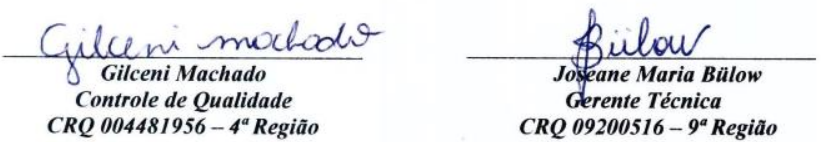


\section{RELATÓRIO DE ENSAIO N ${ }^{\circ}$ 292996/2014-0 - Piracicaba Processo Comercial $N^{\circ} 23961 / 2014-2$}

\begin{tabular}{|l|l|}
\hline \multicolumn{2}{|c|}{ DADOS REFERENTES AO CLIENTE } \\
\hline Empresa solicitante: & Fundacao Parque de Alta Tecnologia da Regiao de Ipero e Adjacencias \\
\hline Endereço: & Rua Jose Antonio Scaciota, 165 - - Portal do Cedro - Iperó - SP - CEP: 18.560-000 . \\
\hline Nome do Solicitante: & Carla Marçal \\
\hline
\end{tabular}

\section{DADOS REFERENTES A AMOSTRA}

Identificação do Cliente: Amostra Rotulada como:

Coletor:

BAI 1

Água Subterrânea Projeto Mestrado

\begin{tabular}{|l|l|l|l|l|}
\hline Data da entrada no laboratório: & 04/11/2014 01:26 & Data de Elaboração do RE: & 14/11/2014
\end{tabular}

\section{RESULTADOS PARA A AMOSTRA}

\begin{tabular}{|c|c|c|c|c|c|c|}
\hline Parâmetros & CAS & Unidade & LQ & Resultados analíticos & Incerteza & Data do Ensaio \\
\hline 1,1,1-Tricloroetano & $71-55-6$ & $\mu \mathrm{g} / \mathrm{L}$ & 1 & $<1$ & n.a. & 13/11/2014 03:41 \\
\hline 1,1,2-Tricloroetano & $79-00-5$ & $\mu \mathrm{g} / \mathrm{L}$ & 1 & $<1$ & n.a. & 13/11/2014 03:41 \\
\hline 1,1,2,2-Tetracloroetano & $79-34-5$ & $\mu \mathrm{g} / \mathrm{L}$ & 1 & $<1$ & n.a. & 13/11/2014 03:41 \\
\hline 1,1-Dicloroetano & $75-34-3$ & $\mu \mathrm{g} / \mathrm{L}$ & 1 & $<1$ & n.a. & 13/11/2014 03:41 \\
\hline 1,1-Dicloroeteno & $75-35-4$ & $\mu \mathrm{g} / \mathrm{L}$ & 1 & $<1$ & n.a. & 13/11/2014 03:41 \\
\hline 1,1-Dicloropropeno & $563-58-6$ & $\mu \mathrm{g} / \mathrm{L}$ & 1 & $<1$ & n.a. & 13/11/2014 03:41 \\
\hline 1,2,3-Triclorobenzeno & $87-61-6$ & $\mu \mathrm{g} / \mathrm{L}$ & 1 & $<1$ & n.a. & 13/11/2014 03:41 \\
\hline 1,2,4-Triclorobenzeno & $120-82-1$ & $\mu \mathrm{g} / \mathrm{L}$ & 1 & $<1$ & n.a. & 13/11/2014 03:41 \\
\hline 1,2-Dibromo-3-Cloropropano & $96-12-8$ & $\mu \mathrm{g} / \mathrm{L}$ & 5 & $<5$ & n.a. & 13/11/2014 03:41 \\
\hline 1,2-Dicloroetano & $107-06-2$ & $\mu \mathrm{g} / \mathrm{L}$ & 1 & $<1$ & n.a. & 13/11/2014 03:41 \\
\hline 1,2-Dicloropropano & $78-87-5$ & $\mu \mathrm{g} / \mathrm{L}$ & 1 & $<1$ & n.a. & 13/11/2014 03:41 \\
\hline 1,3-Dicloropropano & $142-28-9$ & $\mu \mathrm{g} / \mathrm{L}$ & 5 & $<5$ & n.a. & 13/11/2014 03:41 \\
\hline 1,4-Diclorobenzeno & $106-46-7$ & $\mu \mathrm{g} / \mathrm{L}$ & 1 & $<1$ & n.a. & 13/11/2014 03:41 \\
\hline 2,2-Dicloropropano & $594-20-7$ & $\mu \mathrm{g} / \mathrm{L}$ & 1 & $<1$ & n.a. & 13/11/2014 03:41 \\
\hline 4-Metil-2-Pentanona & $108-10-1$ & $\mu \mathrm{g} / \mathrm{L}$ & 5 & $<5$ & n.a. & 13/11/2014 03:41 \\
\hline Benzeno & $71-43-2$ & $\mu \mathrm{g} / \mathrm{L}$ & 1 & $<1$ & n.a. & 13/11/2014 03:41 \\
\hline Bromobenzeno & $108-86-1$ & $\mu \mathrm{g} / \mathrm{L}$ & 1 & $<1$ & n.a. & 13/11/2014 03:41 \\
\hline Bromodiclorometano & $75-27-4$ & $\mu \mathrm{g} / \mathrm{L}$ & 1 & $<1$ & n.a. & 13/11/2014 03:41 \\
\hline Bromofórmio & $75-25-2$ & $\mu \mathrm{g} / \mathrm{L}$ & 1 & $<1$ & n.a. & 13/11/2014 03:41 \\
\hline Bromoclorometano & $74-97-5$ & $\mu \mathrm{g} / \mathrm{L}$ & 5 & $<5$ & n.a. & 13/11/2014 03:41 \\
\hline Cis-1,2-Dicloroeteno & $156-59-2$ & $\mu \mathrm{g} / \mathrm{L}$ & 1 & $<1$ & n.a. & 13/11/2014 03:41 \\
\hline Cis-1,3-Dicloropropeno & $10061-01-5$ & $\mu \mathrm{g} / \mathrm{L}$ & 1 & $<1$ & n.a. & 13/11/2014 03:41 \\
\hline Diclorometano & $75-09-2$ & $\mu \mathrm{g} / \mathrm{L}$ & 1 & $<1$ & n.a. & 13/11/2014 03:41 \\
\hline Cloreto de Vinila & $75-01-4$ & $\mu \mathrm{g} / \mathrm{L}$ & 1 & $<1$ & n.a. & 13/11/2014 03:41 \\
\hline Clorobenzeno & $108-90-7$ & $\mu \mathrm{g} / \mathrm{L}$ & 1 & $<1$ & n.a. & 13/11/2014 03:41 \\
\hline Cloroetano & $75-00-3$ & $\mu \mathrm{g} / \mathrm{L}$ & 1 & $<1$ & n.a. & 13/11/2014 03:41 \\
\hline Clorofórmio & $67-66-3$ & $\mu \mathrm{g} / \mathrm{L}$ & 1 & $<1$ & n.a. & 13/11/2014 03:41 \\
\hline Clorometano & $74-87-3$ & $\mu \mathrm{g} / \mathrm{L}$ & 10 & $<10$ & n.a. & 13/11/2014 03:41 \\
\hline Dibromoclorometano & $124-48-1$ & $\mu \mathrm{g} / \mathrm{L}$ & 1 & $<1$ & n.a. & 13/11/2014 03:41 \\
\hline Dissulfeto de Carbono & $75-15-0$ & $\mu \mathrm{g} / \mathrm{L}$ & 1 & $<1$ & n.a. & 13/11/2014 03:41 \\
\hline Estireno & $100-42-5$ & $\mu \mathrm{g} / \mathrm{L}$ & 1 & $<1$ & n.a. & 13/11/2014 03:41 \\
\hline Etilbenzeno & $100-41-4$ & $\mu \mathrm{g} / \mathrm{L}$ & 1 & $<1$ & n.a. & 13/11/2014 03:41 \\
\hline Hexaclorobutadieno & $87-68-3$ & $\mu \mathrm{g} / \mathrm{L}$ & 1 & $<1$ & n.a. & 13/11/2014 03:41 \\
\hline m,p-Xilenos & --- & $\mu \mathrm{g} / \mathrm{L}$ & 2 & $<2$ & n.a. & 13/11/2014 03:41 \\
\hline o-Xileno & $95-47-6$ & $\mu \mathrm{g} / \mathrm{L}$ & 1 & $<1$ & n.a. & 13/11/2014 03:41 \\
\hline p-Isopropiltolueno & $99-87-6$ & $\mu \mathrm{g} / \mathrm{L}$ & 1 & $<1$ & n.a. & 13/11/2014 03:41 \\
\hline Tetracloreto de Carbono & $56-23-5$ & $\mu \mathrm{g} / \mathrm{L}$ & 1 & $<1$ & n.a. & 13/11/2014 03:41 \\
\hline Tetracloroeteno & $127-18-4$ & $\mu \mathrm{g} / \mathrm{L}$ & 1 & 40,8 & 7,8 & 13/11/2014 03:41 \\
\hline Tolueno & $108-88-3$ & $\mu \mathrm{g} / \mathrm{L}$ & 1 & $<1$ & n.a. & 13/11/2014 03:41 \\
\hline Trans-1,2-Dicloroeteno & $156-60-5$ & $\mu \mathrm{g} / \mathrm{L}$ & 1 & $<1$ & n.a. & 13/11/2014 03:41 \\
\hline Tricloroeteno & 79-01-6 & $\mu \mathrm{g} / \mathrm{L}$ & 1 & $<1$ & n.a. & 13/11/2014 03:41 \\
\hline 1,1,1,2-Tetracloroetano & $630-20-6$ & $\mu \mathrm{g} / \mathrm{L}$ & 1 & $<1$ & n.a. & 13/11/2014 03:41 \\
\hline
\end{tabular}




\begin{tabular}{|c|c|c|c|c|c|c|}
\hline Parâmetros & CAS & Unidade & LQ & Resultados analíticos & Incerteza & Data do Ensaio \\
\hline 1,2,3-Tricloropropano & $96-18-4$ & $\mu \mathrm{g} / \mathrm{L}$ & 5 & $<5$ & n.a. & 13/11/2014 03:41 \\
\hline 1,3,5-Trimetilbenzeno & $108-67-8$ & $\mu \mathrm{g} / \mathrm{L}$ & 1 & $<1$ & n.a. & 13/11/2014 03:41 \\
\hline 1,2,4-Trimetilbenzeno & $95-63-6$ & $\mu \mathrm{g} / \mathrm{L}$ & 1 & $<1$ & n.a. & $13 / 11 / 201403: 41$ \\
\hline 1,2-Dibromoetano & $106-93-4$ & $\mu \mathrm{g} / \mathrm{L}$ & 1 & $<1$ & n.a. & $13 / 11 / 201403: 41$ \\
\hline 1,2-Diclorobenzeno & $95-50-1$ & $\mu \mathrm{g} / \mathrm{L}$ & 1 & $<1$ & n.a. & 13/11/2014 03:41 \\
\hline 1,3-Diclorobenzeno & $541-73-1$ & $\mu \mathrm{g} / \mathrm{L}$ & 1 & $<1$ & n.a. & $13 / 11 / 201403: 41$ \\
\hline 2-Clorotolueno & $95-49-8$ & $\mu \mathrm{g} / \mathrm{L}$ & 1 & $<1$ & n.a. & $13 / 11 / 201403: 41$ \\
\hline Dibromometano & $74-95-3$ & $\mu \mathrm{g} / \mathrm{L}$ & 1 & $<1$ & n.a. & $13 / 11 / 201403: 41$ \\
\hline Metiletilcetona & 78-93-3 & $\mu \mathrm{g} / \mathrm{L}$ & 2500 & $<2500$ & n.a. & 13/11/2014 03:41 \\
\hline Naftaleno & $91-20-3$ & $\mu \mathrm{g} / \mathrm{L}$ & 1 & $<1$ & n.a. & $13 / 11 / 201403: 41$ \\
\hline n-Butilbenzeno & $104-51-8$ & $\mu \mathrm{g} / \mathrm{L}$ & 1 & $<1$ & n.a. & 13/11/2014 03:41 \\
\hline n-Propilbenzeno & $103-65-1$ & $\mu \mathrm{g} / \mathrm{L}$ & 1 & $<1$ & n.a. & $13 / 11 / 201403: 41$ \\
\hline 4-Clorotolueno & $106-43-4$ & $\mu \mathrm{g} / \mathrm{L}$ & 1 & $<1$ & n.a. & 13/11/2014 03:41 \\
\hline sec-Butilbenzeno & $135-98-8$ & $\mu \mathrm{g} / \mathrm{L}$ & 1 & $<1$ & n.a. & 13/11/2014 03:41 \\
\hline terc-Butilbenzeno & $98-06-6$ & $\mu \mathrm{g} / \mathrm{L}$ & 1 & $<1$ & n.a. & 13/11/2014 03:41 \\
\hline trans-1,3-Dicloropropeno & $10061-02-6$ & $\mu \mathrm{g} / \mathrm{L}$ & 1 & $<1$ & n.a. & $13 / 11 / 201403: 41$ \\
\hline Isopropilbenzeno & $98-82-8$ & $\mu \mathrm{g} / \mathrm{L}$ & 1 & $<1$ & n.a. & $13 / 11 / 201403: 41$ \\
\hline 1,3,5-Triclorobenzeno & $108-70-3$ & $\mu \mathrm{g} / \mathrm{L}$ & 1 & $<1$ & n.a. & 13/11/2014 03:41 \\
\hline
\end{tabular}

\section{CONTROLE DE QUALIDADE DO LABORATÓRIO}

302692/2014-0 - Branco de Análise - VOC - Água

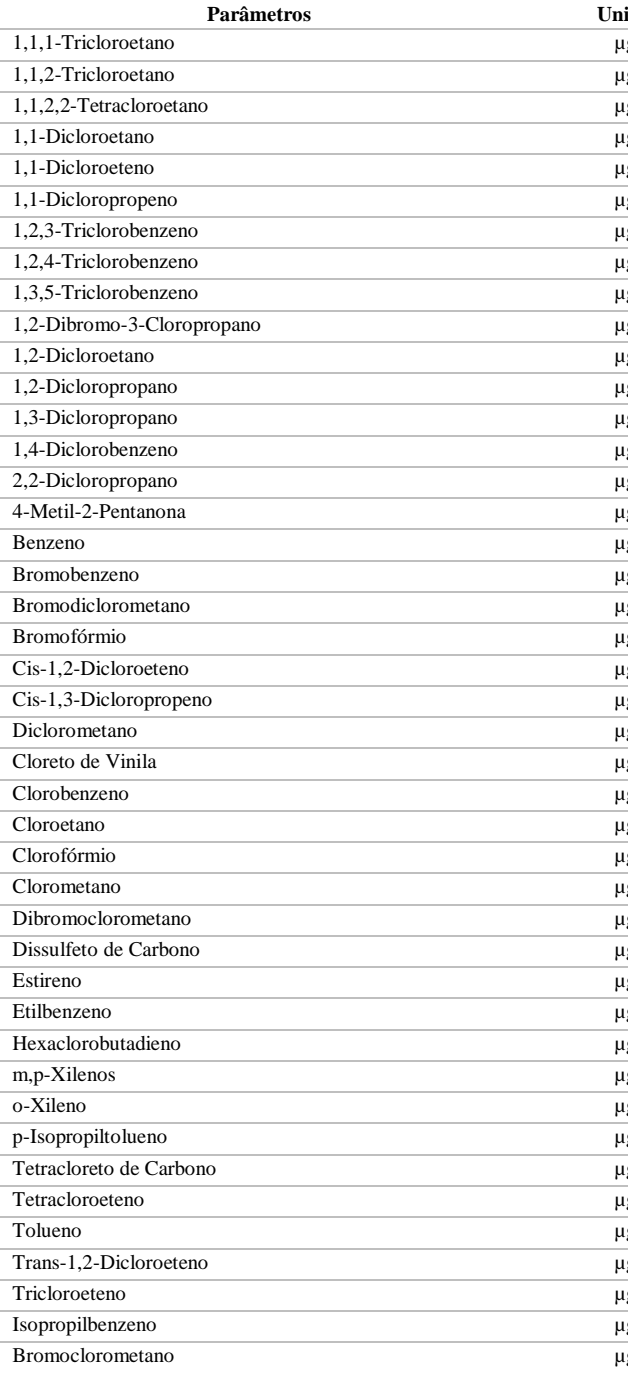

Controle de Qualidade - VOC - Água

\begin{tabular}{|c|c|c|}
\hline Unidade & LQ & Resultados analíticos \\
\hline$\mu \mathrm{g} / \mathrm{L}$ & 1 & $<1$ \\
\hline$\mu \mathrm{g} / \mathrm{L}$ & 1 & $<1$ \\
\hline$\mu \mathrm{g} / \mathrm{L}$ & 1 & $<1$ \\
\hline$\mu \mathrm{g} / \mathrm{L}$ & 1 & $<1$ \\
\hline$\mu \mathrm{g} / \mathrm{L}$ & 1 & $<1$ \\
\hline$\mu \mathrm{g} / \mathrm{L}$ & 1 & $<1$ \\
\hline$\mu \mathrm{g} / \mathrm{L}$ & 1 & $<1$ \\
\hline$\mu \mathrm{g} / \mathrm{L}$ & 1 & $<1$ \\
\hline$\mu \mathrm{g} / \mathrm{L}$ & 1 & $<1$ \\
\hline$\mu \mathrm{g} / \mathrm{L}$ & 5 & $<5$ \\
\hline$\mu \mathrm{g} / \mathrm{L}$ & 1 & $<1$ \\
\hline$\mu \mathrm{g} / \mathrm{L}$ & 1 & $<1$ \\
\hline$\mu \mathrm{g} / \mathrm{L}$ & 5 & $<5$ \\
\hline$\mu \mathrm{g} / \mathrm{L}$ & 1 & $<1$ \\
\hline$\mu \mathrm{g} / \mathrm{L}$ & 1 & $<1$ \\
\hline$\mu \mathrm{g} / \mathrm{L}$ & 5 & $<5$ \\
\hline$\mu \mathrm{g} / \mathrm{L}$ & 1 & $<1$ \\
\hline$\mu \mathrm{g} / \mathrm{L}$ & 1 & $<1$ \\
\hline$\mu \mathrm{g} / \mathrm{L}$ & 1 & $<1$ \\
\hline$\mu \mathrm{g} / \mathrm{L}$ & 1 & $<1$ \\
\hline$\mu \mathrm{g} / \mathrm{L}$ & 1 & $<1$ \\
\hline$\mu \mathrm{g} / \mathrm{L}$ & 1 & $<1$ \\
\hline$\mu \mathrm{g} / \mathrm{L}$ & 1 & $<1$ \\
\hline$\mu \mathrm{g} / \mathrm{L}$ & 1 & $<1$ \\
\hline$\mu \mathrm{g} / \mathrm{L}$ & 1 & $<1$ \\
\hline$\mu \mathrm{g} / \mathrm{L}$ & 1 & $<1$ \\
\hline$\mu \mathrm{g} / \mathrm{L}$ & 1 & $<1$ \\
\hline$\mu \mathrm{g} / \mathrm{L}$ & 10 & $<10$ \\
\hline$\mu \mathrm{g} / \mathrm{L}$ & 1 & $<1$ \\
\hline$\mu \mathrm{g} / \mathrm{L}$ & 1 & $<1$ \\
\hline$\mu \mathrm{g} / \mathrm{L}$ & 1 & $<1$ \\
\hline$\mu \mathrm{g} / \mathrm{L}$ & 1 & $<1$ \\
\hline$\mu \mathrm{g} / \mathrm{L}$ & 1 & $<1$ \\
\hline$\mu \mathrm{g} / \mathrm{L}$ & 2 & $<2$ \\
\hline$\mu \mathrm{g} / \mathrm{L}$ & 1 & $<1$ \\
\hline$\mu \mathrm{g} / \mathrm{L}$ & 1 & $<1$ \\
\hline$\mu \mathrm{g} / \mathrm{L}$ & 1 & $<1$ \\
\hline$\mu \mathrm{g} / \mathrm{L}$ & 1 & $<1$ \\
\hline$\mu \mathrm{g} / \mathrm{L}$ & 1 & $<1$ \\
\hline$\mu \mathrm{g} / \mathrm{L}$ & 1 & $<1$ \\
\hline$\mu \mathrm{g} / \mathrm{L}$ & 1 & $<1$ \\
\hline$\mu \mathrm{g} / \mathrm{L}$ & 1 & $<1$ \\
\hline$\mu \mathrm{g} / \mathrm{L}$ & 5 & $<5$ \\
\hline
\end{tabular}




\begin{tabular}{|c|c|c|c|c|}
\hline Parâmetros & $\begin{array}{l}\text { Quantidade } \\
\text { Adicionada }\end{array}$ & Unidade & $\begin{array}{c}\text { Resultado da } \\
\text { Recuperação (\%) }\end{array}$ & Faixa Aceitável de Recuperação (\%) \\
\hline \multicolumn{5}{|c|}{ 302694/2014-0 - Amostra Controle - VOC - Água } \\
\hline 1,1-Dicloroeteno & 20 & $\mu \mathrm{g} / \mathrm{L}$ & 100 & $70-130$ \\
\hline Benzeno & 20 & $\mu \mathrm{g} / \mathrm{L}$ & 125 & $70-130$ \\
\hline Tricloroeteno & 20 & $\mu \mathrm{g} / \mathrm{L}$ & 110 & $70-130$ \\
\hline Tolueno & 20 & $\mu \mathrm{g} / \mathrm{L}$ & 95 & $70-130$ \\
\hline Clorobenzeno & 20 & $\mu \mathrm{g} / \mathrm{L}$ & 105 & $70-130$ \\
\hline \multicolumn{5}{|c|}{$\begin{array}{l}\text { Surrogates } \\
\text { 302692/2014-0 - Branco de Análise - VOC - Água }\end{array}$} \\
\hline p-Bromofluorbenzeno & 20 & $\%$ & 76,5 & $70-130$ \\
\hline Dibromofluorometano & 20 & $\%$ & 130 & $70-130$ \\
\hline \multicolumn{5}{|c|}{ 302694/2014-0 - Amostra Controle - VOC - Água } \\
\hline p-Bromofluorbenzeno & 20 & $\%$ & 78,6 & $70-130$ \\
\hline Dibromofluorometano & 20 & $\%$ & 130 & $70-130$ \\
\hline \multicolumn{5}{|l|}{ 292996/2014-0 - BAI 1} \\
\hline Dibromofluorometano & 20 & $\%$ & 95,8 & $70-130$ \\
\hline p-Bromofluorbenzeno & 20 & $\%$ & 72,1 & $70-130$ \\
\hline
\end{tabular}

Notas

LQ = Limite de Quantificação.

n.a. $=$ Não Aplicável.

Abrangência

$\mathrm{O}(\mathrm{s})$ resultado(s) referem-se somente à(s) amostra(s) analisada(s).

Este Relatório de Ensaio só pode ser reproduzido por inteiro e sem nenhuma alteração.

Plano de Amostragem

Plano de amostragem de responsabilidade do interessado.

Responsabilidade Técnica

Os ensaios foram realizados na unidade da Bioagri Ambiental Ltda. - Matriz, situada na Rua Aljovil Martini, 177/201, Bairro Dois Córregos, Cep. 14420-833, Piracicaba/SP, registrada no CRQ 4 Região sob n⿳亠丷厂 $16082-\mathrm{F}$ e responsabilidade técnica do profissional Marcos Donizete Ceccatto, CRQ n ${ }^{\circ} 04364387,4^{\mathrm{a}}$.Região.

Referências Metodológicas

Análises foram realizadas conforme a última versão do Standard Methods for the Examination of Water \& Wastewater 22nd 2012(SMWW), EPA e ABNT (quando aplicável). VOC: EPA 8260 C: 2006, 5021A: 2003

Metiletilcetona: EPA 8260 C: 2006, 5021 A: 2003

Revisores

Débora Fernandes da Silva

Chave de Validação: 8bcea165f3fc852e1e788882554cfadd
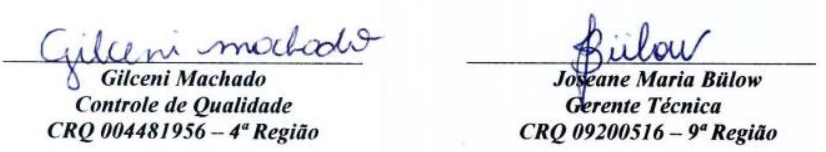


\section{RELATÓRIO DE ENSAIO N ${ }^{\circ}$ 292997/2014-0 - Piracicaba Processo Comercial $N^{\circ} 23961 / 2014-2$}

\begin{tabular}{|l|l|}
\hline \multicolumn{2}{|c|}{ DADOS REFERENTES AO CLIENTE } \\
\hline Empresa solicitante: & Fundacao Parque de Alta Tecnologia da Regiao de Ipero e Adjacencias \\
\hline Endereço: & Rua Jose Antonio Scaciota, 165 - - Portal do Cedro - Iperó - SP - CEP: 18.560-000 . \\
\hline Nome do Solicitante: & Carla Marçal \\
\hline
\end{tabular}

\section{DADOS REFERENTES A AMOSTRA}

Identificação do Cliente: Amostra Rotulada como:

Coletor:

BAI 2

Data da entrada no laboratório:

Água Subterrânea Projeto Mestrado Interessado

\begin{tabular}{l|l} 
Data da coleta: & 02/11/2014 22:59:00
\end{tabular}

\section{RESULTADOS PARA A AMOSTRA}

\begin{tabular}{|c|c|c|c|c|c|c|}
\hline Parâmetros & CAS & Unidade & LQ & Resultados analíticos & Incerteza & Data do Ensaio \\
\hline 1,1,1-Tricloroetano & $71-55-6$ & $\mu \mathrm{g} / \mathrm{L}$ & 1 & $<1$ & n.a. & 13/11/2014 04:06 \\
\hline 1,1,2-Tricloroetano & $79-00-5$ & $\mu \mathrm{g} / \mathrm{L}$ & 1 & $<1$ & n.a. & 13/11/2014 04:06 \\
\hline 1,1,2,2-Tetracloroetano & $79-34-5$ & $\mu \mathrm{g} / \mathrm{L}$ & 1 & $<1$ & n.a. & 13/11/2014 04:06 \\
\hline 1,1-Dicloroetano & $75-34-3$ & $\mu \mathrm{g} / \mathrm{L}$ & 1 & $<1$ & n.a. & 13/11/2014 04:06 \\
\hline 1,1-Dicloroeteno & $75-35-4$ & $\mu \mathrm{g} / \mathrm{L}$ & 1 & $<1$ & n.a. & 13/11/2014 04:06 \\
\hline 1,1-Dicloropropeno & $563-58-6$ & $\mu \mathrm{g} / \mathrm{L}$ & 1 & $<1$ & n.a. & 13/11/2014 04:06 \\
\hline 1,2,3-Triclorobenzeno & $87-61-6$ & $\mu \mathrm{g} / \mathrm{L}$ & 1 & $<1$ & n.a. & 13/11/2014 04:06 \\
\hline 1,2,4-Triclorobenzeno & $120-82-1$ & $\mu \mathrm{g} / \mathrm{L}$ & 1 & $<1$ & n.a. & 13/11/2014 04:06 \\
\hline 1,2-Dibromo-3-Cloropropano & $96-12-8$ & $\mu \mathrm{g} / \mathrm{L}$ & 5 & $<5$ & n.a. & 13/11/2014 04:06 \\
\hline 1,2-Dicloroetano & $107-06-2$ & $\mu \mathrm{g} / \mathrm{L}$ & 1 & $<1$ & n.a. & 13/11/2014 04:06 \\
\hline 1,2-Dicloropropano & $78-87-5$ & $\mu \mathrm{g} / \mathrm{L}$ & 1 & $<1$ & n.a. & 13/11/2014 04:06 \\
\hline 1,3-Dicloropropano & $142-28-9$ & $\mu \mathrm{g} / \mathrm{L}$ & 5 & $<5$ & n.a. & 13/11/2014 04:06 \\
\hline 1,4-Diclorobenzeno & $106-46-7$ & $\mu \mathrm{g} / \mathrm{L}$ & 1 & $<1$ & n.a. & 13/11/2014 04:06 \\
\hline 2,2-Dicloropropano & $594-20-7$ & $\mu \mathrm{g} / \mathrm{L}$ & 1 & $<1$ & n.a. & 13/11/2014 04:06 \\
\hline 4-Metil-2-Pentanona & $108-10-1$ & $\mu \mathrm{g} / \mathrm{L}$ & 5 & $<5$ & n.a. & 13/11/2014 04:06 \\
\hline Benzeno & $71-43-2$ & $\mu \mathrm{g} / \mathrm{L}$ & 1 & $<1$ & n.a. & 13/11/2014 04:06 \\
\hline Bromobenzeno & $108-86-1$ & $\mu \mathrm{g} / \mathrm{L}$ & 1 & $<1$ & n.a. & 13/11/2014 04:06 \\
\hline Bromodiclorometano & $75-27-4$ & $\mu \mathrm{g} / \mathrm{L}$ & 1 & $<1$ & n.a. & 13/11/2014 04:06 \\
\hline Bromofórmio & $75-25-2$ & $\mu \mathrm{g} / \mathrm{L}$ & 1 & $<1$ & n.a. & 13/11/2014 04:06 \\
\hline Bromoclorometano & $74-97-5$ & $\mu \mathrm{g} / \mathrm{L}$ & 5 & $<5$ & n.a. & 13/11/2014 04:06 \\
\hline Cis-1,2-Dicloroeteno & $156-59-2$ & $\mu \mathrm{g} / \mathrm{L}$ & 1 & $<1$ & n.a. & 13/11/2014 04:06 \\
\hline Cis-1,3-Dicloropropeno & $10061-01-5$ & $\mu \mathrm{g} / \mathrm{L}$ & 1 & $<1$ & n.a. & 13/11/2014 04:06 \\
\hline Diclorometano & $75-09-2$ & $\mu \mathrm{g} / \mathrm{L}$ & 1 & $<1$ & n.a. & 13/11/2014 04:06 \\
\hline Cloreto de Vinila & $75-01-4$ & $\mu \mathrm{g} / \mathrm{L}$ & 1 & $<1$ & n.a. & 13/11/2014 04:06 \\
\hline Clorobenzeno & $108-90-7$ & $\mu \mathrm{g} / \mathrm{L}$ & 1 & $<1$ & n.a. & 13/11/2014 04:06 \\
\hline Cloroetano & $75-00-3$ & $\mu \mathrm{g} / \mathrm{L}$ & 1 & $<1$ & n.a. & 13/11/2014 04:06 \\
\hline Clorofórmio & $67-66-3$ & $\mu \mathrm{g} / \mathrm{L}$ & 1 & $<1$ & n.a. & 13/11/2014 04:06 \\
\hline Clorometano & $74-87-3$ & $\mu \mathrm{g} / \mathrm{L}$ & 10 & $<10$ & n.a. & 13/11/2014 04:06 \\
\hline Dibromoclorometano & $124-48-1$ & $\mu \mathrm{g} / \mathrm{L}$ & 1 & $<1$ & n.a. & 13/11/2014 04:06 \\
\hline Dissulfeto de Carbono & $75-15-0$ & $\mu \mathrm{g} / \mathrm{L}$ & 1 & $<1$ & n.a. & 13/11/2014 04:06 \\
\hline Estireno & $100-42-5$ & $\mu \mathrm{g} / \mathrm{L}$ & 1 & $<1$ & n.a. & 13/11/2014 04:06 \\
\hline Etilbenzeno & $100-41-4$ & $\mu \mathrm{g} / \mathrm{L}$ & 1 & $<1$ & n.a. & 13/11/2014 04:06 \\
\hline Hexaclorobutadieno & $87-68-3$ & $\mu \mathrm{g} / \mathrm{L}$ & 1 & $<1$ & n.a. & 13/11/2014 04:06 \\
\hline m,p-Xilenos & --- & $\mu \mathrm{g} / \mathrm{L}$ & 2 & $<2$ & n.a. & 13/11/2014 04:06 \\
\hline o-Xileno & $95-47-6$ & $\mu \mathrm{g} / \mathrm{L}$ & 1 & $<1$ & n.a. & 13/11/2014 04:06 \\
\hline p-Isopropiltolueno & $99-87-6$ & $\mu \mathrm{g} / \mathrm{L}$ & 1 & $<1$ & n.a. & 13/11/2014 04:06 \\
\hline Tetracloreto de Carbono & $56-23-5$ & $\mu \mathrm{g} / \mathrm{L}$ & 1 & $<1$ & n.a. & 13/11/2014 04:06 \\
\hline Tetracloroeteno & $127-18-4$ & $\mu \mathrm{g} / \mathrm{L}$ & 1 & 27,3 & 5,2 & 13/11/2014 04:06 \\
\hline Tolueno & $108-88-3$ & $\mu \mathrm{g} / \mathrm{L}$ & 1 & $<1$ & n.a. & 13/11/2014 04:06 \\
\hline Trans-1,2-Dicloroeteno & $156-60-5$ & $\mu \mathrm{g} / \mathrm{L}$ & 1 & $<1$ & n.a. & 13/11/2014 04:06 \\
\hline Tricloroeteno & $79-01-6$ & $\mu \mathrm{g} / \mathrm{L}$ & 1 & $<1$ & n.a. & 13/11/2014 04:06 \\
\hline 1,1,1,2-Tetracloroetano & $630-20-6$ & $\mu \mathrm{g} / \mathrm{L}$ & 1 & $<1$ & n.a. & 13/11/2014 04:06 \\
\hline
\end{tabular}




\begin{tabular}{|c|c|c|c|c|c|c|}
\hline Parâmetros & CAS & Unidade & LQ & Resultados analíticos & Incerteza & Data do Ensaio \\
\hline 1,2,3-Tricloropropano & $96-18-4$ & $\mu \mathrm{g} / \mathrm{L}$ & 5 & $<5$ & n.a. & 13/11/2014 04:06 \\
\hline 1,3,5-Trimetilbenzeno & $108-67-8$ & $\mu \mathrm{g} / \mathrm{L}$ & 1 & $<1$ & n.a. & 13/11/2014 04:06 \\
\hline 1,2,4-Trimetilbenzeno & $95-63-6$ & $\mu \mathrm{g} / \mathrm{L}$ & 1 & $<1$ & n.a. & 13/11/2014 04:06 \\
\hline 1,2-Dibromoetano & $106-93-4$ & $\mu \mathrm{g} / \mathrm{L}$ & 1 & $<1$ & n.a. & 13/11/2014 04:06 \\
\hline 1,2-Diclorobenzeno & $95-50-1$ & $\mu \mathrm{g} / \mathrm{L}$ & 1 & $<1$ & n.a. & 13/11/2014 04:06 \\
\hline 1,3-Diclorobenzeno & $541-73-1$ & $\mu \mathrm{g} / \mathrm{L}$ & 1 & $<1$ & n.a. & 13/11/2014 04:06 \\
\hline 2-Clorotolueno & $95-49-8$ & $\mu \mathrm{g} / \mathrm{L}$ & 1 & $<1$ & n.a. & 13/11/2014 04:06 \\
\hline Dibromometano & $74-95-3$ & $\mu \mathrm{g} / \mathrm{L}$ & 1 & $<1$ & n.a. & 13/11/2014 04:06 \\
\hline Metiletilcetona & $78-93-3$ & $\mu \mathrm{g} / \mathrm{L}$ & 2500 & $<2500$ & n.a. & 13/11/2014 04:06 \\
\hline Naftaleno & $91-20-3$ & $\mu \mathrm{g} / \mathrm{L}$ & 1 & $<1$ & n.a. & 13/11/2014 04:06 \\
\hline n-Butilbenzeno & $104-51-8$ & $\mu \mathrm{g} / \mathrm{L}$ & 1 & $<1$ & n.a. & 13/11/2014 04:06 \\
\hline n-Propilbenzeno & $103-65-1$ & $\mu \mathrm{g} / \mathrm{L}$ & 1 & $<1$ & n.a. & 13/11/2014 04:06 \\
\hline 4-Clorotolueno & $106-43-4$ & $\mu \mathrm{g} / \mathrm{L}$ & 1 & $<1$ & n.a. & 13/11/2014 04:06 \\
\hline sec-Butilbenzeno & $135-98-8$ & $\mu \mathrm{g} / \mathrm{L}$ & 1 & $<1$ & n.a. & 13/11/2014 04:06 \\
\hline terc-Butilbenzeno & $98-06-6$ & $\mu \mathrm{g} / \mathrm{L}$ & 1 & $<1$ & n.a. & 13/11/2014 04:06 \\
\hline trans-1,3-Dicloropropeno & $10061-02-6$ & $\mu \mathrm{g} / \mathrm{L}$ & 1 & $<1$ & n.a. & 13/11/2014 04:06 \\
\hline Isopropilbenzeno & $98-82-8$ & $\mu \mathrm{g} / \mathrm{L}$ & 1 & $<1$ & n.a. & 13/11/2014 04:06 \\
\hline 1,3,5-Triclorobenzeno & 108-70-3 & $\mu \mathrm{g} / \mathrm{L}$ & 1 & $<1$ & n.a. & 13/11/2014 04:06 \\
\hline
\end{tabular}

\section{CONTROLE DE QUALIDADE DO LABORATÓRIO}

302692/2014-0 - Branco de Análise - VOC - Água

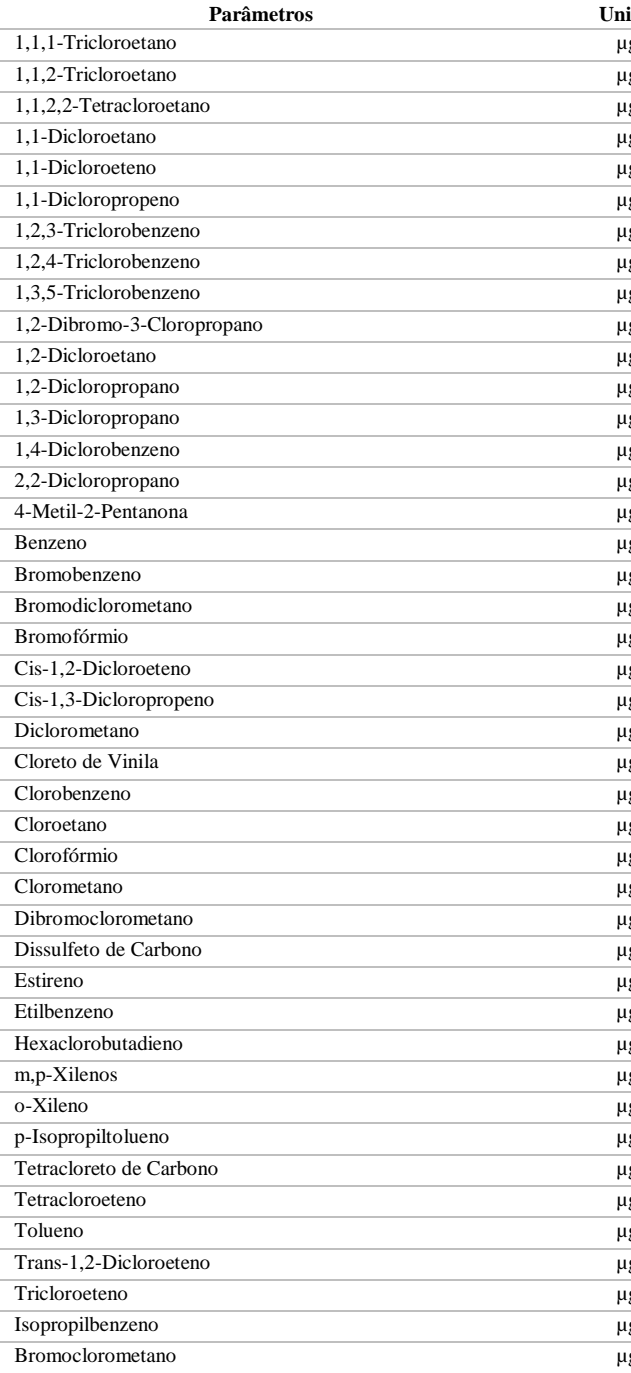

Controle de Qualidade - VOC - Água

\begin{tabular}{|c|c|c|}
\hline Unidade & LQ & Resultados analíticos \\
\hline$\mu \mathrm{g} / \mathrm{L}$ & 1 & $<1$ \\
\hline$\mu \mathrm{g} / \mathrm{L}$ & 1 & $<1$ \\
\hline$\mu \mathrm{g} / \mathrm{L}$ & 1 & $<1$ \\
\hline$\mu \mathrm{g} / \mathrm{L}$ & 1 & $<1$ \\
\hline$\mu g / L$ & 1 & $<1$ \\
\hline$\mu \mathrm{g} / \mathrm{L}$ & 1 & $<1$ \\
\hline$\mu \mathrm{g} / \mathrm{L}$ & 1 & $<1$ \\
\hline$\mu \mathrm{g} / \mathrm{L}$ & 1 & $<1$ \\
\hline$\mu \mathrm{g} / \mathrm{L}$ & 1 & $<1$ \\
\hline$\mu \mathrm{g} / \mathrm{L}$ & 5 & $<5$ \\
\hline$\mu \mathrm{g} / \mathrm{L}$ & 1 & $<1$ \\
\hline$\mu \mathrm{g} / \mathrm{L}$ & 1 & $<1$ \\
\hline$\mu \mathrm{g} / \mathrm{L}$ & 5 & $<5$ \\
\hline$\mu \mathrm{g} / \mathrm{L}$ & 1 & $<1$ \\
\hline$\mu \mathrm{g} / \mathrm{L}$ & 1 & $<1$ \\
\hline$\mu \mathrm{g} / \mathrm{L}$ & 5 & $<5$ \\
\hline$\mu \mathrm{g} / \mathrm{L}$ & 1 & $<1$ \\
\hline$\mu \mathrm{g} / \mathrm{L}$ & 1 & $<1$ \\
\hline$\mu \mathrm{g} / \mathrm{L}$ & 1 & $<1$ \\
\hline$\mu \mathrm{g} / \mathrm{L}$ & 1 & $<1$ \\
\hline$\mu \mathrm{g} / \mathrm{L}$ & 1 & $<1$ \\
\hline$\mu \mathrm{g} / \mathrm{L}$ & 1 & $<1$ \\
\hline$\mu \mathrm{g} / \mathrm{L}$ & 1 & $<1$ \\
\hline$\mu \mathrm{g} / \mathrm{L}$ & 1 & $<1$ \\
\hline$\mu \mathrm{g} / \mathrm{L}$ & 1 & $<1$ \\
\hline$\mu \mathrm{g} / \mathrm{L}$ & 1 & $<1$ \\
\hline$\mu \mathrm{g} / \mathrm{L}$ & 1 & $<1$ \\
\hline$\mu \mathrm{g} / \mathrm{L}$ & 10 & $<10$ \\
\hline$\mu \mathrm{g} / \mathrm{L}$ & 1 & $<1$ \\
\hline$\mu \mathrm{g} / \mathrm{L}$ & 1 & $<1$ \\
\hline$\mu \mathrm{g} / \mathrm{L}$ & 1 & $<1$ \\
\hline$\mu \mathrm{g} / \mathrm{L}$ & 1 & $<1$ \\
\hline$\mu \mathrm{g} / \mathrm{L}$ & 1 & $<1$ \\
\hline$\mu \mathrm{g} / \mathrm{L}$ & 2 & $<2$ \\
\hline$\mu \mathrm{g} / \mathrm{L}$ & 1 & $<1$ \\
\hline$\mu \mathrm{g} / \mathrm{L}$ & 1 & $<1$ \\
\hline$\mu \mathrm{g} / \mathrm{L}$ & 1 & $<1$ \\
\hline$\mu \mathrm{g} / \mathrm{L}$ & 1 & $<1$ \\
\hline$\mu \mathrm{g} / \mathrm{L}$ & 1 & $<1$ \\
\hline$\mu \mathrm{g} / \mathrm{L}$ & 1 & $<1$ \\
\hline$\mu \mathrm{g} / \mathrm{L}$ & 1 & $<1$ \\
\hline$\mu \mathrm{g} / \mathrm{L}$ & 1 & $<1$ \\
\hline$\mu \mathrm{g} / \mathrm{L}$ & 5 & $<5$ \\
\hline
\end{tabular}




\begin{tabular}{|c|c|c|c|c|}
\hline Parâmetros & $\begin{array}{l}\text { Quantidade } \\
\text { Adicionada }\end{array}$ & Unidade & $\begin{array}{c}\text { Resultado da } \\
\text { Recuperação (\%) }\end{array}$ & Faixa Aceitável de Recuperação (\%) \\
\hline \multicolumn{5}{|c|}{ 302694/2014-0 - Amostra Controle - VOC - Água } \\
\hline 1,1-Dicloroeteno & 20 & $\mu \mathrm{g} / \mathrm{L}$ & 100 & $70-130$ \\
\hline Benzeno & 20 & $\mu \mathrm{g} / \mathrm{L}$ & 125 & $70-130$ \\
\hline Tricloroeteno & 20 & $\mu \mathrm{g} / \mathrm{L}$ & 110 & $70-130$ \\
\hline Tolueno & 20 & $\mu \mathrm{g} / \mathrm{L}$ & 95 & $70-130$ \\
\hline Clorobenzeno & 20 & $\mu \mathrm{g} / \mathrm{L}$ & 105 & $70-130$ \\
\hline \multicolumn{5}{|c|}{$\begin{array}{l}\text { Surrogates } \\
\text { 302692/2014-0 - Branco de Análise - VOC - Água }\end{array}$} \\
\hline p-Bromofluorbenzeno & 20 & $\%$ & 76,5 & $70-130$ \\
\hline Dibromofluorometano & 20 & $\%$ & 130 & $70-130$ \\
\hline \multicolumn{5}{|c|}{ 302694/2014-0 - Amostra Controle - VOC - Água } \\
\hline p-Bromofluorbenzeno & 20 & $\%$ & 78,6 & $70-130$ \\
\hline Dibromofluorometano & 20 & $\%$ & 130 & $70-130$ \\
\hline \multicolumn{5}{|l|}{ 292997/2014-0 - BAI 2} \\
\hline Dibromofluorometano & 20 & $\%$ & 95,7 & $70-130$ \\
\hline p-Bromofluorbenzeno & 20 & $\%$ & 73,9 & $70-130$ \\
\hline
\end{tabular}

Notas

LQ = Limite de Quantificação.

n.a. $=$ Não Aplicável.

Abrangência

$\mathrm{O}(\mathrm{s})$ resultado(s) referem-se somente à(s) amostra(s) analisada(s).

Este Relatório de Ensaio só pode ser reproduzido por inteiro e sem nenhuma alteração.

Plano de Amostragem

Plano de amostragem de responsabilidade do interessado.

Responsabilidade Técnica

Os ensaios foram realizados na unidade da Bioagri Ambiental Ltda. - Matriz, situada na Rua Aljovil Martini, 177/201, Bairro Dois Córregos, Cep. 14420-833, Piracicaba/SP, registrada no CRQ 4 Região sob n⿳亠丷厂 $16082-\mathrm{F}$ e responsabilidade técnica do profissional Marcos Donizete Ceccatto, CRQ n ${ }^{\circ} 04364387,4^{\mathrm{a}}$.Região.

Referências Metodológicas

Análises foram realizadas conforme a última versão do Standard Methods for the Examination of Water \& Wastewater 22nd 2012(SMWW), EPA e ABNT (quando aplicável). VOC: EPA 8260 C: 2006, 5021A: 2003

Metiletilcetona: EPA 8260 C: 2006, 5021 A: 2003

Revisores

Débora Fernandes da Silva

Chave de Validação: 905ece19da26c68b2287053ba55eed1a
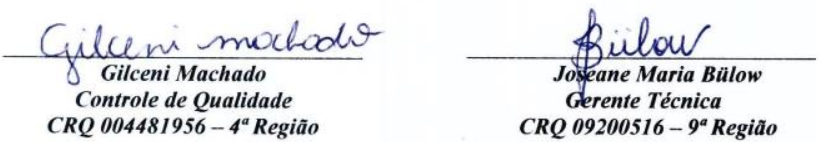


\section{RELATÓRIO DE ENSAIO N ${ }^{\circ}$ 292998/2014-0 - Piracicaba Processo Comercial $N^{\circ} 23961 / 2014-2$}

\begin{tabular}{|l|l|}
\hline \multicolumn{2}{|c|}{ DADOS REFERENTES AO CLIENTE } \\
\hline Empresa solicitante: & Fundacao Parque de Alta Tecnologia da Regiao de Ipero e Adjacencias \\
\hline Endereço: & Rua Jose Antonio Scaciota, 165 - - Portal do Cedro - Iperó - SP - CEP: 18.560-000 . \\
\hline Nome do Solicitante: & Carla Marçal \\
\hline
\end{tabular}

\section{DADOS REFERENTES A AMOSTRA}

Identificação do Cliente: Amostra Rotulada como:

Coletor:

BAI 3

Data da entrada no laboratório:

Água Subterrânea Projeto Mestrado Interessado

\begin{tabular}{l|l} 
Data da coleta: & 02/11/2014 23:00:00
\end{tabular}

\section{RESULTADOS PARA A AMOSTRA}

\begin{tabular}{|c|c|c|c|c|c|c|}
\hline Parâmetros & CAS & Unidade & LQ & Resultados analíticos & Incerteza & Data do Ensaio \\
\hline 1,1,1-Tricloroetano & $71-55-6$ & $\mu \mathrm{g} / \mathrm{L}$ & 1 & $<1$ & n.a. & $13 / 11 / 201404: 30$ \\
\hline 1,1,2-Tricloroetano & $79-00-5$ & $\mu \mathrm{g} / \mathrm{L}$ & 1 & $<1$ & n.a. & 13/11/2014 04:30 \\
\hline 1,1,2,2-Tetracloroetano & $79-34-5$ & $\mu \mathrm{g} / \mathrm{L}$ & 1 & $<1$ & n.a. & 13/11/2014 04:30 \\
\hline 1,1-Dicloroetano & $75-34-3$ & $\mu \mathrm{g} / \mathrm{L}$ & 1 & $<1$ & n.a. & $13 / 11 / 201404: 30$ \\
\hline 1,1-Dicloroeteno & $75-35-4$ & $\mu \mathrm{g} / \mathrm{L}$ & 1 & $<1$ & n.a. & $13 / 11 / 201404: 30$ \\
\hline 1,1-Dicloropropeno & $563-58-6$ & $\mu \mathrm{g} / \mathrm{L}$ & 1 & $<1$ & n.a. & 13/11/2014 04:30 \\
\hline 1,2,3-Triclorobenzeno & $87-61-6$ & $\mu \mathrm{g} / \mathrm{L}$ & 1 & $<1$ & n.a. & 13/11/2014 04:30 \\
\hline 1,2,4-Triclorobenzeno & $120-82-1$ & $\mu \mathrm{g} / \mathrm{L}$ & 1 & $<1$ & n.a. & 13/11/2014 04:30 \\
\hline 1,2-Dibromo-3-Cloropropano & $96-12-8$ & $\mu \mathrm{g} / \mathrm{L}$ & 5 & $<5$ & n.a. & 13/11/2014 04:30 \\
\hline 1,2-Dicloroetano & $107-06-2$ & $\mu \mathrm{g} / \mathrm{L}$ & 1 & $<1$ & n.a. & $13 / 11 / 201404: 30$ \\
\hline 1,2-Dicloropropano & $78-87-5$ & $\mu \mathrm{g} / \mathrm{L}$ & 1 & $<1$ & n.a. & 13/11/2014 04:30 \\
\hline 1,3-Dicloropropano & $142-28-9$ & $\mu \mathrm{g} / \mathrm{L}$ & 5 & $<5$ & n.a. & 13/11/2014 04:30 \\
\hline 1,4-Diclorobenzeno & $106-46-7$ & $\mu \mathrm{g} / \mathrm{L}$ & 1 & $<1$ & n.a. & $13 / 11 / 201404: 30$ \\
\hline 2,2-Dicloropropano & $594-20-7$ & $\mu \mathrm{g} / \mathrm{L}$ & 1 & $<1$ & n.a. & 13/11/2014 04:30 \\
\hline 4-Metil-2-Pentanona & $108-10-1$ & $\mu \mathrm{g} / \mathrm{L}$ & 5 & $<5$ & n.a. & $13 / 11 / 201404: 30$ \\
\hline Benzeno & $71-43-2$ & $\mu \mathrm{g} / \mathrm{L}$ & 1 & $<1$ & n.a. & 13/11/2014 04:30 \\
\hline Bromobenzeno & $108-86-1$ & $\mu \mathrm{g} / \mathrm{L}$ & 1 & $<1$ & n.a. & 13/11/2014 04:30 \\
\hline Bromodiclorometano & $75-27-4$ & $\mu \mathrm{g} / \mathrm{L}$ & 1 & $<1$ & n.a. & 13/11/2014 04:30 \\
\hline Bromofórmio & $75-25-2$ & $\mu \mathrm{g} / \mathrm{L}$ & 1 & $<1$ & n.a. & 13/11/2014 04:30 \\
\hline Bromoclorometano & $74-97-5$ & $\mu \mathrm{g} / \mathrm{L}$ & 5 & $<5$ & n.a. & 13/11/2014 04:30 \\
\hline Cis-1,2-Dicloroeteno & $156-59-2$ & $\mu \mathrm{g} / \mathrm{L}$ & 1 & $<1$ & n.a. & 13/11/2014 04:30 \\
\hline Cis-1,3-Dicloropropeno & $10061-01-5$ & $\mu \mathrm{g} / \mathrm{L}$ & 1 & $<1$ & n.a. & 13/11/2014 04:30 \\
\hline Diclorometano & $75-09-2$ & $\mu \mathrm{g} / \mathrm{L}$ & 1 & $<1$ & n.a. & 13/11/2014 04:30 \\
\hline Cloreto de Vinila & $75-01-4$ & $\mu \mathrm{g} / \mathrm{L}$ & 1 & $<1$ & n.a. & 13/11/2014 04:30 \\
\hline Clorobenzeno & $108-90-7$ & $\mu \mathrm{g} / \mathrm{L}$ & 1 & $<1$ & n.a. & 13/11/2014 04:30 \\
\hline Cloroetano & $75-00-3$ & $\mu \mathrm{g} / \mathrm{L}$ & 1 & $<1$ & n.a. & 13/11/2014 04:30 \\
\hline Clorofórmio & $67-66-3$ & $\mu \mathrm{g} / \mathrm{L}$ & 1 & $<1$ & n.a. & 13/11/2014 04:30 \\
\hline Clorometano & $74-87-3$ & $\mu \mathrm{g} / \mathrm{L}$ & 10 & $<10$ & n.a. & 13/11/2014 04:30 \\
\hline Dibromoclorometano & $124-48-1$ & $\mu \mathrm{g} / \mathrm{L}$ & 1 & $<1$ & n.a. & 13/11/2014 04:30 \\
\hline Dissulfeto de Carbono & $75-15-0$ & $\mu \mathrm{g} / \mathrm{L}$ & 1 & $<1$ & n.a. & $13 / 11 / 201404: 30$ \\
\hline Estireno & $100-42-5$ & $\mu \mathrm{g} / \mathrm{L}$ & 1 & $<1$ & n.a. & 13/11/2014 04:30 \\
\hline Etilbenzeno & $100-41-4$ & $\mu \mathrm{g} / \mathrm{L}$ & 1 & $<1$ & n.a. & 13/11/2014 04:30 \\
\hline Hexaclorobutadieno & $87-68-3$ & $\mu \mathrm{g} / \mathrm{L}$ & 1 & $<1$ & n.a. & 13/11/2014 04:30 \\
\hline m,p-Xilenos & --- & $\mu \mathrm{g} / \mathrm{L}$ & 2 & $<2$ & n.a. & 13/11/2014 04:30 \\
\hline o-Xileno & $95-47-6$ & $\mu \mathrm{g} / \mathrm{L}$ & 1 & $<1$ & n.a. & 13/11/2014 04:30 \\
\hline p-Isopropiltolueno & $99-87-6$ & $\mu \mathrm{g} / \mathrm{L}$ & 1 & $<1$ & n.a. & 13/11/2014 04:30 \\
\hline Tetracloreto de Carbono & $56-23-5$ & $\mu \mathrm{g} / \mathrm{L}$ & 1 & $<1$ & n.a. & 13/11/2014 04:30 \\
\hline Tetracloroeteno & $127-18-4$ & $\mu \mathrm{g} / \mathrm{L}$ & 1 & 41,0 & 7,8 & 13/11/2014 04:30 \\
\hline Tolueno & $108-88-3$ & $\mu \mathrm{g} / \mathrm{L}$ & 1 & $<1$ & n.a. & $13 / 11 / 201404: 30$ \\
\hline Trans-1,2-Dicloroeteno & $156-60-5$ & $\mu \mathrm{g} / \mathrm{L}$ & 1 & $<1$ & n.a. & 13/11/2014 04:30 \\
\hline Tricloroeteno & $79-01-6$ & $\mu \mathrm{g} / \mathrm{L}$ & 1 & $<1$ & n.a. & 13/11/2014 04:30 \\
\hline 1,1,1,2-Tetracloroetano & $630-20-6$ & $\mu \mathrm{g} / \mathrm{L}$ & 1 & $<1$ & n.a. & 13/11/2014 04:30 \\
\hline
\end{tabular}




\begin{tabular}{|c|c|c|c|c|c|c|}
\hline Parâmetros & CAS & Unidade & LQ & Resultados analíticos & Incerteza & Data do Ensaio \\
\hline 1,2,3-Tricloropropano & $96-18-4$ & $\mu \mathrm{g} / \mathrm{L}$ & 5 & $<5$ & n.a. & 13/11/2014 04:30 \\
\hline 1,3,5-Trimetilbenzeno & $108-67-8$ & $\mu \mathrm{g} / \mathrm{L}$ & 1 & $<1$ & n.a. & 13/11/2014 04:30 \\
\hline 1,2,4-Trimetilbenzeno & $95-63-6$ & $\mu \mathrm{g} / \mathrm{L}$ & 1 & $<1$ & n.a. & 13/11/2014 04:30 \\
\hline 1,2-Dibromoetano & $106-93-4$ & $\mu \mathrm{g} / \mathrm{L}$ & 1 & $<1$ & n.a. & 13/11/2014 04:30 \\
\hline 1,2-Diclorobenzeno & $95-50-1$ & $\mu \mathrm{g} / \mathrm{L}$ & 1 & $<1$ & n.a. & 13/11/2014 04:30 \\
\hline 1,3-Diclorobenzeno & $541-73-1$ & $\mu \mathrm{g} / \mathrm{L}$ & 1 & $<1$ & n.a. & $13 / 11 / 201404: 30$ \\
\hline 2-Clorotolueno & $95-49-8$ & $\mu \mathrm{g} / \mathrm{L}$ & 1 & $<1$ & n.a. & $13 / 11 / 201404: 30$ \\
\hline Dibromometano & $74-95-3$ & $\mu \mathrm{g} / \mathrm{L}$ & 1 & $<1$ & n.a. & $13 / 11 / 201404: 30$ \\
\hline Metiletilcetona & $78-93-3$ & $\mu \mathrm{g} / \mathrm{L}$ & 2500 & $<2500$ & n.a. & 13/11/2014 04:30 \\
\hline Naftaleno & $91-20-3$ & $\mu \mathrm{g} / \mathrm{L}$ & 1 & $<1$ & n.a. & 13/11/2014 04:30 \\
\hline n-Butilbenzeno & $104-51-8$ & $\mu \mathrm{g} / \mathrm{L}$ & 1 & $<1$ & n.a. & $13 / 11 / 201404: 30$ \\
\hline n-Propilbenzeno & $103-65-1$ & $\mu \mathrm{g} / \mathrm{L}$ & 1 & $<1$ & n.a. & 13/11/2014 04:30 \\
\hline 4-Clorotolueno & $106-43-4$ & $\mu \mathrm{g} / \mathrm{L}$ & 1 & $<1$ & n.a. & $13 / 11 / 201404: 30$ \\
\hline sec-Butilbenzeno & $135-98-8$ & $\mu \mathrm{g} / \mathrm{L}$ & 1 & $<1$ & n.a. & 13/11/2014 04:30 \\
\hline terc-Butilbenzeno & $98-06-6$ & $\mu \mathrm{g} / \mathrm{L}$ & 1 & $<1$ & n.a. & 13/11/2014 04:30 \\
\hline trans-1,3-Dicloropropeno & $10061-02-6$ & $\mu \mathrm{g} / \mathrm{L}$ & 1 & $<1$ & n.a. & $13 / 11 / 201404: 30$ \\
\hline Isopropilbenzeno & $98-82-8$ & $\mu \mathrm{g} / \mathrm{L}$ & 1 & $<1$ & n.a. & 13/11/2014 04:30 \\
\hline 1,3,5-Triclorobenzeno & $108-70-3$ & $\mu \mathrm{g} / \mathrm{L}$ & 1 & $<1$ & n.a. & 13/11/2014 04:30 \\
\hline
\end{tabular}

\section{CONTROLE DE QUALIDADE DO LABORATÓRIO}

302692/2014-0 - Branco de Análise - VOC - Água

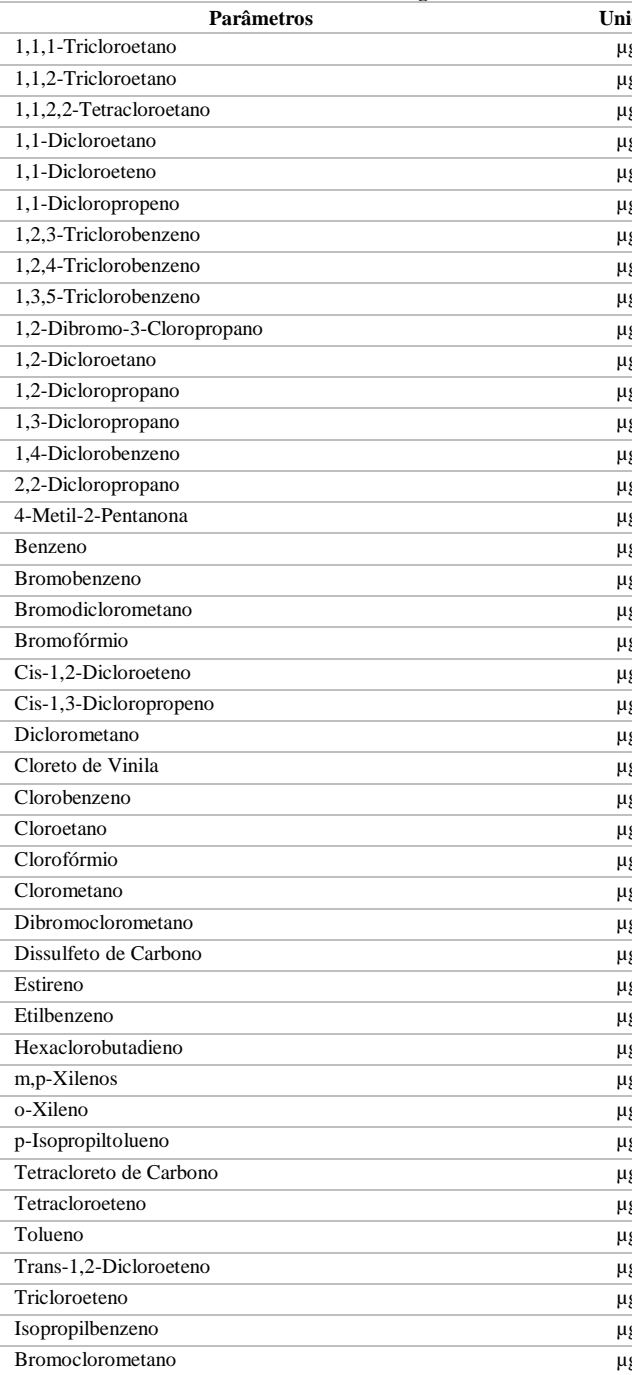

Controle de Qualidade - VOC - Água

\begin{tabular}{|c|c|c|}
\hline Unidade & LQ & Resultados analíticos \\
\hline$\mu \mathrm{g} / \mathrm{L}$ & 1 & $<1$ \\
\hline$\mu \mathrm{g} / \mathrm{L}$ & 1 & $<1$ \\
\hline$\mu \mathrm{g} / \mathrm{L}$ & 1 & $<1$ \\
\hline$\mu \mathrm{g} / \mathrm{L}$ & 1 & $<1$ \\
\hline$\mu \mathrm{g} / \mathrm{L}$ & 1 & $<1$ \\
\hline$\mu \mathrm{g} / \mathrm{L}$ & 1 & $<1$ \\
\hline$\mu \mathrm{g} / \mathrm{L}$ & 1 & $<1$ \\
\hline$\mu \mathrm{g} / \mathrm{L}$ & 1 & $<1$ \\
\hline$\mu \mathrm{g} / \mathrm{L}$ & 1 & $<1$ \\
\hline$\mu \mathrm{g} / \mathrm{L}$ & 5 & $<5$ \\
\hline$\mu \mathrm{g} / \mathrm{L}$ & 1 & $<1$ \\
\hline$\mu \mathrm{g} / \mathrm{L}$ & 1 & $<1$ \\
\hline$\mu \mathrm{g} / \mathrm{L}$ & 5 & $<5$ \\
\hline$\mu \mathrm{g} / \mathrm{L}$ & 1 & $<1$ \\
\hline$\mu \mathrm{g} / \mathrm{L}$ & 1 & $<1$ \\
\hline$\mu \mathrm{g} / \mathrm{L}$ & 5 & $<5$ \\
\hline$\mu \mathrm{g} / \mathrm{L}$ & 1 & $<1$ \\
\hline$\mu \mathrm{g} / \mathrm{L}$ & 1 & $<1$ \\
\hline$\mu \mathrm{g} / \mathrm{L}$ & 1 & $<1$ \\
\hline$\mu \mathrm{g} / \mathrm{L}$ & 1 & $<1$ \\
\hline$\mu \mathrm{g} / \mathrm{L}$ & 1 & $<1$ \\
\hline$\mu \mathrm{g} / \mathrm{L}$ & 1 & $<1$ \\
\hline$\mu \mathrm{g} / \mathrm{L}$ & 1 & $<1$ \\
\hline$\mu \mathrm{g} / \mathrm{L}$ & 1 & $<1$ \\
\hline$\mu \mathrm{g} / \mathrm{L}$ & 1 & $<1$ \\
\hline$\mu \mathrm{g} / \mathrm{L}$ & 1 & $<1$ \\
\hline$\mu \mathrm{g} / \mathrm{L}$ & 1 & $<1$ \\
\hline$\mu \mathrm{g} / \mathrm{L}$ & 10 & $<10$ \\
\hline$\mu \mathrm{g} / \mathrm{L}$ & 1 & $<1$ \\
\hline$\mu \mathrm{g} / \mathrm{L}$ & 1 & $<1$ \\
\hline$\mu \mathrm{g} / \mathrm{L}$ & 1 & $<1$ \\
\hline$\mu \mathrm{g} / \mathrm{L}$ & 1 & $<1$ \\
\hline$\mu \mathrm{g} / \mathrm{L}$ & 1 & $<1$ \\
\hline$\mu \mathrm{g} / \mathrm{L}$ & 2 & $<2$ \\
\hline$\mu \mathrm{g} / \mathrm{L}$ & 1 & $<1$ \\
\hline$\mu \mathrm{g} / \mathrm{L}$ & 1 & $<1$ \\
\hline$\mu \mathrm{g} / \mathrm{L}$ & 1 & $<1$ \\
\hline$\mu \mathrm{g} / \mathrm{L}$ & 1 & $<1$ \\
\hline$\mu \mathrm{g} / \mathrm{L}$ & 1 & $<1$ \\
\hline$\mu \mathrm{g} / \mathrm{L}$ & 1 & $<1$ \\
\hline$\mu \mathrm{g} / \mathrm{L}$ & 1 & $<1$ \\
\hline$\mu \mathrm{g} / \mathrm{L}$ & 1 & $<1$ \\
\hline$\mu \mathrm{g} / \mathrm{L}$ & 5 & $<5$ \\
\hline
\end{tabular}




\begin{tabular}{|c|c|c|c|c|}
\hline Parâmetros & $\begin{array}{l}\text { Quantidade } \\
\text { Adicionada }\end{array}$ & Unidade & $\begin{array}{c}\text { Resultado da } \\
\text { Recuperação (\%) }\end{array}$ & Faixa Aceitável de Recuperação (\%) \\
\hline \multicolumn{5}{|c|}{ 302694/2014-0 - Amostra Controle - VOC - Água } \\
\hline 1,1-Dicloroeteno & 20 & $\mu \mathrm{g} / \mathrm{L}$ & 100 & $70-130$ \\
\hline Benzeno & 20 & $\mu \mathrm{g} / \mathrm{L}$ & 125 & $70-130$ \\
\hline Tricloroeteno & 20 & $\mu \mathrm{g} / \mathrm{L}$ & 110 & $70-130$ \\
\hline Tolueno & 20 & $\mu \mathrm{g} / \mathrm{L}$ & 95 & $70-130$ \\
\hline Clorobenzeno & 20 & $\mu \mathrm{g} / \mathrm{L}$ & 105 & $70-130$ \\
\hline \multicolumn{5}{|c|}{$\begin{array}{l}\text { Surrogates } \\
\text { 302692/2014-0 - Branco de Análise - VOC - Água }\end{array}$} \\
\hline p-Bromofluorbenzeno & 20 & $\%$ & 76,5 & $70-130$ \\
\hline Dibromofluorometano & 20 & $\%$ & 130 & $70-130$ \\
\hline \multicolumn{5}{|c|}{ 302694/2014-0 - Amostra Controle - VOC - Água } \\
\hline p-Bromofluorbenzeno & 20 & $\%$ & 78,6 & $70-130$ \\
\hline Dibromofluorometano & 20 & $\%$ & 130 & $70-130$ \\
\hline \multicolumn{5}{|l|}{ 292998/2014-0 - BAI 3} \\
\hline Dibromofluorometano & 20 & $\%$ & 95,6 & $70-130$ \\
\hline p-Bromofluorbenzeno & 20 & $\%$ & 74,4 & $70-130$ \\
\hline
\end{tabular}

Notas

LQ = Limite de Quantificação.

n.a. $=$ Não Aplicável.

Abrangência

$\mathrm{O}(\mathrm{s})$ resultado(s) referem-se somente à(s) amostra(s) analisada(s).

Este Relatório de Ensaio só pode ser reproduzido por inteiro e sem nenhuma alteração.

Plano de Amostragem

Plano de amostragem de responsabilidade do interessado.

Responsabilidade Técnica

Os ensaios foram realizados na unidade da Bioagri Ambiental Ltda. - Matriz, situada na Rua Aljovil Martini, 177/201, Bairro Dois Córregos, Cep. 14420-833, Piracicaba/SP, registrada no CRQ 4 Região sob n⿳亠丷厂 $16082-\mathrm{F}$ e responsabilidade técnica do profissional Marcos Donizete Ceccatto, CRQ n ${ }^{\circ} 04364387,4^{\mathrm{a}}$.Região.

Referências Metodológicas

Análises foram realizadas conforme a última versão do Standard Methods for the Examination of Water \& Wastewater 22nd 2012(SMWW), EPA e ABNT (quando aplicável). VOC: EPA 8260 C: 2006, 5021A: 2003

Metiletilcetona: EPA 8260 C: 2006, 5021 A: 2003

Revisores

Débora Fernandes da Silva

Chave de Validação: cf0f1202b80e5ed6478825597f4077e8
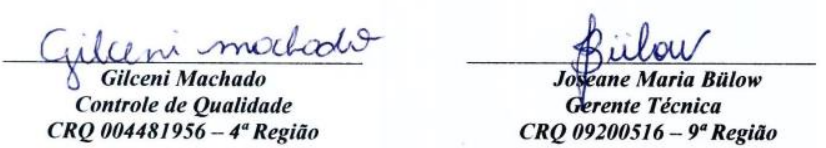


\section{RELATÓRIO DE ENSAIO N ${ }^{\circ}$ 292999/2014-0 - Piracicaba Processo Comercial $N^{\circ} 23961 / 2014-2$}

\begin{tabular}{|l|l|}
\hline \multicolumn{2}{|c|}{ DADOS REFERENTES AO CLIENTE } \\
\hline Empresa solicitante: & Fundacao Parque de Alta Tecnologia da Regiao de Ipero e Adjacencias \\
\hline Endereço: & Rua Jose Antonio Scaciota, 165 - - Portal do Cedro - Iperó - SP - CEP: 18.560-000 . \\
\hline Nome do Solicitante: & Carla Marçal \\
\hline
\end{tabular}

\section{DADOS REFERENTES A AMOSTRA}

\begin{tabular}{|l|l|l|l|l|l|}
\hline Identificação do Cliente: & \multicolumn{4}{|l}{ BAF 1} \\
\hline Amostra Rotulada como: & \multicolumn{2}{|l|}{ Água Subterrânea Projeto Mestrado } \\
\hline Coletor: & Interessado & Data da coleta: & $03 / 11 / 2014$ 00:52:00 \\
\hline Data da entrada no laboratório: & $04 / 11 / 201401: 27$ & Data de Elaboração do RE: & $14 / 11 / 2014$ \\
\hline
\end{tabular}

\section{RESULTADOS PARA A AMOSTRA}

\begin{tabular}{|c|c|c|c|c|c|c|}
\hline Parâmetros & CAS & Unidade & LQ & Resultados analíticos & Incerteza & Data do Ensaio \\
\hline 1,1,1-Tricloroetano & $71-55-6$ & $\mu \mathrm{g} / \mathrm{L}$ & 1 & $<1$ & n.a. & 14/11/2014 08:03 \\
\hline 1,1,2-Tricloroetano & $79-00-5$ & $\mu \mathrm{g} / \mathrm{L}$ & 1 & $<1$ & n.a. & 14/11/2014 08:03 \\
\hline 1,1,2,2-Tetracloroetano & $79-34-5$ & $\mu \mathrm{g} / \mathrm{L}$ & 1 & $<1$ & n.a. & 14/11/2014 08:03 \\
\hline 1,1-Dicloroetano & $75-34-3$ & $\mu \mathrm{g} / \mathrm{L}$ & 1 & $<1$ & n.a. & 14/11/2014 08:03 \\
\hline 1,1-Dicloroeteno & $75-35-4$ & $\mu \mathrm{g} / \mathrm{L}$ & 1 & $<1$ & n.a. & 14/11/2014 08:03 \\
\hline 1,1-Dicloropropeno & $563-58-6$ & $\mu \mathrm{g} / \mathrm{L}$ & 1 & $<1$ & n.a. & 14/11/2014 08:03 \\
\hline 1,2,3-Triclorobenzeno & $87-61-6$ & $\mu \mathrm{g} / \mathrm{L}$ & 1 & $<1$ & n.a. & 14/11/2014 08:03 \\
\hline 1,2,4-Triclorobenzeno & $120-82-1$ & $\mu \mathrm{g} / \mathrm{L}$ & 1 & $<1$ & n.a. & 14/11/2014 08:03 \\
\hline 1,2-Dibromo-3-Cloropropano & $96-12-8$ & $\mu \mathrm{g} / \mathrm{L}$ & 5 & $<5$ & n.a. & 14/11/2014 08:03 \\
\hline 1,2-Dicloroetano & $107-06-2$ & $\mu \mathrm{g} / \mathrm{L}$ & 1 & $<1$ & n.a. & 14/11/2014 08:03 \\
\hline 1,2-Dicloropropano & $78-87-5$ & $\mu \mathrm{g} / \mathrm{L}$ & 1 & $<1$ & n.a. & 14/11/2014 08:03 \\
\hline 1,3-Dicloropropano & $142-28-9$ & $\mu \mathrm{g} / \mathrm{L}$ & 5 & $<5$ & n.a. & 14/11/2014 08:03 \\
\hline 1,4-Diclorobenzeno & $106-46-7$ & $\mu \mathrm{g} / \mathrm{L}$ & 1 & $<1$ & n.a. & 14/11/2014 08:03 \\
\hline 2,2-Dicloropropano & $594-20-7$ & $\mu \mathrm{g} / \mathrm{L}$ & 1 & $<1$ & n.a. & 14/11/2014 08:03 \\
\hline 4-Metil-2-Pentanona & $108-10-1$ & $\mu \mathrm{g} / \mathrm{L}$ & 5 & $<5$ & n.a. & 14/11/2014 08:03 \\
\hline Benzeno & $71-43-2$ & $\mu \mathrm{g} / \mathrm{L}$ & 1 & $<1$ & n.a. & 14/11/2014 08:03 \\
\hline Bromobenzeno & $108-86-1$ & $\mu \mathrm{g} / \mathrm{L}$ & 1 & $<1$ & n.a. & 14/11/2014 08:03 \\
\hline Bromodiclorometano & $75-27-4$ & $\mu \mathrm{g} / \mathrm{L}$ & 1 & $<1$ & n.a. & 14/11/2014 08:03 \\
\hline Bromofórmio & $75-25-2$ & $\mu \mathrm{g} / \mathrm{L}$ & 1 & $<1$ & n.a. & 14/11/2014 08:03 \\
\hline Bromoclorometano & $74-97-5$ & $\mu \mathrm{g} / \mathrm{L}$ & 5 & $<5$ & n.a. & 14/11/2014 08:03 \\
\hline Cis-1,2-Dicloroeteno & $156-59-2$ & $\mu \mathrm{g} / \mathrm{L}$ & 1 & $<1$ & n.a. & 14/11/2014 08:03 \\
\hline Cis-1,3-Dicloropropeno & $10061-01-5$ & $\mu \mathrm{g} / \mathrm{L}$ & 1 & $<1$ & n.a. & 14/11/2014 08:03 \\
\hline Diclorometano & $75-09-2$ & $\mu \mathrm{g} / \mathrm{L}$ & 1 & $<1$ & n.a. & 14/11/2014 08:03 \\
\hline Cloreto de Vinila & $75-01-4$ & $\mu \mathrm{g} / \mathrm{L}$ & 1 & $<1$ & n.a. & 14/11/2014 08:03 \\
\hline Clorobenzeno & $108-90-7$ & $\mu \mathrm{g} / \mathrm{L}$ & 1 & $<1$ & n.a. & 14/11/2014 08:03 \\
\hline Cloroetano & $75-00-3$ & $\mu \mathrm{g} / \mathrm{L}$ & 1 & $<1$ & n.a. & 14/11/2014 08:03 \\
\hline Clorofórmio & $67-66-3$ & $\mu \mathrm{g} / \mathrm{L}$ & 1 & $<1$ & n.a. & 14/11/2014 08:03 \\
\hline Clorometano & $74-87-3$ & $\mu \mathrm{g} / \mathrm{L}$ & 10 & $<10$ & n.a. & 14/11/2014 08:03 \\
\hline Dibromoclorometano & $124-48-1$ & $\mu \mathrm{g} / \mathrm{L}$ & 1 & $<1$ & n.a. & 14/11/2014 08:03 \\
\hline Dissulfeto de Carbono & $75-15-0$ & $\mu \mathrm{g} / \mathrm{L}$ & 1 & $<1$ & n.a. & 14/11/2014 08:03 \\
\hline Estireno & $100-42-5$ & $\mu \mathrm{g} / \mathrm{L}$ & 1 & $<1$ & n.a. & 14/11/2014 08:03 \\
\hline Etilbenzeno & $100-41-4$ & $\mu \mathrm{g} / \mathrm{L}$ & 1 & $<1$ & n.a. & 14/11/2014 08:03 \\
\hline Hexaclorobutadieno & $87-68-3$ & $\mu \mathrm{g} / \mathrm{L}$ & 1 & $<1$ & n.a. & 14/11/2014 08:03 \\
\hline m,p-Xilenos & --- & $\mu \mathrm{g} / \mathrm{L}$ & 2 & $<2$ & n.a. & 14/11/2014 08:03 \\
\hline o-Xileno & $95-47-6$ & $\mu \mathrm{g} / \mathrm{L}$ & 1 & $<1$ & n.a. & 14/11/2014 08:03 \\
\hline p-Isopropiltolueno & $99-87-6$ & $\mu \mathrm{g} / \mathrm{L}$ & 1 & $<1$ & n.a. & 14/11/2014 08:03 \\
\hline Tetracloreto de Carbono & $56-23-5$ & $\mu \mathrm{g} / \mathrm{L}$ & 1 & $<1$ & n.a. & 14/11/2014 08:03 \\
\hline Tetracloroeteno & $127-18-4$ & $\mu \mathrm{g} / \mathrm{L}$ & 1 & 21,9 & 4,2 & 14/11/2014 08:03 \\
\hline Tolueno & $108-88-3$ & $\mu \mathrm{g} / \mathrm{L}$ & 1 & $<1$ & n.a. & 14/11/2014 08:03 \\
\hline Trans-1,2-Dicloroeteno & $156-60-5$ & $\mu \mathrm{g} / \mathrm{L}$ & 1 & $<1$ & n.a. & 14/11/2014 08:03 \\
\hline Tricloroeteno & $79-01-6$ & $\mu \mathrm{g} / \mathrm{L}$ & 1 & $<1$ & n.a. & 14/11/2014 08:03 \\
\hline 1,1,1,2-Tetracloroetano & $630-20-6$ & $\mu \mathrm{g} / \mathrm{L}$ & 1 & $<1$ & n.a. & 14/11/2014 08:03 \\
\hline
\end{tabular}




\begin{tabular}{|c|c|c|c|c|c|c|}
\hline Parâmetros & CAS & Unidade & LQ & Resultados analíticos & Incerteza & Data do Ensaio \\
\hline 1,2,3-Tricloropropano & $96-18-4$ & $\mu \mathrm{g} / \mathrm{L}$ & 5 & $<5$ & n.a. & 14/11/2014 08:03 \\
\hline 1,3,5-Trimetilbenzeno & $108-67-8$ & $\mu \mathrm{g} / \mathrm{L}$ & 1 & $<1$ & n.a. & 14/11/2014 08:03 \\
\hline 1,2,4-Trimetilbenzeno & $95-63-6$ & $\mu \mathrm{g} / \mathrm{L}$ & 1 & $<1$ & n.a. & 14/11/2014 08:03 \\
\hline 1,2-Dibromoetano & $106-93-4$ & $\mu \mathrm{g} / \mathrm{L}$ & 1 & $<1$ & n.a. & 14/11/2014 08:03 \\
\hline 1,2-Diclorobenzeno & $95-50-1$ & $\mu \mathrm{g} / \mathrm{L}$ & 1 & $<1$ & n.a. & 14/11/2014 08:03 \\
\hline 1,3-Diclorobenzeno & $541-73-1$ & $\mu \mathrm{g} / \mathrm{L}$ & 1 & $<1$ & n.a. & 14/11/2014 08:03 \\
\hline 2-Clorotolueno & $95-49-8$ & $\mu \mathrm{g} / \mathrm{L}$ & 1 & $<1$ & n.a. & 14/11/2014 08:03 \\
\hline Dibromometano & $74-95-3$ & $\mu \mathrm{g} / \mathrm{L}$ & 1 & $<1$ & n.a. & 14/11/2014 08:03 \\
\hline Metiletilcetona & 78-93-3 & $\mu \mathrm{g} / \mathrm{L}$ & 2500 & $<2500$ & n.a. & 14/11/2014 09:10 \\
\hline Naftaleno & $91-20-3$ & $\mu \mathrm{g} / \mathrm{L}$ & 1 & $<1$ & n.a. & 14/11/2014 08:03 \\
\hline n-Butilbenzeno & $104-51-8$ & $\mu \mathrm{g} / \mathrm{L}$ & 1 & $<1$ & n.a. & 14/11/2014 08:03 \\
\hline n-Propilbenzeno & $103-65-1$ & $\mu \mathrm{g} / \mathrm{L}$ & 1 & $<1$ & n.a. & 14/11/2014 08:03 \\
\hline 4-Clorotolueno & $106-43-4$ & $\mu \mathrm{g} / \mathrm{L}$ & 1 & $<1$ & n.a. & 14/11/2014 08:03 \\
\hline sec-Butilbenzeno & $135-98-8$ & $\mu \mathrm{g} / \mathrm{L}$ & 1 & $<1$ & n.a. & 14/11/2014 08:03 \\
\hline terc-Butilbenzeno & $98-06-6$ & $\mu \mathrm{g} / \mathrm{L}$ & 1 & $<1$ & n.a. & 14/11/2014 08:03 \\
\hline trans-1,3-Dicloropropeno & $10061-02-6$ & $\mu \mathrm{g} / \mathrm{L}$ & 1 & $<1$ & n.a. & 14/11/2014 08:03 \\
\hline Isopropilbenzeno & $98-82-8$ & $\mu \mathrm{g} / \mathrm{L}$ & 1 & $<1$ & n.a. & 14/11/2014 08:03 \\
\hline 1,3,5-Triclorobenzeno & $108-70-3$ & $\mu \mathrm{g} / \mathrm{L}$ & 1 & $<1$ & n.a. & 14/11/2014 08:03 \\
\hline
\end{tabular}

\section{CONTROLE DE QUALIDADE DO LABORATÓRIO}

302697/2014-0 - Branco de Análise - VOC - Água

\begin{tabular}{|c|c|}
\hline \multirow{2}{*}{\multicolumn{2}{|c|}{$\begin{array}{ll} & \text { Parâmetros } \\
1,1,1-\text { Tricloroetano } & \end{array}$}} \\
\hline & \\
\hline \multicolumn{2}{|l|}{ 1,1,2-Tricloroetano } \\
\hline \multicolumn{2}{|l|}{ 1,1,2,2-Tetracloroetano } \\
\hline \multicolumn{2}{|l|}{ 1,1-Dicloroetano } \\
\hline \multicolumn{2}{|l|}{ 1,1-Dicloroeteno } \\
\hline \multicolumn{2}{|l|}{ 1,1-Dicloropropeno } \\
\hline \multicolumn{2}{|l|}{ 1,2,3-Triclorobenzeno } \\
\hline \multicolumn{2}{|l|}{ 1,2,4-Triclorobenzeno } \\
\hline \multicolumn{2}{|l|}{ 1,3,5-Triclorobenzeno } \\
\hline \multicolumn{2}{|l|}{ 1,2-Dibromo-3-Cloropropano } \\
\hline \multicolumn{2}{|l|}{ 1,2-Dicloroetano } \\
\hline \multicolumn{2}{|l|}{ 1,2-Dicloropropano } \\
\hline \multicolumn{2}{|l|}{ 1,3-Dicloropropano } \\
\hline \multicolumn{2}{|l|}{ 1,4-Diclorobenzeno } \\
\hline \multicolumn{2}{|l|}{ 2,2-Dicloropropano } \\
\hline \multicolumn{2}{|l|}{ 4-Metil-2-Pentanona } \\
\hline \multicolumn{2}{|l|}{ Benzeno } \\
\hline \multicolumn{2}{|l|}{ Bromobenzeno } \\
\hline \multicolumn{2}{|l|}{ Bromodiclorometano } \\
\hline \multicolumn{2}{|l|}{ Bromofórmio } \\
\hline \multicolumn{2}{|l|}{ Cis-1,2-Dicloroeteno } \\
\hline \multicolumn{2}{|l|}{ Cis-1,3-Dicloropropeno } \\
\hline \multicolumn{2}{|l|}{ Diclorometano } \\
\hline \multicolumn{2}{|l|}{ Cloreto de Vinila } \\
\hline \multicolumn{2}{|l|}{ Clorobenzeno } \\
\hline \multicolumn{2}{|l|}{ Cloroetano } \\
\hline Clorofórmio & \\
\hline Clorometano & \\
\hline Dibromoclorometano & \\
\hline Dissulfeto de Carbono & \\
\hline Estireno & \\
\hline Etilbenzeno & \\
\hline Hexaclorobutadieno & \\
\hline m,p-Xilenos & \\
\hline o-Xileno & \\
\hline p-Isopropiltolueno & \\
\hline Tetracloreto de Carbono & \\
\hline Tetracloroeteno & \\
\hline Tolueno & \\
\hline Trans-1,2-Dicloroeteno & \\
\hline Tricloroeteno & \\
\hline Isopropilbenzeno & \\
\hline Bromoclorometano & \\
\hline
\end{tabular}

Controle de Qualidade - VOC - Água

\begin{tabular}{|c|c|c|}
\hline Unidade & LQ & Resultados analíticos \\
\hline$\mu \mathrm{g} / \mathrm{L}$ & 1 & $<1$ \\
\hline$\mu \mathrm{g} / \mathrm{L}$ & 1 & $<1$ \\
\hline$\mu \mathrm{g} / \mathrm{L}$ & 1 & $<1$ \\
\hline$\mu \mathrm{g} / \mathrm{L}$ & 1 & $<1$ \\
\hline$\mu \mathrm{g} / \mathrm{L}$ & 1 & $<1$ \\
\hline$\mu \mathrm{g} / \mathrm{L}$ & 1 & $<1$ \\
\hline$\mu \mathrm{g} / \mathrm{L}$ & 1 & $<1$ \\
\hline$\mu \mathrm{g} / \mathrm{L}$ & 1 & $<1$ \\
\hline$\mu \mathrm{g} / \mathrm{L}$ & 1 & $<1$ \\
\hline$\mu \mathrm{g} / \mathrm{L}$ & 5 & $<5$ \\
\hline$\mu \mathrm{g} / \mathrm{L}$ & 1 & $<1$ \\
\hline$\mu \mathrm{g} / \mathrm{L}$ & 1 & $<1$ \\
\hline$\mu \mathrm{g} / \mathrm{L}$ & 5 & $<5$ \\
\hline$\mu \mathrm{g} / \mathrm{L}$ & 1 & $<1$ \\
\hline$\mu \mathrm{g} / \mathrm{L}$ & 1 & $<1$ \\
\hline$\mu \mathrm{g} / \mathrm{L}$ & 5 & $<5$ \\
\hline$\mu \mathrm{g} / \mathrm{L}$ & 1 & $<1$ \\
\hline$\mu \mathrm{g} / \mathrm{L}$ & 1 & $<1$ \\
\hline$\mu \mathrm{g} / \mathrm{L}$ & 1 & $<1$ \\
\hline$\mu \mathrm{g} / \mathrm{L}$ & 1 & $<1$ \\
\hline$\mu \mathrm{g} / \mathrm{L}$ & 1 & $<1$ \\
\hline$\mu \mathrm{g} / \mathrm{L}$ & 1 & $<1$ \\
\hline$\mu \mathrm{g} / \mathrm{L}$ & 1 & $<1$ \\
\hline$\mu \mathrm{g} / \mathrm{L}$ & 1 & $<1$ \\
\hline$\mu \mathrm{g} / \mathrm{L}$ & 1 & $<1$ \\
\hline$\mu \mathrm{g} / \mathrm{L}$ & 1 & $<1$ \\
\hline$\mu \mathrm{g} / \mathrm{L}$ & 1 & $<1$ \\
\hline$\mu \mathrm{g} / \mathrm{L}$ & 10 & $<10$ \\
\hline$\mu \mathrm{g} / \mathrm{L}$ & 1 & $<1$ \\
\hline$\mu \mathrm{g} / \mathrm{L}$ & 1 & $<1$ \\
\hline$\mu \mathrm{g} / \mathrm{L}$ & 1 & $<1$ \\
\hline$\mu \mathrm{g} / \mathrm{L}$ & 1 & $<1$ \\
\hline$\mu \mathrm{g} / \mathrm{L}$ & 1 & $<1$ \\
\hline$\mu \mathrm{g} / \mathrm{L}$ & 2 & $<2$ \\
\hline$\mu \mathrm{g} / \mathrm{L}$ & 1 & $<1$ \\
\hline$\mu \mathrm{g} / \mathrm{L}$ & 1 & $<1$ \\
\hline$\mu \mathrm{g} / \mathrm{L}$ & 1 & $<1$ \\
\hline$\mu \mathrm{g} / \mathrm{L}$ & 1 & $<1$ \\
\hline$\mu \mathrm{g} / \mathrm{L}$ & 1 & $<1$ \\
\hline$\mu \mathrm{g} / \mathrm{L}$ & 1 & $<1$ \\
\hline$\mu \mathrm{g} / \mathrm{L}$ & 1 & $<1$ \\
\hline$\mu \mathrm{g} / \mathrm{L}$ & 1 & $<1$ \\
\hline$\mu \mathrm{g} / \mathrm{L}$ & 5 & $<5$ \\
\hline
\end{tabular}




\begin{tabular}{|c|c|c|c|c|}
\hline Parâmetros & $\begin{array}{l}\text { Quantidade } \\
\text { Adicionada }\end{array}$ & Unidade & $\begin{array}{c}\text { Resultado da } \\
\text { Recuperação (\%) }\end{array}$ & Faixa Aceitável de Recuperação (\%) \\
\hline \multicolumn{5}{|c|}{ 302698/2014-0 - Amostra Controle - VOC - Água } \\
\hline 1,1-Dicloroeteno & 20 & $\mu \mathrm{g} / \mathrm{L}$ & 70 & $70-130$ \\
\hline Benzeno & 20 & $\mu \mathrm{g} / \mathrm{L}$ & 70 & $70-130$ \\
\hline Tricloroeteno & 20 & $\mu \mathrm{g} / \mathrm{L}$ & 80 & $70-130$ \\
\hline Tolueno & 20 & $\mu \mathrm{g} / \mathrm{L}$ & 75 & $70-130$ \\
\hline Clorobenzeno & 20 & $\mu \mathrm{g} / \mathrm{L}$ & 80 & $70-130$ \\
\hline \multicolumn{5}{|c|}{$\begin{array}{l}\text { Surrogates } \\
\text { 302697/2014-0 - Branco de Análise - VOC - Água }\end{array}$} \\
\hline p-Bromofluorbenzeno & 20 & $\%$ & 71,3 & $70-130$ \\
\hline Dibromofluorometano & 20 & $\%$ & 78,3 & $70-130$ \\
\hline \multicolumn{5}{|c|}{ 302698/2014-0 - Amostra Controle - VOC - Água } \\
\hline p-Bromofluorbenzeno & 20 & $\%$ & 76,3 & $70-130$ \\
\hline Dibromofluorometano & 20 & $\%$ & 89,4 & $70-130$ \\
\hline \multicolumn{5}{|l|}{ 292999/2014-0 - BAF 1} \\
\hline Dibromofluorometano & 20 & $\%$ & 81,7 & $70-130$ \\
\hline p-Bromofluorbenzeno & 20 & $\%$ & 71,6 & $70-130$ \\
\hline
\end{tabular}

Notas

LQ = Limite de Quantificação.

n.a. $=$ Não Aplicável.

Abrangência

$\mathrm{O}(\mathrm{s})$ resultado(s) referem-se somente à(s) amostra(s) analisada(s).

Este Relatório de Ensaio só pode ser reproduzido por inteiro e sem nenhuma alteração.

Plano de Amostragem

Plano de amostragem de responsabilidade do interessado.

Responsabilidade Técnica

Os ensaios foram realizados na unidade da Bioagri Ambiental Ltda. - Matriz, situada na Rua Aljovil Martini, 177/201, Bairro Dois Córregos, Cep. 14420-833, Piracicaba/SP, registrada no CRQ 4 Região sob no $16082-\mathrm{F}$ e responsabilidade técnica do profissional Marcos Donizete Ceccatto, CRQ n⿳ ${ }^{\circ} 04364387,4^{\mathrm{a}}$.Região.

Referências Metodológicas

Análises foram realizadas conforme a última versão do Standard Methods for the Examination of Water \& Wastewater 22nd 2012(SMWW), EPA e ABNT (quando aplicável). VOC: EPA 8260 C: 2006, 5021A: 2003

Metiletilcetona: EPA 8260 C: 2006, 5021 A: 2003

Revisores

Luci Carla Gheleri Andrietta

Chave de Validação: 3f60a2a5c082f6bec5d2733fa57f0cee
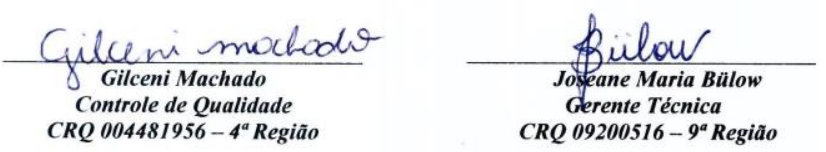


\section{RELATÓRIO DE ENSAIO $\mathrm{N}^{\circ}$ 293000/2014-0 - Piracicaba} Processo Comercial $N^{\circ}$ 23961/2014-2

\begin{tabular}{|l|l|}
\hline \multicolumn{2}{|c|}{ DADOS REFERENTES AO CLIENTE } \\
\hline Empresa solicitante: & Fundacao Parque de Alta Tecnologia da Regiao de Ipero e Adjacencias \\
\hline Endereço: & Rua Jose Antonio Scaciota, 165 - - Portal do Cedro - Iperó - SP - CEP: 18.560-000 . \\
\hline Nome do Solicitante: & Carla Marçal \\
\hline
\end{tabular}

\section{DADOS REFERENTES A AMOSTRA}

Identificação do Cliente:

BAF 2

Amostra Rotulada como:

Coletor:

Água Subterrânea Projeto Mestrado

\begin{tabular}{|l|l|l|l|l|l|l}
\hline Data da entrada no laboratório: & 04/11/2014 01:27 & Data de Elaboração do RE: & 14/11/2014
\end{tabular}

\section{RESULTADOS PARA A AMOSTRA}

\begin{tabular}{|c|c|c|c|c|c|c|}
\hline Parâmetros & CAS & Unidade & LQ & Resultados analíticos & Incerteza & Data do Ensaio \\
\hline 1,1,1-Tricloroetano & $71-55-6$ & $\mu \mathrm{g} / \mathrm{L}$ & 1 & $<1$ & n.a. & $13 / 11 / 201410: 59$ \\
\hline 1,1,2-Tricloroetano & $79-00-5$ & $\mu \mathrm{g} / \mathrm{L}$ & 1 & $<1$ & n.a. & 13/11/2014 10:59 \\
\hline 1,1,2,2-Tetracloroetano & $79-34-5$ & $\mu \mathrm{g} / \mathrm{L}$ & 1 & $<1$ & n.a. & $13 / 11 / 201410: 59$ \\
\hline 1,1-Dicloroetano & $75-34-3$ & $\mu \mathrm{g} / \mathrm{L}$ & 1 & $<1$ & n.a. & $13 / 11 / 201410: 59$ \\
\hline 1,1-Dicloroeteno & $75-35-4$ & $\mu \mathrm{g} / \mathrm{L}$ & 1 & $<1$ & n.a. & $13 / 11 / 201410: 59$ \\
\hline 1,1-Dicloropropeno & $563-58-6$ & $\mu \mathrm{g} / \mathrm{L}$ & 1 & $<1$ & n.a. & $13 / 11 / 201410: 59$ \\
\hline 1,2,3-Triclorobenzeno & $87-61-6$ & $\mu \mathrm{g} / \mathrm{L}$ & 1 & $<1$ & n.a. & 13/11/2014 10:59 \\
\hline 1,2,4-Triclorobenzeno & $120-82-1$ & $\mu \mathrm{g} / \mathrm{L}$ & 1 & $<1$ & n.a. & 13/11/2014 10:59 \\
\hline 1,2-Dibromo-3-Cloropropano & $96-12-8$ & $\mu \mathrm{g} / \mathrm{L}$ & 5 & $<5$ & n.a. & $13 / 11 / 201410: 59$ \\
\hline 1,2-Dicloroetano & $107-06-2$ & $\mu \mathrm{g} / \mathrm{L}$ & 1 & $<1$ & n.a. & $13 / 11 / 201410: 59$ \\
\hline 1,2-Dicloropropano & $78-87-5$ & $\mu \mathrm{g} / \mathrm{L}$ & 1 & $<1$ & n.a. & 13/11/2014 10:59 \\
\hline 1,3-Dicloropropano & $142-28-9$ & $\mu \mathrm{g} / \mathrm{L}$ & 5 & $<5$ & n.a. & 13/11/2014 10:59 \\
\hline 1,4-Diclorobenzeno & $106-46-7$ & $\mu \mathrm{g} / \mathrm{L}$ & 1 & $<1$ & n.a. & $13 / 11 / 201410: 59$ \\
\hline 2,2-Dicloropropano & $594-20-7$ & $\mu \mathrm{g} / \mathrm{L}$ & 1 & $<1$ & n.a. & 13/11/2014 10:59 \\
\hline 4-Metil-2-Pentanona & $108-10-1$ & $\mu \mathrm{g} / \mathrm{L}$ & 5 & $<5$ & n.a. & $13 / 11 / 201410: 59$ \\
\hline Benzeno & $71-43-2$ & $\mu \mathrm{g} / \mathrm{L}$ & 1 & $<1$ & n.a. & $13 / 11 / 201410: 59$ \\
\hline Bromobenzeno & $108-86-1$ & $\mu \mathrm{g} / \mathrm{L}$ & 1 & $<1$ & n.a. & 13/11/2014 10:59 \\
\hline Bromodiclorometano & $75-27-4$ & $\mu \mathrm{g} / \mathrm{L}$ & 1 & $<1$ & n.a. & $13 / 11 / 201410: 59$ \\
\hline Bromofórmio & $75-25-2$ & $\mu \mathrm{g} / \mathrm{L}$ & 1 & $<1$ & n.a. & 13/11/2014 10:59 \\
\hline Bromoclorometano & $74-97-5$ & $\mu \mathrm{g} / \mathrm{L}$ & 5 & $<5$ & n.a. & $13 / 11 / 201410: 59$ \\
\hline Cis-1,2-Dicloroeteno & $156-59-2$ & $\mu \mathrm{g} / \mathrm{L}$ & 1 & $<1$ & n.a. & 13/11/2014 10:59 \\
\hline Cis-1,3-Dicloropropeno & $10061-01-5$ & $\mu \mathrm{g} / \mathrm{L}$ & 1 & $<1$ & n.a. & 13/11/2014 10:59 \\
\hline Diclorometano & $75-09-2$ & $\mu \mathrm{g} / \mathrm{L}$ & 1 & $<1$ & n.a. & $13 / 11 / 201410: 59$ \\
\hline Cloreto de Vinila & 75-01-4 & $\mu \mathrm{g} / \mathrm{L}$ & 1 & $<1$ & n.a. & $13 / 11 / 201410: 59$ \\
\hline Clorobenzeno & $108-90-7$ & $\mu \mathrm{g} / \mathrm{L}$ & 1 & $<1$ & n.a. & 13/11/2014 10:59 \\
\hline Cloroetano & $75-00-3$ & $\mu \mathrm{g} / \mathrm{L}$ & 1 & $<1$ & n.a. & 13/11/2014 10:59 \\
\hline Clorofórmio & $67-66-3$ & $\mu \mathrm{g} / \mathrm{L}$ & 1 & $<1$ & n.a. & 13/11/2014 10:59 \\
\hline Clorometano & $74-87-3$ & $\mu \mathrm{g} / \mathrm{L}$ & 10 & $<10$ & n.a. & $13 / 11 / 201410: 59$ \\
\hline Dibromoclorometano & $124-48-1$ & $\mu \mathrm{g} / \mathrm{L}$ & 1 & $<1$ & n.a. & 13/11/2014 10:59 \\
\hline Dissulfeto de Carbono & $75-15-0$ & $\mu \mathrm{g} / \mathrm{L}$ & 1 & $<1$ & n.a. & $13 / 11 / 201410: 59$ \\
\hline Estireno & $100-42-5$ & $\mu \mathrm{g} / \mathrm{L}$ & 1 & $<1$ & n.a. & 13/11/2014 10:59 \\
\hline Etilbenzeno & $100-41-4$ & $\mu \mathrm{g} / \mathrm{L}$ & 1 & $<1$ & n.a. & 13/11/2014 10:59 \\
\hline Hexaclorobutadieno & $87-68-3$ & $\mu \mathrm{g} / \mathrm{L}$ & 1 & $<1$ & n.a. & $13 / 11 / 201410: 59$ \\
\hline $\mathrm{m}, \mathrm{p}$-Xilenos & --- & $\mu \mathrm{g} / \mathrm{L}$ & 2 & $<2$ & n.a. & $13 / 11 / 201410: 59$ \\
\hline o-Xileno & $95-47-6$ & $\mu \mathrm{g} / \mathrm{L}$ & 1 & $<1$ & n.a. & $13 / 11 / 201410: 59$ \\
\hline p-Isopropiltolueno & $99-87-6$ & $\mu \mathrm{g} / \mathrm{L}$ & 1 & $<1$ & n.a. & 13/11/2014 10:59 \\
\hline Tetracloreto de Carbono & $56-23-5$ & $\mu \mathrm{g} / \mathrm{L}$ & 1 & $<1$ & n.a. & 13/11/2014 10:59 \\
\hline Tetracloroeteno & $127-18-4$ & $\mu \mathrm{g} / \mathrm{L}$ & 1 & 31,5 & 6 & 13/11/2014 10:59 \\
\hline Tolueno & $108-88-3$ & $\mu \mathrm{g} / \mathrm{L}$ & 1 & $<1$ & n.a. & $13 / 11 / 201410: 59$ \\
\hline Trans-1,2-Dicloroeteno & $156-60-5$ & $\mu \mathrm{g} / \mathrm{L}$ & 1 & $<1$ & n.a. & 13/11/2014 10:59 \\
\hline Tricloroeteno & $79-01-6$ & $\mu \mathrm{g} / \mathrm{L}$ & 1 & $<1$ & n.a. & 13/11/2014 10:59 \\
\hline 1,1,1,2-Tetracloroetano & $630-20-6$ & $\mu \mathrm{g} / \mathrm{L}$ & 1 & $<1$ & n.a. & $13 / 11 / 201410: 59$ \\
\hline
\end{tabular}




\begin{tabular}{|c|c|c|c|c|c|c|}
\hline Parâmetros & CAS & Unidade & LQ & Resultados analíticos & Incerteza & Data do Ensaio \\
\hline 1,2,3-Tricloropropano & $96-18-4$ & $\mu \mathrm{g} / \mathrm{L}$ & 5 & $<5$ & n.a. & 13/11/2014 10:59 \\
\hline 1,3,5-Trimetilbenzeno & $108-67-8$ & $\mu \mathrm{g} / \mathrm{L}$ & 1 & $<1$ & n.a. & 13/11/2014 10:59 \\
\hline 1,2,4-Trimetilbenzeno & $95-63-6$ & $\mu \mathrm{g} / \mathrm{L}$ & 1 & $<1$ & n.a. & 13/11/2014 10:59 \\
\hline 1,2-Dibromoetano & $106-93-4$ & $\mu \mathrm{g} / \mathrm{L}$ & 1 & $<1$ & n.a. & 13/11/2014 10:59 \\
\hline 1,2-Diclorobenzeno & $95-50-1$ & $\mu \mathrm{g} / \mathrm{L}$ & 1 & $<1$ & n.a. & 13/11/2014 10:59 \\
\hline 1,3-Diclorobenzeno & $541-73-1$ & $\mu \mathrm{g} / \mathrm{L}$ & 1 & $<1$ & n.a. & $13 / 11 / 201410: 59$ \\
\hline 2-Clorotolueno & $95-49-8$ & $\mu \mathrm{g} / \mathrm{L}$ & 1 & $<1$ & n.a. & $13 / 11 / 201410: 59$ \\
\hline Dibromometano & $74-95-3$ & $\mu \mathrm{g} / \mathrm{L}$ & 1 & $<1$ & n.a. & $13 / 11 / 201410: 59$ \\
\hline Metiletilcetona & $78-93-3$ & $\mu \mathrm{g} / \mathrm{L}$ & 2500 & $<2500$ & n.a. & 13/11/2014 10:59 \\
\hline Naftaleno & $91-20-3$ & $\mu \mathrm{g} / \mathrm{L}$ & 1 & $<1$ & n.a. & $13 / 11 / 201410: 59$ \\
\hline n-Butilbenzeno & $104-51-8$ & $\mu \mathrm{g} / \mathrm{L}$ & 1 & $<1$ & n.a. & $13 / 11 / 201410: 59$ \\
\hline n-Propilbenzeno & $103-65-1$ & $\mu \mathrm{g} / \mathrm{L}$ & 1 & $<1$ & n.a. & 13/11/2014 10:59 \\
\hline 4-Clorotolueno & $106-43-4$ & $\mu \mathrm{g} / \mathrm{L}$ & 1 & $<1$ & n.a. & $13 / 11 / 201410: 59$ \\
\hline sec-Butilbenzeno & $135-98-8$ & $\mu \mathrm{g} / \mathrm{L}$ & 1 & $<1$ & n.a. & 13/11/2014 10:59 \\
\hline terc-Butilbenzeno & $98-06-6$ & $\mu \mathrm{g} / \mathrm{L}$ & 1 & $<1$ & n.a. & $13 / 11 / 201410: 59$ \\
\hline trans-1,3-Dicloropropeno & $10061-02-6$ & $\mu \mathrm{g} / \mathrm{L}$ & 1 & $<1$ & n.a. & 13/11/2014 10:59 \\
\hline Isopropilbenzeno & $98-82-8$ & $\mu \mathrm{g} / \mathrm{L}$ & 1 & $<1$ & n.a. & 13/11/2014 10:59 \\
\hline 1,3,5-Triclorobenzeno & $108-70-3$ & $\mu \mathrm{g} / \mathrm{L}$ & 1 & $<1$ & n.a. & 13/11/2014 10:59 \\
\hline
\end{tabular}

\section{CONTROLE DE QUALIDADE DO LABORATÓRIO}

302697/2014-0 - Branco de Análise - VOC - Água

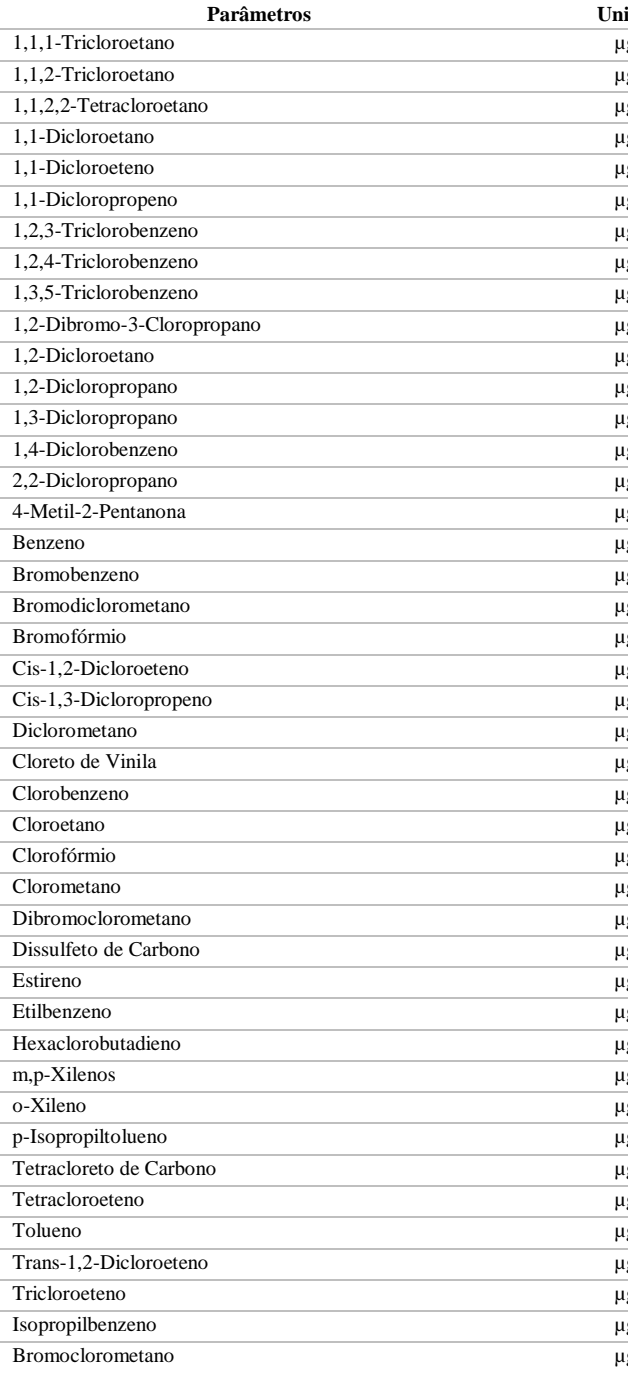

Controle de Qualidade - VOC - Água

\begin{tabular}{|c|c|c|}
\hline Unidade & LQ & Resultados analíticos \\
\hline$\mu \mathrm{g} / \mathrm{L}$ & 1 & $<1$ \\
\hline$\mu \mathrm{g} / \mathrm{L}$ & 1 & $<1$ \\
\hline$\mu \mathrm{g} / \mathrm{L}$ & 1 & $<1$ \\
\hline$\mu \mathrm{g} / \mathrm{L}$ & 1 & $<1$ \\
\hline$\mu \mathrm{g} / \mathrm{L}$ & 1 & $<1$ \\
\hline$\mu \mathrm{g} / \mathrm{L}$ & 1 & $<1$ \\
\hline$\mu \mathrm{g} / \mathrm{L}$ & 1 & $<1$ \\
\hline$\mu \mathrm{g} / \mathrm{L}$ & 1 & $<1$ \\
\hline$\mu \mathrm{g} / \mathrm{L}$ & 1 & $<1$ \\
\hline$\mu \mathrm{g} / \mathrm{L}$ & 5 & $<5$ \\
\hline$\mu \mathrm{g} / \mathrm{L}$ & 1 & $<1$ \\
\hline$\mu \mathrm{g} / \mathrm{L}$ & 1 & $<1$ \\
\hline$\mu \mathrm{g} / \mathrm{L}$ & 5 & $<5$ \\
\hline$\mu \mathrm{g} / \mathrm{L}$ & 1 & $<1$ \\
\hline$\mu \mathrm{g} / \mathrm{L}$ & 1 & $<1$ \\
\hline$\mu \mathrm{g} / \mathrm{L}$ & 5 & $<5$ \\
\hline$\mu \mathrm{g} / \mathrm{L}$ & 1 & $<1$ \\
\hline$\mu \mathrm{g} / \mathrm{L}$ & 1 & $<1$ \\
\hline$\mu \mathrm{g} / \mathrm{L}$ & 1 & $<1$ \\
\hline$\mu \mathrm{g} / \mathrm{L}$ & 1 & $<1$ \\
\hline$\mu \mathrm{g} / \mathrm{L}$ & 1 & $<1$ \\
\hline$\mu \mathrm{g} / \mathrm{L}$ & 1 & $<1$ \\
\hline$\mu \mathrm{g} / \mathrm{L}$ & 1 & $<1$ \\
\hline$\mu \mathrm{g} / \mathrm{L}$ & 1 & $<1$ \\
\hline$\mu \mathrm{g} / \mathrm{L}$ & 1 & $<1$ \\
\hline$\mu \mathrm{g} / \mathrm{L}$ & 1 & $<1$ \\
\hline$\mu \mathrm{g} / \mathrm{L}$ & 1 & $<1$ \\
\hline$\mu \mathrm{g} / \mathrm{L}$ & 10 & $<10$ \\
\hline$\mu \mathrm{g} / \mathrm{L}$ & 1 & $<1$ \\
\hline$\mu \mathrm{g} / \mathrm{L}$ & 1 & $<1$ \\
\hline$\mu \mathrm{g} / \mathrm{L}$ & 1 & $<1$ \\
\hline$\mu \mathrm{g} / \mathrm{L}$ & 1 & $<1$ \\
\hline$\mu \mathrm{g} / \mathrm{L}$ & 1 & $<1$ \\
\hline$\mu \mathrm{g} / \mathrm{L}$ & 2 & $<2$ \\
\hline$\mu \mathrm{g} / \mathrm{L}$ & 1 & $<1$ \\
\hline$\mu \mathrm{g} / \mathrm{L}$ & 1 & $<1$ \\
\hline$\mu \mathrm{g} / \mathrm{L}$ & 1 & $<1$ \\
\hline$\mu \mathrm{g} / \mathrm{L}$ & 1 & $<1$ \\
\hline$\mu \mathrm{g} / \mathrm{L}$ & 1 & $<1$ \\
\hline$\mu \mathrm{g} / \mathrm{L}$ & 1 & $<1$ \\
\hline$\mu \mathrm{g} / \mathrm{L}$ & 1 & $<1$ \\
\hline$\mu \mathrm{g} / \mathrm{L}$ & 1 & $<1$ \\
\hline$\mu \mathrm{g} / \mathrm{L}$ & 5 & $<5$ \\
\hline
\end{tabular}




\begin{tabular}{|c|c|c|c|c|}
\hline Parâmetros & $\begin{array}{l}\text { Quantidade } \\
\text { Adicionada }\end{array}$ & Unidade & $\begin{array}{c}\text { Resultado da } \\
\text { Recuperação (\%) }\end{array}$ & Faixa Aceitável de Recuperação (\%) \\
\hline \multicolumn{5}{|c|}{ 302698/2014-0 - Amostra Controle - VOC - Água } \\
\hline 1,1-Dicloroeteno & 20 & $\mu \mathrm{g} / \mathrm{L}$ & 70 & $70-130$ \\
\hline Benzeno & 20 & $\mu \mathrm{g} / \mathrm{L}$ & 70 & $70-130$ \\
\hline Tricloroeteno & 20 & $\mu \mathrm{g} / \mathrm{L}$ & 80 & $70-130$ \\
\hline Tolueno & 20 & $\mu \mathrm{g} / \mathrm{L}$ & 75 & $70-130$ \\
\hline Clorobenzeno & 20 & $\mu \mathrm{g} / \mathrm{L}$ & 80 & $70-130$ \\
\hline \multicolumn{5}{|c|}{$\begin{array}{l}\text { Surrogates } \\
\text { 302697/2014-0 - Branco de Análise - VOC - Água }\end{array}$} \\
\hline p-Bromofluorbenzeno & 20 & $\%$ & 71,3 & $70-130$ \\
\hline Dibromofluorometano & 20 & $\%$ & 78,3 & $70-130$ \\
\hline \multicolumn{5}{|c|}{ 302698/2014-0 - Amostra Controle - VOC - Água } \\
\hline p-Bromofluorbenzeno & 20 & $\%$ & 76,3 & $70-130$ \\
\hline Dibromofluorometano & 20 & $\%$ & 89,4 & $70-130$ \\
\hline \multicolumn{5}{|l|}{ 293000/2014-0 - BAF 2} \\
\hline Dibromofluorometano & 20 & $\%$ & 97,7 & $70-130$ \\
\hline p-Bromofluorbenzeno & 20 & $\%$ & 73,9 & $70-130$ \\
\hline
\end{tabular}

Notas

LQ = Limite de Quantificação.

n.a. $=$ Não Aplicável.

Abrangência

$\mathrm{O}(\mathrm{s})$ resultado(s) referem-se somente à(s) amostra(s) analisada(s).

Este Relatório de Ensaio só pode ser reproduzido por inteiro e sem nenhuma alteração.

Plano de Amostragem

Plano de amostragem de responsabilidade do interessado.

Responsabilidade Técnica

Os ensaios foram realizados na unidade da Bioagri Ambiental Ltda. - Matriz, situada na Rua Aljovil Martini, 177/201, Bairro Dois Córregos, Cep. 14420-833, Piracicaba/SP, registrada no CRQ 4 Região sob no $16082-\mathrm{F}$ e responsabilidade técnica do profissional Marcos Donizete Ceccatto, CRQ n⿳ ${ }^{\circ} 04364387,4^{\mathrm{a}}$.Região.

Referências Metodológicas

Análises foram realizadas conforme a última versão do Standard Methods for the Examination of Water \& Wastewater 22nd 2012(SMWW), EPA e ABNT (quando aplicável). VOC: EPA 8260 C: 2006, 5021A: 2003

Metiletilcetona: EPA 8260 C: 2006, 5021 A: 2003

Revisores

Débora Fernandes da Silva

Chave de Validação: d88cdc5bca6e4ef9f6365a3b14e7a585
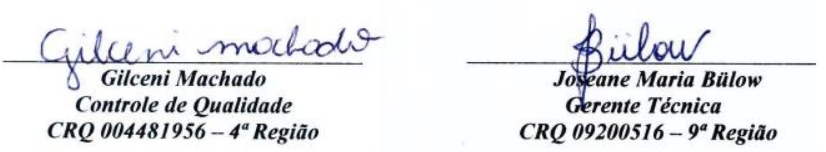


\section{RELATÓRIO DE ENSAIO N ${ }^{\circ}$ 293001/2014-0 - Piracicaba Processo Comercial $N^{\circ}$ 23961/2014-2}

\begin{tabular}{|l|l|}
\hline \multicolumn{2}{|c|}{ DADOS REFERENTES AO CLIENTE } \\
\hline Empresa solicitante: & Fundacao Parque de Alta Tecnologia da Regiao de Ipero e Adjacencias \\
\hline Endereço: & Rua Jose Antonio Scaciota, 165 - - Portal do Cedro - Iperó - SP - CEP: 18.560-000 . \\
\hline Nome do Solicitante: & Carla Marçal \\
\hline
\end{tabular}

\section{DADOS REFERENTES A AMOSTRA}

\begin{tabular}{|l|l|l|l|l|l|}
\hline Identificação do Cliente: & \multicolumn{4}{|l}{ BAF 3} & \multicolumn{3}{l}{$l$} \\
\hline Amostra Rotulada como: & \multicolumn{2}{|l|}{ Água Subterrânea Projeto Mestrado } \\
\hline Coletor: & Interessado & Data da coleta: & $03 / 11 / 2014$ 00:54:00 \\
\hline Data da entrada no laboratório: & $04 / 11 / 201401: 27$ & Data de Elaboração do RE: & $14 / 11 / 2014$ \\
\hline
\end{tabular}

\section{RESULTADOS PARA A AMOSTRA}

\begin{tabular}{|c|c|c|c|c|c|c|}
\hline Parâmetros & CAS & Unidade & LQ & Resultados analíticos & Incerteza & Data do Ensaio \\
\hline 1,1,1-Tricloroetano & $71-55-6$ & $\mu \mathrm{g} / \mathrm{L}$ & 1 & $<1$ & n.a. & 14/11/2014 03:29 \\
\hline 1,1,2-Tricloroetano & $79-00-5$ & $\mu \mathrm{g} / \mathrm{L}$ & 1 & $<1$ & n.a. & $14 / 11 / 201403: 29$ \\
\hline 1,1,2,2-Tetracloroetano & $79-34-5$ & $\mu \mathrm{g} / \mathrm{L}$ & 1 & $<1$ & n.a. & 14/11/2014 03:29 \\
\hline 1,1-Dicloroetano & $75-34-3$ & $\mu \mathrm{g} / \mathrm{L}$ & 1 & $<1$ & n.a. & 14/11/2014 03:29 \\
\hline 1,1-Dicloroeteno & $75-35-4$ & $\mu \mathrm{g} / \mathrm{L}$ & 1 & $<1$ & n.a. & 14/11/2014 03:29 \\
\hline 1,1-Dicloropropeno & $563-58-6$ & $\mu \mathrm{g} / \mathrm{L}$ & 1 & $<1$ & n.a. & 14/11/2014 03:29 \\
\hline 1,2,3-Triclorobenzeno & $87-61-6$ & $\mu \mathrm{g} / \mathrm{L}$ & 1 & $<1$ & n.a. & 14/11/2014 03:29 \\
\hline 1,2,4-Triclorobenzeno & $120-82-1$ & $\mu \mathrm{g} / \mathrm{L}$ & 1 & $<1$ & n.a. & 14/11/2014 03:29 \\
\hline 1,2-Dibromo-3-Cloropropano & $96-12-8$ & $\mu \mathrm{g} / \mathrm{L}$ & 5 & $<5$ & n.a. & 14/11/2014 03:29 \\
\hline 1,2-Dicloroetano & $107-06-2$ & $\mu \mathrm{g} / \mathrm{L}$ & 1 & $<1$ & n.a. & 14/11/2014 03:29 \\
\hline 1,2-Dicloropropano & $78-87-5$ & $\mu \mathrm{g} / \mathrm{L}$ & 1 & $<1$ & n.a. & 14/11/2014 03:29 \\
\hline 1,3-Dicloropropano & $142-28-9$ & $\mu \mathrm{g} / \mathrm{L}$ & 5 & $<5$ & n.a. & 14/11/2014 03:29 \\
\hline 1,4-Diclorobenzeno & $106-46-7$ & $\mu \mathrm{g} / \mathrm{L}$ & 1 & $<1$ & n.a. & 14/11/2014 03:29 \\
\hline 2,2-Dicloropropano & $594-20-7$ & $\mu \mathrm{g} / \mathrm{L}$ & 1 & $<1$ & n.a. & 14/11/2014 03:29 \\
\hline 4-Metil-2-Pentanona & $108-10-1$ & $\mu \mathrm{g} / \mathrm{L}$ & 5 & $<5$ & n.a. & 14/11/2014 03:29 \\
\hline Benzeno & $71-43-2$ & $\mu \mathrm{g} / \mathrm{L}$ & 1 & $<1$ & n.a. & $14 / 11 / 201403: 29$ \\
\hline Bromobenzeno & $108-86-1$ & $\mu \mathrm{g} / \mathrm{L}$ & 1 & $<1$ & n.a. & 14/11/2014 03:29 \\
\hline Bromodiclorometano & $75-27-4$ & $\mu \mathrm{g} / \mathrm{L}$ & 1 & $<1$ & n.a. & 14/11/2014 03:29 \\
\hline Bromofórmio & $75-25-2$ & $\mu \mathrm{g} / \mathrm{L}$ & 1 & $<1$ & n.a. & 14/11/2014 03:29 \\
\hline Bromoclorometano & $74-97-5$ & $\mu \mathrm{g} / \mathrm{L}$ & 5 & $<5$ & n.a. & 14/11/2014 03:29 \\
\hline Cis-1,2-Dicloroeteno & $156-59-2$ & $\mu \mathrm{g} / \mathrm{L}$ & 1 & $<1$ & n.a. & 14/11/2014 03:29 \\
\hline Cis-1,3-Dicloropropeno & $10061-01-5$ & $\mu \mathrm{g} / \mathrm{L}$ & 1 & $<1$ & n.a. & 14/11/2014 03:29 \\
\hline Diclorometano & $75-09-2$ & $\mu \mathrm{g} / \mathrm{L}$ & 1 & $<1$ & n.a. & $14 / 11 / 201403: 29$ \\
\hline Cloreto de Vinila & $75-01-4$ & $\mu \mathrm{g} / \mathrm{L}$ & 1 & $<1$ & n.a. & 14/11/2014 03:29 \\
\hline Clorobenzeno & $108-90-7$ & $\mu \mathrm{g} / \mathrm{L}$ & 1 & $<1$ & n.a. & 14/11/2014 03:29 \\
\hline Cloroetano & $75-00-3$ & $\mu \mathrm{g} / \mathrm{L}$ & 1 & $<1$ & n.a. & 14/11/2014 03:29 \\
\hline Clorofórmio & $67-66-3$ & $\mu \mathrm{g} / \mathrm{L}$ & 1 & $<1$ & n.a. & 14/11/2014 03:29 \\
\hline Clorometano & $74-87-3$ & $\mu \mathrm{g} / \mathrm{L}$ & 10 & $<10$ & n.a. & 14/11/2014 03:29 \\
\hline Dibromoclorometano & $124-48-1$ & $\mu \mathrm{g} / \mathrm{L}$ & 1 & $<1$ & n.a. & 14/11/2014 03:29 \\
\hline Dissulfeto de Carbono & $75-15-0$ & $\mu \mathrm{g} / \mathrm{L}$ & 1 & $<1$ & n.a. & 14/11/2014 03:29 \\
\hline Estireno & $100-42-5$ & $\mu \mathrm{g} / \mathrm{L}$ & 1 & $<1$ & n.a. & 14/11/2014 03:29 \\
\hline Etilbenzeno & $100-41-4$ & $\mu \mathrm{g} / \mathrm{L}$ & 1 & $<1$ & n.a. & 14/11/2014 03:29 \\
\hline Hexaclorobutadieno & $87-68-3$ & $\mu \mathrm{g} / \mathrm{L}$ & 1 & $<1$ & n.a. & 14/11/2014 03:29 \\
\hline m,p-Xilenos & --- & $\mu \mathrm{g} / \mathrm{L}$ & 2 & $<2$ & n.a. & 14/11/2014 03:29 \\
\hline o-Xileno & $95-47-6$ & $\mu \mathrm{g} / \mathrm{L}$ & 1 & $<1$ & n.a. & 14/11/2014 03:29 \\
\hline p-Isopropiltolueno & $99-87-6$ & $\mu \mathrm{g} / \mathrm{L}$ & 1 & $<1$ & n.a. & 14/11/2014 03:29 \\
\hline Tetracloreto de Carbono & $56-23-5$ & $\mu \mathrm{g} / \mathrm{L}$ & 1 & $<1$ & n.a. & 14/11/2014 03:29 \\
\hline Tetracloroeteno & $127-18-4$ & $\mu \mathrm{g} / \mathrm{L}$ & 10 & 81,6 & 16 & 14/11/2014 03:29 \\
\hline Tolueno & $108-88-3$ & $\mu \mathrm{g} / \mathrm{L}$ & 1 & $<1$ & n.a. & 14/11/2014 03:29 \\
\hline Trans-1,2-Dicloroeteno & $156-60-5$ & $\mu \mathrm{g} / \mathrm{L}$ & 1 & $<1$ & n.a. & 14/11/2014 03:29 \\
\hline Tricloroeteno & $79-01-6$ & $\mu \mathrm{g} / \mathrm{L}$ & 1 & $<1$ & n.a. & 14/11/2014 03:29 \\
\hline 1,1,1,2-Tetracloroetano & $630-20-6$ & $\mu \mathrm{g} / \mathrm{L}$ & 1 & $<1$ & n.a. & 14/11/2014 03:29 \\
\hline
\end{tabular}




\begin{tabular}{|c|c|c|c|c|c|c|}
\hline Parâmetros & CAS & Unidade & LQ & Resultados analíticos & Incerteza & Data do Ensaio \\
\hline 1,2,3-Tricloropropano & $96-18-4$ & $\mu \mathrm{g} / \mathrm{L}$ & 5 & $<5$ & n.a. & 14/11/2014 03:29 \\
\hline 1,3,5-Trimetilbenzeno & $108-67-8$ & $\mu \mathrm{g} / \mathrm{L}$ & 1 & $<1$ & n.a. & 14/11/2014 03:29 \\
\hline 1,2,4-Trimetilbenzeno & $95-63-6$ & $\mu \mathrm{g} / \mathrm{L}$ & 1 & $<1$ & n.a. & 14/11/2014 03:29 \\
\hline 1,2-Dibromoetano & $106-93-4$ & $\mu \mathrm{g} / \mathrm{L}$ & 1 & $<1$ & n.a. & 14/11/2014 03:29 \\
\hline 1,2-Diclorobenzeno & $95-50-1$ & $\mu \mathrm{g} / \mathrm{L}$ & 1 & $<1$ & n.a. & 14/11/2014 03:29 \\
\hline 1,3-Diclorobenzeno & $541-73-1$ & $\mu \mathrm{g} / \mathrm{L}$ & 1 & $<1$ & n.a. & 14/11/2014 03:29 \\
\hline 2-Clorotolueno & $95-49-8$ & $\mu \mathrm{g} / \mathrm{L}$ & 1 & $<1$ & n.a. & $14 / 11 / 201403: 29$ \\
\hline Dibromometano & $74-95-3$ & $\mu \mathrm{g} / \mathrm{L}$ & 1 & $<1$ & n.a. & $14 / 11 / 201403: 29$ \\
\hline Metiletilcetona & 78-93-3 & $\mu \mathrm{g} / \mathrm{L}$ & 2500 & $<2500$ & n.a. & 14/11/2014 03:53 \\
\hline Naftaleno & $91-20-3$ & $\mu \mathrm{g} / \mathrm{L}$ & 1 & $<1$ & n.a. & 14/11/2014 03:29 \\
\hline n-Butilbenzeno & $104-51-8$ & $\mu \mathrm{g} / \mathrm{L}$ & 1 & $<1$ & n.a. & $14 / 11 / 201403: 29$ \\
\hline n-Propilbenzeno & $103-65-1$ & $\mu \mathrm{g} / \mathrm{L}$ & 1 & $<1$ & n.a. & $14 / 11 / 201403: 29$ \\
\hline 4-Clorotolueno & $106-43-4$ & $\mu \mathrm{g} / \mathrm{L}$ & 1 & $<1$ & n.a. & $14 / 11 / 201403: 29$ \\
\hline sec-Butilbenzeno & $135-98-8$ & $\mu \mathrm{g} / \mathrm{L}$ & 1 & $<1$ & n.a. & 14/11/2014 03:29 \\
\hline terc-Butilbenzeno & $98-06-6$ & $\mu \mathrm{g} / \mathrm{L}$ & 1 & $<1$ & n.a. & 14/11/2014 03:29 \\
\hline trans-1,3-Dicloropropeno & $10061-02-6$ & $\mu \mathrm{g} / \mathrm{L}$ & 1 & $<1$ & n.a. & $14 / 11 / 201403: 29$ \\
\hline Isopropilbenzeno & $98-82-8$ & $\mu \mathrm{g} / \mathrm{L}$ & 1 & $<1$ & n.a. & 14/11/2014 03:29 \\
\hline 1,3,5-Triclorobenzeno & $108-70-3$ & $\mu \mathrm{g} / \mathrm{L}$ & 1 & $<1$ & n.a. & 14/11/2014 03:29 \\
\hline
\end{tabular}

\section{CONTROLE DE QUALIDADE DO LABORATÓRIO}

302697/2014-0 - Branco de Análise - VOC - Água

\begin{tabular}{|c|c|}
\hline \multirow{2}{*}{\multicolumn{2}{|c|}{$\begin{array}{ll} & \text { Parâmetros } \\
1,1,1-\text { Tricloroetano } & \end{array}$}} \\
\hline & \\
\hline \multicolumn{2}{|l|}{ 1,1,2-Tricloroetano } \\
\hline \multicolumn{2}{|l|}{ 1,1,2,2-Tetracloroetano } \\
\hline \multicolumn{2}{|l|}{ 1,1-Dicloroetano } \\
\hline \multicolumn{2}{|l|}{ 1,1-Dicloroeteno } \\
\hline \multicolumn{2}{|l|}{ 1,1-Dicloropropeno } \\
\hline \multicolumn{2}{|l|}{ 1,2,3-Triclorobenzeno } \\
\hline \multicolumn{2}{|l|}{ 1,2,4-Triclorobenzeno } \\
\hline \multicolumn{2}{|l|}{ 1,3,5-Triclorobenzeno } \\
\hline \multicolumn{2}{|l|}{ 1,2-Dibromo-3-Cloropropano } \\
\hline \multicolumn{2}{|l|}{ 1,2-Dicloroetano } \\
\hline \multicolumn{2}{|l|}{ 1,2-Dicloropropano } \\
\hline \multicolumn{2}{|l|}{ 1,3-Dicloropropano } \\
\hline \multicolumn{2}{|l|}{ 1,4-Diclorobenzeno } \\
\hline \multicolumn{2}{|l|}{ 2,2-Dicloropropano } \\
\hline \multicolumn{2}{|l|}{ 4-Metil-2-Pentanona } \\
\hline \multicolumn{2}{|l|}{ Benzeno } \\
\hline \multicolumn{2}{|l|}{ Bromobenzeno } \\
\hline \multicolumn{2}{|l|}{ Bromodiclorometano } \\
\hline \multicolumn{2}{|l|}{ Bromofórmio } \\
\hline \multicolumn{2}{|l|}{ Cis-1,2-Dicloroeteno } \\
\hline \multicolumn{2}{|l|}{ Cis-1,3-Dicloropropeno } \\
\hline \multicolumn{2}{|l|}{ Diclorometano } \\
\hline \multicolumn{2}{|l|}{ Cloreto de Vinila } \\
\hline \multicolumn{2}{|l|}{ Clorobenzeno } \\
\hline \multicolumn{2}{|l|}{ Cloroetano } \\
\hline Clorofórmio & \\
\hline Clorometano & \\
\hline Dibromoclorometano & \\
\hline Dissulfeto de Carbono & \\
\hline Estireno & \\
\hline Etilbenzeno & \\
\hline Hexaclorobutadieno & \\
\hline m,p-Xilenos & \\
\hline o-Xileno & \\
\hline p-Isopropiltolueno & \\
\hline Tetracloreto de Carbono & \\
\hline Tetracloroeteno & \\
\hline Tolueno & \\
\hline Trans-1,2-Dicloroeteno & \\
\hline Tricloroeteno & \\
\hline Isopropilbenzeno & \\
\hline Bromoclorometano & \\
\hline
\end{tabular}

Controle de Qualidade - VOC - Água

\begin{tabular}{|c|c|c|}
\hline Unidade & LQ & Resultados analíticos \\
\hline$\mu \mathrm{g} / \mathrm{L}$ & 1 & $<1$ \\
\hline$\mu \mathrm{g} / \mathrm{L}$ & 1 & $<1$ \\
\hline$\mu \mathrm{g} / \mathrm{L}$ & 1 & $<1$ \\
\hline$\mu \mathrm{g} / \mathrm{L}$ & 1 & $<1$ \\
\hline$\mu \mathrm{g} / \mathrm{L}$ & 1 & $<1$ \\
\hline$\mu \mathrm{g} / \mathrm{L}$ & 1 & $<1$ \\
\hline$\mu \mathrm{g} / \mathrm{L}$ & 1 & $<1$ \\
\hline$\mu \mathrm{g} / \mathrm{L}$ & 1 & $<1$ \\
\hline$\mu \mathrm{g} / \mathrm{L}$ & 1 & $<1$ \\
\hline$\mu \mathrm{g} / \mathrm{L}$ & 5 & $<5$ \\
\hline$\mu \mathrm{g} / \mathrm{L}$ & 1 & $<1$ \\
\hline$\mu \mathrm{g} / \mathrm{L}$ & 1 & $<1$ \\
\hline$\mu \mathrm{g} / \mathrm{L}$ & 5 & $<5$ \\
\hline$\mu \mathrm{g} / \mathrm{L}$ & 1 & $<1$ \\
\hline$\mu \mathrm{g} / \mathrm{L}$ & 1 & $<1$ \\
\hline$\mu \mathrm{g} / \mathrm{L}$ & 5 & $<5$ \\
\hline$\mu \mathrm{g} / \mathrm{L}$ & 1 & $<1$ \\
\hline$\mu \mathrm{g} / \mathrm{L}$ & 1 & $<1$ \\
\hline$\mu \mathrm{g} / \mathrm{L}$ & 1 & $<1$ \\
\hline$\mu \mathrm{g} / \mathrm{L}$ & 1 & $<1$ \\
\hline$\mu \mathrm{g} / \mathrm{L}$ & 1 & $<1$ \\
\hline$\mu \mathrm{g} / \mathrm{L}$ & 1 & $<1$ \\
\hline$\mu \mathrm{g} / \mathrm{L}$ & 1 & $<1$ \\
\hline$\mu \mathrm{g} / \mathrm{L}$ & 1 & $<1$ \\
\hline$\mu \mathrm{g} / \mathrm{L}$ & 1 & $<1$ \\
\hline$\mu \mathrm{g} / \mathrm{L}$ & 1 & $<1$ \\
\hline$\mu \mathrm{g} / \mathrm{L}$ & 1 & $<1$ \\
\hline$\mu \mathrm{g} / \mathrm{L}$ & 10 & $<10$ \\
\hline$\mu \mathrm{g} / \mathrm{L}$ & 1 & $<1$ \\
\hline$\mu \mathrm{g} / \mathrm{L}$ & 1 & $<1$ \\
\hline$\mu \mathrm{g} / \mathrm{L}$ & 1 & $<1$ \\
\hline$\mu \mathrm{g} / \mathrm{L}$ & 1 & $<1$ \\
\hline$\mu \mathrm{g} / \mathrm{L}$ & 1 & $<1$ \\
\hline$\mu \mathrm{g} / \mathrm{L}$ & 2 & $<2$ \\
\hline$\mu \mathrm{g} / \mathrm{L}$ & 1 & $<1$ \\
\hline$\mu \mathrm{g} / \mathrm{L}$ & 1 & $<1$ \\
\hline$\mu \mathrm{g} / \mathrm{L}$ & 1 & $<1$ \\
\hline$\mu \mathrm{g} / \mathrm{L}$ & 1 & $<1$ \\
\hline$\mu \mathrm{g} / \mathrm{L}$ & 1 & $<1$ \\
\hline$\mu \mathrm{g} / \mathrm{L}$ & 1 & $<1$ \\
\hline$\mu \mathrm{g} / \mathrm{L}$ & 1 & $<1$ \\
\hline$\mu \mathrm{g} / \mathrm{L}$ & 1 & $<1$ \\
\hline$\mu \mathrm{g} / \mathrm{L}$ & 5 & $<5$ \\
\hline
\end{tabular}




\begin{tabular}{|c|c|c|c|c|}
\hline Parâmetros & $\begin{array}{l}\text { Quantidade } \\
\text { Adicionada }\end{array}$ & Unidade & $\begin{array}{c}\text { Resultado da } \\
\text { Recuperação (\%) }\end{array}$ & Faixa Aceitável de Recuperação (\%) \\
\hline \multicolumn{5}{|c|}{ 302698/2014-0 - Amostra Controle - VOC - Água } \\
\hline 1,1-Dicloroeteno & 20 & $\mu \mathrm{g} / \mathrm{L}$ & 70 & $70-130$ \\
\hline Benzeno & 20 & $\mu \mathrm{g} / \mathrm{L}$ & 70 & $70-130$ \\
\hline Tricloroeteno & 20 & $\mu \mathrm{g} / \mathrm{L}$ & 80 & $70-130$ \\
\hline Tolueno & 20 & $\mu \mathrm{g} / \mathrm{L}$ & 75 & $70-130$ \\
\hline Clorobenzeno & 20 & $\mu \mathrm{g} / \mathrm{L}$ & 80 & $70-130$ \\
\hline \multicolumn{5}{|c|}{$\begin{array}{l}\text { Surrogates } \\
\text { 302697/2014-0 - Branco de Análise - VOC - Água }\end{array}$} \\
\hline p-Bromofluorbenzeno & 20 & $\%$ & 71,3 & $70-130$ \\
\hline Dibromofluorometano & 20 & $\%$ & 78,3 & $70-130$ \\
\hline \multicolumn{5}{|c|}{ 302698/2014-0 - Amostra Controle - VOC - Água } \\
\hline p-Bromofluorbenzeno & 20 & $\%$ & 76,3 & $70-130$ \\
\hline Dibromofluorometano & 20 & $\%$ & 89,4 & $70-130$ \\
\hline \multicolumn{5}{|l|}{ 293001/2014-0 - BAF 3} \\
\hline Dibromofluorometano & 20 & $\%$ & 95,7 & $70-130$ \\
\hline p-Bromofluorbenzeno & 20 & $\%$ & 73,2 & $70-130$ \\
\hline
\end{tabular}

Notas

LQ = Limite de Quantificação

n.a. $=$ Não Aplicável.

Abrangência

$\mathrm{O}(\mathrm{s})$ resultado(s) referem-se somente à(s) amostra(s) analisada(s).

Este Relatório de Ensaio só pode ser reproduzido por inteiro e sem nenhuma alteração.

Plano de Amostragem

Plano de amostragem de responsabilidade do interessado.

Responsabilidade Técnica

Os ensaios foram realizados na unidade da Bioagri Ambiental Ltda. - Matriz, situada na Rua Aljovil Martini, 177/201, Bairro Dois Córregos, Cep. 14420-833, Piracicaba/SP, registrada no CRQ 4 Região sob no $16082-\mathrm{F}$ e responsabilidade técnica do profissional Marcos Donizete Ceccatto, CRQ n ${ }^{\circ} 04364387,4^{\mathrm{a}}$.Região.

Referências Metodológicas

Análises foram realizadas conforme a última versão do Standard Methods for the Examination of Water \& Wastewater 22nd 2012(SMWW), EPA e ABNT (quando aplicável). VOC: EPA 8260 C: 2006, 5021A: 2003

Metiletilcetona: EPA 8260 C: 2006, 5021 A: 2003

Revisores

Débora Fernandes da Silva

Luci Carla Gheleri Andrietta

Chave de Validação: 717fc6ba9fb4da7ff9394c2ddaf3ffd4
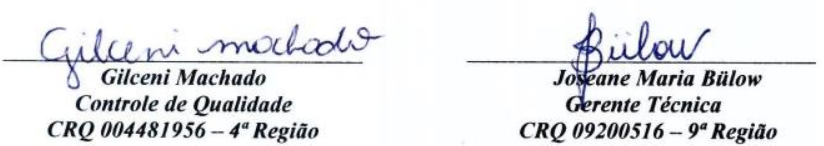


\section{RELATÓRIO DE ENSAIO N ${ }^{\circ}$ 292984/2014-0 - Piracicaba Processo Comercial $N^{\circ}$ 23961/2014-2}

\begin{tabular}{|l|l|}
\hline \multicolumn{2}{|c|}{ DADOS REFERENTES AO CLIENTE } \\
\hline Empresa solicitante: & Fundacao Parque de Alta Tecnologia da Regiao de Ipero e Adjacencias \\
\hline Endereço: & Rua Jose Antonio Scaciota, 165 - - Portal do Cedro - Iperó - SP - CEP: 18.560-000 . \\
\hline Nome do Solicitante: & Carla Marçal \\
\hline
\end{tabular}

\section{DADOS REFERENTES A AMOSTRA}

Identificação do Cliente: Amostra Rotulada como:

Coletor:

ASI 1

Água Subterrânea Projeto Mestrado

\begin{tabular}{|l|l|l|l|l|}
\hline Data da entrada no laboratório: & 04/11/2014 01:22 & Data de Elaboração do RE: & 14/11/2014
\end{tabular}

\section{RESULTADOS PARA A AMOSTRA}

\begin{tabular}{|c|c|c|c|c|c|c|}
\hline Parâmetros & CAS & Unidade & LQ & Resultados analíticos & Incerteza & Data do Ensaio \\
\hline 1,1,1-Tricloroetano & $71-55-6$ & $\mu \mathrm{g} / \mathrm{L}$ & 1 & $<1$ & n.a. & $14 / 11 / 201404: 42$ \\
\hline 1,1,2-Tricloroetano & $79-00-5$ & $\mu \mathrm{g} / \mathrm{L}$ & 1 & $<1$ & n.a. & 14/11/2014 04:42 \\
\hline 1,1,2,2-Tetracloroetano & $79-34-5$ & $\mu \mathrm{g} / \mathrm{L}$ & 1 & $<1$ & n.a. & $14 / 11 / 201404: 42$ \\
\hline 1,1-Dicloroetano & $75-34-3$ & $\mu \mathrm{g} / \mathrm{L}$ & 1 & $<1$ & n.a. & 14/11/2014 04:42 \\
\hline 1,1-Dicloroeteno & $75-35-4$ & $\mu \mathrm{g} / \mathrm{L}$ & 1 & $<1$ & n.a. & $14 / 11 / 201404: 42$ \\
\hline 1,1-Dicloropropeno & $563-58-6$ & $\mu \mathrm{g} / \mathrm{L}$ & 1 & $<1$ & n.a. & $14 / 11 / 201404: 42$ \\
\hline 1,2,3-Triclorobenzeno & $87-61-6$ & $\mu \mathrm{g} / \mathrm{L}$ & 1 & $<1$ & n.a. & $14 / 11 / 201404: 42$ \\
\hline 1,2,4-Triclorobenzeno & $120-82-1$ & $\mu \mathrm{g} / \mathrm{L}$ & 1 & $<1$ & n.a. & $14 / 11 / 201404: 42$ \\
\hline 1,2-Dibromo-3-Cloropropano & $96-12-8$ & $\mu \mathrm{g} / \mathrm{L}$ & 5 & $<5$ & n.a. & $14 / 11 / 201404: 42$ \\
\hline 1,2-Dicloroetano & $107-06-2$ & $\mu \mathrm{g} / \mathrm{L}$ & 1 & $<1$ & n.a. & $14 / 11 / 201404: 42$ \\
\hline 1,2-Dicloropropano & $78-87-5$ & $\mu \mathrm{g} / \mathrm{L}$ & 1 & $<1$ & n.a. & 14/11/2014 04:42 \\
\hline 1,3-Dicloropropano & $142-28-9$ & $\mu \mathrm{g} / \mathrm{L}$ & 5 & $<5$ & n.a. & $14 / 11 / 201404: 42$ \\
\hline 1,4-Diclorobenzeno & $106-46-7$ & $\mu \mathrm{g} / \mathrm{L}$ & 1 & $<1$ & n.a. & $14 / 11 / 201404: 42$ \\
\hline 2,2-Dicloropropano & $594-20-7$ & $\mu \mathrm{g} / \mathrm{L}$ & 1 & $<1$ & n.a. & 14/11/2014 04:42 \\
\hline 4-Metil-2-Pentanona & $108-10-1$ & $\mu \mathrm{g} / \mathrm{L}$ & 5 & $<5$ & n.a. & $14 / 11 / 201404: 42$ \\
\hline Benzeno & $71-43-2$ & $\mu \mathrm{g} / \mathrm{L}$ & 1 & $<1$ & n.a. & 14/11/2014 04:42 \\
\hline Bromobenzeno & $108-86-1$ & $\mu \mathrm{g} / \mathrm{L}$ & 1 & $<1$ & n.a. & 14/11/2014 04:42 \\
\hline Bromodiclorometano & $75-27-4$ & $\mu \mathrm{g} / \mathrm{L}$ & 1 & $<1$ & n.a. & 14/11/2014 04:42 \\
\hline Bromofórmio & $75-25-2$ & $\mu \mathrm{g} / \mathrm{L}$ & 1 & $<1$ & n.a. & 14/11/2014 04:42 \\
\hline Bromoclorometano & $74-97-5$ & $\mu \mathrm{g} / \mathrm{L}$ & 5 & $<5$ & n.a. & 14/11/2014 04:42 \\
\hline Cis-1,2-Dicloroeteno & $156-59-2$ & $\mu \mathrm{g} / \mathrm{L}$ & 1 & $<1$ & n.a. & 14/11/2014 04:42 \\
\hline Cis-1,3-Dicloropropeno & $10061-01-5$ & $\mu \mathrm{g} / \mathrm{L}$ & 1 & $<1$ & n.a. & 14/11/2014 04:42 \\
\hline Diclorometano & $75-09-2$ & $\mu \mathrm{g} / \mathrm{L}$ & 1 & $<1$ & n.a. & 14/11/2014 04:42 \\
\hline Cloreto de Vinila & $75-01-4$ & $\mu \mathrm{g} / \mathrm{L}$ & 1 & $<1$ & n.a. & $14 / 11 / 201404: 42$ \\
\hline Clorobenzeno & $108-90-7$ & $\mu \mathrm{g} / \mathrm{L}$ & 1 & $<1$ & n.a. & 14/11/2014 04:42 \\
\hline Cloroetano & $75-00-3$ & $\mu \mathrm{g} / \mathrm{L}$ & 1 & $<1$ & n.a. & 14/11/2014 04:42 \\
\hline Clorofórmio & $67-66-3$ & $\mu \mathrm{g} / \mathrm{L}$ & 1 & $<1$ & n.a. & $14 / 11 / 201404: 42$ \\
\hline Clorometano & $74-87-3$ & $\mu \mathrm{g} / \mathrm{L}$ & 10 & $<10$ & n.a. & 14/11/2014 04:42 \\
\hline Dibromoclorometano & $124-48-1$ & $\mu \mathrm{g} / \mathrm{L}$ & 1 & $<1$ & n.a. & 14/11/2014 04:42 \\
\hline Dissulfeto de Carbono & $75-15-0$ & $\mu \mathrm{g} / \mathrm{L}$ & 1 & $<1$ & n.a. & 14/11/2014 04:42 \\
\hline Estireno & $100-42-5$ & $\mu \mathrm{g} / \mathrm{L}$ & 1 & $<1$ & n.a. & 14/11/2014 04:42 \\
\hline Etilbenzeno & $100-41-4$ & $\mu \mathrm{g} / \mathrm{L}$ & 1 & $<1$ & n.a. & 14/11/2014 04:42 \\
\hline Hexaclorobutadieno & $87-68-3$ & $\mu \mathrm{g} / \mathrm{L}$ & 1 & $<1$ & n.a. & 14/11/2014 04:42 \\
\hline $\mathrm{m}, \mathrm{p}$-Xilenos & --- & $\mu \mathrm{g} / \mathrm{L}$ & 2 & $<2$ & n.a. & 14/11/2014 04:42 \\
\hline o-Xileno & $95-47-6$ & $\mu \mathrm{g} / \mathrm{L}$ & 1 & $<1$ & n.a. & 14/11/2014 04:42 \\
\hline p-Isopropiltolueno & $99-87-6$ & $\mu \mathrm{g} / \mathrm{L}$ & 1 & $<1$ & n.a. & 14/11/2014 04:42 \\
\hline Tetracloreto de Carbono & $56-23-5$ & $\mu \mathrm{g} / \mathrm{L}$ & 1 & $<1$ & n.a. & 14/11/2014 04:42 \\
\hline Tetracloroeteno & $127-18-4$ & $\mu \mathrm{g} / \mathrm{L}$ & 10 & 115 & 22 & 14/11/2014 04:42 \\
\hline Tolueno & $108-88-3$ & $\mu \mathrm{g} / \mathrm{L}$ & 1 & $<1$ & n.a. & $14 / 11 / 201404: 42$ \\
\hline Trans-1,2-Dicloroeteno & $156-60-5$ & $\mu \mathrm{g} / \mathrm{L}$ & 1 & $<1$ & n.a. & 14/11/2014 04:42 \\
\hline Tricloroeteno & 79-01-6 & $\mu \mathrm{g} / \mathrm{L}$ & 1 & $<1$ & n.a. & $14 / 11 / 201404: 42$ \\
\hline 1,1,1,2-Tetracloroetano & $630-20-6$ & $\mu \mathrm{g} / \mathrm{L}$ & 1 & $<1$ & n.a. & 14/11/2014 04:42 \\
\hline
\end{tabular}




\begin{tabular}{|c|c|c|c|c|c|c|}
\hline Parâmetros & CAS & Unidade & LQ & Resultados analíticos & Incerteza & Data do Ensaio \\
\hline 1,2,3-Tricloropropano & $96-18-4$ & $\mu \mathrm{g} / \mathrm{L}$ & 5 & $<5$ & n.a. & 14/11/2014 04:42 \\
\hline 1,3,5-Trimetilbenzeno & $108-67-8$ & $\mu \mathrm{g} / \mathrm{L}$ & 1 & $<1$ & n.a. & 14/11/2014 04:42 \\
\hline 1,2,4-Trimetilbenzeno & $95-63-6$ & $\mu \mathrm{g} / \mathrm{L}$ & 1 & $<1$ & n.a. & 14/11/2014 04:42 \\
\hline 1,2-Dibromoetano & $106-93-4$ & $\mu \mathrm{g} / \mathrm{L}$ & 1 & $<1$ & n.a. & 14/11/2014 04:42 \\
\hline 1,2-Diclorobenzeno & $95-50-1$ & $\mu \mathrm{g} / \mathrm{L}$ & 1 & $<1$ & n.a. & 14/11/2014 04:42 \\
\hline 1,3-Diclorobenzeno & $541-73-1$ & $\mu \mathrm{g} / \mathrm{L}$ & 1 & $<1$ & n.a. & 14/11/2014 04:42 \\
\hline 2-Clorotolueno & $95-49-8$ & $\mu \mathrm{g} / \mathrm{L}$ & 1 & $<1$ & n.a. & $14 / 11 / 201404: 42$ \\
\hline Dibromometano & $74-95-3$ & $\mu \mathrm{g} / \mathrm{L}$ & 1 & $<1$ & n.a. & 14/11/2014 04:42 \\
\hline Metiletilcetona & $78-93-3$ & $\mu \mathrm{g} / \mathrm{L}$ & 2500 & $<2500$ & n.a. & 14/11/2014 05:06 \\
\hline Naftaleno & $91-20-3$ & $\mu \mathrm{g} / \mathrm{L}$ & 1 & $<1$ & n.a. & 14/11/2014 04:42 \\
\hline n-Butilbenzeno & $104-51-8$ & $\mu \mathrm{g} / \mathrm{L}$ & 1 & $<1$ & n.a. & 14/11/2014 04:42 \\
\hline n-Propilbenzeno & $103-65-1$ & $\mu \mathrm{g} / \mathrm{L}$ & 1 & $<1$ & n.a. & $14 / 11 / 201404: 42$ \\
\hline 4-Clorotolueno & $106-43-4$ & $\mu \mathrm{g} / \mathrm{L}$ & 1 & $<1$ & n.a. & 14/11/2014 04:42 \\
\hline sec-Butilbenzeno & $135-98-8$ & $\mu \mathrm{g} / \mathrm{L}$ & 1 & $<1$ & n.a. & $14 / 11 / 201404: 42$ \\
\hline terc-Butilbenzeno & $98-06-6$ & $\mu \mathrm{g} / \mathrm{L}$ & 1 & $<1$ & n.a. & 14/11/2014 04:42 \\
\hline trans-1,3-Dicloropropeno & $10061-02-6$ & $\mu \mathrm{g} / \mathrm{L}$ & 1 & $<1$ & n.a. & 14/11/2014 04:42 \\
\hline Isopropilbenzeno & $98-82-8$ & $\mu \mathrm{g} / \mathrm{L}$ & 1 & $<1$ & n.a. & 14/11/2014 04:42 \\
\hline 1,3,5-Triclorobenzeno & $108-70-3$ & $\mu \mathrm{g} / \mathrm{L}$ & 1 & $<1$ & n.a. & 14/11/2014 04:42 \\
\hline
\end{tabular}

\section{CONTROLE DE QUALIDADE DO LABORATÓRIO}

302692/2014-0 - Branco de Análise - VOC - Água

\begin{tabular}{|c|c|}
\hline \multirow{2}{*}{\multicolumn{2}{|c|}{$\begin{array}{ll} & \text { Parâmetros } \\
1,1,1-\text { Tricloroetano } & \end{array}$}} \\
\hline & \\
\hline \multicolumn{2}{|l|}{ 1,1,2-Tricloroetano } \\
\hline \multicolumn{2}{|l|}{ 1,1,2,2-Tetracloroetano } \\
\hline \multicolumn{2}{|l|}{ 1,1-Dicloroetano } \\
\hline \multicolumn{2}{|l|}{ 1,1-Dicloroeteno } \\
\hline \multicolumn{2}{|l|}{ 1,1-Dicloropropeno } \\
\hline \multicolumn{2}{|l|}{ 1,2,3-Triclorobenzeno } \\
\hline \multicolumn{2}{|l|}{ 1,2,4-Triclorobenzeno } \\
\hline \multicolumn{2}{|l|}{ 1,3,5-Triclorobenzeno } \\
\hline \multicolumn{2}{|l|}{ 1,2-Dibromo-3-Cloropropano } \\
\hline \multicolumn{2}{|l|}{ 1,2-Dicloroetano } \\
\hline \multicolumn{2}{|l|}{ 1,2-Dicloropropano } \\
\hline \multicolumn{2}{|l|}{ 1,3-Dicloropropano } \\
\hline \multicolumn{2}{|l|}{ 1,4-Diclorobenzeno } \\
\hline \multicolumn{2}{|l|}{ 2,2-Dicloropropano } \\
\hline \multicolumn{2}{|l|}{ 4-Metil-2-Pentanona } \\
\hline \multicolumn{2}{|l|}{ Benzeno } \\
\hline \multicolumn{2}{|l|}{ Bromobenzeno } \\
\hline \multicolumn{2}{|l|}{ Bromodiclorometano } \\
\hline \multicolumn{2}{|l|}{ Bromofórmio } \\
\hline \multicolumn{2}{|l|}{ Cis-1,2-Dicloroeteno } \\
\hline \multicolumn{2}{|l|}{ Cis-1,3-Dicloropropeno } \\
\hline \multicolumn{2}{|l|}{ Diclorometano } \\
\hline \multicolumn{2}{|l|}{ Cloreto de Vinila } \\
\hline \multicolumn{2}{|l|}{ Clorobenzeno } \\
\hline \multicolumn{2}{|l|}{ Cloroetano } \\
\hline Clorofórmio & \\
\hline Clorometano & \\
\hline Dibromoclorometano & \\
\hline Dissulfeto de Carbono & \\
\hline Estireno & \\
\hline Etilbenzeno & \\
\hline Hexaclorobutadieno & \\
\hline m,p-Xilenos & \\
\hline o-Xileno & \\
\hline p-Isopropiltolueno & \\
\hline Tetracloreto de Carbono & \\
\hline Tetracloroeteno & \\
\hline Tolueno & \\
\hline Trans-1,2-Dicloroeteno & \\
\hline Tricloroeteno & \\
\hline Isopropilbenzeno & \\
\hline Bromoclorometano & \\
\hline
\end{tabular}

Controle de Qualidade - VOC - Água

\begin{tabular}{|c|c|c|}
\hline Unidade & LQ & Resultados analíticos \\
\hline$\mu \mathrm{g} / \mathrm{L}$ & 1 & $<1$ \\
\hline$\mu \mathrm{g} / \mathrm{L}$ & 1 & $<1$ \\
\hline$\mu \mathrm{g} / \mathrm{L}$ & 1 & $<1$ \\
\hline$\mu \mathrm{g} / \mathrm{L}$ & 1 & $<1$ \\
\hline$\mu \mathrm{g} / \mathrm{L}$ & 1 & $<1$ \\
\hline$\mu \mathrm{g} / \mathrm{L}$ & 1 & $<1$ \\
\hline$\mu \mathrm{g} / \mathrm{L}$ & 1 & $<1$ \\
\hline$\mu \mathrm{g} / \mathrm{L}$ & 1 & $<1$ \\
\hline$\mu \mathrm{g} / \mathrm{L}$ & 1 & $<1$ \\
\hline$\mu \mathrm{g} / \mathrm{L}$ & 5 & $<5$ \\
\hline$\mu \mathrm{g} / \mathrm{L}$ & 1 & $<1$ \\
\hline$\mu \mathrm{g} / \mathrm{L}$ & 1 & $<1$ \\
\hline$\mu \mathrm{g} / \mathrm{L}$ & 5 & $<5$ \\
\hline$\mu \mathrm{g} / \mathrm{L}$ & 1 & $<1$ \\
\hline$\mu \mathrm{g} / \mathrm{L}$ & 1 & $<1$ \\
\hline$\mu \mathrm{g} / \mathrm{L}$ & 5 & $<5$ \\
\hline$\mu \mathrm{g} / \mathrm{L}$ & 1 & $<1$ \\
\hline$\mu \mathrm{g} / \mathrm{L}$ & 1 & $<1$ \\
\hline$\mu \mathrm{g} / \mathrm{L}$ & 1 & $<1$ \\
\hline$\mu \mathrm{g} / \mathrm{L}$ & 1 & $<1$ \\
\hline$\mu \mathrm{g} / \mathrm{L}$ & 1 & $<1$ \\
\hline$\mu \mathrm{g} / \mathrm{L}$ & 1 & $<1$ \\
\hline$\mu \mathrm{g} / \mathrm{L}$ & 1 & $<1$ \\
\hline$\mu \mathrm{g} / \mathrm{L}$ & 1 & $<1$ \\
\hline$\mu \mathrm{g} / \mathrm{L}$ & 1 & $<1$ \\
\hline$\mu \mathrm{g} / \mathrm{L}$ & 1 & $<1$ \\
\hline$\mu \mathrm{g} / \mathrm{L}$ & 1 & $<1$ \\
\hline$\mu \mathrm{g} / \mathrm{L}$ & 10 & $<10$ \\
\hline$\mu \mathrm{g} / \mathrm{L}$ & 1 & $<1$ \\
\hline$\mu \mathrm{g} / \mathrm{L}$ & 1 & $<1$ \\
\hline$\mu \mathrm{g} / \mathrm{L}$ & 1 & $<1$ \\
\hline$\mu \mathrm{g} / \mathrm{L}$ & 1 & $<1$ \\
\hline$\mu \mathrm{g} / \mathrm{L}$ & 1 & $<1$ \\
\hline$\mu \mathrm{g} / \mathrm{L}$ & 2 & $<2$ \\
\hline$\mu \mathrm{g} / \mathrm{L}$ & 1 & $<1$ \\
\hline$\mu \mathrm{g} / \mathrm{L}$ & 1 & $<1$ \\
\hline$\mu \mathrm{g} / \mathrm{L}$ & 1 & $<1$ \\
\hline$\mu \mathrm{g} / \mathrm{L}$ & 1 & $<1$ \\
\hline$\mu \mathrm{g} / \mathrm{L}$ & 1 & $<1$ \\
\hline$\mu \mathrm{g} / \mathrm{L}$ & 1 & $<1$ \\
\hline$\mu \mathrm{g} / \mathrm{L}$ & 1 & $<1$ \\
\hline$\mu \mathrm{g} / \mathrm{L}$ & 1 & $<1$ \\
\hline$\mu \mathrm{g} / \mathrm{L}$ & 5 & $<5$ \\
\hline
\end{tabular}




\begin{tabular}{|c|c|c|c|c|}
\hline Parâmetros & $\begin{array}{l}\text { Quantidade } \\
\text { Adicionada }\end{array}$ & Unidade & $\begin{array}{c}\text { Resultado da } \\
\text { Recuperação (\%) }\end{array}$ & Faixa Aceitável de Recuperação (\%) \\
\hline \multicolumn{5}{|c|}{ 302694/2014-0 - Amostra Controle - VOC - Água } \\
\hline 1,1-Dicloroeteno & 20 & $\mu \mathrm{g} / \mathrm{L}$ & 100 & $70-130$ \\
\hline Benzeno & 20 & $\mu \mathrm{g} / \mathrm{L}$ & 125 & $70-130$ \\
\hline Tricloroeteno & 20 & $\mu \mathrm{g} / \mathrm{L}$ & 110 & $70-130$ \\
\hline Tolueno & 20 & $\mu \mathrm{g} / \mathrm{L}$ & 95 & $70-130$ \\
\hline Clorobenzeno & 20 & $\mu \mathrm{g} / \mathrm{L}$ & 105 & $70-130$ \\
\hline \multicolumn{5}{|c|}{$\begin{array}{l}\text { Surrogates } \\
\text { 302692/2014-0 - Branco de Análise - VOC - Água }\end{array}$} \\
\hline p-Bromofluorbenzeno & 20 & $\%$ & 76,5 & $70-130$ \\
\hline Dibromofluorometano & 20 & $\%$ & 130 & $70-130$ \\
\hline \multicolumn{5}{|c|}{ 302694/2014-0 - Amostra Controle - VOC - Água } \\
\hline p-Bromofluorbenzeno & 20 & $\%$ & 78,6 & $70-130$ \\
\hline Dibromofluorometano & 20 & $\%$ & 130 & $70-130$ \\
\hline \multicolumn{5}{|l|}{ 292984/2014-0 - ASI 1} \\
\hline Dibromofluorometano & 20 & $\%$ & 92,2 & $70-130$ \\
\hline p-Bromofluorbenzeno & 20 & $\%$ & 70,3 & $70-130$ \\
\hline
\end{tabular}

Notas

LQ = Limite de Quantificação

n.a. $=$ Não Aplicável.

Abrangência

$\mathrm{O}(\mathrm{s})$ resultado(s) referem-se somente à(s) amostra(s) analisada(s).

Este Relatório de Ensaio só pode ser reproduzido por inteiro e sem nenhuma alteração.

Plano de Amostragem

Plano de amostragem de responsabilidade do interessado.

Responsabilidade Técnica

Os ensaios foram realizados na unidade da Bioagri Ambiental Ltda. - Matriz, situada na Rua Aljovil Martini, 177/201, Bairro Dois Córregos, Cep. 14420-833, Piracicaba/SP, registrada no CRQ 4 Região sob no $16082-\mathrm{F}$ e responsabilidade técnica do profissional Marcos Donizete Ceccatto, CRQ n ${ }^{\circ} 04364387,4^{\mathrm{a}}$.Região.

Referências Metodológicas

Análises foram realizadas conforme a última versão do Standard Methods for the Examination of Water \& Wastewater 22nd 2012(SMWW), EPA e ABNT (quando aplicável). VOC: EPA 8260 C: 2006, 5021A: 2003

Metiletilcetona: EPA 8260 C: 2006, 5021 A: 2003

Revisores

Débora Fernandes da Silva

Luci Carla Gheleri Andrietta

Chave de Validação: 7bf9f0f2a97f70c2e58774918bcf19a5
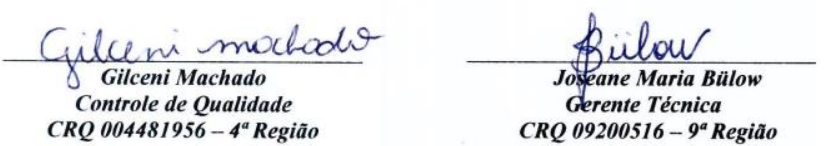


\section{RELATÓRIO DE ENSAIO N ${ }^{\circ}$ 292985/2014-0 - Piracicaba Processo Comercial $N^{\circ}$ 23961/2014-2}

\begin{tabular}{|l|l|}
\hline \multicolumn{2}{|c|}{ DADOS REFERENTES AO CLIENTE } \\
\hline Empresa solicitante: & Fundacao Parque de Alta Tecnologia da Regiao de Ipero e Adjacencias \\
\hline Endereço: & Rua Jose Antonio Scaciota, 165 - - Portal do Cedro - Iperó - SP - CEP: 18.560-000 . \\
\hline Nome do Solicitante: & Carla Marçal \\
\hline
\end{tabular}

\section{DADOS REFERENTES A AMOSTRA}

Identificação do Cliente: Amostra Rotulada como:

Coletor:

ASI 2

Água Subterrânea Projeto Mestrado

\begin{tabular}{|l|l|l|l|l|}
\hline Data da entrada no laboratório: & 04/11/2014 01:22 & Data de Elaboração do RE: & 14/11/2014
\end{tabular}

\section{RESULTADOS PARA A AMOSTRA}

\begin{tabular}{|c|c|c|c|c|c|c|}
\hline Parâmetros & CAS & Unidade & LQ & Resultados analíticos & Incerteza & Data do Ensaio \\
\hline 1,1,1-Tricloroetano & $71-55-6$ & $\mu \mathrm{g} / \mathrm{L}$ & 1 & $<1$ & n.a. & 13/11/2014 06:08 \\
\hline 1,1,2-Tricloroetano & $79-00-5$ & $\mu \mathrm{g} / \mathrm{L}$ & 1 & $<1$ & n.a. & 13/11/2014 06:08 \\
\hline 1,1,2,2-Tetracloroetano & $79-34-5$ & $\mu \mathrm{g} / \mathrm{L}$ & 1 & $<1$ & n.a. & 13/11/2014 06:08 \\
\hline 1,1-Dicloroetano & $75-34-3$ & $\mu \mathrm{g} / \mathrm{L}$ & 1 & $<1$ & n.a. & 13/11/2014 06:08 \\
\hline 1,1-Dicloroeteno & $75-35-4$ & $\mu \mathrm{g} / \mathrm{L}$ & 1 & $<1$ & n.a. & 13/11/2014 06:08 \\
\hline 1,1-Dicloropropeno & $563-58-6$ & $\mu \mathrm{g} / \mathrm{L}$ & 1 & $<1$ & n.a. & 13/11/2014 06:08 \\
\hline 1,2,3-Triclorobenzeno & $87-61-6$ & $\mu \mathrm{g} / \mathrm{L}$ & 1 & $<1$ & n.a. & 13/11/2014 06:08 \\
\hline 1,2,4-Triclorobenzeno & $120-82-1$ & $\mu \mathrm{g} / \mathrm{L}$ & 1 & $<1$ & n.a. & 13/11/2014 06:08 \\
\hline 1,2-Dibromo-3-Cloropropano & $96-12-8$ & $\mu \mathrm{g} / \mathrm{L}$ & 5 & $<5$ & n.a. & 13/11/2014 06:08 \\
\hline 1,2-Dicloroetano & $107-06-2$ & $\mu \mathrm{g} / \mathrm{L}$ & 1 & $<1$ & n.a. & 13/11/2014 06:08 \\
\hline 1,2-Dicloropropano & $78-87-5$ & $\mu \mathrm{g} / \mathrm{L}$ & 1 & $<1$ & n.a. & 13/11/2014 06:08 \\
\hline 1,3-Dicloropropano & $142-28-9$ & $\mu \mathrm{g} / \mathrm{L}$ & 5 & $<5$ & n.a. & 13/11/2014 06:08 \\
\hline 1,4-Diclorobenzeno & $106-46-7$ & $\mu \mathrm{g} / \mathrm{L}$ & 1 & $<1$ & n.a. & 13/11/2014 06:08 \\
\hline 2,2-Dicloropropano & $594-20-7$ & $\mu \mathrm{g} / \mathrm{L}$ & 1 & $<1$ & n.a. & 13/11/2014 06:08 \\
\hline 4-Metil-2-Pentanona & $108-10-1$ & $\mu \mathrm{g} / \mathrm{L}$ & 5 & $<5$ & n.a. & 13/11/2014 06:08 \\
\hline Benzeno & $71-43-2$ & $\mu \mathrm{g} / \mathrm{L}$ & 1 & $<1$ & n.a. & 13/11/2014 06:08 \\
\hline Bromobenzeno & $108-86-1$ & $\mu \mathrm{g} / \mathrm{L}$ & 1 & $<1$ & n.a. & 13/11/2014 06:08 \\
\hline Bromodiclorometano & $75-27-4$ & $\mu \mathrm{g} / \mathrm{L}$ & 1 & $<1$ & n.a. & 13/11/2014 06:08 \\
\hline Bromofórmio & $75-25-2$ & $\mu \mathrm{g} / \mathrm{L}$ & 1 & $<1$ & n.a. & 13/11/2014 06:08 \\
\hline Bromoclorometano & $74-97-5$ & $\mu \mathrm{g} / \mathrm{L}$ & 5 & $<5$ & n.a. & 13/11/2014 06:08 \\
\hline Cis-1,2-Dicloroeteno & $156-59-2$ & $\mu \mathrm{g} / \mathrm{L}$ & 1 & $<1$ & n.a. & 13/11/2014 06:08 \\
\hline Cis-1,3-Dicloropropeno & $10061-01-5$ & $\mu \mathrm{g} / \mathrm{L}$ & 1 & $<1$ & n.a. & 13/11/2014 06:08 \\
\hline Diclorometano & $75-09-2$ & $\mu \mathrm{g} / \mathrm{L}$ & 1 & $<1$ & n.a. & 13/11/2014 06:08 \\
\hline Cloreto de Vinila & 75-01-4 & $\mu \mathrm{g} / \mathrm{L}$ & 1 & $<1$ & n.a. & 13/11/2014 06:08 \\
\hline Clorobenzeno & $108-90-7$ & $\mu \mathrm{g} / \mathrm{L}$ & 1 & $<1$ & n.a. & 13/11/2014 06:08 \\
\hline Cloroetano & $75-00-3$ & $\mu \mathrm{g} / \mathrm{L}$ & 1 & $<1$ & n.a. & 13/11/2014 06:08 \\
\hline Clorofórmio & $67-66-3$ & $\mu \mathrm{g} / \mathrm{L}$ & 1 & $<1$ & n.a. & 13/11/2014 06:08 \\
\hline Clorometano & $74-87-3$ & $\mu \mathrm{g} / \mathrm{L}$ & 10 & $<10$ & n.a. & 13/11/2014 06:08 \\
\hline Dibromoclorometano & $124-48-1$ & $\mu \mathrm{g} / \mathrm{L}$ & 1 & $<1$ & n.a. & 13/11/2014 06:08 \\
\hline Dissulfeto de Carbono & $75-15-0$ & $\mu \mathrm{g} / \mathrm{L}$ & 1 & $<1$ & n.a. & 13/11/2014 06:08 \\
\hline Estireno & $100-42-5$ & $\mu \mathrm{g} / \mathrm{L}$ & 1 & $<1$ & n.a. & 13/11/2014 06:08 \\
\hline Etilbenzeno & $100-41-4$ & $\mu \mathrm{g} / \mathrm{L}$ & 1 & $<1$ & n.a. & 13/11/2014 06:08 \\
\hline Hexaclorobutadieno & $87-68-3$ & $\mu \mathrm{g} / \mathrm{L}$ & 1 & $<1$ & n.a. & 13/11/2014 06:08 \\
\hline m,p-Xilenos & --- & $\mu \mathrm{g} / \mathrm{L}$ & 2 & $<2$ & n.a. & 13/11/2014 06:08 \\
\hline o-Xileno & $95-47-6$ & $\mu \mathrm{g} / \mathrm{L}$ & 1 & $<1$ & n.a. & 13/11/2014 06:08 \\
\hline p-Isopropiltolueno & $99-87-6$ & $\mu \mathrm{g} / \mathrm{L}$ & 1 & $<1$ & n.a. & 13/11/2014 06:08 \\
\hline Tetracloreto de Carbono & $56-23-5$ & $\mu \mathrm{g} / \mathrm{L}$ & 1 & $<1$ & n.a. & 13/11/2014 06:08 \\
\hline Tetracloroeteno & $127-18-4$ & $\mu \mathrm{g} / \mathrm{L}$ & 10 & 106 & 20 & 13/11/2014 06:08 \\
\hline Tolueno & $108-88-3$ & $\mu \mathrm{g} / \mathrm{L}$ & 1 & $<1$ & n.a. & 13/11/2014 06:08 \\
\hline Trans-1,2-Dicloroeteno & $156-60-5$ & $\mu \mathrm{g} / \mathrm{L}$ & 1 & $<1$ & n.a. & 13/11/2014 06:08 \\
\hline Tricloroeteno & $79-01-6$ & $\mu \mathrm{g} / \mathrm{L}$ & 1 & $<1$ & n.a. & 13/11/2014 06:08 \\
\hline 1,1,1,2-Tetracloroetano & $630-20-6$ & $\mu \mathrm{g} / \mathrm{L}$ & 1 & $<1$ & n.a. & 13/11/2014 06:08 \\
\hline
\end{tabular}




\begin{tabular}{|c|c|c|c|c|c|c|}
\hline Parâmetros & CAS & Unidade & LQ & Resultados analíticos & Incerteza & Data do Ensaio \\
\hline 1,2,3-Tricloropropano & $96-18-4$ & $\mu \mathrm{g} / \mathrm{L}$ & 5 & $<5$ & n.a. & 13/11/2014 06:08 \\
\hline 1,3,5-Trimetilbenzeno & $108-67-8$ & $\mu \mathrm{g} / \mathrm{L}$ & 1 & $<1$ & n.a. & 13/11/2014 06:08 \\
\hline 1,2,4-Trimetilbenzeno & $95-63-6$ & $\mu \mathrm{g} / \mathrm{L}$ & 1 & $<1$ & n.a. & 13/11/2014 06:08 \\
\hline 1,2-Dibromoetano & $106-93-4$ & $\mu \mathrm{g} / \mathrm{L}$ & 1 & $<1$ & n.a. & 13/11/2014 06:08 \\
\hline 1,2-Diclorobenzeno & $95-50-1$ & $\mu \mathrm{g} / \mathrm{L}$ & 1 & $<1$ & n.a. & 13/11/2014 06:08 \\
\hline 1,3-Diclorobenzeno & $541-73-1$ & $\mu \mathrm{g} / \mathrm{L}$ & 1 & $<1$ & n.a. & 13/11/2014 06:08 \\
\hline 2-Clorotolueno & $95-49-8$ & $\mu \mathrm{g} / \mathrm{L}$ & 1 & $<1$ & n.a. & 13/11/2014 06:08 \\
\hline Dibromometano & $74-95-3$ & $\mu \mathrm{g} / \mathrm{L}$ & 1 & $<1$ & n.a. & 13/11/2014 06:08 \\
\hline Metiletilcetona & $78-93-3$ & $\mu \mathrm{g} / \mathrm{L}$ & 2500 & $<2500$ & n.a. & 13/11/2014 06:33 \\
\hline Naftaleno & $91-20-3$ & $\mu \mathrm{g} / \mathrm{L}$ & 1 & $<1$ & n.a. & 13/11/2014 06:08 \\
\hline n-Butilbenzeno & $104-51-8$ & $\mu \mathrm{g} / \mathrm{L}$ & 1 & $<1$ & n.a. & 13/11/2014 06:08 \\
\hline n-Propilbenzeno & $103-65-1$ & $\mu \mathrm{g} / \mathrm{L}$ & 1 & $<1$ & n.a. & 13/11/2014 06:08 \\
\hline 4-Clorotolueno & $106-43-4$ & $\mu \mathrm{g} / \mathrm{L}$ & 1 & $<1$ & n.a. & 13/11/2014 06:08 \\
\hline sec-Butilbenzeno & $135-98-8$ & $\mu \mathrm{g} / \mathrm{L}$ & 1 & $<1$ & n.a. & 13/11/2014 06:08 \\
\hline terc-Butilbenzeno & $98-06-6$ & $\mu \mathrm{g} / \mathrm{L}$ & 1 & $<1$ & n.a. & 13/11/2014 06:08 \\
\hline trans-1,3-Dicloropropeno & $10061-02-6$ & $\mu \mathrm{g} / \mathrm{L}$ & 1 & $<1$ & n.a. & 13/11/2014 06:08 \\
\hline Isopropilbenzeno & $98-82-8$ & $\mu \mathrm{g} / \mathrm{L}$ & 1 & $<1$ & n.a. & 13/11/2014 06:08 \\
\hline 1,3,5-Triclorobenzeno & $108-70-3$ & $\mu \mathrm{g} / \mathrm{L}$ & 1 & $<1$ & n.a. & 13/11/2014 06:08 \\
\hline
\end{tabular}

\section{CONTROLE DE QUALIDADE DO LABORATÓRIO}

302692/2014-0 - Branco de Análise - VOC - Água

\begin{tabular}{|c|c|}
\hline \multirow{2}{*}{\multicolumn{2}{|c|}{$\begin{array}{ll} & \text { Parâmetros } \\
1,1,1-\text { Tricloroetano } & \end{array}$}} \\
\hline & \\
\hline \multicolumn{2}{|l|}{ 1,1,2-Tricloroetano } \\
\hline \multicolumn{2}{|l|}{ 1,1,2,2-Tetracloroetano } \\
\hline \multicolumn{2}{|l|}{ 1,1-Dicloroetano } \\
\hline \multicolumn{2}{|l|}{ 1,1-Dicloroeteno } \\
\hline \multicolumn{2}{|l|}{ 1,1-Dicloropropeno } \\
\hline \multicolumn{2}{|l|}{ 1,2,3-Triclorobenzeno } \\
\hline \multicolumn{2}{|l|}{ 1,2,4-Triclorobenzeno } \\
\hline \multicolumn{2}{|l|}{ 1,3,5-Triclorobenzeno } \\
\hline \multicolumn{2}{|l|}{ 1,2-Dibromo-3-Cloropropano } \\
\hline \multicolumn{2}{|l|}{ 1,2-Dicloroetano } \\
\hline \multicolumn{2}{|l|}{ 1,2-Dicloropropano } \\
\hline \multicolumn{2}{|l|}{ 1,3-Dicloropropano } \\
\hline \multicolumn{2}{|l|}{ 1,4-Diclorobenzeno } \\
\hline \multicolumn{2}{|l|}{ 2,2-Dicloropropano } \\
\hline \multicolumn{2}{|l|}{ 4-Metil-2-Pentanona } \\
\hline \multicolumn{2}{|l|}{ Benzeno } \\
\hline \multicolumn{2}{|l|}{ Bromobenzeno } \\
\hline \multicolumn{2}{|l|}{ Bromodiclorometano } \\
\hline \multicolumn{2}{|l|}{ Bromofórmio } \\
\hline \multicolumn{2}{|l|}{ Cis-1,2-Dicloroeteno } \\
\hline \multicolumn{2}{|l|}{ Cis-1,3-Dicloropropeno } \\
\hline \multicolumn{2}{|l|}{ Diclorometano } \\
\hline \multicolumn{2}{|l|}{ Cloreto de Vinila } \\
\hline \multicolumn{2}{|l|}{ Clorobenzeno } \\
\hline \multicolumn{2}{|l|}{ Cloroetano } \\
\hline Clorofórmio & \\
\hline Clorometano & \\
\hline Dibromoclorometano & \\
\hline Dissulfeto de Carbono & \\
\hline Estireno & \\
\hline Etilbenzeno & \\
\hline Hexaclorobutadieno & \\
\hline m,p-Xilenos & \\
\hline o-Xileno & \\
\hline p-Isopropiltolueno & \\
\hline Tetracloreto de Carbono & \\
\hline Tetracloroeteno & \\
\hline Tolueno & \\
\hline Trans-1,2-Dicloroeteno & \\
\hline Tricloroeteno & \\
\hline Isopropilbenzeno & \\
\hline Bromoclorometano & \\
\hline
\end{tabular}

Controle de Qualidade - VOC - Água

\begin{tabular}{|c|c|c|}
\hline Unidade & LQ & Resultados analíticos \\
\hline$\mu \mathrm{g} / \mathrm{L}$ & 1 & $<1$ \\
\hline$\mu \mathrm{g} / \mathrm{L}$ & 1 & $<1$ \\
\hline$\mu \mathrm{g} / \mathrm{L}$ & 1 & $<1$ \\
\hline$\mu \mathrm{g} / \mathrm{L}$ & 1 & $<1$ \\
\hline$\mu g / L$ & 1 & $<1$ \\
\hline$\mu \mathrm{g} / \mathrm{L}$ & 1 & $<1$ \\
\hline$\mu \mathrm{g} / \mathrm{L}$ & 1 & $<1$ \\
\hline$\mu \mathrm{g} / \mathrm{L}$ & 1 & $<1$ \\
\hline$\mu \mathrm{g} / \mathrm{L}$ & 1 & $<1$ \\
\hline$\mu \mathrm{g} / \mathrm{L}$ & 5 & $<5$ \\
\hline$\mu \mathrm{g} / \mathrm{L}$ & 1 & $<1$ \\
\hline$\mu \mathrm{g} / \mathrm{L}$ & 1 & $<1$ \\
\hline$\mu \mathrm{g} / \mathrm{L}$ & 5 & $<5$ \\
\hline$\mu \mathrm{g} / \mathrm{L}$ & 1 & $<1$ \\
\hline$\mu \mathrm{g} / \mathrm{L}$ & 1 & $<1$ \\
\hline$\mu \mathrm{g} / \mathrm{L}$ & 5 & $<5$ \\
\hline$\mu \mathrm{g} / \mathrm{L}$ & 1 & $<1$ \\
\hline$\mu \mathrm{g} / \mathrm{L}$ & 1 & $<1$ \\
\hline$\mu \mathrm{g} / \mathrm{L}$ & 1 & $<1$ \\
\hline$\mu \mathrm{g} / \mathrm{L}$ & 1 & $<1$ \\
\hline$\mu \mathrm{g} / \mathrm{L}$ & 1 & $<1$ \\
\hline$\mu \mathrm{g} / \mathrm{L}$ & 1 & $<1$ \\
\hline$\mu \mathrm{g} / \mathrm{L}$ & 1 & $<1$ \\
\hline$\mu \mathrm{g} / \mathrm{L}$ & 1 & $<1$ \\
\hline$\mu \mathrm{g} / \mathrm{L}$ & 1 & $<1$ \\
\hline$\mu \mathrm{g} / \mathrm{L}$ & 1 & $<1$ \\
\hline$\mu \mathrm{g} / \mathrm{L}$ & 1 & $<1$ \\
\hline$\mu \mathrm{g} / \mathrm{L}$ & 10 & $<10$ \\
\hline$\mu \mathrm{g} / \mathrm{L}$ & 1 & $<1$ \\
\hline$\mu \mathrm{g} / \mathrm{L}$ & 1 & $<1$ \\
\hline$\mu \mathrm{g} / \mathrm{L}$ & 1 & $<1$ \\
\hline$\mu \mathrm{g} / \mathrm{L}$ & 1 & $<1$ \\
\hline$\mu \mathrm{g} / \mathrm{L}$ & 1 & $<1$ \\
\hline$\mu \mathrm{g} / \mathrm{L}$ & 2 & $<2$ \\
\hline$\mu \mathrm{g} / \mathrm{L}$ & 1 & $<1$ \\
\hline$\mu \mathrm{g} / \mathrm{L}$ & 1 & $<1$ \\
\hline$\mu \mathrm{g} / \mathrm{L}$ & 1 & $<1$ \\
\hline$\mu \mathrm{g} / \mathrm{L}$ & 1 & $<1$ \\
\hline$\mu \mathrm{g} / \mathrm{L}$ & 1 & $<1$ \\
\hline$\mu \mathrm{g} / \mathrm{L}$ & 1 & $<1$ \\
\hline$\mu \mathrm{g} / \mathrm{L}$ & 1 & $<1$ \\
\hline$\mu \mathrm{g} / \mathrm{L}$ & 1 & $<1$ \\
\hline$\mu \mathrm{g} / \mathrm{L}$ & 5 & $<5$ \\
\hline
\end{tabular}




\begin{tabular}{|c|c|c|c|c|}
\hline Parâmetros & $\begin{array}{l}\text { Quantidade } \\
\text { Adicionada }\end{array}$ & Unidade & $\begin{array}{c}\text { Resultado da } \\
\text { Recuperação (\%) }\end{array}$ & Faixa Aceitável de Recuperação (\%) \\
\hline \multicolumn{5}{|c|}{ 302694/2014-0 - Amostra Controle - VOC - Água } \\
\hline 1,1-Dicloroeteno & 20 & $\mu \mathrm{g} / \mathrm{L}$ & 100 & $70-130$ \\
\hline Benzeno & 20 & $\mu \mathrm{g} / \mathrm{L}$ & 125 & $70-130$ \\
\hline Tricloroeteno & 20 & $\mu \mathrm{g} / \mathrm{L}$ & 110 & $70-130$ \\
\hline Tolueno & 20 & $\mu \mathrm{g} / \mathrm{L}$ & 95 & $70-130$ \\
\hline Clorobenzeno & 20 & $\mu \mathrm{g} / \mathrm{L}$ & 105 & $70-130$ \\
\hline \multicolumn{5}{|c|}{$\begin{array}{l}\text { Surrogates } \\
\text { 302692/2014-0 - Branco de Análise - VOC - Água }\end{array}$} \\
\hline p-Bromofluorbenzeno & 20 & $\%$ & 76,5 & $70-130$ \\
\hline Dibromofluorometano & 20 & $\%$ & 130 & $70-130$ \\
\hline \multicolumn{5}{|c|}{ 302694/2014-0 - Amostra Controle - VOC - Água } \\
\hline p-Bromofluorbenzeno & 20 & $\%$ & 78,6 & $70-130$ \\
\hline Dibromofluorometano & 20 & $\%$ & 130 & $70-130$ \\
\hline \multicolumn{5}{|l|}{ 292985/2014-0 - ASI 2} \\
\hline Dibromofluorometano & 20 & $\%$ & 95,7 & $70-130$ \\
\hline p-Bromofluorbenzeno & 20 & $\%$ & 71,4 & $70-130$ \\
\hline
\end{tabular}

Notas

LQ = Limite de Quantificação

n.a. $=$ Não Aplicável.

Abrangência

$\mathrm{O}(\mathrm{s})$ resultado(s) referem-se somente à(s) amostra(s) analisada(s).

Este Relatório de Ensaio só pode ser reproduzido por inteiro e sem nenhuma alteração.

Plano de Amostragem

Plano de amostragem de responsabilidade do interessado.

Responsabilidade Técnica

Os ensaios foram realizados na unidade da Bioagri Ambiental Ltda. - Matriz, situada na Rua Aljovil Martini, 177/201, Bairro Dois Córregos, Cep. 14420-833, Piracicaba/SP, registrada no CRQ 4 Região sob no $16082-\mathrm{F}$ e responsabilidade técnica do profissional Marcos Donizete Ceccatto, CRQ n ${ }^{\circ} 04364387,4^{\mathrm{a}}$.Região.

Referências Metodológicas

Análises foram realizadas conforme a última versão do Standard Methods for the Examination of Water \& Wastewater 22nd 2012(SMWW), EPA e ABNT (quando aplicável). VOC: EPA 8260 C: 2006, 5021A: 2003

Metiletilcetona: EPA 8260 C: 2006, 5021 A: 2003

Revisores

Débora Fernandes da Silva

Renato Augusto Duarte Gava

Chave de Validação: d76cff53a63088f17b037c759ed66ebf
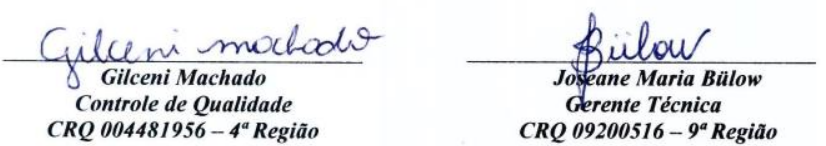


\section{RELATÓRIO DE ENSAIO N $^{\circ}$ 292986/2014-0 - Piracicaba} Processo Comercial $N^{\circ}$ 23961/2014-2

\begin{tabular}{|l|l|}
\hline \multicolumn{2}{|c|}{ DADOS REFERENTES AO CLIENTE } \\
\hline Empresa solicitante: & Fundacao Parque de Alta Tecnologia da Regiao de Ipero e Adjacencias \\
\hline Endereço: & Rua Jose Antonio Scaciota, 165 - - Portal do Cedro - Iperó - SP - CEP: 18.560-000 . \\
\hline Nome do Solicitante: & Carla Marçal \\
\hline
\end{tabular}

\section{DADOS REFERENTES A AMOSTRA}

Identificação do Cliente: Amostra Rotulada como:

Coletor:

ASI 3

Água Subterrânea Projeto Mestrado

\begin{tabular}{|l|l|l|l|l|l|l|l|}
\hline Data da entrada no laboratório: & 04/11/2014 01:22 & Data de Elaboração do RE: & 14/11/2014
\end{tabular}

\section{RESULTADOS PARA A AMOSTRA}

\begin{tabular}{|c|c|c|c|c|c|c|}
\hline Parâmetros & CAS & Unidade & LQ & Resultados analíticos & Incerteza & Data do Ensaio \\
\hline 1,1,1-Tricloroetano & $71-55-6$ & $\mu \mathrm{g} / \mathrm{L}$ & 1 & $<1$ & n.a. & 13/11/2014 06:57 \\
\hline 1,1,2-Tricloroetano & $79-00-5$ & $\mu \mathrm{g} / \mathrm{L}$ & 1 & $<1$ & n.a. & 13/11/2014 06:57 \\
\hline 1,1,2,2-Tetracloroetano & $79-34-5$ & $\mu \mathrm{g} / \mathrm{L}$ & 1 & $<1$ & n.a. & 13/11/2014 06:57 \\
\hline 1,1-Dicloroetano & $75-34-3$ & $\mu \mathrm{g} / \mathrm{L}$ & 1 & $<1$ & n.a. & 13/11/2014 06:57 \\
\hline 1,1-Dicloroeteno & $75-35-4$ & $\mu \mathrm{g} / \mathrm{L}$ & 1 & $<1$ & n.a. & 13/11/2014 06:57 \\
\hline 1,1-Dicloropropeno & $563-58-6$ & $\mu \mathrm{g} / \mathrm{L}$ & 1 & $<1$ & n.a. & 13/11/2014 06:57 \\
\hline 1,2,3-Triclorobenzeno & $87-61-6$ & $\mu \mathrm{g} / \mathrm{L}$ & 1 & $<1$ & n.a. & 13/11/2014 06:57 \\
\hline 1,2,4-Triclorobenzeno & $120-82-1$ & $\mu \mathrm{g} / \mathrm{L}$ & 1 & $<1$ & n.a. & 13/11/2014 06:57 \\
\hline 1,2-Dibromo-3-Cloropropano & $96-12-8$ & $\mu \mathrm{g} / \mathrm{L}$ & 5 & $<5$ & n.a. & 13/11/2014 06:57 \\
\hline 1,2-Dicloroetano & $107-06-2$ & $\mu \mathrm{g} / \mathrm{L}$ & 1 & $<1$ & n.a. & 13/11/2014 06:57 \\
\hline 1,2-Dicloropropano & $78-87-5$ & $\mu \mathrm{g} / \mathrm{L}$ & 1 & $<1$ & n.a. & 13/11/2014 06:57 \\
\hline 1,3-Dicloropropano & $142-28-9$ & $\mu \mathrm{g} / \mathrm{L}$ & 5 & $<5$ & n.a. & 13/11/2014 06:57 \\
\hline 1,4-Diclorobenzeno & $106-46-7$ & $\mu \mathrm{g} / \mathrm{L}$ & 1 & $<1$ & n.a. & 13/11/2014 06:57 \\
\hline 2,2-Dicloropropano & $594-20-7$ & $\mu \mathrm{g} / \mathrm{L}$ & 1 & $<1$ & n.a. & 13/11/2014 06:57 \\
\hline 4-Metil-2-Pentanona & $108-10-1$ & $\mu \mathrm{g} / \mathrm{L}$ & 5 & $<5$ & n.a. & 13/11/2014 06:57 \\
\hline Benzeno & $71-43-2$ & $\mu \mathrm{g} / \mathrm{L}$ & 1 & $<1$ & n.a. & 13/11/2014 06:57 \\
\hline Bromobenzeno & $108-86-1$ & $\mu \mathrm{g} / \mathrm{L}$ & 1 & $<1$ & n.a. & 13/11/2014 06:57 \\
\hline Bromodiclorometano & $75-27-4$ & $\mu \mathrm{g} / \mathrm{L}$ & 1 & $<1$ & n.a. & 13/11/2014 06:57 \\
\hline Bromofórmio & $75-25-2$ & $\mu \mathrm{g} / \mathrm{L}$ & 1 & $<1$ & n.a. & 13/11/2014 06:57 \\
\hline Bromoclorometano & $74-97-5$ & $\mu \mathrm{g} / \mathrm{L}$ & 5 & $<5$ & n.a. & 13/11/2014 06:57 \\
\hline Cis-1,2-Dicloroeteno & $156-59-2$ & $\mu \mathrm{g} / \mathrm{L}$ & 1 & $<1$ & n.a. & 13/11/2014 06:57 \\
\hline Cis-1,3-Dicloropropeno & $10061-01-5$ & $\mu \mathrm{g} / \mathrm{L}$ & 1 & $<1$ & n.a. & 13/11/2014 06:57 \\
\hline Diclorometano & $75-09-2$ & $\mu \mathrm{g} / \mathrm{L}$ & 1 & $<1$ & n.a. & 13/11/2014 06:57 \\
\hline Cloreto de Vinila & $75-01-4$ & $\mu \mathrm{g} / \mathrm{L}$ & 1 & $<1$ & n.a. & 13/11/2014 06:57 \\
\hline Clorobenzeno & $108-90-7$ & $\mu \mathrm{g} / \mathrm{L}$ & 1 & $<1$ & n.a. & 13/11/2014 06:57 \\
\hline Cloroetano & $75-00-3$ & $\mu \mathrm{g} / \mathrm{L}$ & 1 & $<1$ & n.a. & 13/11/2014 06:57 \\
\hline Clorofórmio & $67-66-3$ & $\mu \mathrm{g} / \mathrm{L}$ & 1 & $<1$ & n.a. & 13/11/2014 06:57 \\
\hline Clorometano & $74-87-3$ & $\mu \mathrm{g} / \mathrm{L}$ & 10 & $<10$ & n.a. & 13/11/2014 06:57 \\
\hline Dibromoclorometano & $124-48-1$ & $\mu \mathrm{g} / \mathrm{L}$ & 1 & $<1$ & n.a. & 13/11/2014 06:57 \\
\hline Dissulfeto de Carbono & $75-15-0$ & $\mu \mathrm{g} / \mathrm{L}$ & 1 & $<1$ & n.a. & 13/11/2014 06:57 \\
\hline Estireno & $100-42-5$ & $\mu \mathrm{g} / \mathrm{L}$ & 1 & $<1$ & n.a. & 13/11/2014 06:57 \\
\hline Etilbenzeno & $100-41-4$ & $\mu \mathrm{g} / \mathrm{L}$ & 1 & $<1$ & n.a. & 13/11/2014 06:57 \\
\hline Hexaclorobutadieno & $87-68-3$ & $\mu \mathrm{g} / \mathrm{L}$ & 1 & $<1$ & n.a. & 13/11/2014 06:57 \\
\hline m,p-Xilenos & --- & $\mu \mathrm{g} / \mathrm{L}$ & 2 & $<2$ & n.a. & 13/11/2014 06:57 \\
\hline o-Xileno & $95-47-6$ & $\mu \mathrm{g} / \mathrm{L}$ & 1 & $<1$ & n.a. & 13/11/2014 06:57 \\
\hline p-Isopropiltolueno & $99-87-6$ & $\mu \mathrm{g} / \mathrm{L}$ & 1 & $<1$ & n.a. & 13/11/2014 06:57 \\
\hline Tetracloreto de Carbono & $56-23-5$ & $\mu \mathrm{g} / \mathrm{L}$ & 1 & $<1$ & n.a. & 13/11/2014 06:57 \\
\hline Tetracloroeteno & $127-18-4$ & $\mu \mathrm{g} / \mathrm{L}$ & 10 & 106 & 20 & 13/11/2014 06:57 \\
\hline Tolueno & $108-88-3$ & $\mu \mathrm{g} / \mathrm{L}$ & 1 & $<1$ & n.a. & 13/11/2014 06:57 \\
\hline Trans-1,2-Dicloroeteno & $156-60-5$ & $\mu \mathrm{g} / \mathrm{L}$ & 1 & $<1$ & n.a. & 13/11/2014 06:57 \\
\hline Tricloroeteno & $79-01-6$ & $\mu \mathrm{g} / \mathrm{L}$ & 1 & $<1$ & n.a. & 13/11/2014 06:57 \\
\hline 1,1,1,2-Tetracloroetano & $630-20-6$ & $\mu \mathrm{g} / \mathrm{L}$ & 1 & $<1$ & n.a. & 13/11/2014 06:57 \\
\hline
\end{tabular}




\begin{tabular}{|c|c|c|c|c|c|c|}
\hline Parâmetros & CAS & Unidade & LQ & Resultados analíticos & Incerteza & Data do Ensaio \\
\hline 1,2,3-Tricloropropano & $96-18-4$ & $\mu \mathrm{g} / \mathrm{L}$ & 5 & $<5$ & n.a. & 13/11/2014 06:57 \\
\hline 1,3,5-Trimetilbenzeno & $108-67-8$ & $\mu \mathrm{g} / \mathrm{L}$ & 1 & $<1$ & n.a. & $13 / 11 / 201406: 57$ \\
\hline 1,2,4-Trimetilbenzeno & $95-63-6$ & $\mu \mathrm{g} / \mathrm{L}$ & 1 & $<1$ & n.a. & 13/11/2014 06:57 \\
\hline 1,2-Dibromoetano & $106-93-4$ & $\mu \mathrm{g} / \mathrm{L}$ & 1 & $<1$ & n.a. & $13 / 11 / 201406: 57$ \\
\hline 1,2-Diclorobenzeno & $95-50-1$ & $\mu \mathrm{g} / \mathrm{L}$ & 1 & $<1$ & n.a. & 13/11/2014 06:57 \\
\hline 1,3-Diclorobenzeno & $541-73-1$ & $\mu \mathrm{g} / \mathrm{L}$ & 1 & $<1$ & n.a. & 13/11/2014 06:57 \\
\hline 2-Clorotolueno & $95-49-8$ & $\mu \mathrm{g} / \mathrm{L}$ & 1 & $<1$ & n.a. & 13/11/2014 06:57 \\
\hline Dibromometano & $74-95-3$ & $\mu \mathrm{g} / \mathrm{L}$ & 1 & $<1$ & n.a. & 13/11/2014 06:57 \\
\hline Metiletilcetona & $78-93-3$ & $\mu \mathrm{g} / \mathrm{L}$ & 2500 & $<2500$ & n.a. & 13/11/2014 07:22 \\
\hline Naftaleno & $91-20-3$ & $\mu \mathrm{g} / \mathrm{L}$ & 1 & $<1$ & n.a. & 13/11/2014 06:57 \\
\hline n-Butilbenzeno & $104-51-8$ & $\mu \mathrm{g} / \mathrm{L}$ & 1 & $<1$ & n.a. & 13/11/2014 06:57 \\
\hline n-Propilbenzeno & $103-65-1$ & $\mu \mathrm{g} / \mathrm{L}$ & 1 & $<1$ & n.a. & 13/11/2014 06:57 \\
\hline 4-Clorotolueno & $106-43-4$ & $\mu \mathrm{g} / \mathrm{L}$ & 1 & $<1$ & n.a. & 13/11/2014 06:57 \\
\hline sec-Butilbenzeno & $135-98-8$ & $\mu \mathrm{g} / \mathrm{L}$ & 1 & $<1$ & n.a. & 13/11/2014 06:57 \\
\hline terc-Butilbenzeno & $98-06-6$ & $\mu \mathrm{g} / \mathrm{L}$ & 1 & $<1$ & n.a. & 13/11/2014 06:57 \\
\hline trans-1,3-Dicloropropeno & 10061-02-6 & $\mu \mathrm{g} / \mathrm{L}$ & 1 & $<1$ & n.a. & 13/11/2014 06:57 \\
\hline Isopropilbenzeno & $98-82-8$ & $\mu \mathrm{g} / \mathrm{L}$ & 1 & $<1$ & n.a. & 13/11/2014 06:57 \\
\hline 1,3,5-Triclorobenzeno & $108-70-3$ & $\mu \mathrm{g} / \mathrm{L}$ & 1 & $<1$ & n.a. & 13/11/2014 06:57 \\
\hline
\end{tabular}

\section{CONTROLE DE QUALIDADE DO LABORATÓRIO}

302692/2014-0 - Branco de Análise - VOC - Água

\begin{tabular}{|c|c|}
\hline \multirow{2}{*}{\multicolumn{2}{|c|}{$\begin{array}{ll} & \text { Parâmetros } \\
1,1,1-\text { Tricloroetano } & \end{array}$}} \\
\hline & \\
\hline \multicolumn{2}{|l|}{ 1,1,2-Tricloroetano } \\
\hline \multicolumn{2}{|l|}{ 1,1,2,2-Tetracloroetano } \\
\hline \multicolumn{2}{|l|}{ 1,1-Dicloroetano } \\
\hline \multicolumn{2}{|l|}{ 1,1-Dicloroeteno } \\
\hline \multicolumn{2}{|l|}{ 1,1-Dicloropropeno } \\
\hline \multicolumn{2}{|l|}{ 1,2,3-Triclorobenzeno } \\
\hline \multicolumn{2}{|l|}{ 1,2,4-Triclorobenzeno } \\
\hline \multicolumn{2}{|l|}{ 1,3,5-Triclorobenzeno } \\
\hline \multicolumn{2}{|l|}{ 1,2-Dibromo-3-Cloropropano } \\
\hline \multicolumn{2}{|l|}{ 1,2-Dicloroetano } \\
\hline \multicolumn{2}{|l|}{ 1,2-Dicloropropano } \\
\hline \multicolumn{2}{|l|}{ 1,3-Dicloropropano } \\
\hline \multicolumn{2}{|l|}{ 1,4-Diclorobenzeno } \\
\hline \multicolumn{2}{|l|}{ 2,2-Dicloropropano } \\
\hline \multicolumn{2}{|l|}{ 4-Metil-2-Pentanona } \\
\hline \multicolumn{2}{|l|}{ Benzeno } \\
\hline \multicolumn{2}{|l|}{ Bromobenzeno } \\
\hline \multicolumn{2}{|l|}{ Bromodiclorometano } \\
\hline \multicolumn{2}{|l|}{ Bromofórmio } \\
\hline \multicolumn{2}{|l|}{ Cis-1,2-Dicloroeteno } \\
\hline \multicolumn{2}{|l|}{ Cis-1,3-Dicloropropeno } \\
\hline \multicolumn{2}{|l|}{ Diclorometano } \\
\hline \multicolumn{2}{|l|}{ Cloreto de Vinila } \\
\hline \multicolumn{2}{|l|}{ Clorobenzeno } \\
\hline \multicolumn{2}{|l|}{ Cloroetano } \\
\hline Clorofórmio & \\
\hline Clorometano & \\
\hline Dibromoclorometano & \\
\hline Dissulfeto de Carbono & \\
\hline Estireno & \\
\hline Etilbenzeno & \\
\hline Hexaclorobutadieno & \\
\hline m,p-Xilenos & \\
\hline o-Xileno & \\
\hline p-Isopropiltolueno & \\
\hline Tetracloreto de Carbono & \\
\hline Tetracloroeteno & \\
\hline Tolueno & \\
\hline Trans-1,2-Dicloroeteno & \\
\hline Tricloroeteno & \\
\hline Isopropilbenzeno & \\
\hline Bromoclorometano & \\
\hline
\end{tabular}

Controle de Qualidade - VOC - Água

\begin{tabular}{|c|c|c|}
\hline Unidade & LQ & Resultados analíticos \\
\hline$\mu \mathrm{g} / \mathrm{L}$ & 1 & $<1$ \\
\hline$\mu \mathrm{g} / \mathrm{L}$ & 1 & $<1$ \\
\hline$\mu \mathrm{g} / \mathrm{L}$ & 1 & $<1$ \\
\hline$\mu \mathrm{g} / \mathrm{L}$ & 1 & $<1$ \\
\hline$\mu g / L$ & 1 & $<1$ \\
\hline$\mu \mathrm{g} / \mathrm{L}$ & 1 & $<1$ \\
\hline$\mu \mathrm{g} / \mathrm{L}$ & 1 & $<1$ \\
\hline$\mu \mathrm{g} / \mathrm{L}$ & 1 & $<1$ \\
\hline$\mu \mathrm{g} / \mathrm{L}$ & 1 & $<1$ \\
\hline$\mu \mathrm{g} / \mathrm{L}$ & 5 & $<5$ \\
\hline$\mu \mathrm{g} / \mathrm{L}$ & 1 & $<1$ \\
\hline$\mu \mathrm{g} / \mathrm{L}$ & 1 & $<1$ \\
\hline$\mu \mathrm{g} / \mathrm{L}$ & 5 & $<5$ \\
\hline$\mu \mathrm{g} / \mathrm{L}$ & 1 & $<1$ \\
\hline$\mu \mathrm{g} / \mathrm{L}$ & 1 & $<1$ \\
\hline$\mu \mathrm{g} / \mathrm{L}$ & 5 & $<5$ \\
\hline$\mu \mathrm{g} / \mathrm{L}$ & 1 & $<1$ \\
\hline$\mu \mathrm{g} / \mathrm{L}$ & 1 & $<1$ \\
\hline$\mu \mathrm{g} / \mathrm{L}$ & 1 & $<1$ \\
\hline$\mu \mathrm{g} / \mathrm{L}$ & 1 & $<1$ \\
\hline$\mu \mathrm{g} / \mathrm{L}$ & 1 & $<1$ \\
\hline$\mu \mathrm{g} / \mathrm{L}$ & 1 & $<1$ \\
\hline$\mu \mathrm{g} / \mathrm{L}$ & 1 & $<1$ \\
\hline$\mu \mathrm{g} / \mathrm{L}$ & 1 & $<1$ \\
\hline$\mu \mathrm{g} / \mathrm{L}$ & 1 & $<1$ \\
\hline$\mu \mathrm{g} / \mathrm{L}$ & 1 & $<1$ \\
\hline$\mu \mathrm{g} / \mathrm{L}$ & 1 & $<1$ \\
\hline$\mu \mathrm{g} / \mathrm{L}$ & 10 & $<10$ \\
\hline$\mu \mathrm{g} / \mathrm{L}$ & 1 & $<1$ \\
\hline$\mu \mathrm{g} / \mathrm{L}$ & 1 & $<1$ \\
\hline$\mu \mathrm{g} / \mathrm{L}$ & 1 & $<1$ \\
\hline$\mu \mathrm{g} / \mathrm{L}$ & 1 & $<1$ \\
\hline$\mu \mathrm{g} / \mathrm{L}$ & 1 & $<1$ \\
\hline$\mu \mathrm{g} / \mathrm{L}$ & 2 & $<2$ \\
\hline$\mu \mathrm{g} / \mathrm{L}$ & 1 & $<1$ \\
\hline$\mu \mathrm{g} / \mathrm{L}$ & 1 & $<1$ \\
\hline$\mu \mathrm{g} / \mathrm{L}$ & 1 & $<1$ \\
\hline$\mu \mathrm{g} / \mathrm{L}$ & 1 & $<1$ \\
\hline$\mu \mathrm{g} / \mathrm{L}$ & 1 & $<1$ \\
\hline$\mu \mathrm{g} / \mathrm{L}$ & 1 & $<1$ \\
\hline$\mu \mathrm{g} / \mathrm{L}$ & 1 & $<1$ \\
\hline$\mu \mathrm{g} / \mathrm{L}$ & 1 & $<1$ \\
\hline$\mu \mathrm{g} / \mathrm{L}$ & 5 & $<5$ \\
\hline
\end{tabular}




\begin{tabular}{|c|c|c|c|c|}
\hline Parâmetros & $\begin{array}{l}\text { Quantidade } \\
\text { Adicionada }\end{array}$ & Unidade & $\begin{array}{c}\text { Resultado da } \\
\text { Recuperação (\%) }\end{array}$ & Faixa Aceitável de Recuperação (\%) \\
\hline \multicolumn{5}{|c|}{ 302694/2014-0 - Amostra Controle - VOC - Água } \\
\hline 1,1-Dicloroeteno & 20 & $\mu \mathrm{g} / \mathrm{L}$ & 100 & $70-130$ \\
\hline Benzeno & 20 & $\mu \mathrm{g} / \mathrm{L}$ & 125 & $70-130$ \\
\hline Tricloroeteno & 20 & $\mu \mathrm{g} / \mathrm{L}$ & 110 & $70-130$ \\
\hline Tolueno & 20 & $\mu \mathrm{g} / \mathrm{L}$ & 95 & $70-130$ \\
\hline Clorobenzeno & 20 & $\mu \mathrm{g} / \mathrm{L}$ & 105 & $70-130$ \\
\hline \multicolumn{5}{|c|}{$\begin{array}{l}\text { Surrogates } \\
\text { 302692/2014-0 - Branco de Análise - VOC - Água }\end{array}$} \\
\hline p-Bromofluorbenzeno & 20 & $\%$ & 76,5 & $70-130$ \\
\hline Dibromofluorometano & 20 & $\%$ & 130 & $70-130$ \\
\hline \multicolumn{5}{|c|}{ 302694/2014-0 - Amostra Controle - VOC - Água } \\
\hline p-Bromofluorbenzeno & 20 & $\%$ & 78,6 & $70-130$ \\
\hline Dibromofluorometano & 20 & $\%$ & 130 & $70-130$ \\
\hline \multicolumn{5}{|l|}{ 292986/2014-0 - ASI 3} \\
\hline Dibromofluorometano & 20 & $\%$ & 95,8 & $70-130$ \\
\hline p-Bromofluorbenzeno & 20 & $\%$ & 70,5 & $70-130$ \\
\hline
\end{tabular}

Notas

LQ = Limite de Quantificação.

n.a. $=$ Não Aplicável.

Abrangência

$\mathrm{O}(\mathrm{s})$ resultado(s) referem-se somente à(s) amostra(s) analisada(s).

Este Relatório de Ensaio só pode ser reproduzido por inteiro e sem nenhuma alteração.

Plano de Amostragem

Plano de amostragem de responsabilidade do interessado.

Responsabilidade Técnica

Os ensaios foram realizados na unidade da Bioagri Ambiental Ltda. - Matriz, situada na Rua Aljovil Martini, 177/201, Bairro Dois Córregos, Cep. 14420-833, Piracicaba/SP, registrada no CRQ 4 Região sob no $16082-\mathrm{F}$ e responsabilidade técnica do profissional Marcos Donizete Ceccatto, CRQ n⿳ ${ }^{\circ} 04364387,4^{\mathrm{a}}$.Região.

Referências Metodológicas

Análises foram realizadas conforme a última versão do Standard Methods for the Examination of Water \& Wastewater 22nd 2012(SMWW), EPA e ABNT (quando aplicável). VOC: EPA 8260 C: 2006, 5021A: 2003

Metiletilcetona: EPA 8260 C: 2006, 5021 A: 2003

Revisores

Débora Fernandes da Silva

Renato Augusto Duarte Gava

Chave de Validação: 725230ef98e0ef14a3f5fa9df5c6d55e
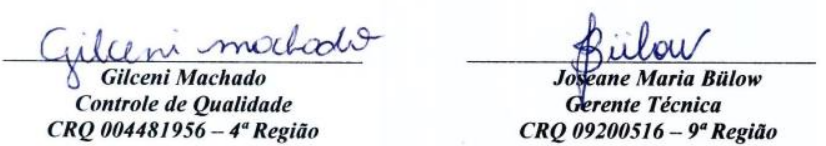


\section{RELATÓRIO DE ENSAIO N ${ }^{\circ}$ 292987/2014-0 - Piracicaba Processo Comercial $N^{\circ} 23961 / 2014-2$}

\begin{tabular}{|l|l|}
\hline \multicolumn{2}{|c|}{ DADOS REFERENTES AO CLIENTE } \\
\hline Empresa solicitante: & Fundacao Parque de Alta Tecnologia da Regiao de Ipero e Adjacencias \\
\hline Endereço: & Rua Jose Antonio Scaciota, 165 - - Portal do Cedro - Iperó - SP - CEP: 18.560-000 . \\
\hline Nome do Solicitante: & Carla Marçal \\
\hline
\end{tabular}

\section{DADOS REFERENTES A AMOSTRA}

Identificação do Cliente: Amostra Rotulada como:

Coletor:

ASF 1

Água Subterrânea Projeto Mestrado

\begin{tabular}{|l|l|l|l|l|}
\hline Data da entrada no laboratório: & 04/11/2014 01:23 & Data de Elaboração do RE: & 14/11/2014
\end{tabular}

\section{RESULTADOS PARA A AMOSTRA}

\begin{tabular}{|c|c|c|c|c|c|c|}
\hline Parâmetros & CAS & Unidade & LQ & Resultados analíticos & Incerteza & Data do Ensaio \\
\hline 1,1,1-Tricloroetano & $71-55-6$ & $\mu \mathrm{g} / \mathrm{L}$ & 1 & $<1$ & n.a. & 13/11/2014 07:46 \\
\hline 1,1,2-Tricloroetano & $79-00-5$ & $\mu \mathrm{g} / \mathrm{L}$ & 1 & $<1$ & n.a. & 13/11/2014 07:46 \\
\hline 1,1,2,2-Tetracloroetano & $79-34-5$ & $\mu \mathrm{g} / \mathrm{L}$ & 1 & $<1$ & n.a. & 13/11/2014 07:46 \\
\hline 1,1-Dicloroetano & $75-34-3$ & $\mu \mathrm{g} / \mathrm{L}$ & 1 & $<1$ & n.a. & 13/11/2014 07:46 \\
\hline 1,1-Dicloroeteno & $75-35-4$ & $\mu \mathrm{g} / \mathrm{L}$ & 1 & $<1$ & n.a. & 13/11/2014 07:46 \\
\hline 1,1-Dicloropropeno & $563-58-6$ & $\mu \mathrm{g} / \mathrm{L}$ & 1 & $<1$ & n.a. & 13/11/2014 07:46 \\
\hline 1,2,3-Triclorobenzeno & $87-61-6$ & $\mu \mathrm{g} / \mathrm{L}$ & 1 & $<1$ & n.a. & 13/11/2014 07:46 \\
\hline 1,2,4-Triclorobenzeno & $120-82-1$ & $\mu \mathrm{g} / \mathrm{L}$ & 1 & $<1$ & n.a. & 13/11/2014 07:46 \\
\hline 1,2-Dibromo-3-Cloropropano & $96-12-8$ & $\mu \mathrm{g} / \mathrm{L}$ & 5 & $<5$ & n.a. & 13/11/2014 07:46 \\
\hline 1,2-Dicloroetano & $107-06-2$ & $\mu \mathrm{g} / \mathrm{L}$ & 1 & $<1$ & n.a. & 13/11/2014 07:46 \\
\hline 1,2-Dicloropropano & $78-87-5$ & $\mu \mathrm{g} / \mathrm{L}$ & 1 & $<1$ & n.a. & 13/11/2014 07:46 \\
\hline 1,3-Dicloropropano & $142-28-9$ & $\mu \mathrm{g} / \mathrm{L}$ & 5 & $<5$ & n.a. & 13/11/2014 07:46 \\
\hline 1,4-Diclorobenzeno & $106-46-7$ & $\mu \mathrm{g} / \mathrm{L}$ & 1 & $<1$ & n.a. & 13/11/2014 07:46 \\
\hline 2,2-Dicloropropano & $594-20-7$ & $\mu \mathrm{g} / \mathrm{L}$ & 1 & $<1$ & n.a. & 13/11/2014 07:46 \\
\hline 4-Metil-2-Pentanona & $108-10-1$ & $\mu \mathrm{g} / \mathrm{L}$ & 5 & $<5$ & n.a. & 13/11/2014 07:46 \\
\hline Benzeno & $71-43-2$ & $\mu \mathrm{g} / \mathrm{L}$ & 1 & $<1$ & n.a. & 13/11/2014 07:46 \\
\hline Bromobenzeno & $108-86-1$ & $\mu \mathrm{g} / \mathrm{L}$ & 1 & $<1$ & n.a. & 13/11/2014 07:46 \\
\hline Bromodiclorometano & $75-27-4$ & $\mu \mathrm{g} / \mathrm{L}$ & 1 & $<1$ & n.a. & 13/11/2014 07:46 \\
\hline Bromofórmio & $75-25-2$ & $\mu \mathrm{g} / \mathrm{L}$ & 1 & $<1$ & n.a. & 13/11/2014 07:46 \\
\hline Bromoclorometano & $74-97-5$ & $\mu \mathrm{g} / \mathrm{L}$ & 5 & $<5$ & n.a. & 13/11/2014 07:46 \\
\hline Cis-1,2-Dicloroeteno & $156-59-2$ & $\mu \mathrm{g} / \mathrm{L}$ & 1 & $<1$ & n.a. & 13/11/2014 07:46 \\
\hline Cis-1,3-Dicloropropeno & $10061-01-5$ & $\mu \mathrm{g} / \mathrm{L}$ & 1 & $<1$ & n.a. & 13/11/2014 07:46 \\
\hline Diclorometano & $75-09-2$ & $\mu \mathrm{g} / \mathrm{L}$ & 1 & $<1$ & n.a. & 13/11/2014 07:46 \\
\hline Cloreto de Vinila & $75-01-4$ & $\mu \mathrm{g} / \mathrm{L}$ & 1 & $<1$ & n.a. & 13/11/2014 07:46 \\
\hline Clorobenzeno & $108-90-7$ & $\mu \mathrm{g} / \mathrm{L}$ & 1 & $<1$ & n.a. & 13/11/2014 07:46 \\
\hline Cloroetano & $75-00-3$ & $\mu \mathrm{g} / \mathrm{L}$ & 1 & $<1$ & n.a. & 13/11/2014 07:46 \\
\hline Clorofórmio & $67-66-3$ & $\mu \mathrm{g} / \mathrm{L}$ & 1 & $<1$ & n.a. & 13/11/2014 07:46 \\
\hline Clorometano & $74-87-3$ & $\mu \mathrm{g} / \mathrm{L}$ & 10 & $<10$ & n.a. & 13/11/2014 07:46 \\
\hline Dibromoclorometano & $124-48-1$ & $\mu \mathrm{g} / \mathrm{L}$ & 1 & $<1$ & n.a. & 13/11/2014 07:46 \\
\hline Dissulfeto de Carbono & $75-15-0$ & $\mu \mathrm{g} / \mathrm{L}$ & 1 & $<1$ & n.a. & 13/11/2014 07:46 \\
\hline Estireno & $100-42-5$ & $\mu \mathrm{g} / \mathrm{L}$ & 1 & $<1$ & n.a. & 13/11/2014 07:46 \\
\hline Etilbenzeno & $100-41-4$ & $\mu \mathrm{g} / \mathrm{L}$ & 1 & $<1$ & n.a. & 13/11/2014 07:46 \\
\hline Hexaclorobutadieno & $87-68-3$ & $\mu \mathrm{g} / \mathrm{L}$ & 1 & $<1$ & n.a. & 13/11/2014 07:46 \\
\hline m,p-Xilenos & --- & $\mu \mathrm{g} / \mathrm{L}$ & 2 & $<2$ & n.a. & 13/11/2014 07:46 \\
\hline o-Xileno & $95-47-6$ & $\mu \mathrm{g} / \mathrm{L}$ & 1 & $<1$ & n.a. & 13/11/2014 07:46 \\
\hline p-Isopropiltolueno & $99-87-6$ & $\mu \mathrm{g} / \mathrm{L}$ & 1 & $<1$ & n.a. & 13/11/2014 07:46 \\
\hline Tetracloreto de Carbono & $56-23-5$ & $\mu \mathrm{g} / \mathrm{L}$ & 1 & $<1$ & n.a. & 13/11/2014 07:46 \\
\hline Tetracloroeteno & $127-18-4$ & $\mu \mathrm{g} / \mathrm{L}$ & 10 & 90,5 & 17 & 13/11/2014 07:46 \\
\hline Tolueno & $108-88-3$ & $\mu \mathrm{g} / \mathrm{L}$ & 1 & $<1$ & n.a. & 13/11/2014 07:46 \\
\hline Trans-1,2-Dicloroeteno & $156-60-5$ & $\mu \mathrm{g} / \mathrm{L}$ & 1 & $<1$ & n.a. & 13/11/2014 07:46 \\
\hline Tricloroeteno & $79-01-6$ & $\mu \mathrm{g} / \mathrm{L}$ & 1 & $<1$ & n.a. & 13/11/2014 07:46 \\
\hline 1,1,1,2-Tetracloroetano & $630-20-6$ & $\mu \mathrm{g} / \mathrm{L}$ & 1 & $<1$ & n.a. & 13/11/2014 07:46 \\
\hline
\end{tabular}




\begin{tabular}{|c|c|c|c|c|c|c|}
\hline Parâmetros & CAS & Unidade & LQ & Resultados analíticos & Incerteza & Data do Ensaio \\
\hline 1,2,3-Tricloropropano & $96-18-4$ & $\mu \mathrm{g} / \mathrm{L}$ & 5 & $<5$ & n.a. & 13/11/2014 07:46 \\
\hline 1,3,5-Trimetilbenzeno & $108-67-8$ & $\mu \mathrm{g} / \mathrm{L}$ & 1 & $<1$ & n.a. & 13/11/2014 07:46 \\
\hline 1,2,4-Trimetilbenzeno & $95-63-6$ & $\mu \mathrm{g} / \mathrm{L}$ & 1 & $<1$ & n.a. & 13/11/2014 07:46 \\
\hline 1,2-Dibromoetano & $106-93-4$ & $\mu \mathrm{g} / \mathrm{L}$ & 1 & $<1$ & n.a. & 13/11/2014 07:46 \\
\hline 1,2-Diclorobenzeno & $95-50-1$ & $\mu \mathrm{g} / \mathrm{L}$ & 1 & $<1$ & n.a. & 13/11/2014 07:46 \\
\hline 1,3-Diclorobenzeno & $541-73-1$ & $\mu \mathrm{g} / \mathrm{L}$ & 1 & $<1$ & n.a. & 13/11/2014 07:46 \\
\hline 2-Clorotolueno & $95-49-8$ & $\mu \mathrm{g} / \mathrm{L}$ & 1 & $<1$ & n.a. & 13/11/2014 07:46 \\
\hline Dibromometano & $74-95-3$ & $\mu \mathrm{g} / \mathrm{L}$ & 1 & $<1$ & n.a. & 13/11/2014 07:46 \\
\hline Metiletilcetona & $78-93-3$ & $\mu \mathrm{g} / \mathrm{L}$ & 2500 & $<2500$ & n.a. & 13/11/2014 08:10 \\
\hline Naftaleno & $91-20-3$ & $\mu \mathrm{g} / \mathrm{L}$ & 1 & $<1$ & n.a. & 13/11/2014 07:46 \\
\hline n-Butilbenzeno & $104-51-8$ & $\mu \mathrm{g} / \mathrm{L}$ & 1 & $<1$ & n.a. & 13/11/2014 07:46 \\
\hline n-Propilbenzeno & $103-65-1$ & $\mu \mathrm{g} / \mathrm{L}$ & 1 & $<1$ & n.a. & 13/11/2014 07:46 \\
\hline 4-Clorotolueno & $106-43-4$ & $\mu \mathrm{g} / \mathrm{L}$ & 1 & $<1$ & n.a. & 13/11/2014 07:46 \\
\hline sec-Butilbenzeno & $135-98-8$ & $\mu \mathrm{g} / \mathrm{L}$ & 1 & $<1$ & n.a. & 13/11/2014 07:46 \\
\hline terc-Butilbenzeno & $98-06-6$ & $\mu \mathrm{g} / \mathrm{L}$ & 1 & $<1$ & n.a. & 13/11/2014 07:46 \\
\hline trans-1,3-Dicloropropeno & $10061-02-6$ & $\mu \mathrm{g} / \mathrm{L}$ & 1 & $<1$ & n.a. & 13/11/2014 07:46 \\
\hline Isopropilbenzeno & $98-82-8$ & $\mu \mathrm{g} / \mathrm{L}$ & 1 & $<1$ & n.a. & 13/11/2014 07:46 \\
\hline 1,3,5-Triclorobenzeno & $108-70-3$ & $\mu \mathrm{g} / \mathrm{L}$ & 1 & $<1$ & n.a. & 13/11/2014 07:46 \\
\hline
\end{tabular}

\section{CONTROLE DE QUALIDADE DO LABORATÓRIO}

302692/2014-0 - Branco de Análise - VOC - Água

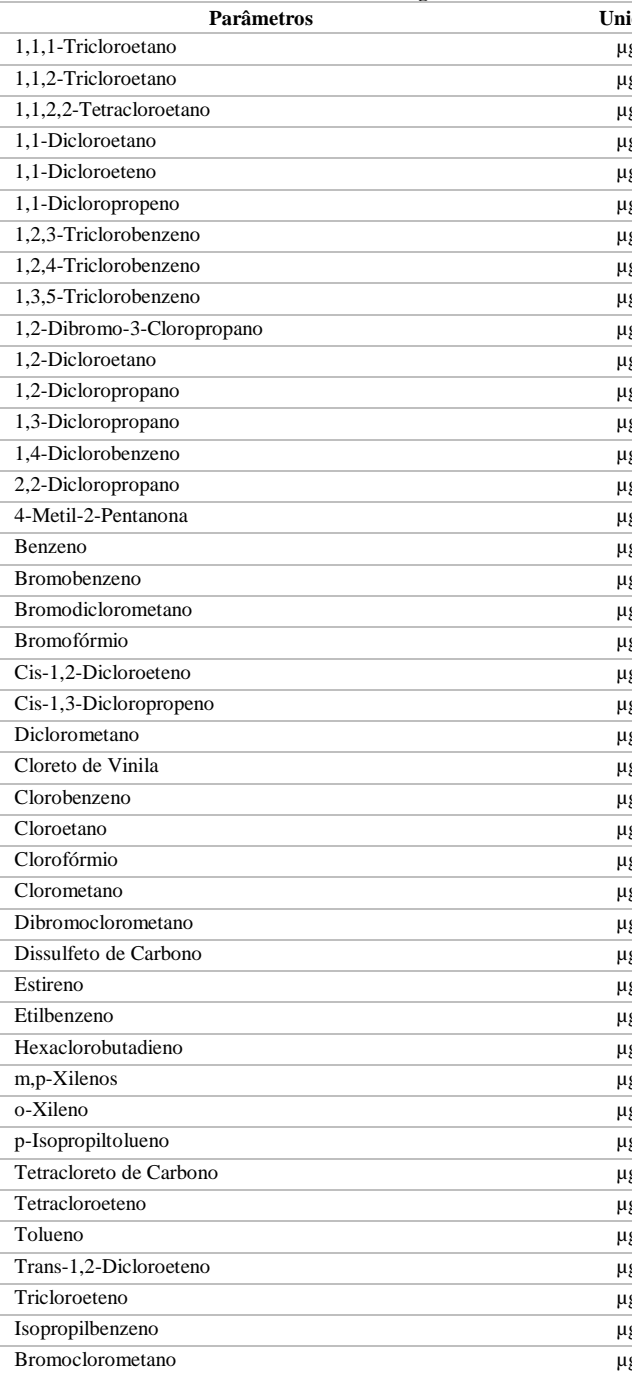

Controle de Qualidade - VOC - Água

\begin{tabular}{|c|c|c|}
\hline Unidade & LQ & Resultados analíticos \\
\hline$\mu \mathrm{g} / \mathrm{L}$ & 1 & $<1$ \\
\hline$\mu \mathrm{g} / \mathrm{L}$ & 1 & $<1$ \\
\hline$\mu \mathrm{g} / \mathrm{L}$ & 1 & $<1$ \\
\hline$\mu \mathrm{g} / \mathrm{L}$ & 1 & $<1$ \\
\hline$\mu \mathrm{g} / \mathrm{L}$ & 1 & $<1$ \\
\hline$\mu \mathrm{g} / \mathrm{L}$ & 1 & $<1$ \\
\hline$\mu \mathrm{g} / \mathrm{L}$ & 1 & $<1$ \\
\hline$\mu \mathrm{g} / \mathrm{L}$ & 1 & $<1$ \\
\hline$\mu \mathrm{g} / \mathrm{L}$ & 1 & $<1$ \\
\hline$\mu \mathrm{g} / \mathrm{L}$ & 5 & $<5$ \\
\hline$\mu \mathrm{g} / \mathrm{L}$ & 1 & $<1$ \\
\hline$\mu \mathrm{g} / \mathrm{L}$ & 1 & $<1$ \\
\hline$\mu \mathrm{g} / \mathrm{L}$ & 5 & $<5$ \\
\hline$\mu \mathrm{g} / \mathrm{L}$ & 1 & $<1$ \\
\hline$\mu \mathrm{g} / \mathrm{L}$ & 1 & $<1$ \\
\hline$\mu \mathrm{g} / \mathrm{L}$ & 5 & $<5$ \\
\hline$\mu \mathrm{g} / \mathrm{L}$ & 1 & $<1$ \\
\hline$\mu \mathrm{g} / \mathrm{L}$ & 1 & $<1$ \\
\hline$\mu \mathrm{g} / \mathrm{L}$ & 1 & $<1$ \\
\hline$\mu \mathrm{g} / \mathrm{L}$ & 1 & $<1$ \\
\hline$\mu \mathrm{g} / \mathrm{L}$ & 1 & $<1$ \\
\hline$\mu \mathrm{g} / \mathrm{L}$ & 1 & $<1$ \\
\hline$\mu \mathrm{g} / \mathrm{L}$ & 1 & $<1$ \\
\hline$\mu \mathrm{g} / \mathrm{L}$ & 1 & $<1$ \\
\hline$\mu \mathrm{g} / \mathrm{L}$ & 1 & $<1$ \\
\hline$\mu \mathrm{g} / \mathrm{L}$ & 1 & $<1$ \\
\hline$\mu \mathrm{g} / \mathrm{L}$ & 1 & $<1$ \\
\hline$\mu \mathrm{g} / \mathrm{L}$ & 10 & $<10$ \\
\hline$\mu \mathrm{g} / \mathrm{L}$ & 1 & $<1$ \\
\hline$\mu \mathrm{g} / \mathrm{L}$ & 1 & $<1$ \\
\hline$\mu \mathrm{g} / \mathrm{L}$ & 1 & $<1$ \\
\hline$\mu \mathrm{g} / \mathrm{L}$ & 1 & $<1$ \\
\hline$\mu \mathrm{g} / \mathrm{L}$ & 1 & $<1$ \\
\hline$\mu \mathrm{g} / \mathrm{L}$ & 2 & $<2$ \\
\hline$\mu \mathrm{g} / \mathrm{L}$ & 1 & $<1$ \\
\hline$\mu \mathrm{g} / \mathrm{L}$ & 1 & $<1$ \\
\hline$\mu \mathrm{g} / \mathrm{L}$ & 1 & $<1$ \\
\hline$\mu \mathrm{g} / \mathrm{L}$ & 1 & $<1$ \\
\hline$\mu \mathrm{g} / \mathrm{L}$ & 1 & $<1$ \\
\hline$\mu \mathrm{g} / \mathrm{L}$ & 1 & $<1$ \\
\hline$\mu \mathrm{g} / \mathrm{L}$ & 1 & $<1$ \\
\hline$\mu \mathrm{g} / \mathrm{L}$ & 1 & $<1$ \\
\hline$\mu \mathrm{g} / \mathrm{L}$ & 5 & $<5$ \\
\hline
\end{tabular}




\begin{tabular}{|c|c|c|c|c|}
\hline Parâmetros & $\begin{array}{l}\text { Quantidade } \\
\text { Adicionada }\end{array}$ & Unidade & $\begin{array}{c}\text { Resultado da } \\
\text { Recuperação (\%) }\end{array}$ & Faixa Aceitável de Recuperação (\%) \\
\hline \multicolumn{5}{|c|}{ 302694/2014-0 - Amostra Controle - VOC - Água } \\
\hline 1,1-Dicloroeteno & 20 & $\mu \mathrm{g} / \mathrm{L}$ & 100 & $70-130$ \\
\hline Benzeno & 20 & $\mu \mathrm{g} / \mathrm{L}$ & 125 & $70-130$ \\
\hline Tricloroeteno & 20 & $\mu \mathrm{g} / \mathrm{L}$ & 110 & $70-130$ \\
\hline Tolueno & 20 & $\mu \mathrm{g} / \mathrm{L}$ & 95 & $70-130$ \\
\hline Clorobenzeno & 20 & $\mu \mathrm{g} / \mathrm{L}$ & 105 & $70-130$ \\
\hline \multicolumn{5}{|c|}{$\begin{array}{l}\text { Surrogates } \\
\text { 302692/2014-0 - Branco de Análise - VOC - Água }\end{array}$} \\
\hline p-Bromofluorbenzeno & 20 & $\%$ & 76,5 & $70-130$ \\
\hline Dibromofluorometano & 20 & $\%$ & 130 & $70-130$ \\
\hline \multicolumn{5}{|c|}{ 302694/2014-0 - Amostra Controle - VOC - Água } \\
\hline p-Bromofluorbenzeno & 20 & $\%$ & 78,6 & $70-130$ \\
\hline Dibromofluorometano & 20 & $\%$ & 130 & $70-130$ \\
\hline \multicolumn{5}{|l|}{ 292987/2014-0 - ASF 1} \\
\hline Dibromofluorometano & 20 & $\%$ & 92,4 & $70-130$ \\
\hline p-Bromofluorbenzeno & 20 & $\%$ & 73,0 & $70-130$ \\
\hline
\end{tabular}

Notas

LQ = Limite de Quantificação.

n.a. $=$ Não Aplicável.

Abrangência

$\mathrm{O}(\mathrm{s})$ resultado(s) referem-se somente à(s) amostra(s) analisada(s).

Este Relatório de Ensaio só pode ser reproduzido por inteiro e sem nenhuma alteração.

Plano de Amostragem

Plano de amostragem de responsabilidade do interessado.

Responsabilidade Técnica

Os ensaios foram realizados na unidade da Bioagri Ambiental Ltda. - Matriz, situada na Rua Aljovil Martini, 177/201, Bairro Dois Córregos, Cep. 14420-833, Piracicaba/SP, registrada no CRQ 4 Região sob no $16082-\mathrm{F}$ e responsabilidade técnica do profissional Marcos Donizete Ceccatto, CRQ n⿳ ${ }^{\circ} 04364387,4^{\mathrm{a}}$.Região.

Referências Metodológicas

Análises foram realizadas conforme a última versão do Standard Methods for the Examination of Water \& Wastewater 22nd 2012(SMWW), EPA e ABNT (quando aplicável). VOC: EPA 8260 C: 2006, 5021A: 2003

Metiletilcetona: EPA 8260 C: 2006, 5021 A: 2003

Revisores

Débora Fernandes da Silva

Renato Augusto Duarte Gava

Chave de Validação: 8884fad063e527809e16d0b1ff906c73
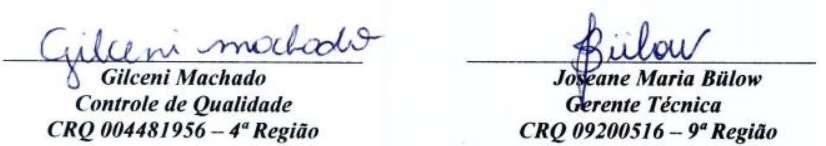


\section{RELATÓRIO DE ENSAIO N ${ }^{\circ}$ 292988/2014-0 - Piracicaba Processo Comercial $N^{\circ}$ 23961/2014-2}

\begin{tabular}{|l|l|}
\hline \multicolumn{2}{|c|}{ DADOS REFERENTES AO CLIENTE } \\
\hline Empresa solicitante: & Fundacao Parque de Alta Tecnologia da Regiao de Ipero e Adjacencias \\
\hline Endereço: & Rua Jose Antonio Scaciota, 165 - - Portal do Cedro - Iperó - SP - CEP: 18.560-000 . \\
\hline Nome do Solicitante: & Carla Marçal \\
\hline
\end{tabular}

\section{DADOS REFERENTES A AMOSTRA}

Identificação do Cliente:

ASF 2

Amostra Rotulada como:

Água Subterrânea Projeto Mestrado

Coletor:

Interessado

Data da coleta: $\quad$ 02/11/2014 23:58:00

\begin{tabular}{|l|l|l|l|l|}
\hline Data da entrada no laboratório: & 04/11/2014 01:23 & Data de Elaboração do RE: & 14/11/2014
\end{tabular}

\section{RESULTADOS PARA A AMOSTRA}

\begin{tabular}{|c|c|c|c|c|c|c|}
\hline Parâmetros & CAS & Unidade & LQ & Resultados analíticos & Incerteza & Data do Ensaio \\
\hline 1,1,1-Tricloroetano & $71-55-6$ & $\mu \mathrm{g} / \mathrm{L}$ & 1 & $<1$ & n.a. & 13/11/2014 08:34 \\
\hline 1,1,2-Tricloroetano & $79-00-5$ & $\mu \mathrm{g} / \mathrm{L}$ & 1 & $<1$ & n.a. & 13/11/2014 08:34 \\
\hline 1,1,2,2-Tetracloroetano & $79-34-5$ & $\mu \mathrm{g} / \mathrm{L}$ & 1 & $<1$ & n.a. & 13/11/2014 08:34 \\
\hline 1,1-Dicloroetano & $75-34-3$ & $\mu \mathrm{g} / \mathrm{L}$ & 1 & $<1$ & n.a. & 13/11/2014 08:34 \\
\hline 1,1-Dicloroeteno & $75-35-4$ & $\mu \mathrm{g} / \mathrm{L}$ & 1 & $<1$ & n.a. & 13/11/2014 08:34 \\
\hline 1,1-Dicloropropeno & $563-58-6$ & $\mu \mathrm{g} / \mathrm{L}$ & 1 & $<1$ & n.a. & 13/11/2014 08:34 \\
\hline 1,2,3-Triclorobenzeno & $87-61-6$ & $\mu \mathrm{g} / \mathrm{L}$ & 1 & $<1$ & n.a. & 13/11/2014 08:34 \\
\hline 1,2,4-Triclorobenzeno & $120-82-1$ & $\mu \mathrm{g} / \mathrm{L}$ & 1 & $<1$ & n.a. & 13/11/2014 08:34 \\
\hline 1,2-Dibromo-3-Cloropropano & $96-12-8$ & $\mu \mathrm{g} / \mathrm{L}$ & 5 & $<5$ & n.a. & 13/11/2014 08:34 \\
\hline 1,2-Dicloroetano & $107-06-2$ & $\mu \mathrm{g} / \mathrm{L}$ & 1 & $<1$ & n.a. & 13/11/2014 08:34 \\
\hline 1,2-Dicloropropano & $78-87-5$ & $\mu \mathrm{g} / \mathrm{L}$ & 1 & $<1$ & n.a. & 13/11/2014 08:34 \\
\hline 1,3-Dicloropropano & $142-28-9$ & $\mu \mathrm{g} / \mathrm{L}$ & 5 & $<5$ & n.a. & 13/11/2014 08:34 \\
\hline 1,4-Diclorobenzeno & $106-46-7$ & $\mu \mathrm{g} / \mathrm{L}$ & 1 & $<1$ & n.a. & 13/11/2014 08:34 \\
\hline 2,2-Dicloropropano & $594-20-7$ & $\mu \mathrm{g} / \mathrm{L}$ & 1 & $<1$ & n.a. & 13/11/2014 08:34 \\
\hline 4-Metil-2-Pentanona & $108-10-1$ & $\mu \mathrm{g} / \mathrm{L}$ & 5 & $<5$ & n.a. & 13/11/2014 08:34 \\
\hline Benzeno & $71-43-2$ & $\mu \mathrm{g} / \mathrm{L}$ & 1 & $<1$ & n.a. & 13/11/2014 08:34 \\
\hline Bromobenzeno & $108-86-1$ & $\mu \mathrm{g} / \mathrm{L}$ & 1 & $<1$ & n.a. & 13/11/2014 08:34 \\
\hline Bromodiclorometano & $75-27-4$ & $\mu \mathrm{g} / \mathrm{L}$ & 1 & $<1$ & n.a. & 13/11/2014 08:34 \\
\hline Bromofórmio & $75-25-2$ & $\mu \mathrm{g} / \mathrm{L}$ & 1 & $<1$ & n.a. & 13/11/2014 08:34 \\
\hline Bromoclorometano & $74-97-5$ & $\mu \mathrm{g} / \mathrm{L}$ & 5 & $<5$ & n.a. & 13/11/2014 08:34 \\
\hline Cis-1,2-Dicloroeteno & $156-59-2$ & $\mu \mathrm{g} / \mathrm{L}$ & 1 & $<1$ & n.a. & 13/11/2014 08:34 \\
\hline Cis-1,3-Dicloropropeno & $10061-01-5$ & $\mu \mathrm{g} / \mathrm{L}$ & 1 & $<1$ & n.a. & 13/11/2014 08:34 \\
\hline Diclorometano & $75-09-2$ & $\mu \mathrm{g} / \mathrm{L}$ & 1 & $<1$ & n.a. & 13/11/2014 08:34 \\
\hline Cloreto de Vinila & $75-01-4$ & $\mu \mathrm{g} / \mathrm{L}$ & 1 & $<1$ & n.a. & 13/11/2014 08:34 \\
\hline Clorobenzeno & $108-90-7$ & $\mu \mathrm{g} / \mathrm{L}$ & 1 & $<1$ & n.a. & 13/11/2014 08:34 \\
\hline Cloroetano & $75-00-3$ & $\mu \mathrm{g} / \mathrm{L}$ & 1 & $<1$ & n.a. & 13/11/2014 08:34 \\
\hline Clorofórmio & $67-66-3$ & $\mu \mathrm{g} / \mathrm{L}$ & 1 & $<1$ & n.a. & 13/11/2014 08:34 \\
\hline Clorometano & $74-87-3$ & $\mu \mathrm{g} / \mathrm{L}$ & 10 & $<10$ & n.a. & 13/11/2014 08:34 \\
\hline Dibromoclorometano & $124-48-1$ & $\mu \mathrm{g} / \mathrm{L}$ & 1 & $<1$ & n.a. & $13 / 11 / 201408: 34$ \\
\hline Dissulfeto de Carbono & $75-15-0$ & $\mu \mathrm{g} / \mathrm{L}$ & 1 & $<1$ & n.a. & 13/11/2014 08:34 \\
\hline Estireno & $100-42-5$ & $\mu \mathrm{g} / \mathrm{L}$ & 1 & $<1$ & n.a. & 13/11/2014 08:34 \\
\hline Etilbenzeno & $100-41-4$ & $\mu \mathrm{g} / \mathrm{L}$ & 1 & $<1$ & n.a. & 13/11/2014 08:34 \\
\hline Hexaclorobutadieno & $87-68-3$ & $\mu \mathrm{g} / \mathrm{L}$ & 1 & $<1$ & n.a. & 13/11/2014 08:34 \\
\hline m,p-Xilenos & --- & $\mu \mathrm{g} / \mathrm{L}$ & 2 & $<2$ & n.a. & 13/11/2014 08:34 \\
\hline o-Xileno & $95-47-6$ & $\mu \mathrm{g} / \mathrm{L}$ & 1 & $<1$ & n.a. & 13/11/2014 08:34 \\
\hline p-Isopropiltolueno & $99-87-6$ & $\mu \mathrm{g} / \mathrm{L}$ & 1 & $<1$ & n.a. & 13/11/2014 08:34 \\
\hline Tetracloreto de Carbono & $56-23-5$ & $\mu \mathrm{g} / \mathrm{L}$ & 1 & $<1$ & n.a. & 13/11/2014 08:34 \\
\hline Tetracloroeteno & $127-18-4$ & $\mu \mathrm{g} / \mathrm{L}$ & 10 & 99,6 & 19 & 13/11/2014 08:34 \\
\hline Tolueno & $108-88-3$ & $\mu \mathrm{g} / \mathrm{L}$ & 1 & $<1$ & n.a. & 13/11/2014 08:34 \\
\hline Trans-1,2-Dicloroeteno & $156-60-5$ & $\mu \mathrm{g} / \mathrm{L}$ & 1 & $<1$ & n.a. & 13/11/2014 08:34 \\
\hline Tricloroeteno & $79-01-6$ & $\mu \mathrm{g} / \mathrm{L}$ & 1 & $<1$ & n.a. & 13/11/2014 08:34 \\
\hline 1,1,1,2-Tetracloroetano & $630-20-6$ & $\mu \mathrm{g} / \mathrm{L}$ & 1 & $<1$ & n.a. & 13/11/2014 08:34 \\
\hline
\end{tabular}




\begin{tabular}{|c|c|c|c|c|c|c|}
\hline Parâmetros & CAS & Unidade & LQ & Resultados analíticos & Incerteza & Data do Ensaio \\
\hline 1,2,3-Tricloropropano & $96-18-4$ & $\mu \mathrm{g} / \mathrm{L}$ & 5 & $<5$ & n.a. & 13/11/2014 08:34 \\
\hline 1,3,5-Trimetilbenzeno & $108-67-8$ & $\mu \mathrm{g} / \mathrm{L}$ & 1 & $<1$ & n.a. & 13/11/2014 08:34 \\
\hline 1,2,4-Trimetilbenzeno & $95-63-6$ & $\mu \mathrm{g} / \mathrm{L}$ & 1 & $<1$ & n.a. & 13/11/2014 08:34 \\
\hline 1,2-Dibromoetano & $106-93-4$ & $\mu \mathrm{g} / \mathrm{L}$ & 1 & $<1$ & n.a. & 13/11/2014 08:34 \\
\hline 1,2-Diclorobenzeno & $95-50-1$ & $\mu \mathrm{g} / \mathrm{L}$ & 1 & $<1$ & n.a. & 13/11/2014 08:34 \\
\hline 1,3-Diclorobenzeno & $541-73-1$ & $\mu \mathrm{g} / \mathrm{L}$ & 1 & $<1$ & n.a. & $13 / 11 / 201408: 34$ \\
\hline 2-Clorotolueno & $95-49-8$ & $\mu \mathrm{g} / \mathrm{L}$ & 1 & $<1$ & n.a. & 13/11/2014 08:34 \\
\hline Dibromometano & $74-95-3$ & $\mu \mathrm{g} / \mathrm{L}$ & 1 & $<1$ & n.a. & 13/11/2014 08:34 \\
\hline Metiletilcetona & 78-93-3 & $\mu \mathrm{g} / \mathrm{L}$ & 2500 & $<2500$ & n.a. & 13/11/2014 08:58 \\
\hline Naftaleno & $91-20-3$ & $\mu \mathrm{g} / \mathrm{L}$ & 1 & $<1$ & n.a. & 13/11/2014 08:34 \\
\hline n-Butilbenzeno & $104-51-8$ & $\mu \mathrm{g} / \mathrm{L}$ & 1 & $<1$ & n.a. & 13/11/2014 08:34 \\
\hline n-Propilbenzeno & 103-65-1 & $\mu \mathrm{g} / \mathrm{L}$ & 1 & $<1$ & n.a. & 13/11/2014 08:34 \\
\hline 4-Clorotolueno & $106-43-4$ & $\mu \mathrm{g} / \mathrm{L}$ & 1 & $<1$ & n.a. & 13/11/2014 08:34 \\
\hline sec-Butilbenzeno & $135-98-8$ & $\mu \mathrm{g} / \mathrm{L}$ & 1 & $<1$ & n.a. & 13/11/2014 08:34 \\
\hline terc-Butilbenzeno & $98-06-6$ & $\mu \mathrm{g} / \mathrm{L}$ & 1 & $<1$ & n.a. & $13 / 11 / 201408: 34$ \\
\hline trans-1,3-Dicloropropeno & $10061-02-6$ & $\mu \mathrm{g} / \mathrm{L}$ & 1 & $<1$ & n.a. & $13 / 11 / 201408: 34$ \\
\hline Isopropilbenzeno & $98-82-8$ & $\mu \mathrm{g} / \mathrm{L}$ & 1 & $<1$ & n.a. & 13/11/2014 08:34 \\
\hline 1,3,5-Triclorobenzeno & $108-70-3$ & $\mu \mathrm{g} / \mathrm{L}$ & 1 & $<1$ & n.a. & 13/11/2014 08:34 \\
\hline
\end{tabular}

\section{CONTROLE DE QUALIDADE DO LABORATÓRIO}

302692/2014-0 - Branco de Análise - VOC - Água

\begin{tabular}{|c|c|}
\hline \multirow{2}{*}{\multicolumn{2}{|c|}{$\begin{array}{ll} & \text { Parâmetros } \\
1,1,1-\text { Tricloroetano } & \end{array}$}} \\
\hline & \\
\hline \multicolumn{2}{|l|}{ 1,1,2-Tricloroetano } \\
\hline \multicolumn{2}{|l|}{ 1,1,2,2-Tetracloroetano } \\
\hline \multicolumn{2}{|l|}{ 1,1-Dicloroetano } \\
\hline \multicolumn{2}{|l|}{ 1,1-Dicloroeteno } \\
\hline \multicolumn{2}{|l|}{ 1,1-Dicloropropeno } \\
\hline \multicolumn{2}{|l|}{ 1,2,3-Triclorobenzeno } \\
\hline \multicolumn{2}{|l|}{ 1,2,4-Triclorobenzeno } \\
\hline \multicolumn{2}{|l|}{ 1,3,5-Triclorobenzeno } \\
\hline \multicolumn{2}{|l|}{ 1,2-Dibromo-3-Cloropropano } \\
\hline \multicolumn{2}{|l|}{ 1,2-Dicloroetano } \\
\hline \multicolumn{2}{|l|}{ 1,2-Dicloropropano } \\
\hline \multicolumn{2}{|l|}{ 1,3-Dicloropropano } \\
\hline \multicolumn{2}{|l|}{ 1,4-Diclorobenzeno } \\
\hline \multicolumn{2}{|l|}{ 2,2-Dicloropropano } \\
\hline \multicolumn{2}{|l|}{ 4-Metil-2-Pentanona } \\
\hline \multicolumn{2}{|l|}{ Benzeno } \\
\hline \multicolumn{2}{|l|}{ Bromobenzeno } \\
\hline \multicolumn{2}{|l|}{ Bromodiclorometano } \\
\hline \multicolumn{2}{|l|}{ Bromofórmio } \\
\hline \multicolumn{2}{|l|}{ Cis-1,2-Dicloroeteno } \\
\hline \multicolumn{2}{|l|}{ Cis-1,3-Dicloropropeno } \\
\hline \multicolumn{2}{|l|}{ Diclorometano } \\
\hline \multicolumn{2}{|l|}{ Cloreto de Vinila } \\
\hline \multicolumn{2}{|l|}{ Clorobenzeno } \\
\hline \multicolumn{2}{|l|}{ Cloroetano } \\
\hline Clorofórmio & \\
\hline Clorometano & \\
\hline Dibromoclorometano & \\
\hline Dissulfeto de Carbono & \\
\hline Estireno & \\
\hline Etilbenzeno & \\
\hline Hexaclorobutadieno & \\
\hline m,p-Xilenos & \\
\hline o-Xileno & \\
\hline p-Isopropiltolueno & \\
\hline Tetracloreto de Carbono & \\
\hline Tetracloroeteno & \\
\hline Tolueno & \\
\hline Trans-1,2-Dicloroeteno & \\
\hline Tricloroeteno & \\
\hline Isopropilbenzeno & \\
\hline Bromoclorometano & \\
\hline
\end{tabular}

Controle de Qualidade - VOC - Água

\begin{tabular}{|c|c|c|}
\hline Unidade & LQ & Resultados analíticos \\
\hline$\mu \mathrm{g} / \mathrm{L}$ & 1 & $<1$ \\
\hline$\mu \mathrm{g} / \mathrm{L}$ & 1 & $<1$ \\
\hline$\mu \mathrm{g} / \mathrm{L}$ & 1 & $<1$ \\
\hline$\mu \mathrm{g} / \mathrm{L}$ & 1 & $<1$ \\
\hline$\mu g / L$ & 1 & $<1$ \\
\hline$\mu \mathrm{g} / \mathrm{L}$ & 1 & $<1$ \\
\hline$\mu \mathrm{g} / \mathrm{L}$ & 1 & $<1$ \\
\hline$\mu \mathrm{g} / \mathrm{L}$ & 1 & $<1$ \\
\hline$\mu \mathrm{g} / \mathrm{L}$ & 1 & $<1$ \\
\hline$\mu \mathrm{g} / \mathrm{L}$ & 5 & $<5$ \\
\hline$\mu \mathrm{g} / \mathrm{L}$ & 1 & $<1$ \\
\hline$\mu \mathrm{g} / \mathrm{L}$ & 1 & $<1$ \\
\hline$\mu \mathrm{g} / \mathrm{L}$ & 5 & $<5$ \\
\hline$\mu \mathrm{g} / \mathrm{L}$ & 1 & $<1$ \\
\hline$\mu \mathrm{g} / \mathrm{L}$ & 1 & $<1$ \\
\hline$\mu \mathrm{g} / \mathrm{L}$ & 5 & $<5$ \\
\hline$\mu \mathrm{g} / \mathrm{L}$ & 1 & $<1$ \\
\hline$\mu \mathrm{g} / \mathrm{L}$ & 1 & $<1$ \\
\hline$\mu \mathrm{g} / \mathrm{L}$ & 1 & $<1$ \\
\hline$\mu \mathrm{g} / \mathrm{L}$ & 1 & $<1$ \\
\hline$\mu \mathrm{g} / \mathrm{L}$ & 1 & $<1$ \\
\hline$\mu \mathrm{g} / \mathrm{L}$ & 1 & $<1$ \\
\hline$\mu \mathrm{g} / \mathrm{L}$ & 1 & $<1$ \\
\hline$\mu \mathrm{g} / \mathrm{L}$ & 1 & $<1$ \\
\hline$\mu \mathrm{g} / \mathrm{L}$ & 1 & $<1$ \\
\hline$\mu \mathrm{g} / \mathrm{L}$ & 1 & $<1$ \\
\hline$\mu \mathrm{g} / \mathrm{L}$ & 1 & $<1$ \\
\hline$\mu \mathrm{g} / \mathrm{L}$ & 10 & $<10$ \\
\hline$\mu \mathrm{g} / \mathrm{L}$ & 1 & $<1$ \\
\hline$\mu \mathrm{g} / \mathrm{L}$ & 1 & $<1$ \\
\hline$\mu \mathrm{g} / \mathrm{L}$ & 1 & $<1$ \\
\hline$\mu \mathrm{g} / \mathrm{L}$ & 1 & $<1$ \\
\hline$\mu \mathrm{g} / \mathrm{L}$ & 1 & $<1$ \\
\hline$\mu \mathrm{g} / \mathrm{L}$ & 2 & $<2$ \\
\hline$\mu \mathrm{g} / \mathrm{L}$ & 1 & $<1$ \\
\hline$\mu \mathrm{g} / \mathrm{L}$ & 1 & $<1$ \\
\hline$\mu \mathrm{g} / \mathrm{L}$ & 1 & $<1$ \\
\hline$\mu \mathrm{g} / \mathrm{L}$ & 1 & $<1$ \\
\hline$\mu \mathrm{g} / \mathrm{L}$ & 1 & $<1$ \\
\hline$\mu \mathrm{g} / \mathrm{L}$ & 1 & $<1$ \\
\hline$\mu \mathrm{g} / \mathrm{L}$ & 1 & $<1$ \\
\hline$\mu \mathrm{g} / \mathrm{L}$ & 1 & $<1$ \\
\hline$\mu \mathrm{g} / \mathrm{L}$ & 5 & $<5$ \\
\hline
\end{tabular}




\begin{tabular}{|c|c|c|c|c|}
\hline Parâmetros & $\begin{array}{l}\text { Quantidade } \\
\text { Adicionada }\end{array}$ & Unidade & $\begin{array}{c}\text { Resultado da } \\
\text { Recuperação (\%) }\end{array}$ & Faixa Aceitável de Recuperação (\%) \\
\hline \multicolumn{5}{|c|}{ 302694/2014-0 - Amostra Controle - VOC - Água } \\
\hline 1,1-Dicloroeteno & 20 & $\mu \mathrm{g} / \mathrm{L}$ & 100 & $70-130$ \\
\hline Benzeno & 20 & $\mu \mathrm{g} / \mathrm{L}$ & 125 & $70-130$ \\
\hline Tricloroeteno & 20 & $\mu \mathrm{g} / \mathrm{L}$ & 110 & $70-130$ \\
\hline Tolueno & 20 & $\mu \mathrm{g} / \mathrm{L}$ & 95 & $70-130$ \\
\hline Clorobenzeno & 20 & $\mu \mathrm{g} / \mathrm{L}$ & 105 & $70-130$ \\
\hline \multicolumn{5}{|c|}{$\begin{array}{l}\text { Surrogates } \\
\text { 302692/2014-0 - Branco de Análise - VOC - Água }\end{array}$} \\
\hline p-Bromofluorbenzeno & 20 & $\%$ & 76,5 & $70-130$ \\
\hline Dibromofluorometano & 20 & $\%$ & 130 & $70-130$ \\
\hline \multicolumn{5}{|c|}{ 302694/2014-0 - Amostra Controle - VOC - Água } \\
\hline p-Bromofluorbenzeno & 20 & $\%$ & 78,6 & $70-130$ \\
\hline Dibromofluorometano & 20 & $\%$ & 130 & $70-130$ \\
\hline \multicolumn{5}{|l|}{ 292988/2014-0 - ASF 2} \\
\hline Dibromofluorometano & 20 & $\%$ & 95,0 & $70-130$ \\
\hline p-Bromofluorbenzeno & 20 & $\%$ & 73,5 & $70-130$ \\
\hline
\end{tabular}

Notas

LQ = Limite de Quantificação.

n.a. $=$ Não Aplicável.

Abrangência

$\mathrm{O}(\mathrm{s})$ resultado(s) referem-se somente à(s) amostra(s) analisada(s).

Este Relatório de Ensaio só pode ser reproduzido por inteiro e sem nenhuma alteração.

Plano de Amostragem

Plano de amostragem de responsabilidade do interessado.

Responsabilidade Técnica

Os ensaios foram realizados na unidade da Bioagri Ambiental Ltda. - Matriz, situada na Rua Aljovil Martini, 177/201, Bairro Dois Córregos, Cep. 14420-833, Piracicaba/SP, registrada no CRQ 4 Região sob n⿳亠丷厂 $16082-\mathrm{F}$ e responsabilidade técnica do profissional Marcos Donizete Ceccatto, CRQ n ${ }^{\circ} 04364387,4^{\mathrm{a}}$.Região.

Referências Metodológicas

Análises foram realizadas conforme a última versão do Standard Methods for the Examination of Water \& Wastewater 22nd 2012(SMWW), EPA e ABNT (quando aplicável). VOC: EPA 8260 C: 2006, 5021A: 2003

Metiletilcetona: EPA 8260 C: 2006, 5021 A: 2003

Revisores

Débora Fernandes da Silva

Chave de Validação: c635e63a898df6b3bd844ade5c0e5d1d
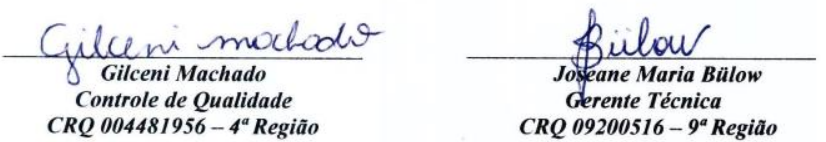


\section{RELATÓRIO DE ENSAIO N ${ }^{\circ}$ 292990/2014-0 - Piracicaba Processo Comercial $N^{\circ}$ 23961/2014-2}

\begin{tabular}{|l|l|}
\hline \multicolumn{2}{|c|}{ DADOS REFERENTES AO CLIENTE } \\
\hline Empresa solicitante: & Fundacao Parque de Alta Tecnologia da Regiao de Ipero e Adjacencias \\
\hline Endereço: & Rua Jose Antonio Scaciota, 165 - - Portal do Cedro - Iperó - SP - CEP: 18.560-000 . \\
\hline Nome do Solicitante: & Carla Marçal \\
\hline
\end{tabular}

\section{DADOS REFERENTES A AMOSTRA}

Identificação do Cliente: Amostra Rotulada como:

Coletor:

BSI 1

Data da entrada no laboratório:

Água Subterrânea Projeto Mestrado Interessado

\begin{tabular}{l|l} 
Data da coleta: & $02 / 11 / 2014$ 23:23:00
\end{tabular}

\section{RESULTADOS PARA A AMOSTRA}

\begin{tabular}{|c|c|c|c|c|c|c|}
\hline Parâmetros & CAS & Unidade & LQ & Resultados analíticos & Incerteza & Data do Ensaio \\
\hline 1,1,1-Tricloroetano & $71-55-6$ & $\mu \mathrm{g} / \mathrm{L}$ & 1 & $<1$ & n.a. & $13 / 11 / 201411: 23$ \\
\hline 1,1,2-Tricloroetano & $79-00-5$ & $\mu \mathrm{g} / \mathrm{L}$ & 1 & $<1$ & n.a. & $13 / 11 / 201411: 23$ \\
\hline 1,1,2,2-Tetracloroetano & $79-34-5$ & $\mu \mathrm{g} / \mathrm{L}$ & 1 & $<1$ & n.a. & 13/11/2014 11:23 \\
\hline 1,1-Dicloroetano & $75-34-3$ & $\mu \mathrm{g} / \mathrm{L}$ & 1 & $<1$ & n.a. & 13/11/2014 11:23 \\
\hline 1,1-Dicloroeteno & $75-35-4$ & $\mu \mathrm{g} / \mathrm{L}$ & 1 & $<1$ & n.a. & $13 / 11 / 201411: 23$ \\
\hline 1,1-Dicloropropeno & $563-58-6$ & $\mu \mathrm{g} / \mathrm{L}$ & 1 & $<1$ & n.a. & $13 / 11 / 201411: 23$ \\
\hline 1,2,3-Triclorobenzeno & $87-61-6$ & $\mu \mathrm{g} / \mathrm{L}$ & 1 & $<1$ & n.a. & $13 / 11 / 201411: 23$ \\
\hline 1,2,4-Triclorobenzeno & $120-82-1$ & $\mu \mathrm{g} / \mathrm{L}$ & 1 & $<1$ & n.a. & $13 / 11 / 201411: 23$ \\
\hline 1,2-Dibromo-3-Cloropropano & $96-12-8$ & $\mu \mathrm{g} / \mathrm{L}$ & 5 & $<5$ & n.a. & 13/11/2014 11:23 \\
\hline 1,2-Dicloroetano & $107-06-2$ & $\mu \mathrm{g} / \mathrm{L}$ & 1 & $<1$ & n.a. & 13/11/2014 11:23 \\
\hline 1,2-Dicloropropano & $78-87-5$ & $\mu \mathrm{g} / \mathrm{L}$ & 1 & $<1$ & n.a. & 13/11/2014 11:23 \\
\hline 1,3-Dicloropropano & $142-28-9$ & $\mu \mathrm{g} / \mathrm{L}$ & 5 & $<5$ & n.a. & 13/11/2014 11:23 \\
\hline 1,4-Diclorobenzeno & $106-46-7$ & $\mu \mathrm{g} / \mathrm{L}$ & 1 & $<1$ & n.a. & 13/11/2014 11:23 \\
\hline 2,2-Dicloropropano & 594-20-7 & $\mu \mathrm{g} / \mathrm{L}$ & 1 & $<1$ & n.a. & 13/11/2014 11:23 \\
\hline 4-Metil-2-Pentanona & $108-10-1$ & $\mu \mathrm{g} / \mathrm{L}$ & 5 & $<5$ & n.a. & $13 / 11 / 201411: 23$ \\
\hline Benzeno & $71-43-2$ & $\mu \mathrm{g} / \mathrm{L}$ & 1 & $<1$ & n.a. & 13/11/2014 11:23 \\
\hline Bromobenzeno & $108-86-1$ & $\mu \mathrm{g} / \mathrm{L}$ & 1 & $<1$ & n.a. & 13/11/2014 11:23 \\
\hline Bromodiclorometano & $75-27-4$ & $\mu \mathrm{g} / \mathrm{L}$ & 1 & $<1$ & n.a. & $13 / 11 / 201411: 23$ \\
\hline Bromofórmio & $75-25-2$ & $\mu \mathrm{g} / \mathrm{L}$ & 1 & $<1$ & n.a. & 13/11/2014 11:23 \\
\hline Bromoclorometano & $74-97-5$ & $\mu \mathrm{g} / \mathrm{L}$ & 5 & $<5$ & n.a. & $13 / 11 / 201411: 23$ \\
\hline Cis-1,2-Dicloroeteno & $156-59-2$ & $\mu \mathrm{g} / \mathrm{L}$ & 1 & $<1$ & n.a. & 13/11/2014 11:23 \\
\hline Cis-1,3-Dicloropropeno & $10061-01-5$ & $\mu \mathrm{g} / \mathrm{L}$ & 1 & $<1$ & n.a. & 13/11/2014 11:23 \\
\hline Diclorometano & $75-09-2$ & $\mu \mathrm{g} / \mathrm{L}$ & 1 & $<1$ & n.a. & 13/11/2014 11:23 \\
\hline Cloreto de Vinila & 75-01-4 & $\mu \mathrm{g} / \mathrm{L}$ & 1 & $<1$ & n.a. & $13 / 11 / 201411: 23$ \\
\hline Clorobenzeno & $108-90-7$ & $\mu \mathrm{g} / \mathrm{L}$ & 1 & $<1$ & n.a. & 13/11/2014 11:23 \\
\hline Cloroetano & $75-00-3$ & $\mu \mathrm{g} / \mathrm{L}$ & 1 & $<1$ & n.a. & $13 / 11 / 201411: 23$ \\
\hline Clorofórmio & $67-66-3$ & $\mu \mathrm{g} / \mathrm{L}$ & 1 & $<1$ & n.a. & 13/11/2014 11:23 \\
\hline Clorometano & $74-87-3$ & $\mu \mathrm{g} / \mathrm{L}$ & 10 & $<10$ & n.a. & $13 / 11 / 201411: 23$ \\
\hline Dibromoclorometano & $124-48-1$ & $\mu \mathrm{g} / \mathrm{L}$ & 1 & $<1$ & n.a. & 13/11/2014 11:23 \\
\hline Dissulfeto de Carbono & $75-15-0$ & $\mu \mathrm{g} / \mathrm{L}$ & 1 & $<1$ & n.a. & $13 / 11 / 201411: 23$ \\
\hline Estireno & $100-42-5$ & $\mu \mathrm{g} / \mathrm{L}$ & 1 & $<1$ & n.a. & 13/11/2014 11:23 \\
\hline Etilbenzeno & $100-41-4$ & $\mu \mathrm{g} / \mathrm{L}$ & 1 & $<1$ & n.a. & 13/11/2014 11:23 \\
\hline Hexaclorobutadieno & $87-68-3$ & $\mu \mathrm{g} / \mathrm{L}$ & 1 & $<1$ & n.a. & 13/11/2014 11:23 \\
\hline $\mathrm{m}, \mathrm{p}$-Xilenos & --- & $\mu \mathrm{g} / \mathrm{L}$ & 2 & $<2$ & n.a. & $13 / 11 / 201411: 23$ \\
\hline o-Xileno & $95-47-6$ & $\mu \mathrm{g} / \mathrm{L}$ & 1 & $<1$ & n.a. & $13 / 11 / 201411: 23$ \\
\hline p-Isopropiltolueno & $99-87-6$ & $\mu \mathrm{g} / \mathrm{L}$ & 1 & $<1$ & n.a. & $13 / 11 / 201411: 23$ \\
\hline Tetracloreto de Carbono & $56-23-5$ & $\mu \mathrm{g} / \mathrm{L}$ & 1 & $<1$ & n.a. & 13/11/2014 11:23 \\
\hline Tetracloroeteno & $127-18-4$ & $\mu \mathrm{g} / \mathrm{L}$ & 10 & 109 & 21 & 13/11/2014 11:23 \\
\hline Tolueno & $108-88-3$ & $\mu \mathrm{g} / \mathrm{L}$ & 1 & $<1$ & n.a. & $13 / 11 / 201411: 23$ \\
\hline Trans-1,2-Dicloroeteno & $156-60-5$ & $\mu \mathrm{g} / \mathrm{L}$ & 1 & $<1$ & n.a. & $13 / 11 / 201411: 23$ \\
\hline Tricloroeteno & $79-01-6$ & $\mu \mathrm{g} / \mathrm{L}$ & 1 & $<1$ & n.a. & 13/11/2014 11:23 \\
\hline 1,1,1,2-Tetracloroetano & $630-20-6$ & $\mu \mathrm{g} / \mathrm{L}$ & 1 & $<1$ & n.a. & $13 / 11 / 201411: 23$ \\
\hline
\end{tabular}




\begin{tabular}{|c|c|c|c|c|c|c|}
\hline Parâmetros & CAS & Unidade & LQ & Resultados analíticos & Incerteza & Data do Ensaio \\
\hline 1,2,3-Tricloropropano & $96-18-4$ & $\mu \mathrm{g} / \mathrm{L}$ & 5 & $<5$ & n.a. & 13/11/2014 11:23 \\
\hline 1,3,5-Trimetilbenzeno & $108-67-8$ & $\mu \mathrm{g} / \mathrm{L}$ & 1 & $<1$ & n.a. & 13/11/2014 11:23 \\
\hline 1,2,4-Trimetilbenzeno & $95-63-6$ & $\mu \mathrm{g} / \mathrm{L}$ & 1 & $<1$ & n.a. & $13 / 11 / 201411: 23$ \\
\hline 1,2-Dibromoetano & $106-93-4$ & $\mu \mathrm{g} / \mathrm{L}$ & 1 & $<1$ & n.a. & 13/11/2014 11:23 \\
\hline 1,2-Diclorobenzeno & $95-50-1$ & $\mu \mathrm{g} / \mathrm{L}$ & 1 & $<1$ & n.a. & $13 / 11 / 201411: 23$ \\
\hline 1,3-Diclorobenzeno & $541-73-1$ & $\mu \mathrm{g} / \mathrm{L}$ & 1 & $<1$ & n.a. & $13 / 11 / 201411: 23$ \\
\hline 2-Clorotolueno & $95-49-8$ & $\mu \mathrm{g} / \mathrm{L}$ & 1 & $<1$ & n.a. & $13 / 11 / 201411: 23$ \\
\hline Dibromometano & $74-95-3$ & $\mu \mathrm{g} / \mathrm{L}$ & 1 & $<1$ & n.a. & 13/11/2014 11:23 \\
\hline Metiletilcetona & 78-93-3 & $\mu \mathrm{g} / \mathrm{L}$ & 2500 & $<2500$ & n.a. & 13/11/2014 11:47 \\
\hline Naftaleno & $91-20-3$ & $\mu \mathrm{g} / \mathrm{L}$ & 1 & $<1$ & n.a. & $13 / 11 / 201411: 23$ \\
\hline n-Butilbenzeno & $104-51-8$ & $\mu \mathrm{g} / \mathrm{L}$ & 1 & $<1$ & n.a. & $13 / 11 / 201411: 23$ \\
\hline n-Propilbenzeno & $103-65-1$ & $\mu \mathrm{g} / \mathrm{L}$ & 1 & $<1$ & n.a. & $13 / 11 / 201411: 23$ \\
\hline 4-Clorotolueno & $106-43-4$ & $\mu \mathrm{g} / \mathrm{L}$ & 1 & $<1$ & n.a. & $13 / 11 / 201411: 23$ \\
\hline sec-Butilbenzeno & $135-98-8$ & $\mu \mathrm{g} / \mathrm{L}$ & 1 & $<1$ & n.a. & 13/11/2014 11:23 \\
\hline terc-Butilbenzeno & $98-06-6$ & $\mu \mathrm{g} / \mathrm{L}$ & 1 & $<1$ & n.a. & 13/11/2014 11:23 \\
\hline trans-1,3-Dicloropropeno & $10061-02-6$ & $\mu \mathrm{g} / \mathrm{L}$ & 1 & $<1$ & n.a. & $13 / 11 / 201411: 23$ \\
\hline Isopropilbenzeno & $98-82-8$ & $\mu \mathrm{g} / \mathrm{L}$ & 1 & $<1$ & n.a. & 13/11/2014 11:23 \\
\hline 1,3,5-Triclorobenzeno & $108-70-3$ & $\mu \mathrm{g} / \mathrm{L}$ & 1 & $<1$ & n.a. & 13/11/2014 11:23 \\
\hline
\end{tabular}

\section{CONTROLE DE QUALIDADE DO LABORATÓRIO}

302692/2014-0 - Branco de Análise - VOC - Água

\begin{tabular}{|c|c|}
\hline \multirow{2}{*}{\multicolumn{2}{|c|}{$\begin{array}{ll} & \text { Parâmetros } \\
1,1,1-\text { Tricloroetano } & \end{array}$}} \\
\hline & \\
\hline \multicolumn{2}{|l|}{ 1,1,2-Tricloroetano } \\
\hline \multicolumn{2}{|l|}{ 1,1,2,2-Tetracloroetano } \\
\hline \multicolumn{2}{|l|}{ 1,1-Dicloroetano } \\
\hline \multicolumn{2}{|l|}{ 1,1-Dicloroeteno } \\
\hline \multicolumn{2}{|l|}{ 1,1-Dicloropropeno } \\
\hline \multicolumn{2}{|l|}{ 1,2,3-Triclorobenzeno } \\
\hline \multicolumn{2}{|l|}{ 1,2,4-Triclorobenzeno } \\
\hline \multicolumn{2}{|l|}{ 1,3,5-Triclorobenzeno } \\
\hline \multicolumn{2}{|l|}{ 1,2-Dibromo-3-Cloropropano } \\
\hline \multicolumn{2}{|l|}{ 1,2-Dicloroetano } \\
\hline \multicolumn{2}{|l|}{ 1,2-Dicloropropano } \\
\hline \multicolumn{2}{|l|}{ 1,3-Dicloropropano } \\
\hline \multicolumn{2}{|l|}{ 1,4-Diclorobenzeno } \\
\hline \multicolumn{2}{|l|}{ 2,2-Dicloropropano } \\
\hline \multicolumn{2}{|l|}{ 4-Metil-2-Pentanona } \\
\hline \multicolumn{2}{|l|}{ Benzeno } \\
\hline \multicolumn{2}{|l|}{ Bromobenzeno } \\
\hline \multicolumn{2}{|l|}{ Bromodiclorometano } \\
\hline \multicolumn{2}{|l|}{ Bromofórmio } \\
\hline \multicolumn{2}{|l|}{ Cis-1,2-Dicloroeteno } \\
\hline \multicolumn{2}{|l|}{ Cis-1,3-Dicloropropeno } \\
\hline \multicolumn{2}{|l|}{ Diclorometano } \\
\hline \multicolumn{2}{|l|}{ Cloreto de Vinila } \\
\hline \multicolumn{2}{|l|}{ Clorobenzeno } \\
\hline \multicolumn{2}{|l|}{ Cloroetano } \\
\hline Clorofórmio & \\
\hline Clorometano & \\
\hline Dibromoclorometano & \\
\hline Dissulfeto de Carbono & \\
\hline Estireno & \\
\hline Etilbenzeno & \\
\hline Hexaclorobutadieno & \\
\hline m,p-Xilenos & \\
\hline o-Xileno & \\
\hline p-Isopropiltolueno & \\
\hline Tetracloreto de Carbono & \\
\hline Tetracloroeteno & \\
\hline Tolueno & \\
\hline Trans-1,2-Dicloroeteno & \\
\hline Tricloroeteno & \\
\hline Isopropilbenzeno & \\
\hline Bromoclorometano & \\
\hline
\end{tabular}

Controle de Qualidade - VOC - Água

\begin{tabular}{|c|c|c|}
\hline Unidade & LQ & Resultados analíticos \\
\hline$\mu \mathrm{g} / \mathrm{L}$ & 1 & $<1$ \\
\hline$\mu \mathrm{g} / \mathrm{L}$ & 1 & $<1$ \\
\hline$\mu \mathrm{g} / \mathrm{L}$ & 1 & $<1$ \\
\hline$\mu \mathrm{g} / \mathrm{L}$ & 1 & $<1$ \\
\hline$\mu g / L$ & 1 & $<1$ \\
\hline$\mu \mathrm{g} / \mathrm{L}$ & 1 & $<1$ \\
\hline$\mu \mathrm{g} / \mathrm{L}$ & 1 & $<1$ \\
\hline$\mu \mathrm{g} / \mathrm{L}$ & 1 & $<1$ \\
\hline$\mu \mathrm{g} / \mathrm{L}$ & 1 & $<1$ \\
\hline$\mu \mathrm{g} / \mathrm{L}$ & 5 & $<5$ \\
\hline$\mu \mathrm{g} / \mathrm{L}$ & 1 & $<1$ \\
\hline$\mu \mathrm{g} / \mathrm{L}$ & 1 & $<1$ \\
\hline$\mu \mathrm{g} / \mathrm{L}$ & 5 & $<5$ \\
\hline$\mu \mathrm{g} / \mathrm{L}$ & 1 & $<1$ \\
\hline$\mu \mathrm{g} / \mathrm{L}$ & 1 & $<1$ \\
\hline$\mu \mathrm{g} / \mathrm{L}$ & 5 & $<5$ \\
\hline$\mu \mathrm{g} / \mathrm{L}$ & 1 & $<1$ \\
\hline$\mu \mathrm{g} / \mathrm{L}$ & 1 & $<1$ \\
\hline$\mu \mathrm{g} / \mathrm{L}$ & 1 & $<1$ \\
\hline$\mu \mathrm{g} / \mathrm{L}$ & 1 & $<1$ \\
\hline$\mu \mathrm{g} / \mathrm{L}$ & 1 & $<1$ \\
\hline$\mu \mathrm{g} / \mathrm{L}$ & 1 & $<1$ \\
\hline$\mu \mathrm{g} / \mathrm{L}$ & 1 & $<1$ \\
\hline$\mu \mathrm{g} / \mathrm{L}$ & 1 & $<1$ \\
\hline$\mu \mathrm{g} / \mathrm{L}$ & 1 & $<1$ \\
\hline$\mu \mathrm{g} / \mathrm{L}$ & 1 & $<1$ \\
\hline$\mu \mathrm{g} / \mathrm{L}$ & 1 & $<1$ \\
\hline$\mu \mathrm{g} / \mathrm{L}$ & 10 & $<10$ \\
\hline$\mu \mathrm{g} / \mathrm{L}$ & 1 & $<1$ \\
\hline$\mu \mathrm{g} / \mathrm{L}$ & 1 & $<1$ \\
\hline$\mu \mathrm{g} / \mathrm{L}$ & 1 & $<1$ \\
\hline$\mu \mathrm{g} / \mathrm{L}$ & 1 & $<1$ \\
\hline$\mu \mathrm{g} / \mathrm{L}$ & 1 & $<1$ \\
\hline$\mu \mathrm{g} / \mathrm{L}$ & 2 & $<2$ \\
\hline$\mu \mathrm{g} / \mathrm{L}$ & 1 & $<1$ \\
\hline$\mu \mathrm{g} / \mathrm{L}$ & 1 & $<1$ \\
\hline$\mu \mathrm{g} / \mathrm{L}$ & 1 & $<1$ \\
\hline$\mu \mathrm{g} / \mathrm{L}$ & 1 & $<1$ \\
\hline$\mu \mathrm{g} / \mathrm{L}$ & 1 & $<1$ \\
\hline$\mu \mathrm{g} / \mathrm{L}$ & 1 & $<1$ \\
\hline$\mu \mathrm{g} / \mathrm{L}$ & 1 & $<1$ \\
\hline$\mu \mathrm{g} / \mathrm{L}$ & 1 & $<1$ \\
\hline$\mu \mathrm{g} / \mathrm{L}$ & 5 & $<5$ \\
\hline
\end{tabular}




\begin{tabular}{|c|c|c|c|c|}
\hline Parâmetros & $\begin{array}{l}\text { Quantidade } \\
\text { Adicionada }\end{array}$ & Unidade & $\begin{array}{c}\text { Resultado da } \\
\text { Recuperação (\%) }\end{array}$ & Faixa Aceitável de Recuperação (\%) \\
\hline \multicolumn{5}{|c|}{ 302694/2014-0 - Amostra Controle - VOC - Água } \\
\hline 1,1-Dicloroeteno & 20 & $\mu \mathrm{g} / \mathrm{L}$ & 100 & $70-130$ \\
\hline Benzeno & 20 & $\mu \mathrm{g} / \mathrm{L}$ & 125 & $70-130$ \\
\hline Tricloroeteno & 20 & $\mu \mathrm{g} / \mathrm{L}$ & 110 & $70-130$ \\
\hline Tolueno & 20 & $\mu \mathrm{g} / \mathrm{L}$ & 95 & $70-130$ \\
\hline Clorobenzeno & 20 & $\mu \mathrm{g} / \mathrm{L}$ & 105 & $70-130$ \\
\hline \multicolumn{5}{|c|}{$\begin{array}{l}\text { Surrogates } \\
\text { 302692/2014-0 - Branco de Análise - VOC - Água }\end{array}$} \\
\hline p-Bromofluorbenzeno & 20 & $\%$ & 76,5 & $70-130$ \\
\hline Dibromofluorometano & 20 & $\%$ & 130 & $70-130$ \\
\hline \multicolumn{5}{|c|}{ 302694/2014-0 - Amostra Controle - VOC - Água } \\
\hline p-Bromofluorbenzeno & 20 & $\%$ & 78,6 & $70-130$ \\
\hline Dibromofluorometano & 20 & $\%$ & 130 & $70-130$ \\
\hline \multicolumn{5}{|l|}{ 292990/2014-0 - BSI 1} \\
\hline Dibromofluorometano & 20 & $\%$ & 95,6 & $70-130$ \\
\hline p-Bromofluorbenzeno & 20 & $\%$ & 71,7 & $70-130$ \\
\hline
\end{tabular}

Notas

LQ = Limite de Quantificação.

n.a. $=$ Não Aplicável.

Abrangência

$\mathrm{O}(\mathrm{s})$ resultado(s) referem-se somente à(s) amostra(s) analisada(s).

Este Relatório de Ensaio só pode ser reproduzido por inteiro e sem nenhuma alteração.

Plano de Amostragem

Plano de amostragem de responsabilidade do interessado.

Responsabilidade Técnica

Os ensaios foram realizados na unidade da Bioagri Ambiental Ltda. - Matriz, situada na Rua Aljovil Martini, 177/201, Bairro Dois Córregos, Cep. 14420-833, Piracicaba/SP, registrada no CRQ 4 Região sob n⿳亠丷厂 $16082-\mathrm{F}$ e responsabilidade técnica do profissional Marcos Donizete Ceccatto, CRQ n ${ }^{\circ} 04364387,4^{\mathrm{a}}$.Região.

Referências Metodológicas

Análises foram realizadas conforme a última versão do Standard Methods for the Examination of Water \& Wastewater 22nd 2012(SMWW), EPA e ABNT (quando aplicável). VOC: EPA 8260 C: 2006, 5021A: 2003

Metiletilcetona: EPA 8260 C: 2006, 5021 A: 2003

Revisores

Débora Fernandes da Silva

Chave de Validação: 312e004d90a1bdf0efac8c76abd3dcea
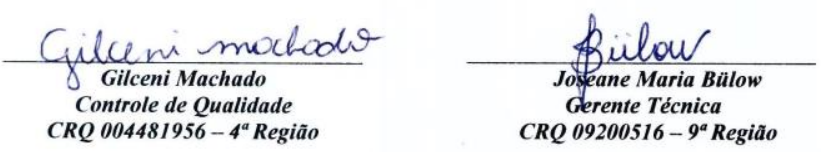


\section{RELATÓRIO DE ENSAIO N ${ }^{\circ}$ 292991/2014-0 - Piracicaba Processo Comercial $N^{\circ} 23961 / 2014-2$}

\begin{tabular}{|l|l|}
\hline \multicolumn{2}{|c|}{ DADOS REFERENTES AO CLIENTE } \\
\hline Empresa solicitante: & Fundacao Parque de Alta Tecnologia da Regiao de Ipero e Adjacencias \\
\hline Endereço: & Rua Jose Antonio Scaciota, 165 - - Portal do Cedro - Iperó - SP - CEP: 18.560-000 . \\
\hline Nome do Solicitante: & Carla Marçal \\
\hline
\end{tabular}

\section{DADOS REFERENTES A AMOSTRA}

Identificação do Cliente: Amostra Rotulada como:

Coletor:

BSI 2

Data da entrada no laboratório:

Água Subterrânea Projeto Mestrado

Interessado

\begin{tabular}{l|l} 
Data da coleta: & 02/11/2014 23:24:00
\end{tabular}

\section{RESULTADOS PARA A AMOSTRA}

\begin{tabular}{|c|c|c|c|c|c|c|}
\hline Parâmetros & CAS & Unidade & LQ & Resultados analíticos & Incerteza & Data do Ensaio \\
\hline 1,1,1-Tricloroetano & $71-55-6$ & $\mu \mathrm{g} / \mathrm{L}$ & 1 & $<1$ & n.a. & 14/11/2014 11:05 \\
\hline 1,1,2-Tricloroetano & $79-00-5$ & $\mu \mathrm{g} / \mathrm{L}$ & 1 & $<1$ & n.a. & 14/11/2014 11:05 \\
\hline 1,1,2,2-Tetracloroetano & $79-34-5$ & $\mu \mathrm{g} / \mathrm{L}$ & 1 & $<1$ & n.a. & 14/11/2014 11:05 \\
\hline 1,1-Dicloroetano & $75-34-3$ & $\mu \mathrm{g} / \mathrm{L}$ & 1 & $<1$ & n.a. & 14/11/2014 11:05 \\
\hline 1,1-Dicloroeteno & $75-35-4$ & $\mu \mathrm{g} / \mathrm{L}$ & 1 & $<1$ & n.a. & 14/11/2014 11:05 \\
\hline 1,1-Dicloropropeno & $563-58-6$ & $\mu \mathrm{g} / \mathrm{L}$ & 1 & $<1$ & n.a. & 14/11/2014 11:05 \\
\hline 1,2,3-Triclorobenzeno & $87-61-6$ & $\mu \mathrm{g} / \mathrm{L}$ & 1 & $<1$ & n.a. & 14/11/2014 11:05 \\
\hline 1,2,4-Triclorobenzeno & $120-82-1$ & $\mu \mathrm{g} / \mathrm{L}$ & 1 & $<1$ & n.a. & 14/11/2014 11:05 \\
\hline 1,2-Dibromo-3-Cloropropano & $96-12-8$ & $\mu \mathrm{g} / \mathrm{L}$ & 5 & $<5$ & n.a. & 14/11/2014 11:05 \\
\hline 1,2-Dicloroetano & $107-06-2$ & $\mu \mathrm{g} / \mathrm{L}$ & 1 & $<1$ & n.a. & 14/11/2014 11:05 \\
\hline 1,2-Dicloropropano & $78-87-5$ & $\mu \mathrm{g} / \mathrm{L}$ & 1 & $<1$ & n.a. & 14/11/2014 11:05 \\
\hline 1,3-Dicloropropano & $142-28-9$ & $\mu \mathrm{g} / \mathrm{L}$ & 5 & $<5$ & n.a. & 14/11/2014 11:05 \\
\hline 1,4-Diclorobenzeno & $106-46-7$ & $\mu \mathrm{g} / \mathrm{L}$ & 1 & $<1$ & n.a. & 14/11/2014 11:05 \\
\hline 2,2-Dicloropropano & 594-20-7 & $\mu \mathrm{g} / \mathrm{L}$ & 1 & $<1$ & n.a. & 14/11/2014 11:05 \\
\hline 4-Metil-2-Pentanona & $108-10-1$ & $\mu \mathrm{g} / \mathrm{L}$ & 5 & $<5$ & n.a. & 14/11/2014 11:05 \\
\hline Benzeno & $71-43-2$ & $\mu \mathrm{g} / \mathrm{L}$ & 1 & $<1$ & n.a. & 14/11/2014 11:05 \\
\hline Bromobenzeno & $108-86-1$ & $\mu \mathrm{g} / \mathrm{L}$ & 1 & $<1$ & n.a. & 14/11/2014 11:05 \\
\hline Bromodiclorometano & $75-27-4$ & $\mu \mathrm{g} / \mathrm{L}$ & 1 & $<1$ & n.a. & 14/11/2014 11:05 \\
\hline Bromofórmio & $75-25-2$ & $\mu \mathrm{g} / \mathrm{L}$ & 1 & $<1$ & n.a. & 14/11/2014 11:05 \\
\hline Bromoclorometano & $74-97-5$ & $\mu \mathrm{g} / \mathrm{L}$ & 5 & $<5$ & n.a. & 14/11/2014 11:05 \\
\hline Cis-1,2-Dicloroeteno & $156-59-2$ & $\mu \mathrm{g} / \mathrm{L}$ & 1 & $<1$ & n.a. & 14/11/2014 11:05 \\
\hline Cis-1,3-Dicloropropeno & $10061-01-5$ & $\mu \mathrm{g} / \mathrm{L}$ & 1 & $<1$ & n.a. & 14/11/2014 11:05 \\
\hline Diclorometano & $75-09-2$ & $\mu \mathrm{g} / \mathrm{L}$ & 1 & $<1$ & n.a. & 14/11/2014 11:05 \\
\hline Cloreto de Vinila & $75-01-4$ & $\mu \mathrm{g} / \mathrm{L}$ & 1 & $<1$ & n.a. & 14/11/2014 11:05 \\
\hline Clorobenzeno & $108-90-7$ & $\mu \mathrm{g} / \mathrm{L}$ & 1 & $<1$ & n.a. & 14/11/2014 11:05 \\
\hline Cloroetano & $75-00-3$ & $\mu \mathrm{g} / \mathrm{L}$ & 1 & $<1$ & n.a. & 14/11/2014 11:05 \\
\hline Clorofórmio & $67-66-3$ & $\mu \mathrm{g} / \mathrm{L}$ & 1 & $<1$ & n.a. & 14/11/2014 11:05 \\
\hline Clorometano & $74-87-3$ & $\mu \mathrm{g} / \mathrm{L}$ & 10 & $<10$ & n.a. & 14/11/2014 11:05 \\
\hline Dibromoclorometano & $124-48-1$ & $\mu \mathrm{g} / \mathrm{L}$ & 1 & $<1$ & n.a. & 14/11/2014 11:05 \\
\hline Dissulfeto de Carbono & $75-15-0$ & $\mu \mathrm{g} / \mathrm{L}$ & 1 & $<1$ & n.a. & 14/11/2014 11:05 \\
\hline Estireno & $100-42-5$ & $\mu \mathrm{g} / \mathrm{L}$ & 1 & $<1$ & n.a. & 14/11/2014 11:05 \\
\hline Etilbenzeno & $100-41-4$ & $\mu \mathrm{g} / \mathrm{L}$ & 1 & $<1$ & n.a. & 14/11/2014 11:05 \\
\hline Hexaclorobutadieno & $87-68-3$ & $\mu \mathrm{g} / \mathrm{L}$ & 1 & $<1$ & n.a. & 14/11/2014 11:05 \\
\hline m,p-Xilenos & --- & $\mu \mathrm{g} / \mathrm{L}$ & 2 & $<2$ & n.a. & 14/11/2014 11:05 \\
\hline o-Xileno & $95-47-6$ & $\mu \mathrm{g} / \mathrm{L}$ & 1 & $<1$ & n.a. & 14/11/2014 11:05 \\
\hline p-Isopropiltolueno & $99-87-6$ & $\mu \mathrm{g} / \mathrm{L}$ & 1 & $<1$ & n.a. & 14/11/2014 11:05 \\
\hline Tetracloreto de Carbono & $56-23-5$ & $\mu \mathrm{g} / \mathrm{L}$ & 1 & $<1$ & n.a. & 14/11/2014 11:05 \\
\hline Tetracloroeteno & $127-18-4$ & $\mu \mathrm{g} / \mathrm{L}$ & 10 & 111 & 21 & 14/11/2014 11:05 \\
\hline Tolueno & $108-88-3$ & $\mu \mathrm{g} / \mathrm{L}$ & 1 & $<1$ & n.a. & 14/11/2014 11:05 \\
\hline Trans-1,2-Dicloroeteno & $156-60-5$ & $\mu \mathrm{g} / \mathrm{L}$ & 1 & $<1$ & n.a. & 14/11/2014 11:05 \\
\hline Tricloroeteno & $79-01-6$ & $\mu \mathrm{g} / \mathrm{L}$ & 1 & $<1$ & n.a. & 14/11/2014 11:05 \\
\hline 1,1,1,2-Tetracloroetano & $630-20-6$ & $\mu \mathrm{g} / \mathrm{L}$ & 1 & $<1$ & n.a. & 14/11/2014 11:05 \\
\hline
\end{tabular}




\begin{tabular}{|c|c|c|c|c|c|c|}
\hline Parâmetros & CAS & Unidade & LQ & Resultados analíticos & Incerteza & Data do Ensaio \\
\hline 1,2,3-Tricloropropano & $96-18-4$ & $\mu \mathrm{g} / \mathrm{L}$ & 5 & $<5$ & n.a. & 14/11/2014 11:05 \\
\hline 1,3,5-Trimetilbenzeno & $108-67-8$ & $\mu \mathrm{g} / \mathrm{L}$ & 1 & $<1$ & n.a. & 14/11/2014 11:05 \\
\hline 1,2,4-Trimetilbenzeno & $95-63-6$ & $\mu \mathrm{g} / \mathrm{L}$ & 1 & $<1$ & n.a. & 14/11/2014 11:05 \\
\hline 1,2-Dibromoetano & $106-93-4$ & $\mu \mathrm{g} / \mathrm{L}$ & 1 & $<1$ & n.a. & 14/11/2014 11:05 \\
\hline 1,2-Diclorobenzeno & $95-50-1$ & $\mu \mathrm{g} / \mathrm{L}$ & 1 & $<1$ & n.a. & 14/11/2014 11:05 \\
\hline 1,3-Diclorobenzeno & $541-73-1$ & $\mu \mathrm{g} / \mathrm{L}$ & 1 & $<1$ & n.a. & 14/11/2014 11:05 \\
\hline 2-Clorotolueno & $95-49-8$ & $\mu \mathrm{g} / \mathrm{L}$ & 1 & $<1$ & n.a. & 14/11/2014 11:05 \\
\hline Dibromometano & $74-95-3$ & $\mu \mathrm{g} / \mathrm{L}$ & 1 & $<1$ & n.a. & 14/11/2014 11:05 \\
\hline Metiletilcetona & 78-93-3 & $\mu \mathrm{g} / \mathrm{L}$ & 2500 & $<2500$ & n.a. & $14 / 11 / 201410: 45$ \\
\hline Naftaleno & $91-20-3$ & $\mu \mathrm{g} / \mathrm{L}$ & 1 & $<1$ & n.a. & 14/11/2014 11:05 \\
\hline n-Butilbenzeno & $104-51-8$ & $\mu \mathrm{g} / \mathrm{L}$ & 1 & $<1$ & n.a. & 14/11/2014 11:05 \\
\hline n-Propilbenzeno & $103-65-1$ & $\mu \mathrm{g} / \mathrm{L}$ & 1 & $<1$ & n.a. & 14/11/2014 11:05 \\
\hline 4-Clorotolueno & $106-43-4$ & $\mu \mathrm{g} / \mathrm{L}$ & 1 & $<1$ & n.a. & 14/11/2014 11:05 \\
\hline sec-Butilbenzeno & $135-98-8$ & $\mu \mathrm{g} / \mathrm{L}$ & 1 & $<1$ & n.a. & 14/11/2014 11:05 \\
\hline terc-Butilbenzeno & $98-06-6$ & $\mu \mathrm{g} / \mathrm{L}$ & 1 & $<1$ & n.a. & 14/11/2014 11:05 \\
\hline trans-1,3-Dicloropropeno & $10061-02-6$ & $\mu \mathrm{g} / \mathrm{L}$ & 1 & $<1$ & n.a. & 14/11/2014 11:05 \\
\hline Isopropilbenzeno & $98-82-8$ & $\mu \mathrm{g} / \mathrm{L}$ & 1 & $<1$ & n.a. & 14/11/2014 11:05 \\
\hline 1,3,5-Triclorobenzeno & $108-70-3$ & $\mu \mathrm{g} / \mathrm{L}$ & 1 & $<1$ & n.a. & 14/11/2014 11:05 \\
\hline
\end{tabular}

\section{CONTROLE DE QUALIDADE DO LABORATÓRIO}

302692/2014-0 - Branco de Análise - VOC - Água

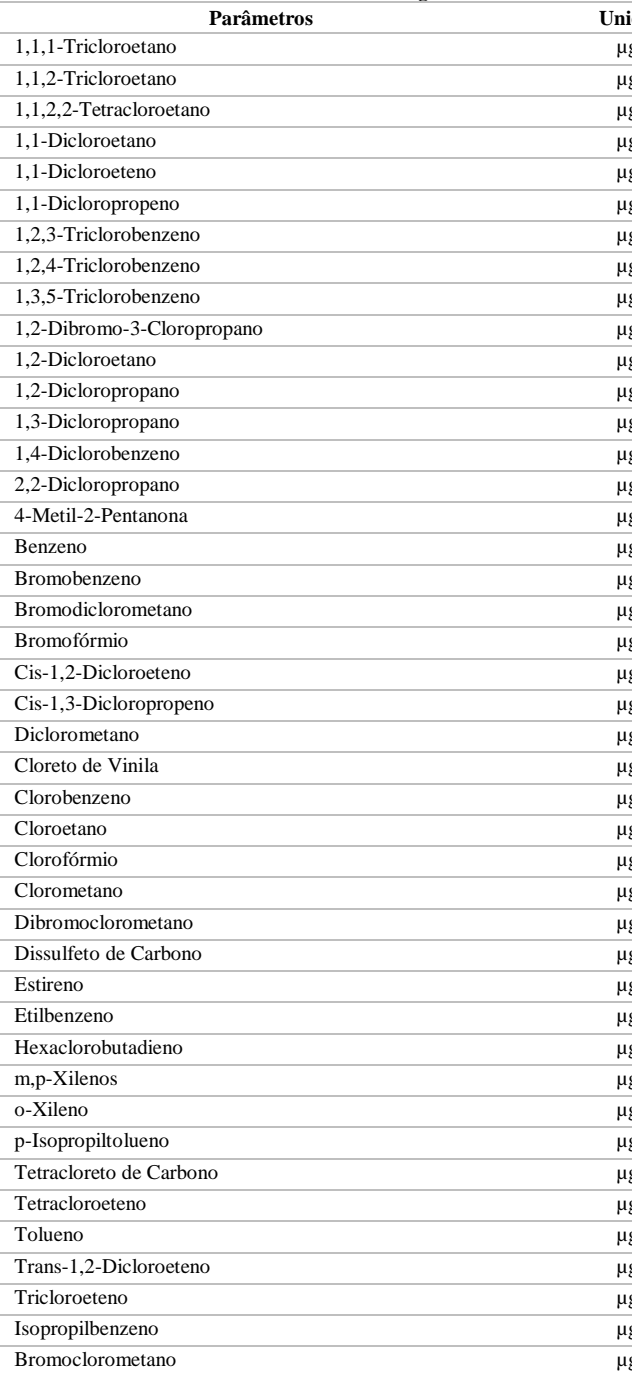

Controle de Qualidade - VOC - Água

\begin{tabular}{|c|c|c|}
\hline Unidade & LQ & Resultados analíticos \\
\hline$\mu \mathrm{g} / \mathrm{L}$ & 1 & $<1$ \\
\hline$\mu \mathrm{g} / \mathrm{L}$ & 1 & $<1$ \\
\hline$\mu \mathrm{g} / \mathrm{L}$ & 1 & $<1$ \\
\hline$\mu \mathrm{g} / \mathrm{L}$ & 1 & $<1$ \\
\hline$\mu \mathrm{g} / \mathrm{L}$ & 1 & $<1$ \\
\hline$\mu \mathrm{g} / \mathrm{L}$ & 1 & $<1$ \\
\hline$\mu \mathrm{g} / \mathrm{L}$ & 1 & $<1$ \\
\hline$\mu \mathrm{g} / \mathrm{L}$ & 1 & $<1$ \\
\hline$\mu \mathrm{g} / \mathrm{L}$ & 1 & $<1$ \\
\hline$\mu \mathrm{g} / \mathrm{L}$ & 5 & $<5$ \\
\hline$\mu \mathrm{g} / \mathrm{L}$ & 1 & $<1$ \\
\hline$\mu \mathrm{g} / \mathrm{L}$ & 1 & $<1$ \\
\hline$\mu \mathrm{g} / \mathrm{L}$ & 5 & $<5$ \\
\hline$\mu \mathrm{g} / \mathrm{L}$ & 1 & $<1$ \\
\hline$\mu \mathrm{g} / \mathrm{L}$ & 1 & $<1$ \\
\hline$\mu \mathrm{g} / \mathrm{L}$ & 5 & $<5$ \\
\hline$\mu \mathrm{g} / \mathrm{L}$ & 1 & $<1$ \\
\hline$\mu \mathrm{g} / \mathrm{L}$ & 1 & $<1$ \\
\hline$\mu \mathrm{g} / \mathrm{L}$ & 1 & $<1$ \\
\hline$\mu \mathrm{g} / \mathrm{L}$ & 1 & $<1$ \\
\hline$\mu \mathrm{g} / \mathrm{L}$ & 1 & $<1$ \\
\hline$\mu \mathrm{g} / \mathrm{L}$ & 1 & $<1$ \\
\hline$\mu \mathrm{g} / \mathrm{L}$ & 1 & $<1$ \\
\hline$\mu \mathrm{g} / \mathrm{L}$ & 1 & $<1$ \\
\hline$\mu \mathrm{g} / \mathrm{L}$ & 1 & $<1$ \\
\hline$\mu \mathrm{g} / \mathrm{L}$ & 1 & $<1$ \\
\hline$\mu \mathrm{g} / \mathrm{L}$ & 1 & $<1$ \\
\hline$\mu \mathrm{g} / \mathrm{L}$ & 10 & $<10$ \\
\hline$\mu \mathrm{g} / \mathrm{L}$ & 1 & $<1$ \\
\hline$\mu \mathrm{g} / \mathrm{L}$ & 1 & $<1$ \\
\hline$\mu \mathrm{g} / \mathrm{L}$ & 1 & $<1$ \\
\hline$\mu \mathrm{g} / \mathrm{L}$ & 1 & $<1$ \\
\hline$\mu \mathrm{g} / \mathrm{L}$ & 1 & $<1$ \\
\hline$\mu \mathrm{g} / \mathrm{L}$ & 2 & $<2$ \\
\hline$\mu \mathrm{g} / \mathrm{L}$ & 1 & $<1$ \\
\hline$\mu \mathrm{g} / \mathrm{L}$ & 1 & $<1$ \\
\hline$\mu \mathrm{g} / \mathrm{L}$ & 1 & $<1$ \\
\hline$\mu \mathrm{g} / \mathrm{L}$ & 1 & $<1$ \\
\hline$\mu \mathrm{g} / \mathrm{L}$ & 1 & $<1$ \\
\hline$\mu \mathrm{g} / \mathrm{L}$ & 1 & $<1$ \\
\hline$\mu \mathrm{g} / \mathrm{L}$ & 1 & $<1$ \\
\hline$\mu \mathrm{g} / \mathrm{L}$ & 1 & $<1$ \\
\hline$\mu \mathrm{g} / \mathrm{L}$ & 5 & $<5$ \\
\hline
\end{tabular}




\begin{tabular}{|c|c|c|c|c|}
\hline Parâmetros & $\begin{array}{l}\text { Quantidade } \\
\text { Adicionada }\end{array}$ & Unidade & $\begin{array}{c}\text { Resultado da } \\
\text { Recuperação (\%) }\end{array}$ & Faixa Aceitável de Recuperação (\%) \\
\hline \multicolumn{5}{|c|}{ 302694/2014-0 - Amostra Controle - VOC - Água } \\
\hline 1,1-Dicloroeteno & 20 & $\mu \mathrm{g} / \mathrm{L}$ & 100 & $70-130$ \\
\hline Benzeno & 20 & $\mu \mathrm{g} / \mathrm{L}$ & 125 & $70-130$ \\
\hline Tricloroeteno & 20 & $\mu \mathrm{g} / \mathrm{L}$ & 110 & $70-130$ \\
\hline Tolueno & 20 & $\mu \mathrm{g} / \mathrm{L}$ & 95 & $70-130$ \\
\hline Clorobenzeno & 20 & $\mu \mathrm{g} / \mathrm{L}$ & 105 & $70-130$ \\
\hline \multicolumn{5}{|c|}{$\begin{array}{l}\text { Surrogates } \\
\text { 302692/2014-0 - Branco de Análise - VOC - Água }\end{array}$} \\
\hline p-Bromofluorbenzeno & 20 & $\%$ & 76,5 & $70-130$ \\
\hline Dibromofluorometano & 20 & $\%$ & 130 & $70-130$ \\
\hline \multicolumn{5}{|c|}{ 302694/2014-0 - Amostra Controle - VOC - Água } \\
\hline p-Bromofluorbenzeno & 20 & $\%$ & 78,6 & $70-130$ \\
\hline Dibromofluorometano & 20 & $\%$ & 130 & $70-130$ \\
\hline \multicolumn{5}{|l|}{ 292991/2014-0 - BSI 2} \\
\hline Dibromofluorometano & 20 & $\%$ & 97,7 & $70-130$ \\
\hline p-Bromofluorbenzeno & 20 & $\%$ & 70,1 & $70-130$ \\
\hline
\end{tabular}

Notas

LQ = Limite de Quantificação.

n.a. $=$ Não Aplicável.

Abrangência

$\mathrm{O}(\mathrm{s})$ resultado(s) referem-se somente à(s) amostra(s) analisada(s).

Este Relatório de Ensaio só pode ser reproduzido por inteiro e sem nenhuma alteração.

Plano de Amostragem

Plano de amostragem de responsabilidade do interessado.

Responsabilidade Técnica

Os ensaios foram realizados na unidade da Bioagri Ambiental Ltda. - Matriz, situada na Rua Aljovil Martini, 177/201, Bairro Dois Córregos, Cep. 14420-833, Piracicaba/SP, registrada no CRQ 4 Região sob no $16082-\mathrm{F}$ e responsabilidade técnica do profissional Marcos Donizete Ceccatto, CRQ n ${ }^{\circ} 04364387,4^{\mathrm{a}}$.Região.

Referências Metodológicas

Análises foram realizadas conforme a última versão do Standard Methods for the Examination of Water \& Wastewater 22nd 2012(SMWW), EPA e ABNT (quando aplicável). VOC: EPA 8260 C: 2006, 5021A: 2003

Metiletilcetona: EPA 8260 C: 2006, 5021 A: 2003

Revisores

Débora Fernandes da Silva

Chave de Validação: dc82091132cae36a38a88fd04c2e4f49
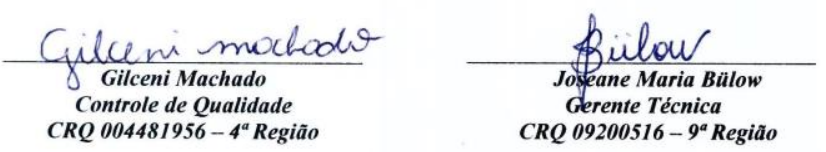


\section{RELATÓRIO DE ENSAIO N ${ }^{\circ}$ 292992/2014-0 - Piracicaba Processo Comercial $N^{\circ}$ 23961/2014-2}

\begin{tabular}{|l|l|}
\hline \multicolumn{2}{|c|}{ DADOS REFERENTES AO CLIENTE } \\
\hline Empresa solicitante: & Fundacao Parque de Alta Tecnologia da Regiao de Ipero e Adjacencias \\
\hline Endereço: & Rua Jose Antonio Scaciota, 165 - - Portal do Cedro - Iperó - SP - CEP: 18.560-000 . \\
\hline Nome do Solicitante: & Carla Marçal \\
\hline
\end{tabular}

\section{DADOS REFERENTES A AMOSTRA}

Identificação do Cliente: Amostra Rotulada como:

Coletor:

BSI 3

Data da entrada no laboratório:

Água Subterrânea Projeto Mestrado

Interessado

\begin{tabular}{l|l} 
Data da coleta: & 02/11/2014 23:25:00
\end{tabular}

\section{RESULTADOS PARA A AMOSTRA}

\begin{tabular}{|c|c|c|c|c|c|c|}
\hline Parâmetros & CAS & Unidade & LQ & Resultados analíticos & Incerteza & Data do Ensaio \\
\hline 1,1,1-Tricloroetano & $71-55-6$ & $\mu \mathrm{g} / \mathrm{L}$ & 1 & $<1$ & n.a. & 14/11/2014 01:24 \\
\hline 1,1,2-Tricloroetano & $79-00-5$ & $\mu \mathrm{g} / \mathrm{L}$ & 1 & $<1$ & n.a. & 14/11/2014 01:24 \\
\hline 1,1,2,2-Tetracloroetano & $79-34-5$ & $\mu \mathrm{g} / \mathrm{L}$ & 1 & $<1$ & n.a. & 14/11/2014 01:24 \\
\hline 1,1-Dicloroetano & $75-34-3$ & $\mu \mathrm{g} / \mathrm{L}$ & 1 & $<1$ & n.a. & 14/11/2014 01:24 \\
\hline 1,1-Dicloroeteno & $75-35-4$ & $\mu \mathrm{g} / \mathrm{L}$ & 1 & $<1$ & n.a. & 14/11/2014 01:24 \\
\hline 1,1-Dicloropropeno & $563-58-6$ & $\mu \mathrm{g} / \mathrm{L}$ & 1 & $<1$ & n.a. & 14/11/2014 01:24 \\
\hline 1,2,3-Triclorobenzeno & $87-61-6$ & $\mu \mathrm{g} / \mathrm{L}$ & 1 & $<1$ & n.a. & 14/11/2014 01:24 \\
\hline 1,2,4-Triclorobenzeno & $120-82-1$ & $\mu \mathrm{g} / \mathrm{L}$ & 1 & $<1$ & n.a. & 14/11/2014 01:24 \\
\hline 1,2-Dibromo-3-Cloropropano & $96-12-8$ & $\mu \mathrm{g} / \mathrm{L}$ & 5 & $<5$ & n.a. & 14/11/2014 01:24 \\
\hline 1,2-Dicloroetano & $107-06-2$ & $\mu \mathrm{g} / \mathrm{L}$ & 1 & $<1$ & n.a. & 14/11/2014 01:24 \\
\hline 1,2-Dicloropropano & $78-87-5$ & $\mu \mathrm{g} / \mathrm{L}$ & 1 & $<1$ & n.a. & 14/11/2014 01:24 \\
\hline 1,3-Dicloropropano & $142-28-9$ & $\mu \mathrm{g} / \mathrm{L}$ & 5 & $<5$ & n.a. & 14/11/2014 01:24 \\
\hline 1,4-Diclorobenzeno & $106-46-7$ & $\mu \mathrm{g} / \mathrm{L}$ & 1 & $<1$ & n.a. & 14/11/2014 01:24 \\
\hline 2,2-Dicloropropano & $594-20-7$ & $\mu \mathrm{g} / \mathrm{L}$ & 1 & $<1$ & n.a. & 14/11/2014 01:24 \\
\hline 4-Metil-2-Pentanona & $108-10-1$ & $\mu \mathrm{g} / \mathrm{L}$ & 5 & $<5$ & n.a. & 14/11/2014 01:24 \\
\hline Benzeno & $71-43-2$ & $\mu \mathrm{g} / \mathrm{L}$ & 1 & $<1$ & n.a. & 14/11/2014 01:24 \\
\hline Bromobenzeno & $108-86-1$ & $\mu \mathrm{g} / \mathrm{L}$ & 1 & $<1$ & n.a. & 14/11/2014 01:24 \\
\hline Bromodiclorometano & $75-27-4$ & $\mu \mathrm{g} / \mathrm{L}$ & 1 & $<1$ & n.a. & 14/11/2014 01:24 \\
\hline Bromofórmio & $75-25-2$ & $\mu \mathrm{g} / \mathrm{L}$ & 1 & $<1$ & n.a. & 14/11/2014 01:24 \\
\hline Bromoclorometano & $74-97-5$ & $\mu \mathrm{g} / \mathrm{L}$ & 5 & $<5$ & n.a. & 14/11/2014 01:24 \\
\hline Cis-1,2-Dicloroeteno & $156-59-2$ & $\mu \mathrm{g} / \mathrm{L}$ & 1 & $<1$ & n.a. & 14/11/2014 01:24 \\
\hline Cis-1,3-Dicloropropeno & $10061-01-5$ & $\mu \mathrm{g} / \mathrm{L}$ & 1 & $<1$ & n.a. & 14/11/2014 01:24 \\
\hline Diclorometano & $75-09-2$ & $\mu \mathrm{g} / \mathrm{L}$ & 1 & $<1$ & n.a. & 14/11/2014 01:24 \\
\hline Cloreto de Vinila & $75-01-4$ & $\mu \mathrm{g} / \mathrm{L}$ & 1 & $<1$ & n.a. & 14/11/2014 01:24 \\
\hline Clorobenzeno & $108-90-7$ & $\mu \mathrm{g} / \mathrm{L}$ & 1 & $<1$ & n.a. & $14 / 11 / 201401: 24$ \\
\hline Cloroetano & $75-00-3$ & $\mu \mathrm{g} / \mathrm{L}$ & 1 & $<1$ & n.a. & 14/11/2014 01:24 \\
\hline Clorofórmio & $67-66-3$ & $\mu \mathrm{g} / \mathrm{L}$ & 1 & $<1$ & n.a. & 14/11/2014 01:24 \\
\hline Clorometano & $74-87-3$ & $\mu \mathrm{g} / \mathrm{L}$ & 10 & $<10$ & n.a. & 14/11/2014 01:24 \\
\hline Dibromoclorometano & $124-48-1$ & $\mu \mathrm{g} / \mathrm{L}$ & 1 & $<1$ & n.a. & $14 / 11 / 201401: 24$ \\
\hline Dissulfeto de Carbono & $75-15-0$ & $\mu \mathrm{g} / \mathrm{L}$ & 1 & $<1$ & n.a. & 14/11/2014 01:24 \\
\hline Estireno & $100-42-5$ & $\mu \mathrm{g} / \mathrm{L}$ & 1 & $<1$ & n.a. & 14/11/2014 01:24 \\
\hline Etilbenzeno & $100-41-4$ & $\mu \mathrm{g} / \mathrm{L}$ & 1 & $<1$ & n.a. & 14/11/2014 01:24 \\
\hline Hexaclorobutadieno & $87-68-3$ & $\mu \mathrm{g} / \mathrm{L}$ & 1 & $<1$ & n.a. & 14/11/2014 01:24 \\
\hline m,p-Xilenos & --- & $\mu \mathrm{g} / \mathrm{L}$ & 2 & $<2$ & n.a. & 14/11/2014 01:24 \\
\hline o-Xileno & $95-47-6$ & $\mu \mathrm{g} / \mathrm{L}$ & 1 & $<1$ & n.a. & 14/11/2014 01:24 \\
\hline p-Isopropiltolueno & $99-87-6$ & $\mu \mathrm{g} / \mathrm{L}$ & 1 & $<1$ & n.a. & 14/11/2014 01:24 \\
\hline Tetracloreto de Carbono & $56-23-5$ & $\mu \mathrm{g} / \mathrm{L}$ & 1 & $<1$ & n.a. & 14/11/2014 01:24 \\
\hline Tetracloroeteno & $127-18-4$ & $\mu \mathrm{g} / \mathrm{L}$ & 1 & 69,6 & 13 & 14/11/2014 01:24 \\
\hline Tolueno & $108-88-3$ & $\mu \mathrm{g} / \mathrm{L}$ & 1 & $<1$ & n.a. & 14/11/2014 01:24 \\
\hline Trans-1,2-Dicloroeteno & $156-60-5$ & $\mu \mathrm{g} / \mathrm{L}$ & 1 & $<1$ & n.a. & 14/11/2014 01:24 \\
\hline Tricloroeteno & $79-01-6$ & $\mu \mathrm{g} / \mathrm{L}$ & 1 & $<1$ & n.a. & 14/11/2014 01:24 \\
\hline 1,1,1,2-Tetracloroetano & $630-20-6$ & $\mu \mathrm{g} / \mathrm{L}$ & 1 & $<1$ & n.a. & 14/11/2014 01:24 \\
\hline
\end{tabular}




\begin{tabular}{|c|c|c|c|c|c|c|}
\hline Parâmetros & CAS & Unidade & LQ & Resultados analíticos & Incerteza & Data do Ensaio \\
\hline 1,2,3-Tricloropropano & $96-18-4$ & $\mu \mathrm{g} / \mathrm{L}$ & 5 & $<5$ & n.a. & 14/11/2014 01:24 \\
\hline 1,3,5-Trimetilbenzeno & $108-67-8$ & $\mu \mathrm{g} / \mathrm{L}$ & 1 & $<1$ & n.a. & $14 / 11 / 201401: 24$ \\
\hline 1,2,4-Trimetilbenzeno & $95-63-6$ & $\mu \mathrm{g} / \mathrm{L}$ & 1 & $<1$ & n.a. & 14/11/2014 01:24 \\
\hline 1,2-Dibromoetano & $106-93-4$ & $\mu \mathrm{g} / \mathrm{L}$ & 1 & $<1$ & n.a. & 14/11/2014 01:24 \\
\hline 1,2-Diclorobenzeno & $95-50-1$ & $\mu \mathrm{g} / \mathrm{L}$ & 1 & $<1$ & n.a. & 14/11/2014 01:24 \\
\hline 1,3-Diclorobenzeno & $541-73-1$ & $\mu \mathrm{g} / \mathrm{L}$ & 1 & $<1$ & n.a. & $14 / 11 / 201401: 24$ \\
\hline 2-Clorotolueno & $95-49-8$ & $\mu \mathrm{g} / \mathrm{L}$ & 1 & $<1$ & n.a. & $14 / 11 / 201401: 24$ \\
\hline Dibromometano & $74-95-3$ & $\mu \mathrm{g} / \mathrm{L}$ & 1 & $<1$ & n.a. & 14/11/2014 01:24 \\
\hline Metiletilcetona & 78-93-3 & $\mu \mathrm{g} / \mathrm{L}$ & 2500 & $<2500$ & n.a. & $14 / 11 / 201401: 24$ \\
\hline Naftaleno & $91-20-3$ & $\mu \mathrm{g} / \mathrm{L}$ & 1 & $<1$ & n.a. & $14 / 11 / 201401: 24$ \\
\hline n-Butilbenzeno & $104-51-8$ & $\mu \mathrm{g} / \mathrm{L}$ & 1 & $<1$ & n.a. & $14 / 11 / 201401: 24$ \\
\hline n-Propilbenzeno & $103-65-1$ & $\mu \mathrm{g} / \mathrm{L}$ & 1 & $<1$ & n.a. & 14/11/2014 01:24 \\
\hline 4-Clorotolueno & $106-43-4$ & $\mu \mathrm{g} / \mathrm{L}$ & 1 & $<1$ & n.a. & $14 / 11 / 201401: 24$ \\
\hline sec-Butilbenzeno & $135-98-8$ & $\mu \mathrm{g} / \mathrm{L}$ & 1 & $<1$ & n.a. & 14/11/2014 01:24 \\
\hline terc-Butilbenzeno & $98-06-6$ & $\mu \mathrm{g} / \mathrm{L}$ & 1 & $<1$ & n.a. & 14/11/2014 01:24 \\
\hline trans-1,3-Dicloropropeno & $10061-02-6$ & $\mu \mathrm{g} / \mathrm{L}$ & 1 & $<1$ & n.a. & $14 / 11 / 201401: 24$ \\
\hline Isopropilbenzeno & $98-82-8$ & $\mu \mathrm{g} / \mathrm{L}$ & 1 & $<1$ & n.a. & 14/11/2014 01:24 \\
\hline 1,3,5-Triclorobenzeno & $108-70-3$ & $\mu \mathrm{g} / \mathrm{L}$ & 1 & $<1$ & n.a. & 14/11/2014 01:24 \\
\hline
\end{tabular}

\section{CONTROLE DE QUALIDADE DO LABORATÓRIO}

302692/2014-0 - Branco de Análise - VOC - Água

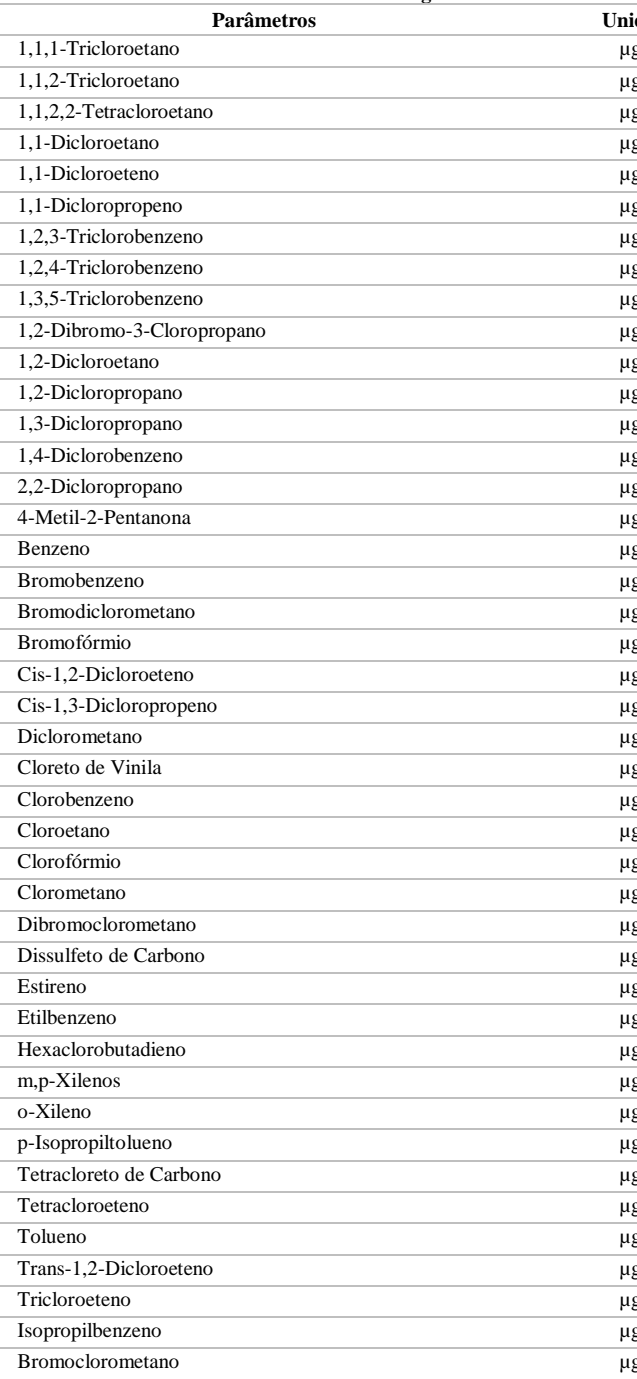

Controle de Qualidade - VOC - Água

\begin{tabular}{|c|c|c|}
\hline Unidade & LQ & Resultados analíticos \\
\hline$\mu \mathrm{g} / \mathrm{L}$ & 1 & $<1$ \\
\hline$\mu \mathrm{g} / \mathrm{L}$ & 1 & $<1$ \\
\hline$\mu \mathrm{g} / \mathrm{L}$ & 1 & $<1$ \\
\hline$\mu \mathrm{g} / \mathrm{L}$ & 1 & $<1$ \\
\hline$\mu \mathrm{g} / \mathrm{L}$ & 1 & $<1$ \\
\hline$\mu \mathrm{g} / \mathrm{L}$ & 1 & $<1$ \\
\hline$\mu \mathrm{g} / \mathrm{L}$ & 1 & $<1$ \\
\hline$\mu \mathrm{g} / \mathrm{L}$ & 1 & $<1$ \\
\hline$\mu \mathrm{g} / \mathrm{L}$ & 1 & $<1$ \\
\hline$\mu \mathrm{g} / \mathrm{L}$ & 5 & $<5$ \\
\hline$\mu \mathrm{g} / \mathrm{L}$ & 1 & $<1$ \\
\hline$\mu \mathrm{g} / \mathrm{L}$ & 1 & $<1$ \\
\hline$\mu \mathrm{g} / \mathrm{L}$ & 5 & $<5$ \\
\hline$\mu \mathrm{g} / \mathrm{L}$ & 1 & $<1$ \\
\hline$\mu \mathrm{g} / \mathrm{L}$ & 1 & $<1$ \\
\hline$\mu \mathrm{g} / \mathrm{L}$ & 5 & $<5$ \\
\hline$\mu \mathrm{g} / \mathrm{L}$ & 1 & $<1$ \\
\hline$\mu \mathrm{g} / \mathrm{L}$ & 1 & $<1$ \\
\hline$\mu \mathrm{g} / \mathrm{L}$ & 1 & $<1$ \\
\hline$\mu \mathrm{g} / \mathrm{L}$ & 1 & $<1$ \\
\hline$\mu \mathrm{g} / \mathrm{L}$ & 1 & $<1$ \\
\hline$\mu \mathrm{g} / \mathrm{L}$ & 1 & $<1$ \\
\hline$\mu \mathrm{g} / \mathrm{L}$ & 1 & $<1$ \\
\hline$\mu \mathrm{g} / \mathrm{L}$ & 1 & $<1$ \\
\hline$\mu \mathrm{g} / \mathrm{L}$ & 1 & $<1$ \\
\hline$\mu \mathrm{g} / \mathrm{L}$ & 1 & $<1$ \\
\hline$\mu \mathrm{g} / \mathrm{L}$ & 1 & $<1$ \\
\hline$\mu \mathrm{g} / \mathrm{L}$ & 10 & $<10$ \\
\hline$\mu \mathrm{g} / \mathrm{L}$ & 1 & $<1$ \\
\hline$\mu \mathrm{g} / \mathrm{L}$ & 1 & $<1$ \\
\hline$\mu \mathrm{g} / \mathrm{L}$ & 1 & $<1$ \\
\hline$\mu \mathrm{g} / \mathrm{L}$ & 1 & $<1$ \\
\hline$\mu \mathrm{g} / \mathrm{L}$ & 1 & $<1$ \\
\hline$\mu \mathrm{g} / \mathrm{L}$ & 2 & $<2$ \\
\hline$\mu \mathrm{g} / \mathrm{L}$ & 1 & $<1$ \\
\hline$\mu \mathrm{g} / \mathrm{L}$ & 1 & $<1$ \\
\hline$\mu \mathrm{g} / \mathrm{L}$ & 1 & $<1$ \\
\hline$\mu \mathrm{g} / \mathrm{L}$ & 1 & $<1$ \\
\hline$\mu \mathrm{g} / \mathrm{L}$ & 1 & $<1$ \\
\hline$\mu \mathrm{g} / \mathrm{L}$ & 1 & $<1$ \\
\hline$\mu \mathrm{g} / \mathrm{L}$ & 1 & $<1$ \\
\hline$\mu \mathrm{g} / \mathrm{L}$ & 1 & $<1$ \\
\hline$\mu \mathrm{g} / \mathrm{L}$ & 5 & $<5$ \\
\hline
\end{tabular}




\begin{tabular}{|c|c|c|c|c|}
\hline Parâmetros & $\begin{array}{l}\text { Quantidade } \\
\text { Adicionada }\end{array}$ & Unidade & $\begin{array}{c}\text { Resultado da } \\
\text { Recuperação (\%) }\end{array}$ & Faixa Aceitável de Recuperação (\%) \\
\hline \multicolumn{5}{|c|}{ 302694/2014-0 - Amostra Controle - VOC - Água } \\
\hline 1,1-Dicloroeteno & 20 & $\mu \mathrm{g} / \mathrm{L}$ & 100 & $70-130$ \\
\hline Benzeno & 20 & $\mu \mathrm{g} / \mathrm{L}$ & 125 & $70-130$ \\
\hline Tricloroeteno & 20 & $\mu \mathrm{g} / \mathrm{L}$ & 110 & $70-130$ \\
\hline Tolueno & 20 & $\mu \mathrm{g} / \mathrm{L}$ & 95 & $70-130$ \\
\hline Clorobenzeno & 20 & $\mu \mathrm{g} / \mathrm{L}$ & 105 & $70-130$ \\
\hline \multicolumn{5}{|c|}{$\begin{array}{l}\text { Surrogates } \\
\text { 302692/2014-0 - Branco de Análise - VOC - Água }\end{array}$} \\
\hline p-Bromofluorbenzeno & 20 & $\%$ & 76,5 & $70-130$ \\
\hline Dibromofluorometano & 20 & $\%$ & 130 & $70-130$ \\
\hline \multicolumn{5}{|c|}{ 302694/2014-0 - Amostra Controle - VOC - Água } \\
\hline p-Bromofluorbenzeno & 20 & $\%$ & 78,6 & $70-130$ \\
\hline Dibromofluorometano & 20 & $\%$ & 130 & $70-130$ \\
\hline \multicolumn{5}{|l|}{ 292992/2014-0 - BSI 3} \\
\hline Dibromofluorometano & 20 & $\%$ & 100 & $70-130$ \\
\hline p-Bromofluorbenzeno & 20 & $\%$ & 72,3 & $70-130$ \\
\hline
\end{tabular}

Notas

LQ = Limite de Quantificação.

n.a. = Não Aplicável.

Abrangência

$\mathrm{O}(\mathrm{s})$ resultado(s) referem-se somente à(s) amostra(s) analisada(s).

Este Relatório de Ensaio só pode ser reproduzido por inteiro e sem nenhuma alteração.

Plano de Amostragem

Plano de amostragem de responsabilidade do interessado.

Responsabilidade Técnica

Os ensaios foram realizados na unidade da Bioagri Ambiental Ltda. - Matriz, situada na Rua Aljovil Martini, 177/201, Bairro Dois Córregos, Cep. 14420-833, Piracicaba/SP, registrada no CRQ 4 Região sob n⿳亠丷厂 $16082-\mathrm{F}$ e responsabilidade técnica do profissional Marcos Donizete Ceccatto, CRQ n ${ }^{\circ} 04364387,4^{\mathrm{a}}$.Região.

Referências Metodológicas

Análises foram realizadas conforme a última versão do Standard Methods for the Examination of Water \& Wastewater 22nd 2012(SMWW), EPA e ABNT (quando aplicável). VOC: EPA 8260 C: 2006, 5021A: 2003

Metiletilcetona: EPA 8260 C: 2006, 5021 A: 2003

Revisores

Débora Fernandes da Silva

Chave de Validação: d6b95f32a61a9c4b7ba2d4487f03aac7
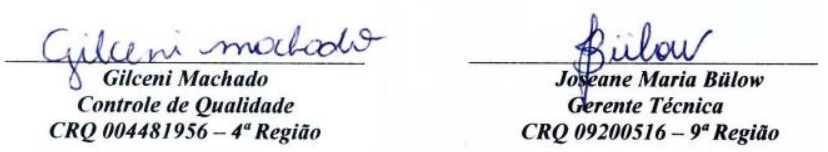


\section{RELATÓRIO DE ENSAIO N ${ }^{\circ}$ 292993/2014-0 - Piracicaba Processo Comercial $N^{\circ} 23961 / 2014-2$}

\begin{tabular}{|l|l|}
\hline \multicolumn{2}{|c|}{ DADOS REFERENTES AO CLIENTE } \\
\hline Empresa solicitante: & Fundacao Parque de Alta Tecnologia da Regiao de Ipero e Adjacencias \\
\hline Endereço: & Rua Jose Antonio Scaciota, 165 - - Portal do Cedro - Iperó - SP - CEP: 18.560-000 . \\
\hline Nome do Solicitante: & Carla Marçal \\
\hline
\end{tabular}

\section{DADOS REFERENTES A AMOSTRA}

Identificação do Cliente: Amostra Rotulada como:

Coletor:

BSF 1

Data da entrada no laboratório:

Água Subterrânea Projeto Mestrado Interessado

Data da coleta: $\quad$ 03/11/2014 01:17:00

\section{RESULTADOS PARA A AMOSTRA}

\begin{tabular}{|c|c|c|c|c|c|c|}
\hline Parâmetros & CAS & Unidade & LQ & Resultados analíticos & Incerteza & Data do Ensaio \\
\hline 1,1,1-Tricloroetano & $71-55-6$ & $\mu \mathrm{g} / \mathrm{L}$ & 1 & $<1$ & n.a. & 14/11/2014 01:48 \\
\hline 1,1,2-Tricloroetano & $79-00-5$ & $\mu \mathrm{g} / \mathrm{L}$ & 1 & $<1$ & n.a. & 14/11/2014 01:48 \\
\hline 1,1,2,2-Tetracloroetano & $79-34-5$ & $\mu \mathrm{g} / \mathrm{L}$ & 1 & $<1$ & n.a. & 14/11/2014 01:48 \\
\hline 1,1-Dicloroetano & $75-34-3$ & $\mu \mathrm{g} / \mathrm{L}$ & 1 & $<1$ & n.a. & 14/11/2014 01:48 \\
\hline 1,1-Dicloroeteno & $75-35-4$ & $\mu \mathrm{g} / \mathrm{L}$ & 1 & $<1$ & n.a. & 14/11/2014 01:48 \\
\hline 1,1-Dicloropropeno & $563-58-6$ & $\mu \mathrm{g} / \mathrm{L}$ & 1 & $<1$ & n.a. & 14/11/2014 01:48 \\
\hline 1,2,3-Triclorobenzeno & $87-61-6$ & $\mu \mathrm{g} / \mathrm{L}$ & 1 & $<1$ & n.a. & 14/11/2014 01:48 \\
\hline 1,2,4-Triclorobenzeno & $120-82-1$ & $\mu \mathrm{g} / \mathrm{L}$ & 1 & $<1$ & n.a. & 14/11/2014 01:48 \\
\hline 1,2-Dibromo-3-Cloropropano & $96-12-8$ & $\mu \mathrm{g} / \mathrm{L}$ & 5 & $<5$ & n.a. & 14/11/2014 01:48 \\
\hline 1,2-Dicloroetano & $107-06-2$ & $\mu \mathrm{g} / \mathrm{L}$ & 1 & $<1$ & n.a. & 14/11/2014 01:48 \\
\hline 1,2-Dicloropropano & $78-87-5$ & $\mu \mathrm{g} / \mathrm{L}$ & 1 & $<1$ & n.a. & 14/11/2014 01:48 \\
\hline 1,3-Dicloropropano & $142-28-9$ & $\mu \mathrm{g} / \mathrm{L}$ & 5 & $<5$ & n.a. & 14/11/2014 01:48 \\
\hline 1,4-Diclorobenzeno & $106-46-7$ & $\mu \mathrm{g} / \mathrm{L}$ & 1 & $<1$ & n.a. & 14/11/2014 01:48 \\
\hline 2,2-Dicloropropano & $594-20-7$ & $\mu \mathrm{g} / \mathrm{L}$ & 1 & $<1$ & n.a. & 14/11/2014 01:48 \\
\hline 4-Metil-2-Pentanona & $108-10-1$ & $\mu \mathrm{g} / \mathrm{L}$ & 5 & $<5$ & n.a. & $14 / 11 / 201401: 48$ \\
\hline Benzeno & $71-43-2$ & $\mu \mathrm{g} / \mathrm{L}$ & 1 & $<1$ & n.a. & 14/11/2014 01:48 \\
\hline Bromobenzeno & $108-86-1$ & $\mu \mathrm{g} / \mathrm{L}$ & 1 & $<1$ & n.a. & 14/11/2014 01:48 \\
\hline Bromodiclorometano & $75-27-4$ & $\mu \mathrm{g} / \mathrm{L}$ & 1 & $<1$ & n.a. & 14/11/2014 01:48 \\
\hline Bromofórmio & $75-25-2$ & $\mu \mathrm{g} / \mathrm{L}$ & 1 & $<1$ & n.a. & 14/11/2014 01:48 \\
\hline Bromoclorometano & $74-97-5$ & $\mu \mathrm{g} / \mathrm{L}$ & 5 & $<5$ & n.a. & 14/11/2014 01:48 \\
\hline Cis-1,2-Dicloroeteno & $156-59-2$ & $\mu \mathrm{g} / \mathrm{L}$ & 1 & $<1$ & n.a. & 14/11/2014 01:48 \\
\hline Cis-1,3-Dicloropropeno & $10061-01-5$ & $\mu \mathrm{g} / \mathrm{L}$ & 1 & $<1$ & n.a. & 14/11/2014 01:48 \\
\hline Diclorometano & $75-09-2$ & $\mu \mathrm{g} / \mathrm{L}$ & 1 & $<1$ & n.a. & 14/11/2014 01:48 \\
\hline Cloreto de Vinila & $75-01-4$ & $\mu \mathrm{g} / \mathrm{L}$ & 1 & $<1$ & n.a. & 14/11/2014 01:48 \\
\hline Clorobenzeno & $108-90-7$ & $\mu \mathrm{g} / \mathrm{L}$ & 1 & $<1$ & n.a. & 14/11/2014 01:48 \\
\hline Cloroetano & $75-00-3$ & $\mu \mathrm{g} / \mathrm{L}$ & 1 & $<1$ & n.a. & 14/11/2014 01:48 \\
\hline Clorofórmio & $67-66-3$ & $\mu \mathrm{g} / \mathrm{L}$ & 1 & $<1$ & n.a. & 14/11/2014 01:48 \\
\hline Clorometano & $74-87-3$ & $\mu \mathrm{g} / \mathrm{L}$ & 10 & $<10$ & n.a. & 14/11/2014 01:48 \\
\hline Dibromoclorometano & $124-48-1$ & $\mu \mathrm{g} / \mathrm{L}$ & 1 & $<1$ & n.a. & 14/11/2014 01:48 \\
\hline Dissulfeto de Carbono & $75-15-0$ & $\mu \mathrm{g} / \mathrm{L}$ & 1 & $<1$ & n.a. & 14/11/2014 01:48 \\
\hline Estireno & $100-42-5$ & $\mu \mathrm{g} / \mathrm{L}$ & 1 & $<1$ & n.a. & 14/11/2014 01:48 \\
\hline Etilbenzeno & $100-41-4$ & $\mu \mathrm{g} / \mathrm{L}$ & 1 & $<1$ & n.a. & 14/11/2014 01:48 \\
\hline Hexaclorobutadieno & $87-68-3$ & $\mu \mathrm{g} / \mathrm{L}$ & 1 & $<1$ & n.a. & 14/11/2014 01:48 \\
\hline m,p-Xilenos & --- & $\mu \mathrm{g} / \mathrm{L}$ & 2 & $<2$ & n.a. & 14/11/2014 01:48 \\
\hline o-Xileno & $95-47-6$ & $\mu \mathrm{g} / \mathrm{L}$ & 1 & $<1$ & n.a. & 14/11/2014 01:48 \\
\hline p-Isopropiltolueno & $99-87-6$ & $\mu \mathrm{g} / \mathrm{L}$ & 1 & $<1$ & n.a. & 14/11/2014 01:48 \\
\hline Tetracloreto de Carbono & $56-23-5$ & $\mu \mathrm{g} / \mathrm{L}$ & 1 & $<1$ & n.a. & 14/11/2014 01:48 \\
\hline Tetracloroeteno & $127-18-4$ & $\mu \mathrm{g} / \mathrm{L}$ & 10 & 94,5 & 18 & 14/11/2014 01:48 \\
\hline Tolueno & $108-88-3$ & $\mu \mathrm{g} / \mathrm{L}$ & 1 & $<1$ & n.a. & 14/11/2014 01:48 \\
\hline Trans-1,2-Dicloroeteno & $156-60-5$ & $\mu \mathrm{g} / \mathrm{L}$ & 1 & $<1$ & n.a. & 14/11/2014 01:48 \\
\hline Tricloroeteno & $79-01-6$ & $\mu \mathrm{g} / \mathrm{L}$ & 1 & $<1$ & n.a. & 14/11/2014 01:48 \\
\hline 1,1,1,2-Tetracloroetano & $630-20-6$ & $\mu \mathrm{g} / \mathrm{L}$ & 1 & $<1$ & n.a. & 14/11/2014 01:48 \\
\hline
\end{tabular}




\begin{tabular}{|c|c|c|c|c|c|c|}
\hline Parâmetros & CAS & Unidade & LQ & Resultados analíticos & Incerteza & Data do Ensaio \\
\hline 1,2,3-Tricloropropano & $96-18-4$ & $\mu \mathrm{g} / \mathrm{L}$ & 5 & $<5$ & n.a. & 14/11/2014 01:48 \\
\hline 1,3,5-Trimetilbenzeno & $108-67-8$ & $\mu \mathrm{g} / \mathrm{L}$ & 1 & $<1$ & n.a. & 14/11/2014 01:48 \\
\hline 1,2,4-Trimetilbenzeno & $95-63-6$ & $\mu \mathrm{g} / \mathrm{L}$ & 1 & $<1$ & n.a. & $14 / 11 / 201401: 48$ \\
\hline 1,2-Dibromoetano & $106-93-4$ & $\mu \mathrm{g} / \mathrm{L}$ & 1 & $<1$ & n.a. & $14 / 11 / 201401: 48$ \\
\hline 1,2-Diclorobenzeno & $95-50-1$ & $\mu \mathrm{g} / \mathrm{L}$ & 1 & $<1$ & n.a. & 14/11/2014 01:48 \\
\hline 1,3-Diclorobenzeno & $541-73-1$ & $\mu \mathrm{g} / \mathrm{L}$ & 1 & $<1$ & n.a. & $14 / 11 / 201401: 48$ \\
\hline 2-Clorotolueno & $95-49-8$ & $\mu \mathrm{g} / \mathrm{L}$ & 1 & $<1$ & n.a. & $14 / 11 / 201401: 48$ \\
\hline Dibromometano & $74-95-3$ & $\mu \mathrm{g} / \mathrm{L}$ & 1 & $<1$ & n.a. & 14/11/2014 01:48 \\
\hline Metiletilcetona & 78-93-3 & $\mu \mathrm{g} / \mathrm{L}$ & 2500 & $<2500$ & n.a. & 14/11/2014 02:13 \\
\hline Naftaleno & $91-20-3$ & $\mu \mathrm{g} / \mathrm{L}$ & 1 & $<1$ & n.a. & $14 / 11 / 201401: 48$ \\
\hline n-Butilbenzeno & $104-51-8$ & $\mu \mathrm{g} / \mathrm{L}$ & 1 & $<1$ & n.a. & $14 / 11 / 201401: 48$ \\
\hline n-Propilbenzeno & $103-65-1$ & $\mu \mathrm{g} / \mathrm{L}$ & 1 & $<1$ & n.a. & $14 / 11 / 201401: 48$ \\
\hline 4-Clorotolueno & $106-43-4$ & $\mu \mathrm{g} / \mathrm{L}$ & 1 & $<1$ & n.a. & $14 / 11 / 201401: 48$ \\
\hline sec-Butilbenzeno & $135-98-8$ & $\mu \mathrm{g} / \mathrm{L}$ & 1 & $<1$ & n.a. & 14/11/2014 01:48 \\
\hline terc-Butilbenzeno & $98-06-6$ & $\mu \mathrm{g} / \mathrm{L}$ & 1 & $<1$ & n.a. & 14/11/2014 01:48 \\
\hline trans-1,3-Dicloropropeno & $10061-02-6$ & $\mu \mathrm{g} / \mathrm{L}$ & 1 & $<1$ & n.a. & $14 / 11 / 201401: 48$ \\
\hline Isopropilbenzeno & $98-82-8$ & $\mu \mathrm{g} / \mathrm{L}$ & 1 & $<1$ & n.a. & 14/11/2014 01:48 \\
\hline 1,3,5-Triclorobenzeno & $108-70-3$ & $\mu \mathrm{g} / \mathrm{L}$ & 1 & $<1$ & n.a. & 14/11/2014 01:48 \\
\hline
\end{tabular}

\section{CONTROLE DE QUALIDADE DO LABORATÓRIO}

302692/2014-0 - Branco de Análise - VOC - Água

\begin{tabular}{|c|c|}
\hline \multirow{2}{*}{\multicolumn{2}{|c|}{$\begin{array}{ll} & \text { Parâmetros } \\
1,1,1-\text { Tricloroetano } & \end{array}$}} \\
\hline & \\
\hline \multicolumn{2}{|l|}{ 1,1,2-Tricloroetano } \\
\hline \multicolumn{2}{|l|}{ 1,1,2,2-Tetracloroetano } \\
\hline \multicolumn{2}{|l|}{ 1,1-Dicloroetano } \\
\hline \multicolumn{2}{|l|}{ 1,1-Dicloroeteno } \\
\hline \multicolumn{2}{|l|}{ 1,1-Dicloropropeno } \\
\hline \multicolumn{2}{|l|}{ 1,2,3-Triclorobenzeno } \\
\hline \multicolumn{2}{|l|}{ 1,2,4-Triclorobenzeno } \\
\hline \multicolumn{2}{|l|}{ 1,3,5-Triclorobenzeno } \\
\hline \multicolumn{2}{|l|}{ 1,2-Dibromo-3-Cloropropano } \\
\hline \multicolumn{2}{|l|}{ 1,2-Dicloroetano } \\
\hline \multicolumn{2}{|l|}{ 1,2-Dicloropropano } \\
\hline \multicolumn{2}{|l|}{ 1,3-Dicloropropano } \\
\hline \multicolumn{2}{|l|}{ 1,4-Diclorobenzeno } \\
\hline \multicolumn{2}{|l|}{ 2,2-Dicloropropano } \\
\hline \multicolumn{2}{|l|}{ 4-Metil-2-Pentanona } \\
\hline \multicolumn{2}{|l|}{ Benzeno } \\
\hline \multicolumn{2}{|l|}{ Bromobenzeno } \\
\hline \multicolumn{2}{|l|}{ Bromodiclorometano } \\
\hline \multicolumn{2}{|l|}{ Bromofórmio } \\
\hline \multicolumn{2}{|l|}{ Cis-1,2-Dicloroeteno } \\
\hline \multicolumn{2}{|l|}{ Cis-1,3-Dicloropropeno } \\
\hline \multicolumn{2}{|l|}{ Diclorometano } \\
\hline \multicolumn{2}{|l|}{ Cloreto de Vinila } \\
\hline \multicolumn{2}{|l|}{ Clorobenzeno } \\
\hline \multicolumn{2}{|l|}{ Cloroetano } \\
\hline Clorofórmio & \\
\hline Clorometano & \\
\hline Dibromoclorometano & \\
\hline Dissulfeto de Carbono & \\
\hline Estireno & \\
\hline Etilbenzeno & \\
\hline Hexaclorobutadieno & \\
\hline m,p-Xilenos & \\
\hline o-Xileno & \\
\hline p-Isopropiltolueno & \\
\hline Tetracloreto de Carbono & \\
\hline Tetracloroeteno & \\
\hline Tolueno & \\
\hline Trans-1,2-Dicloroeteno & \\
\hline Tricloroeteno & \\
\hline Isopropilbenzeno & \\
\hline Bromoclorometano & \\
\hline
\end{tabular}

Controle de Qualidade - VOC - Água

\begin{tabular}{|c|c|c|}
\hline Unidade & LQ & Resultados analíticos \\
\hline$\mu \mathrm{g} / \mathrm{L}$ & 1 & $<1$ \\
\hline$\mu \mathrm{g} / \mathrm{L}$ & 1 & $<1$ \\
\hline$\mu \mathrm{g} / \mathrm{L}$ & 1 & $<1$ \\
\hline$\mu \mathrm{g} / \mathrm{L}$ & 1 & $<1$ \\
\hline$\mu \mathrm{g} / \mathrm{L}$ & 1 & $<1$ \\
\hline$\mu \mathrm{g} / \mathrm{L}$ & 1 & $<1$ \\
\hline$\mu \mathrm{g} / \mathrm{L}$ & 1 & $<1$ \\
\hline$\mu \mathrm{g} / \mathrm{L}$ & 1 & $<1$ \\
\hline$\mu \mathrm{g} / \mathrm{L}$ & 1 & $<1$ \\
\hline$\mu \mathrm{g} / \mathrm{L}$ & 5 & $<5$ \\
\hline$\mu \mathrm{g} / \mathrm{L}$ & 1 & $<1$ \\
\hline$\mu \mathrm{g} / \mathrm{L}$ & 1 & $<1$ \\
\hline$\mu \mathrm{g} / \mathrm{L}$ & 5 & $<5$ \\
\hline$\mu \mathrm{g} / \mathrm{L}$ & 1 & $<1$ \\
\hline$\mu \mathrm{g} / \mathrm{L}$ & 1 & $<1$ \\
\hline$\mu \mathrm{g} / \mathrm{L}$ & 5 & $<5$ \\
\hline$\mu \mathrm{g} / \mathrm{L}$ & 1 & $<1$ \\
\hline$\mu \mathrm{g} / \mathrm{L}$ & 1 & $<1$ \\
\hline$\mu \mathrm{g} / \mathrm{L}$ & 1 & $<1$ \\
\hline$\mu \mathrm{g} / \mathrm{L}$ & 1 & $<1$ \\
\hline$\mu \mathrm{g} / \mathrm{L}$ & 1 & $<1$ \\
\hline$\mu \mathrm{g} / \mathrm{L}$ & 1 & $<1$ \\
\hline$\mu \mathrm{g} / \mathrm{L}$ & 1 & $<1$ \\
\hline$\mu \mathrm{g} / \mathrm{L}$ & 1 & $<1$ \\
\hline$\mu \mathrm{g} / \mathrm{L}$ & 1 & $<1$ \\
\hline$\mu \mathrm{g} / \mathrm{L}$ & 1 & $<1$ \\
\hline$\mu \mathrm{g} / \mathrm{L}$ & 1 & $<1$ \\
\hline$\mu \mathrm{g} / \mathrm{L}$ & 10 & $<10$ \\
\hline$\mu \mathrm{g} / \mathrm{L}$ & 1 & $<1$ \\
\hline$\mu \mathrm{g} / \mathrm{L}$ & 1 & $<1$ \\
\hline$\mu \mathrm{g} / \mathrm{L}$ & 1 & $<1$ \\
\hline$\mu \mathrm{g} / \mathrm{L}$ & 1 & $<1$ \\
\hline$\mu \mathrm{g} / \mathrm{L}$ & 1 & $<1$ \\
\hline$\mu \mathrm{g} / \mathrm{L}$ & 2 & $<2$ \\
\hline$\mu \mathrm{g} / \mathrm{L}$ & 1 & $<1$ \\
\hline$\mu \mathrm{g} / \mathrm{L}$ & 1 & $<1$ \\
\hline$\mu \mathrm{g} / \mathrm{L}$ & 1 & $<1$ \\
\hline$\mu \mathrm{g} / \mathrm{L}$ & 1 & $<1$ \\
\hline$\mu \mathrm{g} / \mathrm{L}$ & 1 & $<1$ \\
\hline$\mu \mathrm{g} / \mathrm{L}$ & 1 & $<1$ \\
\hline$\mu \mathrm{g} / \mathrm{L}$ & 1 & $<1$ \\
\hline$\mu \mathrm{g} / \mathrm{L}$ & 1 & $<1$ \\
\hline$\mu \mathrm{g} / \mathrm{L}$ & 5 & $<5$ \\
\hline
\end{tabular}




\begin{tabular}{|c|c|c|c|c|}
\hline Parâmetros & $\begin{array}{l}\text { Quantidade } \\
\text { Adicionada }\end{array}$ & Unidade & $\begin{array}{c}\text { Resultado da } \\
\text { Recuperação (\%) }\end{array}$ & Faixa Aceitável de Recuperação (\%) \\
\hline \multicolumn{5}{|c|}{ 302694/2014-0 - Amostra Controle - VOC - Água } \\
\hline 1,1-Dicloroeteno & 20 & $\mu \mathrm{g} / \mathrm{L}$ & 100 & $70-130$ \\
\hline Benzeno & 20 & $\mu \mathrm{g} / \mathrm{L}$ & 125 & $70-130$ \\
\hline Tricloroeteno & 20 & $\mu \mathrm{g} / \mathrm{L}$ & 110 & $70-130$ \\
\hline Tolueno & 20 & $\mu \mathrm{g} / \mathrm{L}$ & 95 & $70-130$ \\
\hline Clorobenzeno & 20 & $\mu \mathrm{g} / \mathrm{L}$ & 105 & $70-130$ \\
\hline \multicolumn{5}{|c|}{$\begin{array}{l}\text { Surrogates } \\
\text { 302692/2014-0 - Branco de Análise - VOC - Água }\end{array}$} \\
\hline p-Bromofluorbenzeno & 20 & $\%$ & 76,5 & $70-130$ \\
\hline Dibromofluorometano & 20 & $\%$ & 130 & $70-130$ \\
\hline \multicolumn{5}{|c|}{ 302694/2014-0 - Amostra Controle - VOC - Água } \\
\hline p-Bromofluorbenzeno & 20 & $\%$ & 78,6 & $70-130$ \\
\hline Dibromofluorometano & 20 & $\%$ & 130 & $70-130$ \\
\hline \multicolumn{5}{|l|}{ 292993/2014-0 - BSF 1} \\
\hline Dibromofluorometano & 20 & $\%$ & 97,8 & $70-130$ \\
\hline p-Bromofluorbenzeno & 20 & $\%$ & 73,9 & $70-130$ \\
\hline
\end{tabular}

Notas

LQ = Limite de Quantificação.

n.a. = Não Aplicável.

Abrangência

$\mathrm{O}(\mathrm{s})$ resultado(s) referem-se somente à(s) amostra(s) analisada(s).

Este Relatório de Ensaio só pode ser reproduzido por inteiro e sem nenhuma alteração.

Plano de Amostragem

Plano de amostragem de responsabilidade do interessado.

Responsabilidade Técnica

Os ensaios foram realizados na unidade da Bioagri Ambiental Ltda. - Matriz, situada na Rua Aljovil Martini, 177/201, Bairro Dois Córregos, Cep. 14420-833, Piracicaba/SP, registrada no CRQ 4 Região sob n⿳亠丷厂 $16082-\mathrm{F}$ e responsabilidade técnica do profissional Marcos Donizete Ceccatto, CRQ n ${ }^{\circ} 04364387,4^{\mathrm{a}}$.Região.

Referências Metodológicas

Análises foram realizadas conforme a última versão do Standard Methods for the Examination of Water \& Wastewater 22nd 2012(SMWW), EPA e ABNT (quando aplicável). VOC: EPA 8260 C: 2006, 5021A: 2003

Metiletilcetona: EPA 8260 C: 2006, 5021 A: 2003

Revisores

Débora Fernandes da Silva

Chave de Validação: 62547d9a1f8083717cd5f69f55efad04
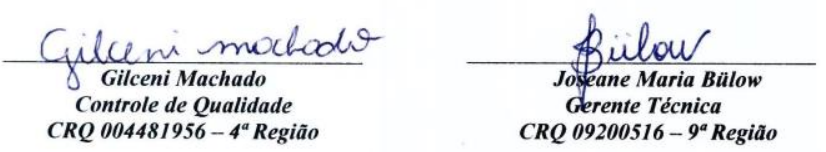


\section{RELATÓRIO DE ENSAIO N ${ }^{\circ}$ 292994/2014-0 - Piracicaba Processo Comercial $N^{\circ}$ 23961/2014-2}

\begin{tabular}{|l|l|}
\hline \multicolumn{2}{|c|}{ DADOS REFERENTES AO CLIENTE } \\
\hline Empresa solicitante: & Fundacao Parque de Alta Tecnologia da Regiao de Ipero e Adjacencias \\
\hline Endereço: & Rua Jose Antonio Scaciota, 165 - - Portal do Cedro - Iperó - SP - CEP: 18.560-000 . \\
\hline Nome do Solicitante: & Carla Marçal \\
\hline
\end{tabular}

\section{DADOS REFERENTES A AMOSTRA}

Identificação do Cliente: Amostra Rotulada como:

Coletor:

BSF 2

Data da entrada no laboratório:

Água Subterrânea Projeto Mestrado

Interessado

Data da coleta: $\quad$ 03/11/2014 01:18:00

\section{RESULTADOS PARA A AMOSTRA}

\begin{tabular}{|c|c|c|c|c|c|c|}
\hline Parâmetros & CAS & Unidade & LQ & Resultados analíticos & Incerteza & Data do Ensaio \\
\hline 1,1,1-Tricloroetano & $71-55-6$ & $\mu \mathrm{g} / \mathrm{L}$ & 1 & $<1$ & n.a. & $14 / 11 / 201402: 38$ \\
\hline 1,1,2-Tricloroetano & $79-00-5$ & $\mu \mathrm{g} / \mathrm{L}$ & 1 & $<1$ & n.a. & 14/11/2014 02:38 \\
\hline 1,1,2,2-Tetracloroetano & $79-34-5$ & $\mu \mathrm{g} / \mathrm{L}$ & 1 & $<1$ & n.a. & $14 / 11 / 201402: 38$ \\
\hline 1,1-Dicloroetano & $75-34-3$ & $\mu \mathrm{g} / \mathrm{L}$ & 1 & $<1$ & n.a. & $14 / 11 / 201402: 38$ \\
\hline 1,1-Dicloroeteno & $75-35-4$ & $\mu \mathrm{g} / \mathrm{L}$ & 1 & $<1$ & n.a. & $14 / 11 / 201402: 38$ \\
\hline 1,1-Dicloropropeno & $563-58-6$ & $\mu \mathrm{g} / \mathrm{L}$ & 1 & $<1$ & n.a. & $14 / 11 / 201402: 38$ \\
\hline 1,2,3-Triclorobenzeno & $87-61-6$ & $\mu \mathrm{g} / \mathrm{L}$ & 1 & $<1$ & n.a. & 14/11/2014 02:38 \\
\hline 1,2,4-Triclorobenzeno & $120-82-1$ & $\mu \mathrm{g} / \mathrm{L}$ & 1 & $<1$ & n.a. & 14/11/2014 02:38 \\
\hline 1,2-Dibromo-3-Cloropropano & $96-12-8$ & $\mu \mathrm{g} / \mathrm{L}$ & 5 & $<5$ & n.a. & $14 / 11 / 201402: 38$ \\
\hline 1,2-Dicloroetano & $107-06-2$ & $\mu \mathrm{g} / \mathrm{L}$ & 1 & $<1$ & n.a. & $14 / 11 / 201402: 38$ \\
\hline 1,2-Dicloropropano & $78-87-5$ & $\mu \mathrm{g} / \mathrm{L}$ & 1 & $<1$ & n.a. & 14/11/2014 02:38 \\
\hline 1,3-Dicloropropano & $142-28-9$ & $\mu \mathrm{g} / \mathrm{L}$ & 5 & $<5$ & n.a. & 14/11/2014 02:38 \\
\hline 1,4-Diclorobenzeno & $106-46-7$ & $\mu \mathrm{g} / \mathrm{L}$ & 1 & $<1$ & n.a. & $14 / 11 / 201402: 38$ \\
\hline 2,2-Dicloropropano & 594-20-7 & $\mu \mathrm{g} / \mathrm{L}$ & 1 & $<1$ & n.a. & $14 / 11 / 201402: 38$ \\
\hline 4-Metil-2-Pentanona & $108-10-1$ & $\mu \mathrm{g} / \mathrm{L}$ & 5 & $<5$ & n.a. & $14 / 11 / 201402: 38$ \\
\hline Benzeno & $71-43-2$ & $\mu \mathrm{g} / \mathrm{L}$ & 1 & $<1$ & n.a. & $14 / 11 / 201402: 38$ \\
\hline Bromobenzeno & $108-86-1$ & $\mu \mathrm{g} / \mathrm{L}$ & 1 & $<1$ & n.a. & 14/11/2014 02:38 \\
\hline Bromodiclorometano & $75-27-4$ & $\mu \mathrm{g} / \mathrm{L}$ & 1 & $<1$ & n.a. & 14/11/2014 02:38 \\
\hline Bromofórmio & $75-25-2$ & $\mu \mathrm{g} / \mathrm{L}$ & 1 & $<1$ & n.a. & $14 / 11 / 201402: 38$ \\
\hline Bromoclorometano & $74-97-5$ & $\mu \mathrm{g} / \mathrm{L}$ & 5 & $<5$ & n.a. & $14 / 11 / 201402: 38$ \\
\hline Cis-1,2-Dicloroeteno & $156-59-2$ & $\mu \mathrm{g} / \mathrm{L}$ & 1 & $<1$ & n.a. & 14/11/2014 02:38 \\
\hline Cis-1,3-Dicloropropeno & $10061-01-5$ & $\mu \mathrm{g} / \mathrm{L}$ & 1 & $<1$ & n.a. & 14/11/2014 02:38 \\
\hline Diclorometano & $75-09-2$ & $\mu \mathrm{g} / \mathrm{L}$ & 1 & $<1$ & n.a. & 14/11/2014 02:38 \\
\hline Cloreto de Vinila & 75-01-4 & $\mu \mathrm{g} / \mathrm{L}$ & 1 & $<1$ & n.a. & 14/11/2014 02:38 \\
\hline Clorobenzeno & $108-90-7$ & $\mu \mathrm{g} / \mathrm{L}$ & 1 & $<1$ & n.a. & $14 / 11 / 201402: 38$ \\
\hline Cloroetano & $75-00-3$ & $\mu \mathrm{g} / \mathrm{L}$ & 1 & $<1$ & n.a. & 14/11/2014 02:38 \\
\hline Clorofórmio & $67-66-3$ & $\mu \mathrm{g} / \mathrm{L}$ & 1 & $<1$ & n.a. & 14/11/2014 02:38 \\
\hline Clorometano & $74-87-3$ & $\mu \mathrm{g} / \mathrm{L}$ & 10 & $<10$ & n.a. & 14/11/2014 02:38 \\
\hline Dibromoclorometano & $124-48-1$ & $\mu \mathrm{g} / \mathrm{L}$ & 1 & $<1$ & n.a. & 14/11/2014 02:38 \\
\hline Dissulfeto de Carbono & $75-15-0$ & $\mu \mathrm{g} / \mathrm{L}$ & 1 & $<1$ & n.a. & $14 / 11 / 201402: 38$ \\
\hline Estireno & $100-42-5$ & $\mu \mathrm{g} / \mathrm{L}$ & 1 & $<1$ & n.a. & 14/11/2014 02:38 \\
\hline Etilbenzeno & $100-41-4$ & $\mu \mathrm{g} / \mathrm{L}$ & 1 & $<1$ & n.a. & 14/11/2014 02:38 \\
\hline Hexaclorobutadieno & $87-68-3$ & $\mu \mathrm{g} / \mathrm{L}$ & 1 & $<1$ & n.a. & 14/11/2014 02:38 \\
\hline m,p-Xilenos & --- & $\mu \mathrm{g} / \mathrm{L}$ & 2 & $<2$ & n.a. & 14/11/2014 02:38 \\
\hline o-Xileno & $95-47-6$ & $\mu \mathrm{g} / \mathrm{L}$ & 1 & $<1$ & n.a. & 14/11/2014 02:38 \\
\hline p-Isopropiltolueno & $99-87-6$ & $\mu \mathrm{g} / \mathrm{L}$ & 1 & $<1$ & n.a. & 14/11/2014 02:38 \\
\hline Tetracloreto de Carbono & $56-23-5$ & $\mu \mathrm{g} / \mathrm{L}$ & 1 & $<1$ & n.a. & 14/11/2014 02:38 \\
\hline Tetracloroeteno & $127-18-4$ & $\mu \mathrm{g} / \mathrm{L}$ & 10 & 84,6 & 16 & 14/11/2014 02:38 \\
\hline Tolueno & $108-88-3$ & $\mu \mathrm{g} / \mathrm{L}$ & 1 & $<1$ & n.a. & $14 / 11 / 201402: 38$ \\
\hline Trans-1,2-Dicloroeteno & $156-60-5$ & $\mu \mathrm{g} / \mathrm{L}$ & 1 & $<1$ & n.a. & 14/11/2014 02:38 \\
\hline Tricloroeteno & $79-01-6$ & $\mu \mathrm{g} / \mathrm{L}$ & 1 & $<1$ & n.a. & 14/11/2014 02:38 \\
\hline 1,1,1,2-Tetracloroetano & $630-20-6$ & $\mu \mathrm{g} / \mathrm{L}$ & 1 & $<1$ & n.a. & $14 / 11 / 201402: 38$ \\
\hline
\end{tabular}




\begin{tabular}{|c|c|c|c|c|c|c|}
\hline Parâmetros & CAS & Unidade & LQ & Resultados analíticos & Incerteza & Data do Ensaio \\
\hline 1,2,3-Tricloropropano & $96-18-4$ & $\mu \mathrm{g} / \mathrm{L}$ & 5 & $<5$ & n.a. & 14/11/2014 02:38 \\
\hline 1,3,5-Trimetilbenzeno & $108-67-8$ & $\mu \mathrm{g} / \mathrm{L}$ & 1 & $<1$ & n.a. & 14/11/2014 02:38 \\
\hline 1,2,4-Trimetilbenzeno & $95-63-6$ & $\mu \mathrm{g} / \mathrm{L}$ & 1 & $<1$ & n.a. & 14/11/2014 02:38 \\
\hline 1,2-Dibromoetano & $106-93-4$ & $\mu \mathrm{g} / \mathrm{L}$ & 1 & $<1$ & n.a. & 14/11/2014 02:38 \\
\hline 1,2-Diclorobenzeno & $95-50-1$ & $\mu \mathrm{g} / \mathrm{L}$ & 1 & $<1$ & n.a. & $14 / 11 / 201402: 38$ \\
\hline 1,3-Diclorobenzeno & $541-73-1$ & $\mu \mathrm{g} / \mathrm{L}$ & 1 & $<1$ & n.a. & $14 / 11 / 201402: 38$ \\
\hline 2-Clorotolueno & $95-49-8$ & $\mu \mathrm{g} / \mathrm{L}$ & 1 & $<1$ & n.a. & $14 / 11 / 201402: 38$ \\
\hline Dibromometano & $74-95-3$ & $\mu \mathrm{g} / \mathrm{L}$ & 1 & $<1$ & n.a. & 14/11/2014 02:38 \\
\hline Metiletilcetona & 78-93-3 & $\mu \mathrm{g} / \mathrm{L}$ & 2500 & $<2500$ & n.a. & 14/11/2014 03:03 \\
\hline Naftaleno & $91-20-3$ & $\mu \mathrm{g} / \mathrm{L}$ & 1 & $<1$ & n.a. & $14 / 11 / 201402: 38$ \\
\hline n-Butilbenzeno & $104-51-8$ & $\mu \mathrm{g} / \mathrm{L}$ & 1 & $<1$ & n.a. & 14/11/2014 02:38 \\
\hline n-Propilbenzeno & $103-65-1$ & $\mu \mathrm{g} / \mathrm{L}$ & 1 & $<1$ & n.a. & $14 / 11 / 201402: 38$ \\
\hline 4-Clorotolueno & $106-43-4$ & $\mu \mathrm{g} / \mathrm{L}$ & 1 & $<1$ & n.a. & $14 / 11 / 201402: 38$ \\
\hline sec-Butilbenzeno & $135-98-8$ & $\mu \mathrm{g} / \mathrm{L}$ & 1 & $<1$ & n.a. & 14/11/2014 02:38 \\
\hline terc-Butilbenzeno & $98-06-6$ & $\mu \mathrm{g} / \mathrm{L}$ & 1 & $<1$ & n.a. & 14/11/2014 02:38 \\
\hline trans-1,3-Dicloropropeno & $10061-02-6$ & $\mu \mathrm{g} / \mathrm{L}$ & 1 & $<1$ & n.a. & $14 / 11 / 201402: 38$ \\
\hline Isopropilbenzeno & $98-82-8$ & $\mu \mathrm{g} / \mathrm{L}$ & 1 & $<1$ & n.a. & $14 / 11 / 201402: 38$ \\
\hline 1,3,5-Triclorobenzeno & $108-70-3$ & $\mu \mathrm{g} / \mathrm{L}$ & 1 & $<1$ & n.a. & 14/11/2014 02:38 \\
\hline
\end{tabular}

\section{CONTROLE DE QUALIDADE DO LABORATÓRIO}

302692/2014-0 - Branco de Análise - VOC - Água

\begin{tabular}{|c|c|}
\hline \multirow{2}{*}{\multicolumn{2}{|c|}{$\begin{array}{ll} & \text { Parâmetros } \\
1,1,1-\text { Tricloroetano } & \end{array}$}} \\
\hline & \\
\hline \multicolumn{2}{|l|}{ 1,1,2-Tricloroetano } \\
\hline \multicolumn{2}{|l|}{ 1,1,2,2-Tetracloroetano } \\
\hline \multicolumn{2}{|l|}{ 1,1-Dicloroetano } \\
\hline \multicolumn{2}{|l|}{ 1,1-Dicloroeteno } \\
\hline \multicolumn{2}{|l|}{ 1,1-Dicloropropeno } \\
\hline \multicolumn{2}{|l|}{ 1,2,3-Triclorobenzeno } \\
\hline \multicolumn{2}{|l|}{ 1,2,4-Triclorobenzeno } \\
\hline \multicolumn{2}{|l|}{ 1,3,5-Triclorobenzeno } \\
\hline \multicolumn{2}{|l|}{ 1,2-Dibromo-3-Cloropropano } \\
\hline \multicolumn{2}{|l|}{ 1,2-Dicloroetano } \\
\hline \multicolumn{2}{|l|}{ 1,2-Dicloropropano } \\
\hline \multicolumn{2}{|l|}{ 1,3-Dicloropropano } \\
\hline \multicolumn{2}{|l|}{ 1,4-Diclorobenzeno } \\
\hline \multicolumn{2}{|l|}{ 2,2-Dicloropropano } \\
\hline \multicolumn{2}{|l|}{ 4-Metil-2-Pentanona } \\
\hline \multicolumn{2}{|l|}{ Benzeno } \\
\hline \multicolumn{2}{|l|}{ Bromobenzeno } \\
\hline \multicolumn{2}{|l|}{ Bromodiclorometano } \\
\hline \multicolumn{2}{|l|}{ Bromofórmio } \\
\hline \multicolumn{2}{|l|}{ Cis-1,2-Dicloroeteno } \\
\hline \multicolumn{2}{|l|}{ Cis-1,3-Dicloropropeno } \\
\hline \multicolumn{2}{|l|}{ Diclorometano } \\
\hline \multicolumn{2}{|l|}{ Cloreto de Vinila } \\
\hline \multicolumn{2}{|l|}{ Clorobenzeno } \\
\hline \multicolumn{2}{|l|}{ Cloroetano } \\
\hline Clorofórmio & \\
\hline Clorometano & \\
\hline Dibromoclorometano & \\
\hline Dissulfeto de Carbono & \\
\hline Estireno & \\
\hline Etilbenzeno & \\
\hline Hexaclorobutadieno & \\
\hline m,p-Xilenos & \\
\hline o-Xileno & \\
\hline p-Isopropiltolueno & \\
\hline Tetracloreto de Carbono & \\
\hline Tetracloroeteno & \\
\hline Tolueno & \\
\hline Trans-1,2-Dicloroeteno & \\
\hline Tricloroeteno & \\
\hline Isopropilbenzeno & \\
\hline Bromoclorometano & \\
\hline
\end{tabular}

Controle de Qualidade - VOC - Água

\begin{tabular}{|c|c|c|}
\hline Unidade & LQ & Resultados analíticos \\
\hline$\mu \mathrm{g} / \mathrm{L}$ & 1 & $<1$ \\
\hline$\mu \mathrm{g} / \mathrm{L}$ & 1 & $<1$ \\
\hline$\mu \mathrm{g} / \mathrm{L}$ & 1 & $<1$ \\
\hline$\mu \mathrm{g} / \mathrm{L}$ & 1 & $<1$ \\
\hline$\mu \mathrm{g} / \mathrm{L}$ & 1 & $<1$ \\
\hline$\mu \mathrm{g} / \mathrm{L}$ & 1 & $<1$ \\
\hline$\mu \mathrm{g} / \mathrm{L}$ & 1 & $<1$ \\
\hline$\mu \mathrm{g} / \mathrm{L}$ & 1 & $<1$ \\
\hline$\mu \mathrm{g} / \mathrm{L}$ & 1 & $<1$ \\
\hline$\mu \mathrm{g} / \mathrm{L}$ & 5 & $<5$ \\
\hline$\mu \mathrm{g} / \mathrm{L}$ & 1 & $<1$ \\
\hline$\mu \mathrm{g} / \mathrm{L}$ & 1 & $<1$ \\
\hline$\mu \mathrm{g} / \mathrm{L}$ & 5 & $<5$ \\
\hline$\mu \mathrm{g} / \mathrm{L}$ & 1 & $<1$ \\
\hline$\mu \mathrm{g} / \mathrm{L}$ & 1 & $<1$ \\
\hline$\mu \mathrm{g} / \mathrm{L}$ & 5 & $<5$ \\
\hline$\mu \mathrm{g} / \mathrm{L}$ & 1 & $<1$ \\
\hline$\mu \mathrm{g} / \mathrm{L}$ & 1 & $<1$ \\
\hline$\mu \mathrm{g} / \mathrm{L}$ & 1 & $<1$ \\
\hline$\mu \mathrm{g} / \mathrm{L}$ & 1 & $<1$ \\
\hline$\mu \mathrm{g} / \mathrm{L}$ & 1 & $<1$ \\
\hline$\mu \mathrm{g} / \mathrm{L}$ & 1 & $<1$ \\
\hline$\mu \mathrm{g} / \mathrm{L}$ & 1 & $<1$ \\
\hline$\mu \mathrm{g} / \mathrm{L}$ & 1 & $<1$ \\
\hline$\mu \mathrm{g} / \mathrm{L}$ & 1 & $<1$ \\
\hline$\mu \mathrm{g} / \mathrm{L}$ & 1 & $<1$ \\
\hline$\mu \mathrm{g} / \mathrm{L}$ & 1 & $<1$ \\
\hline$\mu \mathrm{g} / \mathrm{L}$ & 10 & $<10$ \\
\hline$\mu \mathrm{g} / \mathrm{L}$ & 1 & $<1$ \\
\hline$\mu \mathrm{g} / \mathrm{L}$ & 1 & $<1$ \\
\hline$\mu \mathrm{g} / \mathrm{L}$ & 1 & $<1$ \\
\hline$\mu \mathrm{g} / \mathrm{L}$ & 1 & $<1$ \\
\hline$\mu \mathrm{g} / \mathrm{L}$ & 1 & $<1$ \\
\hline$\mu \mathrm{g} / \mathrm{L}$ & 2 & $<2$ \\
\hline$\mu \mathrm{g} / \mathrm{L}$ & 1 & $<1$ \\
\hline$\mu \mathrm{g} / \mathrm{L}$ & 1 & $<1$ \\
\hline$\mu \mathrm{g} / \mathrm{L}$ & 1 & $<1$ \\
\hline$\mu \mathrm{g} / \mathrm{L}$ & 1 & $<1$ \\
\hline$\mu \mathrm{g} / \mathrm{L}$ & 1 & $<1$ \\
\hline$\mu \mathrm{g} / \mathrm{L}$ & 1 & $<1$ \\
\hline$\mu \mathrm{g} / \mathrm{L}$ & 1 & $<1$ \\
\hline$\mu \mathrm{g} / \mathrm{L}$ & 1 & $<1$ \\
\hline$\mu \mathrm{g} / \mathrm{L}$ & 5 & $<5$ \\
\hline
\end{tabular}




\begin{tabular}{|c|c|c|c|c|}
\hline Parâmetros & $\begin{array}{l}\text { Quantidade } \\
\text { Adicionada }\end{array}$ & Unidade & $\begin{array}{c}\text { Resultado da } \\
\text { Recuperação (\%) }\end{array}$ & Faixa Aceitável de Recuperação (\%) \\
\hline \multicolumn{5}{|c|}{ 302694/2014-0 - Amostra Controle - VOC - Água } \\
\hline 1,1-Dicloroeteno & 20 & $\mu \mathrm{g} / \mathrm{L}$ & 100 & $70-130$ \\
\hline Benzeno & 20 & $\mu \mathrm{g} / \mathrm{L}$ & 125 & $70-130$ \\
\hline Tricloroeteno & 20 & $\mu \mathrm{g} / \mathrm{L}$ & 110 & $70-130$ \\
\hline Tolueno & 20 & $\mu \mathrm{g} / \mathrm{L}$ & 95 & $70-130$ \\
\hline Clorobenzeno & 20 & $\mu \mathrm{g} / \mathrm{L}$ & 105 & $70-130$ \\
\hline \multicolumn{5}{|c|}{$\begin{array}{l}\text { Surrogates } \\
\text { 302692/2014-0 - Branco de Análise - VOC - Água }\end{array}$} \\
\hline p-Bromofluorbenzeno & 20 & $\%$ & 76,5 & $70-130$ \\
\hline Dibromofluorometano & 20 & $\%$ & 130 & $70-130$ \\
\hline \multicolumn{5}{|c|}{ 302694/2014-0 - Amostra Controle - VOC - Água } \\
\hline p-Bromofluorbenzeno & 20 & $\%$ & 78,6 & $70-130$ \\
\hline Dibromofluorometano & 20 & $\%$ & 130 & $70-130$ \\
\hline \multicolumn{5}{|l|}{ 292994/2014-0 - BSF 2} \\
\hline Dibromofluorometano & 20 & $\%$ & 92,2 & $70-130$ \\
\hline p-Bromofluorbenzeno & 20 & $\%$ & 72,7 & $70-130$ \\
\hline
\end{tabular}

Notas

LQ = Limite de Quantificação

n.a. $=$ Não Aplicável.

Abrangência

$\mathrm{O}(\mathrm{s})$ resultado(s) referem-se somente à(s) amostra(s) analisada(s).

Este Relatório de Ensaio só pode ser reproduzido por inteiro e sem nenhuma alteração.

Plano de Amostragem

Plano de amostragem de responsabilidade do interessado.

Responsabilidade Técnica

Os ensaios foram realizados na unidade da Bioagri Ambiental Ltda. - Matriz, situada na Rua Aljovil Martini, 177/201, Bairro Dois Córregos, Cep. 14420-833, Piracicaba/SP, registrada no CRQ 4 Região sob no $16082-\mathrm{F}$ e responsabilidade técnica do profissional Marcos Donizete Ceccatto, CRQ n ${ }^{\circ} 04364387,4^{\mathrm{a}}$.Região.

Referências Metodológicas

Análises foram realizadas conforme a última versão do Standard Methods for the Examination of Water \& Wastewater 22nd 2012(SMWW), EPA e ABNT (quando aplicável). VOC: EPA 8260 C: 2006, 5021A: 2003

Metiletilcetona: EPA 8260 C: 2006, 5021 A: 2003

Revisores

Débora Fernandes da Silva

Luci Carla Gheleri Andrietta

Chave de Validação: 4df054f9a3ed9df0d259a87613b7d81f
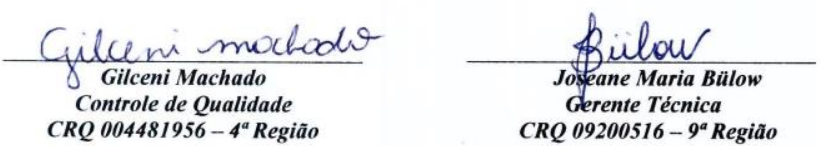


\section{RELATÓRIO DE ENSAIO N ${ }^{\circ}$ 292995/2014-0 - Piracicaba Processo Comercial $N^{\circ}$ 23961/2014-2}

\begin{tabular}{|l|l|}
\hline \multicolumn{2}{|c|}{ DADOS REFERENTES AO CLIENTE } \\
\hline Empresa solicitante: & Fundacao Parque de Alta Tecnologia da Regiao de Ipero e Adjacencias \\
\hline Endereço: & Rua Jose Antonio Scaciota, 165 - - Portal do Cedro - Iperó - SP - CEP: 18.560-000 . \\
\hline Nome do Solicitante: & Carla Marçal \\
\hline
\end{tabular}

\section{DADOS REFERENTES A AMOSTRA}

Identificação do Cliente: Amostra Rotulada como:

Coletor:

BSF 3

Data da entrada no laboratório:

Água Subterrânea Projeto Mestrado

Interessado

Data da coleta: $\quad$ 03/11/2014 01:19:00

\section{RESULTADOS PARA A AMOSTRA}

\begin{tabular}{|c|c|c|c|c|c|c|}
\hline Parâmetros & CAS & Unidade & LQ & Resultados analíticos & Incerteza & Data do Ensaio \\
\hline 1,1,1-Tricloroetano & $71-55-6$ & $\mu \mathrm{g} / \mathrm{L}$ & 1 & $<1$ & n.a. & 13/11/2014 03:17 \\
\hline 1,1,2-Tricloroetano & $79-00-5$ & $\mu \mathrm{g} / \mathrm{L}$ & 1 & $<1$ & n.a. & 13/11/2014 03:17 \\
\hline 1,1,2,2-Tetracloroetano & $79-34-5$ & $\mu \mathrm{g} / \mathrm{L}$ & 1 & $<1$ & n.a. & 13/11/2014 03:17 \\
\hline 1,1-Dicloroetano & $75-34-3$ & $\mu \mathrm{g} / \mathrm{L}$ & 1 & $<1$ & n.a. & 13/11/2014 03:17 \\
\hline 1,1-Dicloroeteno & $75-35-4$ & $\mu \mathrm{g} / \mathrm{L}$ & 1 & $<1$ & n.a. & 13/11/2014 03:17 \\
\hline 1,1-Dicloropropeno & $563-58-6$ & $\mu \mathrm{g} / \mathrm{L}$ & 1 & $<1$ & n.a. & 13/11/2014 03:17 \\
\hline 1,2,3-Triclorobenzeno & $87-61-6$ & $\mu \mathrm{g} / \mathrm{L}$ & 1 & $<1$ & n.a. & 13/11/2014 03:17 \\
\hline 1,2,4-Triclorobenzeno & $120-82-1$ & $\mu \mathrm{g} / \mathrm{L}$ & 1 & $<1$ & n.a. & 13/11/2014 03:17 \\
\hline 1,2-Dibromo-3-Cloropropano & $96-12-8$ & $\mu \mathrm{g} / \mathrm{L}$ & 5 & $<5$ & n.a. & 13/11/2014 03:17 \\
\hline 1,2-Dicloroetano & $107-06-2$ & $\mu \mathrm{g} / \mathrm{L}$ & 1 & $<1$ & n.a. & 13/11/2014 03:17 \\
\hline 1,2-Dicloropropano & $78-87-5$ & $\mu \mathrm{g} / \mathrm{L}$ & 1 & $<1$ & n.a. & 13/11/2014 03:17 \\
\hline 1,3-Dicloropropano & $142-28-9$ & $\mu \mathrm{g} / \mathrm{L}$ & 5 & $<5$ & n.a. & 13/11/2014 03:17 \\
\hline 1,4-Diclorobenzeno & $106-46-7$ & $\mu \mathrm{g} / \mathrm{L}$ & 1 & $<1$ & n.a. & 13/11/2014 03:17 \\
\hline 2,2-Dicloropropano & $594-20-7$ & $\mu \mathrm{g} / \mathrm{L}$ & 1 & $<1$ & n.a. & 13/11/2014 03:17 \\
\hline 4-Metil-2-Pentanona & $108-10-1$ & $\mu \mathrm{g} / \mathrm{L}$ & 5 & $<5$ & n.a. & 13/11/2014 03:17 \\
\hline Benzeno & $71-43-2$ & $\mu \mathrm{g} / \mathrm{L}$ & 1 & $<1$ & n.a. & 13/11/2014 03:17 \\
\hline Bromobenzeno & $108-86-1$ & $\mu \mathrm{g} / \mathrm{L}$ & 1 & $<1$ & n.a. & 13/11/2014 03:17 \\
\hline Bromodiclorometano & $75-27-4$ & $\mu \mathrm{g} / \mathrm{L}$ & 1 & $<1$ & n.a. & 13/11/2014 03:17 \\
\hline Bromofórmio & $75-25-2$ & $\mu \mathrm{g} / \mathrm{L}$ & 1 & $<1$ & n.a. & 13/11/2014 03:17 \\
\hline Bromoclorometano & $74-97-5$ & $\mu \mathrm{g} / \mathrm{L}$ & 5 & $<5$ & n.a. & 13/11/2014 03:17 \\
\hline Cis-1,2-Dicloroeteno & $156-59-2$ & $\mu \mathrm{g} / \mathrm{L}$ & 1 & $<1$ & n.a. & 13/11/2014 03:17 \\
\hline Cis-1,3-Dicloropropeno & $10061-01-5$ & $\mu \mathrm{g} / \mathrm{L}$ & 1 & $<1$ & n.a. & 13/11/2014 03:17 \\
\hline Diclorometano & $75-09-2$ & $\mu \mathrm{g} / \mathrm{L}$ & 1 & $<1$ & n.a. & 13/11/2014 03:17 \\
\hline Cloreto de Vinila & 75-01-4 & $\mu \mathrm{g} / \mathrm{L}$ & 1 & $<1$ & n.a. & 13/11/2014 03:17 \\
\hline Clorobenzeno & $108-90-7$ & $\mu \mathrm{g} / \mathrm{L}$ & 1 & $<1$ & n.a. & 13/11/2014 03:17 \\
\hline Cloroetano & $75-00-3$ & $\mu \mathrm{g} / \mathrm{L}$ & 1 & $<1$ & n.a. & 13/11/2014 03:17 \\
\hline Clorofórmio & $67-66-3$ & $\mu \mathrm{g} / \mathrm{L}$ & 1 & $<1$ & n.a. & 13/11/2014 03:17 \\
\hline Clorometano & $74-87-3$ & $\mu \mathrm{g} / \mathrm{L}$ & 10 & $<10$ & n.a. & 13/11/2014 03:17 \\
\hline Dibromoclorometano & $124-48-1$ & $\mu \mathrm{g} / \mathrm{L}$ & 1 & $<1$ & n.a. & 13/11/2014 03:17 \\
\hline Dissulfeto de Carbono & $75-15-0$ & $\mu \mathrm{g} / \mathrm{L}$ & 1 & $<1$ & n.a. & 13/11/2014 03:17 \\
\hline Estireno & $100-42-5$ & $\mu \mathrm{g} / \mathrm{L}$ & 1 & $<1$ & n.a. & 13/11/2014 03:17 \\
\hline Etilbenzeno & $100-41-4$ & $\mu \mathrm{g} / \mathrm{L}$ & 1 & $<1$ & n.a. & 13/11/2014 03:17 \\
\hline Hexaclorobutadieno & $87-68-3$ & $\mu \mathrm{g} / \mathrm{L}$ & 1 & $<1$ & n.a. & 13/11/2014 03:17 \\
\hline m,p-Xilenos & --- & $\mu \mathrm{g} / \mathrm{L}$ & 2 & $<2$ & n.a. & 13/11/2014 03:17 \\
\hline o-Xileno & $95-47-6$ & $\mu \mathrm{g} / \mathrm{L}$ & 1 & $<1$ & n.a. & 13/11/2014 03:17 \\
\hline p-Isopropiltolueno & $99-87-6$ & $\mu \mathrm{g} / \mathrm{L}$ & 1 & $<1$ & n.a. & 13/11/2014 03:17 \\
\hline Tetracloreto de Carbono & $56-23-5$ & $\mu \mathrm{g} / \mathrm{L}$ & 1 & $<1$ & n.a. & 13/11/2014 03:17 \\
\hline Tetracloroeteno & $127-18-4$ & $\mu \mathrm{g} / \mathrm{L}$ & 1 & 34,5 & 6,6 & 13/11/2014 03:17 \\
\hline Tolueno & $108-88-3$ & $\mu \mathrm{g} / \mathrm{L}$ & 1 & $<1$ & n.a. & 13/11/2014 03:17 \\
\hline Trans-1,2-Dicloroeteno & $156-60-5$ & $\mu \mathrm{g} / \mathrm{L}$ & 1 & $<1$ & n.a. & 13/11/2014 03:17 \\
\hline Tricloroeteno & $79-01-6$ & $\mu \mathrm{g} / \mathrm{L}$ & 1 & $<1$ & n.a. & 13/11/2014 03:17 \\
\hline 1,1,1,2-Tetracloroetano & $630-20-6$ & $\mu \mathrm{g} / \mathrm{L}$ & 1 & $<1$ & n.a. & 13/11/2014 03:17 \\
\hline
\end{tabular}




\begin{tabular}{|c|c|c|c|c|c|c|}
\hline Parâmetros & CAS & Unidade & LQ & Resultados analíticos & Incerteza & Data do Ensaio \\
\hline 1,2,3-Tricloropropano & $96-18-4$ & $\mu \mathrm{g} / \mathrm{L}$ & 5 & $<5$ & n.a. & 13/11/2014 03:17 \\
\hline 1,3,5-Trimetilbenzeno & $108-67-8$ & $\mu \mathrm{g} / \mathrm{L}$ & 1 & $<1$ & n.a. & 13/11/2014 03:17 \\
\hline 1,2,4-Trimetilbenzeno & $95-63-6$ & $\mu \mathrm{g} / \mathrm{L}$ & 1 & $<1$ & n.a. & 13/11/2014 03:17 \\
\hline 1,2-Dibromoetano & $106-93-4$ & $\mu \mathrm{g} / \mathrm{L}$ & 1 & $<1$ & n.a. & 13/11/2014 03:17 \\
\hline 1,2-Diclorobenzeno & $95-50-1$ & $\mu \mathrm{g} / \mathrm{L}$ & 1 & $<1$ & n.a. & 13/11/2014 03:17 \\
\hline 1,3-Diclorobenzeno & $541-73-1$ & $\mu \mathrm{g} / \mathrm{L}$ & 1 & $<1$ & n.a. & 13/11/2014 03:17 \\
\hline 2-Clorotolueno & $95-49-8$ & $\mu \mathrm{g} / \mathrm{L}$ & 1 & $<1$ & n.a. & 13/11/2014 03:17 \\
\hline Dibromometano & $74-95-3$ & $\mu \mathrm{g} / \mathrm{L}$ & 1 & $<1$ & n.a. & 13/11/2014 03:17 \\
\hline Metiletilcetona & $78-93-3$ & $\mu \mathrm{g} / \mathrm{L}$ & 2500 & $<2500$ & n.a. & 13/11/2014 03:17 \\
\hline Naftaleno & $91-20-3$ & $\mu \mathrm{g} / \mathrm{L}$ & 1 & $<1$ & n.a. & 13/11/2014 03:17 \\
\hline n-Butilbenzeno & $104-51-8$ & $\mu \mathrm{g} / \mathrm{L}$ & 1 & $<1$ & n.a. & 13/11/2014 03:17 \\
\hline n-Propilbenzeno & $103-65-1$ & $\mu \mathrm{g} / \mathrm{L}$ & 1 & $<1$ & n.a. & 13/11/2014 03:17 \\
\hline 4-Clorotolueno & $106-43-4$ & $\mu \mathrm{g} / \mathrm{L}$ & 1 & $<1$ & n.a. & 13/11/2014 03:17 \\
\hline sec-Butilbenzeno & $135-98-8$ & $\mu \mathrm{g} / \mathrm{L}$ & 1 & $<1$ & n.a. & 13/11/2014 03:17 \\
\hline terc-Butilbenzeno & $98-06-6$ & $\mu \mathrm{g} / \mathrm{L}$ & 1 & $<1$ & n.a. & 13/11/2014 03:17 \\
\hline trans-1,3-Dicloropropeno & $10061-02-6$ & $\mu \mathrm{g} / \mathrm{L}$ & 1 & $<1$ & n.a. & 13/11/2014 03:17 \\
\hline Isopropilbenzeno & $98-82-8$ & $\mu \mathrm{g} / \mathrm{L}$ & 1 & $<1$ & n.a. & 13/11/2014 03:17 \\
\hline 1,3,5-Triclorobenzeno & $108-70-3$ & $\mu \mathrm{g} / \mathrm{L}$ & 1 & $<1$ & n.a. & 13/11/2014 03:17 \\
\hline
\end{tabular}

\section{CONTROLE DE QUALIDADE DO LABORATÓRIO}

302692/2014-0 - Branco de Análise - VOC - Água

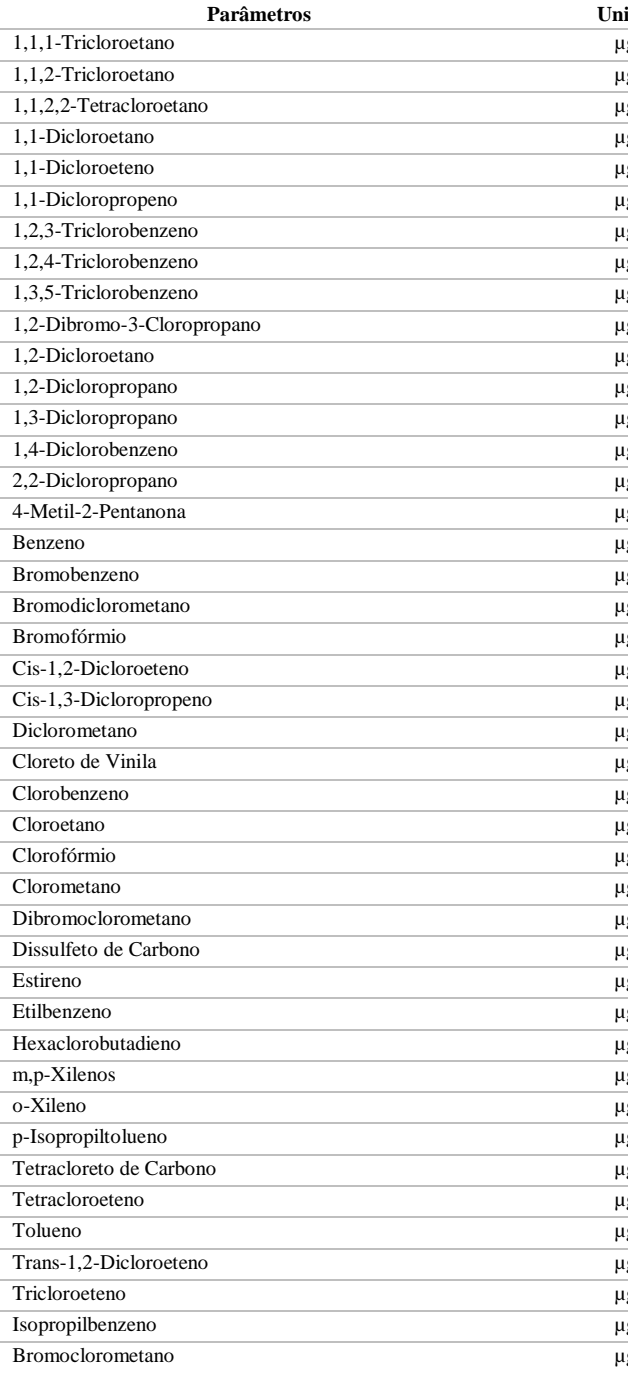

Controle de Qualidade - VOC - Água

\begin{tabular}{|c|c|c|}
\hline Unidade & LQ & Resultados analíticos \\
\hline$\mu \mathrm{g} / \mathrm{L}$ & 1 & $<1$ \\
\hline$\mu \mathrm{g} / \mathrm{L}$ & 1 & $<1$ \\
\hline$\mu \mathrm{g} / \mathrm{L}$ & 1 & $<1$ \\
\hline$\mu \mathrm{g} / \mathrm{L}$ & 1 & $<1$ \\
\hline$\mu \mathrm{g} / \mathrm{L}$ & 1 & $<1$ \\
\hline$\mu \mathrm{g} / \mathrm{L}$ & 1 & $<1$ \\
\hline$\mu \mathrm{g} / \mathrm{L}$ & 1 & $<1$ \\
\hline$\mu \mathrm{g} / \mathrm{L}$ & 1 & $<1$ \\
\hline$\mu \mathrm{g} / \mathrm{L}$ & 1 & $<1$ \\
\hline$\mu \mathrm{g} / \mathrm{L}$ & 5 & $<5$ \\
\hline$\mu \mathrm{g} / \mathrm{L}$ & 1 & $<1$ \\
\hline$\mu \mathrm{g} / \mathrm{L}$ & 1 & $<1$ \\
\hline$\mu \mathrm{g} / \mathrm{L}$ & 5 & $<5$ \\
\hline$\mu \mathrm{g} / \mathrm{L}$ & 1 & $<1$ \\
\hline$\mu \mathrm{g} / \mathrm{L}$ & 1 & $<1$ \\
\hline$\mu \mathrm{g} / \mathrm{L}$ & 5 & $<5$ \\
\hline$\mu \mathrm{g} / \mathrm{L}$ & 1 & $<1$ \\
\hline$\mu \mathrm{g} / \mathrm{L}$ & 1 & $<1$ \\
\hline$\mu \mathrm{g} / \mathrm{L}$ & 1 & $<1$ \\
\hline$\mu \mathrm{g} / \mathrm{L}$ & 1 & $<1$ \\
\hline$\mu \mathrm{g} / \mathrm{L}$ & 1 & $<1$ \\
\hline$\mu \mathrm{g} / \mathrm{L}$ & 1 & $<1$ \\
\hline$\mu \mathrm{g} / \mathrm{L}$ & 1 & $<1$ \\
\hline$\mu \mathrm{g} / \mathrm{L}$ & 1 & $<1$ \\
\hline$\mu \mathrm{g} / \mathrm{L}$ & 1 & $<1$ \\
\hline$\mu \mathrm{g} / \mathrm{L}$ & 1 & $<1$ \\
\hline$\mu \mathrm{g} / \mathrm{L}$ & 1 & $<1$ \\
\hline$\mu \mathrm{g} / \mathrm{L}$ & 10 & $<10$ \\
\hline$\mu \mathrm{g} / \mathrm{L}$ & 1 & $<1$ \\
\hline$\mu \mathrm{g} / \mathrm{L}$ & 1 & $<1$ \\
\hline$\mu \mathrm{g} / \mathrm{L}$ & 1 & $<1$ \\
\hline$\mu \mathrm{g} / \mathrm{L}$ & 1 & $<1$ \\
\hline$\mu \mathrm{g} / \mathrm{L}$ & 1 & $<1$ \\
\hline$\mu \mathrm{g} / \mathrm{L}$ & 2 & $<2$ \\
\hline$\mu \mathrm{g} / \mathrm{L}$ & 1 & $<1$ \\
\hline$\mu \mathrm{g} / \mathrm{L}$ & 1 & $<1$ \\
\hline$\mu \mathrm{g} / \mathrm{L}$ & 1 & $<1$ \\
\hline$\mu \mathrm{g} / \mathrm{L}$ & 1 & $<1$ \\
\hline$\mu \mathrm{g} / \mathrm{L}$ & 1 & $<1$ \\
\hline$\mu \mathrm{g} / \mathrm{L}$ & 1 & $<1$ \\
\hline$\mu \mathrm{g} / \mathrm{L}$ & 1 & $<1$ \\
\hline$\mu \mathrm{g} / \mathrm{L}$ & 1 & $<1$ \\
\hline$\mu \mathrm{g} / \mathrm{L}$ & 5 & $<5$ \\
\hline
\end{tabular}




\begin{tabular}{|c|c|c|c|c|}
\hline Parâmetros & $\begin{array}{l}\text { Quantidade } \\
\text { Adicionada }\end{array}$ & Unidade & $\begin{array}{c}\text { Resultado da } \\
\text { Recuperação (\%) }\end{array}$ & Faixa Aceitável de Recuperação (\%) \\
\hline \multicolumn{5}{|c|}{ 302694/2014-0 - Amostra Controle - VOC - Água } \\
\hline 1,1-Dicloroeteno & 20 & $\mu \mathrm{g} / \mathrm{L}$ & 100 & $70-130$ \\
\hline Benzeno & 20 & $\mu \mathrm{g} / \mathrm{L}$ & 125 & $70-130$ \\
\hline Tricloroeteno & 20 & $\mu \mathrm{g} / \mathrm{L}$ & 110 & $70-130$ \\
\hline Tolueno & 20 & $\mu \mathrm{g} / \mathrm{L}$ & 95 & $70-130$ \\
\hline Clorobenzeno & 20 & $\mu \mathrm{g} / \mathrm{L}$ & 105 & $70-130$ \\
\hline \multicolumn{5}{|c|}{$\begin{array}{l}\text { Surrogates } \\
\text { 302692/2014-0 - Branco de Análise - VOC - Água }\end{array}$} \\
\hline p-Bromofluorbenzeno & 20 & $\%$ & 76,5 & $70-130$ \\
\hline Dibromofluorometano & 20 & $\%$ & 130 & $70-130$ \\
\hline \multicolumn{5}{|c|}{ 302694/2014-0 - Amostra Controle - VOC - Água } \\
\hline p-Bromofluorbenzeno & 20 & $\%$ & 78,6 & $70-130$ \\
\hline Dibromofluorometano & 20 & $\%$ & 130 & $70-130$ \\
\hline \multicolumn{5}{|l|}{ 292995/2014-0 - BSF 3} \\
\hline Dibromofluorometano & 20 & $\%$ & 93,9 & $70-130$ \\
\hline p-Bromofluorbenzeno & 20 & $\%$ & 76,6 & $70-130$ \\
\hline
\end{tabular}

Notas

LQ = Limite de Quantificação.

n.a. $=$ Não Aplicável.

Abrangência

$\mathrm{O}(\mathrm{s})$ resultado(s) referem-se somente à(s) amostra(s) analisada(s).

Este Relatório de Ensaio só pode ser reproduzido por inteiro e sem nenhuma alteração.

Plano de Amostragem

Plano de amostragem de responsabilidade do interessado.

Responsabilidade Técnica

Os ensaios foram realizados na unidade da Bioagri Ambiental Ltda. - Matriz, situada na Rua Aljovil Martini, 177/201, Bairro Dois Córregos, Cep. 14420-833, Piracicaba/SP, registrada no CRQ 4 Região sob n⿳亠丷厂 $16082-\mathrm{F}$ e responsabilidade técnica do profissional Marcos Donizete Ceccatto, CRQ n ${ }^{\circ} 04364387,4^{\mathrm{a}}$.Região.

Referências Metodológicas

Análises foram realizadas conforme a última versão do Standard Methods for the Examination of Water \& Wastewater 22nd 2012(SMWW), EPA e ABNT (quando aplicável). VOC: EPA 8260 C: 2006, 5021A: 2003

Metiletilcetona: EPA 8260 C: 2006, 5021 A: 2003

Revisores

Débora Fernandes da Silva

Chave de Validação: ee02e3b7ee91f03ccc5445e2a26cbcf8
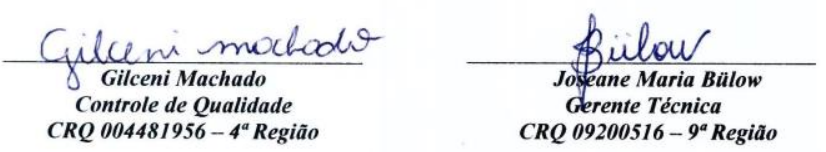


\section{RELATÓRIO DE ENSAIO N $^{\circ}$ 283874/2014-0 - Piracicaba Processo Comercial $N^{\circ}$ 23961/2014-2}

\begin{tabular}{|l|l|}
\hline \multicolumn{2}{|c|}{ DADOS REFERENTES AO CLIENTE } \\
\hline Empresa solicitante: & Fundacao Parque de Alta Tecnologia da Regiao de Ipero e Adjacencias \\
\hline Endereço: & Rua Jose Antonio Scaciota, 165 - - Portal do Cedro - Iperó - SP - CEP: 18.560-000 . \\
\hline Nome do Solicitante: & Carla Marçal \\
\hline
\end{tabular}

\begin{tabular}{|l|l|l|l|l|}
\hline \multicolumn{5}{|c|}{ DADOS REFERENTES A AMOSTRA } \\
\hline Identificação do Cliente: & CGBI-1 \\
\hline Amostra Rotulada como: & Solo Projeto Mestrado & Data da coleta: & \multicolumn{2}{|c|}{$23 / 10 / 2014$ 18:00:00 } \\
\hline Coletor: & Interessado & Data de Elaboração do RE: & $31 / 10 / 2014$ \\
\hline Data da entrada no laboratório: & $25 / 10 / 201408: 25$ & &
\end{tabular}

\section{RESULTADOS PARA A AMOSTRA}

\begin{tabular}{|c|c|c|c|c|c|c|}
\hline Parâmetros & CAS & Unidade & LQ & Resultados analíticos & Incerteza & Data do Ensaio \\
\hline 1,1,1-Tricloroetano & $71-55-6$ & $\mathrm{mg} / \mathrm{kg}$ & 0,1 & $<0,1$ & n.a. & 29/10/2014 21:08 \\
\hline 1,1,2-Tricloroetano & $79-00-5$ & $\mathrm{mg} / \mathrm{kg}$ & 0,1 & $<0,1$ & n.a. & 29/10/2014 21:08 \\
\hline 1,1,2,2-Tetracloroetano & $79-34-5$ & $\mathrm{mg} / \mathrm{kg}$ & 0,1 & $<0,1$ & n.a. & 29/10/2014 21:08 \\
\hline 1,1-Dicloroetano & $75-34-3$ & $\mathrm{mg} / \mathrm{kg}$ & 0,1 & $<0,1$ & n.a. & 29/10/2014 21:08 \\
\hline 1,1-Dicloroeteno & $75-35-4$ & $\mathrm{mg} / \mathrm{kg}$ & 0,05 & $<0,05$ & n.a. & 29/10/2014 21:08 \\
\hline 1,1-Dicloropropeno & $563-58-6$ & $\mathrm{mg} / \mathrm{kg}$ & 0,1 & $<0,1$ & n.a. & $29 / 10 / 201421: 08$ \\
\hline 1,2,3-Triclorobenzeno & $87-61-6$ & $\mathrm{mg} / \mathrm{kg}$ & 0,1 & $<0,1$ & n.a. & 29/10/2014 21:08 \\
\hline 1,2,4-Triclorobenzeno & $120-82-1$ & $\mathrm{mg} / \mathrm{kg}$ & 0,1 & $<0,1$ & n.a. & 29/10/2014 21:08 \\
\hline 1,2-Dibromo-3-Cloropropano & $96-12-8$ & $\mathrm{mg} / \mathrm{kg}$ & 0,1 & $<0,1$ & n.a. & 29/10/2014 21:08 \\
\hline 1,2-Dicloroetano & $107-06-2$ & $\mathrm{mg} / \mathrm{kg}$ & 0,1 & $<0,1$ & n.a. & 29/10/2014 21:08 \\
\hline 1,2-Dicloropropano & $78-87-5$ & $\mathrm{mg} / \mathrm{kg}$ & 0,1 & $<0,1$ & n.a. & $29 / 10 / 201421: 08$ \\
\hline 1,3-Diclorobenzeno & 541-73-1 & $\mathrm{mg} / \mathrm{kg}$ & 0,1 & $<0,1$ & n.a. & 29/10/2014 21:08 \\
\hline 2,2-Dicloropropano & $594-20-7$ & $\mathrm{mg} / \mathrm{kg}$ & 0,1 & $<0,1$ & n.a. & 29/10/2014 21:08 \\
\hline 4-Metil-2-Pentanona & $108-10-1$ & $\mathrm{mg} / \mathrm{kg}$ & 0,1 & $<0,1$ & n.a. & $29 / 10 / 201421: 08$ \\
\hline Benzeno & $71-43-2$ & $\mathrm{mg} / \mathrm{kg}$ & 0,05 & $<0,05$ & n.a. & 29/10/2014 21:08 \\
\hline Bromobenzeno & $108-86-1$ & $\mathrm{mg} / \mathrm{kg}$ & 0,1 & $<0,1$ & n.a. & 29/10/2014 21:08 \\
\hline Bromodiclorometano & $75-27-4$ & $\mathrm{mg} / \mathrm{kg}$ & 0,1 & $<0,1$ & n.a. & 29/10/2014 21:08 \\
\hline Bromofórmio & $75-25-2$ & $\mathrm{mg} / \mathrm{kg}$ & 0,1 & $<0,1$ & n.a. & 29/10/2014 21:08 \\
\hline Bromometano & $74-83-9$ & $\mathrm{mg} / \mathrm{kg}$ & 0,1 & $<0,1$ & n.a. & 29/10/2014 21:08 \\
\hline Cis-1,2-Dicloroeteno & $156-59-2$ & $\mathrm{mg} / \mathrm{kg}$ & 0,1 & $<0,1$ & n.a. & $29 / 10 / 201421: 08$ \\
\hline Cis-1,3-Dicloropropeno & $10061-01-5$ & $\mathrm{mg} / \mathrm{kg}$ & 0,1 & $<0,1$ & n.a. & 29/10/2014 21:08 \\
\hline Diclorometano & $75-09-2$ & $\mathrm{mg} / \mathrm{kg}$ & 0,1 & $<0,1$ & n.a. & 29/10/2014 21:08 \\
\hline Cloreto de Vinila & $75-01-4$ & $\mathrm{mg} / \mathrm{kg}$ & 0,02 & $<0,02$ & n.a. & 29/10/2014 21:08 \\
\hline Clorobenzeno & $108-90-7$ & $\mathrm{mg} / \mathrm{kg}$ & 0,1 & $<0,1$ & n.a. & 29/10/2014 21:08 \\
\hline Cloroetano & $75-00-3$ & $\mathrm{mg} / \mathrm{kg}$ & 0,1 & $<0,1$ & n.a. & 29/10/2014 21:08 \\
\hline Clorofórmio & $67-66-3$ & $\mathrm{mg} / \mathrm{kg}$ & 0,1 & $<0,1$ & n.a. & $29 / 10 / 201421: 08$ \\
\hline Clorometano & $74-87-3$ & $\mathrm{mg} / \mathrm{kg}$ & 0,1 & $<0,1$ & n.a. & 29/10/2014 21:08 \\
\hline Dibromoclorometano & $124-48-1$ & $\mathrm{mg} / \mathrm{kg}$ & 0,1 & $<0,1$ & n.a. & 29/10/2014 21:08 \\
\hline Dissulfeto de Carbono & $75-15-0$ & $\mathrm{mg} / \mathrm{kg}$ & 0,1 & $<0,1$ & n.a. & 29/10/2014 21:08 \\
\hline Estireno & $100-42-5$ & $\mathrm{mg} / \mathrm{kg}$ & 0,1 & $<0,1$ & n.a. & 29/10/2014 21:08 \\
\hline Etilbenzeno & $100-41-4$ & $\mathrm{mg} / \mathrm{kg}$ & 0,05 & $<0,05$ & n.a. & 29/10/2014 21:08 \\
\hline Hexaclorobutadieno & $87-68-3$ & $\mathrm{mg} / \mathrm{kg}$ & 0,1 & $<0,1$ & n.a. & 29/10/2014 21:08 \\
\hline m,p-Xilenos & --- & $\mathrm{mg} / \mathrm{kg}$ & 0,1 & $<0,1$ & n.a. & 29/10/2014 21:08 \\
\hline o-Xileno & $95-47-6$ & $\mathrm{mg} / \mathrm{kg}$ & 0,05 & $<0,05$ & n.a. & 29/10/2014 21:08 \\
\hline p-Isopropiltolueno & $99-87-6$ & $\mathrm{mg} / \mathrm{kg}$ & 0,1 & $<0,1$ & n.a. & 29/10/2014 21:08 \\
\hline Tetracloroeteno & $127-18-4$ & $\mathrm{mg} / \mathrm{kg}$ & 1 & 3,7 & 0,74 & 29/10/2014 21:08 \\
\hline Tetracloreto de Carbono & $56-23-5$ & $\mathrm{mg} / \mathrm{kg}$ & 0,1 & $<0,1$ & n.a. & 29/10/2014 21:08 \\
\hline Tolueno & $108-88-3$ & $\mathrm{mg} / \mathrm{kg}$ & 0,05 & $<0,05$ & n.a. & 29/10/2014 21:08 \\
\hline Trans-1,2-Dicloroeteno & $156-60-5$ & $\mathrm{mg} / \mathrm{kg}$ & 0,1 & $<0,1$ & n.a. & 29/10/2014 21:08 \\
\hline Tricloroeteno & $79-01-6$ & $\mathrm{mg} / \mathrm{kg}$ & 0,1 & $<0,1$ & n.a. & 29/10/2014 21:08 \\
\hline 1,1,1,2-Tetracloroetano & $630-20-6$ & $\mathrm{mg} / \mathrm{kg}$ & 0,1 & $<0,1$ & n.a. & 29/10/2014 21:08 \\
\hline 1,2,3-Tricloropropano & $96-18-4$ & $\mathrm{mg} / \mathrm{kg}$ & 0,1 & $<0,1$ & n.a. & 29/10/2014 21:08 \\
\hline
\end{tabular}




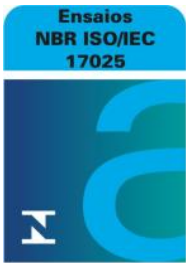

CRL 0172

\begin{tabular}{|c|c|c|c|c|c|c|}
\hline Parâmetros & CAS & Unidade & LQ & Resultados analíticos & Incerteza & Data do Ensaio \\
\hline 1,3,5-Trimetilbenzeno & $108-67-8$ & $\mathrm{mg} / \mathrm{kg}$ & 0,1 & $<0,1$ & n.a. & 29/10/2014 21:08 \\
\hline 1,2,4-Trimetilbenzeno & $95-63-6$ & $\mathrm{mg} / \mathrm{kg}$ & 0,1 & $<0,1$ & n.a. & 29/10/2014 21:08 \\
\hline 1,2-Dibromoetano & $106-93-4$ & $\mathrm{mg} / \mathrm{kg}$ & 0,1 & $<0,1$ & n.a. & 29/10/2014 21:08 \\
\hline 1,2-Diclorobenzeno & $95-50-1$ & $\mathrm{mg} / \mathrm{kg}$ & 0,1 & $<0,1$ & n.a. & 29/10/2014 21:08 \\
\hline 2-Clorotolueno & $95-49-8$ & $\mathrm{mg} / \mathrm{kg}$ & 0,1 & $<0,1$ & n.a. & 29/10/2014 21:08 \\
\hline Dibromometano & $74-95-3$ & $\mathrm{mg} / \mathrm{kg}$ & 0,1 & $<0,1$ & n.a. & 29/10/2014 21:08 \\
\hline Metiletilcetona & $78-93-3$ & $\mathrm{mg} / \mathrm{kg}$ & 25 & $<25$ & n.a. & 29/10/2014 21:32 \\
\hline Naftaleno & $91-20-3$ & $\mathrm{mg} / \mathrm{kg}$ & 0,1 & $<0,1$ & n.a. & 29/10/2014 21:08 \\
\hline n-Butilbenzeno & $104-51-8$ & $\mathrm{mg} / \mathrm{kg}$ & 0,1 & $<0,1$ & n.a. & 29/10/2014 21:08 \\
\hline n-Propilbenzeno & $103-65-1$ & $\mathrm{mg} / \mathrm{kg}$ & 0,1 & $<0,1$ & n.a. & 29/10/2014 21:08 \\
\hline 4-Clorotolueno & $106-43-4$ & $\mathrm{mg} / \mathrm{kg}$ & 0,1 & $<0,1$ & n.a. & 29/10/2014 21:08 \\
\hline sec-Butilbenzeno & $135-98-8$ & $\mathrm{mg} / \mathrm{kg}$ & 0,1 & $<0,1$ & n.a. & 29/10/2014 21:08 \\
\hline terc-Butilbenzeno & $98-06-6$ & $\mathrm{mg} / \mathrm{kg}$ & 0,1 & $<0,1$ & n.a. & 29/10/2014 21:08 \\
\hline trans-1,3-Dicloropropeno & $10061-02-6$ & $\mathrm{mg} / \mathrm{kg}$ & 0,1 & $<0,1$ & n.a. & 29/10/2014 21:08 \\
\hline Isopropilbenzeno & $98-82-8$ & $\mathrm{mg} / \mathrm{kg}$ & 0,1 & $<0,1$ & n.a. & 29/10/2014 21:08 \\
\hline 1,4-Diclorobenzeno & 106-46-7 & $\mathrm{mg} / \mathrm{kg}$ & 0,1 & $<0,1$ & n.a. & 29/10/2014 21:08 \\
\hline 1,3,5-Triclorobenzeno & $108-70-3$ & $\mathrm{mg} / \mathrm{kg}$ & 0,1 & $<0,1$ & n.a. & 29/10/2014 21:08 \\
\hline 1,3-Dicloropropano & $142-28-9$ & $\mathrm{mg} / \mathrm{kg}$ & 0,1 & $<0,1$ & n.a. & 29/10/2014 21:08 \\
\hline
\end{tabular}

\section{CONTROLE DE Q UALIDADE DO LABORATÓRIO}

Controle de Q ualidade - VOC - Solo

284309/2014-0 - Branco de Análise - VOC - Solo

\section{Parâmetros}

1,1,1-Tricloroetano

1,1,2-Tricloroetano

1,1,2,2-Tetracloroetano

1,1-Dicloroetano

1,1-Dicloroeteno

1,1-Dicloropropeno

1,2,3-Triclorobenzeno

1,2,4-Triclorobenzeno

1,2-Dibromo-3-Cloropropano

1,2-Dicloroetano

1,2-Dicloropropano

1,3-Dicloropropano

1,4-Diclorobenzeno

2,2-Dicloropropano

4-Metil-2-Pentanon

Benzeno

Bromobenzeno

Bromodiclorometano

Bromofórmio

Bromometano

Cis-1,2-Dicloroeteno

Cis-1,3-Dicloropropeno

Diclorometano

Cloreto de Vinila

Clorobenzeno

Cloroetano

Clorofórmio

Clorometano

Dibromoclorometano

Dissulfeto de Carbono

Estireno

Etilbenzeno

Hexaclorobutadieno

m,p-Xilenos

o-Xileno

p-Isopropiltolueno

Tetracloreto de Carbono

Tetracloroeteno

Tolueno

Trans-1,2-Dicloroeteno

Tricloroeteno

1,3,5-Triclorobenzeno $\mathrm{mg} / \mathrm{kg}$

$\mathrm{mg} / \mathrm{kg}$

$\mathrm{mg} / \mathrm{kg}$

$\mathrm{mg} / \mathrm{kg}$

$\mathrm{mg} / \mathrm{kg}$

$\mathrm{mg} / \mathrm{kg}$

$\mathrm{mg} / \mathrm{kg}$

$\mathrm{mg} / \mathrm{kg}$

$\mathrm{mg} / \mathrm{kg}$

$\mathrm{mg} / \mathrm{kg}$

$\mathrm{mg} / \mathrm{kg}$

$\mathrm{mg} / \mathrm{kg}$

$\mathrm{mg} / \mathrm{kg}$

$\mathrm{mg} / \mathrm{kg}$

$\mathrm{mg} / \mathrm{kg}$

$\mathrm{mg} / \mathrm{kg}$

$\mathrm{mg} / \mathrm{kg}$

$\mathrm{mg} / \mathrm{kg}$

$\mathrm{mg} / \mathrm{kg}$

$\mathrm{mg} / \mathrm{kg}$

$\mathrm{mg} / \mathrm{kg}$

$\mathrm{mg} / \mathrm{kg}$

$\mathrm{mg} / \mathrm{kg}$

$\mathrm{mg} / \mathrm{kg}$

$\mathrm{mg} / \mathrm{kg}$

$\mathrm{mg} / \mathrm{kg}$

$\mathrm{mg} / \mathrm{kg}$

$\mathrm{mg} / \mathrm{kg}$

$\mathrm{mg} / \mathrm{kg}$

$\mathrm{mg} / \mathrm{kg}$

$\mathrm{mg} / \mathrm{kg}$

$\mathrm{mg} / \mathrm{kg}$

$\mathrm{mg} / \mathrm{kg}$

$\mathrm{mg} / \mathrm{kg}$

$\mathrm{mg} / \mathrm{kg}$

$\mathrm{mg} / \mathrm{kg}$

$\mathrm{mg} / \mathrm{kg}$

$\mathrm{mg} / \mathrm{kg}$

$\mathrm{mg} / \mathrm{kg}$

$\mathrm{mg} / \mathrm{kg}$

$\mathrm{mg} / \mathrm{kg}$

$\mathrm{mg} / \mathrm{kg}$

\begin{tabular}{|c|c|}
\hline LQ & Resultados analíticos \\
\hline 0,01 & $<0,01$ \\
\hline 0,01 & $<0,01$ \\
\hline 0,01 & $<0,01$ \\
\hline 0,01 & $<0,01$ \\
\hline 0,01 & $<0,01$ \\
\hline 0,01 & $<0,01$ \\
\hline 0,01 & $<0,01$ \\
\hline 0,01 & $<0,01$ \\
\hline 0,01 & $<0,01$ \\
\hline 0,01 & $<0,01$ \\
\hline 0,01 & $<0,01$ \\
\hline 0,01 & $<0,01$ \\
\hline 0,01 & $<0,01$ \\
\hline 0,01 & $<0,01$ \\
\hline 0,01 & $<0,01$ \\
\hline 0,01 & $<0,01$ \\
\hline 0,01 & $<0,01$ \\
\hline 0,01 & $<0,01$ \\
\hline 0,01 & $<0,01$ \\
\hline 0,01 & $<0,01$ \\
\hline 0,01 & $<0,01$ \\
\hline 0,01 & $<0,01$ \\
\hline 0,01 & $<0,01$ \\
\hline 0,002 & $<0,002$ \\
\hline 0,01 & $<0,01$ \\
\hline 0,01 & $<0,01$ \\
\hline 0,01 & $<0,01$ \\
\hline 0,01 & $<0,01$ \\
\hline 0,01 & $<0,01$ \\
\hline 0,01 & $<0,01$ \\
\hline 0,01 & $<0,01$ \\
\hline 0,01 & $<0,01$ \\
\hline 0,01 & $<0,01$ \\
\hline 0,01 & $<0,01$ \\
\hline 0,01 & $<0,01$ \\
\hline 0,01 & $<0,01$ \\
\hline 0,01 & $<0,01$ \\
\hline 0,01 & $<0,01$ \\
\hline 0,01 & $<0,01$ \\
\hline 0,01 & $<0,01$ \\
\hline 0,01 & $<0,01$ \\
\hline 0,01 & $<0,01$ \\
\hline
\end{tabular}

Ensaios de Recuperação 


\begin{tabular}{|c|c|c|c|c|}
\hline \multicolumn{5}{|c|}{ 284310/2014-0 - LCS - VOC - Solo } \\
\hline 1,1-Dicloroeteno & 0,05 & $\mathrm{mg} / \mathrm{kg}$ & 62 & $60-140$ \\
\hline Benzeno & 0,05 & $\mathrm{mg} / \mathrm{kg}$ & 73 & $60-140$ \\
\hline Tricloroeteno & 0,05 & $\mathrm{mg} / \mathrm{kg}$ & 82 & $60-140$ \\
\hline Tolueno & 0,05 & $\mathrm{mg} / \mathrm{kg}$ & 84 & $60-140$ \\
\hline Clorobenzeno & 0,05 & $\mathrm{mg} / \mathrm{kg}$ & 67 & $60-140$ \\
\hline \multicolumn{5}{|c|}{$\begin{array}{l}\text { Surrogates } \\
\text { 284309/2014-0 - Branco de Análise - VOC - Solo }\end{array}$} \\
\hline p-Bromofluorbenzeno & 0,05 & $\%$ & 120 & $60-140$ \\
\hline Dibrom ofluorometano & 0,05 & $\%$ & 110 & $60-140$ \\
\hline \multicolumn{5}{|c|}{ 284310/2014-0 - LCS - VOC - Solo } \\
\hline p-Bromofluorbenzeno & 0,05 & $\%$ & 120 & $60-140$ \\
\hline Dibrom ofluorometano & 0,05 & $\%$ & 83 & $60-140$ \\
\hline \multicolumn{5}{|c|}{ 283874/2014-0 - CGBI-1 } \\
\hline Dibrom ofluorometano & 0,05 & $\%$ & Amostra Diluída & $60-140$ \\
\hline p-Bromofluorbenzeno & 0,05 & $\%$ & Amostra Diluída & $60-140$ \\
\hline
\end{tabular}

Notas

LQ = Limite de Quantificação.

n.a. = Não Aplicável.

Abrangência

$O$ (s) resultado(s) referem-se somente à(s) amostra(s) analisada(s).

Este Relatório de Ensaio só pode ser reproduzido por inteiro e sem nenhuma alteração.

Plano de Amostragem

Plano de amostragem de responsabilidade do interessado.

Responsabilidade Técnica

Os ensaios foram realizados na unidade da Bioagri Ambiental Ltda. - Matriz, situada na Rua Aljovil Martini, 177/201, Bairro Dois Córregos, Cep. 14420-833, Piracicaba/SP, registrada no CRQ 4 Região sob n $16082-F$ e responsabilidade técnica do profissional José Carlos Moretti, CRQ n 04107238, $4^{\text {a. }}$.Região.

Referências Metodológicas

Análises foram realizadas conforme a última versão do Standard Methods for the Examination of Water \& Wastewater 22nd 2012(SMWW), EPA e ABNT (quando aplicável). VOC: EPA 8260 C: 2006, 5021 A: 2003

Metiletilcetona: EPA 8260 C: 2006, 5021 A: 2003

Revisores

Débora Fernandes da Silva

Chave de Validação: ef9aacca91c4614f8fcaa5f51b201d62

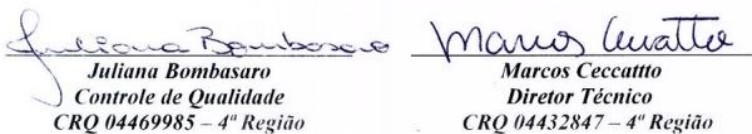




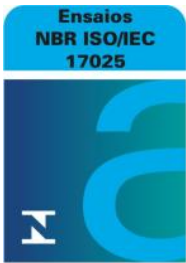

CRL 0172

\begin{tabular}{|c|c|c|c|c|c|c|}
\hline Parâmetros & CAS & Unidade & LQ & Resultados analíticos & Incerteza & Data do Ensaio \\
\hline 1,3,5-Trimetilbenzeno & $108-67-8$ & $\mathrm{mg} / \mathrm{kg}$ & 0,1 & $<0,1$ & n.a. & 29/10/2014 22:20 \\
\hline 1,2,4-Trimetilbenzeno & $95-63-6$ & $\mathrm{mg} / \mathrm{kg}$ & 0,1 & $<0,1$ & n.a. & 29/10/2014 22:20 \\
\hline 1,2-Dibromoetano & $106-93-4$ & $\mathrm{mg} / \mathrm{kg}$ & 0,1 & $<0,1$ & n.a. & $29 / 10 / 201422: 20$ \\
\hline 1,2-Diclorobenzeno & $95-50-1$ & $\mathrm{mg} / \mathrm{kg}$ & 0,1 & $<0,1$ & n.a. & $29 / 10 / 201422: 20$ \\
\hline 2-Clorotolueno & $95-49-8$ & $\mathrm{mg} / \mathrm{kg}$ & 0,1 & $<0,1$ & n.a. & $29 / 10 / 201422: 20$ \\
\hline Dibromometano & $74-95-3$ & $\mathrm{mg} / \mathrm{kg}$ & 0,1 & $<0,1$ & n.a. & 29/10/2014 22:20 \\
\hline Metiletilcetona & $78-93-3$ & $\mathrm{mg} / \mathrm{kg}$ & 25 & $<25$ & n.a. & 29/10/2014 22:20 \\
\hline Naftaleno & $91-20-3$ & $\mathrm{mg} / \mathrm{kg}$ & 0,1 & $<0,1$ & n.a. & $29 / 10 / 201422: 20$ \\
\hline n-Butilbenzeno & $104-51-8$ & $\mathrm{mg} / \mathrm{kg}$ & 0,1 & $<0,1$ & n.a. & $29 / 10 / 201422: 20$ \\
\hline n-Propilbenzeno & $103-65-1$ & $\mathrm{mg} / \mathrm{kg}$ & 0,1 & $<0,1$ & n.a. & 29/10/2014 22:20 \\
\hline 4-Clorotolueno & $106-43-4$ & $\mathrm{mg} / \mathrm{kg}$ & 0,1 & $<0,1$ & n.a. & $29 / 10 / 201422: 20$ \\
\hline sec-Butilbenzeno & $135-98-8$ & $\mathrm{mg} / \mathrm{kg}$ & 0,1 & $<0,1$ & n.a. & $29 / 10 / 201422: 20$ \\
\hline terc-Butilbenzeno & $98-06-6$ & $\mathrm{mg} / \mathrm{kg}$ & 0,1 & $<0,1$ & n.a. & $29 / 10 / 201422: 20$ \\
\hline trans-1,3-Dicloropropeno & 10061-02-6 & $\mathrm{mg} / \mathrm{kg}$ & 0,1 & $<0,1$ & n.a. & $29 / 10 / 201422: 20$ \\
\hline Isopropilbenzeno & $98-82-8$ & $\mathrm{mg} / \mathrm{kg}$ & 0,1 & $<0,1$ & n.a. & $29 / 10 / 201422: 20$ \\
\hline 1,4-Diclorobenzeno & $106-46-7$ & $\mathrm{mg} / \mathrm{kg}$ & 0,1 & $<0,1$ & n.a. & 29/10/2014 22:20 \\
\hline 1,3,5-Triclorobenzeno & $108-70-3$ & $\mathrm{mg} / \mathrm{kg}$ & 0,1 & $<0,1$ & n.a. & 29/10/2014 22:20 \\
\hline 1,3-Dicloropropano & $142-28-9$ & $\mathrm{mg} / \mathrm{kg}$ & 0,1 & $<0,1$ & n.a. & $29 / 10 / 201422: 20$ \\
\hline
\end{tabular}

\section{CONTROLE DE Q UALIDADE DO LABORATÓRIO}

Controle de Q ualidade - VOC - Solo

284309/2014-0 - Branco de Análise - VOC - Solo

\section{Parâmetros}

1,1,1-Tricloroetano

1,1,2-Tricloroetano

1,1,2,2-Tetracloroetano

1,1-Dicloroetano

1,1-Dicloroeteno

1,1-Dicloropropeno

1,2,3-Triclorobenzeno

1,2,4-Triclorobenzeno

1,2-Dibromo-3-Cloropropano

1,2-Dicloroetano

1,2-Dicloropropano

1,3-Dicloropropano

1,4-Diclorobenzeno

2,2-Dicloropropano

4-Metil-2-Pentanon

Benzeno

Bromobenzeno

Bromodiclorometano

Bromofórmio

Bromometano

Cis-1,2-Dicloroeteno

Cis-1,3-Dicloropropeno

Diclorometano

Cloreto de Vinila

Clorobenzeno

Cloroetano

Clorofórmio

Clorometano

Dibromoclorometano

Dissulfeto de Carbono

Estireno

Etilbenzeno

Hexaclorobutadieno

m,p-Xilenos

o-Xileno

p-Isopropiltolueno

Tetracloreto de Carbono

Tetracloroeteno

Tolueno

Trans-1,2-Dicloroeteno

Tricloroeteno

1,3,5-Triclorobenzeno $\mathrm{mg} / \mathrm{kg}$

$\mathrm{mg} / \mathrm{kg}$

$\mathrm{mg} / \mathrm{kg}$

$\mathrm{mg} / \mathrm{kg}$

$\mathrm{mg} / \mathrm{kg}$

$\mathrm{mg} / \mathrm{kg}$

$\mathrm{mg} / \mathrm{kg}$

$\mathrm{mg} / \mathrm{kg}$

$\mathrm{mg} / \mathrm{kg}$

$\mathrm{mg} / \mathrm{kg}$

$\mathrm{mg} / \mathrm{kg}$

$\mathrm{mg} / \mathrm{kg}$

$\mathrm{mg} / \mathrm{kg}$

$\mathrm{mg} / \mathrm{kg}$

$\mathrm{mg} / \mathrm{kg}$

$\mathrm{mg} / \mathrm{kg}$

$\mathrm{mg} / \mathrm{kg}$

$\mathrm{mg} / \mathrm{kg}$

$\mathrm{mg} / \mathrm{kg}$

$\mathrm{mg} / \mathrm{kg}$

$\mathrm{mg} / \mathrm{kg}$

$\mathrm{mg} / \mathrm{kg}$

$\mathrm{mg} / \mathrm{kg}$

$\mathrm{mg} / \mathrm{kg}$

$\mathrm{mg} / \mathrm{kg}$

$\mathrm{mg} / \mathrm{kg}$

$\mathrm{mg} / \mathrm{kg}$

$\mathrm{mg} / \mathrm{kg}$

$\mathrm{mg} / \mathrm{kg}$

$\mathrm{mg} / \mathrm{kg}$

$\mathrm{mg} / \mathrm{kg}$

$\mathrm{mg} / \mathrm{kg}$

$\mathrm{mg} / \mathrm{kg}$

$\mathrm{mg} / \mathrm{kg}$

$\mathrm{mg} / \mathrm{kg}$

$\mathrm{mg} / \mathrm{kg}$

$\mathrm{mg} / \mathrm{kg}$

$\mathrm{mg} / \mathrm{kg}$

$\mathrm{mg} / \mathrm{kg}$

$\mathrm{mg} / \mathrm{kg}$

$\mathrm{mg} / \mathrm{kg}$

$\mathrm{mg} / \mathrm{kg}$

\begin{tabular}{|c|c|}
\hline LQ & Resultados analíticos \\
\hline 0,01 & $<0,01$ \\
\hline 0,01 & $<0,01$ \\
\hline 0,01 & $<0,01$ \\
\hline 0,01 & $<0,01$ \\
\hline 0,01 & $<0,01$ \\
\hline 0,01 & $<0,01$ \\
\hline 0,01 & $<0,01$ \\
\hline 0,01 & $<0,01$ \\
\hline 0,01 & $<0,01$ \\
\hline 0,01 & $<0,01$ \\
\hline 0,01 & $<0,01$ \\
\hline 0,01 & $<0,01$ \\
\hline 0,01 & $<0,01$ \\
\hline 0,01 & $<0,01$ \\
\hline 0,01 & $<0,01$ \\
\hline 0,01 & $<0,01$ \\
\hline 0,01 & $<0,01$ \\
\hline 0,01 & $<0,01$ \\
\hline 0,01 & $<0,01$ \\
\hline 0,01 & $<0,01$ \\
\hline 0,01 & $<0,01$ \\
\hline 0,01 & $<0,01$ \\
\hline 0,01 & $<0,01$ \\
\hline 0,002 & $<0,002$ \\
\hline 0,01 & $<0,01$ \\
\hline 0,01 & $<0,01$ \\
\hline 0,01 & $<0,01$ \\
\hline 0,01 & $<0,01$ \\
\hline 0,01 & $<0,01$ \\
\hline 0,01 & $<0,01$ \\
\hline 0,01 & $<0,01$ \\
\hline 0,01 & $<0,01$ \\
\hline 0,01 & $<0,01$ \\
\hline 0,01 & $<0,01$ \\
\hline 0,01 & $<0,01$ \\
\hline 0,01 & $<0,01$ \\
\hline 0,01 & $<0,01$ \\
\hline 0,01 & $<0,01$ \\
\hline 0,01 & $<0,01$ \\
\hline 0,01 & $<0,01$ \\
\hline 0,01 & $<0,01$ \\
\hline 0,01 & $<0,01$ \\
\hline
\end{tabular}

Ensaios de Recuperação 


\begin{tabular}{|c|c|c|c|c|}
\hline \multicolumn{5}{|c|}{ 284310/2014-0 - LCS - VOC - Solo } \\
\hline 1,1-Dicloroeteno & 0,05 & $\mathrm{mg} / \mathrm{kg}$ & 62 & $60-140$ \\
\hline Benzeno & 0,05 & $\mathrm{mg} / \mathrm{kg}$ & 73 & $60-140$ \\
\hline Tricloroeteno & 0,05 & $\mathrm{mg} / \mathrm{kg}$ & 82 & $60-140$ \\
\hline Tolueno & 0,05 & $\mathrm{mg} / \mathrm{kg}$ & 84 & $60-140$ \\
\hline Clorobenzeno & 0,05 & $\mathrm{mg} / \mathrm{kg}$ & 67 & $60-140$ \\
\hline \multicolumn{5}{|c|}{$\begin{array}{l}\text { Surrogates } \\
\text { 284309/2014-0 - Branco de Análise - VOC - Solo }\end{array}$} \\
\hline p-Bromofluorbenzeno & 0,05 & $\%$ & 120 & $60-140$ \\
\hline Dibrom ofluorometano & 0,05 & $\%$ & 110 & $60-140$ \\
\hline \multicolumn{5}{|c|}{ 284310/2014-0 - LCS - VOC - Solo } \\
\hline p-Bromofluorbenzeno & 0,05 & $\%$ & 120 & $60-140$ \\
\hline Dibrom ofluorometano & 0,05 & $\%$ & 83 & $60-140$ \\
\hline \multicolumn{5}{|c|}{ 283875/2014-0 - CGBI-2 } \\
\hline Dibrom ofluorometano & 0,05 & $\%$ & Amostra Diluída & $60-140$ \\
\hline p-Bromofluorbenzeno & 0,05 & $\%$ & Amostra Diluída & $60-140$ \\
\hline
\end{tabular}

Notas

LQ = Limite de Quantificação.

n.a. = Não Aplicável.

Abrangência

$O$ (s) resultado(s) referem-se somente à(s) amostra(s) analisada(s).

Este Relatório de Ensaio só pode ser reproduzido por inteiro e sem nenhuma alteração.

Plano de Amostragem

Plano de amostragem de responsabilidade do interessado.

Responsabilidade Técnica

Os ensaios foram realizados na unidade da Bioagri Ambiental Ltda. - Matriz, situada na Rua Aljovil Martini, 177/201, Bairro Dois Córregos, Cep. 14420-833, Piracicaba/SP, registrada no CRQ 4 Região sob n $16082-F$ e responsabilidade técnica do profissional José Carlos Moretti, CRQ n 04107238, $4^{\text {a. }}$.Região.

Referências Metodológicas

Análises foram realizadas conforme a última versão do Standard Methods for the Examination of Water \& Wastewater 22nd 2012(SMWW), EPA e ABNT (quando aplicável). VOC: EPA 8260 C: 2006, 5021 A: 2003

Metiletilcetona: EPA 8260 C: 2006, 5021 A: 2003

Revisores

Débora Fernandes da Silva

Chave de Validação: dbc689ee0b87c1db2e8bdeb2d7e41f2

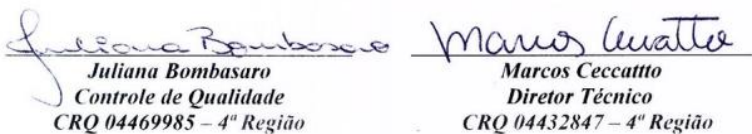




\section{RELATÓRIO DE ENSAIO N $^{\circ}$ 283877/2014-0 - Piracicaba Processo Comercial $N^{\circ}$ 23961/2014-2}

\begin{tabular}{|l|l|}
\hline \multicolumn{2}{|c|}{ DADOS REFERENTES AO CLIENTE } \\
\hline Empresa solicitante: & Fundacao Parque de Alta Tecnologia da Regiao de Ipero e Adjacencias \\
\hline Endereço: & Rua Jose Antonio Scaciota, 165 - - Portal do Cedro - Iperó - SP - CEP: 18.560-000 . \\
\hline Nome do Solicitante: & Carla Marçal \\
\hline
\end{tabular}

\begin{tabular}{|l|l|l|l|l|}
\hline \multicolumn{5}{|c|}{ DADOS REFERENTES A AMOSTRA } \\
\hline Identificação do Cliente: & CGBI-3 & \\
\hline Amostra Rotulada como: & Solo Projeto Mestrado & Data da coleta: & \multicolumn{2}{|c|}{$23 / 10 / 2014$ 18:00:00 } \\
\hline Coletor: & Interessado & Data de Elaboração do RE: & $31 / 10 / 2014$ \\
\hline Data da entrada no laboratório: & $25 / 10 / 2014$ 08:26 & & \\
\hline
\end{tabular}

\section{RESULTADOS PARA A AMOSTRA}

\begin{tabular}{|c|c|c|c|c|c|c|}
\hline Parâmetros & CAS & Unidade & LQ & Resultados analíticos & Incerteza & Data do Ensaio \\
\hline 1,1,1-Tricloroetano & $71-55-6$ & $\mathrm{mg} / \mathrm{kg}$ & 0,1 & $<0,1$ & n.a. & 29/10/2014 22:44 \\
\hline 1,1,2-Tricloroetano & $79-00-5$ & $\mathrm{mg} / \mathrm{kg}$ & 0,1 & $<0,1$ & n.a. & $29 / 10 / 201422: 44$ \\
\hline 1,1,2,2-Tetracloroetano & $79-34-5$ & $\mathrm{mg} / \mathrm{kg}$ & 0,1 & $<0,1$ & n.a. & 29/10/2014 22:44 \\
\hline 1,1-Dicloroetano & $75-34-3$ & $\mathrm{mg} / \mathrm{kg}$ & 0,1 & $<0,1$ & n.a. & $29 / 10 / 201422: 44$ \\
\hline 1,1-Dicloroeteno & $75-35-4$ & $\mathrm{mg} / \mathrm{kg}$ & 0,05 & $<0,05$ & n.a. & $29 / 10 / 201422: 44$ \\
\hline 1,1-Dicloropropeno & $563-58-6$ & $\mathrm{mg} / \mathrm{kg}$ & 0,1 & $<0,1$ & n.a. & $29 / 10 / 201422: 44$ \\
\hline 1,2,3-Triclorobenzeno & $87-61-6$ & $\mathrm{mg} / \mathrm{kg}$ & 0,1 & $<0,1$ & n.a. & $29 / 10 / 201422: 44$ \\
\hline 1,2,4-Triclorobenzeno & $120-82-1$ & $\mathrm{mg} / \mathrm{kg}$ & 0,1 & $<0,1$ & n.a. & $29 / 10 / 201422: 44$ \\
\hline 1,2-Dibromo-3-Cloropropano & $96-12-8$ & $\mathrm{mg} / \mathrm{kg}$ & 0,1 & $<0,1$ & n.a. & 29/10/2014 22:44 \\
\hline 1,2-Dicloroetano & $107-06-2$ & $\mathrm{mg} / \mathrm{kg}$ & 0,1 & $<0,1$ & n.a. & $29 / 10 / 201422: 44$ \\
\hline 1,2-Dicloropropano & $78-87-5$ & $\mathrm{mg} / \mathrm{kg}$ & 0,1 & $<0,1$ & n.a. & $29 / 10 / 201422: 44$ \\
\hline 1,3-Diclorobenzeno & $541-73-1$ & $\mathrm{mg} / \mathrm{kg}$ & 0,1 & $<0,1$ & n.a. & $29 / 10 / 201422: 44$ \\
\hline 2,2-Dicloropropano & $594-20-7$ & $\mathrm{mg} / \mathrm{kg}$ & 0,1 & $<0,1$ & n.a. & 29/10/2014 22:44 \\
\hline 4-Metil-2-Pentanona & $108-10-1$ & $\mathrm{mg} / \mathrm{kg}$ & 0,1 & $<0,1$ & n.a. & $29 / 10 / 201422: 44$ \\
\hline Benzeno & $71-43-2$ & $\mathrm{mg} / \mathrm{kg}$ & 0,05 & $<0,05$ & n.a. & 29/10/2014 22:44 \\
\hline Bromobenzeno & $108-86-1$ & $\mathrm{mg} / \mathrm{kg}$ & 0,1 & $<0,1$ & n.a. & 29/10/2014 22:44 \\
\hline Bromodiclorometano & $75-27-4$ & $\mathrm{mg} / \mathrm{kg}$ & 0,1 & $<0,1$ & n.a. & 29/10/2014 22:44 \\
\hline Bromofórmio & $75-25-2$ & $\mathrm{mg} / \mathrm{kg}$ & 0,1 & $<0,1$ & n.a. & $29 / 10 / 201422: 44$ \\
\hline Bromometano & $74-83-9$ & $\mathrm{mg} / \mathrm{kg}$ & 0,1 & $<0,1$ & n.a. & $29 / 10 / 201422: 44$ \\
\hline Cis-1,2-Dicloroeteno & $156-59-2$ & $\mathrm{mg} / \mathrm{kg}$ & 0,1 & $<0,1$ & n.a. & $29 / 10 / 201422: 44$ \\
\hline Cis-1,3-Dicloropropeno & $10061-01-5$ & $\mathrm{mg} / \mathrm{kg}$ & 0,1 & $<0,1$ & n.a. & 29/10/2014 22:44 \\
\hline Diclorometano & $75-09-2$ & $\mathrm{mg} / \mathrm{kg}$ & 0,1 & $<0,1$ & n.a. & $29 / 10 / 201422: 44$ \\
\hline Cloreto de Vinila & $75-01-4$ & $\mathrm{mg} / \mathrm{kg}$ & 0,02 & $<0,02$ & n.a. & $29 / 10 / 201422: 44$ \\
\hline Clorobenzeno & $108-90-7$ & $\mathrm{mg} / \mathrm{kg}$ & 0,1 & $<0,1$ & n.a. & $29 / 10 / 201422: 44$ \\
\hline Cloroetano & $75-00-3$ & $\mathrm{mg} / \mathrm{kg}$ & 0,1 & $<0,1$ & n.a. & 29/10/2014 22:44 \\
\hline Clorofórmio & $67-66-3$ & $\mathrm{mg} / \mathrm{kg}$ & 0,1 & $<0,1$ & n.a. & $29 / 10 / 201422: 44$ \\
\hline Clorometano & $74-87-3$ & $\mathrm{mg} / \mathrm{kg}$ & 0,1 & $<0,1$ & n.a. & 29/10/2014 22:44 \\
\hline Dibromoclorometano & $124-48-1$ & $\mathrm{mg} / \mathrm{kg}$ & 0,1 & $<0,1$ & n.a. & $29 / 10 / 201422: 44$ \\
\hline Dissulfeto de Carbono & $75-15-0$ & $\mathrm{mg} / \mathrm{kg}$ & 0,1 & $<0,1$ & n.a. & 29/10/2014 22:44 \\
\hline Estireno & $100-42-5$ & $\mathrm{mg} / \mathrm{kg}$ & 0,1 & $<0,1$ & n.a. & $29 / 10 / 201422: 44$ \\
\hline Etilbenzeno & $100-41-4$ & $\mathrm{mg} / \mathrm{kg}$ & 0,05 & $<0,05$ & n.a. & $29 / 10 / 201422: 44$ \\
\hline Hexaclorobutadieno & $87-68-3$ & $\mathrm{mg} / \mathrm{kg}$ & 0,1 & $<0,1$ & n.a. & 29/10/2014 22:44 \\
\hline m,p-Xilenos & --- & $\mathrm{mg} / \mathrm{kg}$ & 0,1 & $<0,1$ & n.a. & 29/10/2014 22:44 \\
\hline o-Xileno & $95-47-6$ & $\mathrm{mg} / \mathrm{kg}$ & 0,05 & $<0,05$ & n.a. & 29/10/2014 22:44 \\
\hline p-Isopropiltolueno & $99-87-6$ & $\mathrm{mg} / \mathrm{kg}$ & 0,1 & $<0,1$ & n.a. & $29 / 10 / 201422: 44$ \\
\hline Tetracloroeteno & $127-18-4$ & $\mathrm{mg} / \mathrm{kg}$ & 1 & 2,0 & 0,4 & $29 / 10 / 201422: 44$ \\
\hline Tetracloreto de Carbono & $56-23-5$ & $\mathrm{mg} / \mathrm{kg}$ & 0,1 & $<0,1$ & n.a. & 29/10/2014 22:44 \\
\hline Tolueno & $108-88-3$ & $\mathrm{mg} / \mathrm{kg}$ & 0,05 & $<0,05$ & n.a. & $29 / 10 / 201422: 44$ \\
\hline Trans-1,2-Dicloroeteno & $156-60-5$ & $\mathrm{mg} / \mathrm{kg}$ & 0,1 & $<0,1$ & n.a. & $29 / 10 / 201422: 44$ \\
\hline Tricloroeteno & $79-01-6$ & $\mathrm{mg} / \mathrm{kg}$ & 0,1 & $<0,1$ & n.a. & $29 / 10 / 201422: 44$ \\
\hline 1,1,1,2-Tetracloroetano & $630-20-6$ & $\mathrm{mg} / \mathrm{kg}$ & 0,1 & $<0,1$ & n.a. & $29 / 10 / 201422: 44$ \\
\hline 1,2,3-Tricloropropano & $96-18-4$ & $\mathrm{mg} / \mathrm{kg}$ & 0,1 & $<0,1$ & n.a. & $29 / 10 / 201422: 44$ \\
\hline
\end{tabular}




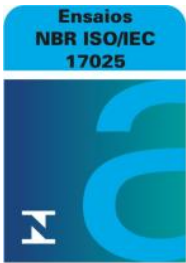

CRL 0172

\begin{tabular}{|c|c|c|c|c|c|c|}
\hline Parâmetros & CAS & Unidade & LQ & Resultados analíticos & Incerteza & Data do Ensaio \\
\hline 1,3,5-Trimetilbenzeno & $108-67-8$ & $\mathrm{mg} / \mathrm{kg}$ & 0,1 & $<0,1$ & n.a. & $29 / 10 / 201422: 44$ \\
\hline 1,2,4-Trimetilbenzeno & $95-63-6$ & $\mathrm{mg} / \mathrm{kg}$ & 0,1 & $<0,1$ & n.a. & 29/10/2014 22:44 \\
\hline 1,2-Dibromoetano & $106-93-4$ & $\mathrm{mg} / \mathrm{kg}$ & 0,1 & $<0,1$ & n.a. & $29 / 10 / 201422: 44$ \\
\hline 1,2-Diclorobenzeno & $95-50-1$ & $\mathrm{mg} / \mathrm{kg}$ & 0,1 & $<0,1$ & n.a. & $29 / 10 / 201422: 44$ \\
\hline 2-Clorotolueno & $95-49-8$ & $\mathrm{mg} / \mathrm{kg}$ & 0,1 & $<0,1$ & n.a. & $29 / 10 / 201422: 44$ \\
\hline Dibromometano & $74-95-3$ & $\mathrm{mg} / \mathrm{kg}$ & 0,1 & $<0,1$ & n.a. & 29/10/2014 22:44 \\
\hline Metiletilcetona & $78-93-3$ & $\mathrm{mg} / \mathrm{kg}$ & 25 & $<25$ & n.a. & 29/10/2014 23:07 \\
\hline Naftaleno & $91-20-3$ & $\mathrm{mg} / \mathrm{kg}$ & 0,1 & $<0,1$ & n.a. & $29 / 10 / 201422: 44$ \\
\hline n-Butilbenzeno & $104-51-8$ & $\mathrm{mg} / \mathrm{kg}$ & 0,1 & $<0,1$ & n.a. & 29/10/2014 22:44 \\
\hline n-Propilbenzeno & $103-65-1$ & $\mathrm{mg} / \mathrm{kg}$ & 0,1 & $<0,1$ & n.a. & 29/10/2014 22:44 \\
\hline 4-Clorotolueno & $106-43-4$ & $\mathrm{mg} / \mathrm{kg}$ & 0,1 & $<0,1$ & n.a. & $29 / 10 / 201422: 44$ \\
\hline sec-Butilbenzeno & $135-98-8$ & $\mathrm{mg} / \mathrm{kg}$ & 0,1 & $<0,1$ & n.a. & 29/10/2014 22:44 \\
\hline terc-Butilbenzeno & $98-06-6$ & $\mathrm{mg} / \mathrm{kg}$ & 0,1 & $<0,1$ & n.a. & $29 / 10 / 201422: 44$ \\
\hline trans-1,3-Dicloropropeno & 10061-02-6 & $\mathrm{mg} / \mathrm{kg}$ & 0,1 & $<0,1$ & n.a. & 29/10/2014 22:44 \\
\hline Isopropilbenzeno & $98-82-8$ & $\mathrm{mg} / \mathrm{kg}$ & 0,1 & $<0,1$ & n.a. & $29 / 10 / 201422: 44$ \\
\hline 1,4-Diclorobenzeno & $106-46-7$ & $\mathrm{mg} / \mathrm{kg}$ & 0,1 & $<0,1$ & n.a. & 29/10/2014 22:44 \\
\hline 1,3,5-Triclorobenzeno & $108-70-3$ & $\mathrm{mg} / \mathrm{kg}$ & 0,1 & $<0,1$ & n.a. & 29/10/2014 22:44 \\
\hline 1,3-Dicloropropano & $142-28-9$ & $\mathrm{mg} / \mathrm{kg}$ & 0,1 & $<0,1$ & n.a. & $29 / 10 / 201422: 44$ \\
\hline
\end{tabular}

\section{CONTROLE DE Q UALIDADE DO LABORATÓRIO}

Controle de Q ualidade - VOC - Solo

284309/2014-0 - Branco de Análise - VOC - Solo

\section{Parâmetros}

1,1,1-Tricloroetano

1,1,2-Tricloroetano

1,1,2,2-Tetracloroetano

1,1-Dicloroetano

1,1-Dicloroeteno

1,1-Dicloropropeno

1,2,3-Triclorobenzeno

1,2,4-Triclorobenzeno

1,2-Dibromo-3-Cloropropano

1,2-Dicloroetano

1,2-Dicloropropano

1,3-Dicloropropano

1,4-Diclorobenzeno

2,2-Dicloropropano

4-Metil-2-Pentanon

Benzeno

Bromobenzeno

Bromodiclorometano

Bromofórmio

Bromometano

Cis-1,2-Dicloroeteno

Cis-1,3-Dicloropropeno

Diclorometano

Cloreto de Vinila

Clorobenzeno

Cloroetano

Clorofórmio

Clorometano

Dibromoclorometano

Dissulfeto de Carbono

Estireno

Etilbenzeno

Hexaclorobutadieno

m,p-Xilenos

o-Xileno

p-Isopropiltolueno

Tetracloreto de Carbono

Tetracloroeteno

Tolueno

Trans-1,2-Dicloroeteno

Tricloroeteno

1,3,5-Triclorobenzeno $\mathrm{mg} / \mathrm{kg}$

$\mathrm{mg} / \mathrm{kg}$

$\mathrm{mg} / \mathrm{kg}$

$\mathrm{mg} / \mathrm{kg}$

$\mathrm{mg} / \mathrm{kg}$

$\mathrm{mg} / \mathrm{kg}$

$\mathrm{mg} / \mathrm{kg}$

$\mathrm{mg} / \mathrm{kg}$

$\mathrm{mg} / \mathrm{kg}$

$\mathrm{mg} / \mathrm{kg}$

$\mathrm{mg} / \mathrm{kg}$

$\mathrm{mg} / \mathrm{kg}$

$\mathrm{mg} / \mathrm{kg}$

$\mathrm{mg} / \mathrm{kg}$

$\mathrm{mg} / \mathrm{kg}$

$\mathrm{mg} / \mathrm{kg}$

$\mathrm{mg} / \mathrm{kg}$

$\mathrm{mg} / \mathrm{kg}$

$\mathrm{mg} / \mathrm{kg}$

$\mathrm{mg} / \mathrm{kg}$

$\mathrm{mg} / \mathrm{kg}$

$\mathrm{mg} / \mathrm{kg}$

$\mathrm{mg} / \mathrm{kg}$

$\mathrm{mg} / \mathrm{kg}$

$\mathrm{mg} / \mathrm{kg}$

$\mathrm{mg} / \mathrm{kg}$

$\mathrm{mg} / \mathrm{kg}$

$\mathrm{mg} / \mathrm{kg}$

$\mathrm{mg} / \mathrm{kg}$

$\mathrm{mg} / \mathrm{kg}$

$\mathrm{mg} / \mathrm{kg}$

$\mathrm{mg} / \mathrm{kg}$

$\mathrm{mg} / \mathrm{kg}$

$\mathrm{mg} / \mathrm{kg}$

$\mathrm{mg} / \mathrm{kg}$

$\mathrm{mg} / \mathrm{kg}$

$\mathrm{mg} / \mathrm{kg}$

$\mathrm{mg} / \mathrm{kg}$

$\mathrm{mg} / \mathrm{kg}$

$\mathrm{mg} / \mathrm{kg}$

$\mathrm{mg} / \mathrm{kg}$

$\mathrm{mg} / \mathrm{kg}$

\begin{tabular}{|c|c|}
\hline LQ & Resultados analíticos \\
\hline 0,01 & $<0,01$ \\
\hline 0,01 & $<0,01$ \\
\hline 0,01 & $<0,01$ \\
\hline 0,01 & $<0,01$ \\
\hline 0,01 & $<0,01$ \\
\hline 0,01 & $<0,01$ \\
\hline 0,01 & $<0,01$ \\
\hline 0,01 & $<0,01$ \\
\hline 0,01 & $<0,01$ \\
\hline 0,01 & $<0,01$ \\
\hline 0,01 & $<0,01$ \\
\hline 0,01 & $<0,01$ \\
\hline 0,01 & $<0,01$ \\
\hline 0,01 & $<0,01$ \\
\hline 0,01 & $<0,01$ \\
\hline 0,01 & $<0,01$ \\
\hline 0,01 & $<0,01$ \\
\hline 0,01 & $<0,01$ \\
\hline 0,01 & $<0,01$ \\
\hline 0,01 & $<0,01$ \\
\hline 0,01 & $<0,01$ \\
\hline 0,01 & $<0,01$ \\
\hline 0,01 & $<0,01$ \\
\hline 0,002 & $<0,002$ \\
\hline 0,01 & $<0,01$ \\
\hline 0,01 & $<0,01$ \\
\hline 0,01 & $<0,01$ \\
\hline 0,01 & $<0,01$ \\
\hline 0,01 & $<0,01$ \\
\hline 0,01 & $<0,01$ \\
\hline 0,01 & $<0,01$ \\
\hline 0,01 & $<0,01$ \\
\hline 0,01 & $<0,01$ \\
\hline 0,01 & $<0,01$ \\
\hline 0,01 & $<0,01$ \\
\hline 0,01 & $<0,01$ \\
\hline 0,01 & $<0,01$ \\
\hline 0,01 & $<0,01$ \\
\hline 0,01 & $<0,01$ \\
\hline 0,01 & $<0,01$ \\
\hline 0,01 & $<0,01$ \\
\hline 0,01 & $<0,01$ \\
\hline
\end{tabular}

Ensaios de Recuperação 


\begin{tabular}{|c|c|c|c|c|}
\hline \multicolumn{5}{|c|}{ 284310/2014-0 - LCS - VOC - Solo } \\
\hline 1,1-Dicloroeteno & 0,05 & $\mathrm{mg} / \mathrm{kg}$ & 62 & $60-140$ \\
\hline Benzeno & 0,05 & $\mathrm{mg} / \mathrm{kg}$ & 73 & $60-140$ \\
\hline Tricloroeteno & 0,05 & $\mathrm{mg} / \mathrm{kg}$ & 82 & $60-140$ \\
\hline Tolueno & 0,05 & $\mathrm{mg} / \mathrm{kg}$ & 84 & $60-140$ \\
\hline Clorobenzeno & 0,05 & $\mathrm{mg} / \mathrm{kg}$ & 67 & $60-140$ \\
\hline \multicolumn{5}{|c|}{$\begin{array}{l}\text { Surrogates } \\
\text { 284309/2014-0 - Branco de Análise - VOC - Solo }\end{array}$} \\
\hline p-Bromofluorbenzeno & 0,05 & $\%$ & 120 & $60-140$ \\
\hline Dibrom ofluorometano & 0,05 & $\%$ & 110 & $60-140$ \\
\hline \multicolumn{5}{|c|}{ 284310/2014-0 - LCS - VOC - Solo } \\
\hline p-Bromofluorbenzeno & 0,05 & $\%$ & 120 & $60-140$ \\
\hline Dibrom ofluorometano & 0,05 & $\%$ & 83 & $60-140$ \\
\hline \multicolumn{5}{|c|}{ 283877/2014-0 - CGBI-3 } \\
\hline Dibrom ofluorometano & 0,05 & $\%$ & Amostra Diluída & $60-140$ \\
\hline p-Bromofluorbenzeno & 0,05 & $\%$ & Amostra Diluída & $60-140$ \\
\hline
\end{tabular}

Notas

LQ = Limite de Quantificação.

n.a. = Não Aplicável.

Abrangência

$O$ (s) resultado(s) referem-se somente à(s) amostra(s) analisada(s).

Este Relatório de Ensaio só pode ser reproduzido por inteiro e sem nenhuma alteração.

Plano de Amostragem

Plano de amostragem de responsabilidade do interessado.

Responsabilidade Técnica

Os ensaios foram realizados na unidade da Bioagri Ambiental Ltda. - Matriz, situada na Rua Aljovil Martini, 177/201, Bairro Dois Córregos, Cep. 14420-833, Piracicaba/SP, registrada no CRQ 4 Região sob n $16082-F$ e responsabilidade técnica do profissional José Carlos Moretti, CRQ n 04107238, $4^{\text {a. }}$.Região.

Referências Metodológicas

Análises foram realizadas conforme a última versão do Standard Methods for the Examination of Water \& Wastewater 22nd 2012(SMWW), EPA e ABNT (quando aplicável). VOC: EPA 8260 C: 2006, 5021 A: 2003

Metiletilcetona: EPA 8260 C: 2006, 5021 A: 2003

Revisores

Débora Fernandes da Silva

Chave de Validação: d9c05b9692cd088d003a0f456ba6435b

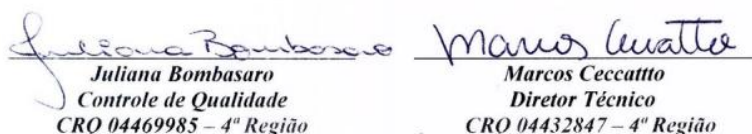




\section{RELATÓRIO DE ENSAIO N $^{\circ}$ 283859/2014-0 - Piracicaba Processo Comercial $N^{\circ}$ 23961/2014-2}

\begin{tabular}{|l|l|}
\hline \multicolumn{2}{|c|}{ DADOS REFERENTES AO CLIENTE } \\
\hline Empresa solicitante: & Fundacao Parque de Alta Tecnologia da Regiao de Ipero e Adjacencias \\
\hline Endereço: & Rua Jose Antonio Scaciota, 165 - - Portal do Cedro - Iperó - SP - CEP: 18.560-000 . \\
\hline Nome do Solicitante: & Carla Marçal \\
\hline
\end{tabular}

\begin{tabular}{|c|c|c|c|c|c|}
\hline \multicolumn{6}{|c|}{ DADOS REFERENTES A AMOSTRA } \\
\hline Identificação do Cliente: & \multicolumn{5}{|c|}{ CGBF-1 } \\
\hline Amostra Rotulada como: & \multicolumn{5}{|c|}{ Solo Projeto Mestrado } \\
\hline Coletor: & \multicolumn{2}{|c|}{ Interessado } & Data da coleta: & $23 / 10 / 201$ & 19:50:00 \\
\hline \multicolumn{2}{|c|}{ Data da entrada no laboratório: } & 25/10/2014 08:19 & \multicolumn{3}{|c|}{\begin{tabular}{|l|l|} 
Data de Elaboração do RE: & $31 / 10 / 2014$
\end{tabular}} \\
\hline
\end{tabular}

\section{RESULTADOS PARA A AMOSTRA}

\begin{tabular}{|c|c|c|c|c|c|c|}
\hline Parâmetros & CAS & Unidade & LQ & Resultados analíticos & Incerteza & Data do Ensaio \\
\hline 1,1,1-Tricloroetano & $71-55-6$ & $\mathrm{mg} / \mathrm{kg}$ & 0,1 & $<0,1$ & n.a. & 29/10/2014 19:09 \\
\hline 1,1,2-Tricloroetano & $79-00-5$ & $\mathrm{mg} / \mathrm{kg}$ & 0,1 & $<0,1$ & n.a. & 29/10/2014 19:09 \\
\hline 1,1,2,2-Tetracloroetano & $79-34-5$ & $\mathrm{mg} / \mathrm{kg}$ & 0,1 & $<0,1$ & n.a. & 29/10/2014 19:09 \\
\hline 1,1-Dicloroetano & $75-34-3$ & $\mathrm{mg} / \mathrm{kg}$ & 0,1 & $<0,1$ & n.a. & 29/10/2014 19:09 \\
\hline 1,1-Dicloroeteno & $75-35-4$ & $\mathrm{mg} / \mathrm{kg}$ & 0,05 & $<0,05$ & n.a. & 29/10/2014 19:09 \\
\hline 1,1-Dicloropropeno & $563-58-6$ & $\mathrm{mg} / \mathrm{kg}$ & 0,1 & $<0,1$ & n.a. & 29/10/2014 19:09 \\
\hline 1,2,3-Triclorobenzeno & $87-61-6$ & $\mathrm{mg} / \mathrm{kg}$ & 0,1 & $<0,1$ & n.a. & 29/10/2014 19:09 \\
\hline 1,2,4-Triclorobenzeno & $120-82-1$ & $\mathrm{mg} / \mathrm{kg}$ & 0,1 & $<0,1$ & n.a. & 29/10/2014 19:09 \\
\hline 1,2-Dibromo-3-Cloropropano & $96-12-8$ & $\mathrm{mg} / \mathrm{kg}$ & 0,1 & $<0,1$ & n.a. & 29/10/2014 19:09 \\
\hline 1,2-Dicloroetano & $107-06-2$ & $\mathrm{mg} / \mathrm{kg}$ & 0,1 & $<0,1$ & n.a. & 29/10/2014 19:09 \\
\hline 1,2-Dicloropropano & $78-87-5$ & $\mathrm{mg} / \mathrm{kg}$ & 0,1 & $<0,1$ & n.a. & 29/10/2014 19:09 \\
\hline 1,3-Diclorobenzeno & $541-73-1$ & $\mathrm{mg} / \mathrm{kg}$ & 0,1 & $<0,1$ & n.a. & 29/10/2014 19:09 \\
\hline 2,2-Dicloropropano & $594-20-7$ & $\mathrm{mg} / \mathrm{kg}$ & 0,1 & $<0,1$ & n.a. & 29/10/2014 19:09 \\
\hline 4-Metil-2-Pentanona & $108-10-1$ & $\mathrm{mg} / \mathrm{kg}$ & 0,1 & $<0,1$ & n.a. & 29/10/2014 19:09 \\
\hline Benzeno & $71-43-2$ & $\mathrm{mg} / \mathrm{kg}$ & 0,05 & $<0,05$ & n.a. & 29/10/2014 19:09 \\
\hline Bromobenzeno & $108-86-1$ & $\mathrm{mg} / \mathrm{kg}$ & 0,1 & $<0,1$ & n.a. & 29/10/2014 19:09 \\
\hline Bromodiclorometano & $75-27-4$ & $\mathrm{mg} / \mathrm{kg}$ & 0,1 & $<0,1$ & n.a. & 29/10/2014 19:09 \\
\hline Bromofórmio & $75-25-2$ & $\mathrm{mg} / \mathrm{kg}$ & 0,1 & $<0,1$ & n.a. & 29/10/2014 19:09 \\
\hline Bromometano & $74-83-9$ & $\mathrm{mg} / \mathrm{kg}$ & 0,1 & $<0,1$ & n.a. & 29/10/2014 19:09 \\
\hline Cis-1,2-Dicloroeteno & $156-59-2$ & $\mathrm{mg} / \mathrm{kg}$ & 0,1 & $<0,1$ & n.a. & 29/10/2014 19:09 \\
\hline Cis-1,3-Dicloropropeno & $10061-01-5$ & $\mathrm{mg} / \mathrm{kg}$ & 0,1 & $<0,1$ & n.a. & 29/10/2014 19:09 \\
\hline Diclorometano & $75-09-2$ & $\mathrm{mg} / \mathrm{kg}$ & 0,1 & $<0,1$ & n.a. & 29/10/2014 19:09 \\
\hline Cloreto de Vinila & 75-01-4 & $\mathrm{mg} / \mathrm{kg}$ & 0,02 & $<0,02$ & n.a. & 29/10/2014 19:09 \\
\hline Clorobenzeno & $108-90-7$ & $\mathrm{mg} / \mathrm{kg}$ & 0,1 & $<0,1$ & n.a. & 29/10/2014 19:09 \\
\hline Cloroetano & $75-00-3$ & $\mathrm{mg} / \mathrm{kg}$ & 0,1 & $<0,1$ & n.a. & 29/10/2014 19:09 \\
\hline Clorofórmio & $67-66-3$ & $\mathrm{mg} / \mathrm{kg}$ & 0,1 & $<0,1$ & n.a. & 29/10/2014 19:09 \\
\hline Clorometano & $74-87-3$ & $\mathrm{mg} / \mathrm{kg}$ & 0,1 & $<0,1$ & n.a. & 29/10/2014 19:09 \\
\hline Dibromoclorometano & $124-48-1$ & $\mathrm{mg} / \mathrm{kg}$ & 0,1 & $<0,1$ & n.a. & 29/10/2014 19:09 \\
\hline Dissulfeto de Carbono & $75-15-0$ & $\mathrm{mg} / \mathrm{kg}$ & 0,1 & $<0,1$ & n.a. & 29/10/2014 19:09 \\
\hline Estireno & $100-42-5$ & $\mathrm{mg} / \mathrm{kg}$ & 0,1 & $<0,1$ & n.a. & 29/10/2014 19:09 \\
\hline Etilbenzeno & $100-41-4$ & $\mathrm{mg} / \mathrm{kg}$ & 0,05 & $<0,05$ & n.a. & 29/10/2014 19:09 \\
\hline Hexaclorobutadieno & $87-68-3$ & $\mathrm{mg} / \mathrm{kg}$ & 0,1 & $<0,1$ & n.a. & 29/10/2014 19:09 \\
\hline m,p-Xilenos & --- & $\mathrm{mg} / \mathrm{kg}$ & 0,1 & $<0,1$ & n.a. & 29/10/2014 19:09 \\
\hline o-Xileno & $95-47-6$ & $\mathrm{mg} / \mathrm{kg}$ & 0,05 & $<0,05$ & n.a. & 29/10/2014 19:09 \\
\hline p-Isopropiltolueno & $99-87-6$ & $\mathrm{mg} / \mathrm{kg}$ & 0,1 & $<0,1$ & n.a. & 29/10/2014 19:09 \\
\hline Tetracloroeteno & $127-18-4$ & $\mathrm{mg} / \mathrm{kg}$ & 0,1 & $<0,1$ & n.a. & 29/10/2014 19:09 \\
\hline Tetracloreto de Carbono & $56-23-5$ & $\mathrm{mg} / \mathrm{kg}$ & 0,1 & $<0,1$ & n.a. & 29/10/2014 19:09 \\
\hline Tolueno & $108-88-3$ & $\mathrm{mg} / \mathrm{kg}$ & 0,05 & $<0,05$ & n.a. & 29/10/2014 19:09 \\
\hline Trans-1,2-Dicloroeteno & $156-60-5$ & $\mathrm{mg} / \mathrm{kg}$ & 0,1 & $<0,1$ & n.a. & 29/10/2014 19:09 \\
\hline Tricloroeteno & $79-01-6$ & $\mathrm{mg} / \mathrm{kg}$ & 0,1 & $<0,1$ & n.a. & 29/10/2014 19:09 \\
\hline 1,1,1,2-Tetracloroetano & $630-20-6$ & $\mathrm{mg} / \mathrm{kg}$ & 0,1 & $<0,1$ & n.a. & 29/10/2014 19:09 \\
\hline 1,2,3-Tricloropropano & $96-18-4$ & $\mathrm{mg} / \mathrm{kg}$ & 0,1 & $<0,1$ & n.a. & 29/10/2014 19:09 \\
\hline
\end{tabular}




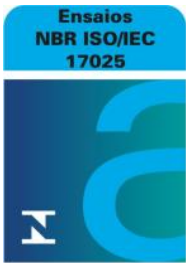

CRL 0172

\begin{tabular}{|c|c|c|c|c|c|c|}
\hline Parâmetros & CAS & Unidade & LQ & Resultados analíticos & Incerteza & Data do Ensaio \\
\hline 1,3,5-Trimetilbenzeno & $108-67-8$ & $\mathrm{mg} / \mathrm{kg}$ & 0,1 & $<0,1$ & n.a. & 29/10/2014 19:09 \\
\hline 1,2,4-Trimetilbenzeno & $95-63-6$ & $\mathrm{mg} / \mathrm{kg}$ & 0,1 & $<0,1$ & n.a. & 29/10/2014 19:09 \\
\hline 1,2-Dibromoetano & $106-93-4$ & $\mathrm{mg} / \mathrm{kg}$ & 0,1 & $<0,1$ & n.a. & 29/10/2014 19:09 \\
\hline 1,2-Diclorobenzeno & $95-50-1$ & $\mathrm{mg} / \mathrm{kg}$ & 0,1 & $<0,1$ & n.a. & 29/10/2014 19:09 \\
\hline 2-Clorotolueno & $95-49-8$ & $\mathrm{mg} / \mathrm{kg}$ & 0,1 & $<0,1$ & n.a. & 29/10/2014 19:09 \\
\hline Dibromometano & $74-95-3$ & $\mathrm{mg} / \mathrm{kg}$ & 0,1 & $<0,1$ & n.a. & 29/10/2014 19:09 \\
\hline Metiletilcetona & $78-93-3$ & $\mathrm{mg} / \mathrm{kg}$ & 25 & $<25$ & n.a. & 29/10/2014 19:09 \\
\hline Naftaleno & $91-20-3$ & $\mathrm{mg} / \mathrm{kg}$ & 0,1 & $<0,1$ & n.a. & 29/10/2014 19:09 \\
\hline n-Butilbenzeno & $104-51-8$ & $\mathrm{mg} / \mathrm{kg}$ & 0,1 & $<0,1$ & n.a. & 29/10/2014 19:09 \\
\hline n-Propilbenzeno & $103-65-1$ & $\mathrm{mg} / \mathrm{kg}$ & 0,1 & $<0,1$ & n.a. & 29/10/2014 19:09 \\
\hline 4-Clorotolueno & $106-43-4$ & $\mathrm{mg} / \mathrm{kg}$ & 0,1 & $<0,1$ & n.a. & 29/10/2014 19:09 \\
\hline sec-Butilbenzeno & $135-98-8$ & $\mathrm{mg} / \mathrm{kg}$ & 0,1 & $<0,1$ & n.a. & 29/10/2014 19:09 \\
\hline terc-Butilbenzeno & $98-06-6$ & $\mathrm{mg} / \mathrm{kg}$ & 0,1 & $<0,1$ & n.a. & 29/10/2014 19:09 \\
\hline trans-1,3-Dicloropropeno & $10061-02-6$ & $\mathrm{mg} / \mathrm{kg}$ & 0,1 & $<0,1$ & n.a. & 29/10/2014 19:09 \\
\hline Isopropilbenzeno & $98-82-8$ & $\mathrm{mg} / \mathrm{kg}$ & 0,1 & $<0,1$ & n.a. & 29/10/2014 19:09 \\
\hline 1,4-Diclorobenzeno & $106-46-7$ & $\mathrm{mg} / \mathrm{kg}$ & 0,1 & $<0,1$ & n.a. & 29/10/2014 19:09 \\
\hline 1,3,5-Triclorobenzeno & $108-70-3$ & $\mathrm{mg} / \mathrm{kg}$ & 0,1 & $<0,1$ & n.a. & 29/10/2014 19:09 \\
\hline 1,3-Dicloropropano & $142-28-9$ & $\mathrm{mg} / \mathrm{kg}$ & 0,1 & $<0,1$ & n.a. & 29/10/2014 19:09 \\
\hline
\end{tabular}

\section{CONTROLE DE Q UALIDADE DO LABORATÓRIO}

Controle de Q ualidade - VOC - Solo

284309/2014-0 - Branco de Análise - VOC - Solo

\section{Parâmetros}

1,1,1-Tricloroetano

1,1,2-Tricloroetano

1,1,2,2-Tetracloroetano

1,1-Dicloroetano

1,1-Dicloroeteno

1,1-Dicloropropeno

1,2,3-Triclorobenzeno

1,2,4-Triclorobenzeno

1,2-Dibromo-3-Cloropropano

1,2-Dicloroetano

1,2-Dicloropropano

1,3-Dicloropropano

1,4-Diclorobenzeno

2,2-Dicloropropano

4-Metil-2-Pentanon

Benzeno

Bromobenzeno

Bromodiclorometano

Bromofórmio

Bromometano

Cis-1,2-Dicloroeteno

Cis-1,3-Dicloropropeno

Diclorometano

Cloreto de Vinila

Clorobenzeno

Cloroetano

Clorofórmio

Clorometano

Dibromoclorometano

Dissulfeto de Carbono

Estireno

Etilbenzeno

Hexaclorobutadieno

m,p-Xilenos

o-Xileno

p-Isopropiltolueno

Tetracloreto de Carbono

Tetracloroeteno

Tolueno

Trans-1,2-Dicloroeteno

Tricloroeteno

1,3,5-Triclorobenzeno $\mathrm{mg} / \mathrm{kg}$

$\mathrm{mg} / \mathrm{kg}$

$\mathrm{mg} / \mathrm{kg}$

$\mathrm{mg} / \mathrm{kg}$

$\mathrm{mg} / \mathrm{kg}$

$\mathrm{mg} / \mathrm{kg}$

$\mathrm{mg} / \mathrm{kg}$

$\mathrm{mg} / \mathrm{kg}$

$\mathrm{mg} / \mathrm{kg}$

$\mathrm{mg} / \mathrm{kg}$

$\mathrm{mg} / \mathrm{kg}$

$\mathrm{mg} / \mathrm{kg}$

$\mathrm{mg} / \mathrm{kg}$

$\mathrm{mg} / \mathrm{kg}$

$\mathrm{mg} / \mathrm{kg}$

$\mathrm{mg} / \mathrm{kg}$

$\mathrm{mg} / \mathrm{kg}$

$\mathrm{mg} / \mathrm{kg}$

$\mathrm{mg} / \mathrm{kg}$

$\mathrm{mg} / \mathrm{kg}$

$\mathrm{mg} / \mathrm{kg}$

$\mathrm{mg} / \mathrm{kg}$

$\mathrm{mg} / \mathrm{kg}$

$\mathrm{mg} / \mathrm{kg}$

$\mathrm{mg} / \mathrm{kg}$

$\mathrm{mg} / \mathrm{kg}$

$\mathrm{mg} / \mathrm{kg}$

$\mathrm{mg} / \mathrm{kg}$

$\mathrm{mg} / \mathrm{kg}$

$\mathrm{mg} / \mathrm{kg}$

$\mathrm{mg} / \mathrm{kg}$

$\mathrm{mg} / \mathrm{kg}$

$\mathrm{mg} / \mathrm{kg}$

$\mathrm{mg} / \mathrm{kg}$

$\mathrm{mg} / \mathrm{kg}$

$\mathrm{mg} / \mathrm{kg}$

$\mathrm{mg} / \mathrm{kg}$

$\mathrm{mg} / \mathrm{kg}$

$\mathrm{mg} / \mathrm{kg}$

$\mathrm{mg} / \mathrm{kg}$

$\mathrm{mg} / \mathrm{kg}$

$\mathrm{mg} / \mathrm{kg}$

\begin{tabular}{|c|c|}
\hline LQ & Resultados analíticos \\
\hline 0,01 & $<0,01$ \\
\hline 0,01 & $<0,01$ \\
\hline 0,01 & $<0,01$ \\
\hline 0,01 & $<0,01$ \\
\hline 0,01 & $<0,01$ \\
\hline 0,01 & $<0,01$ \\
\hline 0,01 & $<0,01$ \\
\hline 0,01 & $<0,01$ \\
\hline 0,01 & $<0,01$ \\
\hline 0,01 & $<0,01$ \\
\hline 0,01 & $<0,01$ \\
\hline 0,01 & $<0,01$ \\
\hline 0,01 & $<0,01$ \\
\hline 0,01 & $<0,01$ \\
\hline 0,01 & $<0,01$ \\
\hline 0,01 & $<0,01$ \\
\hline 0,01 & $<0,01$ \\
\hline 0,01 & $<0,01$ \\
\hline 0,01 & $<0,01$ \\
\hline 0,01 & $<0,01$ \\
\hline 0,01 & $<0,01$ \\
\hline 0,01 & $<0,01$ \\
\hline 0,01 & $<0,01$ \\
\hline 0,002 & $<0,002$ \\
\hline 0,01 & $<0,01$ \\
\hline 0,01 & $<0,01$ \\
\hline 0,01 & $<0,01$ \\
\hline 0,01 & $<0,01$ \\
\hline 0,01 & $<0,01$ \\
\hline 0,01 & $<0,01$ \\
\hline 0,01 & $<0,01$ \\
\hline 0,01 & $<0,01$ \\
\hline 0,01 & $<0,01$ \\
\hline 0,01 & $<0,01$ \\
\hline 0,01 & $<0,01$ \\
\hline 0,01 & $<0,01$ \\
\hline 0,01 & $<0,01$ \\
\hline 0,01 & $<0,01$ \\
\hline 0,01 & $<0,01$ \\
\hline 0,01 & $<0,01$ \\
\hline 0,01 & $<0,01$ \\
\hline 0,01 & $<0,01$ \\
\hline
\end{tabular}

Ensaios de Recuperação 


\begin{tabular}{|c|c|c|c|c|}
\hline \multicolumn{5}{|c|}{ 284310/2014-0 - LCS - VOC - Solo } \\
\hline 1,1-Dicloroeteno & 0,05 & $\mathrm{mg} / \mathrm{kg}$ & 62 & $60-140$ \\
\hline Benzeno & 0,05 & $\mathrm{mg} / \mathrm{kg}$ & 73 & $60-140$ \\
\hline Tricloroeteno & 0,05 & $\mathrm{mg} / \mathrm{kg}$ & 82 & $60-140$ \\
\hline Tolueno & 0,05 & $\mathrm{mg} / \mathrm{kg}$ & 84 & $60-140$ \\
\hline Clorobenzeno & 0,05 & $\mathrm{mg} / \mathrm{kg}$ & 67 & $60-140$ \\
\hline \multicolumn{5}{|c|}{$\begin{array}{l}\text { Surrogates } \\
\text { 284309/2014-0 - Branco de Análise - VOC - Solo }\end{array}$} \\
\hline p-Bromofluorbenzeno & 0,05 & $\%$ & 120 & $60-140$ \\
\hline Dibrom ofluorometano & 0,05 & $\%$ & 110 & $60-140$ \\
\hline \multicolumn{5}{|c|}{ 284310/2014-0 - LCS - VOC - Solo } \\
\hline p-Bromofluorbenzeno & 0,05 & $\%$ & 120 & $60-140$ \\
\hline Dibrom ofluorometano & 0,05 & $\%$ & 83 & $60-140$ \\
\hline \multicolumn{5}{|c|}{ 283859/2014-0 - CGBF-1 } \\
\hline Dibrom ofluorometano & 0,05 & $\%$ & Amostra Diluída & $60-140$ \\
\hline p-Bromofluorbenzeno & 0,05 & $\%$ & Amostra Diluída & $60-140$ \\
\hline
\end{tabular}

Notas

$\mathrm{LQ}=$ Limite de Quantificação.

n.a. = Não Aplicável.

Abrangência

$O$ (s) resultado(s) referem-se somente à(s) amostra(s) analisada(s).

Este Relatório de Ensaio só pode ser reproduzido por inteiro e sem nenhuma alteração.

Plano de Amostragem

Plano de amostragem de responsabilidade do interessado.

Responsabilidade Técnica

Os ensaios foram realizados na unidade da Bioagri Ambiental Ltda. - Matriz, situada na Rua Aljovil Martini, 177/201, Bairro Dois Córregos, Cep. 14420-833, Piracicaba/SP, registrada no CRQ 4 Região sob n $16082-F$ e responsabilidade técnica do profissional José Carlos Moretti, CRQ n 04107238, $4^{\text {a. }}$.Região.

Referências Metodológicas

Análises foram realizadas conforme a última versão do Standard Methods for the Examination of Water \& Wastewater 22nd 2012(SMWW), EPA e ABNT (quando aplicável). VOC: EPA 8260 C: 2006, 5021 A: 2003

Metiletilcetona: EPA 8260 C: 2006, 5021 A: 2003

Revisores

Débora Fernandes da Silva

Chave de Validação: 25882b22e9e56fa65be3fa09dfff3cfb

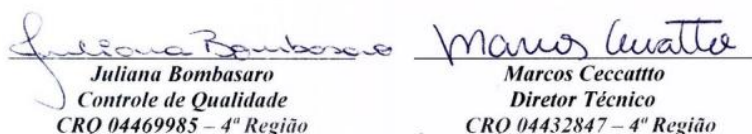




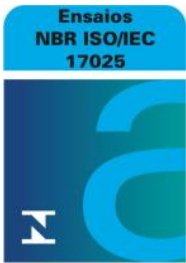

CRL 0172

\begin{tabular}{|c|c|c|c|c|c|c|}
\hline Parâmetros & CAS & Unidade & LQ & Resultados analíticos & Incerteza & Data do Ensaio \\
\hline 1,3,5-Trimetilbenzeno & $108-67-8$ & $\mathrm{mg} / \mathrm{kg}$ & 0,1 & $<0,1$ & n.a. & $29 / 10 / 2014$ 19:56 \\
\hline 1,2,4-Trimetilbenzeno & $95-63-6$ & $\mathrm{mg} / \mathrm{kg}$ & 0,1 & $<0,1$ & n.a. & 29/10/2014 19:56 \\
\hline 1,2-Dibromoetano & $106-93-4$ & $\mathrm{mg} / \mathrm{kg}$ & 0,1 & $<0,1$ & n.a. & $29 / 10 / 2014$ 19:56 \\
\hline 1,2-Diclorobenzeno & $95-50-1$ & $\mathrm{mg} / \mathrm{kg}$ & 0,1 & $<0,1$ & n.a. & 29/10/2014 19:56 \\
\hline 2-Clorotolueno & $95-49-8$ & $\mathrm{mg} / \mathrm{kg}$ & 0,1 & $<0,1$ & n.a. & 29/10/2014 19:56 \\
\hline Dibromometano & $74-95-3$ & $\mathrm{mg} / \mathrm{kg}$ & 0,1 & $<0,1$ & n.a. & 29/10/2014 19:56 \\
\hline Metiletilcetona & $78-93-3$ & $\mathrm{mg} / \mathrm{kg}$ & 25 & $<25$ & n.a. & 29/10/2014 19:56 \\
\hline Naftaleno & $91-20-3$ & $\mathrm{mg} / \mathrm{kg}$ & 0,1 & $<0,1$ & n.a. & 29/10/2014 19:56 \\
\hline n-Butilbenzeno & $104-51-8$ & $\mathrm{mg} / \mathrm{kg}$ & 0,1 & $<0,1$ & n.a. & 29/10/2014 19:56 \\
\hline n-Propilbenzeno & $103-65-1$ & $\mathrm{mg} / \mathrm{kg}$ & 0,1 & $<0,1$ & n.a. & 29/10/2014 19:56 \\
\hline 4-Clorotolueno & $106-43-4$ & $\mathrm{mg} / \mathrm{kg}$ & 0,1 & $<0,1$ & n.a. & 29/10/2014 19:56 \\
\hline sec-Butilbenzeno & $135-98-8$ & $\mathrm{mg} / \mathrm{kg}$ & 0,1 & $<0,1$ & n.a. & $29 / 10 / 2014$ 19:56 \\
\hline terc-Butilbenzeno & $98-06-6$ & $\mathrm{mg} / \mathrm{kg}$ & 0,1 & $<0,1$ & n.a. & $29 / 10 / 201419: 56$ \\
\hline trans-1,3-Dicloropropeno & 10061-02-6 & $\mathrm{mg} / \mathrm{kg}$ & 0,1 & $<0,1$ & n.a. & 29/10/2014 19:56 \\
\hline Isopropilbenzeno & $98-82-8$ & $\mathrm{mg} / \mathrm{kg}$ & 0,1 & $<0,1$ & n.a. & $29 / 10 / 201419: 56$ \\
\hline 1,4-Diclorobenzeno & $106-46-7$ & $\mathrm{mg} / \mathrm{kg}$ & 0,1 & $<0,1$ & n.a. & 29/10/2014 19:56 \\
\hline 1,3,5-Triclorobenzeno & $108-70-3$ & $\mathrm{mg} / \mathrm{kg}$ & 0,1 & $<0,1$ & n.a. & 29/10/2014 19:56 \\
\hline 1,3-Dicloropropano & $142-28-9$ & $\mathrm{mg} / \mathrm{kg}$ & 0,1 & $<0,1$ & n.a. & 29/10/2014 19:56 \\
\hline
\end{tabular}

\section{CONTROLE DE Q UALIDADE DO LABORATÓRIO}

Controle de Q ualidade - VOC - Solo

284309/2014-0 - Branco de Análise - VOC - Solo

\section{Parâmetros}

1,1,1-Tricloroetano

1,1,2-Tricloroetano

1,1,2,2-Tetracloroetano

1,1-Dicloroetano

1,1-Dicloroeteno

1,1-Dicloropropeno

1,2,3-Triclorobenzeno

1,2,4-Triclorobenzeno

1,2-Dibromo-3-Cloropropano

1,2-Dicloroetano

1,2-Dicloropropano

1,3-Dicloropropano

1,4-Diclorobenzeno

2,2-Dicloropropano

4-Metil-2-Pentanon

Benzeno

Bromobenzeno

Bromodiclorometano

Bromofórmio

Bromometano

Cis-1,2-Dicloroeteno

Cis-1,3-Dicloropropeno

Diclorometano

Cloreto de Vinila

Clorobenzeno

Cloroetano

Clorofórmio

Clorometano

Dibromoclorometano

Dissulfeto de Carbono

Estireno

Etilbenzeno

Hexaclorobutadieno

m,p-Xilenos

o-Xileno

p-Isopropiltolueno

Tetracloreto de Carbono

Tetracloroeteno

Tolueno

Trans-1,2-Dicloroeteno

Tricloroeteno

1,3,5-Triclorobenzeno $\mathrm{mg} / \mathrm{kg}$

$\mathrm{mg} / \mathrm{kg}$

$\mathrm{mg} / \mathrm{kg}$

$\mathrm{mg} / \mathrm{kg}$

$\mathrm{mg} / \mathrm{kg}$

$\mathrm{mg} / \mathrm{kg}$

$\mathrm{mg} / \mathrm{kg}$

$\mathrm{mg} / \mathrm{kg}$

$\mathrm{mg} / \mathrm{kg}$

$\mathrm{mg} / \mathrm{kg}$

$\mathrm{mg} / \mathrm{kg}$

$\mathrm{mg} / \mathrm{kg}$

$\mathrm{mg} / \mathrm{kg}$

$\mathrm{mg} / \mathrm{kg}$

$\mathrm{mg} / \mathrm{kg}$

$\mathrm{mg} / \mathrm{kg}$

$\mathrm{mg} / \mathrm{kg}$

$\mathrm{mg} / \mathrm{kg}$

$\mathrm{mg} / \mathrm{kg}$

$\mathrm{mg} / \mathrm{kg}$

$\mathrm{mg} / \mathrm{kg}$

$\mathrm{mg} / \mathrm{kg}$

$\mathrm{mg} / \mathrm{kg}$

$\mathrm{mg} / \mathrm{kg}$

$\mathrm{mg} / \mathrm{kg}$

$\mathrm{mg} / \mathrm{kg}$

$\mathrm{mg} / \mathrm{kg}$

$\mathrm{mg} / \mathrm{kg}$

$\mathrm{mg} / \mathrm{kg}$

$\mathrm{mg} / \mathrm{kg}$

$\mathrm{mg} / \mathrm{kg}$

$\mathrm{mg} / \mathrm{kg}$

$\mathrm{mg} / \mathrm{kg}$

$\mathrm{mg} / \mathrm{kg}$

$\mathrm{mg} / \mathrm{kg}$

$\mathrm{mg} / \mathrm{kg}$

$\mathrm{mg} / \mathrm{kg}$

$\mathrm{mg} / \mathrm{kg}$

$\mathrm{mg} / \mathrm{kg}$

$\mathrm{mg} / \mathrm{kg}$

$\mathrm{mg} / \mathrm{kg}$

$\mathrm{mg} / \mathrm{kg}$

\begin{tabular}{|c|c|}
\hline LQ & Resultados analíticos \\
\hline 0,01 & $<0,01$ \\
\hline 0,01 & $<0,01$ \\
\hline 0,01 & $<0,01$ \\
\hline 0,01 & $<0,01$ \\
\hline 0,01 & $<0,01$ \\
\hline 0,01 & $<0,01$ \\
\hline 0,01 & $<0,01$ \\
\hline 0,01 & $<0,01$ \\
\hline 0,01 & $<0,01$ \\
\hline 0,01 & $<0,01$ \\
\hline 0,01 & $<0,01$ \\
\hline 0,01 & $<0,01$ \\
\hline 0,01 & $<0,01$ \\
\hline 0,01 & $<0,01$ \\
\hline 0,01 & $<0,01$ \\
\hline 0,01 & $<0,01$ \\
\hline 0,01 & $<0,01$ \\
\hline 0,01 & $<0,01$ \\
\hline 0,01 & $<0,01$ \\
\hline 0,01 & $<0,01$ \\
\hline 0,01 & $<0,01$ \\
\hline 0,01 & $<0,01$ \\
\hline 0,01 & $<0,01$ \\
\hline 0,002 & $<0,002$ \\
\hline 0,01 & $<0,01$ \\
\hline 0,01 & $<0,01$ \\
\hline 0,01 & $<0,01$ \\
\hline 0,01 & $<0,01$ \\
\hline 0,01 & $<0,01$ \\
\hline 0,01 & $<0,01$ \\
\hline 0,01 & $<0,01$ \\
\hline 0,01 & $<0,01$ \\
\hline 0,01 & $<0,01$ \\
\hline 0,01 & $<0,01$ \\
\hline 0,01 & $<0,01$ \\
\hline 0,01 & $<0,01$ \\
\hline 0,01 & $<0,01$ \\
\hline 0,01 & $<0,01$ \\
\hline 0,01 & $<0,01$ \\
\hline 0,01 & $<0,01$ \\
\hline 0,01 & $<0,01$ \\
\hline 0,01 & $<0,01$ \\
\hline
\end{tabular}

Ensaios de Recuperação 


\begin{tabular}{|c|c|c|c|c|}
\hline \multicolumn{5}{|c|}{ 284310/2014-0 - LCS - VOC - Solo } \\
\hline 1,1-Dicloroeteno & 0,05 & $\mathrm{mg} / \mathrm{kg}$ & 62 & $60-140$ \\
\hline Benzeno & 0,05 & $\mathrm{mg} / \mathrm{kg}$ & 73 & $60-140$ \\
\hline Tricloroeteno & 0,05 & $\mathrm{mg} / \mathrm{kg}$ & 82 & $60-140$ \\
\hline Tolueno & 0,05 & $\mathrm{mg} / \mathrm{kg}$ & 84 & $60-140$ \\
\hline Clorobenzeno & 0,05 & $\mathrm{mg} / \mathrm{kg}$ & 67 & $60-140$ \\
\hline \multicolumn{5}{|c|}{$\begin{array}{l}\text { Surrogates } \\
\text { 284309/2014-0 - Branco de Análise - VOC - Solo }\end{array}$} \\
\hline p-Bromofluorbenzeno & 0,05 & $\%$ & 120 & $60-140$ \\
\hline Dibrom ofluorometano & 0,05 & $\%$ & 110 & $60-140$ \\
\hline \multicolumn{5}{|c|}{ 284310/2014-0 - LCS - VOC - Solo } \\
\hline p-Bromofluorbenzeno & 0,05 & $\%$ & 120 & $60-140$ \\
\hline Dibrom ofluorometano & 0,05 & $\%$ & 83 & $60-140$ \\
\hline \multicolumn{5}{|c|}{ 283860/2014-0 - CGBF-2 } \\
\hline Dibrom ofluorometano & 0,05 & $\%$ & Amostra Diluída & $60-140$ \\
\hline p-Bromofluorbenzeno & 0,05 & $\%$ & Amostra Diluída & $60-140$ \\
\hline
\end{tabular}

Notas

LQ = Limite de Quantificação.

n.a. = Não Aplicável.

Abrangência

$O$ (s) resultado(s) referem-se somente à(s) amostra(s) analisada(s).

Este Relatório de Ensaio só pode ser reproduzido por inteiro e sem nenhuma alteração.

Plano de Amostragem

Plano de amostragem de responsabilidade do interessado.

Responsabilidade Técnica

Os ensaios foram realizados na unidade da Bioagri Ambiental Ltda. - Matriz, situada na Rua Aljovil Martini, 177/201, Bairro Dois Córregos, Cep. 14420-833, Piracicaba/SP, registrada no CRQ 4 Região sob n $16082-F$ e responsabilidade técnica do profissional José Carlos Moretti, CRQ n 04107238, $4^{\text {a. }}$.Região.

Referências Metodológicas

Análises foram realizadas conforme a última versão do Standard Methods for the Examination of Water \& Wastewater 22nd 2012(SMWW), EPA e ABNT (quando aplicável). VOC: EPA 8260 C: 2006, 5021 A: 2003

Metiletilcetona: EPA 8260 C: 2006, 5021 A: 2003

Revisores

Débora Fernandes da Silva

Chave de Validação: 1d6ee753e3bd405ae0e5adfc97b571eb

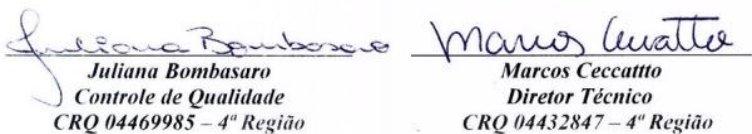




\section{RELATÓRIO DE ENSAIO N $^{\circ}$ 283861/2014-0 - Piracicaba Processo Comercial $N^{\circ}$ 23961/2014-2}

\begin{tabular}{|l|l|}
\hline \multicolumn{2}{|c|}{ DADOS REFERENTES AO CLIENTE } \\
\hline Empresa solicitante: & Fundacao Parque de Alta Tecnologia da Regiao de Ipero e Adjacencias \\
\hline Endereço: & Rua Jose Antonio Scaciota, 165 - - Portal do Cedro - Iperó - SP - CEP: 18.560-000 . \\
\hline Nome do Solicitante: & Carla Marçal \\
\hline
\end{tabular}

\begin{tabular}{|l|l|l|l|l|}
\hline \multicolumn{5}{|c|}{ DADOS REFERENTES A AMOSTRA } \\
\hline Identificação do Cliente: & CGBF-3 & \\
\hline Amostra Rotulada como: & Solo Projeto Mestrado & Data da coleta: & \multicolumn{2}{|c|}{$23 / 10 / 2014$ 19:50:00 } \\
\hline Coletor: & Interessado & Data de Elaboração do RE: & $31 / 10 / 2014$ \\
\hline Data da entrada no laboratório: & $25 / 10 / 201408: 19$ & &
\end{tabular}

\section{RESULTADOS PARA A AMOSTRA}

\begin{tabular}{|c|c|c|c|c|c|c|}
\hline Parâmetros & CAS & Unidade & LQ & Resultados analíticos & Incerteza & Data do Ensaio \\
\hline 1,1,1-Tricloroetano & $71-55-6$ & $\mathrm{mg} / \mathrm{kg}$ & 0,1 & $<0,1$ & n.a. & $29 / 10 / 201420: 44$ \\
\hline 1,1,2-Tricloroetano & $79-00-5$ & $\mathrm{mg} / \mathrm{kg}$ & 0,1 & $<0,1$ & n.a. & 29/10/2014 20:44 \\
\hline 1,1,2,2-Tetracloroetano & $79-34-5$ & $\mathrm{mg} / \mathrm{kg}$ & 0,1 & $<0,1$ & n.a. & 29/10/2014 20:44 \\
\hline 1,1-Dicloroetano & $75-34-3$ & $\mathrm{mg} / \mathrm{kg}$ & 0,1 & $<0,1$ & n.a. & $29 / 10 / 201420: 44$ \\
\hline 1,1-Dicloroeteno & $75-35-4$ & $\mathrm{mg} / \mathrm{kg}$ & 0,05 & $<0,05$ & n.a. & 29/10/2014 20:44 \\
\hline 1,1-Dicloropropeno & $563-58-6$ & $\mathrm{mg} / \mathrm{kg}$ & 0,1 & $<0,1$ & n.a. & $29 / 10 / 201420: 44$ \\
\hline 1,2,3-Triclorobenzeno & $87-61-6$ & $\mathrm{mg} / \mathrm{kg}$ & 0,1 & $<0,1$ & n.a. & 29/10/2014 20:44 \\
\hline 1,2,4-Triclorobenzeno & $120-82-1$ & $\mathrm{mg} / \mathrm{kg}$ & 0,1 & $<0,1$ & n.a. & $29 / 10 / 201420: 44$ \\
\hline 1,2-Dibromo-3-Cloropropano & $96-12-8$ & $\mathrm{mg} / \mathrm{kg}$ & 0,1 & $<0,1$ & n.a. & 29/10/2014 20:44 \\
\hline 1,2-Dicloroetano & $107-06-2$ & $\mathrm{mg} / \mathrm{kg}$ & 0,1 & $<0,1$ & n.a. & $29 / 10 / 201420: 44$ \\
\hline 1,2-Dicloropropano & $78-87-5$ & $\mathrm{mg} / \mathrm{kg}$ & 0,1 & $<0,1$ & n.a. & 29/10/2014 20:44 \\
\hline 1,3-Diclorobenzeno & $541-73-1$ & $\mathrm{mg} / \mathrm{kg}$ & 0,1 & $<0,1$ & n.a. & 29/10/2014 20:44 \\
\hline 2,2-Dicloropropano & $594-20-7$ & $\mathrm{mg} / \mathrm{kg}$ & 0,1 & $<0,1$ & n.a. & $29 / 10 / 201420: 44$ \\
\hline 4-Metil-2-Pentanona & $108-10-1$ & $\mathrm{mg} / \mathrm{kg}$ & 0,1 & $<0,1$ & n.a. & 29/10/2014 20:44 \\
\hline Benzeno & $71-43-2$ & $\mathrm{mg} / \mathrm{kg}$ & 0,05 & $<0,05$ & n.a. & 29/10/2014 20:44 \\
\hline Bromobenzeno & $108-86-1$ & $\mathrm{mg} / \mathrm{kg}$ & 0,1 & $<0,1$ & n.a. & 29/10/2014 20:44 \\
\hline Bromodiclorometano & $75-27-4$ & $\mathrm{mg} / \mathrm{kg}$ & 0,1 & $<0,1$ & n.a. & 29/10/2014 20:44 \\
\hline Bromofórmio & $75-25-2$ & $\mathrm{mg} / \mathrm{kg}$ & 0,1 & $<0,1$ & n.a. & $29 / 10 / 201420: 44$ \\
\hline Bromometano & $74-83-9$ & $\mathrm{mg} / \mathrm{kg}$ & 0,1 & $<0,1$ & n.a. & 29/10/2014 20:44 \\
\hline Cis-1,2-Dicloroeteno & $156-59-2$ & $\mathrm{mg} / \mathrm{kg}$ & 0,1 & $<0,1$ & n.a. & 29/10/2014 20:44 \\
\hline Cis-1,3-Dicloropropeno & $10061-01-5$ & $\mathrm{mg} / \mathrm{kg}$ & 0,1 & $<0,1$ & n.a. & 29/10/2014 20:44 \\
\hline Diclorometano & $75-09-2$ & $\mathrm{mg} / \mathrm{kg}$ & 0,1 & $<0,1$ & n.a. & 29/10/2014 20:44 \\
\hline Cloreto de Vinila & $75-01-4$ & $\mathrm{mg} / \mathrm{kg}$ & 0,02 & $<0,02$ & n.a. & 29/10/2014 20:44 \\
\hline Clorobenzeno & $108-90-7$ & $\mathrm{mg} / \mathrm{kg}$ & 0,1 & $<0,1$ & n.a. & 29/10/2014 20:44 \\
\hline Cloroetano & $75-00-3$ & $\mathrm{mg} / \mathrm{kg}$ & 0,1 & $<0,1$ & n.a. & 29/10/2014 20:44 \\
\hline Clorofórmio & $67-66-3$ & $\mathrm{mg} / \mathrm{kg}$ & 0,1 & $<0,1$ & n.a. & 29/10/2014 20:44 \\
\hline Clorometano & $74-87-3$ & $\mathrm{mg} / \mathrm{kg}$ & 0,1 & $<0,1$ & n.a. & 29/10/2014 20:44 \\
\hline Dibromoclorometano & $124-48-1$ & $\mathrm{mg} / \mathrm{kg}$ & 0,1 & $<0,1$ & n.a. & 29/10/2014 20:44 \\
\hline Dissulfeto de Carbono & $75-15-0$ & $\mathrm{mg} / \mathrm{kg}$ & 0,1 & $<0,1$ & n.a. & 29/10/2014 20:44 \\
\hline Estireno & $100-42-5$ & $\mathrm{mg} / \mathrm{kg}$ & 0,1 & $<0,1$ & n.a. & 29/10/2014 20:44 \\
\hline Etilbenzeno & $100-41-4$ & $\mathrm{mg} / \mathrm{kg}$ & 0,05 & $<0,05$ & n.a. & 29/10/2014 20:44 \\
\hline Hexaclorobutadieno & $87-68-3$ & $\mathrm{mg} / \mathrm{kg}$ & 0,1 & $<0,1$ & n.a. & 29/10/2014 20:44 \\
\hline m,p-Xilenos & --- & $\mathrm{mg} / \mathrm{kg}$ & 0,1 & $<0,1$ & n.a. & 29/10/2014 20:44 \\
\hline o-Xileno & $95-47-6$ & $\mathrm{mg} / \mathrm{kg}$ & 0,05 & $<0,05$ & n.a. & 29/10/2014 20:44 \\
\hline p-Isopropiltolueno & $99-87-6$ & $\mathrm{mg} / \mathrm{kg}$ & 0,1 & $<0,1$ & n.a. & $29 / 10 / 201420: 44$ \\
\hline Tetracloroeteno & $127-18-4$ & $\mathrm{mg} / \mathrm{kg}$ & 0,1 & $<0,1$ & n.a. & 29/10/2014 20:44 \\
\hline Tetracloreto de Carbono & $56-23-5$ & $\mathrm{mg} / \mathrm{kg}$ & 0,1 & $<0,1$ & n.a. & 29/10/2014 20:44 \\
\hline Tolueno & $108-88-3$ & $\mathrm{mg} / \mathrm{kg}$ & 0,05 & $<0,05$ & n.a. & 29/10/2014 20:44 \\
\hline Trans-1,2-Dicloroeteno & $156-60-5$ & $\mathrm{mg} / \mathrm{kg}$ & 0,1 & $<0,1$ & n.a. & $29 / 10 / 201420: 44$ \\
\hline Tricloroeteno & $79-01-6$ & $\mathrm{mg} / \mathrm{kg}$ & 0,1 & $<0,1$ & n.a. & $29 / 10 / 201420: 44$ \\
\hline 1,1,1,2-Tetracloroetano & $630-20-6$ & $\mathrm{mg} / \mathrm{kg}$ & 0,1 & $<0,1$ & n.a. & 29/10/2014 20:44 \\
\hline 1,2,3-Tricloropropano & $96-18-4$ & $\mathrm{mg} / \mathrm{kg}$ & 0,1 & $<0,1$ & n.a. & $29 / 10 / 201420: 44$ \\
\hline
\end{tabular}




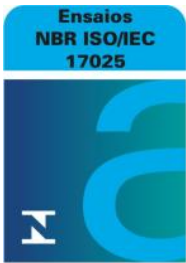

CRL 0172

\begin{tabular}{|c|c|c|c|c|c|c|}
\hline Parâmetros & CAS & Unidade & LQ & Resultados analíticos & Incerteza & Data do Ensaio \\
\hline 1,3,5-Trimetilbenzeno & $108-67-8$ & $\mathrm{mg} / \mathrm{kg}$ & 0,1 & $<0,1$ & n.a. & 29/10/2014 20:44 \\
\hline 1,2,4-Trimetilbenzeno & $95-63-6$ & $\mathrm{mg} / \mathrm{kg}$ & 0,1 & $<0,1$ & n.a. & 29/10/2014 20:44 \\
\hline 1,2-Dibromoetano & $106-93-4$ & $\mathrm{mg} / \mathrm{kg}$ & 0,1 & $<0,1$ & n.a. & $29 / 10 / 201420: 44$ \\
\hline 1,2-Diclorobenzeno & $95-50-1$ & $\mathrm{mg} / \mathrm{kg}$ & 0,1 & $<0,1$ & n.a. & 29/10/2014 20:44 \\
\hline 2-Clorotolueno & $95-49-8$ & $\mathrm{mg} / \mathrm{kg}$ & 0,1 & $<0,1$ & n.a. & 29/10/2014 20:44 \\
\hline Dibromometano & $74-95-3$ & $\mathrm{mg} / \mathrm{kg}$ & 0,1 & $<0,1$ & n.a. & 29/10/2014 20:44 \\
\hline Metiletilcetona & $78-93-3$ & $\mathrm{mg} / \mathrm{kg}$ & 25 & $<25$ & n.a. & 29/10/2014 20:44 \\
\hline Naftaleno & $91-20-3$ & $\mathrm{mg} / \mathrm{kg}$ & 0,1 & $<0,1$ & n.a. & 29/10/2014 20:44 \\
\hline n-Butilbenzeno & $104-51-8$ & $\mathrm{mg} / \mathrm{kg}$ & 0,1 & $<0,1$ & n.a. & $29 / 10 / 201420: 44$ \\
\hline n-Propilbenzeno & $103-65-1$ & $\mathrm{mg} / \mathrm{kg}$ & 0,1 & $<0,1$ & n.a. & 29/10/2014 20:44 \\
\hline 4-Clorotolueno & $106-43-4$ & $\mathrm{mg} / \mathrm{kg}$ & 0,1 & $<0,1$ & n.a. & 29/10/2014 20:44 \\
\hline sec-Butilbenzeno & $135-98-8$ & $\mathrm{mg} / \mathrm{kg}$ & 0,1 & $<0,1$ & n.a. & 29/10/2014 20:44 \\
\hline terc-Butilbenzeno & $98-06-6$ & $\mathrm{mg} / \mathrm{kg}$ & 0,1 & $<0,1$ & n.a. & $29 / 10 / 201420: 44$ \\
\hline trans-1,3-Dicloropropeno & 10061-02-6 & $\mathrm{mg} / \mathrm{kg}$ & 0,1 & $<0,1$ & n.a. & 29/10/2014 20:44 \\
\hline Isopropilbenzeno & $98-82-8$ & $\mathrm{mg} / \mathrm{kg}$ & 0,1 & $<0,1$ & n.a. & $29 / 10 / 201420: 44$ \\
\hline 1,4-Diclorobenzeno & $106-46-7$ & $\mathrm{mg} / \mathrm{kg}$ & 0,1 & $<0,1$ & n.a. & 29/10/2014 20:44 \\
\hline 1,3,5-Triclorobenzeno & $108-70-3$ & $\mathrm{mg} / \mathrm{kg}$ & 0,1 & $<0,1$ & n.a. & 29/10/2014 20:44 \\
\hline 1,3-Dicloropropano & $142-28-9$ & $\mathrm{mg} / \mathrm{kg}$ & 0,1 & $<0,1$ & n.a. & 29/10/2014 20:44 \\
\hline
\end{tabular}

\section{CONTROLE DE Q UALIDADE DO LABORATÓRIO}

Controle de Q ualidade - VOC - Solo

284309/2014-0 - Branco de Análise - VOC - Solo

\section{Parâmetros}

1,1,1-Tricloroetano

1,1,2-Tricloroetano

1,1,2,2-Tetracloroetano

1,1-Dicloroetano

1,1-Dicloroeteno

1,1-Dicloropropeno

1,2,3-Triclorobenzeno

1,2,4-Triclorobenzeno

1,2-Dibromo-3-Cloropropano

1,2-Dicloroetano

1,2-Dicloropropano

1,3-Dicloropropano

1,4-Diclorobenzeno

2,2-Dicloropropano

4-Metil-2-Pentanon

Benzeno

Bromobenzeno

Bromodiclorometano

Bromofórmio

Bromometano

Cis-1,2-Dicloroeteno

Cis-1,3-Dicloropropeno

Diclorometano

Cloreto de Vinila

Clorobenzeno

Cloroetano

Clorofórmio

Clorometano

Dibromoclorometano

Dissulfeto de Carbono

Estireno

Etilbenzeno

Hexaclorobutadieno

m,p-Xilenos

o-Xileno

p-Isopropiltolueno

Tetracloreto de Carbono

Tetracloroeteno

Tolueno

Trans-1,2-Dicloroeteno

Tricloroeteno

1,3,5-Triclorobenzeno $\mathrm{mg} / \mathrm{kg}$

$\mathrm{mg} / \mathrm{kg}$

$\mathrm{mg} / \mathrm{kg}$

$\mathrm{mg} / \mathrm{kg}$

$\mathrm{mg} / \mathrm{kg}$

$\mathrm{mg} / \mathrm{kg}$

$\mathrm{mg} / \mathrm{kg}$

$\mathrm{mg} / \mathrm{kg}$

$\mathrm{mg} / \mathrm{kg}$

$\mathrm{mg} / \mathrm{kg}$

$\mathrm{mg} / \mathrm{kg}$

$\mathrm{mg} / \mathrm{kg}$

$\mathrm{mg} / \mathrm{kg}$

$\mathrm{mg} / \mathrm{kg}$

$\mathrm{mg} / \mathrm{kg}$

$\mathrm{mg} / \mathrm{kg}$

$\mathrm{mg} / \mathrm{kg}$

$\mathrm{mg} / \mathrm{kg}$

$\mathrm{mg} / \mathrm{kg}$

$\mathrm{mg} / \mathrm{kg}$

$\mathrm{mg} / \mathrm{kg}$

$\mathrm{mg} / \mathrm{kg}$

$\mathrm{mg} / \mathrm{kg}$

$\mathrm{mg} / \mathrm{kg}$

$\mathrm{mg} / \mathrm{kg}$

$\mathrm{mg} / \mathrm{kg}$

$\mathrm{mg} / \mathrm{kg}$

$\mathrm{mg} / \mathrm{kg}$

$\mathrm{mg} / \mathrm{kg}$

$\mathrm{mg} / \mathrm{kg}$

$\mathrm{mg} / \mathrm{kg}$

$\mathrm{mg} / \mathrm{kg}$

$\mathrm{mg} / \mathrm{kg}$

$\mathrm{mg} / \mathrm{kg}$

$\mathrm{mg} / \mathrm{kg}$

$\mathrm{mg} / \mathrm{kg}$

$\mathrm{mg} / \mathrm{kg}$

$\mathrm{mg} / \mathrm{kg}$

$\mathrm{mg} / \mathrm{kg}$

$\mathrm{mg} / \mathrm{kg}$

$\mathrm{mg} / \mathrm{kg}$

$\mathrm{mg} / \mathrm{kg}$

\begin{tabular}{|c|c|}
\hline LQ & Resultados analíticos \\
\hline 0,01 & $<0,01$ \\
\hline 0,01 & $<0,01$ \\
\hline 0,01 & $<0,01$ \\
\hline 0,01 & $<0,01$ \\
\hline 0,01 & $<0,01$ \\
\hline 0,01 & $<0,01$ \\
\hline 0,01 & $<0,01$ \\
\hline 0,01 & $<0,01$ \\
\hline 0,01 & $<0,01$ \\
\hline 0,01 & $<0,01$ \\
\hline 0,01 & $<0,01$ \\
\hline 0,01 & $<0,01$ \\
\hline 0,01 & $<0,01$ \\
\hline 0,01 & $<0,01$ \\
\hline 0,01 & $<0,01$ \\
\hline 0,01 & $<0,01$ \\
\hline 0,01 & $<0,01$ \\
\hline 0,01 & $<0,01$ \\
\hline 0,01 & $<0,01$ \\
\hline 0,01 & $<0,01$ \\
\hline 0,01 & $<0,01$ \\
\hline 0,01 & $<0,01$ \\
\hline 0,01 & $<0,01$ \\
\hline 0,002 & $<0,002$ \\
\hline 0,01 & $<0,01$ \\
\hline 0,01 & $<0,01$ \\
\hline 0,01 & $<0,01$ \\
\hline 0,01 & $<0,01$ \\
\hline 0,01 & $<0,01$ \\
\hline 0,01 & $<0,01$ \\
\hline 0,01 & $<0,01$ \\
\hline 0,01 & $<0,01$ \\
\hline 0,01 & $<0,01$ \\
\hline 0,01 & $<0,01$ \\
\hline 0,01 & $<0,01$ \\
\hline 0,01 & $<0,01$ \\
\hline 0,01 & $<0,01$ \\
\hline 0,01 & $<0,01$ \\
\hline 0,01 & $<0,01$ \\
\hline 0,01 & $<0,01$ \\
\hline 0,01 & $<0,01$ \\
\hline 0,01 & $<0,01$ \\
\hline
\end{tabular}

Ensaios de Recuperação 


\begin{tabular}{|c|c|c|c|c|}
\hline \multicolumn{5}{|c|}{ 284310/2014-0 - LCS - VOC - Solo } \\
\hline 1,1-Dicloroeteno & 0,05 & $\mathrm{mg} / \mathrm{kg}$ & 62 & $60-140$ \\
\hline Benzeno & 0,05 & $\mathrm{mg} / \mathrm{kg}$ & 73 & $60-140$ \\
\hline Tricloroeteno & 0,05 & $\mathrm{mg} / \mathrm{kg}$ & 82 & $60-140$ \\
\hline Tolueno & 0,05 & $\mathrm{mg} / \mathrm{kg}$ & 84 & $60-140$ \\
\hline Clorobenzeno & 0,05 & $\mathrm{mg} / \mathrm{kg}$ & 67 & $60-140$ \\
\hline \multicolumn{5}{|c|}{$\begin{array}{l}\text { Surrogates } \\
\text { 284309/2014-0 - Branco de Análise - VOC - Solo }\end{array}$} \\
\hline p-Bromofluorbenzeno & 0,05 & $\%$ & 120 & $60-140$ \\
\hline Dibrom ofluorometano & 0,05 & $\%$ & 110 & $60-140$ \\
\hline \multicolumn{5}{|c|}{ 284310/2014-0 - LCS - VOC - Solo } \\
\hline p-Bromofluorbenzeno & 0,05 & $\%$ & 120 & $60-140$ \\
\hline Dibrom ofluorometano & 0,05 & $\%$ & 83 & $60-140$ \\
\hline \multicolumn{5}{|c|}{ 283861/2014-0 - CGBF-3 } \\
\hline Dibrom ofluorometano & 0,05 & $\%$ & Amostra Diluída & $60-140$ \\
\hline p-Bromofluorbenzeno & 0,05 & $\%$ & Amostra Diluída & $60-140$ \\
\hline
\end{tabular}

Notas

$\mathrm{LQ}=$ Limite de Quantificação.

n.a. = Não Aplicável.

Abrangência

$O$ (s) resultado(s) referem-se somente à(s) amostra(s) analisada(s).

Este Relatório de Ensaio só pode ser reproduzido por inteiro e sem nenhuma alteração.

Plano de Amostragem

Plano de amostragem de responsabilidade do interessado.

Responsabilidade Técnica

Os ensaios foram realizados na unidade da Bioagri Ambiental Ltda. - Matriz, situada na Rua Aljovil Martini, 177/201, Bairro Dois Córregos, Cep. 14420-833, Piracicaba/SP, registrada no CRQ 4 Região sob n $16082-F$ e responsabilidade técnica do profissional José Carlos Moretti, CRQ n 04107238, $4^{\text {a. }}$.Região.

Referências Metodológicas

Análises foram realizadas conforme a última versão do Standard Methods for the Examination of Water \& Wastewater 22nd 2012(SMWW), EPA e ABNT (quando aplicável). VOC: EPA 8260 C: 2006, 5021 A: 2003

Metiletilcetona: EPA 8260 C: 2006, 5021 A: 2003

Revisores

Débora Fernandes da Silva

Chave de Validaç̃a: 0c24bdf5ab964de009517f44569244e3

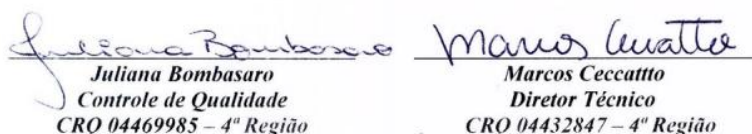




\section{RELATÓRIO DE ENSAIO N $^{\circ}$ 283878/2014-0 - Piracicaba Processo Comercial $N^{\circ}$ 23961/2014-2}

\begin{tabular}{|l|l|}
\hline \multicolumn{2}{|c|}{ DADOS REFERENTES AO CLIENTE } \\
\hline Empresa solicitante: & Fundacao Parque de Alta Tecnologia da Regiao de Ipero e Adjacencias \\
\hline Endereço: & Rua Jose Antonio Scaciota, 165 - - Portal do Cedro - Iperó - SP - CEP: 18.560-000 . \\
\hline Nome do Solicitante: & Carla Marçal \\
\hline
\end{tabular}

\begin{tabular}{|l|l|l|l|l|}
\hline \multicolumn{5}{|c|}{ DADOS REFERENTES A AMOSTRA } \\
\hline Identificação do Cliente: & \multicolumn{4}{|l|}{ CGBIA-1 } \\
\hline Amostra Rotulada como: & Água Subterrânea Projeto Mestrado \\
\hline Coletor: & Interessado & Data da coleta: & \multicolumn{2}{|l|}{ 23/10/2014 18:00:00 } \\
\hline Data da entrada no laboratório: & $25 / 10 / 201408: 26$ & Data de Elaboração do RE: & $03 / 11 / 2014$ \\
\hline
\end{tabular}

\section{RESULTADOS PARA A AMOSTRA}

\begin{tabular}{|c|c|c|c|c|c|c|}
\hline Parâmetros & CAS & Unidade & LQ & Resultados analíticos & Incerteza & Data do Ensaio \\
\hline 1,1,1-Tricloroetano & $71-55-6$ & $\mu \mathrm{g} / \mathrm{L}$ & 100 & $<100$ & n.a. & 29/10/2014 06:36 \\
\hline 1,1,2-Tricloroetano & $79-00-5$ & $\mu \mathrm{g} / \mathrm{L}$ & 100 & $<100$ & n.a. & 29/10/2014 06:36 \\
\hline 1,1,2,2-Tetracloroetano & $79-34-5$ & $\mu \mathrm{g} / \mathrm{L}$ & 100 & $<100$ & n.a. & 29/10/2014 06:36 \\
\hline 1,1-Dicloroetano & 75-34-3 & $\mu \mathrm{g} / \mathrm{L}$ & 100 & $<100$ & n.a. & 29/10/2014 06:36 \\
\hline 1,1-Dicloroeteno & $75-35-4$ & $\mu \mathrm{g} / \mathrm{L}$ & 100 & $<100$ & n.a. & 29/10/2014 06:36 \\
\hline 1,1-Dicloropropeno & $563-58-6$ & $\mu \mathrm{g} / \mathrm{L}$ & 100 & $<100$ & n.a. & 29/10/2014 06:36 \\
\hline 1,2,3-Triclorobenzeno & $87-61-6$ & $\mu \mathrm{g} / \mathrm{L}$ & 100 & $<100$ & n.a. & 29/10/2014 06:36 \\
\hline 1,2,4-Triclorobenzeno & $120-82-1$ & $\mu \mathrm{g} / \mathrm{L}$ & 100 & $<100$ & n.a. & 29/10/2014 06:36 \\
\hline 1,2-Dibromo-3-Cloropropano & $96-12-8$ & $\mu \mathrm{g} / \mathrm{L}$ & 500 & $<500$ & n.a. & 29/10/2014 06:36 \\
\hline 1,2-Dicloroetano & $107-06-2$ & $\mu \mathrm{g} / \mathrm{L}$ & 100 & $<100$ & n.a. & 29/10/2014 06:36 \\
\hline 1,2-Dicloropropano & $78-87-5$ & $\mu \mathrm{g} / \mathrm{L}$ & 100 & $<100$ & n.a. & $29 / 10 / 201406: 36$ \\
\hline 1,3-Dicloropropano & $142-28-9$ & $\mu \mathrm{g} / \mathrm{L}$ & 500 & $<500$ & n.a. & 29/10/2014 06:36 \\
\hline 1,4-Diclorobenzeno & $106-46-7$ & $\mu \mathrm{g} / \mathrm{L}$ & 100 & $<100$ & n.a. & 29/10/2014 06:36 \\
\hline 2,2-Dicloropropano & $594-20-7$ & $\mu \mathrm{g} / \mathrm{L}$ & 100 & $<100$ & n.a. & 29/10/2014 06:36 \\
\hline 4-Metil-2-Pentanona & $108-10-1$ & $\mu \mathrm{g} / \mathrm{L}$ & 500 & $<500$ & n.a. & 29/10/2014 06:36 \\
\hline Benzeno & $71-43-2$ & $\mu \mathrm{g} / \mathrm{L}$ & 100 & $<100$ & n.a. & 29/10/2014 06:36 \\
\hline Bromobenzeno & $108-86-1$ & $\mu \mathrm{g} / \mathrm{L}$ & 100 & $<100$ & n.a. & 29/10/2014 06:36 \\
\hline Bromodiclorometano & $75-27-4$ & $\mu \mathrm{g} / \mathrm{L}$ & 100 & $<100$ & n.a. & 29/10/2014 06:36 \\
\hline Bromofórmio & $75-25-2$ & $\mu \mathrm{g} / \mathrm{L}$ & 100 & $<100$ & n.a. & 29/10/2014 06:36 \\
\hline Bromoclorometano & $74-97-5$ & $\mu \mathrm{g} / \mathrm{L}$ & 500 & $<500$ & n.a. & 29/10/2014 06:36 \\
\hline Cis-1,2-Dicloroeteno & $156-59-2$ & $\mu \mathrm{g} / \mathrm{L}$ & 100 & $<100$ & n.a. & 29/10/2014 06:36 \\
\hline Cis-1,3-Dicloropropeno & 10061-01-5 & $\mu \mathrm{g} / \mathrm{L}$ & 100 & $<100$ & n.a. & 29/10/2014 06:36 \\
\hline Diclorometano & $75-09-2$ & $\mu \mathrm{g} / \mathrm{L}$ & 100 & $<100$ & n.a. & 29/10/2014 06:36 \\
\hline Cloreto de Vinila & 75-01-4 & $\mu \mathrm{g} / \mathrm{L}$ & 100 & $<100$ & n.a. & 29/10/2014 06:36 \\
\hline Clorobenzeno & $108-90-7$ & $\mu \mathrm{g} / \mathrm{L}$ & 100 & $<100$ & n.a. & 29/10/2014 06:36 \\
\hline Cloroetano & $75-00-3$ & $\mu \mathrm{g} / \mathrm{L}$ & 100 & $<100$ & n.a. & 29/10/2014 06:36 \\
\hline Clorofórmio & $67-66-3$ & $\mu \mathrm{g} / \mathrm{L}$ & 100 & $<100$ & n.a. & 29/10/2014 06:36 \\
\hline Clorometano & $74-87-3$ & $\mu \mathrm{g} / \mathrm{L}$ & 1000 & $<1000$ & n.a. & 29/10/2014 06:36 \\
\hline Dibromoclorometano & $124-48-1$ & $\mu \mathrm{g} / \mathrm{L}$ & 100 & $<100$ & n.a. & 29/10/2014 06:36 \\
\hline Dissulfeto de Carbono & $75-15-0$ & $\mu \mathrm{g} / \mathrm{L}$ & 100 & $<100$ & n.a. & 29/10/2014 06:36 \\
\hline Estireno & $100-42-5$ & $\mu \mathrm{g} / \mathrm{L}$ & 100 & $<100$ & n.a. & 29/10/2014 06:36 \\
\hline Etilbenzeno & $100-41-4$ & $\mu \mathrm{g} / \mathrm{L}$ & 100 & $<100$ & n.a. & 29/10/2014 06:36 \\
\hline Hexaclorobutadieno & $87-68-3$ & $\mu \mathrm{g} / \mathrm{L}$ & 100 & $<100$ & n.a. & 29/10/2014 06:36 \\
\hline $\mathrm{m}, \mathrm{p}$-Xilenos & --- & $\mu \mathrm{g} / \mathrm{L}$ & 200 & $<200$ & n.a. & 29/10/2014 06:36 \\
\hline o-Xileno & $95-47-6$ & $\mu \mathrm{g} / \mathrm{L}$ & 100 & $<100$ & n.a. & 29/10/2014 06:36 \\
\hline p-Isopropiltolueno & $99-87-6$ & $\mu \mathrm{g} / \mathrm{L}$ & 100 & $<100$ & n.a. & 29/10/2014 06:36 \\
\hline Tetracloreto de Carbono & $56-23-5$ & $\mu \mathrm{g} / \mathrm{L}$ & 100 & $<100$ & n.a. & 29/10/2014 06:36 \\
\hline Tetracloroeteno & $127-18-4$ & $\mu \mathrm{g} / \mathrm{L}$ & 1000 & 55800 & 11000 & 29/10/2014 06:36 \\
\hline Tolueno & $108-88-3$ & $\mu \mathrm{g} / \mathrm{L}$ & 100 & $<100$ & n.a. & 29/10/2014 06:36 \\
\hline Trans-1,2-Dicloroeteno & $156-60-5$ & $\mu \mathrm{g} / \mathrm{L}$ & 100 & $<100$ & n.a. & 29/10/2014 06:36 \\
\hline Tricloroeteno & $79-01-6$ & $\mu \mathrm{g} / \mathrm{L}$ & 100 & $<100$ & n.a. & 29/10/2014 06:36 \\
\hline 1,1,1,2-Tetracloroetano & $630-20-6$ & $\mu \mathrm{g} / \mathrm{L}$ & 100 & $<100$ & n.a. & 29/10/2014 06:36 \\
\hline
\end{tabular}




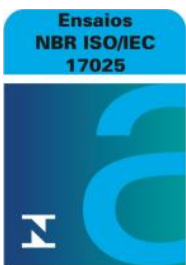

CRL 0172

\begin{tabular}{|c|c|c|c|c|c|c|}
\hline Parâmetros & CAS & Unidade & LQ & Resultados analíticos & Incerteza & Data do Ensaio \\
\hline 1,2,3-Tricloropropano & $96-18-4$ & $\mu \mathrm{g} / \mathrm{L}$ & 500 & $<500$ & n.a. & 29/10/2014 06:36 \\
\hline 1,3,5-Trimetilbenzeno & $108-67-8$ & $\mu \mathrm{g} / \mathrm{L}$ & 100 & $<100$ & n.a. & 29/10/2014 06:36 \\
\hline 1,2,4-Trimetilbenzeno & $95-63-6$ & $\mu \mathrm{g} / \mathrm{L}$ & 100 & $<100$ & n.a. & 29/10/2014 06:36 \\
\hline 1,2-Dibromoetano & $106-93-4$ & $\mu \mathrm{g} / \mathrm{L}$ & 100 & $<100$ & n.a. & 29/10/2014 06:36 \\
\hline 1,2-Diclorobenzeno & $95-50-1$ & $\mu \mathrm{g} / \mathrm{L}$ & 100 & $<100$ & n.a. & 29/10/2014 06:36 \\
\hline 1,3-Diclorobenzeno & $541-73-1$ & $\mu \mathrm{g} / \mathrm{L}$ & 100 & $<100$ & n.a. & $29 / 10 / 201406: 36$ \\
\hline 2-Clorotolueno & $95-49-8$ & $\mu \mathrm{g} / \mathrm{L}$ & 100 & $<100$ & n.a. & 29/10/2014 06:36 \\
\hline Dibromometano & $74-95-3$ & $\mu \mathrm{g} / \mathrm{L}$ & 100 & $<100$ & n.a. & $29 / 10 / 201406: 36$ \\
\hline Metiletilcetona & $78-93-3$ & $\mu \mathrm{g} / \mathrm{L}$ & 250000 & $<250000$ & n.a. & $30 / 10 / 2014$ 09:44 \\
\hline Naftaleno & $91-20-3$ & $\mu \mathrm{g} / \mathrm{L}$ & 100 & $<100$ & n.a. & 29/10/2014 06:36 \\
\hline n-Butilbenzeno & $104-51-8$ & $\mu \mathrm{g} / \mathrm{L}$ & 100 & $<100$ & n.a. & 29/10/2014 06:36 \\
\hline n-Propilbenzeno & $103-65-1$ & $\mu \mathrm{g} / \mathrm{L}$ & 100 & $<100$ & n.a. & 29/10/2014 06:36 \\
\hline 4-Clorotolueno & $106-43-4$ & $\mu \mathrm{g} / \mathrm{L}$ & 100 & $<100$ & n.a. & 29/10/2014 06:36 \\
\hline sec-Butilbenzeno & $135-98-8$ & $\mu \mathrm{g} / \mathrm{L}$ & 100 & $<100$ & n.a. & 29/10/2014 06:36 \\
\hline terc-Butilbenzeno & 98-06-6 & $\mu \mathrm{g} / \mathrm{L}$ & 100 & $<100$ & n.a. & 29/10/2014 06:36 \\
\hline trans-1,3-Dicloropropeno & $10061-02-6$ & $\mu \mathrm{g} / \mathrm{L}$ & 100 & $<100$ & n.a. & $29 / 10 / 2014$ 06:36 \\
\hline Isopropilbenzeno & $98-82-8$ & $\mu \mathrm{g} / \mathrm{L}$ & 100 & $<100$ & n.a. & 29/10/2014 06:36 \\
\hline 1,3,5-Triclorobenzeno & $108-70-3$ & $\mu \mathrm{g} / \mathrm{L}$ & 100 & $<100$ & n.a. & $29 / 10 / 2014$ 06:36 \\
\hline
\end{tabular}

\section{CONTROLE DE Q UALIDADE DO LABORATÓRIO}

Controle de Q ualidade - VOC - Água

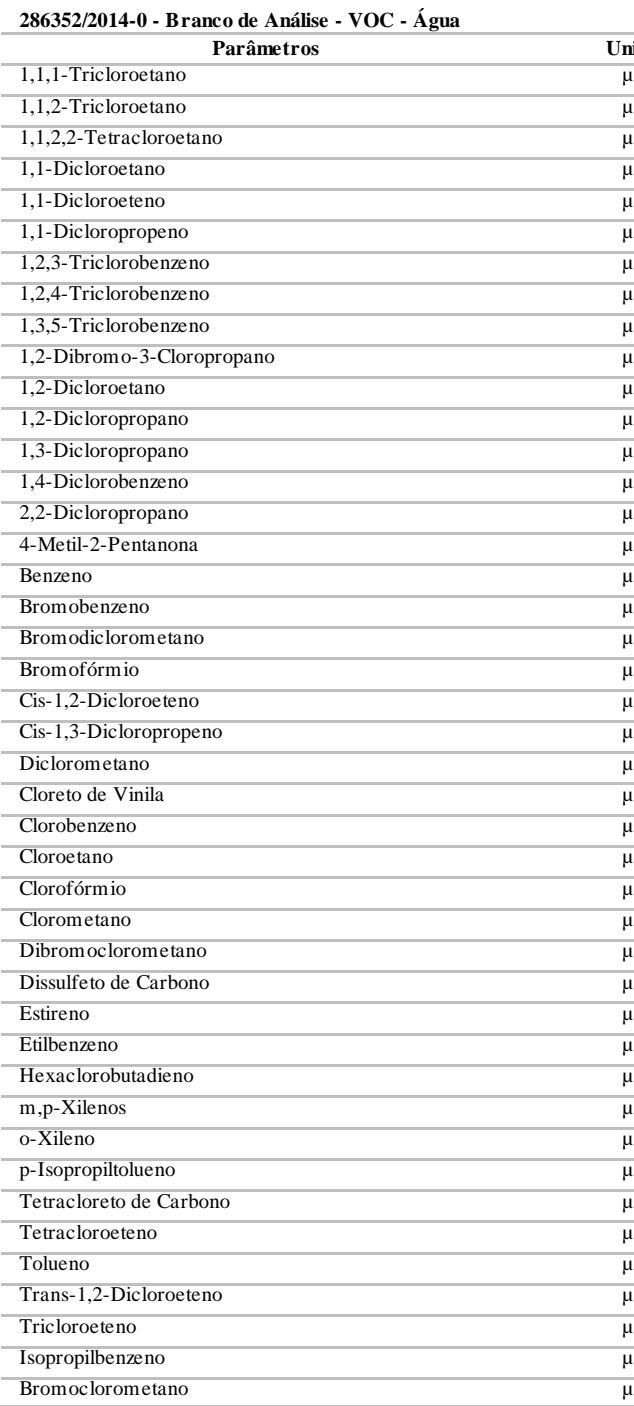

\begin{tabular}{|c|c|c|}
\hline Inidade & LQ & Resultados analíticos \\
\hline$\mu \mathrm{g} / \mathrm{L}$ & 1 & $<1$ \\
\hline$\mu \mathrm{g} / \mathrm{L}$ & 1 & $<1$ \\
\hline$\mu \mathrm{g} / \mathrm{L}$ & 1 & $<1$ \\
\hline$\mu \mathrm{g} / \mathrm{L}$ & 1 & $<1$ \\
\hline$\mu \mathrm{g} / \mathrm{L}$ & 1 & $<1$ \\
\hline$\mu \mathrm{g} / \mathrm{L}$ & 1 & $<1$ \\
\hline$\mu \mathrm{g} / \mathrm{L}$ & 1 & $<1$ \\
\hline$\mu \mathrm{g} / \mathrm{L}$ & 1 & $<1$ \\
\hline$\mu \mathrm{g} / \mathrm{L}$ & 1 & $<1$ \\
\hline$\mu \mathrm{g} / \mathrm{L}$ & 5 & $<5$ \\
\hline$\mu \mathrm{g} / \mathrm{L}$ & 1 & $<1$ \\
\hline$\mu \mathrm{g} / \mathrm{L}$ & 1 & $<1$ \\
\hline$\mu \mathrm{g} / \mathrm{L}$ & 5 & $<5$ \\
\hline$\mu \mathrm{g} / \mathrm{L}$ & 1 & $<1$ \\
\hline$\mu \mathrm{g} / \mathrm{L}$ & 1 & $<1$ \\
\hline$\mu \mathrm{g} / \mathrm{L}$ & 5 & $<5$ \\
\hline$\mu \mathrm{g} / \mathrm{L}$ & 1 & $<1$ \\
\hline$\mu \mathrm{g} / \mathrm{L}$ & 1 & $<1$ \\
\hline$\mu \mathrm{g} / \mathrm{L}$ & 1 & $<1$ \\
\hline$\mu \mathrm{g} / \mathrm{L}$ & 1 & $<1$ \\
\hline$\mu \mathrm{g} / \mathrm{L}$ & 1 & $<1$ \\
\hline$\mu \mathrm{g} / \mathrm{L}$ & 1 & $<1$ \\
\hline$\mu \mathrm{g} / \mathrm{L}$ & 1 & $<1$ \\
\hline$\mu \mathrm{g} / \mathrm{L}$ & 1 & $<1$ \\
\hline$\mu \mathrm{g} / \mathrm{L}$ & 1 & $<1$ \\
\hline$\mu \mathrm{g} / \mathrm{L}$ & 1 & $<1$ \\
\hline$\mu \mathrm{g} / \mathrm{L}$ & 1 & $<1$ \\
\hline$\mu \mathrm{g} / \mathrm{L}$ & 10 & $<10$ \\
\hline$\mu \mathrm{g} / \mathrm{L}$ & 1 & $<1$ \\
\hline$\mu \mathrm{g} / \mathrm{L}$ & 1 & $<1$ \\
\hline$\mu \mathrm{g} / \mathrm{L}$ & 1 & $<1$ \\
\hline$\mu \mathrm{g} / \mathrm{L}$ & 1 & $<1$ \\
\hline$\mu \mathrm{g} / \mathrm{L}$ & 1 & $<1$ \\
\hline$\mu \mathrm{g} / \mathrm{L}$ & 2 & $<2$ \\
\hline$\mu \mathrm{g} / \mathrm{L}$ & 1 & $<1$ \\
\hline$\mu \mathrm{g} / \mathrm{L}$ & 1 & $<1$ \\
\hline$\mu \mathrm{g} / \mathrm{L}$ & 1 & $<1$ \\
\hline$\mu \mathrm{g} / \mathrm{L}$ & 1 & $<1$ \\
\hline$\mu \mathrm{g} / \mathrm{L}$ & 1 & $<1$ \\
\hline$\mu \mathrm{g} / \mathrm{L}$ & 1 & $<1$ \\
\hline$\mu \mathrm{g} / \mathrm{L}$ & 1 & $<1$ \\
\hline$\mu \mathrm{g} / \mathrm{L}$ & 1 & $<1$ \\
\hline$\mu \mathrm{g} / \mathrm{L}$ & 5 & $<5$ \\
\hline
\end{tabular}




\begin{tabular}{|c|c|c|c|c|}
\hline Parâmetros & $\begin{array}{l}\text { Q uantidade } \\
\text { Adicionada }\end{array}$ & Unidade & $\begin{array}{c}\text { Resultado da } \\
\text { Recuperação (\%) }\end{array}$ & Faixa Aceitável de Recuperação (\%) \\
\hline \multicolumn{5}{|c|}{ 286353/2014-0 - Amostra Controle - VOC - Água } \\
\hline 1,1-Dicloroeteno & 20 & $\mu \mathrm{g} / \mathrm{L}$ & 90 & $70-130$ \\
\hline Benzeno & 20 & $\mu \mathrm{g} / \mathrm{L}$ & 95 & $70-130$ \\
\hline Tricloroeteno & 20 & $\mu \mathrm{g} / \mathrm{L}$ & 90 & $70-130$ \\
\hline Tolueno & 20 & $\mu \mathrm{g} / \mathrm{L}$ & 90 & $70-130$ \\
\hline Clorobenzeno & 20 & $\mu \mathrm{g} / \mathrm{L}$ & 95 & $70-130$ \\
\hline \multicolumn{5}{|c|}{$\begin{array}{l}\text { Surrogates } \\
\text { 286352/2014-0 - B ranco de Análise - VOC - Água }\end{array}$} \\
\hline p-Bromofluorbenzeno & 20 & $\%$ & 97,0 & $70-130$ \\
\hline Dibrom ofluorometano & 20 & $\%$ & 108 & $70-130$ \\
\hline \multicolumn{5}{|c|}{ 286353/2014-0 - Amostra Controle - VOC - Água } \\
\hline p-Bromofluorbenzeno & 20 & $\%$ & 93,4 & $70-130$ \\
\hline Dibromofluorometano & 20 & $\%$ & 98,3 & $70-130$ \\
\hline \multicolumn{5}{|l|}{ 283878/2014-0 - CGBIA-1 } \\
\hline Dibrom ofluorometano & 20 & $\%$ & Amostra Diluída & $70-130$ \\
\hline p-Bromofluorbenzeno & 20 & $\%$ & Amostra Diluída & $70-130$ \\
\hline
\end{tabular}

Notas

$\mathrm{LQ}=$ Limite de Quantificação

n.a. = Não Aplicável.

Abrangência

(s) resultado(s) referem-se somente à(s) amostra(s) analisada(s).

Este Relatório de Ensaio só pode ser reproduzido por inteiro e sem nenhuma alteração.

Plano de Amostragem

Plano de amostragem de responsabilidade do interessado

Responsabilidade Técnica

Os ensaios foram realizados na unidade da Bioagri Ambiental Ltda. - Matriz, situada na Rua Aljovil Martini, 177/201, Bairro Dois Córregos, Cep. 14420-833, Piracicaba/SP, registrada no CRQ 4ª Região sob nº 16082-Fe responsabilidade técnica do profissional José Carlos Moretti, CRQ nº 04107238, $4^{a}$.Região.

Referências Metodológicas

Análises foram realizadas conforme a última versão do Standard Methods for the Examination of Water \& Wastewater 22nd 2012(SMWW), EPA e ABNT (quando aplicável).

VOC: EPA 8260 C: 2006, 5021A: 2003

Metiletilcetona: EPA 8260 C: 2006,5021 A: 2003

Revisores

Daniela Rodrigues Bandoria

Chave de Validação: 98d4839a5ccdf05073082e5cb8302e47

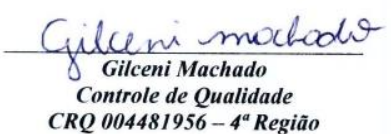

CRQ 004481956-4 Região

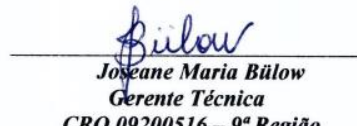

CRQ 09200516- $9^{a}$ Região 


\section{RELATÓRIO DE ENSAIO N $^{\circ}$ 283880/2014-0 - Piracicaba Processo Comercial $N^{\circ}$ 23961/2014-2}

\begin{tabular}{|l|l|}
\hline \multicolumn{2}{|c|}{ DADOS REFERENTES AO CLIENTE } \\
\hline Empresa solicitante: & Fundacao Parque de Alta Tecnologia da Regiao de Ipero e Adjacencias \\
\hline Endereço: & Rua Jose Antonio Scaciota, 165 - - Portal do Cedro - Iperó - SP - CEP: 18.560-000 . \\
\hline Nome do Solicitante: & Carla Marçal \\
\hline
\end{tabular}

\begin{tabular}{|l|l|l|l|l|}
\hline \multicolumn{5}{|c|}{ DADOS REFERENTES A AMOSTRA } \\
\hline Identificação do Cliente: & \multicolumn{4}{|l|}{ CGBIA-2 } \\
\hline Amostra Rotulada como: & Água Subterrânea Projeto Mestrado \\
\hline Coletor: & Interessado & Data da coleta: & \multicolumn{2}{|l|}{ 23/10/2014 18:00:00 } \\
\hline Data da entrada no laboratório: & $25 / 10 / 201408: 26$ & Data de Elaboração do RE: & $03 / 11 / 2014$ \\
\hline
\end{tabular}

\section{RESULTADOS PARA A AMOSTRA}

\begin{tabular}{|c|c|c|c|c|c|c|}
\hline Parâmetros & CAS & Unidade & LQ & Resultados analíticos & Incerteza & Data do Ensaio \\
\hline 1,1,1-Tricloroetano & $71-55-6$ & $\mu \mathrm{g} / \mathrm{L}$ & 100 & $<100$ & n.a. & 29/10/2014 07:00 \\
\hline 1,1,2-Tricloroetano & $79-00-5$ & $\mu \mathrm{g} / \mathrm{L}$ & 100 & $<100$ & n.a. & 29/10/2014 07:00 \\
\hline 1,1,2,2-Tetracloroetano & $79-34-5$ & $\mu \mathrm{g} / \mathrm{L}$ & 100 & $<100$ & n.a. & 29/10/2014 07:00 \\
\hline 1,1-Dicloroetano & 75-34-3 & $\mu \mathrm{g} / \mathrm{L}$ & 100 & $<100$ & n.a. & 29/10/2014 07:00 \\
\hline 1,1-Dicloroeteno & $75-35-4$ & $\mu \mathrm{g} / \mathrm{L}$ & 100 & $<100$ & n.a. & 29/10/2014 07:00 \\
\hline 1,1-Dicloropropeno & $563-58-6$ & $\mu \mathrm{g} / \mathrm{L}$ & 100 & $<100$ & n.a. & 29/10/2014 07:00 \\
\hline 1,2,3-Triclorobenzeno & $87-61-6$ & $\mu \mathrm{g} / \mathrm{L}$ & 100 & $<100$ & n.a. & 29/10/2014 07:00 \\
\hline 1,2,4-Triclorobenzeno & $120-82-1$ & $\mu \mathrm{g} / \mathrm{L}$ & 100 & $<100$ & n.a. & 29/10/2014 07:00 \\
\hline 1,2-Dibromo-3-Cloropropano & $96-12-8$ & $\mu \mathrm{g} / \mathrm{L}$ & 500 & $<500$ & n.a. & 29/10/2014 07:00 \\
\hline 1,2-Dicloroetano & $107-06-2$ & $\mu \mathrm{g} / \mathrm{L}$ & 100 & $<100$ & n.a. & 29/10/2014 07:00 \\
\hline 1,2-Dicloropropano & $78-87-5$ & $\mu \mathrm{g} / \mathrm{L}$ & 100 & $<100$ & n.a. & 29/10/2014 07:00 \\
\hline 1,3-Dicloropropano & $142-28-9$ & $\mu \mathrm{g} / \mathrm{L}$ & 500 & $<500$ & n.a. & 29/10/2014 07:00 \\
\hline 1,4-Diclorobenzeno & $106-46-7$ & $\mu \mathrm{g} / \mathrm{L}$ & 100 & $<100$ & n.a. & 29/10/2014 07:00 \\
\hline 2,2-Dicloropropano & $594-20-7$ & $\mu \mathrm{g} / \mathrm{L}$ & 100 & $<100$ & n.a. & 29/10/2014 07:00 \\
\hline 4-Metil-2-Pentanona & $108-10-1$ & $\mu \mathrm{g} / \mathrm{L}$ & 500 & $<500$ & n.a. & 29/10/2014 07:00 \\
\hline Benzeno & $71-43-2$ & $\mu \mathrm{g} / \mathrm{L}$ & 100 & $<100$ & n.a. & 29/10/2014 07:00 \\
\hline Bromobenzeno & $108-86-1$ & $\mu \mathrm{g} / \mathrm{L}$ & 100 & $<100$ & n.a. & 29/10/2014 07:00 \\
\hline Bromodiclorometano & $75-27-4$ & $\mu \mathrm{g} / \mathrm{L}$ & 100 & $<100$ & n.a. & 29/10/2014 07:00 \\
\hline Bromofórmio & $75-25-2$ & $\mu \mathrm{g} / \mathrm{L}$ & 100 & $<100$ & n.a. & 29/10/2014 07:00 \\
\hline Bromoclorometano & $74-97-5$ & $\mu \mathrm{g} / \mathrm{L}$ & 500 & $<500$ & n.a. & 29/10/2014 07:00 \\
\hline Cis-1,2-Dicloroeteno & $156-59-2$ & $\mu \mathrm{g} / \mathrm{L}$ & 100 & $<100$ & n.a. & 29/10/2014 07:00 \\
\hline Cis-1,3-Dicloropropeno & 10061-01-5 & $\mu \mathrm{g} / \mathrm{L}$ & 100 & $<100$ & n.a. & 29/10/2014 07:00 \\
\hline Diclorometano & $75-09-2$ & $\mu \mathrm{g} / \mathrm{L}$ & 100 & $<100$ & n.a. & 29/10/2014 07:00 \\
\hline Cloreto de Vinila & 75-01-4 & $\mu \mathrm{g} / \mathrm{L}$ & 100 & $<100$ & n.a. & 29/10/2014 07:00 \\
\hline Clorobenzeno & $108-90-7$ & $\mu \mathrm{g} / \mathrm{L}$ & 100 & $<100$ & n.a. & 29/10/2014 07:00 \\
\hline Cloroetano & $75-00-3$ & $\mu \mathrm{g} / \mathrm{L}$ & 100 & $<100$ & n.a. & 29/10/2014 07:00 \\
\hline Clorofórmio & $67-66-3$ & $\mu \mathrm{g} / \mathrm{L}$ & 100 & $<100$ & n.a. & 29/10/2014 07:00 \\
\hline Clorometano & $74-87-3$ & $\mu \mathrm{g} / \mathrm{L}$ & 1000 & $<1000$ & n.a. & 29/10/2014 07:00 \\
\hline Dibromoclorometano & $124-48-1$ & $\mu \mathrm{g} / \mathrm{L}$ & 100 & $<100$ & n.a. & 29/10/2014 07:00 \\
\hline Dissulfeto de Carbono & $75-15-0$ & $\mu \mathrm{g} / \mathrm{L}$ & 100 & $<100$ & n.a. & 29/10/2014 07:00 \\
\hline Estireno & $100-42-5$ & $\mu \mathrm{g} / \mathrm{L}$ & 100 & $<100$ & n.a. & 29/10/2014 07:00 \\
\hline Etilbenzeno & $100-41-4$ & $\mu \mathrm{g} / \mathrm{L}$ & 100 & $<100$ & n.a. & 29/10/2014 07:00 \\
\hline Hexaclorobutadieno & $87-68-3$ & $\mu \mathrm{g} / \mathrm{L}$ & 100 & $<100$ & n.a. & 29/10/2014 07:00 \\
\hline $\mathrm{m}, \mathrm{p}$-Xilenos & --- & $\mu \mathrm{g} / \mathrm{L}$ & 200 & $<200$ & n.a. & 29/10/2014 07:00 \\
\hline o-Xileno & $95-47-6$ & $\mu \mathrm{g} / \mathrm{L}$ & 100 & $<100$ & n.a. & 29/10/2014 07:00 \\
\hline p-Isopropiltolueno & $99-87-6$ & $\mu \mathrm{g} / \mathrm{L}$ & 100 & $<100$ & n.a. & 29/10/2014 07:00 \\
\hline Tetracloreto de Carbono & $56-23-5$ & $\mu \mathrm{g} / \mathrm{L}$ & 100 & $<100$ & n.a. & 29/10/2014 07:00 \\
\hline Tetracloroeteno & $127-18-4$ & $\mu \mathrm{g} / \mathrm{L}$ & 1000 & 61800 & 12000 & 29/10/2014 07:00 \\
\hline Tolueno & $108-88-3$ & $\mu \mathrm{g} / \mathrm{L}$ & 100 & $<100$ & n.a. & 29/10/2014 07:00 \\
\hline Trans-1,2-Dicloroeteno & $156-60-5$ & $\mu \mathrm{g} / \mathrm{L}$ & 100 & $<100$ & n.a. & 29/10/2014 07:00 \\
\hline Tricloroeteno & $79-01-6$ & $\mu \mathrm{g} / \mathrm{L}$ & 100 & $<100$ & n.a. & 29/10/2014 07:00 \\
\hline 1,1,1,2-Tetracloroetano & $630-20-6$ & $\mu \mathrm{g} / \mathrm{L}$ & 100 & $<100$ & n.a. & 29/10/2014 07:00 \\
\hline
\end{tabular}




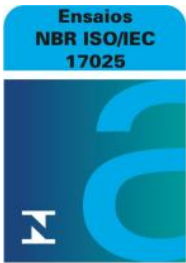

CRL 0172

\begin{tabular}{|c|c|c|c|c|c|c|}
\hline Parâmetros & CAS & Unidade & LQ & Resultados analíticos & Incerteza & Data do Ensaio \\
\hline 1,2,3-Tricloropropano & $96-18-4$ & $\mu \mathrm{g} / \mathrm{L}$ & 500 & $<500$ & n.a. & 29/10/2014 07:00 \\
\hline 1,3,5-Trimetilbenzeno & $108-67-8$ & $\mu \mathrm{g} / \mathrm{L}$ & 100 & $<100$ & n.a. & 29/10/2014 07:00 \\
\hline 1,2,4-Trimetilbenzeno & $95-63-6$ & $\mu \mathrm{g} / \mathrm{L}$ & 100 & $<100$ & n.a. & 29/10/2014 07:00 \\
\hline 1,2-Dibromoetano & $106-93-4$ & $\mu \mathrm{g} / \mathrm{L}$ & 100 & $<100$ & n.a. & 29/10/2014 07:00 \\
\hline 1,2-Diclorobenzeno & $95-50-1$ & $\mu \mathrm{g} / \mathrm{L}$ & 100 & $<100$ & n.a. & 29/10/2014 07:00 \\
\hline 1,3-Diclorobenzeno & $541-73-1$ & $\mu \mathrm{g} / \mathrm{L}$ & 100 & $<100$ & n.a. & 29/10/2014 07:00 \\
\hline 2-Clorotolueno & $95-49-8$ & $\mu \mathrm{g} / \mathrm{L}$ & 100 & $<100$ & n.a. & 29/10/2014 07:00 \\
\hline Dibromometano & $74-95-3$ & $\mu \mathrm{g} / \mathrm{L}$ & 100 & $<100$ & n.a. & 29/10/2014 07:00 \\
\hline Metiletilcetona & $78-93-3$ & $\mu \mathrm{g} / \mathrm{L}$ & 250000 & $<250000$ & n.a. & $30 / 10 / 201410: 09$ \\
\hline Naftaleno & $91-20-3$ & $\mu \mathrm{g} / \mathrm{L}$ & 100 & $<100$ & n.a. & 29/10/2014 07:00 \\
\hline n-Butilbenzeno & $104-51-8$ & $\mu \mathrm{g} / \mathrm{L}$ & 100 & $<100$ & n.a. & 29/10/2014 07:00 \\
\hline n-Propilbenzeno & $103-65-1$ & $\mu \mathrm{g} / \mathrm{L}$ & 100 & $<100$ & n.a. & $29 / 10 / 2014$ 07:00 \\
\hline 4-Clorotolueno & $106-43-4$ & $\mu \mathrm{g} / \mathrm{L}$ & 100 & $<100$ & n.a. & 29/10/2014 07:00 \\
\hline sec-Butilbenzeno & $135-98-8$ & $\mu \mathrm{g} / \mathrm{L}$ & 100 & $<100$ & n.a. & 29/10/2014 07:00 \\
\hline terc-Butilbenzeno & 98-06-6 & $\mu \mathrm{g} / \mathrm{L}$ & 100 & $<100$ & n.a. & 29/10/2014 07:00 \\
\hline trans-1,3-Dicloropropeno & $10061-02-6$ & $\mu \mathrm{g} / \mathrm{L}$ & 100 & $<100$ & n.a. & 29/10/2014 07:00 \\
\hline Isopropilbenzeno & $98-82-8$ & $\mu \mathrm{g} / \mathrm{L}$ & 100 & $<100$ & n.a. & 29/10/2014 07:00 \\
\hline 1,3,5-Triclorobenzeno & $108-70-3$ & $\mu \mathrm{g} / \mathrm{L}$ & 100 & $<100$ & n.a. & 29/10/2014 07:00 \\
\hline
\end{tabular}

\section{CONTROLE DE Q UALIDADE DO LABORATÓRIO}

Controle de Q ualidade - VOC - Água

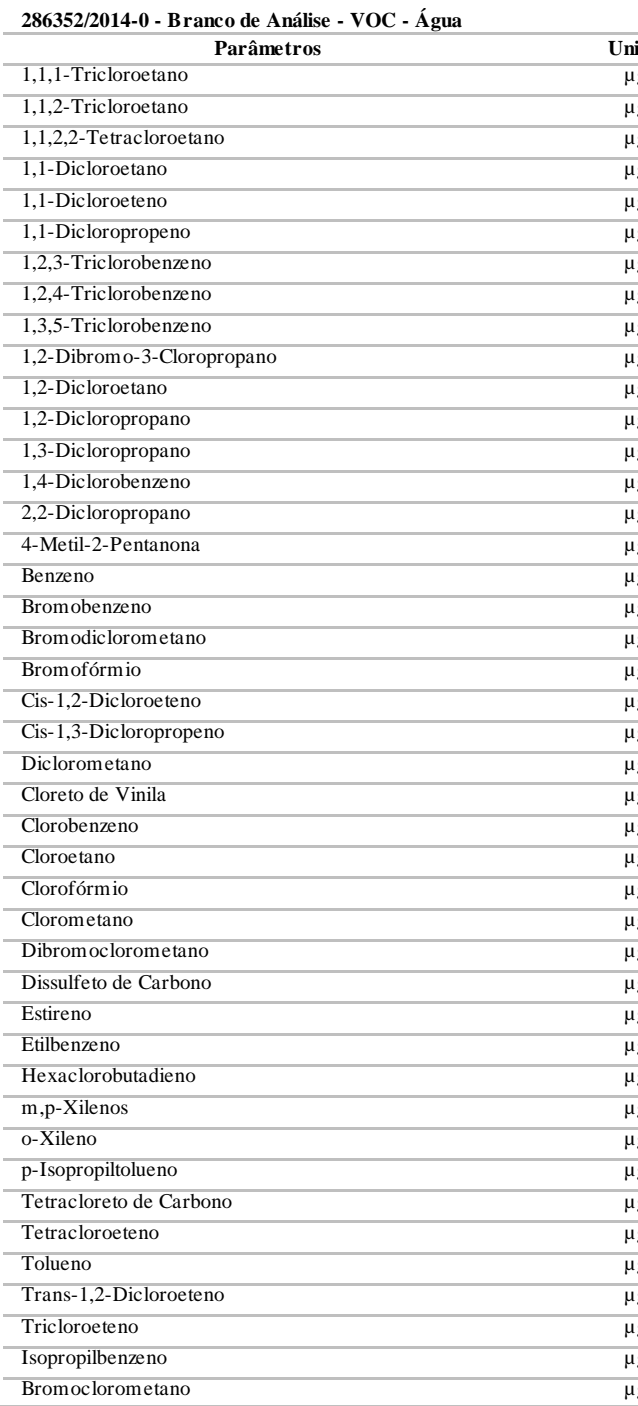

\begin{tabular}{|c|c|c|}
\hline Inidade & LQ & Resultados analíticos \\
\hline$\mu \mathrm{g} / \mathrm{L}$ & 1 & $<1$ \\
\hline$\mu \mathrm{g} / \mathrm{L}$ & 1 & $<1$ \\
\hline$\mu \mathrm{g} / \mathrm{L}$ & 1 & $<1$ \\
\hline$\mu \mathrm{g} / \mathrm{L}$ & 1 & $<1$ \\
\hline$\mu \mathrm{g} / \mathrm{L}$ & 1 & $<1$ \\
\hline$\mu \mathrm{g} / \mathrm{L}$ & 1 & $<1$ \\
\hline$\mu \mathrm{g} / \mathrm{L}$ & 1 & $<1$ \\
\hline$\mu \mathrm{g} / \mathrm{L}$ & 1 & $<1$ \\
\hline$\mu \mathrm{g} / \mathrm{L}$ & 1 & $<1$ \\
\hline$\mu \mathrm{g} / \mathrm{L}$ & 5 & $<5$ \\
\hline$\mu \mathrm{g} / \mathrm{L}$ & 1 & $<1$ \\
\hline$\mu \mathrm{g} / \mathrm{L}$ & 1 & $<1$ \\
\hline$\mu \mathrm{g} / \mathrm{L}$ & 5 & $<5$ \\
\hline$\mu \mathrm{g} / \mathrm{L}$ & 1 & $<1$ \\
\hline$\mu \mathrm{g} / \mathrm{L}$ & 1 & $<1$ \\
\hline$\mu \mathrm{g} / \mathrm{L}$ & 5 & $<5$ \\
\hline$\mu \mathrm{g} / \mathrm{L}$ & 1 & $<1$ \\
\hline$\mu \mathrm{g} / \mathrm{L}$ & 1 & $<1$ \\
\hline$\mu \mathrm{g} / \mathrm{L}$ & 1 & $<1$ \\
\hline$\mu \mathrm{g} / \mathrm{L}$ & 1 & $<1$ \\
\hline$\mu \mathrm{g} / \mathrm{L}$ & 1 & $<1$ \\
\hline$\mu \mathrm{g} / \mathrm{L}$ & 1 & $<1$ \\
\hline$\mu \mathrm{g} / \mathrm{L}$ & 1 & $<1$ \\
\hline$\mu \mathrm{g} / \mathrm{L}$ & 1 & $<1$ \\
\hline$\mu \mathrm{g} / \mathrm{L}$ & 1 & $<1$ \\
\hline$\mu \mathrm{g} / \mathrm{L}$ & 1 & $<1$ \\
\hline$\mu \mathrm{g} / \mathrm{L}$ & 1 & $<1$ \\
\hline$\mu \mathrm{g} / \mathrm{L}$ & 10 & $<10$ \\
\hline$\mu \mathrm{g} / \mathrm{L}$ & 1 & $<1$ \\
\hline$\mu \mathrm{g} / \mathrm{L}$ & 1 & $<1$ \\
\hline$\mu \mathrm{g} / \mathrm{L}$ & 1 & $<1$ \\
\hline$\mu \mathrm{g} / \mathrm{L}$ & 1 & $<1$ \\
\hline$\mu \mathrm{g} / \mathrm{L}$ & 1 & $<1$ \\
\hline$\mu \mathrm{g} / \mathrm{L}$ & 2 & $<2$ \\
\hline$\mu \mathrm{g} / \mathrm{L}$ & 1 & $<1$ \\
\hline$\mu \mathrm{g} / \mathrm{L}$ & 1 & $<1$ \\
\hline$\mu \mathrm{g} / \mathrm{L}$ & 1 & $<1$ \\
\hline$\mu \mathrm{g} / \mathrm{L}$ & 1 & $<1$ \\
\hline$\mu \mathrm{g} / \mathrm{L}$ & 1 & $<1$ \\
\hline$\mu \mathrm{g} / \mathrm{L}$ & 1 & $<1$ \\
\hline$\mu \mathrm{g} / \mathrm{L}$ & 1 & $<1$ \\
\hline$\mu \mathrm{g} / \mathrm{L}$ & 1 & $<1$ \\
\hline$\mu \mathrm{g} / \mathrm{L}$ & 5 & $<5$ \\
\hline
\end{tabular}




\begin{tabular}{|c|c|c|c|c|}
\hline Parâmetros & $\begin{array}{l}\text { Q uantidade } \\
\text { Adicionada }\end{array}$ & Unidade & $\begin{array}{c}\text { Resultado da } \\
\text { Recuperação (\%) }\end{array}$ & Faixa Aceitável de Recuperação (\%) \\
\hline \multicolumn{5}{|c|}{ 286353/2014-0 - Amostra Controle - VOC - Água } \\
\hline 1,1-Dicloroeteno & 20 & $\mu \mathrm{g} / \mathrm{L}$ & 90 & $70-130$ \\
\hline Benzeno & 20 & $\mu \mathrm{g} / \mathrm{L}$ & 95 & $70-130$ \\
\hline Tricloroeteno & 20 & $\mu \mathrm{g} / \mathrm{L}$ & 90 & $70-130$ \\
\hline Tolueno & 20 & $\mu \mathrm{g} / \mathrm{L}$ & 90 & $70-130$ \\
\hline Clorobenzeno & 20 & $\mu \mathrm{g} / \mathrm{L}$ & 95 & $70-130$ \\
\hline \multicolumn{5}{|c|}{$\begin{array}{l}\text { Surrogates } \\
\text { 286352/2014-0 - Branco de Análise - VOC - Água }\end{array}$} \\
\hline p-Bromofluorbenzeno & 20 & $\%$ & 97,0 & $70-130$ \\
\hline Dibrom ofluorometano & 20 & $\%$ & 108 & $70-130$ \\
\hline \multicolumn{5}{|c|}{ 286353/2014-0 - Amostra Controle - VOC - Água } \\
\hline p-Bromofluorbenzeno & 20 & $\%$ & 93,4 & $70-130$ \\
\hline Dibrom ofluorometano & 20 & $\%$ & 98,3 & $70-130$ \\
\hline \multicolumn{5}{|l|}{ 283880/2014-0 - CGBIA-2 } \\
\hline Dibrom ofluorometano & 20 & $\%$ & Amostra Diluída & $70-130$ \\
\hline p-Bromofluorbenzeno & 20 & $\%$ & Amostra Diluída & $70-130$ \\
\hline
\end{tabular}

Notas

$L Q=$ Limite de Quantificação

n.a. = Não Aplicável.

Abrangência

(s) resultado(s) referem-se somente à(s) amostra(s) analisada(s).

Este Relatório de Ensaio só pode ser reproduzido por inteiro e sem nenhuma alteração.

Plano de Amostragem

Plano de amostragem de responsabilidade do interessado

Responsabilidade Técnica

Os ensaios foram realizados na unidade da Bioagri Ambiental Ltda. - Matriz, situada na Rua Aljovil Martini, 177/201, Bairro Dois Córregos, Cep. 14420-833, Piracicaba/SP, registrada no CRQ 4ª Região sob nº 16082-Fe responsabilidade técnica do profissional José Carlos Moretti, CRQ nº 04107238, $4^{a}$.Região.

Referências Metodológicas

Análises foram realizadas conforme a última versão do Standard Methods for the Examination of Water \& Wastewater 22nd 2012(SMWW), EPA e ABNT (quando aplicável).

VOC: EPA 8260 C: 2006, 5021A: 2003

Metiletilcetona: EPA 8260 C: 2006,5021 A: 2003

Revisores

Débora Fernandes da Silva

Daniela Rodrigues Bandoria

Chave de Validação: 5d025ba97b3d14d949b7ed2elc79ab20

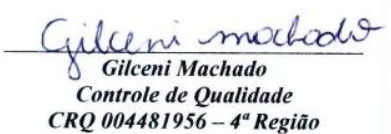

CRQ 004481956-4 Região

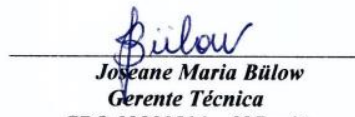

CRQ 09200516- - $9^{a}$ Região 


\section{RELATÓRIO DE ENSAIO N $^{\circ}$ 283881/2014-0 - Piracicaba Processo Comercial $N^{\circ}$ 23961/2014-2}

\begin{tabular}{|l|l|}
\hline \multicolumn{2}{|c|}{ DADOS REFERENTES AO CLIENTE } \\
\hline Empresa solicitante: & Fundacao Parque de Alta Tecnologia da Regiao de Ipero e Adjacencias \\
\hline Endereço: & Rua Jose Antonio Scaciota, 165 - - Portal do Cedro - Iperó - SP - CEP: 18.560-000 . \\
\hline Nome do Solicitante: & Carla Marçal \\
\hline
\end{tabular}

\begin{tabular}{|l|l|l|l|l|}
\hline \multicolumn{5}{|c|}{ DADOS REFERENTES A AMOSTRA } \\
\hline Identificação do Cliente: & \multicolumn{1}{|l|}{ CGBIA-3 } & \\
\hline Amostra Rotulada como: & Água Subterrânea Projeto Mestrado \\
\hline Coletor: & Interessado & Data da coleta: & \multicolumn{2}{|l|}{ 23/10/2014 18:00:00 } \\
\hline Data da entrada no laboratório: & $25 / 10 / 2014$ 08:27 & Data de Elaboração do RE: & $03 / 11 / 2014$ \\
\hline
\end{tabular}

\section{RESULTADOS PARA A AMOSTRA}

\begin{tabular}{|c|c|c|c|c|c|c|}
\hline Parâmetros & CAS & Unidade & LQ & Resultados analíticos & Incerteza & Data do Ensaio \\
\hline 1,1,1-Tricloroetano & $71-55-6$ & $\mu \mathrm{g} / \mathrm{L}$ & 100 & $<100$ & n.a. & 29/10/2014 07:24 \\
\hline 1,1,2-Tricloroetano & $79-00-5$ & $\mu \mathrm{g} / \mathrm{L}$ & 100 & $<100$ & n.a. & $29 / 10 / 201407: 24$ \\
\hline 1,1,2,2-Tetracloroetano & $79-34-5$ & $\mu \mathrm{g} / \mathrm{L}$ & 100 & $<100$ & n.a. & 29/10/2014 07:24 \\
\hline 1,1-Dicloroetano & $75-34-3$ & $\mu \mathrm{g} / \mathrm{L}$ & 100 & $<100$ & n.a. & 29/10/2014 07:24 \\
\hline 1,1-Dicloroeteno & $75-35-4$ & $\mu \mathrm{g} / \mathrm{L}$ & 100 & $<100$ & n.a. & 29/10/2014 07:24 \\
\hline 1,1-Dicloropropeno & $563-58-6$ & $\mu \mathrm{g} / \mathrm{L}$ & 100 & $<100$ & n.a. & 29/10/2014 07:24 \\
\hline 1,2,3-Triclorobenzeno & $87-61-6$ & $\mu \mathrm{g} / \mathrm{L}$ & 100 & $<100$ & n.a. & 29/10/2014 07:24 \\
\hline 1,2,4-Triclorobenzeno & $120-82-1$ & $\mu \mathrm{g} / \mathrm{L}$ & 100 & $<100$ & n.a. & 29/10/2014 07:24 \\
\hline 1,2-Dibromo-3-Cloropropano & $96-12-8$ & $\mu \mathrm{g} / \mathrm{L}$ & 500 & $<500$ & n.a. & $29 / 10 / 2014$ 07:24 \\
\hline 1,2-Dicloroetano & $107-06-2$ & $\mu \mathrm{g} / \mathrm{L}$ & 100 & $<100$ & n.a. & 29/10/2014 07:24 \\
\hline 1,2-Dicloropropano & $78-87-5$ & $\mu \mathrm{g} / \mathrm{L}$ & 100 & $<100$ & n.a. & 29/10/2014 07:24 \\
\hline 1,3-Dicloropropano & $142-28-9$ & $\mu \mathrm{g} / \mathrm{L}$ & 500 & $<500$ & n.a. & 29/10/2014 07:24 \\
\hline 1,4-Diclorobenzeno & $106-46-7$ & $\mu \mathrm{g} / \mathrm{L}$ & 100 & $<100$ & n.a. & 29/10/2014 07:24 \\
\hline 2,2-Dicloropropano & $594-20-7$ & $\mu \mathrm{g} / \mathrm{L}$ & 100 & $<100$ & n.a. & $29 / 10 / 201407: 24$ \\
\hline 4-Metil-2-Pentanona & $108-10-1$ & $\mu \mathrm{g} / \mathrm{L}$ & 500 & $<500$ & n.a. & 29/10/2014 07:24 \\
\hline Benzeno & $71-43-2$ & $\mu \mathrm{g} / \mathrm{L}$ & 100 & $<100$ & n.a. & 29/10/2014 07:24 \\
\hline Bromobenzeno & $108-86-1$ & $\mu \mathrm{g} / \mathrm{L}$ & 100 & $<100$ & n.a. & 29/10/2014 07:24 \\
\hline Bromodiclorometano & $75-27-4$ & $\mu \mathrm{g} / \mathrm{L}$ & 100 & $<100$ & n.a. & $29 / 10 / 201407: 24$ \\
\hline Bromofórmio & $75-25-2$ & $\mu \mathrm{g} / \mathrm{L}$ & 100 & $<100$ & n.a. & $29 / 10 / 201407: 24$ \\
\hline Bromoclorometano & $74-97-5$ & $\mu \mathrm{g} / \mathrm{L}$ & 500 & $<500$ & n.a. & 29/10/2014 07:24 \\
\hline Cis-1,2-Dicloroeteno & $156-59-2$ & $\mu \mathrm{g} / \mathrm{L}$ & 100 & $<100$ & n.a. & 29/10/2014 07:24 \\
\hline Cis-1,3-Dicloropropeno & $10061-01-5$ & $\mu \mathrm{g} / \mathrm{L}$ & 100 & $<100$ & n.a. & $29 / 10 / 201407: 24$ \\
\hline Diclorometano & $75-09-2$ & $\mu \mathrm{g} / \mathrm{L}$ & 100 & $<100$ & n.a. & $29 / 10 / 201407: 24$ \\
\hline Cloreto de Vinila & 75-01-4 & $\mu \mathrm{g} / \mathrm{L}$ & 100 & $<100$ & n.a. & 29/10/2014 07:24 \\
\hline Clorobenzeno & $108-90-7$ & $\mu \mathrm{g} / \mathrm{L}$ & 100 & $<100$ & n.a. & 29/10/2014 07:24 \\
\hline Cloroetano & $75-00-3$ & $\mu \mathrm{g} / \mathrm{L}$ & 100 & $<100$ & n.a. & $29 / 10 / 201407: 24$ \\
\hline Clorofórmio & $67-66-3$ & $\mu \mathrm{g} / \mathrm{L}$ & 100 & $<100$ & n.a. & 29/10/2014 07:24 \\
\hline Clorometano & $74-87-3$ & $\mu \mathrm{g} / \mathrm{L}$ & 1000 & $<1000$ & n.a. & 29/10/2014 07:24 \\
\hline Dibromoclorometano & $124-48-1$ & $\mu \mathrm{g} / \mathrm{L}$ & 100 & $<100$ & n.a. & 29/10/2014 07:24 \\
\hline Dissulfeto de Carbono & $75-15-0$ & $\mu \mathrm{g} / \mathrm{L}$ & 100 & $<100$ & n.a. & 29/10/2014 07:24 \\
\hline Estireno & $100-42-5$ & $\mu \mathrm{g} / \mathrm{L}$ & 100 & $<100$ & n.a. & 29/10/2014 07:24 \\
\hline Etilbenzeno & $100-41-4$ & $\mu \mathrm{g} / \mathrm{L}$ & 100 & $<100$ & n.a. & 29/10/2014 07:24 \\
\hline Hexaclorobutadieno & $87-68-3$ & $\mu \mathrm{g} / \mathrm{L}$ & 100 & $<100$ & n.a. & 29/10/2014 07:24 \\
\hline $\mathrm{m}, \mathrm{p}$-Xilenos & --- & $\mu \mathrm{g} / \mathrm{L}$ & 200 & $<200$ & n.a. & 29/10/2014 07:24 \\
\hline o-Xileno & $95-47-6$ & $\mu \mathrm{g} / \mathrm{L}$ & 100 & $<100$ & n.a. & 29/10/2014 07:24 \\
\hline p-Isopropiltolueno & $99-87-6$ & $\mu \mathrm{g} / \mathrm{L}$ & 100 & $<100$ & n.a. & 29/10/2014 07:24 \\
\hline Tetracloreto de Carbono & $56-23-5$ & $\mu \mathrm{g} / \mathrm{L}$ & 100 & $<100$ & n.a. & 29/10/2014 07:24 \\
\hline Tetracloroeteno & $127-18-4$ & $\mu \mathrm{g} / \mathrm{L}$ & 1000 & 57200 & 11000 & 29/10/2014 07:24 \\
\hline Tolueno & $108-88-3$ & $\mu \mathrm{g} / \mathrm{L}$ & 100 & $<100$ & n.a. & 29/10/2014 07:24 \\
\hline Trans-1,2-Dicloroeteno & $156-60-5$ & $\mu \mathrm{g} / \mathrm{L}$ & 100 & $<100$ & n.a. & 29/10/2014 07:24 \\
\hline Tricloroeteno & $79-01-6$ & $\mu \mathrm{g} / \mathrm{L}$ & 100 & $<100$ & n.a. & 29/10/2014 07:24 \\
\hline 1,1,1,2-Tetracloroetano & $630-20-6$ & $\mu \mathrm{g} / \mathrm{L}$ & 100 & $<100$ & n.a. & 29/10/2014 07:24 \\
\hline
\end{tabular}




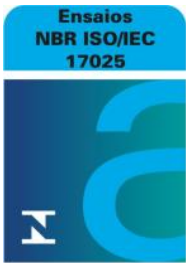

CRL 0172

\begin{tabular}{|c|c|c|c|c|c|c|}
\hline Parâmetros & CAS & Unidade & LQ & Resultados analíticos & Incerteza & Data do Ensaio \\
\hline 1,2,3-Tricloropropano & $96-18-4$ & $\mu \mathrm{g} / \mathrm{L}$ & 500 & $<500$ & n.a. & 29/10/2014 07:24 \\
\hline 1,3,5-Trimetilbenzeno & $108-67-8$ & $\mu \mathrm{g} / \mathrm{L}$ & 100 & $<100$ & n.a. & 29/10/2014 07:24 \\
\hline 1,2,4-Trimetilbenzeno & $95-63-6$ & $\mu \mathrm{g} / \mathrm{L}$ & 100 & $<100$ & n.a. & $29 / 10 / 2014$ 07:24 \\
\hline 1,2-Dibromoetano & $106-93-4$ & $\mu \mathrm{g} / \mathrm{L}$ & 100 & $<100$ & n.a. & 29/10/2014 07:24 \\
\hline 1,2-Diclorobenzeno & $95-50-1$ & $\mu \mathrm{g} / \mathrm{L}$ & 100 & $<100$ & n.a. & $29 / 10 / 2014$ 07:24 \\
\hline 1,3-Diclorobenzeno & $541-73-1$ & $\mu \mathrm{g} / \mathrm{L}$ & 100 & $<100$ & n.a. & 29/10/2014 07:24 \\
\hline 2-Clorotolueno & $95-49-8$ & $\mu \mathrm{g} / \mathrm{L}$ & 100 & $<100$ & n.a. & 29/10/2014 07:24 \\
\hline Dibromometano & $74-95-3$ & $\mu \mathrm{g} / \mathrm{L}$ & 100 & $<100$ & n.a. & $29 / 10 / 2014$ 07:24 \\
\hline Metiletilcetona & $78-93-3$ & $\mu \mathrm{g} / \mathrm{L}$ & 250000 & $<250000$ & n.a. & $30 / 10 / 201410: 32$ \\
\hline Naftaleno & $91-20-3$ & $\mu \mathrm{g} / \mathrm{L}$ & 100 & $<100$ & n.a. & 29/10/2014 07:24 \\
\hline n-Butilbenzeno & $104-51-8$ & $\mu \mathrm{g} / \mathrm{L}$ & 100 & $<100$ & n.a. & 29/10/2014 07:24 \\
\hline n-Propilbenzeno & $103-65-1$ & $\mu \mathrm{g} / \mathrm{L}$ & 100 & $<100$ & n.a. & $29 / 10 / 2014$ 07:24 \\
\hline 4-Clorotolueno & $106-43-4$ & $\mu \mathrm{g} / \mathrm{L}$ & 100 & $<100$ & n.a. & 29/10/2014 07:24 \\
\hline sec-Butilbenzeno & $135-98-8$ & $\mu \mathrm{g} / \mathrm{L}$ & 100 & $<100$ & n.a. & 29/10/2014 07:24 \\
\hline terc-Butilbenzeno & 98-06-6 & $\mu \mathrm{g} / \mathrm{L}$ & 100 & $<100$ & n.a. & 29/10/2014 07:24 \\
\hline trans-1,3-Dicloropropeno & $10061-02-6$ & $\mu \mathrm{g} / \mathrm{L}$ & 100 & $<100$ & n.a. & 29/10/2014 07:24 \\
\hline Isopropilbenzeno & $98-82-8$ & $\mu \mathrm{g} / \mathrm{L}$ & 100 & $<100$ & n.a. & 29/10/2014 07:24 \\
\hline 1,3,5-Triclorobenzeno & $108-70-3$ & $\mu \mathrm{g} / \mathrm{L}$ & 100 & $<100$ & n.a. & $29 / 10 / 2014$ 07:24 \\
\hline
\end{tabular}

\section{CONTROLE DE Q UALIDADE DO LABORATÓRIO}

Controle de Q ualidade - VOC - Água

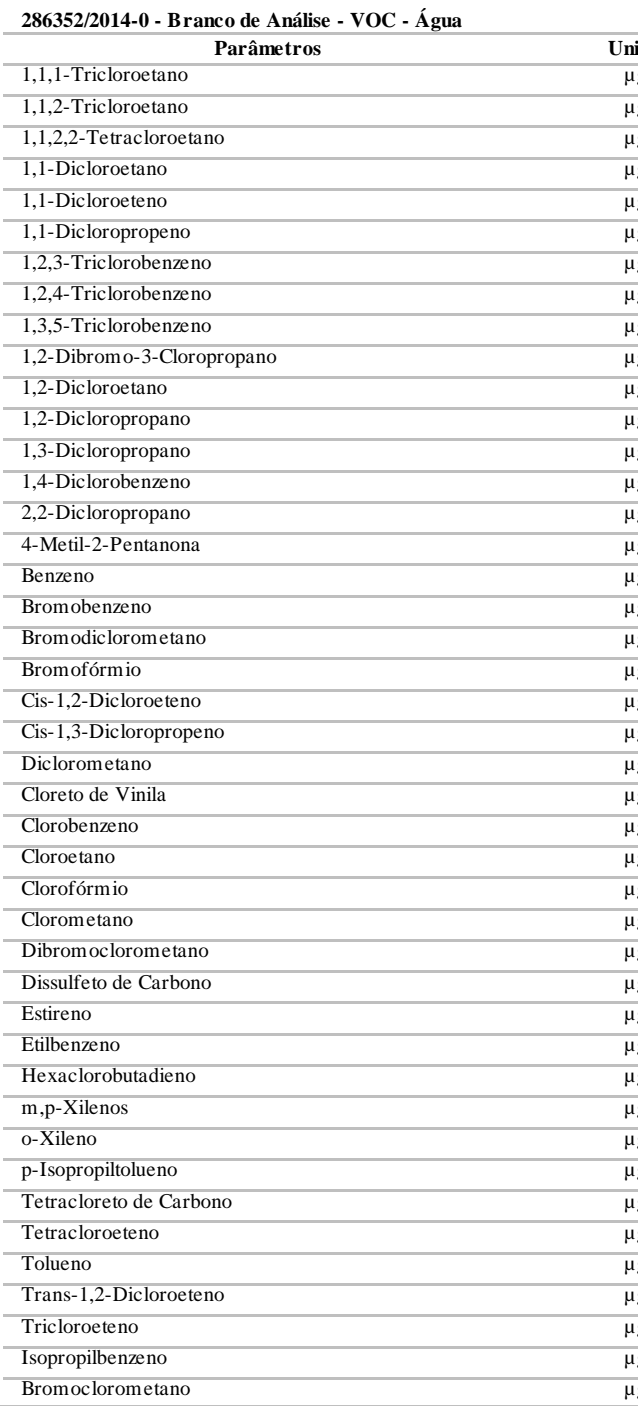

\begin{tabular}{|c|c|c|}
\hline Inidade & LQ & Resultados analíticos \\
\hline$\mu \mathrm{g} / \mathrm{L}$ & 1 & $<1$ \\
\hline$\mu \mathrm{g} / \mathrm{L}$ & 1 & $<1$ \\
\hline$\mu \mathrm{g} / \mathrm{L}$ & 1 & $<1$ \\
\hline$\mu \mathrm{g} / \mathrm{L}$ & 1 & $<1$ \\
\hline$\mu \mathrm{g} / \mathrm{L}$ & 1 & $<1$ \\
\hline$\mu \mathrm{g} / \mathrm{L}$ & 1 & $<1$ \\
\hline$\mu \mathrm{g} / \mathrm{L}$ & 1 & $<1$ \\
\hline$\mu \mathrm{g} / \mathrm{L}$ & 1 & $<1$ \\
\hline$\mu \mathrm{g} / \mathrm{L}$ & 1 & $<1$ \\
\hline$\mu \mathrm{g} / \mathrm{L}$ & 5 & $<5$ \\
\hline$\mu \mathrm{g} / \mathrm{L}$ & 1 & $<1$ \\
\hline$\mu \mathrm{g} / \mathrm{L}$ & 1 & $<1$ \\
\hline$\mu \mathrm{g} / \mathrm{L}$ & 5 & $<5$ \\
\hline$\mu \mathrm{g} / \mathrm{L}$ & 1 & $<1$ \\
\hline$\mu \mathrm{g} / \mathrm{L}$ & 1 & $<1$ \\
\hline$\mu \mathrm{g} / \mathrm{L}$ & 5 & $<5$ \\
\hline$\mu \mathrm{g} / \mathrm{L}$ & 1 & $<1$ \\
\hline$\mu \mathrm{g} / \mathrm{L}$ & 1 & $<1$ \\
\hline$\mu \mathrm{g} / \mathrm{L}$ & 1 & $<1$ \\
\hline$\mu \mathrm{g} / \mathrm{L}$ & 1 & $<1$ \\
\hline$\mu \mathrm{g} / \mathrm{L}$ & 1 & $<1$ \\
\hline$\mu \mathrm{g} / \mathrm{L}$ & 1 & $<1$ \\
\hline$\mu \mathrm{g} / \mathrm{L}$ & 1 & $<1$ \\
\hline$\mu \mathrm{g} / \mathrm{L}$ & 1 & $<1$ \\
\hline$\mu \mathrm{g} / \mathrm{L}$ & 1 & $<1$ \\
\hline$\mu \mathrm{g} / \mathrm{L}$ & 1 & $<1$ \\
\hline$\mu \mathrm{g} / \mathrm{L}$ & 1 & $<1$ \\
\hline$\mu \mathrm{g} / \mathrm{L}$ & 10 & $<10$ \\
\hline$\mu \mathrm{g} / \mathrm{L}$ & 1 & $<1$ \\
\hline$\mu \mathrm{g} / \mathrm{L}$ & 1 & $<1$ \\
\hline$\mu \mathrm{g} / \mathrm{L}$ & 1 & $<1$ \\
\hline$\mu \mathrm{g} / \mathrm{L}$ & 1 & $<1$ \\
\hline$\mu \mathrm{g} / \mathrm{L}$ & 1 & $<1$ \\
\hline$\mu \mathrm{g} / \mathrm{L}$ & 2 & $<2$ \\
\hline$\mu \mathrm{g} / \mathrm{L}$ & 1 & $<1$ \\
\hline$\mu \mathrm{g} / \mathrm{L}$ & 1 & $<1$ \\
\hline$\mu \mathrm{g} / \mathrm{L}$ & 1 & $<1$ \\
\hline$\mu \mathrm{g} / \mathrm{L}$ & 1 & $<1$ \\
\hline$\mu \mathrm{g} / \mathrm{L}$ & 1 & $<1$ \\
\hline$\mu \mathrm{g} / \mathrm{L}$ & 1 & $<1$ \\
\hline$\mu \mathrm{g} / \mathrm{L}$ & 1 & $<1$ \\
\hline$\mu \mathrm{g} / \mathrm{L}$ & 1 & $<1$ \\
\hline$\mu \mathrm{g} / \mathrm{L}$ & 5 & $<5$ \\
\hline
\end{tabular}




\begin{tabular}{|c|c|c|c|c|}
\hline Parâmetros & $\begin{array}{l}\text { Q uantidade } \\
\text { Adicionada }\end{array}$ & Unidade & $\begin{array}{c}\text { Resultado da } \\
\text { Recuperação (\%) }\end{array}$ & Faixa Aceitável de Recuperação (\%) \\
\hline \multicolumn{5}{|c|}{ 286353/2014-0 - Amostra Controle - VOC - Água } \\
\hline 1,1-Dicloroeteno & 20 & $\mu \mathrm{g} / \mathrm{L}$ & 90 & $70-130$ \\
\hline Benzeno & 20 & $\mu \mathrm{g} / \mathrm{L}$ & 95 & $70-130$ \\
\hline Tricloroeteno & 20 & $\mu \mathrm{g} / \mathrm{L}$ & 90 & $70-130$ \\
\hline Tolueno & 20 & $\mu \mathrm{g} / \mathrm{L}$ & 90 & $70-130$ \\
\hline Clorobenzeno & 20 & $\mu \mathrm{g} / \mathrm{L}$ & 95 & $70-130$ \\
\hline \multicolumn{5}{|c|}{$\begin{array}{l}\text { Surrogates } \\
\text { 286352/2014-0 - Branco de Análise - VOC - Água }\end{array}$} \\
\hline p-Bromofluorbenzeno & 20 & $\%$ & 97,0 & $70-130$ \\
\hline Dibrom ofluorometano & 20 & $\%$ & 108 & $70-130$ \\
\hline \multicolumn{5}{|c|}{ 286353/2014-0 - Amostra Controle - VOC - Água } \\
\hline p-Bromofluorbenzeno & 20 & $\%$ & 93,4 & $70-130$ \\
\hline Dibrom ofluorometano & 20 & $\%$ & 98,3 & $70-130$ \\
\hline \multicolumn{5}{|l|}{ 283881/2014-0 - CGBIA-3 } \\
\hline Dibrom ofluorometano & 20 & $\%$ & Amostra Diluída & $70-130$ \\
\hline p-Bromofluorbenzeno & 20 & $\%$ & Amostra Diluída & $70-130$ \\
\hline
\end{tabular}

Notas

LQ = Limite de Quantificação

n.a. = Não Aplicável.

Abrangência

(s) resultado(s) referem-se somente à(s) amostra(s) analisada(s).

Este Relatório de Ensaio só pode ser reproduzido por inteiro e sem nenhuma alteração.

Plano de Amostragem

Plano de amostragem de responsabilidade do interessado

Responsabilidade Técnic

Os ensaios foram realizados na unidade da Bioagri Ambiental Ltda. - Matriz, situada na Rua Aljovil Martini, 177/201, Bairro Dois Córregos, Cep. 14420-833, Piracicaba/SP, registrada no CRQ 4ª Região sob n $16082-\mathrm{Fe}$ responsabilidade técnica do profissional José Carlos Moretti, CRQ n 04107238, $4^{\text {a. }}$.Região.

Referências Metodológicas

Análises foram realizadas conforme a última versão do Standard Methods for the Examination of Water \& Wastewater 22nd 2012(SMWW), EPA e ABNT (quando aplicável).

VOC: EPA 8260 C: 2006, 5021A: 2003

Metiletilcetona: EPA $8260 \mathrm{C}: 2006,5021$ A: 2003

Revisores

Débora Fernandes da Silva

Daniela Rodrigues Bandoria

Chave de Validação: 8de911ad715cc 18a535d1bdf5a442a28

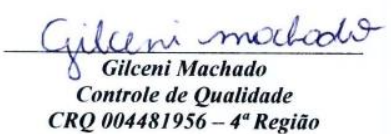

CRQ 004481956 - $4^{a}$ Região

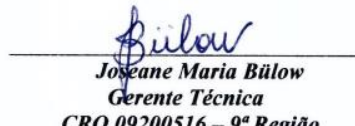

CRQ 09200516-9 $9^{a}$ Região 


\section{RELATÓRIO DE ENSAIO N $^{\circ}$ 283883/2014-0 - Piracicaba Processo Comercial $N^{\circ}$ 23961/2014-2}

\begin{tabular}{|l|l|}
\hline \multicolumn{2}{|c|}{ DADOS REFERENTES AO CLIENTE } \\
\hline Empresa solicitante: & Fundacao Parque de Alta Tecnologia da Regiao de Ipero e Adjacencias \\
\hline Endereço: & Rua Jose Antonio Scaciota, 165 - - Portal do Cedro - Iperó - SP - CEP: 18.560-000 . \\
\hline Nome do Solicitante: & Carla Marçal \\
\hline
\end{tabular}

\begin{tabular}{|l|l|l|l|l|}
\hline \multicolumn{5}{|c|}{ DADOS REFERENTES A AMOSTRA } \\
\hline Identificação do Cliente: & \multicolumn{4}{|l|}{ CGBFA-1 } \\
\hline Amostra Rotulada como: & Água Subterrânea Projeto Mestrado \\
\hline Coletor: & Interessado & Data da coleta: & \multicolumn{2}{|l|}{ 23/10/2014 19:50:00 } \\
\hline Data da entrada no laboratório: & $25 / 10 / 201408: 28$ & Data de Elaboração do RE: & $03 / 11 / 2014$ \\
\hline
\end{tabular}

\section{RESULTADOS PARA A AMOSTRA}

\begin{tabular}{|c|c|c|c|c|c|c|}
\hline Parâmetros & CAS & Unidade & LQ & Resultados analíticos & Incerteza & Data do Ensaio \\
\hline 1,1,1-Tricloroetano & $71-55-6$ & $\mu \mathrm{g} / \mathrm{L}$ & 1 & $<1$ & n.a. & $30 / 10 / 201400: 43$ \\
\hline 1,1,2-Tricloroetano & $79-00-5$ & $\mu \mathrm{g} / \mathrm{L}$ & 1 & $<1$ & n.a. & $30 / 10 / 201400: 43$ \\
\hline 1,1,2,2-Tetracloroetano & $79-34-5$ & $\mu \mathrm{g} / \mathrm{L}$ & 1 & $<1$ & n.a. & $30 / 10 / 201400: 43$ \\
\hline 1,1-Dicloroetano & $75-34-3$ & $\mu \mathrm{g} / \mathrm{L}$ & 1 & $<1$ & n.a. & $30 / 10 / 201400: 43$ \\
\hline 1,1-Dicloroeteno & $75-35-4$ & $\mu \mathrm{g} / \mathrm{L}$ & 1 & $<1$ & n.a. & $30 / 10 / 201400: 43$ \\
\hline 1,1-Dicloropropeno & $563-58-6$ & $\mu \mathrm{g} / \mathrm{L}$ & 1 & $<1$ & n.a. & $30 / 10 / 201400: 43$ \\
\hline 1,2,3-Triclorobenzeno & $87-61-6$ & $\mu \mathrm{g} / \mathrm{L}$ & 1 & $<1$ & n.a. & $30 / 10 / 201400: 43$ \\
\hline 1,2,4-Triclorobenzeno & $120-82-1$ & $\mu \mathrm{g} / \mathrm{L}$ & 1 & $<1$ & n.a. & $30 / 10 / 201400: 43$ \\
\hline 1,2-Dibromo-3-Cloropropano & $96-12-8$ & $\mu \mathrm{g} / \mathrm{L}$ & 5 & $<5$ & n.a. & $30 / 10 / 201400: 43$ \\
\hline 1,2-Dicloroetano & $107-06-2$ & $\mu \mathrm{g} / \mathrm{L}$ & 1 & $<1$ & n.a. & $30 / 10 / 201400: 43$ \\
\hline 1,2-Dicloropropano & $78-87-5$ & $\mu \mathrm{g} / \mathrm{L}$ & 1 & $<1$ & n.a. & $30 / 10 / 201400: 43$ \\
\hline 1,3-Dicloropropano & $142-28-9$ & $\mu \mathrm{g} / \mathrm{L}$ & 5 & $<5$ & n.a. & $30 / 10 / 201400: 43$ \\
\hline 1,4-Diclorobenzeno & $106-46-7$ & $\mu \mathrm{g} / \mathrm{L}$ & 1 & $<1$ & n.a. & 30/10/2014 00:43 \\
\hline 2,2-Dicloropropano & $594-20-7$ & $\mu \mathrm{g} / \mathrm{L}$ & 1 & $<1$ & n.a. & $30 / 10 / 201400: 43$ \\
\hline 4-Metil-2-Pentanona & $108-10-1$ & $\mu \mathrm{g} / \mathrm{L}$ & 5 & $<5$ & n.a. & $30 / 10 / 201400: 43$ \\
\hline Benzeno & $71-43-2$ & $\mu \mathrm{g} / \mathrm{L}$ & 1 & $<1$ & n.a. & $30 / 10 / 201400: 43$ \\
\hline Bromobenzeno & $108-86-1$ & $\mu \mathrm{g} / \mathrm{L}$ & 1 & $<1$ & n.a. & $30 / 10 / 201400: 43$ \\
\hline Bromodiclorometano & $75-27-4$ & $\mu \mathrm{g} / \mathrm{L}$ & 1 & $<1$ & n.a. & $30 / 10 / 201400: 43$ \\
\hline Bromofórmio & $75-25-2$ & $\mu \mathrm{g} / \mathrm{L}$ & 1 & $<1$ & n.a. & $30 / 10 / 2014$ 00:43 \\
\hline Bromoclorometano & $74-97-5$ & $\mu \mathrm{g} / \mathrm{L}$ & 5 & $<5$ & n.a. & $30 / 10 / 201400: 43$ \\
\hline Cis-1,2-Dicloroeteno & $156-59-2$ & $\mu \mathrm{g} / \mathrm{L}$ & 1 & $<1$ & n.a. & $30 / 10 / 201400: 43$ \\
\hline Cis-1,3-Dicloropropeno & 10061-01-5 & $\mu \mathrm{g} / \mathrm{L}$ & 1 & $<1$ & n.a. & $30 / 10 / 201400: 43$ \\
\hline Diclorometano & $75-09-2$ & $\mu \mathrm{g} / \mathrm{L}$ & 1 & $<1$ & n.a. & $30 / 10 / 2014$ 00:43 \\
\hline Cloreto de Vinila & 75-01-4 & $\mu \mathrm{g} / \mathrm{L}$ & 1 & $<1$ & n.a. & $30 / 10 / 201400: 43$ \\
\hline Clorobenzeno & $108-90-7$ & $\mu \mathrm{g} / \mathrm{L}$ & 1 & $<1$ & n.a. & $30 / 10 / 201400: 43$ \\
\hline Cloroetano & $75-00-3$ & $\mu \mathrm{g} / \mathrm{L}$ & 1 & $<1$ & n.a. & $30 / 10 / 201400: 43$ \\
\hline Clorofórmio & $67-66-3$ & $\mu \mathrm{g} / \mathrm{L}$ & 1 & $<1$ & n.a. & $30 / 10 / 201400: 43$ \\
\hline Clorometano & $74-87-3$ & $\mu \mathrm{g} / \mathrm{L}$ & 10 & $<10$ & n.a. & $30 / 10 / 201400: 43$ \\
\hline Dibromoclorometano & $124-48-1$ & $\mu \mathrm{g} / \mathrm{L}$ & 1 & $<1$ & n.a. & 30/10/2014 00:43 \\
\hline Dissulfeto de Carbono & $75-15-0$ & $\mu \mathrm{g} / \mathrm{L}$ & 1 & $<1$ & n.a. & $30 / 10 / 201400: 43$ \\
\hline Estireno & $100-42-5$ & $\mu \mathrm{g} / \mathrm{L}$ & 1 & $<1$ & n.a. & $30 / 10 / 2014$ 00:43 \\
\hline Etilbenzeno & $100-41-4$ & $\mu \mathrm{g} / \mathrm{L}$ & 1 & $<1$ & n.a. & $30 / 10 / 201400: 43$ \\
\hline Hexaclorobutadieno & $87-68-3$ & $\mu \mathrm{g} / \mathrm{L}$ & 1 & $<1$ & n.a. & $30 / 10 / 201400: 43$ \\
\hline m,p-Xilenos & --- & $\mu \mathrm{g} / \mathrm{L}$ & 2 & $<2$ & n.a. & $30 / 10 / 2014$ 00:43 \\
\hline o-Xileno & $95-47-6$ & $\mu \mathrm{g} / \mathrm{L}$ & 1 & $<1$ & n.a. & $30 / 10 / 201400: 43$ \\
\hline p-Isopropiltolueno & $99-87-6$ & $\mu \mathrm{g} / \mathrm{L}$ & 1 & $<1$ & n.a. & $30 / 10 / 201400: 43$ \\
\hline Tetracloreto de Carbono & $56-23-5$ & $\mu \mathrm{g} / \mathrm{L}$ & 1 & $<1$ & n.a. & $30 / 10 / 201400: 43$ \\
\hline Tetracloroeteno & $127-18-4$ & $\mu \mathrm{g} / \mathrm{L}$ & 1 & $<1$ & n.a. & $30 / 10 / 2014$ 00:43 \\
\hline Tolueno & $108-88-3$ & $\mu \mathrm{g} / \mathrm{L}$ & 1 & $<1$ & n.a. & $30 / 10 / 201400: 43$ \\
\hline Trans-1,2-Dicloroeteno & $156-60-5$ & $\mu \mathrm{g} / \mathrm{L}$ & 1 & $<1$ & n.a. & $30 / 10 / 201400: 43$ \\
\hline Tricloroeteno & $79-01-6$ & $\mu \mathrm{g} / \mathrm{L}$ & 1 & $<1$ & n.a. & $30 / 10 / 201400: 43$ \\
\hline 1,1,1,2-Tetracloroetano & $630-20-6$ & $\mu \mathrm{g} / \mathrm{L}$ & 1 & $<1$ & n.a. & $30 / 10 / 201400: 43$ \\
\hline
\end{tabular}




\begin{tabular}{|c|c|c|c|c|c|c|}
\hline Parâmetros & CAS & Unidade & LQ & Resultados analíticos & Incerteza & Data do Ensaio \\
\hline 1,2,3-Tricloropropano & $96-18-4$ & $\mu \mathrm{g} / \mathrm{L}$ & 5 & $<5$ & n.a. & $30 / 10 / 201400: 43$ \\
\hline 1,3,5-Trimetilbenzeno & $108-67-8$ & $\mu \mathrm{g} / \mathrm{L}$ & 1 & $<1$ & n.a. & $30 / 10 / 201400: 43$ \\
\hline 1,2,4-Trimetilbenzeno & $95-63-6$ & $\mu \mathrm{g} / \mathrm{L}$ & 1 & $<1$ & n.a. & $30 / 10 / 201400: 43$ \\
\hline 1,2-Dibromoetano & $106-93-4$ & $\mu \mathrm{g} / \mathrm{L}$ & 1 & $<1$ & n.a. & $30 / 10 / 201400: 43$ \\
\hline 1,2-Diclorobenzeno & $95-50-1$ & $\mu \mathrm{g} / \mathrm{L}$ & 1 & $<1$ & n.a. & $30 / 10 / 201400: 43$ \\
\hline 1,3-Diclorobenzeno & $541-73-1$ & $\mu \mathrm{g} / \mathrm{L}$ & 1 & $<1$ & n.a. & $30 / 10 / 201400: 43$ \\
\hline 2-Clorotolueno & $95-49-8$ & $\mu \mathrm{g} / \mathrm{L}$ & 1 & $<1$ & n.a. & $30 / 10 / 201400: 43$ \\
\hline Dibromometano & $74-95-3$ & $\mu \mathrm{g} / \mathrm{L}$ & 1 & $<1$ & n.a. & $30 / 10 / 201400: 43$ \\
\hline Metiletilcetona & $78-93-3$ & $\mu \mathrm{g} / \mathrm{L}$ & 25000 & $<25000$ & n.a. & $30 / 10 / 201400: 08$ \\
\hline Naftaleno & $91-20-3$ & $\mu g / L$ & 1 & $<1$ & n.a. & $30 / 10 / 201400: 43$ \\
\hline n-Butilbenzeno & $104-51-8$ & $\mu \mathrm{g} / \mathrm{L}$ & 1 & $<1$ & n.a. & $30 / 10 / 201400: 43$ \\
\hline n-Propilbenzeno & $103-65-1$ & $\mu \mathrm{g} / \mathrm{L}$ & 1 & $<1$ & n.a. & $30 / 10 / 201400: 43$ \\
\hline 4-Clorotolueno & $106-43-4$ & $\mu \mathrm{g} / \mathrm{L}$ & 1 & $<1$ & n.a. & $30 / 10 / 201400: 43$ \\
\hline sec-Butilbenzeno & $135-98-8$ & $\mu \mathrm{g} / \mathrm{L}$ & 1 & $<1$ & n.a. & $30 / 10 / 201400: 43$ \\
\hline terc-Butilbenzeno & $98-06-6$ & $\mu \mathrm{g} / \mathrm{L}$ & 1 & $<1$ & n.a. & $30 / 10 / 201400: 43$ \\
\hline trans-1,3-Dicloropropeno & 10061-02-6 & $\mu \mathrm{g} / \mathrm{L}$ & 1 & $<1$ & n.a. & $30 / 10 / 201400: 43$ \\
\hline Isopropilbenzeno & $98-82-8$ & $\mu \mathrm{g} / \mathrm{L}$ & 1 & $<1$ & n.a. & $30 / 10 / 201400: 43$ \\
\hline 1,3,5-Triclorobenzeno & $108-70-3$ & $\mu \mathrm{g} / \mathrm{L}$ & 1 & $<1$ & n.a. & $30 / 10 / 2014$ 00:43 \\
\hline
\end{tabular}

\section{CONTROLE DE Q UALIDADE DO LAB ORATÓRIO}

Controle de Q ualidade - VOC - Água

286352/2014-0 - Branco de Análise - VOC - Água

1,1,1-Tricloroetano Parâmetros

1,1,2-Tricloroetano

1,1,2,2-Tetracloroetano

1,1-Dicloroetano

1,1-Dicloroeteno

1,1-Dicloropropeno

1,2,3-Triclorobenzeno

1,2,4-Triclorobenzeno

1,3,5-Triclorobenzeno

1,2-Dibromo-3-Cloropropano

1,2-Dicloroetano

1,2-Dicloropropano

1,3-Dicloropropano

1,4-Diclorobenzeno

2,2-Dicloropropano

4-Metil-2-Pentanona

Benzeno

Bromobenzeno

Bromodiclorometano

Bromofórmio

Cis-1,2-Dicloroeteno

Cis-1,3-Dicloropropeno

Diclorometano

Cloreto de Vinila

Clorobenzeno

Cloroetano

Clorofórmio

Clorometano

Dibromoclorometano

Dissulfeto de Carbono

Estireno

Etilbenzeno

Hexaclorobutadieno

m,p-Xilenos

o-Xileno

p-Isopropiltolueno

Tetracloreto de Carbono

Tetracloroeteno

Tolueno

Trans-1,2-Dicloroeteno

Tricloroeteno

Isopropilbenzeno

Bromoclorometano

\begin{tabular}{|c|c|c|}
\hline Unidade & LQ & Resultados analíticos \\
\hline$\mu \mathrm{g} / \mathrm{L}$ & 1 & $<1$ \\
\hline$\mu \mathrm{g} / \mathrm{L}$ & 1 & $<1$ \\
\hline$\mu \mathrm{g} / \mathrm{L}$ & 1 & $<1$ \\
\hline$\mu \mathrm{g} / \mathrm{L}$ & 1 & $<1$ \\
\hline$\mu \mathrm{g} / \mathrm{L}$ & 1 & $<1$ \\
\hline$\mu \mathrm{g} / \mathrm{L}$ & 1 & $<1$ \\
\hline$\mu \mathrm{g} / \mathrm{L}$ & 1 & $<1$ \\
\hline$\mu \mathrm{g} / \mathrm{L}$ & 1 & $<1$ \\
\hline$\mu \mathrm{g} / \mathrm{L}$ & 1 & $<1$ \\
\hline$\mu \mathrm{g} / \mathrm{L}$ & 5 & $<5$ \\
\hline$\mu \mathrm{g} / \mathrm{L}$ & 1 & $<1$ \\
\hline$\mu \mathrm{g} / \mathrm{L}$ & 1 & $<1$ \\
\hline$\mu \mathrm{g} / \mathrm{L}$ & 5 & $<5$ \\
\hline$\mu \mathrm{g} / \mathrm{L}$ & 1 & $<1$ \\
\hline$\mu \mathrm{g} / \mathrm{L}$ & 1 & $<1$ \\
\hline$\mu \mathrm{g} / \mathrm{L}$ & 5 & $<5$ \\
\hline$\mu \mathrm{g} / \mathrm{L}$ & 1 & $<1$ \\
\hline$\mu \mathrm{g} / \mathrm{L}$ & 1 & $<1$ \\
\hline$\mu \mathrm{g} / \mathrm{L}$ & 1 & $<1$ \\
\hline$\mu \mathrm{g} / \mathrm{L}$ & 1 & $<1$ \\
\hline$\mu \mathrm{g} / \mathrm{L}$ & 1 & $<1$ \\
\hline$\mu \mathrm{g} / \mathrm{L}$ & 1 & $<1$ \\
\hline$\mu \mathrm{g} / \mathrm{L}$ & 1 & $<1$ \\
\hline$\mu \mathrm{g} / \mathrm{L}$ & 1 & $<1$ \\
\hline$\mu \mathrm{g} / \mathrm{L}$ & 1 & $<1$ \\
\hline$\mu \mathrm{g} / \mathrm{L}$ & 1 & $<1$ \\
\hline$\mu \mathrm{g} / \mathrm{L}$ & 1 & $<1$ \\
\hline$\mu \mathrm{g} / \mathrm{L}$ & 10 & $<10$ \\
\hline$\mu \mathrm{g} / \mathrm{L}$ & 1 & $<1$ \\
\hline$\mu \mathrm{g} / \mathrm{L}$ & 1 & $<1$ \\
\hline$\mu \mathrm{g} / \mathrm{L}$ & 1 & $<1$ \\
\hline$\mu \mathrm{g} / \mathrm{L}$ & 1 & $<1$ \\
\hline$\mu \mathrm{g} / \mathrm{L}$ & 1 & $<1$ \\
\hline$\mu \mathrm{g} / \mathrm{L}$ & 2 & $<2$ \\
\hline$\mu \mathrm{g} / \mathrm{L}$ & 1 & $<1$ \\
\hline$\mu \mathrm{g} / \mathrm{L}$ & 1 & $<1$ \\
\hline$\mu \mathrm{g} / \mathrm{L}$ & 1 & $<1$ \\
\hline$\mu \mathrm{g} / \mathrm{L}$ & 1 & $<1$ \\
\hline$\mu \mathrm{g} / \mathrm{L}$ & 1 & $<1$ \\
\hline$\mu \mathrm{g} / \mathrm{L}$ & 1 & $<1$ \\
\hline$\mu \mathrm{g} / \mathrm{L}$ & 1 & $<1$ \\
\hline$\mu \mathrm{g} / \mathrm{L}$ & 1 & $<1$ \\
\hline$\mu \mathrm{g} / \mathrm{L}$ & 5 & $<5$ \\
\hline
\end{tabular}




\begin{tabular}{|c|c|c|c|c|}
\hline Parâmetros & $\begin{array}{l}\text { Q uantidade } \\
\text { Adicionada }\end{array}$ & Unidade & $\begin{array}{c}\text { Resultado da } \\
\text { Recuperação (\%) }\end{array}$ & Faixa Aceitável de Recuperação (\%) \\
\hline \multicolumn{5}{|c|}{ 286353/2014-0 - Amostra Controle - VOC - Água } \\
\hline 1,1-Dicloroeteno & 20 & $\mu \mathrm{g} / \mathrm{L}$ & 90 & $70-130$ \\
\hline Benzeno & 20 & $\mu \mathrm{g} / \mathrm{L}$ & 95 & $70-130$ \\
\hline Tricloroeteno & 20 & $\mu \mathrm{g} / \mathrm{L}$ & 90 & $70-130$ \\
\hline Tolueno & 20 & $\mu \mathrm{g} / \mathrm{L}$ & 90 & $70-130$ \\
\hline Clorobenzeno & 20 & $\mu \mathrm{g} / \mathrm{L}$ & 95 & $70-130$ \\
\hline \multicolumn{5}{|c|}{$\begin{array}{l}\text { Surrogates } \\
\text { 286352/2014-0 - B ranco de Análise - VOC - Água }\end{array}$} \\
\hline p-Bromofluorbenzeno & 20 & $\%$ & 97,0 & $70-130$ \\
\hline Dibrom ofluorometano & 20 & $\%$ & 108 & $70-130$ \\
\hline \multicolumn{5}{|c|}{ 286353/2014-0 - Amostra Controle - VOC - Água } \\
\hline p-Bromofluorbenzeno & 20 & $\%$ & 93,4 & $70-130$ \\
\hline Dibromofluorometano & 20 & $\%$ & 98,3 & $70-130$ \\
\hline \multicolumn{5}{|l|}{ 283883/2014-0 - CGBFA-1 } \\
\hline Dibromofluorometano & 20 & $\%$ & 98,8 & $70-130$ \\
\hline p-Bromofluorbenzeno & 20 & $\%$ & 93,3 & $70-130$ \\
\hline
\end{tabular}

Notas

LQ = Limite de Quantificação.

n.a. $=$ Não Aplicável

Abrangência

(s) resultado(s) referem-se somente à(s) amostra(s) analisada(s).

Este Relatório de Ensaio só pode ser reproduzido por inteiro e sem nenhuma alteração.

Plano de Amostragem

Plano de amostragem de responsabilidade do interessado.

Responsabilidade Técnica

Os ensaios foram realizados na unidade da Bioagri Ambiental Ltda. - Matriz, situada na Rua Aljovil Martini, 177/201, Bairro Dois Córregos, Cep. 14420-833, Piracicaba/SP, registrada no CRQ 4ª Região sob n $16082-\mathrm{Fe}$ responsabilidade técnica do profissional José Carlos Moretti, CRQ n 04107238, $4^{\text {a. }}$.Região.

Referências Metodológicas

Análises foram realizadas conforme a última versão do Standard Methods for the Examination of Water \& Wastewater 22nd 2012(SMWW), EPA e ABNT (quando aplicável). VOC: EPA 8260 C: 2006, 5021A: 2003

Metiletilcetona: EPA 8260 C: 2006,5021 A: 2003

Revisores

Débora Fernandes da Silva

Daniela Rodrigues Bandoria

Chave de Validação: 261f577217357d373eb8a6b5ee45c2ce

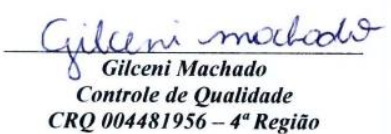

CRQ 004481956-4 Região

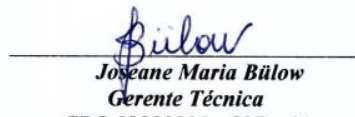

CRQ 09200516-9a Região 


\section{RELATÓRIO DE ENSAIO N $^{\circ}$ 283884/2014-0 - Piracicaba Processo Comercial $N^{\circ}$ 23961/2014-2}

\begin{tabular}{|l|l|}
\hline \multicolumn{2}{|c|}{ DADOS REFERENTES AO CLIENTE } \\
\hline Empresa solicitante: & Fundacao Parque de Alta Tecnologia da Regiao de Ipero e Adjacencias \\
\hline Endereço: & Rua Jose Antonio Scaciota, 165 - - Portal do Cedro - Iperó - SP - CEP: 18.560-000 . \\
\hline Nome do Solicitante: & Carla Marçal \\
\hline
\end{tabular}

\begin{tabular}{|l|l|l|l|l|}
\hline \multicolumn{5}{|c|}{ DADOS REFERENTES A AMOSTRA } \\
\hline Identificação do Cliente: & \multicolumn{4}{|l|}{ CGBFA-2 } \\
\hline Amostra Rotulada como: & Água Subterrânea Projeto Mestrado \\
\hline Coletor: & Interessado & Data da coleta: & \multicolumn{2}{|l|}{ 23/10/2014 19:50:00 } \\
\hline Data da entrada no laboratório: & $25 / 10 / 201408: 28$ & Data de Elaboração do RE: & $03 / 11 / 2014$ \\
\hline
\end{tabular}

\section{RESULTADOS PARA A AMOSTRA}

\begin{tabular}{|c|c|c|c|c|c|c|}
\hline Parâmetros & CAS & Unidade & LQ & Resultados analíticos & Incerteza & Data do Ensaio \\
\hline 1,1,1-Tricloroetano & $71-55-6$ & $\mu \mathrm{g} / \mathrm{L}$ & 1 & $<1$ & n.a. & 30/10/2014 01:07 \\
\hline 1,1,2-Tricloroetano & $79-00-5$ & $\mu \mathrm{g} / \mathrm{L}$ & 1 & $<1$ & n.a. & 30/10/2014 01:07 \\
\hline 1,1,2,2-Tetracloroetano & $79-34-5$ & $\mu \mathrm{g} / \mathrm{L}$ & 1 & $<1$ & n.a. & $30 / 10 / 201401: 07$ \\
\hline 1,1-Dicloroetano & $75-34-3$ & $\mu \mathrm{g} / \mathrm{L}$ & 1 & $<1$ & n.a. & 30/10/2014 01:07 \\
\hline 1,1-Dicloroeteno & $75-35-4$ & $\mu \mathrm{g} / \mathrm{L}$ & 1 & $<1$ & n.a. & 30/10/2014 01:07 \\
\hline 1,1-Dicloropropeno & $563-58-6$ & $\mu \mathrm{g} / \mathrm{L}$ & 1 & $<1$ & n.a. & 30/10/2014 01:07 \\
\hline 1,2,3-Triclorobenzeno & $87-61-6$ & $\mu \mathrm{g} / \mathrm{L}$ & 1 & $<1$ & n.a. & 30/10/2014 01:07 \\
\hline 1,2,4-Triclorobenzeno & $120-82-1$ & $\mu \mathrm{g} / \mathrm{L}$ & 1 & $<1$ & n.a. & 30/10/2014 01:07 \\
\hline 1,2-Dibromo-3-Cloropropano & $96-12-8$ & $\mu \mathrm{g} / \mathrm{L}$ & 5 & $<5$ & n.a. & 30/10/2014 01:07 \\
\hline 1,2-Dicloroetano & $107-06-2$ & $\mu \mathrm{g} / \mathrm{L}$ & 1 & $<1$ & n.a. & 30/10/2014 01:07 \\
\hline 1,2-Dicloropropano & $78-87-5$ & $\mu \mathrm{g} / \mathrm{L}$ & 1 & $<1$ & n.a. & $30 / 10 / 201401: 07$ \\
\hline 1,3-Dicloropropano & $142-28-9$ & $\mu \mathrm{g} / \mathrm{L}$ & 5 & $<5$ & n.a. & 30/10/2014 01:07 \\
\hline 1,4-Diclorobenzeno & $106-46-7$ & $\mu \mathrm{g} / \mathrm{L}$ & 1 & $<1$ & n.a. & 30/10/2014 01:07 \\
\hline 2,2-Dicloropropano & $594-20-7$ & $\mu \mathrm{g} / \mathrm{L}$ & 1 & $<1$ & n.a. & 30/10/2014 01:07 \\
\hline 4-Metil-2-Pentanona & $108-10-1$ & $\mu \mathrm{g} / \mathrm{L}$ & 5 & $<5$ & n.a. & 30/10/2014 01:07 \\
\hline Benzeno & $71-43-2$ & $\mu \mathrm{g} / \mathrm{L}$ & 1 & $<1$ & n.a. & $30 / 10 / 2014$ 01:07 \\
\hline Bromobenzeno & $108-86-1$ & $\mu \mathrm{g} / \mathrm{L}$ & 1 & $<1$ & n.a. & 30/10/2014 01:07 \\
\hline Bromodiclorometano & $75-27-4$ & $\mu \mathrm{g} / \mathrm{L}$ & 1 & $<1$ & n.a. & 30/10/2014 01:07 \\
\hline Bromofórmio & $75-25-2$ & $\mu \mathrm{g} / \mathrm{L}$ & 1 & $<1$ & n.a. & 30/10/2014 01:07 \\
\hline Bromoclorometano & $74-97-5$ & $\mu \mathrm{g} / \mathrm{L}$ & 5 & $<5$ & n.a. & 30/10/2014 01:07 \\
\hline Cis-1,2-Dicloroeteno & $156-59-2$ & $\mu \mathrm{g} / \mathrm{L}$ & 1 & $<1$ & n.a. & 30/10/2014 01:07 \\
\hline Cis-1,3-Dicloropropeno & 10061-01-5 & $\mu \mathrm{g} / \mathrm{L}$ & 1 & $<1$ & n.a. & 30/10/2014 01:07 \\
\hline Diclorometano & $75-09-2$ & $\mu \mathrm{g} / \mathrm{L}$ & 1 & $<1$ & n.a. & 30/10/2014 01:07 \\
\hline Cloreto de Vinila & 75-01-4 & $\mu \mathrm{g} / \mathrm{L}$ & 1 & $<1$ & n.a. & 30/10/2014 01:07 \\
\hline Clorobenzeno & $108-90-7$ & $\mu \mathrm{g} / \mathrm{L}$ & 1 & $<1$ & n.a. & 30/10/2014 01:07 \\
\hline Cloroetano & $75-00-3$ & $\mu \mathrm{g} / \mathrm{L}$ & 1 & $<1$ & n.a. & 30/10/2014 01:07 \\
\hline Clorofórmio & $67-66-3$ & $\mu \mathrm{g} / \mathrm{L}$ & 1 & $<1$ & n.a. & 30/10/2014 01:07 \\
\hline Clorometano & $74-87-3$ & $\mu \mathrm{g} / \mathrm{L}$ & 10 & $<10$ & n.a. & 30/10/2014 01:07 \\
\hline Dibromoclorometano & $124-48-1$ & $\mu \mathrm{g} / \mathrm{L}$ & 1 & $<1$ & n.a. & 30/10/2014 01:07 \\
\hline Dissulfeto de Carbono & $75-15-0$ & $\mu \mathrm{g} / \mathrm{L}$ & 1 & $<1$ & n.a. & 30/10/2014 01:07 \\
\hline Estireno & $100-42-5$ & $\mu \mathrm{g} / \mathrm{L}$ & 1 & $<1$ & n.a. & 30/10/2014 01:07 \\
\hline Etilbenzeno & $100-41-4$ & $\mu \mathrm{g} / \mathrm{L}$ & 1 & $<1$ & n.a. & 30/10/2014 01:07 \\
\hline Hexaclorobutadieno & $87-68-3$ & $\mu \mathrm{g} / \mathrm{L}$ & 1 & $<1$ & n.a. & 30/10/2014 01:07 \\
\hline m,p-Xilenos & --- & $\mu \mathrm{g} / \mathrm{L}$ & 2 & $<2$ & n.a. & 30/10/2014 01:07 \\
\hline o-Xileno & $95-47-6$ & $\mu \mathrm{g} / \mathrm{L}$ & 1 & $<1$ & n.a. & 30/10/2014 01:07 \\
\hline p-Isopropiltolueno & $99-87-6$ & $\mu \mathrm{g} / \mathrm{L}$ & 1 & $<1$ & n.a. & 30/10/2014 01:07 \\
\hline Tetracloreto de Carbono & $56-23-5$ & $\mu \mathrm{g} / \mathrm{L}$ & 1 & $<1$ & n.a. & 30/10/2014 01:07 \\
\hline Tetracloroeteno & $127-18-4$ & $\mu \mathrm{g} / \mathrm{L}$ & 1 & $<1$ & n.a. & 30/10/2014 01:07 \\
\hline Tolueno & $108-88-3$ & $\mu \mathrm{g} / \mathrm{L}$ & 1 & $<1$ & n.a. & 30/10/2014 01:07 \\
\hline Trans-1,2-Dicloroeteno & $156-60-5$ & $\mu \mathrm{g} / \mathrm{L}$ & 1 & $<1$ & n.a. & 30/10/2014 01:07 \\
\hline Tricloroeteno & $79-01-6$ & $\mu \mathrm{g} / \mathrm{L}$ & 1 & $<1$ & n.a. & 30/10/2014 01:07 \\
\hline 1,1,1,2-Tetracloroetano & $630-20-6$ & $\mu \mathrm{g} / \mathrm{L}$ & 1 & $<1$ & n.a. & 30/10/2014 01:07 \\
\hline
\end{tabular}




\begin{tabular}{|c|c|c|c|c|c|c|}
\hline Parâmetros & CAS & Unidade & LQ & Resultados analíticos & Incerteza & Data do Ensaio \\
\hline 1,2,3-Tricloropropano & $96-18-4$ & $\mu \mathrm{g} / \mathrm{L}$ & 5 & $<5$ & n.a. & 30/10/2014 01:07 \\
\hline 1,3,5-Trimetilbenzeno & $108-67-8$ & $\mu \mathrm{g} / \mathrm{L}$ & 1 & $<1$ & n.a. & 30/10/2014 01:07 \\
\hline 1,2,4-Trimetilbenzeno & $95-63-6$ & $\mu \mathrm{g} / \mathrm{L}$ & 1 & $<1$ & n.a. & 30/10/2014 01:07 \\
\hline 1,2-Dibromoetano & $106-93-4$ & $\mu \mathrm{g} / \mathrm{L}$ & 1 & $<1$ & n.a. & $30 / 10 / 201401: 07$ \\
\hline 1,2-Diclorobenzeno & $95-50-1$ & $\mu \mathrm{g} / \mathrm{L}$ & 1 & $<1$ & n.a. & $30 / 10 / 201401: 07$ \\
\hline 1,3-Diclorobenzeno & $541-73-1$ & $\mu \mathrm{g} / \mathrm{L}$ & 1 & $<1$ & n.a. & $30 / 10 / 201401: 07$ \\
\hline 2-Clorotolueno & $95-49-8$ & $\mu \mathrm{g} / \mathrm{L}$ & 1 & $<1$ & n.a. & 30/10/2014 01:07 \\
\hline Dibromometano & $74-95-3$ & $\mu \mathrm{g} / \mathrm{L}$ & 1 & $<1$ & n.a. & 30/10/2014 01:07 \\
\hline Metiletilcetona & $78-93-3$ & $\mu \mathrm{g} / \mathrm{L}$ & 25000 & $<25000$ & n.a. & $30 / 10 / 201400: 56$ \\
\hline Naftaleno & $91-20-3$ & $\mu g / L$ & 1 & $<1$ & n.a. & 30/10/2014 01:07 \\
\hline n-Butilbenzeno & $104-51-8$ & $\mu \mathrm{g} / \mathrm{L}$ & 1 & $<1$ & n.a. & 30/10/2014 01:07 \\
\hline n-Propilbenzeno & $103-65-1$ & $\mu \mathrm{g} / \mathrm{L}$ & 1 & $<1$ & n.a. & 30/10/2014 01:07 \\
\hline 4-Clorotolueno & $106-43-4$ & $\mu \mathrm{g} / \mathrm{L}$ & 1 & $<1$ & n.a. & $30 / 10 / 201401: 07$ \\
\hline sec-Butilbenzeno & $135-98-8$ & $\mu \mathrm{g} / \mathrm{L}$ & 1 & $<1$ & n.a. & 30/10/2014 01:07 \\
\hline terc-Butilbenzeno & $98-06-6$ & $\mu \mathrm{g} / \mathrm{L}$ & 1 & $<1$ & n.a. & $30 / 10 / 201401: 07$ \\
\hline trans-1,3-Dicloropropeno & $10061-02-6$ & $\mu \mathrm{g} / \mathrm{L}$ & 1 & $<1$ & n.a. & $30 / 10 / 2014$ 01:07 \\
\hline Isopropilbenzeno & $98-82-8$ & $\mu \mathrm{g} / \mathrm{L}$ & 1 & $<1$ & n.a. & $30 / 10 / 2014$ 01:07 \\
\hline 1,3,5-Triclorobenzeno & $108-70-3$ & $\mu \mathrm{g} / \mathrm{L}$ & 1 & $<1$ & n.a. & 30/10/2014 01:07 \\
\hline
\end{tabular}

\section{CONTROLE DE Q UALIDADE DO LAB ORATÓRIO}

Controle de Q ualidade - VOC - Água

286352/2014-0 - Branco de Análise - VOC - Água

1,1,1-Tricloroetano Parâmetros

1,1,2-Tricloroetano

1,1,2,2-Tetracloroetano

1,1-Dicloroetano

1,1-Dicloroeteno

1,1-Dicloropropeno

1,2,3-Triclorobenzeno

1,2,4-Triclorobenzeno

1,3,5-Triclorobenzeno

1,2-Dibromo-3-Cloropropano

1,2-Dicloroetano

1,2-Dicloropropano

1,3-Dicloropropano

1,4-Diclorobenzeno

2,2-Dicloropropano

4-Metil-2-Pentanona

Benzeno

Bromobenzeno

Bromodiclorometano

Bromofórmio

Cis-1,2-Dicloroeteno

Cis-1,3-Dicloropropeno

Diclorometano

Cloreto de Vinila

Clorobenzeno

Cloroetano

Clorofórmio

Clorometano

Dibromoclorometano

Dissulfeto de Carbono

Estireno

Etilbenzeno

Hexaclorobutadieno

m,p-Xilenos

o-Xileno

p-Isopropiltolueno

Tetracloreto de Carbono

Tetracloroeteno

Tolueno

Trans-1,2-Dicloroeteno

Tricloroeteno

Isopropilbenzeno

Bromoclorometano

\begin{tabular}{|c|c|c|}
\hline Unidade & LQ & Resultados analíticos \\
\hline$\mu \mathrm{g} / \mathrm{L}$ & 1 & $<1$ \\
\hline$\mu \mathrm{g} / \mathrm{L}$ & 1 & $<1$ \\
\hline$\mu \mathrm{g} / \mathrm{L}$ & 1 & $<1$ \\
\hline$\mu \mathrm{g} / \mathrm{L}$ & 1 & $<1$ \\
\hline$\mu \mathrm{g} / \mathrm{L}$ & 1 & $<1$ \\
\hline$\mu \mathrm{g} / \mathrm{L}$ & 1 & $<1$ \\
\hline$\mu \mathrm{g} / \mathrm{L}$ & 1 & $<1$ \\
\hline$\mu \mathrm{g} / \mathrm{L}$ & 1 & $<1$ \\
\hline$\mu \mathrm{g} / \mathrm{L}$ & 1 & $<1$ \\
\hline$\mu \mathrm{g} / \mathrm{L}$ & 5 & $<5$ \\
\hline$\mu \mathrm{g} / \mathrm{L}$ & 1 & $<1$ \\
\hline$\mu \mathrm{g} / \mathrm{L}$ & 1 & $<1$ \\
\hline$\mu \mathrm{g} / \mathrm{L}$ & 5 & $<5$ \\
\hline$\mu \mathrm{g} / \mathrm{L}$ & 1 & $<1$ \\
\hline$\mu \mathrm{g} / \mathrm{L}$ & 1 & $<1$ \\
\hline$\mu \mathrm{g} / \mathrm{L}$ & 5 & $<5$ \\
\hline$\mu \mathrm{g} / \mathrm{L}$ & 1 & $<1$ \\
\hline$\mu \mathrm{g} / \mathrm{L}$ & 1 & $<1$ \\
\hline$\mu \mathrm{g} / \mathrm{L}$ & 1 & $<1$ \\
\hline$\mu \mathrm{g} / \mathrm{L}$ & 1 & $<1$ \\
\hline$\mu \mathrm{g} / \mathrm{L}$ & 1 & $<1$ \\
\hline$\mu \mathrm{g} / \mathrm{L}$ & 1 & $<1$ \\
\hline$\mu \mathrm{g} / \mathrm{L}$ & 1 & $<1$ \\
\hline$\mu \mathrm{g} / \mathrm{L}$ & 1 & $<1$ \\
\hline$\mu \mathrm{g} / \mathrm{L}$ & 1 & $<1$ \\
\hline$\mu \mathrm{g} / \mathrm{L}$ & 1 & $<1$ \\
\hline$\mu \mathrm{g} / \mathrm{L}$ & 1 & $<1$ \\
\hline$\mu \mathrm{g} / \mathrm{L}$ & 10 & $<10$ \\
\hline$\mu \mathrm{g} / \mathrm{L}$ & 1 & $<1$ \\
\hline$\mu \mathrm{g} / \mathrm{L}$ & 1 & $<1$ \\
\hline$\mu \mathrm{g} / \mathrm{L}$ & 1 & $<1$ \\
\hline$\mu \mathrm{g} / \mathrm{L}$ & 1 & $<1$ \\
\hline$\mu \mathrm{g} / \mathrm{L}$ & 1 & $<1$ \\
\hline$\mu \mathrm{g} / \mathrm{L}$ & 2 & $<2$ \\
\hline$\mu \mathrm{g} / \mathrm{L}$ & 1 & $<1$ \\
\hline$\mu \mathrm{g} / \mathrm{L}$ & 1 & $<1$ \\
\hline$\mu \mathrm{g} / \mathrm{L}$ & 1 & $<1$ \\
\hline$\mu \mathrm{g} / \mathrm{L}$ & 1 & $<1$ \\
\hline$\mu \mathrm{g} / \mathrm{L}$ & 1 & $<1$ \\
\hline$\mu \mathrm{g} / \mathrm{L}$ & 1 & $<1$ \\
\hline$\mu \mathrm{g} / \mathrm{L}$ & 1 & $<1$ \\
\hline$\mu \mathrm{g} / \mathrm{L}$ & 1 & $<1$ \\
\hline$\mu \mathrm{g} / \mathrm{L}$ & 5 & $<5$ \\
\hline
\end{tabular}




\begin{tabular}{|c|c|c|c|c|}
\hline Parâmetros & $\begin{array}{l}\text { Q uantidade } \\
\text { Adicionada }\end{array}$ & Unidade & $\begin{array}{c}\text { Resultado da } \\
\text { Recuperação (\%) }\end{array}$ & Faixa Aceitável de Recuperação (\%) \\
\hline \multicolumn{5}{|c|}{ 286353/2014-0 - Amostra Controle - VOC - Água } \\
\hline 1,1-Dicloroeteno & 20 & $\mu \mathrm{g} / \mathrm{L}$ & 90 & $70-130$ \\
\hline Benzeno & 20 & $\mu \mathrm{g} / \mathrm{L}$ & 95 & $70-130$ \\
\hline Tricloroeteno & 20 & $\mu \mathrm{g} / \mathrm{L}$ & 90 & $70-130$ \\
\hline Tolueno & 20 & $\mu \mathrm{g} / \mathrm{L}$ & 90 & $70-130$ \\
\hline Clorobenzeno & 20 & $\mu \mathrm{g} / \mathrm{L}$ & 95 & $70-130$ \\
\hline \multicolumn{5}{|c|}{$\begin{array}{l}\text { Surrogates } \\
\text { 286352/2014-0 - Branco de Análise - VOC - Água }\end{array}$} \\
\hline p-Bromofluorbenzeno & 20 & $\%$ & 97,0 & $70-130$ \\
\hline Dibrom ofluorometano & 20 & $\%$ & 108 & $70-130$ \\
\hline \multicolumn{5}{|c|}{ 286353/2014-0 - Amostra Controle - VOC - Água } \\
\hline p-Bromofluorbenzeno & 20 & $\%$ & 93,4 & $70-130$ \\
\hline Dibrom ofluorometano & 20 & $\%$ & 98,3 & $70-130$ \\
\hline \multicolumn{5}{|l|}{ 283884/2014-0 - CGBFA-2 } \\
\hline Dibrom ofluorometano & 20 & $\%$ & 95,0 & $70-130$ \\
\hline p-Bromofluorbenzeno & 20 & $\%$ & 93,6 & $70-130$ \\
\hline
\end{tabular}

Notas

LQ = Limite de Quantificação.

n.a. $=$ Não Aplicável

Abrangência

(s) resultado(s) referem-se somente à(s) amostra(s) analisada(s).

Este Relatório de Ensaio só pode ser reproduzido por inteiro e sem nenhuma alteração.

Plano de Amostragem

Plano de amostragem de responsabilidade do interessado

Responsabilidade Técnic

Os ensaios foram realizados na unidade da Bioagri Ambiental Ltda. - Matriz, situada na Rua Aljovil Martini, 177/201, Bairro Dois Córregos, Cep. 14420-833, Piracicaba/SP, registrada no CRQ 4ª Região sob n $16082-F$ e responsabilidade técnica do profissional José Carlos Moretti, CRQ n 04107238, $4^{a}$.Região.

Referências Metodológicas

Análises foram realizadas conforme a última versão do Standard Methods for the Examination of Water \& Wastewater 22nd 2012(SMWW), EPA e ABNT (quando aplicável).

VOC: EPA 8260 C: 2006, 5021A: 2003

Metiletilcetona: EPA 8260 C: 2006, 5021 A: 2003

Revisores

Débora Fernandes da Silva

Daniela Rodrigues Bandoria

Chave de Validação: 88b6c89c439a2dceab977b6a42cddb92

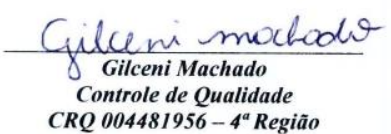

CRQ 004481956 - $4^{a}$ Região

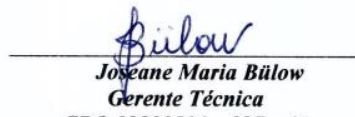

CRQ 09200516-9a Região 


\section{RELATÓRIO DE ENSAIO N $^{\circ}$ 283885/2014-0 - Piracicaba Processo Comercial $N^{\circ}$ 23961/2014-2}

\begin{tabular}{|l|l|}
\hline \multicolumn{2}{|c|}{ DADOS REFERENTES AO CLIENTE } \\
\hline Empresa solicitante: & Fundacao Parque de Alta Tecnologia da Regiao de Ipero e Adjacencias \\
\hline Endereço: & Rua Jose Antonio Scaciota, 165 - - Portal do Cedro - Iperó - SP - CEP: 18.560-000 . \\
\hline Nome do Solicitante: & Carla Marçal \\
\hline
\end{tabular}

\begin{tabular}{|l|l|l|l|l|}
\hline \multicolumn{5}{|c|}{ DADOS REFERENTES A AMOSTRA } \\
\hline Identificação do Cliente: & \multicolumn{4}{|l|}{ CGBFA-3 } \\
\hline Amostra Rotulada como: & Água Subterrânea Projeto Mestrado \\
\hline Coletor: & Interessado & Data da coleta: & \multicolumn{2}{|l|}{ 23/10/2014 19:50:00 } \\
\hline Data da entrada no laboratório: & $25 / 10 / 201408: 28$ & Data de Elaboração do RE: & $03 / 11 / 2014$ \\
\hline
\end{tabular}

\section{RESULTADOS PARA A AMOSTRA}

\begin{tabular}{|c|c|c|c|c|c|c|}
\hline Parâmetros & CAS & Unidade & LQ & Resultados analíticos & Incerteza & Data do Ensaio \\
\hline 1,1,1-Tricloroetano & $71-55-6$ & $\mu \mathrm{g} / \mathrm{L}$ & 1 & $<1$ & n.a. & 30/10/2014 01:31 \\
\hline 1,1,2-Tricloroetano & $79-00-5$ & $\mu \mathrm{g} / \mathrm{L}$ & 1 & $<1$ & n.a. & $30 / 10 / 201401: 31$ \\
\hline 1,1,2,2-Tetracloroetano & $79-34-5$ & $\mu \mathrm{g} / \mathrm{L}$ & 1 & $<1$ & n.a. & $30 / 10 / 201401: 31$ \\
\hline 1,1-Dicloroetano & 75-34-3 & $\mu \mathrm{g} / \mathrm{L}$ & 1 & $<1$ & n.a. & $30 / 10 / 201401: 31$ \\
\hline 1,1-Dicloroeteno & $75-35-4$ & $\mu \mathrm{g} / \mathrm{L}$ & 1 & $<1$ & n.a. & $30 / 10 / 201401: 31$ \\
\hline 1,1-Dicloropropeno & $563-58-6$ & $\mu \mathrm{g} / \mathrm{L}$ & 1 & $<1$ & n.a. & $30 / 10 / 201401: 31$ \\
\hline 1,2,3-Triclorobenzeno & $87-61-6$ & $\mu \mathrm{g} / \mathrm{L}$ & 1 & $<1$ & n.a. & $30 / 10 / 201401: 31$ \\
\hline 1,2,4-Triclorobenzeno & $120-82-1$ & $\mu \mathrm{g} / \mathrm{L}$ & 1 & $<1$ & n.a. & $30 / 10 / 201401: 31$ \\
\hline 1,2-Dibromo-3-Cloropropano & $96-12-8$ & $\mu \mathrm{g} / \mathrm{L}$ & 5 & $<5$ & n.a. & $30 / 10 / 201401: 31$ \\
\hline 1,2-Dicloroetano & $107-06-2$ & $\mu \mathrm{g} / \mathrm{L}$ & 1 & $<1$ & n.a. & $30 / 10 / 201401: 31$ \\
\hline 1,2-Dicloropropano & $78-87-5$ & $\mu \mathrm{g} / \mathrm{L}$ & 1 & $<1$ & n.a. & $30 / 10 / 201401: 31$ \\
\hline 1,3-Dicloropropano & $142-28-9$ & $\mu \mathrm{g} / \mathrm{L}$ & 5 & $<5$ & n.a. & $30 / 10 / 201401: 31$ \\
\hline 1,4-Diclorobenzeno & $106-46-7$ & $\mu \mathrm{g} / \mathrm{L}$ & 1 & $<1$ & n.a. & 30/10/2014 01:31 \\
\hline 2,2-Dicloropropano & $594-20-7$ & $\mu \mathrm{g} / \mathrm{L}$ & 1 & $<1$ & n.a. & 30/10/2014 01:31 \\
\hline 4-Metil-2-Pentanona & $108-10-1$ & $\mu \mathrm{g} / \mathrm{L}$ & 5 & $<5$ & n.a. & 30/10/2014 01:31 \\
\hline Benzeno & $71-43-2$ & $\mu \mathrm{g} / \mathrm{L}$ & 1 & $<1$ & n.a. & $30 / 10 / 201401: 31$ \\
\hline Bromobenzeno & $108-86-1$ & $\mu \mathrm{g} / \mathrm{L}$ & 1 & $<1$ & n.a. & $30 / 10 / 201401: 31$ \\
\hline Bromodiclorometano & $75-27-4$ & $\mu \mathrm{g} / \mathrm{L}$ & 1 & $<1$ & n.a. & $30 / 10 / 201401: 31$ \\
\hline Bromofórmio & $75-25-2$ & $\mu \mathrm{g} / \mathrm{L}$ & 1 & $<1$ & n.a. & 30/10/2014 01:31 \\
\hline Bromoclorometano & $74-97-5$ & $\mu \mathrm{g} / \mathrm{L}$ & 5 & $<5$ & n.a. & $30 / 10 / 201401: 31$ \\
\hline Cis-1,2-Dicloroeteno & $156-59-2$ & $\mu \mathrm{g} / \mathrm{L}$ & 1 & $<1$ & n.a. & $30 / 10 / 2014$ 01:31 \\
\hline Cis-1,3-Dicloropropeno & 10061-01-5 & $\mu \mathrm{g} / \mathrm{L}$ & 1 & $<1$ & n.a. & $30 / 10 / 201401: 31$ \\
\hline Diclorometano & $75-09-2$ & $\mu \mathrm{g} / \mathrm{L}$ & 1 & $<1$ & n.a. & $30 / 10 / 201401: 31$ \\
\hline Cloreto de Vinila & 75-01-4 & $\mu \mathrm{g} / \mathrm{L}$ & 1 & $<1$ & n.a. & 30/10/2014 01:31 \\
\hline Clorobenzeno & $108-90-7$ & $\mu \mathrm{g} / \mathrm{L}$ & 1 & $<1$ & n.a. & $30 / 10 / 201401: 31$ \\
\hline Cloroetano & $75-00-3$ & $\mu \mathrm{g} / \mathrm{L}$ & 1 & $<1$ & n.a. & $30 / 10 / 201401: 31$ \\
\hline Clorofórmio & $67-66-3$ & $\mu \mathrm{g} / \mathrm{L}$ & 1 & $<1$ & n.a. & $30 / 10 / 201401: 31$ \\
\hline Clorometano & $74-87-3$ & $\mu \mathrm{g} / \mathrm{L}$ & 10 & $<10$ & n.a. & 30/10/2014 01:31 \\
\hline Dibromoclorometano & $124-48-1$ & $\mu \mathrm{g} / \mathrm{L}$ & 1 & $<1$ & n.a. & 30/10/2014 01:31 \\
\hline Dissulfeto de Carbono & $75-15-0$ & $\mu \mathrm{g} / \mathrm{L}$ & 1 & $<1$ & n.a. & $30 / 10 / 201401: 31$ \\
\hline Estireno & $100-42-5$ & $\mu \mathrm{g} / \mathrm{L}$ & 1 & $<1$ & n.a. & 30/10/2014 01:31 \\
\hline Etilbenzeno & $100-41-4$ & $\mu \mathrm{g} / \mathrm{L}$ & 1 & $<1$ & n.a. & 30/10/2014 01:31 \\
\hline Hexaclorobutadieno & $87-68-3$ & $\mu \mathrm{g} / \mathrm{L}$ & 1 & $<1$ & n.a. & $30 / 10 / 201401: 31$ \\
\hline m,p-Xilenos & --- & $\mu \mathrm{g} / \mathrm{L}$ & 2 & $<2$ & n.a. & $30 / 10 / 2014$ 01:31 \\
\hline o-Xileno & $95-47-6$ & $\mu \mathrm{g} / \mathrm{L}$ & 1 & $<1$ & n.a. & 30/10/2014 01:31 \\
\hline p-Isopropiltolueno & $99-87-6$ & $\mu \mathrm{g} / \mathrm{L}$ & 1 & $<1$ & n.a. & $30 / 10 / 201401: 31$ \\
\hline Tetracloreto de Carbono & $56-23-5$ & $\mu \mathrm{g} / \mathrm{L}$ & 1 & $<1$ & n.a. & $30 / 10 / 201401: 31$ \\
\hline Tetracloroeteno & $127-18-4$ & $\mu \mathrm{g} / \mathrm{L}$ & 1 & $<1$ & n.a. & 30/10/2014 01:31 \\
\hline Tolueno & $108-88-3$ & $\mu \mathrm{g} / \mathrm{L}$ & 1 & $<1$ & n.a. & $30 / 10 / 201401: 31$ \\
\hline Trans-1,2-Dicloroeteno & $156-60-5$ & $\mu \mathrm{g} / \mathrm{L}$ & 1 & $<1$ & n.a. & $30 / 10 / 201401: 31$ \\
\hline Tricloroeteno & $79-01-6$ & $\mu \mathrm{g} / \mathrm{L}$ & 1 & $<1$ & n.a. & $30 / 10 / 201401: 31$ \\
\hline 1,1,1,2-Tetracloroetano & $630-20-6$ & $\mu \mathrm{g} / \mathrm{L}$ & 1 & $<1$ & n.a. & 30/10/2014 01:31 \\
\hline
\end{tabular}




\begin{tabular}{|c|c|c|c|c|c|c|}
\hline Parâmetros & CAS & Unidade & LQ & Resultados analíticos & Incerteza & Data do Ensaio \\
\hline 1,2,3-Tricloropropano & $96-18-4$ & $\mu \mathrm{g} / \mathrm{L}$ & 5 & $<5$ & n.a. & $30 / 10 / 201401: 31$ \\
\hline 1,3,5-Trimetilbenzeno & $108-67-8$ & $\mu \mathrm{g} / \mathrm{L}$ & 1 & $<1$ & n.a. & $30 / 10 / 201401: 31$ \\
\hline 1,2,4-Trimetilbenzeno & $95-63-6$ & $\mu \mathrm{g} / \mathrm{L}$ & 1 & $<1$ & n.a. & $30 / 10 / 201401: 31$ \\
\hline 1,2-Dibromoetano & $106-93-4$ & $\mu \mathrm{g} / \mathrm{L}$ & 1 & $<1$ & n.a. & $30 / 10 / 201401: 31$ \\
\hline 1,2-Diclorobenzeno & $95-50-1$ & $\mu \mathrm{g} / \mathrm{L}$ & 1 & $<1$ & n.a. & $30 / 10 / 201401: 31$ \\
\hline 1,3-Diclorobenzeno & $541-73-1$ & $\mu \mathrm{g} / \mathrm{L}$ & 1 & $<1$ & n.a. & $30 / 10 / 201401: 31$ \\
\hline 2-Clorotolueno & $95-49-8$ & $\mu \mathrm{g} / \mathrm{L}$ & 1 & $<1$ & n.a. & $30 / 10 / 201401: 31$ \\
\hline Dibromometano & $74-95-3$ & $\mu \mathrm{g} / \mathrm{L}$ & 1 & $<1$ & n.a. & $30 / 10 / 201401: 31$ \\
\hline Metiletilcetona & $78-93-3$ & $\mu \mathrm{g} / \mathrm{L}$ & 25000 & $<25000$ & n.a. & $30 / 10 / 201401: 44$ \\
\hline Naftaleno & $91-20-3$ & $\mu g / L$ & 1 & $<1$ & n.a. & 30/10/2014 01:31 \\
\hline n-Butilbenzeno & $104-51-8$ & $\mu \mathrm{g} / \mathrm{L}$ & 1 & $<1$ & n.a. & $30 / 10 / 201401: 31$ \\
\hline n-Propilbenzeno & $103-65-1$ & $\mu \mathrm{g} / \mathrm{L}$ & 1 & $<1$ & n.a. & $30 / 10 / 2014$ 01:31 \\
\hline 4-Clorotolueno & $106-43-4$ & $\mu \mathrm{g} / \mathrm{L}$ & 1 & $<1$ & n.a. & $30 / 10 / 201401: 31$ \\
\hline sec-Butilbenzeno & $135-98-8$ & $\mu \mathrm{g} / \mathrm{L}$ & 1 & $<1$ & n.a. & $30 / 10 / 201401: 31$ \\
\hline terc-Butilbenzeno & $98-06-6$ & $\mu \mathrm{g} / \mathrm{L}$ & 1 & $<1$ & n.a. & $30 / 10 / 201401: 31$ \\
\hline trans-1,3-Dicloropropeno & 10061-02-6 & $\mu \mathrm{g} / \mathrm{L}$ & 1 & $<1$ & n.a. & $30 / 10 / 201401: 31$ \\
\hline Isopropilbenzeno & $98-82-8$ & $\mu \mathrm{g} / \mathrm{L}$ & 1 & $<1$ & n.a. & $30 / 10 / 2014$ 01:31 \\
\hline 1,3,5-Triclorobenzeno & $108-70-3$ & $\mu \mathrm{g} / \mathrm{L}$ & 1 & $<1$ & n.a. & $30 / 10 / 2014$ 01:31 \\
\hline
\end{tabular}

\section{CONTROLE DE Q UALIDADE DO LAB ORATÓRIO}

Controle de Q ualidade - VOC - Água

286352/2014-0 - Branco de Análise - VOC - Água

1,1,1-Tricloroetano Parâmetros

1,1,2-Tricloroetano

1,1,2,2-Tetracloroetano

1,1-Dicloroetano

1,1-Dicloroeteno

1,1-Dicloropropeno

1,2,3-Triclorobenzeno

1,2,4-Triclorobenzeno

1,3,5-Triclorobenzeno

1,2-Dibromo-3-Cloropropano

1,2-Dicloroetano

1,2-Dicloropropano

1,3-Dicloropropano

1,4-Diclorobenzeno

2,2-Dicloropropano

4-Metil-2-Pentanona

Benzeno

Bromobenzeno

Bromodiclorometano

Bromofórmio

Cis-1,2-Dicloroeteno

Cis-1,3-Dicloropropeno

Diclorometano

Cloreto de Vinila

Clorobenzeno

Cloroetano

Clorofórmio

Clorometano

Dibromoclorometano

Dissulfeto de Carbono

Estireno

Etilbenzeno

Hexaclorobutadieno

m,p-Xilenos

o-Xileno

p-Isopropiltolueno

Tetracloreto de Carbono

Tetracloroeteno

Tolueno

Trans-1,2-Dicloroeteno

Tricloroeteno

Isopropilbenzeno

Bromoclorometano

\begin{tabular}{|c|c|c|}
\hline Unidade & LQ & Resultados analíticos \\
\hline$\mu \mathrm{g} / \mathrm{L}$ & 1 & $<1$ \\
\hline$\mu \mathrm{g} / \mathrm{L}$ & 1 & $<1$ \\
\hline$\mu \mathrm{g} / \mathrm{L}$ & 1 & $<1$ \\
\hline$\mu \mathrm{g} / \mathrm{L}$ & 1 & $<1$ \\
\hline$\mu \mathrm{g} / \mathrm{L}$ & 1 & $<1$ \\
\hline$\mu \mathrm{g} / \mathrm{L}$ & 1 & $<1$ \\
\hline$\mu \mathrm{g} / \mathrm{L}$ & 1 & $<1$ \\
\hline$\mu \mathrm{g} / \mathrm{L}$ & 1 & $<1$ \\
\hline$\mu \mathrm{g} / \mathrm{L}$ & 1 & $<1$ \\
\hline$\mu \mathrm{g} / \mathrm{L}$ & 5 & $<5$ \\
\hline$\mu \mathrm{g} / \mathrm{L}$ & 1 & $<1$ \\
\hline$\mu \mathrm{g} / \mathrm{L}$ & 1 & $<1$ \\
\hline$\mu \mathrm{g} / \mathrm{L}$ & 5 & $<5$ \\
\hline$\mu \mathrm{g} / \mathrm{L}$ & 1 & $<1$ \\
\hline$\mu \mathrm{g} / \mathrm{L}$ & 1 & $<1$ \\
\hline$\mu \mathrm{g} / \mathrm{L}$ & 5 & $<5$ \\
\hline$\mu \mathrm{g} / \mathrm{L}$ & 1 & $<1$ \\
\hline$\mu \mathrm{g} / \mathrm{L}$ & 1 & $<1$ \\
\hline$\mu \mathrm{g} / \mathrm{L}$ & 1 & $<1$ \\
\hline$\mu \mathrm{g} / \mathrm{L}$ & 1 & $<1$ \\
\hline$\mu \mathrm{g} / \mathrm{L}$ & 1 & $<1$ \\
\hline$\mu \mathrm{g} / \mathrm{L}$ & 1 & $<1$ \\
\hline$\mu \mathrm{g} / \mathrm{L}$ & 1 & $<1$ \\
\hline$\mu \mathrm{g} / \mathrm{L}$ & 1 & $<1$ \\
\hline$\mu \mathrm{g} / \mathrm{L}$ & 1 & $<1$ \\
\hline$\mu \mathrm{g} / \mathrm{L}$ & 1 & $<1$ \\
\hline$\mu \mathrm{g} / \mathrm{L}$ & 1 & $<1$ \\
\hline$\mu \mathrm{g} / \mathrm{L}$ & 10 & $<10$ \\
\hline$\mu \mathrm{g} / \mathrm{L}$ & 1 & $<1$ \\
\hline$\mu \mathrm{g} / \mathrm{L}$ & 1 & $<1$ \\
\hline$\mu \mathrm{g} / \mathrm{L}$ & 1 & $<1$ \\
\hline$\mu \mathrm{g} / \mathrm{L}$ & 1 & $<1$ \\
\hline$\mu \mathrm{g} / \mathrm{L}$ & 1 & $<1$ \\
\hline$\mu \mathrm{g} / \mathrm{L}$ & 2 & $<2$ \\
\hline$\mu \mathrm{g} / \mathrm{L}$ & 1 & $<1$ \\
\hline$\mu \mathrm{g} / \mathrm{L}$ & 1 & $<1$ \\
\hline$\mu \mathrm{g} / \mathrm{L}$ & 1 & $<1$ \\
\hline$\mu \mathrm{g} / \mathrm{L}$ & 1 & $<1$ \\
\hline$\mu \mathrm{g} / \mathrm{L}$ & 1 & $<1$ \\
\hline$\mu \mathrm{g} / \mathrm{L}$ & 1 & $<1$ \\
\hline$\mu \mathrm{g} / \mathrm{L}$ & 1 & $<1$ \\
\hline$\mu \mathrm{g} / \mathrm{L}$ & 1 & $<1$ \\
\hline$\mu \mathrm{g} / \mathrm{L}$ & 5 & $<5$ \\
\hline
\end{tabular}




\begin{tabular}{|c|c|c|c|c|}
\hline Parâmetros & $\begin{array}{l}\text { Q uantidade } \\
\text { Adicionada }\end{array}$ & Unidade & $\begin{array}{c}\text { Resultado da } \\
\text { Recuperação (\%) }\end{array}$ & Faixa Aceitável de Recuperação (\%) \\
\hline \multicolumn{5}{|c|}{ 286353/2014-0 - Amostra Controle - VOC - Água } \\
\hline 1,1-Dicloroeteno & 20 & $\mu \mathrm{g} / \mathrm{L}$ & 90 & $70-130$ \\
\hline Benzeno & 20 & $\mu \mathrm{g} / \mathrm{L}$ & 95 & $70-130$ \\
\hline Tricloroeteno & 20 & $\mu \mathrm{g} / \mathrm{L}$ & 90 & $70-130$ \\
\hline Tolueno & 20 & $\mu \mathrm{g} / \mathrm{L}$ & 90 & $70-130$ \\
\hline Clorobenzeno & 20 & $\mu \mathrm{g} / \mathrm{L}$ & 95 & $70-130$ \\
\hline \multicolumn{5}{|c|}{$\begin{array}{l}\text { Surrogates } \\
\text { 286352/2014-0 - B ranco de Análise - VOC - Água }\end{array}$} \\
\hline p-Bromofluorbenzeno & 20 & $\%$ & 97,0 & $70-130$ \\
\hline Dibrom ofluorometano & 20 & $\%$ & 108 & $70-130$ \\
\hline \multicolumn{5}{|c|}{ 286353/2014-0 - Amostra Controle - VOC - Água } \\
\hline p-Bromofluorbenzeno & 20 & $\%$ & 93,4 & $70-130$ \\
\hline Dibromofluorometano & 20 & $\%$ & 98,3 & $70-130$ \\
\hline \multicolumn{5}{|l|}{ 283885/2014-0 - CGBFA-3 } \\
\hline Dibromofluorometano & 20 & $\%$ & 101 & $70-130$ \\
\hline p-Bromofluorbenzeno & 20 & $\%$ & 103 & $70-130$ \\
\hline
\end{tabular}

Notas

LQ = Limite de Quantificação.

n.a. $=$ Não Aplicável

Abrangência

(s) resultado(s) referem-se somente à(s) amostra(s) analisada(s).

Este Relatório de Ensaio só pode ser reproduzido por inteiro e sem nenhuma alteração.

Plano de Amostragem

Plano de amostragem de responsabilidade do interessado.

Responsabilidade Técnica

Os ensaios foram realizados na unidade da Bioagri Ambiental Ltda. - Matriz, situada na Rua Aljovil Martini, 177/201, Bairro Dois Córregos, Cep. 14420-833, Piracicaba/SP, registrada no CRQ 4ª Região sob n $16082-\mathrm{Fe}$ responsabilidade técnica do profissional José Carlos Moretti, CRQ n 04107238, $4^{\text {a. }}$.Região.

Referências Metodológicas

Análises foram realizadas conforme a última versão do Standard Methods for the Examination of Water \& Wastewater 22nd 2012(SMWW), EPA e ABNT (quando aplicável). VOC: EPA 8260 C: 2006, 5021A: 2003

Metiletilcetona: EPA 8260 C: 2006, 5021 A: 2003

Revisores

Débora Fernandes da Silva

Daniela Rodrigues Bandoria

Chave de Validação: aeb334da58b8eceb45ac6c43fe054cd2

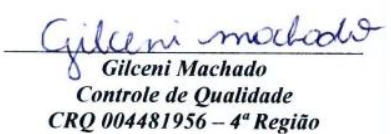

CRQ 004481956-4 Região

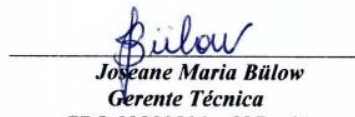

CRQ 09200516-9a Região 


\section{RELATÓRIO DE ENSAIO N $^{\circ}$ 283862/2014-0 - Piracicaba Processo Comercial $N^{\circ}$ 23961/2014-2}

\begin{tabular}{|l|l|}
\hline \multicolumn{2}{|c|}{ DADOS REFERENTES AO CLIENTE } \\
\hline Empresa solicitante: & Fundacao Parque de Alta Tecnologia da Regiao de Ipero e Adjacencias \\
\hline Endereço: & Rua Jose Antonio Scaciota, 165 - - Portal do Cedro - Iperó - SP - CEP: 18.560-000 . \\
\hline Nome do Solicitante: & Carla Marçal \\
\hline
\end{tabular}

\begin{tabular}{|l|l|l|l|l|}
\hline \multicolumn{5}{|c|}{ DADOS REFERENTES A AMOSTRA } \\
\hline Identificação do Cliente: & \multicolumn{4}{|l|}{ CGBT-1 } \\
\hline Amostra Rotulada como: & Água Subterrânea Projeto Mestrado \\
\hline Coletor: & Interessado & Data da coleta: & \multicolumn{2}{|l|}{ 23/10/2014 19:50:00 } \\
\hline Data da entrada no laboratório: & $25 / 10 / 201408: 21$ & Data de Elaboração do RE: & $03 / 11 / 2014$ \\
\hline
\end{tabular}

\section{RESULTADOS PARA A AMOSTRA}

\begin{tabular}{|c|c|c|c|c|c|c|}
\hline Parâmetros & CAS & Unidade & LQ & Resultados analíticos & Incerteza & Data do Ensaio \\
\hline 1,1,1-Tricloroetano & $71-55-6$ & $\mu \mathrm{g} / \mathrm{L}$ & 10 & $<10$ & n.a. & 29/10/2014 04:11 \\
\hline 1,1,2-Tricloroetano & $79-00-5$ & $\mu \mathrm{g} / \mathrm{L}$ & 10 & $<10$ & n.a. & 29/10/2014 04:11 \\
\hline 1,1,2,2-Tetracloroetano & $79-34-5$ & $\mu \mathrm{g} / \mathrm{L}$ & 10 & $<10$ & n.a. & 29/10/2014 04:11 \\
\hline 1,1-Dicloroetano & $75-34-3$ & $\mu \mathrm{g} / \mathrm{L}$ & 10 & $<10$ & n.a. & 29/10/2014 04:11 \\
\hline 1,1-Dicloroeteno & $75-35-4$ & $\mu \mathrm{g} / \mathrm{L}$ & 10 & $<10$ & n.a. & 29/10/2014 04:11 \\
\hline 1,1-Dicloropropeno & $563-58-6$ & $\mu \mathrm{g} / \mathrm{L}$ & 10 & $<10$ & n.a. & $29 / 10 / 201404: 11$ \\
\hline 1,2,3-Triclorobenzeno & $87-61-6$ & $\mu \mathrm{g} / \mathrm{L}$ & 10 & $<10$ & n.a. & 29/10/2014 04:11 \\
\hline 1,2,4-Triclorobenzeno & $120-82-1$ & $\mu \mathrm{g} / \mathrm{L}$ & 10 & $<10$ & n.a. & 29/10/2014 04:11 \\
\hline 1,2-Dibromo-3-Cloropropano & $96-12-8$ & $\mu \mathrm{g} / \mathrm{L}$ & 50 & $<50$ & n.a. & 29/10/2014 04:11 \\
\hline 1,2-Dicloroetano & $107-06-2$ & $\mu \mathrm{g} / \mathrm{L}$ & 10 & $<10$ & n.a. & 29/10/2014 04:11 \\
\hline 1,2-Dicloropropano & $78-87-5$ & $\mu \mathrm{g} / \mathrm{L}$ & 10 & $<10$ & n.a. & $29 / 10 / 201404: 11$ \\
\hline 1,3-Dicloropropano & $142-28-9$ & $\mu \mathrm{g} / \mathrm{L}$ & 50 & $<50$ & n.a. & 29/10/2014 04:11 \\
\hline 1,4-Diclorobenzeno & $106-46-7$ & $\mu \mathrm{g} / \mathrm{L}$ & 10 & $<10$ & n.a. & 29/10/2014 04:11 \\
\hline 2,2-Dicloropropano & $594-20-7$ & $\mu \mathrm{g} / \mathrm{L}$ & 10 & $<10$ & n.a. & 29/10/2014 04:11 \\
\hline 4-Metil-2-Pentanona & $108-10-1$ & $\mu \mathrm{g} / \mathrm{L}$ & 50 & $<50$ & n.a. & 29/10/2014 04:11 \\
\hline Benzeno & $71-43-2$ & $\mu \mathrm{g} / \mathrm{L}$ & 10 & $<10$ & n.a. & 29/10/2014 04:11 \\
\hline Bromobenzeno & $108-86-1$ & $\mu \mathrm{g} / \mathrm{L}$ & 10 & $<10$ & n.a. & 29/10/2014 04:11 \\
\hline Bromodiclorometano & $75-27-4$ & $\mu \mathrm{g} / \mathrm{L}$ & 10 & $<10$ & n.a. & 29/10/2014 04:11 \\
\hline Bromofórmio & $75-25-2$ & $\mu \mathrm{g} / \mathrm{L}$ & 10 & $<10$ & n.a. & 29/10/2014 04:11 \\
\hline Bromoclorometano & $74-97-5$ & $\mu \mathrm{g} / \mathrm{L}$ & 50 & $<50$ & n.a. & 29/10/2014 04:11 \\
\hline Cis-1,2-Dicloroeteno & $156-59-2$ & $\mu \mathrm{g} / \mathrm{L}$ & 10 & $<10$ & n.a. & 29/10/2014 04:11 \\
\hline Cis-1,3-Dicloropropeno & 10061-01-5 & $\mu \mathrm{g} / \mathrm{L}$ & 10 & $<10$ & n.a. & 29/10/2014 04:11 \\
\hline Diclorometano & $75-09-2$ & $\mu \mathrm{g} / \mathrm{L}$ & 10 & $<10$ & n.a. & $29 / 10 / 201404: 11$ \\
\hline Cloreto de Vinila & 75-01-4 & $\mu \mathrm{g} / \mathrm{L}$ & 10 & $<10$ & n.a. & 29/10/2014 04:11 \\
\hline Clorobenzeno & $108-90-7$ & $\mu \mathrm{g} / \mathrm{L}$ & 10 & $<10$ & n.a. & 29/10/2014 04:11 \\
\hline Cloroetano & $75-00-3$ & $\mu \mathrm{g} / \mathrm{L}$ & 10 & $<10$ & n.a. & 29/10/2014 04:11 \\
\hline Clorofórmio & $67-66-3$ & $\mu \mathrm{g} / \mathrm{L}$ & 10 & $<10$ & n.a. & 29/10/2014 04:11 \\
\hline Clorometano & $74-87-3$ & $\mu \mathrm{g} / \mathrm{L}$ & 100 & $<100$ & n.a. & 29/10/2014 04:11 \\
\hline Dibromoclorometano & $124-48-1$ & $\mu \mathrm{g} / \mathrm{L}$ & 10 & $<10$ & n.a. & 29/10/2014 04:11 \\
\hline Dissulfeto de Carbono & $75-15-0$ & $\mu \mathrm{g} / \mathrm{L}$ & 10 & $<10$ & n.a. & 29/10/2014 04:11 \\
\hline Estireno & $100-42-5$ & $\mu \mathrm{g} / \mathrm{L}$ & 10 & $<10$ & n.a. & 29/10/2014 04:11 \\
\hline Etilbenzeno & $100-41-4$ & $\mu \mathrm{g} / \mathrm{L}$ & 10 & $<10$ & n.a. & 29/10/2014 04:11 \\
\hline Hexaclorobutadieno & $87-68-3$ & $\mu \mathrm{g} / \mathrm{L}$ & 10 & $<10$ & n.a. & 29/10/2014 04:11 \\
\hline $\mathrm{m}, \mathrm{p}$-Xilenos & --- & $\mu \mathrm{g} / \mathrm{L}$ & 20 & $<20$ & n.a. & 29/10/2014 04:11 \\
\hline o-Xileno & $95-47-6$ & $\mu \mathrm{g} / \mathrm{L}$ & 10 & $<10$ & n.a. & 29/10/2014 04:11 \\
\hline p-Isopropiltolueno & $99-87-6$ & $\mu \mathrm{g} / \mathrm{L}$ & 10 & $<10$ & n.a. & 29/10/2014 04:11 \\
\hline Tetracloreto de Carbono & $56-23-5$ & $\mu \mathrm{g} / \mathrm{L}$ & 10 & $<10$ & n.a. & 29/10/2014 04:11 \\
\hline Tetracloroeteno & $127-18-4$ & $\mu \mathrm{g} / \mathrm{L}$ & 1000 & 16200 & 3100 & 29/10/2014 04:11 \\
\hline Tolueno & $108-88-3$ & $\mu \mathrm{g} / \mathrm{L}$ & 10 & $<10$ & n.a. & 29/10/2014 04:11 \\
\hline Trans-1,2-Dicloroeteno & $156-60-5$ & $\mu \mathrm{g} / \mathrm{L}$ & 10 & $<10$ & n.a. & 29/10/2014 04:11 \\
\hline Tricloroeteno & $79-01-6$ & $\mu \mathrm{g} / \mathrm{L}$ & 10 & $<10$ & n.a. & 29/10/2014 04:11 \\
\hline 1,1,1,2-Tetracloroetano & $630-20-6$ & $\mu \mathrm{g} / \mathrm{L}$ & 10 & $<10$ & n.a. & $29 / 10 / 201404: 11$ \\
\hline
\end{tabular}




\begin{tabular}{|c|c|c|c|c|c|c|}
\hline Parâmetros & CAS & Unidade & LQ & Resultados analíticos & Incerteza & Data do Ensaio \\
\hline 1,2,3-Tricloropropano & $96-18-4$ & $\mu \mathrm{g} / \mathrm{L}$ & 50 & $<50$ & n.a. & 29/10/2014 04:11 \\
\hline 1,3,5-Trimetilbenzeno & $108-67-8$ & $\mu \mathrm{g} / \mathrm{L}$ & 10 & $<10$ & n.a. & 29/10/2014 04:11 \\
\hline 1,2,4-Trimetilbenzeno & $95-63-6$ & $\mu \mathrm{g} / \mathrm{L}$ & 10 & $<10$ & n.a. & 29/10/2014 04:11 \\
\hline 1,2-Dibromoetano & $106-93-4$ & $\mu \mathrm{g} / \mathrm{L}$ & 10 & $<10$ & n.a. & 29/10/2014 04:11 \\
\hline 1,2-Diclorobenzeno & $95-50-1$ & $\mu \mathrm{g} / \mathrm{L}$ & 10 & $<10$ & n.a. & 29/10/2014 04:11 \\
\hline 1,3-Diclorobenzeno & $541-73-1$ & $\mu \mathrm{g} / \mathrm{L}$ & 10 & $<10$ & n.a. & 29/10/2014 04:11 \\
\hline 2-Clorotolueno & $95-49-8$ & $\mu \mathrm{g} / \mathrm{L}$ & 10 & $<10$ & n.a. & 29/10/2014 04:11 \\
\hline Dibromometano & $74-95-3$ & $\mu \mathrm{g} / \mathrm{L}$ & 10 & $<10$ & n.a. & 29/10/2014 04:11 \\
\hline Metiletilcetona & $78-93-3$ & $\mu \mathrm{g} / \mathrm{L}$ & 25000 & $<25000$ & n.a. & 30/10/2014 02:32 \\
\hline Naftaleno & $91-20-3$ & $\mu \mathrm{g} / \mathrm{L}$ & 10 & $<10$ & n.a. & 29/10/2014 04:11 \\
\hline n-Butilbenzeno & $104-51-8$ & $\mu \mathrm{g} / \mathrm{L}$ & 10 & $<10$ & n.a. & 29/10/2014 04:11 \\
\hline n-Propilbenzeno & $103-65-1$ & $\mu \mathrm{g} / \mathrm{L}$ & 10 & $<10$ & n.a. & 29/10/2014 04:11 \\
\hline 4-Clorotolueno & $106-43-4$ & $\mu \mathrm{g} / \mathrm{L}$ & 10 & $<10$ & n.a. & 29/10/2014 04:11 \\
\hline sec-Butilbenzeno & $135-98-8$ & $\mu \mathrm{g} / \mathrm{L}$ & 10 & $<10$ & n.a. & 29/10/2014 04:11 \\
\hline terc-Butilbenzeno & $98-06-6$ & $\mu \mathrm{g} / \mathrm{L}$ & 10 & $<10$ & n.a. & 29/10/2014 04:11 \\
\hline trans-1,3-Dicloropropeno & $10061-02-6$ & $\mu \mathrm{g} / \mathrm{L}$ & 10 & $<10$ & n.a. & 29/10/2014 04:11 \\
\hline Isopropilbenzeno & $98-82-8$ & $\mu \mathrm{g} / \mathrm{L}$ & 10 & $<10$ & n.a. & 29/10/2014 04:11 \\
\hline 1,3,5-Triclorobenzeno & $108-70-3$ & $\mu \mathrm{g} / \mathrm{L}$ & 10 & $<10$ & n.a. & 29/10/2014 04:11 \\
\hline
\end{tabular}

\section{CONTROLE DE Q UALIDADE DO LAB ORATÓRIO}

Controle de Q ualidade - VOC - Água

286352/2014-0 - Branco de Análise - VOC - Água

1,1,1-Tricloroetano Parâmetros

1,1,2-Tricloroetano

1,1,2,2-Tetracloroetano

1,1-Dicloroetano

1,1-Dicloroeteno

1,1-Dicloropropeno

1,2,3-Triclorobenzeno

1,2,4-Triclorobenzeno

1,3,5-Triclorobenzeno

1,2-Dibromo-3-Cloropropano

1,2-Dicloroetano

1,2-Dicloropropano

1,3-Dicloropropano

1,4-Diclorobenzeno

2,2-Dicloropropano

4-Metil-2-Pentanona

Benzeno

Bromobenzeno

Bromodiclorometano

Bromofórmio

Cis-1,2-Dicloroeteno

Cis-1,3-Dicloropropeno

Diclorometano

Cloreto de Vinila

Clorobenzeno

Cloroetano

Clorofórmio

Clorometano

Dibromoclorometano

Dissulfeto de Carbono

Estireno

Etilbenzeno

Hexaclorobutadieno

m,p-Xilenos

o-Xileno

p-Isopropiltolueno

Tetracloreto de Carbono

Tetracloroeteno

Tolueno

Trans-1,2-Dicloroeteno

Tricloroeteno

Isopropilbenzeno

Bromoclorometano

\begin{tabular}{|c|c|c|}
\hline Unidade & LQ & Resultados analíticos \\
\hline$\mu \mathrm{g} / \mathrm{L}$ & 1 & $<1$ \\
\hline$\mu \mathrm{g} / \mathrm{L}$ & 1 & $<1$ \\
\hline$\mu \mathrm{g} / \mathrm{L}$ & 1 & $<1$ \\
\hline$\mu \mathrm{g} / \mathrm{L}$ & 1 & $<1$ \\
\hline$\mu \mathrm{g} / \mathrm{L}$ & 1 & $<1$ \\
\hline$\mu \mathrm{g} / \mathrm{L}$ & 1 & $<1$ \\
\hline$\mu \mathrm{g} / \mathrm{L}$ & 1 & $<1$ \\
\hline$\mu \mathrm{g} / \mathrm{L}$ & 1 & $<1$ \\
\hline$\mu \mathrm{g} / \mathrm{L}$ & 1 & $<1$ \\
\hline$\mu \mathrm{g} / \mathrm{L}$ & 5 & $<5$ \\
\hline$\mu \mathrm{g} / \mathrm{L}$ & 1 & $<1$ \\
\hline$\mu \mathrm{g} / \mathrm{L}$ & 1 & $<1$ \\
\hline$\mu \mathrm{g} / \mathrm{L}$ & 5 & $<5$ \\
\hline$\mu \mathrm{g} / \mathrm{L}$ & 1 & $<1$ \\
\hline$\mu \mathrm{g} / \mathrm{L}$ & 1 & $<1$ \\
\hline$\mu \mathrm{g} / \mathrm{L}$ & 5 & $<5$ \\
\hline$\mu \mathrm{g} / \mathrm{L}$ & 1 & $<1$ \\
\hline$\mu \mathrm{g} / \mathrm{L}$ & 1 & $<1$ \\
\hline$\mu \mathrm{g} / \mathrm{L}$ & 1 & $<1$ \\
\hline$\mu \mathrm{g} / \mathrm{L}$ & 1 & $<1$ \\
\hline$\mu \mathrm{g} / \mathrm{L}$ & 1 & $<1$ \\
\hline$\mu \mathrm{g} / \mathrm{L}$ & 1 & $<1$ \\
\hline$\mu \mathrm{g} / \mathrm{L}$ & 1 & $<1$ \\
\hline$\mu \mathrm{g} / \mathrm{L}$ & 1 & $<1$ \\
\hline$\mu \mathrm{g} / \mathrm{L}$ & 1 & $<1$ \\
\hline$\mu \mathrm{g} / \mathrm{L}$ & 1 & $<1$ \\
\hline$\mu \mathrm{g} / \mathrm{L}$ & 1 & $<1$ \\
\hline$\mu \mathrm{g} / \mathrm{L}$ & 10 & $<10$ \\
\hline$\mu \mathrm{g} / \mathrm{L}$ & 1 & $<1$ \\
\hline$\mu \mathrm{g} / \mathrm{L}$ & 1 & $<1$ \\
\hline$\mu \mathrm{g} / \mathrm{L}$ & 1 & $<1$ \\
\hline$\mu \mathrm{g} / \mathrm{L}$ & 1 & $<1$ \\
\hline$\mu \mathrm{g} / \mathrm{L}$ & 1 & $<1$ \\
\hline$\mu \mathrm{g} / \mathrm{L}$ & 2 & $<2$ \\
\hline$\mu \mathrm{g} / \mathrm{L}$ & 1 & $<1$ \\
\hline$\mu \mathrm{g} / \mathrm{L}$ & 1 & $<1$ \\
\hline$\mu \mathrm{g} / \mathrm{L}$ & 1 & $<1$ \\
\hline$\mu \mathrm{g} / \mathrm{L}$ & 1 & $<1$ \\
\hline$\mu \mathrm{g} / \mathrm{L}$ & 1 & $<1$ \\
\hline$\mu \mathrm{g} / \mathrm{L}$ & 1 & $<1$ \\
\hline$\mu \mathrm{g} / \mathrm{L}$ & 1 & $<1$ \\
\hline$\mu \mathrm{g} / \mathrm{L}$ & 1 & $<1$ \\
\hline$\mu \mathrm{g} / \mathrm{L}$ & 5 & $<5$ \\
\hline
\end{tabular}




\begin{tabular}{|c|c|c|c|c|}
\hline Parâmetros & $\begin{array}{l}\text { Q uantidade } \\
\text { Adicionada }\end{array}$ & Unidade & $\begin{array}{c}\text { Resultado da } \\
\text { Recuperação (\%) }\end{array}$ & Faixa Aceitável de Recuperação (\%) \\
\hline \multicolumn{5}{|c|}{ 286353/2014-0 - Amostra Controle - VOC - Água } \\
\hline 1,1-Dicloroeteno & 20 & $\mu \mathrm{g} / \mathrm{L}$ & 90 & $70-130$ \\
\hline Benzeno & 20 & $\mu \mathrm{g} / \mathrm{L}$ & 95 & $70-130$ \\
\hline Tricloroeteno & 20 & $\mu \mathrm{g} / \mathrm{L}$ & 90 & $70-130$ \\
\hline Tolueno & 20 & $\mu \mathrm{g} / \mathrm{L}$ & 90 & $70-130$ \\
\hline Clorobenzeno & 20 & $\mu \mathrm{g} / \mathrm{L}$ & 95 & $70-130$ \\
\hline \multicolumn{5}{|c|}{$\begin{array}{l}\text { Surrogates } \\
\text { 286352/2014-0 - B ranco de Análise - VOC - Água }\end{array}$} \\
\hline p-Bromofluorbenzeno & 20 & $\%$ & 97,0 & $70-130$ \\
\hline Dibrom ofluorometano & 20 & $\%$ & 108 & $70-130$ \\
\hline \multicolumn{5}{|c|}{ 286353/2014-0 - Amostra Controle - VOC - Água } \\
\hline p-Bromofluorbenzeno & 20 & $\%$ & 93,4 & $70-130$ \\
\hline Dibromofluorometano & 20 & $\%$ & 98,3 & $70-130$ \\
\hline \multicolumn{5}{|l|}{ 283862/2014-0 - CGBT-1 } \\
\hline Dibrom ofluorometano & 20 & $\%$ & Amostra Diluída & $70-130$ \\
\hline p-Bromofluorbenzeno & 20 & $\%$ & Amostra Diluída & $70-130$ \\
\hline
\end{tabular}

Notas

LQ = Limite de Quantificação.

n.a. $=$ Não Aplicável

Abrangência

(s) resultado(s) referem-se somente à(s) amostra(s) analisada(s).

Este Relatório de Ensaio só pode ser reproduzido por inteiro e sem nenhuma alteração.

Plano de Amostragem

Plano de amostragem de responsabilidade do interessado

Responsabilidade Técnic

Os ensaios foram realizados na unidade da Bioagri Ambiental Ltda. - Matriz, situada na Rua Aljovil Martini, 177/201, Bairro Dois Córregos, Cep. 14420-833, Piracicaba/SP, registrada no CRQ 4ª Região sob n $16082-F$ e responsabilidade técnica do profissional José Carlos Moretti, CRQ n 04107238, $4^{a}$.Região.

Referências Metodológicas

Análises foram realizadas conforme a última versão do Standard Methods for the Examination of Water \& Wastewater 22nd 2012(SMWW), EPA e ABNT (quando aplicável). VOC: EPA 8260 C: 2006, 5021A: 2003

Metiletilcetona: EPA 8260 C: 2006,5021 A: 2003

Revisores

Débora Fernandes da Silva

Daniela Rodrigues Bandoria

Chave de Validação: 92c67e2ef59a4d97fbf3b3b0b66df318

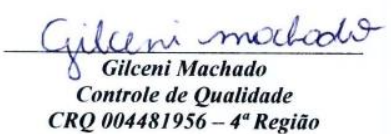

CRQ 004481956-4 Região

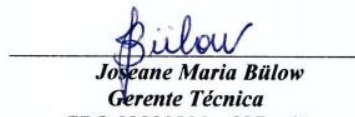

CRQ 09200516-9a Região 


\section{RELATÓRIO DE ENSAIO N $^{\circ}$ 283863/2014-0 - Piracicaba Processo Comercial $N^{\circ}$ 23961/2014-2}

\begin{tabular}{|l|l|}
\hline \multicolumn{2}{|c|}{ DADOS REFERENTES AO CLIENTE } \\
\hline Empresa solicitante: & Fundacao Parque de Alta Tecnologia da Regiao de Ipero e Adjacencias \\
\hline Endereço: & Rua Jose Antonio Scaciota, 165 - - Portal do Cedro - Iperó - SP - CEP: 18.560-000 . \\
\hline Nome do Solicitante: & Carla Marçal \\
\hline
\end{tabular}

\begin{tabular}{|l|l|l|l|l|}
\hline \multicolumn{5}{|c|}{ DADOS REFERENTES A AMOSTRA } \\
\hline Identificação do Cliente: & \multicolumn{4}{|l|}{ CGBT-2 } \\
\hline Amostra Rotulada como: & Água Subterrânea Projeto Mestrado \\
\hline Coletor: & Interessado & Data da coleta: & \multicolumn{2}{|l|}{ 23/10/2014 19:50:00 } \\
\hline Data da entrada no laboratório: & $25 / 10 / 201408: 21$ & Data de Elaboração do RE: & $03 / 11 / 2014$ \\
\hline
\end{tabular}

\section{RESULTADOS PARA A AMOSTRA}

\begin{tabular}{|c|c|c|c|c|c|c|}
\hline Parâmetros & CAS & Unidade & LQ & Resultados analíticos & Incerteza & Data do Ensaio \\
\hline 1,1,1-Tricloroetano & $71-55-6$ & $\mu \mathrm{g} / \mathrm{L}$ & 10 & $<10$ & n.a. & 29/10/2014 04:35 \\
\hline 1,1,2-Tricloroetano & $79-00-5$ & $\mu \mathrm{g} / \mathrm{L}$ & 10 & $<10$ & n.a. & $29 / 10 / 201404: 35$ \\
\hline 1,1,2,2-Tetracloroetano & $79-34-5$ & $\mu \mathrm{g} / \mathrm{L}$ & 10 & $<10$ & n.a. & $29 / 10 / 201404: 35$ \\
\hline 1,1-Dicloroetano & $75-34-3$ & $\mu \mathrm{g} / \mathrm{L}$ & 10 & $<10$ & n.a. & 29/10/2014 04:35 \\
\hline 1,1-Dicloroeteno & $75-35-4$ & $\mu \mathrm{g} / \mathrm{L}$ & 10 & $<10$ & n.a. & 29/10/2014 04:35 \\
\hline 1,1-Dicloropropeno & $563-58-6$ & $\mu \mathrm{g} / \mathrm{L}$ & 10 & $<10$ & n.a. & $29 / 10 / 201404: 35$ \\
\hline 1,2,3-Triclorobenzeno & $87-61-6$ & $\mu \mathrm{g} / \mathrm{L}$ & 10 & $<10$ & n.a. & $29 / 10 / 201404: 35$ \\
\hline 1,2,4-Triclorobenzeno & $120-82-1$ & $\mu \mathrm{g} / \mathrm{L}$ & 10 & $<10$ & n.a. & 29/10/2014 04:35 \\
\hline 1,2-Dibromo-3-Cloropropano & $96-12-8$ & $\mu \mathrm{g} / \mathrm{L}$ & 50 & $<50$ & n.a. & 29/10/2014 04:35 \\
\hline 1,2-Dicloroetano & $107-06-2$ & $\mu \mathrm{g} / \mathrm{L}$ & 10 & $<10$ & n.a. & 29/10/2014 04:35 \\
\hline 1,2-Dicloropropano & $78-87-5$ & $\mu \mathrm{g} / \mathrm{L}$ & 10 & $<10$ & n.a. & $29 / 10 / 201404: 35$ \\
\hline 1,3-Dicloropropano & $142-28-9$ & $\mu \mathrm{g} / \mathrm{L}$ & 50 & $<50$ & n.a. & $29 / 10 / 201404: 35$ \\
\hline 1,4-Diclorobenzeno & $106-46-7$ & $\mu \mathrm{g} / \mathrm{L}$ & 10 & $<10$ & n.a. & $29 / 10 / 201404: 35$ \\
\hline 2,2-Dicloropropano & $594-20-7$ & $\mu \mathrm{g} / \mathrm{L}$ & 10 & $<10$ & n.a. & $29 / 10 / 201404: 35$ \\
\hline 4-Metil-2-Pentanona & $108-10-1$ & $\mu \mathrm{g} / \mathrm{L}$ & 50 & $<50$ & n.a. & 29/10/2014 04:35 \\
\hline Benzeno & $71-43-2$ & $\mu \mathrm{g} / \mathrm{L}$ & 10 & $<10$ & n.a. & 29/10/2014 04:35 \\
\hline Bromobenzeno & $108-86-1$ & $\mu \mathrm{g} / \mathrm{L}$ & 10 & $<10$ & n.a. & 29/10/2014 04:35 \\
\hline Bromodiclorometano & $75-27-4$ & $\mu \mathrm{g} / \mathrm{L}$ & 10 & $<10$ & n.a. & $29 / 10 / 201404: 35$ \\
\hline Bromofórmio & $75-25-2$ & $\mu \mathrm{g} / \mathrm{L}$ & 10 & $<10$ & n.a. & 29/10/2014 04:35 \\
\hline Bromoclorometano & $74-97-5$ & $\mu \mathrm{g} / \mathrm{L}$ & 50 & $<50$ & n.a. & $29 / 10 / 201404: 35$ \\
\hline Cis-1,2-Dicloroeteno & $156-59-2$ & $\mu \mathrm{g} / \mathrm{L}$ & 10 & $<10$ & n.a. & 29/10/2014 04:35 \\
\hline Cis-1,3-Dicloropropeno & $10061-01-5$ & $\mu \mathrm{g} / \mathrm{L}$ & 10 & $<10$ & n.a. & 29/10/2014 04:35 \\
\hline Diclorometano & $75-09-2$ & $\mu \mathrm{g} / \mathrm{L}$ & 10 & $<10$ & n.a. & 29/10/2014 04:35 \\
\hline Cloreto de Vinila & 75-01-4 & $\mu \mathrm{g} / \mathrm{L}$ & 10 & $<10$ & n.a. & 29/10/2014 04:35 \\
\hline Clorobenzeno & $108-90-7$ & $\mu \mathrm{g} / \mathrm{L}$ & 10 & $<10$ & n.a. & 29/10/2014 04:35 \\
\hline Cloroetano & $75-00-3$ & $\mu \mathrm{g} / \mathrm{L}$ & 10 & $<10$ & n.a. & $29 / 10 / 201404: 35$ \\
\hline Clorofórmio & $67-66-3$ & $\mu \mathrm{g} / \mathrm{L}$ & 10 & $<10$ & n.a. & 29/10/2014 04:35 \\
\hline Clorometano & $74-87-3$ & $\mu \mathrm{g} / \mathrm{L}$ & 100 & $<100$ & n.a. & 29/10/2014 04:35 \\
\hline Dibromoclorometano & $124-48-1$ & $\mu \mathrm{g} / \mathrm{L}$ & 10 & $<10$ & n.a. & 29/10/2014 04:35 \\
\hline Dissulfeto de Carbono & $75-15-0$ & $\mu \mathrm{g} / \mathrm{L}$ & 10 & $<10$ & n.a. & $29 / 10 / 201404: 35$ \\
\hline Estireno & $100-42-5$ & $\mu \mathrm{g} / \mathrm{L}$ & 10 & $<10$ & n.a. & 29/10/2014 04:35 \\
\hline Etilbenzeno & $100-41-4$ & $\mu \mathrm{g} / \mathrm{L}$ & 10 & $<10$ & n.a. & 29/10/2014 04:35 \\
\hline Hexaclorobutadieno & $87-68-3$ & $\mu \mathrm{g} / \mathrm{L}$ & 10 & $<10$ & n.a. & 29/10/2014 04:35 \\
\hline $\mathrm{m}, \mathrm{p}$-Xilenos & --- & $\mu \mathrm{g} / \mathrm{L}$ & 20 & $<20$ & n.a. & 29/10/2014 04:35 \\
\hline o-Xileno & $95-47-6$ & $\mu \mathrm{g} / \mathrm{L}$ & 10 & $<10$ & n.a. & 29/10/2014 04:35 \\
\hline p-Isopropiltolueno & $99-87-6$ & $\mu \mathrm{g} / \mathrm{L}$ & 10 & $<10$ & n.a. & 29/10/2014 04:35 \\
\hline Tetracloreto de Carbono & $56-23-5$ & $\mu \mathrm{g} / \mathrm{L}$ & 10 & $<10$ & n.a. & 29/10/2014 04:35 \\
\hline Tetracloroeteno & $127-18-4$ & $\mu \mathrm{g} / \mathrm{L}$ & 1000 & 16500 & 3100 & 29/10/2014 04:35 \\
\hline Tolueno & $108-88-3$ & $\mu \mathrm{g} / \mathrm{L}$ & 10 & $<10$ & n.a. & 29/10/2014 04:35 \\
\hline Trans-1,2-Dicloroeteno & $156-60-5$ & $\mu \mathrm{g} / \mathrm{L}$ & 10 & $<10$ & n.a. & 29/10/2014 04:35 \\
\hline Tricloroeteno & $79-01-6$ & $\mu \mathrm{g} / \mathrm{L}$ & 10 & $<10$ & n.a. & $29 / 10 / 201404: 35$ \\
\hline 1,1,1,2-Tetracloroetano & $630-20-6$ & $\mu \mathrm{g} / \mathrm{L}$ & 10 & $<10$ & n.a. & $29 / 10 / 201404: 35$ \\
\hline
\end{tabular}




\begin{tabular}{|c|c|c|c|c|c|c|}
\hline Parâmetros & CAS & Unidade & LQ & Resultados analíticos & Incerteza & Data do Ensaio \\
\hline 1,2,3-Tricloropropano & $96-18-4$ & $\mu \mathrm{g} / \mathrm{L}$ & 50 & $<50$ & n.a. & $29 / 10 / 201404: 35$ \\
\hline 1,3,5-Trimetilbenzeno & $108-67-8$ & $\mu \mathrm{g} / \mathrm{L}$ & 10 & $<10$ & n.a. & 29/10/2014 04:35 \\
\hline 1,2,4-Trimetilbenzeno & $95-63-6$ & $\mu \mathrm{g} / \mathrm{L}$ & 10 & $<10$ & n.a. & 29/10/2014 04:35 \\
\hline 1,2-Dibromoetano & $106-93-4$ & $\mu \mathrm{g} / \mathrm{L}$ & 10 & $<10$ & n.a. & $29 / 10 / 201404: 35$ \\
\hline 1,2-Diclorobenzeno & $95-50-1$ & $\mu \mathrm{g} / \mathrm{L}$ & 10 & $<10$ & n.a. & 29/10/2014 04:35 \\
\hline 1,3-Diclorobenzeno & $541-73-1$ & $\mu \mathrm{g} / \mathrm{L}$ & 10 & $<10$ & n.a. & 29/10/2014 04:35 \\
\hline 2-Clorotolueno & $95-49-8$ & $\mu \mathrm{g} / \mathrm{L}$ & 10 & $<10$ & n.a. & 29/10/2014 04:35 \\
\hline Dibromometano & $74-95-3$ & $\mu \mathrm{g} / \mathrm{L}$ & 10 & $<10$ & n.a. & 29/10/2014 04:35 \\
\hline Metiletilcetona & 78-93-3 & $\mu \mathrm{g} / \mathrm{L}$ & 25000 & $<25000$ & n.a. & $30 / 10 / 201403: 20$ \\
\hline Naftaleno & $91-20-3$ & $\mu g / L$ & 10 & $<10$ & n.a. & 29/10/2014 04:35 \\
\hline n-Butilbenzeno & $104-51-8$ & $\mu \mathrm{g} / \mathrm{L}$ & 10 & $<10$ & n.a. & $29 / 10 / 201404: 35$ \\
\hline n-Propilbenzeno & $103-65-1$ & $\mu \mathrm{g} / \mathrm{L}$ & 10 & $<10$ & n.a. & $29 / 10 / 2014$ 04:35 \\
\hline 4-Clorotolueno & $106-43-4$ & $\mu \mathrm{g} / \mathrm{L}$ & 10 & $<10$ & n.a. & $29 / 10 / 201404: 35$ \\
\hline sec-Butilbenzeno & $135-98-8$ & $\mu \mathrm{g} / \mathrm{L}$ & 10 & $<10$ & n.a. & 29/10/2014 04:35 \\
\hline terc-Butilbenzeno & $98-06-6$ & $\mu \mathrm{g} / \mathrm{L}$ & 10 & $<10$ & n.a. & $29 / 10 / 201404: 35$ \\
\hline trans-1,3-Dicloropropeno & $10061-02-6$ & $\mu \mathrm{g} / \mathrm{L}$ & 10 & $<10$ & n.a. & 29/10/2014 04:35 \\
\hline Isopropilbenzeno & $98-82-8$ & $\mu \mathrm{g} / \mathrm{L}$ & 10 & $<10$ & n.a. & 29/10/2014 04:35 \\
\hline 1,3,5-Triclorobenzeno & $108-70-3$ & $\mu \mathrm{g} / \mathrm{L}$ & 10 & $<10$ & n.a. & 29/10/2014 04:35 \\
\hline
\end{tabular}

\section{CONTROLE DE Q UALIDADE DO LAB ORATÓRIO}

Controle de Q ualidade - VOC - Água

286352/2014-0 - Branco de Análise - VOC - Água

1,1,1-Tricloroetano Parâmetros

1,1,2-Tricloroetano

1,1,2,2-Tetracloroetano

1,1-Dicloroetano

1,1-Dicloroeteno

1,1-Dicloropropeno

1,2,3-Triclorobenzeno

1,2,4-Triclorobenzeno

1,3,5-Triclorobenzeno

1,2-Dibromo-3-Cloropropano

1,2-Dicloroetano

1,2-Dicloropropano

1,3-Dicloropropano

1,4-Diclorobenzeno

2,2-Dicloropropano

4-Metil-2-Pentanona

Benzeno

Bromobenzeno

Bromodiclorometano

Bromofórmio

Cis-1,2-Dicloroeteno

Cis-1,3-Dicloropropeno

Diclorometano

Cloreto de Vinila

Clorobenzeno

Cloroetano

Clorofórmio

Clorometano

Dibromoclorometano

Dissulfeto de Carbono

Estireno

Etilbenzeno

Hexaclorobutadieno

$\mathrm{m}, \mathrm{p}$-Xilenos

o-Xileno

p-Isopropiltolueno

Tetracloreto de Carbono

Tetracloroeteno

Tolueno

Trans-1,2-Dicloroeteno

Tricloroeteno

Isopropilbenzeno

Bromoclorometano

\begin{tabular}{|c|c|c|}
\hline Unidade & LQ & Resultados analíticos \\
\hline$\mu \mathrm{g} / \mathrm{L}$ & 1 & $<1$ \\
\hline$\mu \mathrm{g} / \mathrm{L}$ & 1 & $<1$ \\
\hline$\mu \mathrm{g} / \mathrm{L}$ & 1 & $<1$ \\
\hline$\mu \mathrm{g} / \mathrm{L}$ & 1 & $<1$ \\
\hline$\mu \mathrm{g} / \mathrm{L}$ & 1 & $<1$ \\
\hline$\mu \mathrm{g} / \mathrm{L}$ & 1 & $<1$ \\
\hline$\mu \mathrm{g} / \mathrm{L}$ & 1 & $<1$ \\
\hline$\mu \mathrm{g} / \mathrm{L}$ & 1 & $<1$ \\
\hline$\mu \mathrm{g} / \mathrm{L}$ & 1 & $<1$ \\
\hline$\mu \mathrm{g} / \mathrm{L}$ & 5 & $<5$ \\
\hline$\mu \mathrm{g} / \mathrm{L}$ & 1 & $<1$ \\
\hline$\mu \mathrm{g} / \mathrm{L}$ & 1 & $<1$ \\
\hline$\mu \mathrm{g} / \mathrm{L}$ & 5 & $<5$ \\
\hline$\mu \mathrm{g} / \mathrm{L}$ & 1 & $<1$ \\
\hline$\mu \mathrm{g} / \mathrm{L}$ & 1 & $<1$ \\
\hline$\mu \mathrm{g} / \mathrm{L}$ & 5 & $<5$ \\
\hline$\mu \mathrm{g} / \mathrm{L}$ & 1 & $<1$ \\
\hline$\mu \mathrm{g} / \mathrm{L}$ & 1 & $<1$ \\
\hline$\mu \mathrm{g} / \mathrm{L}$ & 1 & $<1$ \\
\hline$\mu \mathrm{g} / \mathrm{L}$ & 1 & $<1$ \\
\hline$\mu \mathrm{g} / \mathrm{L}$ & 1 & $<1$ \\
\hline$\mu \mathrm{g} / \mathrm{L}$ & 1 & $<1$ \\
\hline$\mu \mathrm{g} / \mathrm{L}$ & 1 & $<1$ \\
\hline$\mu \mathrm{g} / \mathrm{L}$ & 1 & $<1$ \\
\hline$\mu \mathrm{g} / \mathrm{L}$ & 1 & $<1$ \\
\hline$\mu \mathrm{g} / \mathrm{L}$ & 1 & $<1$ \\
\hline$\mu \mathrm{g} / \mathrm{L}$ & 1 & $<1$ \\
\hline$\mu \mathrm{g} / \mathrm{L}$ & 10 & $<10$ \\
\hline$\mu \mathrm{g} / \mathrm{L}$ & 1 & $<1$ \\
\hline$\mu \mathrm{g} / \mathrm{L}$ & 1 & $<1$ \\
\hline$\mu \mathrm{g} / \mathrm{L}$ & 1 & $<1$ \\
\hline$\mu \mathrm{g} / \mathrm{L}$ & 1 & $<1$ \\
\hline$\mu \mathrm{g} / \mathrm{L}$ & 1 & $<1$ \\
\hline$\mu \mathrm{g} / \mathrm{L}$ & 2 & $<2$ \\
\hline$\mu \mathrm{g} / \mathrm{L}$ & 1 & $<1$ \\
\hline$\mu \mathrm{g} / \mathrm{L}$ & 1 & $<1$ \\
\hline$\mu \mathrm{g} / \mathrm{L}$ & 1 & $<1$ \\
\hline$\mu \mathrm{g} / \mathrm{L}$ & 1 & $<1$ \\
\hline$\mu \mathrm{g} / \mathrm{L}$ & 1 & $<1$ \\
\hline$\mu \mathrm{g} / \mathrm{L}$ & 1 & $<1$ \\
\hline$\mu \mathrm{g} / \mathrm{L}$ & 1 & $<1$ \\
\hline$\mu \mathrm{g} / \mathrm{L}$ & 1 & $<1$ \\
\hline$\mu \mathrm{g} / \mathrm{L}$ & 5 & $<5$ \\
\hline
\end{tabular}




\begin{tabular}{|c|c|c|c|c|}
\hline Parâmetros & $\begin{array}{l}\text { Q uantidade } \\
\text { Adicionada }\end{array}$ & Unidade & $\begin{array}{c}\text { Resultado da } \\
\text { Recuperação (\%) }\end{array}$ & Faixa Aceitável de Recuperação (\%) \\
\hline \multicolumn{5}{|c|}{ 286353/2014-0 - Amostra Controle - VOC - Água } \\
\hline 1,1-Dicloroeteno & 20 & $\mu \mathrm{g} / \mathrm{L}$ & 90 & $70-130$ \\
\hline Benzeno & 20 & $\mu \mathrm{g} / \mathrm{L}$ & 95 & $70-130$ \\
\hline Tricloroeteno & 20 & $\mu \mathrm{g} / \mathrm{L}$ & 90 & $70-130$ \\
\hline Tolueno & 20 & $\mu \mathrm{g} / \mathrm{L}$ & 90 & $70-130$ \\
\hline Clorobenzeno & 20 & $\mu \mathrm{g} / \mathrm{L}$ & 95 & $70-130$ \\
\hline \multicolumn{5}{|c|}{$\begin{array}{l}\text { Surrogates } \\
\text { 286352/2014-0 - Branco de Análise - VOC - Água }\end{array}$} \\
\hline p-Bromofluorbenzeno & 20 & $\%$ & 97,0 & $70-130$ \\
\hline Dibrom ofluorometano & 20 & $\%$ & 108 & $70-130$ \\
\hline \multicolumn{5}{|c|}{ 286353/2014-0 - Amostra Controle - VOC - Água } \\
\hline p-Bromofluorbenzeno & 20 & $\%$ & 93,4 & $70-130$ \\
\hline Dibrom ofluorometano & 20 & $\%$ & 98,3 & $70-130$ \\
\hline \multicolumn{5}{|l|}{ 283863/2014-0 - CGBT-2 } \\
\hline Dibromofluorometano & 20 & $\%$ & Amostra Diluída & $70-130$ \\
\hline p-Bromofluorbenzeno & 20 & $\%$ & Amostra Diluída & $70-130$ \\
\hline
\end{tabular}

Notas

LQ = Limite de Quantificação.

n.a. $=$ Não Aplicável

Abrangência

(s) resultado(s) referem-se somente à(s) amostra(s) analisada(s).

Este Relatório de Ensaio só pode ser reproduzido por inteiro e sem nenhuma alteração.

Plano de Amostragem

Plano de amostragem de responsabilidade do interessado.

Responsabilidade Técnica

Os ensaios foram realizados na unidade da Bioagri Ambiental Ltda. - Matriz, situada na Rua Aljovil Martini, 177/201, Bairro Dois Córregos, Cep. 14420-833, Piracicaba/SP, registrada no CRQ 4ª Região sob n $16082-\mathrm{Fe}$ responsabilidade técnica do profissional José Carlos Moretti, CRQ n 04107238, $4^{\text {a. }}$.Região.

Referências Metodológicas

Análises foram realizadas conforme a última versão do Standard Methods for the Examination of Water \& Wastewater 22nd 2012(SMWW), EPA e ABNT (quando aplicável). VOC: EPA 8260 C: 2006, 5021A: 2003

Metiletilcetona: EPA 8260 C: 2006,5021 A: 2003

Revisores

Débora Fernandes da Silva

Daniela Rodrigues Bandoria

Chave de Validação: 01cc80c021368c93f67cff48948a5eb5

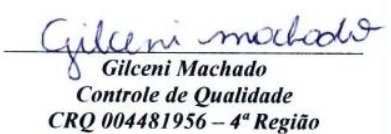

CRQ 004481956-4 Região

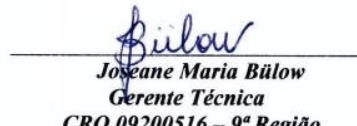

CRQ 09200516-9 $9^{a}$ Região 


\section{RELATÓRIO DE ENSAIO N $^{\circ}$ 283864/2014-0 - Piracicaba Processo Comercial $N^{\circ}$ 23961/2014-2}

\begin{tabular}{|l|l|}
\hline \multicolumn{2}{|c|}{ DADOS REFERENTES AO CLIENTE } \\
\hline Empresa solicitante: & Fundacao Parque de Alta Tecnologia da Regiao de Ipero e Adjacencias \\
\hline Endereço: & Rua Jose Antonio Scaciota, 165 - - Portal do Cedro - Iperó - SP - CEP: 18.560-000 . \\
\hline Nome do Solicitante: & Carla Marçal \\
\hline
\end{tabular}

\begin{tabular}{|l|l|l|l|l|}
\hline \multicolumn{5}{|c|}{ DADOS REFERENTES A AMOSTRA } \\
\hline Identificação do Cliente: & \multicolumn{4}{|l|}{ CGBT-3 } \\
\hline Amostra Rotulada como: & Água Subterrânea Projeto Mestrado \\
\hline Coletor: & Interessado & Data da coleta: & \multicolumn{2}{|l|}{ 23/10/2014 19:50:00 } \\
\hline Data da entrada no laboratório: & $25 / 10 / 201408: 22$ & Data de Elaboração do RE: & $03 / 11 / 2014$ \\
\hline
\end{tabular}

\section{RESULTADOS PARA A AMOSTRA}

\begin{tabular}{|c|c|c|c|c|c|c|}
\hline Parâmetros & CAS & Unidade & LQ & Resultados analíticos & Incerteza & Data do Ensaio \\
\hline 1,1,1-Tricloroetano & $71-55-6$ & $\mu \mathrm{g} / \mathrm{L}$ & 10 & $<10$ & n.a. & 29/10/2014 04:59 \\
\hline 1,1,2-Tricloroetano & $79-00-5$ & $\mu \mathrm{g} / \mathrm{L}$ & 10 & $<10$ & n.a. & 29/10/2014 04:59 \\
\hline 1,1,2,2-Tetracloroetano & $79-34-5$ & $\mu \mathrm{g} / \mathrm{L}$ & 10 & $<10$ & n.a. & 29/10/2014 04:59 \\
\hline 1,1-Dicloroetano & $75-34-3$ & $\mu \mathrm{g} / \mathrm{L}$ & 10 & $<10$ & n.a. & 29/10/2014 04:59 \\
\hline 1,1-Dicloroeteno & $75-35-4$ & $\mu \mathrm{g} / \mathrm{L}$ & 10 & $<10$ & n.a. & $29 / 10 / 201404: 59$ \\
\hline 1,1-Dicloropropeno & $563-58-6$ & $\mu \mathrm{g} / \mathrm{L}$ & 10 & $<10$ & n.a. & $29 / 10 / 201404: 59$ \\
\hline 1,2,3-Triclorobenzeno & $87-61-6$ & $\mu \mathrm{g} / \mathrm{L}$ & 10 & $<10$ & n.a. & $29 / 10 / 201404: 59$ \\
\hline 1,2,4-Triclorobenzeno & $120-82-1$ & $\mu \mathrm{g} / \mathrm{L}$ & 10 & $<10$ & n.a. & 29/10/2014 04:59 \\
\hline 1,2-Dibromo-3-Cloropropano & $96-12-8$ & $\mu \mathrm{g} / \mathrm{L}$ & 50 & $<50$ & n.a. & 29/10/2014 04:59 \\
\hline 1,2-Dicloroetano & $107-06-2$ & $\mu \mathrm{g} / \mathrm{L}$ & 10 & $<10$ & n.a. & 29/10/2014 04:59 \\
\hline 1,2-Dicloropropano & $78-87-5$ & $\mu \mathrm{g} / \mathrm{L}$ & 10 & $<10$ & n.a. & $29 / 10 / 201404: 59$ \\
\hline 1,3-Dicloropropano & $142-28-9$ & $\mu \mathrm{g} / \mathrm{L}$ & 50 & $<50$ & n.a. & $29 / 10 / 201404: 59$ \\
\hline 1,4-Diclorobenzeno & $106-46-7$ & $\mu \mathrm{g} / \mathrm{L}$ & 10 & $<10$ & n.a. & $29 / 10 / 201404: 59$ \\
\hline 2,2-Dicloropropano & $594-20-7$ & $\mu \mathrm{g} / \mathrm{L}$ & 10 & $<10$ & n.a. & $29 / 10 / 201404: 59$ \\
\hline 4-Metil-2-Pentanona & $108-10-1$ & $\mu \mathrm{g} / \mathrm{L}$ & 50 & $<50$ & n.a. & 29/10/2014 04:59 \\
\hline Benzeno & $71-43-2$ & $\mu \mathrm{g} / \mathrm{L}$ & 10 & $<10$ & n.a. & 29/10/2014 04:59 \\
\hline Bromobenzeno & $108-86-1$ & $\mu \mathrm{g} / \mathrm{L}$ & 10 & $<10$ & n.a. & 29/10/2014 04:59 \\
\hline Bromodiclorometano & $75-27-4$ & $\mu \mathrm{g} / \mathrm{L}$ & 10 & $<10$ & n.a. & $29 / 10 / 201404: 59$ \\
\hline Bromofórmio & $75-25-2$ & $\mu \mathrm{g} / \mathrm{L}$ & 10 & $<10$ & n.a. & 29/10/2014 04:59 \\
\hline Bromoclorometano & $74-97-5$ & $\mu \mathrm{g} / \mathrm{L}$ & 50 & $<50$ & n.a. & 29/10/2014 04:59 \\
\hline Cis-1,2-Dicloroeteno & $156-59-2$ & $\mu \mathrm{g} / \mathrm{L}$ & 10 & $<10$ & n.a. & 29/10/2014 04:59 \\
\hline Cis-1,3-Dicloropropeno & 10061-01-5 & $\mu \mathrm{g} / \mathrm{L}$ & 10 & $<10$ & n.a. & 29/10/2014 04:59 \\
\hline Diclorometano & $75-09-2$ & $\mu \mathrm{g} / \mathrm{L}$ & 10 & $<10$ & n.a. & 29/10/2014 04:59 \\
\hline Cloreto de Vinila & 75-01-4 & $\mu \mathrm{g} / \mathrm{L}$ & 10 & $<10$ & n.a. & 29/10/2014 04:59 \\
\hline Clorobenzeno & $108-90-7$ & $\mu \mathrm{g} / \mathrm{L}$ & 10 & $<10$ & n.a. & $29 / 10 / 201404: 59$ \\
\hline Cloroetano & $75-00-3$ & $\mu \mathrm{g} / \mathrm{L}$ & 10 & $<10$ & n.a. & $29 / 10 / 201404: 59$ \\
\hline Clorofórmio & $67-66-3$ & $\mu \mathrm{g} / \mathrm{L}$ & 10 & $<10$ & n.a. & 29/10/2014 04:59 \\
\hline Clorometano & $74-87-3$ & $\mu \mathrm{g} / \mathrm{L}$ & 100 & $<100$ & n.a. & 29/10/2014 04:59 \\
\hline Dibromoclorometano & $124-48-1$ & $\mu \mathrm{g} / \mathrm{L}$ & 10 & $<10$ & n.a. & 29/10/2014 04:59 \\
\hline Dissulfeto de Carbono & $75-15-0$ & $\mu \mathrm{g} / \mathrm{L}$ & 10 & $<10$ & n.a. & $29 / 10 / 201404: 59$ \\
\hline Estireno & $100-42-5$ & $\mu \mathrm{g} / \mathrm{L}$ & 10 & $<10$ & n.a. & 29/10/2014 04:59 \\
\hline Etilbenzeno & $100-41-4$ & $\mu \mathrm{g} / \mathrm{L}$ & 10 & $<10$ & n.a. & $29 / 10 / 201404: 59$ \\
\hline Hexaclorobutadieno & $87-68-3$ & $\mu \mathrm{g} / \mathrm{L}$ & 10 & $<10$ & n.a. & 29/10/2014 04:59 \\
\hline $\mathrm{m}, \mathrm{p}$-Xilenos & --- & $\mu \mathrm{g} / \mathrm{L}$ & 20 & $<20$ & n.a. & 29/10/2014 04:59 \\
\hline o-Xileno & $95-47-6$ & $\mu \mathrm{g} / \mathrm{L}$ & 10 & $<10$ & n.a. & 29/10/2014 04:59 \\
\hline p-Isopropiltolueno & $99-87-6$ & $\mu \mathrm{g} / \mathrm{L}$ & 10 & $<10$ & n.a. & 29/10/2014 04:59 \\
\hline Tetracloreto de Carbono & $56-23-5$ & $\mu \mathrm{g} / \mathrm{L}$ & 10 & $<10$ & n.a. & 29/10/2014 04:59 \\
\hline Tetracloroeteno & $127-18-4$ & $\mu \mathrm{g} / \mathrm{L}$ & 1000 & 14200 & 2700 & 29/10/2014 04:59 \\
\hline Tolueno & $108-88-3$ & $\mu \mathrm{g} / \mathrm{L}$ & 10 & $<10$ & n.a. & 29/10/2014 04:59 \\
\hline Trans-1,2-Dicloroeteno & $156-60-5$ & $\mu \mathrm{g} / \mathrm{L}$ & 10 & $<10$ & n.a. & 29/10/2014 04:59 \\
\hline Tricloroeteno & $79-01-6$ & $\mu \mathrm{g} / \mathrm{L}$ & 10 & $<10$ & n.a. & $29 / 10 / 201404: 59$ \\
\hline 1,1,1,2-Tetracloroetano & $630-20-6$ & $\mu \mathrm{g} / \mathrm{L}$ & 10 & $<10$ & n.a. & $29 / 10 / 201404: 59$ \\
\hline
\end{tabular}




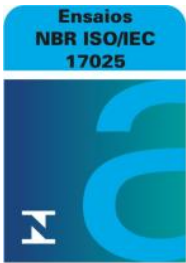

CRL 0172

\begin{tabular}{|c|c|c|c|c|c|c|}
\hline Parâmetros & CAS & Unidade & LQ & Resultados analíticos & Incerteza & Data do Ensaio \\
\hline 1,2,3-Tricloropropano & $96-18-4$ & $\mu \mathrm{g} / \mathrm{L}$ & 50 & $<50$ & n.a. & 29/10/2014 04:59 \\
\hline 1,3,5-Trimetilbenzeno & $108-67-8$ & $\mu \mathrm{g} / \mathrm{L}$ & 10 & $<10$ & n.a. & 29/10/2014 04:59 \\
\hline 1,2,4-Trimetilbenzeno & $95-63-6$ & $\mu \mathrm{g} / \mathrm{L}$ & 10 & $<10$ & n.a. & 29/10/2014 04:59 \\
\hline 1,2-Dibromoetano & $106-93-4$ & $\mu \mathrm{g} / \mathrm{L}$ & 10 & $<10$ & n.a. & 29/10/2014 04:59 \\
\hline 1,2-Diclorobenzeno & $95-50-1$ & $\mu \mathrm{g} / \mathrm{L}$ & 10 & $<10$ & n.a. & 29/10/2014 04:59 \\
\hline 1,3-Diclorobenzeno & $541-73-1$ & $\mu \mathrm{g} / \mathrm{L}$ & 10 & $<10$ & n.a. & 29/10/2014 04:59 \\
\hline 2-Clorotolueno & $95-49-8$ & $\mu \mathrm{g} / \mathrm{L}$ & 10 & $<10$ & n.a. & 29/10/2014 04:59 \\
\hline Dibromometano & 74-95-3 & $\mu \mathrm{g} / \mathrm{L}$ & 10 & $<10$ & n.a. & 29/10/2014 04:59 \\
\hline Metiletilcetona & 78-93-3 & $\mu \mathrm{g} / \mathrm{L}$ & 25000 & $<25000$ & n.a. & 30/10/2014 04:08 \\
\hline Naftaleno & $91-20-3$ & $\mu \mathrm{g} / \mathrm{L}$ & 10 & $<10$ & n.a. & 29/10/2014 04:59 \\
\hline n-Butilbenzeno & $104-51-8$ & $\mu \mathrm{g} / \mathrm{L}$ & 10 & $<10$ & n.a. & 29/10/2014 04:59 \\
\hline n-Propilbenzeno & $103-65-1$ & $\mu \mathrm{g} / \mathrm{L}$ & 10 & $<10$ & n.a. & 29/10/2014 04:59 \\
\hline 4-Clorotolueno & $106-43-4$ & $\mu \mathrm{g} / \mathrm{L}$ & 10 & $<10$ & n.a. & $29 / 10 / 201404: 59$ \\
\hline sec-Butilbenzeno & $135-98-8$ & $\mu \mathrm{g} / \mathrm{L}$ & 10 & $<10$ & n.a. & 29/10/2014 04:59 \\
\hline terc-Butilbenzeno & 98-06-6 & $\mu \mathrm{g} / \mathrm{L}$ & 10 & $<10$ & n.a. & 29/10/2014 04:59 \\
\hline trans-1,3-Dicloropropeno & $10061-02-6$ & $\mu \mathrm{g} / \mathrm{L}$ & 10 & $<10$ & n.a. & 29/10/2014 04:59 \\
\hline Isopropilbenzeno & $98-82-8$ & $\mu \mathrm{g} / \mathrm{L}$ & 10 & $<10$ & n.a. & 29/10/2014 04:59 \\
\hline 1,3,5-Triclorobenzeno & $108-70-3$ & $\mu \mathrm{g} / \mathrm{L}$ & 10 & $<10$ & n.a. & 29/10/2014 04:59 \\
\hline
\end{tabular}

\section{CONTROLE DE Q UALIDADE DO LAB ORATÓRIO}

Controle de Q ualidade - VOC - Água

286352/2014-0 - Branco de Análise - VOC - Água

Parâmetros

1,1,2-Tricloroetano

1,1,2,2-Tetracloroetano

1,1-Dicloroetano

1,1-Dicloroeteno

1,1-Dicloropropeno

1,2,3-Triclorobenzeno

1,2,4-Triclorobenzeno

1,3,5-Triclorobenzeno

1,2-Dibromo-3-Cloropropano

1,2-Dicloroetano

1,2-Dicloropropano

1,3-Dicloropropano

1,4-Diclorobenzeno

2,2-Dicloropropano

4-Metil-2-Pentanona

Benzeno

Bromobenzeno

Bromodiclorometano

Bromofórmio

Cis-1,2-Dicloroeteno

Cis-1,3-Dicloropropeno

Diclorometano

Cloreto de Vinila

Clorobenzeno

Cloroetano

Clorofórmio

Clorometano

Dibromoclorometano

Dissulfeto de Carbono

Estireno

Etilbenzeno

Hexaclorobutadieno

m,p-Xilenos

o-Xileno

p-Isopropiltolueno

Tetracloreto de Carbono

Tetracloroeteno

Tolueno

Trans-1,2-Dicloroeteno

Tricloroeteno

Isopropilbenzeno

Bromoclorometano
Unidade

$\mu \mathrm{g} / \mathrm{L}$

$\mu \mathrm{g} / \mathrm{L}$

$\mu \mathrm{g} / \mathrm{L}$

$\mu \mathrm{g} / \mathrm{L}$

$\mu \mathrm{g} / \mathrm{L}$

$\mu \mathrm{g} / \mathrm{L}$

$\mu \mathrm{g} / \mathrm{L}$

$\mu \mathrm{g} / \mathrm{L}$

$\mu \mathrm{g} / \mathrm{L}$

$\mu \mathrm{g} / \mathrm{L}$

$\mu \mathrm{g} / \mathrm{L}$

$\mu \mathrm{g} / \mathrm{L}$

$\mu \mathrm{g} / \mathrm{L}$

$\mu \mathrm{g} / \mathrm{L}$

$\mu \mathrm{g} / \mathrm{L}$

$\mu \mathrm{g} / \mathrm{L}$

$\mu \mathrm{g} / \mathrm{L}$

$\mu \mathrm{g} / \mathrm{L}$

$\mu \mathrm{g} / \mathrm{L}$

$\mu \mathrm{g} / \mathrm{L}$

$\mu \mathrm{g} / \mathrm{L}$

$\mu \mathrm{g} / \mathrm{L}$

$\mu \mathrm{g} / \mathrm{L}$

$\mu \mathrm{g} / \mathrm{L}$

$\mu \mathrm{g} / \mathrm{L}$

$\mu \mathrm{g} / \mathrm{L}$

$\mu \mathrm{g} / \mathrm{L}$

$\mu \mathrm{g} / \mathrm{L}$

$\mu \mathrm{g} / \mathrm{L}$

$\mu \mathrm{g} / \mathrm{L}$

$\mu \mathrm{g} / \mathrm{L}$

$\mu \mathrm{g} / \mathrm{L}$

$\mu \mathrm{g} / \mathrm{L}$

$\mu \mathrm{g} / \mathrm{L}$

$\mu \mathrm{g} / \mathrm{L}$

$\mu \mathrm{g} / \mathrm{L}$

$\mu \mathrm{g} / \mathrm{L}$

$\mu \mathrm{g} / \mathrm{L}$

$\mu \mathrm{g} / \mathrm{L}$

$\mu \mathrm{g} / \mathrm{L}$

$\mu \mathrm{g} / \mathrm{L}$

$\mu \mathrm{g} / \mathrm{L}$

$\begin{array}{cc}\text { LQ } & \text { Resultados analíticos } \\ 1 & <1\end{array}$

$<1$

$<1$

$\begin{array}{ll}1 & <1 \\ 1 & <1\end{array}$

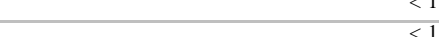

$<1$

$1<1$

$\begin{array}{ll}1 & <1 \\ 5 & <5\end{array}$

$1<<1$

$<1$
$<5$

$1<1$

$5-12$

$5<<$

$1<<1$

$\begin{array}{ll}1 & <1 \\ 1 & <1\end{array}$

$\begin{array}{ll}1 & <1 \\ 1 & <1 \\ 1 & <1\end{array}$

$1<1$

$<1$

$1<1$




\begin{tabular}{|c|c|c|c|c|}
\hline Parâmetros & $\begin{array}{l}\text { Q uantidade } \\
\text { Adicionada }\end{array}$ & Unidade & $\begin{array}{c}\text { Resultado da } \\
\text { Recuperação (\%) }\end{array}$ & Faixa Aceitável de Recuperação (\%) \\
\hline \multicolumn{5}{|c|}{ 286353/2014-0 - Amostra Controle - VOC - Água } \\
\hline 1,1-Dicloroeteno & 20 & $\mu \mathrm{g} / \mathrm{L}$ & 90 & $70-130$ \\
\hline Benzeno & 20 & $\mu \mathrm{g} / \mathrm{L}$ & 95 & $70-130$ \\
\hline Tricloroeteno & 20 & $\mu \mathrm{g} / \mathrm{L}$ & 90 & $70-130$ \\
\hline Tolueno & 20 & $\mu \mathrm{g} / \mathrm{L}$ & 90 & $70-130$ \\
\hline Clorobenzeno & 20 & $\mu \mathrm{g} / \mathrm{L}$ & 95 & $70-130$ \\
\hline \multicolumn{5}{|c|}{$\begin{array}{l}\text { Surrogates } \\
\text { 286352/2014-0 - Branco de Análise - VOC - Água }\end{array}$} \\
\hline p-Bromofluorbenzeno & 20 & $\%$ & 97,0 & $70-130$ \\
\hline Dibrom ofluorometano & 20 & $\%$ & 108 & $70-130$ \\
\hline \multicolumn{5}{|c|}{ 286353/2014-0 - Amostra Controle - VOC - Água } \\
\hline p-Bromofluorbenzeno & 20 & $\%$ & 93,4 & $70-130$ \\
\hline Dibrom ofluorometano & 20 & $\%$ & 98,3 & $70-130$ \\
\hline \multicolumn{5}{|l|}{ 283864/2014-0 - CGBT-3 } \\
\hline Dibromofluorometano & 20 & $\%$ & Amostra Diluída & $70-130$ \\
\hline p-Bromofluorbenzeno & 20 & $\%$ & Amostra Diluída & $70-130$ \\
\hline
\end{tabular}

Notas

LQ = Limite de Quantificação.

n.a. $=$ Não Aplicável

Abrangência

(s) resultado(s) referem-se somente à(s) amostra(s) analisada(s).

Este Relatório de Ensaio só pode ser reproduzido por inteiro e sem nenhuma alteração.

Plano de Amostragem

Plano de amostragem de responsabilidade do interessado.

Responsabilidade Técnica

Os ensaios foram realizados na unidade da Bioagri Ambiental Ltda. - Matriz, situada na Rua Aljovil Martini, 177/201, Bairro Dois Córregos, Cep. 14420-833, Piracicaba/SP, registrada no CRQ 4ª Região sob n $16082-\mathrm{Fe}$ responsabilidade técnica do profissional José Carlos Moretti, CRQ n 04107238, $4^{\text {a. }}$.Região.

Referências Metodológicas

Análises foram realizadas conforme a última versão do Standard Methods for the Examination of Water \& Wastewater 22nd 2012(SMWW), EPA e ABNT (quando aplicável). VOC: EPA 8260 C: 2006, 5021A: 2003

Metiletilcetona: EPA 8260 C: 2006, 5021 A: 2003

Revisores

Débora Fernandes da Silva

Daniela Rodrigues Bandoria

Chave de Validação: 7856aa5a870669a835edd1b62ee37bd7

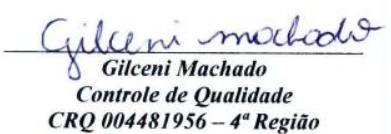

CRQ 004481956-4 Região

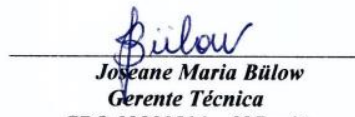

CRQ 09200516-9a Região 


\section{RELATÓRIO DE ENSAIO N $^{\circ}$ 283886/2014-0 - Piracicaba Processo Comercial $N^{\circ}$ 23961/2014-2}

\begin{tabular}{|l|l|}
\hline \multicolumn{2}{|c|}{ DADOS REFERENTES AO CLIENTE } \\
\hline Empresa solicitante: & Fundacao Parque de Alta Tecnologia da Regiao de Ipero e Adjacencias \\
\hline Endereço: & Rua Jose Antonio Scaciota, 165 - - Portal do Cedro - Iperó - SP - CEP: 18.560-000 . \\
\hline Nome do Solicitante: & Carla Marçal \\
\hline
\end{tabular}

\section{DADOS REFERENTES A AMOSTRA}

\begin{tabular}{|c|c|c|c|c|c|}
\hline Identificação do Cliente: & \multicolumn{5}{|c|}{ CAI-1 } \\
\hline Amostra Rotulada como: & \multicolumn{5}{|c|}{ Solo Projeto Mestrado } \\
\hline Coletor: & \multicolumn{2}{|c|}{ Interessado } & Data da coleta: & \multicolumn{2}{|c|}{ 24/10/2014 14:00:00 } \\
\hline \multicolumn{2}{|c|}{ Data da entrada no laboratório: } & 25/10/2014 08:29 & \multicolumn{2}{|c|}{ Data de Elaboração do RE: } & $03 / 11 / 2014$ \\
\hline
\end{tabular}

\section{RESULTADOS PARA A AMOSTRA}

\begin{tabular}{|c|c|c|c|c|c|c|}
\hline Parâmetros & CAS & Unidade & LQ & Resultados analíticos & Incerteza & Data do Ensaio \\
\hline 1,1,1-Tricloroetano & $71-55-6$ & $\mathrm{mg} / \mathrm{kg}$ & 0,01 & $<0,01$ & n.a. & $29 / 10 / 201417: 22$ \\
\hline 1,1,2-Tricloroetano & $79-00-5$ & $\mathrm{mg} / \mathrm{kg}$ & 0,01 & $<0,01$ & n.a. & $29 / 10 / 201417: 22$ \\
\hline 1,1,2,2-Tetracloroetano & $79-34-5$ & $\mathrm{mg} / \mathrm{kg}$ & 0,01 & $<0,01$ & n.a. & $29 / 10 / 201417: 22$ \\
\hline 1,1-Dicloroetano & $75-34-3$ & $\mathrm{mg} / \mathrm{kg}$ & 0,01 & $<0,01$ & n.a. & $29 / 10 / 201417: 22$ \\
\hline 1,1-Dicloroeteno & $75-35-4$ & $\mathrm{mg} / \mathrm{kg}$ & 0,01 & $<0,01$ & n.a. & $29 / 10 / 201417: 22$ \\
\hline 1,1-Dicloropropeno & $563-58-6$ & $\mathrm{mg} / \mathrm{kg}$ & 0,01 & $<0,01$ & n.a. & $29 / 10 / 201417: 22$ \\
\hline 1,2,3-Triclorobenzeno & $87-61-6$ & $\mathrm{mg} / \mathrm{kg}$ & 0,01 & $<0,01$ & n.a. & $29 / 10 / 201417: 22$ \\
\hline 1,2,4-Triclorobenzeno & $120-82-1$ & $\mathrm{mg} / \mathrm{kg}$ & 0,01 & $<0,01$ & n.a. & 29/10/2014 17:22 \\
\hline 1,2-Dibromo-3-Cloropropano & $96-12-8$ & $\mathrm{mg} / \mathrm{kg}$ & 0,01 & $<0,01$ & n.a. & $29 / 10 / 201417: 22$ \\
\hline 1,2-Dicloroetano & $107-06-2$ & $\mathrm{mg} / \mathrm{kg}$ & 0,01 & $<0,01$ & n.a. & $29 / 10 / 201417: 22$ \\
\hline 1,2-Dicloropropano & $78-87-5$ & $\mathrm{mg} / \mathrm{kg}$ & 0,01 & $<0,01$ & n.a. & $29 / 10 / 201417: 22$ \\
\hline 1,3-Diclorobenzeno & $541-73-1$ & $\mathrm{mg} / \mathrm{kg}$ & 0,01 & $<0,01$ & n.a. & $29 / 10 / 201417: 22$ \\
\hline 2,2-Dicloropropano & $594-20-7$ & $\mathrm{mg} / \mathrm{kg}$ & 0,01 & $<0,01$ & n.a. & $29 / 10 / 2014$ 17:22 \\
\hline 4-Metil-2-Pentanona & $108-10-1$ & $\mathrm{mg} / \mathrm{kg}$ & 0,01 & $<0,01$ & n.a. & $29 / 10 / 201417: 22$ \\
\hline Benzeno & $71-43-2$ & $\mathrm{mg} / \mathrm{kg}$ & 0,01 & $<0,01$ & n.a. & $29 / 10 / 201417: 22$ \\
\hline Bromobenzeno & $108-86-1$ & $\mathrm{mg} / \mathrm{kg}$ & 0,01 & $<0,01$ & n.a. & $29 / 10 / 201417: 22$ \\
\hline Bromodiclorometano & $75-27-4$ & $\mathrm{mg} / \mathrm{kg}$ & 0,01 & $<0,01$ & n.a. & 29/10/2014 17:22 \\
\hline Bromofórmio & $75-25-2$ & $\mathrm{mg} / \mathrm{kg}$ & 0,01 & $<0,01$ & n.a. & $29 / 10 / 201417: 22$ \\
\hline Bromometano & $74-83-9$ & $\mathrm{mg} / \mathrm{kg}$ & 0,01 & $<0,01$ & n.a. & $29 / 10 / 201417: 22$ \\
\hline Cis-1,2-Dicloroeteno & $156-59-2$ & $\mathrm{mg} / \mathrm{kg}$ & 0,01 & $<0,01$ & n.a. & $29 / 10 / 201417: 22$ \\
\hline Cis-1,3-Dicloropropeno & $10061-01-5$ & $\mathrm{mg} / \mathrm{kg}$ & 0,01 & $<0,01$ & n.a. & $29 / 10 / 201417: 22$ \\
\hline Diclorometano & $75-09-2$ & $\mathrm{mg} / \mathrm{kg}$ & 0,01 & $<0,01$ & n.a. & $29 / 10 / 201417: 22$ \\
\hline Cloreto de Vinila & $75-01-4$ & $\mathrm{mg} / \mathrm{kg}$ & 0,002 & $<0,002$ & n.a. & $29 / 10 / 201417: 22$ \\
\hline Clorobenzeno & $108-90-7$ & $\mathrm{mg} / \mathrm{kg}$ & 0,01 & $<0,01$ & n.a. & $29 / 10 / 201417: 22$ \\
\hline Cloroetano & $75-00-3$ & $\mathrm{mg} / \mathrm{kg}$ & 0,01 & $<0,01$ & n.a. & 29/10/2014 17:22 \\
\hline Clorofórmio & $67-66-3$ & $\mathrm{mg} / \mathrm{kg}$ & 0,01 & $<0,01$ & n.a. & $29 / 10 / 201417: 22$ \\
\hline Clorometano & $74-87-3$ & $\mathrm{mg} / \mathrm{kg}$ & 0,01 & $<0,01$ & n.a. & $29 / 10 / 201417: 22$ \\
\hline Dibromoclorometano & $124-48-1$ & $\mathrm{mg} / \mathrm{kg}$ & 0,01 & $<0,01$ & n.a. & $29 / 10 / 201417: 22$ \\
\hline Dissulfeto de Carbono & $75-15-0$ & $\mathrm{mg} / \mathrm{kg}$ & 0,01 & $<0,01$ & n.a. & $29 / 10 / 201417: 22$ \\
\hline Estireno & $100-42-5$ & $\mathrm{mg} / \mathrm{kg}$ & 0,01 & $<0,01$ & n.a. & $29 / 10 / 201417: 22$ \\
\hline Etilbenzeno & $100-41-4$ & $\mathrm{mg} / \mathrm{kg}$ & 0,01 & $<0,01$ & n.a. & 29/10/2014 17:22 \\
\hline Hexaclorobutadieno & $87-68-3$ & $\mathrm{mg} / \mathrm{kg}$ & 0,01 & $<0,01$ & n.a. & $29 / 10 / 201417: 22$ \\
\hline m,p-Xilenos & --- & $\mathrm{mg} / \mathrm{kg}$ & 0,01 & $<0,01$ & n.a. & 29/10/2014 17:22 \\
\hline o-Xileno & $95-47-6$ & $\mathrm{mg} / \mathrm{kg}$ & 0,01 & $<0,01$ & n.a. & $29 / 10 / 2014$ 17:22 \\
\hline p-Isopropiltolueno & $99-87-6$ & $\mathrm{mg} / \mathrm{kg}$ & 0,01 & $<0,01$ & n.a. & 29/10/2014 17:22 \\
\hline Tetracloroeteno & $127-18-4$ & $\mathrm{mg} / \mathrm{kg}$ & 1,19 & 11,8 & 2,4 & $29 / 10 / 201417: 22$ \\
\hline Tetracloreto de Carbono & $56-23-5$ & $\mathrm{mg} / \mathrm{kg}$ & 0,01 & $<0,01$ & n.a. & 29/10/2014 17:22 \\
\hline Tolueno & $108-88-3$ & $\mathrm{mg} / \mathrm{kg}$ & 0,01 & $<0,01$ & n.a. & $29 / 10 / 201417: 22$ \\
\hline Trans-1,2-Dicloroeteno & $156-60-5$ & $\mathrm{mg} / \mathrm{kg}$ & 0,01 & $<0,01$ & n.a. & $29 / 10 / 201417: 22$ \\
\hline Tricloroeteno & $79-01-6$ & $\mathrm{mg} / \mathrm{kg}$ & 0,01 & $<0,01$ & n.a. & $29 / 10 / 201417: 22$ \\
\hline 1,1,1,2-Tetracloroetano & $630-20-6$ & $\mathrm{mg} / \mathrm{kg}$ & 0,01 & $<0,01$ & n.a. & $29 / 10 / 201417: 22$ \\
\hline 1,2,3-Tricloropropano & $96-18-4$ & $\mathrm{mg} / \mathrm{kg}$ & 0,01 & $<0,01$ & n.a. & $29 / 10 / 201417: 22$ \\
\hline
\end{tabular}




\begin{tabular}{|c|c|c|c|c|c|c|}
\hline Parâmetros & CAS & Unidade & LQ & Resultados analíticos & Incerteza & Data do Ensaio \\
\hline 1,3,5-Trimetilbenzeno & $108-67-8$ & $\mathrm{mg} / \mathrm{kg}$ & 0,01 & $<0,01$ & n.a. & 29/10/2014 17:22 \\
\hline 1,2,4-Trimetilbenzeno & $95-63-6$ & $\mathrm{mg} / \mathrm{kg}$ & 0,01 & $<0,01$ & n.a. & $29 / 10 / 201417: 22$ \\
\hline 1,2-Dibromoetano & $106-93-4$ & $\mathrm{mg} / \mathrm{kg}$ & 0,01 & $<0,01$ & n.a. & $29 / 10 / 201417: 22$ \\
\hline 1,2-Diclorobenzeno & $95-50-1$ & $\mathrm{mg} / \mathrm{kg}$ & 0,01 & $<0,01$ & n.a. & $29 / 10 / 201417: 22$ \\
\hline 2-Clorotolueno & $95-49-8$ & $\mathrm{mg} / \mathrm{kg}$ & 0,01 & $<0,01$ & n.a. & 29/10/2014 17:22 \\
\hline Dibromometano & $74-95-3$ & $\mathrm{mg} / \mathrm{kg}$ & 0,01 & $<0,01$ & n.a. & 29/10/2014 17:22 \\
\hline Metiletilcetona & 78-93-3 & $\mathrm{mg} / \mathrm{kg}$ & 3 & $<3$ & n.a. & $30 / 10 / 201405: 30$ \\
\hline Naftaleno & $91-20-3$ & $\mathrm{mg} / \mathrm{kg}$ & 0,01 & $<0,01$ & n.a. & $29 / 10 / 201417: 22$ \\
\hline n-Butilbenzeno & $104-51-8$ & $\mathrm{mg} / \mathrm{kg}$ & 0,01 & $<0,01$ & n.a. & $29 / 10 / 201417: 22$ \\
\hline n-Propilbenzeno & $103-65-1$ & $\mathrm{mg} / \mathrm{kg}$ & 0,01 & $<0,01$ & n.a. & 29/10/2014 17:22 \\
\hline 4-Clorotolueno & $106-43-4$ & $\mathrm{mg} / \mathrm{kg}$ & 0,01 & $<0,01$ & n.a. & $29 / 10 / 201417: 22$ \\
\hline sec-Butilbenzeno & $135-98-8$ & $\mathrm{mg} / \mathrm{kg}$ & 0,01 & $<0,01$ & n.a. & $29 / 10 / 201417: 22$ \\
\hline terc-Butilbenzeno & $98-06-6$ & $\mathrm{mg} / \mathrm{kg}$ & 0,01 & $<0,01$ & n.a. & $29 / 10 / 201417: 22$ \\
\hline trans-1,3-Dicloropropeno & $10061-02-6$ & $\mathrm{mg} / \mathrm{kg}$ & 0,01 & $<0,01$ & n.a. & $29 / 10 / 201417: 22$ \\
\hline Isopropilbenzeno & $98-82-8$ & $\mathrm{mg} / \mathrm{kg}$ & 0,01 & $<0,01$ & n.a. & $29 / 10 / 201417: 22$ \\
\hline 1,4-Diclorobenzeno & $106-46-7$ & $\mathrm{mg} / \mathrm{kg}$ & 0,01 & $<0,01$ & n.a. & 29/10/2014 17:22 \\
\hline 1,3,5-Triclorobenzeno & $108-70-3$ & $\mathrm{mg} / \mathrm{kg}$ & 0,01 & $<0,01$ & n.a. & $29 / 10 / 2014$ 17:22 \\
\hline 1,3-Dicloropropano & $142-28-9$ & $\mathrm{mg} / \mathrm{kg}$ & 0,01 & $<0,01$ & n.a. & $29 / 10 / 201417: 22$ \\
\hline Porcentagem de Sólidos & --- & $\% \mathrm{p} / \mathrm{p}$ & 0,05 & 83,7 & 8,4 & 01/11/2014 07:57 \\
\hline
\end{tabular}

\section{CONTROLE DE Q UALIDADE DO LAB ORATÓRIO}

284309/2014-0 - B ranco de Análise - VOC - Solo

Controle de $Q$ ualidade - VOC - Solo

\begin{tabular}{|c|c|c|c|}
\hline Parâmetros & Unidade & LQ & Resultados analíticos \\
\hline 1,1,1-Tricloroetano & $\mathrm{mg} / \mathrm{kg}$ & 0,01 & $<0,01$ \\
\hline 1,1,2-Tricloroetano & $\mathrm{mg} / \mathrm{kg}$ & 0,01 & $<0,01$ \\
\hline 1,1,2,2-Tetracloroetano & $\mathrm{mg} / \mathrm{kg}$ & 0,01 & $<0,01$ \\
\hline 1,1-Dicloroetano & $\mathrm{mg} / \mathrm{kg}$ & 0,01 & $<0,01$ \\
\hline 1,1-Dicloroeteno & $\mathrm{mg} / \mathrm{kg}$ & 0,01 & $<0,01$ \\
\hline 1,1-Dicloropropeno & $\mathrm{mg} / \mathrm{kg}$ & 0,01 & $<0,01$ \\
\hline 1,2,3-Triclorobenzeno & $\mathrm{mg} / \mathrm{kg}$ & 0,01 & $<0,01$ \\
\hline 1,2,4-Triclorobenzeno & $\mathrm{mg} / \mathrm{kg}$ & 0,01 & $<0,01$ \\
\hline 1,2-Dibromo-3-Cloropropano & $\mathrm{mg} / \mathrm{kg}$ & 0,01 & $<0,01$ \\
\hline 1,2-Dicloroetano & $\mathrm{mg} / \mathrm{kg}$ & 0,01 & $<0,01$ \\
\hline 1,2-Dicloropropano & $\mathrm{mg} / \mathrm{kg}$ & 0,01 & $<0,01$ \\
\hline 1,3-Dicloropropano & $\mathrm{mg} / \mathrm{kg}$ & 0,01 & $<0,01$ \\
\hline 1,4-Diclorobenzeno & $\mathrm{mg} / \mathrm{kg}$ & 0,01 & $<0,01$ \\
\hline 2,2-Dicloropropano & $\mathrm{mg} / \mathrm{kg}$ & 0,01 & $<0,01$ \\
\hline 4-Metil-2-Pentanona & $\mathrm{mg} / \mathrm{kg}$ & 0,01 & $<0,01$ \\
\hline Benzeno & $\mathrm{mg} / \mathrm{kg}$ & 0,01 & $<0,01$ \\
\hline Bromobenzeno & $\mathrm{mg} / \mathrm{kg}$ & 0,01 & $<0,01$ \\
\hline Bromodiclorometano & $\mathrm{mg} / \mathrm{kg}$ & 0,01 & $<0,01$ \\
\hline Bromofórmio & $\mathrm{mg} / \mathrm{kg}$ & 0,01 & $<0,01$ \\
\hline Bromometano & $\mathrm{mg} / \mathrm{kg}$ & 0,01 & $<0,01$ \\
\hline Cis-1,2-Dicloroeteno & $\mathrm{mg} / \mathrm{kg}$ & 0,01 & $<0,01$ \\
\hline Cis-1,3-Dicloropropeno & $\mathrm{mg} / \mathrm{kg}$ & 0,01 & $<0,01$ \\
\hline Diclorometano & $\mathrm{mg} / \mathrm{kg}$ & 0,01 & $<0,01$ \\
\hline Cloreto de Vinila & $\mathrm{mg} / \mathrm{kg}$ & 0,002 & $<0,002$ \\
\hline Clorobenzeno & $\mathrm{mg} / \mathrm{kg}$ & 0,01 & $<0,01$ \\
\hline Cloroetano & $\mathrm{mg} / \mathrm{kg}$ & 0,01 & $<0,01$ \\
\hline Clorofórmio & $\mathrm{mg} / \mathrm{kg}$ & 0,01 & $<0,01$ \\
\hline Clorometano & $\mathrm{mg} / \mathrm{kg}$ & 0,01 & $<0,01$ \\
\hline Dibromoclorometano & $\mathrm{mg} / \mathrm{kg}$ & 0,01 & $<0,01$ \\
\hline Dissulfeto de Carbono & $\mathrm{mg} / \mathrm{kg}$ & 0,01 & $<0,01$ \\
\hline Estireno & $\mathrm{mg} / \mathrm{kg}$ & 0,01 & $<0,01$ \\
\hline Etilbenzeno & $\mathrm{mg} / \mathrm{kg}$ & 0,01 & $<0,01$ \\
\hline Hexaclorobutadieno & $\mathrm{mg} / \mathrm{kg}$ & 0,01 & $<0,01$ \\
\hline m,p-Xilenos & $\mathrm{mg} / \mathrm{kg}$ & 0,01 & $<0,01$ \\
\hline o-Xileno & $\mathrm{mg} / \mathrm{kg}$ & 0,01 & $<0,01$ \\
\hline p-Isopropiltolueno & $\mathrm{mg} / \mathrm{kg}$ & 0,01 & $<0,01$ \\
\hline Tetracloreto de Carbono & $\mathrm{mg} / \mathrm{kg}$ & 0,01 & $<0,01$ \\
\hline Tetracloroeteno & $\mathrm{mg} / \mathrm{kg}$ & 0,01 & $<0,01$ \\
\hline Tolueno & $\mathrm{mg} / \mathrm{kg}$ & 0,01 & $<0,01$ \\
\hline Trans-1,2-Dicloroeteno & $\mathrm{mg} / \mathrm{kg}$ & 0,01 & $<0,01$ \\
\hline Tricloroeteno & $\mathrm{mg} / \mathrm{kg}$ & 0,01 & $<0,01$ \\
\hline 1,3,5-Triclorobenzeno & $\mathrm{mg} / \mathrm{kg}$ & 0,01 & $<0,01$ \\
\hline
\end{tabular}




\begin{tabular}{|c|c|c|c|c|}
\hline Parâmetros & $\begin{array}{l}\text { Q uantidade } \\
\text { Adicionada }\end{array}$ & Unidade & $\begin{array}{c}\text { Resultado da } \\
\text { Recuperação (\%) }\end{array}$ & Faixa Aceitável de Recuperação (\%) \\
\hline \multicolumn{5}{|l|}{ 284310/2014-0 - LCS - VOC - Solo } \\
\hline 1,1-Dicloroeteno & 0,05 & $\mathrm{mg} / \mathrm{kg}$ & 62 & $60-140$ \\
\hline Benzeno & 0,05 & $\mathrm{mg} / \mathrm{kg}$ & 73 & $60-140$ \\
\hline Tricloroeteno & 0,05 & $\mathrm{mg} / \mathrm{kg}$ & 82 & $60-140$ \\
\hline Tolueno & 0,05 & $\mathrm{mg} / \mathrm{kg}$ & 84 & $60-140$ \\
\hline Clorobenzeno & 0,05 & $\mathrm{mg} / \mathrm{kg}$ & 67 & $60-140$ \\
\hline \multicolumn{5}{|c|}{$\begin{array}{l}\text { Surrogates } \\
\quad 284309 / 2014-0 \text { - Branco de Análise - VOC - Solo }\end{array}$} \\
\hline p-Bromofluorbenzeno & 0,05 & $\%$ & 120 & $60-140$ \\
\hline Dibrom ofluorometano & 0,05 & $\%$ & 110 & $60-140$ \\
\hline \multicolumn{5}{|l|}{ 284310/2014-0 - LCS - VOC - Solo } \\
\hline p-Bromofluorbenzeno & 0,05 & $\%$ & 120 & $60-140$ \\
\hline Dibrom ofluorometano & 0,05 & $\%$ & 83 & $60-140$ \\
\hline \multicolumn{5}{|l|}{ 283886/2014-0 - CAI-1 } \\
\hline Dibrom ofluorometano & 0,05 & $\%$ & 70 & $60-140$ \\
\hline p-Bromofluorbenzeno & 0,05 & $\%$ & 75 & $60-140$ \\
\hline
\end{tabular}

Notas

$\mathrm{LQ}=$ Limite de Quantificação

n.a. $=$ Não Aplicável

Abrangência

(s) resultado(s) referem-se somente à(s) amostra(s) analisada(s).

Este Relatório de Ensaio só pode ser reproduzido por inteiro e sem nenhuma alteração.

Plano de Amostragem

Plano de amostragem de responsabilidade do interessado

Responsabilidade Técnica

Os ensaios foram realizados na unidade da Bioagri Ambiental Ltda. - Matriz, situada na Rua Aljovil Martini, 177/201, Bairro Dois Córregos, Cep. 14420-833, Piracicaba/SP, registrada no CRQ 4ª Região sob nº 16082-Fe responsabilidade técnica do profissional José Carlos Moretti, CRQ nº 04107238, $4^{a}$.Região.

Referências Metodológicas

Análises foram realizadas conforme a última versão do Standard Methods for the Examination of Water \& Wastewater 22nd 2012(SMWW), EPA e ABNT (quando aplicável).

Porcentagem de Sólidos e Cinzas: POP PA 058 - Rev. 02

VOC: EPA 8260 C: 2006,5021 A: 2003

Metiletilcetona: EPA 8260 C: 2006, 5021 A: 2003

Revisores

Débora Fernandes da Silva

Chave de Validação: e931b93d245ca9ebca98c2dclcbf3f25

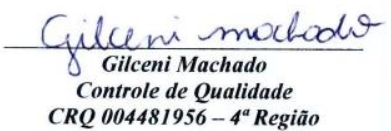

CRQ 004481956 - $4^{a}$ Região

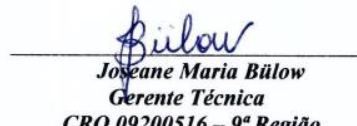

CRQ 09200516-9 $9^{a}$ Região 


\section{RELATÓRIO DE ENSAIO N $^{\circ}$ 283887/2014-0 - Piracicaba Processo Comercial $N^{\circ}$ 23961/2014-2}

\begin{tabular}{|l|l|}
\hline \multicolumn{2}{|c|}{ DADOS REFERENTES AO CLIENTE } \\
\hline Empresa solicitante: & Fundacao Parque de Alta Tecnologia da Regiao de Ipero e Adjacencias \\
\hline Endereço: & Rua Jose Antonio Scaciota, 165 - - Portal do Cedro - Iperó - SP - CEP: 18.560-000 . \\
\hline Nome do Solicitante: & Carla Marçal \\
\hline
\end{tabular}

\section{DADOS REFERENTES A AMOSTRA}

\begin{tabular}{|l|l|l|l|l|}
\hline Identificação do Cliente: & CAI-2 \\
\hline Amostra Rotulada como: & \multicolumn{4}{|l|}{ Solo Projeto Mestrado } \\
\hline Coletor: & Interessado & Data da coleta: & 24/10/2014 14:00:00 \\
\hline Data da entrada no laboratório: & $25 / 10 / 2014$ 08:30 & Data de Elaboração do RE: & $05 / 11 / 2014$ \\
\hline
\end{tabular}

\section{RESULTADOS PARA A AMOSTRA}

\begin{tabular}{|c|c|c|c|c|c|c|}
\hline Parâmetros & CAS & Unidade & LQ & Resultados analíticos & Incerteza & Data do Ensaio \\
\hline 1,1,1-Tricloroetano & $71-55-6$ & $\mathrm{mg} / \mathrm{kg}$ & 0,01 & $<0,01$ & n.a. & 29/10/2014 18:10 \\
\hline 1,1,2-Tricloroetano & $79-00-5$ & $\mathrm{mg} / \mathrm{kg}$ & 0,01 & $<0,01$ & n.a. & 29/10/2014 18:10 \\
\hline 1,1,2,2-Tetracloroetano & $79-34-5$ & $\mathrm{mg} / \mathrm{kg}$ & 0,01 & $<0,01$ & n.a. & 29/10/2014 18:10 \\
\hline 1,1-Dicloroetano & $75-34-3$ & $\mathrm{mg} / \mathrm{kg}$ & 0,01 & $<0,01$ & n.a. & 29/10/2014 18:10 \\
\hline 1,1-Dicloroeteno & $75-35-4$ & $\mathrm{mg} / \mathrm{kg}$ & 0,01 & $<0,01$ & n.a. & 29/10/2014 18:10 \\
\hline 1,1-Dicloropropeno & $563-58-6$ & $\mathrm{mg} / \mathrm{kg}$ & 0,01 & $<0,01$ & n.a. & $29 / 10 / 201418: 10$ \\
\hline 1,2,3-Triclorobenzeno & $87-61-6$ & $\mathrm{mg} / \mathrm{kg}$ & 0,01 & $<0,01$ & n.a. & 29/10/2014 18:10 \\
\hline 1,2,4-Triclorobenzeno & $120-82-1$ & $\mathrm{mg} / \mathrm{kg}$ & 0,01 & $<0,01$ & n.a. & $29 / 10 / 201418: 10$ \\
\hline 1,2-Dibromo-3-Cloropropano & $96-12-8$ & $\mathrm{mg} / \mathrm{kg}$ & 0,01 & $<0,01$ & n.a. & 29/10/2014 18:10 \\
\hline 1,2-Dicloroetano & $107-06-2$ & $\mathrm{mg} / \mathrm{kg}$ & 0,01 & $<0,01$ & n.a. & 29/10/2014 18:10 \\
\hline 1,2-Dicloropropano & $78-87-5$ & $\mathrm{mg} / \mathrm{kg}$ & 0,01 & $<0,01$ & n.a. & $29 / 10 / 201418: 10$ \\
\hline 1,3-Diclorobenzeno & $541-73-1$ & $\mathrm{mg} / \mathrm{kg}$ & 0,01 & $<0,01$ & n.a. & 29/10/2014 18:10 \\
\hline 2,2-Dicloropropano & $594-20-7$ & $\mathrm{mg} / \mathrm{kg}$ & 0,01 & $<0,01$ & n.a. & $29 / 10 / 201418: 10$ \\
\hline 4-Metil-2-Pentanona & $108-10-1$ & $\mathrm{mg} / \mathrm{kg}$ & 0,01 & $<0,01$ & n.a. & 29/10/2014 18:10 \\
\hline Benzeno & $71-43-2$ & $\mathrm{mg} / \mathrm{kg}$ & 0,01 & $<0,01$ & n.a. & 29/10/2014 18:10 \\
\hline Bromobenzeno & $108-86-1$ & $\mathrm{mg} / \mathrm{kg}$ & 0,01 & $<0,01$ & n.a. & 29/10/2014 18:10 \\
\hline Bromodiclorometano & $75-27-4$ & $\mathrm{mg} / \mathrm{kg}$ & 0,01 & $<0,01$ & n.a. & 29/10/2014 18:10 \\
\hline Bromofórmio & $75-25-2$ & $\mathrm{mg} / \mathrm{kg}$ & 0,01 & $<0,01$ & n.a. & $29 / 10 / 201418: 10$ \\
\hline Bromometano & $74-83-9$ & $\mathrm{mg} / \mathrm{kg}$ & 0,01 & $<0,01$ & n.a. & 29/10/2014 18:10 \\
\hline Cis-1,2-Dicloroeteno & $156-59-2$ & $\mathrm{mg} / \mathrm{kg}$ & 0,01 & $<0,01$ & n.a. & $29 / 10 / 201418: 10$ \\
\hline Cis-1,3-Dicloropropeno & $10061-01-5$ & $\mathrm{mg} / \mathrm{kg}$ & 0,01 & $<0,01$ & n.a. & 29/10/2014 18:10 \\
\hline Diclorometano & $75-09-2$ & $\mathrm{mg} / \mathrm{kg}$ & 0,01 & $<0,01$ & n.a. & 29/10/2014 18:10 \\
\hline Cloreto de Vinila & $75-01-4$ & $\mathrm{mg} / \mathrm{kg}$ & 0,002 & $<0,002$ & n.a. & 29/10/2014 18:10 \\
\hline Clorobenzeno & $108-90-7$ & $\mathrm{mg} / \mathrm{kg}$ & 0,01 & $<0,01$ & n.a. & 29/10/2014 18:10 \\
\hline Cloroetano & $75-00-3$ & $\mathrm{mg} / \mathrm{kg}$ & 0,01 & $<0,01$ & n.a. & 29/10/2014 18:10 \\
\hline Clorofórmio & $67-66-3$ & $\mathrm{mg} / \mathrm{kg}$ & 0,01 & $<0,01$ & n.a. & $29 / 10 / 201418: 10$ \\
\hline Clorometano & $74-87-3$ & $\mathrm{mg} / \mathrm{kg}$ & 0,01 & $<0,01$ & n.a. & 29/10/2014 18:10 \\
\hline Dibromoclorometano & $124-48-1$ & $\mathrm{mg} / \mathrm{kg}$ & 0,01 & $<0,01$ & n.a. & $29 / 10 / 201418: 10$ \\
\hline Dissulfeto de Carbono & $75-15-0$ & $\mathrm{mg} / \mathrm{kg}$ & 0,01 & $<0,01$ & n.a. & 29/10/2014 18:10 \\
\hline Estireno & $100-42-5$ & $\mathrm{mg} / \mathrm{kg}$ & 0,01 & $<0,01$ & n.a. & 29/10/2014 18:10 \\
\hline Etilbenzeno & $100-41-4$ & $\mathrm{mg} / \mathrm{kg}$ & 0,01 & $<0,01$ & n.a. & $29 / 10 / 201418: 10$ \\
\hline Hexaclorobutadieno & $87-68-3$ & $\mathrm{mg} / \mathrm{kg}$ & 0,01 & $<0,01$ & n.a. & 29/10/2014 18:10 \\
\hline m,p-Xilenos & --- & $\mathrm{mg} / \mathrm{kg}$ & 0,01 & $<0,01$ & n.a. & 29/10/2014 18:10 \\
\hline o-Xileno & $95-47-6$ & $\mathrm{mg} / \mathrm{kg}$ & 0,01 & $<0,01$ & n.a. & 29/10/2014 18:10 \\
\hline p-Isopropiltolueno & $99-87-6$ & $\mathrm{mg} / \mathrm{kg}$ & 0,01 & $<0,01$ & n.a. & 29/10/2014 18:10 \\
\hline Tetracloroeteno & $127-18-4$ & $\mathrm{mg} / \mathrm{kg}$ & 1,2 & 11,4 & 2,3 & 29/10/2014 18:10 \\
\hline Tetracloreto de Carbono & $56-23-5$ & $\mathrm{mg} / \mathrm{kg}$ & 0,01 & $<0,01$ & n.a. & 29/10/2014 18:10 \\
\hline Tolueno & $108-88-3$ & $\mathrm{mg} / \mathrm{kg}$ & 0,01 & $<0,01$ & n.a. & 29/10/2014 18:10 \\
\hline Trans-1,2-Dicloroeteno & $156-60-5$ & $\mathrm{mg} / \mathrm{kg}$ & 0,01 & $<0,01$ & n.a. & 29/10/2014 18:10 \\
\hline Tricloroeteno & $79-01-6$ & $\mathrm{mg} / \mathrm{kg}$ & 0,01 & $<0,01$ & n.a. & $29 / 10 / 201418: 10$ \\
\hline 1,1,1,2-Tetracloroetano & $630-20-6$ & $\mathrm{mg} / \mathrm{kg}$ & 0,01 & $<0,01$ & n.a. & 29/10/2014 18:10 \\
\hline 1,2,3-Tricloropropano & $96-18-4$ & $\mathrm{mg} / \mathrm{kg}$ & 0,01 & $<0,01$ & n.a. & 29/10/2014 18:10 \\
\hline
\end{tabular}




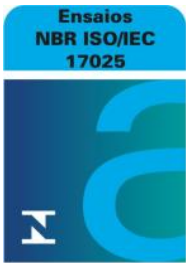

CRL 0172

\begin{tabular}{|c|c|c|c|c|c|c|}
\hline Parâmetros & CAS & Unidade & LQ & Resultados analíticos & Incerteza & Data do Ensaio \\
\hline 1,3,5-Trimetilbenzeno & $108-67-8$ & $\mathrm{mg} / \mathrm{kg}$ & 0,01 & $<0,01$ & n.a. & $29 / 10 / 201418: 10$ \\
\hline 1,2,4-Trimetilbenzeno & $95-63-6$ & $\mathrm{mg} / \mathrm{kg}$ & 0,01 & $<0,01$ & n.a. & 29/10/2014 18:10 \\
\hline 1,2-Dibromoetano & 106-93-4 & $\mathrm{mg} / \mathrm{kg}$ & 0,01 & $<0,01$ & n.a. & 29/10/2014 18:10 \\
\hline 1,2-Diclorobenzeno & $95-50-1$ & $\mathrm{mg} / \mathrm{kg}$ & 0,01 & $<0,01$ & n.a. & 29/10/2014 18:10 \\
\hline 2-Clorotolueno & $95-49-8$ & $\mathrm{mg} / \mathrm{kg}$ & 0,01 & $<0,01$ & n.a. & $29 / 10 / 201418: 10$ \\
\hline Dibromometano & $74-95-3$ & $\mathrm{mg} / \mathrm{kg}$ & 0,01 & $<0,01$ & n.a. & 29/10/2014 18:10 \\
\hline Metiletilcetona & 78-93-3 & $\mathrm{mg} / \mathrm{kg}$ & 3 & $<3$ & n.a. & $30 / 10 / 201405: 54$ \\
\hline Naftaleno & $91-20-3$ & $\mathrm{mg} / \mathrm{kg}$ & 0,01 & $<0,01$ & n.a. & 29/10/2014 18:10 \\
\hline n-Butilbenzeno & $104-51-8$ & $\mathrm{mg} / \mathrm{kg}$ & 0,01 & $<0,01$ & n.a. & 29/10/2014 18:10 \\
\hline n-Propilbenzeno & $103-65-1$ & $\mathrm{mg} / \mathrm{kg}$ & 0,01 & $<0,01$ & n.a. & 29/10/2014 18:10 \\
\hline 4-Clorotolueno & $106-43-4$ & $\mathrm{mg} / \mathrm{kg}$ & 0,01 & $<0,01$ & n.a. & $29 / 10 / 201418: 10$ \\
\hline sec-Butilbenzeno & $135-98-8$ & $\mathrm{mg} / \mathrm{kg}$ & 0,01 & $<0,01$ & n.a. & 29/10/2014 18:10 \\
\hline terc-Butilbenzeno & $98-06-6$ & $\mathrm{mg} / \mathrm{kg}$ & 0,01 & $<0,01$ & n.a. & $29 / 10 / 201418: 10$ \\
\hline trans-1,3-Dicloropropeno & $10061-02-6$ & $\mathrm{mg} / \mathrm{kg}$ & 0,01 & $<0,01$ & n.a. & 29/10/2014 18:10 \\
\hline Isopropilbenzeno & $98-82-8$ & $\mathrm{mg} / \mathrm{kg}$ & 0,01 & $<0,01$ & n.a. & $29 / 10 / 201418: 10$ \\
\hline 1,4-Diclorobenzeno & $106-46-7$ & $\mathrm{mg} / \mathrm{kg}$ & 0,01 & $<0,01$ & n.a. & 29/10/2014 18:10 \\
\hline 1,3,5-Triclorobenzeno & $108-70-3$ & $\mathrm{mg} / \mathrm{kg}$ & 0,01 & $<0,01$ & n.a. & 29/10/2014 18:10 \\
\hline 1,3-Dicloropropano & $142-28-9$ & $\mathrm{mg} / \mathrm{kg}$ & 0,01 & $<0,01$ & n.a. & $29 / 10 / 201418: 10$ \\
\hline Porcentagem de Sólidos & --- & $\% \mathrm{p} / \mathrm{p}$ & 0,05 & 83,6 & 8,4 & 01/11/2014 07:57 \\
\hline
\end{tabular}

\section{CONTROLE DE Q UALIDADE DO LAB ORATÓRIO}

284309/2014-0 - B ranco de Análise - VOC - Solo

Controle de $Q$ ualidade - VOC - Solo

\begin{tabular}{|c|c|c|c|}
\hline Parâmetros & Unidade & LQ & Resultados analíticos \\
\hline 1,1,1-Tricloroetano & $\mathrm{mg} / \mathrm{kg}$ & 0,01 & $<0,01$ \\
\hline 1,1,2-Tricloroetano & $\mathrm{mg} / \mathrm{kg}$ & 0,01 & $<0,01$ \\
\hline 1,1,2,2-Tetracloroetano & $\mathrm{mg} / \mathrm{kg}$ & 0,01 & $<0,01$ \\
\hline 1,1-Dicloroetano & $\mathrm{mg} / \mathrm{kg}$ & 0,01 & $<0,01$ \\
\hline 1,1-Dicloroeteno & $\mathrm{mg} / \mathrm{kg}$ & 0,01 & $<0,01$ \\
\hline 1,1-Dicloropropeno & $\mathrm{mg} / \mathrm{kg}$ & 0,01 & $<0,01$ \\
\hline 1,2,3-Triclorobenzeno & $\mathrm{mg} / \mathrm{kg}$ & 0,01 & $<0,01$ \\
\hline 1,2,4-Triclorobenzeno & $\mathrm{mg} / \mathrm{kg}$ & 0,01 & $<0,01$ \\
\hline 1,2-Dibromo-3-Cloropropano & $\mathrm{mg} / \mathrm{kg}$ & 0,01 & $<0,01$ \\
\hline 1,2-Dicloroetano & $\mathrm{mg} / \mathrm{kg}$ & 0,01 & $<0,01$ \\
\hline 1,2-Dicloropropano & $\mathrm{mg} / \mathrm{kg}$ & 0,01 & $<0,01$ \\
\hline 1,3-Dicloropropano & $\mathrm{mg} / \mathrm{kg}$ & 0,01 & $<0,01$ \\
\hline 1,4-Diclorobenzeno & $\mathrm{mg} / \mathrm{kg}$ & 0,01 & $<0,01$ \\
\hline 2,2-Dicloropropano & $\mathrm{mg} / \mathrm{kg}$ & 0,01 & $<0,01$ \\
\hline 4-Metil-2-Pentanona & $\mathrm{mg} / \mathrm{kg}$ & 0,01 & $<0,01$ \\
\hline Benzeno & $\mathrm{mg} / \mathrm{kg}$ & 0,01 & $<0,01$ \\
\hline Bromobenzeno & $\mathrm{mg} / \mathrm{kg}$ & 0,01 & $<0,01$ \\
\hline Bromodiclorometano & $\mathrm{mg} / \mathrm{kg}$ & 0,01 & $<0,01$ \\
\hline Bromofórmio & $\mathrm{mg} / \mathrm{kg}$ & 0,01 & $<0,01$ \\
\hline Bromometano & $\mathrm{mg} / \mathrm{kg}$ & 0,01 & $<0,01$ \\
\hline Cis-1,2-Dicloroeteno & $\mathrm{mg} / \mathrm{kg}$ & 0,01 & $<0,01$ \\
\hline Cis-1,3-Dicloropropeno & $\mathrm{mg} / \mathrm{kg}$ & 0,01 & $<0,01$ \\
\hline Diclorometano & $\mathrm{mg} / \mathrm{kg}$ & 0,01 & $<0,01$ \\
\hline Cloreto de Vinila & $\mathrm{mg} / \mathrm{kg}$ & 0,002 & $<0,002$ \\
\hline Clorobenzeno & $\mathrm{mg} / \mathrm{kg}$ & 0,01 & $<0,01$ \\
\hline Cloroetano & $\mathrm{mg} / \mathrm{kg}$ & 0,01 & $<0,01$ \\
\hline Clorofórmio & $\mathrm{mg} / \mathrm{kg}$ & 0,01 & $<0,01$ \\
\hline Clorometano & $\mathrm{mg} / \mathrm{kg}$ & 0,01 & $<0,01$ \\
\hline Dibromoclorometano & $\mathrm{mg} / \mathrm{kg}$ & 0,01 & $<0,01$ \\
\hline Dissulfeto de Carbono & $\mathrm{mg} / \mathrm{kg}$ & 0,01 & $<0,01$ \\
\hline Estireno & $\mathrm{mg} / \mathrm{kg}$ & 0,01 & $<0,01$ \\
\hline Etilbenzeno & $\mathrm{mg} / \mathrm{kg}$ & 0,01 & $<0,01$ \\
\hline Hexaclorobutadieno & $\mathrm{mg} / \mathrm{kg}$ & 0,01 & $<0,01$ \\
\hline $\mathrm{m}, \mathrm{p}$-Xilenos & $\mathrm{mg} / \mathrm{kg}$ & 0,01 & $<0,01$ \\
\hline o-Xileno & $\mathrm{mg} / \mathrm{kg}$ & 0,01 & $<0,01$ \\
\hline p-Isopropiltolueno & $\mathrm{mg} / \mathrm{kg}$ & 0,01 & $<0,01$ \\
\hline Tetracloreto de Carbono & $\mathrm{mg} / \mathrm{kg}$ & 0,01 & $<0,01$ \\
\hline Tetracloroeteno & $\mathrm{mg} / \mathrm{kg}$ & 0,01 & $<0,01$ \\
\hline Tolueno & $\mathrm{mg} / \mathrm{kg}$ & 0,01 & $<0,01$ \\
\hline Trans-1,2-Dicloroeteno & $\mathrm{mg} / \mathrm{kg}$ & 0,01 & $<0,01$ \\
\hline Tricloroeteno & $\mathrm{mg} / \mathrm{kg}$ & 0,01 & $<0,01$ \\
\hline 1,3,5-Triclorobenzeno & $\mathrm{mg} / \mathrm{kg}$ & 0,01 & $<0,01$ \\
\hline
\end{tabular}




\begin{tabular}{|c|c|c|c|c|}
\hline Parâmetros & $\begin{array}{l}\text { Q uantidade } \\
\text { Adicionada }\end{array}$ & Unidade & $\begin{array}{c}\text { Resultado da } \\
\text { Recuperação (\%) }\end{array}$ & Faixa Aceitável de Recuperação (\%) \\
\hline \multicolumn{5}{|l|}{ 284310/2014-0 - LCS - VOC - Solo } \\
\hline 1,1-Dicloroeteno & 0,05 & $\mathrm{mg} / \mathrm{kg}$ & 62 & $60-140$ \\
\hline Benzeno & 0,05 & $\mathrm{mg} / \mathrm{kg}$ & 73 & $60-140$ \\
\hline Tricloroeteno & 0,05 & $\mathrm{mg} / \mathrm{kg}$ & 82 & $60-140$ \\
\hline Tolueno & 0,05 & $\mathrm{mg} / \mathrm{kg}$ & 84 & $60-140$ \\
\hline Clorobenzeno & 0,05 & $\mathrm{mg} / \mathrm{kg}$ & 67 & $60-140$ \\
\hline \multicolumn{5}{|c|}{$\begin{array}{l}\text { Surrogates } \\
\quad 284309 / 2014-0 \text { - Branco de Análise - VOC - Solo }\end{array}$} \\
\hline p-Bromofluorbenzeno & 0,05 & $\%$ & 120 & $60-140$ \\
\hline Dibrom ofluorometano & 0,05 & $\%$ & 110 & $60-140$ \\
\hline \multicolumn{5}{|l|}{ 284310/2014-0 - LCS - VOC - Solo } \\
\hline p-Bromofluorbenzeno & 0,05 & $\%$ & 120 & $60-140$ \\
\hline Dibrom ofluorometano & 0,05 & $\%$ & 83 & $60-140$ \\
\hline \multicolumn{5}{|l|}{ 283887/2014-0 - CAI-2 } \\
\hline Dibrom ofluorometano & 0,05 & $\%$ & 72 & $60-140$ \\
\hline p-Bromofluorbenzeno & 0,05 & $\%$ & 90 & $60-140$ \\
\hline
\end{tabular}

Notas

LQ = Limite de Quantificação.

n.a. $=$ Não Aplicável.

Abrangência

$\mathrm{O}$ (s) resultado(s) referem-se somente à(s) amostra(s) analisada(s).

Este Relatório de Ensaio só pode ser reproduzido por inteiro e sem nenhuma alteração.

Plano de Amostragem

Plano de amostragem de responsabilidade do interessado

Responsabilidade Técnica

Os ensaios foram realizados na unidade da Bioagri Ambiental Ltda. - Matriz, situada na Rua Aljovil Martini, 177/201, Bairro Dois Córregos, Cep. 14420-833, Piracicaba/SP, registrada no CRQ 4ª Região sob nº 16082-Fe responsabilidade técnica do profissional José Carlos Moretti, CRQ nº 04107238, $4^{a}$.Região.

Referências Metodológicas

Análises foram realizadas conforme a última versão do Standard Methods for the Examination of Water \& Wastewater 22nd 2012(SMWW), EPA e ABNT (quando aplicável).

Porcentagem de Sólidos e Cinzas: POP PA 058 - Rev. 02

VOC: EPA 8260 C: 2006,5021 A: 2003

Metiletilcetona: EPA 8260 C: $2006,5021 \mathrm{~A}: 2003$

Revisores

Débora Fernandes da Silva

Marlon Felicio Forti

Chave de Validação: 1867ace61ee43ffa86a30713c8f9496e

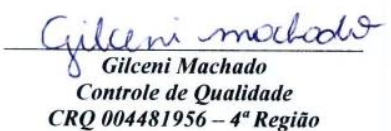

CRQ 004481956-4 Região

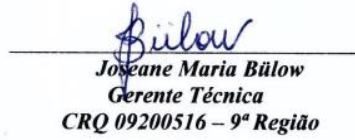




\section{RELATÓRIO DE ENSAIO N $^{\circ}$ 283888/2014-0 - Piracicaba Processo Comercial $N^{\circ}$ 23961/2014-2}

\begin{tabular}{|l|l|}
\hline \multicolumn{2}{|c|}{ DADOS REFERENTES AO CLIENTE } \\
\hline Empresa solicitante: & Fundacao Parque de Alta Tecnologia da Regiao de Ipero e Adjacencias \\
\hline Endereço: & Rua Jose Antonio Scaciota, 165 - - Portal do Cedro - Iperó - SP - CEP: 18.560-000 . \\
\hline Nome do Solicitante: & Carla Marçal \\
\hline
\end{tabular}

\section{DADOS REFERENTES A AMOSTRA}

\begin{tabular}{|l|l|l|l|l|}
\hline Identificação do Cliente: & CAI-3 \\
\hline Amostra Rotulada como: & Solo Projeto Mestrado & \multicolumn{5}{l|}{} \\
\hline Coletor: & Interessado & Data da coleta: & $24 / 10 / 2014$ 14:00:00 \\
\hline Data da entrada no laboratório: & $25 / 10 / 201408: 30$ & Data de Elaboração do RE: & $05 / 11 / 2014$ \\
\hline
\end{tabular}

\section{RESULTADOS PARA A AMOSTRA}

\begin{tabular}{|c|c|c|c|c|c|c|}
\hline Parâmetros & CAS & Unidade & LQ & Resultados analíticos & Incerteza & Data do Ensaio \\
\hline 1,1,1-Tricloroetano & $71-55-6$ & $\mathrm{mg} / \mathrm{kg}$ & 0,01 & $<0,01$ & n.a. & $29 / 10 / 201418: 58$ \\
\hline 1,1,2-Tricloroetano & $79-00-5$ & $\mathrm{mg} / \mathrm{kg}$ & 0,01 & $<0,01$ & n.a. & $29 / 10 / 201418: 58$ \\
\hline 1,1,2,2-Tetracloroetano & $79-34-5$ & $\mathrm{mg} / \mathrm{kg}$ & 0,01 & $<0,01$ & n.a. & $29 / 10 / 201418: 58$ \\
\hline 1,1-Dicloroetano & $75-34-3$ & $\mathrm{mg} / \mathrm{kg}$ & 0,01 & $<0,01$ & n.a. & 29/10/2014 18:58 \\
\hline 1,1-Dicloroeteno & $75-35-4$ & $\mathrm{mg} / \mathrm{kg}$ & 0,01 & $<0,01$ & n.a. & $29 / 10 / 201418: 58$ \\
\hline 1,1-Dicloropropeno & $563-58-6$ & $\mathrm{mg} / \mathrm{kg}$ & 0,01 & $<0,01$ & n.a. & $29 / 10 / 201418: 58$ \\
\hline 1,2,3-Triclorobenzeno & $87-61-6$ & $\mathrm{mg} / \mathrm{kg}$ & 0,01 & $<0,01$ & n.a. & $29 / 10 / 201418: 58$ \\
\hline 1,2,4-Triclorobenzeno & $120-82-1$ & $\mathrm{mg} / \mathrm{kg}$ & 0,01 & $<0,01$ & n.a. & $29 / 10 / 201418: 58$ \\
\hline 1,2-Dibromo-3-Cloropropano & $96-12-8$ & $\mathrm{mg} / \mathrm{kg}$ & 0,01 & $<0,01$ & n.a. & $29 / 10 / 201418: 58$ \\
\hline 1,2-Dicloroetano & $107-06-2$ & $\mathrm{mg} / \mathrm{kg}$ & 0,01 & $<0,01$ & n.a. & $29 / 10 / 201418: 58$ \\
\hline 1,2-Dicloropropano & $78-87-5$ & $\mathrm{mg} / \mathrm{kg}$ & 0,01 & $<0,01$ & n.a. & $29 / 10 / 201418: 58$ \\
\hline 1,3-Diclorobenzeno & 541-73-1 & $\mathrm{mg} / \mathrm{kg}$ & 0,01 & $<0,01$ & n.a. & 29/10/2014 18:58 \\
\hline 2,2-Dicloropropano & $594-20-7$ & $\mathrm{mg} / \mathrm{kg}$ & 0,01 & $<0,01$ & n.a. & $29 / 10 / 201418: 58$ \\
\hline 4-Metil-2-Pentanona & $108-10-1$ & $\mathrm{mg} / \mathrm{kg}$ & 0,01 & $<0,01$ & n.a. & $29 / 10 / 201418: 58$ \\
\hline Benzeno & $71-43-2$ & $\mathrm{mg} / \mathrm{kg}$ & 0,01 & $<0,01$ & n.a. & $29 / 10 / 201418: 58$ \\
\hline Bromobenzeno & $108-86-1$ & $\mathrm{mg} / \mathrm{kg}$ & 0,01 & $<0,01$ & n.a. & $29 / 10 / 201418: 58$ \\
\hline Bromodiclorometano & $75-27-4$ & $\mathrm{mg} / \mathrm{kg}$ & 0,01 & $<0,01$ & n.a. & $29 / 10 / 201418: 58$ \\
\hline Bromofórmio & $75-25-2$ & $\mathrm{mg} / \mathrm{kg}$ & 0,01 & $<0,01$ & n.a. & $29 / 10 / 201418: 58$ \\
\hline Bromometano & $74-83-9$ & $\mathrm{mg} / \mathrm{kg}$ & 0,01 & $<0,01$ & n.a. & $29 / 10 / 201418: 58$ \\
\hline Cis-1,2-Dicloroeteno & $156-59-2$ & $\mathrm{mg} / \mathrm{kg}$ & 0,01 & $<0,01$ & n.a. & $29 / 10 / 201418: 58$ \\
\hline Cis-1,3-Dicloropropeno & $10061-01-5$ & $\mathrm{mg} / \mathrm{kg}$ & 0,01 & $<0,01$ & n.a. & $29 / 10 / 201418: 58$ \\
\hline Diclorometano & $75-09-2$ & $\mathrm{mg} / \mathrm{kg}$ & 0,01 & $<0,01$ & n.a. & $29 / 10 / 201418: 58$ \\
\hline Cloreto de Vinila & $75-01-4$ & $\mathrm{mg} / \mathrm{kg}$ & 0,002 & $<0,002$ & n.a. & $29 / 10 / 201418: 58$ \\
\hline Clorobenzeno & $108-90-7$ & $\mathrm{mg} / \mathrm{kg}$ & 0,01 & $<0,01$ & n.a. & $29 / 10 / 201418: 58$ \\
\hline Cloroetano & $75-00-3$ & $\mathrm{mg} / \mathrm{kg}$ & 0,01 & $<0,01$ & n.a. & $29 / 10 / 201418: 58$ \\
\hline Clorofórmio & $67-66-3$ & $\mathrm{mg} / \mathrm{kg}$ & 0,01 & $<0,01$ & n.a. & $29 / 10 / 201418: 58$ \\
\hline Clorometano & $74-87-3$ & $\mathrm{mg} / \mathrm{kg}$ & 0,01 & $<0,01$ & n.a. & $29 / 10 / 201418: 58$ \\
\hline Dibromoclorometano & $124-48-1$ & $\mathrm{mg} / \mathrm{kg}$ & 0,01 & $<0,01$ & n.a. & $29 / 10 / 201418: 58$ \\
\hline Dissulfeto de Carbono & $75-15-0$ & $\mathrm{mg} / \mathrm{kg}$ & 0,01 & $<0,01$ & n.a. & $29 / 10 / 201418: 58$ \\
\hline Estireno & $100-42-5$ & $\mathrm{mg} / \mathrm{kg}$ & 0,01 & $<0,01$ & n.a. & $29 / 10 / 201418: 58$ \\
\hline Etilbenzeno & $100-41-4$ & $\mathrm{mg} / \mathrm{kg}$ & 0,01 & $<0,01$ & n.a. & $29 / 10 / 201418: 58$ \\
\hline Hexaclorobutadieno & $87-68-3$ & $\mathrm{mg} / \mathrm{kg}$ & 0,01 & $<0,01$ & n.a. & $29 / 10 / 201418: 58$ \\
\hline m,p-Xilenos & --- & $\mathrm{mg} / \mathrm{kg}$ & 0,01 & $<0,01$ & n.a. & $29 / 10 / 201418: 58$ \\
\hline o-Xileno & $95-47-6$ & $\mathrm{mg} / \mathrm{kg}$ & 0,01 & $<0,01$ & n.a. & $29 / 10 / 201418: 58$ \\
\hline p-Isopropiltolueno & $99-87-6$ & $\mathrm{mg} / \mathrm{kg}$ & 0,01 & $<0,01$ & n.a. & $29 / 10 / 201418: 58$ \\
\hline Tetracloroeteno & $127-18-4$ & $\mathrm{mg} / \mathrm{kg}$ & 1,2 & 10,4 & 2,1 & $29 / 10 / 201418: 58$ \\
\hline Tetracloreto de Carbono & $56-23-5$ & $\mathrm{mg} / \mathrm{kg}$ & 0,01 & $<0,01$ & n.a. & 29/10/2014 18:58 \\
\hline Tolueno & $108-88-3$ & $\mathrm{mg} / \mathrm{kg}$ & 0,01 & $<0,01$ & n.a. & $29 / 10 / 201418: 58$ \\
\hline Trans-1,2-Dicloroeteno & $156-60-5$ & $\mathrm{mg} / \mathrm{kg}$ & 0,01 & $<0,01$ & n.a. & $29 / 10 / 201418: 58$ \\
\hline Tricloroeteno & $79-01-6$ & $\mathrm{mg} / \mathrm{kg}$ & 0,01 & $<0,01$ & n.a. & $29 / 10 / 201418: 58$ \\
\hline 1,1,1,2-Tetracloroetano & $630-20-6$ & $\mathrm{mg} / \mathrm{kg}$ & 0,01 & $<0,01$ & n.a. & $29 / 10 / 201418: 58$ \\
\hline 1,2,3-Tricloropropano & $96-18-4$ & $\mathrm{mg} / \mathrm{kg}$ & 0,01 & $<0,01$ & n.a. & $29 / 10 / 201418: 58$ \\
\hline
\end{tabular}




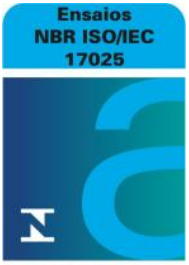

CRL 0172

\begin{tabular}{|c|c|c|c|c|c|c|}
\hline Parâmetros & CAS & Unidade & LQ & Resultados analíticos & Incerteza & Data do Ensaio \\
\hline 1,3,5-Trimetilbenzeno & $108-67-8$ & $\mathrm{mg} / \mathrm{kg}$ & 0,01 & $<0,01$ & n.a. & $29 / 10 / 201418: 58$ \\
\hline 1,2,4-Trimetilbenzeno & $95-63-6$ & $\mathrm{mg} / \mathrm{kg}$ & 0,01 & $<0,01$ & n.a. & $29 / 10 / 201418: 58$ \\
\hline 1,2-Dibromoetano & $106-93-4$ & $\mathrm{mg} / \mathrm{kg}$ & 0,01 & $<0,01$ & n.a. & $29 / 10 / 201418: 58$ \\
\hline 1,2-Diclorobenzeno & $95-50-1$ & $\mathrm{mg} / \mathrm{kg}$ & 0,01 & $<0,01$ & n.a. & $29 / 10 / 201418: 58$ \\
\hline 2-Clorotolueno & $95-49-8$ & $\mathrm{mg} / \mathrm{kg}$ & 0,01 & $<0,01$ & n.a. & $29 / 10 / 201418: 58$ \\
\hline Dibromometano & $74-95-3$ & $\mathrm{mg} / \mathrm{kg}$ & 0,01 & $<0,01$ & n.a. & $29 / 10 / 201418: 58$ \\
\hline Metiletilcetona & 78-93-3 & $\mathrm{mg} / \mathrm{kg}$ & 3 & $<3$ & n.a. & $30 / 10 / 201406: 18$ \\
\hline Naftaleno & $91-20-3$ & $\mathrm{mg} / \mathrm{kg}$ & 0,01 & $<0,01$ & n.a. & 29/10/2014 18:58 \\
\hline n-Butilbenzeno & $104-51-8$ & $\mathrm{mg} / \mathrm{kg}$ & 0,01 & $<0,01$ & n.a. & 29/10/2014 18:58 \\
\hline n-Propilbenzeno & $103-65-1$ & $\mathrm{mg} / \mathrm{kg}$ & 0,01 & $<0,01$ & n.a. & $29 / 10 / 201418: 58$ \\
\hline 4-Clorotolueno & $106-43-4$ & $\mathrm{mg} / \mathrm{kg}$ & 0,01 & $<0,01$ & n.a. & $29 / 10 / 201418: 58$ \\
\hline sec-Butilbenzeno & $135-98-8$ & $\mathrm{mg} / \mathrm{kg}$ & 0,01 & $<0,01$ & n.a. & $29 / 10 / 201418: 58$ \\
\hline terc-Butilbenzeno & $98-06-6$ & $\mathrm{mg} / \mathrm{kg}$ & 0,01 & $<0,01$ & n.a. & $29 / 10 / 201418: 58$ \\
\hline trans-1,3-Dicloropropeno & $10061-02-6$ & $\mathrm{mg} / \mathrm{kg}$ & 0,01 & $<0,01$ & n.a. & $29 / 10 / 201418: 58$ \\
\hline Isopropilbenzeno & $98-82-8$ & $\mathrm{mg} / \mathrm{kg}$ & 0,01 & $<0,01$ & n.a. & $29 / 10 / 201418: 58$ \\
\hline 1,4-Diclorobenzeno & $106-46-7$ & $\mathrm{mg} / \mathrm{kg}$ & 0,01 & $<0,01$ & n.a. & $29 / 10 / 201418: 58$ \\
\hline 1,3,5-Triclorobenzeno & $108-70-3$ & $\mathrm{mg} / \mathrm{kg}$ & 0,01 & $<0,01$ & n.a. & $29 / 10 / 201418: 58$ \\
\hline 1,3-Dicloropropano & $142-28-9$ & $\mathrm{mg} / \mathrm{kg}$ & 0,01 & $<0,01$ & n.a. & 29/10/2014 18:58 \\
\hline Porcentagem de Sólidos & --- & $\% \mathrm{p} / \mathrm{p}$ & 0,05 & 83,2 & 8,3 & 01/11/2014 07:57 \\
\hline
\end{tabular}

\section{CONTROLE DE Q UALIDADE DO LAB ORATÓRIO}

284309/2014-0 - Branco de Análise - VOC - Solo

Controle de $Q$ ualidade - VOC - Solo

\begin{tabular}{|c|c|c|c|}
\hline Parâmetros & Unidade & LQ & Resultados analíticos \\
\hline 1,1,1-Tricloroetano & $\mathrm{mg} / \mathrm{kg}$ & 0,01 & $<0,01$ \\
\hline 1,1,2-Tricloroetano & $\mathrm{mg} / \mathrm{kg}$ & 0,01 & $<0,01$ \\
\hline 1,1,2,2-Tetracloroetano & $\mathrm{mg} / \mathrm{kg}$ & 0,01 & $<0,01$ \\
\hline 1,1-Dicloroetano & $\mathrm{mg} / \mathrm{kg}$ & 0,01 & $<0,01$ \\
\hline 1,1-Dicloroeteno & $\mathrm{mg} / \mathrm{kg}$ & 0,01 & $<0,01$ \\
\hline 1,1-Dicloropropeno & $\mathrm{mg} / \mathrm{kg}$ & 0,01 & $<0,01$ \\
\hline 1,2,3-Triclorobenzeno & $\mathrm{mg} / \mathrm{kg}$ & 0,01 & $<0,01$ \\
\hline 1,2,4-Triclorobenzeno & $\mathrm{mg} / \mathrm{kg}$ & 0,01 & $<0,01$ \\
\hline 1,2-Dibromo-3-Cloropropano & $\mathrm{mg} / \mathrm{kg}$ & 0,01 & $<0,01$ \\
\hline 1,2-Dicloroetano & $\mathrm{mg} / \mathrm{kg}$ & 0,01 & $<0,01$ \\
\hline 1,2-Dicloropropano & $\mathrm{mg} / \mathrm{kg}$ & 0,01 & $<0,01$ \\
\hline 1,3-Dicloropropano & $\mathrm{mg} / \mathrm{kg}$ & 0,01 & $<0,01$ \\
\hline 1,4-Diclorobenzeno & $\mathrm{mg} / \mathrm{kg}$ & 0,01 & $<0,01$ \\
\hline 2,2-Dicloropropano & $\mathrm{mg} / \mathrm{kg}$ & 0,01 & $<0,01$ \\
\hline 4-Metil-2-Pentanona & $\mathrm{mg} / \mathrm{kg}$ & 0,01 & $<0,01$ \\
\hline Benzeno & $\mathrm{mg} / \mathrm{kg}$ & 0,01 & $<0,01$ \\
\hline Bromobenzeno & $\mathrm{mg} / \mathrm{kg}$ & 0,01 & $<0,01$ \\
\hline Bromodiclorometano & $\mathrm{mg} / \mathrm{kg}$ & 0,01 & $<0,01$ \\
\hline Bromofórmio & $\mathrm{mg} / \mathrm{kg}$ & 0,01 & $<0,01$ \\
\hline Bromometano & $\mathrm{mg} / \mathrm{kg}$ & 0,01 & $<0,01$ \\
\hline Cis-1,2-Dicloroeteno & $\mathrm{mg} / \mathrm{kg}$ & 0,01 & $<0,01$ \\
\hline Cis-1,3-Dicloropropeno & $\mathrm{mg} / \mathrm{kg}$ & 0,01 & $<0,01$ \\
\hline Diclorometano & $\mathrm{mg} / \mathrm{kg}$ & 0,01 & $<0,01$ \\
\hline Cloreto de Vinila & $\mathrm{mg} / \mathrm{kg}$ & 0,002 & $<0,002$ \\
\hline Clorobenzeno & $\mathrm{mg} / \mathrm{kg}$ & 0,01 & $<0,01$ \\
\hline Cloroetano & $\mathrm{mg} / \mathrm{kg}$ & 0,01 & $<0,01$ \\
\hline Clorofórmio & $\mathrm{mg} / \mathrm{kg}$ & 0,01 & $<0,01$ \\
\hline Clorometano & $\mathrm{mg} / \mathrm{kg}$ & 0,01 & $<0,01$ \\
\hline Dibromoclorometano & $\mathrm{mg} / \mathrm{kg}$ & 0,01 & $<0,01$ \\
\hline Dissulfeto de Carbono & $\mathrm{mg} / \mathrm{kg}$ & 0,01 & $<0,01$ \\
\hline Estireno & $\mathrm{mg} / \mathrm{kg}$ & 0,01 & $<0,01$ \\
\hline Etilbenzeno & $\mathrm{mg} / \mathrm{kg}$ & 0,01 & $<0,01$ \\
\hline Hexaclorobutadieno & $\mathrm{mg} / \mathrm{kg}$ & 0,01 & $<0,01$ \\
\hline m,p-Xilenos & $\mathrm{mg} / \mathrm{kg}$ & 0,01 & $<0,01$ \\
\hline o-Xileno & $\mathrm{mg} / \mathrm{kg}$ & 0,01 & $<0,01$ \\
\hline p-Isopropiltolueno & $\mathrm{mg} / \mathrm{kg}$ & 0,01 & $<0,01$ \\
\hline Tetracloreto de Carbono & $\mathrm{mg} / \mathrm{kg}$ & 0,01 & $<0,01$ \\
\hline Tetracloroeteno & $\mathrm{mg} / \mathrm{kg}$ & 0,01 & $<0,01$ \\
\hline Tolueno & $\mathrm{mg} / \mathrm{kg}$ & 0,01 & $<0,01$ \\
\hline Trans-1,2-Dicloroeteno & $\mathrm{mg} / \mathrm{kg}$ & 0,01 & $<0,01$ \\
\hline Tricloroeteno & $\mathrm{mg} / \mathrm{kg}$ & 0,01 & $<0,01$ \\
\hline 1,3,5-Triclorobenzeno & $\mathrm{mg} / \mathrm{kg}$ & 0,01 & $<0,01$ \\
\hline
\end{tabular}




\begin{tabular}{|c|c|c|c|c|}
\hline Parâmetros & $\begin{array}{l}\text { Q uantidade } \\
\text { Adicionada }\end{array}$ & Unidade & $\begin{array}{c}\text { Resultado da } \\
\text { Recuperação (\%) }\end{array}$ & Faixa Aceitável de Recuperação (\%) \\
\hline \multicolumn{5}{|l|}{ 284310/2014-0 - LCS - VOC - Solo } \\
\hline 1,1-Dicloroeteno & 0,05 & $\mathrm{mg} / \mathrm{kg}$ & 62 & $60-140$ \\
\hline Benzeno & 0,05 & $\mathrm{mg} / \mathrm{kg}$ & 73 & $60-140$ \\
\hline Tricloroeteno & 0,05 & $\mathrm{mg} / \mathrm{kg}$ & 82 & $60-140$ \\
\hline Tolueno & 0,05 & $\mathrm{mg} / \mathrm{kg}$ & 84 & $60-140$ \\
\hline Clorobenzeno & 0,05 & $\mathrm{mg} / \mathrm{kg}$ & 67 & $60-140$ \\
\hline \multicolumn{5}{|c|}{$\begin{array}{l}\text { Surrogates } \\
\quad 284309 / 2014-0 \text { - Branco de Análise - VOC - Solo }\end{array}$} \\
\hline p-Bromofluorbenzeno & 0,05 & $\%$ & 120 & $60-140$ \\
\hline Dibrom ofluorometano & 0,05 & $\%$ & 110 & $60-140$ \\
\hline \multicolumn{5}{|l|}{ 284310/2014-0 - LCS - VOC - Solo } \\
\hline p-Bromofluorbenzeno & 0,05 & $\%$ & 120 & $60-140$ \\
\hline Dibrom ofluorometano & 0,05 & $\%$ & 83 & $60-140$ \\
\hline \multicolumn{5}{|l|}{ 283888/2014-0 - CAI-3 } \\
\hline Dibromofluorometano & 0,05 & $\%$ & 60 & $60-140$ \\
\hline p-Bromofluorbenzeno & 0,05 & $\%$ & 82 & $60-140$ \\
\hline
\end{tabular}

Notas

LQ = Limite de Quantificação.

n.a. $=$ Não Aplicável.

Abrangência

$\mathrm{O}$ (s) resultado(s) referem-se somente à(s) amostra(s) analisada(s).

Este Relatório de Ensaio só pode ser reproduzido por inteiro e sem nenhuma alteração.

Plano de Amostragem

Plano de amostragem de responsabilidade do interessado.

Responsabilidade Técnica

Os ensaios foram realizados na unidade da Bioagri Ambiental Ltda. - Matriz, situada na Rua Aljovil Martini, 177/201, Bairro Dois Córregos, Cep. 14420-833, Piracicaba/SP, registrada no CRQ 4ª Região sob nº 16082-Fe responsabilidade técnica do profissional José Carlos Moretti, CRQ nº 04107238, $4^{a}$.Região.

Referências Metodológicas

Análises foram realizadas conforme a última versão do Standard Methods for the Examination of Water \& Wastewater 22nd 2012(SMWW), EPA e ABNT (quando aplicável).

Porcentagem de Sólidos e Cinzas: POP PA 058 - Rev. 02

VOC: EPA 8260 C: 2006, 5021 A: 2003

Metiletilcetona: EPA 8260 C: 2006, 5021 A: 2003

Revisores

Débora Fernandes da Silva

Marlon Felicio Forti

Chave de Validação: d6eae98d684b4b36ace575c05852772e

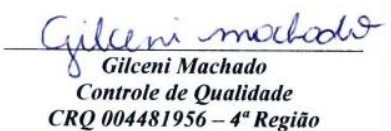

CRQ 004481956-4 Região

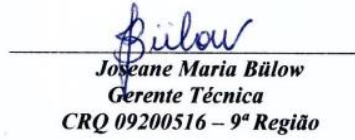




\section{RELATÓRIO DE ENSAIO N $^{\circ}$ 283865/2014-0 - Piracicaba Processo Comercial $N^{\circ}$ 23961/2014-2}

\begin{tabular}{|l|l|}
\hline \multicolumn{2}{|c|}{ DADOS REFERENTES AO CLIENTE } \\
\hline Empresa solicitante: & Fundacao Parque de Alta Tecnologia da Regiao de Ipero e Adjacencias \\
\hline Endereço: & Rua Jose Antonio Scaciota, 165 - - Portal do Cedro - Iperó - SP - CEP: 18.560-000 . \\
\hline Nome do Solicitante: & Carla Marçal \\
\hline
\end{tabular}

\section{DADOS REFERENTES A AMOSTRA}

\begin{tabular}{|l|l|l|l|l|}
\hline Identificação do Cliente: & CAF-1 \\
\hline Amostra Rotulada como: & Solo Projeto Mestrado & \multicolumn{5}{l|}{} \\
\hline Coletor: & Interessado & Data da coleta: & $24 / 10 / 2014$ & $16: 00: 00$ \\
\hline Data da entrada no laboratório: & $25 / 10 / 201408: 22$ & Data de Elaboração do RE: & $03 / 11 / 2014$ \\
\hline
\end{tabular}

\section{RESULTADOS PARA A AMOSTRA}

\begin{tabular}{|c|c|c|c|c|c|c|}
\hline Parâmetros & CAS & Unidade & LQ & Resultados analíticos & Incerteza & Data do Ensaio \\
\hline 1,1,1-Tricloroetano & $71-55-6$ & $\mathrm{mg} / \mathrm{kg}$ & 0,01 & $<0,01$ & n.a. & $30 / 10 / 201404: 18$ \\
\hline 1,1,2-Tricloroetano & $79-00-5$ & $\mathrm{mg} / \mathrm{kg}$ & 0,01 & $<0,01$ & n.a. & $30 / 10 / 201404: 18$ \\
\hline 1,1,2,2-Tetracloroetano & $79-34-5$ & $\mathrm{mg} / \mathrm{kg}$ & 0,01 & $<0,01$ & n.a. & $30 / 10 / 201404: 18$ \\
\hline 1,1-Dicloroetano & $75-34-3$ & $\mathrm{mg} / \mathrm{kg}$ & 0,01 & $<0,01$ & n.a. & $30 / 10 / 201404: 18$ \\
\hline 1,1-Dicloroeteno & $75-35-4$ & $\mathrm{mg} / \mathrm{kg}$ & 0,01 & $<0,01$ & n.a. & $30 / 10 / 201404: 18$ \\
\hline 1,1-Dicloropropeno & $563-58-6$ & $\mathrm{mg} / \mathrm{kg}$ & 0,01 & $<0,01$ & n.a. & $30 / 10 / 201404: 18$ \\
\hline 1,2,3-Triclorobenzeno & $87-61-6$ & $\mathrm{mg} / \mathrm{kg}$ & 0,01 & $<0,01$ & n.a. & $30 / 10 / 201404: 18$ \\
\hline 1,2,4-Triclorobenzeno & $120-82-1$ & $\mathrm{mg} / \mathrm{kg}$ & 0,01 & $<0,01$ & n.a. & $30 / 10 / 201404: 18$ \\
\hline 1,2-Dibromo-3-Cloropropano & $96-12-8$ & $\mathrm{mg} / \mathrm{kg}$ & 0,01 & $<0,01$ & n.a. & $30 / 10 / 201404: 18$ \\
\hline 1,2-Dicloroetano & $107-06-2$ & $\mathrm{mg} / \mathrm{kg}$ & 0,01 & $<0,01$ & n.a. & $30 / 10 / 201404: 18$ \\
\hline 1,2-Dicloropropano & $78-87-5$ & $\mathrm{mg} / \mathrm{kg}$ & 0,01 & $<0,01$ & n.a. & $30 / 10 / 201404: 18$ \\
\hline 1,3-Diclorobenzeno & $541-73-1$ & $\mathrm{mg} / \mathrm{kg}$ & 0,01 & $<0,01$ & n.a. & $30 / 10 / 201404: 18$ \\
\hline 2,2-Dicloropropano & $594-20-7$ & $\mathrm{mg} / \mathrm{kg}$ & 0,01 & $<0,01$ & n.a. & $30 / 10 / 201404: 18$ \\
\hline 4-Metil-2-Pentanona & $108-10-1$ & $\mathrm{mg} / \mathrm{kg}$ & 0,01 & $<0,01$ & n.a. & $30 / 10 / 201404: 18$ \\
\hline Benzeno & $71-43-2$ & $\mathrm{mg} / \mathrm{kg}$ & 0,01 & $<0,01$ & n.a. & $30 / 10 / 2014$ 04:18 \\
\hline Bromobenzeno & $108-86-1$ & $\mathrm{mg} / \mathrm{kg}$ & 0,01 & $<0,01$ & n.a. & $30 / 10 / 2014$ 04:18 \\
\hline Bromodiclorometano & $75-27-4$ & $\mathrm{mg} / \mathrm{kg}$ & 0,01 & $<0,01$ & n.a. & $30 / 10 / 201404: 18$ \\
\hline Bromofórmio & $75-25-2$ & $\mathrm{mg} / \mathrm{kg}$ & 0,01 & $<0,01$ & n.a. & $30 / 10 / 201404: 18$ \\
\hline Bromometano & $74-83-9$ & $\mathrm{mg} / \mathrm{kg}$ & 0,01 & $<0,01$ & n.a. & $30 / 10 / 201404: 18$ \\
\hline Cis-1,2-Dicloroeteno & $156-59-2$ & $\mathrm{mg} / \mathrm{kg}$ & 0,01 & $<0,01$ & n.a. & $30 / 10 / 201404: 18$ \\
\hline Cis-1,3-Dicloropropeno & $10061-01-5$ & $\mathrm{mg} / \mathrm{kg}$ & 0,01 & $<0,01$ & n.a. & $30 / 10 / 2014$ 04:18 \\
\hline Diclorometano & $75-09-2$ & $\mathrm{mg} / \mathrm{kg}$ & 0,01 & $<0,01$ & n.a. & $30 / 10 / 201404: 18$ \\
\hline Cloreto de Vinila & $75-01-4$ & $\mathrm{mg} / \mathrm{kg}$ & 0,002 & $<0,002$ & n.a. & $30 / 10 / 2014$ 04:18 \\
\hline Clorobenzeno & $108-90-7$ & $\mathrm{mg} / \mathrm{kg}$ & 0,01 & $<0,01$ & n.a. & $30 / 10 / 201404: 18$ \\
\hline Cloroetano & $75-00-3$ & $\mathrm{mg} / \mathrm{kg}$ & 0,01 & $<0,01$ & n.a. & $30 / 10 / 201404: 18$ \\
\hline Clorofórmio & $67-66-3$ & $\mathrm{mg} / \mathrm{kg}$ & 0,01 & $<0,01$ & n.a. & $30 / 10 / 201404: 18$ \\
\hline Clorometano & $74-87-3$ & $\mathrm{mg} / \mathrm{kg}$ & 0,01 & $<0,01$ & n.a. & $30 / 10 / 201404: 18$ \\
\hline Dibromoclorometano & $124-48-1$ & $\mathrm{mg} / \mathrm{kg}$ & 0,01 & $<0,01$ & n.a. & $30 / 10 / 2014$ 04:18 \\
\hline Dissulfeto de Carbono & $75-15-0$ & $\mathrm{mg} / \mathrm{kg}$ & 0,01 & $<0,01$ & n.a. & $30 / 10 / 2014$ 04:18 \\
\hline Estireno & $100-42-5$ & $\mathrm{mg} / \mathrm{kg}$ & 0,01 & $<0,01$ & n.a. & $30 / 10 / 2014$ 04:18 \\
\hline Etilbenzeno & $100-41-4$ & $\mathrm{mg} / \mathrm{kg}$ & 0,01 & $<0,01$ & n.a. & $30 / 10 / 201404: 18$ \\
\hline Hexaclorobutadieno & $87-68-3$ & $\mathrm{mg} / \mathrm{kg}$ & 0,01 & $<0,01$ & n.a. & $30 / 10 / 201404: 18$ \\
\hline $\mathrm{m}, \mathrm{p}$-Xilenos & --- & $\mathrm{mg} / \mathrm{kg}$ & 0,01 & $<0,01$ & n.a. & $30 / 10 / 201404: 18$ \\
\hline o-Xileno & $95-47-6$ & $\mathrm{mg} / \mathrm{kg}$ & 0,01 & $<0,01$ & n.a. & $30 / 10 / 2014$ 04:18 \\
\hline p-Isopropiltolueno & $99-87-6$ & $\mathrm{mg} / \mathrm{kg}$ & 0,01 & $<0,01$ & n.a. & $30 / 10 / 201404: 18$ \\
\hline Tetracloroeteno & $127-18-4$ & $\mathrm{mg} / \mathrm{kg}$ & 0,01 & 0,048 & 0,0096 & $30 / 10 / 201404: 18$ \\
\hline Tetracloreto de Carbono & $56-23-5$ & $\mathrm{mg} / \mathrm{kg}$ & 0,01 & $<0,01$ & n.a. & 30/10/2014 04:18 \\
\hline Tolueno & $108-88-3$ & $\mathrm{mg} / \mathrm{kg}$ & 0,01 & $<0,01$ & n.a. & $30 / 10 / 201404: 18$ \\
\hline Trans-1,2-Dicloroeteno & $156-60-5$ & $\mathrm{mg} / \mathrm{kg}$ & 0,01 & $<0,01$ & n.a. & $30 / 10 / 201404: 18$ \\
\hline Tricloroeteno & $79-01-6$ & $\mathrm{mg} / \mathrm{kg}$ & 0,01 & $<0,01$ & n.a. & $30 / 10 / 201404: 18$ \\
\hline 1,1,1,2-Tetracloroetano & $630-20-6$ & $\mathrm{mg} / \mathrm{kg}$ & 0,01 & $<0,01$ & n.a. & $30 / 10 / 201404: 18$ \\
\hline 1,2,3-Tricloropropano & $96-18-4$ & $\mathrm{mg} / \mathrm{kg}$ & 0,01 & $<0,01$ & n.a. & 30/10/2014 04:18 \\
\hline
\end{tabular}




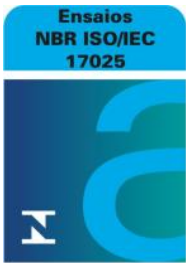

CRL 0172

\begin{tabular}{|c|c|c|c|c|c|c|}
\hline Parâmetros & CAS & Unidade & LQ & Resultados analíticos & Incerteza & Data do Ensaio \\
\hline 1,3,5-Trimetilbenzeno & $108-67-8$ & $\mathrm{mg} / \mathrm{kg}$ & 0,01 & $<0,01$ & n.a. & $30 / 10 / 201404: 18$ \\
\hline 1,2,4-Trimetilbenzeno & $95-63-6$ & $\mathrm{mg} / \mathrm{kg}$ & 0,01 & $<0,01$ & n.a. & $30 / 10 / 201404: 18$ \\
\hline 1,2-Dibromoetano & $106-93-4$ & $\mathrm{mg} / \mathrm{kg}$ & 0,01 & $<0,01$ & n.a. & $30 / 10 / 201404: 18$ \\
\hline 1,2-Diclorobenzeno & $95-50-1$ & $\mathrm{mg} / \mathrm{kg}$ & 0,01 & $<0,01$ & n.a. & $30 / 10 / 201404: 18$ \\
\hline 2-Clorotolueno & $95-49-8$ & $\mathrm{mg} / \mathrm{kg}$ & 0,01 & $<0,01$ & n.a. & $30 / 10 / 2014$ 04:18 \\
\hline Dibromometano & $74-95-3$ & $\mathrm{mg} / \mathrm{kg}$ & 0,01 & $<0,01$ & n.a. & $30 / 10 / 201404: 18$ \\
\hline Metiletilcetona & 78-93-3 & $\mathrm{mg} / \mathrm{kg}$ & 3 & $<3$ & n.a. & $30 / 10 / 201404: 18$ \\
\hline Naftaleno & $91-20-3$ & $\mathrm{mg} / \mathrm{kg}$ & 0,01 & $<0,01$ & n.a. & $30 / 10 / 201404: 18$ \\
\hline n-Butilbenzeno & $104-51-8$ & $\mathrm{mg} / \mathrm{kg}$ & 0,01 & $<0,01$ & n.a. & $30 / 10 / 201404: 18$ \\
\hline n-Propilbenzeno & $103-65-1$ & $\mathrm{mg} / \mathrm{kg}$ & 0,01 & $<0,01$ & n.a. & $30 / 10 / 201404: 18$ \\
\hline 4-Clorotolueno & $106-43-4$ & $\mathrm{mg} / \mathrm{kg}$ & 0,01 & $<0,01$ & n.a. & $30 / 10 / 201404: 18$ \\
\hline sec-Butilbenzeno & $135-98-8$ & $\mathrm{mg} / \mathrm{kg}$ & 0,01 & $<0,01$ & n.a. & $30 / 10 / 201404: 18$ \\
\hline terc-Butilbenzeno & $98-06-6$ & $\mathrm{mg} / \mathrm{kg}$ & 0,01 & $<0,01$ & n.a. & $30 / 10 / 201404: 18$ \\
\hline trans-1,3-Dicloropropeno & $10061-02-6$ & $\mathrm{mg} / \mathrm{kg}$ & 0,01 & $<0,01$ & n.a. & $30 / 10 / 201404: 18$ \\
\hline Isopropilbenzeno & $98-82-8$ & $\mathrm{mg} / \mathrm{kg}$ & 0,01 & $<0,01$ & n.a. & $30 / 10 / 201404: 18$ \\
\hline 1,4-Diclorobenzeno & $106-46-7$ & $\mathrm{mg} / \mathrm{kg}$ & 0,01 & $<0,01$ & n.a. & $30 / 10 / 2014$ 04:18 \\
\hline 1,3,5-Triclorobenzeno & $108-70-3$ & $\mathrm{mg} / \mathrm{kg}$ & 0,01 & $<0,01$ & n.a. & $30 / 10 / 201404: 18$ \\
\hline 1,3-Dicloropropano & $142-28-9$ & $\mathrm{mg} / \mathrm{kg}$ & 0,01 & $<0,01$ & n.a. & $30 / 10 / 201404: 18$ \\
\hline Porcentagem de Sólidos & --- & $\% \mathrm{p} / \mathrm{p}$ & 0,05 & 84,0 & 8,4 & 01/11/2014 07:56 \\
\hline
\end{tabular}

\section{CONTROLE DE Q UALIDADE DO LAB ORATÓRIO}

284309/2014-0 - Branco de Análise - VOC - Solo

Controle de $Q$ ualidade - VOC - Solo

\begin{tabular}{|c|c|c|c|}
\hline Parâmetros & Unidade & LQ & Resultados analíticos \\
\hline 1,1,1-Tricloroetano & $\mathrm{mg} / \mathrm{kg}$ & 0,01 & $<0,01$ \\
\hline 1,1,2-Tricloroetano & $\mathrm{mg} / \mathrm{kg}$ & 0,01 & $<0,01$ \\
\hline 1,1,2,2-Tetracloroetano & $\mathrm{mg} / \mathrm{kg}$ & 0,01 & $<0,01$ \\
\hline 1,1-Dicloroetano & $\mathrm{mg} / \mathrm{kg}$ & 0,01 & $<0,01$ \\
\hline 1,1-Dicloroeteno & $\mathrm{mg} / \mathrm{kg}$ & 0,01 & $<0,01$ \\
\hline 1,1-Dicloropropeno & $\mathrm{mg} / \mathrm{kg}$ & 0,01 & $<0,01$ \\
\hline 1,2,3-Triclorobenzeno & $\mathrm{mg} / \mathrm{kg}$ & 0,01 & $<0,01$ \\
\hline 1,2,4-Triclorobenzeno & $\mathrm{mg} / \mathrm{kg}$ & 0,01 & $<0,01$ \\
\hline 1,2-Dibromo-3-Cloropropano & $\mathrm{mg} / \mathrm{kg}$ & 0,01 & $<0,01$ \\
\hline 1,2-Dicloroetano & $\mathrm{mg} / \mathrm{kg}$ & 0,01 & $<0,01$ \\
\hline 1,2-Dicloropropano & $\mathrm{mg} / \mathrm{kg}$ & 0,01 & $<0,01$ \\
\hline 1,3-Dicloropropano & $\mathrm{mg} / \mathrm{kg}$ & 0,01 & $<0,01$ \\
\hline 1,4-Diclorobenzeno & $\mathrm{mg} / \mathrm{kg}$ & 0,01 & $<0,01$ \\
\hline 2,2-Dicloropropano & $\mathrm{mg} / \mathrm{kg}$ & 0,01 & $<0,01$ \\
\hline 4-Metil-2-Pentanona & $\mathrm{mg} / \mathrm{kg}$ & 0,01 & $<0,01$ \\
\hline Benzeno & $\mathrm{mg} / \mathrm{kg}$ & 0,01 & $<0,01$ \\
\hline Bromobenzeno & $\mathrm{mg} / \mathrm{kg}$ & 0,01 & $<0,01$ \\
\hline Bromodiclorometano & $\mathrm{mg} / \mathrm{kg}$ & 0,01 & $<0,01$ \\
\hline Bromofórmio & $\mathrm{mg} / \mathrm{kg}$ & 0,01 & $<0,01$ \\
\hline Bromometano & $\mathrm{mg} / \mathrm{kg}$ & 0,01 & $<0,01$ \\
\hline Cis-1,2-Dicloroeteno & $\mathrm{mg} / \mathrm{kg}$ & 0,01 & $<0,01$ \\
\hline Cis-1,3-Dicloropropeno & $\mathrm{mg} / \mathrm{kg}$ & 0,01 & $<0,01$ \\
\hline Diclorometano & $\mathrm{mg} / \mathrm{kg}$ & 0,01 & $<0,01$ \\
\hline Cloreto de Vinila & $\mathrm{mg} / \mathrm{kg}$ & 0,002 & $<0,002$ \\
\hline Clorobenzeno & $\mathrm{mg} / \mathrm{kg}$ & 0,01 & $<0,01$ \\
\hline Cloroetano & $\mathrm{mg} / \mathrm{kg}$ & 0,01 & $<0,01$ \\
\hline Clorofórmio & $\mathrm{mg} / \mathrm{kg}$ & 0,01 & $<0,01$ \\
\hline Clorometano & $\mathrm{mg} / \mathrm{kg}$ & 0,01 & $<0,01$ \\
\hline Dibromoclorometano & $\mathrm{mg} / \mathrm{kg}$ & 0,01 & $<0,01$ \\
\hline Dissulfeto de Carbono & $\mathrm{mg} / \mathrm{kg}$ & 0,01 & $<0,01$ \\
\hline Estireno & $\mathrm{mg} / \mathrm{kg}$ & 0,01 & $<0,01$ \\
\hline Etilbenzeno & $\mathrm{mg} / \mathrm{kg}$ & 0,01 & $<0,01$ \\
\hline Hexaclorobutadieno & $\mathrm{mg} / \mathrm{kg}$ & 0,01 & $<0,01$ \\
\hline m,p-Xilenos & $\mathrm{mg} / \mathrm{kg}$ & 0,01 & $<0,01$ \\
\hline o-Xileno & $\mathrm{mg} / \mathrm{kg}$ & 0,01 & $<0,01$ \\
\hline p-Isopropiltolueno & $\mathrm{mg} / \mathrm{kg}$ & 0,01 & $<0,01$ \\
\hline Tetracloreto de Carbono & $\mathrm{mg} / \mathrm{kg}$ & 0,01 & $<0,01$ \\
\hline Tetracloroeteno & $\mathrm{mg} / \mathrm{kg}$ & 0,01 & $<0,01$ \\
\hline Tolueno & $\mathrm{mg} / \mathrm{kg}$ & 0,01 & $<0,01$ \\
\hline Trans-1,2-Dicloroeteno & $\mathrm{mg} / \mathrm{kg}$ & 0,01 & $<0,01$ \\
\hline Tricloroeteno & $\mathrm{mg} / \mathrm{kg}$ & 0,01 & $<0,01$ \\
\hline 1,3,5-Triclorobenzeno & $\mathrm{mg} / \mathrm{kg}$ & 0,01 & $<0,01$ \\
\hline
\end{tabular}




\begin{tabular}{|c|c|c|c|c|}
\hline Parâmetros & $\begin{array}{l}\text { Q uantidade } \\
\text { Adicionada }\end{array}$ & Unidade & $\begin{array}{c}\text { Resultado da } \\
\text { Recuperação (\%) }\end{array}$ & Faixa Aceitável de Recuperação (\%) \\
\hline \multicolumn{5}{|l|}{ 284310/2014-0 - LCS - VOC - Solo } \\
\hline 1,1-Dicloroeteno & 0,05 & $\mathrm{mg} / \mathrm{kg}$ & 62 & $60-140$ \\
\hline Benzeno & 0,05 & $\mathrm{mg} / \mathrm{kg}$ & 73 & $60-140$ \\
\hline Tricloroeteno & 0,05 & $\mathrm{mg} / \mathrm{kg}$ & 82 & $60-140$ \\
\hline Tolueno & 0,05 & $\mathrm{mg} / \mathrm{kg}$ & 84 & $60-140$ \\
\hline Clorobenzeno & 0,05 & $\mathrm{mg} / \mathrm{kg}$ & 67 & $60-140$ \\
\hline \multicolumn{5}{|c|}{$\begin{array}{l}\text { Surrogates } \\
\quad 284309 / 2014-0 \text { - Branco de Análise - VOC - Solo }\end{array}$} \\
\hline p-Bromofluorbenzeno & 0,05 & $\%$ & 120 & $60-140$ \\
\hline Dibrom ofluorometano & 0,05 & $\%$ & 110 & $60-140$ \\
\hline \multicolumn{5}{|l|}{ 284310/2014-0 - LCS - VOC - Solo } \\
\hline p-Bromofluorbenzeno & 0,05 & $\%$ & 120 & $60-140$ \\
\hline Dibrom ofluorometano & 0,05 & $\%$ & 83 & $60-140$ \\
\hline \multicolumn{5}{|l|}{ 283865/2014-0 - CAF-1 } \\
\hline Dibromofluorometano & 0,05 & $\%$ & 67 & $60-140$ \\
\hline p-Bromofluorbenzeno & 0,05 & $\%$ & 84 & $60-140$ \\
\hline
\end{tabular}

Notas

LQ = Limite de Quantificação.

n.a. $=$ Não Aplicável

Abrangência

$\mathrm{O}$ (s) resultado(s) referem-se somente à(s) amostra(s) analisada(s).

Este Relatório de Ensaio só pode ser reproduzido por inteiro e sem nenhuma alteração.

Plano de Amostragem

Plano de amostragem de responsabilidade do interessado

Responsabilidade Técnica

Os ensaios foram realizados na unidade da Bioagri Ambiental Ltda. - Matriz, situada na Rua Aljovil Martini, 177/201, Bairro Dois Córregos, Cep. 14420-833, Piracicaba/SP, registrada no CRQ 4ª Região sob n $16082-\mathrm{Fe}$ responsabilidade técnica do profissional José Carlos Moretti, CRQ n 04107238, $4^{a}$.Região.

Referências Metodológicas

Análises foram realizadas conforme a última versão do Standard Methods for the Examination of Water \& Wastewater 22nd 2012(SMWW), EPA e ABNT (quando aplicável).

Porcentagem de Sólidos e Cinzas: POP PA 058 - Rev. 02

VOC: EPA 8260 C: 2006,5021 A: 2003

Metiletilcetona: EPA 8260 C: 2006, 5021 A: 2003

Revisores

Débora Fernandes da Silva

Chave de Validação: 11a23befb323c9d0520078381044b008

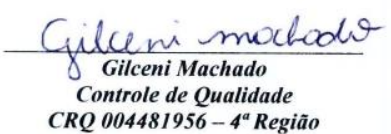

CRQ 004481956 - $4^{a}$ Região

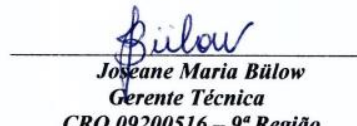

CRQ 09200516-9 $9^{a}$ Região 


\section{RELATÓRIO DE ENSAIO N $^{\circ}$ 283866/2014-0 - Piracicaba Processo Comercial $N^{\circ}$ 23961/2014-2}

\begin{tabular}{|l|l|}
\hline \multicolumn{2}{|c|}{ DADOS REFERENTES AO CLIENTE } \\
\hline Empresa solicitante: & Fundacao Parque de Alta Tecnologia da Regiao de Ipero e Adjacencias \\
\hline Endereço: & Rua Jose Antonio Scaciota, 165 - - Portal do Cedro - Iperó - SP - CEP: 18.560-000 . \\
\hline Nome do Solicitante: & Carla Marçal \\
\hline
\end{tabular}

\section{DADOS REFERENTES A AMOSTRA}

\begin{tabular}{|l|l|l|l|l|}
\hline Identificação do Cliente: & CAF-2 \\
\hline Amostra Rotulada como: & Solo Projeto Mestrado & Data da coleta: & $24 / 10 / 2014$ & $16: 00: 00$ \\
\hline Coletor: & Interessado & Data de Elaboração do RE: & $03 / 11 / 2014$ \\
\hline Data da entrada no laboratório: & $25 / 10 / 201408: 23$ & \multicolumn{5}{l}{$\mid l$} \\
\hline
\end{tabular}

\section{RESULTADOS PARA A AMOSTRA}

\begin{tabular}{|c|c|c|c|c|c|c|}
\hline Parâmetros & CAS & Unidade & LQ & Resultados analíticos & Incerteza & Data do Ensaio \\
\hline 1,1,1-Tricloroetano & $71-55-6$ & $\mathrm{mg} / \mathrm{kg}$ & 0,01 & $<0,01$ & n.a. & $30 / 10 / 201404: 42$ \\
\hline 1,1,2-Tricloroetano & $79-00-5$ & $\mathrm{mg} / \mathrm{kg}$ & 0,01 & $<0,01$ & n.a. & $30 / 10 / 201404: 42$ \\
\hline 1,1,2,2-Tetracloroetano & $79-34-5$ & $\mathrm{mg} / \mathrm{kg}$ & 0,01 & $<0,01$ & n.a. & $30 / 10 / 201404: 42$ \\
\hline 1,1-Dicloroetano & $75-34-3$ & $\mathrm{mg} / \mathrm{kg}$ & 0,01 & $<0,01$ & n.a. & $30 / 10 / 201404: 42$ \\
\hline 1,1-Dicloroeteno & $75-35-4$ & $\mathrm{mg} / \mathrm{kg}$ & 0,01 & $<0,01$ & n.a. & $30 / 10 / 201404: 42$ \\
\hline 1,1-Dicloropropeno & $563-58-6$ & $\mathrm{mg} / \mathrm{kg}$ & 0,01 & $<0,01$ & n.a. & $30 / 10 / 201404: 42$ \\
\hline 1,2,3-Triclorobenzeno & $87-61-6$ & $\mathrm{mg} / \mathrm{kg}$ & 0,01 & $<0,01$ & n.a. & $30 / 10 / 201404: 42$ \\
\hline 1,2,4-Triclorobenzeno & $120-82-1$ & $\mathrm{mg} / \mathrm{kg}$ & 0,01 & $<0,01$ & n.a. & $30 / 10 / 201404: 42$ \\
\hline 1,2-Dibromo-3-Cloropropano & $96-12-8$ & $\mathrm{mg} / \mathrm{kg}$ & 0,01 & $<0,01$ & n.a. & $30 / 10 / 201404: 42$ \\
\hline 1,2-Dicloroetano & $107-06-2$ & $\mathrm{mg} / \mathrm{kg}$ & 0,01 & $<0,01$ & n.a. & $30 / 10 / 201404: 42$ \\
\hline 1,2-Dicloropropano & $78-87-5$ & $\mathrm{mg} / \mathrm{kg}$ & 0,01 & $<0,01$ & n.a. & $30 / 10 / 201404: 42$ \\
\hline 1,3-Diclorobenzeno & 541-73-1 & $\mathrm{mg} / \mathrm{kg}$ & 0,01 & $<0,01$ & n.a. & $30 / 10 / 201404: 42$ \\
\hline 2,2-Dicloropropano & $594-20-7$ & $\mathrm{mg} / \mathrm{kg}$ & 0,01 & $<0,01$ & n.a. & $30 / 10 / 201404: 42$ \\
\hline 4-Metil-2-Pentanona & $108-10-1$ & $\mathrm{mg} / \mathrm{kg}$ & 0,01 & $<0,01$ & n.a. & $30 / 10 / 2014$ 04:42 \\
\hline Benzeno & $71-43-2$ & $\mathrm{mg} / \mathrm{kg}$ & 0,01 & $<0,01$ & n.a. & $30 / 10 / 2014$ 04:42 \\
\hline Bromobenzeno & $108-86-1$ & $\mathrm{mg} / \mathrm{kg}$ & 0,01 & $<0,01$ & n.a. & $30 / 10 / 2014$ 04:42 \\
\hline Bromodiclorometano & $75-27-4$ & $\mathrm{mg} / \mathrm{kg}$ & 0,01 & $<0,01$ & n.a. & $30 / 10 / 201404: 42$ \\
\hline Bromofórmio & $75-25-2$ & $\mathrm{mg} / \mathrm{kg}$ & 0,01 & $<0,01$ & n.a. & $30 / 10 / 201404: 42$ \\
\hline Bromometano & $74-83-9$ & $\mathrm{mg} / \mathrm{kg}$ & 0,01 & $<0,01$ & n.a. & $30 / 10 / 201404: 42$ \\
\hline Cis-1,2-Dicloroeteno & $156-59-2$ & $\mathrm{mg} / \mathrm{kg}$ & 0,01 & $<0,01$ & n.a. & $30 / 10 / 2014$ 04:42 \\
\hline Cis-1,3-Dicloropropeno & 10061-01-5 & $\mathrm{mg} / \mathrm{kg}$ & 0,01 & $<0,01$ & n.a. & $30 / 10 / 2014$ 04:42 \\
\hline Diclorometano & $75-09-2$ & $\mathrm{mg} / \mathrm{kg}$ & 0,01 & $<0,01$ & n.a. & $30 / 10 / 201404: 42$ \\
\hline Cloreto de Vinila & $75-01-4$ & $\mathrm{mg} / \mathrm{kg}$ & 0,002 & $<0,002$ & n.a. & $30 / 10 / 2014$ 04:42 \\
\hline Clorobenzeno & $108-90-7$ & $\mathrm{mg} / \mathrm{kg}$ & 0,01 & $<0,01$ & n.a. & $30 / 10 / 201404: 42$ \\
\hline Cloroetano & $75-00-3$ & $\mathrm{mg} / \mathrm{kg}$ & 0,01 & $<0,01$ & n.a. & $30 / 10 / 201404: 42$ \\
\hline Clorofórmio & $67-66-3$ & $\mathrm{mg} / \mathrm{kg}$ & 0,01 & $<0,01$ & n.a. & $30 / 10 / 201404: 42$ \\
\hline Clorometano & $74-87-3$ & $\mathrm{mg} / \mathrm{kg}$ & 0,01 & $<0,01$ & n.a. & $30 / 10 / 201404: 42$ \\
\hline Dibromoclorometano & $124-48-1$ & $\mathrm{mg} / \mathrm{kg}$ & 0,01 & $<0,01$ & n.a. & $30 / 10 / 201404: 42$ \\
\hline Dissulfeto de Carbono & $75-15-0$ & $\mathrm{mg} / \mathrm{kg}$ & 0,01 & $<0,01$ & n.a. & $30 / 10 / 2014$ 04:42 \\
\hline Estireno & $100-42-5$ & $\mathrm{mg} / \mathrm{kg}$ & 0,01 & $<0,01$ & n.a. & $30 / 10 / 2014$ 04:42 \\
\hline Etilbenzeno & $100-41-4$ & $\mathrm{mg} / \mathrm{kg}$ & 0,01 & $<0,01$ & n.a. & $30 / 10 / 2014$ 04:42 \\
\hline Hexaclorobutadieno & $87-68-3$ & $\mathrm{mg} / \mathrm{kg}$ & 0,01 & $<0,01$ & n.a. & $30 / 10 / 201404: 42$ \\
\hline $\mathrm{m}, \mathrm{p}$-Xilenos & --- & $\mathrm{mg} / \mathrm{kg}$ & 0,01 & $<0,01$ & n.a. & $30 / 10 / 201404: 42$ \\
\hline o-Xileno & $95-47-6$ & $\mathrm{mg} / \mathrm{kg}$ & 0,01 & $<0,01$ & n.a. & $30 / 10 / 201404: 42$ \\
\hline p-Isopropiltolueno & $99-87-6$ & $\mathrm{mg} / \mathrm{kg}$ & 0,01 & $<0,01$ & n.a. & $30 / 10 / 2014$ 04:42 \\
\hline Tetracloroeteno & $127-18-4$ & $\mathrm{mg} / \mathrm{kg}$ & 0,01 & 0,017 & 0,0034 & $30 / 10 / 201404: 42$ \\
\hline Tetracloreto de Carbono & $56-23-5$ & $\mathrm{mg} / \mathrm{kg}$ & 0,01 & $<0,01$ & n.a. & $30 / 10 / 2014$ 04:42 \\
\hline Tolueno & $108-88-3$ & $\mathrm{mg} / \mathrm{kg}$ & 0,01 & $<0,01$ & n.a. & $30 / 10 / 201404: 42$ \\
\hline Trans-1,2-Dicloroeteno & $156-60-5$ & $\mathrm{mg} / \mathrm{kg}$ & 0,01 & $<0,01$ & n.a. & $30 / 10 / 201404: 42$ \\
\hline Tricloroeteno & $79-01-6$ & $\mathrm{mg} / \mathrm{kg}$ & 0,01 & $<0,01$ & n.a. & $30 / 10 / 201404: 42$ \\
\hline 1,1,1,2-Tetracloroetano & $630-20-6$ & $\mathrm{mg} / \mathrm{kg}$ & 0,01 & $<0,01$ & n.a. & $30 / 10 / 201404: 42$ \\
\hline 1,2,3-Tricloropropano & $96-18-4$ & $\mathrm{mg} / \mathrm{kg}$ & 0,01 & $<0,01$ & n.a. & 30/10/2014 04:42 \\
\hline
\end{tabular}




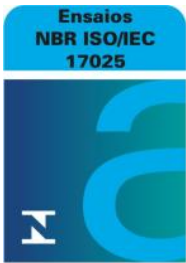

CRL 0172

\begin{tabular}{|c|c|c|c|c|c|c|}
\hline Parâmetros & CAS & Unidade & LQ & Resultados analíticos & Incerteza & Data do Ensaio \\
\hline 1,3,5-Trimetilbenzeno & $108-67-8$ & $\mathrm{mg} / \mathrm{kg}$ & 0,01 & $<0,01$ & n.a. & $30 / 10 / 201404: 42$ \\
\hline 1,2,4-Trimetilbenzeno & $95-63-6$ & $\mathrm{mg} / \mathrm{kg}$ & 0,01 & $<0,01$ & n.a. & 30/10/2014 04:42 \\
\hline 1,2-Dibromoetano & $106-93-4$ & $\mathrm{mg} / \mathrm{kg}$ & 0,01 & $<0,01$ & n.a. & $30 / 10 / 2014$ 04:42 \\
\hline 1,2-Diclorobenzeno & $95-50-1$ & $\mathrm{mg} / \mathrm{kg}$ & 0,01 & $<0,01$ & n.a. & 30/10/2014 04:42 \\
\hline 2-Clorotolueno & $95-49-8$ & $\mathrm{mg} / \mathrm{kg}$ & 0,01 & $<0,01$ & n.a. & $30 / 10 / 201404: 42$ \\
\hline Dibromometano & $74-95-3$ & $\mathrm{mg} / \mathrm{kg}$ & 0,01 & $<0,01$ & n.a. & $30 / 10 / 201404: 42$ \\
\hline Metiletilcetona & 78-93-3 & $\mathrm{mg} / \mathrm{kg}$ & 3 & $<3$ & n.a. & $30 / 10 / 201404: 42$ \\
\hline Naftaleno & $91-20-3$ & $\mathrm{mg} / \mathrm{kg}$ & 0,01 & $<0,01$ & n.a. & $30 / 10 / 2014$ 04:42 \\
\hline n-Butilbenzeno & $104-51-8$ & $\mathrm{mg} / \mathrm{kg}$ & 0,01 & $<0,01$ & n.a. & $30 / 10 / 2014$ 04:42 \\
\hline n-Propilbenzeno & $103-65-1$ & $\mathrm{mg} / \mathrm{kg}$ & 0,01 & $<0,01$ & n.a. & $30 / 10 / 201404: 42$ \\
\hline 4-Clorotolueno & $106-43-4$ & $\mathrm{mg} / \mathrm{kg}$ & 0,01 & $<0,01$ & n.a. & $30 / 10 / 201404: 42$ \\
\hline sec-Butilbenzeno & $135-98-8$ & $\mathrm{mg} / \mathrm{kg}$ & 0,01 & $<0,01$ & n.a. & $30 / 10 / 2014$ 04:42 \\
\hline terc-Butilbenzeno & $98-06-6$ & $\mathrm{mg} / \mathrm{kg}$ & 0,01 & $<0,01$ & n.a. & $30 / 10 / 201404: 42$ \\
\hline trans-1,3-Dicloropropeno & $10061-02-6$ & $\mathrm{mg} / \mathrm{kg}$ & 0,01 & $<0,01$ & n.a. & $30 / 10 / 2014$ 04:42 \\
\hline Isopropilbenzeno & $98-82-8$ & $\mathrm{mg} / \mathrm{kg}$ & 0,01 & $<0,01$ & n.a. & $30 / 10 / 201404: 42$ \\
\hline 1,4-Diclorobenzeno & $106-46-7$ & $\mathrm{mg} / \mathrm{kg}$ & 0,01 & $<0,01$ & n.a. & $30 / 10 / 2014$ 04:42 \\
\hline 1,3,5-Triclorobenzeno & $108-70-3$ & $\mathrm{mg} / \mathrm{kg}$ & 0,01 & $<0,01$ & n.a. & $30 / 10 / 201404: 42$ \\
\hline 1,3-Dicloropropano & $142-28-9$ & $\mathrm{mg} / \mathrm{kg}$ & 0,01 & $<0,01$ & n.a. & 30/10/2014 04:42 \\
\hline Porcentagem de Sólidos & --- & $\% \mathrm{p} / \mathrm{p}$ & 0,05 & 84,5 & 8,5 & 01/11/2014 07:57 \\
\hline
\end{tabular}

\section{CONTROLE DE Q UALIDADE DO LAB ORATÓRIO}

284309/2014-0 - Branco de Análise - VOC - Solo

Controle de $Q$ ualidade - VOC - Solo

\begin{tabular}{|c|c|c|c|}
\hline Parâmetros & Unidade & LQ & Resultados analíticos \\
\hline 1,1,1-Tricloroetano & $\mathrm{mg} / \mathrm{kg}$ & 0,01 & $<0,01$ \\
\hline 1,1,2-Tricloroetano & $\mathrm{mg} / \mathrm{kg}$ & 0,01 & $<0,01$ \\
\hline 1,1,2,2-Tetracloroetano & $\mathrm{mg} / \mathrm{kg}$ & 0,01 & $<0,01$ \\
\hline 1,1-Dicloroetano & $\mathrm{mg} / \mathrm{kg}$ & 0,01 & $<0,01$ \\
\hline 1,1-Dicloroeteno & $\mathrm{mg} / \mathrm{kg}$ & 0,01 & $<0,01$ \\
\hline 1,1-Dicloropropeno & $\mathrm{mg} / \mathrm{kg}$ & 0,01 & $<0,01$ \\
\hline 1,2,3-Triclorobenzeno & $\mathrm{mg} / \mathrm{kg}$ & 0,01 & $<0,01$ \\
\hline 1,2,4-Triclorobenzeno & $\mathrm{mg} / \mathrm{kg}$ & 0,01 & $<0,01$ \\
\hline 1,2-Dibromo-3-Cloropropano & $\mathrm{mg} / \mathrm{kg}$ & 0,01 & $<0,01$ \\
\hline 1,2-Dicloroetano & $\mathrm{mg} / \mathrm{kg}$ & 0,01 & $<0,01$ \\
\hline 1,2-Dicloropropano & $\mathrm{mg} / \mathrm{kg}$ & 0,01 & $<0,01$ \\
\hline 1,3-Dicloropropano & $\mathrm{mg} / \mathrm{kg}$ & 0,01 & $<0,01$ \\
\hline 1,4-Diclorobenzeno & $\mathrm{mg} / \mathrm{kg}$ & 0,01 & $<0,01$ \\
\hline 2,2-Dicloropropano & $\mathrm{mg} / \mathrm{kg}$ & 0,01 & $<0,01$ \\
\hline 4-Metil-2-Pentanona & $\mathrm{mg} / \mathrm{kg}$ & 0,01 & $<0,01$ \\
\hline Benzeno & $\mathrm{mg} / \mathrm{kg}$ & 0,01 & $<0,01$ \\
\hline Bromobenzeno & $\mathrm{mg} / \mathrm{kg}$ & 0,01 & $<0,01$ \\
\hline Bromodiclorometano & $\mathrm{mg} / \mathrm{kg}$ & 0,01 & $<0,01$ \\
\hline Bromofórmio & $\mathrm{mg} / \mathrm{kg}$ & 0,01 & $<0,01$ \\
\hline Bromometano & $\mathrm{mg} / \mathrm{kg}$ & 0,01 & $<0,01$ \\
\hline Cis-1,2-Dicloroeteno & $\mathrm{mg} / \mathrm{kg}$ & 0,01 & $<0,01$ \\
\hline Cis-1,3-Dicloropropeno & $\mathrm{mg} / \mathrm{kg}$ & 0,01 & $<0,01$ \\
\hline Diclorometano & $\mathrm{mg} / \mathrm{kg}$ & 0,01 & $<0,01$ \\
\hline Cloreto de Vinila & $\mathrm{mg} / \mathrm{kg}$ & 0,002 & $<0,002$ \\
\hline Clorobenzeno & $\mathrm{mg} / \mathrm{kg}$ & 0,01 & $<0,01$ \\
\hline Cloroetano & $\mathrm{mg} / \mathrm{kg}$ & 0,01 & $<0,01$ \\
\hline Clorofórmio & $\mathrm{mg} / \mathrm{kg}$ & 0,01 & $<0,01$ \\
\hline Clorometano & $\mathrm{mg} / \mathrm{kg}$ & 0,01 & $<0,01$ \\
\hline Dibromoclorometano & $\mathrm{mg} / \mathrm{kg}$ & 0,01 & $<0,01$ \\
\hline Dissulfeto de Carbono & $\mathrm{mg} / \mathrm{kg}$ & 0,01 & $<0,01$ \\
\hline Estireno & $\mathrm{mg} / \mathrm{kg}$ & 0,01 & $<0,01$ \\
\hline Etilbenzeno & $\mathrm{mg} / \mathrm{kg}$ & 0,01 & $<0,01$ \\
\hline Hexaclorobutadieno & $\mathrm{mg} / \mathrm{kg}$ & 0,01 & $<0,01$ \\
\hline $\mathrm{m}, \mathrm{p}$-Xilenos & $\mathrm{mg} / \mathrm{kg}$ & 0,01 & $<0,01$ \\
\hline o-Xileno & $\mathrm{mg} / \mathrm{kg}$ & 0,01 & $<0,01$ \\
\hline p-Isopropiltolueno & $\mathrm{mg} / \mathrm{kg}$ & 0,01 & $<0,01$ \\
\hline Tetracloreto de Carbono & $\mathrm{mg} / \mathrm{kg}$ & 0,01 & $<0,01$ \\
\hline Tetracloroeteno & $\mathrm{mg} / \mathrm{kg}$ & 0,01 & $<0,01$ \\
\hline Tolueno & $\mathrm{mg} / \mathrm{kg}$ & 0,01 & $<0,01$ \\
\hline Trans-1,2-Dicloroeteno & $\mathrm{mg} / \mathrm{kg}$ & 0,01 & $<0,01$ \\
\hline Tricloroeteno & $\mathrm{mg} / \mathrm{kg}$ & 0,01 & $<0,01$ \\
\hline 1,3,5-Triclorobenzeno & $\mathrm{mg} / \mathrm{kg}$ & 0,01 & $<0,01$ \\
\hline
\end{tabular}




\begin{tabular}{|c|c|c|c|c|}
\hline Parâmetros & $\begin{array}{l}\text { Q uantidade } \\
\text { Adicionada }\end{array}$ & Unidade & $\begin{array}{c}\text { Resultado da } \\
\text { Recuperação (\%) }\end{array}$ & Faixa Aceitável de Recuperação (\%) \\
\hline \multicolumn{5}{|l|}{ 284310/2014-0 - LCS - VOC - Solo } \\
\hline 1,1-Dicloroeteno & 0,05 & $\mathrm{mg} / \mathrm{kg}$ & 62 & $60-140$ \\
\hline Benzeno & 0,05 & $\mathrm{mg} / \mathrm{kg}$ & 73 & $60-140$ \\
\hline Tricloroeteno & 0,05 & $\mathrm{mg} / \mathrm{kg}$ & 82 & $60-140$ \\
\hline Tolueno & 0,05 & $\mathrm{mg} / \mathrm{kg}$ & 84 & $60-140$ \\
\hline Clorobenzeno & 0,05 & $\mathrm{mg} / \mathrm{kg}$ & 67 & $60-140$ \\
\hline \multicolumn{5}{|c|}{$\begin{array}{l}\text { Surrogates } \\
\quad 284309 / 2014-0 \text { - Branco de Análise - VOC - Solo }\end{array}$} \\
\hline p-Bromofluorbenzeno & 0,05 & $\%$ & 120 & $60-140$ \\
\hline Dibrom ofluorometano & 0,05 & $\%$ & 110 & $60-140$ \\
\hline \multicolumn{5}{|l|}{ 284310/2014-0 - LCS - VOC - Solo } \\
\hline p-Bromofluorbenzeno & 0,05 & $\%$ & 120 & $60-140$ \\
\hline Dibrom ofluorometano & 0,05 & $\%$ & 83 & $60-140$ \\
\hline \multicolumn{5}{|l|}{ 283866/2014-0 - CAF-2 } \\
\hline Dibromofluorometano & 0,05 & $\%$ & 65 & $60-140$ \\
\hline p-Bromofluorbenzeno & 0,05 & $\%$ & 80 & $60-140$ \\
\hline
\end{tabular}

Notas

$\mathrm{LQ}=$ Limite de Quantificação

n.a. = Não Aplicável.

Abrangência

(s) resultado(s) referem-se somente à(s) amostra(s) analisada(s).

Este Relatório de Ensaio só pode ser reproduzido por inteiro e sem nenhuma alteração.

Plano de Amostragem

Plano de amostragem de responsabilidade do interessado

Responsabilidade Técnica

Os ensaios foram realizados na unidade da Bioagri Ambiental Ltda. - Matriz, situada na Rua Aljovil Martini, 177/201, Bairro Dois Córregos, Cep. 14420-833, Piracicaba/SP, registrada no CRQ 4ª Região sob nº 16082-Fe responsabilidade técnica do profissional José Carlos Moretti, CRQ nº 04107238, $4^{a}$.Região.

Referências Metodológicas

Análises foram realizadas conforme a última versão do Standard Methods for the Examination of Water \& Wastewater 22nd 2012(SMWW), EPA e ABNT (quando aplicável).

Porcentagem de Sólidos e Cinzas: POP PA 058 - Rev. 02

VOC: EPA 8260 C: 2006,5021 A: 2003

Metiletilcetona: EPA 8260 C: 2006,5021 A: 2003

Revisores

Débora Fernandes da Silva

Chave de Validação: b5514c875c12940af7eca7b0179c44ae

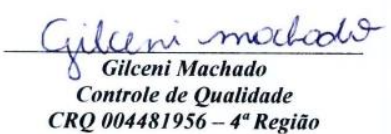

CRQ 004481956 - $4^{a}$ Região

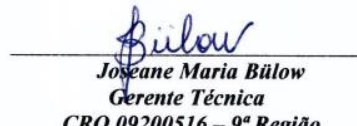

CRQ 09200516-9 $9^{a}$ Região 


\section{RELATÓRIO DE ENSAIO N $^{\circ}$ 283867/2014-0 - Piracicaba Processo Comercial $N^{\circ}$ 23961/2014-2}

\begin{tabular}{|l|l|}
\hline \multicolumn{2}{|c|}{ DADOS REFERENTES AO CLIENTE } \\
\hline Empresa solicitante: & Fundacao Parque de Alta Tecnologia da Regiao de Ipero e Adjacencias \\
\hline Endereço: & Rua Jose Antonio Scaciota, 165 - - Portal do Cedro - Iperó - SP - CEP: 18.560-000 . \\
\hline Nome do Solicitante: & Carla Marçal \\
\hline
\end{tabular}

\section{DADOS REFERENTES A AMOSTRA}

\begin{tabular}{|l|l|l|l|l|}
\hline Identificação do Cliente: & CAF-3 \\
\hline Amostra Rotulada como: & Solo Projeto Mestrado & \multicolumn{5}{l|}{} \\
\hline Coletor: & Interessado & Data da coleta: & $24 / 10 / 2014$ & $16: 00: 00$ \\
\hline Data da entrada no laboratório: & $25 / 10 / 201408: 23$ & Data de Elaboração do RE: & $03 / 11 / 2014$ \\
\hline
\end{tabular}

\section{RESULTADOS PARA A AMOSTRA}

\begin{tabular}{|c|c|c|c|c|c|c|}
\hline Parâmetros & CAS & Unidade & LQ & Resultados analíticos & Incerteza & Data do Ensaio \\
\hline 1,1,1-Tricloroetano & $71-55-6$ & $\mathrm{mg} / \mathrm{kg}$ & 0,01 & $<0,01$ & n.a. & $30 / 10 / 201405: 06$ \\
\hline 1,1,2-Tricloroetano & $79-00-5$ & $\mathrm{mg} / \mathrm{kg}$ & 0,01 & $<0,01$ & n.a. & 30/10/2014 05:06 \\
\hline 1,1,2,2-Tetracloroetano & $79-34-5$ & $\mathrm{mg} / \mathrm{kg}$ & 0,01 & $<0,01$ & n.a. & $30 / 10 / 2014$ 05:06 \\
\hline 1,1-Dicloroetano & $75-34-3$ & $\mathrm{mg} / \mathrm{kg}$ & 0,01 & $<0,01$ & n.a. & $30 / 10 / 2014$ 05:06 \\
\hline 1,1-Dicloroeteno & $75-35-4$ & $\mathrm{mg} / \mathrm{kg}$ & 0,01 & $<0,01$ & n.a. & $30 / 10 / 2014$ 05:06 \\
\hline 1,1-Dicloropropeno & $563-58-6$ & $\mathrm{mg} / \mathrm{kg}$ & 0,01 & $<0,01$ & n.a. & 30/10/2014 05:06 \\
\hline 1,2,3-Triclorobenzeno & $87-61-6$ & $\mathrm{mg} / \mathrm{kg}$ & 0,01 & $<0,01$ & n.a. & $30 / 10 / 2014$ 05:06 \\
\hline 1,2,4-Triclorobenzeno & $120-82-1$ & $\mathrm{mg} / \mathrm{kg}$ & 0,01 & $<0,01$ & n.a. & $30 / 10 / 2014$ 05:06 \\
\hline 1,2-Dibromo-3-Cloropropano & $96-12-8$ & $\mathrm{mg} / \mathrm{kg}$ & 0,01 & $<0,01$ & n.a. & 30/10/2014 05:06 \\
\hline 1,2-Dicloroetano & $107-06-2$ & $\mathrm{mg} / \mathrm{kg}$ & 0,01 & $<0,01$ & n.a. & $30 / 10 / 201405: 06$ \\
\hline 1,2-Dicloropropano & $78-87-5$ & $\mathrm{mg} / \mathrm{kg}$ & 0,01 & $<0,01$ & n.a. & $30 / 10 / 2014$ 05:06 \\
\hline 1,3-Diclorobenzeno & $541-73-1$ & $\mathrm{mg} / \mathrm{kg}$ & 0,01 & $<0,01$ & n.a. & 30/10/2014 05:06 \\
\hline 2,2-Dicloropropano & $594-20-7$ & $\mathrm{mg} / \mathrm{kg}$ & 0,01 & $<0,01$ & n.a. & $30 / 10 / 2014$ 05:06 \\
\hline 4-Metil-2-Pentanona & $108-10-1$ & $\mathrm{mg} / \mathrm{kg}$ & 0,01 & $<0,01$ & n.a. & $30 / 10 / 2014$ 05:06 \\
\hline Benzeno & $71-43-2$ & $\mathrm{mg} / \mathrm{kg}$ & 0,01 & $<0,01$ & n.a. & 30/10/2014 05:06 \\
\hline Bromobenzeno & $108-86-1$ & $\mathrm{mg} / \mathrm{kg}$ & 0,01 & $<0,01$ & n.a. & $30 / 10 / 2014$ 05:06 \\
\hline Bromodiclorometano & $75-27-4$ & $\mathrm{mg} / \mathrm{kg}$ & 0,01 & $<0,01$ & n.a. & $30 / 10 / 201405: 06$ \\
\hline Bromofórmio & $75-25-2$ & $\mathrm{mg} / \mathrm{kg}$ & 0,01 & $<0,01$ & n.a. & $30 / 10 / 201405: 06$ \\
\hline Bromometano & $74-83-9$ & $\mathrm{mg} / \mathrm{kg}$ & 0,01 & $<0,01$ & n.a. & 30/10/2014 05:06 \\
\hline Cis-1,2-Dicloroeteno & $156-59-2$ & $\mathrm{mg} / \mathrm{kg}$ & 0,01 & $<0,01$ & n.a. & $30 / 10 / 2014$ 05:06 \\
\hline Cis-1,3-Dicloropropeno & 10061-01-5 & $\mathrm{mg} / \mathrm{kg}$ & 0,01 & $<0,01$ & n.a. & 30/10/2014 05:06 \\
\hline Diclorometano & $75-09-2$ & $\mathrm{mg} / \mathrm{kg}$ & 0,01 & $<0,01$ & n.a. & 30/10/2014 05:06 \\
\hline Cloreto de Vinila & $75-01-4$ & $\mathrm{mg} / \mathrm{kg}$ & 0,002 & $<0,002$ & n.a. & 30/10/2014 05:06 \\
\hline Clorobenzeno & $108-90-7$ & $\mathrm{mg} / \mathrm{kg}$ & 0,01 & $<0,01$ & n.a. & $30 / 10 / 201405: 06$ \\
\hline Cloroetano & $75-00-3$ & $\mathrm{mg} / \mathrm{kg}$ & 0,01 & $<0,01$ & n.a. & $30 / 10 / 201405: 06$ \\
\hline Clorofórmio & $67-66-3$ & $\mathrm{mg} / \mathrm{kg}$ & 0,01 & $<0,01$ & n.a. & $30 / 10 / 201405: 06$ \\
\hline Clorometano & $74-87-3$ & $\mathrm{mg} / \mathrm{kg}$ & 0,01 & $<0,01$ & n.a. & 30/10/2014 05:06 \\
\hline Dibromoclorometano & $124-48-1$ & $\mathrm{mg} / \mathrm{kg}$ & 0,01 & $<0,01$ & n.a. & $30 / 10 / 201405: 06$ \\
\hline Dissulfeto de Carbono & $75-15-0$ & $\mathrm{mg} / \mathrm{kg}$ & 0,01 & $<0,01$ & n.a. & 30/10/2014 05:06 \\
\hline Estireno & $100-42-5$ & $\mathrm{mg} / \mathrm{kg}$ & 0,01 & $<0,01$ & n.a. & $30 / 10 / 2014$ 05:06 \\
\hline Etilbenzeno & $100-41-4$ & $\mathrm{mg} / \mathrm{kg}$ & 0,01 & $<0,01$ & n.a. & $30 / 10 / 2014$ 05:06 \\
\hline Hexaclorobutadieno & $87-68-3$ & $\mathrm{mg} / \mathrm{kg}$ & 0,01 & $<0,01$ & n.a. & $30 / 10 / 201405: 06$ \\
\hline $\mathrm{m}, \mathrm{p}$-Xilenos & --- & $\mathrm{mg} / \mathrm{kg}$ & 0,01 & $<0,01$ & n.a. & $30 / 10 / 201405: 06$ \\
\hline o-Xileno & $95-47-6$ & $\mathrm{mg} / \mathrm{kg}$ & 0,01 & $<0,01$ & n.a. & 30/10/2014 05:06 \\
\hline p-Isopropiltolueno & $99-87-6$ & $\mathrm{mg} / \mathrm{kg}$ & 0,01 & $<0,01$ & n.a. & $30 / 10 / 2014$ 05:06 \\
\hline Tetracloroeteno & $127-18-4$ & $\mathrm{mg} / \mathrm{kg}$ & 0,01 & 0,013 & 0,0026 & 30/10/2014 05:06 \\
\hline Tetracloreto de Carbono & $56-23-5$ & $\mathrm{mg} / \mathrm{kg}$ & 0,01 & $<0,01$ & n.a. & $30 / 10 / 201405: 06$ \\
\hline Tolueno & $108-88-3$ & $\mathrm{mg} / \mathrm{kg}$ & 0,01 & $<0,01$ & n.a. & 30/10/2014 05:06 \\
\hline Trans-1,2-Dicloroeteno & $156-60-5$ & $\mathrm{mg} / \mathrm{kg}$ & 0,01 & $<0,01$ & n.a. & $30 / 10 / 201405: 06$ \\
\hline Tricloroeteno & $79-01-6$ & $\mathrm{mg} / \mathrm{kg}$ & 0,01 & $<0,01$ & n.a. & $30 / 10 / 201405: 06$ \\
\hline 1,1,1,2-Tetracloroetano & $630-20-6$ & $\mathrm{mg} / \mathrm{kg}$ & 0,01 & $<0,01$ & n.a. & $30 / 10 / 201405: 06$ \\
\hline 1,2,3-Tricloropropano & $96-18-4$ & $\mathrm{mg} / \mathrm{kg}$ & 0,01 & $<0,01$ & n.a. & 30/10/2014 05:06 \\
\hline
\end{tabular}




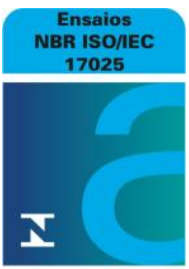

CRL 0172

\begin{tabular}{|c|c|c|c|c|c|c|}
\hline Parâmetros & CAS & Unidade & LQ & Resultados analíticos & Incerteza & Data do Ensaio \\
\hline 1,3,5-Trimetilbenzeno & $108-67-8$ & $\mathrm{mg} / \mathrm{kg}$ & 0,01 & $<0,01$ & n.a. & $30 / 10 / 2014$ 05:06 \\
\hline 1,2,4-Trimetilbenzeno & $95-63-6$ & $\mathrm{mg} / \mathrm{kg}$ & 0,01 & $<0,01$ & n.a. & 30/10/2014 05:06 \\
\hline 1,2-Dibromoetano & $106-93-4$ & $\mathrm{mg} / \mathrm{kg}$ & 0,01 & $<0,01$ & n.a. & $30 / 10 / 201405: 06$ \\
\hline 1,2-Diclorobenzeno & $95-50-1$ & $\mathrm{mg} / \mathrm{kg}$ & 0,01 & $<0,01$ & n.a. & 30/10/2014 05:06 \\
\hline 2-Clorotolueno & $95-49-8$ & $\mathrm{mg} / \mathrm{kg}$ & 0,01 & $<0,01$ & n.a. & $30 / 10 / 2014$ 05:06 \\
\hline Dibromometano & $74-95-3$ & $\mathrm{mg} / \mathrm{kg}$ & 0,01 & $<0,01$ & n.a. & $30 / 10 / 2014$ 05:06 \\
\hline Metiletilcetona & 78-93-3 & $\mathrm{mg} / \mathrm{kg}$ & 3 & $<3$ & n.a. & $30 / 10 / 2014$ 05:06 \\
\hline Naftaleno & $91-20-3$ & $\mathrm{mg} / \mathrm{kg}$ & 0,01 & $<0,01$ & n.a. & 30/10/2014 05:06 \\
\hline n-Butilbenzeno & $104-51-8$ & $\mathrm{mg} / \mathrm{kg}$ & 0,01 & $<0,01$ & n.a. & 30/10/2014 05:06 \\
\hline n-Propilbenzeno & $103-65-1$ & $\mathrm{mg} / \mathrm{kg}$ & 0,01 & $<0,01$ & n.a. & 30/10/2014 05:06 \\
\hline 4-Clorotolueno & $106-43-4$ & $\mathrm{mg} / \mathrm{kg}$ & 0,01 & $<0,01$ & n.a. & 30/10/2014 05:06 \\
\hline sec-Butilbenzeno & $135-98-8$ & $\mathrm{mg} / \mathrm{kg}$ & 0,01 & $<0,01$ & n.a. & 30/10/2014 05:06 \\
\hline terc-Butilbenzeno & $98-06-6$ & $\mathrm{mg} / \mathrm{kg}$ & 0,01 & $<0,01$ & n.a. & $30 / 10 / 2014$ 05:06 \\
\hline trans-1,3-Dicloropropeno & $10061-02-6$ & $\mathrm{mg} / \mathrm{kg}$ & 0,01 & $<0,01$ & n.a. & $30 / 10 / 2014$ 05:06 \\
\hline Isopropilbenzeno & $98-82-8$ & $\mathrm{mg} / \mathrm{kg}$ & 0,01 & $<0,01$ & n.a. & $30 / 10 / 2014$ 05:06 \\
\hline 1,4-Diclorobenzeno & $106-46-7$ & $\mathrm{mg} / \mathrm{kg}$ & 0,01 & $<0,01$ & n.a. & $30 / 10 / 2014$ 05:06 \\
\hline 1,3,5-Triclorobenzeno & $108-70-3$ & $\mathrm{mg} / \mathrm{kg}$ & 0,01 & $<0,01$ & n.a. & 30/10/2014 05:06 \\
\hline 1,3-Dicloropropano & $142-28-9$ & $\mathrm{mg} / \mathrm{kg}$ & 0,01 & $<0,01$ & n.a. & $30 / 10 / 2014$ 05:06 \\
\hline Porcentagem de Sólidos & --- & $\% \mathrm{p} / \mathrm{p}$ & 0,05 & 84,0 & 8,4 & 01/11/2014 07:57 \\
\hline
\end{tabular}

\section{CONTROLE DE Q UALIDADE DO LAB ORATÓRIO}

284309/2014-0 - Branco de Análise - VOC - Solo

Controle de $Q$ ualidade - VOC - Solo

\begin{tabular}{|c|c|c|c|}
\hline Parâmetros & Unidade & LQ & Resultados analíticos \\
\hline 1,1,1-Tricloroetano & $\mathrm{mg} / \mathrm{kg}$ & 0,01 & $<0,01$ \\
\hline 1,1,2-Tricloroetano & $\mathrm{mg} / \mathrm{kg}$ & 0,01 & $<0,01$ \\
\hline 1,1,2,2-Tetracloroetano & $\mathrm{mg} / \mathrm{kg}$ & 0,01 & $<0,01$ \\
\hline 1,1-Dicloroetano & $\mathrm{mg} / \mathrm{kg}$ & 0,01 & $<0,01$ \\
\hline 1,1-Dicloroeteno & $\mathrm{mg} / \mathrm{kg}$ & 0,01 & $<0,01$ \\
\hline 1,1-Dicloropropeno & $\mathrm{mg} / \mathrm{kg}$ & 0,01 & $<0,01$ \\
\hline 1,2,3-Triclorobenzeno & $\mathrm{mg} / \mathrm{kg}$ & 0,01 & $<0,01$ \\
\hline 1,2,4-Triclorobenzeno & $\mathrm{mg} / \mathrm{kg}$ & 0,01 & $<0,01$ \\
\hline 1,2-Dibromo-3-Cloropropano & $\mathrm{mg} / \mathrm{kg}$ & 0,01 & $<0,01$ \\
\hline 1,2-Dicloroetano & $\mathrm{mg} / \mathrm{kg}$ & 0,01 & $<0,01$ \\
\hline 1,2-Dicloropropano & $\mathrm{mg} / \mathrm{kg}$ & 0,01 & $<0,01$ \\
\hline 1,3-Dicloropropano & $\mathrm{mg} / \mathrm{kg}$ & 0,01 & $<0,01$ \\
\hline 1,4-Diclorobenzeno & $\mathrm{mg} / \mathrm{kg}$ & 0,01 & $<0,01$ \\
\hline 2,2-Dicloropropano & $\mathrm{mg} / \mathrm{kg}$ & 0,01 & $<0,01$ \\
\hline 4-Metil-2-Pentanona & $\mathrm{mg} / \mathrm{kg}$ & 0,01 & $<0,01$ \\
\hline Benzeno & $\mathrm{mg} / \mathrm{kg}$ & 0,01 & $<0,01$ \\
\hline Bromobenzeno & $\mathrm{mg} / \mathrm{kg}$ & 0,01 & $<0,01$ \\
\hline Bromodiclorometano & $\mathrm{mg} / \mathrm{kg}$ & 0,01 & $<0,01$ \\
\hline Bromofórmio & $\mathrm{mg} / \mathrm{kg}$ & 0,01 & $<0,01$ \\
\hline Bromometano & $\mathrm{mg} / \mathrm{kg}$ & 0,01 & $<0,01$ \\
\hline Cis-1,2-Dicloroeteno & $\mathrm{mg} / \mathrm{kg}$ & 0,01 & $<0,01$ \\
\hline Cis-1,3-Dicloropropeno & $\mathrm{mg} / \mathrm{kg}$ & 0,01 & $<0,01$ \\
\hline Diclorometano & $\mathrm{mg} / \mathrm{kg}$ & 0,01 & $<0,01$ \\
\hline Cloreto de Vinila & $\mathrm{mg} / \mathrm{kg}$ & 0,002 & $<0,002$ \\
\hline Clorobenzeno & $\mathrm{mg} / \mathrm{kg}$ & 0,01 & $<0,01$ \\
\hline Cloroetano & $\mathrm{mg} / \mathrm{kg}$ & 0,01 & $<0,01$ \\
\hline Clorofórmio & $\mathrm{mg} / \mathrm{kg}$ & 0,01 & $<0,01$ \\
\hline Clorometano & $\mathrm{mg} / \mathrm{kg}$ & 0,01 & $<0,01$ \\
\hline Dibromoclorometano & $\mathrm{mg} / \mathrm{kg}$ & 0,01 & $<0,01$ \\
\hline Dissulfeto de Carbono & $\mathrm{mg} / \mathrm{kg}$ & 0,01 & $<0,01$ \\
\hline Estireno & $\mathrm{mg} / \mathrm{kg}$ & 0,01 & $<0,01$ \\
\hline Etilbenzeno & $\mathrm{mg} / \mathrm{kg}$ & 0,01 & $<0,01$ \\
\hline Hexaclorobutadieno & $\mathrm{mg} / \mathrm{kg}$ & 0,01 & $<0,01$ \\
\hline m,p-Xilenos & $\mathrm{mg} / \mathrm{kg}$ & 0,01 & $<0,01$ \\
\hline o-Xileno & $\mathrm{mg} / \mathrm{kg}$ & 0,01 & $<0,01$ \\
\hline p-Isopropiltolueno & $\mathrm{mg} / \mathrm{kg}$ & 0,01 & $<0,01$ \\
\hline Tetracloreto de Carbono & $\mathrm{mg} / \mathrm{kg}$ & 0,01 & $<0,01$ \\
\hline Tetracloroeteno & $\mathrm{mg} / \mathrm{kg}$ & 0,01 & $<0,01$ \\
\hline Tolueno & $\mathrm{mg} / \mathrm{kg}$ & 0,01 & $<0,01$ \\
\hline Trans-1,2-Dicloroeteno & $\mathrm{mg} / \mathrm{kg}$ & 0,01 & $<0,01$ \\
\hline Tricloroeteno & $\mathrm{mg} / \mathrm{kg}$ & 0,01 & $<0,01$ \\
\hline 1,3,5-Triclorobenzeno & $\mathrm{mg} / \mathrm{kg}$ & 0,01 & $<0,01$ \\
\hline
\end{tabular}




\begin{tabular}{|c|c|c|c|c|}
\hline Parâmetros & $\begin{array}{l}\text { Q uantidade } \\
\text { Adicionada }\end{array}$ & Unidade & $\begin{array}{c}\text { Resultado da } \\
\text { Recuperação (\%) }\end{array}$ & Faixa Aceitável de Recuperação (\%) \\
\hline \multicolumn{5}{|l|}{ 284310/2014-0 - LCS - VOC - Solo } \\
\hline 1,1-Dicloroeteno & 0,05 & $\mathrm{mg} / \mathrm{kg}$ & 62 & $60-140$ \\
\hline Benzeno & 0,05 & $\mathrm{mg} / \mathrm{kg}$ & 73 & $60-140$ \\
\hline Tricloroeteno & 0,05 & $\mathrm{mg} / \mathrm{kg}$ & 82 & $60-140$ \\
\hline Tolueno & 0,05 & $\mathrm{mg} / \mathrm{kg}$ & 84 & $60-140$ \\
\hline Clorobenzeno & 0,05 & $\mathrm{mg} / \mathrm{kg}$ & 67 & $60-140$ \\
\hline \multicolumn{5}{|c|}{$\begin{array}{l}\text { Surrogates } \\
\quad 284309 / 2014-0 \text { - Branco de Análise - VOC - Solo }\end{array}$} \\
\hline p-Bromofluorbenzeno & 0,05 & $\%$ & 120 & $60-140$ \\
\hline Dibrom ofluorometano & 0,05 & $\%$ & 110 & $60-140$ \\
\hline \multicolumn{5}{|l|}{ 284310/2014-0 - LCS - VOC - Solo } \\
\hline p-Bromofluorbenzeno & 0,05 & $\%$ & 120 & $60-140$ \\
\hline Dibrom ofluorometano & 0,05 & $\%$ & 83 & $60-140$ \\
\hline \multicolumn{5}{|l|}{ 283867/2014-0 - CAF-3 } \\
\hline Dibromofluorometano & 0,05 & $\%$ & 69 & $60-140$ \\
\hline p-Bromofluorbenzeno & 0,05 & $\%$ & 83 & $60-140$ \\
\hline
\end{tabular}

Notas

$\mathrm{LQ}=$ Limite de Quantificação

n.a. $=$ Não Aplicável

Abrangência

(s) resultado(s) referem-se somente à(s) amostra(s) analisada(s).

Este Relatório de Ensaio só pode ser reproduzido por inteiro e sem nenhuma alteração.

Plano de Amostragem

Plano de amostragem de responsabilidade do interessado

Responsabilidade Técnica

Os ensaios foram realizados na unidade da Bioagri Ambiental Ltda. - Matriz, situada na Rua Aljovil Martini, 177/201, Bairro Dois Córregos, Cep. 14420-833, Piracicaba/SP, registrada no CRQ 4ª Região sob nº 16082-Fe responsabilidade técnica do profissional José Carlos Moretti, CRQ nº 04107238, $4^{a}$.Região.

Referências Metodológicas

Análises foram realizadas conforme a última versão do Standard Methods for the Examination of Water \& Wastewater 22nd 2012(SMWW), EPA e ABNT (quando aplicável).

Porcentagem de Sólidos e Cinzas: POP PA 058 - Rev. 02

VOC: EPA 8260 C: 2006,5021 A: 2003

Metiletilcetona: EPA 8260 C: 2006,5021 A: 2003

Revisores

Débora Fernandes da Silva

Chave de Validação: 330c7788cd1db980b21ca1c55cd5d02b

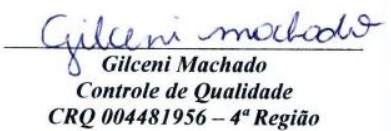

CRQ 004481956 - $4^{a}$ Região

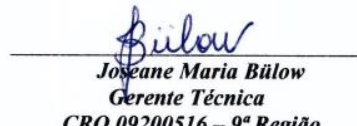

CRQ 09200516-9 $9^{a}$ Região 


\section{RELATÓRIO DE ENSAIO N $^{\circ}$ 283853/2014-0 - Piracicaba Processo Comercial $N^{\circ}$ 23961/2014-2}

\begin{tabular}{|l|l|}
\hline \multicolumn{2}{|c|}{ DADOS REFERENTES AO CLIENTE } \\
\hline Empresa solicitante: & Fundacao Parque de Alta Tecnologia da Regiao de Ipero e Adjacencias \\
\hline Endereço: & Rua Jose Antonio Scaciota, 165 - - Portal do Cedro - Iperó - SP - CEP: 18.560-000 . \\
\hline Nome do Solicitante: & Carla Marçal \\
\hline
\end{tabular}

\begin{tabular}{|l|l|l|l|l|}
\hline \multicolumn{5}{|c|}{ DADOS REFERENTES A AMOSTRA } \\
\hline Identificação do Cliente: & CAIA-1 & \\
\hline Amostra Rotulada como: & Água Subterrânea Projeto Mestrado \\
\hline Coletor: & Interessado & Data da coleta: & \multicolumn{2}{|l|}{$24 / 10 / 2014$ 14:00:00 } \\
\hline Data da entrada no laboratório: & $25 / 10 / 201408: 15$ & Data de Elaboração do RE: & $31 / 10 / 2014$ \\
\hline
\end{tabular}

\section{RESULTADOS PARA A AMOSTRA}

\begin{tabular}{|c|c|c|c|c|c|c|}
\hline Parâmetros & CAS & Unidade & LQ & Resultados analíticos & Incerteza & Data do Ensaio \\
\hline 1,1,1-Tricloroetano & $71-55-6$ & $\mu \mathrm{g} / \mathrm{L}$ & 100 & $<100$ & n.a. & 29/10/2014 01:47 \\
\hline 1,1,2-Tricloroetano & $79-00-5$ & $\mu \mathrm{g} / \mathrm{L}$ & 100 & $<100$ & n.a. & 29/10/2014 01:47 \\
\hline 1,1,2,2-Tetracloroetano & $79-34-5$ & $\mu \mathrm{g} / \mathrm{L}$ & 100 & $<100$ & n.a. & 29/10/2014 01:47 \\
\hline 1,1-Dicloroetano & $75-34-3$ & $\mu \mathrm{g} / \mathrm{L}$ & 100 & $<100$ & n.a. & 29/10/2014 01:47 \\
\hline 1,1-Dicloroeteno & $75-35-4$ & $\mu \mathrm{g} / \mathrm{L}$ & 100 & $<100$ & n.a. & 29/10/2014 01:47 \\
\hline 1,1-Dicloropropeno & $563-58-6$ & $\mu \mathrm{g} / \mathrm{L}$ & 100 & $<100$ & n.a. & 29/10/2014 01:47 \\
\hline 1,2,3-Triclorobenzeno & $87-61-6$ & $\mu \mathrm{g} / \mathrm{L}$ & 100 & $<100$ & n.a. & 29/10/2014 01:47 \\
\hline 1,2,4-Triclorobenzeno & $120-82-1$ & $\mu \mathrm{g} / \mathrm{L}$ & 100 & $<100$ & n.a. & 29/10/2014 01:47 \\
\hline 1,2-Dibromo-3-Cloropropano & $96-12-8$ & $\mu \mathrm{g} / \mathrm{L}$ & 500 & $<500$ & n.a. & 29/10/2014 01:47 \\
\hline 1,2-Dicloroetano & $107-06-2$ & $\mu \mathrm{g} / \mathrm{L}$ & 100 & $<100$ & n.a. & 29/10/2014 01:47 \\
\hline 1,2-Dicloropropano & $78-87-5$ & $\mu \mathrm{g} / \mathrm{L}$ & 100 & $<100$ & n.a. & 29/10/2014 01:47 \\
\hline 1,3-Dicloropropano & $142-28-9$ & $\mu \mathrm{g} / \mathrm{L}$ & 500 & $<500$ & n.a. & 29/10/2014 01:47 \\
\hline 1,4-Diclorobenzeno & $106-46-7$ & $\mu \mathrm{g} / \mathrm{L}$ & 100 & $<100$ & n.a. & 29/10/2014 01:47 \\
\hline 2,2-Dicloropropano & $594-20-7$ & $\mu \mathrm{g} / \mathrm{L}$ & 100 & $<100$ & n.a. & 29/10/2014 01:47 \\
\hline 4-Metil-2-Pentanona & $108-10-1$ & $\mu \mathrm{g} / \mathrm{L}$ & 500 & $<500$ & n.a. & 29/10/2014 01:47 \\
\hline Benzeno & $71-43-2$ & $\mu \mathrm{g} / \mathrm{L}$ & 100 & $<100$ & n.a. & 29/10/2014 01:47 \\
\hline Bromobenzeno & $108-86-1$ & $\mu \mathrm{g} / \mathrm{L}$ & 100 & $<100$ & n.a. & 29/10/2014 01:47 \\
\hline Bromodiclorometano & $75-27-4$ & $\mu \mathrm{g} / \mathrm{L}$ & 100 & $<100$ & n.a. & $29 / 10 / 201401: 47$ \\
\hline Bromofórmio & $75-25-2$ & $\mu \mathrm{g} / \mathrm{L}$ & 100 & $<100$ & n.a. & 29/10/2014 01:47 \\
\hline Bromoclorometano & $74-97-5$ & $\mu \mathrm{g} / \mathrm{L}$ & 500 & $<500$ & n.a. & 29/10/2014 01:47 \\
\hline Cis-1,2-Dicloroeteno & $156-59-2$ & $\mu \mathrm{g} / \mathrm{L}$ & 100 & $<100$ & n.a. & 29/10/2014 01:47 \\
\hline Cis-1,3-Dicloropropeno & $10061-01-5$ & $\mu \mathrm{g} / \mathrm{L}$ & 100 & $<100$ & n.a. & 29/10/2014 01:47 \\
\hline Diclorometano & $75-09-2$ & $\mu \mathrm{g} / \mathrm{L}$ & 100 & $<100$ & n.a. & 29/10/2014 01:47 \\
\hline Cloreto de Vinila & 75-01-4 & $\mu \mathrm{g} / \mathrm{L}$ & 100 & $<100$ & n.a. & 29/10/2014 01:47 \\
\hline Clorobenzeno & $108-90-7$ & $\mu \mathrm{g} / \mathrm{L}$ & 100 & $<100$ & n.a. & 29/10/2014 01:47 \\
\hline Cloroetano & $75-00-3$ & $\mu \mathrm{g} / \mathrm{L}$ & 100 & $<100$ & n.a. & 29/10/2014 01:47 \\
\hline Clorofórmio & $67-66-3$ & $\mu \mathrm{g} / \mathrm{L}$ & 100 & $<100$ & n.a. & 29/10/2014 01:47 \\
\hline Clorometano & $74-87-3$ & $\mu \mathrm{g} / \mathrm{L}$ & 1000 & $<1000$ & n.a. & 29/10/2014 01:47 \\
\hline Dibromoclorometano & $124-48-1$ & $\mu \mathrm{g} / \mathrm{L}$ & 100 & $<100$ & n.a. & 29/10/2014 01:47 \\
\hline Dissulfeto de Carbono & $75-15-0$ & $\mu \mathrm{g} / \mathrm{L}$ & 100 & $<100$ & n.a. & 29/10/2014 01:47 \\
\hline Estireno & $100-42-5$ & $\mu \mathrm{g} / \mathrm{L}$ & 100 & $<100$ & n.a. & 29/10/2014 01:47 \\
\hline Etilbenzeno & $100-41-4$ & $\mu \mathrm{g} / \mathrm{L}$ & 100 & $<100$ & n.a. & 29/10/2014 01:47 \\
\hline Hexaclorobutadieno & $87-68-3$ & $\mu \mathrm{g} / \mathrm{L}$ & 100 & $<100$ & n.a. & 29/10/2014 01:47 \\
\hline $\mathrm{m}, \mathrm{p}$-Xilenos & --- & $\mu \mathrm{g} / \mathrm{L}$ & 200 & $<200$ & n.a. & 29/10/2014 01:47 \\
\hline o-Xileno & $95-47-6$ & $\mu \mathrm{g} / \mathrm{L}$ & 100 & $<100$ & n.a. & 29/10/2014 01:47 \\
\hline p-Isopropiltolueno & $99-87-6$ & $\mu \mathrm{g} / \mathrm{L}$ & 100 & $<100$ & n.a. & 29/10/2014 01:47 \\
\hline Tetracloreto de Carbono & $56-23-5$ & $\mu \mathrm{g} / \mathrm{L}$ & 100 & $<100$ & n.a. & 29/10/2014 01:47 \\
\hline Tetracloroeteno & $127-18-4$ & $\mu \mathrm{g} / \mathrm{L}$ & 1000 & 59400 & 11000 & 29/10/2014 01:47 \\
\hline Tolueno & $108-88-3$ & $\mu \mathrm{g} / \mathrm{L}$ & 100 & $<100$ & n.a. & 29/10/2014 01:47 \\
\hline Trans-1,2-Dicloroeteno & $156-60-5$ & $\mu \mathrm{g} / \mathrm{L}$ & 100 & $<100$ & n.a. & 29/10/2014 01:47 \\
\hline Tricloroeteno & $79-01-6$ & $\mu \mathrm{g} / \mathrm{L}$ & 100 & $<100$ & n.a. & 29/10/2014 01:47 \\
\hline 1,1,1,2-Tetracloroetano & $630-20-6$ & $\mu \mathrm{g} / \mathrm{L}$ & 100 & $<100$ & n.a. & 29/10/2014 01:47 \\
\hline
\end{tabular}




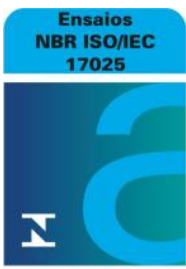

CRL 0172

\begin{tabular}{|c|c|c|c|c|c|c|}
\hline Parâmetros & CAS & Unidade & LQ & Resultados analíticos & Incerteza & Data do Ensaio \\
\hline 1,2,3-Tricloropropano & $96-18-4$ & $\mu \mathrm{g} / \mathrm{L}$ & 500 & $<500$ & n.a. & 29/10/2014 01:47 \\
\hline 1,3,5-Trimetilbenzeno & $108-67-8$ & $\mu \mathrm{g} / \mathrm{L}$ & 100 & $<100$ & n.a. & 29/10/2014 01:47 \\
\hline 1,2,4-Trimetilbenzeno & $95-63-6$ & $\mu \mathrm{g} / \mathrm{L}$ & 100 & $<100$ & n.a. & $29 / 10 / 201401: 47$ \\
\hline 1,2-Dibromoetano & $106-93-4$ & $\mu \mathrm{g} / \mathrm{L}$ & 100 & $<100$ & n.a. & 29/10/2014 01:47 \\
\hline 1,2-Diclorobenzeno & $95-50-1$ & $\mu \mathrm{g} / \mathrm{L}$ & 100 & $<100$ & n.a. & 29/10/2014 01:47 \\
\hline 1,3-Diclorobenzeno & $541-73-1$ & $\mu \mathrm{g} / \mathrm{L}$ & 100 & $<100$ & n.a. & 29/10/2014 01:47 \\
\hline 2-Clorotolueno & $95-49-8$ & $\mu \mathrm{g} / \mathrm{L}$ & 100 & $<100$ & n.a. & 29/10/2014 01:47 \\
\hline Dibromometano & $74-95-3$ & $\mu \mathrm{g} / \mathrm{L}$ & 100 & $<100$ & n.a. & $29 / 10 / 201401: 47$ \\
\hline Metiletilcetona & $78-93-3$ & $\mu \mathrm{g} / \mathrm{L}$ & 250000 & $<250000$ & n.a. & $30 / 10 / 201408: 33$ \\
\hline Naftaleno & $91-20-3$ & $\mu \mathrm{g} / \mathrm{L}$ & 100 & $<100$ & n.a. & 29/10/2014 01:47 \\
\hline n-Butilbenzeno & $104-51-8$ & $\mu \mathrm{g} / \mathrm{L}$ & 100 & $<100$ & n.a. & 29/10/2014 01:47 \\
\hline n-Propilbenzeno & $103-65-1$ & $\mu \mathrm{g} / \mathrm{L}$ & 100 & $<100$ & n.a. & $29 / 10 / 201401: 47$ \\
\hline 4-Clorotolueno & $106-43-4$ & $\mu \mathrm{g} / \mathrm{L}$ & 100 & $<100$ & n.a. & 29/10/2014 01:47 \\
\hline sec-Butilbenzeno & $135-98-8$ & $\mu \mathrm{g} / \mathrm{L}$ & 100 & $<100$ & n.a. & 29/10/2014 01:47 \\
\hline terc-Butilbenzeno & 98-06-6 & $\mu \mathrm{g} / \mathrm{L}$ & 100 & $<100$ & n.a. & 29/10/2014 01:47 \\
\hline trans-1,3-Dicloropropeno & $10061-02-6$ & $\mu \mathrm{g} / \mathrm{L}$ & 100 & $<100$ & n.a. & 29/10/2014 01:47 \\
\hline Isopropilbenzeno & $98-82-8$ & $\mu \mathrm{g} / \mathrm{L}$ & 100 & $<100$ & n.a. & 29/10/2014 01:47 \\
\hline 1,3,5-Triclorobenzeno & $108-70-3$ & $\mu \mathrm{g} / \mathrm{L}$ & 100 & $<100$ & n.a. & 29/10/2014 01:47 \\
\hline
\end{tabular}

\section{CONTROLE DE Q UALIDADE DO LABORATÓRIO}

Controle de Q ualidade - VOC - Água

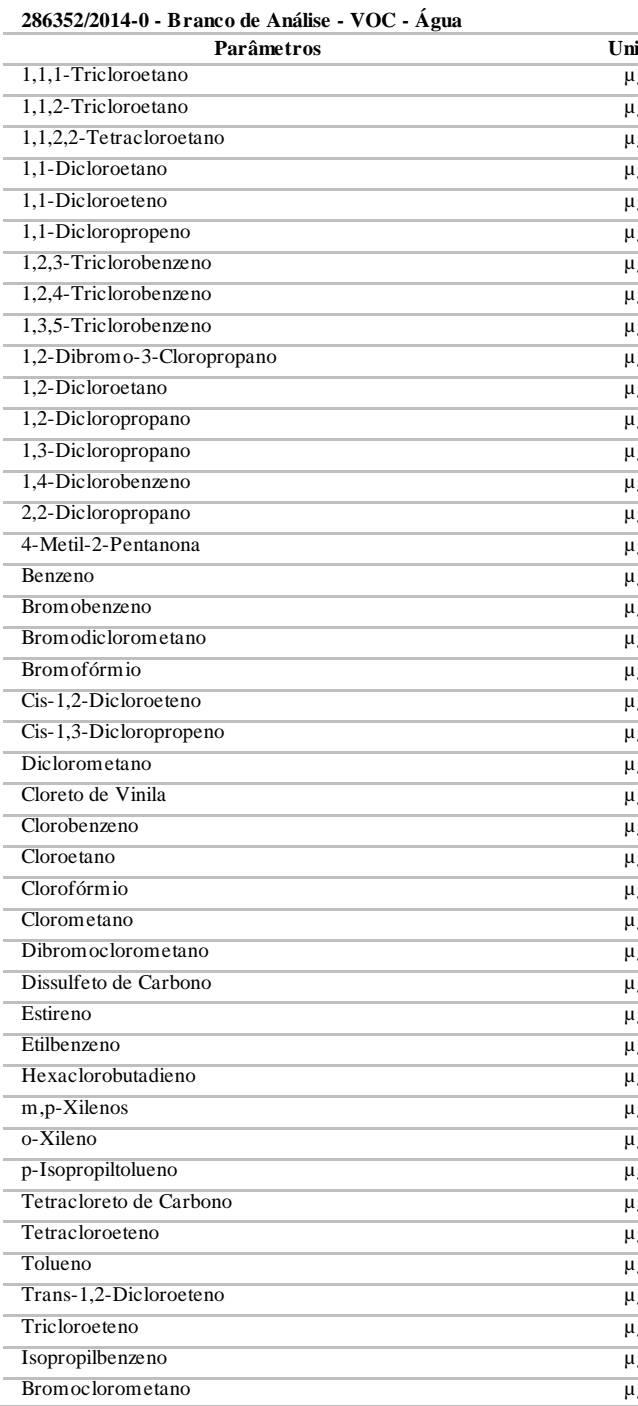

\begin{tabular}{|c|c|c|}
\hline Inidade & LQ & Resultados analíticos \\
\hline$\mu \mathrm{g} / \mathrm{L}$ & 1 & $<1$ \\
\hline$\mu \mathrm{g} / \mathrm{L}$ & 1 & $<1$ \\
\hline$\mu \mathrm{g} / \mathrm{L}$ & 1 & $<1$ \\
\hline$\mu \mathrm{g} / \mathrm{L}$ & 1 & $<1$ \\
\hline$\mu \mathrm{g} / \mathrm{L}$ & 1 & $<1$ \\
\hline$\mu \mathrm{g} / \mathrm{L}$ & 1 & $<1$ \\
\hline$\mu \mathrm{g} / \mathrm{L}$ & 1 & $<1$ \\
\hline$\mu \mathrm{g} / \mathrm{L}$ & 1 & $<1$ \\
\hline$\mu \mathrm{g} / \mathrm{L}$ & 1 & $<1$ \\
\hline$\mu \mathrm{g} / \mathrm{L}$ & 5 & $<5$ \\
\hline$\mu \mathrm{g} / \mathrm{L}$ & 1 & $<1$ \\
\hline$\mu \mathrm{g} / \mathrm{L}$ & 1 & $<1$ \\
\hline$\mu \mathrm{g} / \mathrm{L}$ & 5 & $<5$ \\
\hline$\mu \mathrm{g} / \mathrm{L}$ & 1 & $<1$ \\
\hline$\mu \mathrm{g} / \mathrm{L}$ & 1 & $<1$ \\
\hline$\mu \mathrm{g} / \mathrm{L}$ & 5 & $<5$ \\
\hline$\mu \mathrm{g} / \mathrm{L}$ & 1 & $<1$ \\
\hline$\mu \mathrm{g} / \mathrm{L}$ & 1 & $<1$ \\
\hline$\mu \mathrm{g} / \mathrm{L}$ & 1 & $<1$ \\
\hline$\mu \mathrm{g} / \mathrm{L}$ & 1 & $<1$ \\
\hline$\mu \mathrm{g} / \mathrm{L}$ & 1 & $<1$ \\
\hline$\mu \mathrm{g} / \mathrm{L}$ & 1 & $<1$ \\
\hline$\mu \mathrm{g} / \mathrm{L}$ & 1 & $<1$ \\
\hline$\mu \mathrm{g} / \mathrm{L}$ & 1 & $<1$ \\
\hline$\mu \mathrm{g} / \mathrm{L}$ & 1 & $<1$ \\
\hline$\mu \mathrm{g} / \mathrm{L}$ & 1 & $<1$ \\
\hline$\mu \mathrm{g} / \mathrm{L}$ & 1 & $<1$ \\
\hline$\mu \mathrm{g} / \mathrm{L}$ & 10 & $<10$ \\
\hline$\mu \mathrm{g} / \mathrm{L}$ & 1 & $<1$ \\
\hline$\mu \mathrm{g} / \mathrm{L}$ & 1 & $<1$ \\
\hline$\mu \mathrm{g} / \mathrm{L}$ & 1 & $<1$ \\
\hline$\mu \mathrm{g} / \mathrm{L}$ & 1 & $<1$ \\
\hline$\mu \mathrm{g} / \mathrm{L}$ & 1 & $<1$ \\
\hline$\mu \mathrm{g} / \mathrm{L}$ & 2 & $<2$ \\
\hline$\mu \mathrm{g} / \mathrm{L}$ & 1 & $<1$ \\
\hline$\mu \mathrm{g} / \mathrm{L}$ & 1 & $<1$ \\
\hline$\mu \mathrm{g} / \mathrm{L}$ & 1 & $<1$ \\
\hline$\mu \mathrm{g} / \mathrm{L}$ & 1 & $<1$ \\
\hline$\mu \mathrm{g} / \mathrm{L}$ & 1 & $<1$ \\
\hline$\mu \mathrm{g} / \mathrm{L}$ & 1 & $<1$ \\
\hline$\mu \mathrm{g} / \mathrm{L}$ & 1 & $<1$ \\
\hline$\mu \mathrm{g} / \mathrm{L}$ & 1 & $<1$ \\
\hline$\mu \mathrm{g} / \mathrm{L}$ & 5 & $<5$ \\
\hline
\end{tabular}




\begin{tabular}{|c|c|c|c|c|}
\hline Parâmetros & $\begin{array}{l}\text { Q uantidade } \\
\text { Adicionada }\end{array}$ & Unidade & $\begin{array}{c}\text { Resultado da } \\
\text { Recuperação (\%) }\end{array}$ & Faixa Aceitável de Recuperação (\%) \\
\hline \multicolumn{5}{|c|}{ 286353/2014-0 - Amostra Controle - VOC - Água } \\
\hline 1,1-Dicloroeteno & 20 & $\mu \mathrm{g} / \mathrm{L}$ & 90 & $70-130$ \\
\hline Benzeno & 20 & $\mu \mathrm{g} / \mathrm{L}$ & 95 & $70-130$ \\
\hline Tricloroeteno & 20 & $\mu \mathrm{g} / \mathrm{L}$ & 90 & $70-130$ \\
\hline Tolueno & 20 & $\mu \mathrm{g} / \mathrm{L}$ & 90 & $70-130$ \\
\hline Clorobenzeno & 20 & $\mu \mathrm{g} / \mathrm{L}$ & 95 & $70-130$ \\
\hline \multicolumn{5}{|c|}{$\begin{array}{l}\text { Surrogates } \\
\text { 286352/2014-0 - Branco de Análise - VOC - Água }\end{array}$} \\
\hline p-Bromofluorbenzeno & 20 & $\%$ & 97,0 & $70-130$ \\
\hline Dibrom ofluorometano & 20 & $\%$ & 108 & $70-130$ \\
\hline \multicolumn{5}{|c|}{ 286353/2014-0 - Amostra Controle - VOC - Água } \\
\hline p-Bromofluorbenzeno & 20 & $\%$ & 93,4 & $70-130$ \\
\hline Dibrom ofluorometano & 20 & $\%$ & 98,3 & $70-130$ \\
\hline \multicolumn{5}{|l|}{ 283853/2014-0 - CAIA-1 } \\
\hline Dibromofluorometano & 20 & $\%$ & Amostra Diluída & $70-130$ \\
\hline p-Bromofluorbenzeno & 20 & $\%$ & Amostra Diluída & $70-130$ \\
\hline
\end{tabular}

Notas

LQ = Limite de Quantificação.

n.a. $=$ Não Aplicável

Abrangência

(s) resultado(s) referem-se somente à(s) amostra(s) analisada(s).

Este Relatório de Ensaio só pode ser reproduzido por inteiro e sem nenhuma alteração.

Plano de Amostragem

Plano de amostragem de responsabilidade do interessado

Responsabilidade Técnic

Os ensaios foram realizados na unidade da Bioagri Ambiental Ltda. - Matriz, situada na Rua Aljovil Martini, 177/201, Bairro Dois Córregos, Cep. 14420-833, Piracicaba/SP, registrada no CRQ 4ª Região sob n $16082-F$ e responsabilidade técnica do profissional José Carlos Moretti, CRQ n 04107238, $4^{a}$.Região.

Referências Metodológicas

Análises foram realizadas conforme a última versão do Standard Methods for the Examination of Water \& Wastewater 22nd 2012(SMWW), EPA e ABNT (quando aplicável). VOC: EPA 8260 C: 2006, 5021A: 2003

Metiletilcetona: EPA 8260 C: 2006, 5021 A: 2003

Revisores

Débora Fernandes da Silva

Luci Carla Gheleri Andrietta

Chave de Validação: 8fb4612e697fc70a6ad34468aefle7e7

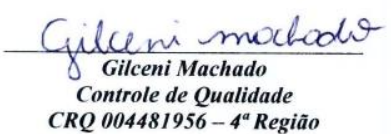

CRQ 004481956 - $4^{a}$ Região

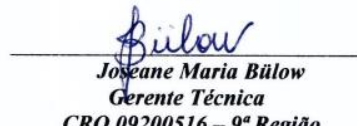

CRQ 09200516-9 $9^{a}$ Região 


\section{RELATÓRIO DE ENSAIO N $^{\circ}$ 283854/2014-0 - Piracicaba Processo Comercial $N^{\circ}$ 23961/2014-2}

\begin{tabular}{|l|l|}
\hline \multicolumn{2}{|c|}{ DADOS REFERENTES AO CLIENTE } \\
\hline Empresa solicitante: & Fundacao Parque de Alta Tecnologia da Regiao de Ipero e Adjacencias \\
\hline Endereço: & Rua Jose Antonio Scaciota, 165 - - Portal do Cedro - Iperó - SP - CEP: 18.560-000 . \\
\hline Nome do Solicitante: & Carla Marçal \\
\hline
\end{tabular}

\begin{tabular}{|l|l|l|l|l|}
\hline \multicolumn{5}{|c|}{ DADOS REFERENTES A AMOSTRA } \\
\hline Identificação do Cliente: & CAIA-2 & \\
\hline Amostra Rotulada como: & Água Subterrânea Projeto Mestrado \\
\hline Coletor: & Interessado & Data da coleta: & \multicolumn{2}{|l|}{$24 / 10 / 2014$ 14:00:00 } \\
\hline Data da entrada no laboratório: & $25 / 10 / 201408: 16$ & Data de Elaboração do RE: & $31 / 10 / 2014$ \\
\hline
\end{tabular}

\section{RESULTADOS PARA A AMOSTRA}

\begin{tabular}{|c|c|c|c|c|c|c|}
\hline Parâmetros & CAS & Unidade & LQ & Resultados analíticos & Incerteza & Data do Ensaio \\
\hline 1,1,1-Tricloroetano & $71-55-6$ & $\mu \mathrm{g} / \mathrm{L}$ & 100 & $<100$ & n.a. & 29/10/2014 02:11 \\
\hline 1,1,2-Tricloroetano & $79-00-5$ & $\mu \mathrm{g} / \mathrm{L}$ & 100 & $<100$ & n.a. & 29/10/2014 02:11 \\
\hline 1,1,2,2-Tetracloroetano & $79-34-5$ & $\mu \mathrm{g} / \mathrm{L}$ & 100 & $<100$ & n.a. & 29/10/2014 02:11 \\
\hline 1,1-Dicloroetano & 75-34-3 & $\mu \mathrm{g} / \mathrm{L}$ & 100 & $<100$ & n.a. & 29/10/2014 02:11 \\
\hline 1,1-Dicloroeteno & $75-35-4$ & $\mu \mathrm{g} / \mathrm{L}$ & 100 & $<100$ & n.a. & 29/10/2014 02:11 \\
\hline 1,1-Dicloropropeno & $563-58-6$ & $\mu \mathrm{g} / \mathrm{L}$ & 100 & $<100$ & n.a. & $29 / 10 / 201402: 11$ \\
\hline 1,2,3-Triclorobenzeno & $87-61-6$ & $\mu \mathrm{g} / \mathrm{L}$ & 100 & $<100$ & n.a. & 29/10/2014 02:11 \\
\hline 1,2,4-Triclorobenzeno & $120-82-1$ & $\mu \mathrm{g} / \mathrm{L}$ & 100 & $<100$ & n.a. & 29/10/2014 02:11 \\
\hline 1,2-Dibromo-3-Cloropropano & $96-12-8$ & $\mu \mathrm{g} / \mathrm{L}$ & 500 & $<500$ & n.a. & 29/10/2014 02:11 \\
\hline 1,2-Dicloroetano & $107-06-2$ & $\mu \mathrm{g} / \mathrm{L}$ & 100 & $<100$ & n.a. & 29/10/2014 02:11 \\
\hline 1,2-Dicloropropano & $78-87-5$ & $\mu \mathrm{g} / \mathrm{L}$ & 100 & $<100$ & n.a. & $29 / 10 / 201402: 11$ \\
\hline 1,3-Dicloropropano & $142-28-9$ & $\mu \mathrm{g} / \mathrm{L}$ & 500 & $<500$ & n.a. & 29/10/2014 02:11 \\
\hline 1,4-Diclorobenzeno & $106-46-7$ & $\mu \mathrm{g} / \mathrm{L}$ & 100 & $<100$ & n.a. & 29/10/2014 02:11 \\
\hline 2,2-Dicloropropano & $594-20-7$ & $\mu \mathrm{g} / \mathrm{L}$ & 100 & $<100$ & n.a. & 29/10/2014 02:11 \\
\hline 4-Metil-2-Pentanona & $108-10-1$ & $\mu \mathrm{g} / \mathrm{L}$ & 500 & $<500$ & n.a. & 29/10/2014 02:11 \\
\hline Benzeno & $71-43-2$ & $\mu \mathrm{g} / \mathrm{L}$ & 100 & $<100$ & n.a. & 29/10/2014 02:11 \\
\hline Bromobenzeno & $108-86-1$ & $\mu \mathrm{g} / \mathrm{L}$ & 100 & $<100$ & n.a. & 29/10/2014 02:11 \\
\hline Bromodiclorometano & $75-27-4$ & $\mu \mathrm{g} / \mathrm{L}$ & 100 & $<100$ & n.a. & 29/10/2014 02:11 \\
\hline Bromofórmio & $75-25-2$ & $\mu \mathrm{g} / \mathrm{L}$ & 100 & $<100$ & n.a. & 29/10/2014 02:11 \\
\hline Bromoclorometano & $74-97-5$ & $\mu \mathrm{g} / \mathrm{L}$ & 500 & $<500$ & n.a. & 29/10/2014 02:11 \\
\hline Cis-1,2-Dicloroeteno & $156-59-2$ & $\mu \mathrm{g} / \mathrm{L}$ & 100 & $<100$ & n.a. & 29/10/2014 02:11 \\
\hline Cis-1,3-Dicloropropeno & 10061-01-5 & $\mu \mathrm{g} / \mathrm{L}$ & 100 & $<100$ & n.a. & 29/10/2014 02:11 \\
\hline Diclorometano & $75-09-2$ & $\mu \mathrm{g} / \mathrm{L}$ & 100 & $<100$ & n.a. & 29/10/2014 02:11 \\
\hline Cloreto de Vinila & 75-01-4 & $\mu \mathrm{g} / \mathrm{L}$ & 100 & $<100$ & n.a. & 29/10/2014 02:11 \\
\hline Clorobenzeno & $108-90-7$ & $\mu \mathrm{g} / \mathrm{L}$ & 100 & $<100$ & n.a. & 29/10/2014 02:11 \\
\hline Cloroetano & $75-00-3$ & $\mu \mathrm{g} / \mathrm{L}$ & 100 & $<100$ & n.a. & $29 / 10 / 201402: 11$ \\
\hline Clorofórmio & $67-66-3$ & $\mu \mathrm{g} / \mathrm{L}$ & 100 & $<100$ & n.a. & 29/10/2014 02:11 \\
\hline Clorometano & $74-87-3$ & $\mu \mathrm{g} / \mathrm{L}$ & 1000 & $<1000$ & n.a. & 29/10/2014 02:11 \\
\hline Dibromoclorometano & $124-48-1$ & $\mu \mathrm{g} / \mathrm{L}$ & 100 & $<100$ & n.a. & 29/10/2014 02:11 \\
\hline Dissulfeto de Carbono & $75-15-0$ & $\mu \mathrm{g} / \mathrm{L}$ & 100 & $<100$ & n.a. & 29/10/2014 02:11 \\
\hline Estireno & $100-42-5$ & $\mu \mathrm{g} / \mathrm{L}$ & 100 & $<100$ & n.a. & 29/10/2014 02:11 \\
\hline Etilbenzeno & $100-41-4$ & $\mu \mathrm{g} / \mathrm{L}$ & 100 & $<100$ & n.a. & 29/10/2014 02:11 \\
\hline Hexaclorobutadieno & $87-68-3$ & $\mu \mathrm{g} / \mathrm{L}$ & 100 & $<100$ & n.a. & 29/10/2014 02:11 \\
\hline $\mathrm{m}, \mathrm{p}$-Xilenos & --- & $\mu \mathrm{g} / \mathrm{L}$ & 200 & $<200$ & n.a. & 29/10/2014 02:11 \\
\hline o-Xileno & $95-47-6$ & $\mu \mathrm{g} / \mathrm{L}$ & 100 & $<100$ & n.a. & 29/10/2014 02:11 \\
\hline p-Isopropiltolueno & $99-87-6$ & $\mu \mathrm{g} / \mathrm{L}$ & 100 & $<100$ & n.a. & $29 / 10 / 201402: 11$ \\
\hline Tetracloreto de Carbono & $56-23-5$ & $\mu \mathrm{g} / \mathrm{L}$ & 100 & $<100$ & n.a. & 29/10/2014 02:11 \\
\hline Tetracloroeteno & $127-18-4$ & $\mu \mathrm{g} / \mathrm{L}$ & 1000 & 61200 & 12000 & 29/10/2014 02:11 \\
\hline Tolueno & $108-88-3$ & $\mu \mathrm{g} / \mathrm{L}$ & 100 & $<100$ & n.a. & 29/10/2014 02:11 \\
\hline Trans-1,2-Dicloroeteno & $156-60-5$ & $\mu \mathrm{g} / \mathrm{L}$ & 100 & $<100$ & n.a. & 29/10/2014 02:11 \\
\hline Tricloroeteno & $79-01-6$ & $\mu \mathrm{g} / \mathrm{L}$ & 100 & $<100$ & n.a. & 29/10/2014 02:11 \\
\hline 1,1,1,2-Tetracloroetano & $630-20-6$ & $\mu \mathrm{g} / \mathrm{L}$ & 100 & $<100$ & n.a. & 29/10/2014 02:11 \\
\hline
\end{tabular}




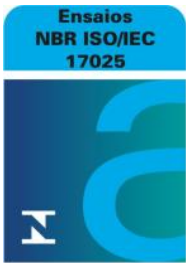

CRL 0172

\begin{tabular}{|c|c|c|c|c|c|c|}
\hline Parâmetros & CAS & Unidade & LQ & Resultados analíticos & Incerteza & Data do Ensaio \\
\hline 1,2,3-Tricloropropano & $96-18-4$ & $\mu \mathrm{g} / \mathrm{L}$ & 500 & $<500$ & n.a. & 29/10/2014 02:11 \\
\hline 1,3,5-Trimetilbenzeno & $108-67-8$ & $\mu \mathrm{g} / \mathrm{L}$ & 100 & $<100$ & n.a. & 29/10/2014 02:11 \\
\hline 1,2,4-Trimetilbenzeno & $95-63-6$ & $\mu \mathrm{g} / \mathrm{L}$ & 100 & $<100$ & n.a. & 29/10/2014 02:11 \\
\hline 1,2-Dibromoetano & $106-93-4$ & $\mu \mathrm{g} / \mathrm{L}$ & 100 & $<100$ & n.a. & 29/10/2014 02:11 \\
\hline 1,2-Diclorobenzeno & $95-50-1$ & $\mu \mathrm{g} / \mathrm{L}$ & 100 & $<100$ & n.a. & 29/10/2014 02:11 \\
\hline 1,3-Diclorobenzeno & $541-73-1$ & $\mu \mathrm{g} / \mathrm{L}$ & 100 & $<100$ & n.a. & 29/10/2014 02:11 \\
\hline 2-Clorotolueno & $95-49-8$ & $\mu \mathrm{g} / \mathrm{L}$ & 100 & $<100$ & n.a. & 29/10/2014 02:11 \\
\hline Dibromometano & $74-95-3$ & $\mu \mathrm{g} / \mathrm{L}$ & 100 & $<100$ & n.a. & 29/10/2014 02:11 \\
\hline Metiletilcetona & 78-93-3 & $\mu \mathrm{g} / \mathrm{L}$ & 250000 & $<250000$ & n.a. & $30 / 10 / 201408: 57$ \\
\hline Naftaleno & $91-20-3$ & $\mu \mathrm{g} / \mathrm{L}$ & 100 & $<100$ & n.a. & 29/10/2014 02:11 \\
\hline n-Butilbenzeno & $104-51-8$ & $\mu \mathrm{g} / \mathrm{L}$ & 100 & $<100$ & n.a. & 29/10/2014 02:11 \\
\hline n-Propilbenzeno & $103-65-1$ & $\mu \mathrm{g} / \mathrm{L}$ & 100 & $<100$ & n.a. & 29/10/2014 02:11 \\
\hline 4-Clorotolueno & $106-43-4$ & $\mu \mathrm{g} / \mathrm{L}$ & 100 & $<100$ & n.a. & $29 / 10 / 201402: 11$ \\
\hline sec-Butilbenzeno & $135-98-8$ & $\mu \mathrm{g} / \mathrm{L}$ & 100 & $<100$ & n.a. & 29/10/2014 02:11 \\
\hline terc-Butilbenzeno & $98-06-6$ & $\mu \mathrm{g} / \mathrm{L}$ & 100 & $<100$ & n.a. & $29 / 10 / 201402: 11$ \\
\hline trans-1,3-Dicloropropeno & $10061-02-6$ & $\mu \mathrm{g} / \mathrm{L}$ & 100 & $<100$ & n.a. & 29/10/2014 02:11 \\
\hline Isopropilbenzeno & $98-82-8$ & $\mu \mathrm{g} / \mathrm{L}$ & 100 & $<100$ & n.a. & 29/10/2014 02:11 \\
\hline 1,3,5-Triclorobenzeno & $108-70-3$ & $\mu \mathrm{g} / \mathrm{L}$ & 100 & $<100$ & n.a. & 29/10/2014 02:11 \\
\hline
\end{tabular}

\section{CONTROLE DE Q UALIDADE DO LABORATÓRIO}

Controle de Q ualidade - VOC - Água

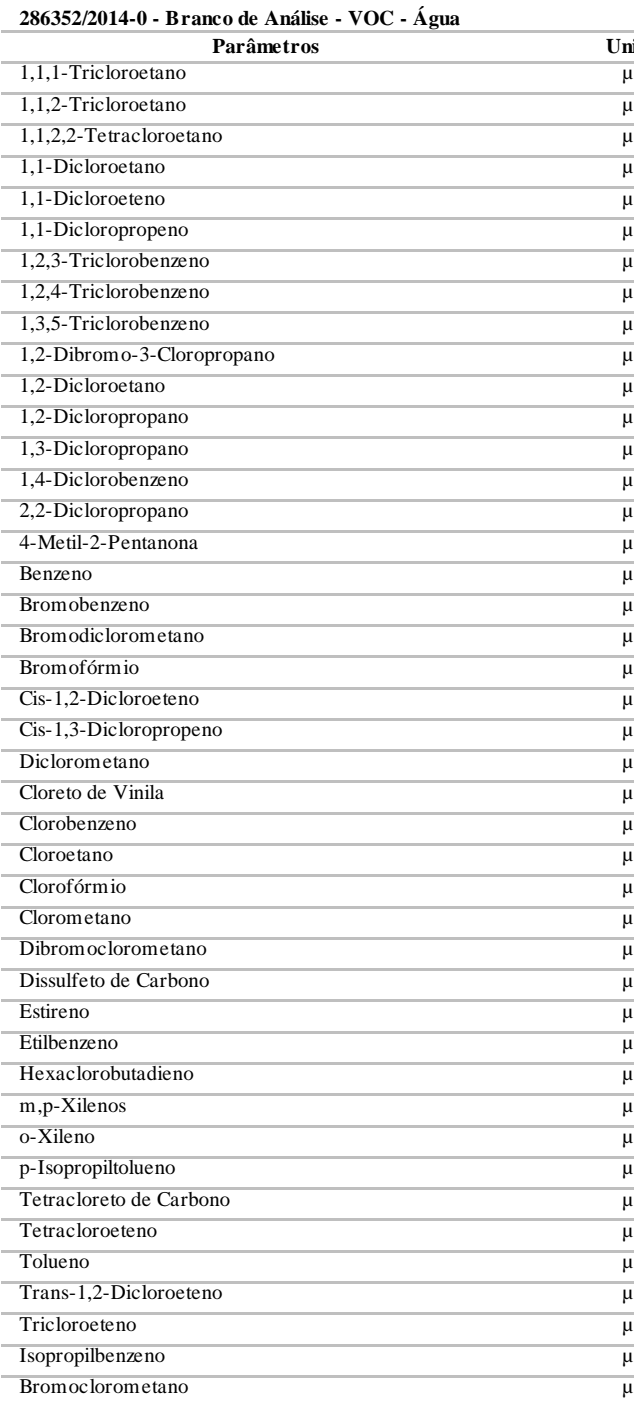

\begin{tabular}{|c|c|c|}
\hline Inidade & LQ & Resultados analíticos \\
\hline$\mu \mathrm{g} / \mathrm{L}$ & 1 & $<1$ \\
\hline$\mu \mathrm{g} / \mathrm{L}$ & 1 & $<1$ \\
\hline$\mu \mathrm{g} / \mathrm{L}$ & 1 & $<1$ \\
\hline$\mu \mathrm{g} / \mathrm{L}$ & 1 & $<1$ \\
\hline$\mu \mathrm{g} / \mathrm{L}$ & 1 & $<1$ \\
\hline$\mu \mathrm{g} / \mathrm{L}$ & 1 & $<1$ \\
\hline$\mu \mathrm{g} / \mathrm{L}$ & 1 & $<1$ \\
\hline$\mu \mathrm{g} / \mathrm{L}$ & 1 & $<1$ \\
\hline$\mu \mathrm{g} / \mathrm{L}$ & 1 & $<1$ \\
\hline$\mu \mathrm{g} / \mathrm{L}$ & 5 & $<5$ \\
\hline$\mu \mathrm{g} / \mathrm{L}$ & 1 & $<1$ \\
\hline$\mu \mathrm{g} / \mathrm{L}$ & 1 & $<1$ \\
\hline$\mu \mathrm{g} / \mathrm{L}$ & 5 & $<5$ \\
\hline$\mu \mathrm{g} / \mathrm{L}$ & 1 & $<1$ \\
\hline$\mu \mathrm{g} / \mathrm{L}$ & 1 & $<1$ \\
\hline$\mu \mathrm{g} / \mathrm{L}$ & 5 & $<5$ \\
\hline$\mu \mathrm{g} / \mathrm{L}$ & 1 & $<1$ \\
\hline$\mu \mathrm{g} / \mathrm{L}$ & 1 & $<1$ \\
\hline$\mu \mathrm{g} / \mathrm{L}$ & 1 & $<1$ \\
\hline$\mu \mathrm{g} / \mathrm{L}$ & 1 & $<1$ \\
\hline$\mu \mathrm{g} / \mathrm{L}$ & 1 & $<1$ \\
\hline$\mu \mathrm{g} / \mathrm{L}$ & 1 & $<1$ \\
\hline$\mu \mathrm{g} / \mathrm{L}$ & 1 & $<1$ \\
\hline$\mu \mathrm{g} / \mathrm{L}$ & 1 & $<1$ \\
\hline$\mu \mathrm{g} / \mathrm{L}$ & 1 & $<1$ \\
\hline$\mu \mathrm{g} / \mathrm{L}$ & 1 & $<1$ \\
\hline$\mu \mathrm{g} / \mathrm{L}$ & 1 & $<1$ \\
\hline$\mu \mathrm{g} / \mathrm{L}$ & 10 & $<10$ \\
\hline$\mu \mathrm{g} / \mathrm{L}$ & 1 & $<1$ \\
\hline$\mu \mathrm{g} / \mathrm{L}$ & 1 & $<1$ \\
\hline$\mu \mathrm{g} / \mathrm{L}$ & 1 & $<1$ \\
\hline$\mu \mathrm{g} / \mathrm{L}$ & 1 & $<1$ \\
\hline$\mu \mathrm{g} / \mathrm{L}$ & 1 & $<1$ \\
\hline$\mu \mathrm{g} / \mathrm{L}$ & 2 & $<2$ \\
\hline$\mu \mathrm{g} / \mathrm{L}$ & 1 & $<1$ \\
\hline$\mu \mathrm{g} / \mathrm{L}$ & 1 & $<1$ \\
\hline$\mu \mathrm{g} / \mathrm{L}$ & 1 & $<1$ \\
\hline$\mu \mathrm{g} / \mathrm{L}$ & 1 & $<1$ \\
\hline$\mu \mathrm{g} / \mathrm{L}$ & 1 & $<1$ \\
\hline$\mu \mathrm{g} / \mathrm{L}$ & 1 & $<1$ \\
\hline$\mu \mathrm{g} / \mathrm{L}$ & 1 & $<1$ \\
\hline$\mu \mathrm{g} / \mathrm{L}$ & 1 & $<1$ \\
\hline$\mu \mathrm{g} / \mathrm{L}$ & 5 & $<5$ \\
\hline
\end{tabular}




\begin{tabular}{|c|c|c|c|c|}
\hline Parâmetros & $\begin{array}{l}\text { Q uantidade } \\
\text { Adicionada }\end{array}$ & Unidade & $\begin{array}{c}\text { Resultado da } \\
\text { Recuperação (\%) }\end{array}$ & Faixa Aceitável de Recuperação (\%) \\
\hline \multicolumn{5}{|c|}{ 286353/2014-0 - Amostra Controle - VOC - Água } \\
\hline 1,1-Dicloroeteno & 20 & $\mu \mathrm{g} / \mathrm{L}$ & 90 & $70-130$ \\
\hline Benzeno & 20 & $\mu \mathrm{g} / \mathrm{L}$ & 95 & $70-130$ \\
\hline Tricloroeteno & 20 & $\mu \mathrm{g} / \mathrm{L}$ & 90 & $70-130$ \\
\hline Tolueno & 20 & $\mu \mathrm{g} / \mathrm{L}$ & 90 & $70-130$ \\
\hline Clorobenzeno & 20 & $\mu \mathrm{g} / \mathrm{L}$ & 95 & $70-130$ \\
\hline \multicolumn{5}{|c|}{$\begin{array}{l}\text { Surrogates } \\
\text { 286352/2014-0 - Branco de Análise - VOC - Água }\end{array}$} \\
\hline p-Bromofluorbenzeno & 20 & $\%$ & 97,0 & $70-130$ \\
\hline Dibrom ofluorometano & 20 & $\%$ & 108 & $70-130$ \\
\hline \multicolumn{5}{|c|}{ 286353/2014-0 - Amostra Controle - VOC - Água } \\
\hline p-Bromofluorbenzeno & 20 & $\%$ & 93,4 & $70-130$ \\
\hline Dibrom ofluorometano & 20 & $\%$ & 98,3 & $70-130$ \\
\hline \multicolumn{5}{|l|}{ 283854/2014-0 - CAIA-2 } \\
\hline Dibromofluorometano & 20 & $\%$ & Amostra Diluída & $70-130$ \\
\hline p-Bromofluorbenzeno & 20 & $\%$ & Amostra Diluída & $70-130$ \\
\hline
\end{tabular}

Notas

LQ = Limite de Quantificação.

n.a. $=$ Não Aplicável

Abrangência

(s) resultado(s) referem-se somente à(s) amostra(s) analisada(s).

Este Relatório de Ensaio só pode ser reproduzido por inteiro e sem nenhuma alteração.

Plano de Amostragem

Plano de amostragem de responsabilidade do interessado.

Responsabilidade Técnica

Os ensaios foram realizados na unidade da Bioagri Ambiental Ltda. - Matriz, situada na Rua Aljovil Martini, 177/201, Bairro Dois Córregos, Cep. 14420-833, Piracicaba/SP, registrada no CRQ 4ª Região sob n $16082-F$ e responsabilidade técnica do profissional José Carlos Moretti, CRQ n 04107238, $4^{a}$.Região.

Referências Metodológicas

Análises foram realizadas conforme a última versão do Standard Methods for the Examination of Water \& Wastewater 22nd 2012(SMWW), EPA e ABNT (quando aplicável).

VOC: EPA 8260 C: 2006, 5021A: 2003

Metiletilcetona: EPA 8260 C: 2006, 5021 A: 2003

Revisores

Débora Fernandes da Silva

Luci Carla Gheleri Andrietta

Chave de Validação: 8ea752d00d4f89042664945641501926

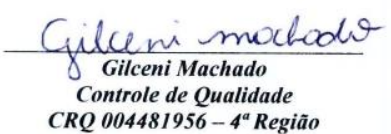

CRQ 004481956 - $4^{a}$ Região

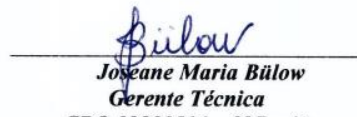

CRQ 09200516-9a Região 


\section{RELATÓRIO DE ENSAIO N $^{\circ}$ 283855/2014-0 - Piracicaba Processo Comercial $N^{\circ}$ 23961/2014-2}

\begin{tabular}{|l|l|}
\hline \multicolumn{2}{|c|}{ DADOS REFERENTES AO CLIENTE } \\
\hline Empresa solicitante: & Fundacao Parque de Alta Tecnologia da Regiao de Ipero e Adjacencias \\
\hline Endereço: & Rua Jose Antonio Scaciota, 165 - - Portal do Cedro - Iperó - SP - CEP: 18.560-000 . \\
\hline Nome do Solicitante: & Carla Marçal \\
\hline
\end{tabular}

\begin{tabular}{|l|l|l|l|l|}
\hline \multicolumn{5}{|c|}{ DADOS REFERENTES A AMOSTRA } \\
\hline Identificação do Cliente: & CAIA-3 & \\
\hline Amostra Rotulada como: & Água Subterrânea Projeto Mestrado \\
\hline Coletor: & Interessado & Data da coleta: & \multicolumn{2}{|l|}{$24 / 10 / 2014$ 14:00:00 } \\
\hline Data da entrada no laboratório: & $25 / 10 / 201408: 17$ & Data de Elaboração do RE: & $31 / 10 / 2014$ \\
\hline
\end{tabular}

\section{RESULTADOS PARA A AMOSTRA}

\begin{tabular}{|c|c|c|c|c|c|c|}
\hline Parâmetros & CAS & Unidade & LQ & Resultados analíticos & Incerteza & Data do Ensaio \\
\hline 1,1,1-Tricloroetano & $71-55-6$ & $\mu \mathrm{g} / \mathrm{L}$ & 100 & $<100$ & n.a. & 29/10/2014 02:35 \\
\hline 1,1,2-Tricloroetano & $79-00-5$ & $\mu \mathrm{g} / \mathrm{L}$ & 100 & $<100$ & n.a. & $29 / 10 / 201402: 35$ \\
\hline 1,1,2,2-Tetracloroetano & $79-34-5$ & $\mu \mathrm{g} / \mathrm{L}$ & 100 & $<100$ & n.a. & $29 / 10 / 201402: 35$ \\
\hline 1,1-Dicloroetano & 75-34-3 & $\mu \mathrm{g} / \mathrm{L}$ & 100 & $<100$ & n.a. & 29/10/2014 02:35 \\
\hline 1,1-Dicloroeteno & $75-35-4$ & $\mu \mathrm{g} / \mathrm{L}$ & 100 & $<100$ & n.a. & $29 / 10 / 201402: 35$ \\
\hline 1,1-Dicloropropeno & $563-58-6$ & $\mu \mathrm{g} / \mathrm{L}$ & 100 & $<100$ & n.a. & $29 / 10 / 201402: 35$ \\
\hline 1,2,3-Triclorobenzeno & $87-61-6$ & $\mu \mathrm{g} / \mathrm{L}$ & 100 & $<100$ & n.a. & $29 / 10 / 201402: 35$ \\
\hline 1,2,4-Triclorobenzeno & $120-82-1$ & $\mu \mathrm{g} / \mathrm{L}$ & 100 & $<100$ & n.a. & $29 / 10 / 201402: 35$ \\
\hline 1,2-Dibromo-3-Cloropropano & $96-12-8$ & $\mu \mathrm{g} / \mathrm{L}$ & 500 & $<500$ & n.a. & $29 / 10 / 201402: 35$ \\
\hline 1,2-Dicloroetano & $107-06-2$ & $\mu \mathrm{g} / \mathrm{L}$ & 100 & $<100$ & n.a. & 29/10/2014 02:35 \\
\hline 1,2-Dicloropropano & $78-87-5$ & $\mu \mathrm{g} / \mathrm{L}$ & 100 & $<100$ & n.a. & $29 / 10 / 201402: 35$ \\
\hline 1,3-Dicloropropano & $142-28-9$ & $\mu \mathrm{g} / \mathrm{L}$ & 500 & $<500$ & n.a. & $29 / 10 / 201402: 35$ \\
\hline 1,4-Diclorobenzeno & $106-46-7$ & $\mu \mathrm{g} / \mathrm{L}$ & 100 & $<100$ & n.a. & 29/10/2014 02:35 \\
\hline 2,2-Dicloropropano & $594-20-7$ & $\mu \mathrm{g} / \mathrm{L}$ & 100 & $<100$ & n.a. & 29/10/2014 02:35 \\
\hline 4-Metil-2-Pentanona & $108-10-1$ & $\mu \mathrm{g} / \mathrm{L}$ & 500 & $<500$ & n.a. & 29/10/2014 02:35 \\
\hline Benzeno & $71-43-2$ & $\mu \mathrm{g} / \mathrm{L}$ & 100 & $<100$ & n.a. & 29/10/2014 02:35 \\
\hline Bromobenzeno & $108-86-1$ & $\mu \mathrm{g} / \mathrm{L}$ & 100 & $<100$ & n.a. & 29/10/2014 02:35 \\
\hline Bromodiclorometano & $75-27-4$ & $\mu \mathrm{g} / \mathrm{L}$ & 100 & $<100$ & n.a. & 29/10/2014 02:35 \\
\hline Bromofórmio & $75-25-2$ & $\mu \mathrm{g} / \mathrm{L}$ & 100 & $<100$ & n.a. & $29 / 10 / 201402: 35$ \\
\hline Bromoclorometano & $74-97-5$ & $\mu \mathrm{g} / \mathrm{L}$ & 500 & $<500$ & n.a. & 29/10/2014 02:35 \\
\hline Cis-1,2-Dicloroeteno & $156-59-2$ & $\mu \mathrm{g} / \mathrm{L}$ & 100 & $<100$ & n.a. & 29/10/2014 02:35 \\
\hline Cis-1,3-Dicloropropeno & 10061-01-5 & $\mu \mathrm{g} / \mathrm{L}$ & 100 & $<100$ & n.a. & 29/10/2014 02:35 \\
\hline Diclorometano & $75-09-2$ & $\mu \mathrm{g} / \mathrm{L}$ & 100 & $<100$ & n.a. & 29/10/2014 02:35 \\
\hline Cloreto de Vinila & 75-01-4 & $\mu \mathrm{g} / \mathrm{L}$ & 100 & $<100$ & n.a. & 29/10/2014 02:35 \\
\hline Clorobenzeno & $108-90-7$ & $\mu \mathrm{g} / \mathrm{L}$ & 100 & $<100$ & n.a. & $29 / 10 / 201402: 35$ \\
\hline Cloroetano & $75-00-3$ & $\mu \mathrm{g} / \mathrm{L}$ & 100 & $<100$ & n.a. & $29 / 10 / 201402: 35$ \\
\hline Clorofórmio & $67-66-3$ & $\mu \mathrm{g} / \mathrm{L}$ & 100 & $<100$ & n.a. & $29 / 10 / 201402: 35$ \\
\hline Clorometano & $74-87-3$ & $\mu \mathrm{g} / \mathrm{L}$ & 1000 & $<1000$ & n.a. & 29/10/2014 02:35 \\
\hline Dibromoclorometano & $124-48-1$ & $\mu \mathrm{g} / \mathrm{L}$ & 100 & $<100$ & n.a. & 29/10/2014 02:35 \\
\hline Dissulfeto de Carbono & $75-15-0$ & $\mu \mathrm{g} / \mathrm{L}$ & 100 & $<100$ & n.a. & $29 / 10 / 201402: 35$ \\
\hline Estireno & $100-42-5$ & $\mu \mathrm{g} / \mathrm{L}$ & 100 & $<100$ & n.a. & 29/10/2014 02:35 \\
\hline Etilbenzeno & $100-41-4$ & $\mu \mathrm{g} / \mathrm{L}$ & 100 & $<100$ & n.a. & 29/10/2014 02:35 \\
\hline Hexaclorobutadieno & $87-68-3$ & $\mu \mathrm{g} / \mathrm{L}$ & 100 & $<100$ & n.a. & $29 / 10 / 201402: 35$ \\
\hline m,p-Xilenos & --- & $\mu \mathrm{g} / \mathrm{L}$ & 200 & $<200$ & n.a. & $29 / 10 / 201402: 35$ \\
\hline o-Xileno & $95-47-6$ & $\mu \mathrm{g} / \mathrm{L}$ & 100 & $<100$ & n.a. & 29/10/2014 02:35 \\
\hline p-Isopropiltolueno & $99-87-6$ & $\mu \mathrm{g} / \mathrm{L}$ & 100 & $<100$ & n.a. & $29 / 10 / 201402: 35$ \\
\hline Tetracloreto de Carbono & $56-23-5$ & $\mu \mathrm{g} / \mathrm{L}$ & 100 & $<100$ & n.a. & $29 / 10 / 201402: 35$ \\
\hline Tetracloroeteno & $127-18-4$ & $\mu \mathrm{g} / \mathrm{L}$ & 1000 & 59900 & 11000 & 29/10/2014 02:35 \\
\hline Tolueno & $108-88-3$ & $\mu \mathrm{g} / \mathrm{L}$ & 100 & $<100$ & n.a. & 29/10/2014 02:35 \\
\hline Trans-1,2-Dicloroeteno & $156-60-5$ & $\mu \mathrm{g} / \mathrm{L}$ & 100 & $<100$ & n.a. & 29/10/2014 02:35 \\
\hline Tricloroeteno & $79-01-6$ & $\mu \mathrm{g} / \mathrm{L}$ & 100 & $<100$ & n.a. & 29/10/2014 02:35 \\
\hline 1,1,1,2-Tetracloroetano & $630-20-6$ & $\mu \mathrm{g} / \mathrm{L}$ & 100 & $<100$ & n.a. & 29/10/2014 02:35 \\
\hline
\end{tabular}




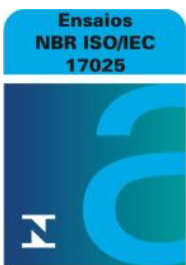

CRL 0172

\begin{tabular}{|c|c|c|c|c|c|c|}
\hline Parâmetros & CAS & Unidade & LQ & Resultados analíticos & Incerteza & Data do Ensaio \\
\hline 1,2,3-Tricloropropano & $96-18-4$ & $\mu \mathrm{g} / \mathrm{L}$ & 500 & $<500$ & n.a. & 29/10/2014 02:35 \\
\hline 1,3,5-Trimetilbenzeno & $108-67-8$ & $\mu \mathrm{g} / \mathrm{L}$ & 100 & $<100$ & n.a. & $29 / 10 / 201402: 35$ \\
\hline 1,2,4-Trimetilbenzeno & $95-63-6$ & $\mu \mathrm{g} / \mathrm{L}$ & 100 & $<100$ & n.a. & $29 / 10 / 201402: 35$ \\
\hline 1,2-Dibromoetano & $106-93-4$ & $\mu \mathrm{g} / \mathrm{L}$ & 100 & $<100$ & n.a. & 29/10/2014 02:35 \\
\hline 1,2-Diclorobenzeno & $95-50-1$ & $\mu \mathrm{g} / \mathrm{L}$ & 100 & $<100$ & n.a. & $29 / 10 / 201402: 35$ \\
\hline 1,3-Diclorobenzeno & $541-73-1$ & $\mu \mathrm{g} / \mathrm{L}$ & 100 & $<100$ & n.a. & $29 / 10 / 201402: 35$ \\
\hline 2-Clorotolueno & $95-49-8$ & $\mu \mathrm{g} / \mathrm{L}$ & 100 & $<100$ & n.a. & $29 / 10 / 201402: 35$ \\
\hline Dibromometano & $74-95-3$ & $\mu \mathrm{g} / \mathrm{L}$ & 100 & $<100$ & n.a. & $29 / 10 / 201402: 35$ \\
\hline Metiletilcetona & $78-93-3$ & $\mu \mathrm{g} / \mathrm{L}$ & 250000 & $<250000$ & n.a. & $30 / 10 / 201409: 20$ \\
\hline Naftaleno & $91-20-3$ & $\mu \mathrm{g} / \mathrm{L}$ & 100 & $<100$ & n.a. & $29 / 10 / 201402: 35$ \\
\hline n-Butilbenzeno & $104-51-8$ & $\mu \mathrm{g} / \mathrm{L}$ & 100 & $<100$ & n.a. & 29/10/2014 02:35 \\
\hline n-Propilbenzeno & $103-65-1$ & $\mu \mathrm{g} / \mathrm{L}$ & 100 & $<100$ & n.a. & $29 / 10 / 201402: 35$ \\
\hline 4-Clorotolueno & $106-43-4$ & $\mu \mathrm{g} / \mathrm{L}$ & 100 & $<100$ & n.a. & 29/10/2014 02:35 \\
\hline sec-Butilbenzeno & $135-98-8$ & $\mu \mathrm{g} / \mathrm{L}$ & 100 & $<100$ & n.a. & 29/10/2014 02:35 \\
\hline terc-Butilbenzeno & 98-06-6 & $\mu \mathrm{g} / \mathrm{L}$ & 100 & $<100$ & n.a. & $29 / 10 / 201402: 35$ \\
\hline trans-1,3-Dicloropropeno & $10061-02-6$ & $\mu \mathrm{g} / \mathrm{L}$ & 100 & $<100$ & n.a. & $29 / 10 / 201402: 35$ \\
\hline Isopropilbenzeno & $98-82-8$ & $\mu \mathrm{g} / \mathrm{L}$ & 100 & $<100$ & n.a. & 29/10/2014 02:35 \\
\hline 1,3,5-Triclorobenzeno & $108-70-3$ & $\mu \mathrm{g} / \mathrm{L}$ & 100 & $<100$ & n.a. & $29 / 10 / 201402: 35$ \\
\hline
\end{tabular}

\section{CONTROLE DE Q UALIDADE DO LABORATÓRIO}

Controle de Q ualidade - VOC - Água

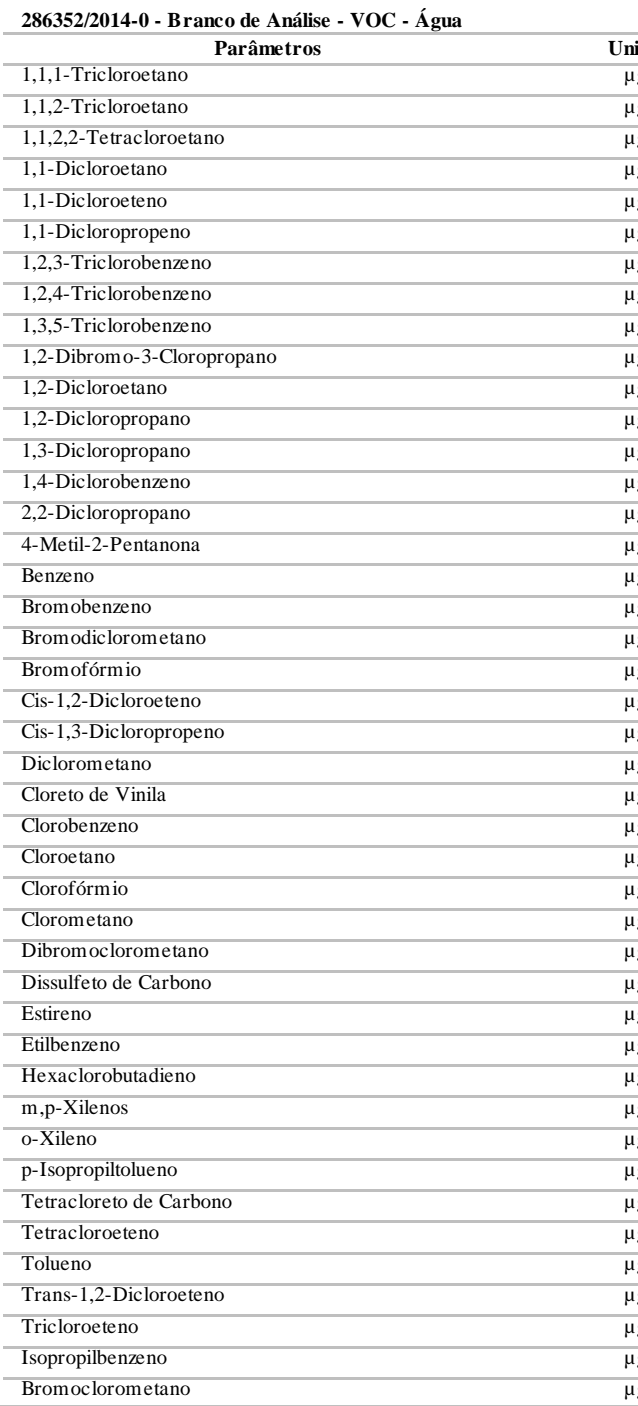

\begin{tabular}{|c|c|c|}
\hline Inidade & LQ & Resultados analíticos \\
\hline$\mu \mathrm{g} / \mathrm{L}$ & 1 & $<1$ \\
\hline$\mu \mathrm{g} / \mathrm{L}$ & 1 & $<1$ \\
\hline$\mu \mathrm{g} / \mathrm{L}$ & 1 & $<1$ \\
\hline$\mu \mathrm{g} / \mathrm{L}$ & 1 & $<1$ \\
\hline$\mu \mathrm{g} / \mathrm{L}$ & 1 & $<1$ \\
\hline$\mu \mathrm{g} / \mathrm{L}$ & 1 & $<1$ \\
\hline$\mu \mathrm{g} / \mathrm{L}$ & 1 & $<1$ \\
\hline$\mu \mathrm{g} / \mathrm{L}$ & 1 & $<1$ \\
\hline$\mu \mathrm{g} / \mathrm{L}$ & 1 & $<1$ \\
\hline$\mu \mathrm{g} / \mathrm{L}$ & 5 & $<5$ \\
\hline$\mu \mathrm{g} / \mathrm{L}$ & 1 & $<1$ \\
\hline$\mu \mathrm{g} / \mathrm{L}$ & 1 & $<1$ \\
\hline$\mu \mathrm{g} / \mathrm{L}$ & 5 & $<5$ \\
\hline$\mu \mathrm{g} / \mathrm{L}$ & 1 & $<1$ \\
\hline$\mu \mathrm{g} / \mathrm{L}$ & 1 & $<1$ \\
\hline$\mu \mathrm{g} / \mathrm{L}$ & 5 & $<5$ \\
\hline$\mu \mathrm{g} / \mathrm{L}$ & 1 & $<1$ \\
\hline$\mu \mathrm{g} / \mathrm{L}$ & 1 & $<1$ \\
\hline$\mu \mathrm{g} / \mathrm{L}$ & 1 & $<1$ \\
\hline$\mu \mathrm{g} / \mathrm{L}$ & 1 & $<1$ \\
\hline$\mu \mathrm{g} / \mathrm{L}$ & 1 & $<1$ \\
\hline$\mu \mathrm{g} / \mathrm{L}$ & 1 & $<1$ \\
\hline$\mu \mathrm{g} / \mathrm{L}$ & 1 & $<1$ \\
\hline$\mu \mathrm{g} / \mathrm{L}$ & 1 & $<1$ \\
\hline$\mu \mathrm{g} / \mathrm{L}$ & 1 & $<1$ \\
\hline$\mu \mathrm{g} / \mathrm{L}$ & 1 & $<1$ \\
\hline$\mu \mathrm{g} / \mathrm{L}$ & 1 & $<1$ \\
\hline$\mu \mathrm{g} / \mathrm{L}$ & 10 & $<10$ \\
\hline$\mu \mathrm{g} / \mathrm{L}$ & 1 & $<1$ \\
\hline$\mu \mathrm{g} / \mathrm{L}$ & 1 & $<1$ \\
\hline$\mu \mathrm{g} / \mathrm{L}$ & 1 & $<1$ \\
\hline$\mu \mathrm{g} / \mathrm{L}$ & 1 & $<1$ \\
\hline$\mu \mathrm{g} / \mathrm{L}$ & 1 & $<1$ \\
\hline$\mu \mathrm{g} / \mathrm{L}$ & 2 & $<2$ \\
\hline$\mu \mathrm{g} / \mathrm{L}$ & 1 & $<1$ \\
\hline$\mu \mathrm{g} / \mathrm{L}$ & 1 & $<1$ \\
\hline$\mu \mathrm{g} / \mathrm{L}$ & 1 & $<1$ \\
\hline$\mu \mathrm{g} / \mathrm{L}$ & 1 & $<1$ \\
\hline$\mu \mathrm{g} / \mathrm{L}$ & 1 & $<1$ \\
\hline$\mu \mathrm{g} / \mathrm{L}$ & 1 & $<1$ \\
\hline$\mu \mathrm{g} / \mathrm{L}$ & 1 & $<1$ \\
\hline$\mu \mathrm{g} / \mathrm{L}$ & 1 & $<1$ \\
\hline$\mu \mathrm{g} / \mathrm{L}$ & 5 & $<5$ \\
\hline
\end{tabular}




\begin{tabular}{|c|c|c|c|c|}
\hline Parâmetros & $\begin{array}{l}\text { Q uantidade } \\
\text { Adicionada }\end{array}$ & Unidade & $\begin{array}{c}\text { Resultado da } \\
\text { Recuperação (\%) }\end{array}$ & Faixa Aceitável de Recuperação (\%) \\
\hline \multicolumn{5}{|c|}{ 286353/2014-0 - Amostra Controle - VOC - Água } \\
\hline 1,1-Dicloroeteno & 20 & $\mu \mathrm{g} / \mathrm{L}$ & 90 & $70-130$ \\
\hline Benzeno & 20 & $\mu \mathrm{g} / \mathrm{L}$ & 95 & $70-130$ \\
\hline Tricloroeteno & 20 & $\mu \mathrm{g} / \mathrm{L}$ & 90 & $70-130$ \\
\hline Tolueno & 20 & $\mu \mathrm{g} / \mathrm{L}$ & 90 & $70-130$ \\
\hline Clorobenzeno & 20 & $\mu \mathrm{g} / \mathrm{L}$ & 95 & $70-130$ \\
\hline \multicolumn{5}{|c|}{$\begin{array}{l}\text { Surrogates } \\
\text { 286352/2014-0 - Branco de Análise - VOC - Água }\end{array}$} \\
\hline p-Bromofluorbenzeno & 20 & $\%$ & 97,0 & $70-130$ \\
\hline Dibrom ofluorometano & 20 & $\%$ & 108 & $70-130$ \\
\hline \multicolumn{5}{|c|}{ 286353/2014-0 - Amostra Controle - VOC - Água } \\
\hline p-Bromofluorbenzeno & 20 & $\%$ & 93,4 & $70-130$ \\
\hline Dibrom ofluorometano & 20 & $\%$ & 98,3 & $70-130$ \\
\hline \multicolumn{5}{|l|}{ 283855/2014-0 - CAIA-3 } \\
\hline Dibromofluorometano & 20 & $\%$ & Amostra Diluída & $70-130$ \\
\hline p-Bromofluorbenzeno & 20 & $\%$ & Amostra Diluída & $70-130$ \\
\hline
\end{tabular}

Notas

LQ = Limite de Quantificação

n.a. $=$ Não Aplicável

Abrangência

(s) resultado(s) referem-se somente à(s) amostra(s) analisada(s).

Este Relatório de Ensaio só pode ser reproduzido por inteiro e sem nenhuma alteração.

Plano de Amostragem

Plano de amostragem de responsabilidade do interessado

Responsabilidade Técnic

Os ensaios foram realizados na unidade da Bioagri Ambiental Ltda. - Matriz, situada na Rua Aljovil Martini, 177/201, Bairro Dois Córregos, Cep. 14420-833, Piracicaba/SP, registrada no CRQ 4ª Região sob nº 16082-Fe responsabilidade técnica do profissional José Carlos Moretti, CRQ nº 04107238, $4^{a}$.Região.

Referências Metodológicas

Análises foram realizadas conforme a última versão do Standard Methods for the Examination of Water \& Wastewater 22nd 2012(SMWW), EPA e ABNT (quando aplicável).

VOC: EPA 8260 C: 2006, 5021A: 2003

Metiletilcetona: EPA 8260 C: 2006,5021 A: 2003

Revisores

Débora Fernandes da Silva

Luci Carla Gheleri Andrietta

Chave de Validação: e4289270370a31a74c 1efe879f0c2d39

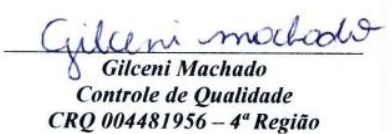

CRQ 004481956 - $4^{a}$ Região

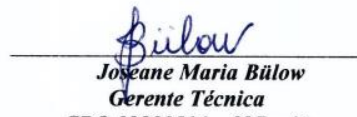

CRQ 09200516-9a Região 


\begin{tabular}{|c|c|c|c|c|c|c|}
\hline Parâmetros & CAS & Unidade & LQ & Resultados analíticos & Incerteza & Data do Ensaio \\
\hline 1,2,3-Tricloropropano & $96-18-4$ & $\mu \mathrm{g} / \mathrm{L}$ & 5 & $<5$ & n.a. & 29/10/2014 23:31 \\
\hline 1,3,5-Trimetilbenzeno & $108-67-8$ & $\mu \mathrm{g} / \mathrm{L}$ & 1 & $<1$ & n.a. & 29/10/2014 23:31 \\
\hline 1,2,4-Trimetilbenzeno & $95-63-6$ & $\mu \mathrm{g} / \mathrm{L}$ & 1 & $<1$ & n.a. & 29/10/2014 23:31 \\
\hline 1,2-Dibromoetano & $106-93-4$ & $\mu \mathrm{g} / \mathrm{L}$ & 1 & $<1$ & n.a. & $29 / 10 / 201423: 31$ \\
\hline 1,2-Diclorobenzeno & $95-50-1$ & $\mu \mathrm{g} / \mathrm{L}$ & 1 & $<1$ & n.a. & 29/10/2014 23:31 \\
\hline 1,3-Diclorobenzeno & $541-73-1$ & $\mu \mathrm{g} / \mathrm{L}$ & 1 & $<1$ & n.a. & 29/10/2014 23:31 \\
\hline 2-Clorotolueno & $95-49-8$ & $\mu \mathrm{g} / \mathrm{L}$ & 1 & $<1$ & n.a. & 29/10/2014 23:31 \\
\hline Dibromometano & $74-95-3$ & $\mu \mathrm{g} / \mathrm{L}$ & 1 & $<1$ & n.a. & 29/10/2014 23:31 \\
\hline Metiletilcetona & $78-93-3$ & $\mu \mathrm{g} / \mathrm{L}$ & 25000 & $<25000$ & n.a. & 29/10/2014 21:45 \\
\hline Naftaleno & $91-20-3$ & $\mu g / L$ & 1 & $<1$ & n.a. & 29/10/2014 23:31 \\
\hline n-Butilbenzeno & $104-51-8$ & $\mu \mathrm{g} / \mathrm{L}$ & 1 & $<1$ & n.a. & $29 / 10 / 201423: 31$ \\
\hline n-Propilbenzeno & $103-65-1$ & $\mu \mathrm{g} / \mathrm{L}$ & 1 & $<1$ & n.a. & 29/10/2014 23:31 \\
\hline 4-Clorotolueno & $106-43-4$ & $\mu \mathrm{g} / \mathrm{L}$ & 1 & $<1$ & n.a. & $29 / 10 / 201423: 31$ \\
\hline sec-Butilbenzeno & $135-98-8$ & $\mu \mathrm{g} / \mathrm{L}$ & 1 & $<1$ & n.a. & 29/10/2014 23:31 \\
\hline terc-Butilbenzeno & $98-06-6$ & $\mu \mathrm{g} / \mathrm{L}$ & 1 & $<1$ & n.a. & $29 / 10 / 201423: 31$ \\
\hline trans-1,3-Dicloropropeno & $10061-02-6$ & $\mu \mathrm{g} / \mathrm{L}$ & 1 & $<1$ & n.a. & $29 / 10 / 201423: 31$ \\
\hline Isopropilbenzeno & $98-82-8$ & $\mu \mathrm{g} / \mathrm{L}$ & 1 & $<1$ & n.a. & $29 / 10 / 201423: 31$ \\
\hline 1,3,5-Triclorobenzeno & $108-70-3$ & $\mu \mathrm{g} / \mathrm{L}$ & 1 & $<1$ & n.a. & $29 / 10 / 201423: 31$ \\
\hline
\end{tabular}

\section{CONTROLE DE Q UALIDADE DO LAB ORATÓRIO}

Controle de Q ualidade - VOC - Água

286352/2014-0 - Branco de Análise - VOC - Água

1,1,1-Tricloroetano Parâmetros

1,1,2-Tricloroetano

1,1,2,2-Tetracloroetano

1,1-Dicloroetano

1,1-Dicloroeteno

1,1-Dicloropropeno

1,2,3-Triclorobenzeno

1,2,4-Triclorobenzeno

1,3,5-Triclorobenzeno

1,2-Dibromo-3-Cloropropano

1,2-Dicloroetano

1,2-Dicloropropano

1,3-Dicloropropano

1,4-Diclorobenzeno

2,2-Dicloropropano

4-Metil-2-Pentanona

Benzeno

Bromobenzeno

Bromodiclorometano

Bromofórmio

Cis-1,2-Dicloroeteno

Cis-1,3-Dicloropropeno

Diclorometano

Cloreto de Vinila

Clorobenzeno

Cloroetano

Clorofórmio

Clorometano

Dibromoclorometano

Dissulfeto de Carbono

Estireno

Etilbenzeno

Hexaclorobutadieno

m,p-Xilenos

o-Xileno

p-Isopropiltolueno

Tetracloreto de Carbono

Tetracloroeteno

Tolueno

Trans-1,2-Dicloroeteno

Tricloroeteno

Isopropilbenzeno

Bromoclorometano

\begin{tabular}{|c|c|c|}
\hline Unidade & LQ & Resultados analíticos \\
\hline$\mu \mathrm{g} / \mathrm{L}$ & 1 & $<1$ \\
\hline$\mu \mathrm{g} / \mathrm{L}$ & 1 & $<1$ \\
\hline$\mu \mathrm{g} / \mathrm{L}$ & 1 & $<1$ \\
\hline$\mu \mathrm{g} / \mathrm{L}$ & 1 & $<1$ \\
\hline$\mu \mathrm{g} / \mathrm{L}$ & 1 & $<1$ \\
\hline$\mu \mathrm{g} / \mathrm{L}$ & 1 & $<1$ \\
\hline$\mu \mathrm{g} / \mathrm{L}$ & 1 & $<1$ \\
\hline$\mu \mathrm{g} / \mathrm{L}$ & 1 & $<1$ \\
\hline$\mu \mathrm{g} / \mathrm{L}$ & 1 & $<1$ \\
\hline$\mu \mathrm{g} / \mathrm{L}$ & 5 & $<5$ \\
\hline$\mu \mathrm{g} / \mathrm{L}$ & 1 & $<1$ \\
\hline$\mu \mathrm{g} / \mathrm{L}$ & 1 & $<1$ \\
\hline$\mu \mathrm{g} / \mathrm{L}$ & 5 & $<5$ \\
\hline$\mu \mathrm{g} / \mathrm{L}$ & 1 & $<1$ \\
\hline$\mu \mathrm{g} / \mathrm{L}$ & 1 & $<1$ \\
\hline$\mu \mathrm{g} / \mathrm{L}$ & 5 & $<5$ \\
\hline$\mu \mathrm{g} / \mathrm{L}$ & 1 & $<1$ \\
\hline$\mu \mathrm{g} / \mathrm{L}$ & 1 & $<1$ \\
\hline$\mu \mathrm{g} / \mathrm{L}$ & 1 & $<1$ \\
\hline$\mu \mathrm{g} / \mathrm{L}$ & 1 & $<1$ \\
\hline$\mu \mathrm{g} / \mathrm{L}$ & 1 & $<1$ \\
\hline$\mu \mathrm{g} / \mathrm{L}$ & 1 & $<1$ \\
\hline$\mu \mathrm{g} / \mathrm{L}$ & 1 & $<1$ \\
\hline$\mu \mathrm{g} / \mathrm{L}$ & 1 & $<1$ \\
\hline$\mu \mathrm{g} / \mathrm{L}$ & 1 & $<1$ \\
\hline$\mu \mathrm{g} / \mathrm{L}$ & 1 & $<1$ \\
\hline$\mu \mathrm{g} / \mathrm{L}$ & 1 & $<1$ \\
\hline$\mu \mathrm{g} / \mathrm{L}$ & 10 & $<10$ \\
\hline$\mu \mathrm{g} / \mathrm{L}$ & 1 & $<1$ \\
\hline$\mu \mathrm{g} / \mathrm{L}$ & 1 & $<1$ \\
\hline$\mu \mathrm{g} / \mathrm{L}$ & 1 & $<1$ \\
\hline$\mu \mathrm{g} / \mathrm{L}$ & 1 & $<1$ \\
\hline$\mu \mathrm{g} / \mathrm{L}$ & 1 & $<1$ \\
\hline$\mu \mathrm{g} / \mathrm{L}$ & 2 & $<2$ \\
\hline$\mu \mathrm{g} / \mathrm{L}$ & 1 & $<1$ \\
\hline$\mu \mathrm{g} / \mathrm{L}$ & 1 & $<1$ \\
\hline$\mu \mathrm{g} / \mathrm{L}$ & 1 & $<1$ \\
\hline$\mu \mathrm{g} / \mathrm{L}$ & 1 & $<1$ \\
\hline$\mu \mathrm{g} / \mathrm{L}$ & 1 & $<1$ \\
\hline$\mu \mathrm{g} / \mathrm{L}$ & 1 & $<1$ \\
\hline$\mu \mathrm{g} / \mathrm{L}$ & 1 & $<1$ \\
\hline$\mu \mathrm{g} / \mathrm{L}$ & 1 & $<1$ \\
\hline$\mu \mathrm{g} / \mathrm{L}$ & 5 & $<5$ \\
\hline
\end{tabular}




\begin{tabular}{|c|c|c|c|c|}
\hline Parâmetros & $\begin{array}{l}\text { Q uantidade } \\
\text { Adicionada }\end{array}$ & Unidade & $\begin{array}{c}\text { Resultado da } \\
\text { Recuperação (\%) }\end{array}$ & Faixa Aceitável de Recuperação (\%) \\
\hline \multicolumn{5}{|c|}{ 286353/2014-0 - Amostra Controle - VOC - Água } \\
\hline 1,1-Dicloroeteno & 20 & $\mu \mathrm{g} / \mathrm{L}$ & 90 & $70-130$ \\
\hline Benzeno & 20 & $\mu \mathrm{g} / \mathrm{L}$ & 95 & $70-130$ \\
\hline Tricloroeteno & 20 & $\mu \mathrm{g} / \mathrm{L}$ & 90 & $70-130$ \\
\hline Tolueno & 20 & $\mu \mathrm{g} / \mathrm{L}$ & 90 & $70-130$ \\
\hline Clorobenzeno & 20 & $\mu \mathrm{g} / \mathrm{L}$ & 95 & $70-130$ \\
\hline \multicolumn{5}{|c|}{$\begin{array}{l}\text { Surrogates } \\
\text { 286352/2014-0 - Branco de Análise - VOC - Água }\end{array}$} \\
\hline p-Bromofluorbenzeno & 20 & $\%$ & 97,0 & $70-130$ \\
\hline Dibrom ofluorometano & 20 & $\%$ & 108 & $70-130$ \\
\hline \multicolumn{5}{|c|}{ 286353/2014-0 - Amostra Controle - VOC - Água } \\
\hline p-Bromofluorbenzeno & 20 & $\%$ & 93,4 & $70-130$ \\
\hline Dibrom ofluorometano & 20 & $\%$ & 98,3 & $70-130$ \\
\hline \multicolumn{5}{|l|}{ 283856/2014-0 - CAFA-1 } \\
\hline Dibromofluorometano & 20 & $\%$ & 108 & $70-130$ \\
\hline p-Bromofluorbenzeno & 20 & $\%$ & 90,9 & $70-130$ \\
\hline
\end{tabular}

Notas

$L Q=$ Limite de Quantificação

n.a. = Não Aplicável.

Abrangência

(s) resultado(s) referem-se somente à(s) amostra(s) analisada(s).

Este Relatório de Ensaio só pode ser reproduzido por inteiro e sem nenhuma alteração.

Plano de Amostragem

Plano de amostragem de responsabilidade do interessado.

Responsabilidade Técnic

Os ensaios foram realizados na unidade da Bioagri Ambiental Ltda. - Matriz, situada na Rua Aljovil Martini, 177/201, Bairro Dois Córregos, Cep. 14420-833, Piracicaba/SP, registrada no CRQ 4ª Região sob nº 16082-Fe responsabilidade técnica do profissional José Carlos Moretti, CRQ nº 04107238, $4^{a}$.Região.

Referências Metodológicas

Análises foram realizadas conforme a última versão do Standard Methods for the Examination of Water \& Wastewater 22nd 2012(SMWW), EPA e ABNT (quando aplicável).

VOC: EPA 8260 C: 2006, 5021A: 2003

Metiletilcetona: EPA $8260 \mathrm{C} \cdot 2006,5021 \mathrm{~A}: 2003$

Revisores

Débora Fernandes da Silva

Luci Carla Gheleri Andrietta

Chave de Validação: f94d86f40c261e4a31b7095658d44df4

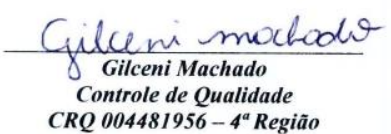

CRQ 004481956-4 Região

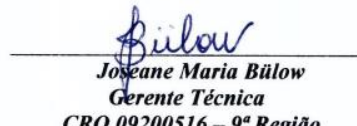

CRQ 09200516-9 $9^{a}$ Região 


\begin{tabular}{|c|c|c|c|c|c|c|}
\hline Parâmetros & CAS & Unidade & LQ & Resultados analíticos & Incerteza & Data do Ensaio \\
\hline 1,2,3-Tricloropropano & $96-18-4$ & $\mu \mathrm{g} / \mathrm{L}$ & 5 & $<5$ & n.a. & 29/10/2014 23:55 \\
\hline 1,3,5-Trimetilbenzeno & $108-67-8$ & $\mu \mathrm{g} / \mathrm{L}$ & 1 & $<1$ & n.a. & 29/10/2014 23:55 \\
\hline 1,2,4-Trimetilbenzeno & $95-63-6$ & $\mu \mathrm{g} / \mathrm{L}$ & 1 & $<1$ & n.a. & $29 / 10 / 201423: 55$ \\
\hline 1,2-Dibromoetano & $106-93-4$ & $\mu \mathrm{g} / \mathrm{L}$ & 1 & $<1$ & n.a. & 29/10/2014 23:55 \\
\hline 1,2-Diclorobenzeno & $95-50-1$ & $\mu \mathrm{g} / \mathrm{L}$ & 1 & $<1$ & n.a. & 29/10/2014 23:55 \\
\hline 1,3-Diclorobenzeno & $541-73-1$ & $\mu \mathrm{g} / \mathrm{L}$ & 1 & $<1$ & n.a. & $29 / 10 / 201423: 55$ \\
\hline 2-Clorotolueno & $95-49-8$ & $\mu \mathrm{g} / \mathrm{L}$ & 1 & $<1$ & n.a. & 29/10/2014 23:55 \\
\hline Dibromometano & $74-95-3$ & $\mu \mathrm{g} / \mathrm{L}$ & 1 & $<1$ & n.a. & 29/10/2014 23:55 \\
\hline Metiletilcetona & $78-93-3$ & $\mu \mathrm{g} / \mathrm{L}$ & 25000 & $<25000$ & n.a. & 29/10/2014 22:33 \\
\hline Naftaleno & $91-20-3$ & $\mu g / L$ & 1 & $<1$ & n.a. & 29/10/2014 23:55 \\
\hline n-Butilbenzeno & $104-51-8$ & $\mu \mathrm{g} / \mathrm{L}$ & 1 & $<1$ & n.a. & 29/10/2014 23:55 \\
\hline n-Propilbenzeno & $103-65-1$ & $\mu \mathrm{g} / \mathrm{L}$ & 1 & $<1$ & n.a. & 29/10/2014 23:55 \\
\hline 4-Clorotolueno & $106-43-4$ & $\mu \mathrm{g} / \mathrm{L}$ & 1 & $<1$ & n.a. & $29 / 10 / 201423: 55$ \\
\hline sec-Butilbenzeno & $135-98-8$ & $\mu \mathrm{g} / \mathrm{L}$ & 1 & $<1$ & n.a. & 29/10/2014 23:55 \\
\hline terc-Butilbenzeno & $98-06-6$ & $\mu \mathrm{g} / \mathrm{L}$ & 1 & $<1$ & n.a. & $29 / 10 / 201423: 55$ \\
\hline trans-1,3-Dicloropropeno & $10061-02-6$ & $\mu \mathrm{g} / \mathrm{L}$ & 1 & $<1$ & n.a. & 29/10/2014 23:55 \\
\hline Isopropilbenzeno & $98-82-8$ & $\mu \mathrm{g} / \mathrm{L}$ & 1 & $<1$ & n.a. & 29/10/2014 23:55 \\
\hline 1,3,5-Triclorobenzeno & $108-70-3$ & $\mu \mathrm{g} / \mathrm{L}$ & 1 & $<1$ & n.a. & $29 / 10 / 201423: 55$ \\
\hline
\end{tabular}

\section{CONTROLE DE Q UALIDADE DO LAB ORATÓRIO}

Controle de Q ualidade - VOC - Água

286352/2014-0 - Branco de Análise - VOC - Água

1,1,1-Tricloroetano Parâmetros

1,1,2-Tricloroetano

1,1,2,2-Tetracloroetano

1,1-Dicloroetano

1,1-Dicloroeteno

1,1-Dicloropropeno

1,2,3-Triclorobenzeno

1,2,4-Triclorobenzeno

1,3,5-Triclorobenzeno

1,2-Dibromo-3-Cloropropano

1,2-Dicloroetano

1,2-Dicloropropano

1,3-Dicloropropano

1,4-Diclorobenzeno

2,2-Dicloropropano

4-Metil-2-Pentanona

Benzeno

Bromobenzeno

Bromodiclorometano

Bromofórmio

Cis-1,2-Dicloroeteno

Cis-1,3-Dicloropropeno

Diclorometano

Cloreto de Vinila

Clorobenzeno

Cloroetano

Clorofórmio

Clorometano

Dibromoclorometano

Dissulfeto de Carbono

Estireno

Etilbenzeno

Hexaclorobutadieno

m,p-Xilenos

o-Xileno

p-Isopropiltolueno

Tetracloreto de Carbono

Tetracloroeteno

Tolueno

Trans-1,2-Dicloroeteno

Tricloroeteno

Isopropilbenzeno

Bromoclorometano

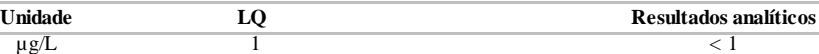

$\mu \mathrm{g} / \mathrm{L}$

$\mu \mathrm{g} / \mathrm{L}$

$\mu \mathrm{g} / \mathrm{L}$

$\mu \mathrm{g} / \mathrm{L}$

$\mu \mathrm{g} / \mathrm{L}$

$\mu \mathrm{g} / \mathrm{L}$

$\mu \mathrm{g} / \mathrm{L}$

$\mu \mathrm{g} / \mathrm{L}$

$\mu \mathrm{g} / \mathrm{L}$

$\mu \mathrm{g} / \mathrm{L}$

$\mu \mathrm{g} / \mathrm{L}$

$\mu \mathrm{g} / \mathrm{L}$

$\mu \mathrm{g} / \mathrm{L}$

$\mu \mathrm{g} / \mathrm{L}$

$\mu \mathrm{g} / \mathrm{L}$

$\mu \mathrm{g} / \mathrm{L}$

$\mu \mathrm{g} / \mathrm{L}$

$\mu \mathrm{g} / \mathrm{L}$

$\mu \mathrm{g} / \mathrm{L}$

$\mu \mathrm{g} / \mathrm{L}$

$\mu \mathrm{g} / \mathrm{L}$

$\mu \mathrm{g} / \mathrm{L}$

$\mu \mathrm{g} / \mathrm{L}$

$\mu \mathrm{g} / \mathrm{L}$

$\mu \mathrm{g} / \mathrm{L}$

$\mu \mathrm{g} / \mathrm{L}$

$\mu \mathrm{g} / \mathrm{L}$

$\mu \mathrm{g} / \mathrm{L}$

$\mu \mathrm{g} / \mathrm{L}$

$\mu \mathrm{g} / \mathrm{L}$

$\mu \mathrm{g} / \mathrm{L}$

$\mu \mathrm{g} / \mathrm{L}$

$\mu \mathrm{g} / \mathrm{L}$

$\mu \mathrm{g} / \mathrm{L}$

$\mu \mathrm{g} / \mathrm{L}$

$\mu \mathrm{g} / \mathrm{L}$

$\mu \mathrm{g} / \mathrm{L}$

$\mu \mathrm{g} / \mathrm{L}$

$\mu \mathrm{g} / \mathrm{L}$

$\mu \mathrm{g} / \mathrm{L}$

$\mu \mathrm{g} / \mathrm{L}$

$\mu \mathrm{g} / \mathrm{L}$

$\mu \mathrm{g} / \mathrm{L}$
Resultados analíticos

$<1$

$<1$

$<1$

$<1$

$<1$

$<1$

$<1$

$<5$

$<<1$

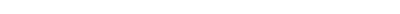

1

$<1$

$<1$

$<1$

$<1$

$<2$

$<1$

$<1$
$<1$

$<1$

$<1$
$<1$

$<1$

$<1$
$<5$ 


\begin{tabular}{|c|c|c|c|c|}
\hline Parâmetros & $\begin{array}{l}\text { Q uantidade } \\
\text { Adicionada }\end{array}$ & Unidade & $\begin{array}{c}\text { Resultado da } \\
\text { Recuperação (\%) }\end{array}$ & Faixa Aceitável de Recuperação (\%) \\
\hline \multicolumn{5}{|c|}{ 286353/2014-0 - Amostra Controle - VOC - Água } \\
\hline 1,1-Dicloroeteno & 20 & $\mu \mathrm{g} / \mathrm{L}$ & 90 & $70-130$ \\
\hline Benzeno & 20 & $\mu \mathrm{g} / \mathrm{L}$ & 95 & $70-130$ \\
\hline Tricloroeteno & 20 & $\mu \mathrm{g} / \mathrm{L}$ & 90 & $70-130$ \\
\hline Tolueno & 20 & $\mu \mathrm{g} / \mathrm{L}$ & 90 & $70-130$ \\
\hline Clorobenzeno & 20 & $\mu \mathrm{g} / \mathrm{L}$ & 95 & $70-130$ \\
\hline \multicolumn{5}{|c|}{$\begin{array}{l}\text { Surrogates } \\
\text { 286352/2014-0 - B ranco de Análise - VOC - Água }\end{array}$} \\
\hline p-Bromofluorbenzeno & 20 & $\%$ & 97,0 & $70-130$ \\
\hline Dibrom ofluorometano & 20 & $\%$ & 108 & $70-130$ \\
\hline \multicolumn{5}{|c|}{ 286353/2014-0 - Amostra Controle - VOC - Água } \\
\hline p-Bromofluorbenzeno & 20 & $\%$ & 93,4 & $70-130$ \\
\hline Dibromofluorometano & 20 & $\%$ & 98,3 & $70-130$ \\
\hline \multicolumn{5}{|l|}{ 283857/2014-0 - CAFA-2 } \\
\hline Dibrom ofluorometano & 20 & $\%$ & 113 & $70-130$ \\
\hline p-Bromofluorbenzeno & 20 & $\%$ & 89,0 & $70-130$ \\
\hline
\end{tabular}

Notas

LQ = Limite de Quantificação.

n.a. $=$ Não Aplicável

Abrangência

(s) resultado(s) referem-se somente à(s) amostra(s) analisada(s).

Este Relatório de Ensaio só pode ser reproduzido por inteiro e sem nenhuma alteração.

Plano de Amostragem

Plano de amostragem de responsabilidade do interessado.

Responsabilidade Técnica

Os ensaios foram realizados na unidade da Bioagri Ambiental Ltda. - Matriz, situada na Rua Aljovil Martini, 177/201, Bairro Dois Córregos, Cep. 14420-833, Piracicaba/SP, registrada no CRQ 4ª Região sob n $16082-\mathrm{Fe}$ responsabilidade técnica do profissional José Carlos Moretti, CRQ n 04107238, $4^{\text {a. }}$.Região.

Referências Metodológicas

Análises foram realizadas conforme a última versão do Standard Methods for the Examination of Water \& Wastewater 22nd 2012(SMWW), EPA e ABNT (quando aplicável). VOC: EPA 8260 C: 2006, 5021A: 2003

Metiletilcetona: EPA 8260 C: 2006, 5021 A: 2003

Revisores

Débora Fernandes da Silva

Luci Carla Gheleri Andrietta

Chave de Validação: d1fb6f9fd07767ed524f48c1bfe2f7eb

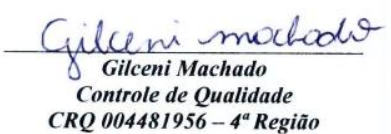

CRQ 004481956-4 Região

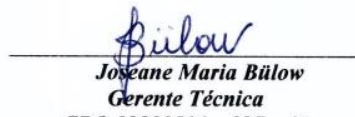

CRQ 09200516-9a Região 


\begin{tabular}{|c|c|c|c|c|c|c|}
\hline Parâmetros & CAS & Unidade & LQ & Resultados analíticos & Incerteza & Data do Ensaio \\
\hline 1,2,3-Tricloropropano & $96-18-4$ & $\mu \mathrm{g} / \mathrm{L}$ & 5 & $<5$ & n.a. & $30 / 10 / 201400: 19$ \\
\hline 1,3,5-Trimetilbenzeno & $108-67-8$ & $\mu \mathrm{g} / \mathrm{L}$ & 1 & $<1$ & n.a. & 30/10/2014 00:19 \\
\hline 1,2,4-Trimetilbenzeno & $95-63-6$ & $\mu \mathrm{g} / \mathrm{L}$ & 1 & $<1$ & n.a. & 30/10/2014 00:19 \\
\hline 1,2-Dibromoetano & $106-93-4$ & $\mu \mathrm{g} / \mathrm{L}$ & 1 & $<1$ & n.a. & $30 / 10 / 201400: 19$ \\
\hline 1,2-Diclorobenzeno & $95-50-1$ & $\mu \mathrm{g} / \mathrm{L}$ & 1 & $<1$ & n.a. & $30 / 10 / 201400: 19$ \\
\hline 1,3-Diclorobenzeno & $541-73-1$ & $\mu \mathrm{g} / \mathrm{L}$ & 1 & $<1$ & n.a. & $30 / 10 / 201400: 19$ \\
\hline 2-Clorotolueno & $95-49-8$ & $\mu \mathrm{g} / \mathrm{L}$ & 1 & $<1$ & n.a. & 30/10/2014 00:19 \\
\hline Dibromometano & $74-95-3$ & $\mu \mathrm{g} / \mathrm{L}$ & 1 & $<1$ & n.a. & $30 / 10 / 201400: 19$ \\
\hline Metiletilcetona & $78-93-3$ & $\mu \mathrm{g} / \mathrm{L}$ & 25000 & $<25000$ & n.a. & $29 / 10 / 201423: 21$ \\
\hline Naftaleno & $91-20-3$ & $\mu g / L$ & 1 & $<1$ & n.a. & 30/10/2014 00:19 \\
\hline n-Butilbenzeno & $104-51-8$ & $\mu \mathrm{g} / \mathrm{L}$ & 1 & $<1$ & n.a. & $30 / 10 / 201400: 19$ \\
\hline n-Propilbenzeno & $103-65-1$ & $\mu \mathrm{g} / \mathrm{L}$ & 1 & $<1$ & n.a. & $30 / 10 / 201400: 19$ \\
\hline 4-Clorotolueno & $106-43-4$ & $\mu \mathrm{g} / \mathrm{L}$ & 1 & $<1$ & n.a. & $30 / 10 / 201400: 19$ \\
\hline sec-Butilbenzeno & $135-98-8$ & $\mu \mathrm{g} / \mathrm{L}$ & 1 & $<1$ & n.a. & $30 / 10 / 201400: 19$ \\
\hline terc-Butilbenzeno & $98-06-6$ & $\mu \mathrm{g} / \mathrm{L}$ & 1 & $<1$ & n.a. & $30 / 10 / 201400: 19$ \\
\hline trans-1,3-Dicloropropeno & $10061-02-6$ & $\mu \mathrm{g} / \mathrm{L}$ & 1 & $<1$ & n.a. & 30/10/2014 00:19 \\
\hline Isopropilbenzeno & $98-82-8$ & $\mu \mathrm{g} / \mathrm{L}$ & 1 & $<1$ & n.a. & $30 / 10 / 201400: 19$ \\
\hline 1,3,5-Triclorobenzeno & $108-70-3$ & $\mu \mathrm{g} / \mathrm{L}$ & 1 & $<1$ & n.a. & $30 / 10 / 2014$ 00:19 \\
\hline
\end{tabular}

\section{CONTROLE DE Q UALIDADE DO LAB ORATÓRIO}

Controle de Q ualidade - VOC - Água

286352/2014-0 - Branco de Análise - VOC - Água

1,1,1-Tricloroetano Parâmetros

1,1,2-Tricloroetano

1,1,2,2-Tetracloroetano

1,1-Dicloroetano

1,1-Dicloroeteno

1,1-Dicloropropeno

1,2,3-Triclorobenzeno

1,2,4-Triclorobenzeno

1,3,5-Triclorobenzeno

1,2-Dibromo-3-Cloropropano

1,2-Dicloroetano

1,2-Dicloropropano

1,3-Dicloropropano

1,4-Diclorobenzeno

2,2-Dicloropropano

4-Metil-2-Pentanona

Benzeno

Bromobenzeno

Bromodiclorometano

Bromofórmio

Cis-1,2-Dicloroeteno

Cis-1,3-Dicloropropeno

Diclorometano

Cloreto de Vinila

Clorobenzeno

Cloroetano

Clorofórmio

Clorometano

Dibromoclorometano

Dissulfeto de Carbono

Estireno

Etilbenzeno

Hexaclorobutadieno

m,p-Xilenos

o-Xileno

p-Isopropiltolueno

Tetracloreto de Carbono

Tetracloroeteno

Tolueno

Trans-1,2-Dicloroeteno

Tricloroeteno

Isopropilbenzeno

Bromoclorometano

\begin{tabular}{|c|c|c|}
\hline Unidade & LQ & Resultados analíticos \\
\hline$\mu \mathrm{g} / \mathrm{L}$ & 1 & $<1$ \\
\hline$\mu \mathrm{g} / \mathrm{L}$ & 1 & $<1$ \\
\hline$\mu \mathrm{g} / \mathrm{L}$ & 1 & $<1$ \\
\hline$\mu \mathrm{g} / \mathrm{L}$ & 1 & $<1$ \\
\hline$\mu \mathrm{g} / \mathrm{L}$ & 1 & $<1$ \\
\hline$\mu \mathrm{g} / \mathrm{L}$ & 1 & $<1$ \\
\hline$\mu \mathrm{g} / \mathrm{L}$ & 1 & $<1$ \\
\hline$\mu \mathrm{g} / \mathrm{L}$ & 1 & $<1$ \\
\hline$\mu \mathrm{g} / \mathrm{L}$ & 1 & $<1$ \\
\hline$\mu \mathrm{g} / \mathrm{L}$ & 5 & $<5$ \\
\hline$\mu \mathrm{g} / \mathrm{L}$ & 1 & $<1$ \\
\hline$\mu \mathrm{g} / \mathrm{L}$ & 1 & $<1$ \\
\hline$\mu \mathrm{g} / \mathrm{L}$ & 5 & $<5$ \\
\hline$\mu \mathrm{g} / \mathrm{L}$ & 1 & $<1$ \\
\hline$\mu \mathrm{g} / \mathrm{L}$ & 1 & $<1$ \\
\hline$\mu \mathrm{g} / \mathrm{L}$ & 5 & $<5$ \\
\hline$\mu \mathrm{g} / \mathrm{L}$ & 1 & $<1$ \\
\hline$\mu \mathrm{g} / \mathrm{L}$ & 1 & $<1$ \\
\hline$\mu \mathrm{g} / \mathrm{L}$ & 1 & $<1$ \\
\hline$\mu \mathrm{g} / \mathrm{L}$ & 1 & $<1$ \\
\hline$\mu \mathrm{g} / \mathrm{L}$ & 1 & $<1$ \\
\hline$\mu \mathrm{g} / \mathrm{L}$ & 1 & $<1$ \\
\hline$\mu \mathrm{g} / \mathrm{L}$ & 1 & $<1$ \\
\hline$\mu \mathrm{g} / \mathrm{L}$ & 1 & $<1$ \\
\hline$\mu \mathrm{g} / \mathrm{L}$ & 1 & $<1$ \\
\hline$\mu \mathrm{g} / \mathrm{L}$ & 1 & $<1$ \\
\hline$\mu \mathrm{g} / \mathrm{L}$ & 1 & $<1$ \\
\hline$\mu \mathrm{g} / \mathrm{L}$ & 10 & $<10$ \\
\hline$\mu \mathrm{g} / \mathrm{L}$ & 1 & $<1$ \\
\hline$\mu \mathrm{g} / \mathrm{L}$ & 1 & $<1$ \\
\hline$\mu \mathrm{g} / \mathrm{L}$ & 1 & $<1$ \\
\hline$\mu \mathrm{g} / \mathrm{L}$ & 1 & $<1$ \\
\hline$\mu \mathrm{g} / \mathrm{L}$ & 1 & $<1$ \\
\hline$\mu \mathrm{g} / \mathrm{L}$ & 2 & $<2$ \\
\hline$\mu \mathrm{g} / \mathrm{L}$ & 1 & $<1$ \\
\hline$\mu \mathrm{g} / \mathrm{L}$ & 1 & $<1$ \\
\hline$\mu \mathrm{g} / \mathrm{L}$ & 1 & $<1$ \\
\hline$\mu \mathrm{g} / \mathrm{L}$ & 1 & $<1$ \\
\hline$\mu \mathrm{g} / \mathrm{L}$ & 1 & $<1$ \\
\hline$\mu \mathrm{g} / \mathrm{L}$ & 1 & $<1$ \\
\hline$\mu \mathrm{g} / \mathrm{L}$ & 1 & $<1$ \\
\hline$\mu \mathrm{g} / \mathrm{L}$ & 1 & $<1$ \\
\hline$\mu \mathrm{g} / \mathrm{L}$ & 5 & $<5$ \\
\hline
\end{tabular}




\begin{tabular}{|c|c|c|c|c|}
\hline Parâmetros & $\begin{array}{l}\text { Q uantidade } \\
\text { Adicionada }\end{array}$ & Unidade & $\begin{array}{c}\text { Resultado da } \\
\text { Recuperação (\%) }\end{array}$ & Faixa Aceitável de Recuperação (\%) \\
\hline \multicolumn{5}{|c|}{ 286353/2014-0 - Amostra Controle - VOC - Água } \\
\hline 1,1-Dicloroeteno & 20 & $\mu \mathrm{g} / \mathrm{L}$ & 90 & $70-130$ \\
\hline Benzeno & 20 & $\mu \mathrm{g} / \mathrm{L}$ & 95 & $70-130$ \\
\hline Tricloroeteno & 20 & $\mu \mathrm{g} / \mathrm{L}$ & 90 & $70-130$ \\
\hline Tolueno & 20 & $\mu \mathrm{g} / \mathrm{L}$ & 90 & $70-130$ \\
\hline Clorobenzeno & 20 & $\mu \mathrm{g} / \mathrm{L}$ & 95 & $70-130$ \\
\hline \multicolumn{5}{|c|}{$\begin{array}{l}\text { Surrogates } \\
\text { 286352/2014-0 - Branco de Análise - VOC - Água }\end{array}$} \\
\hline p-Bromofluorbenzeno & 20 & $\%$ & 97,0 & $70-130$ \\
\hline Dibrom ofluorometano & 20 & $\%$ & 108 & $70-130$ \\
\hline \multicolumn{5}{|c|}{ 286353/2014-0 - Amostra Controle - VOC - Água } \\
\hline p-Bromofluorbenzeno & 20 & $\%$ & 93,4 & $70-130$ \\
\hline Dibrom ofluorometano & 20 & $\%$ & 98,3 & $70-130$ \\
\hline \multicolumn{5}{|l|}{ 283858/2014-0 - CAFA-3 } \\
\hline Dibromofluorometano & 20 & $\%$ & 109 & $70-130$ \\
\hline p-Bromofluorbenzeno & 20 & $\%$ & 89,9 & $70-130$ \\
\hline
\end{tabular}

Notas

LQ = Limite de Quantificação

n.a. $=$ Não Aplicável

Abrangência

(s) resultado(s) referem-se somente à(s) amostra(s) analisada(s).

Este Relatório de Ensaio só pode ser reproduzido por inteiro e sem nenhuma alteração.

Plano de Amostragem

Plano de amostragem de responsabilidade do interessado.

Responsabilidade Técnica

Os ensaios foram realizados na unidade da Bioagri Ambiental Ltda. - Matriz, situada na Rua Aljovil Martini, 177/201, Bairro Dois Córregos, Cep. 14420-833, Piracicaba/SP, registrada no CRQ 4 Região sob n $16082-\mathrm{Fe}$ responsabilidade técnica do profissional José Carlos Moretti, CRQ n 04107238, $4^{\text {a. }}$.Região.

Referências Metodológicas

Análises foram realizadas conforme a última versão do Standard Methods for the Examination of Water \& Wastewater 22nd 2012(SMWW), EPA e ABNT (quando aplicável).

VOC: EPA 8260 C: 2006, 5021A: 2003

Metiletilcetona: EPA 8260 C: 2006, 5021 A: 2003

Revisores

Débora Fernandes da Silva

Daniela Rodrigues Bandoria

Chave de Validação: 4d303853e4b877c6790bba581a92ad9f

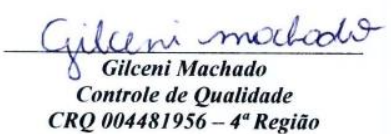

CRQ 004481956 - $4^{a}$ Região

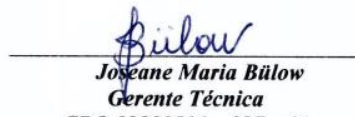

CRQ 09200516-9a Região 


\begin{tabular}{|c|c|c|c|c|c|c|}
\hline Parâmetros & CAS & Unidade & LQ & Resultados analíticos & Incerteza & Data do Ensaio \\
\hline 1,2,3-Tricloropropano & $96-18-4$ & $\mu \mathrm{g} / \mathrm{L}$ & 50 & $<50$ & n.a. & 29/10/2014 05:24 \\
\hline 1,3,5-Trimetilbenzeno & $108-67-8$ & $\mu \mathrm{g} / \mathrm{L}$ & 10 & $<10$ & n.a. & $29 / 10 / 201405: 24$ \\
\hline 1,2,4-Trimetilbenzeno & $95-63-6$ & $\mu \mathrm{g} / \mathrm{L}$ & 10 & $<10$ & n.a. & $29 / 10 / 201405: 24$ \\
\hline 1,2-Dibromoetano & $106-93-4$ & $\mu \mathrm{g} / \mathrm{L}$ & 10 & $<10$ & n.a. & $29 / 10 / 201405: 24$ \\
\hline 1,2-Diclorobenzeno & $95-50-1$ & $\mu \mathrm{g} / \mathrm{L}$ & 10 & $<10$ & n.a. & 29/10/2014 05:24 \\
\hline 1,3-Diclorobenzeno & $541-73-1$ & $\mu \mathrm{g} / \mathrm{L}$ & 10 & $<10$ & n.a. & 29/10/2014 05:24 \\
\hline 2-Clorotolueno & $95-49-8$ & $\mu \mathrm{g} / \mathrm{L}$ & 10 & $<10$ & n.a. & 29/10/2014 05:24 \\
\hline Dibromometano & $74-95-3$ & $\mu \mathrm{g} / \mathrm{L}$ & 10 & $<10$ & n.a. & $29 / 10 / 201405: 24$ \\
\hline Metiletilcetona & 78-93-3 & $\mu \mathrm{g} / \mathrm{L}$ & 25000 & $<25000$ & n.a. & $30 / 10 / 201404: 56$ \\
\hline Naftaleno & $91-20-3$ & $\mu g / L$ & 10 & $<10$ & n.a. & 29/10/2014 05:24 \\
\hline n-Butilbenzeno & $104-51-8$ & $\mu \mathrm{g} / \mathrm{L}$ & 10 & $<10$ & n.a. & $29 / 10 / 201405: 24$ \\
\hline n-Propilbenzeno & $103-65-1$ & $\mu \mathrm{g} / \mathrm{L}$ & 10 & $<10$ & n.a. & $29 / 10 / 201405: 24$ \\
\hline 4-Clorotolueno & $106-43-4$ & $\mu \mathrm{g} / \mathrm{L}$ & 10 & $<10$ & n.a. & $29 / 10 / 201405: 24$ \\
\hline sec-Butilbenzeno & $135-98-8$ & $\mu \mathrm{g} / \mathrm{L}$ & 10 & $<10$ & n.a. & $29 / 10 / 201405: 24$ \\
\hline terc-Butilbenzeno & $98-06-6$ & $\mu \mathrm{g} / \mathrm{L}$ & 10 & $<10$ & n.a. & $29 / 10 / 201405: 24$ \\
\hline trans-1,3-Dicloropropeno & $10061-02-6$ & $\mu \mathrm{g} / \mathrm{L}$ & 10 & $<10$ & n.a. & $29 / 10 / 201405: 24$ \\
\hline Isopropilbenzeno & $98-82-8$ & $\mu \mathrm{g} / \mathrm{L}$ & 10 & $<10$ & n.a. & $29 / 10 / 2014$ 05:24 \\
\hline 1,3,5-Triclorobenzeno & $108-70-3$ & $\mu \mathrm{g} / \mathrm{L}$ & 10 & $<10$ & n.a. & $29 / 10 / 2014$ 05:24 \\
\hline
\end{tabular}

\section{CONTROLE DE Q UALIDADE DO LAB ORATÓRIO}

Controle de Q ualidade - VOC - Água

286352/2014-0 - Branco de Análise - VOC - Água

Parâmetros

1,1,2-Tricloroetano

1,1,2,2-Tetracloroetano

1,1-Dicloroetano

1,1-Dicloroeteno

1,1-Dicloropropeno

1,2,3-Triclorobenzeno

1,2,4-Triclorobenzeno

1,3,5-Triclorobenzeno

1,2-Dibromo-3-Cloropropano

1,2-Dicloroetano

1,2-Dicloropropano

1,3-Dicloropropano

1,4-Diclorobenzeno

2,2-Dicloropropano

4-Metil-2-Pentanona

Benzeno

Bromobenzeno

Bromodiclorometano

Bromofórmio

Cis-1,2-Dicloroeteno

Cis-1,3-Dicloropropeno

Diclorometano

Cloreto de Vinila

Clorobenzeno

Cloroetano

Clorofórmio

Clorometano

Dibromoclorometano

Dissulfeto de Carbono

Estireno

Etilbenzeno

Hexaclorobutadieno

$\mathrm{m}, \mathrm{p}$-Xilenos

o-Xileno

p-Isopropiltolueno

Tetracloreto de Carbono

Tetracloroeteno

Tolueno

Trans-1,2-Dicloroeteno

Tricloroeteno

Isopropilbenzeno

Bromoclorometano

Unida

$\mu \mathrm{g} / \mathrm{L}$

$\mu \mathrm{g} / \mathrm{L}$

$\mu \mathrm{g} / \mathrm{L}$

$\mu \mathrm{g} / \mathrm{L}$

$\mu \mathrm{g} / \mathrm{L}$

$\mu \mathrm{g} / \mathrm{L}$

$\mu \mathrm{g} / \mathrm{L}$

$\mu \mathrm{g} / \mathrm{L}$

$\mu \mathrm{g} / \mathrm{L}$

$\mu \mathrm{g} / \mathrm{L}$

$\mu \mathrm{g} / \mathrm{L}$

$\mu \mathrm{g} / \mathrm{L}$

$\mu \mathrm{g} / \mathrm{L}$

$\mu \mathrm{g} / \mathrm{L}$

$\mu \mathrm{g} / \mathrm{L}$

$\mu \mathrm{g} / \mathrm{L}$

$\mu \mathrm{g} / \mathrm{L}$

$\mu \mathrm{g} / \mathrm{L}$

$\mu \mathrm{g} / \mathrm{L}$

$\mu \mathrm{g} / \mathrm{L}$

$\mu \mathrm{g} / \mathrm{L}$

$\mu \mathrm{g} / \mathrm{L}$

$\mu \mathrm{g} / \mathrm{L}$

$\mu \mathrm{g} / \mathrm{L}$

$\mu \mathrm{g} / \mathrm{L}$

$\mu \mathrm{g} / \mathrm{L}$

$\mu \mathrm{g} / \mathrm{L}$

$\mu \mathrm{g} / \mathrm{L}$

$\mu \mathrm{g} / \mathrm{L}$

$\mu \mathrm{g} / \mathrm{L}$

$\mu \mathrm{g} / \mathrm{L}$

$\mu \mathrm{g} / \mathrm{L}$

$\mu \mathrm{g} / \mathrm{L}$

$\mu \mathrm{g} / \mathrm{L}$

$\mu \mathrm{g} / \mathrm{L}$

$\mu \mathrm{g} / \mathrm{L}$

$\mu \mathrm{g} / \mathrm{L}$

$\mu \mathrm{g} / \mathrm{L}$

$\mu \mathrm{g} / \mathrm{L}$

$\mu \mathrm{g} / \mathrm{L}$

$\mu \mathrm{g} / \mathrm{L}$

$\mu \mathrm{g} / \mathrm{L}$

$\mu \mathrm{g} / \mathrm{L}$

\begin{tabular}{|c|c|}
\hline LQ & Resultados analíticos \\
\hline 1 & $<1$ \\
\hline 1 & $<1$ \\
\hline 1 & $<1$ \\
\hline 1 & $<1$ \\
\hline 1 & $<1$ \\
\hline 1 & $<1$ \\
\hline 1 & $<1$ \\
\hline 1 & $<1$ \\
\hline 1 & $<1$ \\
\hline 5 & $<5$ \\
\hline 1 & $<1$ \\
\hline 1 & $<1$ \\
\hline 5 & $<5$ \\
\hline 1 & $<1$ \\
\hline 1 & $<1$ \\
\hline 5 & $<5$ \\
\hline 1 & $<1$ \\
\hline 1 & $<1$ \\
\hline 1 & $<1$ \\
\hline 1 & $<1$ \\
\hline 1 & $<1$ \\
\hline 1 & $<1$ \\
\hline 1 & $<1$ \\
\hline 1 & $<1$ \\
\hline 1 & $<1$ \\
\hline 1 & $<1$ \\
\hline 1 & $<1$ \\
\hline 10 & $<10$ \\
\hline 1 & $<1$ \\
\hline 1 & $<1$ \\
\hline 1 & $<1$ \\
\hline 1 & $<1$ \\
\hline 1 & $<1$ \\
\hline 2 & $<2$ \\
\hline 1 & $<1$ \\
\hline 1 & $<1$ \\
\hline 1 & $<1$ \\
\hline 1 & $<1$ \\
\hline 1 & $<1$ \\
\hline 1 & $<1$ \\
\hline 1 & $<1$ \\
\hline 1 & $<1$ \\
\hline 5 & $<5$ \\
\hline
\end{tabular}




\begin{tabular}{|c|c|c|c|c|}
\hline Parâmetros & $\begin{array}{l}\text { Q uantidade } \\
\text { Adicionada }\end{array}$ & Unidade & $\begin{array}{c}\text { Resultado da } \\
\text { Recuperação (\%) }\end{array}$ & Faixa Aceitável de Recuperação (\%) \\
\hline \multicolumn{5}{|c|}{ 286353/2014-0 - Amostra Controle - VOC - Água } \\
\hline 1,1-Dicloroeteno & 20 & $\mu \mathrm{g} / \mathrm{L}$ & 90 & $70-130$ \\
\hline Benzeno & 20 & $\mu \mathrm{g} / \mathrm{L}$ & 95 & $70-130$ \\
\hline Tricloroeteno & 20 & $\mu \mathrm{g} / \mathrm{L}$ & 90 & $70-130$ \\
\hline Tolueno & 20 & $\mu \mathrm{g} / \mathrm{L}$ & 90 & $70-130$ \\
\hline Clorobenzeno & 20 & $\mu \mathrm{g} / \mathrm{L}$ & 95 & $70-130$ \\
\hline \multicolumn{5}{|c|}{$\begin{array}{l}\text { Surrogates } \\
\text { 286352/2014-0 - Branco de Análise - VOC - Água }\end{array}$} \\
\hline p-Bromofluorbenzeno & 20 & $\%$ & 97,0 & $70-130$ \\
\hline Dibrom ofluorometano & 20 & $\%$ & 108 & $70-130$ \\
\hline \multicolumn{5}{|c|}{ 286353/2014-0 - Amostra Controle - VOC - Água } \\
\hline p-Bromofluorbenzeno & 20 & $\%$ & 93,4 & $70-130$ \\
\hline Dibrom ofluorometano & 20 & $\%$ & 98,3 & $70-130$ \\
\hline \multicolumn{5}{|l|}{ 283869/2014-0 - CAT-1 } \\
\hline Dibromofluorometano & 20 & $\%$ & Amostra Diluída & $70-130$ \\
\hline p-Bromofluorbenzeno & 20 & $\%$ & Amostra Diluída & $70-130$ \\
\hline
\end{tabular}

Notas

LQ = Limite de Quantificação.

n.a. $=$ Não Aplicável

Abrangência

(s) resultado(s) referem-se somente à(s) amostra(s) analisada(s).

Este Relatório de Ensaio só pode ser reproduzido por inteiro e sem nenhuma alteração.

Plano de Amostragem

Plano de amostragem de responsabilidade do interessado

Responsabilidade Técnic

Os ensaios foram realizados na unidade da Bioagri Ambiental Ltda. - Matriz, situada na Rua Aljovil Martini, 177/201, Bairro Dois Córregos, Cep. 14420-833, Piracicaba/SP, registrada no CRQ 4ª Região sob nº 16082-Fe responsabilidade técnica do profissional José Carlos Moretti, CRQ nº 04107238, $4^{a}$.Região.

Referências Metodológicas

Análises foram realizadas conforme a última versão do Standard Methods for the Examination of Water \& Wastewater 22nd 2012(SMWW), EPA e ABNT (quando aplicável). VOC: EPA 8260 C: 2006, 5021A: 2003

Metiletilcetona: EPA 8260 C: 2006, 5021 A: 2003

Revisores

Débora Fernandes da Silva

Daniela Rodrigues Bandoria

Chave de Validação: 2cdf520e4f7b58ce22fc544c2a0df4b6

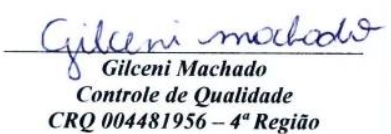

CRQ 004481956-4 Região

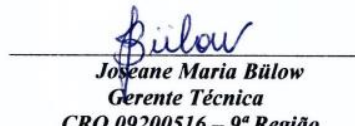

CRQ 09200516-9 $9^{a}$ Região 


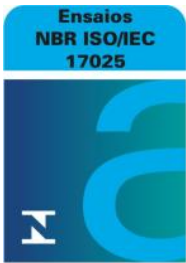

CRL 0172

\begin{tabular}{|c|c|c|c|c|c|c|}
\hline Parâmetros & CAS & Unidade & LQ & Resultados analíticos & Incerteza & Data do Ensaio \\
\hline 1,2,3-Tricloropropano & $96-18-4$ & $\mu \mathrm{g} / \mathrm{L}$ & 50 & $<50$ & n.a. & $29 / 10 / 201405: 48$ \\
\hline 1,3,5-Trime tilbenzeno & $108-67-8$ & $\mu \mathrm{g} / \mathrm{L}$ & 10 & $<10$ & n.a. & 29/10/2014 05:48 \\
\hline 1,2,4-Trimetilbenzeno & $95-63-6$ & $\mu \mathrm{g} / \mathrm{L}$ & 10 & $<10$ & n.a. & 29/10/2014 05:48 \\
\hline 1,2-Dibromoetano & $106-93-4$ & $\mu \mathrm{g} / \mathrm{L}$ & 10 & $<10$ & n.a. & 29/10/2014 05:48 \\
\hline 1,2-Diclorobenzeno & $95-50-1$ & $\mu \mathrm{g} / \mathrm{L}$ & 10 & $<10$ & n.a. & 29/10/2014 05:48 \\
\hline 1,3-Diclorobenzeno & $541-73-1$ & $\mu \mathrm{g} / \mathrm{L}$ & 10 & $<10$ & n.a. & 29/10/2014 05:48 \\
\hline 2-Clorotolueno & $95-49-8$ & $\mu \mathrm{g} / \mathrm{L}$ & 10 & $<10$ & n.a. & 29/10/2014 05:48 \\
\hline Dibromometano & 74-95-3 & $\mu \mathrm{g} / \mathrm{L}$ & 10 & $<10$ & n.a. & 29/10/2014 05:48 \\
\hline Metiletilcetona & 78-93-3 & $\mu \mathrm{g} / \mathrm{L}$ & 25000 & $<25000$ & n.a. & 30/10/2014 07:20 \\
\hline Naftaleno & $91-20-3$ & $\mu \mathrm{g} / \mathrm{L}$ & 10 & $<10$ & n.a. & 29/10/2014 05:48 \\
\hline n-Butilbenzeno & $104-51-8$ & $\mu \mathrm{g} / \mathrm{L}$ & 10 & $<10$ & n.a. & 29/10/2014 05:48 \\
\hline n-Propilbenzeno & $103-65-1$ & $\mu \mathrm{g} / \mathrm{L}$ & 10 & $<10$ & n.a. & 29/10/2014 05:48 \\
\hline 4-Clorotolueno & $106-43-4$ & $\mu \mathrm{g} / \mathrm{L}$ & 10 & $<10$ & n.a. & $29 / 10 / 201405: 48$ \\
\hline sec-Butilbenzeno & $135-98-8$ & $\mu \mathrm{g} / \mathrm{L}$ & 10 & $<10$ & n.a. & 29/10/2014 05:48 \\
\hline terc-Butilbenzeno & 98-06-6 & $\mu \mathrm{g} / \mathrm{L}$ & 10 & $<10$ & n.a. & 29/10/2014 05:48 \\
\hline trans-1,3-Dicloropropeno & $10061-02-6$ & $\mu \mathrm{g} / \mathrm{L}$ & 10 & $<10$ & n.a. & 29/10/2014 05:48 \\
\hline Isopropilbenzeno & $98-82-8$ & $\mu \mathrm{g} / \mathrm{L}$ & 10 & $<10$ & n.a. & 29/10/2014 05:48 \\
\hline 1,3,5-Triclorobenzeno & $108-70-3$ & $\mu \mathrm{g} / \mathrm{L}$ & 10 & $<10$ & n.a. & 29/10/2014 05:48 \\
\hline
\end{tabular}

\section{CONTROLE DE Q UALIDADE DO LAB ORATÓRIO}

Controle de Q ualidade - VOC - Água

286352/2014-0 - Branco de Análise - VOC - Água

Parâmetros

1,1,2-Tricloroetano

1,1,2,2-Tetracloroetano

1,1-Dicloroetano

1,1-Dicloroeteno

1,1-Dicloropropeno

1,2,3-Triclorobenzeno

1,2,4-Triclorobenzeno

1,3,5-Triclorobenzeno

1,2-Dibromo-3-Cloropropano

1,2-Dicloroetano

1,2-Dicloropropano

1,3-Dicloropropano

1,4-Diclorobenzeno

2,2-Dicloropropano

4-Metil-2-Pentanona

Benzeno

Bromobenzeno

Bromodiclorometano

Bromofórmio

Cis-1,2-Dicloroeteno

Cis-1,3-Dicloropropeno

Diclorometano

Cloreto de Vinila

Clorobenzeno

Cloroetano

Clorofórmio

Clorometano

Dibromoclorometano

Dissulfeto de Carbono

Estireno

Etilbenzeno

Hexaclorobutadieno

m,p-Xilenos

o-Xileno

p-Isopropiltolueno

Tetracloreto de Carbono

Tetracloroeteno

Tolueno

Trans-1,2-Dicloroeteno

Tricloroeteno

Isopropilbenzeno

Bromoclorometano
Unidade

$\mu \mathrm{g} / \mathrm{L}$

$\mu \mathrm{g} / \mathrm{L}$

$\mu \mathrm{g} / \mathrm{L}$

$\mu \mathrm{g} / \mathrm{L}$

$\mu \mathrm{g} / \mathrm{L}$

$\mu \mathrm{g} / \mathrm{L}$

$\mu \mathrm{g} / \mathrm{L}$

$\mu \mathrm{g} / \mathrm{L}$

$\mu \mathrm{g} / \mathrm{L}$

$\mu \mathrm{g} / \mathrm{L}$

$\mu \mathrm{g} / \mathrm{L}$

$\mu \mathrm{g} / \mathrm{L}$

$\mu \mathrm{g} / \mathrm{L}$

$\mu \mathrm{g} / \mathrm{L}$

$\mu \mathrm{g} / \mathrm{L}$

$\mu \mathrm{g} / \mathrm{L}$

$\mu \mathrm{g} / \mathrm{L}$

$\mu \mathrm{g} / \mathrm{L}$

$\mu \mathrm{g} / \mathrm{L}$

$\mu \mathrm{g} / \mathrm{L}$

$\mu \mathrm{g} / \mathrm{L}$

$\mu \mathrm{g} / \mathrm{L}$
$\mu \mathrm{g} / \mathrm{L}$

$\mu \mathrm{g} / \mathrm{L}$

$\mu \mathrm{g} / \mathrm{L}$

$\mu \mathrm{g} / \mathrm{L}$

$\mu \mathrm{g} / \mathrm{L}$

$\mu \mathrm{g} / \mathrm{L}$

$\mu \mathrm{g} / \mathrm{L}$

$\mu \mathrm{g} / \mathrm{L}$

$\mu \mathrm{g} / \mathrm{L}$

$\mu \mathrm{g} / \mathrm{L}$

$\mu \mathrm{g} / \mathrm{L}$

$\mu \mathrm{g} / \mathrm{L}$

$\mu \mathrm{g} / \mathrm{L}$

$\mu \mathrm{g} / \mathrm{L}$

$\mu \mathrm{g} / \mathrm{L}$

$\mu \mathrm{g} / \mathrm{L}$

$\mu \mathrm{g} / \mathrm{L}$

$\mu \mathrm{g} / \mathrm{L}$

$\mu \mathrm{g} / \mathrm{L}$

$\mu \mathrm{g} / \mathrm{L}$

$\mu \mathrm{g} / \mathrm{L}$

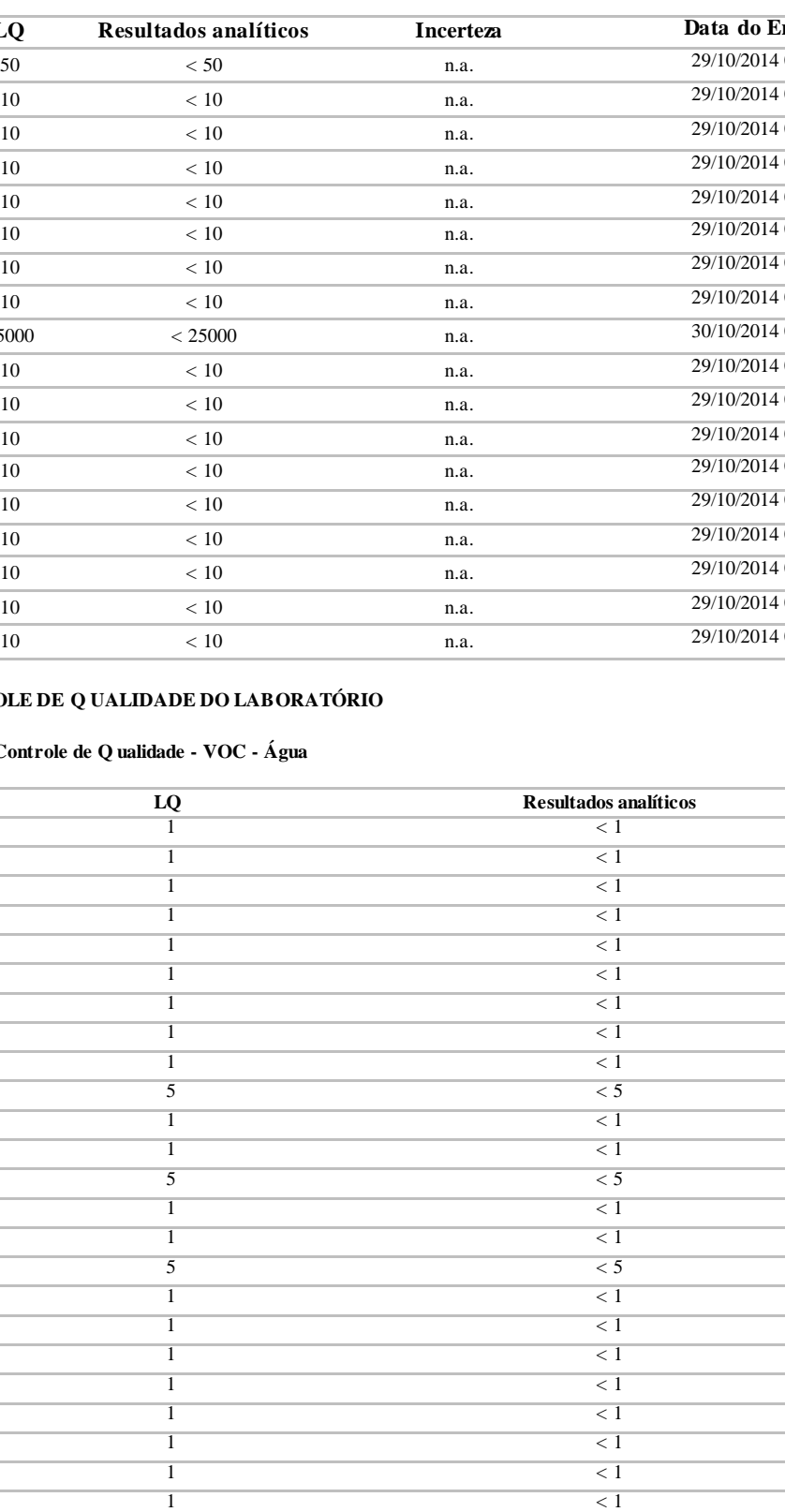

$<1$

$<1$

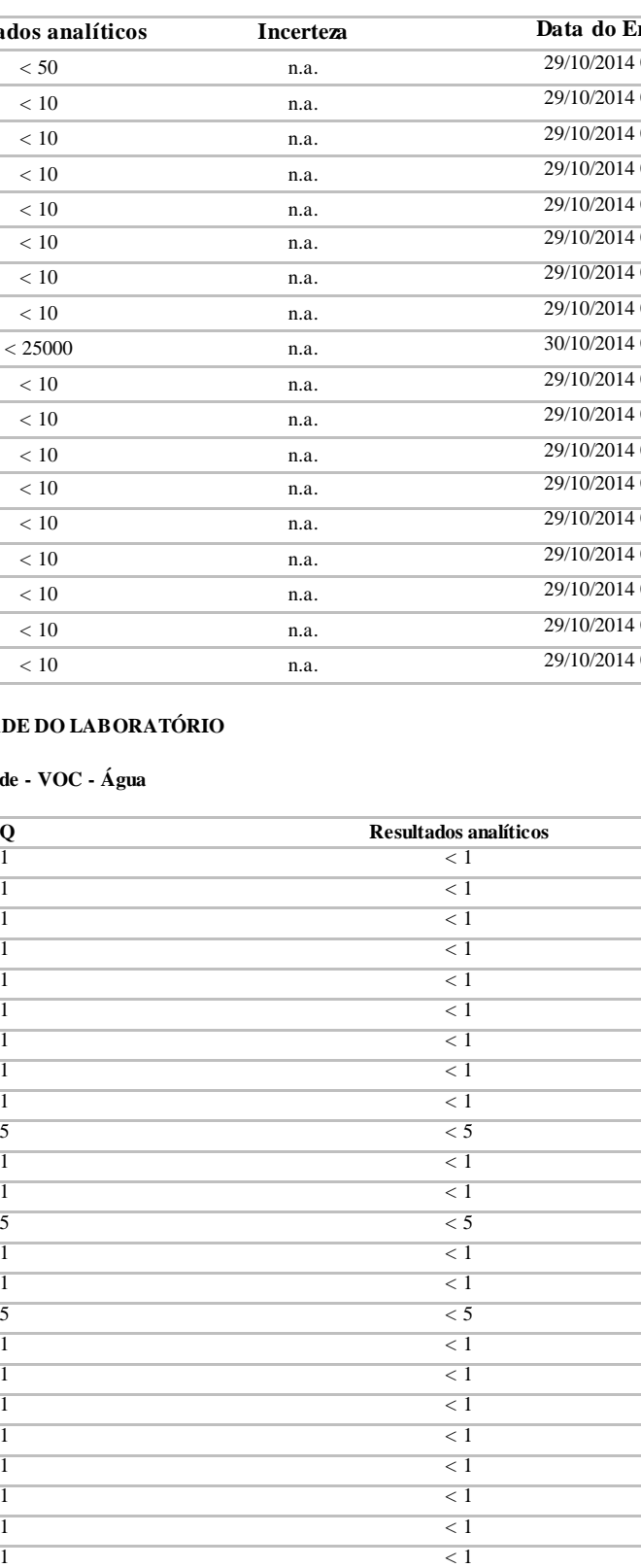

\begin{tabular}{|c|c|c|}
\hline os analíticos & Incerteza & Data do $\mathrm{E}$ \\
\hline$<50$ & n.a. & $29 / 10 / 2014$ \\
\hline$<10$ & n.a. & $29 / 10 / 2014$ \\
\hline$<10$ & n.a. & $29 / 10 / 2014$ \\
\hline$<10$ & n.a. & $29 / 10 / 2014$ \\
\hline$<10$ & n.a. & $29 / 10 / 2014$ \\
\hline$<10$ & n.a. & $29 / 10 / 2014$ \\
\hline$<10$ & n.a. & $29 / 10 / 2014$ \\
\hline$<10$ & n.a. & $29 / 10 / 2014$ \\
\hline 25000 & n.a. & $30 / 10 / 2014$ \\
\hline$<10$ & n.a. & $29 / 10 / 2014$ \\
\hline$<10$ & n.a. & $29 / 10 / 2014$ \\
\hline$<10$ & n.a. & $29 / 10 / 2014$ \\
\hline$<10$ & n.a. & 29/10/2014 \\
\hline$<10$ & n.a. & $29 / 10 / 2014$ \\
\hline$<10$ & n.a. & $29 / 10 / 2014$ \\
\hline$<10$ & n.a. & $29 / 10 / 2014$ \\
\hline$<10$ & n.a. & $29 / 10 / 2014$ \\
\hline$<10$ & n.a. & $29 / 10 / 2014$ \\
\hline \multicolumn{3}{|c|}{ E DO LAB ORATÓRIO } \\
\hline \multicolumn{3}{|l|}{ - VOC - Água } \\
\hline & \multicolumn{2}{|c|}{ Resultados analíticos } \\
\hline & \multicolumn{2}{|c|}{$<1$} \\
\hline & \multicolumn{2}{|c|}{$<1$} \\
\hline & \multicolumn{2}{|c|}{$<1$} \\
\hline & \multicolumn{2}{|c|}{$<1$} \\
\hline & \multicolumn{2}{|c|}{$<1$} \\
\hline & \multicolumn{2}{|c|}{$<1$} \\
\hline & \multicolumn{2}{|c|}{$<1$} \\
\hline & \multicolumn{2}{|c|}{$<1$} \\
\hline & \multicolumn{2}{|c|}{$<1$} \\
\hline & \multicolumn{2}{|c|}{$<5$} \\
\hline & \multicolumn{2}{|c|}{$<1$} \\
\hline & \multicolumn{2}{|c|}{$<1$} \\
\hline & \multicolumn{2}{|c|}{$<5$} \\
\hline & \multicolumn{2}{|c|}{$<1$} \\
\hline & \multicolumn{2}{|c|}{$<1$} \\
\hline & \multicolumn{2}{|c|}{$<5$} \\
\hline & \multicolumn{2}{|c|}{$<1$} \\
\hline & \multicolumn{2}{|c|}{$<1$} \\
\hline & \multicolumn{2}{|c|}{$<1$} \\
\hline & \multicolumn{2}{|c|}{$<1$} \\
\hline & \multicolumn{2}{|c|}{$<1$} \\
\hline & \multicolumn{2}{|c|}{$<1$} \\
\hline & & \\
\hline
\end{tabular}

\begin{tabular}{|c|c|c|}
\hline os analíticos & Incerteza & Data do $\mathrm{E}$ \\
\hline$<50$ & n.a. & $29 / 10 / 2014$ \\
\hline$<10$ & n.a. & $29 / 10 / 2014$ \\
\hline$<10$ & n.a. & $29 / 10 / 2014$ \\
\hline$<10$ & n.a. & $29 / 10 / 2014$ \\
\hline$<10$ & n.a. & $29 / 10 / 2014$ \\
\hline$<10$ & n.a. & $29 / 10 / 2014$ \\
\hline$<10$ & n.a. & $29 / 10 / 2014$ \\
\hline$<10$ & n.a. & $29 / 10 / 2014$ \\
\hline 25000 & n.a. & $30 / 10 / 2014$ \\
\hline$<10$ & n.a. & $29 / 10 / 2014$ \\
\hline$<10$ & n.a. & $29 / 10 / 2014$ \\
\hline$<10$ & n.a. & $29 / 10 / 2014$ \\
\hline$<10$ & n.a. & 29/10/2014 \\
\hline$<10$ & n.a. & $29 / 10 / 2014$ \\
\hline$<10$ & n.a. & $29 / 10 / 2014$ \\
\hline$<10$ & n.a. & $29 / 10 / 2014$ \\
\hline$<10$ & n.a. & $29 / 10 / 2014$ \\
\hline$<10$ & n.a. & $29 / 10 / 2014$ \\
\hline \multicolumn{3}{|c|}{ E DO LAB ORATÓRIO } \\
\hline \multicolumn{3}{|l|}{ - VOC - Água } \\
\hline & \multicolumn{2}{|c|}{ Resultados analíticos } \\
\hline & \multicolumn{2}{|c|}{$<1$} \\
\hline & \multicolumn{2}{|c|}{$<1$} \\
\hline & \multicolumn{2}{|c|}{$<1$} \\
\hline & \multicolumn{2}{|c|}{$<1$} \\
\hline & \multicolumn{2}{|c|}{$<1$} \\
\hline & \multicolumn{2}{|c|}{$<1$} \\
\hline & \multicolumn{2}{|c|}{$<1$} \\
\hline & \multicolumn{2}{|c|}{$<1$} \\
\hline & \multicolumn{2}{|c|}{$<1$} \\
\hline & \multicolumn{2}{|c|}{$<5$} \\
\hline & \multicolumn{2}{|c|}{$<1$} \\
\hline & \multicolumn{2}{|c|}{$<1$} \\
\hline & \multicolumn{2}{|c|}{$<5$} \\
\hline & \multicolumn{2}{|c|}{$<1$} \\
\hline & \multicolumn{2}{|c|}{$<1$} \\
\hline & \multicolumn{2}{|c|}{$<5$} \\
\hline & \multicolumn{2}{|c|}{$<1$} \\
\hline & \multicolumn{2}{|c|}{$<1$} \\
\hline & \multicolumn{2}{|c|}{$<1$} \\
\hline & \multicolumn{2}{|c|}{$<1$} \\
\hline & \multicolumn{2}{|c|}{$<1$} \\
\hline & \multicolumn{2}{|c|}{$<1$} \\
\hline & & \\
\hline
\end{tabular}

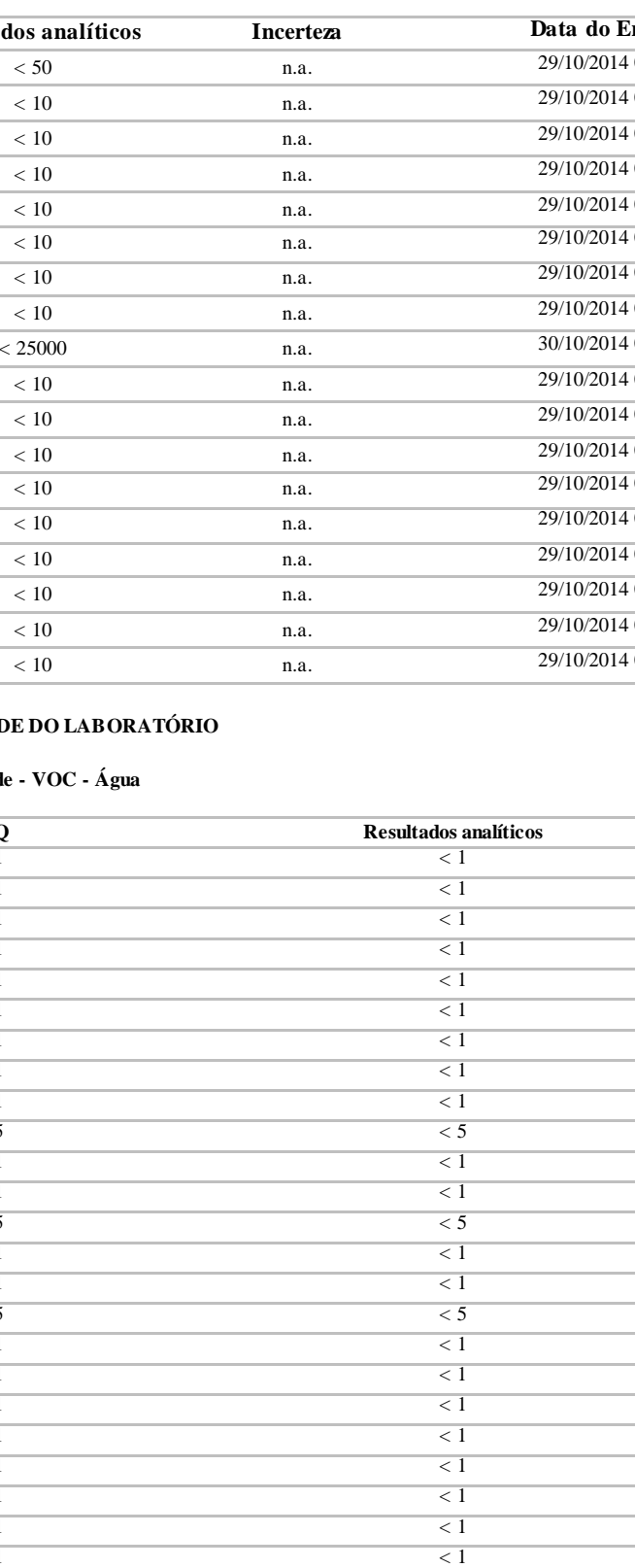

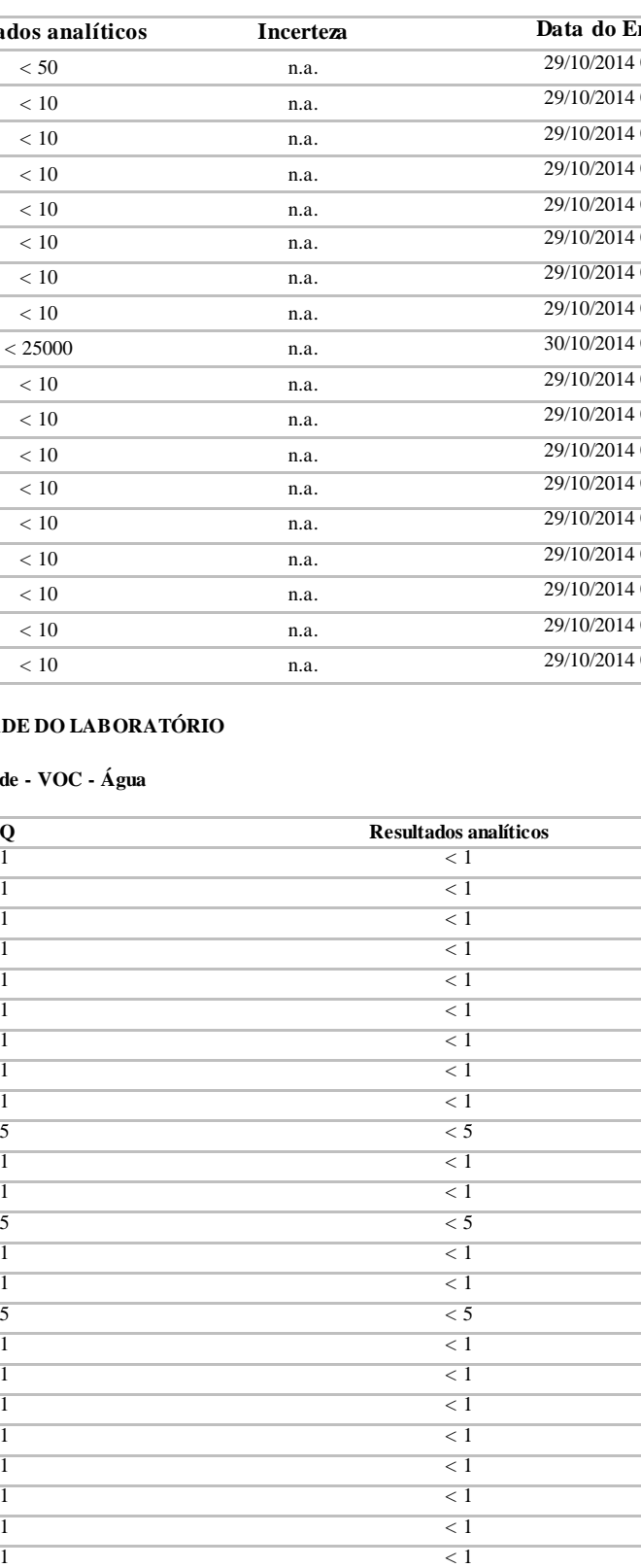

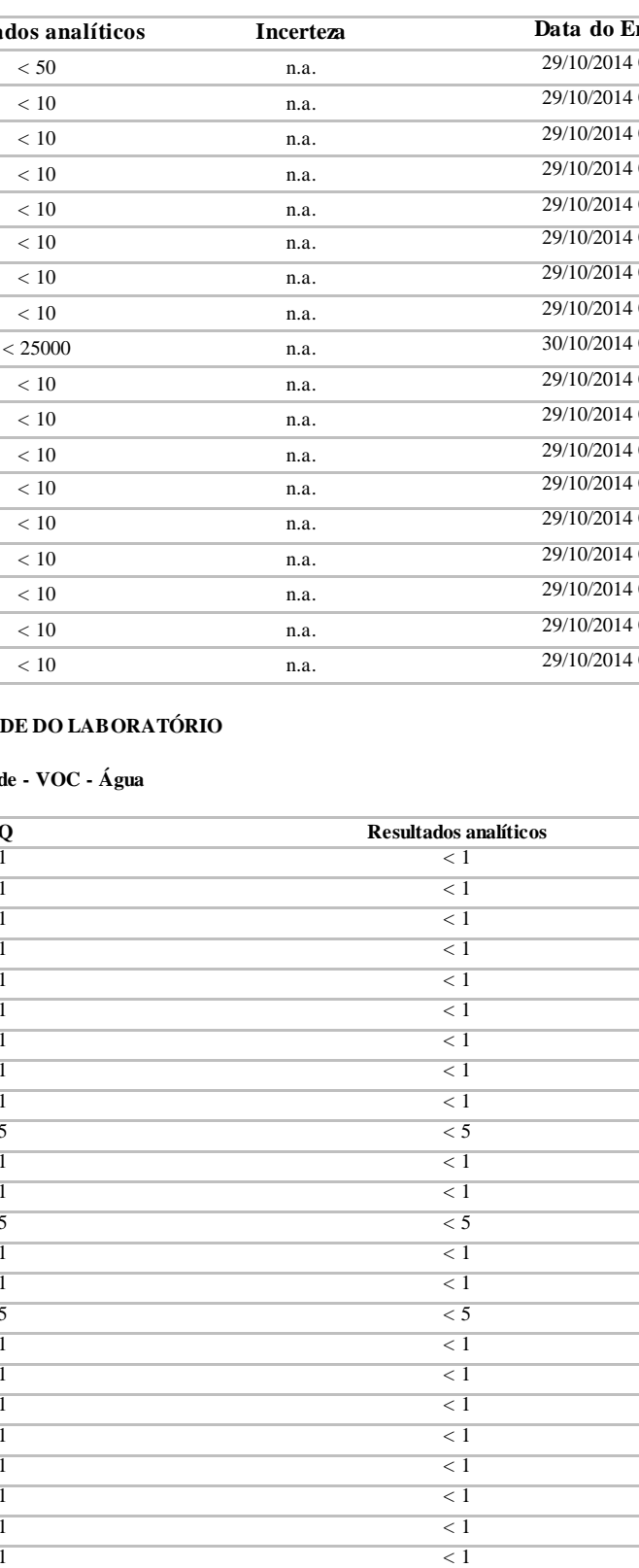

\begin{tabular}{|c|c|c|}
\hline los analíticos & Incerteza & Data do $\mathrm{E}$ \\
\hline$<50$ & n.a. & $29 / 10 / 2014$ \\
\hline$<10$ & n.a. & $29 / 10 / 2014$ \\
\hline$<10$ & n.a. & $29 / 10 / 2014$ \\
\hline$<10$ & n.a. & $29 / 10 / 2014$ \\
\hline$<10$ & n.a. & $29 / 10 / 2014$ \\
\hline$<10$ & n.a. & $29 / 10 / 2014$ \\
\hline$<10$ & n.a. & $29 / 10 / 2014$ \\
\hline$<10$ & n.a. & $29 / 10 / 2014$ \\
\hline 25000 & n.a. & $30 / 10 / 2014$ \\
\hline$<10$ & n.a. & $29 / 10 / 2014$ \\
\hline$<10$ & n.a. & $29 / 10 / 2014$ \\
\hline$<10$ & n.a. & $29 / 10 / 2014$ \\
\hline$<10$ & n.a. & $29 / 10 / 2014$ \\
\hline$<10$ & n.a. & $29 / 10 / 2014$ \\
\hline$<10$ & n.a. & $29 / 10 / 2014$ \\
\hline$<10$ & n.a. & $29 / 10 / 2014$ \\
\hline$<10$ & n.a. & $29 / 10 / 2014$ \\
\hline$<10$ & n.a. & $29 / 10 / 2014$ \\
\hline \multicolumn{3}{|c|}{ E DO LABORATÓRIO } \\
\hline \multicolumn{3}{|l|}{ - VOC - Água } \\
\hline & \multicolumn{2}{|c|}{ Resultados analíticos } \\
\hline & \multicolumn{2}{|c|}{$<1$} \\
\hline & \multicolumn{2}{|c|}{$<1$} \\
\hline & \multicolumn{2}{|c|}{$<1$} \\
\hline & \multicolumn{2}{|c|}{$<1$} \\
\hline & \multicolumn{2}{|c|}{$<1$} \\
\hline & \multicolumn{2}{|c|}{$<1$} \\
\hline & \multicolumn{2}{|c|}{$<1$} \\
\hline & \multicolumn{2}{|c|}{$<1$} \\
\hline & \multicolumn{2}{|c|}{$<1$} \\
\hline & \multicolumn{2}{|c|}{$<5$} \\
\hline & \multicolumn{2}{|c|}{$<1$} \\
\hline & \multicolumn{2}{|c|}{$<1$} \\
\hline & \multicolumn{2}{|c|}{$<5$} \\
\hline & \multicolumn{2}{|c|}{$<1$} \\
\hline & \multicolumn{2}{|c|}{$<1$} \\
\hline & \multicolumn{2}{|c|}{$<5$} \\
\hline & \multicolumn{2}{|c|}{$<1$} \\
\hline & \multicolumn{2}{|c|}{$<1$} \\
\hline & \multicolumn{2}{|c|}{$<1$} \\
\hline & \multicolumn{2}{|c|}{$<1$} \\
\hline & \multicolumn{2}{|c|}{$<1$} \\
\hline & \multicolumn{2}{|c|}{$<1$} \\
\hline & & \\
\hline
\end{tabular}

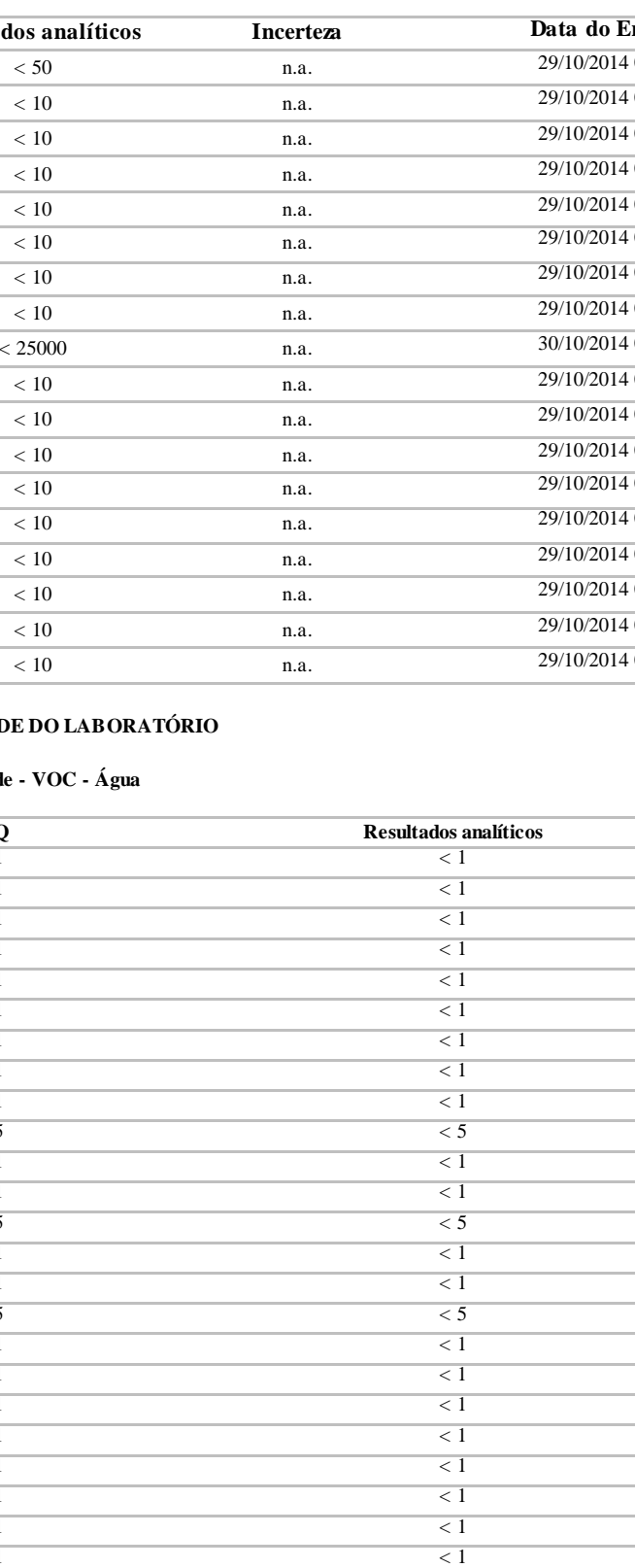

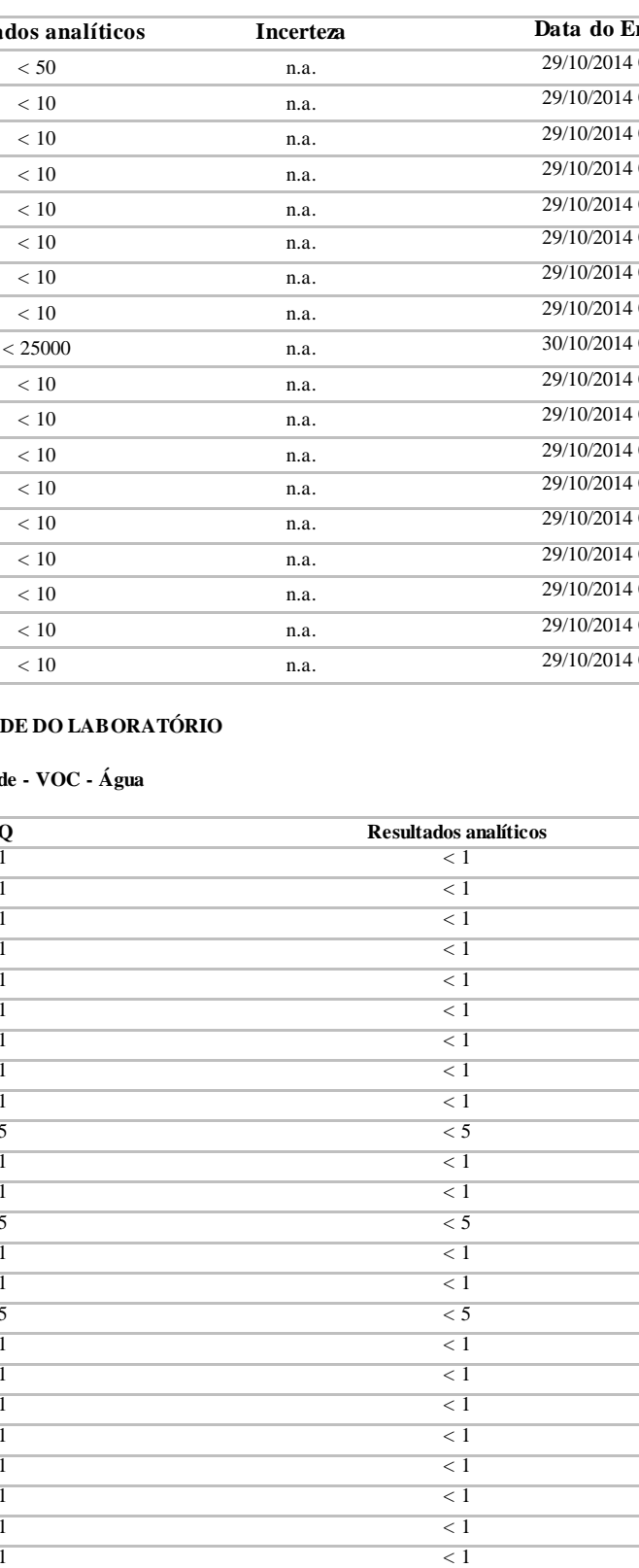

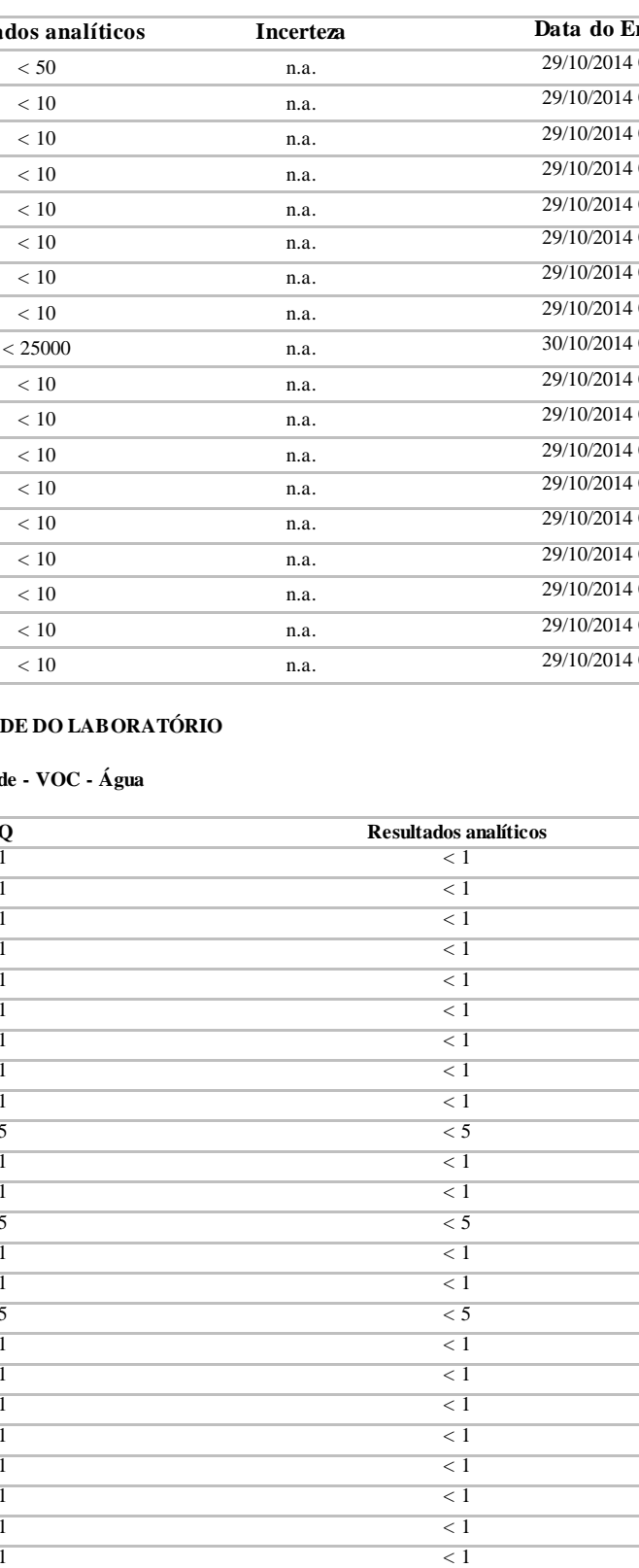

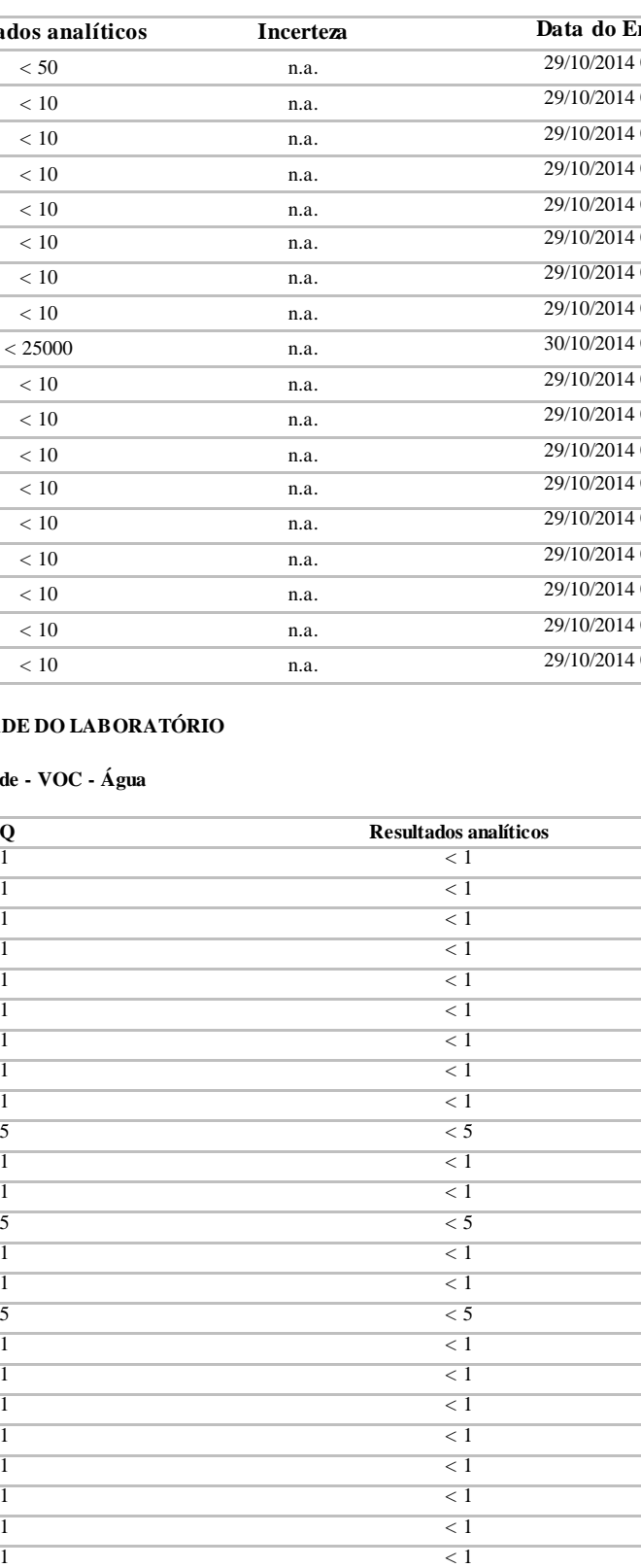

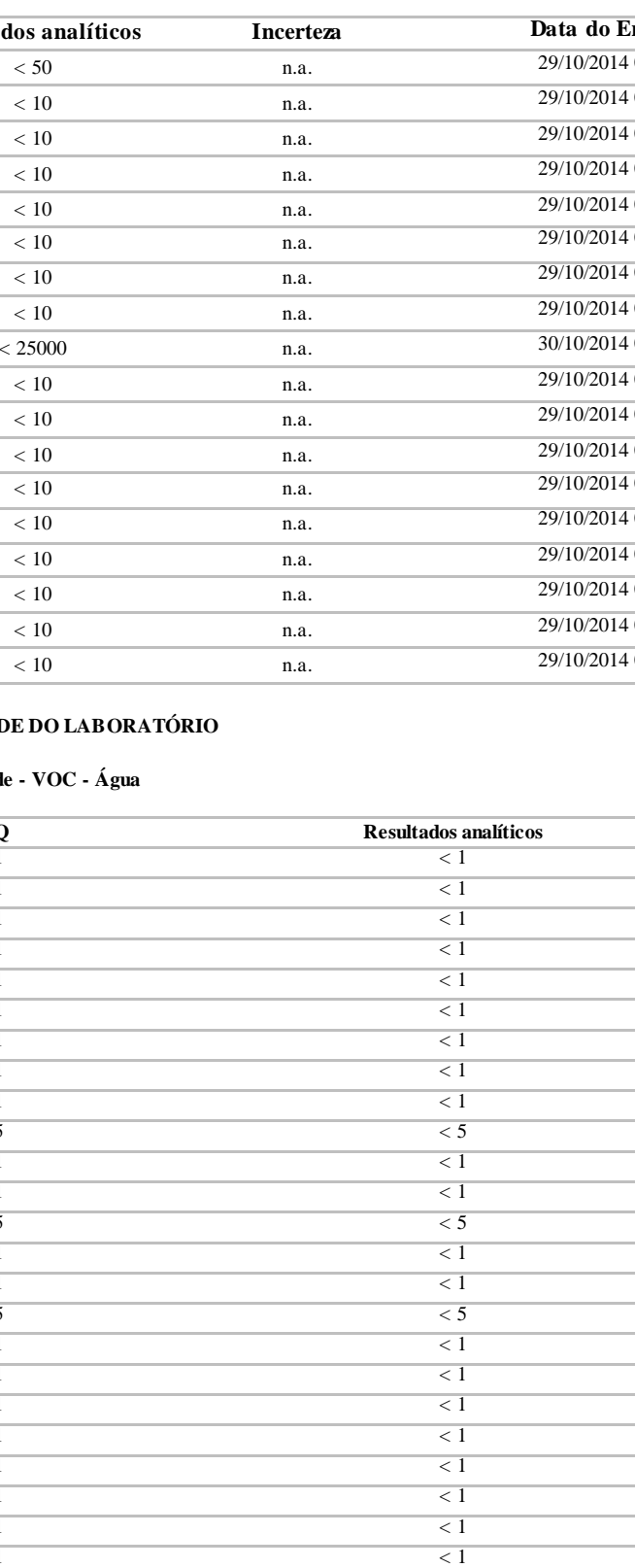

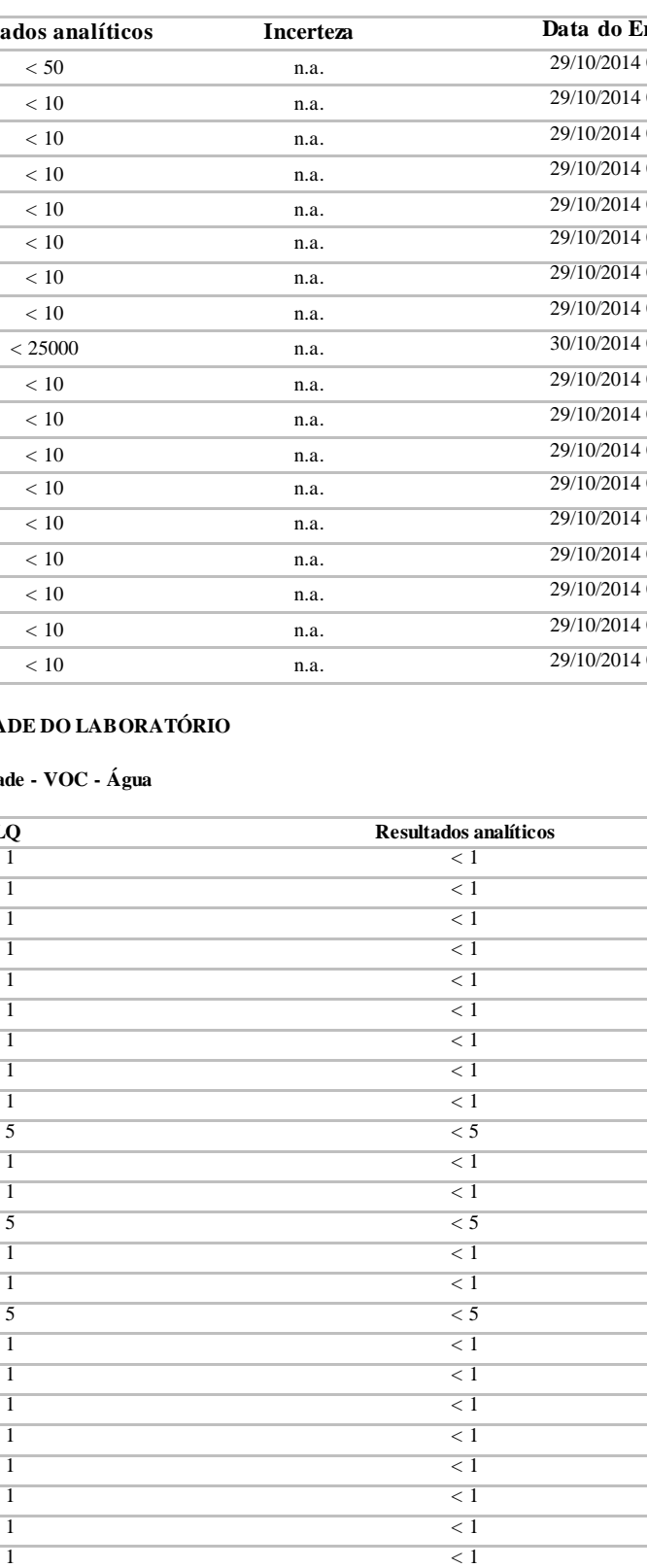

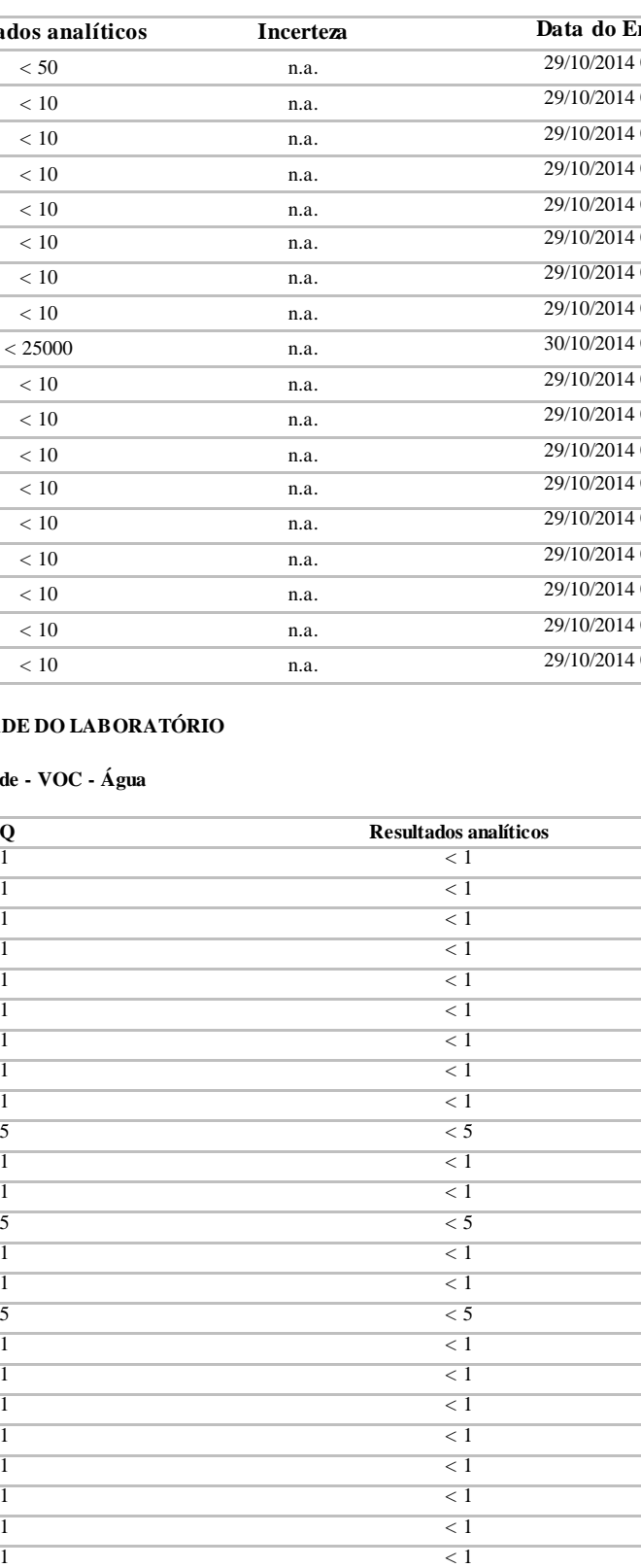

$1<1$

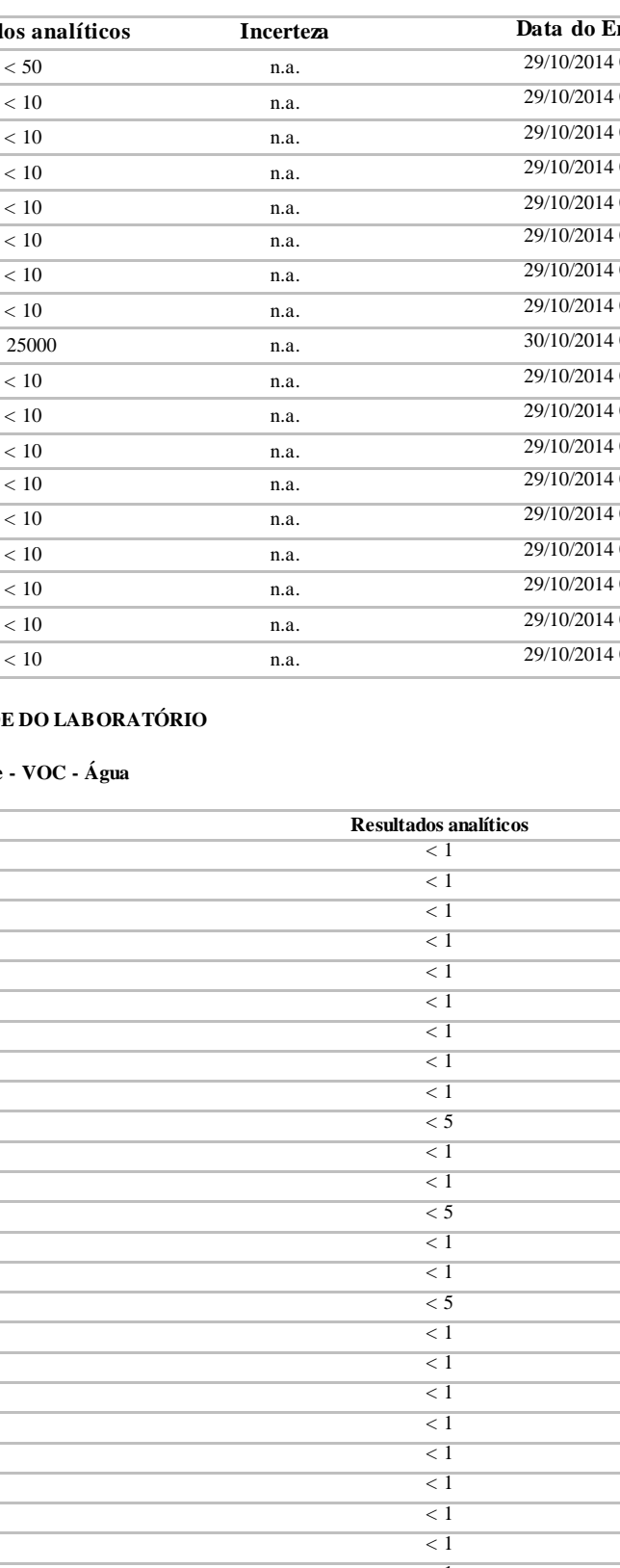

$1<1$




\begin{tabular}{|c|c|c|c|c|}
\hline Parâmetros & $\begin{array}{l}\text { Q uantidade } \\
\text { Adicionada }\end{array}$ & Unidade & $\begin{array}{c}\text { Resultado da } \\
\text { Recuperação (\%) }\end{array}$ & Faixa Aceitável de Recuperação (\%) \\
\hline \multicolumn{5}{|c|}{ 286353/2014-0 - Amostra Controle - VOC - Água } \\
\hline 1,1-Dicloroeteno & 20 & $\mu \mathrm{g} / \mathrm{L}$ & 90 & $70-130$ \\
\hline Benzeno & 20 & $\mu \mathrm{g} / \mathrm{L}$ & 95 & $70-130$ \\
\hline Tricloroeteno & 20 & $\mu \mathrm{g} / \mathrm{L}$ & 90 & $70-130$ \\
\hline Tolueno & 20 & $\mu \mathrm{g} / \mathrm{L}$ & 90 & $70-130$ \\
\hline Clorobenzeno & 20 & $\mu \mathrm{g} / \mathrm{L}$ & 95 & $70-130$ \\
\hline \multicolumn{5}{|c|}{$\begin{array}{l}\text { Surrogates } \\
\text { 286352/2014-0 - Branco de Análise - VOC - Água }\end{array}$} \\
\hline p-Bromofluorbenzeno & 20 & $\%$ & 97,0 & $70-130$ \\
\hline Dibrom ofluorometano & 20 & $\%$ & 108 & $70-130$ \\
\hline \multicolumn{5}{|c|}{ 286353/2014-0 - Amostra Controle - VOC - Água } \\
\hline p-Bromofluorbenzeno & 20 & $\%$ & 93,4 & $70-130$ \\
\hline Dibrom ofluorometano & 20 & $\%$ & 98,3 & $70-130$ \\
\hline \multicolumn{5}{|l|}{ 283870/2014-0 - CAT-2 } \\
\hline Dibromofluorometano & 20 & $\%$ & Amostra Diluída & $70-130$ \\
\hline p-Bromofluorbenzeno & 20 & $\%$ & Amostra Diluída & $70-130$ \\
\hline
\end{tabular}

Notas

LQ = Limite de Quantificação.

n.a. $=$ Não Aplicável

Abrangência

(s) resultado(s) referem-se somente à(s) amostra(s) analisada(s).

Este Relatório de Ensaio só pode ser reproduzido por inteiro e sem nenhuma alteração.

Plano de Amostragem

Plano de amostragem de responsabilidade do interessado.

Responsabilidade Técnica

Os ensaios foram realizados na unidade da Bioagri Ambiental Ltda. - Matriz, situada na Rua Aljovil Martini, 177/201, Bairro Dois Córregos, Cep. 14420-833, Piracicaba/SP, registrada no CRQ 4ª Região sob n $16082-F$ e responsabilidade técnica do profissional José Carlos Moretti, CRQ n 04107238, $4^{a}$.Região.

Referências Metodológicas

Análises foram realizadas conforme a última versão do Standard Methods for the Examination of Water \& Wastewater 22nd 2012(SMWW), EPA e ABNT (quando aplicável).

VOC: EPA 8260 C: 2006, 5021A: 2003

Metiletilcetona: EPA 8260 C: 2006, 5021 A: 2003

Revisores

Débora Fernandes da Silva

Daniela Rodrigues Bandoria

Chave de Validação: 9c70a9bb4ee 158f6e3a49439ed17dc3d

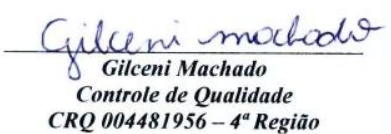

CRQ 004481956-4 Região

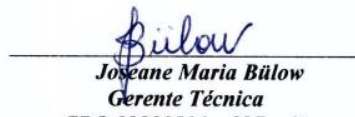

CRQ 09200516-9a Região 


\begin{tabular}{|c|c|c|c|c|c|c|}
\hline Parâmetros & CAS & Unidade & LQ & Resultados analíticos & Incerteza & Data do Ensaio \\
\hline 1,2,3-Tricloropropano & $96-18-4$ & $\mu \mathrm{g} / \mathrm{L}$ & 50 & $<50$ & n.a. & 29/10/2014 06:12 \\
\hline 1,3,5-Trimetilbenzeno & $108-67-8$ & $\mu \mathrm{g} / \mathrm{L}$ & 10 & $<10$ & n.a. & 29/10/2014 06:12 \\
\hline 1,2,4-Trimetilbenzeno & $95-63-6$ & $\mu \mathrm{g} / \mathrm{L}$ & 10 & $<10$ & n.a. & 29/10/2014 06:12 \\
\hline 1,2-Dibromoetano & $106-93-4$ & $\mu \mathrm{g} / \mathrm{L}$ & 10 & $<10$ & n.a. & 29/10/2014 06:12 \\
\hline 1,2-Diclorobenzeno & $95-50-1$ & $\mu \mathrm{g} / \mathrm{L}$ & 10 & $<10$ & n.a. & 29/10/2014 06:12 \\
\hline 1,3-Diclorobenzeno & $541-73-1$ & $\mu \mathrm{g} / \mathrm{L}$ & 10 & $<10$ & n.a. & 29/10/2014 06:12 \\
\hline 2-Clorotolueno & $95-49-8$ & $\mu \mathrm{g} / \mathrm{L}$ & 10 & $<10$ & n.a. & 29/10/2014 06:12 \\
\hline Dibromometano & $74-95-3$ & $\mu \mathrm{g} / \mathrm{L}$ & 10 & $<10$ & n.a. & 29/10/2014 06:12 \\
\hline Metiletilcetona & 78-93-3 & $\mu \mathrm{g} / \mathrm{L}$ & 25000 & $<25000$ & n.a. & 30/10/2014 08:08 \\
\hline Naftaleno & $91-20-3$ & $\mu \mathrm{g} / \mathrm{L}$ & 10 & $<10$ & n.a. & 29/10/2014 06:12 \\
\hline n-Butilbenzeno & $104-51-8$ & $\mu \mathrm{g} / \mathrm{L}$ & 10 & $<10$ & n.a. & 29/10/2014 06:12 \\
\hline n-Propilbenzeno & $103-65-1$ & $\mu \mathrm{g} / \mathrm{L}$ & 10 & $<10$ & n.a. & 29/10/2014 06:12 \\
\hline 4-Clorotolueno & $106-43-4$ & $\mu \mathrm{g} / \mathrm{L}$ & 10 & $<10$ & n.a. & 29/10/2014 06:12 \\
\hline sec-Butilbenzeno & $135-98-8$ & $\mu \mathrm{g} / \mathrm{L}$ & 10 & $<10$ & n.a. & 29/10/2014 06:12 \\
\hline terc-Butilbenzeno & $98-06-6$ & $\mu \mathrm{g} / \mathrm{L}$ & 10 & $<10$ & n.a. & 29/10/2014 06:12 \\
\hline trans-1,3-Dicloropropeno & $10061-02-6$ & $\mu \mathrm{g} / \mathrm{L}$ & 10 & $<10$ & n.a. & 29/10/2014 06:12 \\
\hline Isopropilbenzeno & $98-82-8$ & $\mu \mathrm{g} / \mathrm{L}$ & 10 & $<10$ & n.a. & 29/10/2014 06:12 \\
\hline 1,3,5-Triclorobenzeno & $108-70-3$ & $\mu \mathrm{g} / \mathrm{L}$ & 10 & $<10$ & n.a. & 29/10/2014 06:12 \\
\hline
\end{tabular}

\section{CONTROLE DE Q UALIDADE DO LAB ORATÓRIO}

Controle de Q ualidade - VOC - Água

286352/2014-0 - Branco de Análise - VOC - Água

1,1,1-Tricloroetano Parâmetros

1,1,2-Tricloroetano

1,1,2,2-Tetracloroetano

1,1-Dicloroetano

1,1-Dicloroeteno

1,1-Dicloropropeno

1,2,3-Triclorobenzeno

1,2,4-Triclorobenzeno

1,3,5-Triclorobenzeno

1,2-Dibromo-3-Cloropropano

1,2-Dicloroetano

1,2-Dicloropropano

1,3-Dicloropropano

1,4-Diclorobenzeno

2,2-Dicloropropano

4-Metil-2-Pentanona

Benzeno

Bromobenzeno

Bromodiclorometano

Bromofórmio

Cis-1,2-Dicloroeteno

Cis-1,3-Dicloropropeno

Diclorometano

Cloreto de Vinila

Clorobenzeno

Cloroetano

Clorofórmio

Clorometano

Dibromoclorometano

Dissulfeto de Carbono

Estireno

Etilbenzeno

Hexaclorobutadieno

m,p-Xilenos

o-Xileno

p-Isopropiltolueno

Tetracloreto de Carbono

Tetracloroeteno

Tolueno

Trans-1,2-Dicloroeteno

Tricloroeteno

Isopropilbenzeno

Bromoclorometano

\begin{tabular}{|c|c|c|}
\hline Unidade & LQ & Resultados analíticos \\
\hline$\mu \mathrm{g} / \mathrm{L}$ & 1 & $<1$ \\
\hline$\mu \mathrm{g} / \mathrm{L}$ & 1 & $<1$ \\
\hline$\mu \mathrm{g} / \mathrm{L}$ & 1 & $<1$ \\
\hline$\mu \mathrm{g} / \mathrm{L}$ & 1 & $<1$ \\
\hline$\mu \mathrm{g} / \mathrm{L}$ & 1 & $<1$ \\
\hline$\mu \mathrm{g} / \mathrm{L}$ & 1 & $<1$ \\
\hline$\mu \mathrm{g} / \mathrm{L}$ & 1 & $<1$ \\
\hline$\mu \mathrm{g} / \mathrm{L}$ & 1 & $<1$ \\
\hline$\mu \mathrm{g} / \mathrm{L}$ & 1 & $<1$ \\
\hline$\mu \mathrm{g} / \mathrm{L}$ & 5 & $<5$ \\
\hline$\mu \mathrm{g} / \mathrm{L}$ & 1 & $<1$ \\
\hline$\mu \mathrm{g} / \mathrm{L}$ & 1 & $<1$ \\
\hline$\mu \mathrm{g} / \mathrm{L}$ & 5 & $<5$ \\
\hline$\mu \mathrm{g} / \mathrm{L}$ & 1 & $<1$ \\
\hline$\mu \mathrm{g} / \mathrm{L}$ & 1 & $<1$ \\
\hline$\mu \mathrm{g} / \mathrm{L}$ & 5 & $<5$ \\
\hline$\mu \mathrm{g} / \mathrm{L}$ & 1 & $<1$ \\
\hline$\mu \mathrm{g} / \mathrm{L}$ & 1 & $<1$ \\
\hline$\mu \mathrm{g} / \mathrm{L}$ & 1 & $<1$ \\
\hline$\mu \mathrm{g} / \mathrm{L}$ & 1 & $<1$ \\
\hline$\mu \mathrm{g} / \mathrm{L}$ & 1 & $<1$ \\
\hline$\mu \mathrm{g} / \mathrm{L}$ & 1 & $<1$ \\
\hline$\mu \mathrm{g} / \mathrm{L}$ & 1 & $<1$ \\
\hline$\mu \mathrm{g} / \mathrm{L}$ & 1 & $<1$ \\
\hline$\mu \mathrm{g} / \mathrm{L}$ & 1 & $<1$ \\
\hline$\mu \mathrm{g} / \mathrm{L}$ & 1 & $<1$ \\
\hline$\mu \mathrm{g} / \mathrm{L}$ & 1 & $<1$ \\
\hline$\mu \mathrm{g} / \mathrm{L}$ & 10 & $<10$ \\
\hline$\mu \mathrm{g} / \mathrm{L}$ & 1 & $<1$ \\
\hline$\mu \mathrm{g} / \mathrm{L}$ & 1 & $<1$ \\
\hline$\mu \mathrm{g} / \mathrm{L}$ & 1 & $<1$ \\
\hline$\mu \mathrm{g} / \mathrm{L}$ & 1 & $<1$ \\
\hline$\mu \mathrm{g} / \mathrm{L}$ & 1 & $<1$ \\
\hline$\mu \mathrm{g} / \mathrm{L}$ & 2 & $<2$ \\
\hline$\mu \mathrm{g} / \mathrm{L}$ & 1 & $<1$ \\
\hline$\mu \mathrm{g} / \mathrm{L}$ & 1 & $<1$ \\
\hline$\mu \mathrm{g} / \mathrm{L}$ & 1 & $<1$ \\
\hline$\mu \mathrm{g} / \mathrm{L}$ & 1 & $<1$ \\
\hline$\mu \mathrm{g} / \mathrm{L}$ & 1 & $<1$ \\
\hline$\mu \mathrm{g} / \mathrm{L}$ & 1 & $<1$ \\
\hline$\mu \mathrm{g} / \mathrm{L}$ & 1 & $<1$ \\
\hline$\mu \mathrm{g} / \mathrm{L}$ & 1 & $<1$ \\
\hline$\mu \mathrm{g} / \mathrm{L}$ & 5 & $<5$ \\
\hline
\end{tabular}




\begin{tabular}{|c|c|c|c|c|}
\hline Parâmetros & $\begin{array}{l}\text { Q uantidade } \\
\text { Adicionada }\end{array}$ & Unidade & $\begin{array}{c}\text { Resultado da } \\
\text { Recuperação (\%) }\end{array}$ & Faixa Aceitável de Recuperação (\%) \\
\hline \multicolumn{5}{|c|}{ 286353/2014-0 - Amostra Controle - VOC - Água } \\
\hline 1,1-Dicloroeteno & 20 & $\mu \mathrm{g} / \mathrm{L}$ & 90 & $70-130$ \\
\hline Benzeno & 20 & $\mu \mathrm{g} / \mathrm{L}$ & 95 & $70-130$ \\
\hline Tricloroeteno & 20 & $\mu \mathrm{g} / \mathrm{L}$ & 90 & $70-130$ \\
\hline Tolueno & 20 & $\mu \mathrm{g} / \mathrm{L}$ & 90 & $70-130$ \\
\hline Clorobenzeno & 20 & $\mu \mathrm{g} / \mathrm{L}$ & 95 & $70-130$ \\
\hline \multicolumn{5}{|c|}{$\begin{array}{l}\text { Surrogates } \\
\text { 286352/2014-0 - Branco de Análise - VOC - Água }\end{array}$} \\
\hline p-Bromofluorbenzeno & 20 & $\%$ & 97,0 & $70-130$ \\
\hline Dibrom ofluorometano & 20 & $\%$ & 108 & $70-130$ \\
\hline \multicolumn{5}{|c|}{ 286353/2014-0 - Amostra Controle - VOC - Água } \\
\hline p-Bromofluorbenzeno & 20 & $\%$ & 93,4 & $70-130$ \\
\hline Dibrom ofluorometano & 20 & $\%$ & 98,3 & $70-130$ \\
\hline \multicolumn{5}{|l|}{ 283872/2014-0 - CAT-3 } \\
\hline Dibromofluorometano & 20 & $\%$ & Amostra Diluída & $70-130$ \\
\hline p-Bromofluorbenzeno & 20 & $\%$ & Amostra Diluída & $70-130$ \\
\hline
\end{tabular}

Notas

$\mathrm{LQ}=$ Limite de Quantificação

n.a. = Não Aplicável

Abrangência

(s) resultado(s) referem-se somente à(s) amostra(s) analisada(s).

Este Relatório de Ensaio só pode ser reproduzido por inteiro e sem nenhuma alteração.

Plano de Amostragem

Plano de amostragem de responsabilidade do interessado

Responsabilidade Técnica

Os ensaios foram realizados na unidade da Bioagri Ambiental Ltda. - Matriz, situada na Rua Aljovil Martini, 177/201, Bairro Dois Córregos, Cep. 14420-833, Piracicaba/SP, registrada no CRQ 4ª Região sob nº 16082-Fe responsabilidade técnica do profissional José Carlos Moretti, CRQ nº 04107238, $4^{a}$.Região.

Referências Metodológicas

Análises foram realizadas conforme a última versão do Standard Methods for the Examination of Water \& Wastewater 22nd 2012(SMWW), EPA e ABNT (quando aplicável).

VOC: EPA 8260 C: 2006, 5021A: 2003

Metiletilcetona: EPA $8260 \mathrm{C}: 2006,5021 \mathrm{~A}: 2003$

Revisores

Daniela Rodrigues Bandoria

Chave de Validação: eac38d7f99d544038d5b791861b30ecl

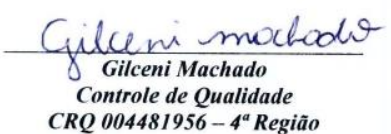

CRQ 004481956-4 Região

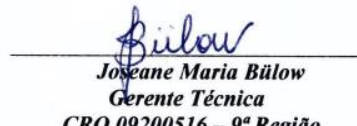

CRQ 09200516-9 $9^{a}$ Região 
APÊNDICE 


\section{MÉTODOS DE CARACTERIZAÇÃO DO SOLO}

\section{A.1 Ensaios Geotécnicos}

Curva granulométrica

O ensaio de granulometria é utilizado para determinar a distribuição granulométrica do solo, ou seja, a percentagem em peso que cada faixa especificada de tamanho de grãos representa na massa seca total utilizada para o ensaio.

O ensaio de granulometria é dividido em duas partes: análise granulométrica por peneiramento e análise granulométrica por sedimentação. Os solos grossos (areias e pedregulhos), com pouca ou nenhuma quantidade de finos, podem ter a sua curva granulométrica inteiramente determinada utilizando-se somente o peneiramento. Em solos com significativas quantidades de finos, deve-se adotar o ensaio de granulometria conjunta, que contempla o peneiramento e a sedimentação, conforme procedimentos estabelecidos na norma ABNT NBR 7181/1984.

\section{Limites de Atterberg}

A consistência está relacionada às forças de adesão e coesão na massa do solo a vários teores de água. O limite de plasticidade corresponde à porcentagem de umidade que separa o comportamento sólido do comportamento plástico. O limite de liquidez indica o teor de água em que as forças coesivas são tão pequenas que o solo pode desagregar e desmoronar sob a aplicação de uma força, ou seja, o limite entre o comportamento plástico e o comportamento líquido. $O$ índice de plasticidade é a diferença entre os limites de liquidez e de plasticidade, correspondendo à faixa de umidades em que o solo tem comportamento plástico. Os procedimentos adotados para determinação dos limites de liquidez e plasticidade seguirão as normas ABNT NBR 6459/1984 e 7180/1984, respectivamente. 
Peso específico dos grãos

A determinação da massa específica dos grãos de solos que passam na peneira de $4,8 \mathrm{~mm}$ é realizada com picnômetro e deve seguir a norma ABNT NBR 6508/1984, O cálculo da massa específica dos grãos do solo $(\delta)$ pode ser expressa pela eq. A.1.1

$$
\delta=\frac{M_{1} * 100 /(100+h)}{\left[\left(M_{1} * 100\right) /(100+h)\right]+M_{\mathrm{g}}-M_{2}} * \delta_{t} \quad(\mathrm{~A} .1 .1)
$$

Onde $M_{1}$ é a massa de solo úmido; $M_{2}$ é a massa do picnômetro + solo + água, na temperatura T do ensaio; $M_{3}$ é a massa do picnômetro cheio de água até a marca de referência na temperatura T do ensaio; $h$ é a umidade inicial da amostra; e $\delta_{t}$ é a massa específica, na temperatura T do ensaio, obtida na Tabela em anexo da norma ABNT supracitada.

Teor de umidade

O teor de umidade é a relação entre a perda de peso de uma amostra de solo e o seu peso após secagem em estufa até o peso se tornar constante, com temperatura mantida entre 105 e $110^{\circ} \mathrm{C}$. Para solos orgânicos, recomenda-se manter a temperatura de $60^{\circ} \mathrm{C}$ na estufa para evitar a oxidação do material e perda da água adsorvida. Com a finalidade de remover apenas a água dos poros, pode-se utilizar como alternativa à estufa, dissecadores a vácuo ou com cloreto de cálcio; neste caso, o processo de secagem de um solo argiloso até o alcance do equilíbrio (peso constante) pode demorar entre 3 e 12 dias, respectivamente, enquanto que para solos arenosos não há diferenças de tempo significativas (Massad, 2007). Por fim, o ensaio para determinação do teor de umidade no solo deve ser realizado de acordo com o anexo da norma ABNT NBR 6457/1986. 


\section{A.2 Ensaios Químicos}

Em razão dos argilo-minerais, substâncias húmicas e óxidos de ferro e alumínio, principais responsáveis pela capacidade de troca de cátions (CTC) dos solos, possuírem a superfície eletricamente carregada por cargas predominantemente negativas (ânions), tendem a atrair e ligar-se a íons e moléculas polarizadas com cargas positivas (cátions).

A capacidade de troca de cátions (CTC) de um solo, de uma argila ou do húmus representa a quantidade total de cátions retidos à superfície desses materiais em condição permutável $\left(\mathrm{Ca}^{2+}+\mathrm{Mg}^{2+}+\mathrm{K}^{+}+\mathrm{H}^{+}+\mathrm{Al}^{3+}\right)$, onde $\circ \mathrm{Ca}^{2+}, \mathrm{Mg}^{2+}, \mathrm{K}^{+}$ representam os cátions essenciais do solo, ${\mathrm{e} \mathrm{H}^{+}}^{+} \mathrm{Al}^{3+}$, cátions potencialmente tóxicos, Um valor baixo de CTC indica que o solo tem pouca capacidade de reter cátions em forma trocável (Ronquim, 2010). A soma de bases trocáveis (SB) de um solo, argila ou húmus representa a soma dos teores de cátions permutáveis $\mathrm{Ca}^{2+}+$ $\mathrm{Mg}^{2+}+\mathrm{K}^{+}$, enquanto a saturação por bases $(\mathrm{V} \%)$ é a SB expressa em porcentagem de capacidade de troca de cátions, conforme a Eq. A.2.1.

$$
V(\%)=100 *(S B / C T C)(\text { A.2.1) }
$$

Além da CTC, SB e V, os seguintes parâmetros serão determinados: pH em água, $\mathrm{pH}$ em $\mathrm{KCl}$, carbono orgânico total (COT em g/ $/ \mathrm{kg}$ ), $\mathrm{P}(\mathrm{mg} / \mathrm{kg}$ ), $\mathrm{K}, \mathrm{Ca}, \mathrm{Mg}, \mathrm{H}+\mathrm{Al}, \mathrm{Al}$, $\mathrm{Na}(\mathrm{mmolc} / \mathrm{kg})$, conforme orientações descritas no Manual de Análises Químicas de Solos, Plantas e Fertilizantes e no Manual de Métodos de Análise de Solos, ambos da Empresa Brasileira de Pesquisa Agropecuária (EMBRAPA).

Para determinação do pH em água, e do pH em KCl, mede-se a concentração de íons $\mathrm{H}^{+}$presentes na solução do solo com um eletrodo combinado imerso, em proporções, respectivamente, de suspensão solo: água de 1:2,5; e suspensão solo: solução de $\mathrm{KCl} 1 \mathrm{M}$ de 1:2,5.

O fósforo (P) é extraído pela solução de Mehlich 1, ou solução duplo-ácida, constituída por mistura de $\mathrm{HCl} 0,05 \mathrm{M}+\mathrm{H}_{2} \mathrm{SO}_{4}$ 0,0125 M. Esta solução impede a 
readsorção do íons $\mathrm{P}$ recém extraídos, que solubilizam entre $\mathrm{pH} 2$ e 3, O P é determinado por espectrofotometria.

O hidrogênio e o alumínio $\left(\mathrm{H}^{+}+\mathrm{Al}^{3+}\right)$, que indicam a acidez potencial, são extraídos com solução de acetato de cálcio até $\mathrm{pH} \mathrm{7,} \mathrm{e} \mathrm{sua} \mathrm{determinação} \mathrm{baseia-se} \mathrm{na}$ propriedade tampão do sal, decorrente da presença de ânions acetatos.

O alumínio $\left(\mathrm{Al}^{3+}\right)$, cálcio $\left(\mathrm{Ca}^{2+}\right)$ e magnésio $\left(\mathrm{Mg}^{2+}\right)$ trocáveis são extraídos com solução de $\mathrm{KCl} 1 \mathrm{M}$. O alumínio é determinado por titulação volumétrica com solução de $\mathrm{NaOH}$, e o cálcio e o magnésio são determinados por espectrofotometria de absorção atômica. $\mathrm{O} \mathrm{Ca}^{2+}$ e $0 \mathrm{Mg}^{2+}$ também podem ser extraídos com solução de acetato de amônio $1 \mathrm{M}$, O potássio $\left(\mathrm{K}^{+}\right)$e o sódio $\left(\mathrm{Na}^{+}\right)$são extraídos com solução de acetato de amônio $1 \mathrm{M}$ ou com solução de Mehlich 1, e determinados, respectivamente, por emissão atômica e fotometria de chama.

A fração de carbono orgânico total é determinada por titulação, e se baseia na oxidação da matéria orgânica a úmido com dicromato de potássio em meio sulfúrico, empregando-se como fonte de energia o calor desprendido do ácido sulfúrico. $\mathrm{O}$ excesso de dicromato após a oxidação é titulado com solução padrão de sulfato ferroso amoniacal (sal de Mohr).

O método para determinação do nitrogênio $\mathrm{N}$ consiste na oxidação com uma mistura de $\mathrm{CuSO}_{4}, \mathrm{H}_{2} \mathrm{SO}_{4}$ e $\mathrm{Na}_{2} \mathrm{SO}_{4}$ ou $\mathrm{K}_{2} \mathrm{SO}_{4}$ (mineralização) e transformação do $\mathrm{N}$ em sulfato de amônio. O sulfato de amônio, em meio alcalino, libera amônia que, em câmara de difusão, é complexada em solução de ácido bórico contendo indicador misto, sendo finalmente determinado por acidimetria $\left(\mathrm{H}_{2} \mathrm{SO}_{4}\right.$ ou $\left.\mathrm{HCl}\right)$.

A matéria orgânica (MO) do solo é um termo utilizado para descrever a porção orgânica total presente no solo, proveniente da decomposição de plantas, microorganismos e resíduos de animais. O processo de decomposição pode criar biopolímeros complexos, de peso molecular elevado (como os ácidos húmicos) e compostos orgânicos mais simples (lignina ou celulose em decomposição). Estes compostos orgânicos mais simples contribuem para a fração de carbono orgânico (f $\left.f_{c o}\right)$ (TOSCANO, 2007). A substância húmica é constituída por compostos fenólicos e nitrogenados, e compostos dos grupos funcionais carboxilas, carbonilas, 
fenilhidroxilas aminas, imidazoles, sulfidrila e sulfônicos, provenientes de plantas e da microbiota (SILVÉRIO; GONÇALVES, 2008).

A determinação do teor de matéria orgânica natural do solo será realizada conforme a norma ABNT NBR 13600/1996, através da queima em mufla, à temperatura de $\left(440 \pm 5^{\circ} \mathrm{C}\right)$, do material previamente seco em estufa, entre 105 e $110^{\circ} \mathrm{C}$. O cálculo do teor de matéria orgânica é expresso pela eq. A.2.2.

$$
M O=(1-B / A) * 100(\text { Equação A.2.2) }
$$

Onde MO é teor de matéria orgânica (\%); A é a massa da amostra seca em estufa (g); e B é a massa da amostra queimada em mufla (g).

A fração de carbono orgânico (fco) ou carbono orgânico total (COT) é a porção da matéria orgânica do solo que está disponível para adsorver ou se ligar quimicamente a contaminantes. Os métodos para determinação da fco são: combustão a úmido e titulação com dicromato de potássio (Walkley-Black e modificações); digestão com peróxido de hidrogênio; perda por ignição a seco (ASTM D2974-00), método Hach 10128; analisador automático; termogravimetria (TAG); e extração por pirofosfato de sódio. Dentre os métodos citados, os três primeiros são os mais utilizados, entretanto o primeiro tende a subestimar os valores de carbono orgânico total, e os outros dois subsequentes estão deixando de ser utilizados devido à baixa velocidade analítica e dificuldade de automação nos laboratórios. Estudos realizados por diversos pesquisadores demonstram que o método mais confiável é a análise instrumental por analisador de TOC, contudo, não é frequentemente aplicado devido ao seu alto custo de aquisição e manutenção do equipamento (SILVÉRIO; GONÇALVES, 2008).

As substâncias húmicas em solos podem ser divididas em três frações principais: ácidos húmicos, ácidos fúlvicos e humina. Os ácidos húmicos e os ácidos fúlvicos são extraídos do solo aplicando-se uma base forte ( $\mathrm{NaOH}$ ou $\mathrm{KOH})$. Ácidos húmicos são insolúveis em pH baixo e são precipitados por adição de um ácido forte (ajuste para $\mathrm{pH} 1 \mathrm{com} \mathrm{HCl}$ ). A humina não pode ser extraída com ácido forte ou base forte (IHSS, 2013). 


\section{A.3 Ensaios Mineralógicos}

\section{Difratometria de raios $X$}

Os minerais, em especial os constituintes da fração argila, controlam as propriedades físicas e químicas do solo. A identificação e caracterização das propriedades dos diferentes minerais do solo ajudam no entendimento do comportamento de contaminantes em subsuperfície. A fração argila do solo é comumente composta de uma mistura de um ou mais minerais aluminossilicatados secundários e minerais primários herdados diretamente do material de origem. A identificação e a estimativa quantitativa das proporções das várias espécies minerais, num sistema policomposto como o solo, exigem a aplicação de diversas análises complementares qualitativas e quantitativas. Um dos métodos mais comumente utilizados é a análise de difração de raios $X$ (Figura A.3.1), que determina o material cristalino mineral das argilas do solo, que produz difração de raios $\mathrm{X}$, (CAMARGO et al, 2009).

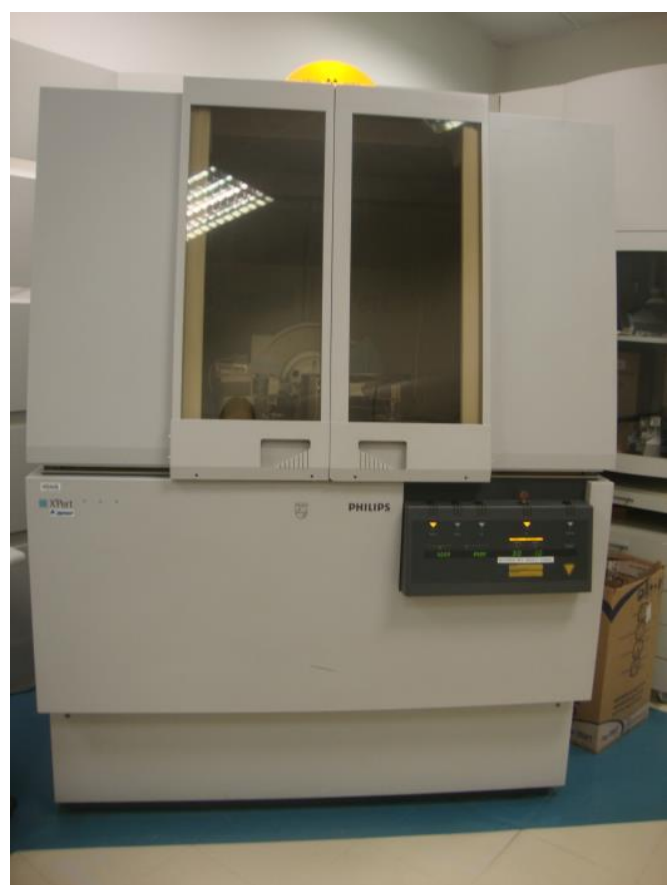

Figura A.3.1 Equipamento de Difratrometria de Raio X do LCT, EPUSP. Marca Philips

Isto ocorre porque na maior parte dos sólidos (cristais), os átomos se ordenam em planos cristalinos separados entre si por distâncias da mesma ordem de grandeza 
dos comprimentos de onda dos raios $X$. Ao incidir um feixe de raios $X$ em um cristal, o mesmo interage com os átomos presentes, originando o fenômeno de difração. $A$ difração de raios $X$ ocorre segundo a Lei de Bragg (eq. A.3.1), a qual estabelece a relação entre o ângulo de difração e a distância entre os planos que a originaram (característicos para cada fase cristalina).

$$
\mathrm{n} \lambda=2 \mathrm{~d} \operatorname{sen} \theta(\mathrm{A})(\mathrm{A} .3 .1)
$$

Onde $\mathrm{n}$ é o número inteiro; $\lambda$ é o comprimento de onda dos raios $\mathrm{X}$ incidentes; $\mathrm{d}$ é a distância interplanar; $\theta$ é o ângulo de difração.

Dentre as vantagens da técnica de difração de raios $X$ para a caracterização de fases, destacam-se a simplicidade e rapidez do método, a confiabilidade dos resultados obtidos, a possibilidade de análise de materiais compostos por uma mistura de fases e uma análise quantitativa dessas fases (ALBERS et, al., 2002).

Teores elevados de quartzo e sua facilidade de orientação resultam em picos bem definidos e de grande intensidade, prejudicando muitas vezes a identificação e caracterização das demais fases. Contudo, Albers et al., (2002) desenvolveram uma metodologia rápida e eficiente para identificar os argilominerais mais comumente encontrados nas argilas nacionais, que minimiza a presença do quartzo e facilita a identificação das demais fases.

Fluorescência de raios $X$

A fluorescência de raios $X$ (FRX) (Figura A.3.2) é uma técnica qualitativa e semiquantitativa, que permite identificar e determinar a proporção em que cada elemento se encontra em amostras de solo, rochas e sedimentos, Assim como a difratometria de raios $X$, a FRX também ocorre segundo a Lei de Bragg (eq. A.3.1). 


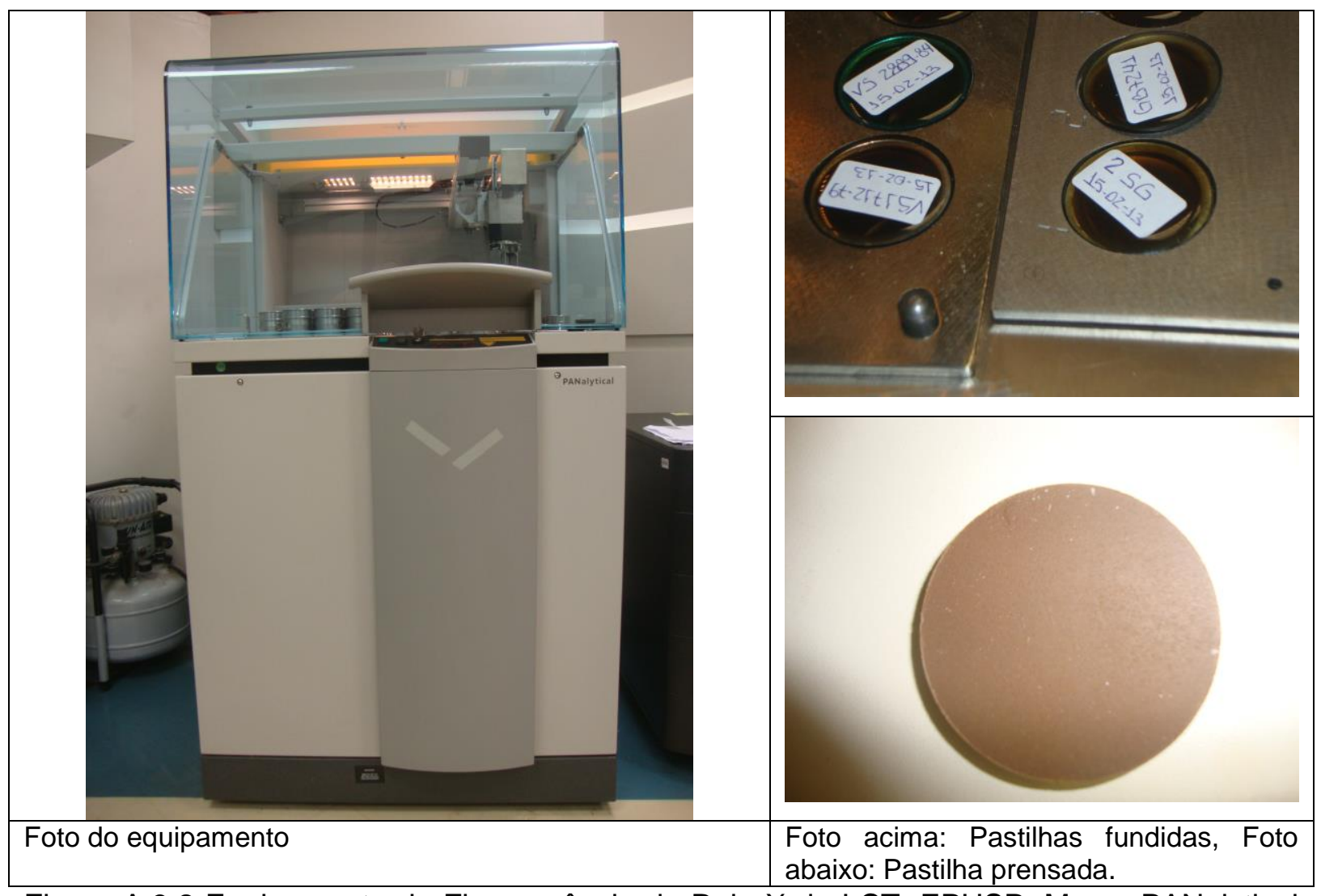

Figura A.3.2 Equipamento de Fluorescência de Raio X do LCT. EPUSP. Marca PANalytical e amostras

A FRX é uma das técnicas analíticas mais utilizadas em geoquímica na determinação de elementos maiores, menores e traços em rochas, solos e sedimentos, Dentre os elementos-traços, os mais favoráveis à determinação por FRX, em função de limites de detecção e abundância na crosta terrestre, são bário $(\mathrm{Ba})$, cério $(\mathrm{Ce})$, cromo $(\mathrm{Cr})$, cobre $(\mathrm{Cu})$, gálio $(\mathrm{Ga})$, lantânio $(\mathrm{La})$, nióbio $(\mathrm{Nb})$, níquel $(\mathrm{Ni})$, chumbo $(\mathrm{Pb})$, rubídio $(\mathrm{Rb})$, escândio $(\mathrm{Sc})$, estrôncio $(\mathrm{Sr})$, tório $(\mathrm{Th})$, vanádio $(\mathrm{V})$, ítrio $(\mathrm{Y})$, zinco $(\mathrm{Zn})$, zircônio $(\mathrm{Zr})$. Os resultados da $\mathrm{FRX}$ sempre são de concentrações elementares totais. A FRX também pode ser útil na análise de amostras mineralizadas, para determinar elementos em concentração anômala como o arsênio (As), antimônio (Sb), bismuto (Bi), tântalo (Ta), e tungstênio (W) (ENZWEILER, 2010).

A preparação das amostras já pulverizadas para análise com FRX é simples, e a fusão das amostras com fundentes (Figura A.3.2, foto Pastilhas fundidas), após o resfriamento, produz vidros. Esta forma de homogeneização da amostra facilita a determinação de elementos maiores e menores como o sódio $(\mathrm{Na})$, magnésio $(\mathrm{Mg})$, 
alumínio $(\mathrm{Al})$, silício $(\mathrm{Si})$, fósforo $(\mathrm{P})$, potássio $(\mathrm{K})$, cálcio $(\mathrm{Ca})$, titânio $(\mathrm{Ti})$, manganês $(\mathrm{Mn})$, e ferro (Fe). A preparação direta de pastilhas prensadas (Figura A.3.2, foto da pastilha prensada) a partir de amostras pulverizadas também é muito usada, mas é mais frequente na determinação de elementos-traço. Os limites de detecção da FRX convencional, da ordem de unidades a dezenas de ppm, não são uniformes para todos os elementos. Elementos leves $(Z<10)$ não são analisados na $F R X$ convencional e a baixa concentração de muitos elementos-traço (metais nobres) em amostras geológicas comuns impede a sua determinação por esta técnica (ENZWEILER, 2010).

$\mathrm{Na}$ fluorescência de raios $\mathrm{X}$ usa-se uma fonte de radiação gama (ou radiação $X$ de elevada energia) para provocar a excitação dos átomos da substância a ser analisada. Os fótons gama emitidos pela fonte são absorvidos pelos átomos da substância através de efeito fotoelétrico, excitando-os. Os elétrons retirados do átomo por efeito fotoelétrico situam-se nos níveis eletrônicos K ou L. Quando o átomo libera energia, pode-se observar fótons $X$ correspondentes às transições eletrônicas $L \rightarrow K, M \rightarrow K$ ou $M \rightarrow L$. $O$ espectro correspondente a essas transições possui uma energia característica para cada tipo de elemento, permitindo fazer a sua identificação (DPFFCUL, 2013). 